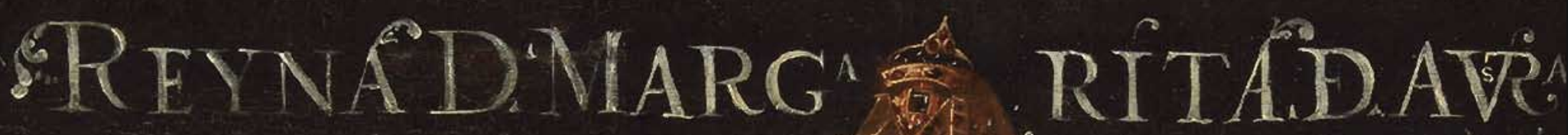
2.:.

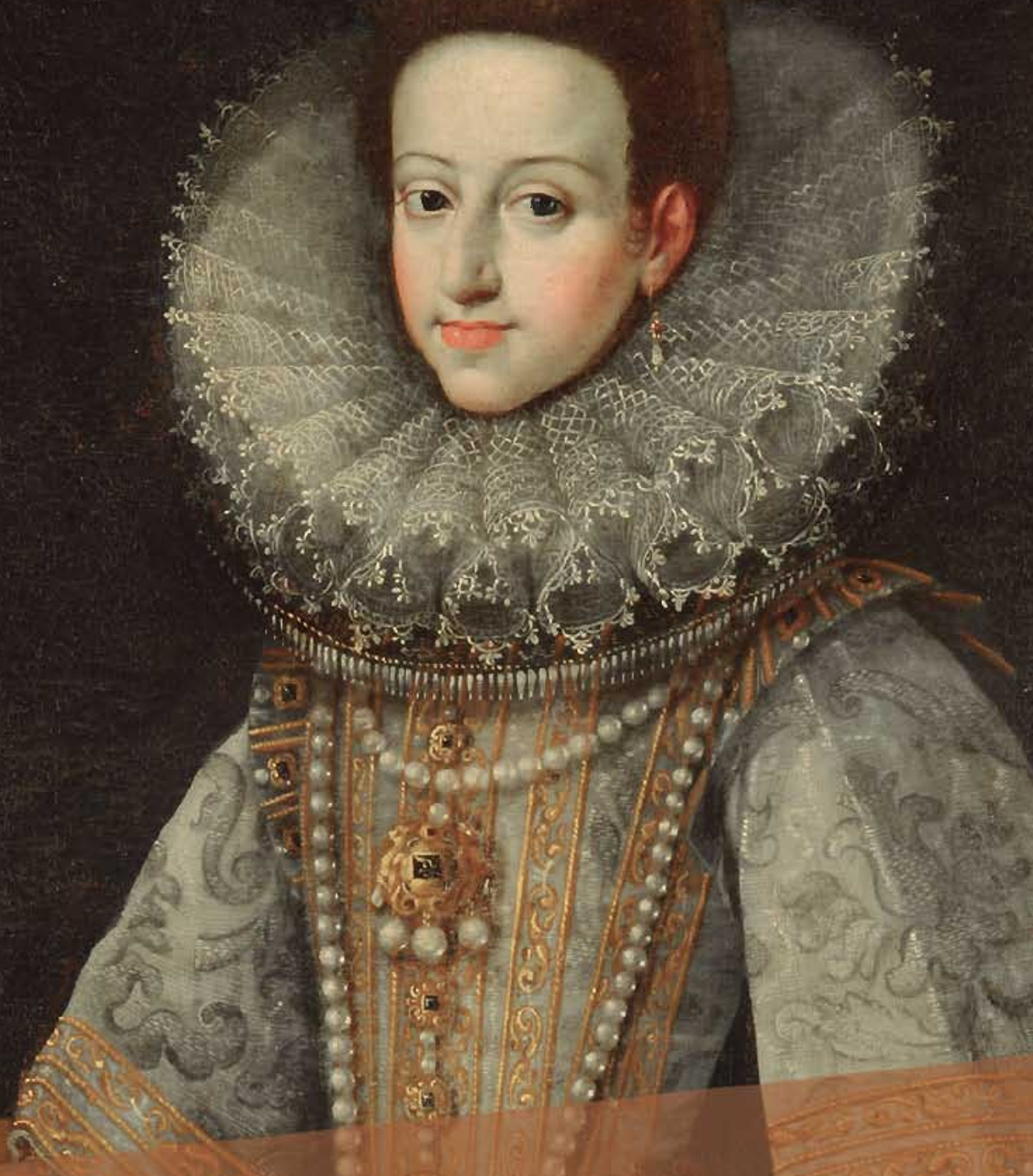

GALERIAS, SERIES ICÓNICAS Y COLECCIONES DE

\title{
RETRATOS ENVALENCIA
}

Teoría y representación del poder en época moderna.

Tesis Doctoral

Cristina

Igual Castelló

\section{Directora}

Inmaculada

Rodríguez Moya
IIJ UNYESTIAT

JAUME I 


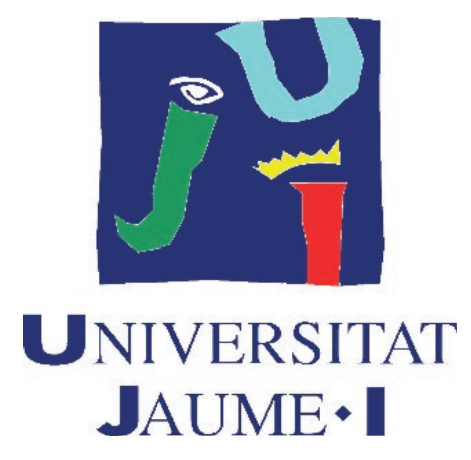

Programa de Doctorado en Historia del Arte

Escuela de Doctorado de la Universitat Jaume I

Galerías, series icónicas y colecciones de retratos en Valencia.

Teoría y representación del poder en época moderna.

Memoria presentada por Cristina Igual Castelló para optar al grado de doctora por la Universitat Jaume I

Doctoranda

Cristina Igual Castelló
Directora

Inmaculada Rodríguez Moya 


\section{Agradecimientos}

La realización de esta tesis doctoral no habría sido posible sin la colaboración de distintos profesionales de archivos, bibliotecas e instituciones académicas. Por ello quiero agradecer la ayuda de Salvador Ferrando Palomares, archivero del Real Colegio Seminario del Corpus Christi; de Ma Carmen Zuriaga, responsable del archivo y de la biblioteca de la Real Academia de Bellas Artes de San Carlos; de David Gimilio Sanz, conservador del Museo de Bellas Artes de Valencia; de David Sánchez Muñoz y de Adrià Besó Ros, técnico y conservador del patrimonio cultural de la Universitat de València respectivamente.

Además, deseo agradecer las consideraciones y observaciones tan oportunas para mejorar el presente trabajo de los profesores Yolanda Gil Saura de la Universitat de València y de Pablo González Tornel de la Universitat Jaume I. Igualmente, se agradecen las recomendaciones de los expertos que evaluaron esta tesis doctoral antes de se depósito definitivo.

También quiero dar las gracias al profesor Víctor Mínguez Cornelles y al equipo de investigación que él mismo encabeza, el Grupo Iconografía e Historia del Arte (IHA) de la Universitat Jaume I, por involucrarme en todas las actividades y darme la oportunidad de aprender como docente e investigadora cada día. 
Especialmente agradecida estoy a la profesora Inmaculada Rodríguez Moya, mi directora de tesis doctoral, pues sus reflexiones me han permitido crecer intelectualmente. Su atenta supervisión no sólo ha tenido lugar en el proceso de realización de esta investigación, sino que asimismo ha sido una magnífica guía para cada comunicación, ponencia o escrito que he realizado en estos años. 


\section{Resumen}

El retrato pictórico y la configuración de series icónicas, galerías y colecciones durante la Edad Moderna es la línea de investigación trabajada en esta tesis doctoral. En concreto, se han seleccionado y analizado nueve conjuntos conservados en Valencia que se pueden clasificar en representaciones regias; como las efigies de la realeza localizadas en el Real Colegio Seminario del Corpus Christi, los monarcas aragoneses hallados en el monasterio de san Miguel de los Reyes y el salón de reyes del palacio de la Generalitat. En imágenes eclesiásticas, estudiadas a través de la serie de prelados de la catedral y las representaciones de frailes y venerables coleccionadas por Juan de Ribera. En retratos de hombres ilustres, categoría observable en la galería de insignes valencianos procedente del monasterio de la Murta, en los efigiados para el paraninfo de la Universitat de València y en el conjunto de retratos de presidentes y directores de la Real Academia de Bellas Artes de San Carlos. Y por último, también se ha considerado oportuno trabajar una galería puntual dedicada a la representación de tipos orientales.

Al tratarse de proyectos artísticos que se desarrollaron con el paso del tiempo en la mayoría de los casos, el marco cronológico de la investigación es amplio. Así pues, el punto de partida se ha establecido a finales del siglo XVI y principios del siglo XVII, cuando nacieron estos grupos de retratos. Por ello, se ha reflexionado acerca de las circunstancias que se dieron para la elaboración de la serie, galería o colección y se han analizado las correspondientes imágenes hasta principios del siglo XIX. La desamortización de 1835 es el otro límite temporal fijado, puesto que fue un momento clave para el devenir de muchos de los conjuntos estudiados. 
De todos ellos, se aprecia que el retrato fue empleado por los órganos de poder desde diferentes ámbitos para crear su propia imagen. Según este enfoque, la metodología empleada combina la Historia de la Cultura con el método iconográfico iconológico. Para conseguir una visión más completa de lo que supuso el retrato y de la función desempeñada en series, galerías y colecciones se le ha otorgado una especial importancia a relacionarlo con otras fuentes escritas contemporáneas. Asimismo, se ha tratado de vincular las imágenes con otras representaciones similares. En suma, se ha podido observar la importancia que tuvieron estos conjuntos en la época y apreciar que formaron parte de un fenómeno mayor, por el cual el retrato seguía manteniendo viva la memoria y la fama de sus efigiados. 


\section{Abstract}

This Ph.D. essay analyses the painted portrait and the establishment of iconic series, galleries and collections of portraits during the Modern Age. Specifically, have been selected nine groups preserved in Valencia. Each of them could be identified in several categories. As royal portraits, we study the paintings located in the library of Real Colegio Seminario del Corpus Christi, some artworks from the monastery of san Miguel de los Reyes and the iconic gallery from the palace of the Generalitat. Also, we analyse ecclesiastical images. For example, the prelate's images from the cathedral of Valencia or the friar's likeness collected by san Juan de Ribera. Other category is the portraits of distinguished figures. In this sense, it is significant to analyse the effigies from the monastery of La Murta, from the assembly hall of Universitat de València and from the Royal Academy of Fine Arts of San Carlos. And finally, being considered opportune to study a particular case about the portrayals of the Turks.

The timeframe for this research is extended because the artistic projects had been increasing over time. This study spans from the end of the sixteenth century and the beginning of the seventeenth century to 1835 , when the confiscation of assets happened.

It is relevant to observe how the powers that be used the portrait to create their own identities. Accordingly, in this thesis two different research methodologies of Art History are applied. On one hand, we used the Culture History and the other the Iconography and Iconology. In addition, it is highly important to know the genre of portraiture and the 
purpose of iconic series, galleries and collections. To achieve this aim the artworks had been related to the contemporaries' written sources. Also the images had been connected with other similar portrayals. As conclusion, this study observes the significance of the artistic projects whereby the portrait kept alive the memory and the fame of the people depicted. 


\section{Índice}

INTRODUCCIÓN.

15

Delimitación del tema.

Estado de la cuestión.

Sobre aspectos generales. 18

Sobre los ejemplos estudiados. 32

Objetivos y estructura.

Metodología.

Capítulo 1. El retrato: Teoría y debate en la Edad MODERNA.

1.1. Los tratadistas y sus cuestiones teóricas en torno al retrato.

1.1.1. Leyendas sobre el nacimiento del retrato.

1.1.2. La efigie y su capacidad de derrotar a la muerte.

1.1.3. El debate entre la imitación y la idealización. 
1.1.4. Imagen dela virtus y ejemplo de decorum.

1.2. Linaje, fama y memoria en la Edad Moderna.

Capítulo 2. Los retratos y sus artífices en el Medio hispano y valenciano. De la reforma católica a la DESAMORTIZACIÓN (1835).

111

2.1. El retrato en el siglo XVI. De las imágenes de donantes al retrato autónomo.

2.1.1. Tiziano Vecellio, Antonio Moro y el retrato de corte.

2.1.2. Los discípulos.

2.2. El retrato en el siglo XVII.

2.2.1. Sociedades urbanas y nuevos tipos de retratos.

2.2.2. Efigies para una Iglesia defensora de la fe católica. Sariñena, Ribalta y Espinosa.

2.3. El retrato en el siglo XVIII y la Academia.

2.3.1. La Real Academia de Bellas Artes de San Carlos.

2.4. El retrato en los inicios de siglo XIX.

2.4.1. La Junta de Iconografía Nacional.

2.4.2. La desamortización de 1835.

Descomposición de algunas galerías de retratos y recopilación de las pinturas. 
3.1. La monarquía en el Colegio Seminario del Corpus Christi.

3.1.1. La galería de retratos.

3.2. Las efigies de monarcas aragoneses en

Nápoles para el monasterio de san Miguel de los Reyes.

3.3. Salón de Reyes en el palacio de la Generalitat de Valencia.

3.3.1. Monarcas de la Corona de Aragón.

3.3.2. Reyes de la dinastía Austria.

3.3.3. Soberanos dela Casa de Borbón.

Capítulo 4. Retratos eclesiásticos.

4.1. Retratos de la cúspide eclesiástica.

La serie icónica de los prelados

valentinos.

4.1.1. El nacimiento dela serie en la segunda mitad del siglo XVI.

4.1.2. El conjunto pictórico en los siglos XVII y XVIII.

4.1.3. Otros episcopologios similares al ejemplo valenciano.

4.1.4. Ideas sobre el arzobispo perfecto en el siglo XVII. 
4.2. Frailes, venerables y beatos del círculo de san Juan de Ribera.

En el camino a la santidad.

4.2.1. Imágenes de la virtud católica.

Las efigies de frailes, venerables y

beatos.

405

CApítulo 5. Retratos de homires IIUSTRES.

5.1. La galería de Varones Ilustres

Valencianos del monasterio de

Nuestra Señora de La Murta (Alzira).

438

5.1.1. Un proyecto para memorar a las

celebridades valencianas.

5.1.2. El devenir de la galería en el siglo XIX.

5.1.3. Ubicación y función de los retratos en su origen y en la actualidad.

5.2. Las efigies del paraninfo de la Universitat de València.

5.2.1. El teatro académico o paraninfo. Una 494 decoración acorde al uso del espacio.

5.2.2. Los retratos del siglo XVII. 495

5.2.3. Los retratos del siglo XVIII. 501

5.2.4. Los retratos del siglo XIX.

524 568

5.3. La colección de retratos en la Real Academia de Bellas Artes de San Carlos. 
5.3.1. Retratos en la sala de juntas a finales del siglo XVIII. De los orígenes al crecimiento de la colección.

5.3.2. Retratos en la sala de juntas tras la desamortización. La llegada de conjuntos foráneos.

643

Capítulo 6. Un caso particular. Retratos de turcos en el Real Colegio Seminario del Corpus Christi. 649

6.1. Crónicas de viajes y catálogos de indumentaria: la fuente visual de los retratos.

6.2. Sultanes, consejeros, guerreros y mercaderes.

6.3. Imágenes de poderosos orientales en la 669 colección artística de san Juan de Ribera.

684

Epílogo. El retrato y SU IMPICACIÓN en LA FiESTA. UNA FUTURA INVESTIGACIÓN.

E.1. Breve recorrido por los festejos celebrados en Valencia durante los siglos XVII y XVIII. 694

E.2. Escritos, imágenes y festejos en el siglo XVIII: Los antecedentes a las celebraciones dedicadas a los infantes gemelos.

E.3. Fiestas por el nacimiento de los nietos gemelos de Carlos III y la paz con Gran Bretaña en 1784. 
E.3.1. Oraciones, poemas y estampas en honor de los infantes gemelos.

E.3.2. Valencia festeja las alegrías de la monarquía en 1784.

Conclusiones.

FUENTES Y BIBLIOGRAFIA.

Fuentes escritas. 757

Bibliografía.

773

LISTADO DE IMÁGENES. 


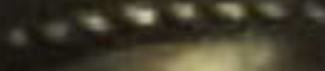

*

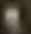

9.

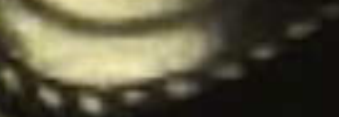

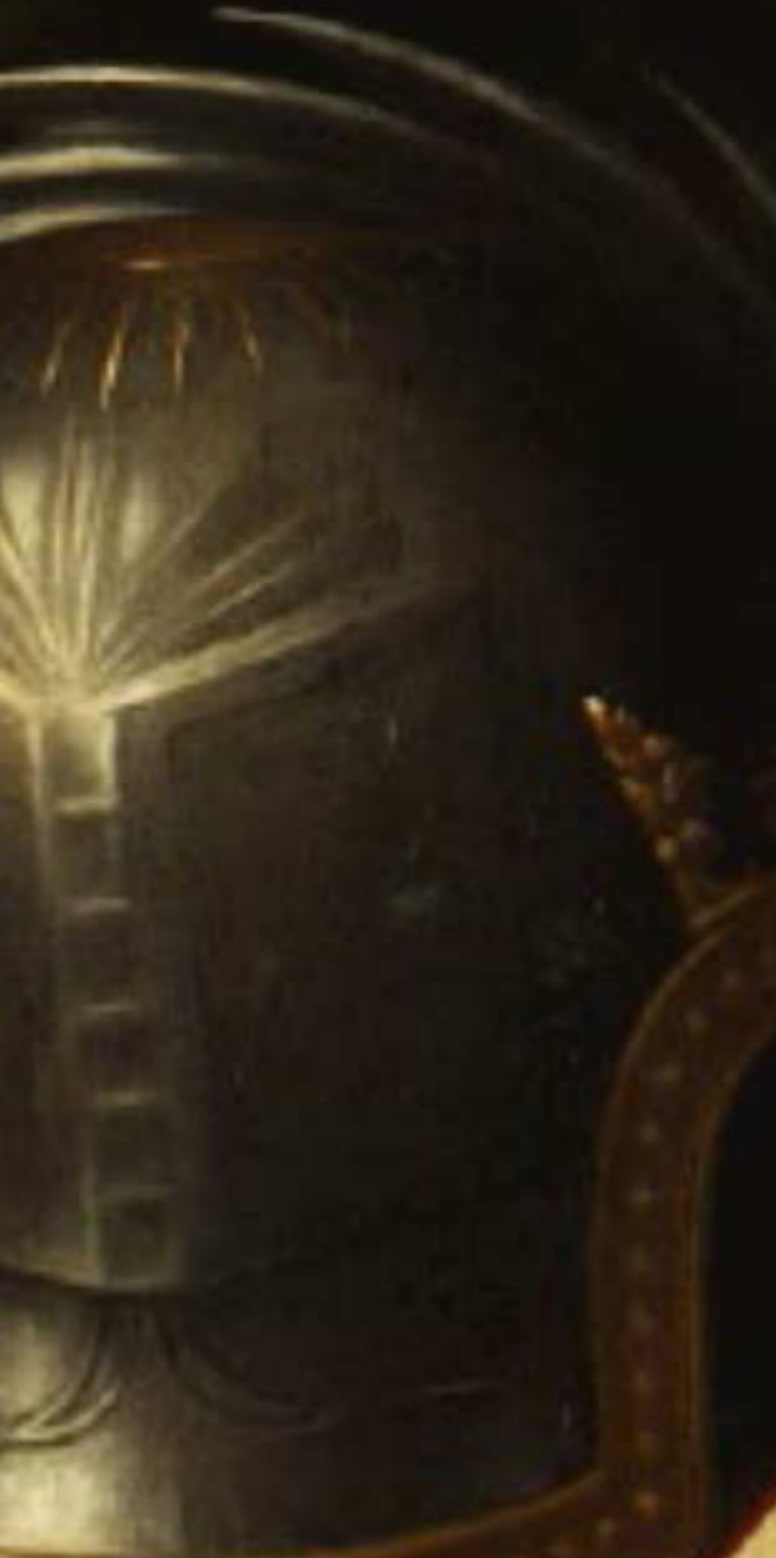

10
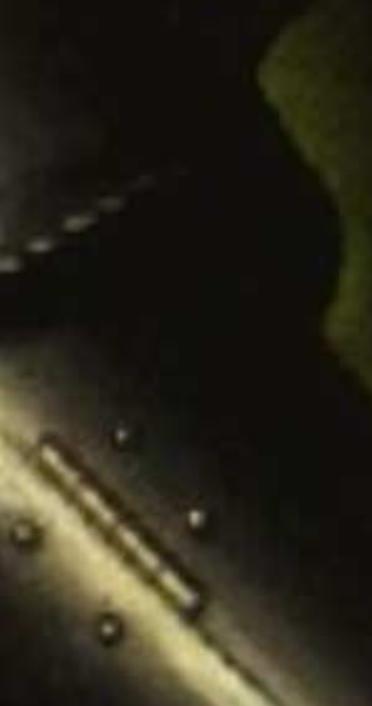

$*$

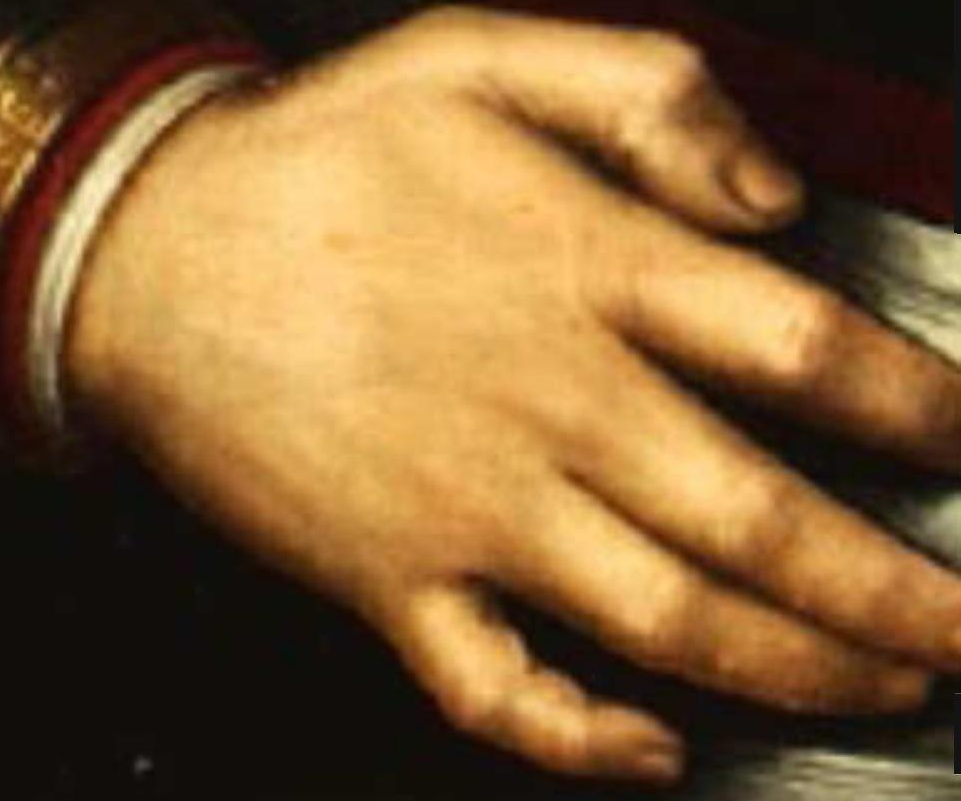

is

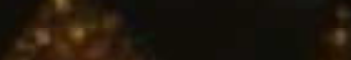

(1.2.

Q.e.

$+2$

$\frac{1}{1}$

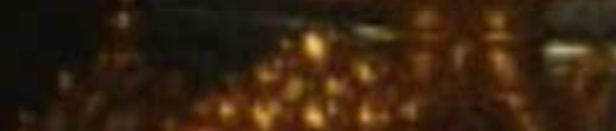

(2) 8

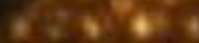
rate

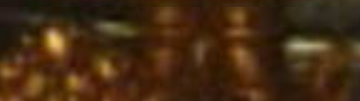

cosentivin

210

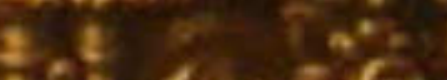

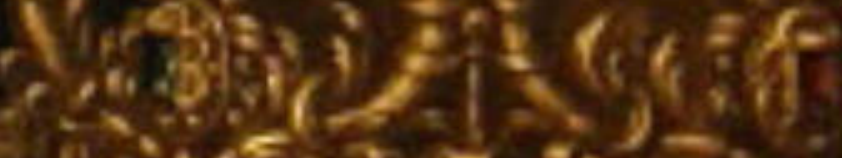

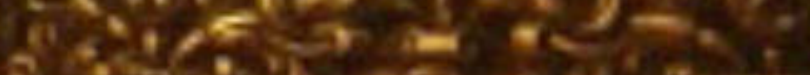
(6)

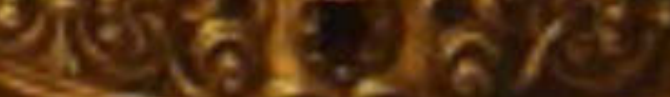

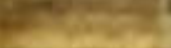
$\left(x+\frac{17}{20}\right.$

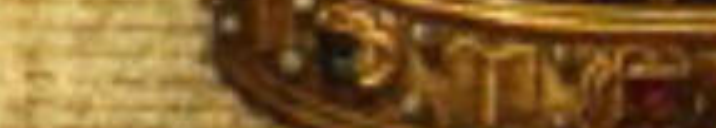

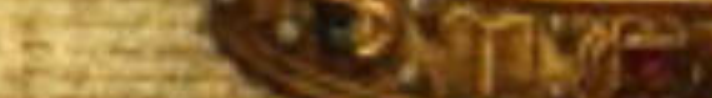

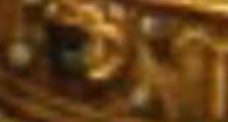
$x^{2}=$

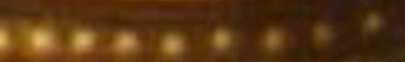

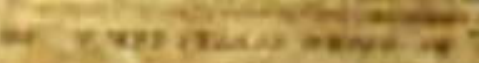




\section{Introducción}

\section{Delimitación del tema.}

Desde su aparición vinculada al contexto funerario en época romana, el retrato es un género artístico que ha ido ampliando sus funciones para satisfacer a una sociedad cada vez más compleja. Por esta razón, en el pasado ya se teorizó acerca de las características y posibilidades que ofrecían los retratos. Efigiarse, desde sus orígenes, estuvo reservado a la clase privilegiada y a las esferas de poder. Permitía mantener la memoria de los fallecidos, era imagen del hombre virtuoso tanto en el plano civil como religioso, visibilizaba la legítima autoridad política y eclesiástica y mostraba la excelencia personificada en cualquiera que fuese su ámbito. El extenso abanico de funciones desempeñadas por esta clase de imágenes se aprecia especialmente en las galerías de retratos y series icónicas. Así pues, en la presente tesis doctoral, centrada en el estudio del retrato pictórico, se ha considerado especialmente necesario poner el foco de atención en varios ejemplos significativos de galerías y conjuntos icónicos conservados en Valencia. De este modo y de manera principal, ha sido posible observar la materialización en numerosas obras artísticas del marco teórico que arropó al género del retrato desde la época moderna.

La investigación ha analizado nueve repertorios que en su mayor parte se pueden denominar galerías. En este estudio concretamente, se ha utilizado dicho término para referir- 
se al conjunto de efigies cuyos retratados tienen numerosos puntos en común y conforman un grupo que expresa una idea determinada. En consecuencia, se encuentran galerías de retratos representando a personas de distinta categoría como monarcas, prelados, varones ilustres o personajes orientales. No obstante, entre todos estos ejemplos, hay tres casos que se pueden considerar, particularmente, series icónicas si se sigue la acepción propuesta por Elías Tormo. ${ }^{1}$ Estas se caracterizan por establecer un orden para la ubicación de cada retrato y por otorgar una mayor importancia a la totalidad de representados que a la individualidad, de este modo se da visibilidad a la verdadera transmisión del poder. Las series icónicas, por tanto, son apropiadas para mostrar en imágenes a la legítima autoridad política y religiosa. Es el caso de los retratos monárquicos del palacio de la Generalitat, de la sucesión de reyes aragoneses al trono de Nápoles procedentes del monasterio de san Miguel de los Reyes y, de las efigies de prelados de la catedral.

Al resto de conjuntos se les puede catalogar de simples galerías de retratos. Cabe recordar que se trata de agrupaciones de imágenes que muestran a personajes con numerosos aspectos en común y en su unidad conforman un discurso determinado. Sin embargo, en ellas no subyace la idea de continuidad y traspaso del poder como sucede en las series icónicas. En este sentido se puede tomar a modo de ejemplo el conjunto de retratos de miembros de la realeza tanto de la Corona de Aragón como a la Casa de Austria que adquirió el patriarca Juan de Ribera. Aquí no se representan exclusivamente a aquellos que accedieron al trono sino que aparecen otras personalidades y por tanto, no se muestra la transmisión de la autoridad regia. Asimismo se pueden incluir dentro de esta denominación aquellos grupos de retratos que efigian a otros personajes relevantes para la sociedad que igualmente fueron vistos

1 Elías Tormo y Monzó, Las viejas series icónicas de los reyes de España, (Junta de Iconografía Nacional, 1917). 
como un modelo a seguir. En esta tesitura se encuentran las representaciones de hombres ilustres como los procedentes del monasterio jerónimo de la Murta o los conservados en el paraninfo de la Universitat de València. Igualmente se encuadra dentro de esta categoría el grupo de representaciones de tipos orientales localizadas en el Real Colegio Seminario del Corpus Christi.

Menos numerosos pero también interesantes son los repertorios de retratos que no fueron concebidos como una unidad desde el inicio aunque comparten unas características concretas. A diferencia de las galerías ex novo, son efigies que se han ido acumulando poco a poco y que podemos relacionar por su significado. Una denominación apropiada a lo largo de este trabajo puede ser colección de retratos, como sucede con las numerosas imágenes de religiosos con posibilidades de alcanzar la santidad que fue aglutinando progresivamente Juan de Ribera, sin una conocida intención de conformar una galería de efigies que implicase mantener reunidas todas las piezas. Otro ejemplo se halla en la recopilación de retratos de presidentes y directores que estuvieron al frente de la Real Academia de Bellas Artes de San Carlos.

Como se ha apuntado previamente, a través del estudio de cada una de las galerías o colección de retratos seleccionada es factible entender la complejidad e importancia que alcanzó este género en tiempos pretéritos. Su relevancia ha pervivido incluso en el presente, prueba de ello es que a en el pasado más reciente y a día de hoy se siguen ampliando algunos de los conjuntos pictóricos aquí analizados. Así pues, al tratarse de un objeto de estudio obligado a crecer en el tiempo no se ha podido establecer un marco cronológico delimitado con claridad y ha sido necesario trabajar en una franja de centurias 
concretas. La investigación arranca de modo general en torno al inicio del siglo XVII puesto que fue palpable el aumento de grupos de retratos en este momento y finaliza en la primera mitad del siglo XIX aproximadamente, cuando la desamortización de 1835 determinó la definitiva ubicación de algunos de los ejemplos trabajados.

\section{Estado de la cuestión.}

Para abordar esta investigación ha sido necesario trabajar con un amplio abanico bibliográfico. No obstante, en el presente apartado tan sólo se ha citado una selección representativa de todas las aportaciones bibliográficas precedentes y que han sido de gran utilidad para conocer el tema tratado. Asimismo, se ha considerado oportuno organizarlo en dos partes. La primera de ellas aborda, esencialmente, cuestiones genéricas acerca del retrato que permitan trazar un contexto cultural para el tema de estudio. Por ello, aquí se ha hecho referencia a las opiniones de los teóricos sobre el género del retrato, se ha hablado del surgimiento del retrato cortesano y de su lenguaje visual. También se ha querido vincularlo con otros conceptos interesantes como la memoria, la fama o el linaje. La segunda parte ya se centra básicamente en los nueve repertorios de retratos que conforman el objeto de estudio de este trabajo, mencionando a los investigadores que han llevado a cabo las principales contribuciones al exhaustivo conocimiento de cada galería, serie o colección analizada.

\section{Sobre aspectos generales.}

La trascendencia de las galerías de efigies y el coleccionismo de retratos en Valencia, principalmente en los tiempos del barroco, es un aspecto que debe seguir estudiándose. La proliferación de estos conjuntos pictóricos en época moderna fue un fenómeno que puso de manifiesto el potencial simbólico 
que guardan los retratos. Entre las diversas funciones que se asociaron a esta clase de imágenes cabe destacar su capacidad para convertirse en la representación del poder. ${ }^{2}$ Si se tiene en cuenta la valoración que ha acompañado al retrato respecto a otros géneros se aprecia que, ya en el Renacimiento, como destacaron Pierre y Galienne Francastel, el retrato gozaba de una menor consideración. Su afirmación se ha sustentado sobre el hecho de no encontrar de forma habitual documentos acreditativos del encargo de efigies, pues normalmente se realizaban a partir de la amistad con el cliente. ${ }^{3}$ Esto también se ha visto en la tradicional jerarquía estipulada por la Academia y la crítica de arte al respecto de las categorías pictóricas. Según esta clasificación eran prioritarios los temas narrativos de índole religiosa, mitológica, histórica o costumbrista sobre los retratos. ${ }^{4}$ No obstante, las obras de naturalezas muer-

2 El análisis del retrato como imagen del poder es un enfoque acertado al que progresivamente se han ido sumando más aportaciones. Véase: Inmaculada Rodríguez Moya y Víctor Mínguez, El retrato del poder, (Universitat Jaume I: Castellón, 2019); Diane H. Bodart, Pouvoirs du portrait sous les Habsbourg d'Espagne, (CTHS: París, 2011); Sociedad Estatal para la Conmemoración de los Centenarios de Felipe II y Carlos V (ed.), El Linaje del emperador: Iglesia de la Preciosa Sangre, Centro de Exposiciones San Jorge, Cáceres: del 24 de octubre de 2000 al 7 de enero de 2001, (2000); Fernando Checa Cremades, 'El retrato del rey: la construcción de una imagen de la majestad en la casa de Austria durante el siglo XVI', en Sociedad Estatal para la Conmemoración de los Centenarios de Felipe II y Carlos V (ed.), Carlos V. Retratos de familia, (Madrid, 2000); Fernando Checa Cremades, Felipe II: mecenas de las artes, (Nerea: Madrid, 1993); Fernando Checa Cremades, Carlos Vy la imagen del héroe en el Renacimiento, (Taurus: Madrid, 1987).

3 Galienne Francastel y Pierre Francastel, El retrato, (Cátedra: Madrid, 1978), pp. 107-188.

4 De hecho, como se puede ver en los estatutos de la Real Academia de Bellas Artes de San Carlos, aquel pintor que desease ingresar en la institución en calidad de académico de mérito debía presentar «un cuadro historiado al menos de dos figuras y un memorial con expresión de su patria.» Archivo de la Real Academia de Bellas Artes de San Carlos: Estatutos de la Real Academia de San Carlos, (Imprenta de don Benito Monfort: Valencia, 1828). Véase el artículo XXIV, dedicado a la recepción de académicos, pp. 65-66. Se trata, por tanto, de un ejemplo de cómo la pintura de historia gozaba de una mejor consideración que el retrato. 
tas y de paisajes aún estaban menos valoradas. La llegada del impresionismo en la segunda mitad del siglo XIX sacudió el pensamiento asentado y las obras de arte comenzaron a apreciarse en función de su valor estético independientemente del género al que perteneciesen. ${ }^{5}$

Con todo ello, los tratadistas del Renacimiento y del Barroco eran conscientes de la relevancia de los retratos. ${ }^{6}$ De lo contrario no habría surgido en ése momento tanta teoría acerca de las posibilidades y de las características inherentes a las efigies. Un estudio de este tema, por tanto, debe partir de las reflexiones vertidas entre los siglos XVI y XVIII por los artistas y teóricos españoles e italianos, puesto que sus ideas se verán reflejadas en las obras pictóricas. Por citar algunos autores clave, conviene tener en cuenta las aportaciones de Francisco de Holanda, Lodovico Dolce, Giovanni Batistta Armenini, Vicente Carducho, Francisco Pacheco, Juan de Butrón, Antonio Palomino y Gregorio Mayans. ${ }^{7}$ Todos ellos han teorizado 20 sobre la función de la pintura y, concretamente, del retrato, han dialogado acerca de la necesidad de imitar o idealizar la naturaleza y han visto en la virtud y el decoro dos elementos fundamentales que debían estar siempre presentes en la rea-

5 Adolfo de Azcárraga, Arte y artistas valencianos, (Ajuntament de València: Valencia, 1999), pp. 191-192.

6 Una obra señera al respecto se encuentra en Édouard Pommier, Théories du portrait. De la Renaissance aux Lumières, (Gallimard: París, 1998) 7 Francisco de Holanda, De la pintura antigua, (Jaime Ratés: Madrid, 1921); Lodovico Dolce, Diálogo de la pintura, titulado Aretino, y otros escritos de arte, (Akal: Madrid, 2010); Giovanni Battista Armenini, De' veri precetti della pittura, (Francesco Tebaldini: Rávena, 1587); Vicente Carducho, Diálogos de la pintura: su defensa, origen, esencia, definición, modos y diferencias, (Francisco Martínez: Madrid, 1633); Francisco Pacheco, Arte de la pintura, (Cátedra: Madrid, 1990); Juan Butrón, Discursos apologéticos en que se defiende la ingenuidad del arte de la pintura; que es liberal de todos los derechos, no inferior a las siete que comúnmente se reciben., (Luís Sánchez: Madrid, 1626); Antonio Palomino de Castro y Velasco, El museo pictórico y escala óptica, (Aguilar: Madrid, 1988); Gregorio Mayans y Siscar, Arte de pintar, (Imprenta de José Rius: Valencia, 1854). 
lización de efigies. La variedad de pareceres existente entre todos ellos también es clara. Algunos vincularon el retrato con la fiel reproducción del semblante humano y para otros, se debía capturar la personalidad del efigiado mediante la utilización de diferentes símbolos. En relación con las opiniones de los diversos tratadistas acerca del grado de semejanza que debía guardar un retrato es necesario tener en cuenta el uso, por parte de algunos historiadores del arte, del término máscara entendido como el rejuvenecimiento de la apariencia representada y plantearse si tiene cabida en las piezas artísticas aquí analizadas. Juan J. Luna consideró que este fenómeno no se dio en el retrato español. Según este autor el artista «buscaba lo justo para complacer o cuando menos, no disgustar en exceso, aunque en muchos casos el espectador actual no tiene claro el grado de verosimilitud de la imagen, puesto que por comparación con otras imágenes y fuentes escritas, se desconoce el grado de lisonja o halago contenido en la figura que tiene ante la vista.» ${ }^{8}$

La virtud y el decoro son dos conceptos esenciales en el estudio de los retratos y por ello, resulta necesario tener presente las consideraciones de los tratadistas citados previamente al respecto. Ser virtuoso era un requisito para retratarse, así el representado se convertía en un modelo a seguir para el resto de la sociedad. A partir del análisis de grupos de retratos pertenecientes a distintos ámbitos, es interesante reflexionar acerca de los diversos modelos de virtud y personajes virtuosos que se convirtieron en un referente para la época. Ser decoroso implicaba representarse fielmente a la categoría social a la que uno mismo pertenecía. Este concepto adquirió una suma importancia cuando ya algunos autores defendían que el retrato no era un género reservado exclusivamente para las altas dignidades, sino que también podía representar a eslabones sociales inferiores siempre y cuando se generase una

8 Juan J. Luna, 'La pintura de retrato en las colecciones del Museo del Prado. De la Edad Media a fines del siglo XIX', en El retrato español en el Museo del Prado, (Museo Nacional del Prado: Madrid, 2015), pp. 9-33. 
imagen honesta al nivel social del retratado. Como se podrá apreciar a lo largo de la investigación, los retratos analizados emplearon múltiples recursos para dejar constancia del papel desempeñado por cada personaje en la sociedad. Los escudos, las condecoraciones, el tipo de indumentaria y las inscripciones fueron los principales medios visuales de los que se sirvieron los artistas para construir la identidad social del efigiado. Una de las razones fundamentales por las que retratarse era mostrar el prestigio social que poseía uno mismo, pues era un género tradicionalmente asociado a personas de estatus elevado. Igualmente, a través de las efigies se presentaban a aquellos personajes paradigmáticos, quienes eran un ejemplo a seguir para la conducta del otro. A lo largo de la investigación se observará que estos anhelos se mantuvieron con el paso del tiempo. Prueba de ello es que la necesidad de crear algunas galerías de retratos surge bajo el deseo de mostrar a hombres célebres del pasado como referentes para la sociedad. También lo es el coleccionar efigies de modélicos religiosos o de acadé22 micos. En cualquier caso, todos ellos son el soporte de la virtud y del decoro. Por tanto, ha sido óptimo el tener en consideración la defensa que hicieron los teóricos del decorum y virtus por ser los dos requisitos indispensables para ser retratados.

Además de todo ello, no se debe perder de vista que la primitiva función del retrato era mantener el recuerdo de los fallecidos y de conseguir hacer de alguna manera presente al ausente. De hecho, habitualmente los estudios acerca de este tema hablan en primer lugar de la potestad que se le confirió al retrato de vencer metafóricamente a la muerte. Así lo hizo, por ejemplo, Diane Bodart, para quien este género podía transportar simbólicamente a la persona representada al lugar y momento presente de quien contempla la imagen. Lo trascendente de los retratos o de las imágenes es la capacidad que han tenido para despertar sentimientos y emociones en el espectador. ${ }^{9}$ Esta potestad que tiene el retrato de dar presen-

9 Bodart, Pouvoirs du portrait.... p. 9.; Otro autor que ha aludido a la función del retrato de mantener la memoria de los efigiados ha sido Felipe 
cia a quien no está físicamente se observa especialmente en el las imágenes regias.

El retrato cortesano, como se verá, dejó su huella en los distintos conjuntos y galerías de efigies monárquicas que por lo general reproducían los modelos creados en la corte. Los trabajos de Falomir, Checa, Ruiz Gómez y Waldmann son un referente para el estudio en este sentido. ${ }^{10}$ Cabe recordar que Carlos V designó a Tiziano como pintor de cámara y el artista fue capaz de concentrar la majestad del emperador en sus retratos ayudándose de una escenografía compuesta por una lujosa estancia y distintos objetos que rebosaban opulencia. También la aportación de Antonio Moro al género del retrato tuvo su impronta en obras posteriores. Otros artistas como Sánchez Coello, Pantoja de la Cruz, Rodrigo de Villandrando y Bartolomé González igualmente condujeron a este género hacia una época dorada en el siglo XVII con Velázquez como máximo exponente. ${ }^{11}$ En consecuencia, adquirieron una gran

Garín Llombart, 'Historia, concepto y prototipo del retrato como género artístico', en Rafael Argullol (ed.), El retrato, (Galaxia Gutenberg: Barcelona, 2004), pp. 9-20.

10 Miguel Falomir Faus, 'El retrato de corte', en Miguel Falomir Faus (ed.), El retrato del Renacimiento, (Museo Nacional del Prado: Madrid, 2008), pp. 109-123; Fernando Checa Cremades, Tiziano y las cortes del Renacimiento, (Marcial Pons Historia: Madrid, 2013); Leticia Ruiz Gómez, 'La creación del retrato español en el siglo XVI', en Leticia Ruiz Gómez (ed.), El retrato español en el Prado. Del Greco a Goya, (Museo Nacional del Prado: Madrid, 2007), pp. 37-43; Susann Waldmann, El artista y su retrato en la España del siglo XVII: una aportación al estudio de la pintura retratista española, (Alianza: Madrid, 2007).

11 Se ha seguido a María Teresa Martín Bourgon, La monarquía española en la pintura: los Austrias, (Carroggio: Barcelona, 2004), pp. 5-9. Esta obra, junto con la publicación de José Luis Sancho, La Monarquía española en la pintura: los Borbones, (Carroggio: Barcelona, 2005), es un buen repertorio de imágenes de la Corona española tanto en el periodo de los Austria como de los Borbón. Sin embargo, la clasificación de los retratos obedece más a 
relevancia las representaciones de cuerpo entero o de tres cuartos, incluyendo fondos neutros y oscuros, en ocasiones sin necesidad de rodearse de demasiados objetos, en los que la majestad recaía completamente en el personaje retratado. Otras veces tan sólo se incluían cortinajes que delimitaban el espacio fingido del real, se jugaba con la inclusión de columnas y ventanales, además de añadir bufetes y coronas. Así se configuró retrato tipo Casa de Austria en palabras de Julián Gállego. ${ }^{12}$ Para el autor, además, los objetos ayudaban a construir el retrato de corte masculino y femenino. En las efigies de los varones suelen aparecer espadas, bastones de mando o guantes. En los retratos de mujeres, es frecuente incluir libros de horas, pañuelos o abanicos. No cabe duda que la imagen del rey estaba escrupulosamente cuidada puesto que su retrato se equiparaba a su propia presencia. Ante la ausencia del monarca, era factible utilizar su efigie en diversas ceremonias. Como se podrá ver en este trabajo, generalmente, las representaciones del soberano tenían un carácter oficial como se observa en 24 las series icónicas y al presidir las juntas celebradas en cualquier institución. De ello se tiene constancia, por ejemplo, a través de los inventarios de bienes de la Real Academia de Bellas Artes de San Carlos de Valencia.

El lenguaje visual de las efigies cortesanas influyó en otros grupos sociales para configurar el suyo propio. Así, se constituían imágenes con un fuerte valor representativo patente al incluir insignias, elementos heráldicos, divisas, alegorías o textos laudatorios. Por esta razón, el análisis de cada una de las pinturas objeto de estudio así como la reflexión acerca del significado de cada conjunto será una tarea a tener en cuenta en esta investigación. De igual modo conviene pensar en la percepción que podía tener el espectador sobre estas obras. Se

aspectos formales que funcionales, organizándolos en aquellos que son de busto, de cuerpo entero, sedentes, ecuestres o alegóricos.

12 Julián Gállego, El pintor, de artesano a artista, (Diputación Provincial de Granada: Granada, 1995). 
trata de un tema que ya ha trabajado Peter Burke en relación a las efigies renacentistas. ${ }^{13} \mathrm{El}$ autor ha remarcado, muy acertadamente, que estas efigies no fueron creadas para nosotros, sino que pertenecen a personas del pasado cuya cultura, forma de pensar y de vivir nos resultan, a la fuerza, extrañas. Dicha circunstancia ha influido en que centrase su investigación en conocer la identidad de los representados, las características del género y en la utilidad otorgada a estas obras de arte.

En ese sentido, las cuestiones que este consolidado historiador se planteó vienen a responder qué clase de personas se retrataban en el siglo XVI y por qué, así como qué significado tenían las pinturas y qué importancia poseían para aquel que las adquiría. La dirección que toma Burke en sus reflexiones es útil e ilustrativa para esta investigación. Tanto las dudas que le asaltan como las respuestas que obtiene encajan con el modo más acertado según nuestra percepción de estudiar el retrato y su papel en galerías y colecciones. Según ha concluido el autor, el perfil de la persona efigiada, siguiendo a los teóricos, eran aquellas consideradas importantes, pues el grueso de la sociedad no era digno de poseer uno de ellos. Sin embargo la realidad era otra, el pueblo común se retrataba ocasionalmente o a menudo, pero son piezas que seguramente han sobrevivido menos que las efigies de los poderosos. En cualquier caso, los retratos vinculados a galerías y colecciones generalmente sí que encajan con el perfil defendido por los tratadistas, pues al formar parte de un todo se busca precisamente el retratar a personalidades relevantes.

Los privilegiados o afamados han sido los principales protagonistas de las galerías y colecciones creadas en el Renacimiento y en el Barroco. Sus retratos han demostrado el progresivo proceso de individualización que había experimentado la imagen del ser humano. Como ha explicado Pope-Henessy, ${ }^{14}$

13 Peter Burke, 'La sociología del retrato', en Rafael Argullol (ed.), El retrato, (Galaxia Gutenberg: Barcelona, 2004), pp. 91-126.

14 John Pope-Hennessy, El retrato en el Renacimiento: conferencias sobre arte, (Akal: Torrejón de Ardoz, 1985). 
la visión antropocéntrica del mundo renacentista, en la cual el hombre es avalado por la fama, la virtud y el éxito, influyó en la difusión de retratos plenamente independientes. Es, por tanto, el triunfo de las imágenes autónomas, desvinculadas de escenas narrativas de índole religiosa, donde el representado ya no aparece presenciando un hecho divino o ejerciendo de donante, sino que es pleno protagonista de sus logros y de su fama. Sebastián de Covarrubias, en el siglo XVII, definió dicho término como «todo aquello que de alguno se divulga, sea bue-no o malo». ${ }^{15}$ De su acepción se puede extraer que la fama se compone de aquello que se dice de nosotros y de la opinión de los demás respecto a nuestra persona. Sin embargo, de cada uno depende en cierta medida la imagen y el parecer que tiene el resto acerca del otro. El éxito o la relevancia profesional es un factor trascendental para construir una reputación deter-minada. Por ello, los retratos de hombres ilustres otorgaron un especial interés a los méritos alcanzados por el efigiado. De este modo, se 26 conseguía que el prestigio y la relevancia social repercutiesen en gozar de una buena fama.

El buen nombre o la notoriedad podían llegar desde la cuna a través de los lazos familiares. En este sentido, cobraron una especial importancia las salas de linajes o las genealogías. De hecho, la Casa de Austria ya se mostró especialmente preocupada por representar su estirpe mediante las imágenes, una inquietud que no era exclusivamente suya pues Alfonso $\mathrm{X}$ el Sabio ya configuró su propia genealogía a través de esculturas. ${ }^{16}$ Las investigaciones de María Kusche son una fuente fundamental para este tema. ${ }^{17}$ La historiadora recreó la gale-

15 Sebastián de Covarrubias, Tesoro de la lengua castellana o española, (Imprenta de Luís Sánchez: Madrid, 1611), p. 583.

16 Víctor Mínguez, 'Elías Tormo iconógrafo', en Luis Arciniega García (ed.), Elías Tormo, apóstol de la historia del arte en España, (Institución Alfonso el Magnánimo: Valencia, 2016), pp. 207-218. 
ría de cuarenta y cinco retratos ubicada en el palacio de El Pardo tras consultar diversos inventarios. Asimismo reflexionó sobre la relación existente entre las piezas, el lugar donde se encontraban y el conjunto de posesiones palaciegas que poseía Felipe II. También realizó una meticulosa descripción de todas las secciones que componían la galería y analizó cada una de las obras.

Asimismo, se debe tener en cuenta la reflexión Juan Miguel Serrera sobre el uso y la función de las salas de linajes o genealógicas en el siglo XVI. ${ }^{18} \mathrm{El}$ sentido de este tipo de conjuntos en concreto se diluía en caso de que se dispersase, por ello la posición de cada una de las piezas no se dejaba al azar y debía guardar un orden determinado para poder así ilustrar la progresiva construcción de la estirpe. El autor también recalcó la actitud de los nobles de recrear galerías de retratos reales en sus hogares, que como se ha visto era muy común. No obstante, en esta práctica se atisba una intención totalmente distinta a los conjuntos dispuestos en las residencias áulicas. La finalidad de la nobleza era engrandecer su casa al disponer de sus propias efigies y de las de los monarcas, que asiduamente habían sido regalos de los propios reyes en agradecimiento de sus servicios. De hecho, Serrera mencionó múltiples casos demostrativos de esta situación. Por ejemplo, Felipe III había ofrecido retratos al almirante de Inglaterra. También el monarca inglés Enrique, probablemente, obsequió con la efigie de su hijo y la suya propia al duque don Martín durante su estancia en Londres. Por ello, en 1581 ambas piezas se registraron en el inventario como bienes de la duquesa de Villahermosa

reconstrucción arquitectónica y el orden de colocación de los cuadros', Archivo español de arte, Vol. 64, no. 253, 1991, pp. 1-28; Maria Kusche Zettelmeyer, 'La antigua galería de retratos del Pardo: su reconstrucción pictórica', Archivo español de arte, Vol. 64, no. 255, 1991, pp. 261-292.

18 Juan Miguel Serrera, 'Alonso Sánchez Coello y la mecánica del retrato de corte.', en Santiago Saavedra (ed.), Alonso Sánchez Coello y el retrato en la corte de Felipe II, (Museo Nacional del Prado: Madrid, 1990), pp. 38-63. 
en Zaragoza. Igualmente, Felipe III agasajó al duque de Uceda con diez retratos de la familia real pintados por Bartolomé González. La reina Margarita de Austria confirió cinco efigies de la realeza a la condesa de Barajas en gratitud de la atención que su familia siempre les había proporcionado a los reyes, príncipes e infantes. Igualmente, Alonso Sánchez Coello pintó quince retratos para Mateo Vázquez, el secretario del rey. ${ }^{19}$

En numerosas ocasiones, los retratos reales se integraban en un conjunto más amplio donde también tenían cabida las imágenes de otros hombres ilustres, como afamados procedentes del ámbito de las letras, militares, cardenales, papas, santos y emperadores. Lucía Varela ha recogido un elevado número de ejemplos al respecto, como la galería que Gonzalo Argote de Molina encargó a Sánchez Coello en 1571, donde se encontraban los retratos de Carlos V, Felipe II, don Juan de Austria y el príncipe don Carlos; otra fue recopilada por Íñigo López de Mendoza e inventariada en 1601 y se hallaron las imágenes de 28 Fernando el Católico, Felipe el Hermoso, Carlos V, Felipe II y Juana de Austria o Jusepe del Castillo, alcalde de grados en la Real Audiencia de Sevilla, quien tenía las efigies de Felipe II, Felipe III e Isabel Clara Eugenia. Otras ya contaban con representaciones de mujeres ilustres entre las que se dispusieron las efigies de damas de la Casa de Austria como sucedió con la galería de Juan García de Oliván, obispo de Urgel, la de Pedro Osorio de Guzmán, segundo hijo del conde de Olivares o la de Manuel Manrique de Lara, duque de Nájera. ${ }^{20}$

El interés de las familias nobiliarias por hacerse con algún re-

19 Serrera, 'Alonso Sánchez Coello y la mecánica del retrato...', pp. 56-58.

20 Lucía Varela, 'El rey fuera de palacio: la repercusión social del retrato regio en el Renacimiento español', en Sociedad Estatal para la Conmemoración de los Centenarios de Felipe II y Carlos V (ed.), El linaje del emperador: Iglesia de la Preciosa Sangre, Centro de Exposiciones San Jorge, Cáceres, del 24 de octubre de 2000 al 7 de enero de 2001, (Madrid, 2000), pp. 99-133. 
pertorio de retratos de la realeza fue un fenómeno que también tuvo su eco en el ámbito valenciano y a ellos, además se le podían añadir imágenes de sus propios parientes y de otras personalidades relevantes. Así configuraban su propia genealogía y linaje en imágenes o simplemente decoraban sus hogares con pinturas de la dinastía reinante, una práctica muy extendida en la época. Pese a que los siguientes ejemplos exceden los límites de la investigación realizada conviene tratarlos brevemente para ilustrar esta situación. Yolanda Gil ${ }^{21}$ ya explicó que la virreina Mencía de Mendoza (1508-1554) mientras vivía en el palacio real por ser la morada de los virreyes engalanó la biblioteca con una amplia colección artística entre la que se encontraban cincuenta y nueve retratos, donde se representaron a sus propios familiares además de nobles y humanistas pertenecientes a su círculo social y a algunos miembros de la Casa de Austria. Juana Hidalgo Ogáyar especificó que la virreina disponía de sesenta y cinco retratos en el conjunto de su colección artística y la ha valorado por ser uno de los primeros ejemplos de galería de retratos en el Renacimiento español, incluso anterior a la del palacio de El Pardo de 1563. Además, se ha visto el antecedente en los conjuntos de efigies de la nobleza flamenca, que Mencía de Mendoza había conocido a raíz de su estancia en los Países Bajos. ${ }^{22} \mathrm{Al}$ pintor Antonio Stella también se le ha atribuido la realización de varios retratos de la familia Vich que, en este caso, no guardaban un sentido unitario.

El virrey Luis Guillermo de Moncada (1614-1672), VII duque de Montalto, quien estuvo en Valencia desde 1652 a 1659, tuvo un gran interés por construir su genealogía a través de numero-

21 Yolanda Gil Saura, 'Les galeries de retrats a la València barroca. La construcció de la memòria', Afers: fulls de recerca i pensament, Vol. 26, no. 70, 2011.

22 Juana Hidalgo Ogáyar, 'Doña Mencía de Mendoza y su residencia en el Palacio del Real en Valencia', Archivo español de arte, Vol. 84, no. 333, 2011, pp. 80-89. 
sas imágenes elaboradas por Giuseppe Faciponti que también decoraron el palacio real. Con anterioridad ya había demostrado su voluntad por crear la memoria familiar a través de obras pictóricas. Por ello, entre sus bienes se registraron los retratos de dos ascendientes suyos que igualmente fueron virreyes en la segunda mitad del siglo XVI, Miguel y Gastón de Moncada. Además se inventariaron varios retratos de su familia, de los miembros de la monarquía y de dos participantes de la revolución napolitana de $1647 .^{23}$

Otro caso importante y recientemente estudiado también por Yolanda $\mathrm{Gil}^{24}$ es el grupo de retratos de la familia Cervellón. Gerardo de Cervellón, VI barón de Oropesa y I conde de Cervellón redactó un memorial en el que se recogían todas las gestas protagonizadas por sus antepasados. Esta obra fue presentada en 1646 al rey. Más tarde, en 1654 recibió el título de conde. En 1658, además, publicó un folleto sobre su genealogía donde se describían cuatro cuadros que, como si de un puzle se tratase, 30 recogían a nueve generaciones de la familia. Se cree que después de esto, el conde encargó la realización de varios retratos de sus antepasados directos y de santos y hombres célebres relacionados con el linaje de esta casa nobiliaria.

La familia de Parcent asimismo contaba con unos cuantos retratos entre sus bienes. En concreto, Constantino Cernesio, según un inventario de 1656 de su casa-palacio, tenía muchísimos de ellos distribuidos en distintas estancias del hogar. Por ejemplo, en la denominada «sala recibidor italiana» había tres efigies de familiares originarios de Italia, en la sala de vestua-

23 Fátima Halcón y Francisco Javier Herrera García, 'Entre Sicilia y España: nuevas aportaciones a la colección artística de Luis Guillermo de Moncada, duque de Montalto (1614-1672), Anuario del Departamento de Historia y Teoría del Arte, no. 28, 2016, pp. 113-139.

24 Yolanda Gil Saura, 'La invención de la genealogía: La galería de retratos de la familia Cervellón', Ars Longa: cuadernos de arte, no. 21, 2012, pp. 277-294. 
rio de la condesa se hallaron cinco más de la familia y en la sala probablemente dedicada a los acontecimientos festivos $\mathrm{y}$ en la destinada a los negocios se dispusieron numerosas representaciones de la Casa de Austria y de personajes de la época como Lope de Vega. ${ }^{25}$ Se trata, por tanto, un ejemplo del tipo de repertorios que solían formar parte de las colecciones nobiliarias en el XVII, eran imágenes de familiares, hombres ilustres y personajes de la dinastía reinante, estos últimos reproducían los retratos cortesanos. En este caso concreto, el poseer dicha clase de pinturas respondía más bien a un signo de respeto y apoyo a la realeza que el hacerse con una genealogía que les facilitase conseguir un título nobiliario, puesto que este ya se les había concedido con anterioridad. ${ }^{26}$

Ma José López Azorín ${ }^{27}$ aportó numerosas referencias documentales acerca de la posesión de retratos de la Casa de Austria entre los bienes de nobles valencianos. Por ejemplo, en 1618 Francisco Gil tenía diecisiete de dichas efigies, en 1637 Francisco Vallebrera había reunido veinticuatro, en 1647 Andrés Monserrat disponía de veintiocho, en 1661 el canónigo Francisco Ferrer de Milán poseía once y en 1669 Ruiz de Lihory, barón de Alcahalí, tan sólo tenía cuatro retratos de la

25 El inventario ha sido trabajado al detalle en: Josep San Ruperto Albert, 'Apuntalarse como noble: cultura, arte y mecenazgo en la Valencia del siglo XVII. Representación y perpetuidad en la familia Cernesio, condes de Parcent', en Amparo Felipo Orts y Carmen Pérez Aparicio (eds.), La nobleza valenciana en la edad moderna: Patrimonio, poder y cultura, (Universitat de València: Valencia, 2014), pp. 237-286.

26 Luis García Martínez, 'La configuración de una colección nobiliaria. El ejemplo de la Casa de Parcent (1656-1927)', Ars bilduma: Revista del Departamento de Historia del Arte y Música de la Universidad del País Vasco, no. 6, 2016, pp. 43-60.

27 Má José López Azorín, Documentos para la historia de la pintura valenciana en el siglo XVII, (Fundación de Apoyo a la Historia del Arte Hispánico: Madrid, 2006). 
mencionada dinastía.

Los casos ya citados sobre la clase de retratos que la nobleza acumuló en sus hogares prácticamente no han llegado a nuestros días. Sin embargo, se puede estudiar una situación similar. San Juan de Ribera compró varias efigies de monarcas y amplió el conjunto encargando la elaboración de otros retratos de la misma temática. No obstante, la galería adquirida por el patriarca a diferencia del resto de ejemplos ha sido analizada en esta investigación principalmente porque en primer lugar se conserva, y por otro lado resulta interesante conectar este conjunto con otra serie icónica y colección de retratos a las que él mismo también estuvo de alguna manera vinculado. Así pues, será necesario reflexionar acerca de la importancia que los retratos tuvieron en la colección artística de este personaje.

\section{Sobre los ejemplos estudiados.}

Las series, galerías o colecciones concretas que se han seleccionado para analizar en este trabajo presentan la particularidad de que, en su mayoría, son proyectos que nacieron y se concluyeron en un dilatado marco cronológico desde finales del siglo XVI hasta la primera mitad del siglo XIX principalmente. Por esta razón y antes de tratar cada conjunto particular, es necesario tener en cuenta los rasgos definitorios de la época que sirvan de contexto al surgimiento y crecimiento de los casos estudiados.

Los antecedentes del retrato moderno, por tanto, se establecen en los retablos góticos y la pintura devocional del siglo XVI, que como ya se ha apuntado previamente, traerá consigo la aparición de los retratos individualizados. Además, a lo largo del gobierno de los Austria pervivió la tradición de vincular la efigie con la pintura religiosa. El retrato era un género subordinado a otro que se entendía como superior pero que permitía señalar la piedad de los representados al mostrarse 
en actitud orante. Incluso surgieron los retratos denominados a lo divino, en los que el efigiado se representó en el papel de un santo, de la Virgen o del niño Dios.

La realidad del siglo XVII dejó su impronta en el arte del retrato, influyendo en el tipo de galerías y colecciones que surgieron, en el perfil de los personajes efigiados y en las funciones atribuidas a las imágenes. Como bien ha explicado Carmen Gracia, durante el periodo barroco y con la reforma católica, el arte apostó con mayor fuerza por representar el sentimiento, la devoción y la moralidad, lo cual influyó en el tipo de retratos a realizar. ${ }^{28}$ Para que esto sucediese, fue necesario que se diesen una serie de circunstancias muy concretas que, siguiendo a Antoni Furió, tienen su origen en la grave crisis económica del siglo XVII. ${ }^{29}$ El periodo de decadencia se acentuó concretamente en Valencia con la expulsión de los moriscos en 1609 , lo cual hizo que el reino perdiese un tercio de su población desencadenando una situación notablemente negativa que desembocó en un clima depresivo. Igualmente, el autor afirmó que dicha exclusión fue tomada con cierta resignación por la monarquía y ello también evidenciaba la debilidad política del rey durante la primera mitad del Seiscientos. Sin embargo, en la medida adoptada contra la población morisca se escondía la intención de posicionar el territorio en la cuestión religiosa y mostrar a sus soberanos como defensores de la fe católica. Al amparo de estas circunstancias específicas nació la serie icónica de prelados de la catedral de Valencia para ofrecer una imagen de estabilidad y continuidad en la Iglesia católica. También, en este mismo periodo, san Juan de Ribera fue recopilando imágenes de frailes y beatos con méritos para ser santificados y sus retratos se emplearon para mostrar a personajes modélicos y ejemplares para el resto de fieles.

El fallecimiento de Carlos II sin descendencia, la guerra por

28 Carmen Gracia, Arte valenciano, (Cátedra: Madrid, 1998).

29 Antoni Furió, Història del País Valencià, (Tres i Quatre: Valencia, 2001). 
la sucesión a la Corona y el triunfo de Felipe d'Anjou, proclamado como Felipe $\mathrm{V}$ de la dinastía Borbón, trajo un cambio de gusto estético que los investigadores no han considerado ni rápido ni homogéneo, pero que se puede observar algunas las galerías trabajadas. Al estudiar proyectos artísticos de dilatada configuración es posible visualizar la evolución estética a través de sus pinturas. El cambio estético se manifestará de forma comedida en las galerías y series, ya que imperaban unas normas de representación características estos conjuntos.

En la implantación del nuevo gusto así como en la producción artística del siglo XVIII tuvo una gran impronta la creación de la Real Academia de Bellas Artes de San Carlos. Esta seguía los pasos de la institución madre ubicada en Madrid que a su vez imitaba el modelo francés y que promulgó la regeneración de la escuela artística. La segunda mitad de siglo se ha catalogado como esplendoroso y prolífico debido, por un lado, a la can34 tidad de pintores que realizaron estancias en Italia. Y por otro, a consecuencia de los artistas que tomaron como referente al neoclasicista Mengs (1728-1779) desde su llegada a Madrid para trabajar al servicio de Carlos III. ${ }^{30}$

Para llevar a cabo esta investigación es fundamental tener conocimientos sobre esta institución por dos razones indispensables. En primer lugar, porque influyó en la implantación de un nuevo estilo artístico. Y seguidamente porque desde el siglo XIX a raíz de las desamortizaciones, la academia manifestó su claro interés por reunir todas las obras de arte posible para su adecuada conservación y protección, garantizando la pervivencia de estos bienes culturales a las generaciones futuras. De ese modo, consiguió concentrar en sus fondos galerías y colecciones, las cuales procedían de otros monasterios valencianos, además de ir configurando sus propios conjuntos.

La historia de la institución y los fondos que la componen ha

30 Luna, 'La pintura de retrato en las colecciones...', p. 25. 
sido recogida en obras de obligada consulta. Salvador Aldana ${ }^{31}$ aportó un estudio general que partía de explicar el origen academias de arte, haciendo referencia a las reuniones que organizaba Platón con sus discípulos en el jardín del barrio ateniense Akademeia. Seguidamente, hablaba de las distintas academias italianas que proliferaron desde el siglo XV siempre matizando qué tipo de enseñanza se impartía en ellas. Ello le dio pie a contextualizar la institución valenciana entre el conglomerado de las homónimas españolas, teniendo presente que la academia madre era la de san Fernando situada en Madrid. Asimismo, habló de los primeros intentos de reglar la formación artística en Valencia. Por ello, aludió a la existencia de un colegio de pintores impulsado por Francisco Ribalta o la academia de pintores localizada en el convento de santo Domingo a mediados del siglo XVII. Sin embargo, ya en el siglo XVIII tuvo lugar el claro precedente de la academia definitiva. Se trata de la aceptada por el rey Fernando VI y dedicada a santa Bárbara, patrona de la reina. Fue un organismo incapaz de sobreponerse a los problemas económicos que le asaltaban desde sus inicios y que acabó desintegrándose después del fallecimiento de los monarcas en 1758 y 1759. Tras ese intento fallido, se consiguió poner en marcha la academia fundada por Carlos III cuyos estatutos finalmente se firmaron en 1766. Por otro lado, el autor elaboró un excepcional trabajo recopilatorio del legado intelectual y artístico que ha aportado la institución. Así pues tuvo en cuenta las fuentes documentales y las numerosas colecciones que configuraban sus fondos.

La contribución de Felipe María Garín ${ }^{32}$ acerca de este tema hablaba sobre el papel pedagógico que ejercía la academia y de su acontecer histórico. Por ello, recogió las modificaciones que

31 Salvador Aldana Fernández, Real Academia de Bellas Artes de San Carlos de Valencia: historia de una institución, (Real Academia de Bellas Artes de San Carlos: Valencia, 2001).

32 Felipe María Garín Ortiz de Taranco, La Academia Valenciana de Bellas Artes: el movimiento academista europeo y su proyección en Valencia, (Real Academia de Bellas Artes de San Carlos: Valencia, 1993). 
se aplicaron a las constituciones y además, la estudió desde dos momentos muy concretos; la segunda mitad del siglo XVIII por ser un periodo de esplendor para la institución y desde la Guerra de la Independencia hasta el liberalismo. También incluyó un interesante apéndice con el listado de sus directores generales, una relación de Juntas Públicas celebradas y las fuentes conservadas en el archivo. En relación a los documentos originales que en la actualidad se custodian en la academia ha resultado de gran eficacia el estudio abordado por Ángela Aldea y Francisco Javier Delicado. ${ }^{33}$ Partiendo de estas aportaciones y teniendo en cuenta los estatutos redactados en el nacimiento de la misma es posible saber las normas que la regían y cómo funcionaba. Asimismo es provechoso para conocer las funciones de los académicos, quienes muchos de ellos fueron retratados.

El siglo XIX fue una época significativa tanto para el retrato como para muchas de las galerías. Durante esta centuria al36 gunas de ellas siguieron creciendo y se crearon otras nuevas que no se enmarcan en los límites de este trabajo, por ejemplo la serie de rectores de la Universitat de València. Asimismo, a raíz del surgimiento de la Junta de Iconografía Nacional se comenzaron a recopilar retratos de ilustres hombres españoles, pues en esta clase de obras artísticas se vio el modo de potenciar los sentimientos nacionalistas. ${ }^{34}$ También hay que tener en cuenta lo que supuso la desamortización para muchos de los conjuntos estudiados. Como han estudiado Javier Delicado y Ester Alba, ${ }^{35}$ a raíz de la expropiación de los bienes artísticos

33 Ángela Aldea Hernández y Francisco Javier Delicado Martínez, El Archivo Histórico de la Real Academia de Bellas Artes de San Carlos y sus fondos documentales, (Diputaciò de València, Area de Cultura: Valencia, 2007).

34 Véase a Inmaculada Rodríguez Moya, 'La Junta de Iconografía Nacional (1876-1961) y el retrato del poder', en Víctor Mínguez (ed.), Las artes y la arquitectura del poder, (Universitat Jaume I: Castellón de la Plana, 2013), pp. 271-296.

35 Francisco Javier Delicado, 'La desamortización eclesiástica de Mendizá- 
a los conventos y monasterios las academias de bellas artes nutrieron sus colecciones para salvaguardar la conservación de las obras.

En cuanto a los ejemplos concretos tratados en esta investigación, han sido un total de nueve y se han clasificado por tipología temática. Así pues, los grupos de efigies se han dividido en retratos regios, en eclesiásticos, de hombres ilustres y aunque conforma un caso excepcional, también se han contemplado a personajes orientales. En estas categorías se pueden encontrar series icónicas, simples galerías o colecciones de retratos en función de la intencionalidad y de las circunstancias que les rodearon. Respecto a las imágenes regias se han analizado tres ejemplos. En primer lugar, necesita un estudio minucioso la galería de miembros de la realeza que se encuentra en la biblioteca del Real Colegio del Seminario del Corpus Christi desde 1615. Este conjunto de efigies ya trabajado por Daniel Benito $^{36}$ tuvo por finalidad remarcar la vinculación familiar de su fundador, san Juan de Ribera, con la monarquía española. Es un ejemplo de cómo a título privado algunas personalidades de la época se hicieron con grupos de retratos para configurar con ellos un discurso genealógico determinado. Respecto a este caso, se echa en falta un análisis de la imagen y su contextualización con otros proyectos artísticos vinculados a san Juan de Ribera. La galería probablemente encargada

bal y las comisiones provinciales de monumentos históricos y artísticos de Valencia, Castellón y Alicante', Archivo de arte valenciano, no. 87, 2006, pp. 81-90; Ester Alba Pagán, 'La génesis del Museo de Bellas Artes de Valencia y la polémica en torno a los bienes desamortizados a través de la prensa valenciana', en Francisco Javier Campos y Fernández de Sevilla (ed.), La desamortización: el expolio del patrimonio artístico y cultural de la Iglesia en España: actas del Simposium 6/9-IX-2007, (Estudios Superiores del Escorial: Madrid, 2007), pp. 723-739.

36 Daniel Benito Goerlich, 'Juan de Ribera y las artes. Sensibilidad, gusto y aliño al servicio de una fe sincera.', El legado del patriarca Juan de Ribera: Pastor Sanctus Virtutis Cultor, IV centenario, (Pentagraf, 2011), p. 221. 
por los monjes jerónimos de san Miguel de los Reyes acerca de los monarcas aragoneses en Nápoles tenía por objetivo honrar la memoria y mostrar el linaje del duque de Calabria, fundador del monasterio. Este conjunto ha sido recientemente estudiado por David Gimilio, ${ }^{37}$ quien ha expuesto sus conclusiones acerca del probable autor de los lienzos. Sin embargo, aún falta elaborar análisis más detallado de las efigies y remarcar el significado del conjunto.

La representación de la transmisión del poder en la monarquía a través del retrato se puede apreciar al estudiar la serie icónica de reyes del palacio de la Generalitat Valenciana. Este caso se ha trabajado tangencialmente en obras que tratan la construcción del complejo arquitectónico, como la aportación de Salvador Aldana. A raíz de ellas conocemos que su ubicación general era el palacio Real de Valencia. ${ }^{38}$ Los investigadores creen que los retratos más antiguos debieron elaborarse en el siglo XVII y algunos de ellos invitan a pensar que fueron realizados por Pablo Pontons y Esteban March. ${ }^{39} \mathrm{~A}$ falta de una contribución más específica sobre estas pinturas, la bibliografía referente a la evolución de la arquitectura nos ha permitido conocer la relación entre las obras y el lugar en el que se ubican. Actualmente los retratos ornamentan una estancia de la primera planta destinada, en origen, a celebrar las reuniones de los diputados. En 1438 y tras una reforma del edificio,

37 David Gimilio Sanz, 'La galería de retratos de la casa real de Aragón en Nápoles', Potestas. Revista del grupo europeo de investigación histórica. Religión, Poder y Monarquía, no. 9, 2016, pp. 167-196.

38 Salvador Aldana Fernández, El Palau de la Generalitat valenciana, (Generalitat Valenciana: Valencia, 1995); Mercedes Gómez-Ferrer Lozano, El Real de Valencia, 1238-1810: historia arquitectónica de un palacio desaparecido, (Institució Alfons el Magnànim: Valencia, 2012).

39 Este es un dato ya aportado por Tormo, Las viejas series icónicas..., pp. 147-153. 
dejó de tener dicha utilidad y pasó a conocerse como sala de la capilla, por el oratorio que se había construido en uno de los extremos. La presencia de las imágenes de los monarcas, desde Jaume I hasta Alfonso XIII, hizo que finalmente este emplazamiento tomase el nombre de Salón de Reyes.

La sucesión de los retratos de reyes simbolizan el traspaso de poder, una idea que también aparece en las dinastías de prelados. Junto con la valenciana, son muchas otras las diócesis que han ilustrado la sucesión de obispos y arzobispos. Así pues las existentes en Tarazona, Zaragoza, Jaén o Toledo se pueden relacionar con la serie icónica de la catedral de Valencia. Inmaculada Rodríguez ya ha analizado cuidadosamente el grupo de retratos de la diócesis de Segorbe-Castellón. ${ }^{40}$ La serie castellonense y la valenciana son los dos principales ejemplos existentes en el espacio del Reino de Valencia puesto que la diócesis de Orihuela también posee efigies de sus dirigentes pero se trata de ejemplos aislados sin llegar a conformar una unidad.

La sacristía nueva de la catedral custodia una ambiciosa recopilación de las imágenes de prelados desde el siglo XIII hasta nuestros días. La serie se inicia con la figura de Ferrer de Pallarés (arzobispo entre los años 1240 -1243), ya que fue el primero en tomar el gobierno de la diócesis tras la Reconquista. Las obras pictóricas que inauguran la dinastía datan de finales del siglo XVI y fueron elaboradas por el taller de Juan de Juanes. Sin embargo, con el tiempo otros artistas afamados como Jacinto Espinosa, Gaspar de Lahuerta o Miguel Parra participaron en este proyecto. Del mismo modo que sucede en otros casos, se aprecia la falta de un estudio detallado que profundice en los entresijos de esta empresa artística.

40 Inmaculada Rodríguez Moya, 'Dinastía de prelados. La serie de retratos de obispos de la diócesis de Segorbe', Sociedad Castellonense de Cultura: Castellón, Boletín de la Sociedad Castellonense de Cultura, no. 79, 1, 2003, pp. 253-274. 
No obstante, conviene partir de los datos proporcionados por Elías Olmos y Canalda, Vicente Cárcel Ortí y José Sanchís y Sivera. ${ }^{41}$ Dichos autores han trabajado la principal documentación de archivo conservada al respecto, así como han dado noticias sobre la autoría de las piezas, su cronología y su ubicación, que como se podrá comprobar más tarde, fue cambiando a lo largo del tiempo. Al manejar la bibliografía existente, queda claro que numerosos estudios han empleado las imágenes de los retratos de modo ilustrativo en las biografías de los obispos y arzobispos, ${ }^{42}$ pero no se ha abordado un estudio de la imagen que tenga en cuenta los recursos visuales utilizados por el artista así como su significado y las intenciones subyacentes en la realización de la galería.

Como se ha avanzado en la delimitación del tema, la principal diferencia entre las series icónicas y el resto de conjuntos es que las primeras representan verdaderamente la transmisión 40 del poder. En definitiva, son una cadena cuyos eslabones adquieren su pleno sentido cuando están ubicados en el puesto correspondiente y no falta ninguno. Sin embargo no sucede exactamente lo mismo, por ejemplo, con las galerías de hombres célebres. En estos casos cada retrato no tiene una localización fijada, no se representa la herencia de un mandato, más bien se muestra a un conjunto de personajes que tienen una serie de rasgos comunes. Por ello, se han concebido como un grupo y su significado completo se consigue al entender la

41 Elías Olmos y Canalda, Los prelados valentinos, (Instituto Jerónimo Zurita: Madrid, 1949); Vicente Cárcel Ortí, Historia de la Iglesia en Valencia, (Arzobispado de Valencia: Valencia, 1986) y José Sanchís y Sivera, La catedral de Valencia: guía histórica y artística, (Librerías París - Valencia: Valencia, 1990).

42 Se sigue esta misma fórmula en el artículo dedicado a los 'Obispos y arzobispos de Valencia' en La llum de les imatges: guia de visita: València, del 4 de febrer al 30 de juny de 1999, (Generalitat Valenciana: Valencia, 1999), pp. 406-419. 
galería como una unidad.

Las galerías de varones ilustres se deben de poner en contexto con la tradición italiana de representar a los máximos exponentes de las ciencias, de las letras y de las artes. La ciudad de Valencia, en la actualidad, dispone de dos magníficos casos que merecen ser estudiados. Por un lado encontramos a los insignes hombres valencianos procedentes del monasterio de Santa María de la Murta y por otro, los retratos situados en el Paraninfo o Teatro Académico de la Universitat. En el siglo XVII, Diego de Vich quiso ensalzar a los valencianos más exitosos en los distintos ámbitos del saber. Por ello, Juan Ribalta y su taller fueron los encargados de elaborar estas efigies que seguidamente se donaron al monasterio alcireño de la Murta. Respecto a este tema, algunos autores ya han compartido el fruto de sus investigaciones. Por ejemplo, Ángela Aldea ${ }^{43}$ la ha estudiado teniendo en cuenta la relevancia de la familia Vich y su relación con el conjunto monástico. También ha reconstruido la sucesión de hechos que alteraron el paradero de la galería hasta depositarse en la Academia de Bellas Artes de San Carlos, a dicha institución pertenecen las pinturas en la actualidad. Otros artículos, como los escritos por Luis Arciniega o López-Yarto, Mateo Gómez y Ruiz Hernando, ${ }^{44}$ permiten adquirir una visión más completa del tema. De hecho,

43 Ángela Aldea Hernández, 'La colección pictórica de Varones Ilustres Valencianos pertenecientes al Monasterio Jerónimo de Nuestra Señora de la Murta de Alzira', en Francisco Javier Campos y Fernández de Sevilla (coord.), La Orden de San Jerónimo y sus monasterios: actas del simposium (II), (Madrid, 1999), vol. I, pp. 529-554.

44 Luis Arciniega García, 'Santa María de la Murta (Alzira): Artífices, comitentes y la «Damnatio Memoriae» de D. Diego de Vich', en F. Javier Campos y Fernández de Sevilla (ed.), La Orden de San Jerónimo y sus monasterios: actas del simposium (II), (Madrid, 1999), vol. I, pp. 269-292; Amelia López-Yarto Elizalde, Isabel Mateo Gómez y Juan Antonio Ruiz Hernando, 'El monasterio jerónimo de Santa María de la Murta (Valencia)', Ars Longa: cuadernos de arte, no. 6, 1995, pp. 17-23. 
Arciniega estudió en profundidad la figura de Diego de Vich mientras que el resto de autores aportaron un enfoque general del monasterio jerónimo. Tras la lectura de estos trabajos se conoce el contexto en el cual se conservaron los retratos. Igualmente, algunas de las obras han formado parte de las piezas expuestas en exposiciones temporales de temas muy variados, lo cual ha propiciado disponer de información más precisa de las mismas. ${ }^{45}$ Sin embargo, continúa siendo necesario hacer una revisión de la documentación conservada en el archivo, elaborar una análisis pormenorizado de cada uno de los retratos y reflexionar sobre la relación entre el espacio en que se ubicaba el conjunto y su significado.

Un nuevo ejemplo de retratos de personalidades ilustres se localiza en el paraninfo de la Universitat de València. La sala, también denominada teatro académico, era el lugar idóneo para celebrar representaciones en griego y latín, debates académicos y reuniones del claustro de docentes. Todos es42 tos eventos estaban presididos, desde su origen, por treinta y cuatro efigies alusivas a los fundadores y otros relevantes personajes vinculados a la institución, quienes desarrollaron excepcionales carreras en medicina, artes, filosofía, jurisprudencia o teología. Al trabajar esta serie, se tiene la obligación de actualizar el conocimiento hasta ahora asentado sobre la

45 Por ello, algunas de estas obras aparecen en los catálogos de exposición. Por ejemplo, el retrato de Fernando I, rey de Nápoles, se ha incluido en Centre Cultural la Beneficència (Valencia), La cultura ceñida: las joyas en la pintura valenciana siglos XV a XVIII: Centre Valencià de Cultura Mediterrània La Beneficència, Valencia del 19 de diciembre de 2000 al 5 de febrero de 2001, (Generalitat Valenciana: Valencia, 2000); Las efigies de Juan Plaza, Benito Perera y Pedro Juan Núñez aparecen en Luis Miguel Enciso Recio y José Miguel Sánchez González (ed.), Reino y ciudad: Valencia en su historia, (Fundación Caja Madrid: Madrid, 2007); Y el retrato de Alejandro VI también se ha localizado en Mariano González Baldoví y Vicente Pons Alós (ed.), El hogar de los Borja: Xàtiva: Museu de l'Almodí, Antic Hospital Major, del 16 de diciembre de 2000 al 28 de febrero de 2001, (Generalitat Valenciana: Valencia, 2001). 
misma. De hecho, a excepción de los análisis exhaustivos que han elaborado Daniel Benito y David Sánchez acerca de algunos de los retratos, el resto de referencias bibliográficas se encuentran a día de hoy obsoletas. ${ }^{46}$ Pese a que la documentación de archivo, por el momento, se resiste y no ofrece datos acerca del encargo, pago o elaboración de las pinturas, sí que conviene realizar un estudio completo de cada una de las imágenes, así como poner en valor la importancia de esta galería por ser un ejemplo pionero entre otras universidades del territorio peninsular.

Otra galería a tratar por ser un caso exótico y distinto a los mencionados anteriormente son los retratos de tipos orientales que se encuentran en el Real Colegio Seminario del Corpus Christi de Valencia. En cualquier caso, la importancia de este conjunto radica en dos aspectos. El primero de ellos, es la razón que probablemente llevó a san Juan de Ribera a adquirirla e incluirla como una parte más de su abundante colección pictórica. El motivo principal de ello ya fue expuesto por Fernando Benito, ${ }^{47}$ quien valoraba esta obtención hecha por el patriarca como un síntoma más de la atracción que el mundo oriental había despertado en Occidente. De hecho, el tener efigies de turcos en la época era bastante común y además, resultaba más barato que conseguir efigies de personas concretas, pues en este caso el parecido quedaba relegado a un segundo plano y el pintor tan sólo se limitaba a reproducir los

46 Las últimas referencias sobre el tema son las dos siguientes: Daniel Benito Goerlich y Amparo José Mora Castro, El Paraninfo de la Universitat de València y sus personajes retratados: testimonio de saber, historia y ceremonia, (Universitat de València: Valencia, 2014); Daniel Benito Goerlich (ed.) y David Sánchez Muñoz (coord.), La Universitat de València y su patrimonio cultural, (Universitat de València: Valencia, 2008).

47 Fernando Benito Doménech, 'Una enigmática serie de pinturas de turcos en Valencia', Boletín de la Sociedad Castellonense de Cultura, Vol. 57-2, 1981, pp. 19-29. 
modelos que circularían mediante estampas. ${ }^{48}$ En este sentido, el segundo es conocer la fuente visual de referencia para el diseño de las imágenes.

Por tanto, resulta conveniente conocer las aportaciones de otros estudiosos sobre el interés generado por Oriente. ${ }^{49} \mathrm{En}$ general, persiste la idea de que la sociedad occidental estaba deseosa de conocer, cada vez más, la realidad de los pueblos orientales, simplemente porque habían sido señalados como enemigos. Así que, necesitaban estudiarlos para poder combatirlos. Para ello, nacieron muchas crónicas de viajes que narraban las expediciones llevadas a cabo por aquellas tierras tan lejanas, a la vez que explicaban las costumbres y el estilo de vida de sus gentes. ${ }^{50}$ Asimismo, los habitantes de estos pueblos se incluyeron en los catálogos de indumentaria tradicional que se difundieron por Europa desde el siglo XVI, poniendo de manifiesto la consciencia europea de la diversidad cultural existente a nivel mundial. ${ }^{51}$ Todo ello impulsó la crea-

48 Idea planteada por Varela, 'El rey fuera de palacio...', p. 99.

49 Por ejemplo, José Julio García Arranz, 'Entre el miedo y la oscuridad: tendencias y variantes en la imagen europea del turco durante los siglos $\mathrm{XV}$ y XVI', en Fiestas y mecenazgo en las relaciones culturales del Mediterráneo en la Edad Moderna, (Universidad de Málaga: Málaga, 2012); Fernando Fernández Lanza, 'Los turcos y lo turco a través de los impresos y manuscritos hispanos del siglo XVI. Propaganda y silencio', en Manuel Casado Arboniés (coord.), Escrituras silenciadas en la época de Cervantes, 2006, (Universidad de Alcalá, Servicio de Publicaciones: Alcalá de Henares, 2006), pp. 75-96.

50 Resulta esencial la consulta de Nicolás de Nicolay, Les quatre premiers livres des navigations et pérégrinations orientales, (Lyon, 1567) en sus diferentes ediciones.

51 De entre el amplio repertorio de libros dedicados al traje en época moderna ha sido especialmente importante conocer a Vecellio para analizar esta galería. Véase Cesare Vecellio, Habiti antichi et moderni di tutto il 
ción de retratos sobre sultanes, guerreros y mercaderes originarios de diversos lugares de la geografía oriental. En efecto, para poder revisar e ir más allá en el estudio de esta galería es imprescindible cohesionar las obras de arte con las crónicas y otras fuentes escritas además de los libros de indumentaria.

Si bien todos los conjuntos hasta ahora mencionados fueron concebidos como una unidad, se encuentran otros dos casos totalmente distintos uno del otro en los que no fue así. Se trata de diversos retratos coincidentes en el perfil del representado y en la finalidad de la imagen. Estos se fueron elaborando progresivamente sin la intención de crear una galería propiamente dicha, por esta razón se ha considerado que un término apropiado para denominarlos es el de colección. En consecuencia, por un lado cabe tener en cuenta la colección de efigies de frailes y venerables que recopiló san Juan de Ribera y por otro, los retratos de presidentes y directores que fue acumulando la Real Academia de Bellas Artes de San Carlos.

Respecto al primer ejemplo, es necesario recordar que la reforma católica y el auge de su credo consiguieron que la Iglesia ejerciese una potente influencia sobre los feligreses. De hecho, los creyentes asumieron con rapidez el ejemplo de frailes, beatos y santos como modelos a seguir en la vida espiritual. En este sentido, san Juan de Ribera contribuyó al enaltecimiento de estos hombres como referentes católicos al ir encargando sus retratos para llenar su seminario de las efigies de prototipos católicos elaborados por artistas como Sariñena, Ribalta o Espinosa. Esta clase de retratos ya han sido estudiados por Fernando Benito, Ferrán Olucha y Alfonso Pérez. ${ }^{52}$ En su con-

Mondo, (Venecia, 1598).

52 Fernando Benito Doménech, Los Ribalta y la pintura valenciana de su tiempo: exposición Lonja de Valencia, octubre - noviembre 1987: Museo del Prado, Palacio de Villahermosa, diciembre 1987 - enero 1988, (Diputación Provincial de Valencia: Valencia, 1987); Fernando Benito Doménech, Juan Sariñena (1545-1619): pintor de la Contrarreforma a Valencia: Museo de Bellas Artes de Valencia, del 19 de diciembre de 2007 al 23 de marzo 
junto, aportan análisis pormenorizados de las piezas pero es pertinente relacionarlas entre sí y vincularlas con el referente visual estipulado para cada una de ellas. Asimismo, cabe investigar si el encargo de estas imágenes fue un hecho aislado o por el contrario fue acompañado de la publicación de hagiografías y la compra de reliquias.

El segundo de los ejemplos estudiados, como se ha indicado, se corresponde con las efigies de presidentes y otros académicos de San Carlos. Los primeros procedían del ámbito político poniendo de manifiesto la estrecha relación entre la academia y el gobierno civil. Los segundos eran profesionales en las distintas disciplinas artísticas y se convirtieron en directores. Las aportaciones fundamentales al conocimiento de esta colección han tenido lugar a partir del análisis monográfico de la producción pictórica de algunos artistas, pues varios de los retratos que pintaron forman parte de este conjunto. En efecto cabe destacar las investigaciones, acerca del artista José 46 Vergara, realizadas por Miguel Ángel Català y David Gimilio. ${ }^{53}$ Una reciente mirada sobre esta colección que también debe ser tenida en cuenta ha sido realizada por Ma Victoria Alon-

de 2008, (Generalitat Valenciana, Consellería de Cultura i Esport, 2007). Fernando Benito Doménech y Ferran Olucha Montins, Urbano Fos, pintor (h. 1615-1658): Museu de Belles Arts de Castelló del 13 de marzo al 15 de junio de 2003, (Generalitat Valenciana: Valencia, 2003); Alfonso E. Pérez Sánchez, Jerónimo Jacinto de Espinosa, 1600-1667: the Spanish Institute, Nueva York (USA), del 19 de noviembre de 2002 al 31 de enero de 2003, (Consorci de Museus de la Comunitat Valenciana: Valencia, 2002).

53 Las publicaciones angulares sobre este tema son las siguientes: Miguel Ángel Catalá Gorgues, El pintor y académico José Vergara (Valencia, 17261799), (Generalitat Valenciana: Valencia, 2004); David Gimilio Sanz, José Vergara 1726-1799: Del tardobarroco al clasicismo dieciochesco, (Conselleria de Cultura, Educació i Esport: Valencia, 2005); David Gimilio Sanz, 'José Vergara Gimeno y la retratística valenciana en el siglo XVIII', Ars Longa: cuadernos de arte, no. 12, 2003, pp. 75-82. 
so, ${ }^{54}$ donde se revelan datos importantes sobre la relevancia de este caso.

En consecuencia, estudiar distintos ejemplos de galerías, series icónicas y colecciones de retratos que, a día de hoy, se conservan en Valencia es un tema cuyo interés histórico y artístico se puede tildar de destacable. Asimismo, conviene dirigir una mirada crítica y analítica acerca de esta cuestión, que además ponga en valor la fuerte carga simbólica, propagandística y cultural que entrañaron sus retratos y en definitiva, así contribuir modestamente a mejorar el conocimiento sobre esto.

\section{Objetivos y estructura.}

Los objetivos de la investigación se han marcado a raíz de trabajar en el estado de la cuestión y al mismo tiempo han determinado la estructura del presente estudio. Para abordar el tema propuesto, la primera de las metas ha sido conocer las consideraciones que los tratadistas ya tenían en la época moderna acerca del retrato. A partir de este objetivo genérico además se pueden entender las opiniones respecto a las cuestiones polémicas que afectarían a la obra de arte, como la imitación o la idealización del representado. Asimismo, también se comprenden los conceptos de virtud y decoro que estuvieron ligados estrechamente a los retratos. Seguidamente se ha considerado conveniente relacionar aquello defendido por los tratadistas con las efigies concretas que componen el objeto de estudio para valorar la correspondencia entre el marco teórico y la práctica.

También ha sido un objetivo el vincular los conjuntos de ar-

$54 \mathrm{M}^{\mathrm{a}}$ Victoria Alonso Cabezas, 'Los inicios de la galería de retratos de la Real Academia de Bellas Artes de San Carlos (1753-1840)', Archivo de arte valenciano, no. 99, 2018, pp. 133-144. 
tísticos estudiados con la situación del retrato en el contexto español y valenciano. De este modo, igualmente se conectan las características y funciones de los retratos en España con las prácticas llevadas a cabo en un espacio geográfico más reducido. Al mismo tiempo se demuestra que el retrato extendió sus rasgos particulares por distintos territorios y se conoce el papel que desempeñó para la sociedad.

Igualmente ha supuesto una meta relevante el estudiar nueve conjuntos de retratos distintos y todos ellos conservados en Valencia, haciendo especial hincapié en reflexionar acerca de su significado como grupo y en observar que fueron imagen del poder en diversos ámbitos como la monarquía, la Iglesia o la élite cultural. En concreto se han seleccionado los siguientes: la galería de la realeza conservada en la biblioteca del Real Seminario del Colegio del Corpus Christi; los retratos de los monarcas aragoneses al frente del trono de Nápoles procedente del monasterio de san Miguel de los Reyes; la serie icó48 nica de monarcas existente en el palacio de la Generalitat; la serie icónica de prelados situada en la catedral; la colección de frailes y beatos recopilada por san Juan de Ribera; la galería de valencianos ilustres procedente del monasterios de Nuestra Señora de la Murta; la galería de relevantes personalidades existente en el paraninfo de la Universitat de València; la colección de retratos de directores y presidentes de la Real Academia de Bellas Artes de San Carlos; y por último, la galería de tipos orientales dispuesto en el Colegio del Corpus Christi.

Otro de los propósitos planteados se ha centrado en estudiar las imágenes que componen los repertorios de retratos, relacionándolas con otras efigies similares y conociendo la apariencia más difundida de muchos efigiados. A su vez, será posible apreciar el lenguaje visual empleado según el cariz de los retratados, ubicación, significado y finalidad de la galería o colección de retratos.

Además, otro de los objetivos estipulados se ha centrado en 
entender que el retrato no fue un elemento aislado, sino que se elaboraron en un contexto donde entroncan con los textos de la época y a veces, en el caso de las imágenes religiosas, con reliquias y hagiografías de los propios efigiados. Una vez analizado el objeto de estudio se ha pretendido ofrecer una definición acertada, y en base a los ejemplos seleccionados, de galería de retratos, serie icónica y colección. Así pues, se determinan las características particulares de cada conjunto y las principales diferencias que justifican la utilización de un término u otro en este estudio específico.

El último de los objetivos se ha centrado en comenzar una nueva investigación que permita conocer otro de los usos otorgado al retrato, concretamente su participación en la fiesta durante la época moderna. Para ello, se ha partido de estudiar concretamente las efigies de los infantes gemelos, nietos de Carlos III, conservadas en la Academia de Bellas Artes de San Carlos y encargadas para formar parte de las decoraciones efímeras en los festejos de 1784 en Valencia.

Con esta investigación, además, se ha pretendido contribuir al conocimiento de las numerosas obras pictóricas aquí tratadas y a la apreciación de estos ejemplos artísticos valencianos que forman parte de nuestro patrimonio. Los objetivos estipulados en esta investigación, a su vez, han influido en la estructura empleada para presentar los resultados de la misma. Así pues, el estudio escrito consta de seis capítulos y un epílogo que pretenden reflejar la consecución de las metas expuestas anteriormente. En primer lugar se ha establecido un marco teórico al objeto de estudio para facilitar su comprensión. Por ello, el primer capítulo se ha centrado principalmente en conocer las reflexiones de los teóricos de la Edad Moderna acerca del retrato, de sus características y del tipo de personas que podían representarse. Asimismo se han hecho unas consideraciones previas respecto al nacimiento de este género vinculándolo con su capacidad para imponerse sobre la muerte del recuerdo. Además, se han analizado las cuestiones que 
crearon controversia entre los tratadistas; por ejemplo la preferencia de efigies naturales o idealizadas, o la necesidad de que el retrato fuese un soporte para la virtud y una muestra de decoro.

El segundo capítulo se ha centrado en conocer a grandes rasgos la situación de este género artístico a lo largo del margen temporal delimitado en este trabajo. En este sentido, se ha hablado del retrato en el siglo XVI por ser el momento de formación de gran parte de los recursos visuales empleados en este tipo de obras. Seguidamente se han tratado las particularidades de los retratos en los siglos XVII y XVIII atendiendo a los principales artistas que cultivaron dicho género. Y finalmente se ha tenido en cuenta la valoración de las efigies en el siglo XIX junto con el surgimiento de la Junta Nacional de Iconografía y con la consecución de la desamortización de 1835, dos hechos que tuvieron un gran impacto para el retrato y para muchas de las obras artísticas estudiadas en esta ocasión.

Del tercer al sexto capítulo se ha desarrollado el grueso de la investigación. En este sentido cada uno de ellos se ha dedicado a conocer galerías o colecciones cuyos efigiados pertenecen a un ámbito del poder determinado. Por ejemplo, en el dedicado a la representación de monarcas se ha estudiado la serie icónica conservada en el palacio de la Generalitat y las galerías de retratos, por un lado la existente en Real Colegio Seminario del Corpus Christi y por otro, la procedente del monasterio de san Miguel de los Reyes. En cuanto al capítulo referente a la Iglesia se han trabajado dos conjuntos diferentes pero igual de interesantes por demostrar la adaptabilidad del retrato. El primero de ellos es la serie icónica de prelados que se encuentra en la catedral de Valencia. El segundo es la colección de efigies que reunió el patriarca Ribera acerca de personajes fallecidos con fama de santidad. El quinto capítulo ha incidido en una nueva clase de representados que tuvo un gran éxito desde el renacimiento, los hombres ilustres. Por esta razón se han analizado la galería de célebres varones procedente del 
monasterio de Nuestra Señora de la Murta (Alcira) y la situada en el paraninfo de la niversitat de Valncia. Asimismo se ha estudiado la colección de retratos de académicos de San Carlos que también se convirtió en una recopilación de imágenes de los dirigentes de la institución. El sexto capítulo se ha centrado en el estudio de una galería de retratos bastante particular y diferente al resto de conjuntos trabajados. Se trata de la representación de tipos orientales que despertaron un especial interés en Occidente a raíz del largo conflicto que se tuvo con el imperio otomano.

Por último se ha añadido un epílogo para adentrarse en una nueva línea de investigación complementaria a la seguida en la presente tesis doctoral. Para entender mejor la dimensión del retrato como instrumento de poder conviene analizar su participación en la fiesta. Así pues, en esta ocasión, se ha trabajado un ejemplo muy concreto de la fiesta barroca con la finalidad de dar un primer paso hacia un futuro estudio más ambicioso. Concretamente se ha analizado la relevancia que tuvieron los retratos en las fiestas organizadas por la ciudad de Valencia en 1784 en agradecimiento al nacimiento de los infantes gemelos, hijos del futuro Carlos IV y su esposa Ma Luisa de Parma y con motivo de la firma de paz con Gran Bretaña. No obstante, conocer y estudiar otras celebraciones festivas en los siglos XVII-XVIII que empleasen retratos en las creaciones artísticas efímeras permitirá ser consciente de la capacidad que tuvieron las imágenes para construir un discurso determinado de carácter político o religioso y exponerlo a la sociedad.

A través de los ejemplos trabajados se puede observar que el retrato, efectivamente, se halla en sintonía con la definición hecha por Sebastián de Covarrubias en el siglo XVII. Así pues, dicho término se entendía como «la figura contrahecha de al-guna persona principal y de cuenta, cuya efigie y semejanza, es justo quede por memoria a los siglos venideros. ${ }^{55}$ Por tanto, 
este tipo de obra pictórica capturaba la identidad del retratado mediante la imagen de su apariencia. Su representación, que debía ser reconocible por los demás, era ejemplo de la fama alcanzada. Los retratos analizados en esta investigación son, en definitiva, representaciones de personas exitosas en distintos ámbitos que se han exhibido como modelos a seguir.

\section{Metodología.}

La metodología empleada para desarrollar esta investigación se halla en consonancia con el posicionamiento metodológico del grupo Iconografía e Historia del Arte (IHA) al cual me encuentro vinculada. El estudio de nuestra disciplina se realiza combinando principalmente dos métodos; la historia de la cultura, surgido de la mano de Burkhardt (1818-1897), y el iconográfico-iconológico, con Aby Warburg (1866-1929) a la cabeza. ${ }^{56}$ Se trata de dos metodologías complementarias que principalmente conciben la obra de arte como un documento 52 histórico, reflejo de una realidad cultural determinada. A día de hoy se siguen empleando eficazmente para las investigaciones histórico-artísticas.

Cabe tener en cuenta que el término «cultura» es por definición opuesto al concepto de naturaleza. La cultura, por tanto, es una creación humana de carácter individual o colectivo. Además es el significado que se atribuye a lo que nos rodea. ${ }^{57}$ Las obras de arte, en definitiva, son un producto cultural al cual van adheridas unas determinadas ideas influidas por el pensamiento y la realidad en la que se generó el objeto artís-

Española, Madrid, 1611, p. 11.

56 Víctor Mínguez e Inmaculada Rodríguez Moya, 'La historia cultural de las imágenes. Una propuesta metodológica en la Universitat Jaume I aplicada al arte de la Edad Moderna', Archivo de arte valenciano, no. 93, 2012, pp. 175-194.

57 Justo Serna Alonso y Anacleto Pons, La historia cultural: autores, obras y lugares, (Akal: Tres Cantos, Madrid, 2005), pp. 6-8. 
tico. Así pues, los retratos son imágenes que guardan en su significado unos rasgos culturales concretos que expresan la mentalidad de la sociedad que los produjo. Por tanto, el conocer las opiniones de los teóricos modernos acerca del retrato revela jugosa información sobre su idiosincrasia y ésta tendrá su traslación a la imagen. Las leyendas respecto al origen de las efigies, las funciones que se le han atribuido, los debates acerca de la estricta imitación o idealización de la persona, considerar la virtud y el decoro como elementos clave en el retrato y concebir el retratarse como una práctica reservada para los privilegiados permiten conocer mejor la mentalidad de una sociedad pasada.

En este sentido, la historia cultural escudriña concienzudamente en textos, imágenes y actos. ${ }^{58}$ Por ello, uno de los objetivos del historiador es preguntarse «por qué llegó a existir un determinado texto o imagen. [...]", de lo contrario "sería imprudente asumir que las novelas o los cuadros son siempre desinteresados, que están libres de pasión o de propaganda. Es bien sabido que lo que advertimos o recordamos es aquello que nos interesa personalmente o encaja con lo que ya creemos. ${ }^{59}$ Esta actitud es fundamental para alcanzar a entender el significado de los conjuntos de retratos y asimismo, invita a contextualizar las imágenes y por ejemplo, conectarlas con textos, otros objetos y celebraciones festivas de la época.

Burke afirmó que un rasgo fundamental de la historia cultural era tener interés por construir identidades. Para ello, se basaba en el estudio de documentos de carácter personal, como las cartas, autobiografías, diarios o crónicas de viajes. ${ }^{60}$ El estudio de los retratos, de alguna manera, también puede contribuir

58 Serna Alonso y Pons, La historia cultural..., p. 176.

59 Peter Burke, ¿Qué es la historia cultural?, (Paidós: Barcelona, 2006), p. 36.

60 Burke, ¿Qué es la historia cultural?, p. 112. 
a construir el conocimiento sobre las identidades. A partir del análisis de la elaboración de galerías, series icónicas y otros grupos de retratos se entiende la identidad como un aspecto que puede ser colectivo y que por ejemplo, relaciona a reyes, prelados u hombres célebres diferenciándolos de los demás. Para conocer la identidad de otras culturas fueron fundamentales las crónicas de viajes. De hecho, y como se podrá observar en el capítulo relativo a los retratos de personajes orientales, se convirtieron en una fuente de conocimiento muy utilizada para ya en el siglo XVI tomar conciencia de la diversidad cultural y darle visibilidad mediante las imágenes.

El método iconográfico-iconológico igualmente necesitó conocer el contexto histórico y cultural de la obra para poder desvelar su significado. Por este motivo, la historia cultural y la iconografía-iconología casan perfectamente en su utilización. Rafael García Mahíques definió la iconología como «la disciplina cuyo cometido propio es la interpretación histórica 54 de las imágenes, es decir la comprensión de éstas como algo que se relaciona con situaciones y ambientes históricos en donde tales imágenes cumplieron una función cultural concreta; como documentos que permiten aproximarnos a una Historia cultural.» ${ }^{61}$ En efecto, para hacer una interpretación de las efigies que han sido objeto de estudio conviene profundizar en la definición de retrato en época moderna, teniendo en cuenta la connotación subjetiva que se le impuso, pues era la imagen de aquel que gozaba de fama y merecía ser recordado por las generaciones venideras. Igualmente es necesario familiarizarse con las normas de representación que se emplearon en la elaboración de retratos así como captar el mensaje emitido a través del lenguaje visual utilizado. Además, se debe entender el retrato según la función que desempeñó en las galerías, series icónicas y otras colecciones. Todo ello junto con el análisis de textos contemporáneos al momento de crea-

61 En Rafael García Mahíques, Iconografía e iconología. Cuestiones de método, (Encuentro: Madrid, 2009), p. 16; Véase también Rafael García Mahíques, Iconografía e iconología, (Encuentro: Madrid, 2008). 
ción de las pinturas estudiadas y la realización de otras obras similares, permite conocer el significado de galerías, series y colecciones y alcanzar a comprender el éxito de estos proyectos artísticos en tiempos barrocos.

Para llevar a cabo esta propuesta metodológica, en primer lugar, se ha realizado una labor de vaciado bibliográfico en numerosas bibliotecas para conocer todos los avances elaborados por otros investigadores sobre este tema. Así pues, se ha buceado entre los fondos bibliográficos de universidades como la Universitat Jaume I, la Universitat de València o la Universidad Complutense de Madrid, por ejemplo. También ha sido muy nutritivo realizar búsquedas en bibliotecas provinciales y nacionales, como la Biblioteca Valenciana, la Biblioteca Nacional de España o Biblioteca Nacional de Francia. Asimismo, ha resultado fundamental consultar los fondos bibliográficos de algunos museos de gran importancia para este tema, como el Museo de Bellas Artes de Valencia o el Museo Nacional del Prado.

Seguidamente se seleccionaron los conjuntos artísticos a trabajar teniendo en cuenta su relevancia histórica y artística así como que se conservaran en la actualidad. Para arrojar más información acerca de las galerías, series y colecciones estudiadas han sido de gran provecho los numerosos documentos consultados en el Archivo del Colegio Seminario del Corpus Christi, en el Archivo Municipal de Valencia, en el Archivo del Reino, en el Archivo de la Diputación de Valencia y en el Archivo de la Real Academia de Bellas Artes de San Carlos.

Las principales fuentes documentales consultadas en los fondos del Colegio del Corpus Christi fueron numerosas cajas de gastos generales con la intención de encontrar pagos relativos a retratos, aunque tan sólo se halló una probable referencia a las efigies compradas en Madrid. Muchas más noticias han aportado todos los inventarios de la sacristía y de la colección artística en general que han registrado la existencia y la loca- 
lización original de los retratos aquí estudiados. El trabajo en el Archivo del Reino y en el Archivo de la Diputación de Valencia ha sido interesante para conocer en profundidad la localización original y lo acontecido con la serie icónica de reyes conservada en el palacio de la Generalitat. Estos datos se han hallado en los correspondientes inventarios así como en el expediente de las reformas que tuvieron lugar en la sede de la Generalitat. El Archivo de la Real Academia de Bellas Artes de San Carlos también ha sido fundamental para encontrar datos sobre los conjuntos artísticos trabajados. Así pues, la consulta de todos los inventarios del siglo XVIII y parte del XIX, los libros de acuerdos tanto de juntas generales como particulares y varios legajos han sido trascendentales para recabar el máximo de noticias posibles acerca de las obras pictóricas que conforman el objeto de estudio. En cuanto al Archivo Municipal de Valencia ha sido eficaz trabajar sus fondos por la riqueza documental que conserva y permite, por ejemplo, conocer en detalle las fiestas públicas que se organizaron en la 56 ciudad en 1784 en la cual los retratos formaron parte del aparato artístico y festivo, como se apreciará en el epílogo de esta investigación.

Con todo ello, se realizó un análisis iconográfico-iconológico de los retratos que configuran cada grupo de efigies que permitiese hacer un ejercicio de reflexión para entender el significado del retrato cuando forma parte de un proyecto artístico mayor cargado de un fuerte sentido simbólico y propagandístico. 


\section{Capítulo 1}

\section{El retrato: Teoría y debate en la Edad Moderna.}

Para comprender en su totalidad el concepto, la relevancia y el uso del género del retrato en el pasado es inevitable profundizar en un marco teórico que proporcione las herramientas necesarias para valorar adecuadamente el retrato pictórico y, en concreto, las galerías de efigies. Así pues, el presente capítulo se articula en torno a dos cuestiones fundamentales. La primera de ellas es el análisis de los aspectos conceptuales planteados por los tratadistas del siglo XVI y que establecieron 59 la norma para la elaboración de retratos. La segunda incide en la relación que se puede establecer entre las funciones de estas imágenes y la definición, propia de la época, de algunos conceptos como linaje, fama o memoria que ya indicaban la superioridad de unas personas sobre otras.

\subsection{Los tratadistas y sus cuestiones teóricas en torno al retrato.}

\subsubsection{Leyendas sobre el nacimiento del retrato.}

Juan de Butrón publicó en 1626 una obra que tenía por finalidad probar la liberalidad de la pintura. Sus reflexiones volcadas en Discursos apologéticos ${ }^{1}$ ayudan a entender la idio-

1 Juan Butrón, Discursos apologéticos en que se defiende la ingenuidad del arte de la pintura; que es liberal de todos los derechos, no inferior a las siete que comúnmente se reciben., (Luís Sánchez: Madrid, 1626). 
sincrasia de la sociedad española y conocer la percepción imperante respecto al retrato. De especial relevancia resulta ser la disertación segunda acerca De los inventores de La Pintura, y de sus principios. El autor planteó la diversidad de opiniones que se establecieron en relación a quién descubrió el arte de la pintura. La respuesta a dicha incógnita era una cuestión complicada como ya atisbaron Plinio y Virgilio. Siguiendo las observaciones de Butrón, Plinio atribuyó a Giges, el de Lidia, el descubrimiento de esta disciplina en Egipto. ${ }^{2}$

Sin embargo Aristóteles creyó que fue Pirro, pariente de Dédalo, quien protagonizó dicho hallazgo en Grecia. Plinio rebatió la afirmación de Aristóteles argumentando que los egipcios la conocían seis mil años antes que los griegos. Además, Teostrato opinó que fue Polignoto, el de Atenas, quien pintó por vez primera a «un hombre, con la boca abierta, mostrando los dientes, y el bulto en la persona de diversos perfiles.» ${ }^{3}$ Butrón ha señalado que a pesar de las distintas hipótesis planteadas sobre su inicio, todos los autores estuvieron de acuerdo en qué fue aquello que la pintura representó por primera vez. Por ello, coincidieron «diciendo, que tuvo principio de perfilar en

2 Armenini (1530 - 1609) también hace referencia a Plinio y al origen egipcio de la pintura. «Es común opinión, honorable jóvenes, de los famosos escritores, que la pintura fue descubierta por los egipcios, y que se originó de la sombra de un hombre, por esto dicen que entre los primeros hubo un cierto Filocles Egipcio y un no sé quién Cleante Corintio, y que Ardice y Telefsno se consideran los primeros que la ejercitaron, solamente con líneas y contornos. Hay también quienes creen que ya antes del diluvio se utilizaba, pero según Plinio, fue Giges Lidio de Egipto, del cual dice que, mirando su propia sombra ante un fuego, tomó un carbón y se contorneó a sí mismo.» en Lib. I, Cap. V. Del origen de la pintura y de su división en partes, con una breve definición de cada una. Véase a Giovanni Battista Armenini y Ma Carmen Bernárdez Sanchís (trad.), De los verdaderos preceptos de la pintura, (Visor Libros: Madrid, 1999), pp. 83-85.

3 Butrón, Discursos apologéticos..., fol. 3-4. Carducho también ha mencionado a Giges, Pirro y Polignoto al hablar del origen de la pintura. Consúltese a Vicente Carducho, Diálogos de la pintura: su defensa, origen, esencia, definición, modos y diferencias, (Francisco Martínez: Madrid, 1633), fol. $223 r$. 
la pared, o suelo la sombra de un hombre, como la claridad del Sol, o de una luz lo permitía, pareciéndoles tenía una semejanza con el todo.. ${ }^{4}$ Según dichos autores, la primera manifestación pictórica que se realizó corresponde con el dibujo de una persona, con lo cual se percibe el deseo de crear una imagen del hombre. Las representaciones de la especie humana desencadenaron el nacimiento de una categoría pictórica muy concreta, el retrato.

De la Antigüedad han llegado narraciones acerca de dicho género que fueron empleadas por otros autores para apoyar su defensa de la dignidad de la pintura. También se ha querido ver en el retrato una herramienta idónea para desatar pasiones humanas como el amor. Por ejemplo, Lodovico Dolce (ca. 1510 - 1568) fundamentó la importancia de la pintura en el aprecio que le tenían monarcas, emperadores y varones ilustres. Es más, explicó la capacidad que posee una efigie de enamorar a aquel que contemple la imagen. Así le sucedió a Apeles, quien quedó prendado de Campaspe al retratarla desnuda. Después de ello, Alejandro Magno reservó la tarea de elaborar retratos única y exclusivamente a dicho pintor. ${ }^{5}$

[...] No hay duda de que cualquier arte es más noble según sea más estimado por los hombres de buena fortuna y por los peregrinos intelectos. La pintura fue estimada con sumo valor en todas las edades por reyes, emperadores y hombres prudentísimos. Es, por lo tanto, muy noble. Esto se demuestra fácilmente con los ejemplos

4 Butrón, Discursos apologéticos..., íbidem.

5 Este dato también ha sido empleado por otros autores en sus escritos. Ejemplo de ello es Carducho, quien especificó que: «Pues siendo esto así, y que vemos las esculturas de aquellos tiempos de Apeles hechas por Lisipo, y por Praxíteles (este señalado del Magno Alejandro, para hacer sus retratos en piedra, y aquel en bronce, como Apeles en colores) [...]" Véase a Carducho, Diálogos de la pintura..., fol. 79v. Sobre el retrato de Alejandro Magno además se puede consultar a Giovanni Paolo Lomazzo, Trattato dell'arte della pittura, scoltura et architettura, (Paolo Gottardo Pontio: Milán, 1585), p. 437. 
que se leen en Plinio y en diversos autores, que escriben que Alejandro Magno apreció tanto la maravillosa excelencia de Apeles que le hizo receptor no sólo de joyas y tesoros, sino también de su querida amiga Campaspe simplemente al saber que Apeles, que la había retratado desnuda, se había enamorado de ella. Liberalidad incomparable y mayor que si le hubiese concedido un reino, ya que importa más regalar las afecciones del ánimo que los reinos y las coronas. [...] Después ordenó que a nadie, exceptuando a Apeles, le fuese permitido retratarlo del natural. Y encontraba tanto placer en la pintura que a menudo iba a verle a sus dependencias y pasaba muchas horas hablando familiarmente con él y viéndolo pintar.

Dignidad de la pintura. ${ }^{6}$

No obstante, la historia de Apeles llegó incluso a ser empleada por autores a finales del siglo XIX al reflexionar sobre el retrato. Al respecto, Ángel Avilés pronunciaba una conferencia para el Círculo de las Bellas Artes en 1886. En el inicio de la intervención recurrió a contar una leyenda griega para ilustrar y justificar que el amor había sido la causa del nacimiento del retrato. Según la mitología, Dibutades, hija de un alfarero de Sicione, deseaba conservar la imagen de su prometido Polemón. El soldado debía marchar a la guerra y separarse de su amada. Por ello, la muchacha «trazó su retrato sobre la pared, siguiendo con carbón los contornos que formaba la sombra proyectada por el perfil de su amante al interceptar la luz de una lámpara. El padre de la joven cubrió ese contorno con barro, que puso luego a cocer en el horno, adquiriendo así consistencia la imagen. ${ }^{7} \mathrm{Si}$ bien el relato sugiere que la primera efigie fue escultórica también se recurren a otras historias que sirvieron de explicación para conocer cuál fue el primer retrato pictórico. El autor ha aludido a distintas historietas

6 Lodovico Dolce, Diálogo de la pintura, titulado Aretino, y otros escritos de arte, (Akal: Madrid, 2010), p. 111.

7 Ángel Avilés, El retrato: conferencias pronunciadas en el Círculo de Bellas Artes, (Tipografía de los Huérfanos: Madrid, 1886), p. 20. 
procedentes de la Antigüedad. Por ejemplo, ha empleado una expresión que se solía decir sobre Apeles, considerado como el primer pintor de retratos, para aludir a su capacidad y talento: «Dos Alejandros hay: el uno invencible, hijo de Filipo; y el otro inimitable, hijo de Apeles.»

También contó otra anécdota sobre Apeles según la cual un bufón de Ptolomeo, monarca de Egipto, le invitó a comer con el rey como si fuese de parte de éste. El soberano le recibió con desagrado y le preguntó el nombre del bufón, Apeles al no conocer su identidad, optó por dibujar su retrato en la pared. Después de finalizada la efigie, Ptolomeo no pudo contener la risa y acabó por reconciliarse con el pintor. ${ }^{8}$ Además, Lodovico Dolce incluyó la misma leyenda como parte de su diálogo para reflexionar sobre la nobleza de la pintura.

Hay más, como cuando Apeles fue conducido a un banquete de un rey enemigo suyo por uno que le tenía envidia. El rey, al reconocerlo, con feroz mirada le preguntó cómo había sido tan atrevido como para haber tenido la osadía de venir a su presencia. Apeles, no encontrando a quien allí le había llevado, tomó un carbón en mano y dibujó rápidamente en la pared la cara de su enemigo de forma tan parecida al natural que, diciéndole al rey: "Éste es quien me ha conducido aquí», el rey lo reconoció gracias a esa pequeña mancha hecha por Apeles; y le perdonó inducido sólo por la maravilla de su arte.

De la dignidad de la pintura. ${ }^{9}$

Para continuar justificando que el amor fue el origen del género, Avilés optó por citar al escritor estadounidense Edgar Allan Poe (1809 - 1849) y explicar brevemente su relato El retrato oval, en principio titulado $L a$ vida en la muerte, escrito en 1842:

8 Avilés, El retrato..., pp. 37-39.

9 Dolce, Diálogo de la pintura..., p. 113. 
Un viajero que, sólo y a caballo, llega al anochecer a las puertas de un castillo, pide en él hospitalidad, se la conceden y le acomodan en una hermosa habitación señorial. A pesar de la fatiga no puede conciliar el sueño, y vagando con la vista desde el lecho, donde yace, fijase en un punto del muro que tiene enfrente y donde la luz de su lámpara se concentra y ve, dentro de dorado marco, una cabeza de mujer bellísima, tan llena de expresión y vida, que no parece pintada, parece que alienta, que va a moverse, que va a hablar. Después de contemplarla absorto largo tiempo, busca la explicación de aquel retrato en la guía descriptiva del ya solitario castillo, y lee que su último señor habíase enamorado locamente y se había unido en matrimonio a una joven hermosísima. Dividían su alma dos pasiones: la pasión de aquella mujer y la pasión de la pintura, y para satisfacerlas a un tiempo, convirtió en estudio una cámara alta de su palacio y encerrado allí con su compañera mientras duraba la luz del día, se dedicó con ardor inextinguible, con afán incansable, a pintar el retrato de su amada. Según adelantaba el retrato, iba la joven palideciendo, iba perdiendo fuerzas y vida, hasta que llegó a ser su imagen perfectísima, y un instante después, al dar el enamorado pintor última pincelada, exhaló ella el postrer aliento: la vida, dice Poe, había pasado del modelo al retrato. ${ }^{10}$

De las varias historias que hablan sobre la creación del retrato es posible extraer algunos aspectos en común de especial interés. En cualquier caso, a través de las efigies se reconoce al otro, como se ha visto en la graciosa anécdota del bufón al servicio del rey Ptolomeo. No obstante, siempre se necesitan para suplir la ausencia del ser querido. La separación entre personas estimadas puede ser temporal, como el guerrero griego que marchó a la batalla y debía volver, o puede convertirse, en definitiva, como la amada del señor del castillo que moría un poco más a medida que se la retrataba. Sin lugar a dudas, en el romántico relato de Poe subyace la idea de que las efigies aparecen para vencer sobre la muerte. El siglo XIX recordaba que 10 Avilés, El retrato..., pp. 34-35. 
la primitiva función de las representaciones de los seres amados recaía en mantener vivo su recuerdo tras el fallecimiento. Esta misma idea ya fue defendida por los teóricos de centurias anteriores. Probablemente, debió estar muy interiorizada a lo largo de los siglos e incluso, se podría decir, maquillada por otras funciones que se le han ido atribuyendo al retrato a medida que la sociedad ha evolucionado y se ha convertido en mucho más compleja.

\subsubsection{La efigie y su capacidad de derrotar a la muerte.}

En previas investigaciones de referencia, como la llevada a cabo por Galienne y Pierre Francastel, ${ }^{11}$ se ha puesto de manifiesto que el retrato es producto de sociedades más avanzadas al considerarlo como una representación, ya que los primitivos eran reacios a verse reflejados en las imágenes por estar convencidos de que eran una realidad. Asimismo, han remarcado que el triunfo sobre la muerte haya sido una de las razones cardinales para que el género perdurase en el tiempo. Poniendo el foco de atención en dicho motivo, los autores entienden que este uso para el retrato se pierde con la llegada del cristianismo por ser una doctrina asentada ideológicamente en la separación del cuerpo y del alma, y por tanto no se puede vincular la vida eterna a la pervivencia de lo físico. Además no se aceptaba que la efigie fuese la conexión entre el mundo terrestre y el más allá. ${ }^{12}$

Aunque el argumento es lógico y no está carente de razón, se entiende que la voluntad de vencer a la muerte es en definitiva prolongar metafóricamente la existencia (no física, pero sí en la memoria) del ser humano. Después de fallecer hay una necesidad inherente en nosotros de seguir recordando a los ausentes. Es natural tener miedo ante la posibilidad de no recordar el rostro de un familiar o amigo. En ese sentido el re11 Galienne Francastel y Pierre Francastel, El retrato, (Cátedra: Madrid, 1978).

12 Francastel, El retrato..., pp. 44- 45. 
trato consigue atrapar la imagen de quien se ha ido. La efigie es, por tanto, un instrumento para no olvidar, puesto que desaparecer de la memoria es dejar de existir definitivamente. Felipe Garín ha defendido esta línea de pensamiento, la cual le ha permitido entender qué es el retrato y por qué se ha consolidado como género pictórico. ${ }^{13}$ Para alcanzar esa finalidad es fundamental tener en cuenta las aportaciones de Leon Battista Alberti (1404-1470) sobre la pintura. Así pues, el tratadista atisbó una fuerza divina en la pintura y en el retrato por representar y mantener vivos a aquellos que ya fenecieron:

[...] che in questo loco si debba mostrare, quanto sia degna la pittura, ne la quale ogni opera, e studio consumiamo. Percioche ella ha veramente in se una certa forza molto divina; non solo, perche come dicono de l'amicitia, la pittura ci faccia esser presenti quei, che sono absenti, ma perche anchora rappresenta a i vivi quei, che son morti dopo lunghi secoli; accioche siano consciuti con gran maraviglia de l'artifice, e piacere di quei, che veggono. $[. . .]^{14}$

Para ratificar la opinión de Alberti y corroborar la solidez de su argumento a lo largo del tiempo, conviene tener en cuenta las consideraciones de otros autores posteriores. Por ejemplo, Armenini elogió la virtud que tenía la pintura para hacer visible lo lejano o falto: "y verdaderamente no sabría imaginar mayor milagro que el nacido de las virtudes humanas, al hacer presente lo que está del todo ausente y hacerlo tan cercano a la realidad, que cualquier implacable ojo se satisface.» ${ }^{15}$ Asimismo, se debe hacer un especial hincapié en dos pasajes de

13 Felipe Garín Llombart, 'Historia, concepto y prototipo del retrato como género artístico', en Rafael Argullol (ed.), El retrato, (Galaxia Gutenberg: Barcelona, 2004), pp. 9-20.

14 Leon Battista Alberti y Lodovico Domenichi (trad.), La pittura di Leo Baptista Alberti, (Gabriel Giolito de Ferrari: Venecia, 1547), Libro secondo, p. 18.

15 Fragmento extraído del Capítulo II. Cuáles son las verdaderas pinturas, 
los discursos apologéticos del ya mencionado Juan de Butrón, donde se ha remarcado el tinte conmemorativo que presenta dicho género al ser un recuerdo de las personas ausentes.

Lactancio Firmiano, lib 2, de origine erroris, capit 2. dice, que no por otro respeto inventaron los antiguos y hoy lo usan los modernos, el hacer los retratos, sino para tener presente en la memoria aquellos a quien la muerte, o la ausencia los quitó de su vista. [...] Largamente Pedro Gregorio lib. 12. de su República, cap. 13. Bien lo sintió así Hilasio en el retrato que de Virgilio quedó después de la muerte de este poeta, pues dice, que si la Parca cortó la feliz estambre de su vida, la Pintura la perpetuó con sus retratos contra los rigores de los agudos silos de su tijera. [...] La mayor de las felicidades para todos, es saber cuál fue la persona que no conocimos, y cuál es el rostro que siempre deseamos tener presente. Esto se hace con los retratos que nos refrescan la memoria de nuestros impulsos. [...] estos deseos se remedian con un retrato de lo que se desea, que es el que nos perpetua; y como dice Plinio a pesar, y envidia de los Dioses, y contra la prolijidad de los siglos nos inmortaliza.

Discurso décimo cuarto. ${ }^{16}$

La memoria ha sido un elemento trascendental para el ser humano desde la Antigüedad hasta nuestros días. Así pues las efigies elaboradas en Roma y circunscritas a un ámbito funerario ya pretendían mantener la huella de las personas fallecidas. Las representaciones ornamentaban tumbas o formaban parte de alhajas, todo ello con una función evocadora del efigiado. ${ }^{17}$ Mediante el retrato es factible que el recuerdo perdure y éste puede actuar como bálsamo para el intenso dolor

y cuál debe ser el verdadero pintor, en Armenini y Bernárdez Sanchís, De los verdaderos preceptos..., pp. 69-70.

16 Butrón, Discursos apologéticos..., fol. 91 - 93.

17 Francastel, El retrato..., íbidem. 
padecido tras la pérdida de un ser querido. En consecuencia, los retratos de personas ahora ausentes incrementan su carga emotiva y son ejemplos de cómo las imágenes despiertan numerosos sentimientos. ${ }^{18}$ De hecho, los teóricos han reflexionado sobre la capacidad de la pintura para interferir en el estado de ánimo. Así lo explicó Lodovico Dolce al hablar de su utilidad, placer y ornamentación.

[...] Porque las imágenes no son solamente, como se dice, libros para ignorantes, sino que (como bellísimos recordatorios) despiertan también la devoción de los entendidos, ensalzando en unos y otros la consideración de lo que en la pintura aparece representado. Así, uno lee que Julio César, viendo en España una estatua de Alejandro Magno, y motivado por ella a considerar que Alejandro, con los mismos años que él tenía en este momento, casi había conquistado el mundo, mientras que él aún no había hecho nada digno de gloria, lloró. Y tanto se inflamó en el deseo de la inmortalidad que se dedicó a continuación a las altas empresas por las cuales no sólo se igualó a Alejandro, sino que le superó. También escribió Salustio que Quinto Fabio y Publio Escipión solían decir que, cuando observaban las imágenes de sus mayores, sentían cómo se encendía en ellos la virtud. No es que la cera o el mármol con que estaba hecha la imagen tuviese tanta fuerza, sino que la llama crecía en el ánimo de aquellos egregios hombres por la memoria de sus hechos ilustres, y no se apagaría hasta que ellos, con sus proezas, no hubiesen igualado su gloria.

Cap. Utilidad, placer y ornamentación. ${ }^{19}$

18 Miguel Falomir Faus, 'Imágenes de poder y evocación de la memoria. Usos y funciones del retrato en la corte de Felipe II', en Sociedad Estatal para la Conmemoración de los Centenarios de Felipe II y Carlos V (ed.), Un príncipe del Renacimiento: Felipe II, un monarca y su época. Museo Nacional del Prado, 13 de octubre de 1998 - 10 de enero de 1999, (Madrid, 1998), pp. 203-228.

19 Dolce, Diálogo de la pintura..., p. 119. 
También Butrón se basó en Plinio para probar que los retratos muestran a personajes modélicos y animan al resto a tomarlos como ejemplos a seguir: "Estas maneras de honras, y modo de conservar los hazañosos hechos de sus abuelos usaron otros muchos, según Plinio, de que se prueba el efecto, y la impresión que hace la pintura en los ánimos, pues para ejemplo los pusieron los antiguos imitando los presentes a obras heroicas con la memoria de sus pasados.» ${ }^{20}$ Esta misma idea también fue asumida por Lomazzo [fig. 1.1] quien resaltó la capacidad alentadora y animadora de las imágenes:

[...] Per ilche non ci dee parere giamai alcuna fática troppò grave per apprendere quest'arte, essendo di tanto diletto, e ornamento, facendo espressamente vedere tante diverse fisionomie d'huomini, e di donne, che rauvivando ne dl'animi nostri la memoria delle virtù de gli antecessori grandi, e illustri, ci vengono à servire non solamente per essemplo, mà anco per uno stimolo d'emulare i fatti, e le imprese loro, caminando per

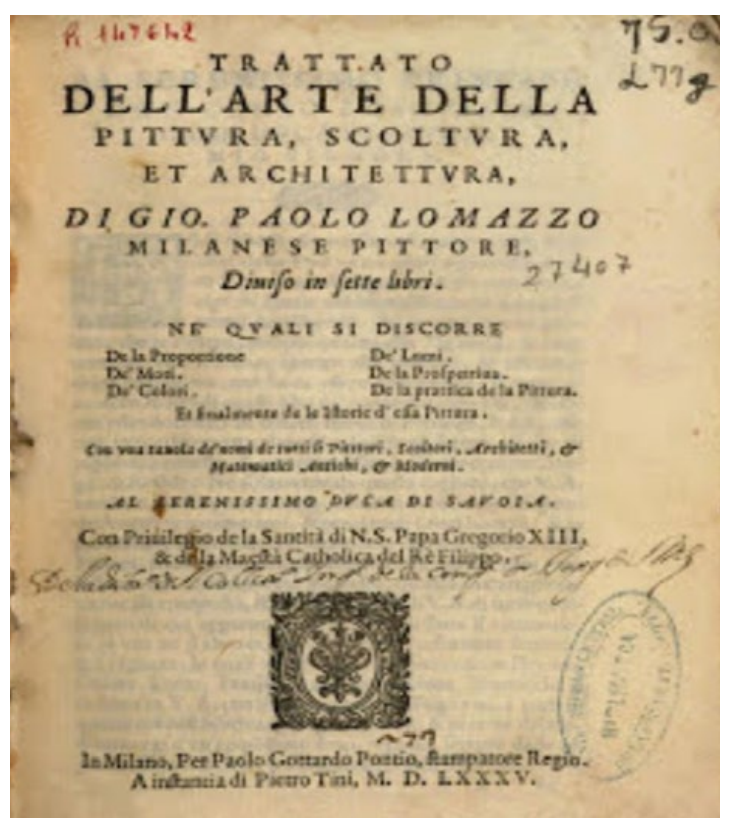

Fig. 1.1. Giovanni Paolo Lomazzo, Trattato dell'arte della pittura, scoltura et architettura, Milán, 1585. i vestigi, ch'egli ci hanno lasiato segnati, e impressi. [... ${ }^{21}$

Asimismo, está presente en los escritos de Armenini al hablar de sus consideraciones acerca de la pintura. En ellas se preocupó por explicar con qué clase de obras se debía decorar cada tipo de arquitectura. Por ejemplo, a determinadas salas de los palacios podían acceder un amplio número de cortesanos 20 Butrón, Discursos apologéticos..., Discurso décimo cuarto, fol. 91.

21 Giovanni Paolo Lomazzo, Trattato dell'arte della pittura, scoltura et architettura, (Paolo Gottardo Pontio: Milán, 1585), p. 435. 
y amistades de la familia real, por tanto, eran espacios muy transitados que necesitaban ser engalanados con pinturas de:

\begin{abstract}
[...] cosas magníficas, de tal manera que representen el valor y las virtudes heroicas de los hombres que han sido merecedores de ellas e ilustres y, dado que más conmueven sus efigies del natural, ya sean antiguas o modernas, que las realizadas de otro modo, será bueno por ello esmerarse en esto más que en cualquier otra cosa. De tal modo que los grandes hombres que las miran ven con estupor en ellas como en pulidos espejos, todas sus maravillosas gestas por las cuales quedarán conmovidos e inducidos a asemejarse a ellos con virtuosas maneras. ${ }^{22}$
\end{abstract}

Como ha indicado el texto, algunas dependencias palaciegas debían albergar pinturas que mostrasen a los hombres que han encarnado el valor y otras virtudes para llevar a cabo acciones honorables. Así pues, y como se tratará posteriormen-

22 Seguidamente, Armenini enumera distintos ejemplos donde las efigies de heroicos personajes han decorado los principales salones áulicos. Por citar algunos de ellos, habla de la efigie natural de Constantino, pintada por Rafael, para mostrar la historia del mencionado emperador en el palacio del pontífice. También en la residencia romana del cardenal Sant'Angelo, Francesco Salviati pintó los retratos al natural de los hombres más destacables de la Casa Farnese con las dignidades que recibieron de la Iglesia y junto con la efigie del pontífice. Igualmente, en dicho lugar, se retrató al emperador Carlos V y al monarca Francisco con otros memorables hombres de su tiempo. Además, menciona casos en los que los palacios seculares han rendido tributo a las hazañas de los antepasados a través de sus retratos. Es el caso de Julio César, quien poseía esculturas de todos aquellos que habían contribuido a la gloria de la república en Roma. También el príncipe Doria, cuenta Armenini, mandó incluir las imágenes de algunos insignes duques de la Casa Doria para engalanar una de las estancias de su palacio situado a las afueras de Génova. Se trataba de representaciones sedentes, de gran tamaño, superando las dimensiones naturales, armados siguiendo la estética clásica y con su correspondiente inscripción que justificaba su labor desempeñada en aras de defender su patria. Véase Armenini y Bernárdez Sanchís, De los verdaderos preceptos..., Capítulo VIII. Que las pinturas de los Palacios deberíanse dar a las personas excelentes. Que las partes de éstos son las salas; cuáles son las pinturas que en ellas conviene hacer, con los ejemplos de los buenos artífices, y de qué modo se hacen, pp. 225-235. 
te, ya se supedita el prestigio de ser representado a ser una persona virtuosa con la finalidad de que el retrato actúe como ideal para el resto de la sociedad.

Juan de Jáuregui (1583 - 1641) escribió en 1618 una de sus rimas para constatar el poder que tienen las imágenes $\mathrm{y}$, concretamente, el retrato para generar emociones en el espectador. El autor proyectó sus consideraciones mediante un diálogo entre la naturaleza, la pintura y la escultura, del cual es conveniente destacar las afirmaciones realizadas por parte de la pintura:

Será ofendiendo mi fama, que en más de un galán y dama, sin conocimiento, o trato, amor encendió su llama, sólo mirando un retrato. ${ }^{23}$

El teórico ha subrayado como una simple efigie ha sido capaz de enamorar tanto a una dama como a un caballero. De este modo, a priori queda patente la supremacía de la pintura para generar sentimientos. La creencia era firme cuando múltiples investigaciones sobre el retrato en el contexto monárquico y cortesano europeo han explicado el papel de las efigies para establecer pactos matrimoniales. Sin embargo, la misma rima ha cuestionado la superioridad de la pintura al referirse a la escultura como la disciplina con mejores dotes para generar afectos.

Es así; mas bien mirado, el que allí la llama enciende no es el retrato pintado; porque el amor sólo atiende al ausente y retratado. Y cuando alguno abrazaba, al simulacro, que amaba,

23 Ramón Fernández, Rimas de Don Juan de Jáuregui, tomo VI, (Imprenta Real: Madrid, 1786), p. 69. 
todo su amoroso afecto

en el mármol se empleaba,

sin pensar en otro objeto.

Diálogo entre la naturaleza y las dos artes, pintura y escultura, de cuya preeminencia se disputa y juzga. Dedicado a los prácticos y teóricos en estas artes. ${ }^{24}$

Las ideas planteadas también subyacen en los memoriales que solicitaban la creación de academias o escuelas de dibujo. Este tipo de documentos ya remarcaban la capacidad del retrato de mantener el recuerdo de los ausentes así como la pintura, en general, podía remitir al pasado. Resulta muy interesante conocer el memorial de autor anónimo fechado en torno al año 1619 dirigido a Felipe III el cual solicitaba la creación de una Academia en Madrid. El mencionado manuscrito fue hallado por Cruzada Villaamil en $1866 .{ }^{25}$ Se trataba de un prototipo de estatutos que en la primera parte del escrito explicaba la importancia de la pintura:

Señor, una de las disciplinas que la ejemplar Antigüedad juzgó en aquellos sus felices siglos, por muy necesaria para la República, fue esta tan hermosa como dificultosa arte de la pintura, por cuyo medio erigiendo estatuas en partes públicas y colocando retratos en partes eminentes, se conservase a pesar del tiempo la memoria de los varones insignes, que hicieran hechos heroicos y famosos, testimonios verdaderos de la virtud y nobleza. ¿Con qué tesoro se paga hacernos presentes las cosas más remotas, pasadas y futuras, emulando tanto la verdad, que en muchos casos sirven de lo mismo que ella? ${ }^{26}$

Las conclusiones de los distintos teóricos e investigadores so-

24 Fernández, Rimas de..., íbidem.

25 Francisco Calvo Serraller, La Teoría de la pintura en el Siglo de Oro, (Cátedra: Madrid, 1981).

26 Serraller, La Teoría de..., p.166. 
bre el origen del retrato y su primera finalidad resulta ser un buen punto de partida para entender la complejidad de dicho género y conocer el amplio significado de los retratos. Como se ha podido comprobar, la especie humana ha tenido la necesidad de construir su propia imagen. Una representación que nace para mantener vivo el recuerdo de los ausentes, que asumió progresivamente más funciones para satisfacer a una sociedad cada vez más compleja y que por ser un género de indudable importancia alimentó diferentes debates entre los teóricos. En efecto, se desató una larga e intensa discusión acerca de si las efigies debían ceñirse a la imitación o podían acercarse a la idealización.

\subsubsection{El debate entre la imitación y la idealización.}

La evolución y el progreso de la sociedad a través del tiempo condicionaron que el retrato adquiriese nuevas razones para existir. Desde el renacimiento, dicho género no sólo fue una consecuencia de esa voluntad humana por vencer a la muerte sino que también fue ligado a las representaciones de la virtud, de la fama o del linaje. Estas nuevas atribuciones produjeron que los teóricos y artistas intercambiasen pareceres acerca de quién, por qué, para qué y de qué modo debían ser retratados. Las opiniones respecto a las teorías del retrato fueron variadas. A grandes rasgos desde el siglo XVI hasta el siglo XVIII, el debate siempre osciló entre la importancia de la estricta imitación de la naturaleza o su idealización. Entre los defensores de la primera opción cabe destacar a Francisco de Holanda (ca. 1517 - 1584), quien tildaba de tarea loable la imitación de la naturaleza.

Hágase como mandades; pues que el tratar de la Pintura es cosa dignísima, y el sacar al natural aquello que sólo Dios hizo por tan investigable sabiduría como Él sabe imitar, quererlo un hombre de tierra imitar, debe de ser cosa muy grande y la mayor que los hombres pueden hacer, a lo menos yo, de no lo saber hacer, por la mayor la 
estimo; otros tenerlo han por menos.

Diálogo I: Cómo pocos pueden hacer perfección. Blas de Perea y Francisco de Holanda. ${ }^{27}$

Giovanni Battista Armenini (1530 - 1609) asimismo entendió que la pintura se correspondía con la imitación de la naturaleza: "Onde per venire alle vera dichiaratione, è da sapere, che la pittura altro no è, che imitiatione, com si vedrà più distesamente, e il pittore, altro ancor egli non è, che imitatore, percioche sempre si rapresenta la forma di quale cosa, ò insensibile, ò sensibile che sia, e que la pittura di ciò manca, non è meritevole, che sia chiamata pittura. [...] ${ }^{28}$ La obra de Lodovico Dolce (ca. 1508/10 - 1568) no alude de forma clara y directa al retrato, pero sus reflexiones sobre la pintura dejan entrever cual fue probablemente su posicionamiento. La definición de pintura establecida por Dolce indica que su función es reproducir la naturaleza.

Digo, pues, que la pintura, en dos palabras, no es otra cosa que la imitación de la naturaleza, y quien en sus obras más se le acerca es el más perfecto maestro. Pero, puesto que esta definición es demasiado breve e incompleta (ya que no distingue al pintor del poeta, porque el poeta se afana también en la imitación), añado que el pintor intenta imitar a través de líneas y de colores (sea en una superficie de madera, en un muro o sobre un lienzo) todo aquello que se muestra al ojo, y el poeta, por medio de las palabras, va imitando no sólo lo que se muestra al ojo, sino también lo que se muestra al intelecto.[...]

Definición de pintura y del oficio del pintor. ${ }^{29}$

27 Francisco de Holanda, De la pintura antigua, (Jaime Ratés: Madrid, 1921), pp. 253-254.

28 Armenini y Bernárdez Sanchís, De los verdaderos preceptos..., pp. 23-24.

29 Dolce, Diálogo de la pintura..., p. 101. 
Sin embargo, dio un paso más y valoró la potestad que tiene la pintura, siempre a través de la copia de la naturaleza, de poder representar pensamientos y sentimientos.

Se puede afirmar que, si bien el pintor no puede pintar las cosas que subyacen al tacto (como sería la frialdad de la nieve) o al gusto (como la dulzura de la miel), no por ello deja de pintar los pensamientos y los afectos del ánimo. [...] Pero los ojos son principalmente las ventanas del alma, y en ellos el pintor puede expresar cualquier pasión de manera oportuna, como las alegrías, el dolor, las iras, los temores, las esperanzas y los deseos. Pero también estas cosas están en función del ojo de los espectadores. [...] Por tanto, el oficio del pintor es representar con su arte cualquier cosa de tal manera similar a las diversas obras de la naturaleza que parezca verdadera. $Y$ el pintor a quien esta semejanza falte no es pintor. Y, por el contrario, tanto mejor y excelente es el pintor cuanto mayormente sus pinturas se asemejan a las cosas naturales $[\ldots]$.

Definición de pintura y del oficio del pintor. ${ }^{30}$

En el periodo barroco, siguiendo la línea de vincular el retrato con la imitación hallamos a Vicente Carducho (ca. 1576-1638), [fig. 1.2] para quien efigiar es un sinónimo de copiar, una acción completamente despojada de logro intelectual. En relación a la imitación del natural, Carducho ha explicado que es producto de la habilidad y que la satisfacción obtenida

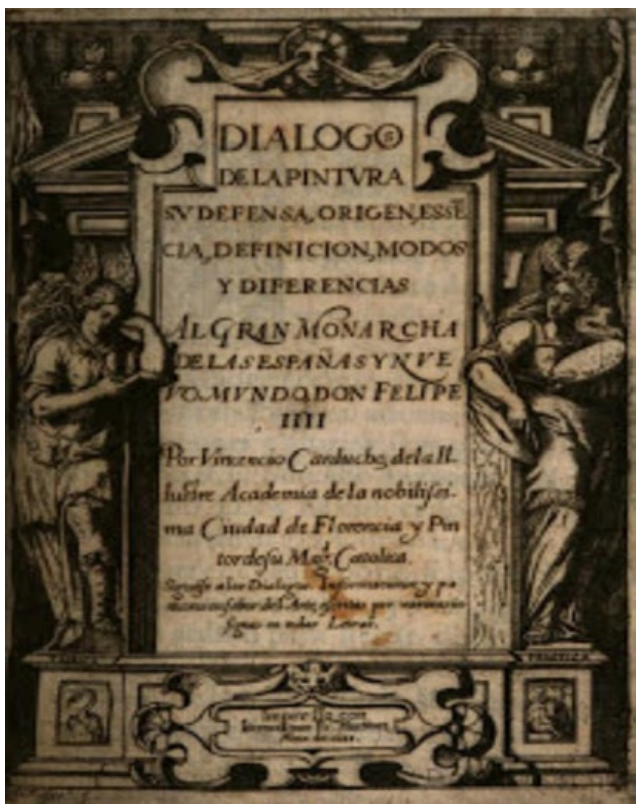

Fig. 1.2. Vicente Carducho, Diálogos de la pintura: su defensa, origen, esencia, definición, modos y diferencias, Madrid, 1633.

30 Dolce, Diálogo de la pintura..., pp. 101-103. 
por el pintor a través de la exclusiva imitación del natural es breve porque procede de la capacidad manual y no responde a una labor intelectual.

[...] Y arte es un hábito operativo, que tiene recta razón de las cosas factibles, bien se verifica y se reconoce esta verdad, que el hacer toca a la parte operativa, que es el arte, y que no es una misma cosa con el saber, que es la ciencia (parte más noble) y si adviertes, el que simplemente imita el natural, no es lo uno ni lo otro, sino un uso cuidadoso de la ciencia, o arte. Y como dice el Lógico, el uso de la ciencia, no es ciencia, y el del arte no es arte: $y$ así siempre este modo de pintar teniendo delante la misma cosa que han de representar, sin más circunstancias, estará sujeto a los sucesos de la fortuna (que pocas veces acierta) y será perecedera la felicidad del que la hubiere alcanzado por este medio; porque como dijo Timoteo Ateniense, la virtud es causa de la felicidad del alma, y no la fortuna.

[...] Antes vuelvo a decir, que en la parte que conviene la imitación de lo natural, te valgas cuanto pudieres, así en la parte propia y real, como en la que participa por accidentes, con que siempre se conocerá en ti el ser científico; que la simple imitación sólo se permite al que retrata, en cuanto a la imitación rigurosa de la forma y color, que para lo perspectivo y prudencial lo habrá de mendigar, y aventurar su opinión. ${ }^{31}$

De igual manera entendía este género Francisco Pacheco (1564 - 1644) [fig. 1.3]. Según él, un pintor tenía la capacidad de perpetuar el recuerdo de la creación divina a través de la imitación de la naturaleza. Un vez más los términos de memoria y retrato van asociados, pues se pretende evitar la completa pérdida del recuerdo, ya que si este desaparece también se diluye la huella dejada tras el paso del ser humano.

31 Carducho, Diálogos de la pintura..., Diálogo cuarto, fol. 48v y fol. 54v. 


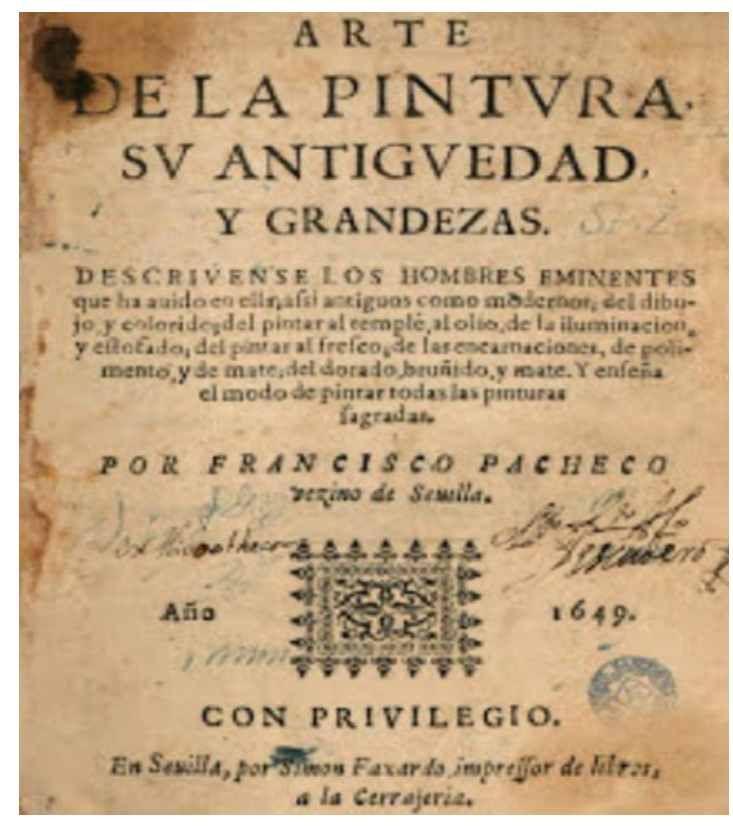

Fig. 1.3. Francisco Pacheco, Arte de la pintura, su antigüedad y grandezas, Sevilla, 1649.

[...] A dos cosas se obliga el que retrata, que, si cumple con ambas, es digno de alabanza: la primera es a que el retrato sea muy parecido a su original, y este es el fin principal para que se hace y con que queda satisfecho el dueño. [...] La segunda obligación es que esté el retrato bien dibujado y pintado con buena manera de colorido, fuerza y relievo. Y esta segunda obligación tiene valor y crédito entre los del arte, porque, sin que sea el dueño conocido, en razón de buena pintura es estimado.

El Arte de la Pintura. Capítulo VIII: De la pintura de animales y aves, pescaderías y bodegones y de la ingeniosa invención de los retratos del natural. ${ }^{32}$

Gregorio Mayans (1699 - 1781), en la misma línea de pensamiento que Carducho o Pacheco, ofreció una sólida apuesta por la reproducción de la naturaleza. La imitación suponía representar la verdad y, por ello, le otorgaba una gran relevancia ya que a través de la misma, la pintura cumplía con su objetivo de figurar los diversos objetos visuales..$^{33} \mathrm{El}$ autor atribuyó al género del retrato una categoría superior a otras

32 Francisco Pacheco, Arte de la pintura, (Cátedra: Madrid, 1990), p. 524.

33 Gregorio Mayans y Siscar, Arte de pintar, (Imprenta de José Rius: Valencia, 1854), Cap. VII, p. 59. 
modalidades cuando en su obra dedicó el capítulo vigésimo primero al modo de efigiar. Conviene hacer hincapié en algunas de sus interesantes afirmaciones que ayudan a entender esta idea. En primer lugar apunta que: «el pintor se hace: el retratista nace: porque de poco servirá el estudio y la práctica de pintar, si no tiene una fantasía conveniente para retratar..134 A su juicio, ésta es una habilidad extraordinaria del artista, y consecuentemente, no todos los pintores tienen la capacidad de efigiar al ser humano. De manera destacada, Mayans a diferencia de otros intelectuales defendió la magnificencia del retrato con abrumadora rotundidad. Sin embargo, conviene preguntarse el por qué no todos los pintores pueden elaborar efigies, la principal razón reside en que el retratista:

[...] se ha de sujetar a la imitación del objeto, malo o bueno de pintar; lo cual no puede hacer sino con mucha violencia, el que no tenga habituado el entendimiento a acomodarse a la vista de ciertas proporciones y formas; y no a las que concibe más perfectas. Los rostros hermosos son más dificultosos de retratar porque tienen más perfecciones; y los defectos de los semblantes son más fáciles de representar que sus perfecciones. El retrato, para que sea verdadero, debe ser bien parecido al original, aunque no esté bien pintado. Faltar a la verdad de objeto no es retratar sino fantasear. Algunos feos, o feas, quieren que los retratistas les hagan recomendables por la hermosura que no tienen. De este achaque suelen padecer los enamorados o vanos; y semejantes retratos suelen valer más por los parecidos a sus originales. ${ }^{35}$

Respecto a esta concepción de Mayans, es necesario analizar su perspectiva personal acerca de la imposibilidad por parte de todos los pintores de ejecutar retratos. Tras reflexionar sobre sus palabras, se puede interpretar que el verdadero motivo no se encuentra en la falta de habilidad para representar

34 Mayans y Siscar, Arte de pintar..., p. 132.

35 Mayans y Siscar, Arte de pintar..., p. 134. 
unos rasgos físicos determinados, lo cual es una competencia puramente formal. Las irregularidades de la fisonomía del representado le caracterizan y le distinguen de otras personas. Los defectos, en definitiva, no son difíciles de plasmar por el artista. La principal diferencia entre que unos pintores puedan retratar y otros no, finalmente, recae en una cuestión de actitud. El artista para elaborar un retrato, según Mayans, debe estar dispuesto a ser fiel a la apariencia del ser humano, dejando constancia justamente tanto de los rasgos bellos como de las imperfecciones. El pintor debe ser honesto ante la imitación del rostro, independientemente de que este se aproxime en mayor o menor medida al canon de belleza. Quizá no todos los pintores podían adoptar esa franqueza ante un encargo por temor de generar cierto descontento entre la clientela, como ya apuntaba Palomino.

En efecto, el minucioso realismo de Mayans se contrapone con la opción escogida por otros escritores sobre combinar la imitación con la mejora del aspecto del efigiado para presentar su imagen más favorecedora. Mayans prefiere el purismo de los rostros, dando acogida a los defectos sin ningún tipo de filtro. Aun así, se hace eco del mismo ejemplo que Palomino, el retrato del rey Antígono de Apeles, para justificar el uso del ingenio artístico con el objetivo de disimular algún defecto sin por ello faltar a la verdad. ${ }^{36}$

En la misma dirección que las reflexiones de Mayans se han encontrado, también, las opiniones ya planteadas por el pintor italiano Antonio Franchi (1638 - 1709) [fig. 1.4]. Según explica el autor, el rostro de una persona se aproxima o se aleja de la idea de belleza. Por tal razón, las caras más bellas son aquellas que se acercan en mayor medida a la idea de belleza o a la perfección estética y consecuentemente se asemejan más entre sí. Sin embargo, los rostros menos bellos se encuentran distanciados de la idea de belleza y en efecto, son muy diferentes unos de otros pues están repletos de defectos y particulari-

36 Mayans y Siscar, Arte de pintar..., pp. 134-135. 
Fig. 1.4. Antonio Franchi Lucchese, La teorica della pittura: ovvero Trattato delle materie piu' necessarie, Lucca, 1739.

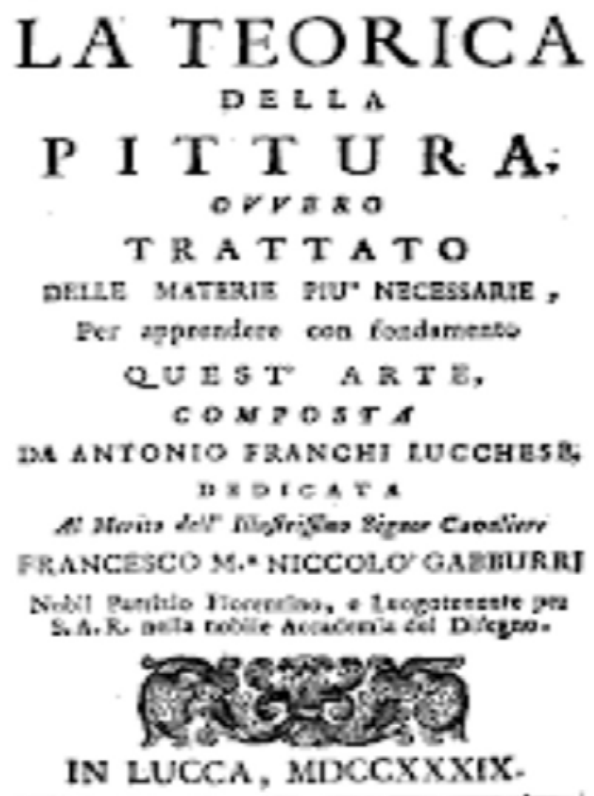

dades que los individualizan. Respecto a la labor del pintor de hacer un retrato, Franchi consideraba más complicado efigiar a una persona físicamente agraciada que a otra que lo fuese menos, pues la dificultad residía en conseguir individualizar a aquellas caras más bonitas y por tanto, más parecidas entre sí.

L'idea della Bellezza è dunque una sola. Ma se è così, dunque quanto più i visi sono belli, tanto più son promissi a detta Idea, e per conseguenza più simili tra di loro. E per contra, più son brutti, tanto più son remoti da detta Idea, e più tra loro dissimili e differenti, rassomigliandosi in questo due linee rettem procedenti da un punto, non paralelle. Queste nel punto sono una sola; fuori di esso in poca distanza son tra se vicine; ma quanto più s'allontanano dal medesimo, più s'allontanano tra di loro. Così accade de' visi belli, tanto più s'avvicinanp al punto, cioè all' Idea della Bellezza, e più fi rendono simili tra di loro. Quanto più se ne dilungano, tanto più tra di loro si rendon dissimili, e imbruttiscono. Ma se i visi quanto più son belli, tanto più son vicini a detta Idea, e più simili tra di loro, dunque facendone i ritratti, devon per necessità esser più difficili a farli somigliare. $E$ ciò, perchè quelle parti componenti il bello di quei volti, essendo pochissimo differenti tra di loro, dee riuscir difficilissimo al Pi- 
ttore l'imitarle con perfezione tale da renderle propiem e interamente distintive, e particolari di quei diversi bei volti. I visi brutti per contra, quanto più deformi, e di fatezze caricate, più son lontani da detta Idea, e più son differenti fra di loro. Adunque per la forza del suo contrario, più devono esser facili a farli somigliare; perchè le parti, che compongono quei brutti mostacci, essendo tra se tanto dissimili, con ogni mediocre imitazione dee riuscire al Pittore di particolarizarle, e renderle propie di quelle diverse brutte Idee. Questa è la ragione dell' opinione, che io tengo sopra questa materia.

Cap. XIX. Perchè i visi, quanto piú son belli, più sono difficili a Pittori il farne ritratti somiglianti; e quanto più son brutti, più gli son facili. ${ }^{37}$

Como alternativa a la estricta imitación en el retrato, otros autores abogaron por su idealización. La preocupación por la imagen que se proyecta de uno mismo es un aspecto que produce bastante interés por quien es representado, pues se trata de construir una efigie que habla de nuestro ser, realizada para la contemplación del otro, y la información emitida en ese discurso visual debía ser acertada. En este sentido, Antonio Palomino (1655 - 1726) ofreció algunas consideraciones sobre el dilema que se le puede plantear al artista respecto al parecido.

Dicha será en este caso encontrar el pintor con sujeto, que se contente con lo parecido, sin buscar lo lisonjeado; siendo cierto, que en los retratos, lo más perfecto es el parecido: y hay casos, en que el pobre pintor se ve en una muy notable tribulación; porque si da gusto a el dueño, pierde el crédito con los desapasionados, que conocen lo desemejante; y si atiende a lo parecido, queda disgustado el diseño y mal pagado el pintor, sin saber cómo escapar de alguno de estos dos escollos.

37 Antonio Franchi Lucchese, La teorica della pittura: ovvero Trattato delle materie piu' necessarie, (Salvatore e Giandomenico Marescandoli: Lucca, 1739), pp. 158-159. 
Libro VI. El aprovechado. Tercer grado de los pintores.

Capítulo II: Del modo de estudiar por el natural y lo que se debe observar en los retratos. ${ }^{38}$

Palomino reconoció que la explícita reproducción de la realidad en un retrato podía sembrar el descontento en el cliente. Como solución, apostó por que el artista fuese fiel a la verdad a la vez que tratase de ensalzar los rasgos más favorecedores del efigiado y disimulase las imperfecciones. Para ilustrar esta idea, el autor también utilizó como ejemplo la representación que Apeles hizo del rey Antígono. El pintor fue avispado para retratar al monarca sin mostrar el defecto físico que tenía en un ojo y sin atentar por ello al semejante.

Y a esto llamamos propiamente estudiar del natural, no copiar, que eso sólo se concede a un retrato, donde la total semejanza es el mayor argumento de su perfección, aunque la perfección no sea su mayor argumento: y aún en esto es necesaria también la discreción e inteligencia del artífice para saber elegir o la luz o el contorno más grato al natural, como lo manifestó Apeles en el retrato del rey Antígono, que siendo defectuoso de un ojo, le pintó de medio de perfil, porque pareciese faltaba el ojo en la pintura y no en el original, huyendo el defecto de mentir con la discreción de ocultar: que en los soberanos es menester grande arte para tocar sus defectos, sin peligrar en la adulación, o tropezar en la irreverencia.

Libro II. Capítulo VIII: Propiedades accidentales dela Pintura. ${ }^{39}$ Además el erudito ha considerado fundamental el claro y oscuro, como base del parecido. Por lo general el artista debía favorecer al retratado a excepción del rostro, donde convenía que fuese más fiel a la verdadera imagen ya que era el elemento más característico de la persona. El rostro individualiza e 38 Antonio Palomino de Castro y Velasco, El museo pictórico y escala óptica, (Aguilar: Madrid, 1988), pp. 199-202.

39 Palomino, El museo pictórico..., p. 158. 
identifica al representado. Por tanto, el pintor debía maquillar la apariencia de otras zonas como las manos, la garganta o ayudar a que el hombre o mujer pintados manifestasen una buena planta. Las ideas de Palomino se pueden relacionar con la noción de dissimulatio, un recurso clásico utilizado por Plinio "el Joven" (61 - 115) o Quintiliano (35 - 95) y exportado al campo de las artes por Alberti. Con esta fórmula se anteponía la dignidad y la nobleza sobre la fidelidad física del efigiado, asociando el retrato con la aristocracia. ${ }^{40}$

En la definición de pintura ofrecida por Juan de Butrón se atisban algunos puntos en común con las consideraciones de Palomino. De hecho, el autor también ha aludido al uso de las luces y las sombras o al efecto de relieve como un instrumento eficaz empleado por la pintura para engañar a la vista. Además, ha enaltecido la capacidad de este arte para copiar y mejorar la propia naturaleza, seleccionando las partes más bellas y desechando aquellas que no lo eran tanto. La reflexión de Butrón, sobre el retrato, defiende la pronunciación de los rasgos más favorecedores y la omisión de los defectos del representado para obtener una imagen de gran calidad estética.

La pintura, según la mejor definición, que a tan noble arte le compete, es un remedo de las obras de Dios, y una emulación de la naturaleza: pues no se halla cosa que aquella crie, a la cual esta no la copie, y felicísimamente la perpetúe. [...] Y finalmente las antiguas y modernas formas así a fuerza del arte las retrata, que infinitas veces enmienda a la misma naturaleza: pues tomando de cada sujeto lo perfecto que en el hizo, y omitiendo la parte, en que parece muchas veces anduvo dormida, la aventaja con tal arte, que tácitamente la reprehende, cuando con justos títulos se le opone.

Discurso primero. ${ }^{41}$

40 Falomir Faus, 'Imágenes de poder y evocación...', p. 210.

41 Butrón, Discursos apologéticos..., fol. 1. 
Siguiendo esta misma tendencia, se hallan los escritos de Antonio Rafael Mengs (1728 - 1779). Los textos, centrados en el tratamiento de la belleza y el gusto en la pintura, contienen diversos fragmentos que conducen a posicionarlo a favor de la idealización en el retrato. Se puede entender que Mengs estuvo de acuerdo con enfatizar los rasgos más bellos del representado cuando afirma que la pintura tiene la capacidad de seleccionar las partes más bellas de la naturaleza para componer una imagen: «La pintura puede escoger lo más hermoso de todo el espectáculo de la naturaleza, recogiendo y juntando las partes de diversos lugares, y las bellezas de distintas personas. ${ }^{42}$ La postura del autor se observa más claramente al considerar las reglas del gusto y decir:

El gusto grandioso consiste en escoger las partes grandes tanto del hombre, como de los demás en toda la naturale$z a, y$ en ocultar las pequeñas y subordinadas, cuando no son absolutamente necesarias. [...] El gusto es también el que determina al pintor a tomar un motivo o fin principal, y que le hace escoger o descartar lo que le es conveniente o contrario: por lo que, cuando se ve una pintura en la cual todo está expresado sin distinción ni variedad, y en que nada se observa de particular, se concluye que el autor no tiene gusto alguno, y que tales pinturas no tienen expresión alguna.

Segunda parte. Del gusto. Capítulo III: Reglas del gusto. ${ }^{43}$

Mengs también mostró su percepción sobre el gusto en este discurso, entendido como el criterio adoptado por el artista para concederle más relevancia a unos aspectos que a otros en la pintura. Cuando el artífice no realiza dicha distinción y todos los elementos son tratados indiferentemente se considera que éste no tiene gusto. En el caso de las efigies, el artista 42 Antón Rafael Mengs, Obras de D. Antonio Rafael Mengs: primer pintor de cámara del rey, (Joseph Nicolás de Azara: Madrid, 1780). Primera parte. De la belleza. Cap. V. El arte puede seuperar a la naturaleza en la belleza, pp. 11-12.

43 Mengs, Obras de D. Antonio Rafael Mengs..., p. 18. 
tiene buen gusto cuando toma los detalles más favorecedores del representado y omite, siempre que sea prescindible, los menos bellos. De este modo es factible construir una imagen bienhechora de la persona, consiguiendo al mismo tiempo, que sea reconocible fácilmente. Conviene reforzar la perspectiva del autor con un último extracto de su obra, en el cual ha valorado la calidad artística de los pintores. Entendía que un buen artífice era aquel que sabía capturar lo ideal, pero era aún mejor artista aquel que sabía conjugar la idealización con la imitación.

Por esto el pintor que tenga mucho de lo ideal deberá ser más estimado, que el que posea la sola imitación; pero como el arte participa de ambas cosas, aquel será mayor maestro que las posea entre ambas. Estas dos partes tienen tal unión entre sí, que la idea, que es la primera del gusto, es el alma; y la imitación del cuerpo. Esta alma, o llamémosla esta razón, debe escoger de todo el espectáculo de la naturaleza las partes más hermosas según las ideas humanas; pero no debe inventar ni crear las que no existen, porque entonces se disminuiría el arte, y perdería, por decirlo así, su cuerpo, oscureciendo su belleza.

Segunda parte. Del gusto. Capítulo IV: Como se combina el gusto con la imitación. ${ }^{44}$

En síntesis, a partir de los fragmentos seleccionados se conoce que la actitud del autor hacia el modo de proceder en el retrato fue defender la imitación mejorada de la naturaleza, pues era una habilidad que la pintura podía desarrollar y que la propia naturaleza era incapaz de conseguir. Todo ser vivo se muestra como es y no cabe la posibilidad de realizar grandes modificaciones, en cambio la pintura puede seleccionar exclusivamente fragmentos de gran belleza para los ojos humanos y concentrar la mayor dosis posible de ésta en una imagen, pero sin dejar de ser identificable con la realidad.

Con ambas posturas se dilucida el variado clima existente res-

44 Mengs, Obras de D. Antonio Rafael Mengs..., p. 20. 
pecto a las teorías del retrato. Cuando parecía que la reproducción fidedigna del individuo era suficiente, la efigie se convirtió en un excelente instrumento de poder, complicando así este género al añadirle una importante carga política y simbólica. Durante la Edad Moderna, la principal aspiración del monarca era hacer alarde de su magnificencia. Por esta razón y como se desarrollará a continuación, varios autores creyeron que este género debía condensar la apariencia, personalidad, virtudes y logros del representado. Esta posibilidad, seguida por los tratadistas Lomazzo (1538 - 1600) y Armenini (1530 1609), entendía que la efigie era el soporte de la virtud..$^{45} \mathrm{El}$ retrato debía asemejarse a la realidad, pero principalmente reflejaba la personalidad y la categoría social del individuo, para lo cual se hacía imprescindible la utilización de distintos símbolos. En consecuencia, un retrato era una imagen subjetiva reveladora de un mensaje, generalmente acordado entre el pintor y el retratado. ${ }^{46}$ Una idea que trascendió la época del Renacimiento hasta llegar al Barroco, donde persistió la división del pensamiento acerca de la estricta imitación o la plasmación de una identidad en la representación del individuo.

\subsubsection{Imagen de la virtus y ejemplo de decorum.}

Desde los inicios del retrato las posibilidades de adquirir uno de ellos o de ser efigiado tan sólo estaban al alcance de un reducido grupo privilegiado. Independientemente de la función que la imagen desempeñase, sin lugar a dudas, siempre estaban ligadas con las altas clases sociales. Cabe recordar que las máscaras mortuorias de época romana eran extraídas de miembros de las familias patricias para formar parte de la galería de retratos de sus difuntos. En la Edad Media, cuando dicho género estaba enormemente inmerso en la pintura reli-

45 Susann Waldmann, El artista y su retrato en la España del siglo XVII: una aportación al estudio de la pintura retratista española, (Alianza: Madrid, 2007), pp. 86-104.

46 Miguel Falomir Faus (ed.), El retrato del Renacimiento, (Museo Nacional del Prado, 2008), pp. 17-21. 
giosa, fueron los donantes aquellos que aparecían representados, presumiendo de su fe, de su nivel social y de su capacidad económica. En la Edad Moderna el efigiarse también era una actividad exclusiva y así lo definió Sebastián de Covarrubias en 1611 al afirmar que el retrato era «la figura contrahecha de alguna persona principal y de cuenta, cuya efigie y semejanza es justo quede por memoria a los siglos venideros. ${ }^{47} \mathrm{La}$ acepción de Covarrubias es de gran interés para estudiar este género en el periodo barroco porque mostraba el pensamiento del momento y justificaba los criterios estipulados para elaborar estas pinturas. Por ello, Carducho ya apuntó que los retratos estaban reservados para las personas relevantes que por distintas circunstancias eran merecedoras de ser recordadas en la posteridad.

[...] Y que además del daño considerable que se seguiría de esto, por ser tan importantes a la religión y culto del verdadero Dios a quien adoramos, y a la república, para los triunfos, victorias, entradas, y muertes de los reyes, y singulares varones: y para las descripciones de las ciudades, o provincias, era no sólo irreverencia, por haber sido pintor mientras vivió entre nosotros Jesucristo señor nuestro, sino poco respecto a san Lucas, y otros santos, contra los retratos de nuestros príncipes, padres y mayores, sin la ofensa particular que se haría a la naturaleza, que imprimió este honrado afecto en los hombres, de honrar al hombre los hechos virtuosos, la memoria de grandes personas, pintando sus acciones, y retratando sus semblantes, y afectos, para despertarnos con su vista a la imitación de las virtudes que conocimos en las personas que representan. ${ }^{48}$

47 Respecto a la definición que Covarrubias hace del término retrato cabe destacar que incluye el término contrahecho entendido como sinónimos de copia o reproducción. Además se define el verbo contrahacer como «imitar alguna cosa, de lo natural o de lo artificial. Contrahecho, lo imitado en esta manera.» Así pues, se constata la relevancia que tiene la imitación en este género. Véase a Sebastián de Covarrubias, Tesoro de la lengua castellana o española, (Imprenta de Luís Sánchez: Madrid, 1611), p. 908.

48 Carducho, Diálogos de la pintura..., fol. 188v-189r. 
A ello, hay que añadir el trampolín que supuso la imprenta, la cual permitió difundir rápidamente las imágenes de santos, gobernantes e intelectuales, quienes a finales de los siglos XV y XVI vieron su representación rápidamente extendida. Asimismo, nuevos sectores de la población tuvieron acceso a los retratos y en consecuencia surgieron nuevas tipologías que permitían diferenciar representaciones de los privilegiados y de la gente sencilla: de cuerpo entero, sedente o ecuestre. ${ }^{49}$ Según algunos tratadistas, su popularización iba acompañada de su decadencia. Por ejemplo, para Lomazzo la pérdida de exclusividad en este género era una herramienta de desacreditación.

Perciò che lo studio i pittori è intorno alle sacre imagini, e appresso i Greci vi era un edito che soli i nobili usasero la pittura, tanto e lontano il pensare che permettessero à huomini plebei, e vili il farsi ritrahere dal naturale; anci questo assolutamente era riservato solamente a Principi e Savi. [...] Per ilche comprendiamo in quanto pregio fosse tenuta da tutti i popoli quest'arte del ritrahere dal naturale massime perche non era se non da eccellenti pittori, scultori e incavatori essercitata; ancora che à tempi nostri si sia divulgata tanto che quasi tutta la sua dignità è perduta, non solamente perche senza alcuna distintione si tolera da principi, e dalle republiche, che ogn'uno con ritratti cerchi di conservare la memoria sua eterna, e immortale, ma anco per che ogni rozzo pittore che à pena sà che cosa sia empiastrare carta vuol ritrahere. ${ }^{50}$

Autores como Francisco de Holanda, Carducho y Palomino coincidieron en que las efigies quedaban reservadas a los soberanos y a los habitantes de prestigio y calidad: «Digo, que tengo para mí, que solamente los claros príncipes y reyes o emperadores merecen ser pintados y que queden sus imágenes y figuras en su buena memoria a los futuros tiempos y 49 Falomir, El retrato del Renacimiento..., pp. 17-21

50 Giovanni Paolo Lomazzo, Trattato dell'arte della pittura, scoltura et architettura, (Paolo Gottatdo Pontio: Milán, 1585), Libro sesto, pp. 431-432. 
edades. $1^{51}$

Cosa pía es, ya más cuando les mueve el amor lícito de los padres, hermanos, parientes, o amigos; y tanto más cuanto fueren personas santas, y virtuosas, para dar motivos a la imitación de aquellas virtudes de que fueron adornados. Y podemos presumir (según dijimos en el origen de la pintura) que nació el uso del retratar con el arte, a fin de hacer falsos dioses en quien idolatrar: después, como escribe Lactancio, solo a los reyes y príncipes fue permitido el retratarse, cuando hubiesen hecho cosas grandes, y gobernado bien, sirviendo esto de cierto premio honroso a su mucho valor, animando con esto a los que sucediesen al gobierno, para que a su imitación procediesen con bondad y justicia.

Diálogo séptimo: De las diferencias y modos de pintar los sucesos e historias sagradas con la decadencia que se de-

be. ${ }^{52}$

En principio, al circunscribir el empleo del retrato con la realeza ya se indica que era un objeto distintivo relacionado con el poder. La imagen del monarca servía de referente para los sucesores en el cargo, quien a través del retrato conocían a quien imitar. A lo largo de la investigación se ha observado que el género introdujo representaciones de otros sectores de la sociedad. Así pues, autores como Butrón, afirmaron que la nobleza se efigiaba para diferenciarse de eslabones sociales inferiores. También matizó que el retrato fue la primera herramienta eficaz para dejar constancia de los ascendientes, honrarlos y mostrar que se formaba parte de una familia privilegiada. Esta intención ha quedado reflejada en alguna de las galerías de linajes estudiadas en el medio valenciano. Sin embargo, la imagen como crédito de la estirpe perdió fuerza en el momento en que se reconoció que la nobleza no es una 51 Holanda, De la pintura..., Diálogo I: Cómo pocos pueden hacer perfección, p. 225.

52 Carducho, Diálogos de la pintura..., fol.110v-111r. 
condición social heredada sino ganada por poseer una serie de cualidades y virtudes.

Antes que por las ramas se conociesen las noblezas, y se
distinguiesen las familias, cada uno en sus escudos traía
pintadas las imágenes, y retratos de sus pasados que ha-
bían hecho hazañas en la guerra tales que pudiesen con
ellas honrarse sus descendientes; de manera que la pin-
tura aclaraba la nobleza, y la distinguía de la plebe. [...]
Para saber si alguien era noble se preguntaba si podía
traer retratos de sus mayores. [...] Dejaron de usarse es-
tas divisas de traer los retratos de sus pasados, porque la
nobleza verdadera no es la heredada, es la adquirida. Así
lo entendió Eurípides según Estebeo sermone 44 . don-
de dice: Noble me parece a mí que es el que adquiere la
nobleza por sus virtudes; villanos, y sin dependencia de
buen linaje, aunque sea de Júpiter, el que lo desmerece
por sus obras.

Discurso decimo tercio. ${ }^{53}$

90

Siguiendo con la reflexión de Butrón, también cabe remarcar que ésta sintoniza a la perfección con el significado del término nobleza en España durante el siglo XVII, donde el concepto se vinculó estrechamente a la idea de virtus. En su definición para la palabra «noble», Sebastián de Covarrubias alude a aquella nobleza alcanzada por herencia, es decir, por haber nacido en el seno de una célebre familia, pero también puede ser noble aquella persona que por su virtud se ha dado a conocer y se ha ganado dicha consideración:

[...] quasi noscibilis, a causa, de que por su virtud, o la de sus antepasados se da a conocer: idem quod illustris, clarus, celeber. Este título se daba antiguamente a los reyes de Castilla. En nuestro tiempo antes de remediarse el exceso de los títulos nadie se satisfacía con él: tanto hace la mudanza de los tiempos. Nobleza, la calidad de ser noble. Ennoblecer, y ennoblecido. Comúnmente llamamos

53 Butrón, Discursos apologéticos..., fol. 45-46. 
hombre noble al que es hidalgo y bien nacido. ${ }^{54}$

Por tanto, apareció la virtus como un nuevo requerimiento para retratarse. El efigiado debía poseer una ética y moral ejemplar. Italia fue pionera en dicha práctica, donde el retrato era considerado una simbiosis entre la reproducción y la imagen ideal, con el fin de responder a la virtus del representado. En esa línea discurrió el pensamiento de Armenini al explicar la habilidad que tiene el retrato para mostrar las virtudes y los logros del retratado y en definitiva perpetuar su memoria:

En verdad son muchos los hombres que se maravillan grandemente y consideran de suprema excelencia a aquel pintor que, al hacer un retrato del natural se aproxima tanto al modelo vivo, que parece demasiado semejante. Yo creo que esta opinión no deriva tanto de su ignorancia cuanto de la condición del tema que, en sí mismo casi para todos es deseable, ya que contrahaciendo la verdadera efigie con esas materias que han de durar algún tiempo, se contribuye en gran medida al nombre y a la posteridad del retratado, porque a través de ellos se conocen y manifiestan sus virtudes durante muchos siglos, y porque al verlos no solamente se representa la imagen real, sino que se recobra también la memoria de todas las virtudes y proezas diseminadas por el mundo, tal como sucede en los sepulcros, al dar noticia a los postreros de las cosas pasadas, y lo que les confirma aún más esta creencia es el conocimiento que adquieren ante su presencia, al ver lo fingido y lo real al mismo tiempo, lo cual viene a ser la causa de que otras pinturas más difíciles y realizadas con mayor estudio no parezcan allí poseer tan gran magisterio.

Capítulo XI. De los retratos del natural, y en qué consiste la dificultas de hacerlos bien y de qué procede. Que la mayoría de las veces aquellos que poseen mayor dibujo y son más celebrados que los demás, los hacen menos semejantes que los pintados por quienes son menos perfec-

54 Covarrubias, Tesoro de la lengua..., p. 564. 
Del mismo modo Giovanni Battista Agucchi (1570-1632) en su Trattatto della Pintura (1607-1615) ha expuesto que el retrato no era la representación de una persona, sino el soporte de una virtus. Sobre ella se sustentan las imágenes de las humildes gentes del pueblo, que encierran cualidades internas y valores morales. Asimismo, a consecuencia de vincular este criterio a la nobleza, el retrato también se encontró en ámbitos distintos a la Iglesia y a la corte. María Elena Manrique Ara ha editado un estudio sobre Jusepe Martínez y sus Discursos practicables, en él se incluye una cita de Agucchi donde se refuerza la idea previamente comentada. El autor opinó que para elaborar un buen retrato, el artista debía profundizar en las cualidades y capacidades del retratado y no sólo ceñirse a unos rasgos físicos determinados: «Ni se crea por eso que no queremos dar la merecida alabanza a aquellos pintores que hacen con excelencia un retrato. Porque para obrar con perfección no se debería indagar cómo fue el rostro de Alejandro o de César, sino el de un rey o capitán magnánimo y fuerte.» ${ }^{56}$

El concebir que las personas virtuosas fuesen las acreditadas para ser representadas contribuyó a añadir una nueva función a las efigies. Desde entonces el retrato se entendió como espejo de comportamiento. Así pues, en los distintos ámbitos como la corte, la Iglesia y otras instituciones retrataron a sus dirigentes y principales personalidades, alabaron su moral y las hazañas conseguidas y los mostraron como ejemplos a seguir para el resto de la sociedad. Como se ha apreciado en el resto de la investigación, la finalidad de los retratos de exponer a personas modélicas e inspiradoras para la sociedad ha estado muy presente en la mayor parte de galerías estudiadas.

Junto con la virtus, igualmente apareció otro elemento nece55 Armenini y Bernárdez Sanchís, De los verdaderos preceptos..., p. 243.

56 Jusepe Martínez, Discursos practicables del nobilísimo arte de la pintura, (Cátedra, 2006), p. 37. 
sario en el género del retrato, el decorum. Ambos aspectos son complementarios uno del otro y fundamentales en la eficaz ejecución de las efigies. La imagen de la persona, además de capturar su esencia humana, entendiéndola principalmente como sus virtudes, también debía presentarse con decoro. Ello suponía construir una efigie en la cual fuese patente la correspondencia entre el rango social del retratado y su imagen y así fue definido por distintos tratadistas tanto italianos como españoles.

Osserva il decoro, cioè la convienienza dell'atto, vesti, sito, e circonstanti della dignità o viltà delle cose che tu vuoi figurare: cioè che il rè sià di barba, aria, e habito grave, e il sito ornato, e i circonstanti stiano con riverenza, ammiratione, e habiti degni e convenienti alla gravità d'una corte reale, e li vili disornati e abbietti, e abbietti, e li loro circonstanti habbino similitudine con atti vili disornati e abbietti, e li loro circonstanti habbino similitudine con atti vili e presuntoso, e tutte le membra corrispondino a tal componimento. Che gl'atti d'un vecchio non siano simili à quelli d'un giovane, e quelli d'una femina à quelli d'un maschio, ne quelli d'un fanciullo.

Cap. CCLI. Dell' osservanza del decoro. ${ }^{57}$

Armenini [fig. 1.5], asimismo, aportó una definición para este concepto y explicó que: «[...] Avendo l'occhio sempre al decoro, il quale altro non è, che quello, che conviene alle persone, à gli habiti e alle qualità di ciascuno, con haver abbinato termine, legge e ordine ad ogni cosa, perche la gratia, e condencentia si discerne per questa parte. ${ }^{58} \mathrm{La}$ conveniencia también fue uno de los factores esenciales de la invención, considerada como la primera parte de la pintura, según Lodovico Dolce. Así pues 57 Rafaelle du Fresne, Trattato della pittura di Lionardo da Vinci, (Giacomo Langlois: París, 1651), p. 72.

58 Giovanni Battista Armenini, De' veri precetti della pittura, (Francesco Tebaldini: Rávena, 1587), p. 145. 
Fig. 1.5. Giovanni Battista Armenini, De' veri precetti della pittura, Rávena, 1587.

\section{DE VERI PRECETTI}

DELLA PIT TVRA

D: M. GIOBATTISTA ARMENINU. 7 , DA FAINZA

L $\quad \mathrm{I} \quad \mathrm{B} \quad \mathrm{t}$ T $\mathrm{T}$ E.

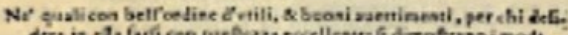

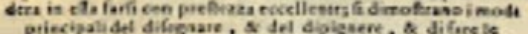

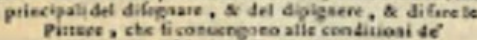

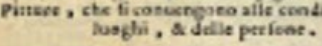

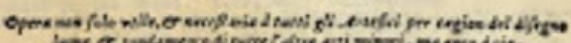

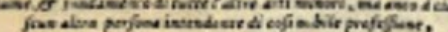

Al Serenifs. Sig, al Signeor GVGLIEL MO Genzaga Ducadi Mantous, di Monferrato, \&cc.

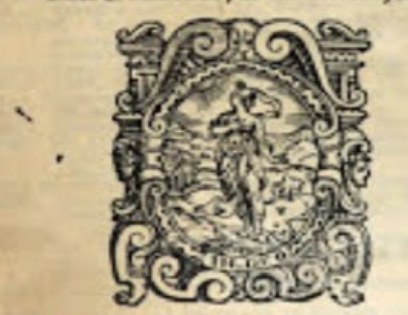

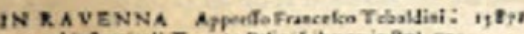

el autor tomó de ejemplos a las figuras de Cristo y de san Pablo y determinó el modo en que deben representarse. Lo más relevante de la reflexión es que Dolce consideró imprescindible pintar a los personajes adecuadamente porque de esa forma se tenía la verdadera efigie. Aquí, por tanto, se ha visto cómo el decoro se ha ligado plenamente al género del retrato.

Y, comenzando por la invención, digo que en ella intervienen varios factores, de los cuales los principales son el orden y la conveniencia. Por ello, si el pintor ha de pintar, por ejemplo a Cristo, o a san Pablo predicando, no está bien que los represente desnudos, o vestidos de soldado o de marinero, sino que necesita pensar en un hábito conveniente a uno y a otro; principalmente, dando a Cristo una efigie grave acompañada de amable benignidad y dulzura, y representando de la misma manera a san Pablo con el aspecto que conviene a tamaño apóstol, para que así el ojo que mira tenga la sensación de ver un verdadero retrato, sea del otorgador de salud, sea del recipiente de la elección.

Primera parte de la pintura: La invención. ${ }^{59}$

Lomazzo y Carducho, en el ámbito italiano y en el contexto español respectivamente, reflexionaron sobre el decorum y 59 Dolce, Diálogo de la pintura..., p. 125. 
acerca de cómo debía ser retratada una persona en función de su consideración. Giovanni Paolo Lomazzo concretamente estableció dos tipos de decoro, por un lado el calificado de natural y por otro, el artificial, siendo este último el que haría referencia a la necesidad de representar al personaje según su posición social y el que dotaba de magnificencia a las imágenes de emperadores y reyes.

Questo decoro, ò vogliam dire positione, si divide in naturale, e artificiale. Decoro naturale chiamano in questa materia, quello che è proprio de l'huomo, che vogliamo ritrahere, come s'un vuol dipingere per essemplo, Catone Viicense, il quale era huomo gravissimo, farà il ritratto, che ne la positione del corpo, et di tutte le parti sue, serverà sempre il medesimo decoro di gravità. Il decoro artificiale, è che quando il prudente pittore dipingendo uno Imperatore, ò un Rè, fà il ritratto loro grave, e pleno di maestà, ancora che per aventura, egli naturalmente non l'habbia: ò dipingendo un soldato, lo mostra pleno di furore, et di sdegno più di quello, ch'egli veramente non fù ne la scaramuccia. ${ }^{60}$

A consecuencia de las normas del decoro, Carducho indicó que los escritores, los comerciantes y los pintores debían representarse con un atributo de su profesión. También aceptó las imágenes de las personas sencillas, pero siempre y cuando se efigiasen fielmente a su estamento. Así pues, es muy frecuente ver retratos y autorretratos de arquitectos, escultores y pintores acompañados de sus herramientas de trabajo.

Y como sería bien se ejecutase con rigor, y guardase el decoro y respeto a tales personas. $Y$ ya que se haya de usar este abuso, sea pintado al capitán valeroso armado, y al artífice con algún instrumento de su arte, como sería al escribano con alguna pluma en la oreja, al mercader con alguna cosa que lo signifique, al pintor con pinceles $y$ colores, y por este modo todos según las calidades de los

60 Lomazzo, Trattato dell'arte della pittura..., Libro primo, p. 30. 
hombres; y no como ahora se usa, que no solo se retratan las personas ordinarísimas, mas con modo, hábito, e insignias impropísimas, que se debería remediar este exceso. Yo he visto retratados a hombres y mujeres muy ordinarios, y de oficios mecánicos (aunque ricos) arrimados a un bufete o silla debajo de cortina, con la gravedad de traje y postura que se debe a los reyes y grandes señores (sin que se le deba retratarse por único en su ejercicio) otros armados, y con bastón, como si fuera un duque de Alba, o marqués del Vasto, que podrá ser que no se haya jamás puesto tales insignias, sino es en comedia, o suiza.

Diálogo séptimo: De las diferencias y modos de pintar los sucesos e historias sagradas con la decadencia que se de-

be. ${ }^{61}$

Un detalle que también pone de manifiesto la condición social del retratado es, sin duda, la indumentaria. De hecho, Mayans le concedió una gran relevancia al vestuario del retratado 96 porque permitía al artista demostrar su habilidad pictórica, y principalmente, era un elemento de decoro, pues los modelos debían posar con los ropajes de acuerdo a su nivel social y el pintor debía ser fiel a ellos. Asimismo el autor entiende el decoro como:

Un honesto uso de las cosas buenas o indiferentes, acomodado con decencia a la verdad de ellas, y al respeto que se debe a las personas de que se trata y con quienes se trata, se ha de procurar guardar diligentísimo cuidado; porque lo que es contrario a la verdad, y aún a la verosimilitud, ofende al entendimiento; lo que es opuesto, a las buenas costumbres, irrita; lo que a la buena crianza, desagrada. ${ }^{62}$

Al estudiar las obras artísticas resulta muy interesante ver cómo el retrato se corresponde con las ideas de virtud y deco-

61 Carducho, Diálogos de la pintura..., fol. 111r-v.

62 Mayans y Siscar, Arte de pintar..., p. 56. 
ro y cómo estas se integran en el lenguaje visual. En relación con el decorum en los retratos, aparecen otras dos cuestiones. La primera de ellas es el uso de la alegoría, y la segunda, el control de la imagen del soberano. En el ámbito español, la utilización de la alegoría fue mínima en este género.

Por lo que respecta a los retratos del monarca y de la corte, era muy recurrente incluir cortinajes, sillas o bufetes que $a$ priori tenían un sentido simbólico. Sin embargo, todos estos elementos comenzaron a reproducirse reiteradamente, perdiendo así su verdadero significado, y convirtiéndose en instrumentos para la composición pictórica. Además, el retrato cortesano estaba concebido para un reducido núcleo de privilegiados, y los ejemplos alegóricos se mantuvieron en otras manifestaciones artísticas, como grabados, medallas o libros, solicitados por un amplio público. ${ }^{63}$ En el siglo XVII se enriqueció la posición del género del retrato, pues aumentaron sus posibilidades y comenzó a ser un demandado por todo tipo de público. Así, parece lógico que a finales del siglo XVI y principios del XVII fuese el momento en que se sitúa el nacimiento de las galerías de efigies estudiadas en esta investigación.

Para recapitular, cabe reseñar, la evolución de las funciones desempeñadas por el retrato desde la Antigüedad, cuando albergaba un papel estrictamente conmemorativo en el espacio funerario. Seguidamente, sin olvidar el primer objetivo, este arte trató de capturar también la personalidad del efigiado. Durante el Renacimiento, ambos elementos, el exterior y el interior del hombre fueron concienzudamente cuidados para elaborar las efigies. Según Pope-Hennessy, en este momento también tuvo lugar la proclamación de la autosuficiencia del hombre. ${ }^{64}$ Bajo este marco el retrato renacentista fue el punto de inicio para las efigies modernas. Así pues, la llegada del periodo Barroco potenció la demanda y la producción de los 63 Falomir Faus, 'Imágenes de poder y evocación...', p. 212.

64 John Pope-Hennessy y Joaquín Bollo Muro (trad.), El retrato en el Renacimiento: conferencias sobre arte, (Akal: Torrejón de Ardoz, 1985), p. 9. 
retratos, los cuales recogen las virtudes del ser humano, quien es representado bajo las reglas del decoro. En este momento, más alejado de las ideas de Lomazzo, aumentó la importancia de las efigies particulares y se representaron a personas de otros niveles sociales. El retrato, progresivamente, dejó de ser un objeto exclusivo de las esferas superiores de la sociedad y acogió al sector más humilde de la población. ${ }^{65}$ Pese a ello, las circunstancias y características de los retratos que son objeto de estudio de esta tesis se adscriben a aquellos que representan a miembros de la clase privilegiada o reconocida socialmente, siendo los frailes y beatos las representaciones de personas más humildes pero que gozaron de una cierta fama, puesto que eran ejemplos de la virtud católica y se acercaban a la santidad.

\subsection{Linaje, fama y memoria en la Edad Moderna.}

Las explicaciones dadas en torno al nacimiento de la pintura y

del retrato, las funciones que se le han atribuido con el tiempo y la relación de este género con los conceptos de virtud y decoro han determinado que seguidamente se reflexione acerca del linaje, la fama y la memoria en época moderna. Así, se puede vislumbrar la estrecha relación que existió entre todos estos términos y es posible comprender la trascendencia del retrato.

De la Edad Moderna proceden numerosos ejemplos donde la efigie es una obra más dentro de un conjunto de numerosos retratos y del cual no debe desvincularse si se desea respetar la función original de la pintura. Así sucede, por ejemplo, con las salas de linajes, cuyo cometido era representar la estirpe y justificar la herencia del poder a través del vínculo sanguíneo. Por ello las obras de este tipo de series se disponían de forma

65 Pierre Civil, 'La familia de Carlos V: Representaciones y política dinástica', en El linaje del emperador: Iglesia de la Preciosa Sangre, Centro de Exposiciones San Jorge, Cáceres, del 24 de octubre de 2000 al 7 de enero de 2001, (Sociedad Estatal para la Conmemoración de los Centenarios de Felipe II y Carlos V: Madrid, 2000), pp. 41-60. 
que la estructura familiar quedase clara. ${ }^{66}$

La necesidad de configurar un determinado linaje no fue algo novedoso desde los tiempos del Renacimiento o del Barroco, sino que ya en época medieval se llevaron a cabo distintas empresas artísticas para construir visualmente la estirpe y la imagen de poder de los monarcas. La representación regia se encontró en pinturas, esculturas, miniaturas, sellos y monedas. Independientemente de si el objeto artístico es autónomo o forma parte de un grupo mayor, al tratarse de imágenes áulicas estarán repletas de alusiones genealógicas a través de inscripciones y de la heráldica. Por ejemplo, Alfonso X el Sabio ya dispuso de una serie de efigies escultóricas de sus antepasados en el denominado Salón de Reyes del alcázar de Segovia [fig. 1.6].

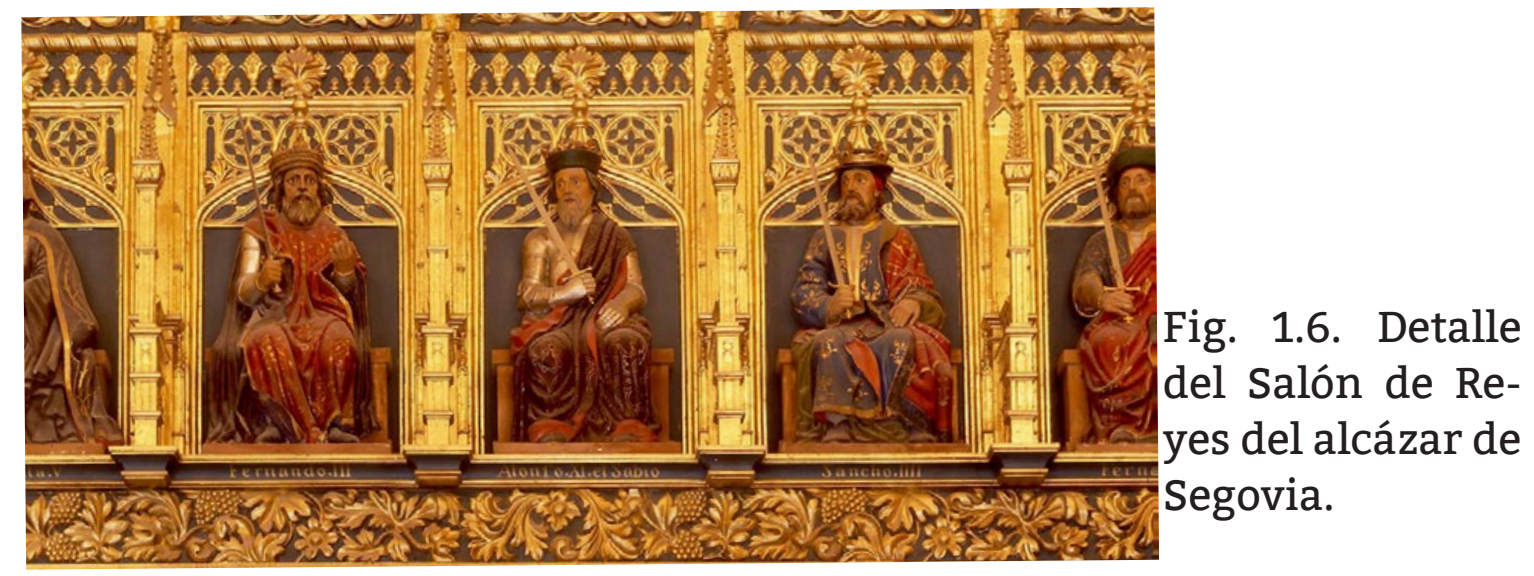

Este conjunto fue ampliado, más tarde, por Felipe II de modo que el árbol familiar entroncaba con su abuela, Juana I de Castilla. Sin embargo, el incendio de 1862 consumió toda la decoración y tan sólo se conserva la sala ${ }^{67}$ Pese a ello, es posible

66 Juan Miguel Serrera, 'Alonso Sánchez Coello y la mecánica del retrato de corte.', en Santiago Saavedra (ed.), Alonso Sánchez Coello y el retrato en la corte de Felipe II, (Museo Nacional del Prado: Madrid, 1990), pp. 38-63.

67 Elías Tormo, Las viejas series icónicas de los reyes de España, (Junta de Iconografía Nacional: Madrid, 1917), pp. 17-29; Víctor Mínguez Cornelles, 'Elías Tormo iconógrafo', en Luis Arciniega García (ed.), Elías Tormo, apóstol de la historia del arte en España, 2016, (Institución Alfonso el Mag- 
conocer el aspecto que tuvo esta estancia en el pasado gracias al Libro de retratos, letreros e insignias reales de los reyes de Oviedo, León y Castilla de la Sala Real de los Alcázares de Segovia que Hernando de Ávila compuso en 1594.

En el caso de la Corona de Aragón, se debe reseñar el deseo del rey Martín el Humano por crear un rollo con la Genealogía de los reyes de Aragón, también conocido como el rollo de Poblet. ${ }^{68}$ Pero hay otros ejemplos, así el palacio real de Barcelona contenía una galería de retratos escultóricos. Igualmente, Gonçal Peris y Jaume Mateu elaboraron en 1427 catorce retratos idealizados para ornamentar la Sala del Consejo en la Casa de la Ciudad de Valencia, de cuyas obras tan sólo se conservan cuatro en la actualidad en el Museu Nacional d'Art de Catalunya [fig. 1.7].69 Además de estas obras medievales, también conviene destacar alguna serie de reyes realizada en el siglo XVI. En este sentido, un ejemplo señero es la galería pintada en 1586 por Felipe Ariosto para el palacio de la Diputación de Zaragoza y cuyas obras retrataban a los reyes de Sobrarbe, a los condes y reyes de Aragón [fig. 1.8]..$^{70}$

nánimo: Valencia, 2016), pp. 207-218. Eduardo de Oliver-Copóns, El Alcazar de Segovia: monografía histórica, (Maxtor: Valladolid, 2002), pp. 230-231. Fernando Collar de Cáceres, 'En torno al Libro de los Reyes de Hernando de Ávila', Boletín del Museo del Prado, Vol. 4, no. 10, 1983, pp. 7-35 y El libro de retratos, letreros e insignias reales de los reyes de Oviedo, León y Castilla, (Edilán: 1985).

68 Amadeo Serra Desfilis, 'La historia de la dinastía en imágenes: Martín el Humano y el rollo genealógico de la Corona de Aragón', Universitat Autònoma de Barcelona: Barcelona, Locus amoenus, no. 6, 2002 - 2003, pp. 57-74. Inmaculada Rodríguez Moya, 'La construcción dinástica de la monarquía: libros iluminados, genealogías y retratos', en Víctor Mínguez (dir.). El linaje del Rey Monje. La configuración cultural e iconográfica de la Corona aragonensis (1164-1516), (Universitat Jaume I: Castellón, 2018), pp. 273-297.

69 Tormo, Las viejas series icónicas..., p. 63.

70 Son señeros los estudios de Carmen Morte García, 'Pintura y política en la época de los Austrias. Los retratos de los reyes de Aragón para la Diputación de Zaragoza (1586), y las copias de 1634 para el Buen Retiro de Madrid (I)', Boletín del Museo del Prado, Vol. 11, no. 29, 1980, pp. 19-36; Carmen Morte García, 'Pintura y política en la época de los Austrias. Los retratos de 


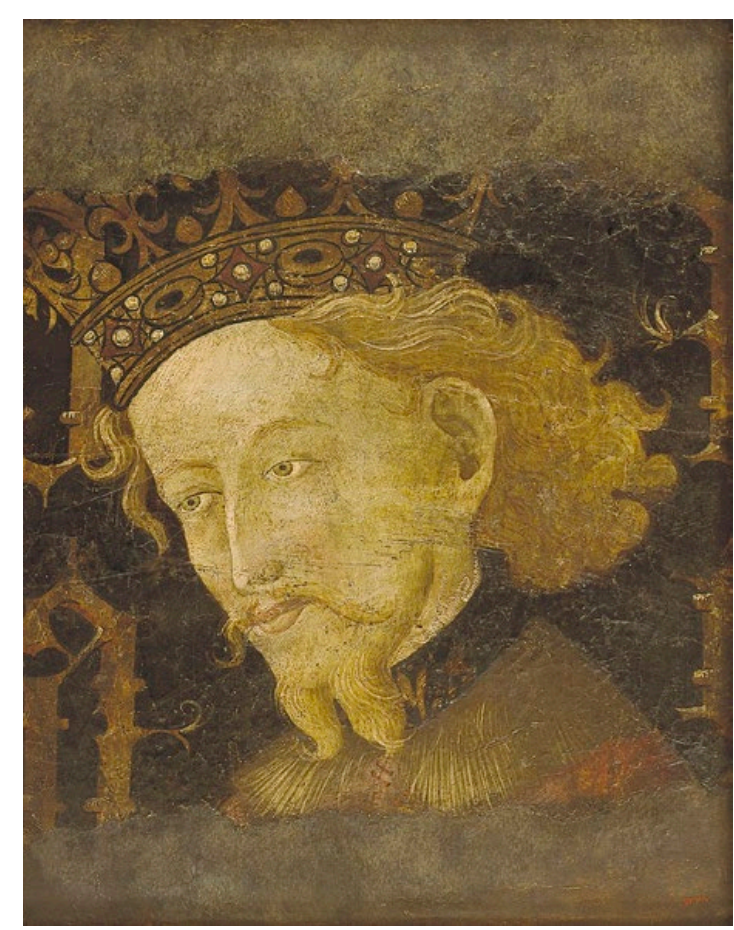

Fig. 1.7. Jaume Mateu - Gonçal Peris, Jaime I el Conquistador, 1427, temple sobre tabla, Barcelona, Museu Nacional d'Art de Catalunya.

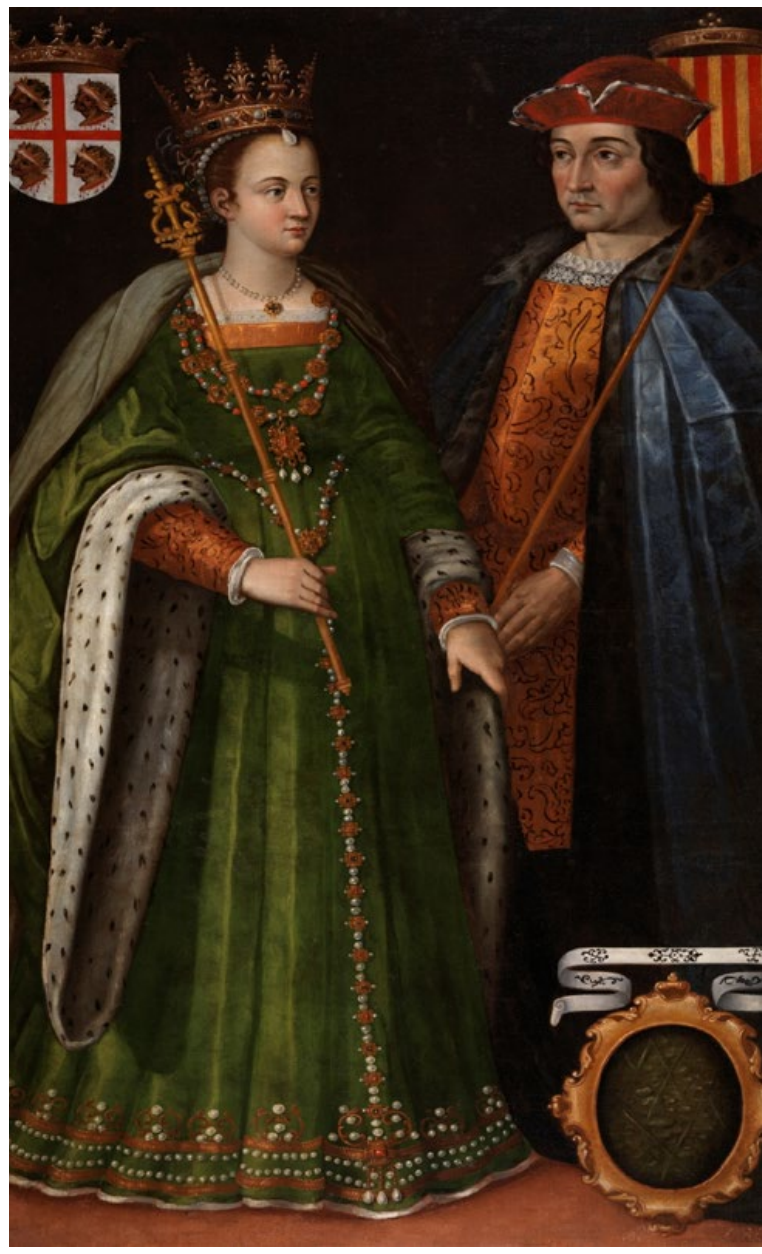

Fig. 1.8. Anónimo (copia de Felipe 101 Ariosto), Petronila Ramírez y Ramón Berenguer IV, 1634, óleo sobre lienzo, Madrid, Museo Nacional del Prado.

Otro proyecto artístico reseñable en el contexto hispánico durante la Edad Moderna fue el atesorado en el palacio del Pardo, el cual ha sido estudiado profundamente por María Kusche. ${ }^{71}$ Su construcción se realizó con la finalidad de ser una morada de descanso desde la época de Carlos V, aunque el emperador nunca llegó a disfrutarla por retirarse directamente al monasterio de Yuste (Cáceres). Sin embargo su hijo Felipe II,

los reyes de Sobrarbe, condes antiguos y reyes de Aragón para la Diputación de Zaragoza (1586), y las copias de 1634 para el Buen Retiro de Madrid (II)', Boletín del Museo del Prado, Vol. 12, no. 30, 1980, pp. 13-28.

71 María Kusche Zettelmeyer, 'La antigua galería de retratos del Pardo: su reconstrucción arquitectónica y el orden de colocación de los cuadros', Archivo español de arte, Vol. 64, no. 253, 1991, pp. 1-28. 
quien había conocido la progresiva edificación del complejo, le dio uso. Basándose en la descripción de Argote de Molina, Kusche ha explicado que la galería estaba compuesta de cuarenta y cinco retratos, casi de cuerpo entero, tanto de la realeza como de otros miembros de la corte. Las pinturas se fechan hacia mediados del siglo XVI puesto que fue en 1567 cuando la sala estuvo definitivamente ornamentada.

Por esta época Felipe II, como se ha comentado anteriormente, ya había prestado especial interés por la serie de retratos áulicos del alcázar segoviano. Así pues, es palpable su interés por dotar a los principales espacios regios de estancias decoradas con esta clase de imágenes. Sin embargo, el 13 de marzo de 1604, durante el reinado de Felipe III y su esposa Margarita, se produjo un incendio en el cuarto de la reina que alcanzó la sala contigua y se destruyeron todas las representaciones que lucían en la parte superior de la estancia. Pese al infortunio, se volvió a construir la decoración de la sala, pero con algunas modificaciones. Ejemplo de ello es el retrato que Juan Pantoja de la Cruz (1553 - 1608) realizó de Carlos V siguiendo el modelo establecido por Tiziano [fig 1.9]. De hecho, la galería tras el incendio remarcaba aún más el linaje de los Habsburgo, remontando sus raíces genealógicas a los Reyes Católicos que emparentaban con miembros recientes de la dinastía, como las hijas de Felipe II junto con sus esposos e hijos. ${ }^{72}$

Además, en 1617 el artista Bartolomé González (1564 - 1627) consiguió el título de pintor del rey, y desde entonces estuvo trabajando para el monarca haciendo numerosos retratos para, por un lado, reconfigurar la galería perdida y por otro, enviar distintas imágenes a las cortes europeas. Por las circunstancias, la mayor parte de estas efigies eran copias de otros originales..$^{73} \mathrm{La}$ citada autora ha incidido en la relevancia 72 María Kusche Zettelmeyer, 'La antigua galería de retratos del Pardo: su reconstrucción pictórica', Archivo español de arte, Vol. 64, no. 255, 1991, pp. 261-292.

73 Alfonso Pérez Sánchez, Pintura barroca en España (1600-1750), (Cátedra: Madrid, 2010), p. 78. 


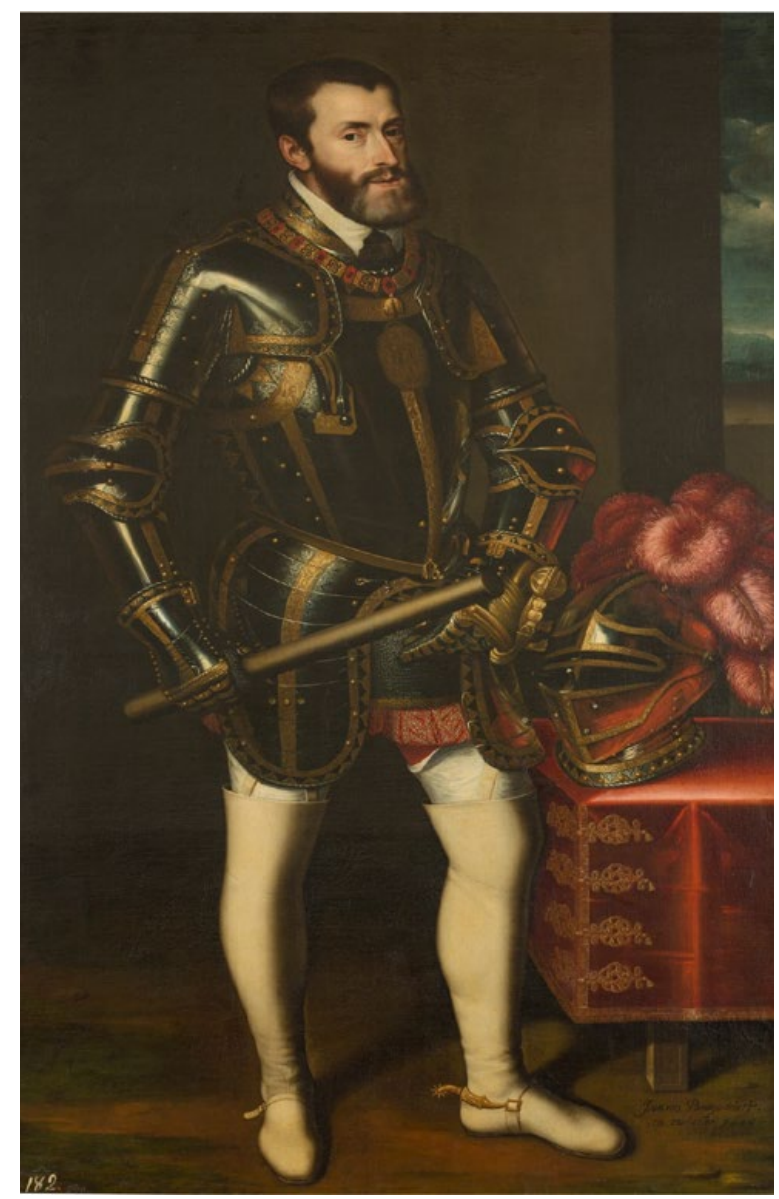

Fig. 1.9. Juan Pantoja de la Cruz, El emperador Carlos V, 1605, óleo sobre lienzo, Madrid, Museo Nacional del Prado.

de este conjunto pictórico teniendo en cuenta el resto de posesiones áulicas de Felipe II. En efecto, el palacio del Pardo era una residencia secundaria destinada al descanso y al recreo que, por su proximidad al alcázar, se convirtió en la segunda residencia oficial del monarca. Su localización, por tanto, determinó que en este caso la galería tuviese un carácter privado. Esto también se explica al ver el germen de todo ello en las obras que el rey había heredado de su tía María de Hungría. Las pinturas, como bien ha aportado Kusche, conectan con la tradición de índole borgoñona, flamenca y alemana de las series de linajes de finales del siglo XIV y principios del XV. Sobre ese primer núcleo, Felipe II diseñó la antigua galería de retratos incluyendo tanto a parientes como a sus amistades más preciadas. No obstante, su disposición guardaba un orden y respetaba los lazos familiares para poner de manifiesto 
la pertenencia a la dinastía Austria. ${ }^{74}$

Ejemplos de salas de linajes también se dan en otros lugares de la geografía europea. Así, es remarcable el encargo que recibió Alonso Sánchez Coello del archiduque Fernando del Tirol quien deseaba poseer una serie de las efigies de las reinas españolas para engalanar la galería que su esposa, la archiduquesa, iba a construir en el castillo de Ambrás en 1565. Unos años más tarde, en 1577 este proyecto debía ampliarse incluyendo a los monarcas varones pero el artista sólo llegó a pintar dos efigies por problemas económicos..$^{75} \mathrm{En}$ cualquier caso, se debe tener en cuenta el importante papel que desempeñó el género del retrato como instrumento de representación del linaje y la especial idoneidad de las galerías de efigies para materializar la idea de transmitir el poder a través de la sangre. Los ejemplos comentados brevemente anteceden y contextualizan, de algún modo, a los tres grupos de retratos monárquicos que se han trabajado en el siguiente capítulo.

De igual modo es interesante estudiar que no sólo la realeza deseó tener esta clase de galerías, sino que la nobleza también ansiaba tenerlas en sus hogares, imitando las existentes en los palacios, aunque por razones completamente distintas. El disponer de un conjunto de estas características señalaba el trato cercano que el noble tenía con los reyes, además de mostrar el respeto y el servicio a la Corona. Igualmente, esta práctica era habitual entre las familias más pudientes que al incluir sus representaciones se estaban enalteciendo a sí mismos. Un ejemplo que se corresponde con esta realidad, como se verá más tarde, es el grupo de retratos de reyes que compró san Juan de Ribera en Madrid y que se encuentra en la biblioteca del Colegio fundado por él mismo.

74 María Kusche Zettelmeyer, 'La antigua galería de retratos del Pardo: Su importancia para la obra de Tiziano, Moro, Sánchez Coello y Sofonisba Anguissola y su significado para Felipe II, su fundador', Instituto Diego Velázquez: Madrid, Archivo español de arte, Vol. 65, no. 257, 1992, pp.1-36.

75 Serrera, 'Alonso Sánchez Coello...', p. 56. 
Por lo general, eran los propios soberanos quienes solían regalar retratos suyos a la nobleza en agradecimiento por su lealtad y entrega. Juan Miguel Serrera destacó las doce efigies que Felipe III decidió regalar al duque de Uceda pintadas por Bartolomé González o el detalle que doña Margarita tuvo con la Condesa de Barajas al obsequiarla con cinco retratos de la familia real elaborados por Pantoja de la Cruz. Otros ejemplos que ha mencionado son los cuarenta y dos retratos de monarcas que figuraron en 1604 en la galería zaragozana del Conde de Sástago; la colección que en 1655 poseía el marqués de Leganés, donde se encontraban las representaciones de Felipe II, sus cuatro esposas y otros reyes europeos; los quince retratos que Sánchez Coello pintó para Mateo Vázquez, secretario del rey; las sesenta y tres efigies que el mismo artista realizó para la casa sevillana de Gonzalo Argote de Molina en torno al $1571 .^{76}$ Las colecciones de imágenes de reyes o de emperadores romanos presentes en los hogares de personas con un alto nivel social y con una posición cercana a la corte junto con los retratos de ellos mismos honraban y ennoblecían su propia casa. Así pues, el poseer retratos de los monarcas no era algo exclusivamente reservado para la familia real sino que también se daba entre otros personajes de prestigio social y de esta forma contribuían a rodearse de dignidad.

Como ya se ha comentado, las galerías de retratos de monarcas daban visibilidad a la estirpe que concentraba el poder. En consecuencia, el término linaje hacía referencia a la relación sanguínea entre los reyes que se suceden en el trono. Así, en el siglo XVII se definía esta palabra como «la descendencia de las casas y familias. Díjose a línea, porque van descendiendo 76 Serrera, 'Alonso Sánchez Coello...', p. 57. Este mismo autor, también ha remarcado la polémica existente en la época por incluir retratos de la realeza en los hogares de personas no pertenecientes a la nobleza. Para ello, toma la reflexión de Alonso de Cabrera en uno de sus sermones en el cual critica a la sociedad española en la época de Felipe II y su fuerte deseo por mostrar vínculos con las esferas del poder: «Ahora no hay que más se use. Quiera uno decir que esta casa es suya, y que viene por línea recta de los reyes godos de España, y haya dineros, que no digo yo con dos testigos, sino con dos docenas los probara.» 
de padres, hijos y nietos, etc, como por línea recta.» ${ }^{77} \mathrm{Si}$ en estos casos, las efigies evidenciaban una prosapia determinada y la transmisión del poder, también hay que valorar otras galerías donde se puede hablar de un linaje simbólico, en las que el vínculo entre sus miembros es de otra índole pero que de forma alegórica conforman una familia donde el traspaso del gobierno y el relevo de este de forma ininterrumpida es, en definitiva, una señal de estabilidad. Esta reflexión se ilustra al conocer, por ejemplo, las series icónicas de prelados que engalanan las sedes de numerosas diócesis por todo el territorio hispánico.

Además de las razones genealógicas, el retrato también estuvo ligado a otros conceptos como la fama o la memoria, términos que caminan hacia la exaltación de la persona efigiada. De hecho, en una sociedad donde la división de clases era muy marcada y donde la religión católica tenía un enorme peso, gozar de cierta fama, en la acepción positiva de la palabra, era una cuestión a valorar. Siguiendo a Covarrubias «[...] es fama todo aquello que de alguno se divulga sea bueno o malo; y así decimos: Fulano es hombre de buena fama o de mala fama. $[\ldots]{ }^{78}$ Esta notoriedad positiva se daba entre la clase privilegiada y probablemente ya se le presuponía una honradez que en aquel momento no se concebía como la integridad de la persona al actuar, sino que su definición conectaba mejor con aquello que se consideraba como buena fama. Por ello, un hombre honrado era "[...] el que está bien reputado y merece que se le haga honra y reverencia [...] ${ }^{79}$

En este sentido, es claro que los retratos son la imagen de personas bien afamadas, consideradas y admirables según la mentalidad de la época. A ellas también se las puede denominar con el término de «ilustres». Ya en el siglo XVII la defini-

77 Covarrubias, Tesoro de la lengua..., p. 768.

78 Covarrubias, Tesoro de la lengua..., p. 583.

79 Covarrubias, Tesoro de la lengua..., p. 697. 
ción oficial que se dio respecto a esta palabra remite al linaje, a la fama y reputación de la persona. Por tanto, se entendía por ilustre al «[...] hombre noble, de alto linaje y de gran renombre y fama, por sí y por sus mayores. [...] La Ley de Partida 3, tit. 14, part. 4 dice así: "Ilustres personas son llamadas en latín las personas honradas de gran guisa, y que son puestos en dignidades, así como los reyes, y los que descienden de ellos, y los otros hombres honrados semejantes de éstos." ${ }^{80}$

Resulta reseñable observar el gran número de galerías dedicadas a hombres ilustres y que, generalmente, de sus representados no se destaca su pertenencia a una determinada familia sino que son valorados por los éxitos académicos o profesionales conseguidos. Las efigies de varones ilustres en los siglos XVII y XVIII, habitualmente, se corresponden con hombres exitosos en el conocimiento de cualquier disciplina propia de las ciencias humanas o de las experimentales y este es un aspecto que no parece contemplar la definición de Covarrubias. Así pues, se observa un desajuste entre la acepción que estrictamente se dio al término «ilustre» y el perfil de aquellas personas que fueron consideradas como tales. Sin embargo, probablemente se deba reflexionar sobre esto y plantearse si los retratos de los llamados hombres ilustres, excelsos en sus áreas de conocimiento, era un modo de justificar a la vez que reivindicar esta consideración que ya se presuponía a monarcas, nobles y determinadas dignidades. En cualquier caso, es patente que los varones ilustres son personas afamadas y dignas de ser retratadas. De hecho, al ser iconos o modelos a seguir en cada uno de sus ámbitos, los hombres ilustres aparecían en aquello que Covarrubias definía por «icones»: «libros de retratos que nos representan las figuras de ilustres varones traen sobre escrito y título, [...]» Por ello, conviene estudiar en profundidad algunas galerías de personajes ilustres y a su vez, entender con mayor claridad la valoración que se tuvo del retrato en el pasado.

80 Covarrubias, Tesoro de la lengua..., p. 731. 
Pertenecer a un determinado linaje, tener fama, considerarse honrado y calificarse de ilustre son cuestiones que confluyeron en las imágenes a través de los retratos y además, contribuyeron a que perdurase la función primitiva de este género; la existencia de la memoria. Una vez más Covarrubias explicó este término diciendo que: «algunas veces se toma memoria por lo que dejan instituido nuestros mayores, por lo cual tenemos memoria de ellos, como hospitales y obras pías. Y éstas son las buenas memorias». Por tanto la memoria es, en definitiva, recordar a nuestros antepasados, pero recordarlos por aquello que han hecho o han enseñado. Así pues, muchas de las efigies estudiadas en esta investigación hacen hincapié en los éxitos de los representados, justificando de esta manera el ser retratados y permanecer en la memoria.

En una sociedad definida por la división de clases, como sucedía por ejemplo en los siglos XVII y XVIII, la muerte era lo único que no entendía de diferencias económicas, culturales o sociales. Sin embargo, fue la propia clase privilegiada la que encontró diversas vías por las que distinguirse, incluso, después de la muerte. Una de ellas, y posiblemente de las más potentes, fue el retrato. Al teorizar acerca de quién puede efigiarse y quién no y al incluir inscripciones conmemorativas con alusiones a los numerosos hitos conseguidos, se está haciendo una selección, una valoración y una discriminación entre aquellos que deben permanecer en el recuerdo de la sociedad, en la mentalidad de las generaciones venideras, y por tanto, mantenerse vivos de forma simbólica, y entre aquellos que no merecieron esta ficticia inmortalidad. 
$x^{2}{ }^{2}$

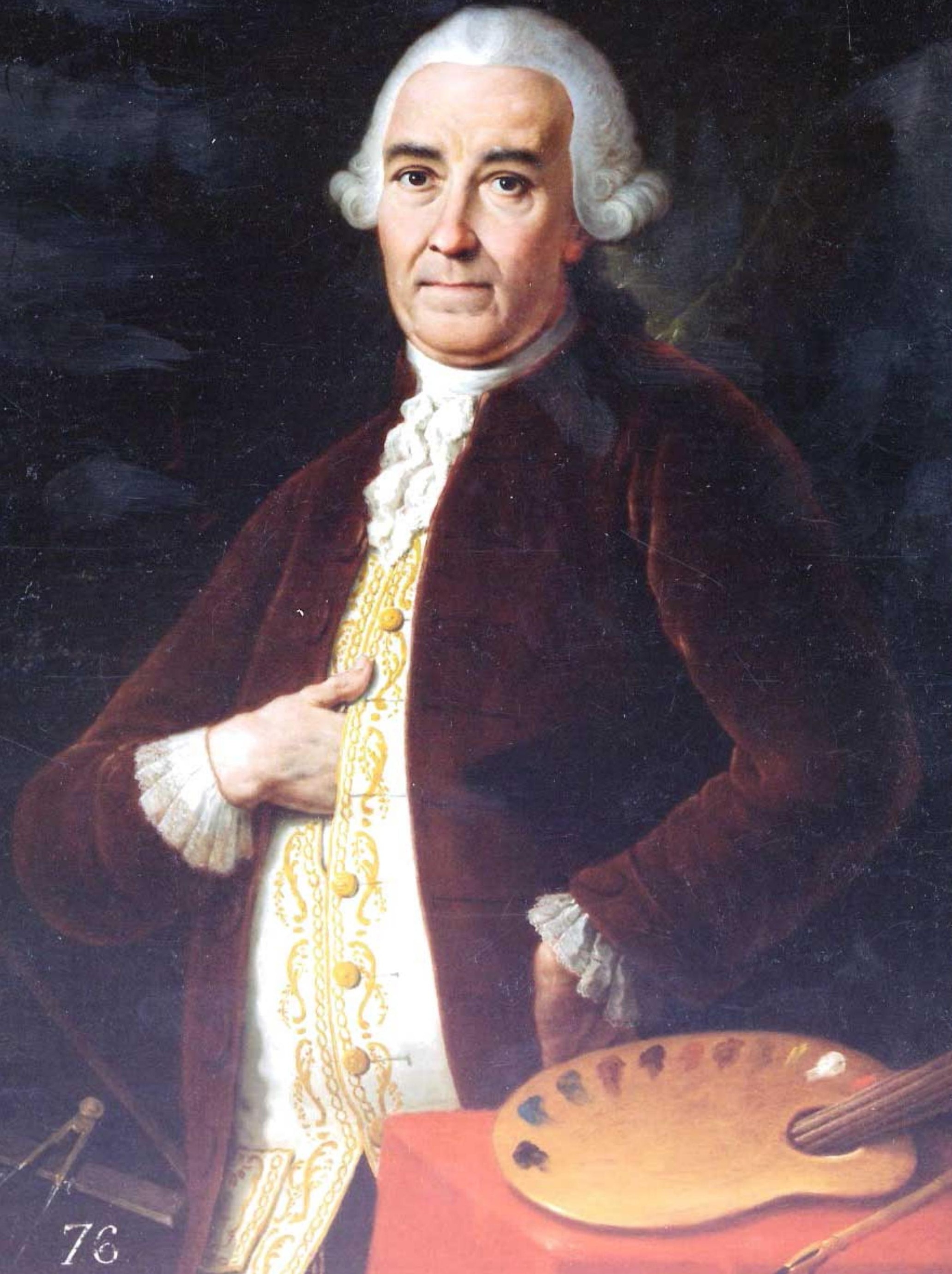




\section{Capítulo 2 \\ Los retratos y sus artífices en el medio hispano y valenciano. De la reforma católica a la desamortización (1835).}

Después de haber tratado distintas cuestiones teóricas acerca del retrato conviene fijar la mirada en la presencia de este género pictórico en el territorio hispánico y valenciano. De este modo es factible apreciar cómo se introdujo un vocabulario y una estética determinada para el retrato en el siglo XVI que siguió influyendo en este género posteriormente. Así, artistas como Tiziano y Antonio Moro dejaron su impronta en otros pintores como Alonso Sánchez Coello (1531-1588) y más tarde en Juan Pantoja de la Cruz (h. 1553 - 1608). El lenguaje empleado para el retrato en esta época, como se observará en los capítulos siguientes, tuvo su repercusión en las obras producidas en Valencia. Igualmente es necesario tener en cuenta quiénes fueron los principales artífices de los retratos estudiados así como se debe ubicar su producción artística en el ámbito espacial y temporal correspondiente. Por ello, también se ha hecho referencia a los autores más significativos que entre sus obras se han encontrado efigies que han engrosado los conjuntos analizados en la presente tesis.

Las galerías de retratos son proyectos artísticos que pueden abarcar un amplio marco cronológico, puesto que a través de varias centurias se han ido configurando. Por dicha razón, esta investigación no se ha podido delimitar en unos años específicos, sino que se ha encuadrado en los siglos más importantes en cuanto a la creación y desarrollo de los conjuntos pictóri- 
cos. Esta circunstancia justifica la existencia del presente capítulo, el cual viene a sintetizar la idea que se tenía del retrato, las características y las circunstancias que arroparon este género entre los siglos XVI y XIX. Por ello, se ha hecho referencia a los precedentes del retrato en el siglo XVI. También se ha reflexionado sobre el papel desempeñado por este género en el ambiente de la reforma católica. Además, se ha valorado la repercusión del cambio estético propio del siglo XVIII y del surgimiento de las academias. Por último, se ha atendido al siglo XIX porque fue determinante para el futuro de muchísimas de las galerías estudiadas. Además, en este tiempo hubo un mayor aprecio por el retrato como se desprende de la creación de la Junta de Iconografía Nacional en 1876, cuyo objetivo era recopilar e inventariar las representaciones de los personajes ilustres españoles. En definitiva, el objetivo es dotar de un marco genérico que contextualice las obras y los artistas que configuraron las series, galerías y colecciones, así como se entiendan las circunstancias que las rodearon.

\subsection{El retrato en el siglo XVI. De las imágenes de donantes al retrato autónomo.}

En el inicio del siglo XVI el género del retrato en el medio hispano aún estaba sujeto a las normas medievales. Por esta razón, lo más común era incluir la efigie del representado en una escena religiosa, habitualmente se trataba de un Cristo como varón de dolores (imago pietatis) o la imagen de alguna santidad por la que se sentía una especial devoción. ${ }^{1}$ En ambos casos el personaje efigiado se mostraba en calidad de donante y así cumplía con varios objetivos a la vez: era retratado, dejaba constancia de su capacidad económica para costear la pieza, mostraba sus devociones particulares, su fe y su deseo

1 Se ha seguido a Leticia Ruiz Gómez, 'La creación del retrato español en el siglo XVI', en Leticia Ruiz Gómez (ed.), El retrato español en el Prado. Del Greco a Goya, (Museo Nacional del Prado: Madrid, 2007), p. 37. 
de conseguir la salvación espiritual. Hay algunos ejemplos procedentes de Valencia de finales del siglo XV y mediados del siglo XVI que se pueden tomar para ver la integración del retrato en escenas devocionales. De Paolo de San Leocadio se conserva La Virgen del caballero de Montesa (fig. 2.1). En el centro de la tabla se encuentra la Virgen entronizada y sosteniendo al niño en brazos y a ambos lados aparecen san Benito y san Bernardo. ${ }^{2}$ Res-

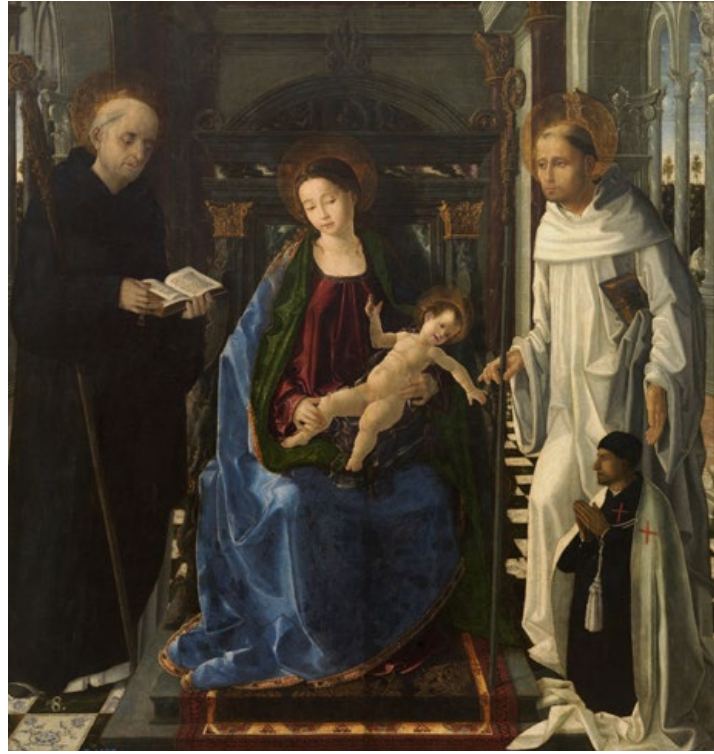

Fig. 2.1. Paolo da San Leocadio, La Virgen del caballero de Montesa, 1472 - 1476, óleo sobre tabla, Madrid, Museo Nacional del Prado. pecto a la figura del donante, se respeta la fórmula tradicional para esta clase de imágenes. Aparece situado en el margen de

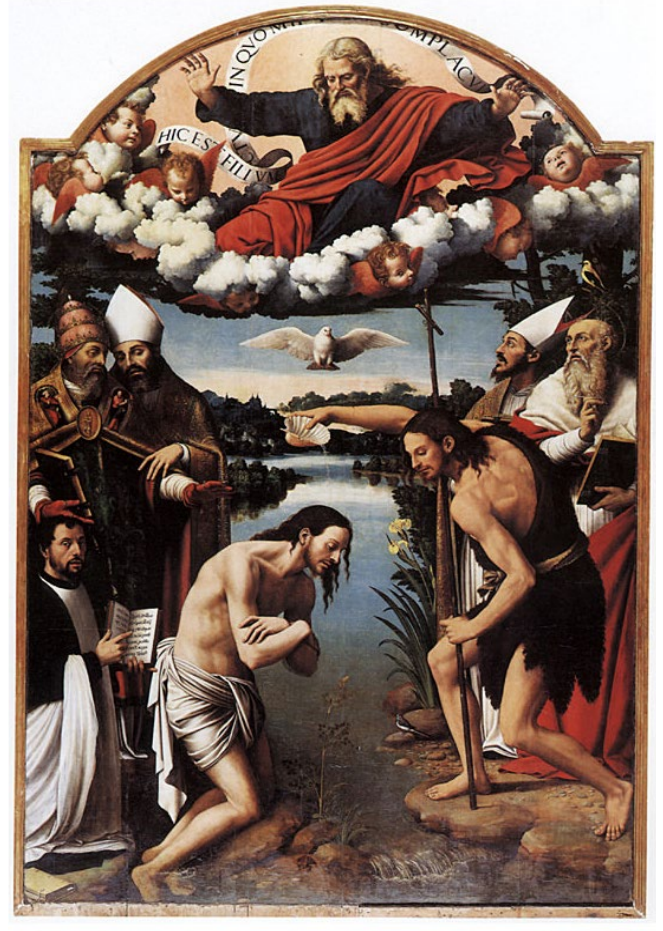

Fig. 2.2. Juan de Juanes, Bautismo de Cristo, 1535, óleo sobre tabla, Valencia, Catedral. la obra, arrodillado y en actitud orante, en este caso ataviado con el hábito de la orden de Montesa. El tamaño de su figura no guarda proporción con el resto de los personajes pues realmente es ajeno a la escena narrativa pero su presencia allí tiene un valor testimonial.

Juan de Juanes (ca. 1500 - 1579) pintó el Bautismo de Cristo (fig. 2.2) incluyendo otros personajes foráneos a los necesarios en la escena principal. Por ello, además de mostrar a Jesús arrodi2 Ximo Company Climent, Paolo da San Leocadio i els inicis de la pintura del Renaixement a Espanya, (CEIC Alfons el Vell: Valencia, 2006). 
llado ante san Juan, a Dios Padre y al Espíritu Santo en forma de paloma, también ha incluido a los padres de la Iglesia; san Jerónimo, san Agustín, san Ambrosio y san Gregorio. Es más, en la parte inferior izquierda se muestra a un sacerdote valenciano, arrodillado, mirando hacia el espectador y sosteniendo un libro abierto. Se trata de Juan Bautista Agnesio (1480 - 1553) reputado teólogo y humanista de la época que aparece retratado en calidad de donante. Borja Franco Llopis ha aportado una interpretación actualizada de la obra que permite conocer en profundidad el significado de la misma. Para ello, el autor ha analizado la relación del artista con el venerable, considerando que el segundo no se limitó a encargar la obra simplemente, sino que participó activamente en la planificación y concepción de la imagen y de su significado. Así en el escrito en griego y hebreo que se encuentra en el libro abierto sostenido por Agnesio, ha visto un mensaje de fomento del bautismo entre los moriscos, idea que encaja satisfactoriamente con el pensamiento del sacerdote y la realidad histó114 rica valenciana. Según Franco Llopis, el objetivo del retratado era promover la conversión de los musulmanes sin obligarles, sino enseñándoles. Además, se incitaba al adoctrinamiento de aquellos fieles convertidos y de aquellos cristianos con pocos conocimientos en materia eclesiástica. ${ }^{3}$

Este mismo personaje ha sido representado en otra de las pinturas de Juanes, La Virgen del venerable Agnesio (fig. 2.3), también conocida como los desposorios místicos del citado protagonista. Al contrario que en el ejemplo anterior, aquí sí que se ha integrado al sacerdote como un personaje más dentro de la escena narrativa y su imagen guarda una mayor armonía con el resto de figuras. Seguramente ello se deba a que se trata de una pintura conmemorativa, realizada como pronto en 1553 , año del fallecimiento de Agnesio. De hecho, se ha apuntado

3 Para tener un mayor conocimiento de esta pintura se ha consultado a Borja Franco Llopis, 'Releyendo la obra de Joan de Joanes. Nuevas aportaciones en torno al Bautismo de Cristo de la Catedral de Valencia y la conversión morisca', Espacio Tiempo y Forma. Serie VII, Historia del Arte, no. 25, 2012, pp. 67-82. 


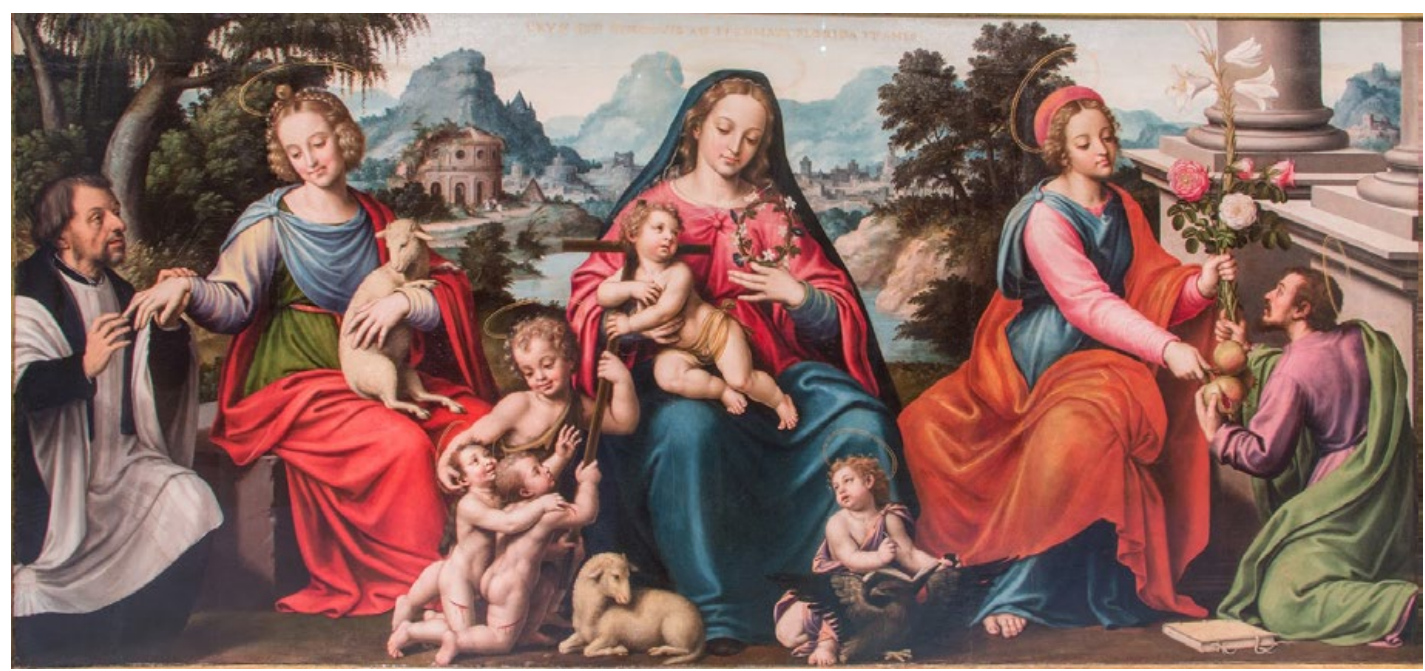

Fig. 2.3. Juan de Juanes, La Virgen del venerable Agnesio, 1553 - 1558, óleo sobre tabla, Valencia, Museo de Bellas Artes.

que fue el conde Francisco Gilabert de Centelles, discípulo del religioso, quien encargó la obra. ${ }^{4}$ Se aprecian tres grupos de personajes dispuestos todos ellos en forma piramidal. A la izquierda se ha representado la unión mística entre el venerable y santa Inés, por ser su protectora. En el centro se ha incluido a la Virgen con el niño, san Juan y varios inocentes. Por último, en el extremo derecho se ha pintado a santa Dorotea y san Teófilo. En este caso, por tanto, se ha visto una evolución en la inclusión de retratos en imágenes religiosas. El venerable Agnesio ya no se ha representado al estilo medieval de los donantes sino que ahora, por la función memorial de la obra, se ha homogeneizado con el resto de figuras formando parte de hilo narrativo de la imagen.

La presencia de donantes en escenas religiosas fue un recurso que se siguió empleando hasta el siglo XVII, aunque fue a mediados del XVI cuando definitivamente se configuró el retrato autónomo. Cabe tener en cuenta que estas piezas se colocaban en las capillas y por tanto, los retratos se hallaban en un espacio de culto y su cometido era distinto al de las repre-

4 Un análisis pormenorizado de la pieza se encuentra en Daniel Benito Goerlich, 'Lectura iconográfica de los "Desposorios místicos del Venerable Agnesio" de Juan de Juanes', Saitabi: revista de la Facultat de Geografia i Història, no. 45, 1995, pp. 53-68. 
sentaciones exentas. Juan de Juanes, apreciado por sus especiales cualidades para el retrato, también elaboró imágenes individuales. En su producción artística es apreciable el doble cariz que tuvo este género, por un lado integrado en escenas religiosas y por otro lado, adquiriendo progresivamente un papel más independiente al realizar efigies particulares. Uno de los ejemplos más significativos es el retrato de Alfonso $V$ de Aragón (fig. 2.4), en el que se ha conseguido recoger el modelo de monarca moderno, aquel que domina tanto la disciplina bélica como cultiva el intelecto. Por ello, se ha vestido con la armadura y en la imagen se han incluido numerosos li- Fig. 2.4. Juan de Juanes, Alfonso $V$ bros abiertos, motivo de uno de sus emblemas, para mostrarlo

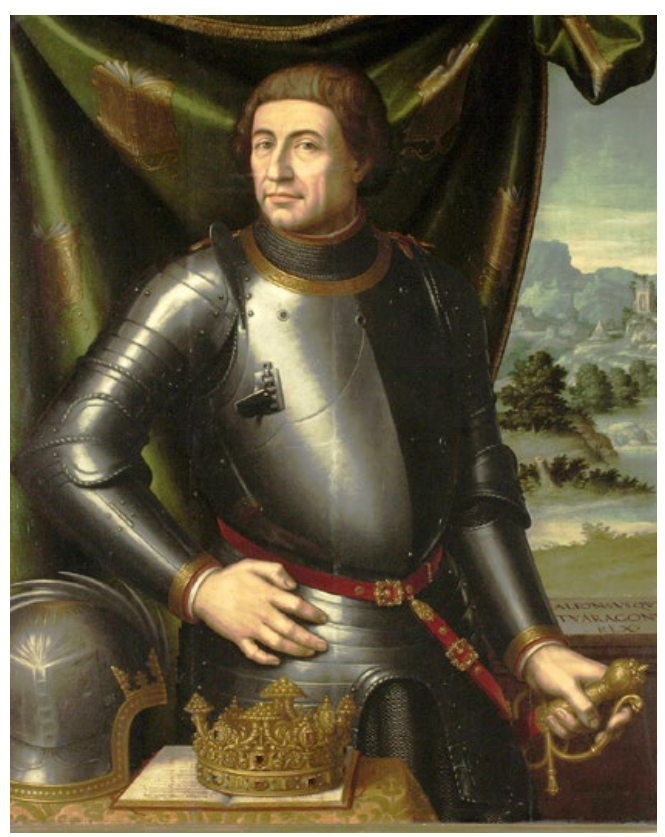

de Aragón, 1557, óleo sobre tabla, Zaragoza, Museo de Zaragoza. como un hombre propio del Renacimiento. La efigie, realizada prácticamente un centenario después de la muerte del rey (1458), fue un encargo hecho por los jurados de la ciudad al pintor valenciano. Así pues, se trata más bien de un retrato representativo de la concepción que se tenía de su persona y que encaja con la imaginería pensada y elaborada para él. ${ }^{5}$

El retrato autónomo, en síntesis, por las funciones que asumió este tipo de imagen así como su formato fue especialmente útil para los usos que la Corona hacía de ellos. Por ejemplo,

5 Se ha seguido el artículo de Gema Belia Capilla Aledón, 'El poder representado: Alfonso V El Magnánimo (1416-1458)', Res publica, Vol. 18, 2007, pp. 375-394. Se trata de un avance a su tesis doctoral que tomó el mismo título que el escrito citado. Aquí, en concreto, a través de algunos ejemplos puntuales ya va ilustrando la idea de que la escritura y las artes visuales estuvieron al servicio del poder político para crear un imagen muy preparada y controlada de Alfonso V de Aragón con el objetivo de legitimarse en su acceso al trono napolitano y proyectarse en el futuro. 
en época de los Reyes Católicos las efigies de los monarcas y familiares eran de un tamaño pequeño para facilitar su transporte dado que no había una residencia cortesana fija.

En definitiva eran objetos de carácter privado, muy eficaces como carta de presentación en las negociaciones matrimoniales y no disponían de la connotación oficial que adoptó este género posteriormente. En consecuencia los retratos individuales estuvieron, desde su aparición, plenamente vinculados a las necesidades y los usos que la monarquía hizo de estas imágenes. Fue con la dinastía Austria, y concretamente a lo largo de los reinados de Carlos V y Felipe II, cuando se fijaron los parámetros básicos para las efigies oficiales que se resumen en lo siguiente; individualización del representado, alusión a su categoría y papel a desempeñar en la sociedad y por último, elaboración de retratos generalmente austeros en cuanto a los aspectos formales. ${ }^{6}$

El siglo XVI, por tanto, estableció el modelo de retrato de corte que perduró hasta el XVIII y que tuvo una gran proyección política y social. Es más, el secreto del éxito fue la capacidad para cumplir con las necesidades representativas de la monarquía, independientemente de las circunstancias políticas y religiosas propias de cada territorio. Por esta razón, el modelo de retrato implantado a raíz de las obras de Tiziano fue empleado en otras cortes europeas protestantes como Holanda, Sajonia o Dinamarca, donde artistas como Adrian Thomasz. Key, Heinrich Göding y Hans Kieper lo pusieron en práctica. ${ }^{7}$ Conviene tener en cuenta el surgimiento del retrato de corte, conocer sus características y su influencia en este género porque como se podrá apreciar más adelante, muchas de las obras valencianas han bebido de las efigies cortesanas.

6 Ruiz Gómez, 'La creación del retrato...', pp. 37 - 39.

7 Idea basada en Miguel Falomir Faus, 'El retrato de corte', en Miguel Falomir Faus (coord.), El retrato del Renacimiento, (Museo Nacional del Prado: Madrid, 2008), pp. 109-123. 


\subsubsection{Tiziano Vecellio, Antonio Moro y el retrato de corte.}

La transformación más significativa en el género del retrato se dio en torno a la coronación de Carlos V como emperador, cuando Tiziano Vecellio (1490 - 1576) demostró ser capaz de elaborar imágenes impregnadas de heroicidad que además podían enseñar diversos aspectos virtuosos del monarca como su capacidad militar, su don para impartir justicia o su inquebrantable fe cristiana. Para ello, el artista veneciano aunó diferentes rasgos estéticos de los modelos germánicos e italianos. De los primeros tomó las representaciones de cuerpo entero, características por su huida de lo rimbombante y alegórico para encontrar la sencillez compositiva. De los segundos incorporó todos los elementos accesorios que daban pie a crear una determinada escenografía como los cortinajes, sillas y bufetes y objetos más personales que aludían directamente al papel monárquico y político del emperador y su familia como los documentos, espadas, yelmos, guantes, 118 pañuelos y abanicos, entre otros. ${ }^{8}$ La inclusión de estos elementos fue acertada para ofrecer un mensaje completo de la identidad del efigiado, pues el capturar tan sólo la apariencia física conllevaba unas limitaciones que podían ser suplidas con la introducción de objetos accesorios y permitían revelar más información acerca de la personalidad y posición social del retratado.

Como ya ha explicado Fernando Checa, el primer contacto entre Tiziano y Carlos V se produjo alrededor de los años 1529 1530, cuando el monarca viajó a Italia por dos razones; una de ellas era resolver las cuestiones políticas pertinentes. La otra era clausurar el ceremonial de su nombramiento como emperador en Bolonia durante el mes de febrero de 1530. Y fue en el transcurso de esta estancia cuando el pintor veneciano elaboró las primeras efigies del césar Austria. Por una carta fechada en Mantua el 10 de octubre de 1529 se ha conocido que el duque Federico II de Gonzaga tenía el deseo de llamar a

8 Ruiz Gómez, 'La creación del retrato...', p. 41. 
la ciudad a Tiziano para retratar al emperador. Por ello, se sobrentiende que fue Federico II quien ejerció de nexo de unión entre Carlos V y el artista. Además, se ha sabido que esta primera representación lo mostraba con armadura pero no se ha conseguido determinar con exactitud qué retrato fue o si finalmente llegó a elaborarse. ${ }^{9}$

Para arrojar más luz acerca de esta primera representación, el autor ha tomado como fuente una descripción de Vasari que tras descubrir algunas confusiones se ha asociado al encargo de un segundo retrato a Tiziano durante la segunda visita del emperador a Bolonia en 1532. Pese a tampoco disponer de la obra original, hay algunas otras imágenes donde Carlos $\mathrm{V}$ viste con armadura y sostiene una espada, que se han considerado próximas a cómo debió ser la pintura original. Así, se tiene constancia de una estampa elaborada por Giovanni Brito (activo entre 1530 - 1550) (fig. 2.5), un retrato hecho por Rubens basado en la estampa de Brito (fig. 2.6), otra estampa de Agos-

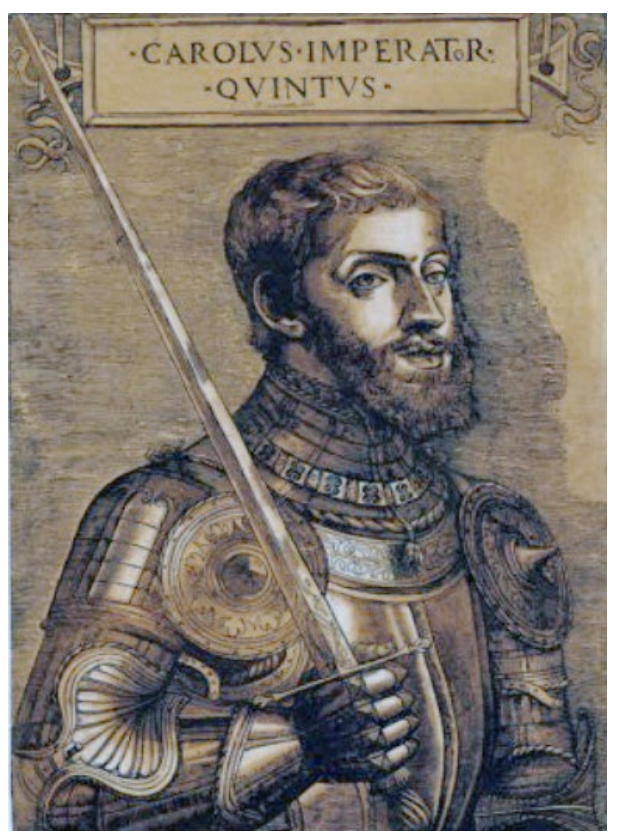

Fig. 2.5. Giovanni Brito, El emperador Carlos V, h. 1540, estampa.

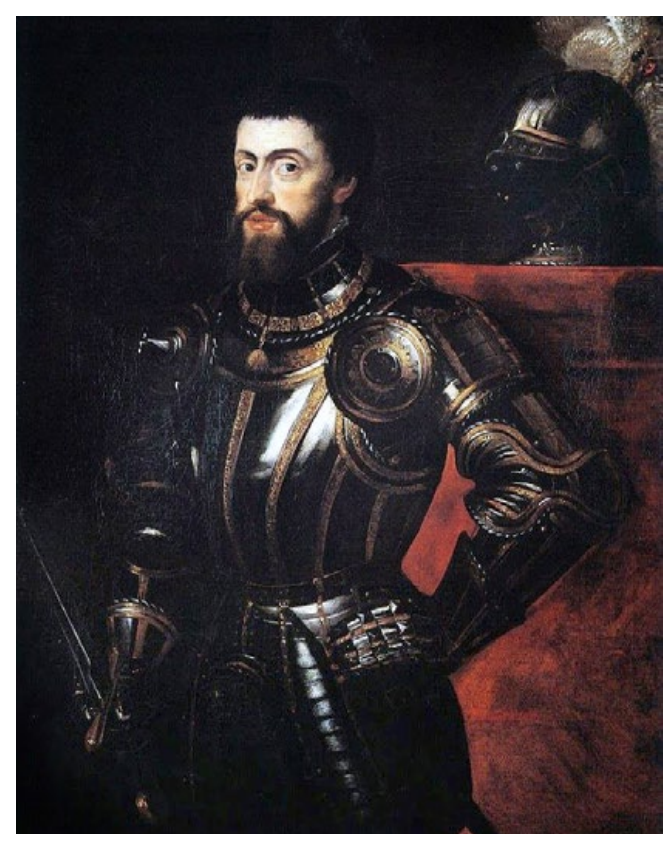

Fig. 2.6. Rubens (copia de Tiziano), Carlos V con armadura, 1603, óleo sobre lienzo, Gran Bretaña, colección particular.

9 Fernando Checa Cremades, Tiziano y las cortes del Renacimiento, (Marcial Pons Historia: Madrid, 2013), pp. 191 - 195. 
tino Veneziano (1490 - 1540) y un retrato anónimo procedente de El Escorial que a día de hoy forma parte de los fondos de Patrimonio Nacional. Lo más significativo de estas imágenes es el valor simbólico que tuvieron, pues Carlos $\mathrm{V}$ fue efigiado según la tradición borgoñona, de medio cuerpo, con armadura y una espada a veces apoyada en el hombro o antecediendo el gesto. La clave de la buena aceptación que tuvo Tiziano desde el inicio por parte de Carlos $\mathrm{V}$ y las cortes imperiales fue su adaptabilidad a las tradiciones y deseos del efigiado sin descuidar la calidad de la pintura y el estilo personal del artista. ${ }^{10}$

Los afamados retratos de cuerpo entero de Tiziano datan de 1532-1533. Una de las grandes aportaciones del artista veneciano fue dotar de majestuosidad a este tipo de efigies que adquirieron una enorme resonancia en el resto de Europa y se establecieron como uno de los formatos más recurrentes y apreciados para las imágenes cortesanas. Ejemplo de ello es el retrato de Carlos $V$ con un perro (fig. 2.7), el cual le abrió las puertas a la corte imperial. ${ }^{11} \mathrm{La}$ imagen es una versión mejorada de la pintura que previamente realizó Jacob Seisenegger (1505 - 1567) basándose a su vez en la tipología ya empleada por Lucas Cranach en 1514 para

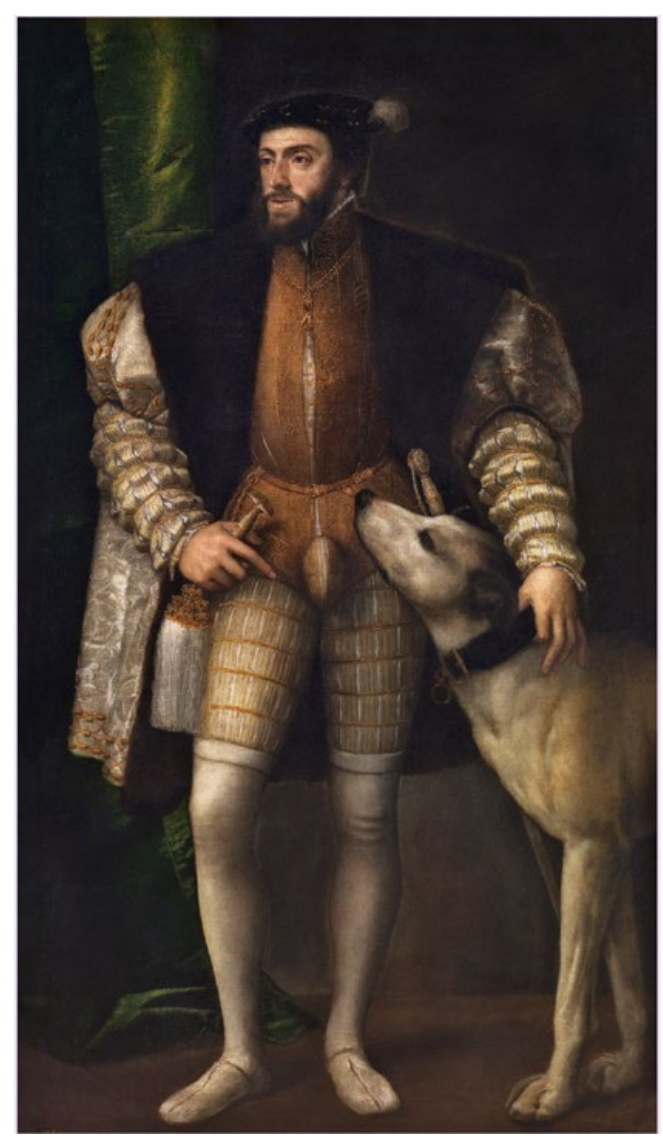

Fig. 2.7. Tiziano, El emperador Carlos V con un perro, 1533, óleo sobre lienzo, Madrid, Museo Nacional del Prado.

Heinrich de Fromme (1514, óleo sobre tabla, Dresde, Staatliche Kunstsammlungen). A partir de la propuesta de Seisenegger Carlos V comenzó, por vez primera, a ser retratado de cuer10 Checa Cremades, Tiziano y las cortes..., pp. 196 - 198.

11 Checa Cremades, Tiziano y las cortes..., pp. 210. 
po entero. La inclusión del perro en las representaciones de gobernantes era una costumbre heredada del retrato borgoñón. La obra de Tiziano se ha considerado una copia mejorada porque al comparar ambas piezas es patente que los rasgos faciales se han dulcificado, el cuerpo se ha estilizado jugando con las vestiduras y con la disposición del emperador en el espacio, haciendo uso de un horizonte bajo que contribuye a conseguir una imagen más majestuosa. ${ }^{12}$

De entre los encargos asumidos por Tiziano para Carlos V hay uno que evidencia la utilización del retrato para mantener en la memoria a los seres queridos ya fallecidos. Poco después de enviudar, el emperador solicitó recuperar el retrato que Isabel de Portugal había enviado a Margarita de Austria, pues desde la pérdida de la emperatriz su imagen adquirió un valor especial por recoger, a su juicio, de forma fidedigna el aspecto de su amada.

Recuerdo que ella [Isabel] envío a nuestra señora tía [Margarita de Austria], su retrato, y no pensando que ella me habría de faltar, no me preocupé de tener su retrato. No he encontrado ninguno mejor que se le parezca que éste. Creo que está en el gabinete de pinturas de nuestra mencionada tía. Os ruego, señora, mi buena hermana, que lo hagáis buscar y si lo encontráis me lo enviéis lo antes que podáis, de manera que no se estropee en el ca$\operatorname{mino}[\ldots] .^{13}$

Este ejemplo, por tanto, nuevamente demuestra que el retrato nació para perpetuar el recuerdo después de la muerte y que, por esta razón, la imagen se ha cargado de emotividad. Es más, ya alrededor de los años 1508 y 1509, Alberto Durero afirmaba que uno de los objetivos principales de la pintura era

12 Falomir ha estudiado pormenorizadamente ambos retratos. Véase las correspondientes fichas catalográficas en Miguel Falomir Faus (coord.), El retrato del Renacimiento, (Museo Nacional del Prado, 2008), pp. 378-380.

13 Checa Cremades, Tiziano y las cortes..., p. 221. 
preservar el aspecto de una persona tras su fallecimiento. ${ }^{14} \mathrm{Es}$, por tanto, evidente que esta función de origen clásico siguió perviviendo a lo largo del tiempo y tenemos casos así también en el Renacimiento.

Entre 1548 y 1549 tuvo lugar el primer viaje Tiziano a Augsburgo para atender los pedidos de la familia imperial. Sus viajes fuera de Italia conociendo sus reticencias a alejarse de su tierra son síntoma de la relevancia para su carrera artística el trabajar para el emperador y su corte. Previendo que durante este viaje tendría que realizar numerosas pinturas, principalmente retratos puesto que eran una herramienta de exaltación personal, fue acompañado de sus hijos Orazio (h. 1528-1576) y Cesare Vecellio (h. 1530-1601) y el pintor alemán Lambert Sustris (1515-1584). ${ }^{15}$

Una de las primeras imágenes que contribuyó a la configura-

ción de la imagen imperial de Carlos V fue su retrato ecuestre conmemorativo del triunfo en Mühlberg (fig.2.8). Seguramente fue un encargo de María de Austria, reina consorte de Hungría, pues así lo invita a pensar la constancia de esta obra en un inventario de 1558 y que después del fallecimiento de la hermana del monarca, tan sólo se haya vuelto a encontrar referencias a la pieza entre todas las obras que configuraron la

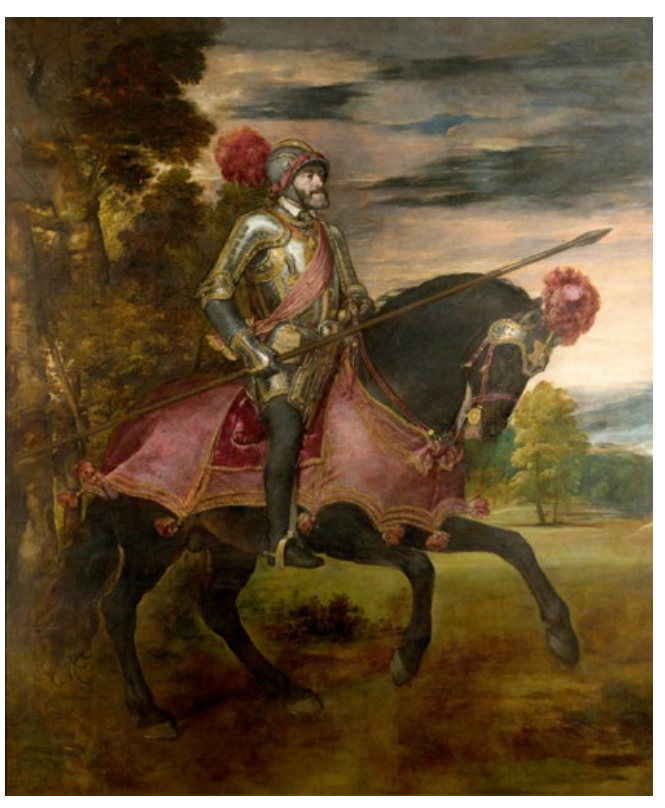

Fig. 2.8. Tiziano, Carlos $V$ en la batalla de Mülhberg, 1548, óleo sobre lienzo, Madrid, Museo Nacional del Prado.

14 Luke Syson, 'Testimonio de rostros, recuerdo de almas', en Miguel Falomir Faus (coord.), El retrato del Renacimiento, (Museo Nacional del Prado: Madrid, 2008), pp. 29-39. 
colección artística de Felipe II. ${ }^{16}$ La tipología de la efigie, como es sabido, hunde sus raíces en la Antigüedad y asocia al emperador Austria con los dirigentes cesáreos. Igualmente, a juzgar por el contexto de la escena representada, así como por la introducción de algunos detalles iconográficos esta imagen se debe entender principalmente en clave política pero también deben verse las cuestiones religiosas, pues en el siglo XVI la política y la religión eran conceptos que iban de la mano.

En síntesis, el retrato muestra a Carlos V victorioso en su conflicto con los príncipes aliados en la Liga de Smalkalda. Las acciones del emperador venían a recriminar y castigar a los señores alemanes por la desobediencia al legítimo rey. De forma más diluida se hace referencia al credo religioso de Carlos V $\mathrm{y}$, en consecuencia, se justifica la lucha contra la considerada herejía protestante. Tan sólo un par de detalles iconográficos reflejan la identidad del emperador como cristiano católico. Uno de ellos es la lanza, arma de san Jorge, quien fue considerado el prototipo de caballero cristiano. El segundo, es la imagen de la Virgen con el Niño grabada en la armadura, hecha hacia 1545 por Helmschmid. ${ }^{17}$ Es el arnés propio del ejercicio de la guerra y no de parada, ello indica que la imagen tiene un sentido conmemorativo de un hecho histórico determinado. Este ejemplo es, por tanto, una de las primeras representaciones del emperador que exalta su poder político y militar, y que dará pie a otros retratos, que no ecuestres, pero sí ataviado con armadura. Tomando las reflexiones de Checa, el retrato de Carlos V en Mülhberg recoge la heroicidad del monarca en una pintura donde la apariencia física se considera fidedigna 16 Checa Cremades, Tiziano y las cortes..., p. 253.

17 A excepción del morrión de tres crestas y de la silla de montar el resto de elementos de la armadura se conservan en la Real Armería. Si bien no hay constancias escritas del nexo entre la armadura y la batalla, sí que se ha sabido que el emperador marchó con ella desde Bruselas a España, camino Yuste y seguramente fue una de sus favoritas puesto que al estar adaptada a su desgaste físico se sentiría cómodo con ella. Álvaro Soler del Campo (coord.), El arte del poder: la Real Armería y el retrato de corte, (Museo Nacional del Prado: Madrid, 2010), p. 138. 
y por tanto, le aporta veracidad a una efigie conmemorativo de un acontecimiento histórico. ${ }^{18}$

Por el contrario, en la imagen de Carlos $V$ sentado (fig. 2.9) se ha preferido mostrarle como un hombre melancólico, sin repudiar por ello a la atmósfera de magnificencia propia de los Austria. La presencia del poder en este tipo de retrato, distinto a las representaciones oficiales regias, es perceptible a través de varios detalles; el distanciamiento entre el efigiado y el espectador, el collar del Toisón de Oro que destaca sobre la austera vestimenta negra, el sillón de terciopelo, el cortinaje damascado y la columna colosal que delimita el espacio interior del paisaje. Lo novedoso de esta imagen, por tanto, es el aunar en una única pintura un retrato de uso privado, despojado del papel representativo y oficial que podía desempeñar, pero que mantiene la magnificencia propia de

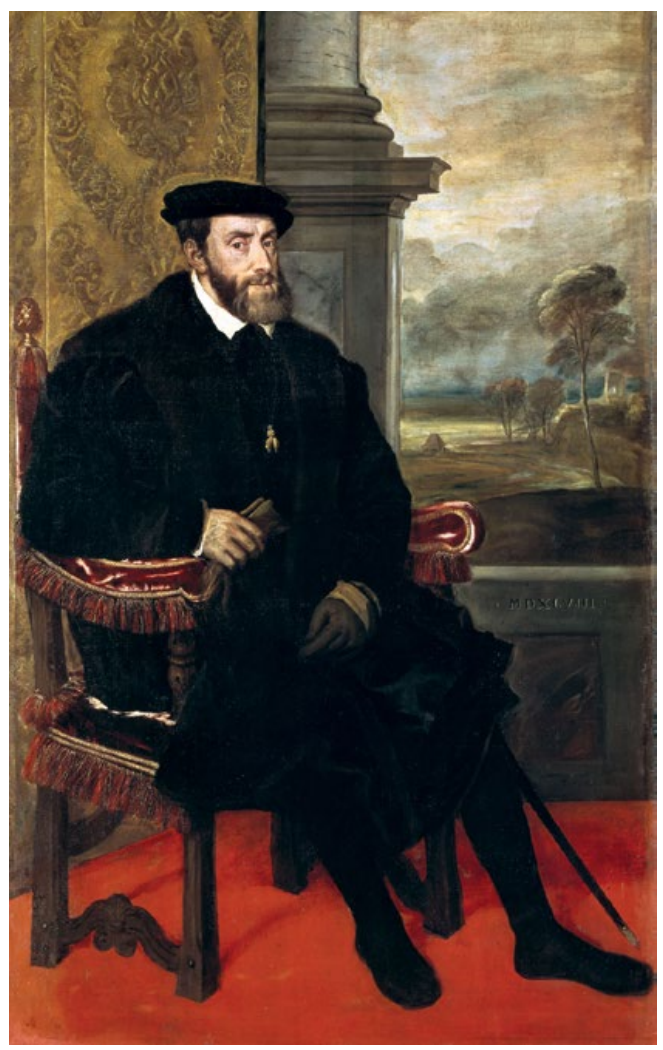

Fig. 2.9. Tiziano, Carlos $V$ sentado, 1548, óleo sobre tela, Múnich, Bayerische Staatgemäldesammlungen, Alte Pinakothek. las efigies públicas. De hecho, seguramente fue algún miembro de la familia Fugger, quienes tenían una estrecha relación con el emperador y habían apoyado su elección como cabeza del Sacro Imperio, quien encargó este retrato..$^{19}$ De ser así, los Fugger se hicieron con una imagen que al estar entre sus posesiones denotaba el aprecio y la amistad cercana que mantenían con Carlos V. Probablemente, no hubiese sido lo mismo si la pintura reprodujese la tipología oficial de los retratos regios, pues al mostrar al em18 Checa Cremades, Tiziano y las cortes..., p. 268. 
perador en un ámbito más íntimo sin desperdiciar un ápice de su poder los Fugger hacían alarde de su proximidad y buena sintonía con el monarca.

Los retratos que Tiziano elaboró de Carlos $\mathrm{V}$ contribuyeron a mejorar las representaciones oficiales, también conocidas como las efigies de estado o de aparato. Así pues, se apostó por las imágenes de cuerpo entero y de tamaño natural, en contraposición de las efigies de busto de tradición medieval. Un claro exponente de este cambio se encuentra en la conocida imagen del emperador ataviado con armadura y botas blancas, sosteniendo el bastón de mando y posando junto a un bufete en el que se ha colocado el yelmo con una cimera compuesta de pomposas plumas. El retrato original y elaborado por el artista veneciano ha llegado a nuestros días a raíz de las copias elaboradas por Juan Pantoja de la Cruz (véase la fig. 1.9). Como se podrá apreciar en el capítulo dedicado a las galerías monárquicas, el prototipo de imagen creado por Tiziano se repitió en distintas ocasiones o fue un modelo inspirador para otros artistas, pues así se observa en el retrato de Carlos V conservado en la biblioteca del Real Colegio Seminario del Corpus Christi de Valencia. De este modo, se puede ver la trascendencia que tuvo el retrato "ticianesco" y comprobar que verdaderamente contribuyó a crear la imagen oficial y de poder del emperador.

María de Austria o de Habsburgo (1505-1558), también conocida como María de Hungría a consecuencia de su enlace matrimonial con el rey Luis II de Hungría en 1521, incitó a estrechar las relaciones entre el emperador, es decir su hermano, y Tiziano. ${ }^{20}$ De este personaje se ha destacado su gusto por el arte, cultivado por su tía Margarita de Austria. La reina María supo ver que el arte podía desempeñar un papel fundamental en la exaltación del poder de la Casa de Austria y especialmente de

20 Sobre el papel desempeñado por María de Hungría respecto a las artes se ha consultado a Cruz María Martínez Marín, 'El mecenazgo artístico de María de Hungría en el contexto europeo', en el VI Congreso virtual sobre Historia de las Mujeres, (Archivo Histórico Diocesano de Jaén: Jaén, 2014), pp. 21-35. 
monarcas y príncipes. Por esta razón no es de extrañar que, como se ha mencionado anteriormente, ella seguramente promoviese la realización del retrato de su hermano victorioso en Mühlberg, siendo consciente de las connotaciones políticas y religiosas que albergaría una efigie contextualizada en un conflicto histórico.

La presencia de retratos en la colección de esta dama puso de manifiesto la importancia de este género pictórico como medio de propaganda y honra al linaje de los Habsburgo y al núcleo familiar, del que ella misma formaba parte. En su inventario post-mortem se ha dejado constancia de las efigies que configuraron su galería de retratos en el palacio de Coundenberg (Bruselas), unas obras que posteriormente heredó su sobrino Felipe II e integró en la colección de El Pardo. Estas obras también fueron pintadas por Tiziano y en ellas se han representado a diversos miembros de los Habsburgo muy cercanos a María de Hungría. Así, por ejemplo, además del famoso retrato ecuestre del emperador, había otros que lo mostraba con armadura y bastón de mando. Siguiendo esta modalidad, se incluyó una efigie de Felipe II armado y con zapatos blancos. También constaba el retrato de la propia María con toca de viuda, creando así un tipo iconográfico que pervivió posteriormente. Por ejemplo, una vez más, se puede remitir a los retratos monárquicos del Colegio del Corpus Christi donde aparece la hermana del emperador como viuda. Asimismo, en la galería familiar también estaban sus sobrinas Cristina y Dorotea, hijas de su hermana Isabel de Austria, cuyos retratos no han llegado a la actualidad. Además, había un retrato de su hermano Fernando I, quien relevó a Carlos V frente al Sacro Imperio. Por último, se encontraban las efigies de Maximiliano II y Fernando II, hijos de Fernando I y sobrinos tanto de Carlos V como de la promotora de la serie..$^{21}$ Era, por ello, un conjunto de piezas compuesta por hermanos, tíos y sobri$21 \mathrm{El} \mathrm{listado} \mathrm{de} \mathrm{retratos} \mathrm{que} \mathrm{aparece} \mathrm{entre} \mathrm{las} \mathrm{posesiones} \mathrm{de} \mathrm{María} \mathrm{de} \mathrm{Hun-}$ gría es verdaderamente extenso y hace gala de la trascendencia de este género en las colecciones reales. De hecho, es relevante la importancia del retrato para configurar genealogías, pues así se comprueba al especificar 
nos principalmente, donde se ha reflejado la transmisión del poder entre familiares y se ha mostrado parte del linaje de la Casa Austria.

La multitud de pinturas elaboradas por Tiziano Vecellio (1490 - 1576) para Carlos V y más tarde para Felipe II, sin duda, tuvieron su eco en las obras realizadas por otros artistas durante el siglo XVI. Así, la producción artística del pintor veneciano se convirtió en un referente en la época al formar parte de la decoración pictórica del monasterio de san Lorenzo de El Escorial, pues esta arquitectura cumbre del Renacimiento era un punto de encuentro de numerosos artistas y personalidades cercanas a la corte. Si bien en sus obras abordó temáticas entre sus bienes que había: "Otro pergamino grande con las genealogías de los reyes de Castilla y casas de Borgoña, muy rico, pintados y retratados en los reyes que ha habido.» Por mencionar algunos ejemplos interesantes, cabe decir que también contaba con un: «retrato de Ludovico, rey de Hungría y Bohemia, marido de la dicha serenísima reina, en lienzo.» «Otro lienzo, y en él retratado el rey don Fernando, hermano de su majestad.» «Un retrato grande del emperador don Carlos nuestro señor, a caballo, armado, con un morrión en la cabeza y descubierto el rostro. Está de la suerte que iba contra los rebeldes cuando prendió al duque de Sajonia. La cual está en un lienzo grande metido en una caja larda, redonda. Hecho el dicho retrato por Tiziano.» «El retrato del rey don Felipe nuestro señor, armado el medio cuerpo, con calzas blancas y zapatos blancos, quitado el morrión y una manopla. Hecho por Tiziano, en lienzo, metido en una caja redonda cubierta de lienzo gordo.» "Otro retrato de la serenísima reina María de Hungría, con su tocado y vestido que traía de ordinario, hecha sobre lienzo por Tiziano.» «El retrato del rey Fernando de romanos, que al presente es emperador, armado y sin morrión, hecho por el dicho Tiziano sobre lienzo.» «El retrato del emperador Carlos V nuestro señor, en lienzo, armado con un bastón hecho por Tiziano.» «El retrato de la emperatriz nuestra señora Isabel, mujer del emperador nuestro señor, en lienzo hecho por el maestro Guillermo.» «El retrato del archiduque Ferdinando, hijo del rey don Fernando emperador, armado y descubierta la cabeza y rostro, hecho por Tiziano.» «Los retratos de cuatro hijas del rey de romanos, que al presente es emperador, en cuatro lienzos hecho por Tiziano.» «El retrato de la reina de Portugal doña Catalina, hermana de nuestro emperador, entero hecho en lienzo por Francisco de Holanda, metido en una caja forrada en terciopelo verde.» Véase a Fernando Checa Cremades, Los inventarios de Carlos $V$ y la familia imperial. The inventories of Charles $V$ and the imperial family, (Fernando Villaverde: Madrid, 2010), vol. 3, pp. 2897, 29132914. 
religiosas, mitológicas y retratos, estos últimos ejercieron su influencia en aquellos artistas vinculados al ámbito cortesano. De hecho, en ocasiones se tomaron las representaciones de Tiziano como modelo para extraer diferentes copias y emplazarlas en nuevos lugares. De este modo se contribuyó a la difusión de un prototipo de retrato regio con tintes de heroicidad que tuvo su trascendencia en las efigies cortesanas posteriores. ${ }^{22}$

Además de Tiziano, Antonio Moro (ca.1516/1519 - 1576) fue otro de los retratistas que dejó su impronta en este género. Ambos artistas junto con otros estipularon el tipo de imagen que caracterizaría a las efigies monárquicas. ${ }^{23}$ Moro, en concreto, consiguió que los modelos de Tiziano fuesen comprensibles para otros artistas, por ello, según Falomir los retratistas de corte de la segunda mitad del siglo XVI deben más a Moro que a Tiziano. La huella del artista flamenco se dio en la Península Ibérica a través de la figura de Sánchez Coello y en Flandes mediante la producción artística de Adrien Thomasz. Key y Frans Pourbus el Joven. ${ }^{24}$ Su llegada a la corte española fue propiciada por Antonio Perrenot (1517-1586) quien era el consejero de la familia imperial en asuntos artísticos. A partir de abril de 1549 comenzó a retratar al futuro Felipe II y progresivamente se fue especializando en efigiar a otros miembros de la Casa de Austria. El Felicísimo viaje del príncipe a los Países Bajos fue determinante para que el artista entrase en contacto con el rey heredero. ${ }^{25}$ Durante el tiempo que estuvo al servicio

22 Alfonso E. Pérez Sánchez, De pintura y pintores: la configuración de los modelos visuales en la pintura española, (Alianza: Madrid, 1993), p. 39.

23 Juan J. Luna, 'La pintura de retrato en las colecciones del Museo del Prado. De la Edad Media a fines del siglo XIX', en El retrato español en el Museo del Prado, (Museo Nacional del Prado: Madrid, 2015), pp. 9-33.

24 Véase a Falomir Faus, 'El retrato de corte'..., p. 122.

25 Almudena Pérez de Tudela Gabaldón, 'Nuevas noticias sobre el primer viaje de Antonio Moro a la Península Ibérica y su entrada al servicio de Felipe II', Archivo Español de Arte, Vol. 89, 2016, pp. 423-429. 
de la monarquía hispánica aportó retratos sobrios en su conjunto pero minuciosos en la representación de la indumentaria y de la joyería, donde la iluminación le permitía potenciar la majestad del efigiado y resaltar el rostro por ser el elemento esencial en cualquier retrato. A modo de ejemplo, conviene citar la efigie del emperador Maximiliano II (fig. 2.10) quien sucedió a su padre Fernando de Austria como emperador del Sacro Imperio Romano Germánico en 1564, y el retrato de su esposa, la emperatriz María de Austria (fig. 2.11), hija de Carlos $\mathrm{V}$ e Isabel de Portugal. Ambas imágenes, que forman pareja, dejan constancia de la influencia de los retratos de Tiziano e ilustran las características propias de la estética de Moro.

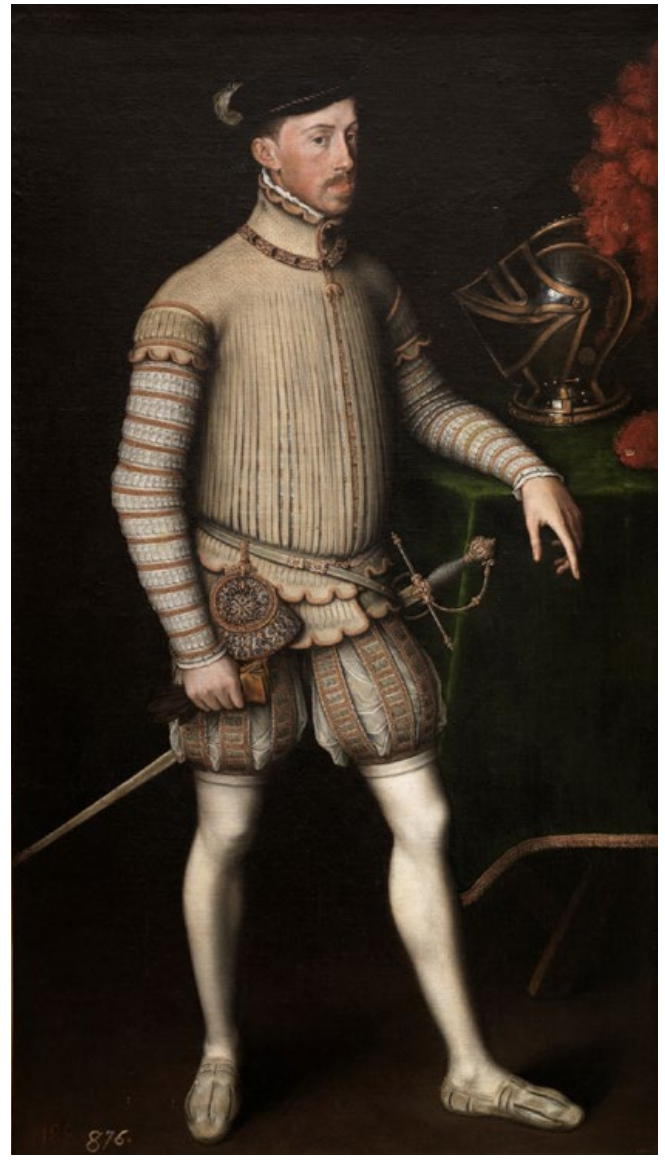

Fig. 2.10. Antonio Moro, El emperador Maximiliano II, 1550, óleo sobre lienzo, Madrid, Museo Nacional del Prado.

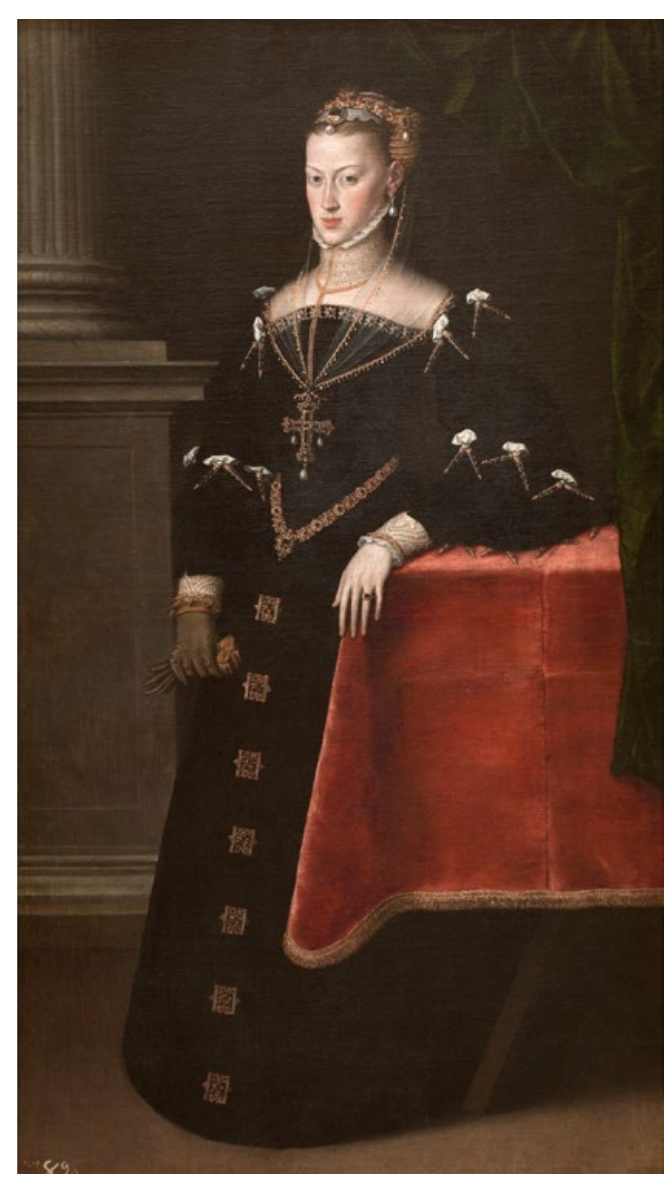

Fig. 2.11. Antonio Moro, La emperatriz María de Austria, esposa de Maximiliano II, 1551, óleo sobre lienzo, Madrid, Museo Nacional del Prado. 


\subsubsection{Los discípulos:}

El primero de los discípulos del maestro veneciano fue Juan Fernández Navarrete, llamado el Mudo, (ca. 1538 - 1579). Su faceta como retratista resulta desconocida pero sí que han quedado constancias documentales de que pintó retratos y que estilísticamente se acercaban a los elaborados por Tiziano. Así pues, a la muerte de Navarrete en El Escorial dejó «ocho retratos sin acabar en lienzos pequeños, un retrato de Juan Andrea Doria, otro del duque de Medinaceli, uno de un clérigo bosquejado y otro de doña Ana Manrique.» ${ }^{26}$ De entre todos ellos cabe destacar la representación de Doria, quien participó en la batalla de Lepanto, y resulta significativo que probablemente Felipe II desease tener una imagen de este compañero de cruzada. Pérez Sánchez se ha servido de las apreciaciones de Francisco Preciado de la Vega en 1765 para justificar la influencia de Tiziano en los retratos de Navarrete: «supo imitarle tanto que sus retratos pasan por obras de su maestro mu130 chas veces. ${ }^{27}$

Alonso Sánchez Coello (1532 - 1588) también fue deudor de Tiziano y Moro y llegó a ser el principal retratista en la corte de Felipe II. Coello conoció al que sería su maestro, Moro, en Lisboa cuando el artista flamenco marchó a Portugal para retratar a la familia real a petición de María de Hungría. Establecido nuevamente en España, comenzó a recibir encargos de retratos reales. Entre 1555-1563, estando en Valladolid, se le encomendó realizar varias pinturas entre las que se encontraban cuatro retratos del príncipe Carlos, hijo de Felipe II y Manuela de Portugal. A día de hoy, ninguno de ellos se ha identificado con los que se conservan entre los fondos del Prado. Posteriormente fue nombrado pintor de cámara aunque se desconoce exactamente el año que asumió este nuevo papel, seguramente fue después de que Moro marchase y Felipe

26 Citado en Pérez Sánchez, De pintura y pintores..., p. 46

27 Citado en Pérez Sánchez, De pintura y pintores..., íbidem. 
II se casase con su tercera esposa, Isabel de Valois, en 1560. En efecto, se ha documentado su presencia en Toledo desde 1559 hasta 1561 cuando la corte estableció su sede temporal en esta ciudad hasta que más tarde ya se trasladó definitivamente a Madrid.

La producción de retratos continuó siendo prolífica en los años sucesivos y especialmente se ha visto la voluntad por recopilar numerosas efigies del infante heredero a la Corona. Don Carlos, quien padecía problemas físicos y mentales seguramente derivados de la consanguinidad de sus progenitores, se sirvió de los retratos para dulcificar su imagen y mostrarse como digno sucesor al trono. Ello explicaría que en la afamada pintura conservada en el Prado, realizada entre 1555 - 1559, se vislumbre a través del ventanal un paisaje en cuyo celaje se distingue a Júpiter y a un águila portando una columna de Hércules, en clara alusión a su pertenencia al linaje de la Casa de Austria (fig. 2.12). Resulta interesante que en mayo de 1568 se registrase el pago de seis retratos hechos por Coello del príncipe Carlos, unas representaciones que tomaron como modelo la que ya hizo Sofonisba Angissola. Probablemente se refiera a aquel retrato que el príncipe se ha vestido con una piel de lince. ${ }^{28}$ Esta imagen, que en origen ya contaba con varias réplicas, fue copiada en otras ocasio-

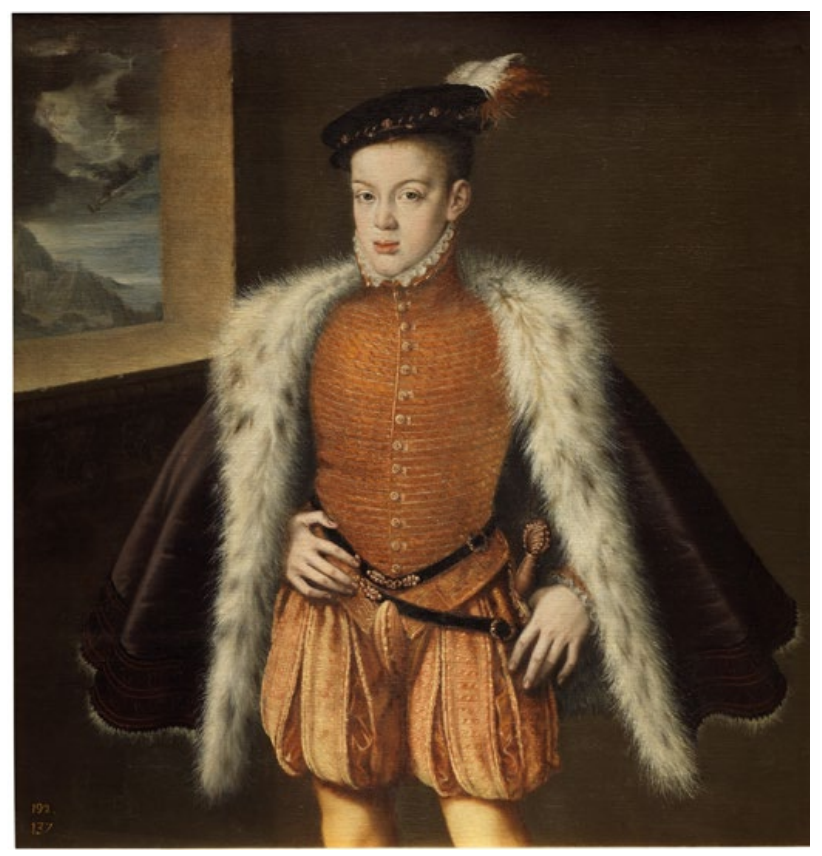

Fig. 2.12. Alonso Sánchez Coello, El príncipe don Carlos, 1555-1559, óleo sobre lienzo, Madrid, Museo Nacional del Prado. nes como se ha podido

28 Stephanie Breuer-Hermann, 'Alonso Sánchez Coello. Vida y obra', en Juan Miguel Serrera (ed.), Alonso Sánchez Coello y el retrato en la corte de Felipe II, (Museo Nacional del Prado: Madrid, 1990), pp. 14-35. 
apreciar al lucir entre las efigies monárquicas del Colegio del Corpus Christi que se estudiarán más adelante. Seguramente el especial interés por esta imagen resida en que debió ser la más cercana a su muerte, pues el heredero falleció en julio de 1568.

Roland de Mois (ca. 1520 - 1593) fue un retratista destacable en Aragón. Según ha explicado Jusepe Martínez, Mois gozó de un enorme aprecio y reconocimiento durante su tiempo. De hecho, cualquier hombre de prestigio deseaba ser representado a través de sus pinceles. Sin embargo, era selectivo con las personas que iba a retratar y por ello, no aceptaba encargos de gente considerada ordinaria. Tampoco acudía a casas particulares, a excepción de las damas, para pintar un retrato sino que trabajaba en su propia casa. Tiziano, sin duda, fue un referente para su producción artística:

El señor duque le ocupó en hacer retratos de la genealogía de su casa, sacándolos de originales muy antiguos, los cuales eran de manera muy seca y de poco dibujo, mas él los redujo a la moderna con tanta gracia y bondad, sin defraudar a lo parecido, que parecía los había sacado del mismo natural; gracia particular y de grande estimación. [...] Su ejercicio principal fue hacer retratos grandes y pequeños: no hubo en aquel tiempo persona de cuenta, que no se hiciera retratar de su mano, y en particular las damas, porque tuvo tal gracia, que sin casi sombras los hacía muy parecidos. En esto imitó mucho a Tiziano. ${ }^{29}$

Juan Pantoja de la Cruz (ca. 1553 - 1608) fue otro de los más señalados seguidores del retrato de corte tratado al estilo de pintores como Tiziano, Antonio Moro y Sánchez Coello. Teniendo estos referentes, Pantoja de la Cruz elaboraba efigies con un gran sentido representativo, de tres cuartos o de cuerpo entero pero siempre manteniendo un distanciamiento con el es-

29 Jusepe Martínez, Discursos practicables del nobilísimo arte de la pintura: Sus rudimentos, medios y fines que enseña la experiencia, con las ejemplares obras insignes de artífices ilustres, (M. Peiró Coso: Zaragoza, 1853), p. 137. 
pectador y algo idealizados. Estas características se aprecian, principalmente, en los retratos de la familia real y de la nobleza. Esta clase de representación cortesana, donde la figura se coloca a veces en contraposto y se ha idealizado ligeramente procede de la estética para héroes de la Antigüedad. Cuando Pantoja estuvo trabajando para la Corona española se encontró con el problema de conjugar equilibradamente el parecido con el efigiado y la idealización, puesto que en el ámbito español el realismo tenía un importante peso. Sus retratos inmortalizaban los rasgos físicos del efigiado, se perpetuaba su memoria y se concentraba una gran dosis representativa donde la imagen llegaba a sustituir al monarca en su ausencia física. ${ }^{30}$

Tras una época al servicio de la corte austriaca, sobre el año 1585 el artista volvió a España, pues vio oportunidades de trabajo como retratista con motivo del enlace matrimonial de la infanta Catalina Micaela y quizás tenía en mente el poder seguir a Sánchez Coello como pintor de cámara cuando éste falleciese y al mismo tiempo, su maestro era la persona indicada para introducirlo en la corte. Realmente, la decisión de Pantoja fue acertada puesto que tras el fallecimiento de su maestro en 1588, él comenzó a trabajar de forma asidua para la corte y normalmente para el infante y futuro Felipe III, a quien empezó a retratar desde muy joven. Ya hacia 1590 lo representó cuando tenía aproximadamente doce años. De esta pintura tan sólo se ha conservado una fotografía en el archivo del Instituto Amatller. ${ }^{31}$

Si se realiza un recorrido panorámico de todas las efigies que se tiene de Felipe III siendo niño es posible apreciar el impacto del lenguaje estético propio de los retratos cortesanos promocionado por Tiziano y Moro. La puesta en escena se ha mante-

30 Maria Kusche Zattelmeyer, Juan Pantoja de la Cruz y sus seguidores. Bartolomé González, Rodrigo de Villandrando y Antonio López Polanco, (Fundación Arte Hispánico: Madrid, 2007), p. 38.

31 Kusche Zattelmeyer, Juan Pantoja de la Cruz..., pp. 49-56. 
nido en cada una de las obras y el posado viene acompañado por un bufete revestido de terciopelo, donde se ha dejado la celada, un cortinaje y una columna sobre pedestal en el fondo. A partir del retrato hecho por Blas del Prado en 1586 (Madrid, Museo Lázaro Galdiano), el infante, entonces con ocho años de edad, ya ostenta el collar del Toisón. Es el preludio del primer retrato, mencionado previamente, que hizo Pantoja de la Cruz en 1590. Aquí, con doce años, el heredero posa con una armadura de parada. Así se estableció el tipo representativo que perduró en las imágenes posteriores del futuro Felipe III. Por ejemplo se cuenta con dos retratos más, del mismo artista, conservados en Viena (KHM); uno de ellos datado alrededor de 1592 y otro de 1594. Ambas pinturas se hallan en la línea de las que Tiziano hizo para Carlos V y Felipe II comentadas anteriormente. De este modo, se sigue configurando en imágenes la línea sucesoria y el linaje de la Casa de Austria en el trono español.

134 Entre las obras de Juan Pantoja también se conoce la realización de dos retratos, de Carlos V y Felipe II respectivamente, en 1599, para la iglesia vieja del monasterio de El Escorial. De ambas obras tan sólo se conserva la correspondiente al emperador y está firmada por Juan Pantoja de la Cruz. Por ello, se deduce que probablemente el mismo artista hizo la efigie de Felipe II. El primer emplazamiento de las pinturas fue la sacristía de la basílica, junto a las representaciones de los entierros y las genealogías de ambos. Más tarde se trasladaron a la iglesia antigua y de ello dieron constancia Francisco de los Santos y Antonio Ponz. Por ejemplo, Francisco de los Santos, en su Descripción del Real Monasterio de San Lorenzo de El Escorial aportó una exhaustiva explicación de la iglesia antigua del convento, allí se conoce que concretamente: "Abajo, delante de los altares colaterales, sobre dos bancos de nogal, en los espacios que hacen allí las paredes de la capilla, están dos retratos; en una parte uno, que es del emperador Carlos Quinto, y a la otra, otro, que es de su hijo Felipe Segundo. Los 
marcos de estos retratos son de bronce dorado al fuego.» ${ }^{32} \mathrm{La}$ imagen del emperador relacionada con esta descripción guarda un formato de tres cuartos y él aparece tras una balaustrada. No obstante, se ha tomado como referente iconográfico la obra de Tiziano de cuerpo entero que, cabe recordar, configuró la representación oficial del monarca. En concreto Maria Kusche ha explicado que la pintura de Pantoja tuvo presente la adaptación que Sánchez Coello había hecho de la obra de Tiziano para la antigua galería de retratos del Pardo. Por ello, esta fue la primera copia de ésa efigie que lució entre el conjunto genealógico que se quemó en 1604, y que además, sirvió de modelo para las otras dos imágenes que Pantoja de la Cruz pintó en 1605 y 1608 para la biblioteca de El Escorial. El artista, además de sus propios apuntes, igualmente pudo tener en cuenta la copia que Rubens hizo del retrato de Tiziano para el emperador. ${ }^{33}$

Pero además, siguiendo la descripción de los Santos, se especifica que en el muro testero de la iglesia antigua lucía una representación del martirio de san Mauricio de El Greco y dicha pintura estaba acompañada por: «[...] cuatro cuadros menores, dos a los lados de abajo, y dos sobre la cornisa. Los dos de abajo son, uno las armas, y blasones de la Real Casa de Austria, y otro de Felipe Segundo y sus mujeres, a la manera que están en la capilla mayor de la iglesia principal en los entierros.» ${ }^{34}$

32 Francisco de los Santos, Descripción del Real Monasterio de San Lorenzo de El Escorial, única maravilla del mundo, fábrica del prudentísimo rey Felipe II, coronada por el católico rey Felipe IV el Grande, con la majestuosa obra del panteón y traslación de los cuerpos reales, reedificada por nuestro rey y señor Carlos II después del incendio, (Imprenta de Bernardo Villa: Madrid, 1681). Discurso X: De la segunda parte, en que se divide la planta, y de los claustros pequeños del convento, con las piezas más notables que hay en ellos. fol. $49 \mathrm{v}$.

33 Kusche Zattelmeyer, Juan Pantoja de la Cruz..., pp. 86-89.

34 de los Santos, Descripción del Real Monasterio de San Lorenzo de El Escorial.., Discurso X: De la segunda parte, en que se divide la planta, y de los 
De forma pareja al san Mauricio se apreciaba una excelente pintura dedicada al martirio san Lorenzo realizada por Luca Cambiaso. La obra, según de los Santos, estuvo expuesta en el altar mayor de la iglesia principal, sobre la custodia. A esta pintura además: «le acompañan cuatro cuadros, como al otro. Los dos de abajo a los lados, son de armas reales, y Carlos Quinto con la emperatriz, y su hija, y hermanas. [...] ${ }^{35}$

En consecuencia, se impuso un tipo de retrato encorsetado, donde se lucían las mejores galas con toda minuciosidad y el fondo era principalmente neutro, vestido con un cortinaje y con un escaso mobiliario complementario como bufetes y sillas. ${ }^{36}$ La tipología de las efigies cortesanas establecidas a raíz de las realizadas por Tiziano se difundió en otros ámbitos geográficos locales y entre otros artistas. Ejemplo de ello son los tres retratos que conserva la Universitat de València y representan a Carlos V (fig. 2.13), Felipe II (fig. 2.14) y Felipe III. Son tres representaciones cuyo autor se desconoce, se han fechado alrededor del año 1599 y la hipótesis consolidada al respecto del origen de estas obras es que se realizaron con motivo de la visita de Felipe III a la Universitat aprovechando su estancia en la ciudad para celebrar su enlace matrimonial. ${ }^{37}$ Esta suposición es coherente teniendo en cuenta que tan sólo se ha decidido retratar al principal protagonista, es decir el monarca, y a sus ascendientes más directos para presentarlo como un eslabón más de la dinastía Habsburgo. Pese a ello,

claustros pequeños del convento, con las piezas más notables que hay en ellos. Fol. 49v-50r.

35 de los Santos, Descripción del Real Monasterio de San Lorenzo de El Escorial.., Francisco de los Santos... Discurso X: De la segunda parte, en que se divide la planta, y de los claustros pequeños del convento, con las piezas más notables que hay en ellos. Fol. 50r.

36 Pérez Sánchez, Pintura barroca..., p. 77.

37 Las referencias bibliográficas más recientes relativas a estas tres pinturas se encuentran en las fichas de catálogo hechas por David Sánchez Muñoz en Benito Goerlich y Sánchez Muñoz, La Universitat de València..., vol. II, pp. 212-217. 


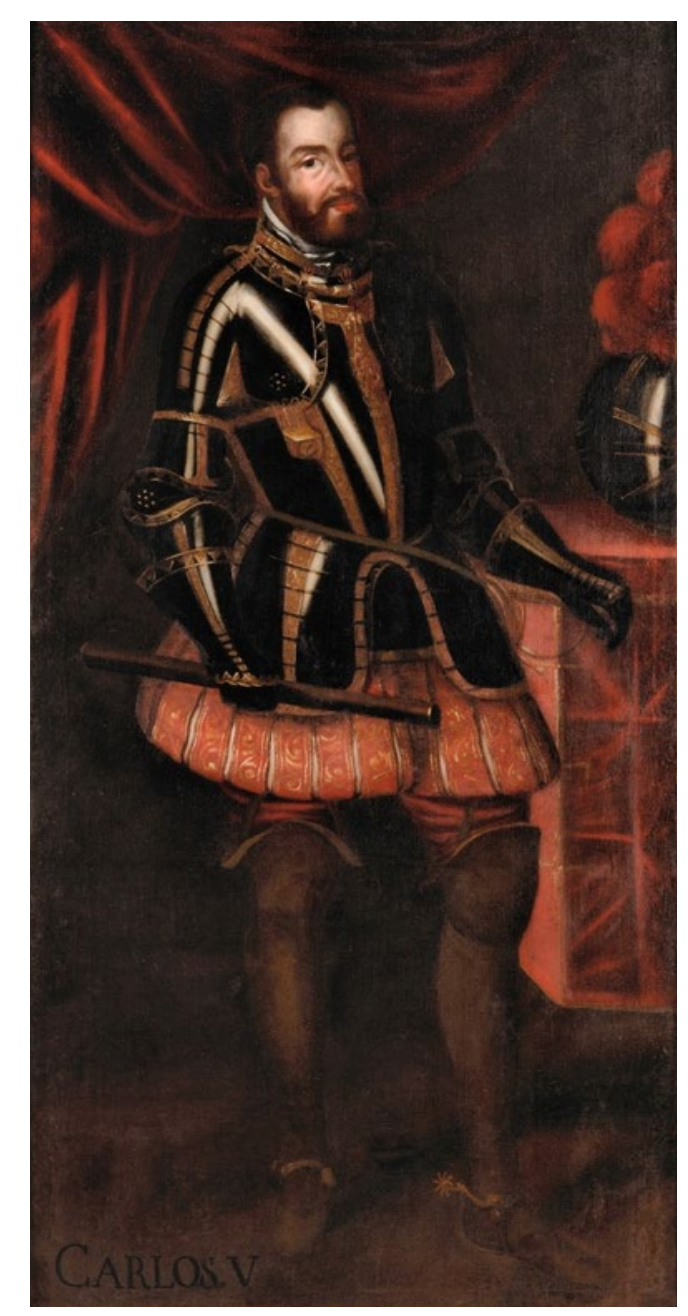

Fig. 2.13. Anónimo, Carlos V, h. 1599, óleo sobre lienzo, Valencia, dependencias rectorales de la Universitat de València.

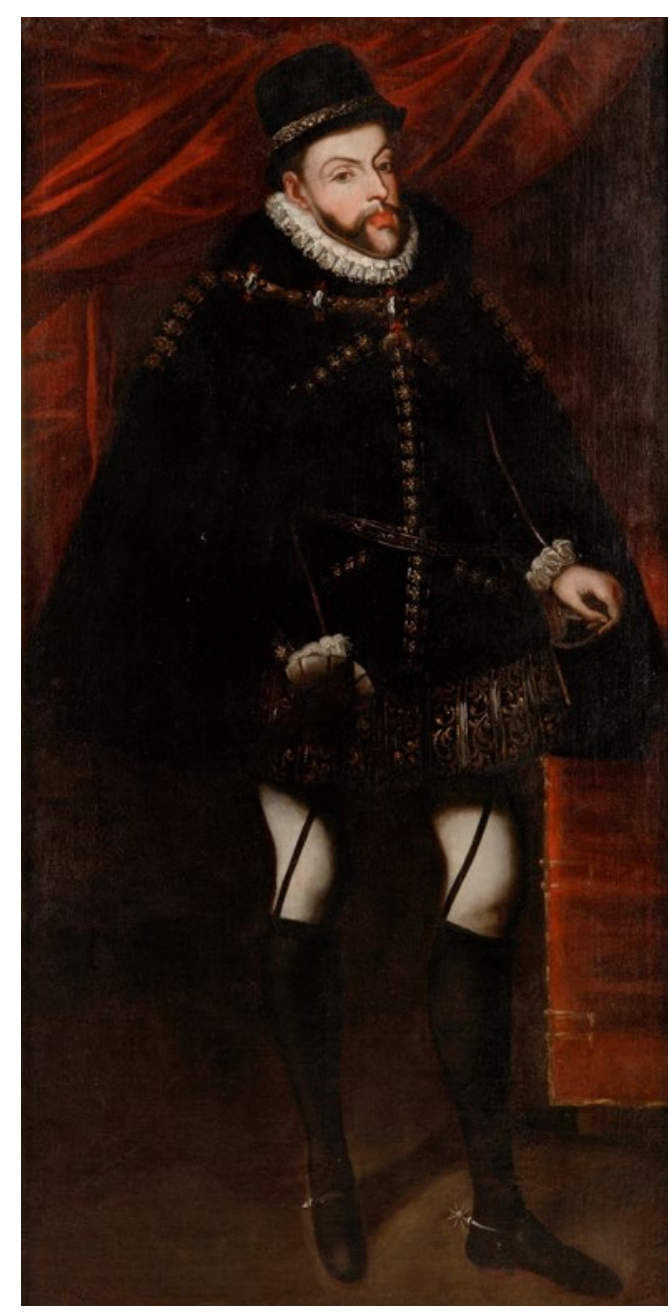

Fig. 2.14. Anónimo, Felipe II, h. 1599, óleo sobre lienzo, Valencia, dependencias rectorales de la Universitat de València.

por el momento no se dispone de documentación de archivo que certifique esta suposición. Las pinturas no se han tratado en los capítulos sucesivos como una galería autónoma porque su elaboración ha respondido a unas circunstancias muy concretas y no ha habido una voluntad de ampliar el conjunto. No obstante, sí que permiten ilustrar la codificación y la continuidad que se dio en el lenguaje estético de los retratos cortesanos.

A grandes rasgos hay diversos puntos en común entre los tres retratos. Estas imágenes en esencia captan la dignidad y el poder de cada monarca. Son representaciones de cuerpo entero emplazadas en un interior áulico tan sólo revestido por un lu- 
joso cortinaje rojo carmesí y un bufete auxiliar sobre el que descansa un casco ornamentado con un penacho de plumas en los casos de Carlos V y Felipe III. Estos dos, además, visten con media armadura, gregüescos, medias y botas. En cambio, Felipe II ha sustituido la media armadura por un jubón negro y sombrero de copa baja. En cualquier caso, las efigies regias de la Universitat beben del modelo cortesano extendido en la época. Por ello el retrato de Felipe III (fig. 2.15) en concreto recuerda a la pintura hecha por Juan Pantoja de la Cruz hacia 1601-1602 donde aparece Felipe III como generalísimo en el sitio de Ostende (fig. 2.16), la cual se ha considerado como el punto de partida para el establecimiento de la imagen oficial

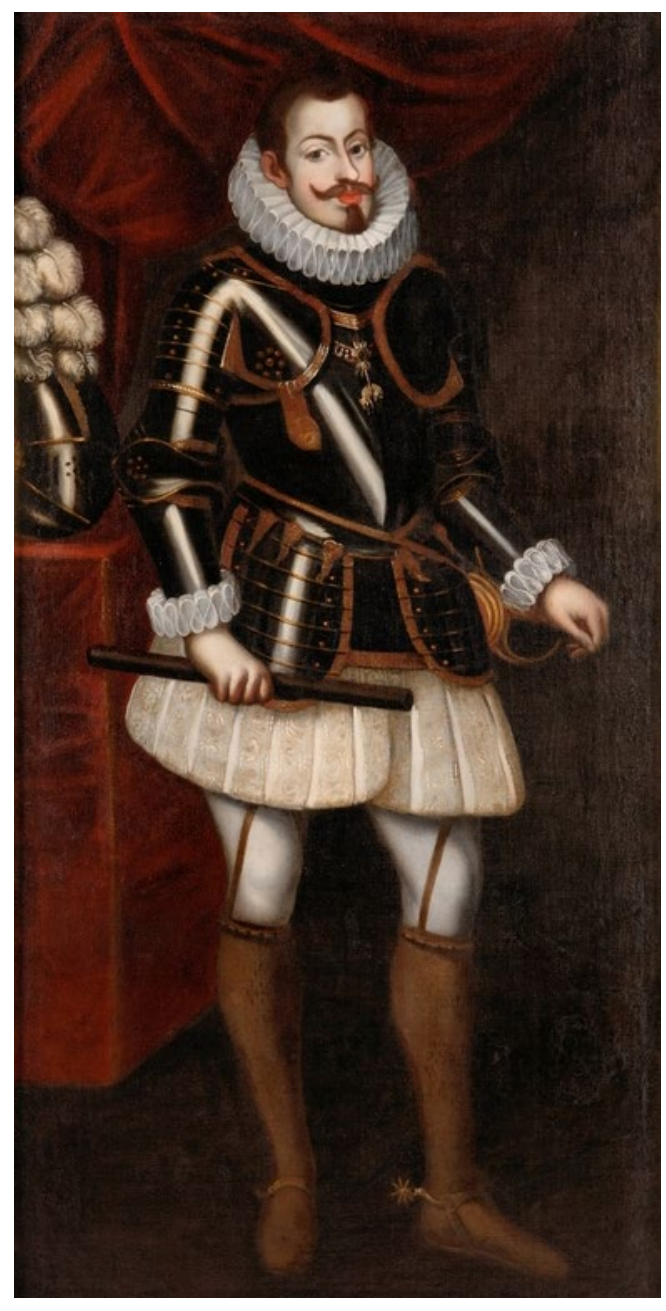

Fig. 2.15. Anónimo, Felipe III, h. 1599, óleo sobre lienzo, Valencia, dependencias rectorales de la Universitat de València.

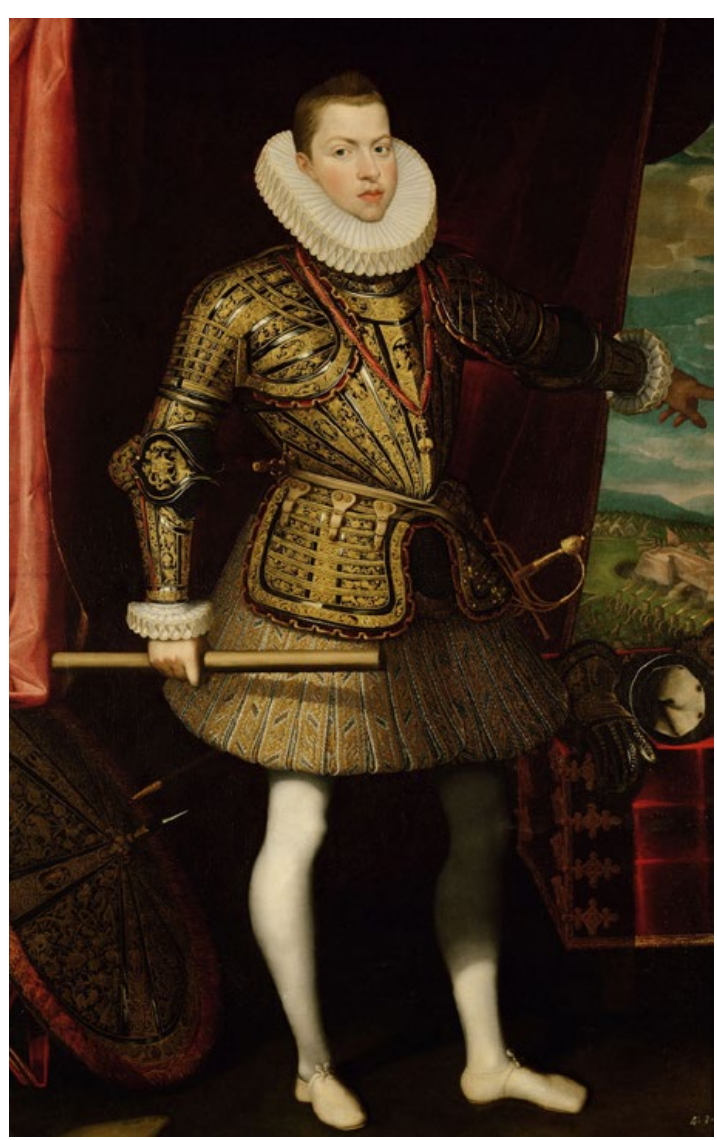

Fig. 2.16. Juan Pantoja de la Cruz, Felipe III como generalísimo en el sitio de Ostende, h. 1601-1602, óleo sobre lienzo, Viena, Kunsthistoriches Museum, Gemäldegalerie. 
del rey en ésa condición. ${ }^{38}$ Asimismo, se emplea un lenguaje visual similar al retrato hecho por Bartolomé González, pintor de su majestad, en 1621 conservado en el Palacio Real del Pardo y emparejado con la efigie de la reina Margarita. Se aprecia, por tanto, la herencia del modelo de retrato también cultivado en España por Antonio Moro a mediados del siglo XVI.

Este lenguaje visual también fue empleado por otros sectores de la sociedad y por tanto, ha quedado patente la codificación que se produjo en las imágenes de carácter oficial. El siglo XVII como se apreciará seguidamente fue una época álgida para este género cuyo foco de producción, desde el gobierno de Carlos V, fue la corte. Asimismo, se dio un importante tráfico de retratos entre las distintas coronas europeas, lo cual facilitó que la imagen oficial de la monarquía se difundiese con cierta rapidez. Las razones para enviar efigies podían ser muy variopintas y muestran el amplio abanico de funciones que tuvieron estas imágenes. De hecho, su envío podía responder a necesidades políticas y representativas, a facilitar acuerdos matrimoniales, a tener retratos de familiares antepasados o a ser un documento conmemorativo de hechos pretéritos. ${ }^{39}$

A través de todas estas posibilidades que tuvo el retrato se pone de manifiesto el poder de las imágenes. Así, lo ha explicado excelentemente Gloria Fossi, quien ha profundizado en la capacidad que tienen las efigies para inmortalizar a las personas retratadas y congelar su belleza, además de estimular la memoria y la imaginación. Igualmente ha considerado que era al retratista a quien se le permitió tener la potestad de generar imágenes tan evocadoras y persuasivas como lo fueron los retratos:

"La memoria" scrive Giambamttista della Portse nel 1602

38 Carmen García-Frías Checa y Javier Jordán de Urríes y de la Colina (coord.), El retrato en las colecciones reales de Patimonio Nacional: de Juan de Flandes a Antonio López, (Patrimonio Nacional, 2014), pp. 178-180.

39 Luna, 'La pintura de retrato en las colecciones...', p. 19. 
non è altro che una intiera pittura custodita in quella tavola animata che noi chiamiano cerebro, e possiamo imaginare persone che ne rappresentino all'animo uns nuova, strana, maravigliosa, inusitata, piacievole, varia e spaventevole pintura. Propio l'ars reminiscendi l'arte della memoria spiega Lina Bolzoni, ci aiuta a capire che i ritratti possono non solo illustrare biografie, ma anche, in un corte senso, sostituirsi a esse, giacché è incommensurabilé il potere evocativo delle imagini. Ed è in primo luogo all'artefice delle imagini che è concessa, tramite il ritratto, una eccezionale facoltà. ${ }^{40}$

La valoración y el uso que se realizó del retrato durante el Renacimiento han puesto de manifiesto el culto a la individualidad y a la personalidad que se estuvo fomentando desde el siglo XV en Italia. Así, se retomaba una práctica propia de la Antigüedad que tenía por objetivo mantener la memoria del efigiado y ello sólo era posible centrándose en aquello que más le caracterizaba e individualizaba del resto de personas, su aspecto físico. No obstante, el retrato debía ser capaz de crear una imagen con dos vertientes; testimonial e ideal. La primera de ellas se preocupaba por recoger fidedignamente la apariencia del efigiado y la segunda trataba de mostrar su interior, su alma, y sus virtudes. Al hilo de la importancia de este género para mantener la memoria del representado, conviene tener presentes las reflexiones de Luke Syson en torno a este tema. ${ }^{41}$ El autor se ha cuestionado la necesidad de perpetuar el recuerdo tras la muerte en una Europa que ya no era pagana. Cabe recordar que en época clásica se creía que la mente y el alma

40 Gloria Fossi, 'Il ritratto tra memoria, realtà e immaginazione', en Gloria Fossi (ed.), Il ritratto, gli artista i modelli, la memoria, (Giunti, 1996), p. 11. También es interesante consultar el texto de Diane Bodart para este catálogo, puesto que explica cómo el retrato en el Quattrocento desempeñaba un papel doble; por un lado era objeto de memoria y por otro lado, era un sustituto ficticio del representado. Véase a Diane Bodart, 'Il ritratto nelle corti europee del Cinquecento', en Gloria Fossi (ed.), Il ritratto, gli artista i modelli, la memoria, (Giunti, 1996), pp. 137 - 172.

41 Syson, 'Testimonio de rostros, recuerdo de almas'..., pp. 23-27. 
eran los dos elementos que hacían de la persona un ser virtuoso así como determinaban su apariencia física, y la belleza se asociaba a la virtud. En la Edad Media las inquietudes apuntaban a definir el alma y más tarde, durante el Renacimiento se siguió reflexionando acerca de la naturaleza y el destino de la misma. Fue sin embargo, a partir del siglo XII, cuando el retrato era la herramienta necesaria y adecuada para mantener vivo el recuerdo de los difuntos y así poder rezar por sus almas. En este momento la idea de la resurrección de la carne al final de los tiempos estaba plenamente asentada, no obstante empezó a adquirir un mayor protagonismo el viaje del alma tras la muerte, un viaje que se realizaba de forma separada al cuerpo y cuyos destinos eran el infierno, el purgatorio o el cielo. Al poder aterrizar en cualquiera de los dos primeros, nunca deseados por los fieles, se extendió la práctica de rogar por el alma de los fallecidos y así confiar en que se encontraban en el plano celestial. Con todo, era fundamental recordar exactamente a la persona fallecida y pedir por su alma a título personal y por esta razón, los cristianos encontraron una fórmula para recordar a los seres queridos; el retrato. La imagen del difunto permitía reconocer, alabar y compadecerse por una única persona.

Siguiendo a Syson, cabe preguntarse si en la época se asociaba el rostro y el cuerpo al alma. Existieron dos posturas al respecto; por un lado aquella que defendía la separación entre lo físico y el espíritu. Por otro lado, aquella que justificaba la relación entre el cuerpo y el alma argumentando que el primero era el vehículo de manifestación del segundo. En cualquier caso, al ser plegarias individualizadas y pensadas para las almas de personas concretas hubo una necesidad de darle una imagen a aquello que era intangible, el espíritu. La imagen como manifestación de ése espíritu llegó a ser tan importante que los retratos pictóricos o escultóricos, como es conocido, asumieron la capacidad de sustituir a la propia persona.

Respecto a las cuestiones estéticas del retrato, esta centuria 
estuvo más encaminada a crear imágenes despojadas de alegorías, elementos simbólicos y fasto, para elaborar retratos austeros, de fondos neutros y especial atención al tratamiento de los volúmenes. ${ }^{42}$ Como se podrá observar en los capítulos sucesivos, las galerías de retratos estudiadas oscilan entre un tipo de efigie todavía pomposa y repleta de elementos complementarios y otras más sobrias, según las características y funcionalidad del propio conjunto.

\subsection{El retrato en el siglo XVII.}

Del retrato hispano y valenciano en el siglo XVII sería necesario destacar dos aspectos fundamentales. El primero de ellos remite a la evolución social que se fue produciendo en los núcleos poblaciones, los cuales dejaron de estar tan fuertemente ruralizados para ser más complejos y urbanos. Por esta razón, y como se va a comentar seguidamente, la tipología de retratos fue en aumento para cumplir con las necesidades de una nueva realidad. De entre todas ellas cabe subrayar las representaciones de la élite cultural de la época, los repertorios de varones ilustres determinaron que el éxito intelectual y profesional también era un pasaporte para ser retratado y pasar a formar parte de aquel reducido núcleo de personas que a través de la imagen prolongarían su recuerdo y remarcarían su legado. La segunda cuestión a tener presente es la utilización que la Iglesia hizo de este género para seguir defendiendo el credo católico. Así pues no sólo se hicieron retratos de los principales dirigentes de las diócesis, personas que contaron con una amplia formación académica y que habían llegado bien lejos dentro de la carrera eclesiástica, sino que además se apostó por efigiar a aquellos que hicieron méritos para aspirar a la santidad. En estos casos concretos, los retratados eran personas más cercanas al pueblo común y su imagen era capaz de cultivar la fe de forma más directa entre la sociedad. Esta clase de representaciones triunfaron entre un pueblo con una fuerte espiritualidad, pues su refugio en la religión fue

42 Luna, 'La pintura de retrato en las colecciones...', íbidem. 
consecuencia de la situación de precariedad económica y una vida repleta de penurias que se dio a raíz de dramáticas actuaciones como la expulsión de los moriscos en 1609, aquellos que representaban una enorme masa de mano de obra.

Mediante la ampliación de tipologías de retratos se puede apreciar que este género tuvo una gran capacidad para adaptarse a las diversas situaciones históricas y sectores de la sociedad y consiguió enriquecerse sin perder la esencia de sus funciones originales. En la presente investigación se cuenta con galerías de efigies que se pueden asociar a uno y otro caso, por esta razón conviene remarcar generalmente las circunstancias que rodearon a la evolución de los retratos a lo largo del Seiscientos, y así se podrá tomar conciencia de la mejora progresiva y el desarrollo que se dio con el tiempo.

\subsubsection{Sociedades urbanas y nuevos tipos de retratos.}

Al inicio del siglo XVII, la sociedad española se fue transformando para ser mucho más urbana. Por ello, las ciudades adquirieron un gran protagonismo y Madrid, Valladolid, Valencia, Sevilla o Zaragoza crecieron considerablemente en lo que a economía, política y cultura se refiere. Asimismo, definitivamente, se consolidó el disponer de una sede cortesana fija. Un nuevo siglo y una nueva realidad obligatoriamente generaron otras demandas en la sociedad y manifestaciones culturales que las solventaran. Por ejemplo, tuvieron una época dorada las fiestas y el teatro. Alrededor del 1600, el retrato amplió su variedad, se empezó a solicitar desde otros sectores de la sociedad y como género consiguió un extraordinario nivel estético y artístico, pues así lo evidencian las obras de Velázquez. Sin embargo, la corte continuó siendo trascendental para la evolución y progreso del retrato. Así pues, se mantuvieron las tipologías y usos tradicionales de estas imágenes. No obstante, también aparecieron novedosas modalidades que ampliaron considerablemente las opciones en los retratos. Por ejemplo, las representaciones de reyes y príncipes como cazadores, 
emplazados en escenas relacionadas con la vida cortesana, explicando así la presencia de sirvientes o retratos de familia. Igualmente las nuevas figuras políticas que aparecieron en esta época, como el valido, adoptaron fórmulas similares a las empleadas por la monarquía para su configurar su propia imagen. ${ }^{43}$

Conviene tener en cuenta la magnitud adquirida por el retrato durante esta centuria pese a que la presente investigación tan sólo aborde la creación y el desarrollo de galerías de efigies y por tanto, no se vea reflejado la variedad tipológica que tuvo lugar en este momento. A través de los conjuntos estudiados en los capítulos sucesivos se constata, a grandes rasgos, la pervivencia de las imágenes oficiales. Para ello, resultó fundamental el papel desempeñado por la corte y el gusto por reunir efigies en los distintos palacios, configurando un discurso visual sobre el linaje regio que, a su vez, sirvió de referente para otros artistas de épocas posteriores.

Las transformaciones sociales, como se ha comentado, también ejercieron su impacto en el retrato. Así, el impulso de los núcleos urbanos trajo consigo la revalorización de las actividades intelectuales, entre las que se encontraban las disciplinas artísticas, humanísticas y científicas. Por esta razón las efigies de los denominados hombres ilustres fueron ganando presencia entre el tradicional repertorio de retratos. Es más, era habitual colocar este tipo de representaciones al inicio de una obra escrita para reforzar la identidad de su autor. Seguramente, el caso más evidente del interés por crear un repertorio de imágenes ilustrativas de la historia cultural fue el Libro de retratos de Pacheco, ${ }^{44}$ donde quedaban reflejadas las principales personalidades del ámbito político, religioso

43 Javier Portús Pérez, 'El siglo XVII: la madurez del género', en Leticia Ruiz Gómez (ed.), El retrato español en el Prado. Del Greco a Goya, (Museo Nacional del Prado: Madrid, 2007), pp. 83-89.

44 Francisco Pacheco, Libro de descripción de verdaderos retratos, de ilustres y memorables varones, (Sevilla, 1599). 
y cultural. Esta clase de efigies también era un instrumento de construcción de una identidad intelectual determinada, de reafirmación profesional y de revalorización del trabajo desempeñado. En definitiva, era una acción más que contribuía a la legitimación por ejemplo, de pintores, escultores o grabadores, entre otros, en calidad de artistas.

Esta empresa por conseguir un reconocimiento a la labor intelectual ya tuvo sus inicios en la Italia renacentista. De hecho, y según explica Joanna Woods-Marsden, ${ }^{45}$ los teóricos de la época ya quisieron darle la merecida importancia al proceso de concepción y diseño mental de la obra. Por ello, en 1400 Cennino Cennini estableció los dos ingredientes necesarios que intervienen en la creación de una pintura o una escultura: la concepción, basada en la imaginación y la proyección intelectual de la obra y la ejecución, centrada en el trabajo manual. Giorgio Vasari, en 1568, empleaba términos similares y se refería al pensamiento y a las manos como los dos componentes necesarios en la producción de obras de arte. Si bien la sociedad renacentista continuaba dándole una mayor importancia a las habilidades manuales como base para elaborar un buen retrato, los artistas trataron de revalorizar el trabajo intelectual, la creatividad y la concepción de la obra.

Por esta razón, en Italia los artistas comenzaron a hacer retratos de sí mismos y a mostrarse en calidad de profesionales dignos de admirar, pero aquellos que iniciaron esta práctica compartían una serie de coordenadas existenciales, sociales y culturales y además, estaban al servicio de la corte. El trabajar en el contexto cortesano fue trascendental para luchar por conseguir un reconocimiento social en el ámbito de poder. A raíz de esto se fue desarrollando el autorretrato y las representaciones de artistas como una variante propia del género para facilitar la reafirmación de los artífices. En definitiva, es el testimonio de la batalla librada por los artesanos para as45 Joanna Woods-Marsden, 'El autorretrato del Renacimiento', en Miguel Falomir Faus (ed.), El retrato del Renacimiento, (Museo Nacional del Prado: Madrid, 2008), pp. 91-107. 
cender socialmente. Desde el siglo XV hasta finales del siglo XVI, el número de artistas que se autorretrataban fue creciendo progresivamente. Sólo en los últimos años del Quinientos ya tuvieron la suficiente autoestima como para retratase a sí mismos y emplear los instrumentos de su profesión de forma orgullosa.

Una vez se fueron popularizando este tipo de representaciones, en el siglo XVII, aumentó el repertorio de pintores que, además, buscaban honores y así conseguir una verdadera mejor valoración social. En esta época, la capacidad de la pintura por transmitir ideas y no sólo imitar la naturaleza, y de ahí ser considerada como una disciplina artística noble, seguía en entredicho. Pese a ello, el marcado afán de coleccionismo por parte de monarcas y otras personalidades destacables incentivó el aprecio hacia los artistas y en ocasiones se recopilaban retratos realizados por determinados autores sin importar la identidad del efigiado, tan sólo por el interés que despertaba la excelencia de su producción artística ${ }^{46} \mathrm{El}$ viraje de la sociedad hacia la urbanidad, la apuesta por las actividades intelectuales y en consecuencia el éxito de las representaciones de varones señeros en las diversas áreas del conocimiento, permite poner en su contexto las galerías y colecciones de retratos dedicadas a hombres ilustres. En el ámbito valenciano, concretamente, deben destacarse tres casos; las efigies procedentes del monasterio de Nuestra Señora de La Murta (Alzira), las ubicadas en el paraninfo de la Universitat de València y las realizadas para la Real Academia de Bellas Artes de San Carlos.

En la línea de la necesidad por conseguir el reconocimiento a la labor, por ejemplo de los pintores, y la intelectualidad de las artes, el medio valenciano ya impulsó la creación de una institución reglada a finales del siglo XVI. El objetivo era dotar al ejercicio de la pintura de un espacio legal en el cual poder desarrollarse y por ello, en 1607, se creó el Colegio de Pinto-

46 Julián Gállego, El pintor, de artesano a artista, (Diputación Provincial de Granada: Granada, 1995). 
res. El nacimiento de este organismo que entendía la pintura como un arte liberal no estuvo falto de polémica, con sus partidarios y detractores. Cabe destacar que entre los defensores se encontraban artistas como Juan Sariñena (ca. 1545 - 1619) o Francisco Ribalta (1565 - 1628) quienes elaboraron excelentes retratos dentro de sus sobresalientes trayectorias profesionales. Como ha explicado Falomir, más que el debate acerca de la liberalidad de la pintura, la pugna entre seguidores y contrarios se centraba más en el control de su práctica en la ciudad. Conviene recordar que a finales del siglo XVI el número de pintores había ascendido considerablemente y el aumento de la demanda había desbordado a los talleres locales. Así pues, la batalla por conseguir el monopolio de la producción artística estaba justificada. Igualmente, el autor ha entendido que la subida de encargos fue consecuencia principalmente de la popularización de la pintura, la cual deja de ser un elemento casi exclusivamente religioso del ámbito privado o público, para poder engalanar las viviendas. ${ }^{47}$

Otro de los aspectos a tener en cuenta en el panorama artístico a comienzos del siglo XVII es que la pintura elaborada por artistas autóctonos quedó relegada a un segundo plano, siendo desplazada por las aportaciones foráneas de los pintores italianos y flamencos. Esta situación crítica respecto a los artífices hispánicos tuvo un mayor reflejo en las ciudades importantes para la corte y en los principales centros comerciales, como Valladolid, Toledo y Madrid en el primer supuesto y Sevilla y Valencia en el segundo caso. Así en los últimos años del siglo XVI el número de encargos asumidos por italianos era elevadísimo y ello contribuyó a ir fomentando un nuevo gusto que, en palabras de Alfonso Pérez Sánchez, desemboca47 Sobre el Colegio de Pintores de 1607 se ha seguido a Miguel Falomir Faus, 'La pintura valenciana del último tercio del siglo XVI y el Colegio de Pintores de 1607', en La pintura y los pintores en la Valencia del Renacimiento,1472-1620, (Consell Valencià de Cultura: Valencia, 1994), pp. 45-59. El autor considera que este organismo ya defendía la liberalidad de la pintura pese a no haber encontrado documentos sobre las constituciones del Colegio, puesto que la difusión de esta idea entre los pintores gozaban de una formación especializada era una realidad a principios del siglo XVII. 
ría en el Barroco español. ${ }^{48}$ Ejemplo de esta realidad es el conjunto de efigies monárquicas atribuidas a Antonio Ricci (c.1565 - 1635) que san Juan de Ribera adquirió a finales de la centu-ria. Además de los retratos de carácter civil también obtuvie-ron una gran relevancia las representaciones eclesiásticas a lo largo de los años sucesivos al Concilio de Trento y en el marco de la fuerte propaganda católica que imperó durante toda la centuria del XVII.

\subsubsection{Efigies para una Iglesia defensora de la fe católica. Sariñena, Ribalta y Espinosa.}

Entre la variedad de tipologías que albergó el género del retrato, una de ellas se empleó para dar visibilidad a los personajes religiosos modélicos, dignos de imitar por sus valores morales y espirituales. Asimismo, esta clase de imágenes sirvieron para difundir los ideales de Trento y por tanto, elaborar una firme defensa del credo católico. La utilización de la pintura para fomentar la fe es una práctica que ya se daba en 1568 cuando comenzó el proceso decorativo del monasterio de san Lorenzo de El Escorial. De hecho, Felipe II tenía por finalidad que las obras artísticas del real sitio agitasen los corazones y cultivasen la devoción entre aquellos que tenían el privilegio de contemplarlas. Así, a través de las representaciones de los santos, por ejemplo, se incitaba a la oración, se ilustraba la virtud católica y se sembraba la fe en Dios. ${ }^{49}$ Este gran proyecto artístico además de convertirse en un foco pictórico trascendental para la pintura hispánica del siglo XVII propagó su finalidad en las pinturas posteriores. Todo ello ha dado pie a dedicar un capítulo a las efigies de carácter eclesiástico, pues los

48 Pérez Sánchez, De pintura y pintores..., pp. 32-33.

49 Esta reflexión ha sido extraída por el autor a partir de la obra de fray José de Sigenza, Historia de la Orden de san Jerónimo (Bailly Baillire e hijos: Madrid, 1907) quien afirmaba lo siguiente: «[...] los santos se han de pintar de manera que no quiten las ganas de rezar en ellos, antes pongan devoción, pues el principal efecto y fin de su pintura ha de ser ésta.» (Volumen 2, Libro cuarto, p. 634). También en Pérez Sánchez, De pintura y pintores..., p. 18. 
retratos tanto de prelados como de otros personajes cercanos a la santidad representaron a personas especialmente devotas que se convirtieron en la imagen de la moral y virtud católica.

En torno al 1600 llegaron a la madurez aquellos artistas que habían nacido en la segunda mitad del siglo XVI y con ellos, la pintura definitivamente se transformó en su realidad estética. En estos casos, se ha apreciado que las obras caminaron de la mano del tenebrismo, jugando con las luces y sombras consiguiendo representar al máximo el relieve de las figuras. En el medio valenciano este cambio se observó en el trabajo de pintores como Juan Sariñena (h. 1545 - 1619) y Francisco Ribalta (1565-1628), de quienes varios de sus retratos forman parte del objeto de estudio de esta investigación. Muchas de las efigies que elaboraron se corresponden con personajes religiosos con posibilidades de conseguir la beatificación y la canonización. Por ejemplo, Sariñena pintó a fray Luis Bertrán y Ribalta a sor Margarita Agulló. En ambos casos, como se apreciará más adelante, el juego de luces y sombras fue un recurso eficaz para exaltar la situación de éxtasis en la cual estaba sumida sor Margarita o el especial fervor que sentía fray Luis ante Cristo crucificado. De este modo, una vez más se puede ver que la Iglesia también hizo acopio, por un lado, del nuevo lenguaje estético que aplicado a la pintura religiosa mostraba la faceta más dramática y devocional de la fe católica. Por otro, empleó el género del retrato para dar visibilidad a modelos de la virtud.

En cualquier caso, los artistas del siglo XVII trabajaron principalmente para clientes eclesiásticos y conventuales, pues la temática religiosa fue la más socorrida en la época. Personajes de gran peso para la sociedad valenciana, como el Patriarca Juan de Ribera, ejercieron de comitentes de destacables artistas como los ya mencionados Sariñena y Ribalta. El primero de ellos se estableció en Valencia a partir de 1580, después de haber permanecido en Italia desde 1570 a 1575. Su producción artística ha supuesto ser una alternativa a la obra renacentis- 
ta de Juanes. Tradicionalmente se le ha considerado un artista que estaba en plena consonancia con la pintura reformada y ello se ha apreciado en el elevado número de retratos tomados del natural donde le otorgó una gran importancia al tratamiento lumínico. ${ }^{50}$ Aunque el perfil de la mayor parte de los retratos hechos por Sariñena es eclesiástico, también conviene aludir a sus trabajos puntuales en el retrato civil. Por ejemplo, cabe recordar su aportación a la galería de monarcas del Corpus Christi que se van a estudiar más adelante, así como mencionar su implicación en uno de los proyectos artísticos civiles más interesante de la época, la decoración de la Sala Nova del palacio de la Generalitat.

La llegada de Francisco Ribalta a Valencia se produjo en un momento muy concreto y trascendental para la evolución de la pintura valenciana. Entre 1590 - 1594 se construyó la capilla del Real Colegio Seminario del Corpus Christi a instancias de Juan de Ribera. Este ambicioso proyecto necesitó del tra150 bajo de pintores locales y foráneos para su decoración, como el genovés Bartolomé Matarana (ca. 1545 - 1605), y por tanto fue un enclave fundamental para compartir conocimientos artísticos. El establecimiento de Ribalta en Valencia desde 1599 estuvo condicionado por la gran demanda de artistas que supuso la ornamentación de la capilla del Corpus Christi. Su contribución a la pintura valenciana hizo que se dejase atrás la estética renacentista para sumergirse plenamente en el naturalismo barroco. Pese a haberse formado en El Escorial, comenzó a interesarse por los cambios lumínicos sobre los cuerpos tras conocer las obras del pintor italiano Cambiaso, quien también había estado en el monasterio madrileño y quien ha sido valorado por ser uno de los primeros impulsores del tenebrismo. No obstante, aquello que más se ha apreciado del artista ha sido su capacidad para nutrirse de los planteamien-

50 Sobre este artista es fundamental la obra de Fernando Benito Doménech, Juan Sariñena (1545-1619) : pintor de la Contrarreforma a Valencia : Museo de Bellas Artes de Valencia, del 19 de diciembre de 2007 al 23 de marzo de 2008, (Generalitat Valenciana, Consellería de Cultura i Esport, 2007). 
tos artísticos de otros pintores. Por ello, y como apuntó Fernando Benito, de su etapa escurialense tomó: «el dramatismo de Navarrete, [...] la monumentalidad de Piombo y la coloración veneciana de Tiziano. De Valencia tomaría en cambio el realismo crudo y la simplicidad de Sariñena, y el idealismo de los arquetipos de Joanes, es decir las dos tendencias estéticas imperantes en Valencia que también quedaban así integradas en el acervo de sus conocimientos. ${ }^{51}$

Las características de Ribalta se pueden observar en alguno de los retratos que se estudiarán a continuación y que ejemplifican la adaptación del género a los avances estéticos. Uno de los principales discípulos de Ribalta, y de quien también se han analizado obras en esta tesis, fue su hijo Juan Ribalta (1597-1628). Él ha firmado pinturas propias desde 1615 y en ellas es palpable su interés por el claroscuro heredado de su padre. Como se observará en el capítulo correspondiente, de Juan Ribalta y de su taller se han estudiado las efigies de hombres ilustres valencianos procedentes de La Murta, cuya existencia entronca perfectamente con la tendencia propia de la época de retratar a dignidades procedentes de diversos ámbitos intelectuales.

La pintura valenciana durante el tiempo de la reforma católica, naturalmente, estaba dirigida a cumplir con las demandas del clero y esta clase social es la que decidía acerca de los temas a representar. En el caso de que algún noble encomendase una obra, generalmente era con el objetivo de donarla a alguna capilla en concreto porque estaba bajo su patronato. Respecto a la clase artesanal, ésta podía encargar la realización de un retablo o una pintura pero siempre se gestionaba a través de las cofradías y de los gremios, por ello eran imágenes que principalmente se destinaban al culto de sus santos patronos. No obstante, en un contexto donde predominó

51 Fernando Benito Doménech, Los Ribalta y la pintura valenciana de su tiempo: exposición Lonja de Valencia, octubre - noviembre 1987: Museo del Prado, Palacio de Villahermosa, diciembre 1987 - enero 1988, (Diputación Provincial de Valencia: Valencia, 1987). 
claramente la elaboración de retratos vinculados a la Iglesia, la principal excepción por ser un proyecto de carácter civil fue la decoración de la Sala Nova del palacio de la Generalitat Valenciana (fig. 2.17). ${ }^{52}$ Este caso, ampliamente estudiado, ${ }^{53}$ no se ha abordado en el presente estudio porque no concuerda con las características comunes que ligan al resto de ejemplos trabajados.

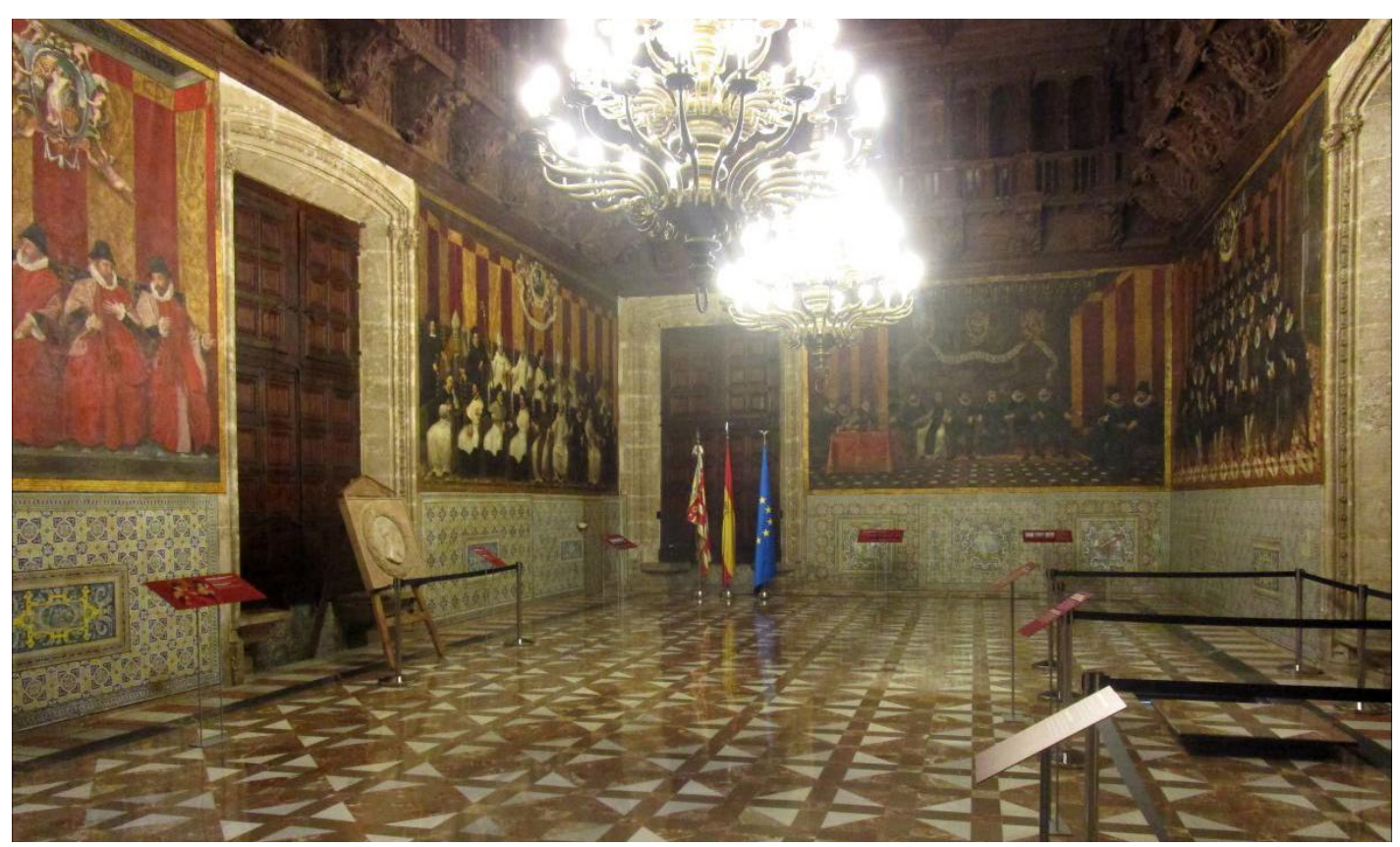

Fig. 2.17. Vista general de la Sala Nova, Valencia, Palacio de la Generalitat.

Otro de los artistas fundamentales en el ámbito valenciano del siglo XVII fue Jerónimo Jacinto de Espinosa (1600 - 1667). Tras pasar su niñez en Cocentaina, a los doce años Jerónimo Jacinto se trasladó junto a su familia a Valencia. Allí se formó como pintor, impregnándose del ambiente ribaltesco y trabajando con su padre Jerónimo Rodríguez de Espinosa (1562 - c.1639). En 1616, el joven estaba inscrito en el Colegio de Pintores y en la documentación pertinente se especificaba que después

52 Benito Doménech, Los Ribalta y la pintura valenciana..., p. 23.

53 Salvador Aldana Fernández, Sala Nova del Palau de la Generalitat Valenciana, (Institut Valencià de Conservació i Restauració de Béns Culturals: Valencia, 2007); Salvador Aldana Fernández, El Palau de la Generalitat valenciana, (Generalitat Valenciana: Valencia, 1995); Salvador Aldana Fernández, 'Iconografía de la Sala Nova del Palau de la Generalitat Valenciana. Nuevas aportaciones', Goya: Revista de arte, no. 246, 1995, pp. 322-327. 
de tres años más de experiencia junto a su progenitor sería designado maestro. ${ }^{54}$ Sus obras se han caracterizado estéticamente por elaborar figuras grandiosas y emplear una iluminación tenebrista. Ambos aspectos denotan la influencia de Ribalta y han quedado reflejados tanto en sus pinturas de escenas religiosas, que eran las más abundantes, como en los contados retratos. Así la efigie de fray Jerónimo Mos (fig. 2.18)

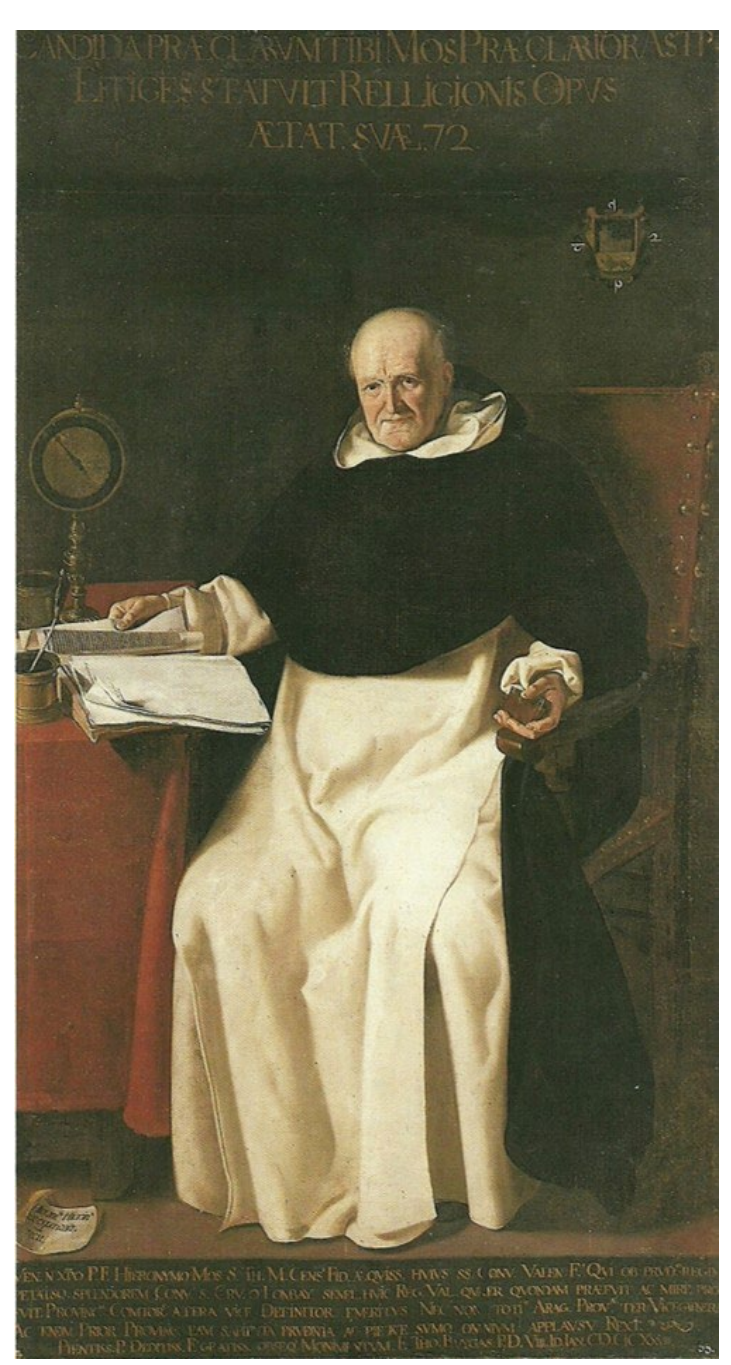

Fig. 2.18. Jerónimo Jacinto Espinosa, Fray Jerónimo Mos, h.1628, óleo sobre lienzo, Valencia, Museo de Bellas Artes. se ha relacionado con la representación de San Bruno (1625-1627, óleo sobre tabla, Valencia Museo de Bellas Artes) de Ribalta en cuanto al tratamiento de las vestiduras y la peculiar utilización de la luz. No obstante, los retratos realizados por Espinosa y estudiados en este trabajo forman parte de determinadas galerías que ya requieren de unas características preestablecidas y diluyen, en cierta medida, las peculiaridades del artista. En esta casuística se encuentran los retratos de Pedro de Urbina y Martín López de Hontíveros pertenecientes a la dinastía de prelados de la catedral de Valencia y el retrato de fray José Sanchís, ubicado en el paraninfo de la universidad valenciana y cuya autoría se ha puesto en cuestión.

Por tanto, la producción de retratos en el siglo XVII además de ampliar su tipología y otorgarle una especial relevancia a

54 Benito Doménech, Los Ribalta y la pintura valenciana..., p. 279. 
la representación de hombres ilustres, estuvo muy controlada por la Iglesia que, por un lado, siguió engrandeciendo las tradicionales series de prelados y por otro encargó numerosos lienzos que mostraban el gozo de los santos y enaltecían sus virtudes empleando el lenguaje propio del tenebrismo. Así pues, los ejemplos más señeros del retrato en el medio valenciano durante esta época se corresponderán en numerosas ocasiones con las representaciones de frailes, venerables, beatos y santos. ${ }^{55}$ De hecho, sólo con consultar los fondos del museo de Bellas Artes de Valencia se puede ver la cantidad de efigies procedentes del siglo XVII que muestran, por citar un ejemplo, a algunos venerables dominicos pintados por Apolinario Larraga. Los conventos eran lugares con elevadas posibilidades de albergar representaciones de sus miembros más ilustres. Sin embargo, el análisis de esta clase de conjuntos es complicado debido a la diseminación o a la destrucción de estas obras a raíz de la desamortización de Mendizábal.

154 Como se estudiará más adelante, son reseñables los numerosos retratos que coleccionó san Juan de Ribera sobre los venerables, beatos y otros religiosos de la época y cuyas imágenes tenía en varias de sus propiedades y en el Colegio del Corpus Christi. Las representaciones de fray Luis Bertrán, del beato Nicolás Factor, de sor Margarita Agulló, de fray Domingo Anadón, del venerable Francisco Jerónimo Simó o del hermano Francisco del Niño Jesús son, en palabras de Fernando Benito, retratos moralizantes. ${ }^{56}$ Por tanto, se deben entender como imágenes que, a través de los personajes pintados, defienden las virtudes católicas y muestran a personas como ejemplos a seguir por su intachable vida espiritual. Su condición de retratos obliga a que uno de los aspectos incuestionable sea el

55 Una obra referente es la tesis doctoral de Andrés Felici Castell, 'La santidad local valenciana: la tradición de sus imágenes y su alcance cultural', Universitat de València, 2016.

56 Fernando Benito Doménech, 'El retrato moralizado en España: Contrarreforma e influencia del retrato como género', en Javier Portús Pérez (ed.), El retrato en el Museo del Prado, (Anaya: Madrid, 1994), pp. 183-191. 
parecido, pues esta es la base de cualquier representación individualizada y máxime cuando el objetivo es presentar a una persona considerada modélica. De hecho, el autor previamente citado hizo hincapié en la importancia del parecido sirviéndose de una anécdota sobre las pautas que Felipe II le indicó a Navarrete el Mudo para decorar los altares del Escorial. El monarca le pidió al artista que: «cuando una figura de un santo se duplicare presentándola más veces, siempre se le hará el rostro de la misma manera, y así lo mismo las ropas sean de un mismo color (...) y si algún santo tuviera retrato propio se pinte conforme a él, el cual se busque donde quiera que le haya con diligencia..157 Por esta razón, cobraron una especial importancia los retratos esbozados tomados en los momentos previos al fallecimiento de la persona y las máscaras mortuorias que permitían trazar la fisionomía del personaje de forma fidedigna, creando así las veras effigies.

En consecuencia, esta clase de imágenes de gran calado en el siglo XVII van ligadas a la reforma de la Iglesia católica y a sus deseos por ensalzar el culto de los santos e ir promoviendo los procesos de beatificación y canonización de aquellos cristianos ejemplares y más cercanos a Dios. Por esta razón, el fomento del culto hacia ellos no sólo se dio a través de las imágenes y en concreto de los retratos, sino también con el potente mercado de las reliquias y la constante publicación de hagiografías.

\subsection{El retrato en el siglo XVIII y la Academia.}

Con el inicio del reinado de una nueva dinastía en el trono español, la Casa de Borbón, también trajo un aire renovador al panorama artístico. No obstante, no fue una transformación homogénea y radical, es decir, los rasgos propios del Barroco siguieron perdurando durante un tiempo entre las obras realizadas para la corte. La progresiva modernización de la pin-

57 Benito Doménech, 'El retrato moralizado en España...', p. 183. 
tura, por tanto, se dio a varios factores. Uno de ellos fue la llegada de pintores procedentes de Italia y Francia. Otro a tener en cuenta fueron los viajes de artistas españoles al extranjero para formarse y absorber otras realidades estéticas. Y por último, no se debe olvidar la fuerte apuesta que la monarquía hizo por las artes. Una postura que ya se percibió en 1721 con la fundación de la Real Fábrica de Tapices de Santa Bárbara, donde muchos de los artistas que pintaron cartones igualmente elaboraron retratos como Andrés de la Calleja (17051785), Francisco Bayeu (1734-1795), Mariano Salvador Maella (1739-1819) o Francisco de Goya (1746-1828), por mencionar algunos ejemplos. Sin embargo, la acción definitiva para dar respaldo a las artes y al mismo tiempo ejercer un control sobre ellas, fue la creación de la Real Academia de Bellas Artes de San Fernando, basándose en la institución francesa.

Especialmente fructífera fue la segunda mitad del siglo XVIII donde la estética barroca empezó a recibir las primeras influencias del neoclasicismo. Estas se produjeron de la mano de Antón Rafael Mengs (1728 - 1779) tras su llegada a la corte madrileña para trabajar al servicio del rey Carlos III (1759 - 1788). Fue, por tanto, un periodo dorado donde la producción artística española encajaba con la realidad europea. La época de auge llegó a su ocaso con la caída del gobierno de Carlos IV (17881808), la crisis monárquica, la invasión francesa y la guerra de la independencia. En cuanto al ámbito valenciano las artes estuvieron ancladas al gusto del Seiscientos hasta bien avanzada la centuria. Madrid seguía siendo el principal foco cultural del momento, pero el surgimiento de las academias facilitó la renovación artística a nivel local. ${ }^{58} \mathrm{La}$ Academia, en definitiva, trajo un cambio en la situación del artista, cuyo trabajo caminó progresivamente hacia su regulación y profesionalización. Si hasta entonces el único lugar de aprendizaje era el taller del pintor, ahora las academias no sólo proporcionaban unos conocimientos técnicos, sino que además instruían en el gusto

58 Juan J. Luna, 'La internacionalización del retrato en el siglo XVIII', en Leticia Ruiz Gómez (ed.), El retrato español en el Prado. Del Greco a Goya, (Museo Nacional del Prado: Madrid, 2007), pp. 133-139. 
estético, y por tanto, fomentaban la admiración por el pasado clásico. En este periodo los artistas, además de los encargos realizados por la Iglesia y la monarquía, vieron como entre la clientela se abría paso la burguesía. ${ }^{59}$

Uno de los principales retratistas estrechamente ligado al surgimiento de la Academia y al panorama artístico valenciano fue José Vergara Gimeno (1726 - 1799). ${ }^{60} \mathrm{En}$ los retratos elaborados por este ya es apreciable el cambio estético de la época y el consecuente abandono del lenguaje barroco para apostar por la delicadeza en las imágenes y el detallismo exacerbado en las pelucas y la indumentaria. Así se aprecia en los casos de las efigies regias. Por ejemplo y como se verá más adelante, un aire afrancesado se observa en las imágenes de Fernando VI y Bárbara de Braganza. Ambas obras se pintaron a raíz del nacimiento de la Academia de Santa Bárbara y el retrato de la reina, concretamente, presidió la sala de juntas. El valor y el uso institucional que se dieron a estos retratos ha estado patente en otros casos posteriores, así la imagen de Carlos III (véase fig. 5.73) fue encomendada para lucir en la correspondiente sala de juntas de la Academia fundada por él mismo. Esta representación, en concreto, se ha basado en el retrato que Mengs hizo del monarca poniendo de manifiesto la presencia de la estética neoclásica en el arte español.

Además de los retratos regios, Vergara también pintó otras efigies, ahora de carácter intelectual, que formaron parte del conjunto pictórico del paraninfo de la Universitat. De entre todas ellas, el retrato de Felipe Bertrán, arzobispo de Valencia, es el que aparece firmado por el pintor. Aquí, el lenguaje vi59 Mercedes Afeda Villar (ed.), Antonio Rafael Mengs, 1728 - 1779. Museo del Prado, junio-julio, 1980, (Ministerio de Cultura, Dirección General del Patrimonio Artístico, Archivos y Museos: Madrid, 1980), p. 15.

60 Son fundamentales las siguientes aportaciones: David Gimilio Sanz, José Vergara 1726-1799: Del tardobarroco al clasicismo dieciochesco, (Conselleria de Cultura, Educació i Esport: Valencia, 2005); Miguel Ángel Catalá Gorgues, El pintor y académico José Vergara (Valencia, 1726-1799), (Generalitat Valenciana: Valencia, 2004). 
sual sigue la estética del retrato barroco seguramente debido a que se trata de una pieza más dentro de un conjunto pictórico y por tanto, respeta las pautas compositivas e iconográficas que han caracterizado a la galería. Junto a este retrato, se encuentran tres más que se corresponden con José Climent, también prelado de Valencia, José Tormo y Francisco Borrull. Si bien tradicionalmente se han considerado anónimos, David Gimilio los ha comparado con la efigie de Felipe Bertrán y las similitudes entre ellos le han llevado a catalogarlos como probables obras de Vergara. ${ }^{61}$

Otros de los máximos pintores en materia de retrato durante esta centuria también se formaron en la Academia. Cabe recordar que Mariano Salvador Maella (1739 - 1819) estudió en San Fernando y Agustín Esteve Marques (1753 - h. 1835) inició su formación en San Carlos para, más tarde, continuar en la madrileña. Esteve estuvo vinculado a la institución valenciana desde su nacimiento, cuando ya contaba con una educación artística previa proporcionada por su padre. En 1770 se trasladó a Madrid y allí conoció las obras de Bayeu, Maella y Mengs. No obstante el artista con quien tuvo una mayor afinidad fue, desde 1775, Goya. De hecho Agustín Esteve fue el retratista más solicitado, después del pintor zaragozano, a partir de 1790. Es más, en numerosas ocasiones realizó copias de los retratos hechos por Goya de Carlos IV y Ma Luisa de Parma, los duques de Osuna, la duquesa de Alba o la de Villafranca, por citar algunos casos. ${ }^{62}$ Un momento verdaderamente significativo en la trayectoria de Esteve se produjo en 1800 cuando fue nombrado pintor de cámara y académico de mérito de 61 David Gimilio Sanz, 'José Vergara Gimeno y la retratística valenciana en el siglo XVIII', Ars Longa: cuadernos de arte, no. 12, 2003, pp. 75-82.

62 Un ejemplo más de la influencia de Goya en la producción de artística de Esteve es el retrato de Fernando VII hecho en 1808 (óleo sobre lienzo, Madrid, colección particular) a petición del Ayuntamiento de Cuenca. En este caso, el pintor valenciano tomó como modelo un retrato del rey, hecho al natural por Goya, principalmente para la realización del rostro. Véase a Arturo Ansón Navarro, 'Un retrato de Fernando VII (1808) obra de Agustín Esteve', Ars Longa: cuadernos de arte, no. 21, 2012, pp. 351-356. 
San Carlos. Diecinueve años después, abandonó la profesión. De este mismo artista se han analizado dos retratos interesantes entre el conjunto de obras que configuran las distintas colecciones. Se trata de las efigies del grabador Fernando Selma (siglo XVIII, óleo sobre lienzo, Valencia, Real Academia de Bellas Artes de San Carlos) y del escultor José Esteve Bonet (siglo XVIII, óleo sobre lienzo, Valencia, Real Academia de Bellas Artes de San Carlos) que forman parte del elenco de académicos efigiados por una gran diversidad de artistas. Cabe recordar que la formación de los principales pintores y la producción del retrato en el siglo XVIII estuvieron asociadas a la aparición de las Academias como instituciones instructivas, reguladoras y consejeras del gusto estético. Por esta razón, y además de contar con un número abundante de retratos de académicos, es necesario explicar brevemente el nacimiento de la Academia de Bellas Artes en Valencia y analizar su organización, pues muchos de aquellos que desempeñaron importantes funciones han sido efigiados para dar visibilidad a las máximas personalidades de esta institución.

\subsubsection{La Real Academia de Bellas Artes de San Carlos.}

Tras el surgimiento de la Academia de Bellas Artes de San Fernando, considerada la institución madre de todas aquellas que vinieron después, el nacimiento de la Academia de San Carlos trajo el cambio definitivo hacia un nuevo modelo estético e influyó en el auge del Neoclasicismo. Es importante destacar que en este momento la Iglesia atravesaba un periodo decadente y por el contrario la urbe volvía a gozar de una economía boyante, la burguesía era una clase adinerada y creciente centrada en la industria y el comercio, y su favorable situación hizo que desease visibilizar su prosperidad ante la sociedad. A raíz de ello, la Iglesia dejó de ser el principal cliente para los artistas y la burguesía era un nuevo sector con posibilidades de demandar obras de arte. En este tiempo, igualmente, cobraron importancia otros géneros pictóricos además del retrato, como el bodegón, los 
paisajes, temas clásicos de carácter histórico y mitológico y escenas populares.

Cabe recordar que los primeros pasos para crear la Academia de Bellas Artes de San Carlos acaecieron en 1754 cuando José e Ignacio Vergara solicitaron al rey Fernando VI el permiso para crear una Academia Pública de Pintura, Escultura y Arquitectura. El monarca consintió la propuesta y la dedicó a santa Bárbara, en honor de su esposa, Bárbara de Braganza. No obstante, su trayectoria fue corta puesto que no podía hacer frente a los inconvenientes económicos que la acechaban y desapareció definitivamente en 1759 cuando ambos reyes ya habían fallecido. ${ }^{63}$

El contratiempo de la Academia de Santa Bárbara no frenó las ansias de los artistas valencianos por conseguir definitivamente una institución que ofreciese una formación reglada a pintores, escultores y arquitectos. Por esa razón en 1762, aque-

llos que habían protagonizado el primer intento, y apoyados por los cargos relevantes del gobierno municipal, se animaron a enviar un memorial a Carlos III para instaurar una escuela que retomase la labor iniciada en 1754 y que había quedado interrumpida. Así pues, las intenciones de los artistas valencianos se comunicaron a la Academia madre puesto que ella era el enlace con el rey. El grabador Manuel Monfort fue quién marchó a Madrid para presentar la propuesta junto con una serie de obras de arte que avalaban la calidad de los artistas valencianos y justificaban la necesidad y conveniencia de poseer esta institución. Finalmente, Carlos III aceptó la idea y en 1766 se redactaron los estatutos que la iban a regir desde su

63 Conviene seguir a Salvador Aldana Fernández, Real Academia de Bellas Artes de San Carlos de Valencia: historia de una institución, (Real Academia de Bellas Artes de San Carlos: Valencia, 2001), p. 33; También puede consultarse a Francisco José León Tello y María M. Virginia Sanz Sanz, La estética académica española en el siglo XVIII: Real Academia de Bellas Artes de San Carlos de Valencia, (Servicio de Estudios Artísticos, Institución Alfonso el Magnánimo, Diputación Provincial de Valencia: Valencia, 1979), pp. 27 - 28. 
nacimiento. Al inicio de los mismos ya se ha dejado constancia de la ayuda económica que anualmente se destinaría a esta nueva institución con el objetivo de evitar su desaparición.

En consulta de 30 de marzo de 1762 hizo presente al Rey su Academia de San Fernando una representación en la que ciudad de Valencia pidió a su Majestad se dignase de autorizar el estudio público, o Academia, de las Artes que deseaba fundar en aquella capital recibiéndola bajo se real protección, aprobando y mandando le fuesen perpetuos treinta mil reales de vellón en cada año con que de una de sus arbitrios la dotaba; sirviéndose de dar las demás providencias precisas para su establecimiento pues por falta de estos poderosos auxilios no pudo subsistir la que en el año 1753 se fundó en la misma ciudad. [...] condescendiendo su Majestad con las repetidas instancias de su Academia de San Fernando, viene en crear y autorizar por ahora como creía y autoriza por la presente, un congreso con el nombre de Junta Preparatoria para la futura Academia de Valencia, a fin de que celebrando las actas $\mathrm{y}$ acuerdos que juzgue convenientes, medite, acuerde y proponga a su Majestad por medio de la de San Fernando las reglas, leyes y estatutos que juzgue más oportunos y a propósito para su gobierno.[... ${ }^{64}$

La lectura de las Reales Órdenes elaboradas por el monarca es interesante y aclaratoria para entender cómo funcionaba la Academia. El primer artículo estipulaba las clases de académicos que la componían. Además, se contaba con un presidente, un vicepresidente, dos consiliarios, dos viceconsiliarios, un secretario, académicos de honor, un director general, dos directores de pintura, dos de escultura, dos de arquitectura y uno de grabado, un teniente director de pintura, otro de escultura y otro de arquitectura, académicos de mérito y

64 Archivo de la Real Academia de Bellas Artes de San Carlos (ARABASC ahora en adelante): Estatutos de la Real Academia de Bellas Artes de San Carlos. 
supernumerarios ${ }^{65}$ Asimismo en el documento se han detallado las funciones a desempeñar por cada tipo de académico, el proceso de selección para adquirir uno de estos títulos y las clases de reuniones que se celebraban, teniendo en cuenta todo tipo de detalles como personas que podían asistir, lugar donde realizarla y posibles temas a tratar.

En consecuencia, y como ha remarcado León Tello y Sanz Sanz ${ }^{66}$ el nacimiento de las Academias de Bellas Artes fue el resultado de la implantación de los ideales políticos propios del despotismo ilustrado. Su objetivo era doble; por un lado, tenía la intención de elevar el acervo cultural de la sociedad. Por ello, se estableció un programa educativo que introducía sesiones académicas, invitaba al diálogo entre el profesorado y el alumnado, y celebraba concursos. Por otro lado, se buscaba el constante alago y gratitud al monarca, quien era encumbrado en distintas poesías y discursos por ser el patrón y el máximo representante de la institución.

Desde la Academia se promovió la elaboración de retratos de cariz institucional que se han analizado en el correspondiente capítulo de este estudio. Pero además la Academia ha sido una institución determinante para la conservación de algunas de las galerías de retratos aquí analizadas por el especial interés que tuvo en recopilar y custodiar todas las obras para proteger el patrimonio artístico y cultural. El deseo de contar con una

65 ARABASC: Estatutos de la Real Academia de Bellas Artes de San Carlos. Artículo I: «Clases de Académicos: Presidente, vicepresidente, 2 consiliarios, 2 viceconsiliarios, secretario, académicos de honor (tantos como se estimen oportunos), director general, dos directores de pintura, dos directores de escultura, dos directores de arquitectura, uno de grabado, un teniente director de pintura y otro de escultura y otro de arquitectura, académicos de mérito y los supernumerarios que se hallasen con la pericia y requisitos correspondientes. [...] Para la custodia de la casa en que ha de residir la Academia, la de sus alhajas, aseo de ellas y las demás servidumbres, había un conserje, un portero y uno o dos hombres bien formados para modelos.»

66 León Tello y Sanz Sanz, La estética académica española..., pp. 57 - 59. 
galería de académicos no fue un fenómeno que surgiese en el siglo XVIII, pues ya anteriormente se crearon algunas academias durante la segunda mitad del siglo XVI. Por ejemplo, la Accademia delle arti del disegno de Florencia estipuló en sus estatutos la necesidad de representar en un friso a los artistas desde Cimabue. ${ }^{67}$ La configuración de galerías de efigies de artistas también se debe conectar con la consolidación del subgénero del autorretrato durante el Renacimiento, comentada anteriormente, y que tendrá su proyección posterior. Tras la elaboración de los autorretratos o las representaciones de otros compañeros de profesión continuaba la voluntad por revalorizar la labor intelectual necesaria para la concepción de la obra de arte.

\subsection{El retrato en los inicios del siglo XIX.}

Debido a que las galerías y colecciones de efigies estudiadas se han construido a lo largo de los siglos XVII y XVIII, algunas de ellas también han crecido en el siglo XIX o en esta misma centuria han llegado a engrosar los fondos de las academias, conviene entender la concepción y aprecio que se tenía acerca de este género en el Ochocientos. En consecuencia, seguidamente se hará referencia a algunos de los principales artistas del siglo XIX, ya que numerosas pinturas suyas forman parte de los conjuntos estudiados. También se tratará sintéticamente la creación y cometido de la Junta de Iconografía Nacional, pues esta institución incidió en la consideración y valoración que se tuvo de los retratos en tiempos decimonónicos. Y por último, otra cuestión a tener presente es la desamortización, ya que fue la clave para que muchas de las obras pasasen a formar parte de determinadas colecciones artísticas además de promover la conservación de estas obras pictóricas.

En el siglo XIX perduró la idea de que el retrato era, por tanto, la definición de uno mismo en imagen. En este sentido, es no-

67 Jennifer Fletcher, 'El retrato renacentista: funciones, usos y exhibición', en Miguel Falomir Faus (ed.), El retrato del Renacimiento, (Museo Nacional del Prado: Madrid, 2008), pp. 71-89. 
torio comprobar la cantidad de efigies que se continuaron elaborando, entre las cuales también destacaron las representaciones de artistas o bien autorretratados o representados por compañeros de profesión. Un vez más, se empleó este género para remarcar la identidad individual y social de uno mismo. Por lo general, los retratos y autorretratos de artistas suelen concentrar la atención en el rostro o en el busto, no se realizan representaciones de tres cuartos o cuerpo entero como sí sucede en las efigies de las principales dignidades de la sociedad y cuya imagen desempeña un papel oficial. Seguramente, es cuando el retrato posee un cariz institucional aquello que influye en la elección del formato de cuerpo entero. Sin embargo, se puede decir que las imágenes de los artistas son más íntimas, y sobre todo los autorretratos, pues en ellos se ha reflejado cómo el autor se ve a sí mismo y lo que cree que es. A su vez, un autorretrato también es una prueba de cómo deseas ser percibido por los demás. Así, probablemente, los artistas fueron cándidos en el momento de reproducir sus propios de-

fectos físicos que trataron a modo de rasgos característicos de la persona. Además, se solían efigiar impecablemente vestidos, en actitudes elegantes y acompañados de objetos accesorios para aludir a su profesión. En cualquier caso, generaron imágenes que eran de su agrado y en las que se veían favorecidos, pero ello no salvaba que la imagen fuese lo suficientemente fiel a la apariencia de la persona para ser reconocible por el resto. ${ }^{68}$

Esta concepción del retrato en el siglo XIX debe entenderse a su vez en un contexto concreto. La principal característica de esta realidad había sido el enriquecimiento de la burguesía en tiempos de Isabel II. Este nuevo sector de la sociedad consideró tener un retrato como un elemento diferenciador y señero 68 Acerca de las representaciones de los propios artistas véase a: Julián Gállego, 'Retratos y autorretratos', en Artistas pintados. Retratos de pintores y escultores del siglo XIX en el Museo del Prado, (Museo Nacional del Prado: Madrid, 1997), pp. 13-38 y a José Luis Díez, 'La imagen del artista en la pintura española del siglo XIX', en Artistas pintados. Retratos de pintores y escultores del siglo XIX en el Museo del Prado, (Museo Nacional del Prado: Madrid, 1997), pp. 39-61.. 
de su condición privilegiada. Por ello, la producción y venta de retratos será una parte importante para el sustento de los artistas.

Cabe tener en cuenta que el final del siglo XVIII y los inicios del siglo XIX no alteró sustancialmente el panorama artístico. Así pues, el arte decimonónico a comienzos de la centuria se basó en las ideas asentadas anteriormente. Con el establecimiento de una monarquía absolutista liderada por la Casa de Borbón en el siglo XVIII, la corte seguía siendo el mayor enclave artístico. Estéticamente, las artes bebían del academicismo clasicista con tintes ilustrados, que a su vez se apoyaba en el lenguaje barroco procedente tanto de Francia como de Italia $y$ en el decorativismo. Sin embargo, a nivel local era un poco más complicado adherirse a la corriente academicista y aún pervivían las tradicionales formas del barroco provincial. ${ }^{69}$

De hecho, el reinado de Fernando VII artísticamente ejemplifica la vigencia de los ideales tradicionales. Esta situación, sobre todo, se ha visto con la elección de Vicente López Portaña (1772 - 1850) como primer pintor de cámara del mencionado monarca. La cronología en la que vivió y las circunstancias profesionales que rodearon a este artista influyeron en que fuese el último pintor de gran prestigio seguidor del academicismo dieciochesco. En palabras de Reyero y Freixa, López encarnó la supervivencia de las «tradiciones barrocas autóctonas en combinación con la normativa clasicista impuesta por las academias desde el siglo XVIII.. ${ }^{70}$ Procedente de una familia de pintores, su formación artística comenzó con las clases de Antonio Villanueva, amigo de la familia y académico de San Carlos. Sin conocer el año exacto en que ingresó en la Academia valenciana, en 1785 ya aparece entre la documentación como opositor al concurso general de 1786.

69 Carlos Reyero y Mireia Freixa, Pintura y escultura en España, 18001910, (Cátedra: Madrid, 2005), p. 17.

70 Reyero y Freixa, Pintura y escultura..., p. 19. 
Tres años después consiguió el premio extraordinario convocado por la misma Academia para estudiar becado en la corte y marchó a Madrid junto con el grabador Rafael Esteve (1772-1847), quien quedó en segunda posición. Allí permaneció hasta 1794, bajo la supervisión de Manuel Monfort, quien controlaba a los becados procedentes de Valencia en la capital cortesana. Durante este tiempo, ingresó en la Academia de San Fernando, conoció la pintura barroca del siglo XVII y copió obras de Luca Giordano y Claudio Coello. También estudió el academicismo clasicista introducido por Rafael Mengs y seguido por Francisco Bayeu y Mariano Salvador Maella. De ellos, tomó la composición y el color. Así, las obras de López se caracterizaron por combinar la admiración hacia el academicismo y mantener la esencia artística valenciana reconocible en el colorido llamativo, las superficies brillantes y el realismo de la pintura, evocador del barroco naturalista de Ribera y Ribalta. En 1792, siendo ya un prestigioso pintor, se estableció nuevamente en Valencia. Allí fue profesor de la Academia de Bellas Artes y en 1801 fue nombrado presidente. A raíz de su vuelta le llovieron numerosos proyectos desde la Iglesia y particulares. Probablemente el pintar algunas obras para la catedral en la década de los noventa, le dio pie a participar en la serie de retratos de los obispos y arzobispos valentinos, como se apreciará seguidamente. ${ }^{71}$

Si bien la producción artística de Vicente López cuenta con pinturas religiosas y de historia, aquí conviene fijar la atención en su faceta como retratista. Sus retratos, principalmente, se caracterizan por ser altamente realistas, pues así lo evidencia una reproducción fidedigna y detallada de los rostros y de la indumentaria en la que consigue capturar la calidad de los tejidos. En el elevado grado de exactitud se ha visto la huella del Barroco valenciano, según José Luís Díez ello se ha visto concretamente en su «obsesión por el dibujo, por reproducir todos y cada uno de los detalles de las figuras de sus re-

71 Adela Espinós Díaz, Vicente López en el Museo de Bellas Artes de Valencia, (Generalitat Valenciana: Valencia, 2013). 
tratos. ${ }^{72}$ Asimismo, sus efigies no son imágenes edulcoradas, se apuesta por la objetividad y la minuciosidad sin dejar de lado el decoro, pues los personajes representados siempre lo hacen fielmente a su condición social. También incorporó recursos propios del romanticismo, como el tipo de puesta en escena o el abrir espacialmente el fondo. Algunos de los retratos analizados en la presente investigación han sido identificados como obras suyas o de su taller. En concreto, se encuentran dos en la serie de obispos y arzobispos valencianos; el retrato de los prelados Antonio Despuig y Dameto y Juan Francisco Jiménez del Río. En ambas pinturas es perceptible el alto grado de realismo en la apariencia del religioso sin sacrificar la magnificencia inherente a formar parte de la cúspide eclesiástica valenciana.

Uno de los hechos históricos que permitió a López mostrar su capacidad y talento para el género del retrato, fue la pintura alegórica que hizo de Carlos IV y su familia siendo homenajeados por la Universidad de Valencia (fig. 2.19). Fue un encargo realizado por el rector de la Universitat, Vicente Blasco García, para ser entregado al rey en su visita a Valencia, que tuvo lugar en 1802 cuando regresaban a Madrid desde Barcelona por el desposorio del Príncipe de Asturias, el futuro Fernando VII y su primera esposa María Antonia de Borbón (1784 - 1806). La obra se ha considerado un gran retrato alegórico cortesano cuyas efigies, generalmente, no se pudieron tomar del natural dado la necesidad de entregar el trabajo concluido durante la visita. Así, el artista empleó como referencia imágenes anteriores como los grabados de Brunetti o las representaciones que aparecían en la Guía de forasteros. El obsequio contó con el beneplácito de Carlos IV y éste nombró a López como pintor honorario de cámara. Fue el inicio de una buena relación profesional con la Corona que alcanzaría el máximo grado, como se ha dicho anteriormente, con su nombramiento como primer pintor de cámara de Fernando VII en 1814, desbancando 72 José Luis Díez, 'El retrato español del siglo XIX', en Javier Portús Pérez (ed.), El retrato español en el Museo del Prado, (Anaya: Madrid, 1994), pp. 323-349 


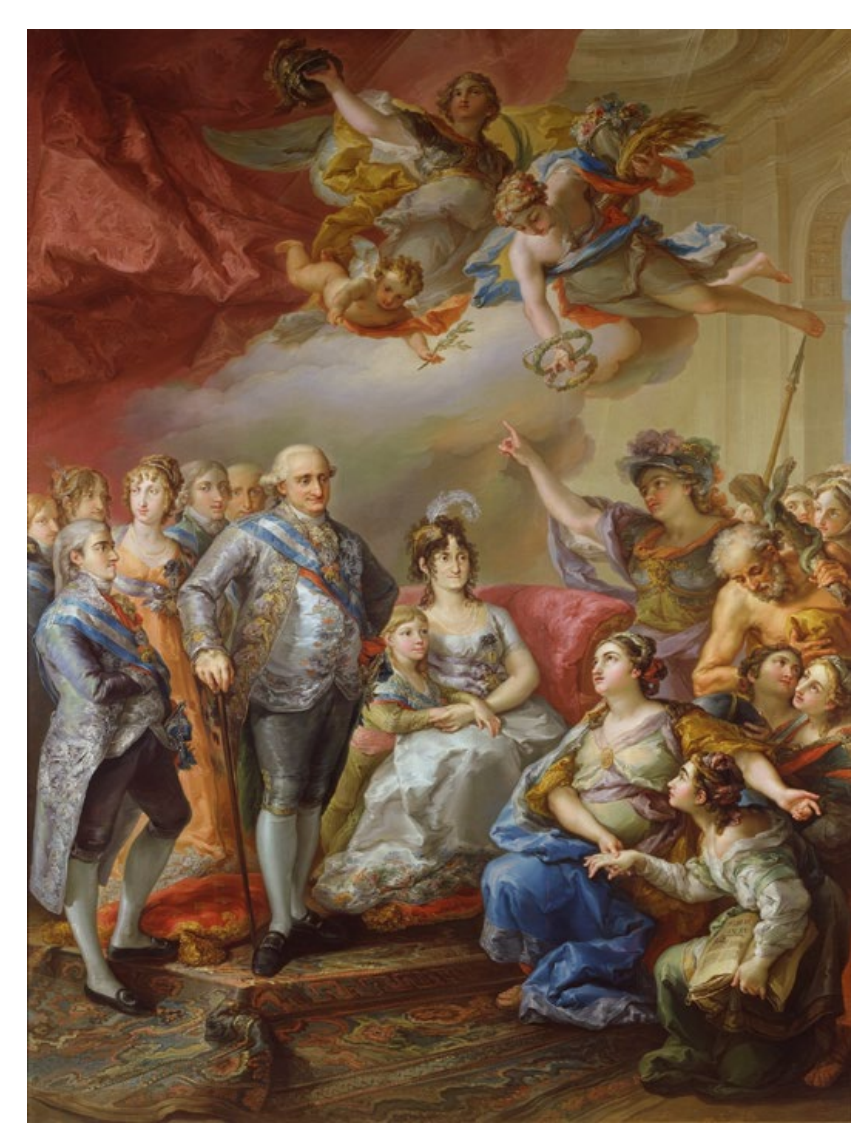

Fig. 2.19. Vicente López, Carlos IV y su familia homenajeados por la Universidad de Valencia, 1802, óleo sobre lienzo, Madrid, Museo Nacional del Prado.
Otras obras de este artista que no han tenido cabida en esta investigación pero se mencionan para conocerlas mínimamente, son el retrato del mariscal Louis Gabriel Suchet (ca. 1813, óleo sobre lienzo, Valencia, Museo de Bellas Artes) y del capitán general Ramón María de Narváez [fig. 2.20]. Se corresponden con efigies de carácter militar que vienen a ejemplificar, una vez más, las aptitudes del artista en este género y muestra la variedad tipológica que también trabajó.

La influencia del arte de López se vio en dos sectores diferenciados. Por un lado, aquellos que nacieron a partir de 1780, se formaron y desarrollaron su trayectoria en la Academia de San Carlos y en el medio valenciano respectivamente. Por otro lado, dejó su estela en aquellos artistas que nacieron alrededor de 1810, se formaron en Madrid y coincidieron con el periodo en que Vicente López trabajó principalmente al servicio de la monarquía española. ${ }^{74}$ El primer grupo es el que más interés despierta para esta investigación, pues a él pertenecieron otros autores que elaboraron alguna de las efigies estudiadas en los capítulos sucesivos. El ejemplo más destacado fue el de

73 Espinós Díaz, Vicente López en el Museo..., pp. 18-19.

74 Reyero y Freixa, Pintura y escultura..., p. 24. 
Miguel Parra (1784-1846), quien también trabajó el género del retrato, aunque normalmente se han valorado más sus obras adscritas a la pintura de flores y a los bodegones.

Retratos asociados a la mano de Parra encontramos de diversa tipología. Por ejemplo, se le atribuyen las efigies de los primeros prelados del siglo XIX, concretamente las representaciones de Joaquín Company Soler (1800-1813), Varemundo Arias Teixeiro (18151824) y Simón López García (1824-1831). Alrededor de la misma época debió pintar las efigies del pintor Luis Antonio Planes (véase la fig. 5.94), del arquitecto Vicente Marzo (véase la fig.

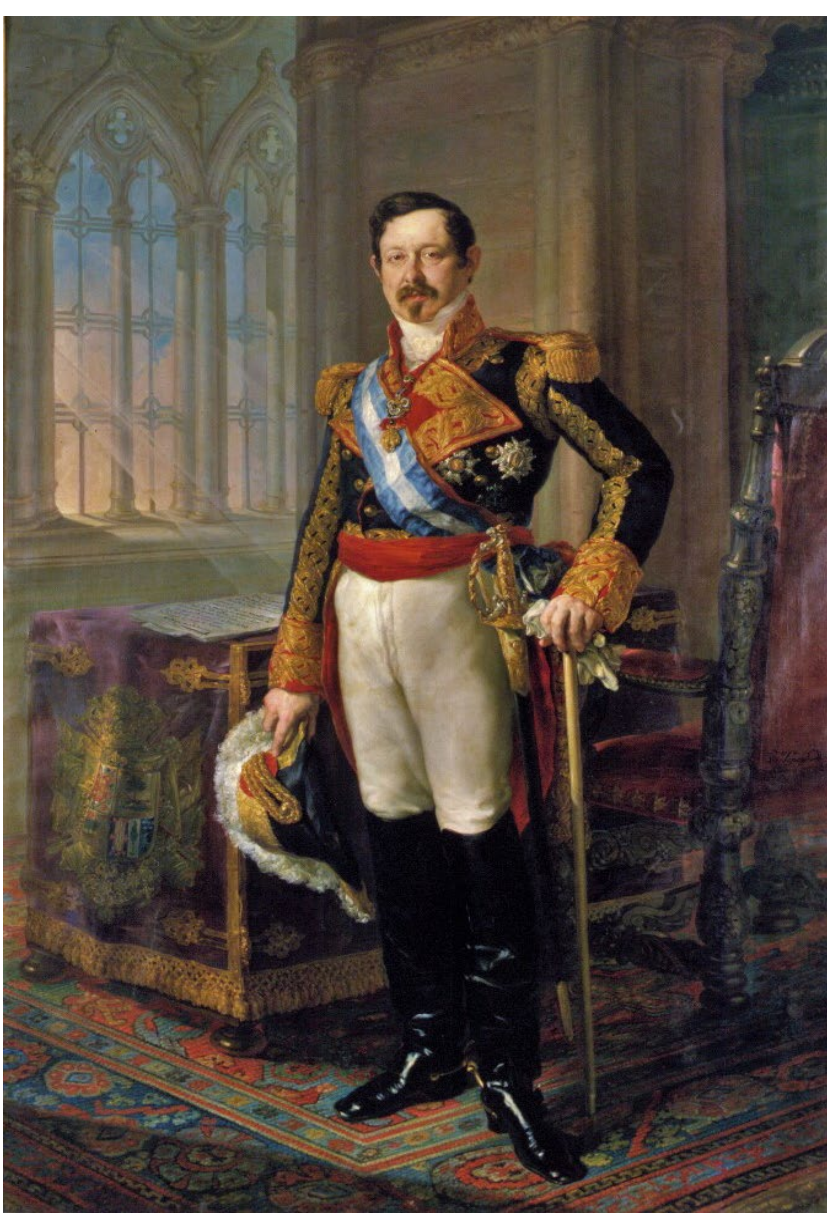

Fig. 2.20. Vicente López, Ramón María de Narváez, h. 1849, óleo sobre lienzo, Valencia, Museo de Bellas Artes.

5.95) y del secretario de la institución Vicente María Vergara (óleo sobre lienzo, Valencia, Real Academia de Bellas Artes de San Carlos). Muchos de ellos se han analizado en el apartado dedicado a los retratos de académicos.

Asimismo, de Miguel Parra también se conservan numerosos retratos de carácter militar que inmortalizan a los capitanes generales de Valencia. Es el caso de Francisco Javier de Elío y de Oloriz (véase la fig. 5.83), de José María de Santocildes (véase la fig. 5.88), de Luis Alejandro Procopio de Bassecourt y Dupire (véase la fig. 5.85) y José O’Donnel (véase la fig. 5.87). Estas pinturas también se han analizado en este trabajo porque fueron presidentes de la Academia, cargo reservado para los 
capitanes generales. Igualmente, perduran dos ejemplos puntuales de efigies monárquicas correspondientes a Fernando VII como capitán general (ca. 1823, óleo sobre lienzo, Valencia, Real Academia de Bellas Artes de San Carlos) e Isabel II niña (ca. 1843, óleo sobre lienzo, Valencia, Real Academia de Bellas Artes de San Carlos).

Otro de los pintores deudores de López fue Vicente Castelló y Amat (1787-1860), uno de los artistas más prolíficos de la primera mitad del siglo XIX. En uno de sus primeros trabajos, Valencia declara la guerra contra Napoleón (1810, Valencia, Museo de Bellas Artes), ya se aprecia su habilidad para retratar a los personajes que formaron parte de este acontecimiento. Sin embargo, el detallismo en la elaboración del rostro y de las manos, aspecto evocador del estilo de Vicente López, se observa en la efigie del escultor José Cloosterman (1787-1860) (1830, Valencia, Museo de Bellas Artes) que se enmarca entre el conjunto de retratos de académicos de San Carlos, pues cabe recordar que él asumió la dirección de la rama de escultura a partir de 1830, dato que ha servido para fechar la pintura. Pese a la minuciosidad en la fisionomía del representado, también se ha identificado una cierta tendencia hacia la simplificación y la reducción de los elementos accesorios al mínimo propia del romanticismo. ${ }^{75}$ En este caso también, se puede detectar la pervivencia de una estética pasada y a su vez, la inclusión de rasgos románticos.

Aunque durante los primeros años del siglo XIX, la Academia fuese la principal institución artística y su control sobre las artes era muy acusado, ello no garantizó el dominio absoluto de una estética determinada. Por esta razón, en el medio español convivían las tradiciones barrocas con el clasicismo académico. A su vez, en el resto de Europa había triunfado plenamente el neoclasicismo basado en el pasado grecorromano. El neoclasicismo propiamente dicho llegó a España coincidiendo

75 Alfonso E. Pérez Sánchez, 'La personalidad artística de Vicente Castelló y Amat', Ars Longa. Cuadernos de arte, 1990, pp. 9-25. 
con el reinado de Carlos IV (1788-1808) y teniendo en cuenta la internacionalización de muchos artistas, quienes habían disfrutado de estancias en ciudades como París o Roma. ${ }^{76}$ Concretamente en el ámbito español son escasos los artistas plenamente neoclásicos, es decir, deudores de David y cuyo arte suponía una revolución en la época. En esa casuística se pueden citar a José Aparicio Inglada (1770-1838), José de Madrazo (1781 - 1859) o Juan Antonio Ribera (1779 - 1860), entre otros pocos. ${ }^{77}$ Los tres estuvieron un tiempo formándose en París y más tarde se trasladaron a Roma donde, al igual que David, su principal referente artístico, se nutrieron de las mismas fuentes que años atrás había empleado el pintor francés. ${ }^{78}$

De entre todos ellos, José Aparicio es el único de raíces valencianas y por ello, su formación comenzó en la Academia de Bellas Artes de San Carlos. Más tarde, y como consta en 1793, fue alumno de la escuela madrileña donde obtuvo un premio por su obra Godoy presentando la Paz a Carlos IV (Madrid, Academia de San Fernando) de claros tintes neoclasicistas y donde ya se ha visto su especial habilidad para loar a aquellas personas poderosas del momento. Este es un aspecto que probablemente también tuvo cabida en los retratos, pues se trata de un género pictórico capaz de exaltar al individuo a través de referencias a su condición social y al alcance de su poder. El premio obtenido en la Academia madrileña le supuso disfrutar de una estancia formativa pensionada en París desde 1799 hasta 1807. Fue entonces cuando conoció y absorbió el estilo de Jacques-Louis David (1748-1825). Posteriormente se estableció en Roma hasta 1815. Durante ése tiempo, el pintar El rescate de los cautivos en tiempos de Carlos III (h. 1813, óleo sobre lienzo, Madrid, Museo Nacional del Prado) le permitió ser nombrado académico de mérito en San Lucas. Allí también fue encarcelado en el castillo de Sant' Angelo por no recono-

76 Reyero y Freixa, Pintura y escultura..., p. 39.

77 Díez, 'El retrato español...', p. 332.

78 Reyero y Freixa, Pintura y escultura..., p. 52. 
cer y jurar lealtad a José Bonaparte al hacerse con el gobierno español. Restaurada ya la Corona, regresó a España y en 1816 fue nombrado pintor de cámara de Fernando VII, igualmente se convirtió en académico de mérito y director de la Academia de San Fernando y por último, en 1828 fue nombrado académico de mérito en San Carlos. ${ }^{79}$

De entre sus retratos destacan aquellos de marcado carácter militar y cuyo patrón suele apreciarse en todos los ejemplos. Son representaciones de busto y no son frontales completamente para favorecer el aspecto de los retratados. La vestimenta más recurrente es su particular uniforme con la banda de general o con distintas insignias. Así se puede observar en un reducido grupo de siete retratos, elaborados alrededor de 1815, y encargados por la Junta de Iconografía Nacional para formar parte de una galería dedicada a españoles ilustres. Cuatro de ellos, además presentan a militares considerados como héroes por su participación en la guerra de la indepen172 dencia y especialmente en la batalla de Bailén (1808). Estas pinturas, en concreto, efigian a Francisco Javier Castaños, I duque de Bailén, Francisco Copons y Navia, conde de Tarifa, Joaquín Navarro Sangrán, también conocido como el general Teodoro Navarro, Tomás Moreno Daoíz, Pedro Agustín Girón, marqués de las Amarillas, Francisco Javier Venegas y Saavedra y Teodoro Reding de Biberegg [fig. 2.21]. ${ }^{80}$

Pese a ser pintor de cámara de Fernando VII, los retratos monárquicos que se conservan, por ejemplo en el Museo Nacional del Prado, no son piezas autónomas y por tanto no se apre-

79 Lorenzo Hernández Guardiola, 'Un discípulo de la Academia de San Carlos: José Aparicio Inglada (1770-1838), pintor neoclásico español', Archivo de arte valenciano, no. 88, 2007, pp. 319-332.

80 Los retratos se referencian en Herbert González Zymla, Catálogo de pinturas de la Real Academia de la Historia, (Real Academia de la Historia: Madrid, 2003). Además, en esta misma obra se indica de la existencia de un retrato de José Patiño Rosales (1878, óleo sobre lienzo, Madrid, Museo Nacional del Prado) realizado por Esteban Aparicio, hijo del pintor José Aparicio, y que también formó parte de la serie de hombres ilustres que quiso recopilar la Junta de Iconografía Nacional. 
cian las características propias de las efigies oficiales. En realidad, son fragmentos de una pintura completa que recoge el Desembarco de Fernando VII en el Puerto de Santa María (Cádiz). La escena al completo presenta la vuelta del monarca del exilio en 1823, su llegada y desembarco en Cádiz y su encuentro con las tropas francesas cómplices, denominadas los Cien Mil Hijos de San Luis y abanderadas

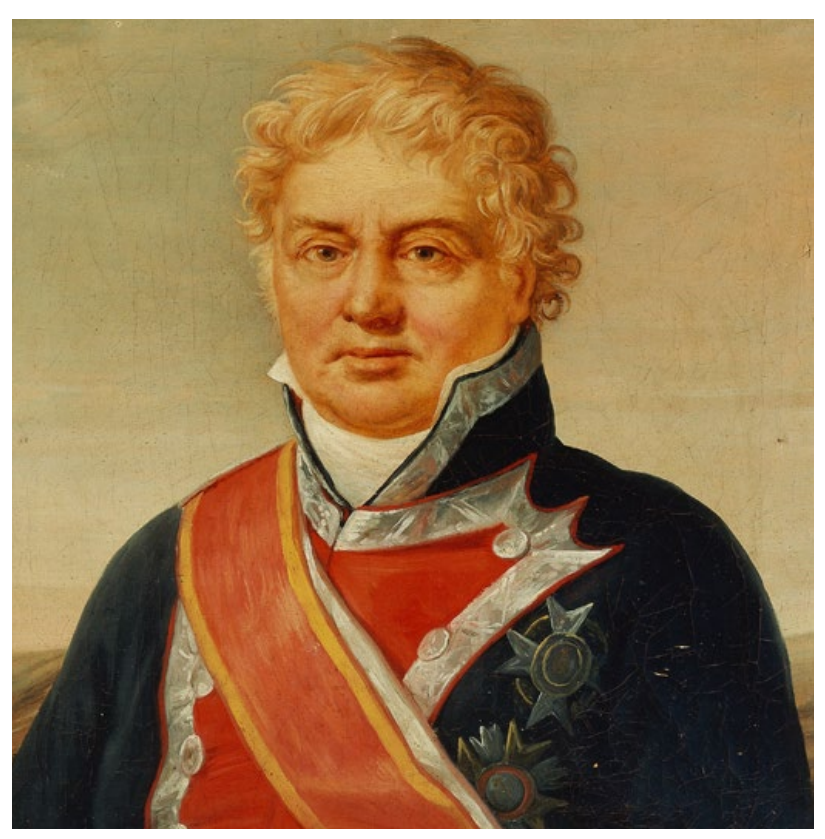

Fig. 2.21. José Aparicio, Teodoro Reding de Biberegg, h.1815, óleo sobre lienzo, Madrid, Museo Nacional del Prado. por Luis Antonio de Borbón, duque de Angulema. Aunque se trata de una pintura con una elevada dosis de contenido histórico y político, se debe valorar el tratamiento individualizado y personalizado que el artista tuvo con cada uno de los personajes. De hecho, en cada uno de ellos se encuentra un retrato. Así por ejemplo, el fragmento conservado del propio Fernando VII lo muestra en calidad de capitán general, con la banda de la Orden de Carlos III y el collar del Toisón, de forma muy similar a la que se aprecia en la serie de reyes del Palacio de la Generalitat que se ha estudiado más adelante.

Se debe tener en cuenta que los cambios estilísticos que también afectaron al género del retrato parecen más comedidos al estudiar galerías de efigies porque hay un sentido unitario que entorpece la plena transformación estética de la imagen, aunque es indudable apreciar los rasgos del nuevo estilo en otros detalles como el vestuario del retratado o el espacio pictórico en el que se integra la figura.

A finales de la centuria aún pervivía el elemento más trascendental del género del retrato, es decir, considerarlo como la definición de uno mismo. Para ello, se debe tomar como re- 
ferencia las reflexiones de Ángel Avilés (1842-1924) que compartió con el Círculo de Bellas Artes de Madrid en 1886.

$\mathrm{Su}$ ponencia constaba de unos pilares fundamentales que aportaban unas consideraciones generales acerca del retrato, seguidas de sus reflexiones en torno a las efigies escultóricas, pictóricas y literarias, exclusivamente. La propia definición propuesta por el autor era una versión mejorada de la acepción que por aquel momento ofrecía la academia española y que entendía el retrato como «pintura o efigie que representa con semejanza la figura de una persona o animal. Descripción de la figura o carácter, o sea de las cualidades físicas y morales de una persona.. ${ }^{81}$ Sin embargo, por ser esta aclaración incompleta a ojos del autor, él prefirió puntualizar que una efigie era «la imagen artística o descripción literaria de un ser» y justificó su explicación argumentando que:

[...] a mi juicio, la voz imagen lleva consigo la idea de figura, efigie, representación y semejanza de un sujeto u objeto, y calificándola de artística, se significa que no se trata de la representación natural, expresada bellísimamente por Víctor Hugo al decir que «en una sola gota de agua se retrata el cielo todo", sino que se expresa la imagen obtenida mediante los recursos del arte. He hecho también la diferencia entre el retrato genuinamente artístico y el literario, por más que la literatura sea una de las bellas artes, acaso la primera de todas ellas, en razón a la naturaleza distinta y a la extensión de sus procedimientos. He usado de la palabra ser, porque en ella no solamente se comprenden las de persona o animal, sino que se extiende al ser humano en su más benévola acepción, que puede retratarse y que en efecto se ha retratado y retrata en obras artísticas. ${ }^{82}$

En consecuencia, retratarse es principalmente mostrarse y

81 Ángel Avilés, El retrato: conferencias pronunciadas en el Círculo de Bellas Artes., (Tipografía de los Huérfanos: Madrid, 1886), pp. 4-5.

82 Avilés, El retrato..., íbidem. 
explicarse a uno mismo, pero no atendiendo a una copia del natural sino empleando las herramientas que proporciona el arte. Por tanto, se entiende que para el autor la efigie es una imagen creada que no se ciñe exclusivamente a enseñar la apariencia física del hombre o de la mujer, sino que va más allá y revela la personalidad e identidad de un individuo determinado. Esta idea ha quedado ampliamente reflejada en la siguiente reflexión:

Pero esta fidelidad no es ni puede ser meramente la fidelidad material. Es preciso que el retrato artístico represente de tal modo las facciones, que por ellas se venga en conocimiento del temperamento, del carácter, de la idiosincrasia, del alma de la persona retratada, y si esto no aparece en la obra de arte, bien puede decirse que la obra no es buena. Para ello debe el artista hacer un estudio completo y perfecto del modelo, y subordinado lo que es común a todos a lo que es típico y característico de la persona a quien vaya a retratar, fijar los rasgos propios de esta, de tal modo que resulten siendo lo más importante, lo que hiera más el ánimo del espectador. Al realizarlo pone el artista algo suyo, su ejecución, su estilo, de modo que los mejores retratos que nos han legado los maestros tienen para nosotros el doble interés, el atractivo doble de la vida inmortal del personaje retratado y el que inspira siempre el genio imperecedero del retratista, y así se observa que retratos de personajes que en la realidad pasarían para nosotros desapercibidos, llegan a ser por el arte origen de profunda emoción estética. ${ }^{83}$

Aunque todas las manifestaciones artísticas hablan del ser humano y de la sociedad que las ha creado, según Avilés, la escultura, la pintura y la literatura especialmente tienen la potestad para «reproducir las obras de la creación y las engendradas por la mente, con una verdad y una riqueza de detalles, que a veces cuando el artista se llama Fidias, Velázquez o Shakespeare, al contemplar sus obras, sentimos la propia o mayor

83 Avilés, El retrato..., pp. $14-15$. 
emoción, si cabe, que ante el natural mismo, y en la educación del sentimiento, que es a mi juicio, el objeto trascendental de las bellas artes, alcanzan un poder a que no llegan las obras naturales.» ${ }^{84}$ En efecto, se aprecia que perdura la idea de que las imágenes tienen la capacidad de generar emociones en aquel que las observa. Entre todas ellas, el retrato es de gran importancia puesto que para Avilés la imagen de la persona es el objeto más preciado. Y para ello, se apoya en las afirmaciones de otros autores. Por ejemplo, de Goethe toma su opinión acerca de que el rostro, la fisionomía y en definitiva la presencia del hombre es la mejor descripción que de él pueda hacerse. También se ayuda de Lavater, escritor del Arte de la Fisiognomía ${ }^{85}$ quien indicó que:

Todo retrato bien hecho es un cuadro interesante, porque da a conocer el alma y el carácter de un individuo particular. Contemplándole vemos a este pensar, sentir y juzgar. Percibimos en él el carácter propio de sus inclinaciones, de sus afectos, de sus pasiones: en una palabra, de las buenas y malas cualidades de su corazón y de su espíritu, y a este respecto el retrato es aún más expresivo que la naturaleza, en la que todo no es sino una sucesión rápida de movimientos variados hasta lo infinito... ${ }^{86}$

Al retrato, en definitiva, durante el siglo XIX se le ha seguido

84 Avilés, El retrato..., p. 9.

85 Hay algunas afirmaciones de Lavater que ponen de manifiesto la consideración del retrato en el siglo XIX. Véase a Johann Caspar Lavater, Physiognomy or the corresponding analogy between the conformation of the features and the ruling passions of the mind, (Cowie: Londres, 1826). "[...] in my opinion nothing can be more true, that the best text for a commentary on man is his presence, his countenance, his form; how important then is the art of portrait painting.» (pp. 299-300) «Each perfect portrait is an important painting since it display the human mind with the peculiarities of personal character. In such we contemplate a being where understanding, inclinations, sensations, passions, good and bad qualities of mind and heart are mingled in a manner peculiar to itself.» (p.301)

86 Avilés, El retrato..., pp. 12-13 
otorgando el poder de mostrar el interior del ser humano. Esta cualidad, con la llegada de la fotografía, se ha utilizado como argumento para desacreditar esta revolución técnica que hacía tambalear el trabajo del pintor. Por ello, Avilés ya defendía que la imagen generada a través de la fotografía era superficial puesto que tan sólo capturaba un instante. En cambio, la pintura podía sintetizar una forma de ser y el paso de toda una vida en un único retrato. ${ }^{87}$

\subsubsection{La Junta de Iconografía Nacional.}

A raíz del sentido de individualidad que imperó en esta centuria, de los deseos de fomentar sentimientos nacionales y de la tradición de efigiar a hombres ilustres, en 1876 se dieron las circunstancias necesarias para crear un organismo dedicado exclusivamente a recopilar los retratos de personajes ilustres españoles, configurando así una iconoteca nacional. Por ello, se creó la Junta de Iconografía Nacional. Fue una iniciativa de Francisco Queipo de Llanos, conde de Toreno y ministro de fomento. El objetivo era disponer de un equipo que llevase a cabo esta empresa y en el momento de su creación contaba con varios miembros entre los cuales se encontraban Valentín Carderera, marqués de Barzanallana y Francisco Asensio Barbieri. Pasaron unos años de búsqueda para dar con una sede estable en la que custodiar todas las obras reunidas y encargadas, no obstante la Junta tuvo que hacer frente a los problemas económicos y a las críticas por los criterios seguidos para la elección y compra de retratos. Por ello, finalmente en 1906

87 Avilés pone de relevancia la superioridad de la pintura sobre la fotografía afirmando que: «Todo lo que el retrato ha ganado en extensión con la fotografía, lo ha perdido en profundidad y belleza, porque los fotógrafos, a quien en sus elegantes versos latinos ha llamado el sabio actual pontífice León XIII 'usurpadores de los rayos de sol' poco pueden poner de su propio sentimiento artístico en sus obras, producto, al fin, casi meramente mecánico. La fotografía, aunque se obtuviera directamente coloreada, jamás matará a la pintura, porque ésta penetra en el individuo, y aquella no pasa de la superficie, porque ésta, en los retratos, puede resumir el ser y la vida toda de una persona, y aquella sólo presenta un momento, que no suele ser ni el mejor ni el más característico.» Avilés, El retrato..., pp. 68-69. 
se hizo una nueva y segunda Junta y ésta tuvo que redactar un reglamento oficial. En este documento, aprobado por Real Orden, se dejaba constancia del deseo de conseguir retratos de todos aquellos españoles que tenían a sus espaldas méritos suficientes en el ámbito nacional, histórico y artístico. Y en caso de extinguirse la institución, como terminó sucediendo en 1970, todo lo recabado por ella sería depositado en la Biblioteca Nacional. A inicios del siglo XX, los miembros de la Junta cada vez procedían más del mundo de la política y no de la cultura, a excepción de Menéndez Pelayo quien ya era director de la Biblioteca Nacional.

Hubo un total interés por inventariar todo tipo de obras retratísticas, así que se fotografiaron numerosas pinturas, esculturas, grabados y se recogieron fotografías originales de los personajes ilustres contemporáneos. Igualmente se registraron los datos más relevantes de cada pieza. Con todo ello, en 1914 se publicó el libro de Retratos de personajes ilustres. ${ }^{88} \mathrm{La}$ publicación es un catálogo que recoge en imágenes numerosos retratos procedentes del ámbito público y privado. Así se han nutrido de las obras halladas en los distintos museos nacionales, en el palacio real, en otros centros estatales y en colecciones privadas. Igualmente se ha invitado al lector a que contribuya a aumentar y mejorar la colección dando aviso de otros retratos y facilitando su fotografiado. También se ha pedido la colaboración para completar y actualizar los datos de aquellas efigies catalogadas como anónimas. Para animar a la participación se ha apelado a la generosidad y al patriotismo de la sociedad, de este modo se aprecia el deseo por parte del Estado de fomentar el sentimiento patriótico y construir una identidad histórica y nacional. Por esta razón los retratos muestran a numerosos personajes españoles importantes para su historia, generalmente, nacidos en el territorio aunque con algunas excepciones. Asimismo, no se ha seguido como criterio la relevancia artística y estética de cada pieza, sino más bien se

88 Junta de Iconografía Nacional, Retratos de personajes ilustres: índice ilustrado de la Junta de Iconografía Nacional, (Madrid, 1914). 
ha preferido acumular un listado de obras interesantes por su valor como documento histórico.

La iniciativa de configurar una galería de retratos en España no fue una acción novedosa, pues en Europa ya se dieron algunos precedentes que sirvieron de modelo para el caso español. Por ejemplo, Francia ya disponía de una galería de hombres ilustres en una sala de Versalles. De hecho, Francisco Queipo de Llanos habló del caso francés como referente para llevar a cabo un proyecto de intenciones similares en España:

No se halla desgraciadamente el tesoro español con los recursos indispensables para organizar museos históricos como el de Versalles, uno de los más honrosos recuerdos del reinado de Luis Felipe, ni para levantar monumentos como el Walhalla de Baviera, gloria del rey Luis, que reunió en aquel magnífico templo griego una colección de bustos-retratos de los preclaros hijos de la Germanía; pero al menos, sí nos es dado coleccionar los retratos de aquellos españoles ilustres, de uno y otro sexo, cuya gloria se refleja sobre nuestra patria, como una de esas inapreciables fuerzas morales de que disponen los pueblos de viejos y nobles blasones, y que sirven como de estímulo poderoso que su porvenir corresponda a lo que exige lo ilustre de su pasado. ${ }^{89}$

El ministro de fomento, en su escrito publicado en la gaceta madrileña, además de remitir a la galería francesa también mencionó otros casos. Por ejemplo, la pinacoteca reunida en el capitolio romano, proyecto impulsado por Pio VII; la serie de retratos de pintores que se configuró en Florencia; y el conjunto de efigies de varones ingleses que se hizo en Kensington. Otro antecedente a tener en cuenta se dio en 1856 cuando ya existía el deseo de componer una galería de hombres ilustres ingleses que configurarían la British Historical Portrait Gallery, pro-

89 Gaceta de Madrid, no 228, 15 de agosto de 1876. Disponible en: https:// www.boe.es/datos/pdfs/BOE//1876/228/A00444-00445.pdf (Fecha de la última consulta: 19/02/2019) 
yecto que desembocó en la National Portrait Gallery. ${ }^{90}$ Es importante destacar que generalmente en todos estos casos procedentes de diversos puntos geográficos se tuvieron en cuenta los mismos criterios para impulsar un proyecto de recolección y configuración de una galería de retratos. Así, en un segundo plano quedó la calidad artística y estética de la obra para primar la fama del efigiado. Por tanto, el retrato se consideró como un testimonio documental de la apariencia de un personaje célebre, trascendente para la historia de la nación y ejemplarizante por sus logros para el resto de la sociedad.

Este fenómeno, como ya indicó Inmaculada Rodríguez en el estudio previamente citado, estuvo estrechamente ligado a las circunstancias de la España decimonónica, cuando se comenzó a valorar la Historia como ciencia y los nacionalismos fueron en crecimiento. Con ello, estas pinacotecas pretendían educar al pueblo mediante las personalidades efigiadas e igualmente el Estado asumió el papel de proteger el patrimonio cultural. Si bien tradicionalmente las galerías de hombres ilustres, existentes desde tiempos renacentistas, fueron de carácter privado, las propuestas decimonónicas se enfocaron a ser visibles al gran público. No obstante, sí que se encuentra un punto en común en este tipo de series a través del tiempo; el empleo del género del retrato para inmortalizar a personalidades del ámbito político, militar, humanístico y científico con la finalidad de que fuesen motivo de orgullo para el resto de la sociedad. De hecho, esta intención se apreciará claramente al abordar la pinacoteca de varones ilustres valencianos procedentes de La Murta, un ejemplo datado en el siglo XVII y que por la documentación de archivo se conoce que deseaba honrar a importantes personajes nacidos en territorio valenciano. Como se ha indicado en el inicio de este apartado, el objetivo de la Junta era configurar una iconoteca nacional. Por esta razón, además de recopilar obras también tenían potestad para 90 Inmaculada Rodríguez Moya, 'La Junta de Iconografía Nacional (18761961) y el retrato del poder', en Víctor Mínguez (ed.), Las artes y la arquitectura del poder, (Universitat Jaume I: Castellón de la Plana, 2013), pp. 271-296. 
encargarlas. Así sucedió con varios retratos de personajes militares, ya citados previamente, hechos por José Aparicio en torno a 1815 y que fueron ensalzados por el papel desempeñado durante la guerra de la Independencia. También se encargó la realización de catorce retratos de reyes godos o monarcas antiguos de España. Asimismo, fue muy frecuente la adquisición de copias. Por ejemplo, se compraron imitaciones hechas por Eduardo Carrió de originales de Vicente López, como el retrato de Pedro Caro Sureda (ca.1878, óleo sobre lienzo, Madrid, Museo Nacional del Prado). Francisco Díaz Carreño copió, por ejemplo, las efigies de Íñigo López de Mendoza, II conde de Tendilla y I marqués de Mondéjar y Francisco Martínez de la Rosa de otros artistas, cuyos originales se han atribuido a Juan Bautista Espinosa y Ángel Saavedra. Asimismo, en el caso del retrato de Melchor de Macanaz (fig. 2.22) se aprecia el mantenimiento del tipo iconográfico en otras obras, como un retrato hecho por Francisco Javier Ramos y la imagen presente en el volumen de Españoles ilustres de 1791 (fig. 2.23). ${ }^{91}$

Matías Moreno González (1840-1906) copió las representaciones de diversos miembros de la cúpula eclesiástica toledana. ${ }^{92}$ En efecto, el pintor reprodujo retratos originales cuyo autor era el Greco y que a priori se encontraban en la biblioteca del palacio arzobispal o en el hospital Tavera, como se aprecia en las efigies de Diego de Covarrubias y Leiva (fig. 2.24) y el cardenal Tavera respectivamente. Ambas copias también fueron depositadas en la Real Academia de la Historia. Igualmente son copias de los retratos ubicados en la biblioteca del palacio arzobispal las efigies del padre Juan de Mariana y el arzobispo Pedro Tenorio. Asimismo tuvo por referente otros conjuntos pictóricos de gran calado en la ciudad. Por ejemplo, el retra91 Retratos de Españoles ilustres con un epítome de sus vidas, (Imprenta Real, siendo su regente D. Lázaro Gacquer: Madrid, 1791), p. 155. Acerca de esta fuente consúltese a Álvaro Molina, 'Retratos de Españoles ilustres con un epítome de sus vidas. Orígenes y gestación de una empresa ilustrada', Archivo Español de Arte, Vol. 89, 2016, pp. 43-60.

92 Datos ya aportados por Rodríguez Moya, 'La Junta de Iconografía Nacional (1876-1961)...', pp. 276-277. 


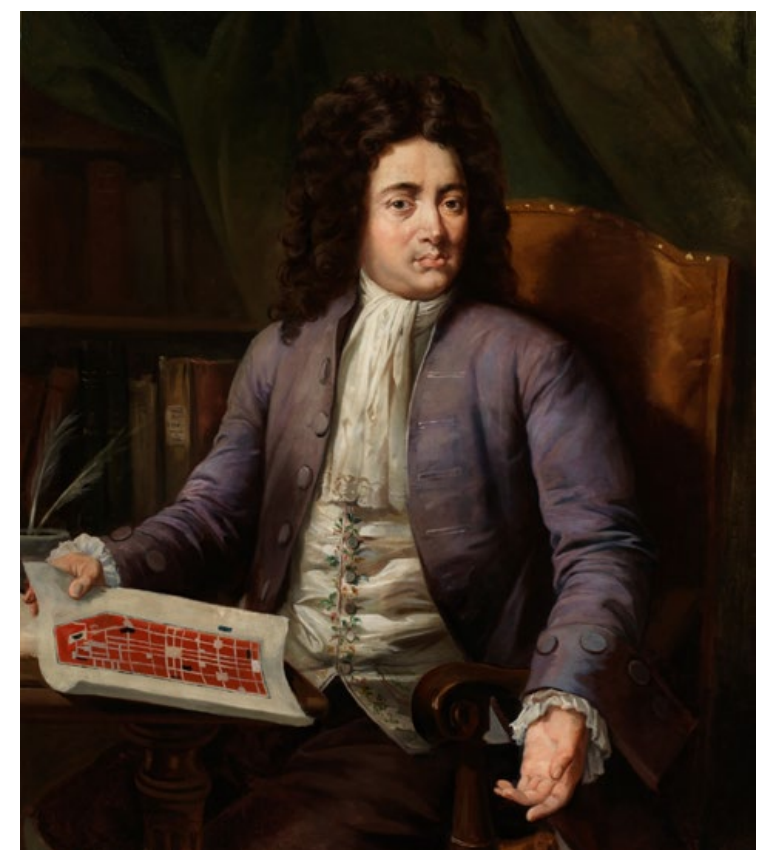

Fig. 2.22. Francisco Díaz Carreño, Melchor de Macanaz, h. 1878, óleo sobre lienzo, Madrid, Museo Nacional del Prado.

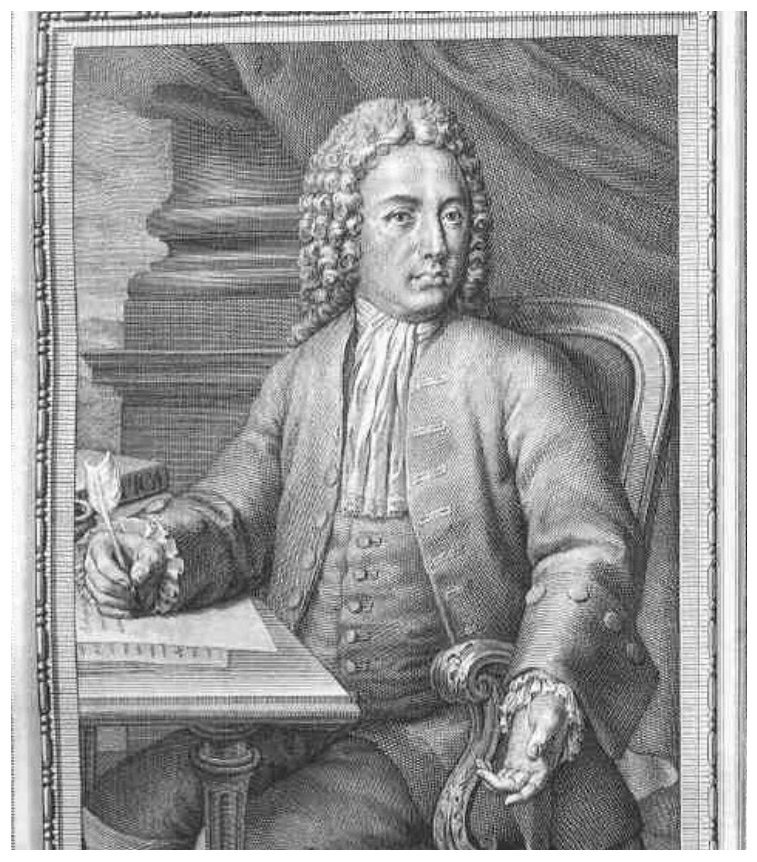

Fig. 2.23. Estampa de Melchor de Macanaz en Españoles ilustres, 1791, Madrid, Biblioteca Universidad Complutense (detalle).

to del cardenal Francisco Antonio de Lorenzana, arzobispo de

Toledo está basado en la efigie localizada en la biblioteca de la catedral. La serie iconográfica de prelados ubicada en la sala capitular de la catedral fue una fuente visual para copiar las efigies del cardenal Cisneros (fig. 2.25) y de Pedro González de Mendoza (ambos originales fueron realizados por Juan de Borgoña), del arzobispo y cardenal Gil Álvarez Carrillo de Albornoz y de Pedro Inguanzo Ribero cuyo retrato original ha sido pintado por Vicente López. ${ }^{93}$ Para la galería de españoles ilustres, Matías Moreno además de realizar numerosas representaciones de dirigentes eclesiásticos hizo una copia del retrato del arquitecto Juan Guas (fig. 2.26), cuya pieza original se encuentra en su capilla funeraria situada en la parroquia de los Santos Justo y Pastor.

De entre el amplio número de obras que configuraron la serie, hay otros ejemplos puntuales que también conviene mencionar, pues son una muestra de la inspiración y reproducción

93 Todas las obras de Matías Moreno pertenecientes a la colección de hombres ilustres se han datado alrededor de 1877-1878, son óleos sobre lienzo o sobre tabla en el caso del cardenal Cisneros, y se encuentran en el Museo Nacional del Prado (Madrid). 


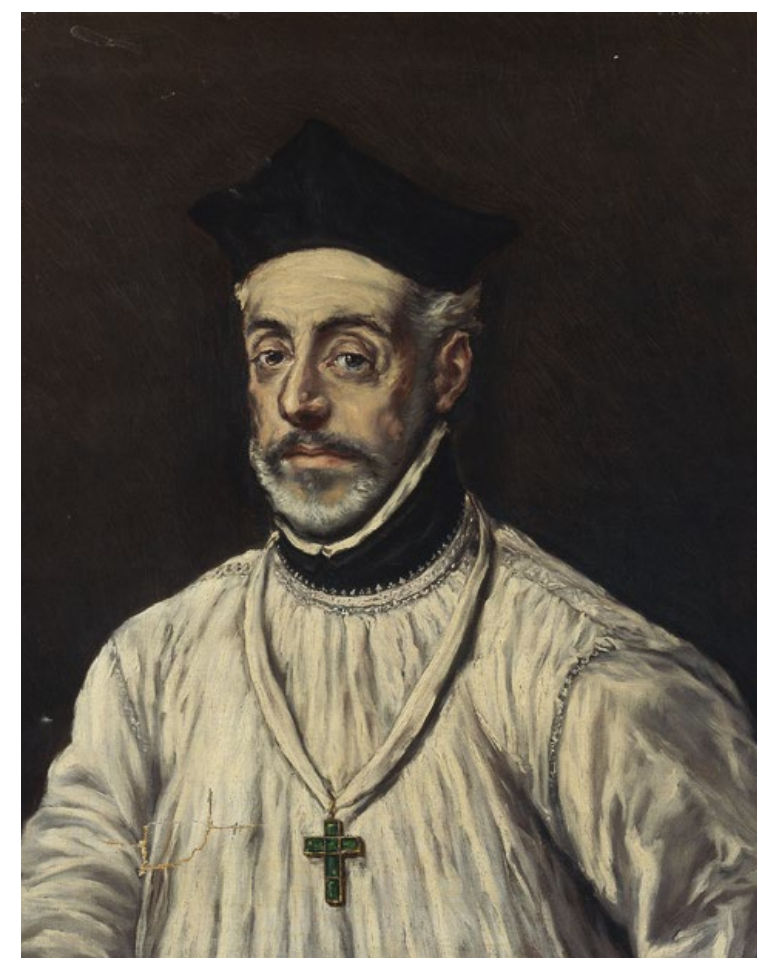

Fig. 2.24. Matías Moreno, Don Diego Covarrubias y Leiva, h. 1878, óleo sobre lienzo, Madrid, Museo Nacional del Prado.

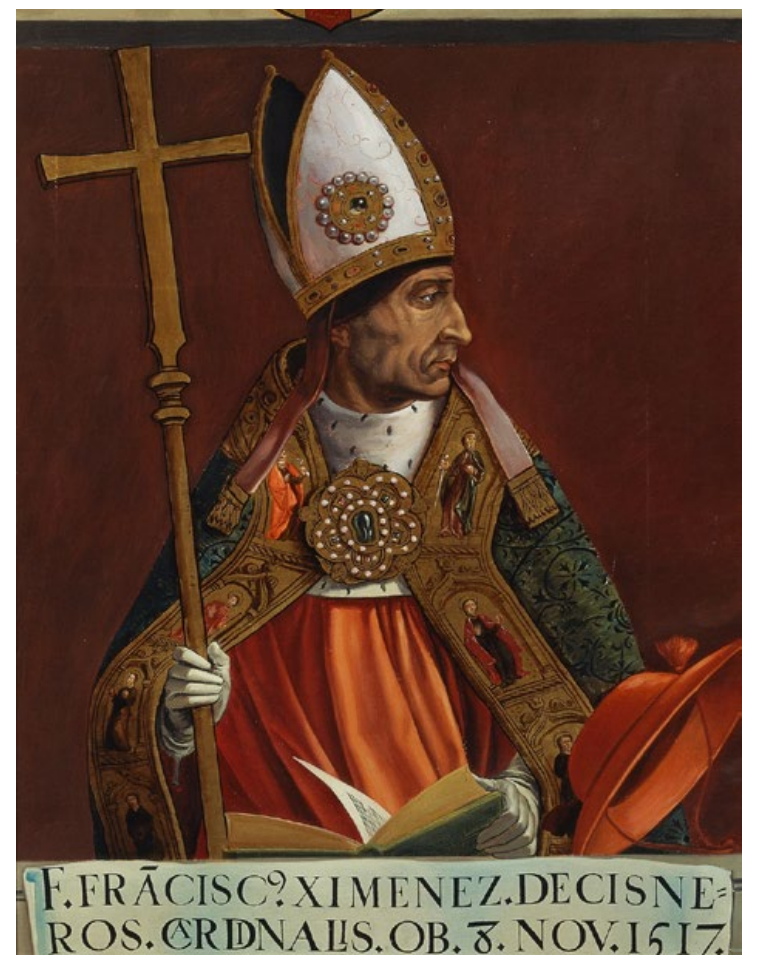

Fig. 2.25. Matías Moreno, El cardenal Cisneros, arzobispo de Toledo, h. 1878, óleo sobre tabla, Madrid, Museo Nacional del Prado. (detalle).

reiterada en un tipo de retrato considerado cercano a la verdadera apariencia del efigiado. Así pues, el caso más señero es la copia realizada por Salvador Martínez Cubells para retratar a san Juan de Ribera (fig. 2.27). Sin duda, la pintura decimonónica se ha basado en el retrato que forma parte de la galería de prelados de la catedral valenciana. Con todo ello, se ha podido apreciar cómo las galerías de retratos tradicionales fueron una fuente visual de elevada importancia para artistas decimonónicos que se encargaron de copiar las representaciones de aquellas personalidades que han formado parte de la historia.

Además de los encargos, otra de las formas de configuración y ampliación de la galería fue la donación de obras. Estas entregas quedaron registradas y publicadas en los correspondientes ejemplares de las gacetas, de este modo se anunciaba quiénes eran aquellos que con gran "generosidad» $\mathrm{y}$ "patriotismo" regalaron retratos privados pero de interés general a la Junta de Iconografía Nacional. Por ello, se conoce que Consuelo Sierra donó el retrato del escritor y político Eugenio Flo- 


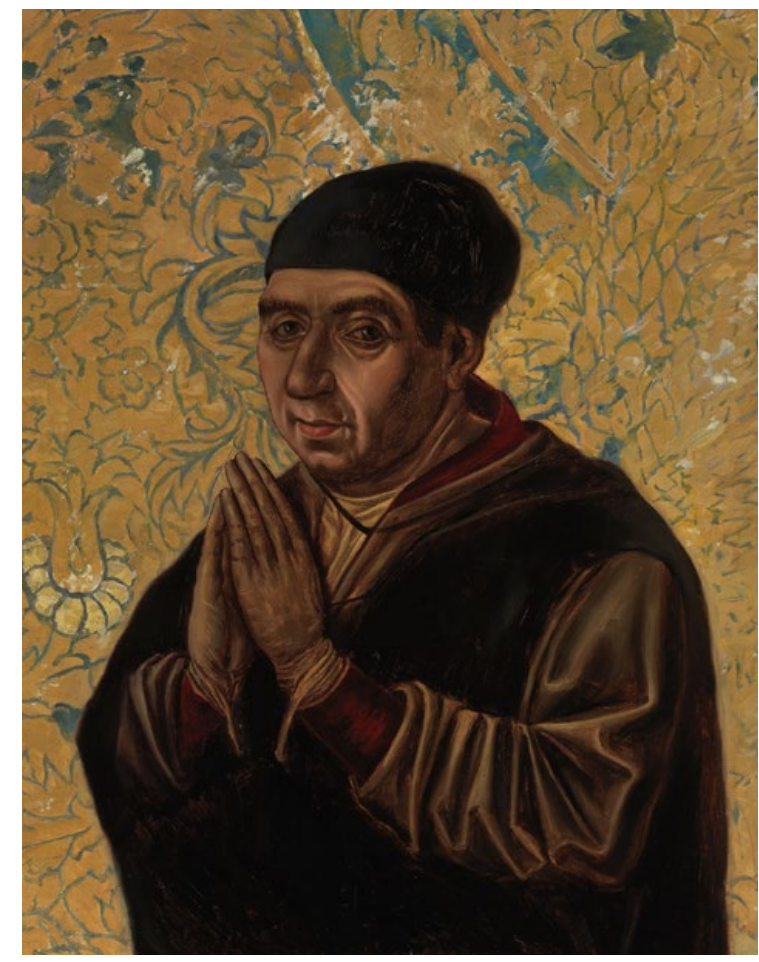

Fig. 2.26. Matías Moreno, El arquitecto Juan Guas, h. 1877, óleo sobre lienzo, Madrid, Museo Nacional del Prado.

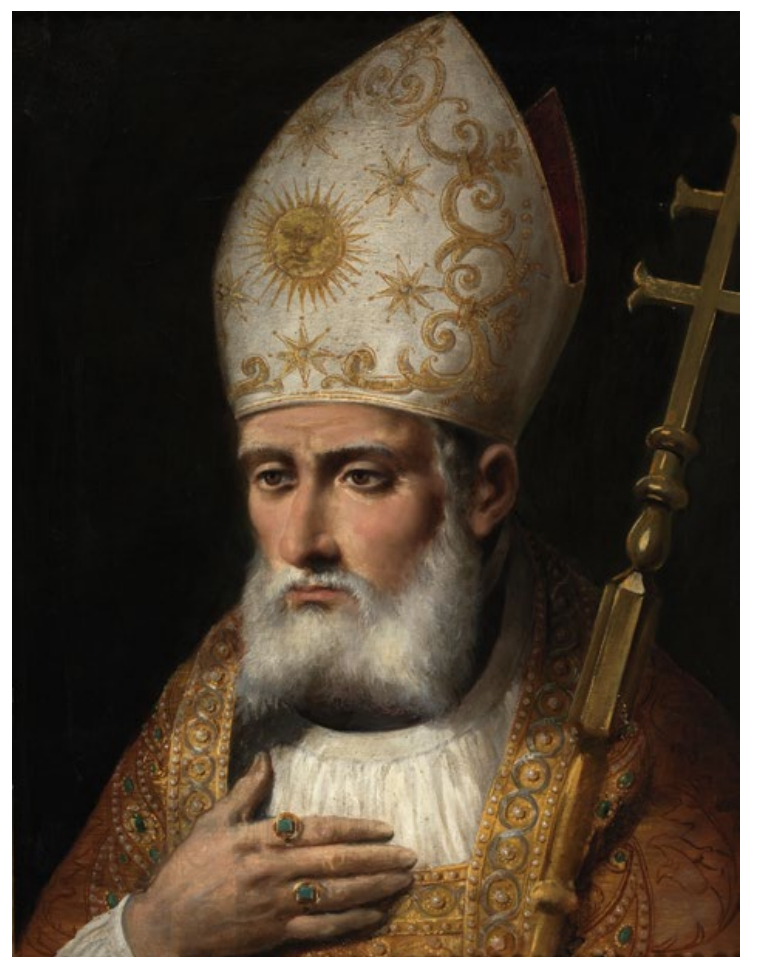

Fig. 2.27. Salvador Martínez Cubells, San Juan de Ribera, 1865, óleo sobre lienzo, Madrid, Museo Nacional del Prado.

rentino Sanz. ${ }^{94}$ Ignacio María Argote, marqués de Cabriñana, entregó las efigies del duque de Montemar y del conde de Campomanes. Manuel José Quintana regaló el retrato del poeta Quintana, su tío, obra firmada por José de Ribelles. Y Miguel de los Santos Álvarez donó una efigie de José de Espronceda. ${ }^{95}$ Para continuar ampliando el repertorio de imágenes de personajes ilustres, incluso a inicios del siglo XX, se convocaron concursos para «otorgar un premio a la mejor colección que le sea presentada de retratos de españoles ilustres, varones y hembras, en letras, artes, ciencias, armas, gobierno y cuantas manifestaciones hayan contribuido a la gloria de la Patria. ${ }^{96}$ Entre los requisitos de la convocatoria cabe destacar que se so94 Gaceta de Madrid, no 328, 24 de noviembre de 1883. Disponible en: https://www.boe.es/datos/pdfs/BOE//1883/328/A00583-00583.pdf (Fecha de la última consulta: 22/02/2019)

95 Información extraída de Rodríguez Moya, 'La Junta de Iconografía Nacional (1876-1961)...', pp. 279.

96 Gaceta de Madrid, no 71, 12 de marzo de 1910. Disponible en: https:// www.boe.es/datos/pdfs/BOE//1910/071/A00525-00525.pdf (Fecha de la última consulta: 22/02/2019) 
licitaba que las efigies correspondiesen a personajes nacidos antes de 1700, que se adjuntase toda la información correspondiente a la localización, referencias y pruebas de la autenticidad de la obra. Este tipo de convocatorias fueron lanzadas por una segunda Junta, creada en 1906, que mantenía la finalidad de reunir y clasificar imágenes de la iconografía nacional. Fue una institución de tendencia conservadora que con el tiempo terminó por diluirse a mediados de la centuria pero su última etapa es una cuestión que ya se excede de los límites de esta investigación y se deberá retomar en futuras ocasiones.

\subsubsection{La desamortización de 1835. Descomposición de algu- nas galerías de retratos y recopilación de las pinturas.}

Pero además de la trascendencia de este género y de su pervivencia como obra artística al servicio del poder, esta centuria también fue destacable por el valor y protección que, a raíz de la desamortización principalmente, se le otorgaron a las obras procedentes de monasterios y conventos. Todas ellas pasaron a engrosar los fondos de las academias locales y a ser conservadas por su valor artístico y cultural, dando lugar a la creación de museos provinciales.

Hay que remontarse a 1812 cuando, durante la ocupación francesa encabezada por el general Suchet se comenzó a plantear la idea de crear un museo nutrido de las colecciones académicas además de concentrar las obras procedentes de los conventos regulares. Por esta razón, fue en este momento cuando ya hubo un deseo de fundar un museo público en la ciudad que estaba en consonancia con los ideales revolucionarios franceses. Una vez terminada la ocupación francesa, algunas de las obras incautadas fueron devueltas y otras siguieron bajo la protección de la Academia de Bellas Artes con el beneplácito de las comunidades religiosas. ${ }^{97}$

97 Francisco Javier Delicado, 'Los orígenes del Museo de Pinturas de Valencia y la Comisión provincial de Monumentos Históricos y Artísticos', Real Academia de Bellas Artes de San Carlos, Archivo de arte valenciano, no. 95, 2014, pp. 123-165. 
El 1 de octubre de 1820 Fernando VII emitió un decreto, conocido también como la Ley de Monacales, por el cual se suprimían todos los monasterios y conventos y se determinaba qué hacer con los bienes allí conservados:

Don Fernando VII por la gracia de Dios, y por la Constitución de la Monarquía española, Rey de las Españas, a todos los presentes vieren y entendieren, sabed: Que las Cortes han decretado, y Nos sancionamos lo siguiente:

[...] Art.1. Se suprimen todos los Monasterios de las órdenes monacales; los de canónigos regulares de S. Benito, de la congregación claustral Tarraconense y CesarAugustana; los de S. Agustín y los Premonstratenses; los conventos y colegios de las órdenes militares de Santiago, Calatrava, Alcántara y Montesa; los de San Juan de Jerusalén; los de S. Juan de Dios y de betlemitas, y todos los demás hospitalarios de cualquiera clase. [...]

23. Todos los bienes muebles e inmuebles de los monasterios, conventos y colegios que se suprimen ahora o que se supriman en lo sucesivo en virtud de los artículos 16, 17, 19 y 20, quedan aplicados al Crédito público; pero sujetos como hasta aquí a las cargas de justicia que tengan, así civiles como eclesiásticas. [...]

27. Los Jefes políticos custodiarán todos los archivos, cuadros, libros y efectos de la biblioteca de los conventos suprimidos, y remitirán inventarios al Gobierno, quien los pasará originales a las cortes para que estas destinen a su biblioteca lo que tengan por conducente, según el reglamento aprobado por las ordinarias.

28. Será cargo del Gobierno aplicar el residuo de los efec- 
tos mencionados en el artículo anterior a las bibliotecas provinciales, museos, academias y demás establecimientos de instrucción pública. ${ }^{98}$

Fue tras esta primera acción cuando se incorporaron numerosas obras artísticas a los fondos de la Academia, de entre todas ellas cabe destacar la serie de varones ilustres procedentes del monasterio jerónimo de Nuestra Señora de La Murta en Alzira, que se estudiará en profundidad más adelante. En este ejemplo concreto jugó un papel trascendental el académico Francisco Xavier Borrull y Vilanova quien mostró un especial interés por recopilar, entregar a la Academia y proteger las pinturas extraídas de los monasterios suprimidos.

A partir de la desamortización de Mendizábal, en 1820, se creó la Comisión Central de Monumentos Historicos-Artísticos con el objetivo de recoger y salvaguardar el patrimonio procedente de la exclaustración de conventos y monasterios, inventariar todos los bienes y organizar los museos. Este organismo contaba con el asesoramiento de tres instituciones; la Real Academia de Bellas Artes de San Carlos, la Real Academia de la Historia y el Ministerio de Fomento. En 1837 ya existía una Junta del Museo que había estado clasificando y distribuyendo las obras procedentes de la desamortización. No obstante, esta junta quedó anulada en 1844 cuando se creó definitivamente la Comisión Provincial de Monumentos Históricos y Artísticos de Valencia, impulsada por numerosos intelectuales temerosos de que las obras de arte se trasladasen fuera del país. Esta comisión, en 1850, publicó el Catálogo de los cuadros y esculturas albergadas en el Museo de Pinturas de la Ciudad. ${ }^{99}$

98 Decreto dado por las Cortes y aprobado por S.M. sobre los monacales y demás conventos de frailes, Madrid: Imprenta de la viuda de López, calle Juanelo. Año 1820.

99 Se ha seguido a Ester Alba Pagán, 'La génesis del Museo de Bellas Artes de Valencia y la polémica en torno a los bienes desamortizados a través de la prensa valenciana', en Francisco Javier Campos (coord.) y Fernández de Sevilla (ed.), La desamortización: el expolio del patrimonio artístico y cultural de la Iglesia en España: actas del Simposium 6/9-IX-2007, (Estudios 
Estas medidas y el interés de un sector intelectual concienciado en proteger y valorar el patrimonio determinaron que muchas obras configurasen los fondos de los futuros museos provinciales. Con todo ello, en definitiva, se fue construyendo una identidad histórica y cultural que trataba de preservar el legado artístico. 


\section{Capítulo 3}

\section{Retratos de la realeza.}

El retrato monárquico fue una de las tipologías fundamentales empleadas en la configuración de galerías de efigies y series icónicas. La representación del poder ha estado estrechamente relacionado con la Corona y ésta se ha servido del retrato para crear sus particulares salas de linajes. En Valencia se conservan tres ejemplos de gran interés que se estudian a continuación. Pese a que cada grupo pictórico se realizó bajo unas circunstancias particulares, conjuntamente hablan de la relevancia del retrato regio en la época moderna y dan visibilidad a las distintas coronas que fueron el germen de la monarquía española. Así se encuentran imágenes de los reyes de Castilla, de Aragón, de la Casa de Austria y de la dinastía de los Borbón.

A finales del siglo XVI y siguiendo la costumbre de la época, el Patriarca Ribera adquirió un conjunto de efigies de miembros de la realeza, actualmente ubicadas en la biblioteca del Real Colegio Seminario del Corpus Christi, y que han sido objeto de estudio en esta investigación. También se han analizado los retratos pintados a finales del siglo XVI o primera mitad del siglo XVII que el monasterio de San Miguel de los Reyes conservaba acerca de monarcas del pasado, concretamente eran imágenes de la realeza en Nápoles. La intención de conformar un determinado linaje a través del retrato subyacía en ambas 
galerías. Sin embargo, el tercer caso estudiado era bien distinto. En el palacio de la Generalitat se puede visitar una serie icónica alusiva a los soberanos del Reino de Valencia desde la reconquista cristiana. El proyecto artístico se inició en el siglo XVII y originalmente engalanaba una de las salas del palacio Real con el objetivo de mostrar el pasado y presente de la monarquía que había gobernado el territorio valenciano.

Los tres ejemplos han contribuido a evidenciar que el retrato era el género adecuado para representar mediante imágenes la estabilidad de la Corona y la transmisión de poder a través de lazos sanguíneos e incluso, para reivindicar y legitimar derechos dinásticos. Además han sido prueba del elevado número de galerías y series que nacieron en esta época. Gran parte de ellas decoraban dependencias de representación del poder y dibujaban la genealogía de la realeza. Así sucedió con las efigies del palacio de El Pardo, el Alcázar Real de Madrid o el Buen Retiro, por ejemplo. Cabe recordar que este tipo de conjuntos no estuvieron reservados exclusivamente para la monarquía, sino que también miembros de la nobleza desearon engalanar sus hogares con las imágenes de los reyes. De este modo, subrayaban su lealtad y señalaban su cercana relación con el soberano a la vez que enaltecían su propia figura.

El retrato monárquico formando parte de galerías y series icónicas tenía la capacidad de mostrar visualmente las virtudes de cada efigiado y los lazos familiares que justificaban sus privilegios y su poder. No obstante, las imágenes no fueron el único soporte idóneo para exaltar a la clase gobernante y perpetuar su legado. En este sentido, las obras escritas que recogían la historia de los monarcas cumplían del mismo modo con las funciones de los retratos. Numerosas publicaciones de esta índole vieron la luz entre los siglos XVI y XVIII y su análisis ha sido muy fructífero porque son contemporáneas a la elaboración y desarrollo de los conjuntos pictóricos estudiados. 
Especialmente significativas han sido las obras referentes a los reyes aragoneses puesto que encierran los orígenes del Reino de Valencia. En 1524 se publicó la Crónica de Aragón de Luca Marineo, donde se hablaba de cada uno de los monarcas que pertenecieron a esta Corona. El punto de partida se estableció en García Ximenez, rey de Sobrarbe, quien inició la guerra contra el pueblo musulmán, y se recogieron a todos los correspondientes reyes hasta Fernando II el Católico, con quien tuvo lugar la alianza con la Corona de Castilla. Además, la crónica muestra gráficamente el linaje de los monarcas aragoneses, ya que en la parte izquierda se incluyen retratos tipo de todos ellos. ${ }^{1}$

Por petición de la Diputación, Gaspar Escolano publicó en dos volúmenes la Decada primera de la historia de la ciudad y reyno de Valencia en $1610 .{ }^{2}$ Estamos ante una obra que sobre todo se centra en la cuestión musulmana, haciendo un especial hincapié en los primeros reyes de Aragón y la figura de Jaime I, narrando con todo lujo de detalles el proceso de reconquista de las tierras valencianas. Otras obras, como el tomo primero de Anales del Reyno de Valencia de fray Francisco Diago (h. 1560 - 1615) también se han centrado en la figura de Jaime I. ${ }^{3}$ Seguidamente, el autor amplió su compilación desde Pedro III hasta Felipe II bajo el título de Apuntamientos. ${ }^{4}$

El tomo VIII del Atlante español de Bernardo Espinalt García, fechado en 1784, se ha centrado en la descripción del Reino 1 Luca Marineo, Crónica de Aragón, (Juan Jofre: Valencia, 1574).

2 Gaspar Escolano, Decada primera de la historia de la ciudad y reyno de Valencia; primera parte ... ; contiene esta decada curiosas generalidades de España y la Historia de Valencia hasta el rey don Pedro hijo del rey don Iayme el Conquistador, (Pedro Patricio Mey: Valencia, 1610).

3 Francisco Diago, Anales del Reyno de Valencia, que corre desde su población después del diluvio hasta la muerte de don Jaime el Conquistador, (Pedro Patricio Mey: Valencia, 1613).

4 Francisco Diago, Apuntamientos para continuar los anales del Reino de Valencia desde el rey Pedro III hasta Felipe II; con un prólogo de José M $^{a}$ Garganta, (Imprenta Hijo de F. Vives Mora: Valencia, 1936). 
de Valencia, ciñéndose principalmente en la reconquista cristiana de la ciudad del Turia y mencionando las arquitecturas más emblemáticas de la localidad. ${ }^{5}$ El cronista Jerónimo Zurita escribió los Anales de la Corona de Aragón, obra que hunde sus raíces en los condes de Aragón y reyes de Sobrarbe. ${ }^{6}$ Además, Pedro Abarca redactó Los reyes de Aragón en anales históricos: distribuidos en dos partes, en ella se presta atención a los monarcas aragoneses desde Alarico hasta Fernando el Católico, estableciendo los límites cronológicos entre los años 800 y $1515 .^{7}$

Como se ha podido vislumbrar tras mencionar algunas fuentes escritas, durante la Edad Moderna hubo un especial interés por recoger la historia áulica de los reyes de Aragón y así igualmente dibujar una de las ramas dinásticas que antecedía a los Austrias. Al analizar los tres conjuntos de retratos monárquicos presentados a continuación es interesante observar que las vías para configurar los árboles genealógicos y justifi-

car el poseer un determinado poder no sólo fueron las obras escritas, sino también las imágenes. De su estudio se pretende arrojar más luz sobre el papel que desempeñaron estas obras en la época, analizar pormenorizadamente los retratos y relacionarlos, en medida de lo posible, con ejemplos similares para extraer conclusiones genéricas acerca de la difusión y de la impronta de la imagen regia.

5 Bernardo Espinalt y García, Atlante Español, ó Descripcion general geográfica, cronológica, é histórica de España, por Reynos y Provincias, de sus ciudades, villas... : [tomo VIII: Descripción del Reino de Valencia Parte I] su autor D. Bernardo Espinalt y Garcia..., (Imprenta de Hilario Santos: Madrid, 1784).

6 Espinalt y García, Atlante Español, ó Descripcion general geográfica, cronológica, é histórica de España, por Reynos y Provincias, de sus ciudades, villas... : [tomo VIII: Descripción del Reino de Valencia Parte I] su autor D. Bernardo Espinalt y Garcia...

7 Pedro Abarca, Los reyes de Aragón en anales históricos, distribuidos en dos partes., (Lucas Pérez, impresor de la Universidad: Salamanca, 1684). 


\subsection{La monarquía en el Colegio Seminario Corpus Christi.}

La biblioteca del Colegio del Corpus Christi alberga una galería de retratos de la realeza hispánica que en origen se encontraban en la residencia de san Juan de Ribera situada en la calle Alboraya, extramuros de la ciudad. Allí lucían las imágenes en el denominado "aposento de los reyes», donde aparecen representados algunos miembros de la Corona de Aragón, de Castilla y de la Casa de Austria. ${ }^{8}$ Se trata de un conjunto que ha ido creciendo en momentos distintos. Las principales aportaciones bibliográficas afirman que la mayor parte de las pinturas fueron hechas por Antonio Ricci en 1592. ${ }^{9}$ Se cree que en este mismo año también se compraron, acogiéndose a que el artista tenía abierto un taller en Madrid y a que el Patriarca viajó a la ciudad en este justo momento. ${ }^{10}$ Según el citado

8 La casa, también conocida como el Palacio del Huerto, era una villa de recreo desaparecida en la actualidad la cual debió reflejar el espíritu ávido de cultura y de conocimiento que caracterizaron al prelado. Por ello, el casón debió estuvo ricamente decorado con pinturas, esculturas, tapices, relojes y otros objetos de valor, además los jardines de la villa contenían fuentes escultóricas e incluso disponía de un pequeño zoológico con diversas especies animales. Véase Daniel Benito Goerlich, 'Imágenes para la reforma del arzobispo Juan de Ribera', en Emilio Callado Estela y Miguel Sorní Navarro (eds., El patriarca Ribera y su tiempo: religión, cultura y política en la Edad Moderna,(Institució Alfons el Magnnim, Diputació de Valncia: Valencia, 2012., p. 610.

9 Se ha seguido a Daniel Benito Goerlich, 'Juan de Ribera y las artes. Sensibilidad, gusto y aliño al servicio de una fe sincera.', en El legado del patriarca Juan de Ribera: Pastor Sanctus Virtutis Cultor, IV centenario, (Pentagraf, 2011, p. 221; y a Fernando Benito Doménech, Juan Sariñena (1545-1619): pintor de la Contrarreforma a Valencia : Museo de Bellas Artes de Valencia, del 19 de diciembre de 2007 al 23 de marzo de 2008, (Generalitat Valenciana, Consellería de Cultura i Esport, 2007.

10 Esta idea se ha apoyado en un documento fechado el 24 de mayo de 1592 donde se especifica la compra de doce retratos al óleo a Ricci por valor de novecientos veinticuatro reales, este dato se ha relacionado con las efigies que componen esta galería. Documento referenciado como Gasto de Cámara en Madrid, mayo 1592, A. G. GH., I., 4, 25. Véase a Benito Doménech, Pinturas y pintores..., pp. 142-143. Este documento no ha sido hallado así que por el momento no se puede sostener con certeza que las pinturas 
autor, aquí adquiriría las representaciones de Alfonso el Bravo, Enrique IV, Carlos V, Isabel de Portugal, Felipe II, María de Austria, Juana de Portugal, el príncipe don Carlos, Isabel Clara Eugenia y Felipe III. Otras tres fueron encargadas a Juan Sariñena en 1597, concretamente las relativas a los siguientes reyes aragoneses; Jaime I, Juan II y Fernando el Católico. Y en teoría, hacia 1608-1609 se le debió comprar nuevamente a Ricci el retrato de Margarita de Austria.

Pese a que se han propuesto tres fechas clave para la configuración de esta galería, se debe contemplar la posibilidad de que tan sólo se construyese en dos años concretos, 1592 y 1597. Del 92 contamos con la documentación de archivo ya estudiada por Benito y del 97 se ha fechado el encargo a Sariñena. No obstante, no se ha determinado la datación del retrato de Isabel la Católica. Lo más natural es que también proceda de 1597 cuando se adquirió la representación de Fernando, su esposo, en el lote de retratos hechos por Sariñena. Aunque, a día de hoy, no se cuenta con más documentación localizada al respecto, sí que se tiene noticia del transporte de trece retratos procedentes de Madrid entre los cuales podría encontrarse la imagen de la Católica. ${ }^{11}$

sean obra de Ricci. Respecto al viaje, en el archivo sí que se ha encontrado una carta de pago que probaría la estancia de Ribera en Madrid entre los meses de abril y junio. ACCV: Gastos generales, 1592. «[...] por los gastos hechos en la despensa en el camino que hemos hecho a Madrid desde el 17 de abril de 1592 que partimos de Valencia hasta el 5 de junio inclusive dicho año que volvimos $[. .$.$] »$

11 Aunque no se han encontrado documentos que certifiquen la compra de estas obras, el archivo sí que conserva una noticia por el pago de 6 libras por el transporte desde Madrid a Valencia: «Señor obispo se ha servido de mandar pagar a Juan López, vecino de Utiel, seis libras por el porte de una caja en que contenía trece retratos de Madrid para el servicio del Patriarca mi señor, en 9 de enero de 1597.» ACCV: Gastos generales, 1597. No obstante, siguen sin cuadrar los números. Por lo que consta en la documentación la serie se compone de catorce efigies y los investigadores han identificado la mano de Sariñena en tres de ellas y, por tanto, se asocian al nombre de Ricci las once obras restantes. La falta de datos más específicos entre la documentación no permite, por el momento, arrojar más luz acerca de la identificación de los trece retratos que llegaron desde Madrid, sin poder 
Este caso ejemplifica que era común en la época que familias nobles y pudientes poseyesen imágenes de la monarquía. Asimismo, se ha visto que la finalidad de este conjunto artístico era remarcar las raíces comunes entre la realeza hispánica y el propio Patriarca. ${ }^{12}$ Pero esta no sería la única acción encaminada a enaltecer el linaje de los Ribera, de hecho Ramón Robres ha explicado que surgieron curiosas leyendas con tintes históricos acerca del nacimiento de esta estirpe. ${ }^{13}$

Su origen se relacionaba con san Rosendo ( $\dagger$ Galicia, 992), de quien se han alabado sus virtudes para ser prelado y se ha dicho que tenía sangre real. Con probabilidad la vinculación del linaje de los Ribera con san Rosendo estaba plenamente asumida, ello explicaría que quizás después del fallecimiento del Patriarca, el Colegio del Corpus Christi adquiriese el retrato y las reliquias del santo. De hecho, entre las pinturas que decoraban la sacristía en 1745 se encontraba un «lienzo de 3 y 5 (palmos) de S. Rosendo Obispo con su marco encarnado y corlado». ${ }^{14}$ Igualmente, en la tercera grada del armario de las reliquias se encontraba «la custodia de san Rosendo pesa de plata trescientas ochenta onzas» y en el cuarto estante concretamente «en una arquita de plata se hallan los certificados auténticos de las reliquias de san Rosendo». ${ }^{15}$

saber con certeza si eran los retratos de miembros de la realeza y qué personajes se habían efigiado.

12 Idea ya expuesta en Juan Miguel Serrera, 'Alonso Sánchez Coello y la mecánica del retrato de corte.', en Santiago Saavedra (ed.), Alonso Sánchez Coello y el retrato en la corte de Felipe II, (Museo Nacional del Prado: Madrid, 1990), p. 57.

13 Ramón Robres Lluch, San Juan de Ribera, patriarca de Antioquía, arzobispo y virrey de Valencia, 1532-1611: un obispo según el ideal de Trento, (Juan Flors: Barcelona, 1960).

14 ACCV: Inventario de la Sagristía. Año 1745, fol. 9r y ACCV: Visita general del Real Colegio Corpus Christi..., fol. 7r, en este caso aparece concretamente en el «paso de la segunda sacristía antes del relicario.»

15 ACCV: Visita general del Real Colegio Corpus Christi..., concretamente 
También se contaba que la familia de los Ribera descendía de Velloso, el hijo bastardo del rey don Ramiro, soberano de León, quien ostentó el título de señor de Cabrera y Ribera tras despojar a los musulmanes de estas tierras. Igualmente, se decía que el castillo del señor se localizaba cerca del río Limia, el cual nacía en Ourense. Se ha dado por cierto que este linaje procedía originariamente de Galicia, desde donde se extendió hacia Toledo, Cataluña y Andalucía, pues la familia de san Juan era natural de Sevilla.

Robres continúa exponiendo que las crónicas relacionan, desde antaño, a esta estirpe con la familia real, a quienes servían en los combates por la reconquista. Por ejemplo, don Pedro Afán de Ribera batalló a favor de los Reyes Católicos para vencer al enemigo musulmán. Del mismo modo el padre del Patriarca, don Pedro Enríquez y Afán de Ribera y Portocarrero (1509-1571) fue:

Sexto conde de los Morales, segundo marqués de Tarifa y primer duque de Alcalá de los Gazules, con cuya grandeza le honró el prudente rey don Felipe II. Le hizo su nombre tan conocido en el mundo, así por lo heroico de sus acciones, y hechos, como por la magnanimidad, y grandeza de sus referidos ascendientes. Fue este excelentísimo príncipe, varón de insigne valor, prudencia, piedad, y juicio; esclarecido en la sangre, lucido en los vasallos, poderos en las rentas, y único en lo político, y militar de sus gobiernos: pues entre otros mereció el de virrey, y capitán general del reino de Cataluña, y el de Nápoles; siendo en uno, y otro, su equidad, rectitud, y prudencia idea ejemplar a las edades venideras. Acreditó esta verdad en España, el gran concepto que nuestros monarcas hicieron, y su prudencia se mereció en aquel reino donde murió, pues en las instrucciones que su majestad da a todos los que premia con aquel puesto, dispone que en todo sigan, e imiten el gobierno y direcciones de don $\mathrm{Pe}$ -

en «Del ramo 1‥ Inventario de las reliquias que hay en dicho armario» e «Inventario de auténticas y otros instrumentos que se encontraron en el relicario", fol. 13r y fol. 30r. 
rafán de Ribera, observando las órdenes, y pragmáticas que publicó en el tiempo que gobernó aquel Reino. ${ }^{16}$

Igualmente los ascendientes por vía paterna se han entroncado con los monarcas castellanos, Alfonso X, Alfonso XI, Isabel la Católica, Carlos I y Felipe II, y con el rey aragonés Fernando el Católico. ${ }^{17}$ Cabe remarcar que el retrato de todos ellos, a excepción de Alfonso XI de Castilla, conocido como el Justiciero, se conservan en la galería de efigies estudiada. El rey cuya imagen se ha perdido era el nexo de unión entre los Trastámara y los Enríquez. Así se justificaba que el parentesco de los antepasados de san Juan de Ribera con la monarquía.

\subsubsection{La galería de retratos:}

Según la documentación de archivo más específica se conoce que en el denominado aposento de los reyes en la casa de la calle de Alboraya lucían catorce lienzos identificables con los siguientes personajes; Jaime I el Conquistador, Juan II, Alfonso el Sabio (probablemente confundido con Alfonso el Bravo), los Reyes Católicos Fernando e Isabel, Carlos V y su esposa Isabel de Portugal, Felipe II, Felipe III y la reina Margarita de Austria, la emperatriz María de Austria viuda, la princesa Juana de Austria, la infanta Isabel Eugenia y el príncipe Carlos de Castilla. Las pinturas se inventariaron el 28 de enero de 1611 y fueron numeradas desde el 254 al 267. Sin embargo, no se citó el retrato de Alfonso XI del que han dado noticia algunos autores:

16 Jacinto Busquets Matoses, Idea ejemplar de prelados, delineada en la vida, y virtudes del venerable varón el ilustrísimo y excelentísimo señor don Juan de Ribera, patriarca de Antioquía, arzobispo de Valencia, su virrey y capitán general, fundador del Real Colegio de Corpus Christ, (Valencia, 1683)., libro I, cap. I, pp. 4 - 5. Si bien hay autores, como Busquets, que profundizan en el origen del linaje de los Ribera, hay otros que tan sólo elogian al padre de san Juan, por ser su ascendiente más directo, consúltese a Francisco Escrivà, Vida del venerable siervo de Dios don Joan de Ribera, patriarca de Antioquía y arzobispo de Valencia, (Roma, 1696).

17 Robres Lluch, San Juan de Ribera, patriarca de Antioquía..., pp. 3 - 5. 
254. Cuadro del rey don Jaime de Aragón y León, el Conquistador, de cinco palmos de caída y cuatro de ancho y el marco de azul, oro y blanco. 255. Cuadro del rey don Juan II, de cinco palmos de caída y cuatro de ancho con el marco azul y blanco. 256. Cuadro del emperador Carlos V de cinco palmos de caída y cuatro de ancho con el marco de oro y azul. 257. Cuadro de la emperatriz doña Isabel, mujer de Carlos V, de cinco palmos de caída y cuatro de ancho con el marco de oro y azul. 258. Cuadro del rey Felipe II de cinco palmos de caída y cuatro de ancho con el marco de oro y azul. 259. Cuadro del rey Felipe III cuando era Príncipe de cinco palmos de caída y cuatro de ancho con marco de oro y azul. 260. Cuadro de la reina de España doña Margarita, de cinco palmos de caída y cuatro de ancho con marco de oro, azul y blanco. 261. Cuadro de la emperatriz doña María viuda de cinco palmos de caída y cuatro de ancho con el marco de oro, azul y blanco. 262. Cuadro de la princesa de Portugal, doña Juana de Austria, con cinco palmos de caída y cuatro de ancho con el marco de oro, azul y blanco. 263. Cuadro de la infanta de Flandes, doña Isabel Eugenia, de cinco palmos de caída y cuatro de ancho con el marco de oro, azul y blanco. 264. Cuadro del príncipe Carlos de Castilla, de cinco palmos de caída y cuatro de ancho en marco de oro, azul y blanco. 265. Cuadro del rey don Fernando, de cinco palmos de caída y cuatro de ancho con el marco de oro, azul y blanco. 266. Cuadro de la reina doña Isabel, de cinco palmos de caída y cuatro de ancho con el marco de oro, azul y blanco. 267. Cuadro del rey don Alfonso el Sabio, de cinco palmos de caída y cuatro de ancho, con el marco de oro, azul y blanco. ${ }^{18}$

Por el momento, no se puede conocer la ubicación original de los retratos ni comprobar si realmente las piezas se colocaron cronológicamente y respetando los lazos familiares. De hecho, el orden en que se inventariaron las efigies como se ha

18 ACCV: Libro de noticias y curiosidades del Real Colegio Corpus Christi..., p. 213. 
visto en el Libro de noticias y curiosidades no responde a estos criterios. Tampoco se ha guardado un sentido claro en la colocación actual de las obras, pues se mezclan en cierta medida miembros de la corona castellana con la aragonesa y la casa de Austria. Al entrar en la biblioteca, se observa que las representaciones se encuentran en cada uno de los muros largos, unas frente a otras. A la derecha y empezando desde la misma puerta de acceso hacia dentro se aprecian las imágenes de; $\mathrm{Al}$ fonso el Bravo (identificado en otras ocasiones como el Sabio), Juan II de Aragón, Isabel Clara Eugenia (hija de Felipe II), Margarita de Austria y su esposo Felipe III, el príncipe Carlos (hijo de Felipe II), Fernando el Católico y Jaime I. En el lado opuesto y siguiendo la dirección contraria, es decir desde el fondo hacia la puerta se cuenta con los retratos de; Isabel la Católica, Carlos V y su esposa Isabel de Portugal y a continuación aparecen sus hijos la emperatriz María de Austria (retratada como viuda), Felipe II y Juana de Austria [fig. 3.1; fig. 3.2; fig. 3.3; fig. 3.4; fig. 3.5].

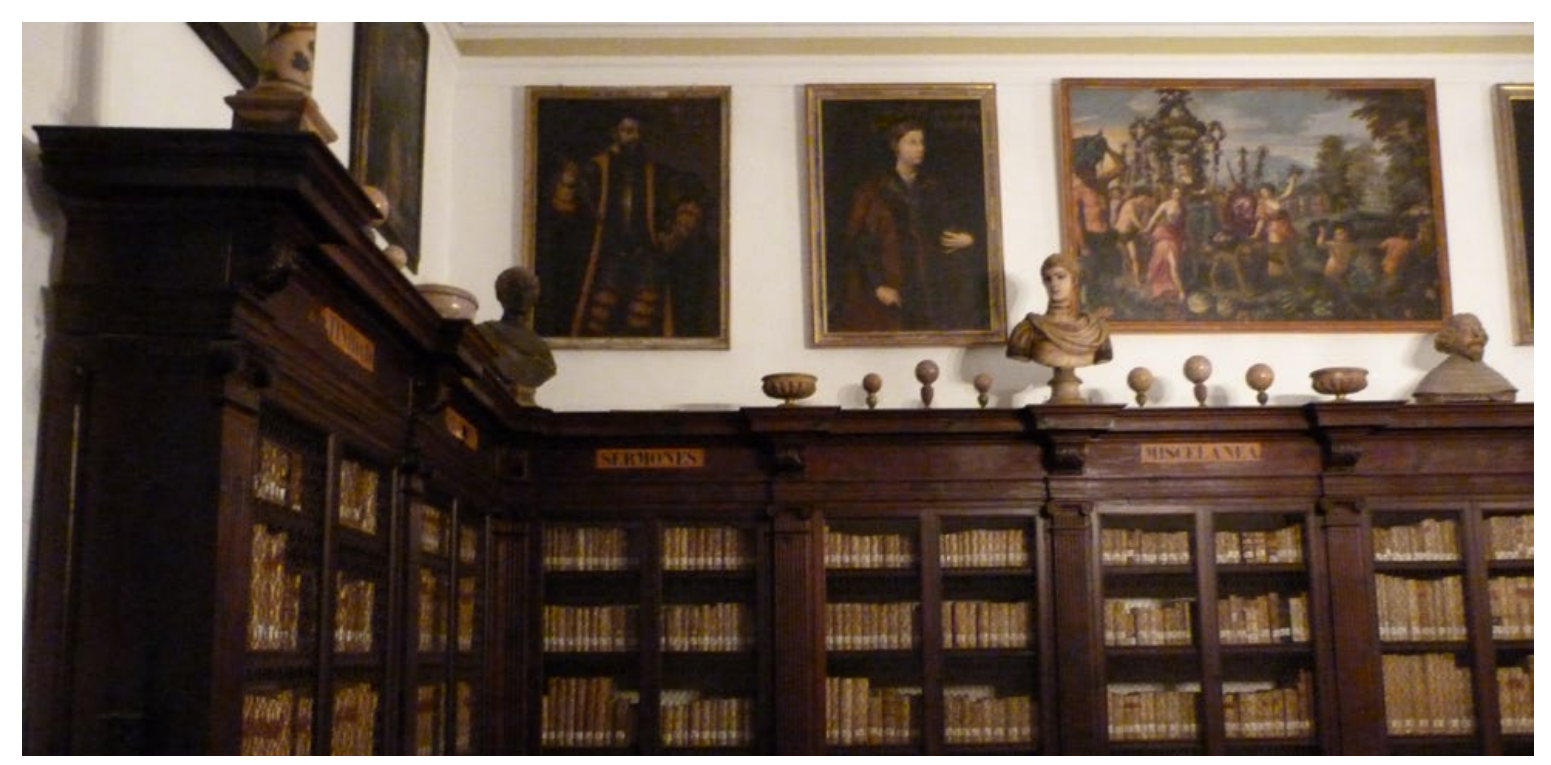

Fig. 3.1. Vista general del muro izquierdo de la biblioteca con los retratos de Alfonso X el Sabio y Juan II de Aragón.

Además, junto a este último retrato se ha dispuesto otra efigie que no estaba mencionada junto al resto de pinturas en la documentación estudiada. Debe tratarse del retrato de Enrique IV de Castilla (1425 - 1474) [fig. 3.6], hijo de Juan II de Castilla y 


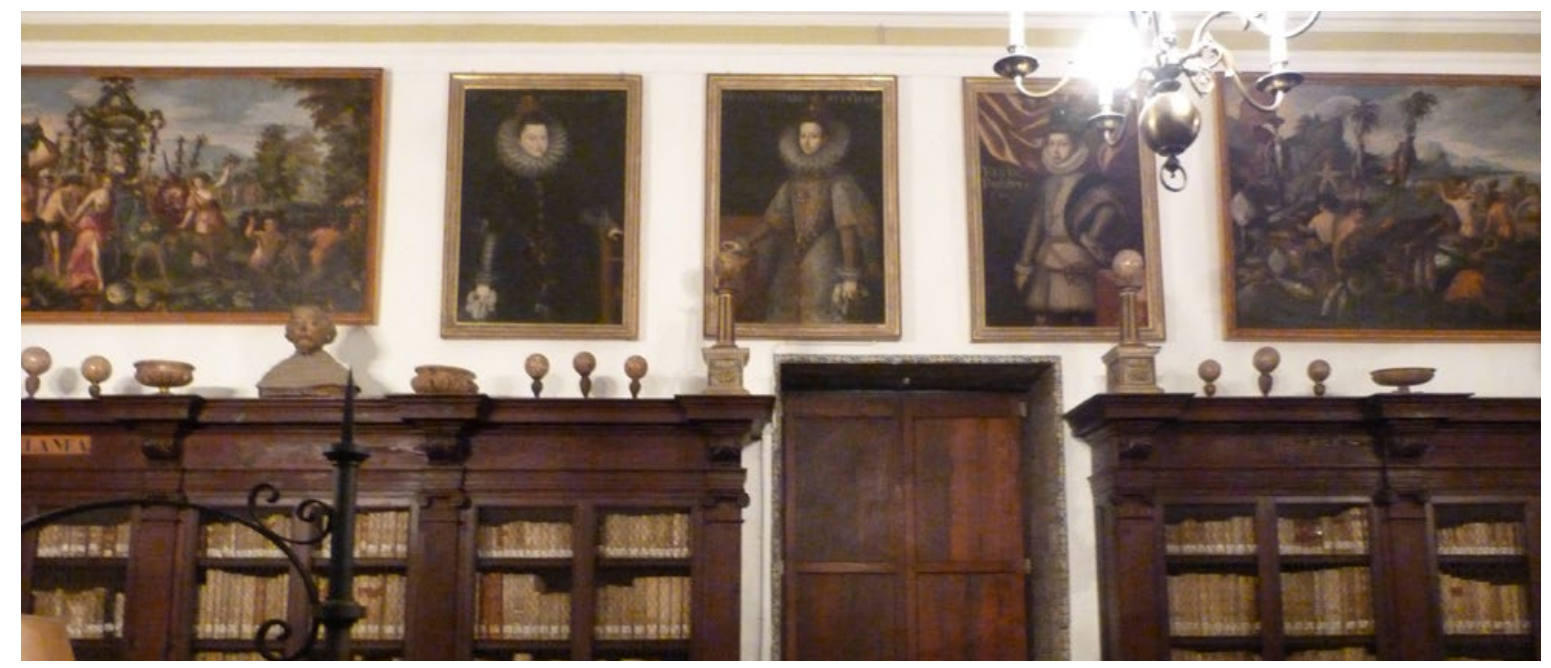

Fig. 3.2. Vista general del muro izquierdo de la biblioteca con los retratos de Isabel Clara Eugenia, Margarita de Austria y Felipe III.

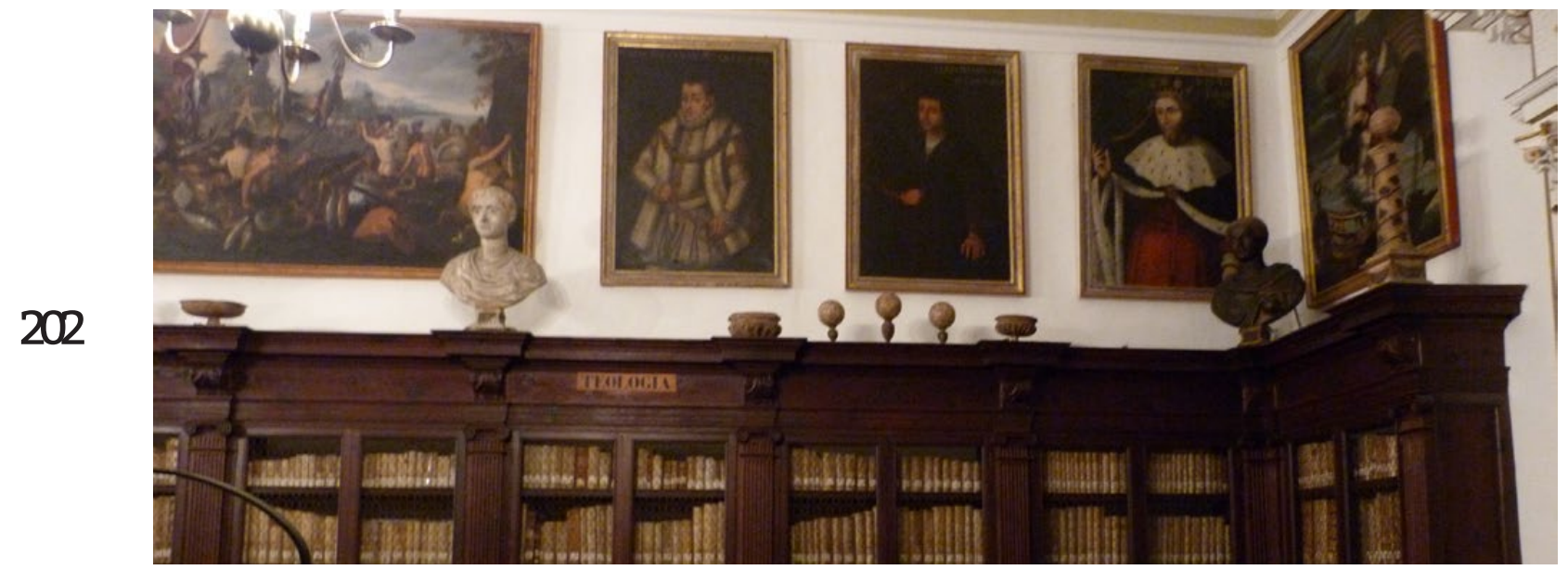

Fig. 3.3. Vista general del muro izquierdo de la biblioteca con los retratos del príncipe Carlos, Fernando el Católico y Jaime I.

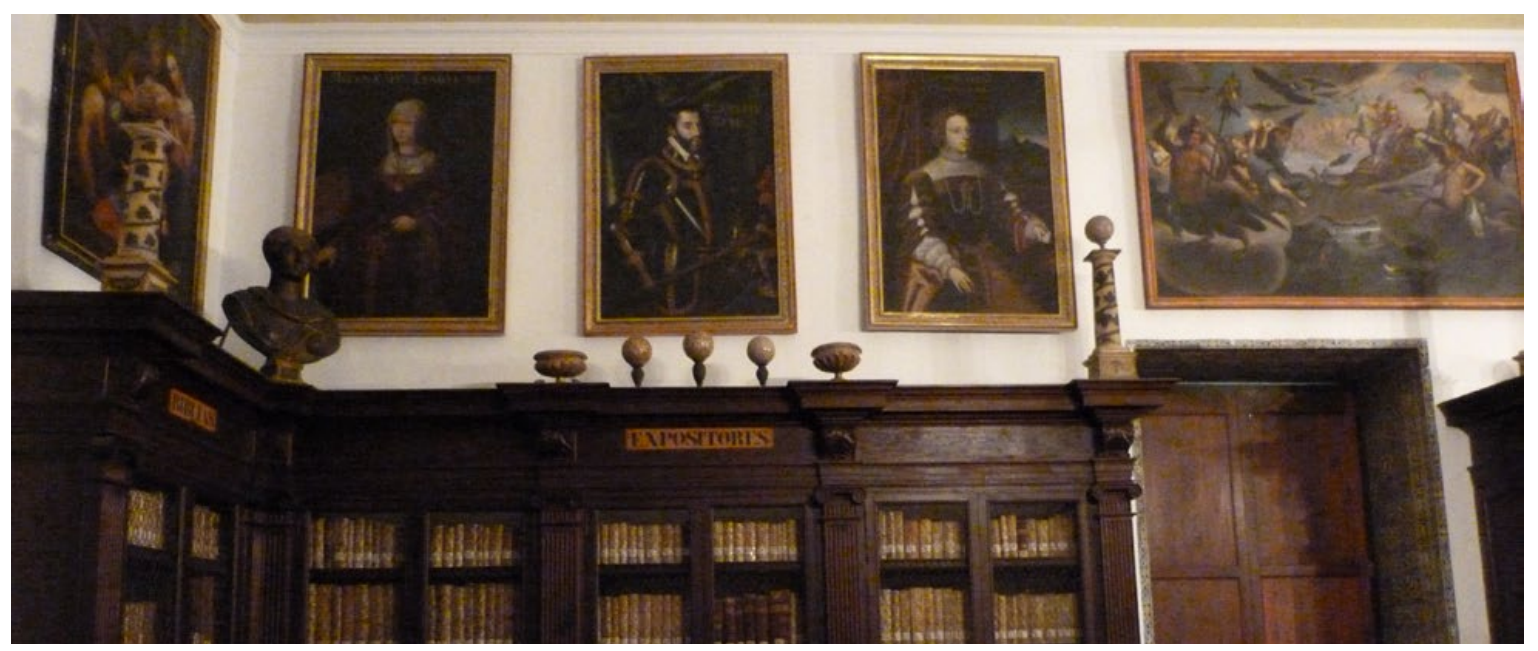

Fig. 3.4. Vista general del muro derecho de la biblioteca con los retratos de Isabel la Católica, Carlos V e Isabel de Portugal. 


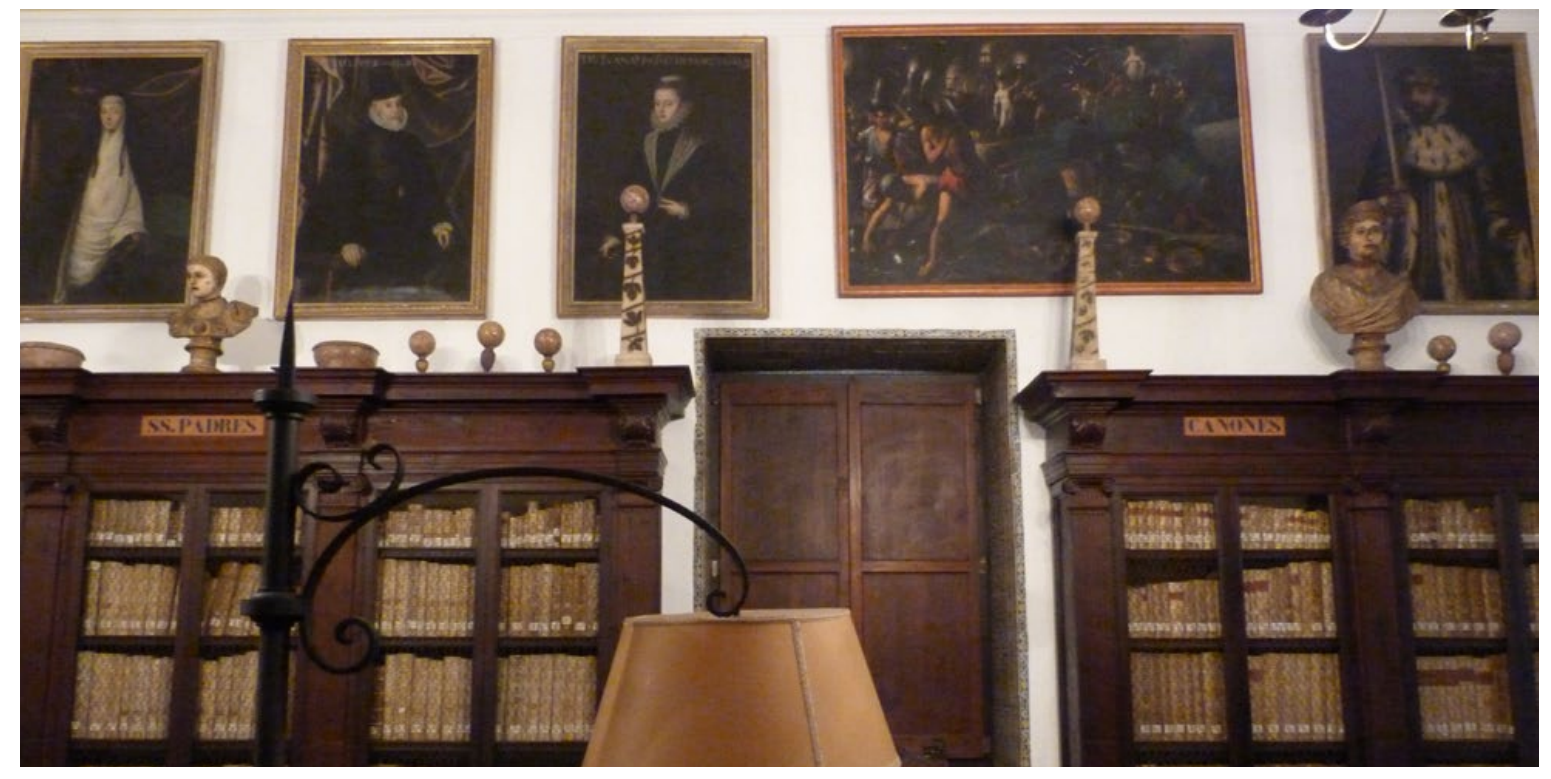

Fig. 3.5. Vista general del muro derecho de la biblioteca con los retratos de María de Austria, Felipe II, Juana de Austria y Enrique IV de Castilla.

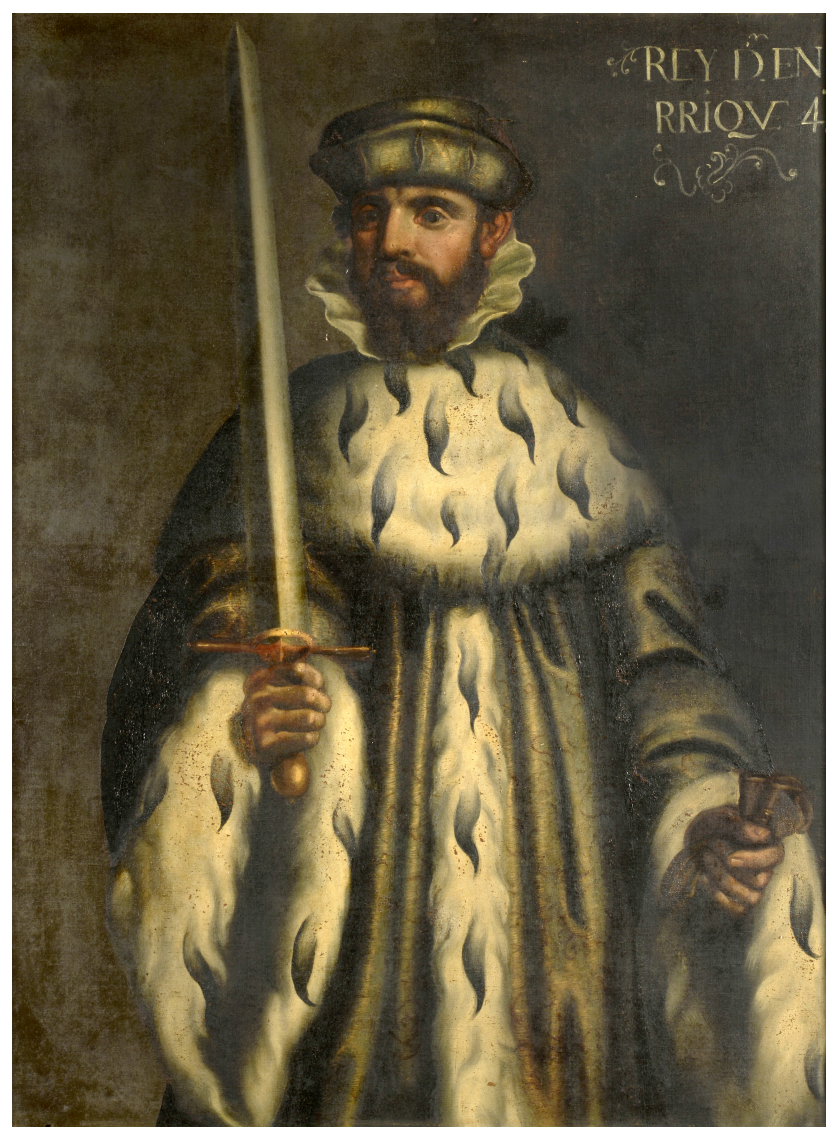

Fig. 3.6. Anónimo, Enrique IV de Castilla, finales del s. XVI - principios del XVII, óleo sobre lienzo, Valencia, Real Colegio Seminario del Corpus Christi. 
María de Aragón. Se le ha representado vestido según la estética medieval, con una capa engalanada por pieles de armiño y sosteniendo una espada. Sería lógico que este personaje formase parte de la galería de retratos si se tiene en cuenta que es el hermano de Isabel la Católica y su predecesor en el trono castellano. Pero también hay que tener en consideración la explicación de Benito acerca de la ausencia de referencias a esta efigie en la documentación. Ya explicó que este retrato en concreto no debía de estar con el resto del conjunto debido al polémico conflicto que tuvo con su hermana Isabel y a que tampoco representaba un lazo primordial que vinculase a la realeza con el Patriarca. ${ }^{19}$

El retrato de Jaime I (1213 - 1276) hecho, en este caso, por Juan Sariñena [fig. 3.7] sigue la imagen idealizada que Juan de Juanes realizó hacia el año 1557 y que ilustró La chrónica o comentario del rey Iacme..$^{20}$ Un poco más tarde, esta misma representación apareció en el De vita et rebus gestis Iacobi I,

Regis Aragonum, cognomento expugnatoris, Libri XX escrito por Bernardino Gómez Miedes en 1582. ${ }^{21}$ Como se podrá apreciar, esta imagen donde el rey aparece coronado, vestido con una túnica roja y una capa real con armiño fue copiada y utilizada en otras ocasiones, como la serie icónica conservada en el palacio de la Generalitat. Otro monarca perteneciente a la rama aragonesa es Juan II (1398 - 1479) cuyo ejemplo sigue el tipo de representación oficial, vestido con capa y llevando tanto la corona como el cetro y empuñando la espada [fig. 3.8].

19 Benito Doménech, Pinturas y pintores..., p. 310.

20 Chronica, o commentari del gloriosissim e invictissim rey en Iacme per la gracia de Deus Rey de Arago, de Mallorques, e de Valencia, Compte de Barcelona, e de Urgell, e de Muntpesller: feyta e scrita per aquell en sal lengua natural, e treyta del Archiu del molt Magnifich Rational de la insigne ciutat de Valencia hon stava custodida, (Casa de la viuda de Juan Mey Flandro: Valencia, 1557).

21 Bernardino Gómez Miedes, De vita et rebus gestis Iacobi I, Regis Aragonum, cognomento expugnatoris, Libri XX, (Viuda de Pedro de Huete: Valencia, 1582). 


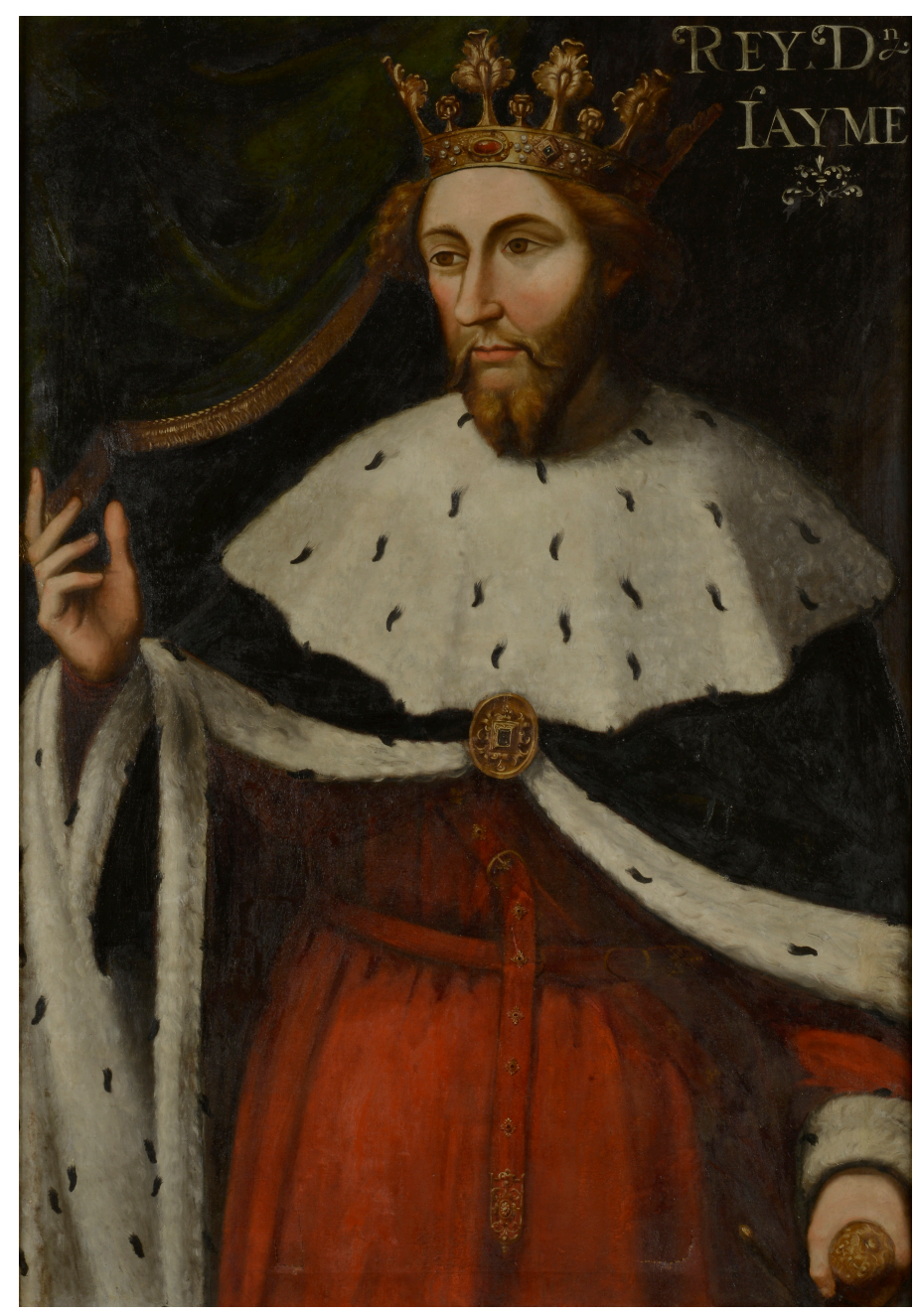

Fig. 3.7. Juan Sariñena, Jaime I, 1597, óleo sobre lienzo, Valencia, Real Colegio Seminario del Corpus Christi.

La identificación del retrato de Alfonso el Bravo [fig. 3.9] y las razones por las que forma parte de esta galería han sido objeto de distintas hipótesis y reflexiones. En primer lugar porque hay una clara contradicción entre las fuentes escritas y la identidad que muestra la propia obra. Mientras que el inventario de 1611 la cataloga como un retrato de Alfonso X el Sabio, la inscripción presente en la efigie habla del rey don Alonso el Bravo. Esta contrariedad sirvió para que Fernando Benito descartase a un personaje y otro, y plantear que el retratado era Alfonso XI el Justiciero (1311-1350), rey de Castilla y León, quien marca el lazo familiar entre los Enríquez de Ribera y los monarcas castellanos. ${ }^{22}$ No obstante, conviene replantearse que quizás sí que se alude al Bravo y que pese ello no se ha des-

22 Benito Doménech, Pinturas y pintores..., íbidem. 


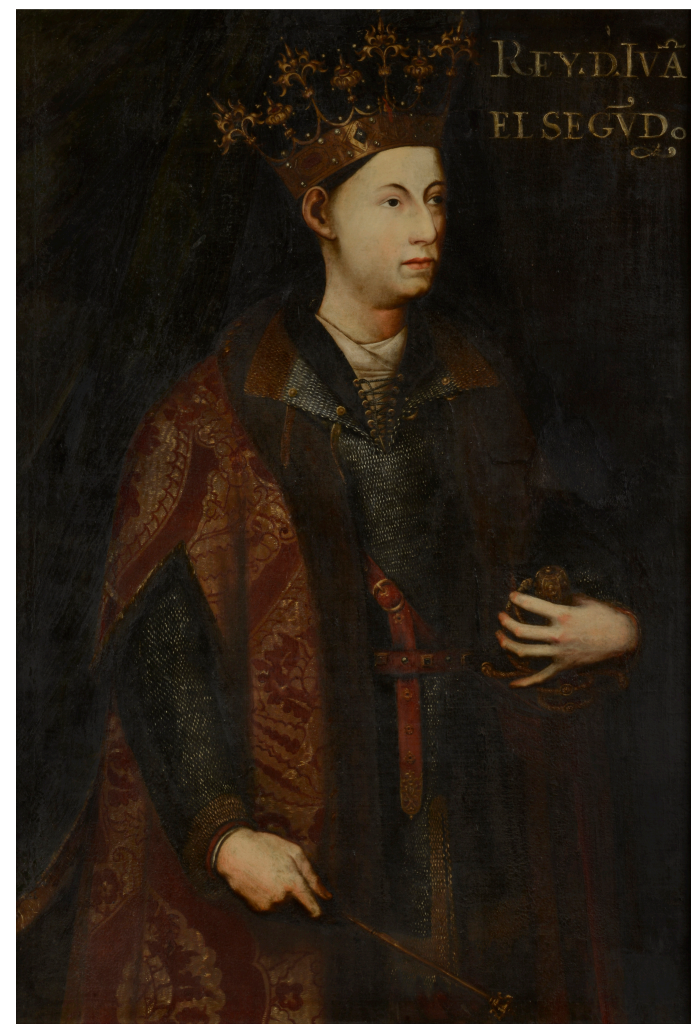

Fig. 3.8. Juan Sariñena, Juan II, 1597, óleo sobre lienzo, Valencia, Real Colegio Seminario del Cor-

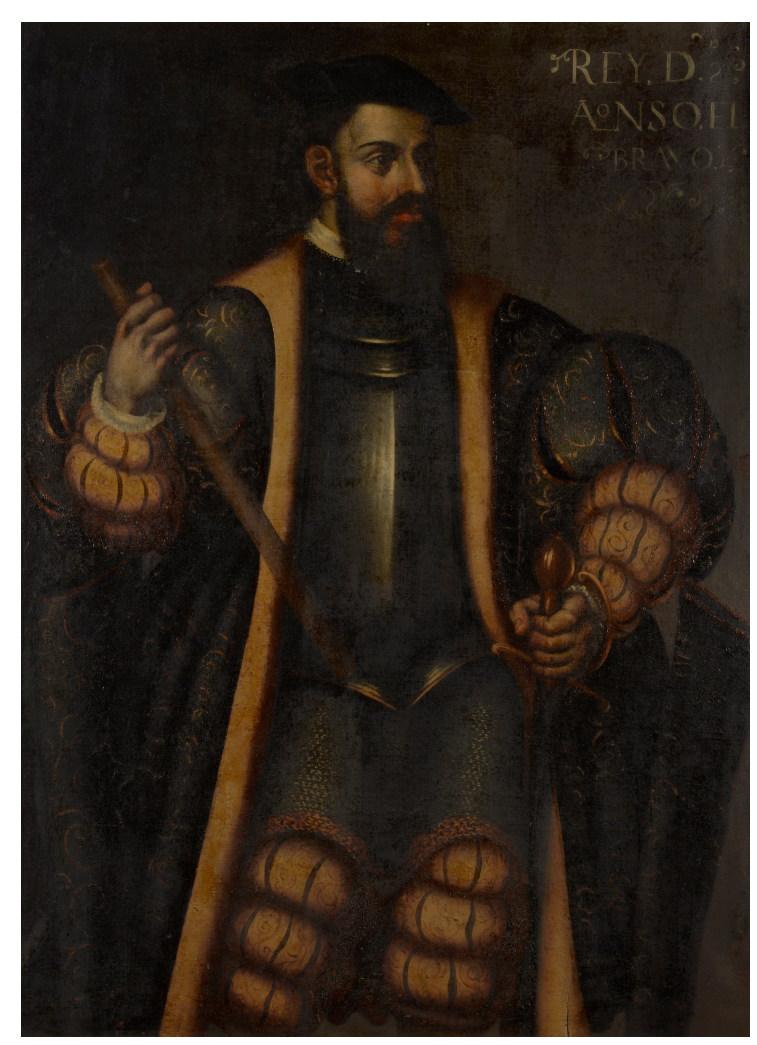

Fig. 3.9. Atribuido a A. Ricci, Alfonso VI el Bravo, 1592, óleo sobre lienzo, Valencia, Real Colegio Seminario del Corpus Christi.

cuidado el trasfondo genealógico. Como ya se ha comentado, el linaje de los Ribera se ha asociado a san Rosendo. Además Hermenegildo Gutiérrez, abuelo del santo, fue pariente, amigo y estrecho colaborador de Alfonso III el Magno (866-910), doceavo rey de Asturias. ${ }^{23}$ Entre los descendientes del Magno se encontraba Alfonso VI el Bravo (1040-1109), rey de León (1065-1072), rey de Castilla y de Galicia (1072-1109).

Por tanto, el poseer una representación de este monarca remitía a los orígenes del linaje del Patriarca así como ya revelaba, una vez más, el parentesco con la realeza castellana. Al margen de sea cual sea la verdadera identidad del representado, se trata de una imagen imaginaria que no concuerda con la imagen propia de un rey medieval, pues la vestimenta se

23 Sobre el linaje de san Rosendo se ha consultado a Emilio Sáez, Los ascendientes de san Rosendo. Notas para el estudio de la monarquía astur-leonesa durante los siglos IX-X, (Consejo Superior de Investigaciones Científicas, Instituto Jerónimo Zurita: Madrid, 1948), p. 13. 
acerca más a la moda renacentista y por ello, el monarca viste con la armadura al completo y el ropón, además de sostener el bastón de mando y empuñar la espada.

Tanto el trono castellano como el aragonés, aunque mantuvieron su independencia, se aliaron a raíz del matrimonio entre Fernando de Aragón e Isabel de Castilla, quienes dieron paso la dinastía Austria española. Así los Reyes Católicos también son parte de este conjunto pictórico. No obstante, la bibliografía apunta que la autoría para ambas piezas es distinta. El retrato de Isabel la Católica sería uno más de los pintados por Antonio Ricci [fig. 3.10] y reproduce la tipología ya empleada en otras obras de la reina. Aparece de pie junto a un sillón sobre el que apoya su mano derecha y con la izquierda sostiene un libro de rezos a la altura de la cintura. El cabello queda parcialmente escondido por la cofia que llega hasta la frente y la toca casi transparente que la recubre. La imagen en su conjunto se puede vincular con otros retratos similares custodiados por el Museo Nacional del Prado [fig. 3.11] y por el Ayuntamiento de Granada [fig. 3.12].

Si bien los retratos de Isabel la Católica conservados en Ma-
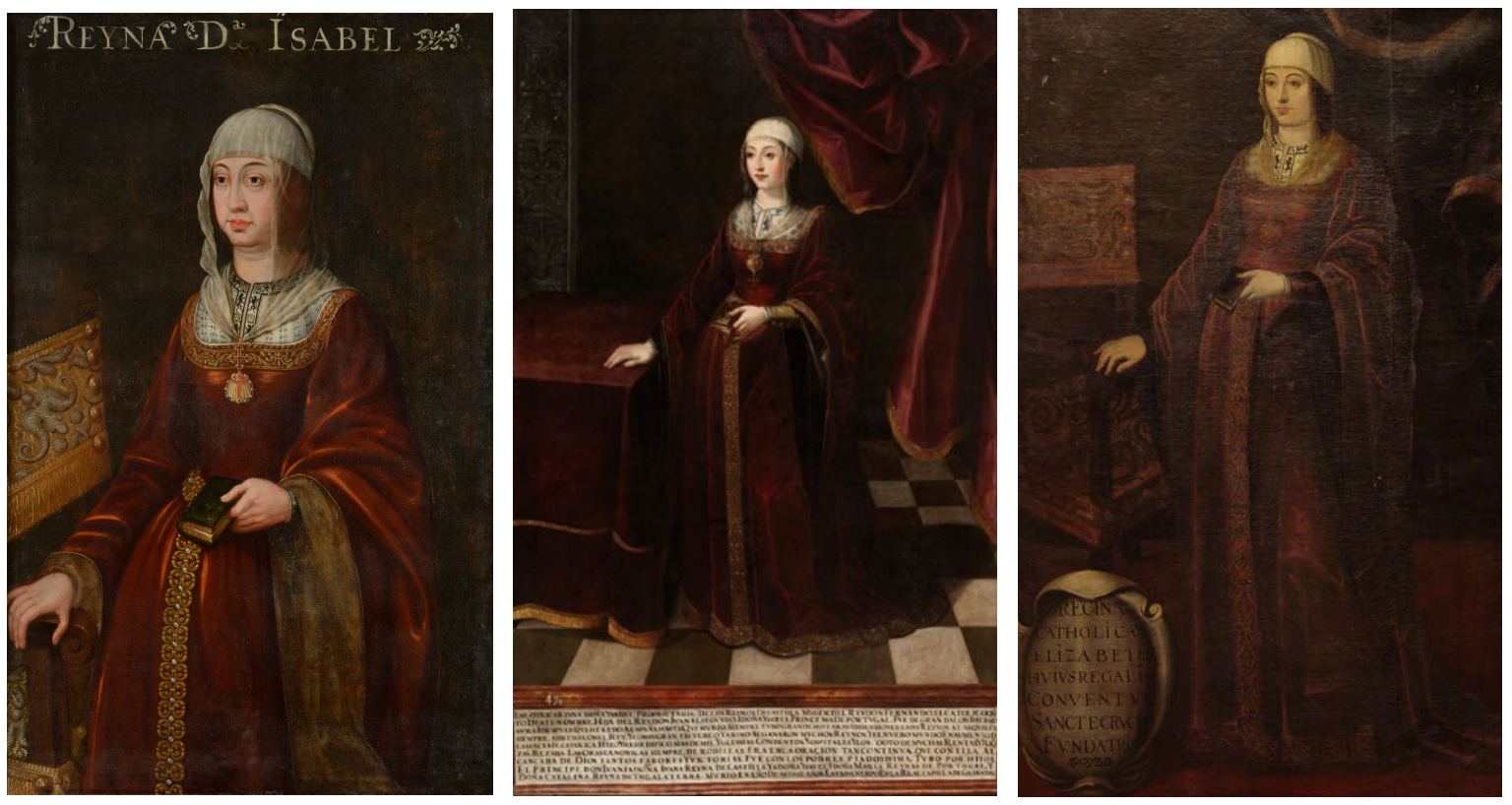

Fig. 3.10. Atribuido a A. Fig. 3.11. Anónimo, Isa- Fig. 3.12. Anónimo, IsaRicci, Isabel la Católica, bel la Católica, siglo bel la Católica, siglo 1597, óleo sobre lienzo, XVII, óleo sobre lienzo, XVII, óleo sobre lienzo, Valencia, Real Colegio Madrid, Museo Nacio- Granada, AyuntamienSeminario del Corpus nal del Prado. Christi. to. 
drid y Granada forman pareja con la efigie de su esposo, en la galería del Colegio no fue Ricci quien pintó la imagen del rey Católico como sí lo había hecho con la reina, sino que esta pintura fue elaborada por Juan Sariñena. En este caso, la imagen es más bien austera, pues el monarca va ataviado con ropajes oscuros que apenas permiten distinguir el collar. Tampoco se ha mostrado luciendo la corona y, el cetro se encuentra sobre un bufete que prácticamente se funde con el fondo [fig. 3.13].

La corona castellana y aragonesa formaron parte de las posesiones de Carlos I de España y V de Alemania, primer monarca de la dinastía Austria que gobernó ambos territorios hispánicos. Su retrato se ha colocado junto al de su abuela y ensalza su faceta militar, pues aparece ataviado completamente con la armadura cuyo yelmo reposa en el bufete, y sostiene la bengala con la mano derecha. Además, ostenta el collar de la orden del Toisón de Oro [fig. 3.14]. La tipología de efigie responde al retrato de corte establecido y reproducido en numerosas oca-

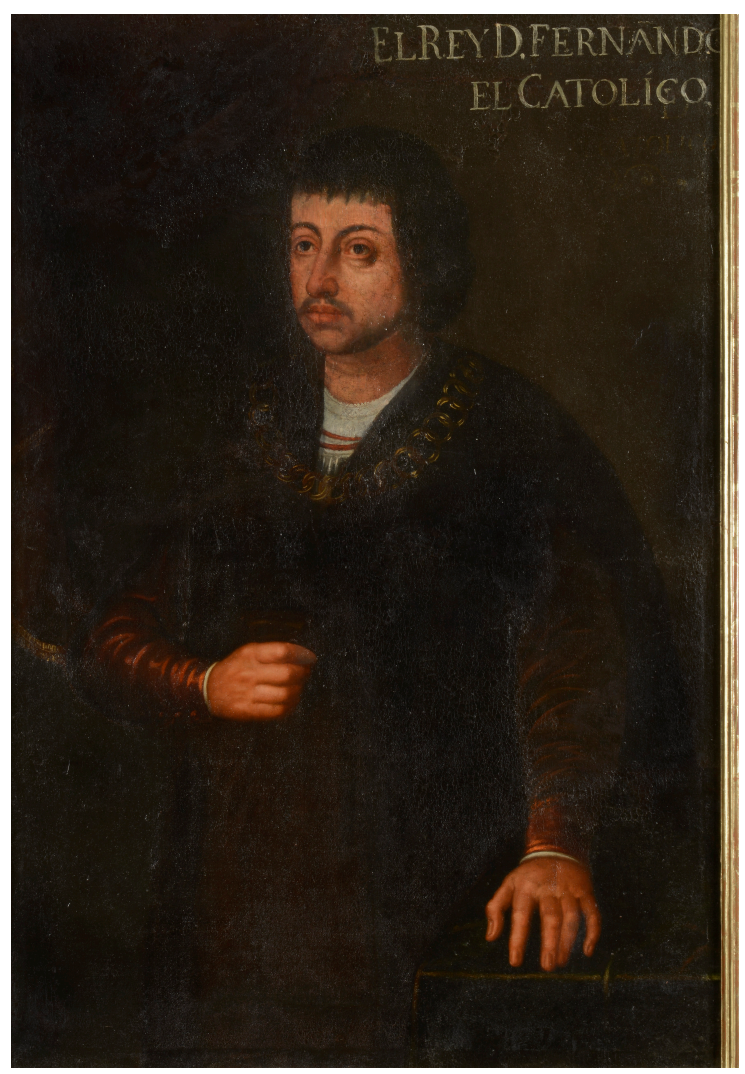

Fig. 3.13. Juan Sariñena, Fernando el Católico, 1597, óleo sobre lienzo, Valencia, Real Colegio Seminario del Corpus Christi.

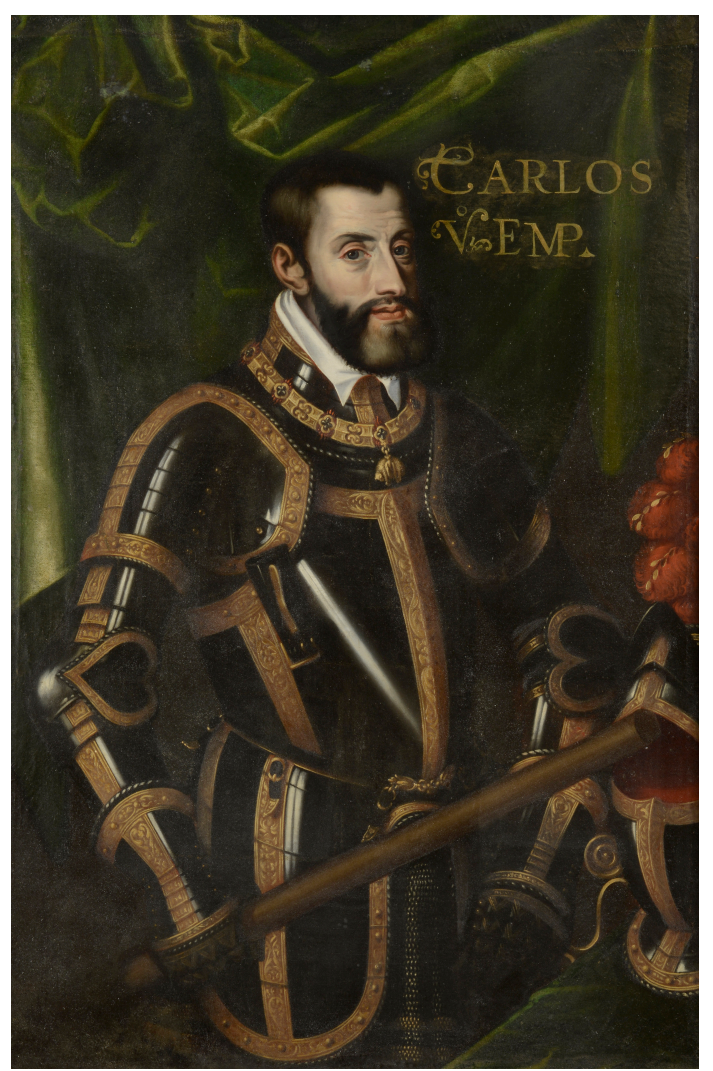

Fig. 3.14. Atribuido a A. Ricci, Carlos V, 1592, óleo sobre lienzo, Valencia, Real Colegio Seminario del Corpus Christi. 
siones por distintos artistas de primera línea como Pantoja de la Cruz (véase la fig. 1.9), pero también de segunda categoría como la obra conservada en la Universitat de València (véase la fig. 2.13).

A continuación, se halla el retrato de su esposa Isabel de Portugal [fig. 3.15]. Se trata de una copia de la pintura de Tiziano [fig. 3.16] que ya estaba finalizada el 1 de septiembre de 1548 y que fue encargada por Carlos $\mathrm{V}$ para recuperar la imagen de su esposa fallecida en 1539. Para ello, el artista veneciano tomó como modelo el retrato que anteriormente había hecho de la emperatriz vestida de negro, llevando flores en su regazo y ostentando la corona imperial que se perdió en el incendio del Pardo en el año 1604. El retrato de Isabel de Portugal principalmente fue un modo de mantener vivo el recuerdo de la dama, así se entiende el especial afecto que el emperador tuvo hacia esta pieza llevándosela consigo a Bruselas en 1556 y a Yuste en 1558. ${ }^{24}$ Jorge Sebastián vio en este retrato el punto de partida para crear la imagen de las reinas en España durante el siglo XVI. ${ }^{25}$ Aparece sedente en el interior de una estancia y el ventanal ubicado a un lado abre el espacio hacia el exterior apreciándose un paisaje. Sostiene un libro de horas y fija la mirada en un punto indeterminado.

Las tres representaciones que lucen continuadamente a las efigies de los emperadores se corresponden con los hijos que sobrevivieron al primer año de vida; María (1528 - 1603), Felipe (1527 - 1598) y Juana (1535 - 1573). María de Austria se ha retratado como viuda [fig. 3.17], pues su primo y esposo el archiduque Maximiliano falleció en 1576. En 1582 volvió a España y se retiró al monasterio madrileño de las Descalzas Reales, 24 Miguel Falomir Faus, Tiziano: 10 de junio -7 de septiembre 2003, Museo Nacional del Prado, (Museo Nacional del Prado: Madrid, 2003)., p. 208.

25 Consúltese la tesis doctoral de Jorge Sebastián Lozano, 'Imágenes femeninas en el arte de corte español en el siglo XVI', Universitat de València, 2005 , p. 56. Además, cabe destacar que el autor ha trabajado los retratos de otras mujeres pertenecientes a la Casa de Austria y ha reflexionado sobre las efigies cortesanas. 


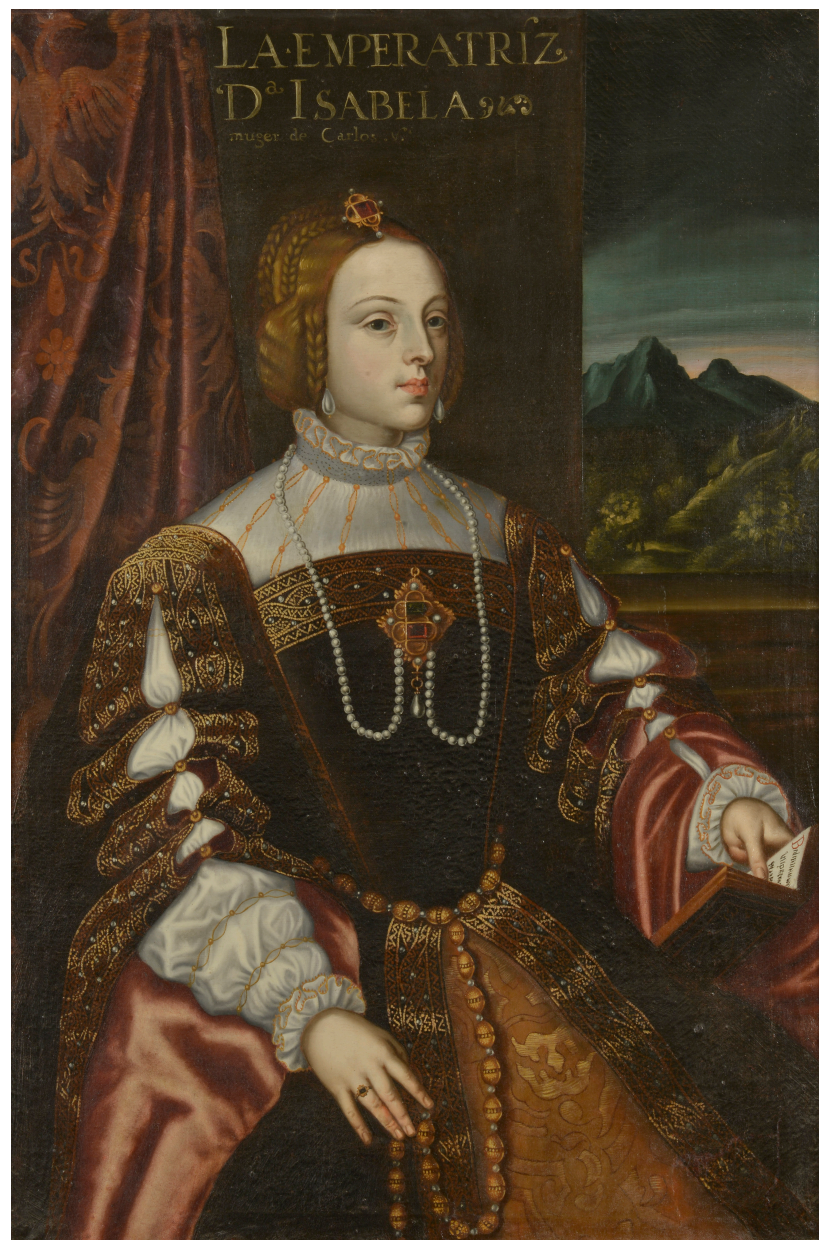

210

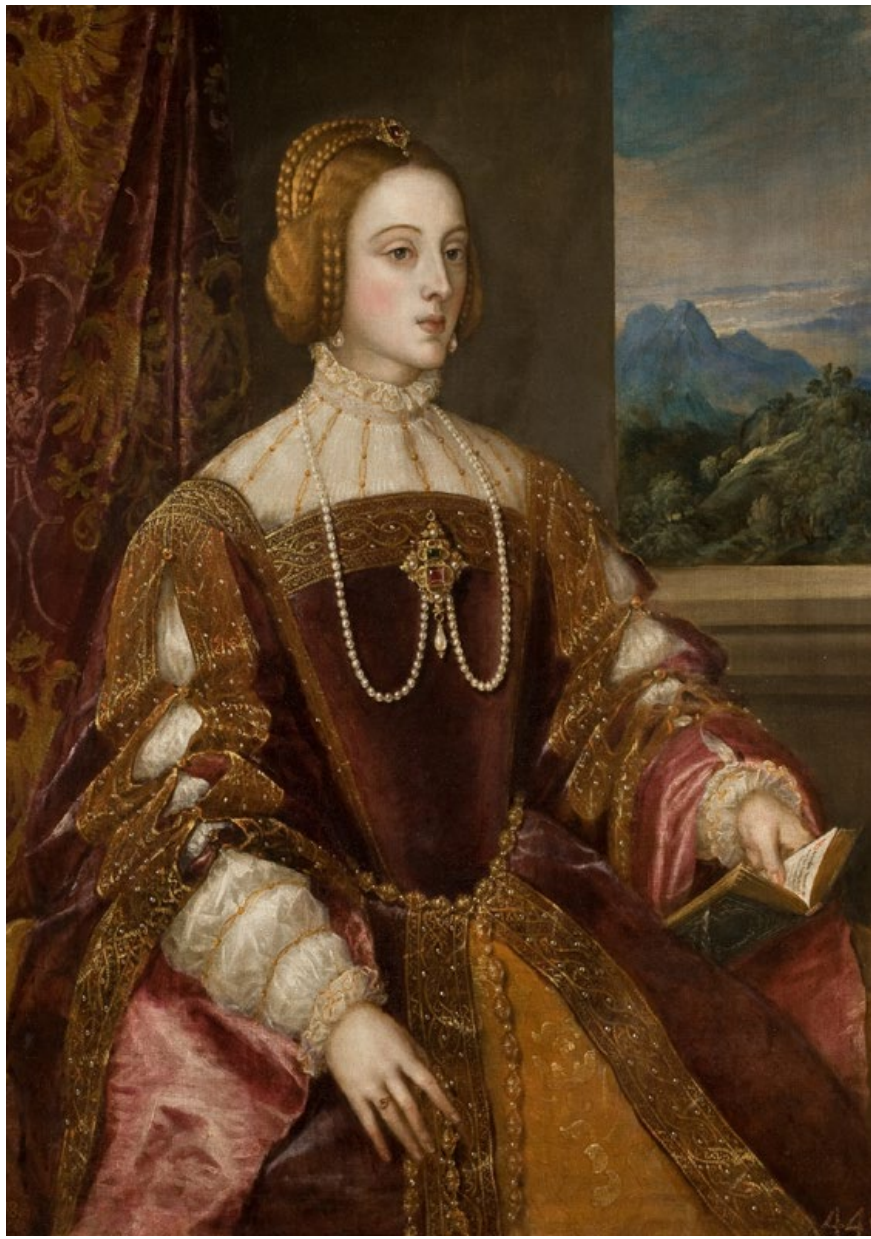

Fig. 3.15. Atribuido a A. Ricci, Isabel de Portugal, 1592, óleo sobre lienzo, Valencia, Real Colegio Seminario del Corpus Christi.
Fig. 3.16. Tiziano, Isabel de Portugal, 1548, óleo sobre lienzo, Madrid, Museo Nacional del Prado. 
fundado por su hermana Juana en 1559. Allí residió con su hija la archiduquesa Margarita de Austria (1567 - 1633), profesa del mismo, hasta su fallecimiento en 1603 . Se le ha retratado con el atuendo propio de las viudas, una toca blanca y negra y el monjil. Como apunta Francisco de Sousa Congosto, este atuendo está inspirado en la Virgen de la Soledad, pieza elaborada por Gaspar Becerra en el siglo XVI para atender al encargo de la reina Isabel de Valois. ${ }^{26}$ En calidad de viuda también la retrató Juan Pantoja de la Cruz, lienzo que se encuentra en el monasterio madrileño [fig. 3.18].

La efigie de Felipe II [fig. 3.19], llamado el Prudente, ha estado marcada por la austeridad y la sobriedad al vestir completamente de negro, con jubón, capa y gorguera, con guantes en la mano derecha y empuñando la espada con la izquierda. El elemento que principalmente pone de manifiesto la dignidad del monarca es el Toisón de Oro. La figura se ha emplazado en el interior de una estancia engalanada por un cortinaje. El retrato, deudor de las imágenes cortesanas, se encuentra en sintonía con la representación de este mismo rey hecha por Juan Pantoja de la Cruz y que luce en la biblioteca del monasterio de El Escorial [fig. 3.20]. Respecto a esta última se conoce que fue entregada en 1597 y en cuanto a su autoría se han barajado dos nombres. Una opción era Sánchez Coello según ha sostenido Kusche basándose en los rasgos estilísticos, además de la falta de documentación y de la firma del artista que apunte lo contrario. Por el contrario, García-Frías considera que pese a estas circunstancias, el retrato puede asociarse a de la Cruz apoyándose en la información recogida en una relación anónima de pinturas del monasterio conservada en la biblioteca de Ajuda de Lisboa y fechada en $1650 .{ }^{27}$

Juana de Austria también se la ha representado ataviada con un vestido negro y una lechuguilla alta. Sus cabellos han que-

26 Francisco de. Sousa Congosto, Introducción a la historia de la indumentaria en España, (Istmo, 2007)., p. 153.

27 Carmen García-Frías Checa, 'La retratística de la Casa de Austria en el Monasterio del Escorial.' en F. Javier Campos y Fernández de Sevilla 


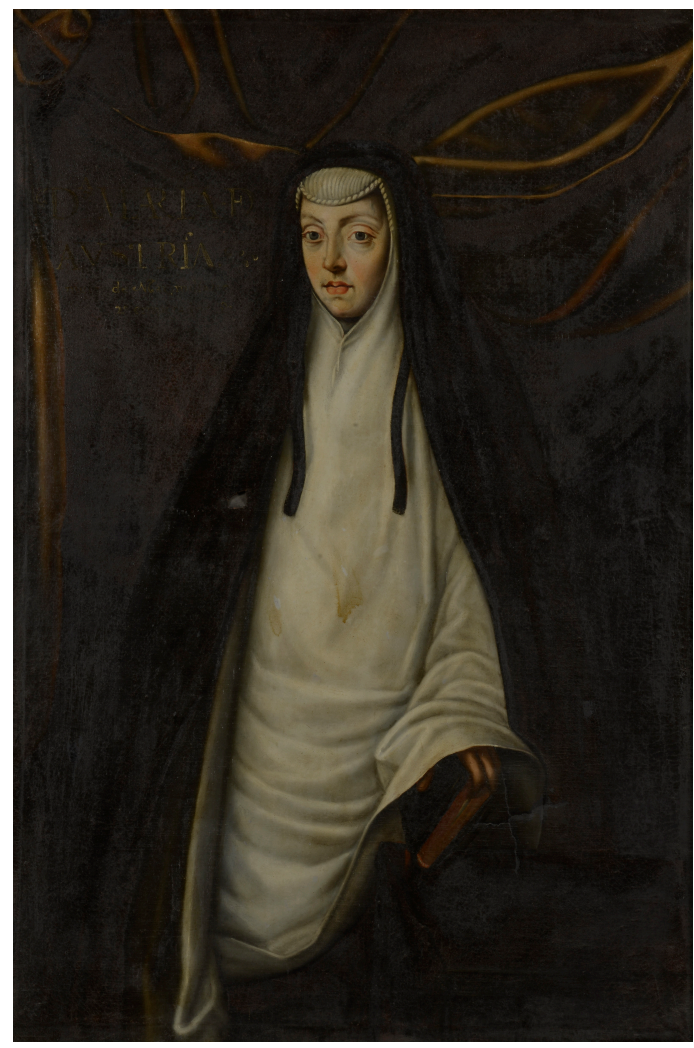

Fig. 3.17. Atribuido a A. Ricci, María de Austria viuda, 1592, óleo sobre lienzo, Valencia, Real Colegio Seminario del 212 Corpus Christi.

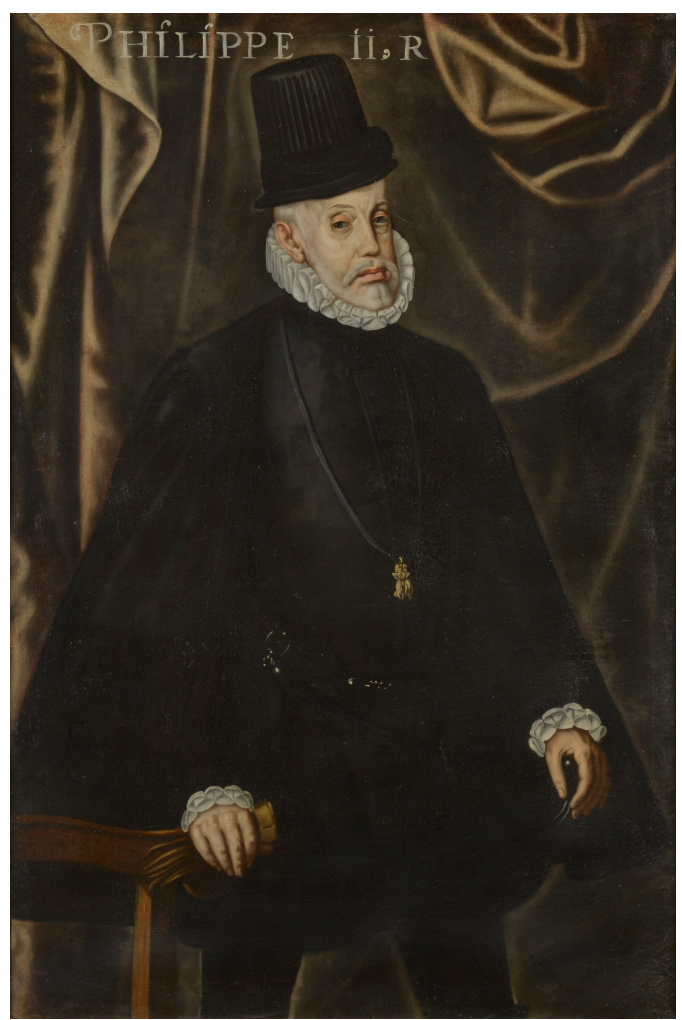

Fig. 3.19. Atribuido a A. Ricci, Felipe II, 1592, óleo sobre lienzo, Valencia, Real Colegio Seminario del Corpus Christi.

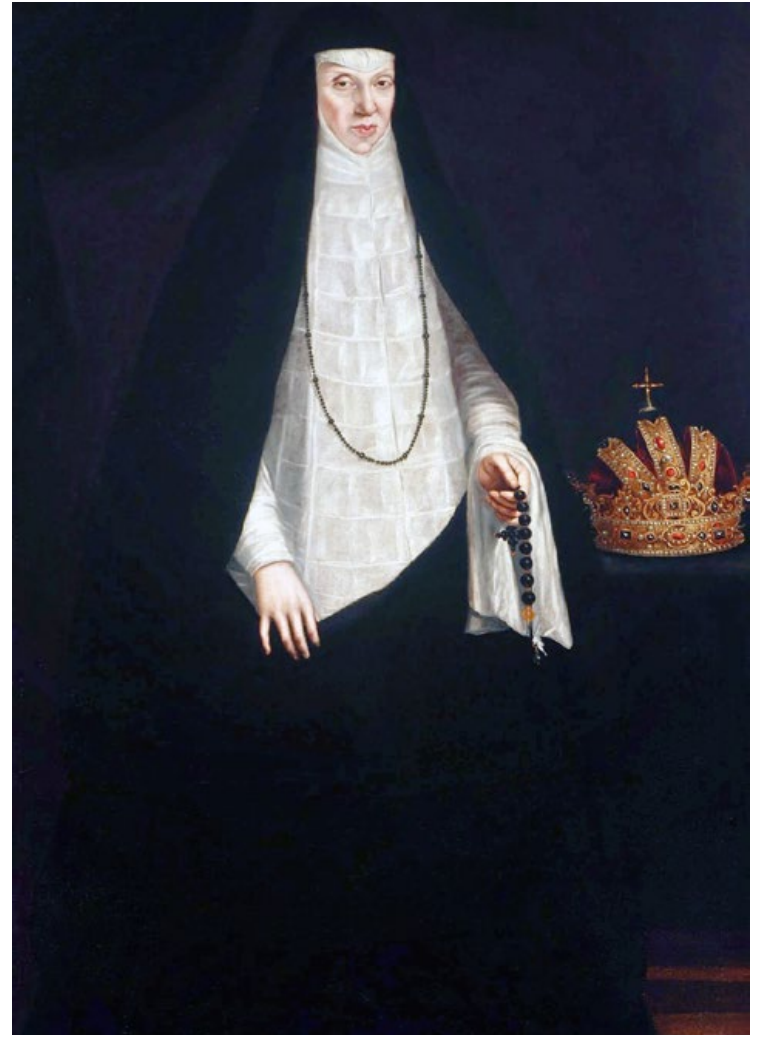

Fig. 3.18. Juan Pantoja de la Cruz, María de Austria, h. 1590, óleo sobre lienzo, Madrid, Monasterio de las Descalzas Reales.

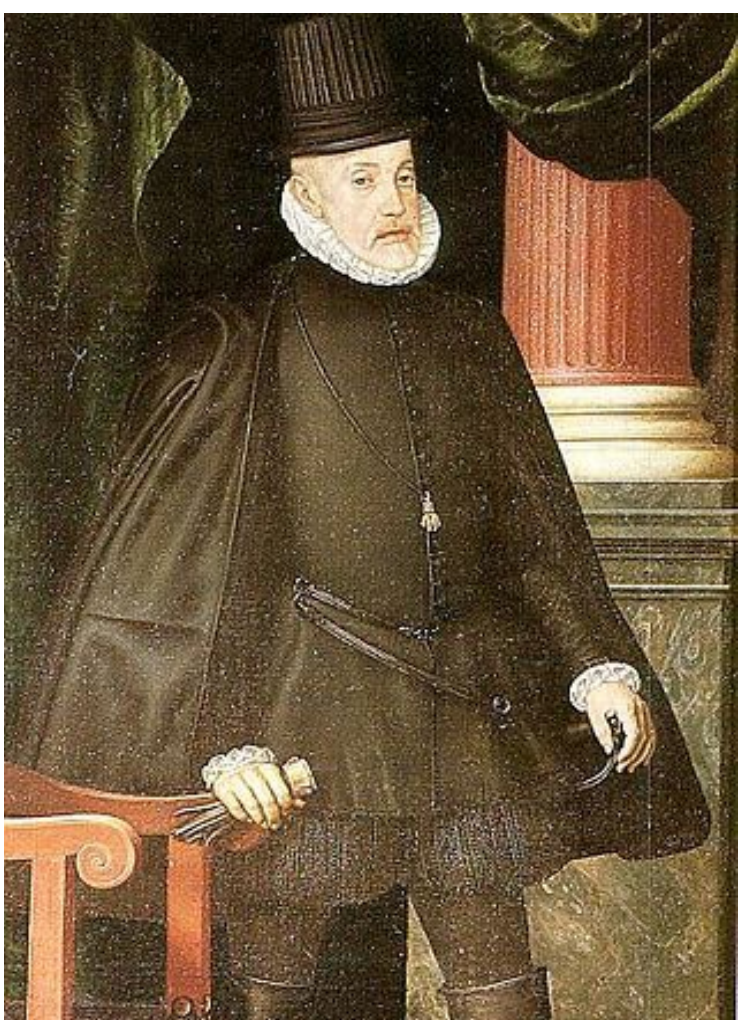

Fig. 3.20. Juan Pantoja de la Cruz, Felipe II, h. 1592, óleo sobre lienzo, Madrid, Monasterio de San Lorenzo del Escorial (detalle). 
dado parcialmente cubiertos por un tocado blanco. En la mano derecha tiene unos guantes y con la izquierda sostiene lo que parece una medalla con un retrato [fig. 3.21]. Alonso Sánchez ya había pintado una imagen semejante donde incluyó la efigie del emperador Carlos V, padre de la efigiada, en el medallón de bronce [fig. 3.22].$^{28}$ Con una indumentaria similar ha aparecido en otro de sus retratos más conocidos, por el ejem-

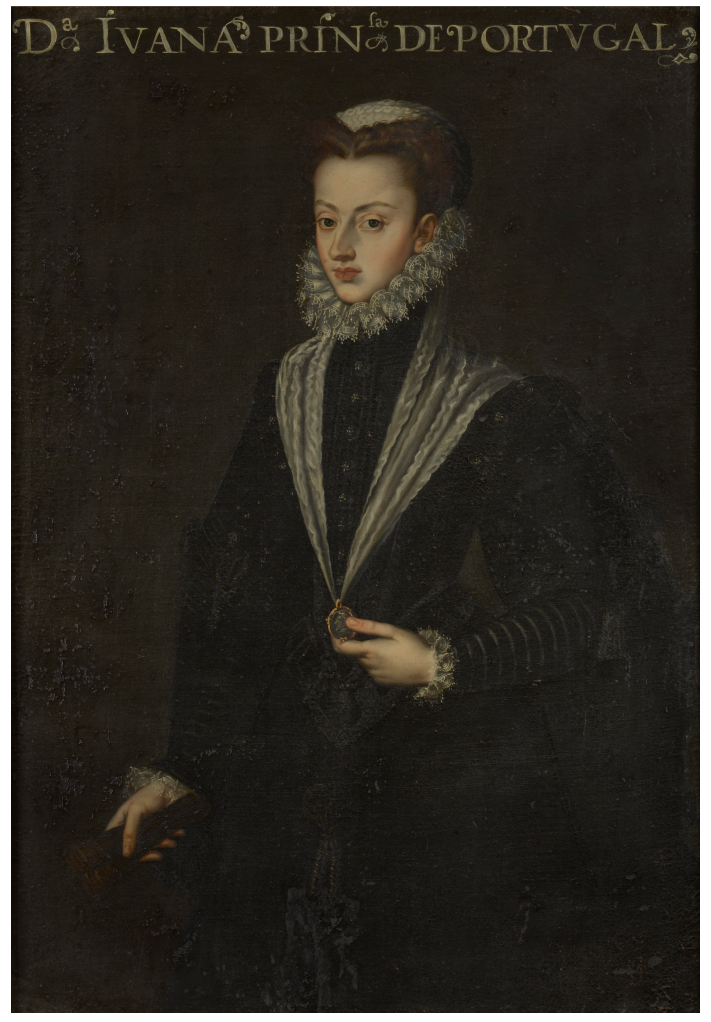

Fig. 3.21. Atribuido a A. Ricci, Juana de Austria, princesa de Portugal, 1592, óleo sobre lienzo, Valencia, Real Colegio Seminario del Corpus Christi.

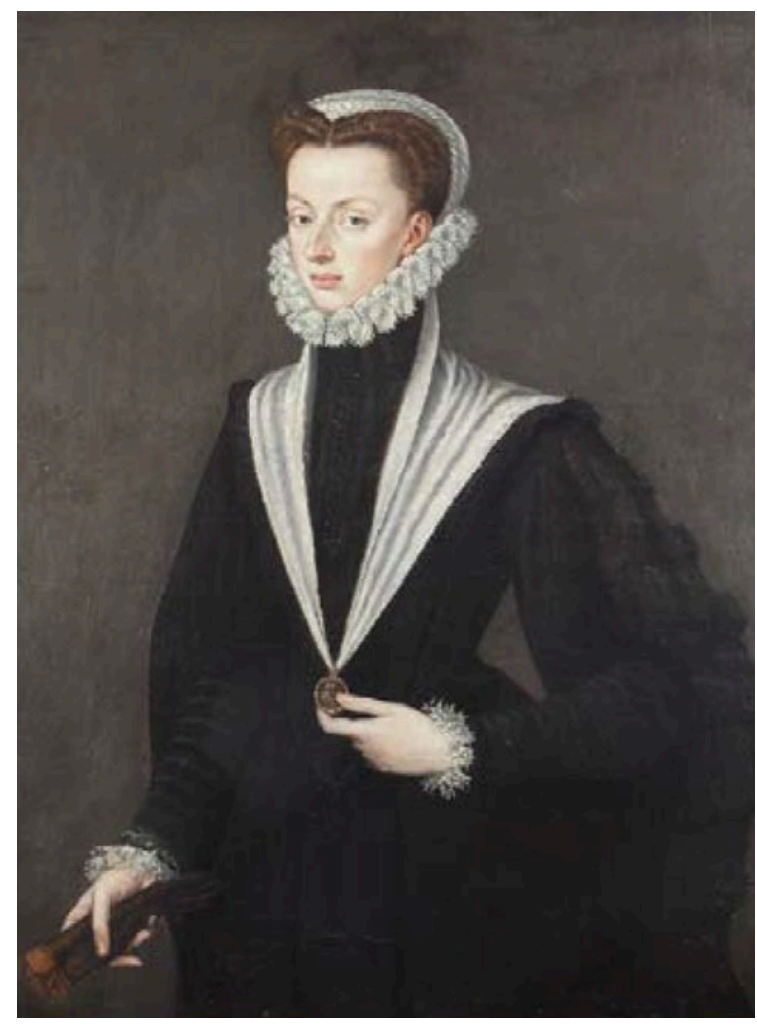

Fig. 3.22. Alonso Sánchez Coello y taller, Juana de Austria, h. 1560, óleo sobre lienzo, Madrid, Monasterio de la Descalzas Reales.

plo el realizado por Tomás Moro (1560, óleo sobre lienzo, Madrid, Museo del Prado). El incluir la efigie de su progenitor en la imagen a través de una medalla es un recurso que también

(coord.), El Monasterio del Escorial y la pintura: actas del Simposium, (Ma-drid, 2001), p. 408.

28 Respecto a los retratos de Juana de Austria, se ha consultado a Annemarie Jordan Gschwend, 'Los retratos de Juana de Austria posteriores a 1554. La imagen de una princesa de Portugal, una regente de España y una jesuita', Reales Sitios: Revista del Patrimonio Nacional, no. 151, 2002, pp. 42-65. 
se ha visto en los retratos pintados por Sánchez Coello (15571559, óleo sobre lienzo, Bilbao, Museo de Bellas Artes). Como se especifica en la parte superior de la obra, se trata de la imagen de «doña Juana, princesa de Portugal». De hecho, en 1553 contrajo matrimonio con el príncipe portugués Juan Manuel, quien desafortunadamente falleció tempranamente, en 1554, tan sólo pocos días antes del nacimiento de su hijo Sebastián (rey de Portugal entre 1568 y 1578). Además de princesa, Juana ejerció como regente de España entre 1554 y 1559 en nombre de su padre Carlos V y su hermano Felipe II. Al terminar su regencia, fundó el monasterio de la Descalzas Reales donde permaneció el resto de sus días. ${ }^{29}$

Justo en el muro opuesto se han dispuesto las efigies de los descendientes de Felipe II, concretamente se identifican a; el príncipe Carlos (1545 - 1568), Isabel Clara Eugenia (1566 1633) y Felipe III (1578 - 1621, rey desde 1598). También se ha incluido la imagen de su esposa Margarita de Austria - Estiria 214 (1584 - 1611). El príncipe Carlos fue el primogénito de Felipe II, fruto de su primer matrimonio con su prima María Manuela de Avis, quien falleció en el puerperio [fig. 3.23]. Las debilidades físicas y psicológicas del príncipe probablemente a causa de la consanguinidad de sus padres trataron de disimularse a través de la idealización de los retratos. Se le ha retratado desde su niñez como legatario de la Casa de Austria. Por ejemplo, una de las efigies hechas por Alonso Sánchez Coello (1555-1559,

29 Acerca del retrato de Juana de Austria pintado por Antonio Moro, véase la ficha de catálogo de Pilar Silva Maroto en Miguel Falomir Faus (ed.), El retrato del Renacimiento, (Museo Nacional del Prado, 2008), p. 400. En el monasterio de Descalzas Reales, Juana de Austria contó con una ambiciosa sección de retratos dentro de su colección artística, concretamente un total de 123 efigies de las cuales 95 pertenecían a sus familiares españoles, portugueses y alemanes. Para un conocimiento más exhaustivo del tema, véase: Ana García Sanz y Leticia Ruiz Gómez, 'Linaje regio y monacal. La galería de retratos de las Descalzas Reales', en El linaje del emperador: Iglesia de la Preciosa Sangre, Centro de Exposiciones San Jorge, Cáceres, del 24 de octubre de 2000 al 7 de enero de 2001 (Sociedad Estatal para la Conmemoración de los Centenarios de Felipe II y Carlos V: Madrid, 2000), pp. 135-158. 
óleo sobre lienzo, Madrid, Museo Nacional del Prado) abre un ventanal a un lado desde donde se observa al dios Júpiter y un águila llevando la columna de Hércules. Una vez más se ha tratado de vincular visualmente a la dinastía Austria con el héroe clásico. Además de este, hay otros retratos de Coello que se conservan en el monasterio de las Descalzas Reales de Madrid o en el Kunsthistoriches Museum de Viena. ${ }^{30}$

No obstante, la pieza que forma parte de la galería del Colegio del Corpus Christi es una copia de una imagen elaborada por Sofonisba de Anguissola (h. 1532 - 1625) [fig. 3.24]. Se corresponde con el último de los retratos del príncipe, pintado en diciembre de 1567, cuando él falleció en 1568. Su rostro es el propio de un joven más maduro con un marcado crecimiento del vello facial. Se ha vestido con un jubón y greguescos de un rico tejido blanco con ornamentos plateados, además la ropa con la piel de armiño contribuye a aumentar la opulencia de las vestiduras. ${ }^{31}$ Destaca el collar de la Orden del Toisón, insignia que Felipe II le entregó en Valladolid el 24 de septiembre de 1559 aunque ya se lo había concedido tres años antes, en 1556, en el capítulo celebrado en Amberes. ${ }^{32}$

El retrato de la infanta Isabel Clara Eugenia [fig. 3.25], herma-

30 Se ha seguido la ficha de catálogo realizada por Almudena Pérez Tudela en Carmen García-Frías Checa y Javier Jordán de Urríes y de la Colina (coord.), El retrato en las colecciones reales de Patrimonio Nacional : de Juan de Flandes a Antonio López, (Madrid: Palacio Real, 2000), pp. 155-158.

31 Almudena Pérez de Tudela ha demostrado el interés que tuvo el príncipe porque se reflejase la exquisitez de los tejidos en el retrato y para ello, ha aportado un documento que especifica lo siguiente: «Mas una vara de tela de plata rasa y de labores que su alteza mandó dar a Sofonisba para muestra de una ropa de un retrato de su alteza." Mercadurías que se sacan de la tienda de Francisco de Briones y Alonso de Castro, AGS, Contaduría Mayor de Cuentas, 1a época, leg. 1056. Consúltese en García-Frías Checa y Jordán de Urríes y de la Colina, El retrato en las colecciones reales de Patrimonio Nacional..., p. 158.

32 Pérez de Tudela en García-Frías Checa y Jordán de Urríes y de la Colina, El retrato en las colecciones reales de Patrimonio Nacional..., p. 155. 

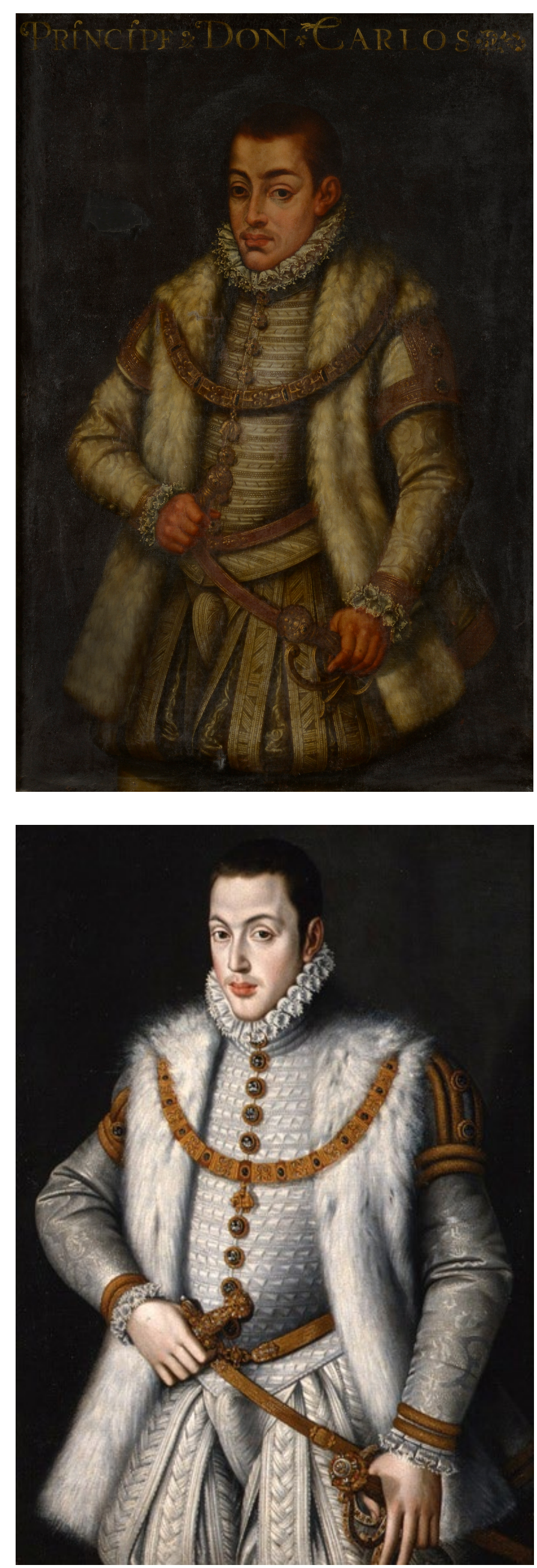

Fig. 3.23. Atribuido a A. Ricci, El príncipe Carlos, 1592, óleo sobre lienzo, Valencia, Real Colegio Seminario del Corpus Christi.
Fig. 3.24. Sofonisba Anguissola, El príncipe Carlos de Austria, 1566, óleo sobre lienzo, Oviedo, Museo de Bellas Artes de Asturias. 
na de Felipe III, encaja con las imágenes propias de la última década del siglo XVI. De hecho, el redondeado rostro enmarcado en una ambiciosa lechuguilla, el cabello recogido y ornamentado con una tiara alta salpicada con perlas es apreciable en otros retratos, como el pintado por Franz Pourbus (ca. 1599, óleo sobre lienzo, Patrimonio Nacional). Con estas mismas características se la observa en el retrato de Juan Pantoja de la Cruz (1598-1599, óleo sobre lienzo, Madrid, Museo del Prado). Pero en este caso, además, se ha incluido un pequeño medallón con la efigie de Felipe II para mostrar el afecto hacia su progenitor, justificar su linaje y legitimar así su poder sobre el territorio de los Países Bajos.

Su postura, quien apoya la mano izquierda sobre una silla y sostiene un pañuelo con la derecha, es simétrica a otra de las efigies conservadas en el Prado [fig. 3.26]. Además, el rostro tan jovial invita a pensar que esta imagen pudo servir de modelo para el retrato perteneciente a la galería de la biblioteca.

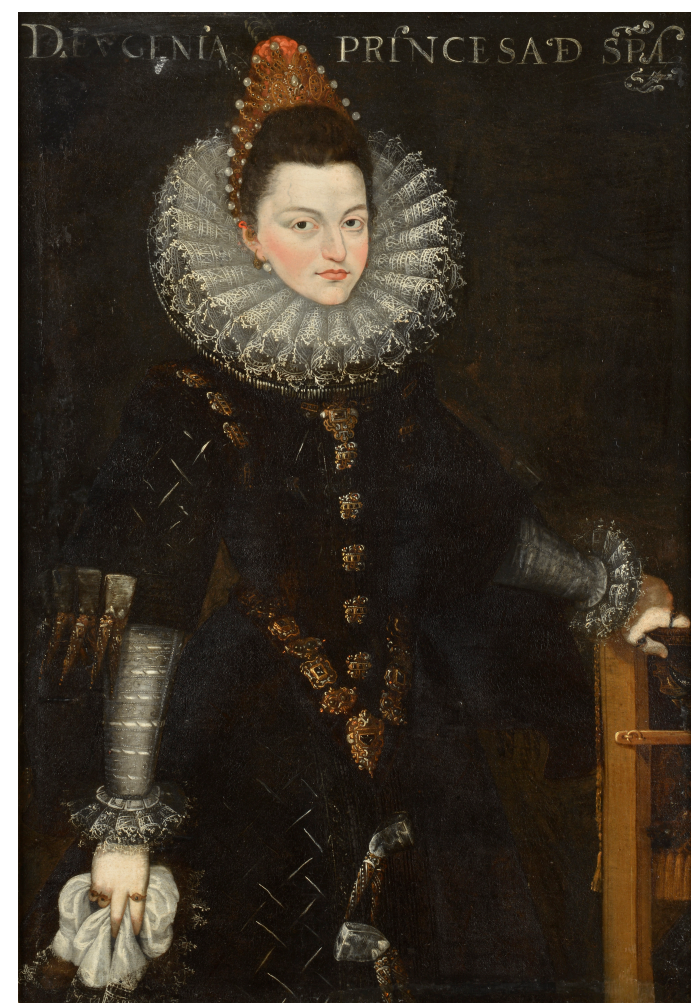

Fig. 3.25. Atribuido a A. Ricci, Isabel Clara Eugenia, 1592, óleo sobre lienzo, Valencia, Real Colegio Seminario del Corpus Christi.

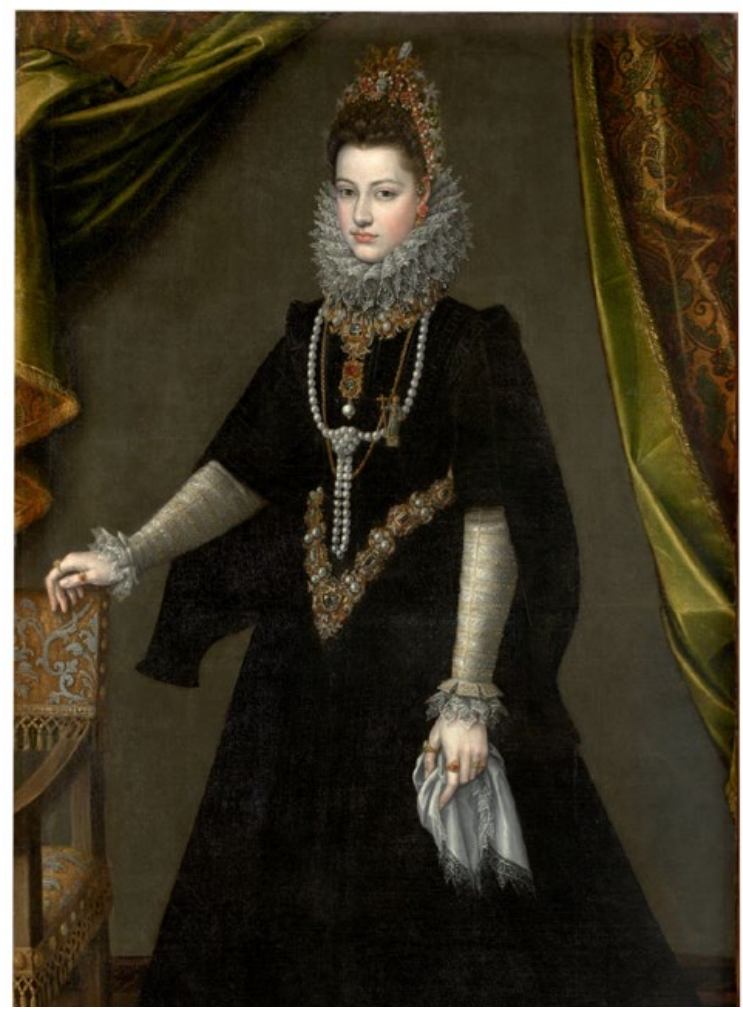

Fig. 3.26. Anónimo, Isabel Clara Eugenia (detalle), 1591-1592, óleo sobre lienzo, Madrid, Museo Nacional del Prado. 
Asimismo, la inscripción la presenta como princesa de España y ello remite a la época anterior a su matrimonio con el archiduque Alberto de Austria (1559-1621). El enlace se celebró por poderes en noviembre de 1598 y más tarde, el 18 de abril de 1599, se ratificó en una doble ceremonia, con su hermano Felipe III y Margarita de Austria, que tuvo lugar en la catedral de Valencia y estuvo oficiada por el arzobispo de dicha ciudad, el patriarca Juan de Ribera. A partir de entonces, se la retrató como gobernadora de los Países Bajos, como el realizado por Rubens y Brueghel el Viejo (h. 1615, óleo sobre lienzo, Madrid, Museo Nacional del Prado).

El joven rey Felipe III se ha retratado en el interior de una estancia engalanada mediante un cortinaje y junto a un bufete. Se ha vestido con un jubón y greguescos, una lechuguilla se ha ceñido a su cuello y también lleva birrete. El principal símbolo de su poder se aprecia en el collar del Toisón de Oro que le pende sobre el pecho [fig. 3.27]. La apariencia del monarca es 218 similar a la que se ve en la Alegoría de la educación de Felipe III (Tiel, h. 1590, óleo sobre lienzo, Madrid, Museo Nacional del Prado) y ello ha servido para datar esta pintura de $1592 .{ }^{33}$

Al lado de la efigie del rey, se ha dispuesto la de su esposa Margarita de Austria, quien luce un elegante vestido con detalles en oro y plata, enjoyada con perlas, lechuguilla tanto en el cuello como en los puños y un peinado alto, denominado de alto copete [fig. 3.28]. Es necesario replantearse los datos hasta ahora asentados en relación a esta pintura principalmente aportados por Fernando Benito, quien ha datado la efigie entre 1608 y 1610. La fecha ha sido atribuida en base a dos cuestiones concretas. La primera de ellas es el pequeño retrato que sostiene Margarita, puesto que en él se ha visto una representación de su hijo, el futuro Felipe IV con tres o cuatro años. ${ }^{34}$ Seguramente esta asociación se ha hecho teniendo en mente

33 Benito Doménech, Pinturas y pintores..., p. 313

34 Benito Doménech, Pinturas y pintores..., pp. 313-314. 


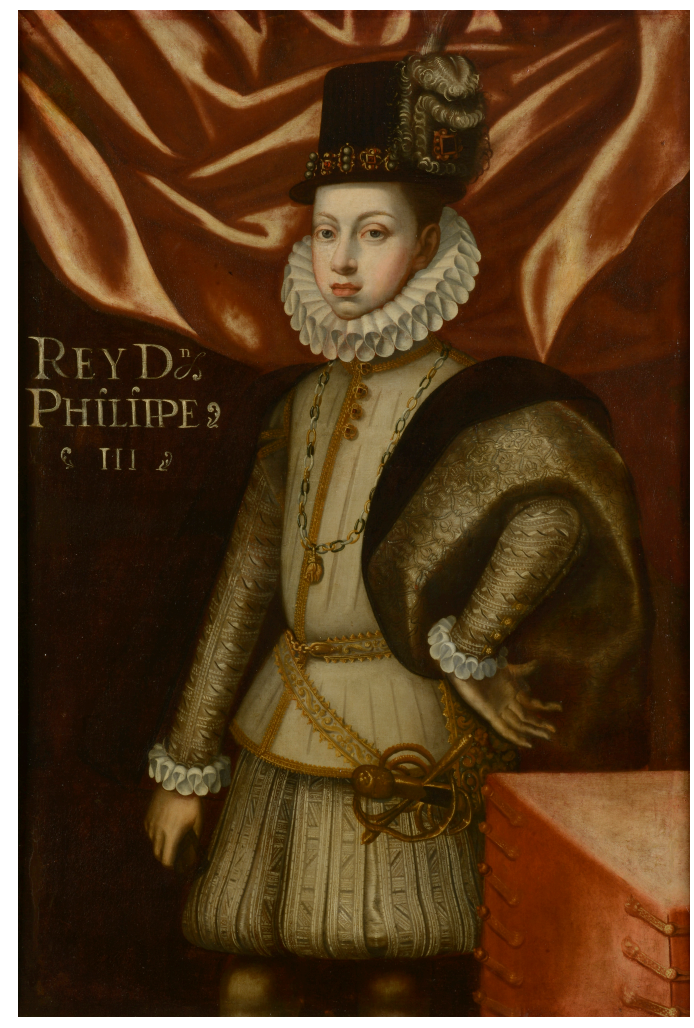

Fig. 3.27. Atribuido a A. Ricci, Felipe III, 1592, óleo sobre lienzo, Valencia, Real Colegio Seminario del Corpus Christi.

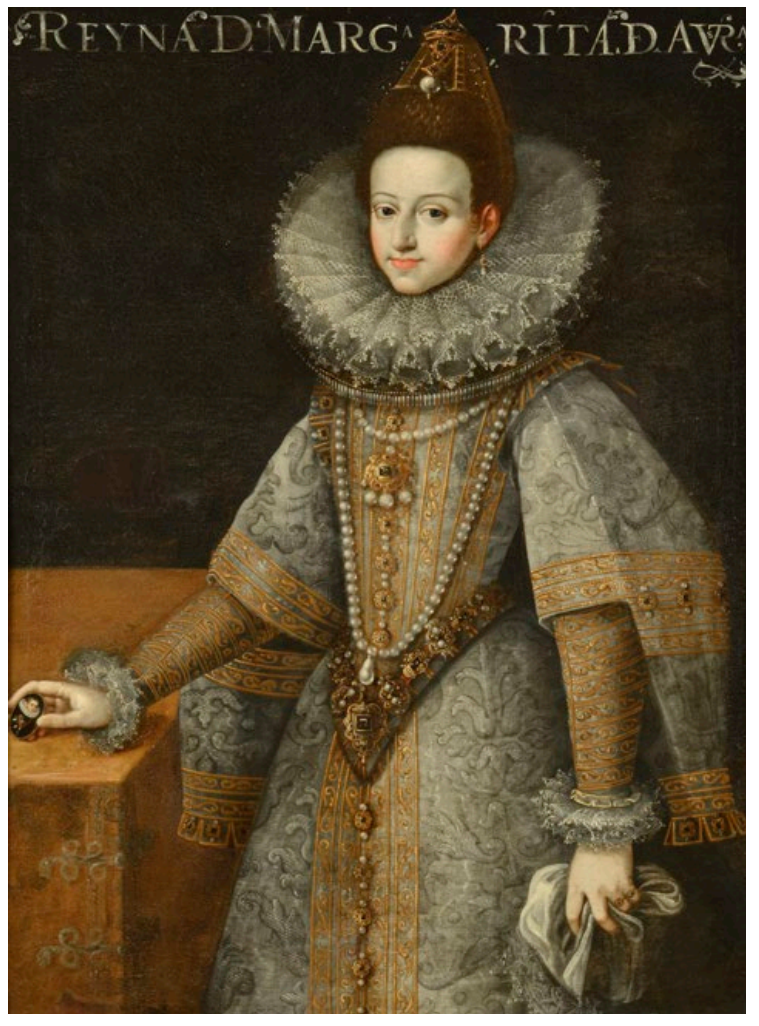

Fig. 3.28. Atribuido a A. Ricci, Margarita de Austria, h. 1597, óleo sobre lienzo, Valencia, Real Colegio Seminario del Corpus Christi.

la efigie de naipe donde el príncipe aparece vestido con coleto negro y lechuguilla (atribuida a Bartolomé González, h. 1615, óleo sobre naipe, Madrid, Museo Lázaro Galdiano). La segunda tiene que ver con la propia imagen de Margarita, en sintonía con otras representaciones ejecutadas por artistas como Pantoja de la Cruz (1606, óleo sobre lienzo, Madrid, Museo Nacional del Prado) o Bartolomé González (1621, óleo sobre lienzo, Patrimonio Nacional)..$^{35}$

Sin embargo, más convincentes resultan las observaciones de Carmen García-Frías Checa, ${ }^{36}$ quien considera que es una de

35 Leticia Ruiz Gómez, El Greco y la pintura española del Renacimiento, (Madrid: Museo del Prado, 2001), p. 178.

36 Agradecer a Carmen García-Frías su ayuda y apreciaciones ya compartidas en un congreso recientemente celebrado y dedicado a la configuración de la imagen de las reinas. Véase a Carmen García-Frías Checa, 'Margarita de Austria, la reina de las Españas, y su imagen retratística', en Mostra Espanha (ed.), La construcción de la imagen de las reinas portuguesas y españolas del siglo XVI al XVII, (Lisboa, 2019). 
las efigies más tempranas de la reina y por tanto, anterior a la fecha de 1609. Sus razones son la apariencia joven la retrata$\mathrm{da}$, la joya en forma de $\mathrm{M}$ dispuesta en el tocado alto que fue un obsequio de su madre ${ }^{37}$ y que el joyel se acerca a los empleados en Centroeuropa. Además, las representaciones de 1609 la muestran con un aspecto más maduro y con las joyas que la van a presentar en calidad de reina de la monarquía hispánica. Respecto al retrato en miniatura donde se había identificado a Felipe IV, García-Frías lo descarta porque los príncipes con cuatro años no suelen aparecen armados, y en este caso viste armadura y además luce el Toisón. Por ello, se inclina a pensar que se trata de una miniatura del propio Felipe III como candidato para la primera hermana.

Teniendo en cuenta todo esto, el retrato de Margarita de Austria que luce en la biblioteca del Colegio del Corpus Christi se puede fechar hacia 1597 como muy pronto, pues cabe recordar que en este año se comenzó a contemplar la posibilidad de 220 que Margarita se convirtiese en esposa del príncipe. De hecho, fue a fines de marzo de 1598 cuando finalmente fue elegida para casarse con el futuro monarca español. ${ }^{38}$

Los retratos de reyes y reinas entre la colección artística de san Juan de Ribera responden a su voluntad por acercarse genealógicamente a la monarquía. Así pues es notorio que, se-

37 Las joyas con la inicial del nombre de la efigiada es un obsequio que ya se ha visto en la celebración de otros matrimonios regios. Por ejemplo, Fernando Checa ha mencionado entre los regalos que se le hicieron a Margarita de Austria (1480-1530) por su enlace con Juan de Aragón y Castilla, hijo de los Reyes Católicos, que se le dio una joya en forma de eme, hecha en oro y ornamentada con diamantes y tres perlas. Véase Fernando Checa Cremades, 'Fiestas, bodas y regalos de matrimonio. Del tesoro principesco al inicio del coleccionismo artístico en las cortes habsbúrgicas de la época de Juana de Castilla (1498 - 1554)', en Miguel Ángel Zalama Rodríguez (ed.), Juana I en Tordesillas: su mundo, su entorno, (2010), pp. 135-162.

38 Se ha seguido a Johann Raine, 'Tú, Austria feliz, cásate: La boda de Margarita, princesa de Austria Interior, con el rey Felipe III de España: 1598/99', Investigaciones Históricas: Época moderna y contemporánea, no 25, 2005, pp. 31-54, p. 37. 
gún reveló Felipe Tarín y Juaneda en 1891, por aquel entonces convivía un retrato del Patriarca con estos retratos regios:

Existen en la biblioteca del Colegio de Corpus-Christi una serie de retratos de reyes, príncipes e infantas de la Casa de Austria, y entre ellos, formando simetría por su tamaño estilo y guarnición, hay uno del fundador de aquel Seminario. De tamaño poco menor que el natural, se destaca sobre el negro fondo, noble, y arrogante sin afectación, la figura de don Juan de Ribera, de más de medio cuerpo; caído el brazo izquierdo sosteniendo en su mano un bonetillo, y sacando graciosamente el derecho por debajo de la manteleta cerrada de sus hábitos, que son violados muy oscuros, casi de color castaño; su mano derecha sostiene entreabierto un pequeño breviario. El rostro, con blanquecinas barbas, revela la bondad de su espíritu. Es un magnífico retrato, de correctísimo dibujo, aunque poco vigor en el colorido. No parece aventurado el suponer, que este cuadro sea una copia muy bien hecha de Alonso Sánchez Coello, pintor de cámara de Felipe II, eminente en el arte de pintar retratos. El personaje retratado representa unos sesenta años. En el ángulo superior izquierdo del cuadro, sobre el fondo está la siguiente inscripción: D. IOANNES A RIBERA PATRIARCHA ANTOCHE ARCHEP VALENTI. ${ }^{39}$

La pintura descrita por Tarín y Juaneda fue obra de Francisco Ribalta (1615, óleo sobre lienzo, Valencia, Real Colegio Seminario del Corpus Christi) y en la actualidad no se halla en la biblioteca. ${ }^{40}$ Sin embargo, sí que se encuentra una representación del padre del Patriarca, Perafán de Ribera. Se trata de un

39 Francisco Tarín y Juaneda, Los retratos del beato Juan de Ribera: estudio iconográfico, (Imprenta de Francisco Vives y Mora: Valencia, 1891), pp. $10-11$.

40 La imagen y los datos acerca de este retratos se pueden encontrar en la tesis doctoral de Raquel Rivera Torres, 'Imagen del prelado don Juan de Ribera. Estudio iconográfico', Universitat de València, Departamento de Historia del Arte, 2015, pp. 492-493. 
modesto busto en el que aparece ataviado con armadura y una breve inscripción identificativa en la zona inferior del lienzo. Además de la lectura dinástica que tradicionalmente se le ha otorgado a esta galería, conviene valorar la posibilidad que estas imágenes también sirvieron de inspiración para el propio Juan de Ribera. De hecho, cabe recordar que encargó a Sariñena la realización de tres efigies correspondientes a los reyes de Aragón; Jaime I, Juan II y Fernando el Católico. La elección concreta de estos soberanos y no otros quizás se pueda explicar teniendo en cuenta que Jaime I abanderó la reconquista cristiana del Reino de Valencia. Juan II fue el progenitor de Fernando II el Católico, de quien se debe destacar su fuerte defensa cristiana llevada a cabo con su esposa Isabel. Asimismo, el matrimonio es el germen para la posterior llegada de la dinastía Austria al territorio hispánico, un linaje especialmente devoto y amante de la limpieza de sangre.

Una vez analizada la galería también conviene plantearse qué otros ejemplos pudieron ser un referente e influir en la configuración de este conjunto. Como se ha podido observar, generalmente las imágenes han reproducido otros retratos cortesanos. Y así ya lo percibió Ponz al describir su visita al Colegio y matizar que en la biblioteca habían «copias de retratos pintados, de reyes y reinas, en las paredes». ${ }^{41}$ Esto apunta a que las efigies que vio Ponz en su día se correspondían con retratos que ya conocía anteriormente y con los que estaba familiarizado.

Los estudios abordados por Kusche para recomponer la galería de retratos de $\mathrm{El} \mathrm{Pardo}{ }^{42}$ han servido para ver que este pro41 Antonio Ponz, Viage de España, (Viuda de Ibarra, Hijos y Compañía: Madrid, 1789), Vol. III, Última carta, p. 253. Disponible en: http://bdhrd.bne.es/viewer.vm?id=00001545458page=1 (Fecha última consulta: 05/02/2020)

42 Maria Kusche Zettelmeyer, 'La antigua galería de retratos del Pardo: su reconstrucción pictórica', Archivo español de arte, Vol. 64, no. 255, 1991, pp. 261-292; Maria Kusche Zettelmeyer, 'La antigua galería de retratos del Pardo: su reconstrucción arquitectónica y el orden de colocación de los 
yecto artístico no debió ser el principal modelo para la galería ahora estudiada. Así pues, los puntos en común de ambos ejemplos son escasos. Son coincidentes en el escoger el formato en tres cuartos para los retratos. También se corresponden iconográficamente, como se ha visto, las efigies de Carlos V y el de su nieto, el príncipe Carlos. Hay otros personajes de la dinastía Austria que igualmente formaron parte del conjunto de El Pardo pero sus imágenes no debieron copiarse exactamente para el Colegio. Así sucede con Isabel de Portugal, Felipe II, María y Juana de Austria. Según Kusche, la galería de El Pardo tenía un retrato de la emperatriz en el que lleva un collar de flores y no de perlas; Felipe II se habría representado armado y en cambio, en el Colegio aparece como anciano; María de Austria fue retratada en calidad de esposa de Maximiliano II (Antonio Moro, 1551, óleo sobre lienzo, Madrid, Museo Nacional del Prado) y en el Corpus Christi ya viste como viuda, pues había perdido a su esposo en 1576; y por último, Juana de Austria estaba retratada con una niña de raza negra. ${ }^{43}$ Además, hay otros casos en los que el efigiado no debió figurar entre el elenco de El Pardo pero sí que ha sido representado en el Colegio. En esta situación se encuentran Felipe III, Margarita de Austria e Isabel Clara Eugenia.

Sin embargo las efigies que lucieron en El Escorial también pudieron ser un referente. La decoración con galerías de retratos en este real sitio, como ha estudiado Carmen García-Frías Checa, ${ }^{44}$ se inició en los últimos años del gobierno de Felipe II cuadros', Archivo español de arte, Vol. 64, no. 253, 1991, pp. 1-28; Maria Kusche Zettelmeyer, 'La antigua galería de retratos del Pardo: Su importancia para la obra de Tiziano, Moro, Sánchez Coello y Sofonisba Anguissola y su significado para Felipe II, su fundador', Archivo español de arte, Vol. 65, no. 257, 1992, pp. 1-36.

43 Kusche Zettelmeyer, 'La antigua galería...su reconstrucción pictórica', p. 264.

44 Carmen García-Frías Checa, 'La retratística de la Casa de Austria en el Monasterio del Escorial', en F. Javier Campos y Fernández de Sevilla (coord.), El Monasterio del Escorial y la pintura: actas del Simposium, (Ma- 
y se concluyó durante el mandato de Felipe III. A lo largo del reinado de ambos monarcas se trabajó en los conjuntos dispuestos en la biblioteca, la celda prioral alta y en la sacristía. Los retratos de la biblioteca se corresponden con los cuatro primeros monarcas pertenecientes a la Casa de Austria, es decir, las efigies de Carlos V, Felipe II, Felipe III y Felipe IV vistas de cuerpo entero y dibujando la línea dinástica del fundador de El Escorial. ${ }^{45}$ De entre todos ellas, las imágenes de Carlos V y Felipe II guardan una clara relación visual con las conservadas en el Colegio del Corpus Christi.

Además, hay otro punto en común entre la decoración pictórica del monasterio madrileño y del seminario valenciano. Allí concretamente también lucían retratos de personalidades consideradas santas en la época, como fray Luis Bertrán y fray Nicolás Factor. Como se observará más adelante, el patriarca Ribera asimismo contaba con efigies de estos dos personajes en su colección artística. Ambas imágenes, se localizaban en la celda alta del prior y compartían espacio con otras dos representaciones de cuerpo entero de Carlos V y Felipe II. Los dos monarcas se han retratado con una edad aproximada de veintisiete o veintiocho años, el primero ataviado de forma muy similar a la que viste en la imagen realizada por Seisenegger y el segundo, con la armadura empleada en la batalla de san Quintín. ${ }^{46}$ A partir de la descripción que Francisco de los Santos hizo en 1657 sobre El Escorial se ha conocido que el drid, 2001), pp. 395-420.

45 Este tipo de decoración ya fue descrita en la literatura de viajes, por ejemplo véase a Juan Álvarez de Colmenar, Les delices dé l'Espagne e du Portugal, 1707, tomo II, p. 291: «Entre la roûte et les cabinets on voit les portraits des quatre prémiers Rois d'Espagne, de la maison d'Austriche.»

46 José de Sigüenza, Fundación del Monasterio de El Escorial por Felipe II (1605), (Madrid: Apostolado de la prensa, 1927). Disponible en: http://bdh. bne.es/bnesearch/CompleteSearch.do?languageView=es\&field=todos\&text=Jos\%c3\%a9+de+Sig\%c3\%bcenza\&showYearItems=Eexact=on\&tex$\mathrm{tH}=\delta$ advanced $=$ false $\delta$ completeText=\&pageSize $=18$ pageSizeAbrv=308pageNumber=5 (Fecha última consulta: 27/12/19) También en García Frías, pp. 401-402. 
conjunto de retratos dispuesto en la celda prioral alta se fue ampliando siguiendo el mismo formato e incluyendo a otros reyes castellanos en calidad de ascendientes de Felipe IV, el monarca reinante por entonces. ${ }^{47}$ Se añadieron, por tanto, las imágenes de Enrique III y Juan II de Castilla, abuelo y padre respectivamente de Enrique IV, quien sí que ha sido representado en la galería del Colegio. Y junto a las mencionadas efigies del emperador y su hijo, se dispusieron los retratos de Felipe III y Felipe IV. Por las fechas de las descripciones de Sigüenza y de los Santos, se deduce que el crecimiento del número de retratos situados en la celda prioral se dio entre 1605 y 1657, cuando ya se había configurado la galería de la realeza hispánica en el Colegio del Corpus Christi. Pese a ello, es interesante ver que el diseñar y crear galerías de retratos en las que mostrar relaciones de parentesco era un fenómeno que pervivía en el tiempo.

\subsection{Las efigies de monarcas aragoneses en Nápoles para el monasterio de san Miguel de los Reyes:}

La información recogida en distintos inventarios habla de la existencia de una modesta galería de retratos regios procedente del monasterio jerónimo de san Miguel de los Reyes y que actualmente se encuentran entre los fondos del Museo de Bellas Artes de Valencia. Entre sus efigiados concretamente se hallan diversos monarcas de la Corona de Aragón que ocuparon el trono napolitano. El estudio más reciente y completo acerca de este conjunto fue elaborado por David Gimilio, quien ha propuesto posibles autores a los lienzos y también ha rastreado los inventarios. ${ }^{48}$ Sin embargo, aún resulta necesa47 Francisco de los Santos, Descripcion breve del monastero de S. Lorenzo El Real de El Escorial. Unica maravilla del mundo: Fabrica del prudentissimo rey Philippo Segundo: Aora nuevamente coronada por el catholico rey Philippo Quarto el Grande con la magestuosa obra de la capilla insigne del pantheon, y traslacion à ella de los cuerpos reales, (Madrid: Imprenta Real, 1657). fol.69v. También mencionado por García Frías, pp. 402-403.

48 David Gimilio Sanz, 'La galería de retratos de la casa real de Aragón en Nápoles', Potestas: Religión, poder y monarquía. Revista del Grupo Europeo de Investigación Histórica, no. 9, 2016, pp. 167-196. 
rio elaborar un análisis más detallado de las imágenes y contextualizarlas con otras galerías y series icónicas que pongan de manifiesto la relevancia del retrato para crear imágenes de poder.

Partiendo de la citada aportación, cabe destacar que su autor ya apreció el interés de estas obras al ser escasas los conjuntos de retratos monárquicos que se conservan en el medio valenciano y por las mínimas referencias que existen entorno a ellos. Así, defendió la hipótesis de que las pinturas respondiesen a un encargo de los monjes jerónimos para honrar la memoria del duque de Calabria. Además se encontrarían en consonancia con otras alusiones dinásticas presentes en el monasterio. Igualmente, las piezas se han considerado realizadas a finales del siglo XVI o mediados del siglo XVII y Gimilio explicó que probablemente fueran pintadas por Gregorio Bausá o Antonio Bisquert. Para ello, argumentó que del primero es conocida su producción en retratos y que además elaboró algunos encar226 gos para el monasterio. ${ }^{49}$ Del segundo, toma en consideración las semejanzas en los rasgos formales de las efigies femeninas con la obra Santa Úrsula y las once mil vírgenes. ${ }^{50}$

Una vez concretada la cronología y la probable autoría de los retratos se debe tener en cuenta las referencias proporcionadas en la documentación de archivo para conocer la identidad de los efigiados, procedencia y posterior lugar de ubicación. Este tipo de documentación ha permitido conocer que los retratos llegaron desde el monasterio para ser custodiados por

49 De hecho, en el citado inventario de 1847 también se relaciona con el círculo de Bausá una imagen del Conquistador: «548. Lienzo, retrato de don Jaime I de Aragón, 8 pies de alto, 3 pulgadas de alto, 4 pies de ancho, 10 pulgadas de ancho, regular, San Miguel de los Reyes, se le atribuye a la escuela de Bausá.» Archivo de la Real Academia de Bellas Artes de San Carlos (ARABASC ahora en adelante): Museo de Pintura y Escultura de la Ciudad de Valencia. Comisión de Monumentos Históricos y Artísticos de la Provincia de Valencia, Archivo 150, s/f.

50 Gimilio Sanz, 'La galería de retratos de la casa real de Aragón...', p. 193. 
la Academia después de la desamortización. No obstante, los datos de unas fuentes y otras no coinciden en su totalidad y tampoco se han registrado el total de imágenes que conforman la galería. El primero de los inventarios en los que ha quedado constancia de estas obras es de 1838 y sirvió de fuente primordial en el estudio de Gimilio. Aquí se especificó que procedentes del «monasterio de san Miguel de los Reyes, extramuros de la ciudad» llegaron «nueve retratos de los duques de Calabria, que son un cuadro que contiene al duque y a la duquesa, otro de doña Julia de Aragón, otro de don Alfonso 5o de Aragón, otro de don Fernando 1 o de Aragón, otro de don Juan de id., otro de don Fadrique de id., otro de doña Úrsula Germana de Foix, otro de doña Isabel de Baucio, otro de doña Isabel de Claramonte, otro de don Alfonso de Aragón.. ${ }^{51}$

De la relación de efigies completa, tan sólo seis se corresponden con las pinturas de esta galería y son concretamente los retratos de Fernando de Aragón y Úrsula Germana de Foix, duques de Calabria, Ferrante o Fernando I, Federico I e Isabel Baucio, Isabel de Claramonte y Alfonso II de Aragón. No se han mencionado a Hipólita María Sforza y Ferrante II que también forman parte del conjunto. Otros retratos citados como el de Alfonso V y Juan II de Aragón no han llegado a la actualidad desde el monasterio de san Miguel de los Reyes. No obstante, sí que se han conservado dos efigies de estos mismo monarcas pintadas por Vicente Salvador Gómez (h. 1637 - h. 1680) y procedentes del convento de santo Domingo..$^{52}$ Respecto a la

51 Archivo de la Diputación de Valencia (ADV ahora en adelante): Resumen de las pinturas, esculturas y grabados que han ingresado en el museo provincial hasta esta fecha de los conventos suprimidos que se expresan en los inventarios cuya copia acompaña, E.8.2, caja 3, 1838, fol. 20r.

52 Las dos pinturas también forman parte de los fondos de la academia de San Carlos y en el inventario de 1847 se han inscrito con los siguientes datos: «547. Lienzo, retrato de don Alonso 5o, rey de Aragón, 7 pies alto, 9 pulgadas alto, 4 pies ancho, 3 pulgadas ancho, regular, Convento de Santo Domingo. 549. Lienzo, retrato de don Juan 2o, rey de Aragón, 7 pies alto, 9 pulgadas alto, 4 pies ancho, 3 pulgadas ancho, deteriorado, Convento de Santo Domingo.» ARABASC: Museo de Pintura y Escultura de la Ciudad 
imagen de Julia de Aragón es una imagen de medio cuerpo y no encaja con el formato estipulado para este grupo de retratos. Además, haría pareja con otra efigie similar de Isabel de Aragón. ${ }^{53}$

Otra fuente principal es el Catálogo de los cuadros que existen en el Museo de pinturas establecido en el edificio del ex-convento del Carmen de esta Capital, con expresión de la clase de pintura, asuntos que representan, autores, escuelas, tamaños, estado de conservación, procedencia respectiva y observaciones generales. ${ }^{54}$ Se trata de un inventario fechado el 1 de mayo de 1847 y firmado por los que entonces eran los directores de pintura de la Academia, Vicente Castelló, Francisco Llorenç y Miguel Pou. Aquí las obras que han sido objeto de estudio se han descrito del siguiente modo:

551. Lienzo, retrato de Alfonso II de Nápoles, 6 pies de alto, 4 pulgadas de alto, 3 pies de ancho, 6 pulgadas de ancho, regular, san Miguel de los Reyes. 552. Lienzo, retrato de don Fernando I de Aragón, 6 pies de alto, 3 pulgadas de alto, 3 pies de ancho, 6 pulgadas ancho, deteriorado, san Miguel de los Reyes. 554. Lienzo, retrato de la reina Isabel de Claramonte, 6 pies de alto, 3 pies de ancho, 6 pulgadas

de Valencia... s/f. También se encuentran identificados en el inventario de 1838 con los números 23 y 24 como retratos procedentes del convento dominico. ADV: Resumen de las pinturas, esculturas y grabados que han ingresado en el museo provincial..., fol. 2r.

53 Ambos retratos que se conservan en la colección artística de la academia y en 1847 igualmente se catalogaron: «540. Lienzo, retrato de Isabela de Aragón y Baucio, 3 pies alto, 7 pulgadas alto, 2 pies ancho, deteriorado, San Miguel de los Reyes, de medio cuerpo. 542. Lienzo, retrato de doña Julia de Aragón y Baucio, 3 pies de alto, 7 pulgadas alto, 2 pies ancho, deteriorado, San Miguel de los Reyes, de medio cuerpo.» ARABASC: Museo de Pintura y Escultura de la Ciudad de Valencia... s/f. Las dos efigiadas eran hermanas del duque de Calabria y sus retratos no guardan el formato de los restantes porque se ha querido mostrar a aquellos antepasados que legitiman el derecho del duque al trono de Nápoles.

54 Este inventario se encuentra en un manuscrito localizado en ARABASC: Museo de Pintura y Escultura de la Ciudad de Valencia... s/f. 
ancho, regular, san Miguel de los Reyes. 555. Lienzo, retrato de doña Úrsula Germana, 6 pies de alto, 2 pulgadas de alto, 3 pies de ancho, 7 pulgadas ancho, regular, san Miguel de los Reyes. 556. Lienzo, retrato de la reina doña Isabela Baucio, 6 pies de alto, 4 pulgadas de alto, 3 pies de ancho, 7 pulgadas ancho, regular, san Miguel de los Reyes. 557. Lienzo, don Fernando de Aragón, 6 pies de alto, 2 pulgadas alto, 3 pies ancho, 7 pulgadas ancho, regular, san Miguel de los Reyes.

En esta segunda fuente al igual que en el inventario de 1838 no se han registrado las pinturas de Hipólita María Sforza y Ferrante II de Aragón, pero tampoco se ha mencionado a Federico I, quien sí constaba en el primer documento. Estas últimas descripciones incluso son más precisas al detallar el estado de conservación de las obras, generalmente bastante deteriorado.

Antes de profundizar en el análisis pormenorizado de los retratos se debe tener presente que estos personajes de la realeza aragonesa además de construir su imagen de poder mediante el retrato también hicieron uso de las fuentes escritas para dejar constancia de su historia y legado. Por tanto, generalmente la creación de galerías de retratos no surgió de forma aislada sino que fue acompañada del nacimiento de numerosos libros. En el caso de Nápoles conviene citar algunas obras que apuntan hacia esta dirección. Por ejemplo, Francisco de Balboa y Paz escribió el Monarchia regum, [fig. 3.29] ${ }^{55}$ donde en el tercer apartado del segundo bloque se habló brevemente de los gobiernos de todos los reyes que forman parte de la galería estudiada. Así pues, se comenzó con el reconocimiento de la legitimidad de Ferrante o Fernando I, hijo natural Alfonso V a asumir el trono de Nápoles. Le sucedió su hijo, fruto del enlace con Isabel de Chiaromonte o Claramonte, Alfonso II. Este finalmente se vio obligado a abdicar a favor de su hijo Ferrante II para, de esta forma, complicar la intromi-

55 Francisco de Balboa y Paz, Monarchia regum, siue accurata imperii synopsis., (Herederos de Juan Domingo Tarini: Turín, 1630). 
sión del rey Carlos VIII de Francia en el trono. Al morir sin descendencia, tomó posesión del trono Federico I, segundo hijo de Ferrante I y por tanto hermano de Alfonso II y tío de Ferrante II. Federico I celebró un segundo matrimonio con Isabel de Baucio y fruto de esta unión nacieron cinco hijos, uno de ellos fue el duque de Calabria y fundador del monasterio de San Miguel de los Reyes, Fernando de Aragón.

Asimismo, resulta interesante la Dell' historia della città e regno di Napoli de Giovanni Antonio Summonte, ${ }^{56}$ en la cual se incluyeron las efigies de Ferrante I, Alfonso II, Ferrante II y Federico I (nombrado en el libro como Federico II). Son representaciones de tres cuartos, donde el monar-

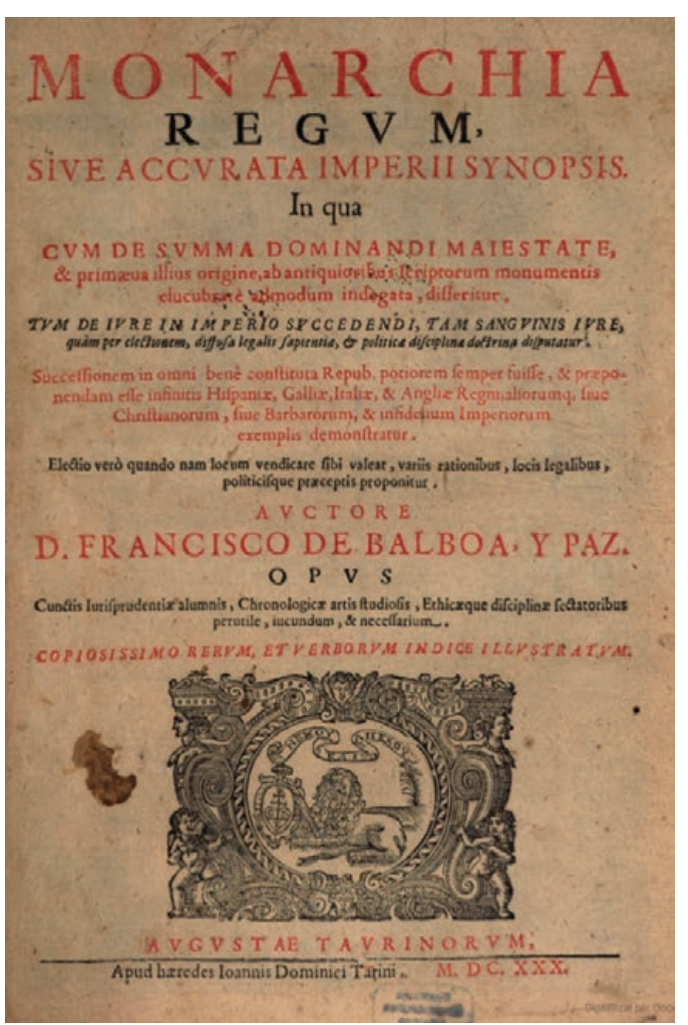

Fig. 3.29. Francisco de Balboa y Paz, Monarchia regum siue accurata imperii synopsis, Herederos de Juan Domingo Tarini, Turín, 1630. ca se ha vestido con la armadura o la capa real, y en ocasiones aparece coronado. Además, en la parte superior se añadió una cartela identificativa y en la inferior aparece el escudo con las barras de Aragón [fig. 3.30]. Si bien, iconográficamente no casan con los retratos del conjunto trabajado, sí que se muestra la voluntad de mostrar la imagen del soberano como parte de la historia del reino napolitano.

Fernando de Aragón (1484 - 1550) duque de Calabria y virrey de Valencia, esposo de Germana de Foix (1488 - 1538) desde 1526, era un hombre de cultura elevada como ha reflejado su personal colección bibliográfica. Además, parte de los libros

56 Giovanni Antonio Summonte, Dell' Historia della citta e regno di Napoli, (Antonio Bulifon: Nápoles, 1675). 
que reunió y que finalmente donó a la biblioteca del monasterio son crónicas de los monarcas de Aragón, obras especí-

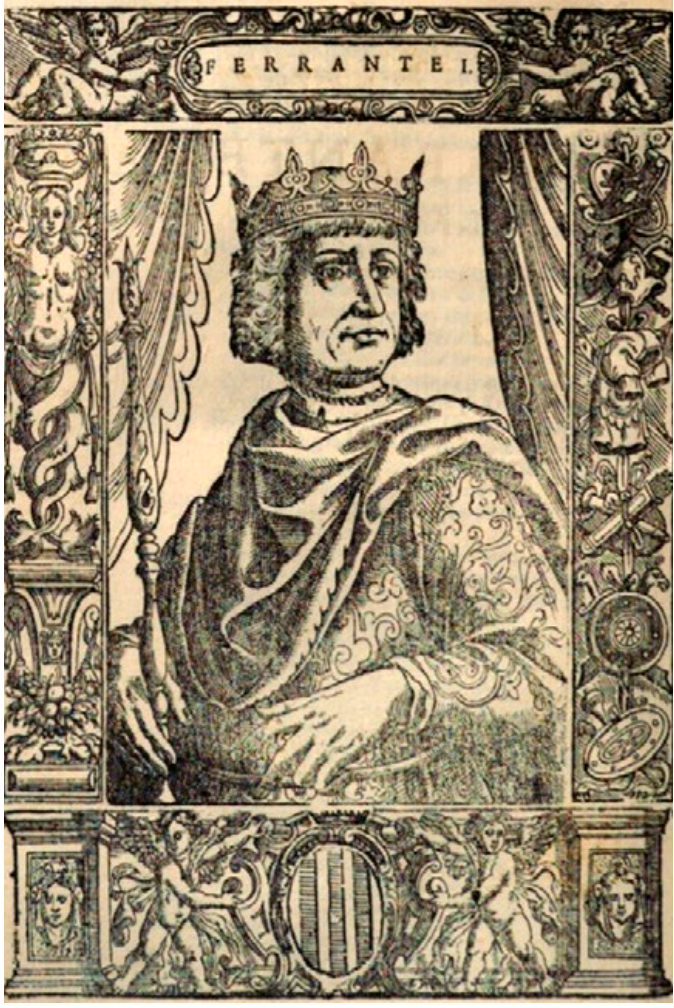

Fig. 3.30. Retrato de Ferrante I en Giovanni Antonio Summonte, Dell' Historia della citta e regno di Napoli, Antonio Bulifon, Nápoles, 1675.

ficas de reyes y de la historia de Nápoles. De esta manera, pudo conocer a sus ascendientes y valorar la relevancia de su propia estirpe. Por ello, algunas de las referencias que aparecen en el inventario de libros post mortem de Fernando de Aragón ilustran esa necesidad de estudiar y legitimar su linaje. Los ejemplares que son de interés para la presente investigación se corresponden con la numeración siguiente:

462. Un libro de Alfonso, rey de Nápoles, en 8o, de mano, en pergamino, cubierto de terciopelo carmesí con manecillas de plata. 499. Crónica de los reyes de Aragón de pliego, cubierto de pergamino. 519. Un libro de los reyes de Aragón, de pergamino, cubierto de cuero leonado.524. Crónica de los reyes de Aragón. De las Infantas. 550. Crónica de Neapolis, de mano, en pergamino, cubierto de cuero negro. 631. Otro libro cubierto de raso carmesí, con la manecilla que parece de plata sobre dorada, con la descripción de las personas reales y capitanes y gente de guerra del Serenísimo Rey de Nápoles, escrito de mano en pergamino. ${ }^{57}$

El gusto por conocer a los antepasados y justificar la pertenencia a un determinado linaje, encaja con lo planteado en

57 Inventario de los libros de Don Fernando de Aragon, Duque de Calabria, (Imprenta Aribau: Madrid, 1875), pp. 47-66. 
otros estudios acerca de que fueron los propios monjes quienes también participaron de la creación de un discurso propagandístico y dinástico que ensalzaba al propio Fernando y remarcaba el valor del monasterio por dos razones principales. La primera de ellas es el haber sido fundado por el último eslabón de los reyes aragoneses que reinaron en Nápoles. La segunda es la creencia que afirma que la Casa de Baucio, de la cual procede Isabel de Baucio, madre de Fernando de Aragón, descendía del rey Baltasar y así se ha hecho constar en su retrato como se verá más adelante.

Analizando escuetamente los retratos que conforman este conjunto generalmente siguen los parámetros estipulados para las representaciones cortesanas. Son imágenes de los reyes y sus correspondientes consortes, efigiados de cuerpo entero, en el interior de una estancia normalmente engalanada con un cortinaje que deja abrir el espacio hacia un paisaje. Tanto varones como mujeres se han revestido de fasto mediante los ricos ropajes y se remite a su poder regio a través de las insignias reales como la corona, el cetro o la capa de armiño. El linaje al cual pertenecen se muestra mediante los escudos heráldicos y las inscripciones insertadas en algunas de las imágenes.

A Ferrante I (1423 - 1494) [fig. 3.31] se le ha representado de perfil ${ }^{58}$ y comunicándose con el arcángel san Miguel. De su atuendo cabe destacar el fastuoso collar con la figura de un armiño. Se trata de una clara referencia a la institución de la

58 Es común encontrar representaciones de Ferrante I de perfil, coronado y con el manto real. Josefina Mateu ya dio a conocer un retrato de similares características junto al sepulcro de ese rey, localizado en la sacristía de San Domenico Maggiore en Nápoles y que, junto con las efigies de Alfonso el Magnánimo, Fernando II y Juana IV, se dispuso por deseo de Felipe II. Aunque, como afirma la autora basándose en Perrotta y Ville Sur-Yllon, la pieza actual sea producto de la restauración hecha en 1709 se inspiró en la pintura original y además bebe de los rasgos ofrecidos en monedas y medallas. Véase Josefina Mateu Ibars, 'Iconografía real de Aragón en San Domenico Maggiore de Nápoles', Butlletí de la Reial Acadèmia de Bones Lletres de Barcelona, no. 29, 1962, pp. 229 - 238. 


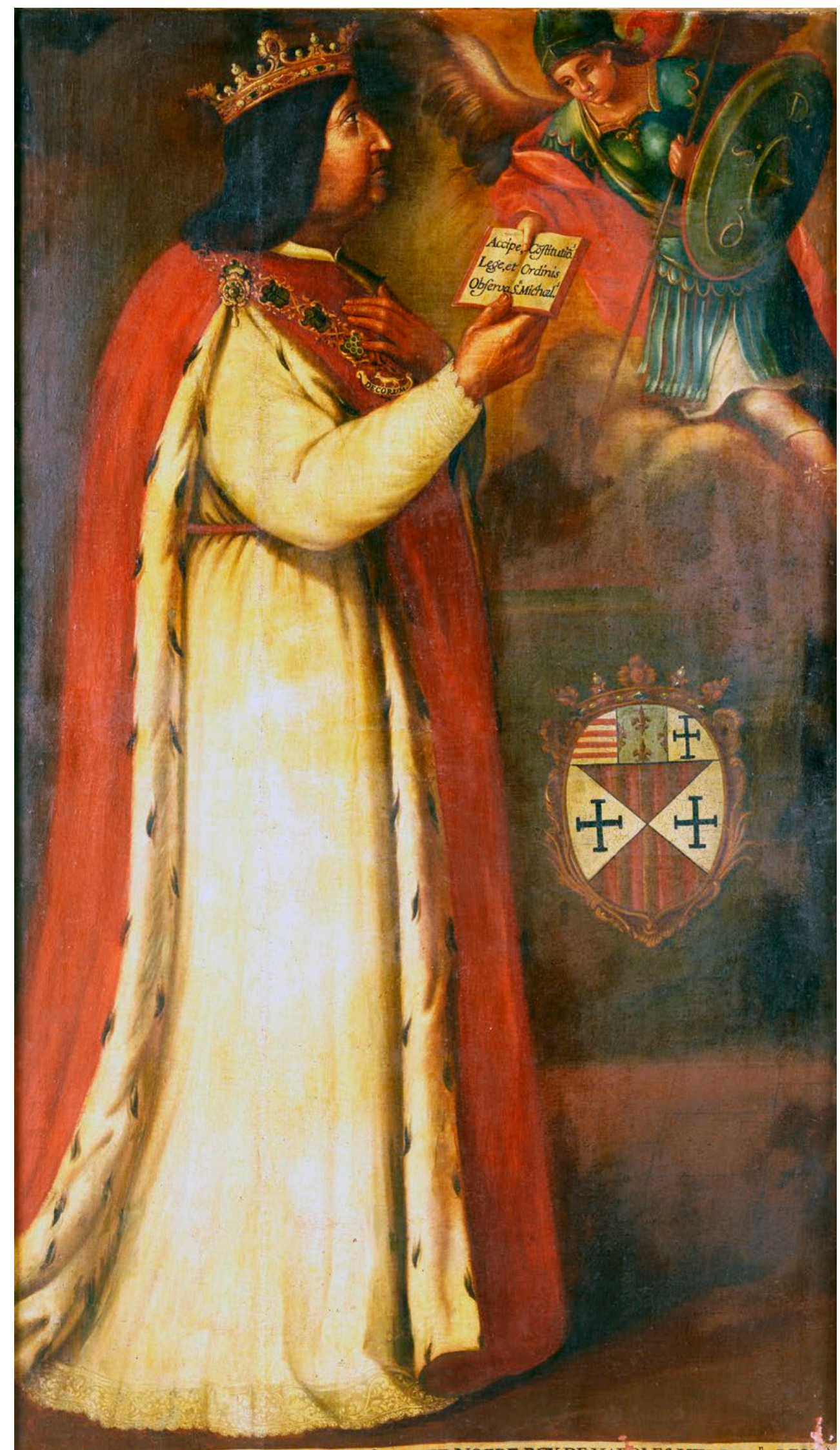

SERENISS.'S D FERNANDO DE ARAGON.I'DE ESTE NOBRE REY DE NA OLES HIJODE D.ALFO' LE AROABUELO DEN.S. FUDAD: CUIEN FUNIWU RF, AL ORDEN D AR MINOY CABALLE: DE ARAGOABUEL DEN

Fig. 3.31. Gregorio Bausá o Antonio Bisquert, Retrato de Ferrante I, finales del s. XVI - mediados del s. XVII, óleo sobre lienzo, Valencia, Museo de Bellas Artes. 
orden de caballería del Armiño o del arcángel san Miguel que fue instaurada por el propio Ferrante I en 1483. El origen de esta empresa se puede encontrar en la obra de Paolo Giovio Diálogo de las empresas militares y amorosas. El autor ha calificado esta creación emblemática de muy hermosa y relata que su surgimiento acaeció tras una traición protagonizada por:

Marino Marçano, duque de Sessa, y príncipe de Rossano, el cual aunque era cuñado del rey, se allegó al duque Juan de Angiò, su enemigo, y procuró de matar al rey su Señor, pero por virtud y sagacidad del rey la traición no hubo lugar: y la Historia de este caso está de metal esculpida sobre la portada de Castelnovo de Nápoles; y viniéndole en su poder el dicho Marino después de luengos tiempos no quiso hacer justicia de él, sino lo puso en prisión, diciendo que no se quería lavar las manos con su propia sangre, diciendo esto por su pariente, aunque le había sido traidor, e ingrato, contra el parecer de sus amigos, y de todos los de su consejo para declaración de este ejemplo de cle,mencia, tomó por empresa un armiño, cercado de un reparo de estiércol, con un mote, que decía, MALO MORI QUAM FOEDARI, siendo de tal naturaleza el armiño que quiere más presto padecer la muerte, y hambre, y sed, que ensuciarse, siéndole forzado para huir, que pase por lugares sucios, por no ensuciar la blancura, y la limpieza de su blanca piel. ${ }^{59}$

La alusión a la citada orden se encuentra tanto en el collar como en la inscripción existente a los pies de la efigie, la cual especifica que el monarca es: «El serenísimo Señor Don Fernando de Aragón I de este nombre, rey de Nápoles, hijo de Don Alfonso de Aragón abuelo de N.S. fundador quien fundó la Real Orden del Armiño y Caballería de San Miguel, por mandato del Señor Arcángel de quien recibió las Constituciones.»

59 Paolo Giovio, Dialogo delas empresas militares, y amorosas, compuesto en lengua italiana ..., (Guillielmo Roville: Lyon - Francia, 1562), p. 29. 
Por esta razón y como se puede observar en el retrato, el rey está recibiendo el correspondiente libro con las Constituciones de la orden, el volumen aparece abierto y en él se puede leer: Accipe, lege et observa Constitutiones Ordinis Santi Michaelis. ${ }^{60}$

Respecto al collar, si se observa con detalle, se puede comprobar que el lado visto por el espectador se compone de cuatro piezas y cada una de ellas contiene un jeroglífico [fig. 3.32]. Resulta muy interesante observar que algunas de estas imágenes también aparecen en forma de medallón flanqueando las seis escenas bélicas que decoran las puertas de bronce de Castelnuovo. ${ }^{61}$ Se trata de jeroglíficos creados para los reyes ascen-

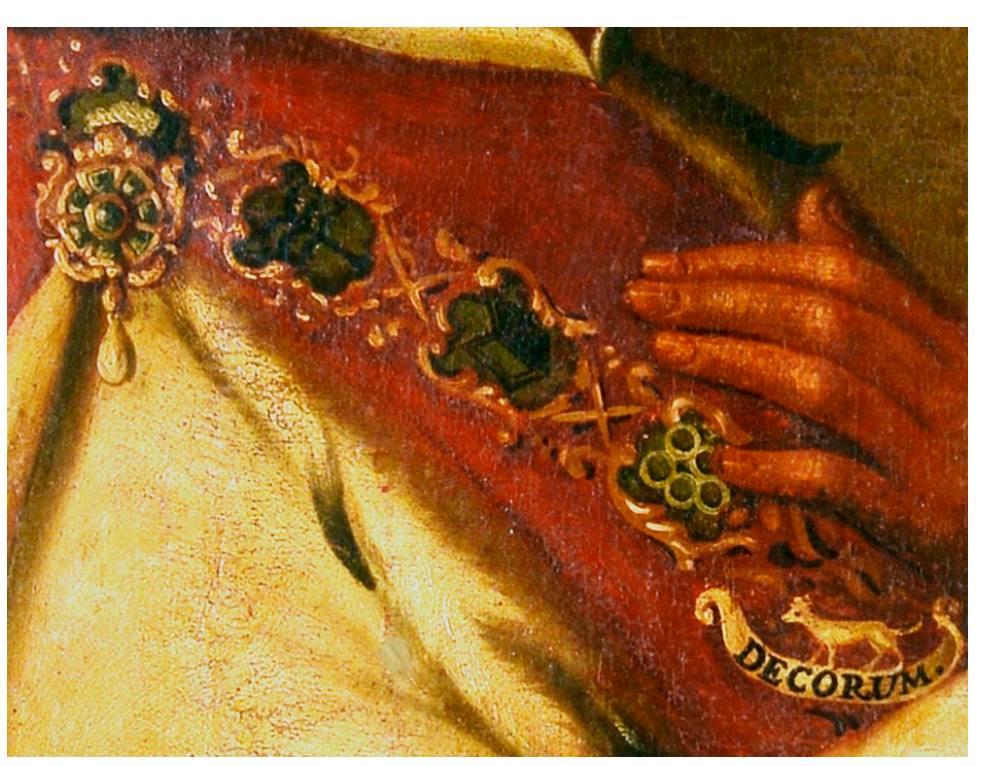
dientes de Ferrante I y por ello, se puede extraer una lectura en clave dinástica del propio collar. Es, por tanto, un elemento más que en la

60 La devoción al arcángel san Miguel principalmente se ha dado entre el estamento militar y ha sido el protector de monarcas, nobles y caballeros. Desde época medieval, se le ha atribuido una capacidad especial para enfrentarse al anticristo, llevar a cabo cruzadas o conseguir brotar aguas milagrosamente sanadoras. Así pues, su repercusión iconográfica fue clara y se incluyó su imagen en numerosos retablos. Igualmente, Francesc Eiximenis dedicó una parte de su Llibre dels Àngels a la figura de este arcángel. Véase Paulino Rodríguez Barral, 'Eiximenis y la iconografía de San Miguel en el gótico catalán', Annals de l'Institut d'Estudis Gironins, Vol. XLVI, 2005, pp. 111-124.

61 Para el conocimiento de la existencia de estos jeroglíficos en las puertas de bronce, ha sido fundamental el análisis de las mencionadas puertas de Joana Barreto, La majeste en images: portraits du pouvoir dans la Naples des Aragon, (Ecole fran-caise de Rome: Rome:, 2013)., pp. 166-170. 
imagen trata de justificar las raíces del monarca, pues cabe recordar que Ferrante I era hijo bastardo de Alfonso el Magnánimo y tuvo la necesidad de reafirmar su legitimidad a través de las artes. ${ }^{62}$ Así pues, el primer motivo que se encuentra, tanto en la puerta de Castelnuovo como en el collar, es un monte repleto de diamantes que Barreto interpretó como la fuerza para tomar el reino de Nápoles. Juan Francisco Esteban Lorente explicó que este motivo aparecía junto con el lema Naturae, non artis opus. Se correspondía con una empresa creada por Paolo Giovio para hablar de las virtudes de Fernando I de Aragón, también llamado de Trastámara o de Antequera, padre de Alfonso $\mathrm{V}$ y abuelo de Ferrante I. ${ }^{63}$

Además, el segundo jeroglífico que aparece es un haz de mijo anudado. En origen se creó para el Magnánimo y estaba acompañado por el mote Non timebo milia populi. Un vez más, la lectura posiblemente más convincente es la de Esteban Lorente quien recurre a la presencia del mijo en el libro bíblico de Ezequiel ${ }^{64}$ cuando se emplea de alimento al narrar el asedio de Jerusalén y lo interpreta como una alusión a las numerosas dificultades afrontadas por Alfonso $\mathrm{V}$ para conquistar Nápoles. ${ }^{65}$

62 Alfonso V no reconoció a Ferrante como hijo hasta el 17 de febrero de 1440, cuando firmó un documento que le avalaba como sucesor de todos los territorios. Un reconocimiento especial tuvo el de Nápoles, donde el 2 de mayo de 1443 se le declaró oficialmente heredero al trono napolitano y se le otorgó el ducado de Calabria. Véase Marqués de Caldas de Montbuy, Los descendientes legitimados de Alfonso el Magnánimo en el trono de Nápoles, (Barcelona, 1951), pp. 28-29.

63 Juan Francisco Esteban Lorente, 'El influjo de la emblemática en el arte aragonés', en José Javier Azanza López y Rafael Zafra (eds.), Emblemata aurea: la emblemática en el arte y la literatura del Siglo de Oro, (Akal Ediciones: Madrid, 2000), pp. 144-162.

64 «Toma también trigo, cebada, habas, lentejas, mijo y espelta: échalos en un recipiente y prepárate con eso la comida. Tú comerás de ese pan durante todo el tiempo que estés acostado de un lado, o sea durante ciento noventa días.» (Ezequiel 4, 9)

65 Esteban Lorente, 'El influjo de la emblemática...', p. 149. El jeroglífico de 
El tercero se corresponde con un libro abierto del cual se puede extraer una lectura doble. Por un lado, es otro de los motivos vinculados a la iconografía del Magnánimo para simbolizar la sabiduría. ${ }^{6}$ Por otro lado, este jeroglífico también fue empleado por Juan II (1398 - 1479), llamado el Grande, hermano de Alfonso V y tío de Ferrante I. En origen se mostraba junto con una inscripción latina que rezaba In libro tuo omnes scribentur para aludir a los vínculos sanguíneos entre los distintos monarcas. ${ }^{67}$

Por el momento, no se puede ofrecer una interpretación clara y lógica del cuarto jeroglífico, que se compone de cinco circunferencias dispuestas unas junto a otras. Quizás, queriendo incluir otro símbolo más de sabiduría se pretenda representar los nudos de Salomón, motivo que se identifica indudablemente en las puertas de bronce del castillo napolitano. Todas las piezas que conforman el collar desembocan en el elemento más relevante de esta joya, el armiño. Que, además, al igual que en los otros casos se encuentra en uno de los medallones de la puerta de Castelnuovo. A través de la empresa del armiño, el rey estaba reivindicando la importancia de la fidelidad que deben guardar los vasallos a su Señor. En este y otros ca-

haz de mijo también está presente en el programa iconográfico que decoraba el pavimento cerámico de los palacios reales de Alfonso el Magnánimo. Consúltese Gema Belia Capilla Aledón, "«Seguidors Vencen», un grito de guerra para el rey', Potestas: Religión, poder y monarquía. Revista del Grupo Europeo de Investigación Histórica, no. 11, 2017, pp. 27-46.

66 «[...] trajo por empresa un libro abierto, como os he dicho, el cual no teniendo anima de ningún mote, muchos dudaban, y no sabían que quería decir, y porque fue rey muy virtuoso, y dechado, y resplandor del arte militar, y de la erudición, y en de platica del gobierno civil, quien decía una cosa, y quien otra; pero al cabo la mayor parte de la gente adivinó, que quería decir, que la libertad era la cosa más preciosa, que podía tener el hombre, y así como prudente, y sabio nunca jamás se quiso casar por no hacerse siervo casándose. Otros dijeron que traía el libro abierto para dar a entender que la perfección del entendimiento humano, consiste en el conocimiento de las ciencias y de las artes liberales, de las cuales su Majestad fue muy estudioso.» Giovio, Dialogo de las empresas militares, ..., pp. 28-29.

67 Esteban Lorente, 'El influjo de la emblemática...', p. 150. 
sos, el lema original se ha sustituido por la palabra decorum, entendiéndola como el respeto que se le debe a una persona con cierta dignidad. Así también ocurre, como se observará más adelante, en el retrato de este soberano que forma parte de la galería de varones valencianos ilustres procedente del monasterio de Nuestra Señora de La Murta (Alzira) y que sin duda ha seguido las directrices de la efigie ahora estudiada (véase la fig. 5.17).

Joana Barreto al estudiar los retratos de poder de los monarcas napolitanos procedentes de Aragón también incidió en la necesidad del rey Ferrante I de recalcar su ascendencia creando una nueva iconografía legitimadora de su poder y reflejo del nexo de unión con su padre. ${ }^{68}$ Por esta razón, en una moneda de cinco ducados de oro se incluyó la inscripción «Coronatus quia legitime certavit», es decir, «la corona que legítimamente sostuvo", rodeando la figura del monarca. La tipología del retrato concuerda con la imagen que nos ocupa pues se aprecia 238 el rostro de perfil, está coronado y además sobre el pecho luce el collar con el armiño. Ello demuestra que la acuñación de monedas sirvió para difundir la imagen oficial del rey y que esta fue adaptada al elaborar otras imágenes. Además, la disposición del retrato en la moneda de cinco ducados (de perfil y hacia la derecha) y la definición de unos rasgos físicos muy concretos (cabello corto y nariz aguileña) ya se encuentran en monedas del Magnánimo. Se trata, por tanto, de otros detalles que fundamentan la utilización de la propia imagen por $\mathrm{Fe}-$ rrante I como instrumento de legitimación dinástica.

Ferrante I casó con Isabel de Chiaromonte (Taranto, c. 1424 Nápoles, 1465), hija del conde de Chiaramonte, uno de los señores más renombrados de Nápoles. Este matrimonio se acordó con el objetivo de disminuir los recelos existentes hacia el rey debido a su infancia como hijo bastardo del Magnánimo. ${ }^{69}$ Ella está representada con el fasto propio de una reina, em68 Barreto, La majeste en images..., p. 103.

69 Caldas de Montbuy, Los descendientes legitimados..., p. 30. 
pleando el lenguaje iconográfico asociado a los retratos de corte [fig. 3.33]. Por ello, aparece en el interior de una estancia engalanada con un cortinaje recogido al lado y un bufete carmesí sobre el cual se deja un libro. Su figura se ha acompañado de las insignias reales, lleva la capa de armiño, sostiene el cetro en su mano izquierda y en la derecha porta la corona, dejando patente su condición de reina consorte.

El sucesor natural de Ferrante I fue Alfonso II de Nápoles, también duque de Calabria, quien se apresuró en mostrarse como sucesor de su padre y orquestó su matrimonio con la hija del duque de Milán, Hipólita María Sforza. El objetivo de este enlace era garantizar su poder sobre el reino pues era un territorio también deseado por el rey Carlos VIII, quien intentó hacerse con el control en cuanto tuvo noticias del fallecimiento de Ferrante I. ${ }^{70}$ Respecto al retrato de Alfonso II (Nápoles, 1448 - Mesina, 1495) [fig. 3.34], según David Gimilio, reproduce el retrato estudiado por Carmen Morte de Jaime II el Justo para la galería de efigies de la Diputación de Zaragoza. ${ }^{71}$ De hecho, en ambos casos viste una cota roja sobre la camisa blanca, una ostentosa capa forrada, luce un fastuoso collar y empuña la espada con la mano derecha. A su izquierda se ha optado por incluir la misma empresa existente en la imagen zaragozana. Se trata de una balanza dorada, sobre un fondo azur y una inscripción que reza "Semper Aequa" para remarcar el equilibrio y la justicia propia del monarca.

El tipo de enlosado de la estancia es idéntico al retrato femenino que se estudia a continuación y que ha contribuido a pensar que ambas piezas son pareja, identificando a la dama como la esposa de Alfonso II de Nápoles, Hipolita María Sfor70 Caldas de Montbuy, Los descendientes legitimados..., pp. 95-96.

71 Gimilio Sanz, 'La galería de retratos de la casa real de Aragón...', p. 191; Carmen Morte García, 'Pintura y política en la época de los Austrias. Los retratos de los reyes de Sobrarbe, condes antiguos y reyes de Aragón para la Diputación de Zaragoza (1586), y las copias de 1634 para el Buen Retiro de Madrid (II)', Boletín del Museo del Prado, Vol.12, no. 30, 1990, pp. 13-28, p. 22. 


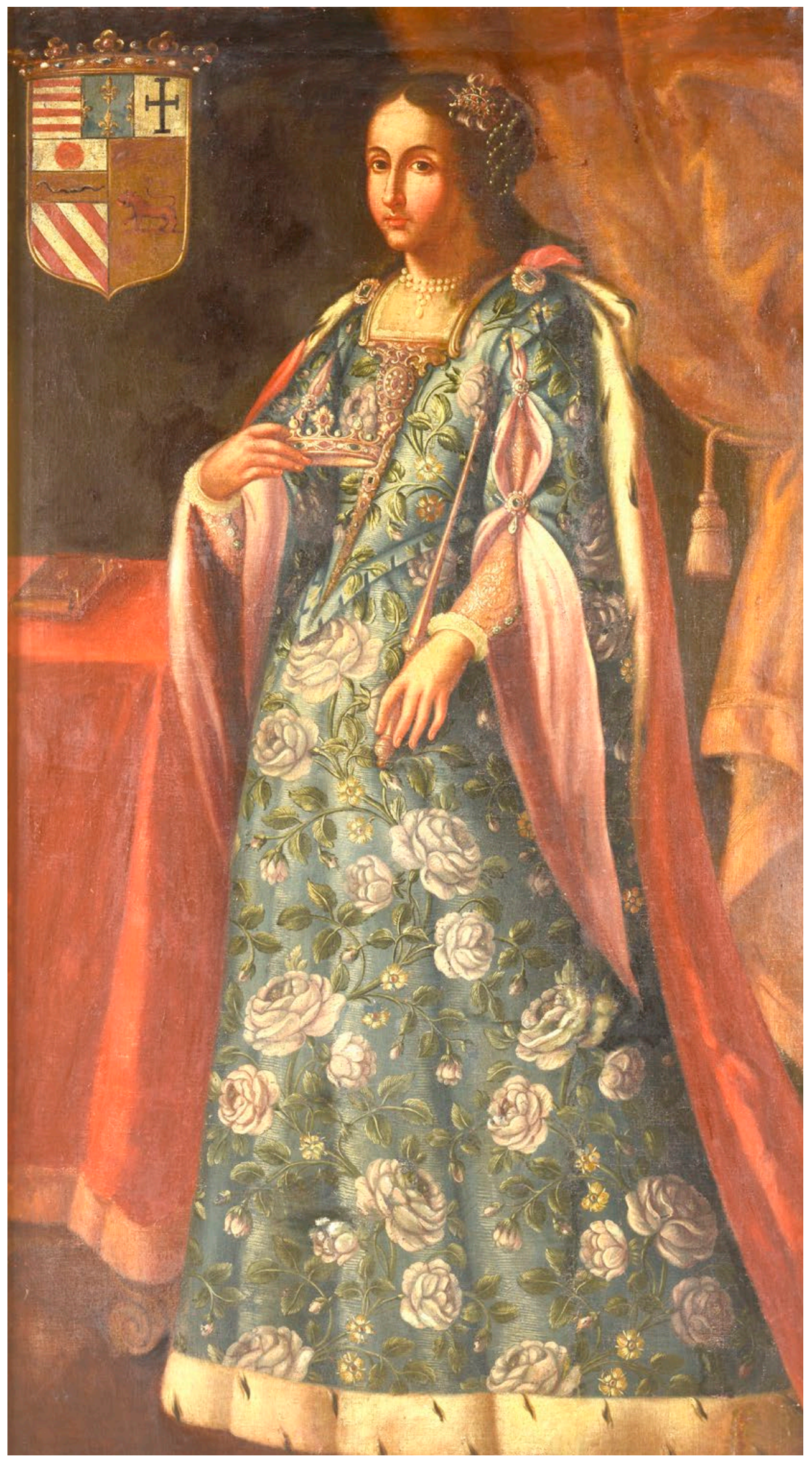

Fig. 3.33. Gregorio Bausá o Antonio Bisquert, Retrato de Isabel de Chiaramonte finales del s. XVI - mediados del s. XVII, óleo sobre lienzo, Valencia, Museo de Bellas Artes. 


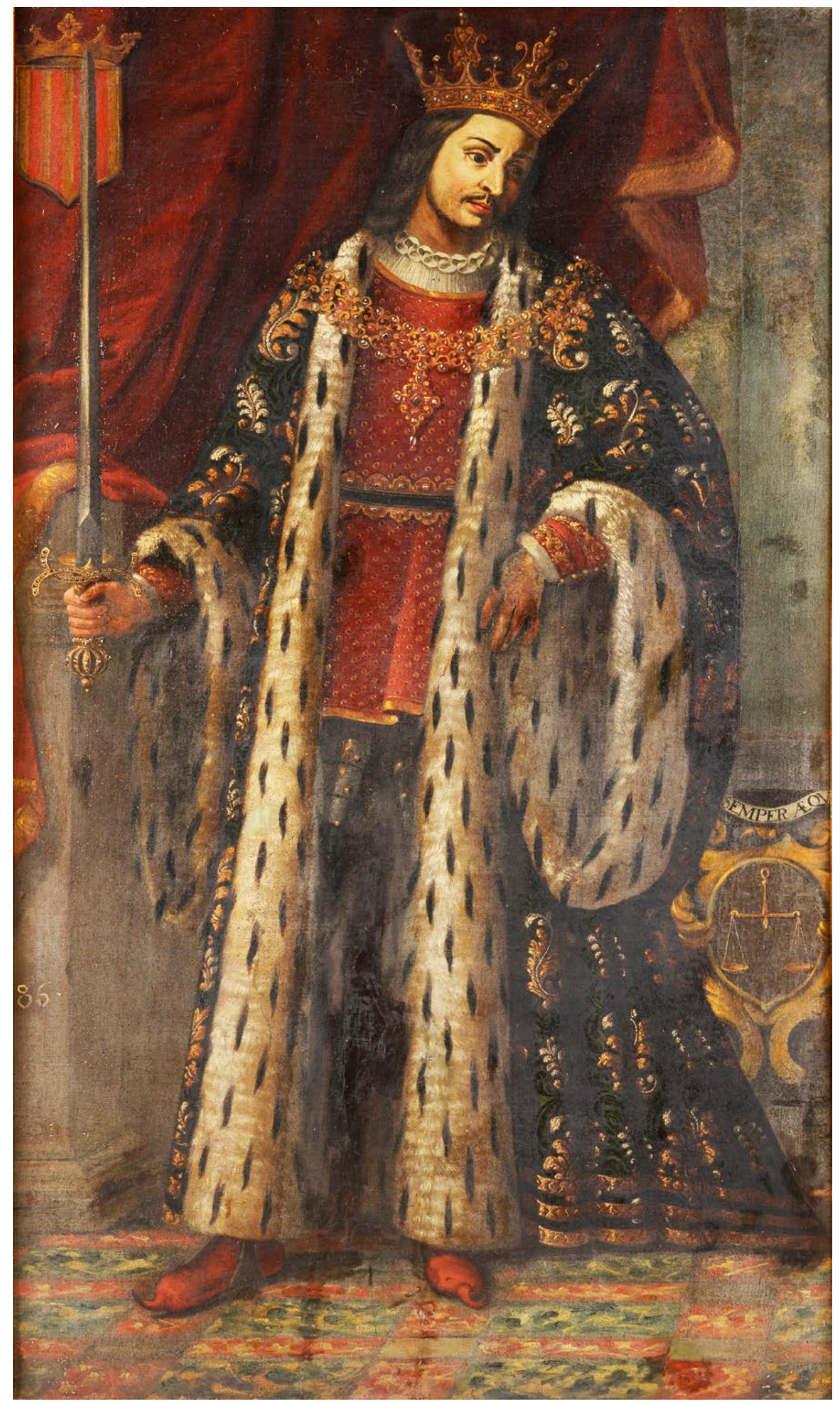

241

Fig. 3.34. Gregorio Bausá o Antonio Bisquert, Retrato de Alfonso II de Nápoles finales del s. XVI - mediados del s. XVII, óleo sobre lienzo, Valencia, Museo de Bellas Artes. 
za. Sin embargo, la efigie del monarca no se corresponde con la iconografía tradicionalmente asociada a su persona. Como bien explicó Barreto, los retratos de Alfonso II se caracterizan por llevar un sombrero, en ocasiones ornamentado con plumas. ${ }^{72}$ Así es como se le representa, por ejemplo, en el libro de Giovanni Antonio Summonte Dell' historia della città ya mencionado o en Ritratti di cento capitani illustri de Filippo Thomassino y Giovan Turpino. ${ }^{73}$ Resulta incongruente ver que a un rey del siglo XV se le acopla la imagen de Jaime II el Justo, un monarca de finales del siglo XIII y principios del XIV, incluyendo la empresa personal y el escudo de barras aragonesas, obviando el napolitano.

Se conoce que Alfonso II utilizó diferentes empresas o jeroglíficos que de haber aparecido en el retrato identificado se le habría reconocido sin cualquier duda. Por citar algunos ejemplos, a él se asocian un haz de flechas con los lemas «no son tales amores», "amor mi distrugge» o «o tala mores ne son 242 passadores» para hablar de los romances extramatrimoniales que se atribuyeron al monarca. También se le vincula un cardo en flor que simboliza la virtud protegida por espinas para aludir a la fidelidad conyugal. En ocasiones se puede encontrar una araña en el centro de su tela para hablar del poder central y discreto del rey. Igualmente, tan sólo puede aparecer la tela siendo este un juego de palabras pues el término italiano «ragno» que significa «araña» es bastante similar a la expresión «Re di Ragona» como aparece ya en retratos de Alfonso V para enfatizar su condición de rey de Aragón. ${ }^{74}$ En definitiva, aún queda por determinar las razones por las que el artista retrató a Alfonso II de Nápoles, si es que verdaderamente se trata de él, utilizando la iconografía de Jaime II. Quizás fuese consecuencia de un error de identificación o quizás el pintor

72 Barreto, La majeste en images..., p. 209.

73 Aliprando Capriolo, Ritrati di cento capitani illustri, (Filippo Tomassino y Giovan Turpino: Roma, 1600).

74 Barreto, La majeste en images..., p. 226-228. 
no tuviese otros referentes visuales para elaborar la imagen.

El retrato que se ha identificado con Hipólita María Sforza (Cremona, 1446 - Nápoles, 1484)[fig. 3.35] tan sólo presenta la figura de la dama ataviada con lujoso vestido rojo bordado con múltiples detalles en plata, posa en una balconada desde la que se aprecia un paisaje. Los signos de opulencia se encuentran por doquier, por ejemplo el cortinaje del fondo, el abanico cerrado hecho de carey o los anillos que engalanan las manos de la retratada. La imagen, en su conjunto, es simétrica a la anterior dando a entender que son una pareja.

La abdicación de Alfonso II al trono de Nápoles tuvo como objetivo asegurar el reinado a su hijo y protegerse del peligro que suponía el rey Carlos VIII de Francia, pues el monarca había perdido la confianza de Florencia y del pontífice Alejandro VI. De este modo, en un acto de generosidad y con la esperanza de recuperar el apoyo florentino y papal dejó paso al gobierno de su hijo Ferrante II (1469 - 1496):

Mucho había trabajado el rey don Alonso en fortificar el reino, así en gente como en todo lo demás que a la fuerza de aquel reino cumplía, teniendo confianza en la ayuda y favor de todos los príncipes de Italia e ir de caída y que los florentines y el papa Alejandro, en quien hasta entonces tenía que le habían de ayudar, ya se le mostraban contrarios, dando lugar al rey de Francia para que pasasen por sus tierras, perdió la esperanza y no halló manera cómo poderse defender en el reino con su gente, por ser poca, y por esta razón quiso apartarse de tantas guerras y desasosiegos como se esperaban, y dejado el reino de Nápoles a su hijo el infante don Fernando, el cual a la sazón era de edad de veinte y seis años, él se pasó a Sicilia creyendo que de aquella manera alguno de los príncipes del reino que habían tomado la parte del rey de Francia, así siendo el infante don Fernando rey de Nápoles se tornarían a reconciliar en su amistad y dejarían a la parte del rey de Francia que habían tomado. ${ }^{75}$

75 Se ha consultado Antonio Rodríguez Villa, Crónicas del Gran Capitán, 


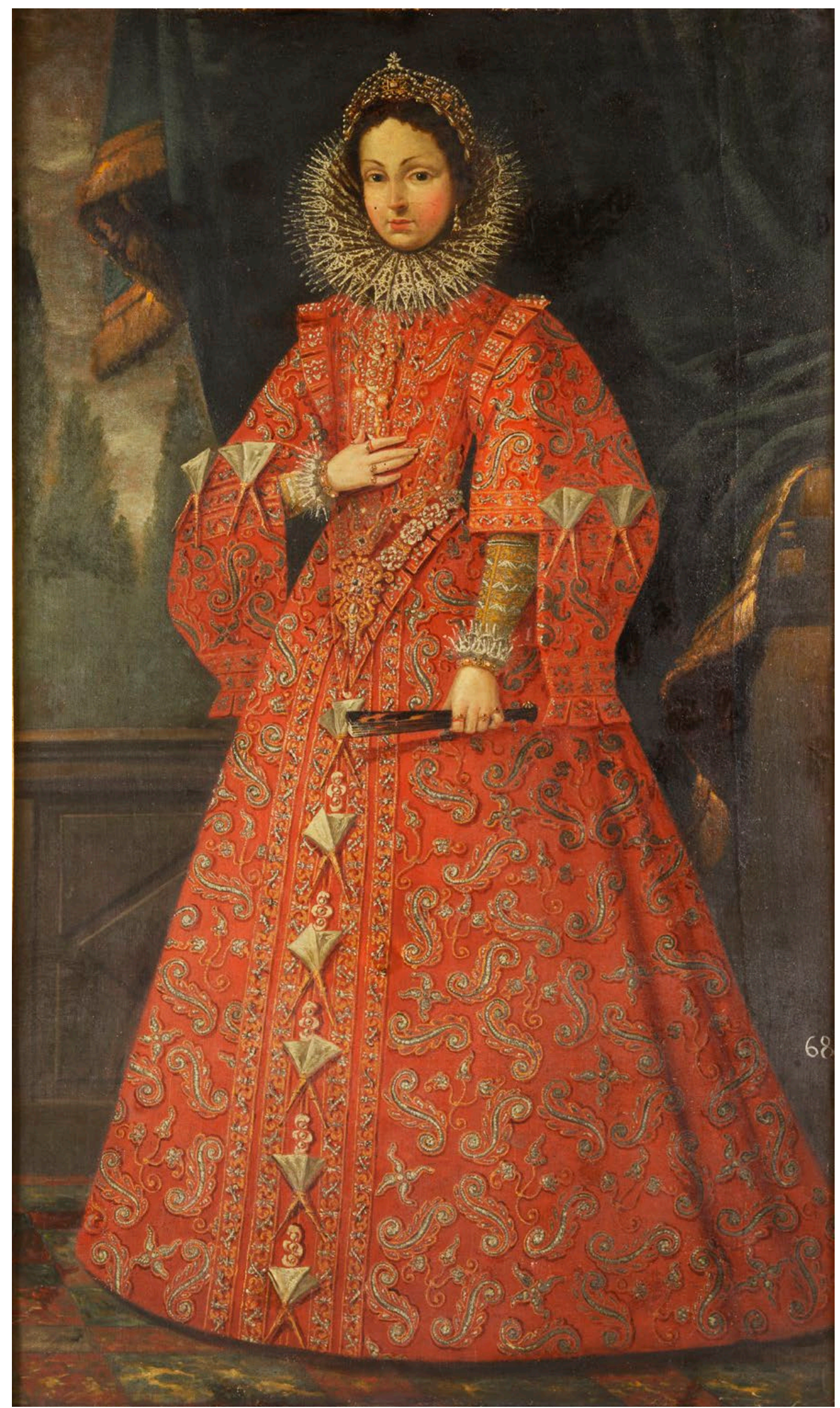

Fig. 3.35. Gregorio Bausá o Antonio Bisquert, Retrato de Hipólita María Sforza, finales del s. XVI - mediados del s. XVII, óleo sobre lienzo, Valencia, Museo de Bellas Artes. 
De la figura de Ferrante II [fig. 3.36] se ha destacado su especial cometido para defender el reino napolitano del monarca francés. Cabe recordar que Carlos VIII mantuvo varias conversaciones con el papado con el único objetivo de conseguir el trono de Nápoles, pero estas negociaciones fueron infructuosas..$^{76}$ De esta forma, se explica que el retrato acentúe su condición de militar y aparezca completamente vestido con la armadura, empuñando una espada aún ensangrentada, y las cabezas de dos víctimas yacen en el suelo junto al victorioso rey. Pese a ello, no se ha dejado de remitir a su condición de monarca pues luce la corona sobre el yelmo. A diferencia de las pinturas anteriores el efigiado no se ha contextualizado en un ambiente áulico, donde los elementos propios del retrato de corte adquieren un gran protagonismo, si no que se ha preferido representarlo como vencedor en alusión a las graves tensiones que mantuvo con Carlos VIII de Francia por el dominio del territorio de Nápoles.

Para poder incluso contextualizar mejor la imagen se pueden plantear algunas reflexiones hipotéticas acerca de los detalles de este retrato. Aunque cabe la posibilidad de que el paisaje que rodea Ferrante II simplemente sea un lugar imaginado, se aprecian algunas particularidades que invitan a pensar que se trate de un espacio inspirado en un lugar concreto. Cabe fijarse en que se ha representado una población bañada por las aguas del mar o de un río, donde se alza majestuosamente una arquitectura cupulada situada en la zona de mayor altura geográfica. Quizás sea una representación de Capua, pues fue uno de los primeros escenarios del conflicto con Carlos VIII. La importancia de esta ciudad residía en encontrarse a escasos kilómetros de Nápoles y ser el enclave perfecto para llegar al corazón del reino.

(Madrid, 1908), Capítulo XVI: 'De cómo el rey don Alonso se fue a Sicilia y dejó en su lugar en el reino de Nápoles a su hijo el infante don Fernando', p. 20.

76 Caldas de Montbuy, Los descendientes legitimados..., p. 116. 


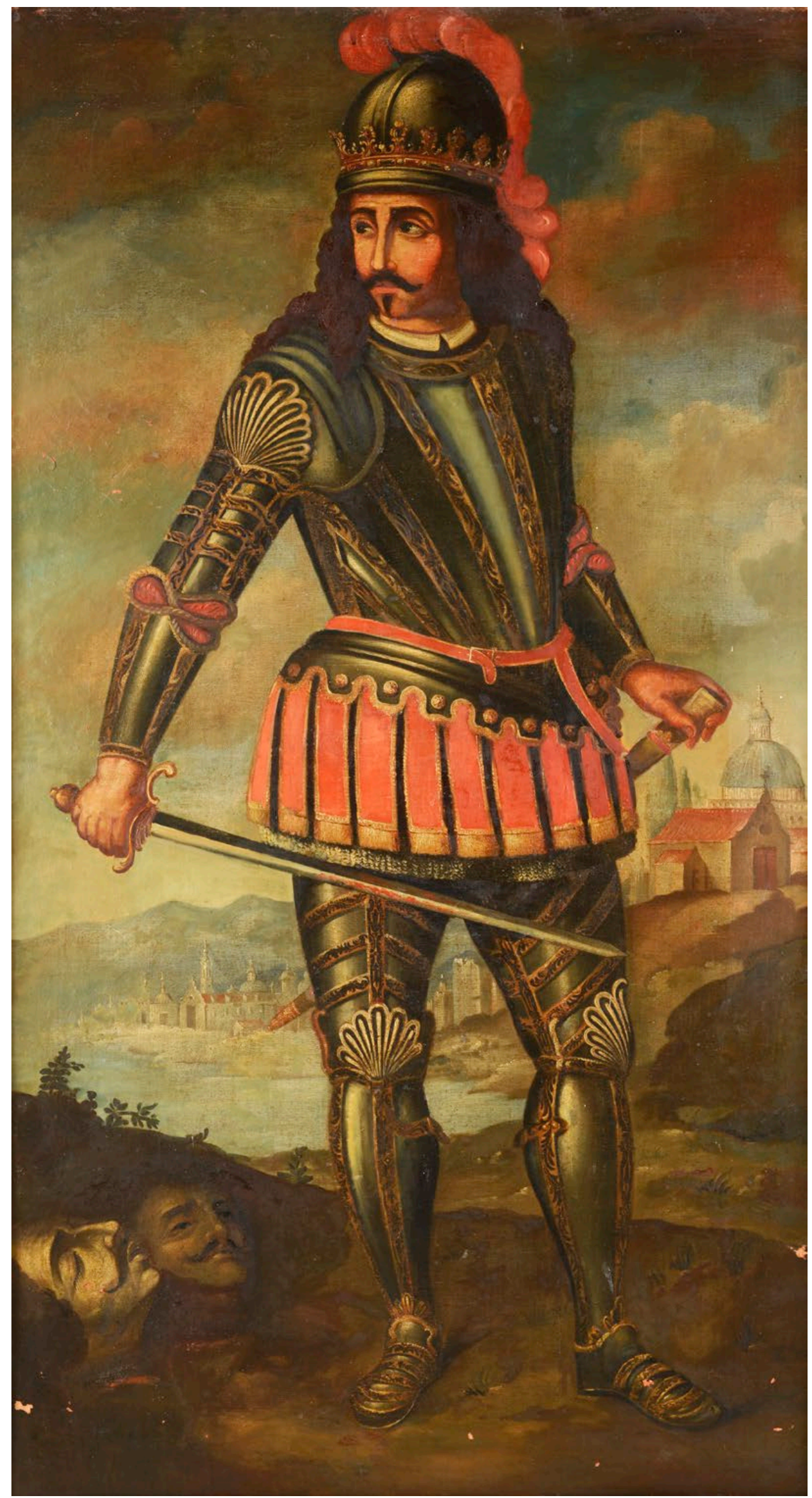

Fig. 3.36. Gregorio Bausá o Antonio Bisquert, Retrato de Ferrante II o Fernando II, finales del s. XVI - mediados del s. XVII, óleo sobre lienzo, Valencia, Museo de Bellas Artes. 
[...] Estuvo algunos días el rey don Fernando en San Germán con su ejército, pero como ya venía el rey de Francia cerca del reino, mudó su ejército de aquel lugar de San Germán y se retrajo a la ribera de un río que está cerca de la ciudad de Capua que llaman Balturno, por donde había de pasar el rey de Francia. Esto hizo el rey don Fernando por razón que estando junto a Capua más presto pudiese socorrer aquella ciudad, y asimismo porque aquel era el camino para la ciudad de Nápoles, y que estando en aquel lugar podría venir a las manos con el rey de Francia y probar sus fuerzas antes que se apoderase mucho en el reino. ${ }^{77}$

Sin embargo, las cabezas yacentes dispuestas a los pies del rey proponen que el espacio representado intente mostrar la isla de Ischia, situada en el mar Tirreno. Allí marchó Ferrante II después que Capua y Nápoles cayesen bajo el control de Carlos VIII para refugiarse en el castillo:

[...] Pues acaeció que llegando el rey don Fernando a Iscla y queriéndose meter en el castillo, el castellano, como había sabido el gran movimiento del reino, no teniendo en nada la debida obediencia a su rey y señor, no le quiso recibir dentro, por lo cual el rey don Fernando, dado caso que de ello le pesase, con mucho sufrimiento y disimulación le rogó le diese lugar para que entrase con su gente y no le quisiese en aquel menester en que puesto estaba de negarle la entrada. El castellano movido de alguna piedad y constriñéndole la naturaleza de su rey y señor, tuvo por bien de recibirle en el castillo, con condición que no entrase más de su persona y sin armas. De esto fue contento el rey don Fernando, pensando que estando él una vez dentro en el castillo, por mal o bien el metería a su gente dentro, la cual estaba en las galeras. Y así fue que entrando el rey en el castillo, yendo familiarmente con el castellano, con un cuchillo que encubiertamente llevaba consigo le mató, de lo cual le avino no poco peli-

77 Rodríguez Villa, Crónicas del..., Cap. XVII: 'De lo que hizo el rey don Fernando después que comenzó a reina, y de cómo habló con los de Nápoles', pp. 20-21. 
gro en si persona, sino que con su gran humanidad venció todo el rigor y fortaleza de la gente que estaba en el castillo, los cuales viendo a su alcaide muerto intentaron alzarse contra el rey y poner las manos en él; pero como él les hablase y les atrajese con sus humanas palabras a su amor, no sólo le recibieron sin hacerle daño, pero tuvieron por muy bueno el castigo que hizo el desobediente castellano. $^{78}$

Otra plausible lectura acerca de este retrato es que las víctimas aparecidas junto a la efigie del rey sean una referencia a los resultados de la deslealtad al soberano, consecuencias manifiestas en el pasaje narrado. El gobierno de Ferrante II estuvo plenamente marcado por este periodo de inestabilidad en el mantenimiento del trono napolitano, su fallecimiento sin descendencia hizo que asumiese el mandato su tío, Federico I:

[...] El rey don Fernando, aquejándole todavía una calenturilla lenta y con la intemperancia del otoño, como dicho es, fue Nuestro Señor servido de llevarle de esta presente vida, y murió en el monte de Soma, no habiendo aún gustado de la alegría de la victoria dejando por heredero del reino a su tío Federico. [...] lo que más los juntaba a dolor y tristeza para tener mayor sentimiento de su muerte en su juvenil edad y floreciente juventud y cuando había de descansar pues tenía pacífico el reino. Y de esta manera todo el placer y alegría que tenían del triunfo y victoria que había habido de sus enemigos se tornó en mucho dolor y tristeza por la muerte de tan noble rey, y con esto se les acrecentaba mucho la pena en ver que en espacio de cuatro años habían sentido la muerte de tres reyes, que fueron el rey don Fernando abuelo de este noble rey, y el rey don Alonso, su padre, que fue a Sicilia y ahora este rey don Fernando, con quien todos vivían muy alegres y contentos y de ellos era muy amado y ellos de él muy

78 Rodríguez Villa, Crónicas del..., Capítulo XIX, 'De cómo el rey don Fernando se partió al castillo del Ovo para desde allí irse a Iscla y del gran recibimiento que los de Nápoles hicieron al rey de Francia' p. 24. 
bien y humanamente tratados..$^{79}$

Federico I (1452 - 1504) [fig. 3.37], el hermano menor de Alfonso II de Nápoles, estuvo al frente del reino napolitano entre 1496 y 1501. La inestabilidad del trono ya existente en el gobierno del monarca anterior no se disolvió durante los escasos años de su reinado. Aunque una de sus primeras actuaciones fue designar a su hijo Fernando, duque de Calabria, como heredero a la Corona, esto nunca se llegó a materializar. El territorio de Nápoles estuvo en constante pugna entre Fernando II el Católico, y los reyes franceses Carlos VIII y su sucesor Luis XII. Uno y los otros discutían sobre su derecho al trono, pero todos estaban de acuerdo en que Federico I por pertenecer a la rama bastarda de Alfonso el Magnánimo no era digno de la Corona napolitana. Además, tampoco vieron con buenos ojos su alianza con el sultán del Imperio Otomano Bayezid II (gobierno desde 1481 - 1512) quien estaba dispuesto a conferirle su protección. De hecho, un embajador del gran turco fue recibido en Nápoles el 1 de febrero de 1500. Así, la entrada en escena de Beyezid II fue vista como una amenaza tanto para los estados italianos como para la cristiandad. Por ello, tras constantes negociaciones y a espaldas de Federico I, Fernando el Católico y Luis XII firmaron el tratado de Granada en ése mismo año. Este acuerdo recogía una serie de cláusulas que repartían el reino de Nápoles entre ambas partes. Finalmente en mayo de 1502, Federico I renunció al trono y cedió sus derechos a la monarquía francesa, y fue entonces cuando Luis XII consiguió los títulos de rey de Nápoles y de Jerusalén. ${ }^{80}$

La imagen de Federico I, nuevamente, vuelve a cumplir con la tradición del retrato de poder. Por ello, el monarca está representado en el interior de una estancia, revestida con un fastuoso cortinaje, junto a un bufete donde se ha colocado la

79 Rodríguez Villa, Crónicas del..., Capítulo XIX: 'De cómo el rey don Fernando se partió al castillo del Ovo para desde allí irse a Iscla y del gran recibimiento que los de Nápoles hicieron al rey de Francia' p. 41.

80 Caldas de Montbuy, Los descendientes legitimados..., pp. 143-184. 


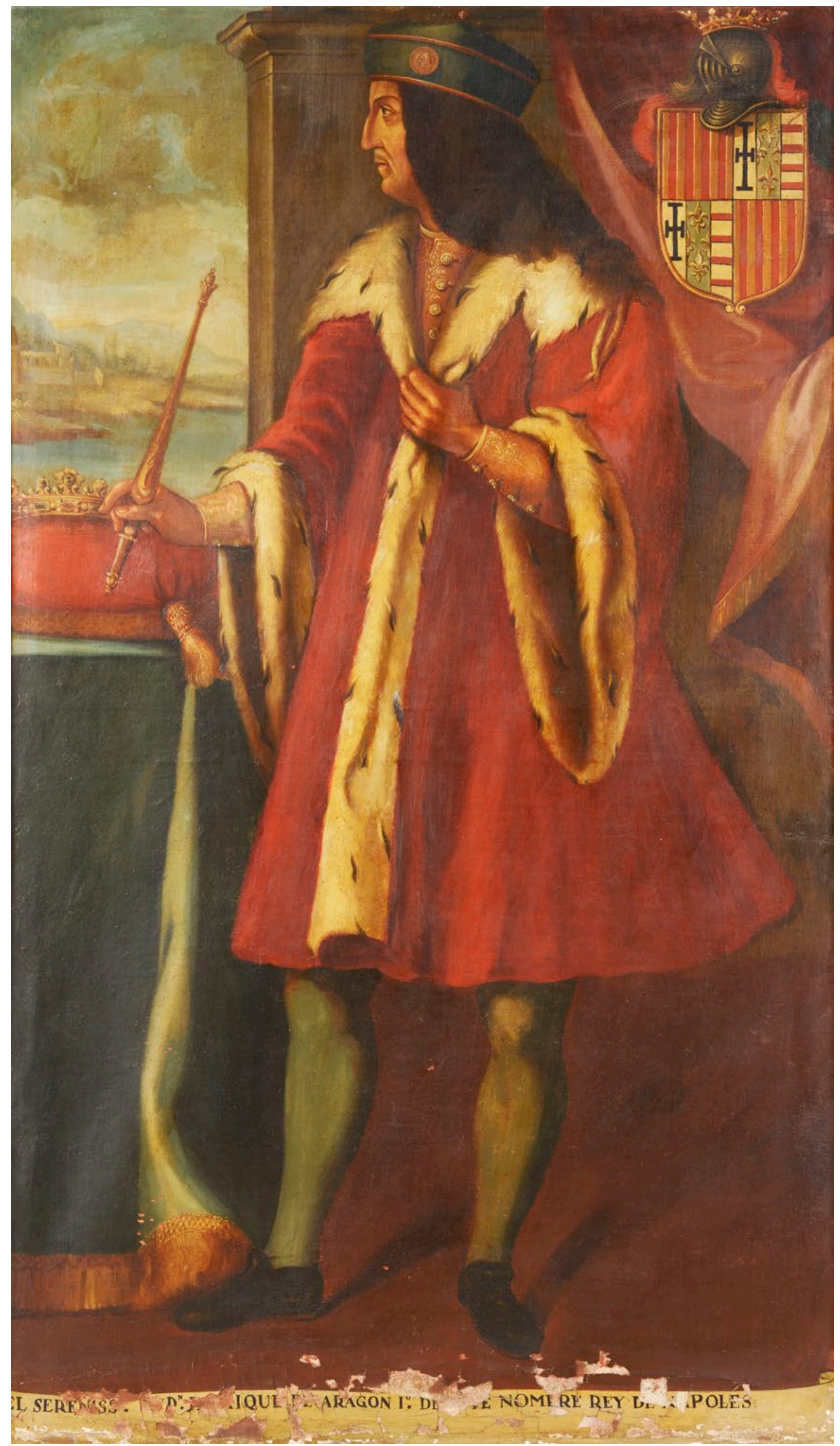

Fig. 3.37. Gregorio Bausá o Antonio Bisquert, Retrato de Federico I, finales del s. XVI - mediados del s. XVII, óleo sobre lienzo, Valencia, Museo de Bellas Artes. 
corona. Se le ha mostrado de perfil, ataviado con calzas y una zamarra roja abierta y bordeada con piel de armiño y llevando un cetro. El espacio se abre por el ventanal a través del cual se muestra abocetadamente una arquitectura en un lugar costero, se trata de un paisaje evocador de las tierras napolitanas. La inscripción que aparece en la parte inferior de la obra se encuentra en un mal estado de conservación, pero aun habiendo perdido numerosos fragmentos de la capa pictórica se puede leer: «El serenísimo don Fadrique de Aragón, I de este nombre rey de Nápoles.» En su conjunto, la pintura reafirma la condición y legitimidad de Federico para ocupar el trono de Nápoles, un derecho muy discutido en su momento.

Este rey tomó por segunda esposa a Isabel de Baucio († 1533) [fig. 3.38] cuyo retrato tiene una composición simétrica respecto al anterior dando a entender que son pareja. Así pues, a ella también se la ha retratado en un interior, ante un ventanal que deja entrever una marina. El fasto propio de la reina es apreciable tanto en sus ricas vestiduras como en las joyas que luce. Lleva la corona real y además su cabello se ha salpicado con numerosas perlas. Del collar pende un medallón que contiene la cruz potenzada del reino de Jerusalén y en el broche se ha incluido una estrella que recuerda a la leyenda que la efigiada, como ya se ha comentado, era una descendiente del rey Baltasar. Estos motivos también se han incluido en su escudo heráldico y la inscripción dispuesta en la parte inferior de la imagen refuerza la identidad de Isabel de Baucio. El texto en concreto reza lo siguiente: "La serenísima reina doña Isabela de Bausio descendiente del señor rey Bathasar, uno de los que en Belén adoraron al Señor. Y de la Real Casa de Francia, mujer del rey don Federique el de Nápoles, y madre del fundador de este Real monasterio de San Miguel de los Reyes.»

Como ya indicaba el retrato analizado previamente, Fernando de Aragón, duque de Calabria fue el fundador del monasterio de donde procede esta galería [fig. 3.39]. Su efigie claramente desempeñaba la función de presentarlo como legítimo suce- 


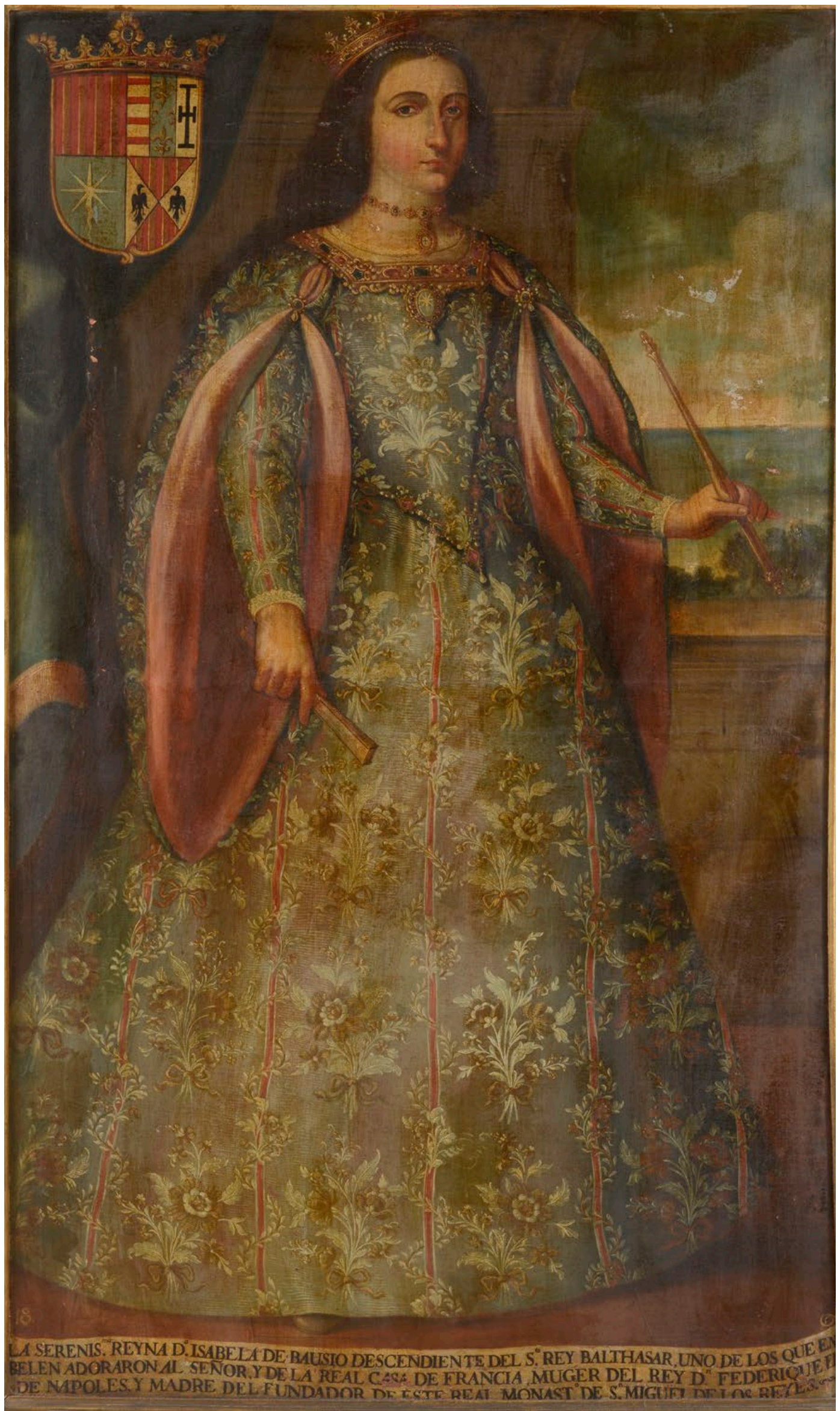

Fig. 3.38. Gregorio Bausá o Antonio Bisquert, Retrato de Isabel de Baucio, finales del s. XVI - mediados del s. XVII, óleo sobre lienzo, Valencia, Museo de Bellas Artes. 
sor al Reino de Nápoles, título que nunca llegó a poseer. Sin embargo, su retrato es la propia imagen oficial de un auténtico rey que se puede justificar por dos razones. La primera es que en 1526 fue designado virrey de Valencia por el emperador Carlos, ése mismo año también casó con Úrsula Germana de Foix, viuda de Fernando el Católico. Ambos ejercieron una intensa actividad cultural en su corte establecida en el palacio Real de Valencia y al estilo de las italianas. La segunda es que a su vez reivindica su derecho a gobernar el reino napolitano, pues era hijo de los últimos reyes de Nápoles pertenecientes a la dinastía de Aragón.

En sintonía con el vocabulario propio del retrato regio, están presentes todos los símbolos de poder como la capa de armiño, el cetro, la corona apoyada en el bufete o el collar. La tipología de esta última joya es similar llevado por su ancestro Ferrante I. Así pues, el collar también se compone de diferentes eslabones donde se aparecen diversos jeroglíficos propios de monarcas anteriores. Entre ellos se pueden distinguir el monte cubierto por diamantes y el haz de mijo anudado, además se ha incluido el armiño junto con la palabra decorum. Por tanto, la alusión al linaje del duque y en consecuencia a la legitimidad de su poder quedó clara mediante su retrato.

Una pareja con la imagen anterior conformaba la efigie de su esposa, Germana de Foix [fig. 3.40]. Se la ha retratado en calidad de virreina, cargo que llegó a ocupar en tres ocasiones. Concretamente en 1507 al estar casada con Fernando el Católico, en 1523 esposada con el marqués de Brandemburgo y en 1526, siendo consorte del duque de Calabria. ${ }^{81}$ Su primer y tercer matrimonio y su condición de fundadora del monasterio son los aspectos destacados de su persona en la inscripción que completa la imagen:

«LA SERENISS. ${ }^{\text {MA }}$ REYNA D. ${ }^{A}$ URSOLA GERMANA, HIJA

81 Regina Pinilla Pérez de Tudela, 'Germana de Foix, una virreina per a València', en Germana de Foix i la societat cortesana del seu temps, (Generalitat Valenciana: Valencia, 2006) pp. 51-67. 


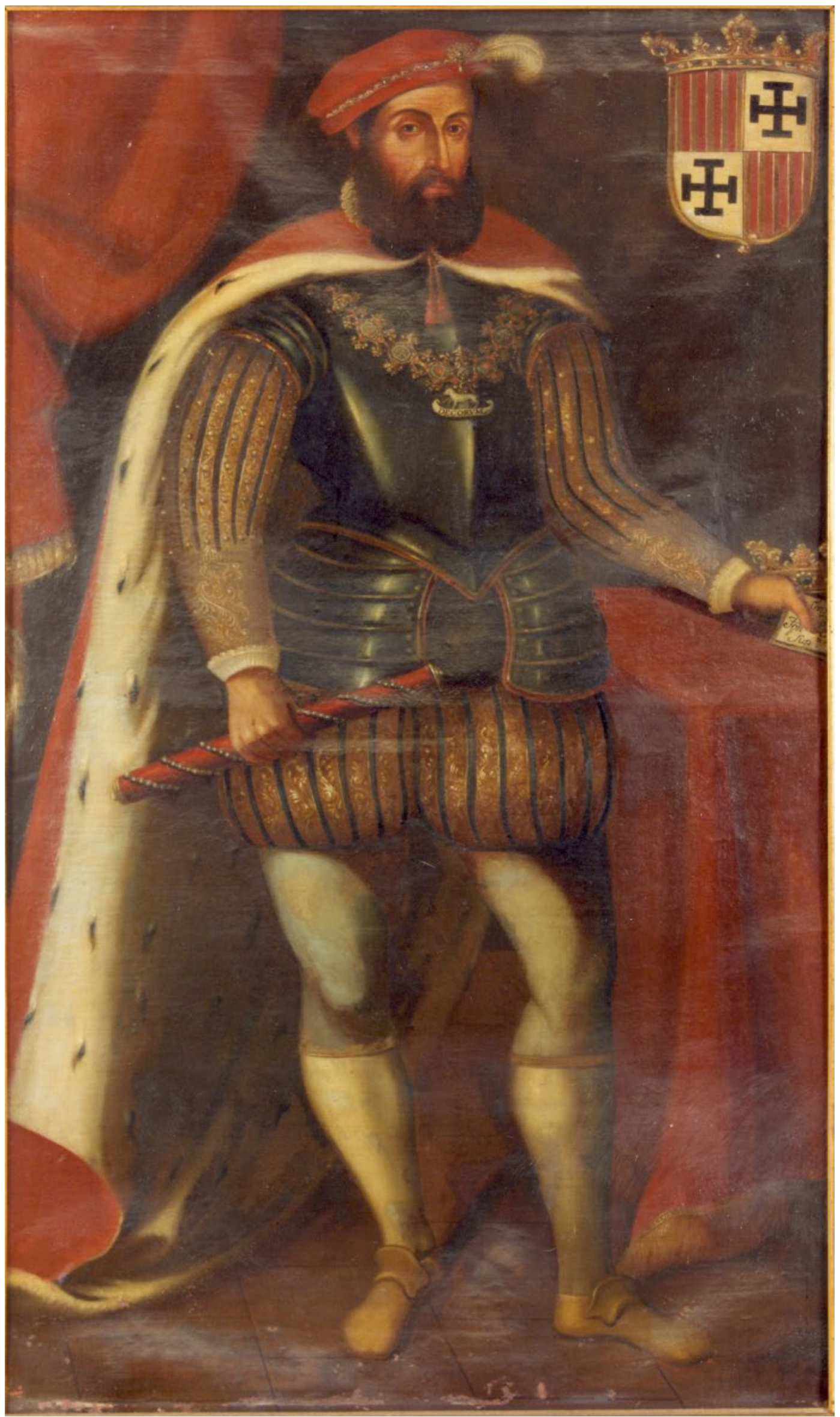

Fig. 3.39. Gregorio Bausá o Antonio Bisquert, Retrato de Fernando de Aragón, duque de Calabria, finales del s. XVI - mediados del s. XVII, óleo sobre lienzo, Valencia, Museo de Bellas Artes. 


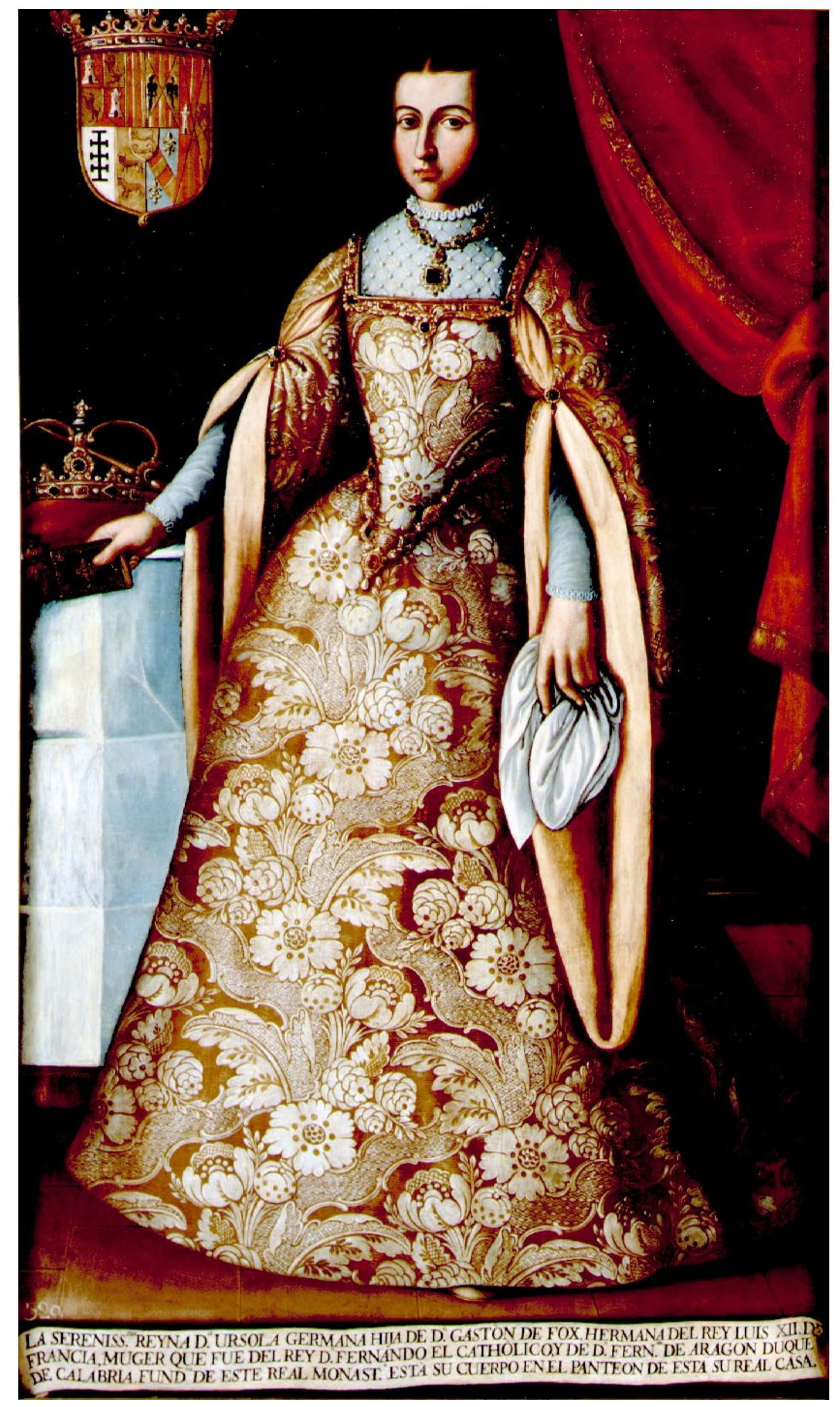

Fig. 3.40. Gregorio Bausá o Antonio Bisquert, Retrato de Úrsula Germana de Foix, duquesa de Calabria, finales del s. XVI-mediados del s. XVII, óleo sobre lienzo, Valencia, Museo de Bellas Artes. 
DE D. ${ }^{N}$ GASTON DE FOX, HERMANA DEL REY LUIS XII DE FRANCIA, MUGER QUE FUE DEL REY D. ${ }^{N}$ FERNANDO EL CATHOLICO Y DE D. ${ }^{N}$ FERN. ${ }^{\text {DO }}$ DE ARAGON DUQUE DE CALABRIA, FUND. ${ }^{\circ R}$ DE ESTE REAL MONAST. ${ }^{\circ}$ ESTÀ SU CUERPO EN EL PANTEON DE ESTA SU REAL CASA.»

Del mismo modo que el retrato de Fernando de Aragón contiene referencias visuales a la imagen de su antepasado, hay una coherencia entre la efigie de Germana y de Isabel de Chiaramonte. Cierta similitud se encuentra en la postura de la efigiada, la ubicación de un cortinaje a la derecha del espectador y un bufete a la izquierda y el jugar con la colocación de tres objetos, la corona, el cetro y el libro. En el caso de los dos primeros, aparecen entre las manos de Isabel y en el bufete junto a Germana. El libro que se ha dispuesto en la mesa de la reina napolitana lo sostiene la virreina en su mano derecha. A través de estos parecidos el retrato de Germana no es simplemente el de una legítima virreina sino también el de una posible reina de Nápoles.

La galería de retratos de reyes de Nápoles pertenecientes a la dinastía de Aragón es significativa porque ilustran el uso que se hizo del retrato para configurar la propia genealogía y reivindicar los derechos obtenidos por consanguinidad y herencia sobre un territorio. El análisis pormenorizado de las pinturas, en definitiva, ha permitido conocer diversos elementos visuales dispuestos a exaltar a los efigiados. Además de todo ello, cabe tener presente que son pinturas de finales del siglo XVI o primera mitad del siglo XVII probablemente encargadas por los propios monjes jerónimos de san Miguel de los Reyes. A través de los retratos de sus fundadores y de los ascendientes del duque de Calabria luciendo en una de las estancias del monasterio se estaba hablando de la trascendencia de su creación y reclamando ser una fundación real. 


\subsection{El Salón de Reyes en el palacio de la Generalitat de Va-}

lencia.

El palacio de la Generalitat Valenciana ha destinado una de sus estancias a contener los retratos de los distintos monarcas que han gobernado el reino desde Jaime I hasta Alfonso XIII [fig. 3.41]. Es una serie icónica de sumo interés que necesita una lectura exhaustiva y reflexiva acerca del empleo del retrato para ilustrar el pasado y presente de la monarquía. La

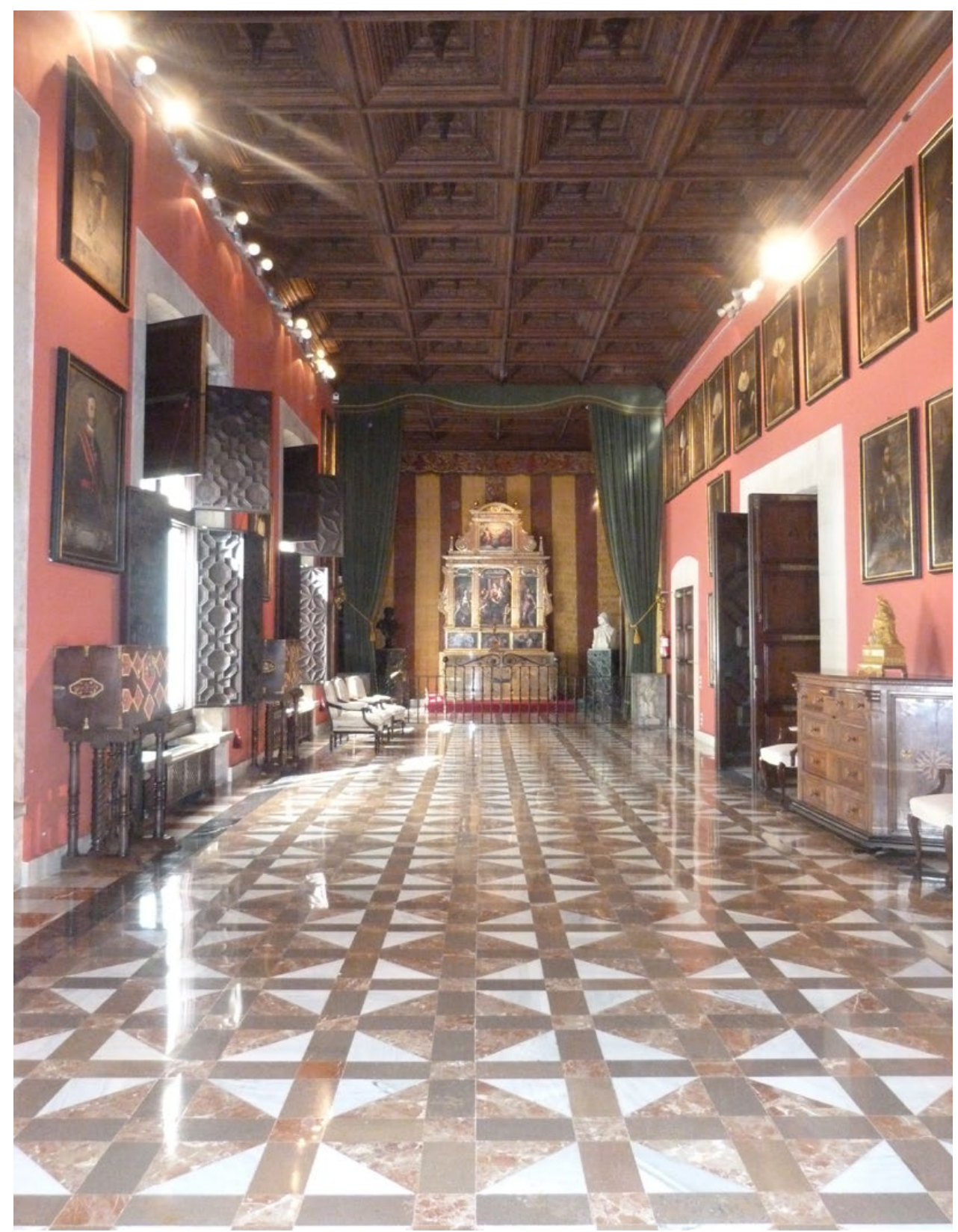

Fig. 3.41. Vista general del Salón de Reyes del palacio de la Generalitat, Valencia. 
bibliografía sobre el tema afirma que las pinturas más antiguas datan del siglo XVII y se atribuyen a los artistas Esteban March (1610 - 1688) y Pablo Pontons († 1668). Habría sido de gran interés que las descripciones realizadas en su día por Xavier Borrull y el conde de Ripalda sobre este espacio y las obras artísticas sitas en él, hubiesen hecho referencia a la serie icónica, pero fue en 1863 cuando al menos se menciona la existencia del conjunto, entonces compuesto por las efigies regias desde Jaime I a Fernando VII. ${ }^{82}$

Aquí no se hizo ninguna alusión a la autoría de las pinturas ni a su localización original. Hubo que esperar a que Francisco Vilanova y Pizcueta, en 1905, apuntase a March como el probable autor de los doce retratos de los reyes de Aragón y Valencia pese a que son de menor calidad artística que los lienzos de March. ${ }^{83}$ Esta misma información fue recogida posteriormente por Martínez Aloy, quien además especificó que la serie se había partido en dos secciones. La primera de ellas se encontraba en la sala grande dorada y se componía de las imágenes de los monarcas aragoneses, desde Jaime I hasta Fernando II. La segunda, desde Carlos I de Castilla hasta Fernando VII se ubicaba en las habitaciones particulares del presidente de la Audiencia, ${ }^{84}$ pues desde 1751 estaba ejerciendo de sede de la Real Audiencia Territorial hasta 1923 que abandonó esta localización para trasladarse al edificio de la aduana.

Más tarde, Elías Tormo hizo un estudio más exhaustivo del

82 Luis Prudencio Álvarez Tejero, Antigüedades y objetos notables de Valencia, (Imprenta de La Opinión, a cargo de D. José Doménech: Valencia, 1863), p. 33.

83 Francisco de P. Vilanova y Pizcueta, Guía artística de Valencia, (Imprenta y litografía de José Ortega: València, 1922), p. 93.

84 José Martínez Aloy, La casa de la diputación, (Establecimiento tipográfico Doménech: Valencia, 1909), p. 7 y pp. 58-59 para la autoría de los retratos. 
conjunto. ${ }^{85}$ Pese a que también las ha datado del siglo XVII, él no creyó que las pinturas fuesen de March, pero tampoco encontró una alternativa lo suficientemente convincente. Le parecieron más bien propias de algún artista castellano, que sin ser brillante podía proceder de una buena escuela. Tormo desconfió en que fuese algún pintor deudor de Ribalta o de Espinosa y lanzó la posibilidad de que se tratase de Pablo Pontons, seguidor de Orrente quien estaba activo en la segunda mitad del siglo XVII.

No obstante, sería conveniente llevar a cabo un estudio pormenorizado que pudiese plantear hipótesis más sólidas acerca de la posible identidad del autor o autores de los retratos. Si se toma como modelo del arte de Pontons la representación de David penitente (1685, óleo sobre lienzo, Morella, iglesia arciprestal de Santa María), se aprecia que el pintor gustó de ser expresivo en los detalles del rostro y de las manos del rey David. Este realismo se echa en falta en la serie de la Generalitat que, a excepción del retrato de Pedro el Ceremonioso, dulcifica bastante la fisionomía de los monarcas y tampoco se observa la angulosidad de la capa del soberano bíblico, donde los pliegues del textil sen encuentran altamente pronunciados dando paso al juego de luces y sombras propio de la estética barroca.

Resulta probable que el artífice de estas obras pertenenciese a una segunda categoría. De hecho, era habitual encargar galerías regias que engalanaban estancias menores a artistas de poco renombre, así Felipe IV encomendó la copia de algunas series monárquicas como la de Portugal para mostrarse, según Diana Carrió-Invernizzi, en calidad de dirigente de todos los territorios de la monarquía hispánica y al mismo tiempo recordar la idoneidad y legitimidad de la Casa de Austria para gobernar un imperio compuesto de extensos territorios. ${ }^{86}$

85 Tormo y Monzó, Las viejas series..., pp. 147-153.

86 Diana Carrió-Invernizzi, 'Las galerías de retratos de virreyes de la Monarquía Hispánica, entre Italia y América (siglos XVI-XVII), en Daniel Aznar, Guillaume Hanotin y Niel F. May (eds.), À la place du roi. Vice-rois, 
Respecto al emplazamiento original de la serie icónica se habla del palacio Real, pero seguramente tras la demolición de edificio en el siglo XIX parte de las pinturas llegarían a la sede de la Generalitat. Cabe matizar que se perdió parcialmente el conjunto porque aquí se han conservado las representaciones de reyes pero la documentación de archivo ha revelado que incluso lucían los retratos de virreyes y capitanes generales. Sin duda, la ornamentación del espacio estaba acorde con el uso del mismo, así pues desempeñó plenas funciones de residencia real durante el gobierno de la Corona de Aragón. Más tarde, tras la alianza de las coronas castellana y aragonesa comenzó a ser la morada de virreyes y con el tiempo, capitanes generales, lo cual explica que el conjunto también contase con otra clase de efigiados. ${ }^{87}$ Por el momento, las pinturas de virreyes y capitanes generales no se han localizado y se desconoce en qué medida se pudieron perder o llegar a colecciones particulares.

260 El amplio repertorio de retratos que se configuró en esta morada áulica, una vez más, viene a mostrar varios aspectos propios del género del retrato en época moderna. Por un lado, las representaciones de reyes ponen de manifiesto la visualización de la estirpe reinante y construyen la historia de la monarquía. Por otro lado, las imágenes de virreyes y de capitanes generales al mismo tiempo evidencian la estructura gubernamental del reino. Como es sabido, la figura del virrey era la propia representación del monarca durante su ausencia, un papel que incluso cobraba una mayor relevancia en los territorios trasatlánticos. Así los retratos de los virreyes decorando sus hogares, al igual que lo hacían los monarcas, tenían asi-

gouverneurs et ambassadeurs dans les monarchies française et espagnole, (Casa de Velázquez: Madrid, 2014), p. 115.

87 Vicente Salvador y Montserrat, marqués de Cruilles, Guía urbana de Valencia, antigua y moderna. Tomo II, (Imprenta de José Rius: Valencia, 1876). p. 228; Esta idea igualmente fue expuesta por Marcos Antonio de Orellana, Valencia antigua y moderna, (Librerías París - Valencia: Valencia, 1924), tomo II, p. 470. 
mismo la finalidad de justificar su legitimidad para el gobierno y repreesentaba el lazo de unión entre la dinastía reinante y el territorio. ${ }^{88}$ En cuanto al capitán general, éste concentró el poder militar a raíz del cambio dinástico y la implantación del decreto de Nueva Planta. Una vez más, su retrato era expresión de su poder civil y recordatorio de la extinción de los virreinatos y el establecimiento del absolutismo en la monarquía hispánica.

El carácter oficial y simbólico de las efigies iba acompañado del ceremonial que tenía lugar en la residencia real, formando parte como una pieza más del amplio engranaje que suponía la exaltación del poder regio. El Real era un espacio donde se llevaban a cabo tareas administrativas, gubernamentales y militares, pero también daba cobijo a actividades sociales. Ya se ha comentado anteriormente que uno de los momentos de mayor esplendor de este complejo se dio en el siglo XVI cuando estuvo ocupado por el virrey y duque de Calabria, Fernando de Aragón. Mencía de Mendoza, su primera esposa, ya acumuló un importante repertorio de efigies compuesto por retratos de diversa índole, algunos de la monarquía, otros de la élite cultural y otros tantos de sus propios familiares. El duque junto con su segunda esposa, Germana de Foix, siguió construyendo una relevante biblioteca y una amplia colección de obras artísticas, como tapices y galerías de retratos, que avalaban ser descendiente de la Corona de Aragón en Nápoles. ${ }^{89}$

La información de archivo, a día de hoy, es limitada y los datos remiten a las obras artísticas de forma superficial. General-

88 Acerca de las efigies de virreyes en el territorio americano de Nueva España, véase a: Inmaculada Rodríguez Moya, La mirada del virrey: iconografía del poder en la Nueva España, (Universitat Jaume I, 2003). También consúltese a Carrió-Invernizzi, 'Las galerías de retratos de virreyes de la Monarquía Hispánica...', pp. 113-134.

89 Luis Arciniega García y Amadeo Serra Desfilis, 'El palacio como escenario de Austrias y Borbones, residencia de virreyes y capitanes generales' en El Palacio Real de Valencia. Los planos de Manuel Cavallero (1802), (Ayuntamiento de Valencia: Valencia, 2006), pp. 91-108. 
mente se menciona su existencia, el número de retratos que componía el grupo de efigies y salas en las que se encontraban. ${ }^{90}$ Las primeras referencias halladas datan de mediados del siglo XVIII, concretamente de 1760 se conservan los Autos de inventario de los bienes de su majestad en el real palacio de Valencia, actuado por el señor marqués de Almunia, su alcaide; con acuerdo y parecer del señor don Joaquín Solsona, su asesor. ${ }^{91}$ Aquí se nombra al salón grande, también denominado de los virreyes o de los capitanes generales, porque se decidió revisar y actualizar el inventario de las pertenencias del rey.

Que habiéndose dignado el rey nuestro señor (que Dios guarde) nombrarle por alcaide de este real palacio, con todos los honores, facultades y preeminencias correspondientes a dicho empleo, según el real título, o nombramiento expedido en Aranjuez en el día veintiocho del pasado mes de abril de este corriente año; y en su virtud el Excelentísimo señor virrey don Manuel de Sada y Antillon, gran castellán de Amposta, gobernador y capitán general de dicha ciudad de Valencia y su reino le había puesto en la posesión de dicho empleo de alcaide: $Y$ para que los bienes y efectos existentes en dicho real palacio propios de su majestad no se extravíen y siempre conste de ellos: Debía mandar y mandó, se pase al salón grande, llamado de los virreyes, donde se hallan los retratos de los que han sido; a la capilla, sacristía y demás lugares que convenga; a fin que se compruebe el inventario últi-

90 Mercedes Gómez-Ferrer ya indicó en qué inventarios del palacio Real datados en el siglo XIX se mencionaban los retratos. Su aportación ha servido para poder iniciar una búsqueda entre la documentación de archivo y además consultar inventarios anteriores, de 1760 y de 1763, donde indirectamente se deja constancia de la galería de efigies. Véase a Mercedes Gómez-Ferrer Lozano, El Real de Valencia, 1238-1810: historia arquitectónica de un palacio desaparecido, (Institució Alfons el Magnànim: Valencia, 2012). Para ubicar en planta las distintas estancias ornamentadas con retratos se han tomado los planos de Manuel Cavallero de 1802 citados previamente.

91 Archivo del Reino de Valencia (ARV de ahora en adelante): Bailía, B, expediente 52. 
mamente hecho por el señor don Joaquín Esteban Ferrer y Pinos, alcaide interino del mencionado real palacio, y autorizo el presente en a los trece días del mes de marzo del año próximo pasado de mil seiscientos cincuenta y nueve de los bienes, ornamentos, alhajas de plata, libros, papeles y demás por si existen en el día de los mismos que entonces se anotaron; y se añadan, los que posteriormente se hayan hecho; formando de todo un nuevo inventario. $[. . .]^{92}$

Además, en ése mismo documento se ha añadido una diligencia en la que se deja constancia de la presencia de cincuenta y tres retratos de virreyes en el mencionado salón. Sin embargo, posteriormente se puede comprobar que estas cifras variaron ligeramente en los diferentes años. Todos estos datos se repiten de forma exacta en un inventario de 1763, donde además de las efigies también había «los cuadros de países que están colocados sobre las puertas de la galería de dicho palacio».

La denominación de la sala ya fue explicada por el marqués de Cruilles en el siglo XIX, pues su apelativo era consecuencia de «contener los retratos de los virreyes que gobernaron el reino, y de cuya colección se conservan muchos en la actual Capitanía General, se leía sobre la puerta de entrada en caracteres galicanos y de ángulos agudos, sobre una lápida negra: Cambra de uxer del Senyor Rey". El término uxer era utilizado para referirse a los capitanes. ${ }^{93}$ Como apuntó Gómez-Ferrer, el salón de los retratos o salón grande, también fue conocido 92 ARV: Bailía, B, expediente 52. Autos de inventario de los bienes de su majestad en el real palacio de Valencia, actuado por el señor marqués de Almunia, su alcaide; con acuerdo y parecer del señor don Joaquín Solsona, su asesor, 1760.

93 También se puede traducir por ujier, cargo que en época medieval se encargaba a custodiar al rey y por ello, se situaba en la antesala del aposento del monarca. Por tanto, el salón de retratos antecedería a la cámara real. Consúltese a Luis Arciniega García y Amadeo Serra Desfilis, 'Cort e Palau de Reu. El Palacio Real en época medieval', en El Palacio Real de Valencia. Los planos de Manuel Cavallero (1802), (Ayuntamiento de Valencia: Valencia, 2006), pp. 83-90. 
como sala de los saraos o de las comedias. Arquitectónicamente fue modificado a principios del siglo XVI cuando se colocó una cubierta de bovedillas y vigas de madera. ${ }^{94}$

Las referencias más detalladas se encuentran en los inventarios de 1800 y 1801, durante los años previos a la destrucción del conjunto arquitectónico. En uno de ellos se dice que en el archivo de la alcaidía habían «sesenta y siete retratos de medio cuerpo con sus marcos dorados de los virreyes y generales que han mandado en este reino», en el salón de comedor lucían "seis retratos de personas reales de cuerpo entero» y en el denominado salón de los ángeles existían «trece retratos de personas reales de cuerpo entero con menos dorado». Esta última estancia era una de las más relevantes del edificio, estaba emplazada en la torre y desde 1719 se engalanó con el escudo y las armas reales sostenidos por las figuras de cuatro ángeles, de ahí la denominación de la sala. ${ }^{95}$ Era un espacio que, como en los palacios medievales y europeos de los papas 264 de Aviñón, se ubicaba en una de las torres un espacio reservado para contener determinadas celebraciones. ${ }^{96}$ Tristemente, al referirse al salón de los retratos no se ha mencionado ninguna de las efigies y tan sólo se ha especificado el mobiliario que formaba parte de la estancia, es decir «tres bancos de pino con cajones y tres mamparas, dos de ellas con vueltas de guadamecíes» [fig. 3.42]. ${ }^{97}$

En otro inventario, ahora de 1801, ya se aprecian cambios en

94 Gómez-Ferrer Lozano, El Real de Valencia..., p. 240.

95 Gómez-Ferrer Lozano, El Real de Valencia..., p. 245.

96 Arciniega García y Serra Desfilis, 'Cort e Palau de Reu. El Palacio Real en época medieval'.

97 ARV: Bailía, B, expediente 52. Expediente 40. Inventario de los efectos pertenecientes a S. M. y que se hallan actualmente en este real palacio, su alcaidía y otros pasajes de la misma. Año 1800, fol. 3-4. El documento está fechado a 29 de marzo de 1800, siendo alcaide don Pedro Vicente y siendo su escribano, Domingo González. 


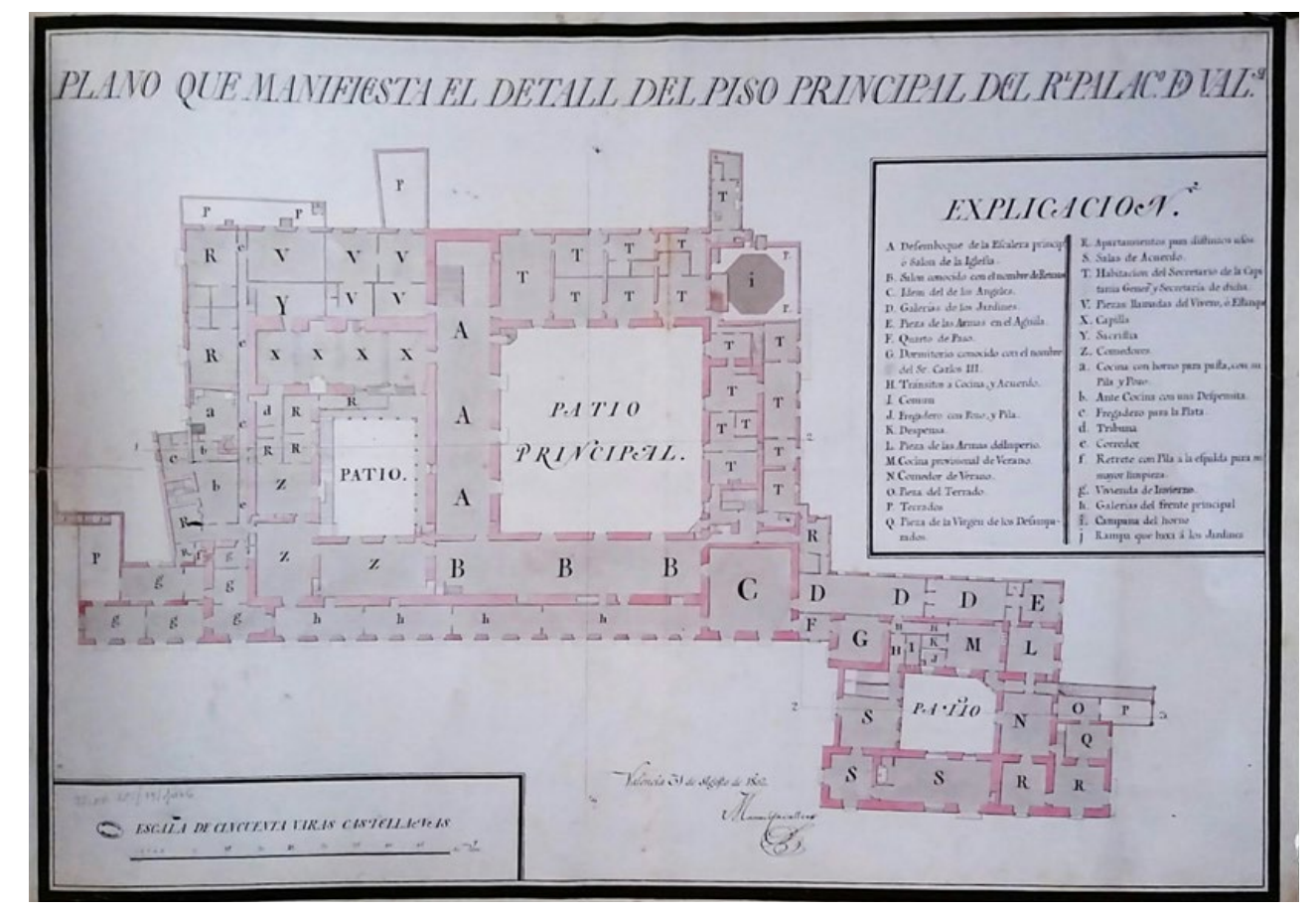

Fig. 3.42. Plano del piso principal del palacio Real de Valencia según Manuel Cavallero en 1802. Véase el Salón de los Retratos (letra B) y el Salón de los Ángeles (letra C).

la ubicación de algunas de las obras. Así, ahora en la entrada a la habitación del secretario, que estaba cerca del salón de virreyes y de la cámara de los ángeles, había «seis retratos de reyes». La descripción del salón de los ángeles ahora es más exhaustiva y dice que allí se encontraba:

El retrato del rey nuestro señor con guarnición dorada. Dos cortinas de tafetán carmesí con dos cordones y borlas de seda. El dosel de damasco carmesí con franja de oro y seda. Una silla de nogal forrada de damasco carmesí con lados [...] de bronce dorado. Una tarima de madera forrada [...]. Trece retratos de reyes con guarniciones todas. Dos cerrojos y llaves. Dos marcos con treinta y dos vidrios cada uno. Otros dos marcos con doce vidrios cada uno. Otros dos marcos con veintiocho vidrios cada uno. Dos marcos con dieciséis vidrios cada uno. ${ }^{98}$

98 ARV: Bailía, B, expediente 52. Inventario de todos los efectos pertenecientes a Su Majestad en las habitaciones de este real palacio que sirven de alojamiento a los excelentísimos señores capitanes generales, y de sus familias. 1801. s/f. Documento datado a 15 de febrero de 1801. Mercedes Gómez-Ferrer en su obra citada, también aporta una referencia del Archivo 
En cuanto al salón de los retratos generales se dice que tenía:

Dos faroles grandes. Tres bancos de madera con respaldo con cuatro cajones cada uno. Un marco con veintiocho vidrios. Otro marco con doce vidrios. Otro marco con dieciocho vidrios. Otro marco con sesenta vidrios. Una lacena con puertas de alambre y lienzo y tres guarniciones de madera. Una mampara de lienzo. Una mampara de lienzo. Un armario con tres estantes. Sesenta y seis retratos con los virreyes y capitanes generales que han gobernado este ejército y reino y se advierten faltan los de los excelentísimos señores duque de la Roca, don Luis de Urbina y don Nicolás de Arredondo. Dos marcos con dieciocho vidrios cada uno. Dos marcos con quince vidrios cada uno. ${ }^{99}$

Los retratos del palacio Real también constan en un nuevo inventario de 1809 - 1810 el cual enumeraba todos los objetos acumulados en el complejo arquitectónico. Según el listado 266 de alhajas, efectos y demás que existían en la sala de los ángeles había «un retrato del rey Nuestro Señor con guarnición dorada», en el comedor se localizaron "seis lienzos de reyes de España con guarniciones doradas» y en la sala destinada a las efigies continuaban luciendo «sesenta y nueve retratos de los capitanes generales pasados». La descripción de los retratos de virreyes y capitanes generales como representaciones de medio cuerpo encaja con el formato adoptado para los retratos de monarcas que han sido objeto de estudio. Las efigies

General de Palacio, Caja 7084, inventario de 1791, donde se especifica que en esta sala había «un dosel de damasco con el retrato de la persona real, un retrato de Cristo crucificado con San Juan y la Magdalena, un retrato del paso de la adúltera y trece retratos de cuerpo mayor de las personas reales con sus marcos dorados." Véase Gómez-Ferrer Lozano, El Real de Valencia..., p. 246.

99 ARV: Bailía, B, expediente 52. Inventario de todos los efectos pertenecientes a Su Majestad en las habitaciones de este real palacio que sirven de alojamiento a los excelentísimos señores capitanes generales, y de sus familias. 1801. s/f. Además, se conserva una copia de este documento en el cual repite la descripción de la estancia de los ángeles, de los virreyes y generales y de la entrada a la habitación del secretario. 
descritas como representaciones de reyes de cuerpo entero eran otras distintas a las que a día de hoy se encuentran en el palacio de la Generalitat y probablemente se perdieron. Cuando la documentación se refiere simplemente a los retratos de reyes y no se aportan más detalles no se puede determinar a qué representaciones regias se alude exactamente.

Por otros datos hallados en el archivo, debe plantearse la duda de si las obras fueron vendidas o depositadas en la Real Hacienda situada en el convento de santo Domingo durante la Guerra de la Independencia y antes de la destrucción de esta arquitectura regia. De hecho, se conserva Un oficio para la venta de las pinturas y otros efectos del palacio del Real o en depósito en el almacén de la Real Hacienda (sito en Santo Domingo) a cargo de don Domingo Beltrán. Año 1810. Este escrito se refiere específicamente a las pertenencias que había en la capilla de abajo del palacio y adjuntaba un listado de las obras que se ha perdido. ${ }^{100}$ No obstante, es probable que los retratos tuviesen un tratamiento similar y fuesen vendidos o depositados en el monasterio dominico. ${ }^{101}$

Como ya se ha apuntado, los retratos de reyes que formaron

100 ARV: Bailía, B, expediente 58. Demolición del Palacio del Real y sus incidentes. 1809 - 1811. Relaciones de los efectos existentes en el Palacio del Real al tiempo de su demolición, y de los entregados después de ella para la fortificación de varios puntos de esta plaza con otros incidentes sobre averiguación del paradero y venta de dichos efectos. 1809-1810, s/f. Respecto al oficio para la venta de pinturas, dice lo siguiente: «Incluyo a Nuestro Señor la adjunta nota de los efectos que existieron en la capilla de abajo del Palacio del Real de esta ciudad, y se hallan en poder de su Alcaide el Brigadier don Pedro Vicente quien los recogió y los salvó al tiempo de la invasión de los enemigos, para que se sirvan V.S. disponer la venta de las pinturas y demás que lo permitan, y se entreguen en el almacén de la Real Hacienda que está en Santo Domingo al cargo de Don Domingo Beltrán.»

101 La búsqueda de datos acerca de estas obras en el archivo del Reino de Valencia ha sido infructuosa por el momento. De hecho, no hay rastro de los retratos de los monarcas en el inventario del convento de santo Domingo en tiempos de la desamortización, tan sólo se remite a pinturas de temática religiosa, efigies de santos y venerables. ARV: Clero, libros, 4185. Inventario de la desamortización, 1835, tomo I. 
parte de la colección artística del Real se encuentran, en la actualidad, en el palacio de la Generalitat. Sin embargo, el Salón de Reyes que se conoce a día de hoy también ha sufrido alteraciones en el pasado y ésta es una acepción relativamente reciente. Concretamente fue entre 1511 y 1515 cuando Joan Mançano tuvo que reconstruir la sala grande y la capilla. En su origen, esta última estancia se empleó para celebrar las sesiones de los diputados desde 1431 y por ello, recibió el nombre de sala de la Diputación. Años más tarde, en 1438 cambió su denominación y pasó a conocerse como la sala de la Capilla, pues había dejado de ser el lugar de reunión de los diputados. ${ }^{102}$

En 1751 el edificio de la Generalitat pasó a ser la sede de la Audiencia. Y ya fue a principios del siglo XX, en el año 1922 en concreto, cuando tras finalizar las obras del palacio de Justicia la Audiencia se trasladó a este otro emplazamiento y el de la Generalitat se entregó nuevamente a la Diputación Provincial. Entre el expediente de cesión del edificio es donde se han hallado las últimas referencias a los retratos, ahora mucho más específicas por mencionar la identidad de cada efigiado. La preocupación de los diputados por ocupar la Generalitat y que allí se continuasen conservando las obras de arte les llevó a supervisar el traslado. Por esta razón, en la sesión de 5 de noviembre de 1920 acordaron que «[...] se comisionará una ponencia de señores Diputados, asistida del señor Cronista de la provincia para que intervenga en el traslado de la actual Audiencia al nuevo edificio, a fin de que queden en el mencionado palacio de la Generalitat todas aquellas joyas artísticas que encierra garantizando documentalmente su permanencia en el mismo.»103

Por el acta de entrega de 23 de mayo de 1923 se ha conocido que el presidente de la Audiencia, siendo 31 de marzo del mis-

102 Salvador Aldana Fernández, El Palau de la Generalitat valenciana, (Generalitat Valenciana: Valencia, 1995), pp. 22 - 28.

103 ADV: Sección A (central), subsección 6 (gobernación), 2 (propiedades y derechos), 5 (edificios), caja 1/1892-1953, Palacio Generalitat, s/f. Acta de 5 de noviembre de 1920. 
mo año, había solicitado Ministro de Gracia y Justicia hacer efectiva la entrega del edificio, incluyendo los retratos que a finales del siglo XIX se encontraban en la denominada sala de la Capilla, cuyo espacio finalmente transformó su nombre a Salón de Reyes:

En consideración a lo expuesto solicito respetuosamente de V.E. se sirva de autorizar a la Junta Consultiva Administrativa para la instalación del Palacio de Justicia de esta Ciudad, para que, dando cumplimiento al R. D. de dieciocho de junio de mil ochocientos noventa y cuatro, y teniéndole a la vez la ley de diecinueve de junio de mil ochocientos noventa y ocho, entregue a la Diputación Provincial el edificio en que estuvo instalada la Audiencia, con el altar y retratos existentes en el mismo y que pertenecieron respectivamente, a la Generalidad y a dicha Corporación. ${ }^{104}$

Con la autorización del ministro a 30 de abril de 1923, se le contestó al presidente de la Audiencia que «S.M. el Rey (que Dios guarde) se ha servido autorizar a la Junta Consultiva y Administrativa para la instalación del Palacio de esa Ciudad para que entregue a la Diputación provincial el edificio denominado Casa de la Generalidad en que estuvo instalada la Audiencia de la misma. De Real Orden lo digo a V. I. para sus conocimientos y demás efectos. [... ]» ${ }^{105}$ Este mismo documento finalmente relata cómo el presidente de la Audiencia junto con el fiscal y el secretario de gobierno hicieron:

Entrega solemne a los señores representantes de la Excma. Diputación provincial del edificio denominado Casa de la Generalidad y objetos siguientes, existentes en el mismo: altar con tríptico y frontales, cuatro de tipo ordinario (uno con dos caras) y otro tejido en oro, plata y sedas, descrito por el Sr. Martínez Aloy, en su obra titulada La Casa de la Diputación, dos cuadros representando

104 ADV: A.6.2.5/caja 1/1892-1953, Palacio Generalitat, s/f. Acta de entrega de 23 de mayo de 1923.

105 ADV: A.6.2.5/caja 1/1892-1953, Palacio Generalitat, s/f. Acta de entrega de 23 de mayo de 1923. 
al Crucificado, que hay en la Capilla, y veintidós retratos de los siguientes Reyes: Jaime I de Aragón y Valencia, Pedro III de Aragón y Valencia, Alfonso III de Aragón y I de Valencia, Jaime II de Aragón y de Valencia, Alfonso IV de Aragón y II de Valencia, Pedro IV de Aragón y II de Valencia, Juan I de Aragón y de Valencia, Martín I de Aragón y de Valencia, Fernando I de Aragón y Valencia, Alfonso V de Aragón y III de Valencia, Juan II de Aragón y Valencia, Fernando II de Aragón y Valencia, Carlos I, Felipe II, Felipe III, Felipe IV y Carlos II de la Casa de Austria. Felipe V, Fernando VI, Carlos III, Carlos IV y Fernando VII de la Casa de Borbón. ${ }^{106}$

Todas estas efigies han conformado el núcleo principal de la serie icónica que muestra a los soberanos que condujeron los designios del territorio valenciano y que necesitan un análisis pormenorizado. Ahora sigue un estudio de las imágenes clasificado en varios apartados para diferenciar a los reyes pertenecientes a la Corona de Aragón, de la Casa de Austria y de la Casa de Borbón. En el caso de los primeros, a su vez se ha hecho un inciso para relacionar su iconografía con otra serie icónica de monarcas aragoneses procedente de Zaragoza.

\subsubsection{Monarcas de la Corona de Aragón:}

Antes de profundizar en el análisis de cada uno de los retratos de esta serie, el caso de la Generalitat se debe vincular con las efigies regias pintadas en 1586 para el palacio de la Diputación de Aragón, situado en Zaragoza. De este modo, será más sencillo observar que las imágenes valencianas reprodujeron una iconografía asentada para los reyes del pasado. Los estudios de Carmen Morte acerca de los retratos zaragozanos han sido fundamentales para poder relacionar unas obras con otras. ${ }^{107}$ El palacio de la Diputación de Aragón, por tanto, albergó una 106 ADV: A.6.2.5/caja 1/1892-1953, Palacio Generalitat, s/f. Acta de entrega de 23 de mayo de 1923.

107 Carmen Morte García, 'Pintura y política en la época de los Austrias. Los retratos de los reyes de Aragón para la Diputación de Zaragoza (1586), y las copias de 1634 para el Buen Retiro de Madrid (I)', Boletín del Museo 
serie icónica pintada de la mano de Felipe Ariosto a partir de 1586. Constaba de un total de cuarenta y dos cuadros, realiza-dos a petición de los diputados aragoneses, que incluían las representaciones de los reyes de Sobrarbe, los condes y los reyes de Aragón, estos últimos son los de mayor interés para esta investigación. Además se añadieron las inscripciones que dejaban constancia del legado de cada monarca. Los textos habían sido pensados por Jerónimo de Blancas y escritos por el iluminador Pedro Sánchez de Ezpeleta. El grupo de piezas concluía con Felipe II de Castilla, quien incluso prefería que la imagen de su padre y la suya propia fuesen pintadas por Sánchez Coello, y en síntesis conseguía hacer un repaso histórico al inicio de la corona aragonesa y además entroncaba de forma natural a los reyes de Aragón con la dinastía de Austria. Desafortunadamente, la serie zaragozana se destruyó al incendiarse el palacio en 1808 durante la Guerra de la Independencia. Sin embargo, el principal testimonio que conduce a conocer cómo debió ser la galería originalmente son las copias de estas obras hechas en 1634 por voluntad de Felipe IV para lucir en una de las estancias del palacio madrileño del Buen Retiro. Para la elaboración de las mismas contrató a los pintores Francisco Camilo, a los hermanos Pedro y Andrés Urzanqui y a Vicente Tió. La realización de copias sin duda ha puesto de manifiesto la relevancia histórica que tuvo el conjunto. 108

Las efigies asumieron un papel principalmente representativo y

del Prado, Vol. 11, no. 29, 1990, pp. 19-36; Carmen Morte García, 'Pintura y política en la época de los Austrias. Los retratos de los reyes de Sobrarbe, condes antiguos y reyes de Aragón para la Diputación de Zaragoza (1586), y las copias de 1634 para el Buen Retiro de Madrid (II)', Boletín del Museo del Prado, Vol. 12, no. 30, 1991, pp. 13-28. Sobre Ariosto consúltese Rodolfo Galeano Carretero, 'La sèrie iconogràfica dels comtes i comtes-reis de Catalunya-Aragó, del pintor Filippo Ariosto, per al Palau de la Generalitat de Catalunya (1587-1588).Art, pactisme i historiografía', Butlletí del Museu Nacional d'Art de Catalunya, no.7, 2004, pp.51-70 y 'Historiografia i iconografia: La sèrie icònica dels Comtes de Barcelona del Palau de la Generalitat de Catalunya (1587-1588)', Arxius de Textos Catalans Antics, no.25, 2006, pp.375-409.

108 Reflexiones de Carmen Morte planteadas en la introducción de la edición en facsímil de Jerónimo de Blancas, Explicación histórica de las inscripciones de los retratos de los reyes de Sobrarbe, condes antiguos, y reyes de Aragón : puestos en la Sala Real de la Diputación de la Ciudad de Zaragoça, y colocación del retrato del Rey N. Señor Don Carlos Segundo, (Cortes de Aragón: Zaragoza, 1996). 
ejemplar desde que fueron ideadas, por ello era necesario que todos mostrasen su plena magnificencia. Se representa-ron de cuerpo entero, con vestiduras civiles o militares, las insignias reales y el escudo de armas, tanto el personal como el del reino. Siguiendo los estudios de la citada autora, los atuendos militares se han reservado para los reyes de Sobrarbe y los condes de Aragón, quienes encarnan los valores del «héroe antiguo». La indumentaria civil, generalmente, reproduce la clase de traje que se llevaba en la ceremonia de la coronación y por ello, se reserva para aquellos que ostentaron el título de monarca de Aragón. Igualmente, estos últimos portan las insignias reales como la corona, el cetro, el collar o el orbe. Cabe plantearse la posibilidad de si los retratos regios de cuerpo entero que se mencionan en la documentación de archivo del palacio Real de Valencia se acercaban mucho más a las pinturas de Zaragoza.

Este proyecto artístico tenía la intención de perpetuar la memoria de los reyes dejando constancia de su imagen de poder. A su vez, se estaba escribiendo la historia de estos monarcas como evidenció la obra, previamente citada, de Jerónimo de Blancas Explicación histórica de las inscripciones de los retratos de los Reyes de Sobrarbe, Condes antiguos, y Reyes de Aragón, puestos en la Sala Real de la Diputación de la Ciudad de Zaragoza, y colocación del Retrato del Rey N. Señor Don Carlos Segundo. Esta fuente escrita incluyó los textos latinos que acompañaban a los retratos, con su traducción castellana y un detallado comentario biográfico de cada monarca, que incluso es de interés para este estudio por proporcionar descripciones clave para entender la iconografía particular de los reyes de Aragón. Además, a partir de la obra de Blancas, Andrés Uztarroz escribió diversas composiciones poéticas y laudatorias para la memoria de los soberanos. ${ }^{109}$

Una vez presentada la serie de retratos del palacio de la Dipu109 Aurora Egido Martínez, 'Retratos de los Reyes de Aragón; de Andrés de Uztarroz y otros poemas de Academia', Cuadernos de historia Jerónimo Zurita, no. 33, 1979, pp. 173-223. 
tación de Aragón para tenerla como referente, conviene detenerse en las efigies que componen el conjunto valenciano y establecer algunos puntos en común entre unas obras y otras para alcanzar una mejor comprensión de las mismas. En la primera imagen se identifica al soberano que abanderó el proceso de reconquista del territorio valenciano, Jaime I de Valencia y de Aragón (reinado entre 1213 - 1276) [fig. 3.43]. Aquí se ha estipulado el tipo de representación que marcará la pauta para el resto de obras. Son retratos de carácter oficial, cuyo formato es de medio cuerpo donde los reyes van ataviados con las vestiduras reales o con armadura y llevan insignias regias como la corona, el collar o la espada. El fondo, por lo general, se ha engalanado con un cortinaje que además se abre hacia el paisaje. En la parte inferior, una cartela especifica la identidad del monarca.

A Jaime I el Conquistador se le ha representado vestido con la capa real de armiño y una corona ornamentada con piedras preciosas y flores de lis. Igualmente, sostiene el cetro en la mano derecha y la espada en la izquierda. Por lo que se intuye en el paisaje del fondo, se ha representado la aparición milagrosa de las siete estrellas que indicaban dónde se encontraba la imagen escondida de la Virgen del Puig:

Había en el Puche un ilustre monasterio de monjes de Benitos y luego que entendieron que Valencia estaba por los moros, cuando se perdió España, sin más aguardar desampararon la tierra: pero como prenda y señal de su vuelta (que confiaban poder hacer algún día con el favor del cielo) abrieron un hoyo profundísimo en la tierra, y metiendo dentro una campana, dejaron depositada debajo de ella una imagen de mármol de la Virgen, muy bien acabada, y de mucha veneración. [...] Estando ya por el rey don Jaime el castillo, acaeció que los centinelas acertaron una noche a volver los ojos hacia las ruinas del templo y les pareció que del cielo bajaba unas hachas encendidas, que tocando el suelo, se hundían en él. Quedaron desde entonces avisados, de mirar más de propósito 


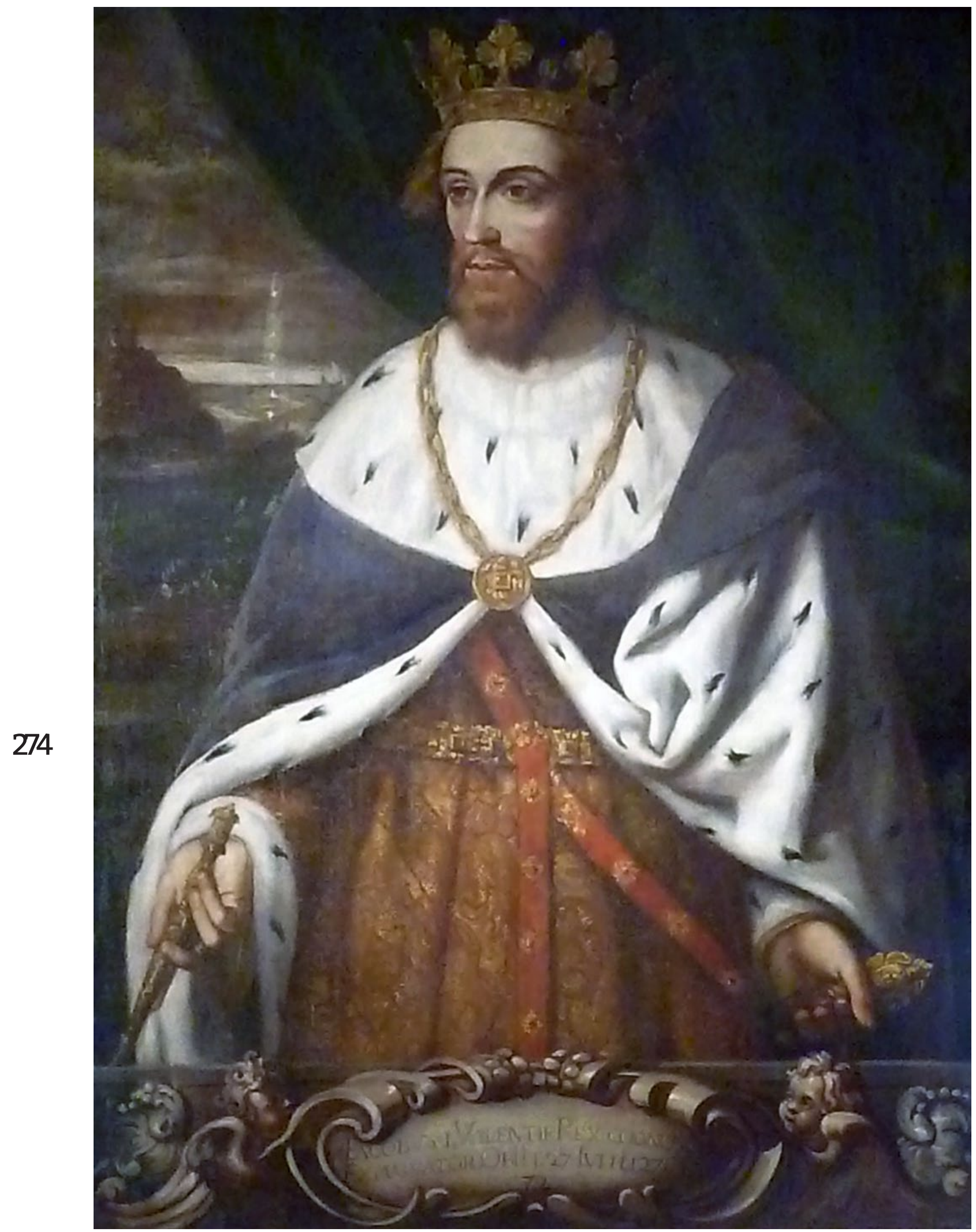

Fig. 3.43. Jaime I de Valencia y de Aragón, el Conquistador, s. XVII, Valencia, palacio de la Generalitat. 
en ello, para las noches siguientes: y vieron por muchos sábados la continuación de bajar las luces, y que esto se hacía por siete veces cada sábado, comenzando desde la hora prima hasta la media noche. Le dieron cuenta de todo a don Guillem d'Entença, castellán del castillo: y placticando en ello, acordaron de conformidad que se cavara en aquel lugar donde se sumergían las luces. ${ }^{110}$

Esta historia se ha representado el fondo del retrato porque según cuentan las fuentes escritas fue un hecho crucial para que el rey acometiese la reconquista del reino y finalmente instaurase una monarquía cristiana en este territorio.

Pasó así, hasta que por los años del Señor de 1236, edificado el castillo que llamaron del Puche, en el monte, o cerro más eminente, para que desde allí comenzasen su conquista los Católicos, guiados del valor, y celo de nuestro invictísimo rey don Jaime; y entregada la fortaleza a don Bernardo Guillen su tío, para que fuese castellano de ella: asistiéndole nuestro padre y glorioso patriarca san Pedro Nolasco, únicamente querido, y favorecido del rey [...]. Y según consta, fue parte principal para alentar el ánimo y corazón del rey a emprender la conquista de este reino, porque le aseguró, con orden del cielo, indubitablemente el próspero suceso [...]. ${ }^{111}$

La inscripción pertinente reza que: «IAcobus I Valentie Rex CogNOM. EXPUGNATOR OBIt, 27 IULII 1276, [AET] 72.» El retrato es similar al ya visto en la galería de efigies monárquicas del Colegio del 110 Gaspar Escolano, Segunda parte de la década primera de la historia de la insigne y coronada ciudad y Reino de Valencia, (Pedro Patricio Mey: Valencia, 1611), libro séptimo, cap. VI. Que prosigue con la descripción del campo de Valencia hasta la villa del Puche de Nuestra Señora, con antigüedades muy curiosas del tiempo de Romanos: y como fue hallada la imagen de nuestra Señora en el tiempo de conquista, pp. 351 - 352. Esta leyenda también aparece en Diago, Anales del Reino de Valencia..., tomo I, libro VIII, cap. XV, p. 302.

111 Francisco Boyl, N.S. del Puche: cámara angelical de María Santísima, (Silvestre Esparza: Valencia, 1631), fol. $2 \mathrm{r}$ - v. Seguidamente se narra la bajada de las siete estrellas. 
Corpus Christi y, por tanto, es un ejemplo más de cómo esta imagen en concreto se repitió en numerosas ocasiones. En cualquier caso, la representación del soberano es de completa amabilidad hacia su persona, una visión positiva que ya se había extendido en la Edad Media. ${ }^{112}$ Así, su retrato imaginado concuerda con la halagüeña descripción de Bernat Desclot, quien lo retrataba de la siguiente manera:

Este rey don Jaime de Aragón fue el hombre más hermoso del mundo; era un palmo más alto que los demás y muy bien formado, y perfecto en todos sus miembros; tenía el rostro sonrosado y fresco, la nariz larga y recta, y la boca grande y bien dibujada, y dientes grandes, bonitos y blancos que parecían perlas, y bonitos cabellos rubios semejantes al hilo de oro, y anchas espaldas, y cuerpo largo y delgado, y los brazos fornidos y bien contorneados, y bellas manos y largos dedos, y los muslos gruesos, y las piernas largas, rectas y gruesas de acuerdo con su medida, y los pies largos y bien formados y calzados elegantemente. $Y$ fue muy atrevido y valeroso en las armas, y fuerte y valiente, y generoso en dar, y agradable a todas las gentes, y muy misericordioso; y puso todo su corazón y toda su voluntad en guerrear contra los sarracenos. ${ }^{113}$

Así, la atribución de unos determinados rasgos físicos y habilidades personales como la fortaleza o valentía se dibuja textualmente en la imagen de un monarca crucial para la Corona de Aragón y para el devenir del Reino de Valencia, pues será

112 Para la iconografía de Jaime I durante la época medieval se puede seguir a Marta Serrano Coll, Jaime I el Conquistador: imágenes medievales de un reinado, (Institución 'Fernando el Católico': Zaragoza, 2008); Marta Serrano Coll, Effigies Regis Aragonum: la imagen figurativa del rey de Aragón en la Edad Media, (Institución Fernando el Católico, Diputación de Zaragoza: Zaragoza, 2015); Marta Serrano Coll, 'Programas ideológicos a través de la imagen: algunos ejemplos de la Edad Media', Medievalista, Vol. n 9, 2011.

113 Este fragmento de Bernat Desclot ha sido citado por María de los Desamparados Cabanes Pecourt, "Jaime I», en Los reyes de Aragón, (Caja de Ahorros de la Inmaculada Aragón: Zaragoza, 1993), pp. 81-90. 
el rey elegido por Dios para defender y conseguir el triunfo del cristianismo ante un territorio de dominio musulmán. En este sentido, Ramón Muntaner remarcó la trascendencia de Jaime I como monarca al especificar que él fue:

Rey de natura, e Rey de virtut, e de gracia: que asenyaladament havets entes que obra de Deus fo lo seu neximent, e dels majors miracles e pus vahibles que may foren feyts, fo aquest. Per que cascun dels Reys que son estats en Aragó, e a Mallorques, e en Sicilia: ne que de aquí en avant serán dels dexendents poden fer compte que son en aquell mateix grau Reys de gracia, e de virtut, e de vera natura. Que axi com Deus los ha creats, axils exalça, e exalçara tostemps contra tots lurs enamichs. ${ }^{114}$

De este modo, Jaime I inaugura la serie de reyes valencianos pertenecientes a la dinastía de Aragón, monarcas que estaban predestinados a asumir dicho papel por voluntad divina y que encarnaron las virtudes de los buenos gobernantes para convertirse en el espejo de su pueblo.

El retrato de Pedro I de Valencia y III de Aragón (reinado entre 1276 - 1285) [fig. 3.44] siguió la tipología de efigies iniciada con la imagen de Jaime I, su padre. En este caso, se ha preferido acentuar su faceta militar vistiéndolo con la armadura y la capa real, como sucede en la copia conservada en el Museo Nacional del Prado perteneciente a la serie de reyes de Aragón pintadas originalmente por Ariosto [fig. 3.45].

Sus gestas bélicas y virtudes le permitieron adquirir el apelativo de «el Grande, por ser tan excelente caballero y gran capitán, para diferenciarle de otros reyes que hubo en Aragón de su nombre; siendo verdaderamente el Príncipe de más generoso ánimo, bien afortunado, cuerdo, sabio, valeroso secreto, 114 Ramón Muntaner, Chronica, o descripcio dels fets, e hazanyes del inclyt rey don Iaume primer, Rey Daragon, de Mallorques, e de Valencia: Compte de Barcelona, e de Muntpesller: e de mols de sos descendents, (Iaume Cortey: Barcelona, 1562), fol. $5 \mathrm{r}$ - v. 
y estimado de todos los reyes cristianos, e infieles que en su tiempo hubo». ${ }^{115}$ Uztarroz entre sus versos también incluyó algunas referencias a detalles iconográficos del retrato que van parejos a los valores asociados a este monarca, por ello dijo que empuñaba "con la diestra mano el acero", ya que tomar la espada era un signo más para remarcar su poder y caballería. ${ }^{116}$ La correspondiente inscripción reza lo siguiente: PETRUS VAL. I ET ARAG. III COG[...] MAGNUS, OBIIT 3 IANUARII 1285 AET 46.

Alabanzas similares se le hicieron a Alfonso I de Valencia y III de Aragón (reinado en 1285 - 1291), el Liberal [fig. 3.46]. Se le ha retratado con ricos ropajes de terciopelo carmesí, con una abotonadura dorada en el cetro y la capa de armiño. Según las fuentes escritas fue «uno de los grandes Príncipes que tuvo esta corona, liberal, casto, y de generosas, y loables costumbres. Unió a sus reinos el de Menorca que, aunque conquistado por su abuelo, quedó con el reconocimiento de dominio, feudo y vasallaje que se le hizo, debajo del mando, y gobierno del rey 278 moro, hasta entonces se apoderó de él.»117 La inscripción ha servido para identificar al efigiado como: ALFONSUS VAL. I. ARAG. III. COGN. LIBERALIS. OBIT 18 IUNII 1291. AET 27.

El retrato de Jaime II de Valencia y de Aragón (reinado en 1291 -1327) [fig. 3.47] lo refleja como el soberano que debe impartir justicia con rectitud, en alusión al sobrenombre que tradicionalmente se le ha otorgado, Jaime II el Justo. Además de su severidad, de este personaje se ha remarcado su espíritu caritativo con las comunidades religiosas y con los peregrinos. ${ }^{118}$

115 Blancas, Explicación histórica..., 1996, p. 246. También puede consultar la versión digital de Jerónimo de Blancas, Inscripciones latinas a los retratos de los reyes de Sobrarbe, condes antiguos y Reyes de Aragon puestos en la Sala Real de la Diputacion de la Ciudad de Zaragoça, (Herederos de Diego Dormer: Zaragoza, 1680).

116 Egido Martínez, 'Retratos de los Reyes...', p. 28, versos 353-354.

117 Blancas, Explicación histórica..., 1996, p. 260.

118 Carmen Orcástegui Gros, 'Jaime II', en Los reyes de Aragón, (Caja de 


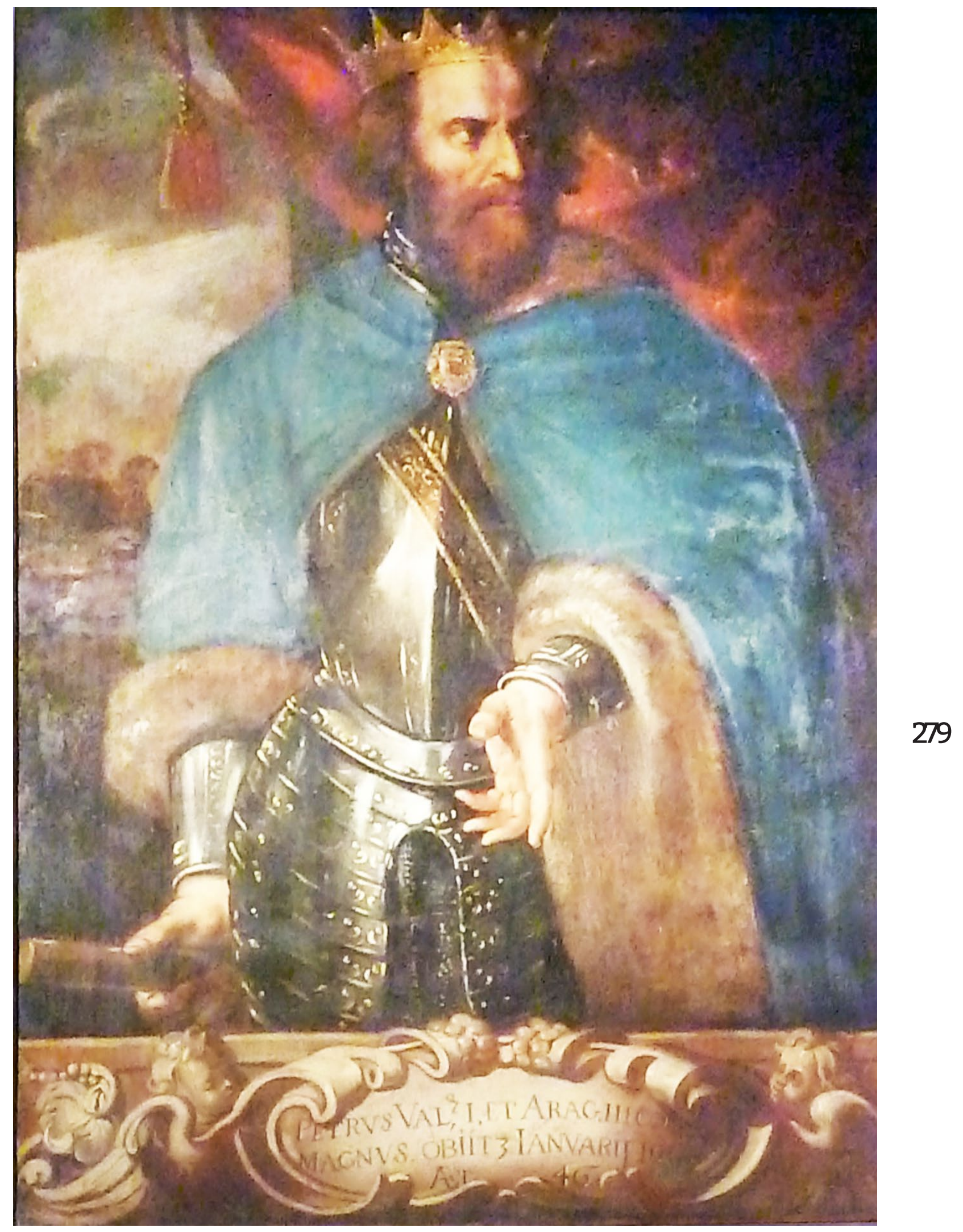

Fig. 3.44. Pedro I de Valencia y III de Aragón, el Grande, s. XVII, Valencia, palacio de la Generalitat. 


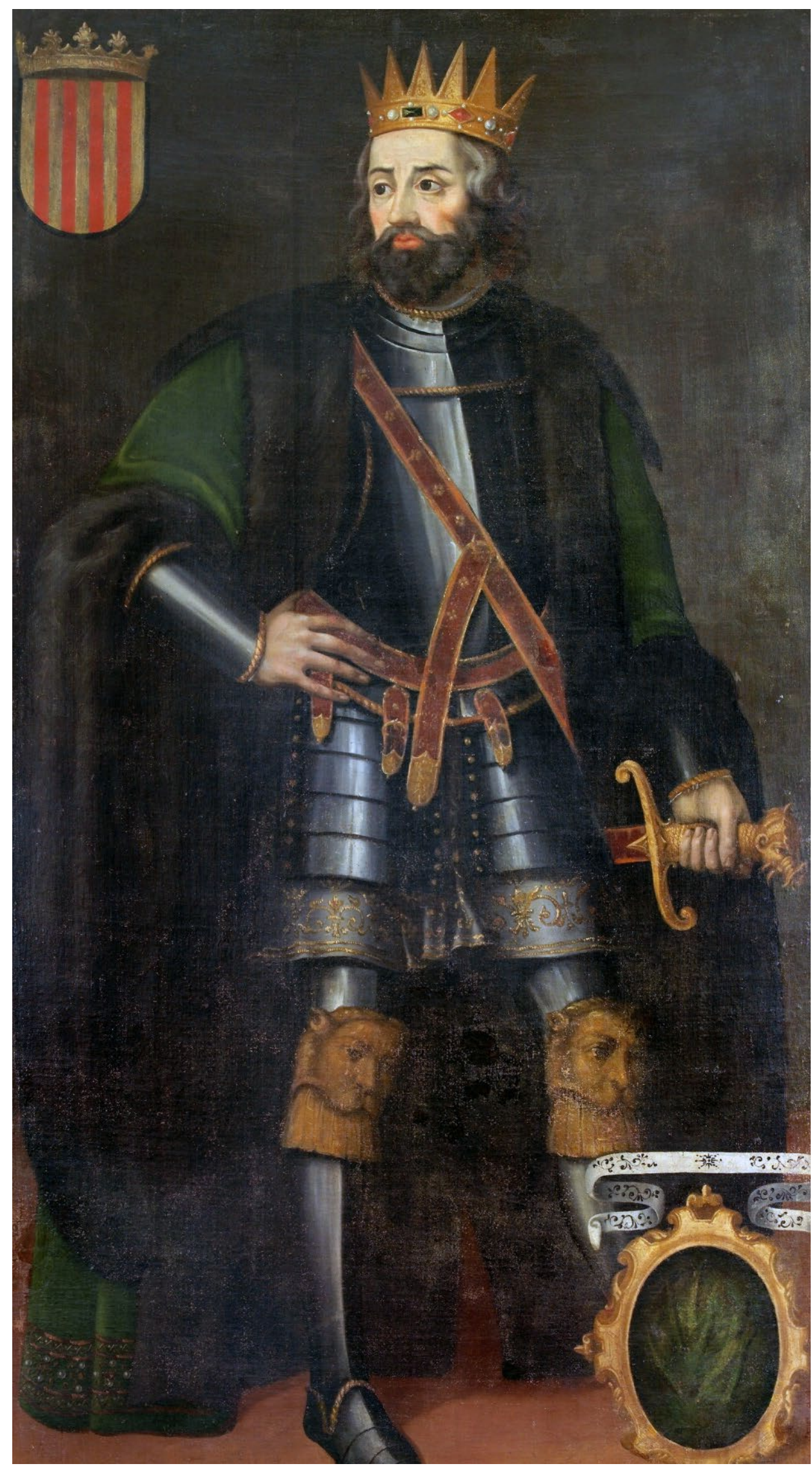

Fig. 3.45. Anónimo (copia de Ariosto), Pedro III, el Grande, 1634, óleo sobre lienzo, Madrid, Museo Nacional del Prado. 


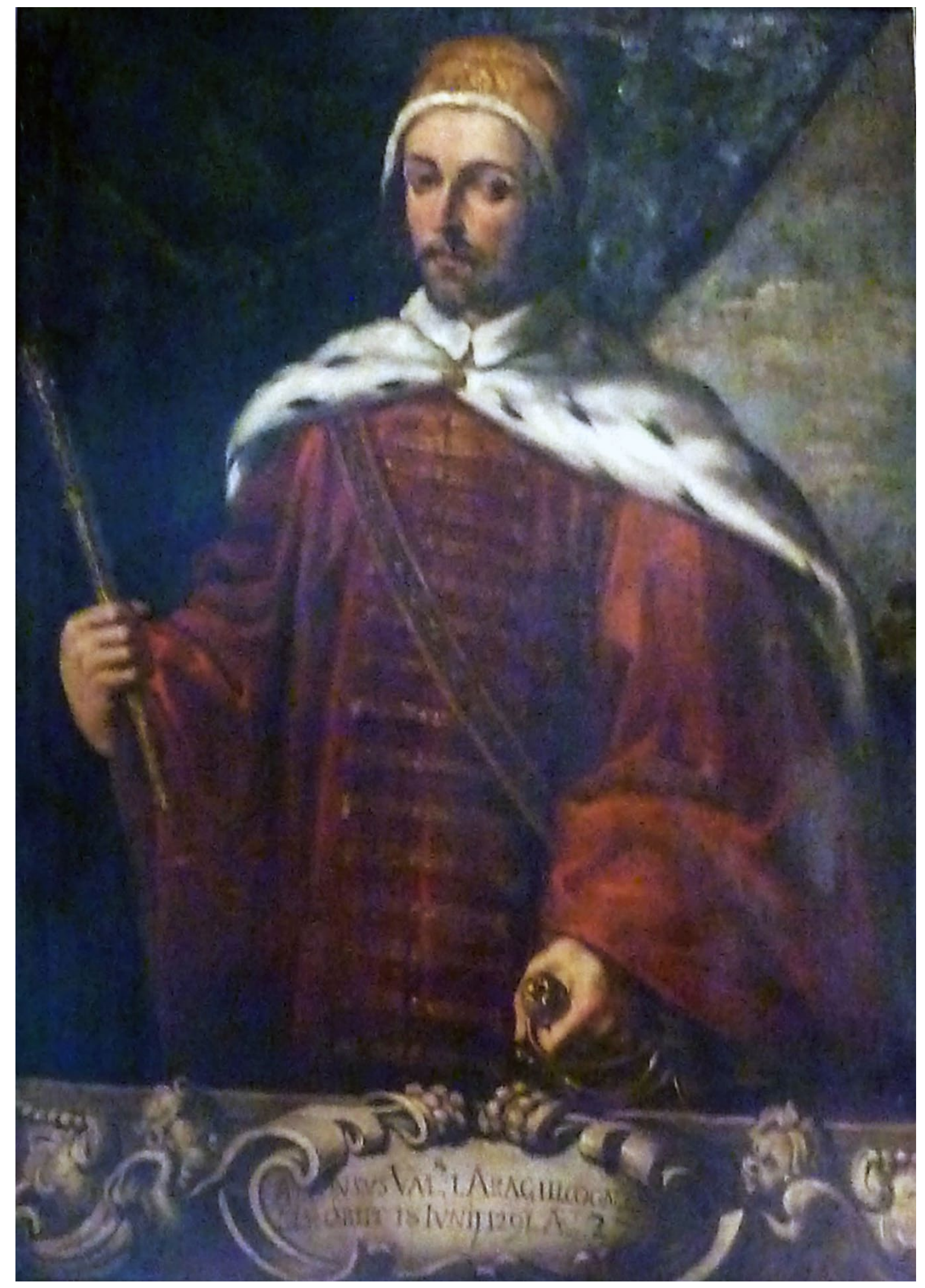

281

Fig. 3.46. Alfonso I de Valencia y III de Aragón, el Liberal, s. XVII, Valencia, palacio de la Generalitat. 


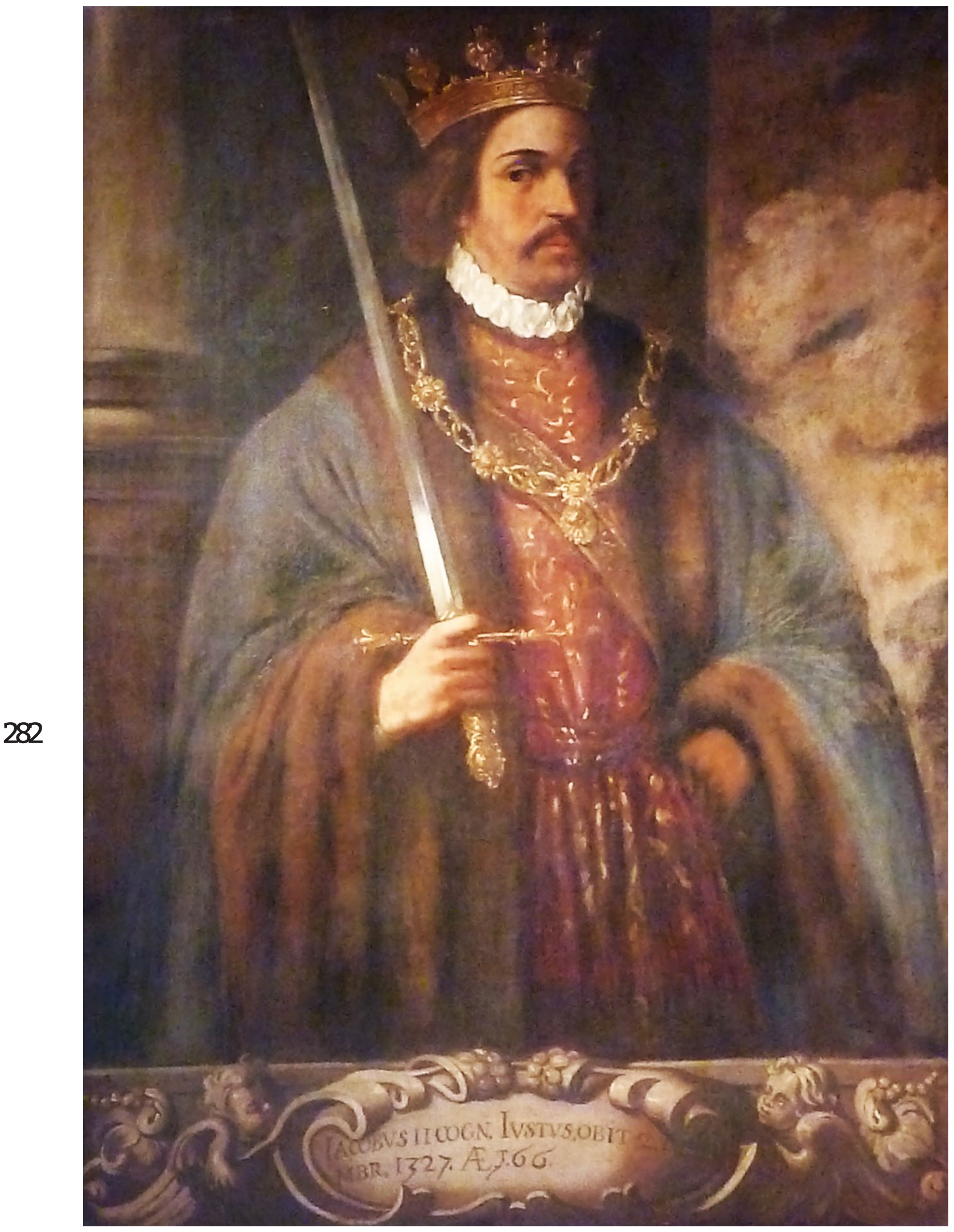

Fig. 3.47. Jaime II de Valencia y de Aragón, el Justo, s. XVII, Valencia, palacio de la Generalitat. 
Jerónimo de Blancas asimismo destacó su sentido de la ecuanimidad:

Jaime Segundo el Justo, hijo de Pedro Tercero, rey de Aragón decimoséptimo, estando en Sicilia poseyendo aquel reino que había obtenido de su padre, fue por la muerte de su hermano don Alonso que murió sin casarse, llamado de los nuestros para entrar en el oficio de rey, y así habiendo venido a esta ciudad y recibido en ella la corona, y el gobierno del reino, claro en la justicia, y equidad, e ilustre en la estimación, y la fama, después también de haber hecho dentro y fuera del reino muy señaladas cosas, acabó su vida a IV de las nonas de noviembre en el año LXVI de su edad y MCCCXXVII del nacimiento del Señor. Reinó XXXVI años, IIII meses y XIV días. ${ }^{119}$

En consecuencia, el artista decidió que la espada adquiriese un especial protagonismo en el conjunto de la imagen. Con los mismos atributos fue representado en el conjunto de retratos pintados por Ariosto y a día de hoy conservados en el Museo Nacional del Prado [fig. 3.48]. Cabe recordar que en la cultura visual barroca, la espada era símbolo de la justicia y de la potestad. En la parte inferior, se especifica lo siguiente: IACOBUS II COGN. IUSTUS, OBIT 2 N[...]MBR, 1327. AET. 66.

Alfonso II de Valencia y IV de Aragón (reinado entre 1327 1336) [fig. 3.49], llamado el Benigno o el Piadoso porque fue «el mas cortés de palavra et el mas familiar et el mas avinent a los sus sozmesos que otro rey que al mundo fues, que así les fue como a conpanyero. [...] Et aquí con muyt mas honramiento que nunca Rey se coronas, fue coronado et untado en Rey».120 Alfonso IV consideraba que el territorio aragonés era «la cabeAhorros de la Inmaculada Aragón: Zaragoza, 1993), pp. 107-112.

119 Blancas, Explicación histórica..., 1996, pp. 265-266.

120 Historia de la corona de Aragón (la más antigua de que se tiene noticia) conocida generalmente con el nombre de Crónica de san Juan de la Peña, (Diputación Provincial: Zaragoza, 1876), Cap. XXXIX. Del rey Alfonso IV, y de todos sus hechos. 


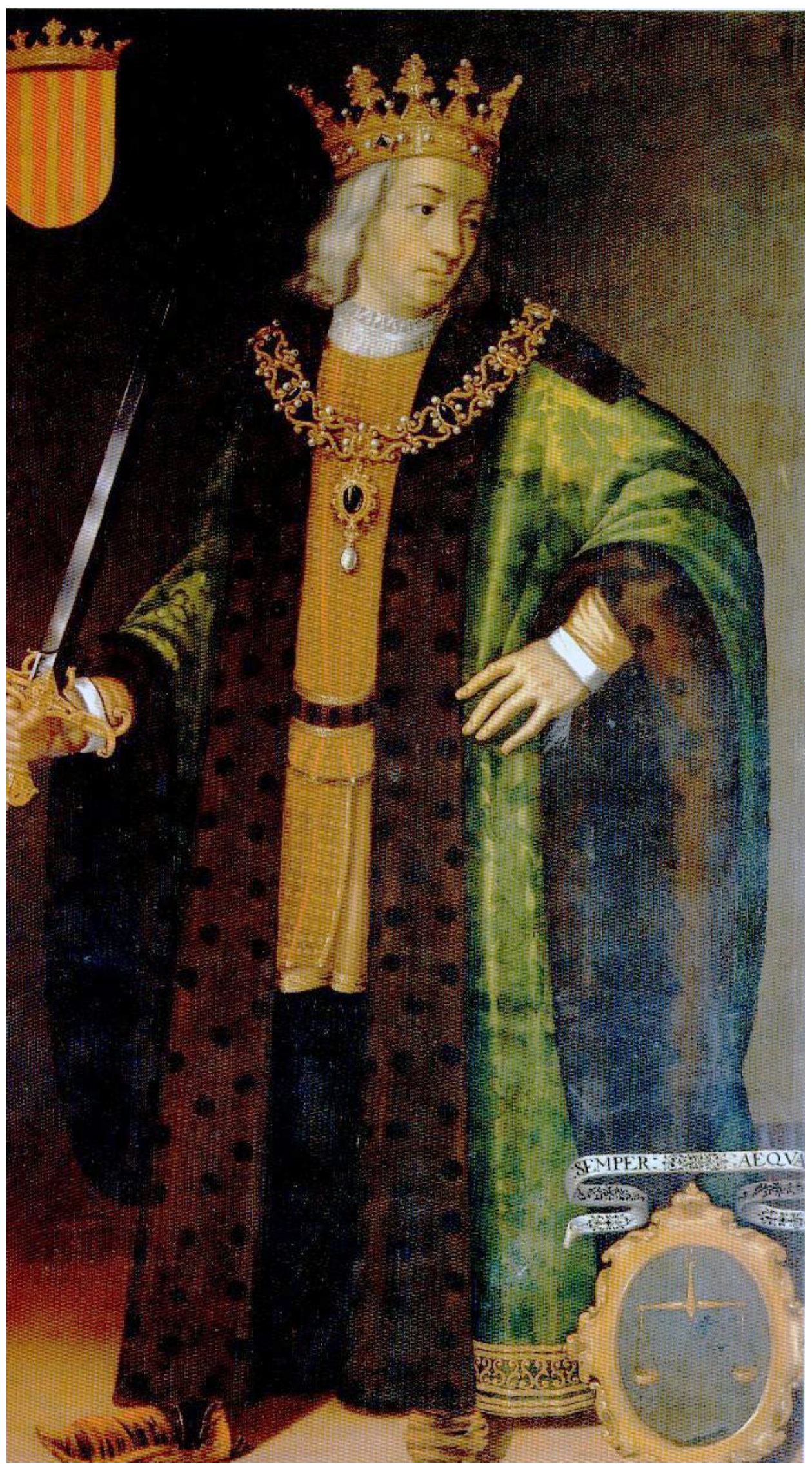

Fig. 3.48. Anónimo (copia de Ariosto), Jaime II, el Justo, 1634, óleo sobre lienzo, Madrid, Museo Nacional del Prado. 


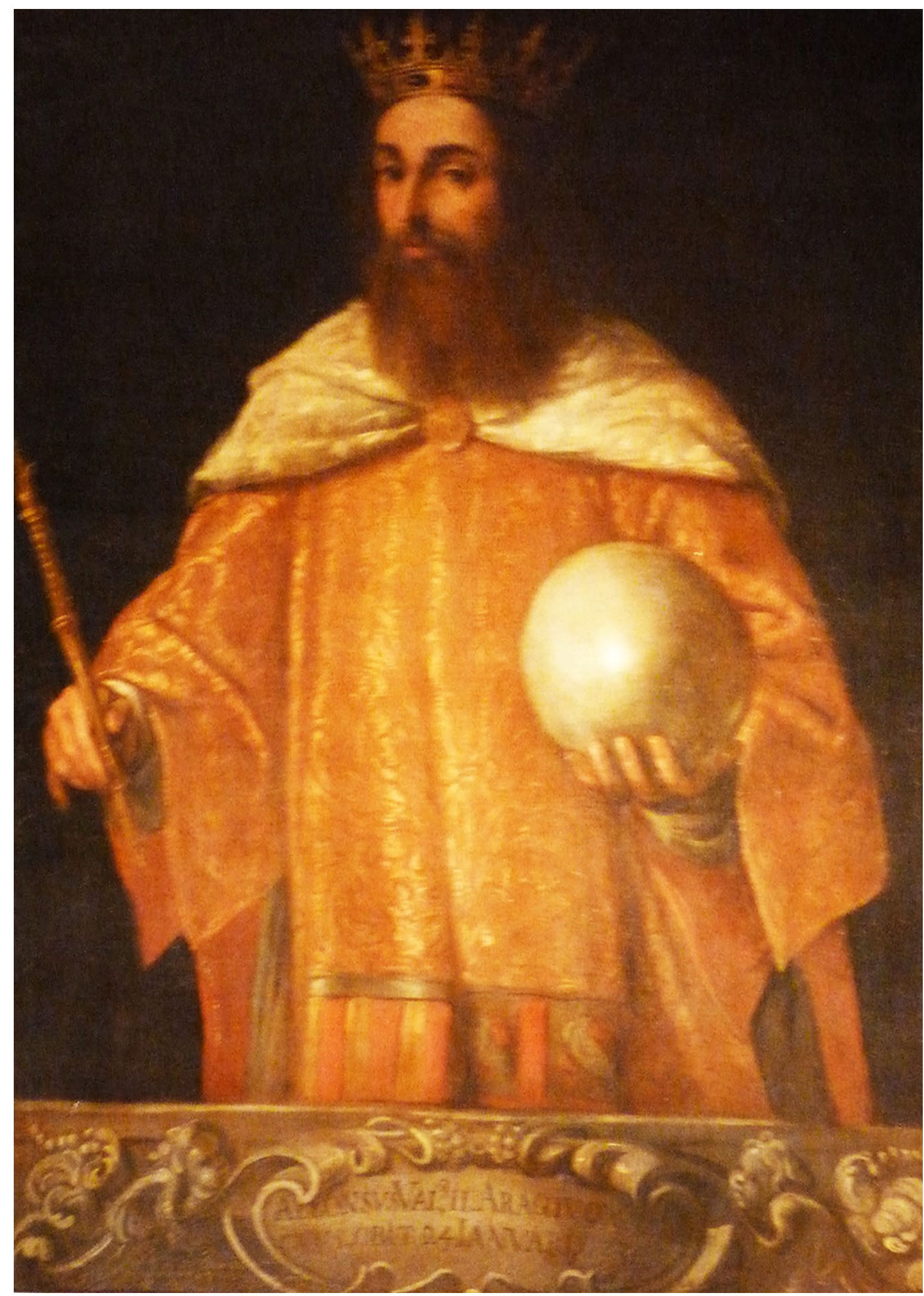

285

Fig. 3.49. Alfonso II de Valencia y IV de Aragón, el Benigno, s. XVII, Valencia, palacio de la Generalitat. 
za de sus reinos y lo principal de su estado" por ello, se coronó en Zaragoza el 3 de abril de $1328 .{ }^{121}$

La ceremonia tuvo lugar en la catedral del Salvador y allí se colocó la tiara engalanada con rubíes, zafiros y perlas, tomó una vara con la mano izquierda en alusión a la justicia y un orbe para remitir a las tierras que Dios le ha concedido y que debe gobernar y defender. ${ }^{122}$ En consecuencia, la efigie de este monarca lo representa en este momento, con los objetos entregados en la coronación. En sus ropajes se deja entrever las cuatro barras de gules del escudo de armas de Aragón, siendo un nuevo guiño a la casa a la cual perteneció y a la preeminencia de esta zona respecto al resto de reinos que conformaron la Corona de Aragón. En lo tocante a la inscripción, se lee lo siguiente: ALFONSUS VAL. II. ARAG. IV. COGN. [BENI]GNUS OBIT 24 IANUARI [1336]. De forma muy similar se le ha mostrado en el conjunto de la Diputación aragonesa [fig. 3.50]. De hecho, Jerónimo Blancas también describió el ambiente fastuoso del que se rodeó Alfonso IV y relató minuciosamente su ceremonia de coronación, haciendo referencia a la entrega de las insignias de poder que aparecen en sus retratos.

[...] el domingo de Pascua de resurrección, en que resolvió ungirse, coronarse, y tomar las reales insignias en la forma acostumbrada, pero con mayor grandeza, aparato, y solemnidad que se había hecho en otras ocasiones, por cuya causa concurrieron a este acto muchos, y muy grandes personajes de diferentes partes, y reinos fuera de la Corona. [...] y el rey de su mano puso la corona, y espada en el altar mayor, y se vistió de un alba, y encima de ella una dalmática real, y su estola, y manípulo, [...] y el rey besó la cruz de su espada, y él mismo se la ciñó, y después de ceñida la arrancó de la vaina, y la blandió tres

121 Guillermo Fatás, Prontuario aragonés del Reino y de la Corona de Aragón, (Cortes de Aragón, 2014).

122 José Luis Corral Lafuente, 'Pedro IV', en Los reyes de Aragón, (Caja de Ahorros de la Inmaculada Aragón: Zaragoza, 1993), pp. 119-128. 


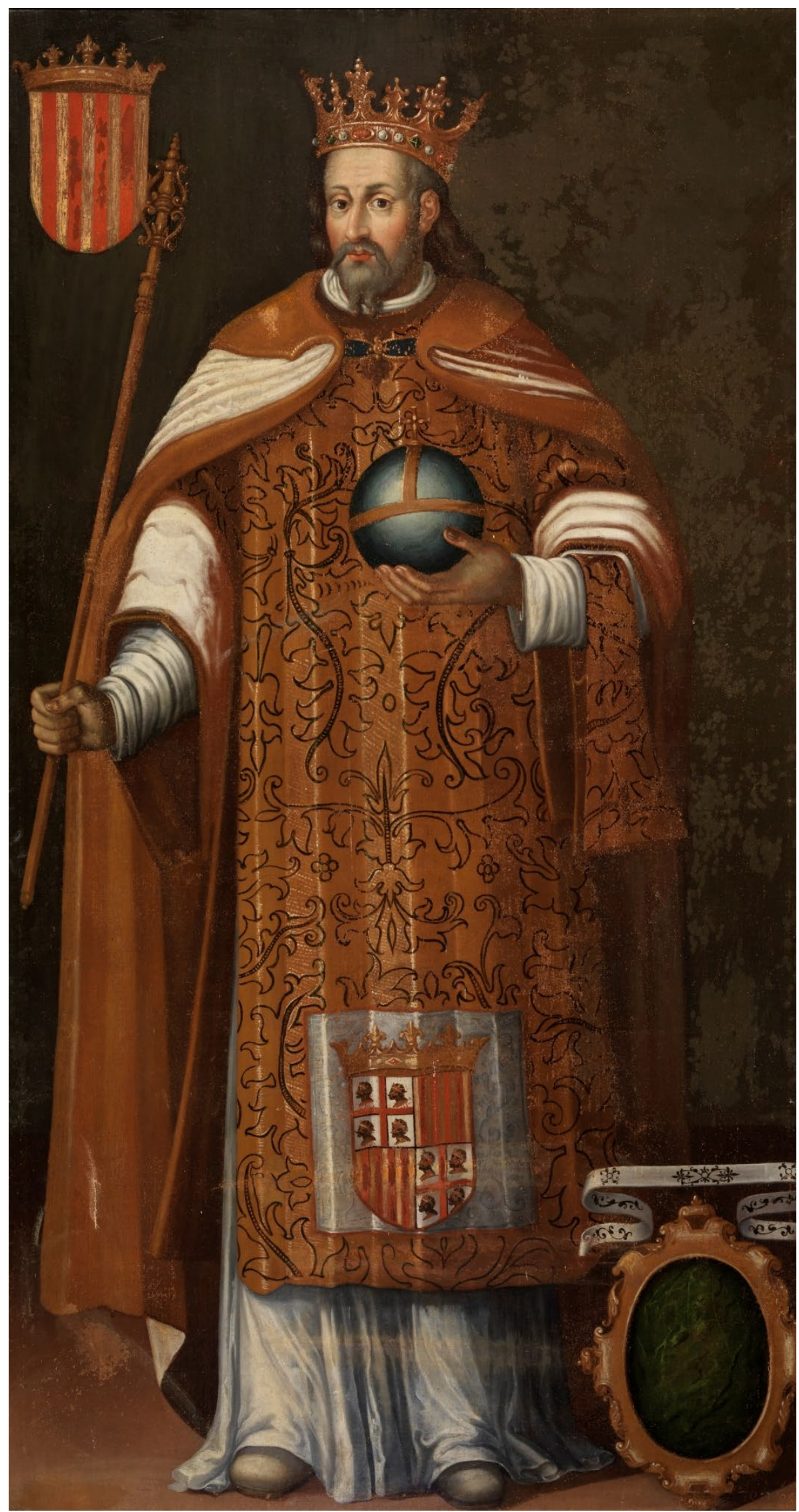

Fig. 3.50. Anónimo (copia de Ariosto), Alfonso IV, el Benigno, 1634, óleo sobre lienzo, Madrid, Museo Nacional del Prado. 
veces. Después que fue cantado el Evangelio, el arzobispo le ungió en la espalda y en el brazo derecho, y acabada la misa, se desciñó la espada y la puso en el altar mayor junto a la corona, y entonces se revistió el infante don Juan, y habiendo comenzado otra misa, el rey tomó la corona del altar, y él mismo se la puso en la cabeza, y teniéndola puesta llegaron los infantes don Juan y don Pedro y don Ramón Berenguer sus hermanos, y se la aderezaron, y entonces todos los prelados y abades y el clero cantaron las oraciones que tiene ordenadas la iglesia para las coronaciones de los reyes, y tomó el rey el cetro, y pomo de oro. $[\ldots]^{123}$

En consecuencia, la efigie del monarca concuerda completamente el relato y por ello, siempre luce la corona, el cetro y el orbe. Además como en la ceremonia de coronación se le ha vestido con un alba sobre la que lleva la dalmática real y el manípulo.

A Pedro II de Valencia y IV de Aragón (reinado entre 1336 1387) [fig. 3.51] se le ha retratado de frente, con expresión severa y mirada decidida hacia el espectador. Una vez más, se le viste con la capa de armiño y porta la corona. Asimismo, se han añadido dos elementos muy característicos en la iconografía de este monarca; el libro y el puñal. El primero de ellos, se puede relacionar con la redacción, en 1344, de las Ordinacions fetes per lo senyor en Pere terz rey d'Aragó sobre lo regiment de tots los officials de la sua cort, es decir, el conjunto de normas que dictaban el funcionamiento de la monarquía aragonesa. Su especial interés por la etiqueta y por ritual le valió para asumir el apelativo del Ceremonioso.

Fue llamado el Ceremonioso por lo observante, celoso y puntual en conservar las ceremonias tocantes al tratamiento, y veneración de la dignidad real; y en prosecución de esto, dio forma en las de su real palacio, y casa, y en las que debían guardarse en adelante cerca de la

123 Blancas, Explicación histórica..., 1996, pp. 280-282. 


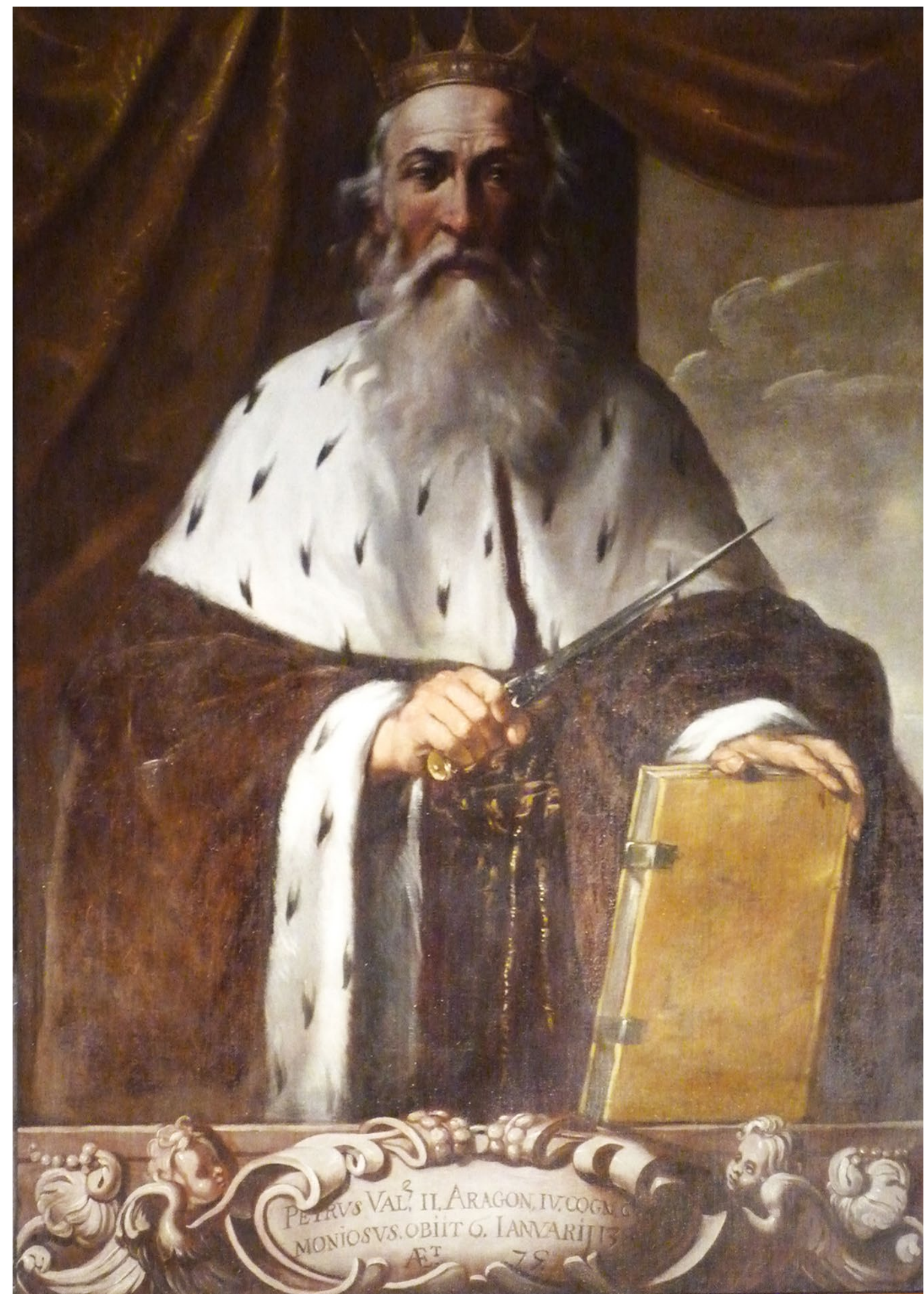

Fig. 3.51. Pedro II de Valencia y IV de Aragón, el Ceremonioso, s. XVII, Valencia, palacio de la Generalitat. 
unción y coronación de los reyes sus sucesores. Fue de los príncipes de mayor viveza, prontitud, y resguardo en la ejecución de sus resoluciones, y máximas de estado, y de la mayor pericia, magnanimidad, gran consejo, e inteligencia del uso, y ejercicio de la guerra, que hubo en su edad, digno de toda estimación, y fama, si su natural ardiente, y rígido, fuera más humano, y templado, y se inclinara más a la piedad, y clemencia, que a la indignación, y castigo. ${ }^{124}$

Sin embargo, también era conocido por Pedro el del punyalet, arma que aparece en empuñando en este retrato. El puñal se convirtió en un elemento propio de su imagen tras utilizarlo para desgarrar los pergaminos, los sellos y las bulas del Privilegio de la Unión o Privilegio General. ${ }^{125}$ Incluso en este suceso llegó a herirse la mano izquierda: «Allí mismo cortó y rasgó el privilegio de la unión con su puñal: fue tanta la ira con que lo cortaba que de la mucha presteza se hirió en la mano izquierda». ${ }^{126}$ Una explicación más dilatada acerca de este hecho la ha proporcionado Jerónimo Blancas al narrar que:

Sacaron de las casas de la ciudad en público el pendón o estandarte de esta congregación, para la defensa que juzgaron común, y para el reparo de la fuerza que pretendían les hacía en ello el rey; el cual después de acomodadas las cosas en la mejor forma que se pudo, obtuvo, con la voluntad de los Estados del reino, en las Cortes que se celebraron en la ciudad de Zaragoza el año siguiente

124 Blancas, Explicación histórica..., 1996, pp. 291- 292.

125 En 1283, la nobleza aragonesa se unió para imponer al rey el cumplimiento del Privilegio General o de la Unión, por el cual el monarca reconocía los fueros y los privilegios tradicionales del territorio de Aragón. Además, se reclamaban una serie de cuestiones económicas y jurídicas y se citaba al rey a reunirse con la nobleza cada 1 de noviembre. En 1348, Pedro IV abolió este pacto tras la batalla de Épila aunque mantuvo algunos de los privilegios. Véase Fatás, Prontuario aragonés..., p. 82.

126 Luca Marineo, Crónica de Aragón, (Juan Jofre: Valencia, 1574), Libro cuarto, fol. XLIXr. 


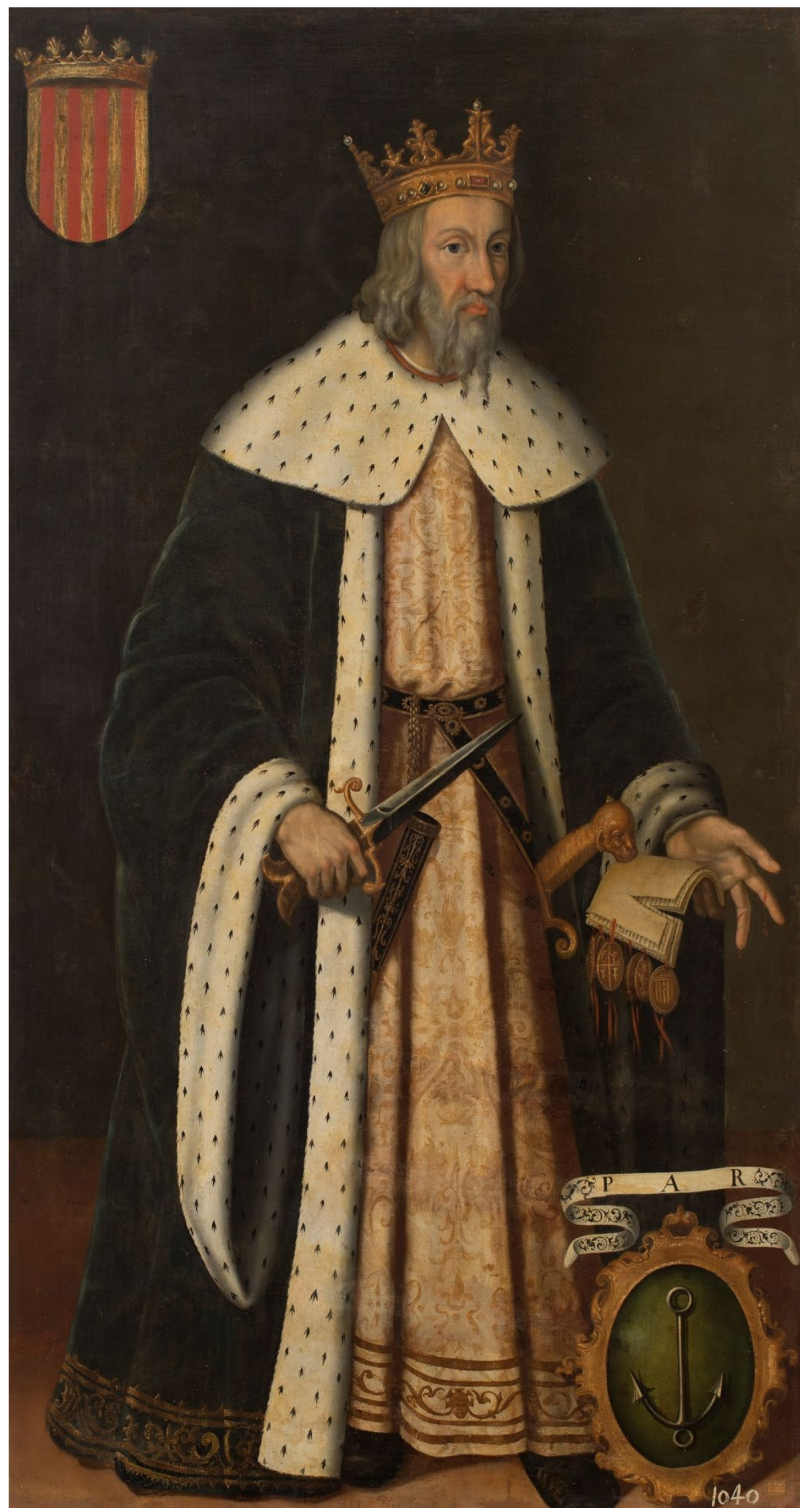

291

Fig. 3.52. Anónimo (copia de Ariosto), Pedro IV, el Ceremonioso, 1634, óleo sobre lienzo, Madrid, Museo Nacional del Prado. 
de mil trescientos y cuarenta y ocho, en cuatro del mes de octubre, la revocación del referido Privilegio, incentivo de algunos inconvenientes que se habían experimentado, que libre ya de lo que podía ocasionarlos, con más equidad, y atención a la justicia, que a la desorden y violencia, se transfirió lo más de su sustancia, y principal justificado fin, en la jurisdicción, y sufragio del justicia de Aragón, y de su corte, según que hasta de presente se ha observado. Casòse aquel Privilegio, y los instrumentos de él se rompieron; el rey por su propia mano cortó con un cuchillo, o daga, que consigo ordinariamente traía, el original, y con tan acelerada acción, que cortándose la mano, la tiñó en sangre, diciendo con aquella viveza de ingenio, y prontitud suya: Muy justa, y natural cosa es, que Privilegio ganado por varones tan grandes, a costa de santa sangre, no se haya de extinguir, y cancelar menos que con sangre real. ${ }^{127}$

Igualmente, Uztarroz habla en su poema de la daga que portaba el Ceremonioso y con la que suele ser representado: «Aquel don Pedro es Ceremonioso / que de la Unión el privilegio santo / procurando romperlo cuidadoso, / tiñó en sus manos de purpúreo acanto / y entonces, exclamando pesaroso, / dijo: "bien es que lo que costó tanto, / ahora lo publiquen mis reales / manos, brotando líquidos corales." „128 La representación del monarca para la serie aragonesa también se hizo eco de estos sucesos e incluyó el libro y el puñal como los atributos más característicos de la imagen del Ceremonioso [fig. 3.52]. Del mismo modo que en todos los casos de la serie icónica valenciana, la cartela incluida en la zona inferior del lienzo determina que se trata de: PETRUS VAL. II. ARAGON IV. COGN. [CERE]MONIOSUS OBIIT 6 IANUARII 13[87] AET. 75.

El retrato de Juan I de Valencia y de Aragón (reinado entre 1387 -1396) [fig. 3.53] más que mostrarlo con las insignias regias, a excepción de la corona, y con todo su poder, se ha preferido re-

127 Blancas, Explicación histórica..., 1996, pp. $294-295$.

128 Egido Martínez, 'Retratos de los Reyes...', p. 29, versos 409-416. 


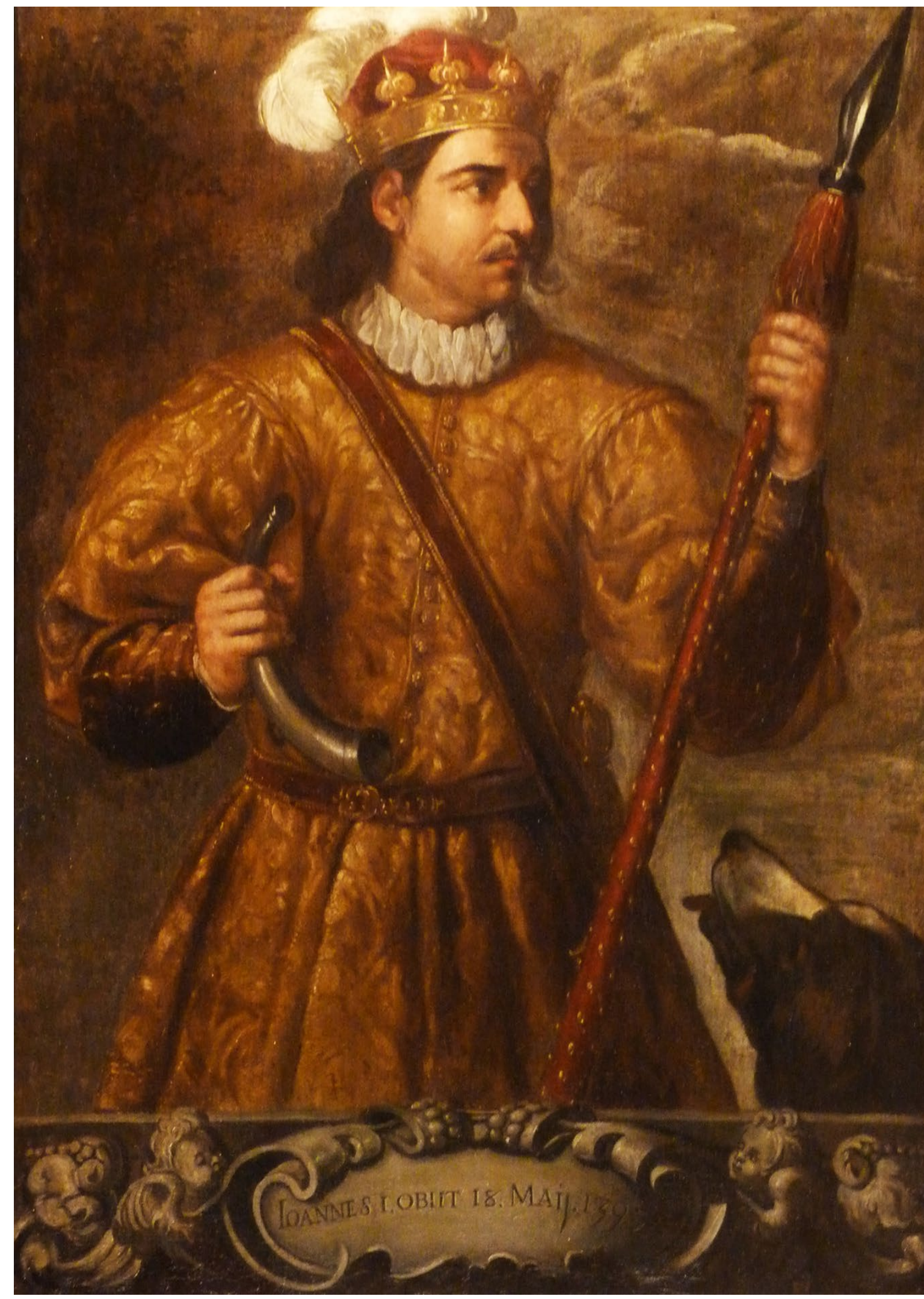

Fig. 3.53. Juan I de Valencia y de Aragón, s. XVII, Valencia, palacio de la Generalitat. 
presentarlo remitiendo a una de sus actividades preferidas, la caza. Por ello, aparece equipado para la práctica de dicha actividad, sosteniendo un cuerno, armado con una lanza y acompañado de un perro. Todo ello le sirvió para ser conocido como Juan el Cazador. La inscripción pertinente es muy escueta y tan sólo se anota: «IOANNES I OBIT 18 MAII 1395» De esta manera se ha obtenido una imagen oficial a la par que íntima del monarca, de quien también se ha recalcado su gusto por las letras, las artes, la astrología y la alquimia. De hecho, artistas, músicos y juglares visitaban asiduamente la corte de Juan I, caracterizada por vivir entre la pompa. ${ }^{129}$ Según de Blancas, el monarca no destacó en el ejercicio de la guerra ni fue especialmente amante de las tareas que implicaban el gobierno del reino, de hecho, su falta de responsabilidad política generó el malestar de muchos de sus vasallos. ${ }^{130}$ En cualquier caso, representar al rey vestido en calidad de cazador se convirtió en la tipología más conocida para sus efigies. De hecho, de igual modo se aprecia en el retrato pintado originalmente por Ariosto [fig. 294 3.54]. Su apariencia incluso ha cobrado un mayor sentido al narrar que su fallecimiento se produjo de forma inesperada mientras se encontraba de caza con algunos otros caballeros por los parajes de Castellón.

[...] luego se fue a la villa de Castellón donde reposó algunos días: y estando allí se fue por aquellos montes cercanos a cazar con muchos caballeros que le acompañaban, Acaeció que los cazadores habían muerto un lobo y estando el rey preguntando si era lobo o loba súbitamente cayó de la mula muerto en tierra. Fue sepultado en Barcelona en la iglesia mayor: después por mandato de su hermano el rey don Martín fue su cuerpo pasado en el monasterio de Poblet. Murió el sobredicho rey don Juan a diecinueve días del mes de mayo en el año del Señor mil trescientos noventa y seis. ${ }^{131}$

129 Ana Isabel Lapeña Paúl, 'Juan I', en Los reyes de Aragón, (Caja de Ahorros de la Inmaculada Aragón: Zaragoza, 1993), pp. 129-134.

130 Blancas, Explicación histórica..., 1996, pp. 311-312.

131 Marineo, Crónica de Aragón..., Libro cuarto, fol. LI v - LII r. 


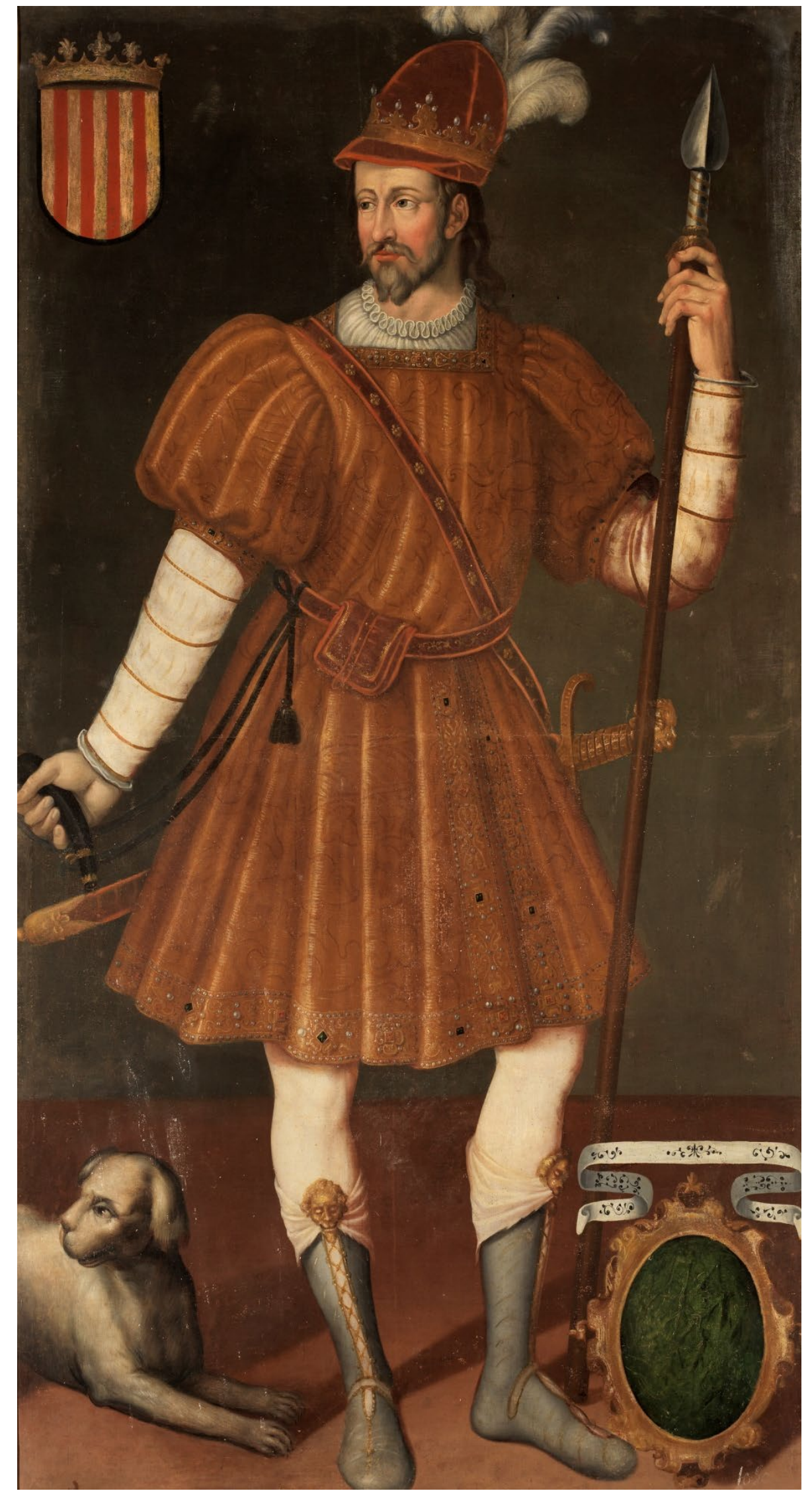

Fig. 3.54. Anónimo (copia de Ariosto), Juan I, 1634, óleo sobre lienzo, Madrid, Museo Nacional del Prado. 
Martín el Humano I de Valencia y de Aragón (reinado entre 1396 - 1410) [fig. 3.55] es representado con un rostro sosegado, acorde con su imagen de benévolo. La indumentaria del monarca concuerda con la descripción que hizo Jerónimo de Blancas de la ceremonia de coronación:

Salió el rey de su aposento vestido de ropa rozagante, que llamaban Manto de tela de oro, y terciopelo carmesí a tiras aforrada toda de armiños. A esta ropa llamaban en aquel tiempo Manto Frederical. Debaxo de este manto llevava el rey una que llamaban cota, que era en lugar de sayo... con muchos pliegues, y las mangas, y braones anchos, y esta cota tambien era lo mesmo, sino que no traía aforros. En la cabeza saco el rey puesto un bonetillo que llamavan chapelete, lleno de perlas y piedras de gran valor. ${ }^{132}$

El retrato ubicado en la Generalitat también encaja en lo primordial de la descripción de la vestimenta del efigiado. Sin embargo, el estado de la pintura no permite observar con claridad si aquí también luce el chapelete. Esta duda no se tiene al observar la imagen perteneciente a la serie aragonesa, pues esta reproduce con todo detalle la descripción de Blancas [fig. 3.56]. El texto de la cartela del lienzo valenciano es bastante escueto y tan sólo revela que se trata de: MARTINUS COGNOM. PIUS OBIT 31 MAI 1410.

Martín I falleció sin descendencia y después de dos años de interregno entre 1410 y 1412, el trono fue asumido por Fernando I de Valencia y de Aragón (reinado entre 1412 - 1416) [fig. 3.57], llamado el Honesto. El compromiso de Caspe entronizaba a un monarca perteneciente también a una dinastía castellana, la Casa de Trastámara. Fernando I era hijo de Juan I de Castilla y Leonor de Aragón, nieto de Pedro IV el Ceremonioso, por tan-

132 Véase Morte García, 'Pintura y política en la época de los Austrias..., (II)'. La autora ha consultado la obra de Jerónimo de Blancas sobre las coronaciones para conocer la ceremonia de Martín I el Humano. 


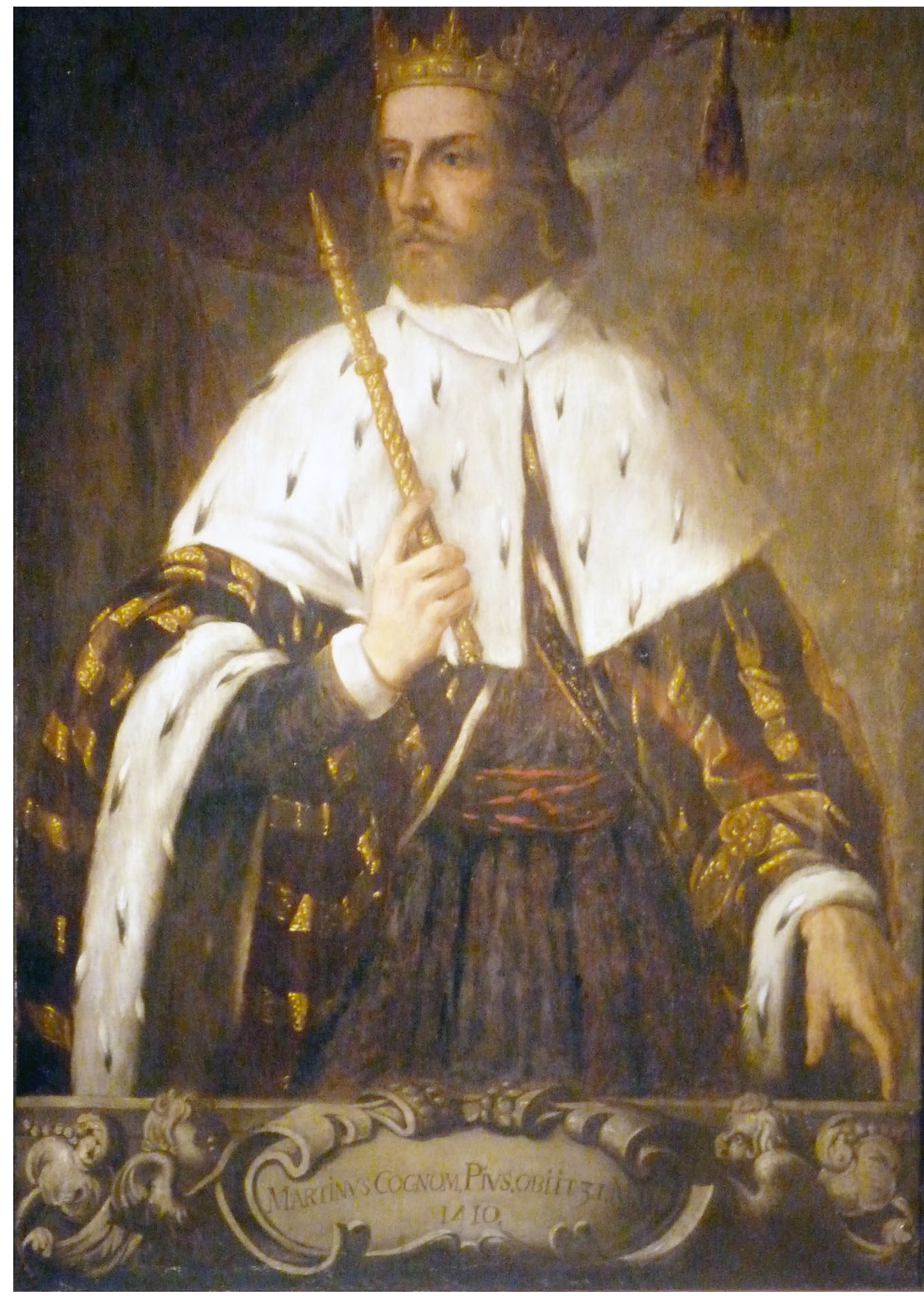

Fig. 3.55. Martín I de Valencia y de Aragón, el Humano, s. XVII, Valencia, palacio de la Generalitat. 


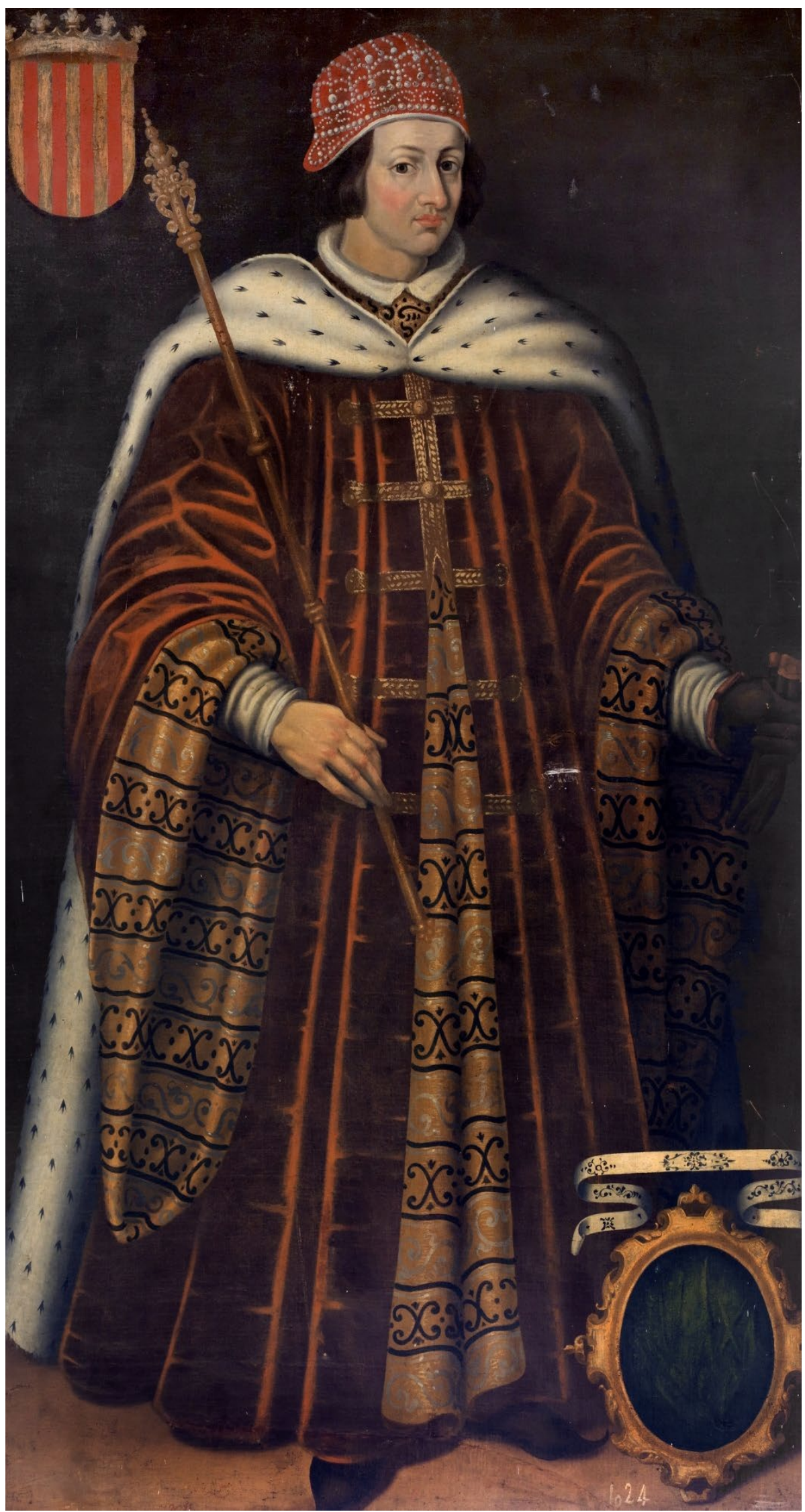

Fig. 3.56. Anónimo (copia de Ariosto), Martín I, el Humano, 1634, óleo sobre lienzo, Madrid, Museo Nacional del Prado. 


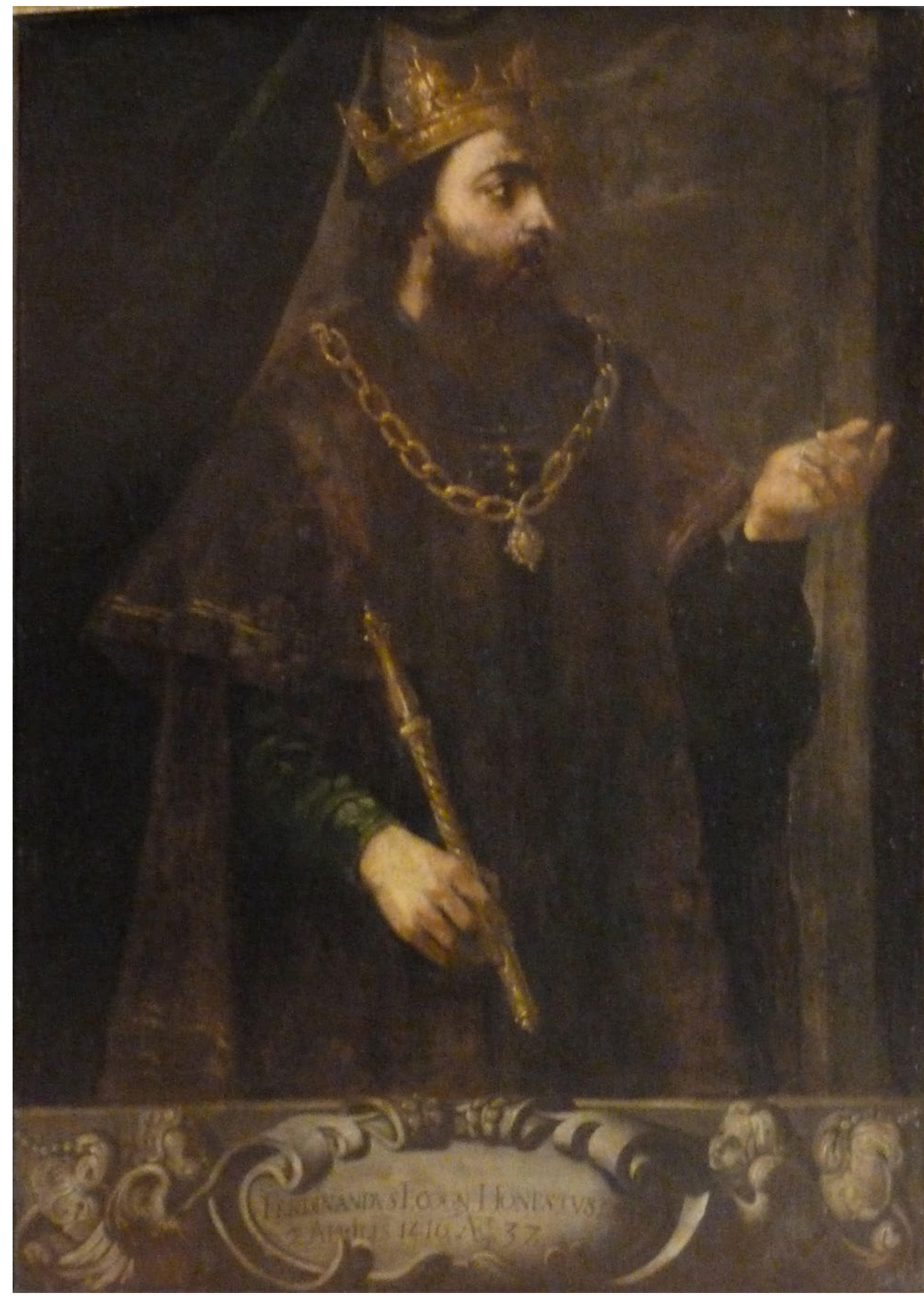

299

Fig. 3.57. Fernando I de Valencia y de Aragón, el Honesto, s. XVII, Valencia, palacio de la Generalitat. 
to, su legitimidad para convertirse en rey le llegaba por vía materna. Además de ser conocido como el Honesto, también era llamado el de Antequera por haber conquistado dicha ciudad al Islam mientras era infante de Castilla. ${ }^{133}$ En este caso, se le ha retratado de perfil llevando como insignias reales la corona, el collar y el cetro. La inscripción dispuesta en la parte inferior de la obra determina que se trata de la efigie de: FERDINANDUS I COGN. HONESTUS OBIT 2 APRILIS 1416, AET. 37.

A Fernando I le sucedió en el trono su hijo, Alfonso III de Valencia y V de Aragón (reinado entre 1416 - 1458) [fig. 3.58], llamado el Magnánimo. Igualmente se le conocía por el sobrenombre del Sabio, puesto que su dedicación al estudio y conocimiento de las letras era admirable en la época, llegando a configurar una amplia biblioteca personal.

Reconociendo muchas veces dentro de mí mismo las virtudes y las gracias excelentes de este rey tan noble vengo señaladamente a maravillarme de una que tan rara es en los príncipes de nuestro tiempo y es que este rey tan señalado siendo ya hombre de cincuenta años y asaz fatigado de cuidados y negocios no se olvidó de trabajar en saber las letras latinas: antes con verdadero amor y deseo de saberlas comenzó a estudiar muy de propósito comenzando desde los primeros principios de la gramática así como los niños comienzan y como si ningún cuidado de otra cosa tuviera. [...] Vino en esto que cuando ya comenzó a gustar de verdad el fruto de las letras fue maravillosa la librería que juntó para sí mismo como para todos los suyos, buscando de todas partes cuantos libros preciosos podía haber, y comprándolos por cualquier precio que por ellos pidiese. [...] Trabajó entre otras cosas que muchos libros griegos fuesen reconocidos y trasladados en latín por varones señalados y en aquella

133 «El sobredicho rey don Fernando antes que fuese llamado para recibir el reino de Aragón había hecho muy cruel guerra a los moros de Granada: les había ganado Antequera y otros señalados lugares matando número grandísimo de ellos.» Marineo, Crónica de Aragón ..., Libro quinto, fol. LV r. 


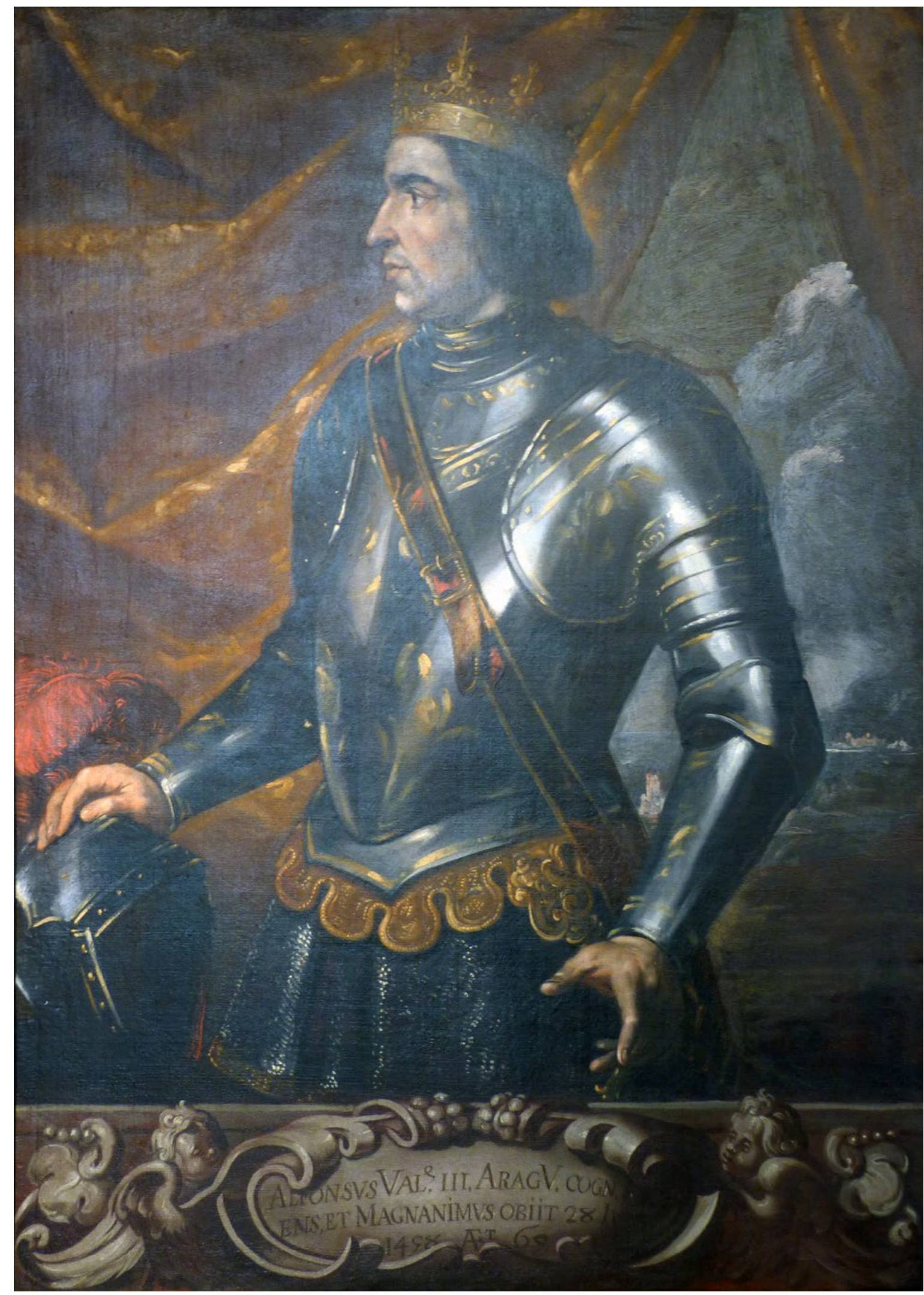

301

Fig. 3.58. Alfonso III de Valencia y $V$ de Aragón, el Magnánimo, s. XVII, Valencia, palacio de la Generalitat. 
facultad bien doctos. Fue tanto el favor que en esto dio y las mercedes que a los sabios hizo que sin duda las letras latinas tornaran a resucitar y ser estimadas: que ya del todo iban perdidas, muertas y casi sin esperanza de tornar al mundo. De tal manera que con este tan señalado príncipe no solo florecieron los buenos capitanes y los que en armas querían señalarse más también: los hombres doctos y que de buenas letras se apreciaron, los poetas y oradores y todos en fin con la grandeza de este príncipe fueron despertados. ${ }^{134}$

Por este motivo, en el conocido retrato elaborado por Juan de Juanes (véase la fig. 2.4) la presencia de un libro abierto en la imagen es permanente: se halla en el bufete bajo la corona, grabado en el yelmo, o como motivo ornamental en el cortinaje del fondo. Así, constantemente se nos remite al bagaje cultural del monarca y a la importancia de ser un gobernante bien preparado tanto en el ejercicio de las armas como del intelecto. Esta misma alusión también se encuentra, aunque de forma menos clara, en la efigie perteneciente a este conjunto. Una vez más, se ha incluido el libro abierto en el yelmo.

Como también se da en otros retratos, el Magnánimo aparece de perfil y ataviado con una armadura. El aspecto del soberano sigue la descripción, más extendida, acerca de su persona. A los cincuenta y ocho años, Alfonso V era «delgado de cuerpo, de rostro pálido y jovial, nariz aguileña, ojos brillantes, cabello negro tendido hasta las orejas, de mediana estatura». ${ }^{135}$ Los rasgos faciales, por tanto, respetan la tipología iconográfica establecida a partir de las medallas de Pisanello [fig. 3.59]. Sirva de muestra la diseñada en 1448 y acuñada en 1449 para la corte de Nápoles. En el anverso se sitúa el busto del rey, de perfil, y a ambos lados aparece el correspondiente yelmo or-

134 Marineo, Crónica de Aragón..., Libro quinto, fol. LVII $r$ - v.

135 Descripción de Piccolomini citada por Juan Manuel Cacho Blecua, 'Alfonso V', en Los reyes de Aragón, (Caja de Ahorros de la Inmaculada Aragón: Zaragoza, 1993), pp. 149-156. 
namentado con el sol y el libro abierto, el cual incluye una inscripción latina referente a la necesidad de ser sabio para poder controlar tu propio destino: «VIR

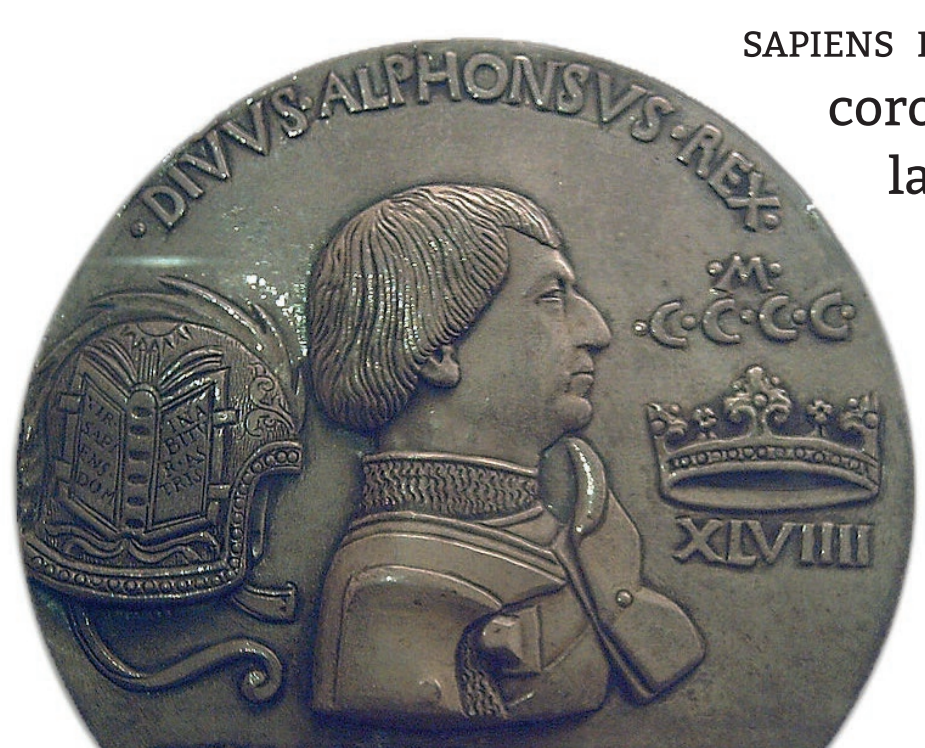

DOMINABITUR ASTRIS", y la corona. En el reverso de la moneda se aprecia la empresa que también aparece en el retrato perteneciente a la serie aragonesa [fig. 3.60]. El mote reza «Liberalitas AugusTA» $y$ en la imagen se identifican cinco águilas contemplando el cadáver de un animal. Asíse habla dela generosidad Fig. 3.59. Pisanello, Medalla de Alfon- del monarca, una de so $V$ de Aragón, 1448-1449, Madrid, las principales virtudes Museo Arqueológico Nacional. morales asignadas a los gobernantes durante el Renacimiento, quien dividió su imperio entre sus herederos. ${ }^{136}$ El Magnánimo legó el reino de Aragón, de Sicilia y otros territorios a su hermano Juan, pues de tal modo lo había dispuesto Fernando de Antequera en su testamento. El 28 de junio de 1458 murió y su hijo Fernando (también llamado Ferrante) heredó el reino de Nápoles, cuya efigie se ha tratado en la galería anterior. De su fallecimiento se hace eco el texto incluido en el retrato valenciano: ALFONSUS VAL. III. ARAG. V. COGN.[SAPI]ENS ET MAGANANIMUS OBIIT 28 [IUNE]1458 AET 68.

Juan II de Valencia y de Aragón (reinado en 1458 - 1479) [fig. 3.61], apelado el Grande, en definitiva recibió de Alfonso V el gobierno sobre las tierras peninsulares de Aragón, Cataluña, el Rosellón, la Cerdaña y Valencia, las insulares de Mallorca, Si-

136 Cacho Blecua, 'Alfonso V'..., p. 153. Además, conviene consultar la tesis de Gema Belia Capilla Aledón, 'El poder representado: Alfonso V el Magnánimo (1416-1458)', Universitat de València, 2015. 


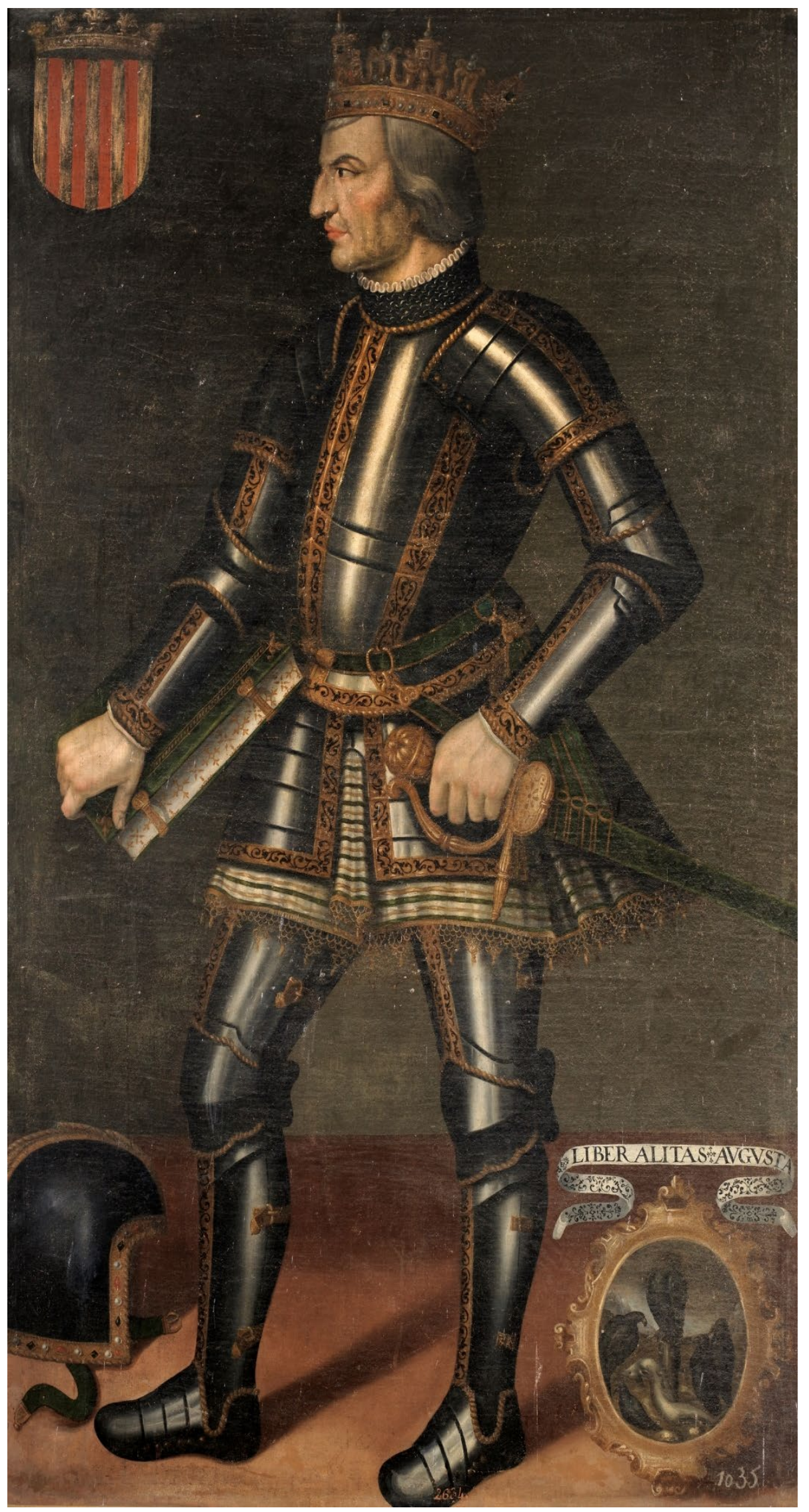

Fig. 3.60. Anónimo (copia de Ariosto), Alfonso V, el Magnánimo, 1634, óleo sobre lienzo, Madrid, Museo Nacional del Prado. 


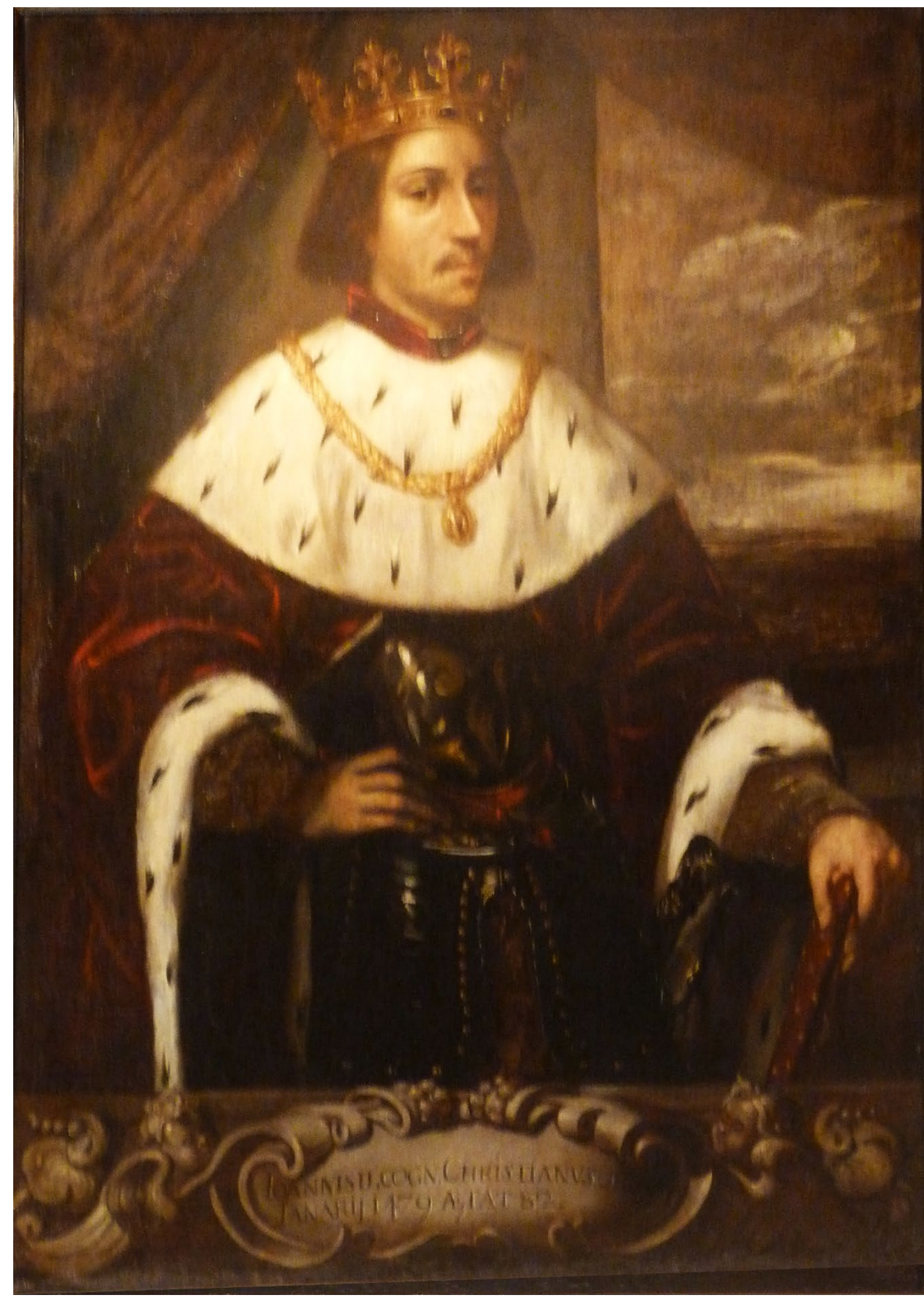

305

Fig. 3.61. Juan II de Valencia y Aragón, el Grande, s. XVII, Valencia, palacio de la Generalitat. 
cilia y Cerdeña, Córcega, y los ducados de Atenas y Neopatria. Su efigie ha respetado la tipología establecida en este conjunto. El rey se muestra luciendo la corona, el collar y la espada, además vistiendo con la capa real de terciopelo y armiño, bajo la cual lleva la armadura. También reposa su mano derecha en un bastón de mando, en alusión a su gobierno. Como especifica la cartela, el monarca falleció el 19 de enero de 1479, a la edad de ochenta y dos años: IOANNIS II. COGN. CHRISTIANUS OB[IIT] 19 IANARII 1479 AETAT 82.

Fernando II de Valencia y de Aragón (reinado en 1479 - 1516) [fig. 3.62], conocido como el Católico, fue el último monarca de la dinastía aragonesa, pues al contraer matrimonio con Isabel de Castilla ambos reinos unieron definitivamente su destino y seguidamente el trono español fue ocupado por los Austria. Según las fuentes escritas, tanto a Fernando como Isabel, se les ha admirado por sus virtudes y por tomar decisiones guiándose por la voluntad Dios y sacrificando los deseos humanos. ${ }^{137}$ 306 Autores como Hernando del Pulgar ( $†$ 1493) describían al Católico como un hombre:

[...] de mediana estatura, bien proporcionado en sus miembros, en las facciones de su rostro bien compuesto, los ojos rientes, los cabellos prietos y llanos, y hombre bien complisionado. [...] Era de buen entendimiento y muy templado en su comer y beber, y en los movimientos de su persona: porque ni la ira ni el placer hacía en él alteración. Cabalgaba muy bien a caballo, en silla de la guisa y de la jineta: justaba sueltamente y con tanta destreza, que ninguno en todos sus reinos lo hacía mejor. Era gran cazador de aves, y hombre de buen esfuerzo, y gran trabajador en las guerras. De su natural condición

137 «Son las virtudes y las excelencias de estos dos reyes gloriosos tales tantas y tan señaladas que con mucha razón todos los hombres de nuestros tiempos con gran admiración las contemplan: y los que vernan cuando las supieren no sin causa se maravillarán. Porque en la verdad más muestran haber hecho sus cosas por consejo y gracia de Dios que con fuerzas humanas.» Marineo, Crónica de Aragón..., Libro quinto, fol. LXVII r. 


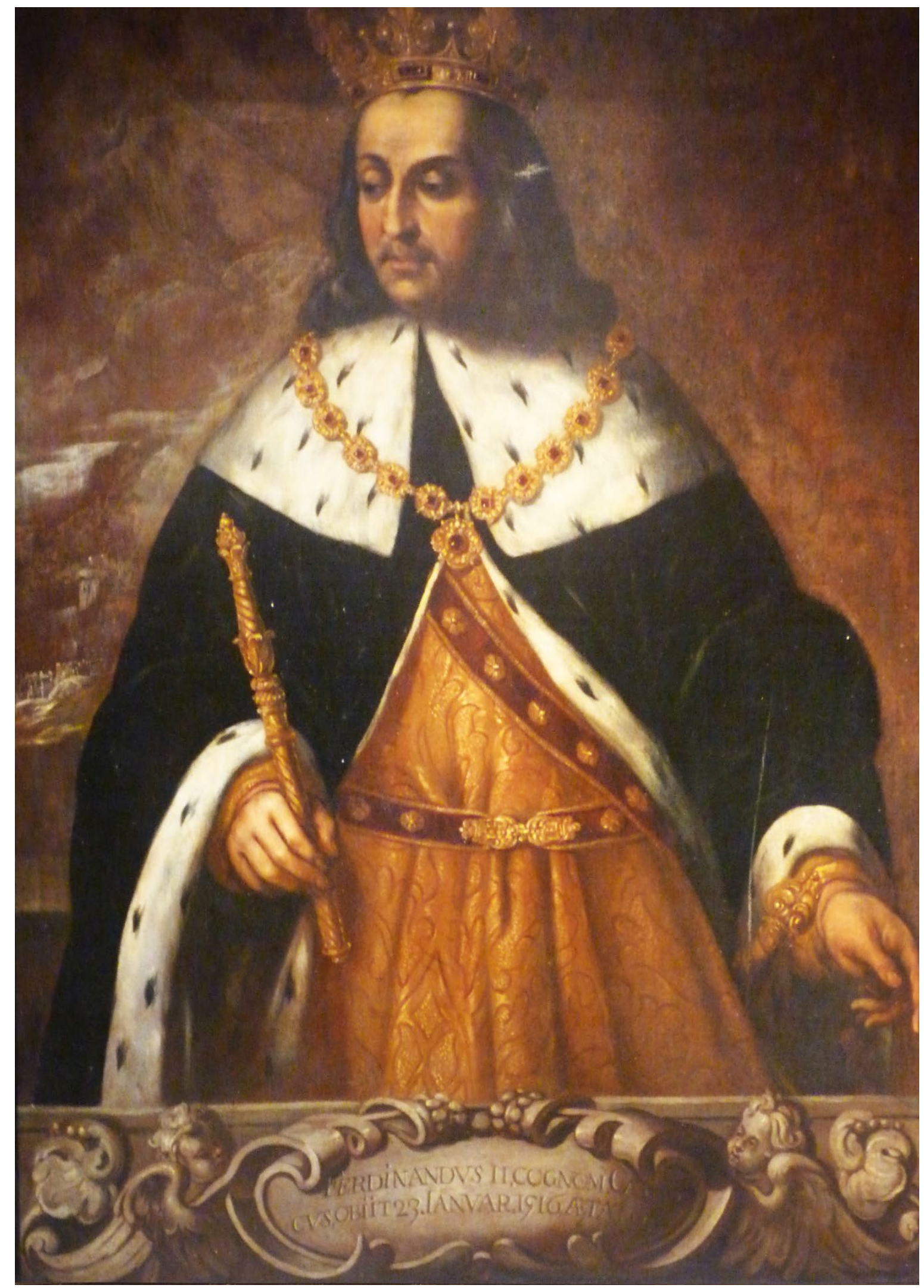

Fig. 3.62. Fernando II de Valencia y de Aragón, el Católico, s. XVII, Valencia, palacio de la Generalitat. 
era inclinado a hacer justicia, y también era piadoso, y se compadecía de los miserables que veía en una angustia.

[...] Hombre era de verdad, como quiera que las necesidades grandes en que le pusieron las guerras, le hacían algunas veces variar. ${ }^{138}$

El retrato de la Generalitat, una vez más, sigue la tipología correspondiente. El fasto de la corona, el collar y el cetro concuerdan con el especial gusto del monarca hacia las joyas. De hecho, se endeudaron las rentas obtenidas de Sicilia durante dos años para poder conseguir un rubí. ${ }^{139}$ En cuanto a la inscripción, se detalla que estamos ante la efigie de: FERDINANDUS II COGNOM. CAT[HOLI]CUS OBIT 23 IANUARI 1516 AETAT [63]

Tras el reinado de Fernando el Católico, el trono derivará en los soberanos de la Casa de Austria y se iniciará una nueva etapa para la monarquía valenciana que también se ha representado en la serie icónica conservada en el palacio de la Generalitat. A grandes rasgos, se han apreciado ciertos puntos en común en cuanto a la iconografía de los monarcas empleada tanto en la serie de la Diputación de Aragón como en la procedente del palacio del Real de Valencia. Estas similitudes se han dado en varias ocasiones, por ejemplo al retratar a Alfonso IV el Benigno, Pedro IV el Ceremonioso o Juan I el Cazador. De todos modos, las fuentes escritas fueron un jugoso complemento a

138 Hernando del Pulgar, Crónica de los señores reyes católicos Don Fernando y Doña Isabel de Castilla y Aragón, (Imprenta de Benito Monfort: Valencia, 1780), capítulo III, De las condiciones y proporciones del rey, p. 36. Según el prólogo de la edición consultada, del Pulgar fue el cronista de los Reyes Católicos y en 1482 comenzó a escribir su obra hasta el año 1490. Seguidamente, el texto llegó a las manos de Lorenzo Galíndez de Carvajal quien se lo entregó a Antonio de Nebrija para que la tradujera. Con el fallecimiento de Nebrija, el manuscrito cayó en el olvido hasta que su hijo Sancho de Nebrija lo imprimió en 1545, y desde entonces se sucedieron diversas ediciones en 1550, 1565 y 1567. En la presente ocasión, se ha consultado esta edición del siglo XVIII la cual fue cotejada con manuscritos antiguos y corregida y ampliada con diversas ilustraciones.

139 Guillermo Redondo Veintemillas, 'Fernando II', en Los reyes de Aragón, (Caja de Ahorros de la Inmaculada Aragón: Zaragoza, 1993), pp. 163174. 
las imágenes pues autores como Jerónimo de Blancas, Luca Marineo o Andrés Uztarroz contribuyeron a generar el retrato literario de los reyes de la Corona de Aragón. Así se creó una imagen de poder propagada tanto a través del retrato como de las obras escritas.

La trascendencia de esta clase de conjuntos se ha puesto de manifiesto al copiarse o servir de inspiración para otros proyectos artísticos. Pero los retratos zaragozanos y valencianos no sólo han tenido aspectos compartidos entre ellos, sino que también se puede establecer una interesante relación con un manuscrito conservado en la Biblioteca Nacional bajo el título Libro de armas y blasones de diversos linajes y retratos. ${ }^{140}$ Los datos acerca de esta obra son mínimos, se desconoce la autoría y a groso modo se ha fechado en el siglo XVI. Aunque las ilustraciones del libro son más esquemáticas, en esencia concuerdan con los retratos estudiados en la definición de los rasgos faciales, las vestiduras y postura del retratado. En este caso, las imágenes responden a un formato de tres cuartos, insertadas en un marco arquitectónico. En la parte superior siempre se puede leer el nombre y la edad en la que fue proclamado rey. En la inferior se especifica los años de gobierno que ostentó y la fecha del óbito.

Los ejemplos que guardan un mayor parecido con los retratos estudiados son Jaime I, Pedro III, Alfonso IV, Pedro IV, Juan I y Juan II [fig. 3.63; fig, 3.64]. Las imágenes que no presentan tantas similitudes se corresponden con las de Alfonso III, Jaime II, Martín el Humano y Fernando II el Católico.

En el mismo manuscrito se ha detectado un error de identificación con las efigies de Fernando I el Honesto y Alfonso V el Magnánimo, pues cada uno ha sido identificado con la imagen del otro. De haber sido correctamente denominadas 140 Disponible en la biblioteca digital de la BNE: http://bdh-rd.bne.es/ viewer.vm?id=0000047553 (Fecha de la última consulta: 06/09/2019) 

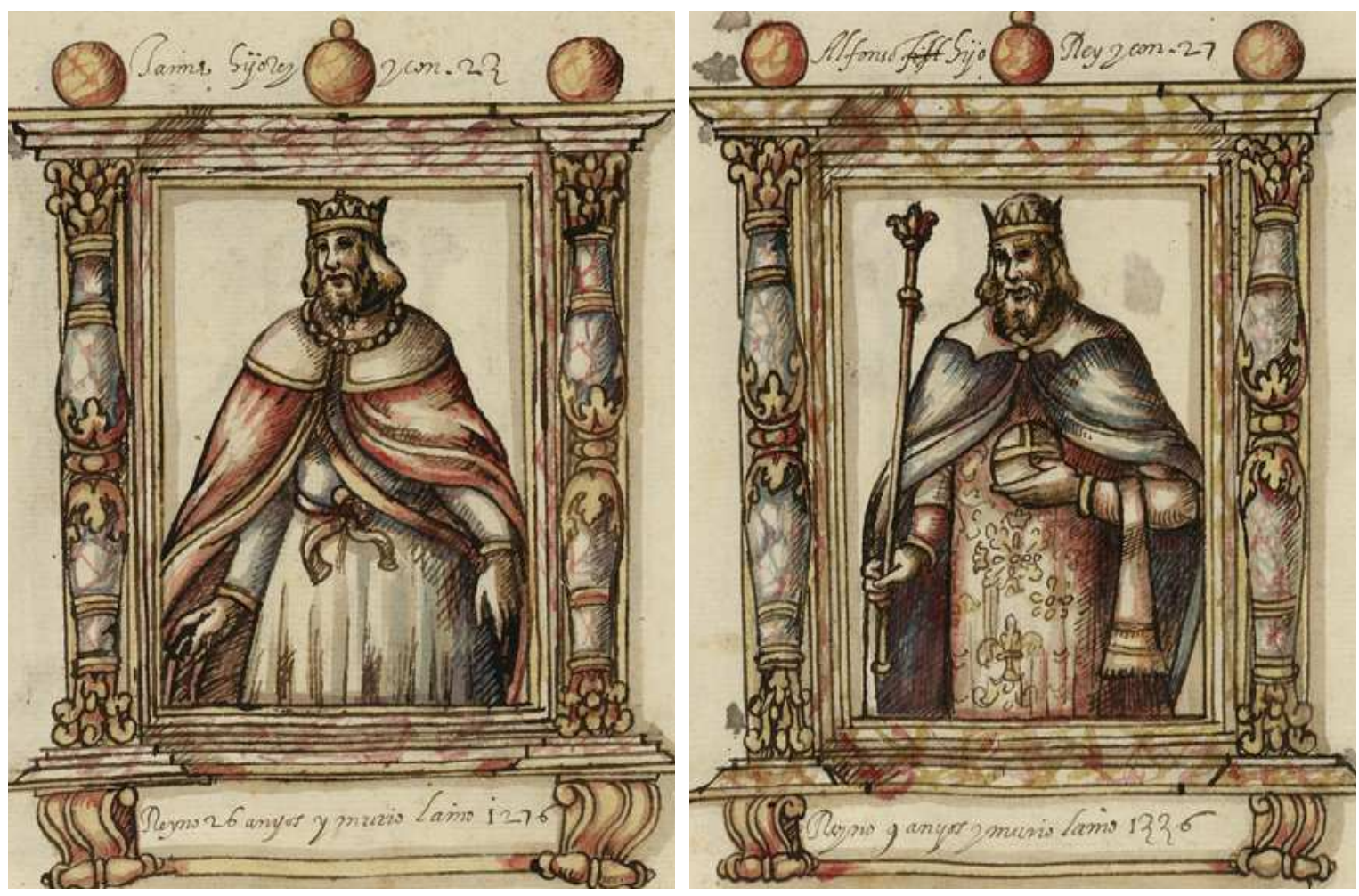

Fig. 3.63. Representación de Jaime I Fig. 3.64. Representación de Alfonso en el Libro de armas y blasones..., s. IV el Benigno en el Libro de armas XVI, manuscrito, Madrid, Biblioteca y blasones..., s. XVI, manuscrito, MaNacional de España.

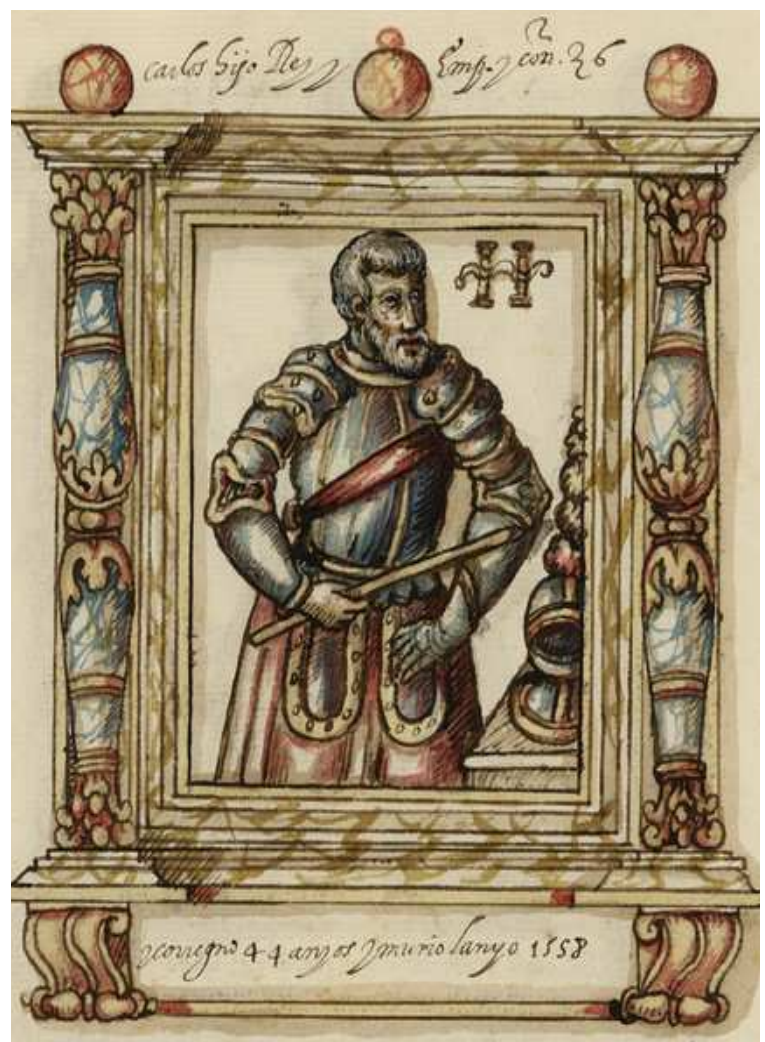
drid, Biblioteca Nacional de España.

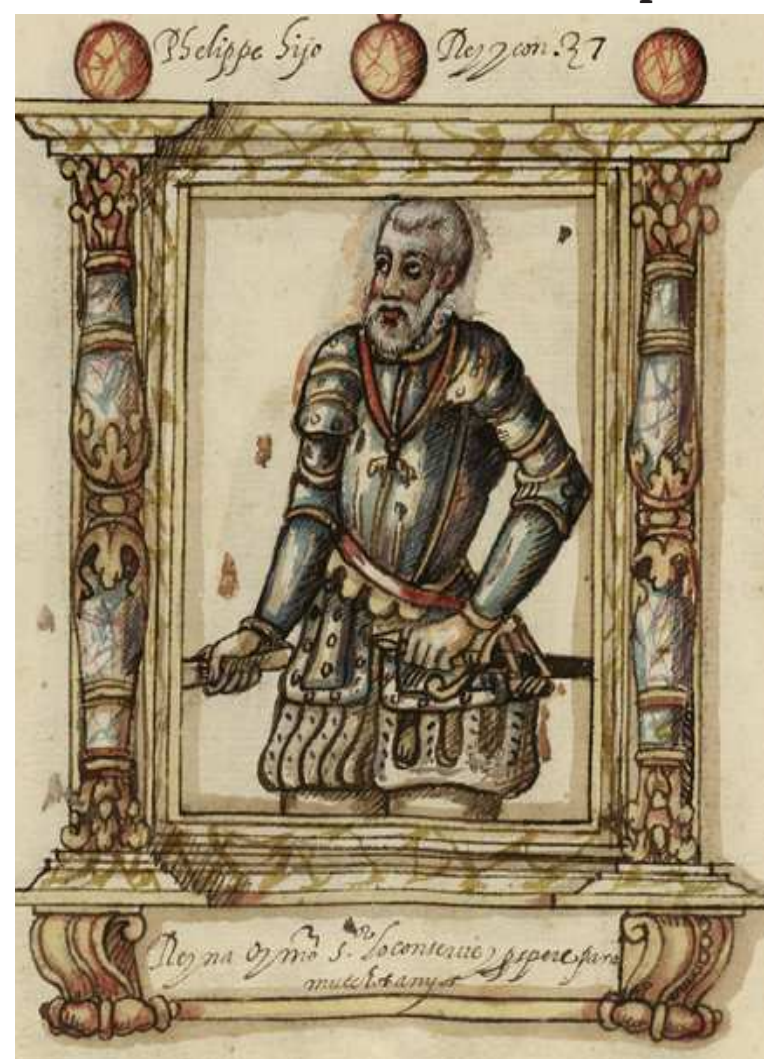

Fig. 3.65. Representación de Carlos Fig. 3.66. Representación de Felipe I de Austria en el Libro de armas y II de Austria en el Libro de armas y blasones..., s. XVI, manuscrito, Ma- blasones..., s. XVI, manuscrito, Madrid, Biblioteca Nacional de España. drid, Biblioteca Nacional de España. 
se tendrían dos casos más de la relación entre las imágenes de este volumen y las pinturas de las series icónicas. Como se observará más adelante la representación de Carlos I de Austria también es bastante similar y la de Felipe II es idéntica [fig. 3.65; fig. 3.66]. Aunque la datación exacta del manuscrito está por determinar se debe tener en cuenta que el último rey representado es Felipe II, al igual que hizo Ariosto, lo cual invita a pensar que el manuscrito fue contemporáneo al conjunto pictórico del palacio de la Diputación de Aragón.

\subsubsection{Reyes de la dinastía Austria:}

La magnificencia y la pompa vista en las representaciones de los reyes de Aragón, quedará en un segundo plano en los retratos pertenecientes a la dinastía Austria. En efecto, las únicas insignias reales que llevan se corresponden con el collar del Toisón de Oro y la espada, pero en ningún caso aparecen coronados ni visten con la capa real.

Carlos I (reinado entre 1516 - 1556) [fig. 3.67] ha sido retratado a modo de caballero dispuesto para la guerra, ataviado con la armadura por completo sobre la cual se aprecia el Toisón y llevando con fuerza el bastón de mando. En la zona inferior de la pintura se ha escrito lo siguiente: CAROLUS MAX. ROM. IMP. V SEMPER AUGUSTUS, OBIIT 21 SEPTEMB. 155[8] AETAT. 58. La imagen, en definitiva, se corresponde con la representación oficial del monarca y una vez más, se puede vincular con la elaborada por Juan Pantoja de la Cruz (1605, óleo sobre lienzo, Madrid, Museo Nacional del Prado). También fue retratado con armadura en la galería de efigies de la Diputación en Zaragoza [fig. 3.68]. En este caso, además, luce la banda de general e incluye su empresa con las dos columnas de Hércules y el lema Plus Ultra, persiguiendo el objetivo de entroncar a la dinastía Austria con el héroe clásico.

Felipe II (reinado entre 1556 - 1598) [fig. 3.69] viste un jubón 


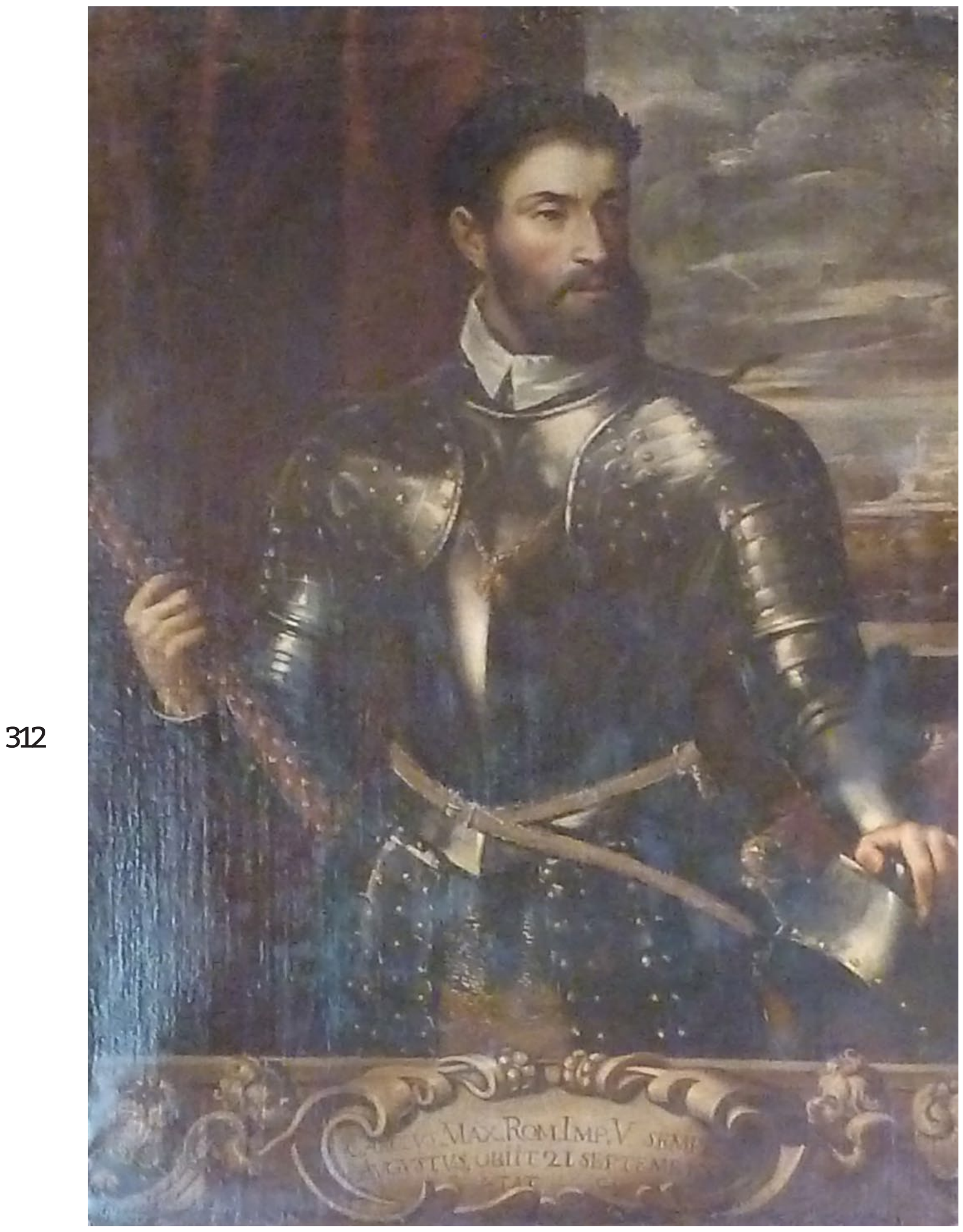

Fig. 3.67. Carlos I, s. XVII, Valencia, palacio de la Generalitat. 


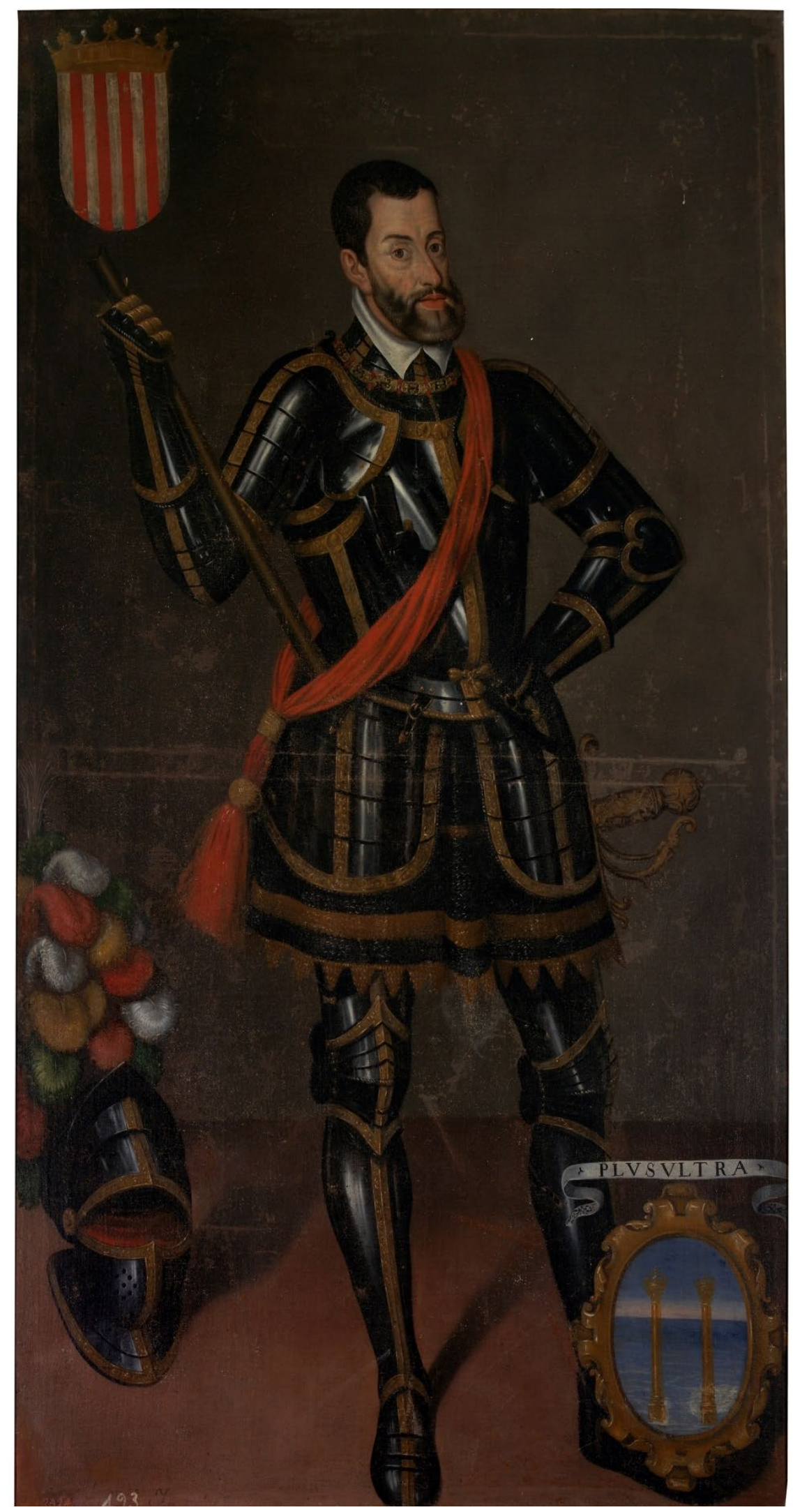

Fig. 3.68. Anónimo (copia de Ariosto), Carlos I emperador, 1634, óleo sobre lienzo, Madrid, Museo Nacional del Prado. 
negro y el único elemento que denota un atisbo de ostentación es el Toisón de Oro que luce con un discreto collar. También sostiene un documento con la mano izquierda para aludir a su gobierno. La estética de la pieza se puede relacionar con otros retratos de este monarca como el pintado por Sofonisba Anguissola [fig. 3.70] o Pantoja de la Cruz (óleo sobre lienzo, Madrid, biblioteca del Monasterio del Escorial). Tras él, el cortinaje rojo que engalana la estancia muestra parte de la arquitectura del Escorial, obra cumbre de este monarca. La cartela insertada en el retrato especifica que se trata de: PHILIPPUS VALENTIAE I, CASTELlaE II COGNOM. PRUdens. OBIIT 13 SEPTEMb. 1598 AETAT 71. En cambio, en el retrato de este rey para la serie zaragozana [fig. 3.71] se ha preferido contribuir a vincular a la monarquía con Heracles. Así, Felipe II es efigiado en calidad de militar como sucedió con Carlos V, haciendo alarde de tal fuerza y poder que tan sólo se explica al pertenecer al linaje del mencionado héroe. En este sentido, la empresa que aparece en el retrato es una alusión al mito de Atalante y el mote reza «Ut 314 quiescat Atlas», es decir, "para que Atlas descanse». Teniendo en cuenta la lectura que se puede hacer de esta empresa, resulta totalmente apropiado incluirla en el retrato. Atlas se ha asociado con Carlos $\mathrm{V}$, quien sostiene con esfuerzo la bóveda celeste como el emperador carga con la Monarquía y, Hércules, quien ayuda a Atlas, se vincula a Felipe II, quien va a suceder a su padre en el trono y, por tanto, le aligerará de tan pesada carga. ${ }^{141}$

141 Teresa Zapata ha explicado que el pasaje protagonizado por Atlas y Hércules tuvo una gran repercusión en España durante el gobierno de los Austrias, desde que Carlos V impulsase una campaña propagandística basada en la antigüedad clásica, para hablar de la responsabilidad y sacrificio que suponía gobernar la Corona y de la ayuda prestada por otros cargos muy cercanos al monarca, como el príncipe heredero, el primer ministro o el virrey. Asimismo, la autora ha remarcado la utilización de esta iconografía en los arcos de diversas entradas triunfales, por ejemplo, en Milán o Amberes. Así, se relacionaba la función del legatario Felipe II respecto a su padre con el papel de Hércules en el episodio de Atlas. Véase a María Teresa Zapata Fernández de la Hoz, 'Atlas - Hércules. Metáfora del poder y gobierno de los Austrias', en Emblemática trascendente: hermenéutica de la 


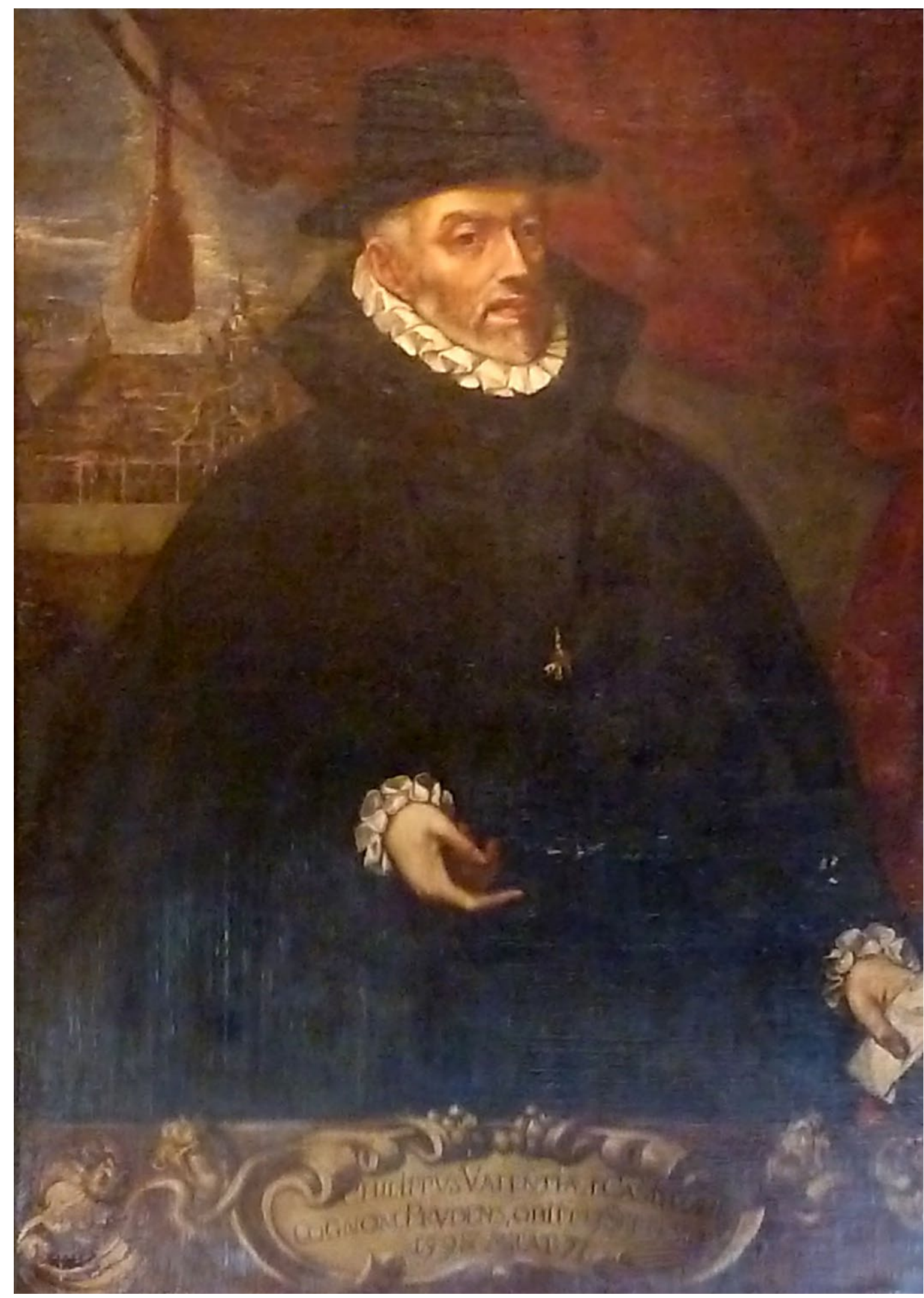

Fig. 3.69. Felipe II, s. XVII, Valencia, palacio de la Generalitat. 


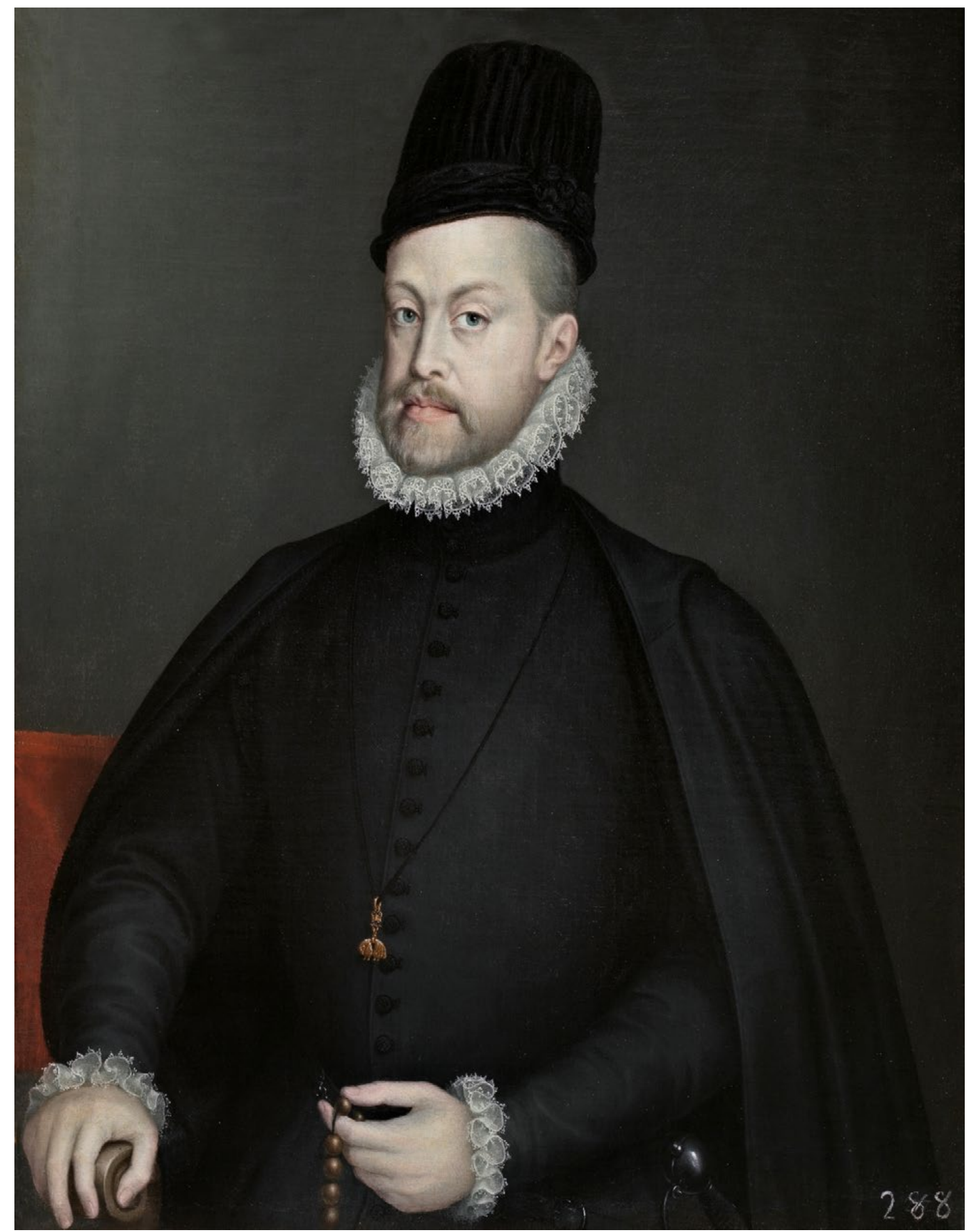

Fig. 3.70. Sofonisba Anguissola, Felipe II, 1573, óleo sobre lienzo, Madrid, Museo Nacional del Prado. 


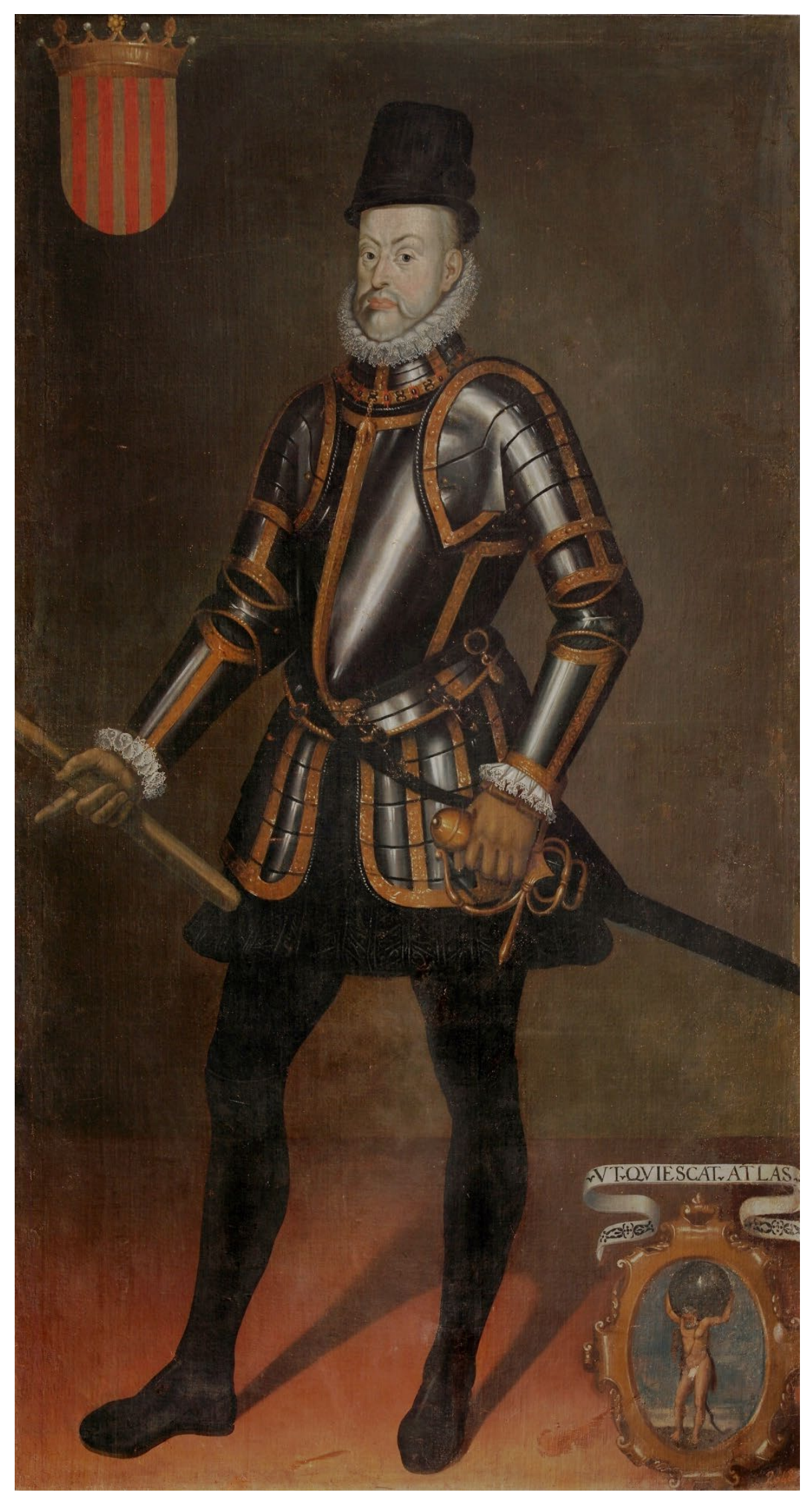

Fig. 3.71. Anónimo (copia de Ariosto), Felipe II el Prudente, 1634, óleo sobre lienzo, Madrid, Museo Nacional del Prado. 
Este mensaje es especialmente oportuno al incluirlo en una serie icónica, donde impera la representación del linaje y de la trasmisión de poder. Igualmente, el poema de Uztarroz equiparaba al soberano con el personaje mítico: «Hércules pues, que Hércules Prudente / Philippo fue el Primero vigilante, / sin que lo ponderoso de aquel orbe / hacerle pueda que la espalda corbe». ${ }^{142}$ De esta manera, se ensalzaba la capacidad del rey para sostener erguido el peso del gobierno, demostrando su valía para reinar.

La imagen de Felipe III (reinado entre 1598 - 1621) [fig. 3.72] contrasta con la de su padre, principalmente por las majestuosas vestiduras que luce en contraposición a los austeros ropajes del Prudente. Este detalle recuerda la pompa y el fasto que imperaban en la corte de Felipe III. Así, viste el jubón y la capa negra completamente decorados en oro. Como sus predecesores, ostenta el collar del Toisón y la espada, además para remitir a sus funciones como gobernante, sostiene un documento en la mano derecha. Siguiendo la tradición del retrato 318 de aparato, tras él se distingue un cortinaje que evoca al palio y se asoma tímidamente una columna, haciendo un guiño a los vínculos habsbúrgicos con Hércules. La cartela identificativa especifica lo siguiente: PHILIPPUS VAL. II. CASTELLE III [...] OBIIT 31 MARTII 1621 AETAT [43].

Aunque también son muy frecuentes las imágenes de Felipe III representado con armadura para acentuar su faceta militar, como sucede en la galería de la Diputación aragonesa, en las dos piezas elaboradas por Juan Pantoja de la Cruz y conservadas en el Museo Nacional del Prado (1606, óleo sobre lienzo, Madrid, Museo Nacional del Prado) y en la biblioteca del Escorial (1609, óleo sobre lienzo, Madrid, Real Monasterio del Escorial), o en el retrato custodiado en la Universitat de València (véase la fig. 2.15), igualmente hay otras que prefieren mostrarlo con sus mejores galas. Así, el retrato anteriormente

imagen, iconología del texto, (Universidad de Navarra, 2011), pp. 785-797.

142 Egido, 'Retratos de los reyes...', p. 32, versos 565 - 568. 


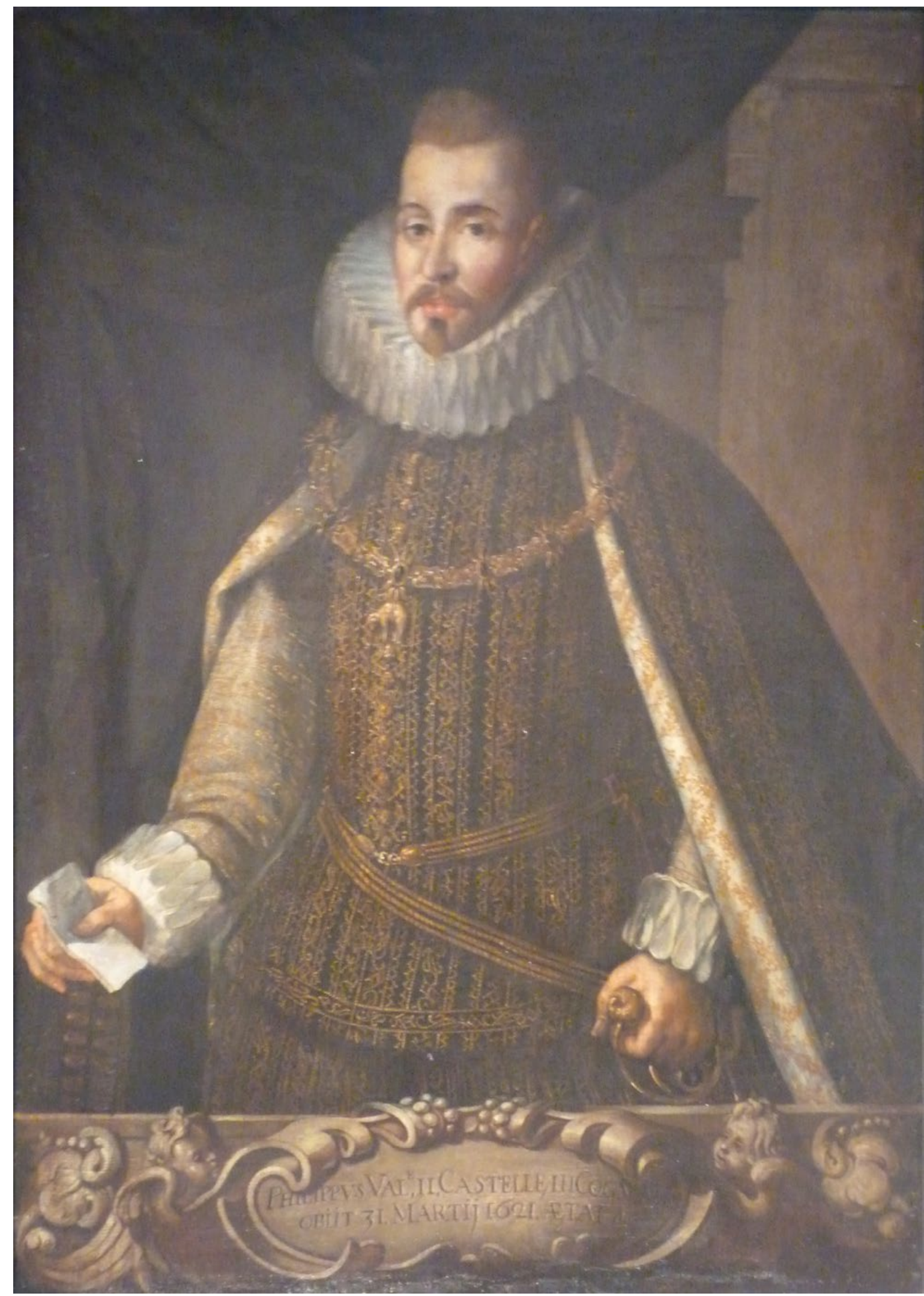

Fig. 3.72. Felipe III, s. XVII, Valencia, palacio de la Generalitat. 
analizado se encontraría en sintonía con la efigie sedente del rey pintada por Bartolomé González [fig. 3.73].

Pese a que Felipe IV (reinado entre 1621 -1665) [fig. 3.74], continuando con la práctica de su padre, delegase los asuntos de Estado en la figura del valido, su retrato remarca el cargo militar asumido por el rey. En efecto, aparece ataviado con una reluciente armadura, sobre la cual destacan el Toisón y la banda de general. Asimismo, le acompañan la espada y la bengala. Nuevamente, el cortinaje del fondo respalda su figura casi en su totalidad y en un segundo plano se intuye un campo de batalla, recordando la intensiva política exterior que se llevó a cabo durante su mandato. La inscripción pertinente lo identifica como: PHILIPPUS VALENTIA III, CASTELLAE IV COGNOM. MAX[IMUS] [...].

Otras piezas que sintonizan con esta imagen son los dos retratos atribuidos al taller de Diego Velázquez. La primera de ellas (ca. 1653, óleo sobre lienzo, Madrid, Museo del Prado) se trata de una representación de cuerpo entero e incluye más elementos secundarios como el bufete sobre el cual se dejan los guantes y el yelmo, y aparece un león, símbolo de poder y fuerza, tras la figura del monarca. También es similar la efigie de Felipe IV en el Hampton Court (ca. 1638, óleo sobre lienzo, Londres, Hampton Court, Royal Collection). ${ }^{143}$ Otras pinturas, en cambio, prefieren representarlo con ostentosos ropajes como se da en el conjunto zaragozano.

La efigie de Carlos II (reinado entre 1665 - 1700), último rey de la dinastía Austria, quien nunca gozó de una excelente salud, debía contribuir a legitimar su capacidad para estar al frente de la Corona española. ${ }^{144}$ Por ello, en ocasiones, sus retratos han incluido representaciones de sus familiares, recordando 143 Acerca de estas pinturas consúltese a Javier Portús Pérez, José Miguel Morán Turina, Andrea Sommer-Mathis, and Diego Velázquez, Velázquez y la familia de Felipe IV : (1650-1680), (Museo Nacional del Prado, 2013).

144 El marcado carácter político de los retratos de Carlos II está presente desde su niñez e incluso se encuentra en las representaciones de su madre en calidad de regente. Las imágenes de ambos, tanto de forma individual 


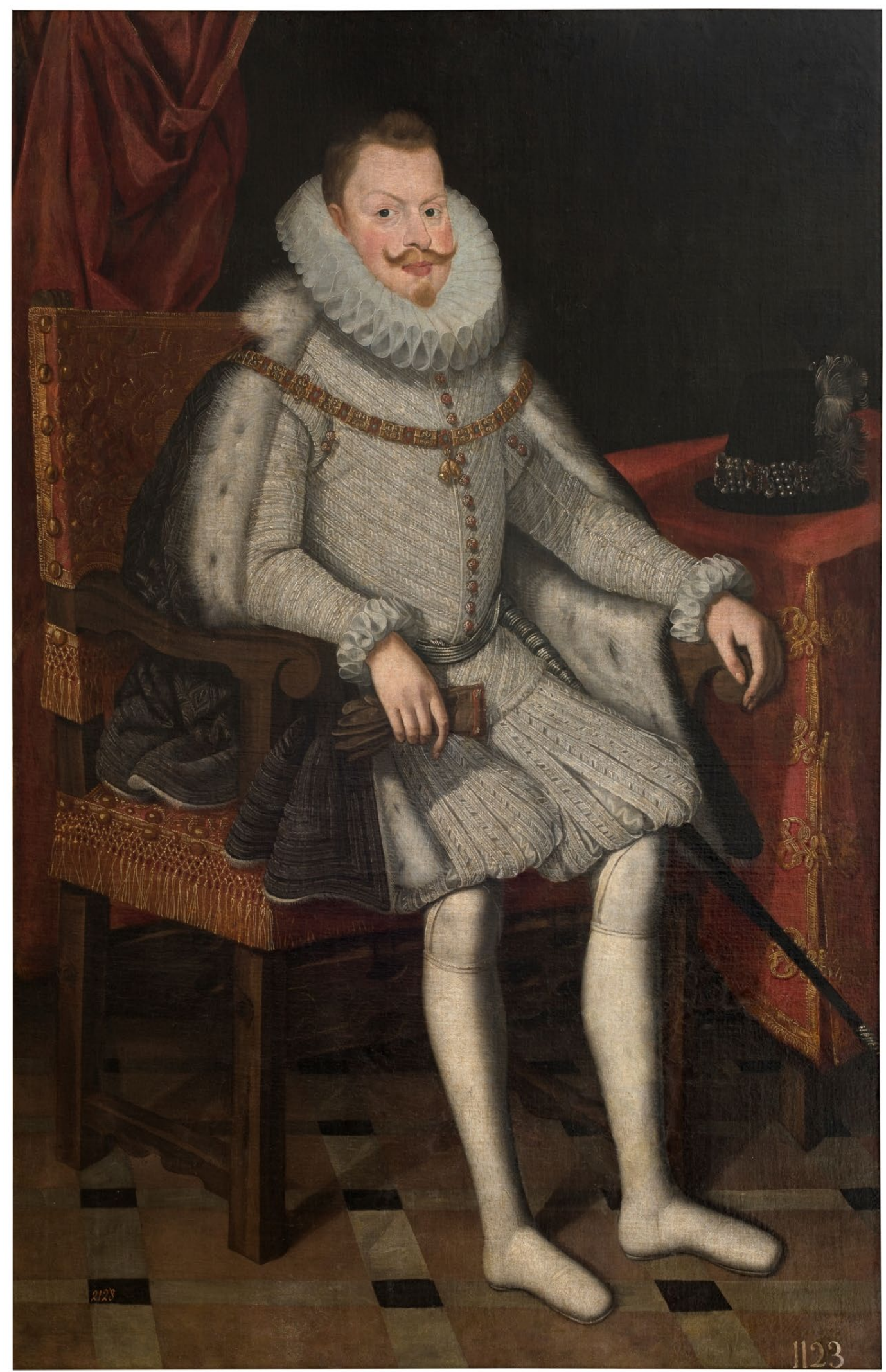

321

Fig. 3.73. Bartolomé González, Felipe III, h. 1615, óleo sobre lienzo, Madrid, Museo Nacional del Prado). 


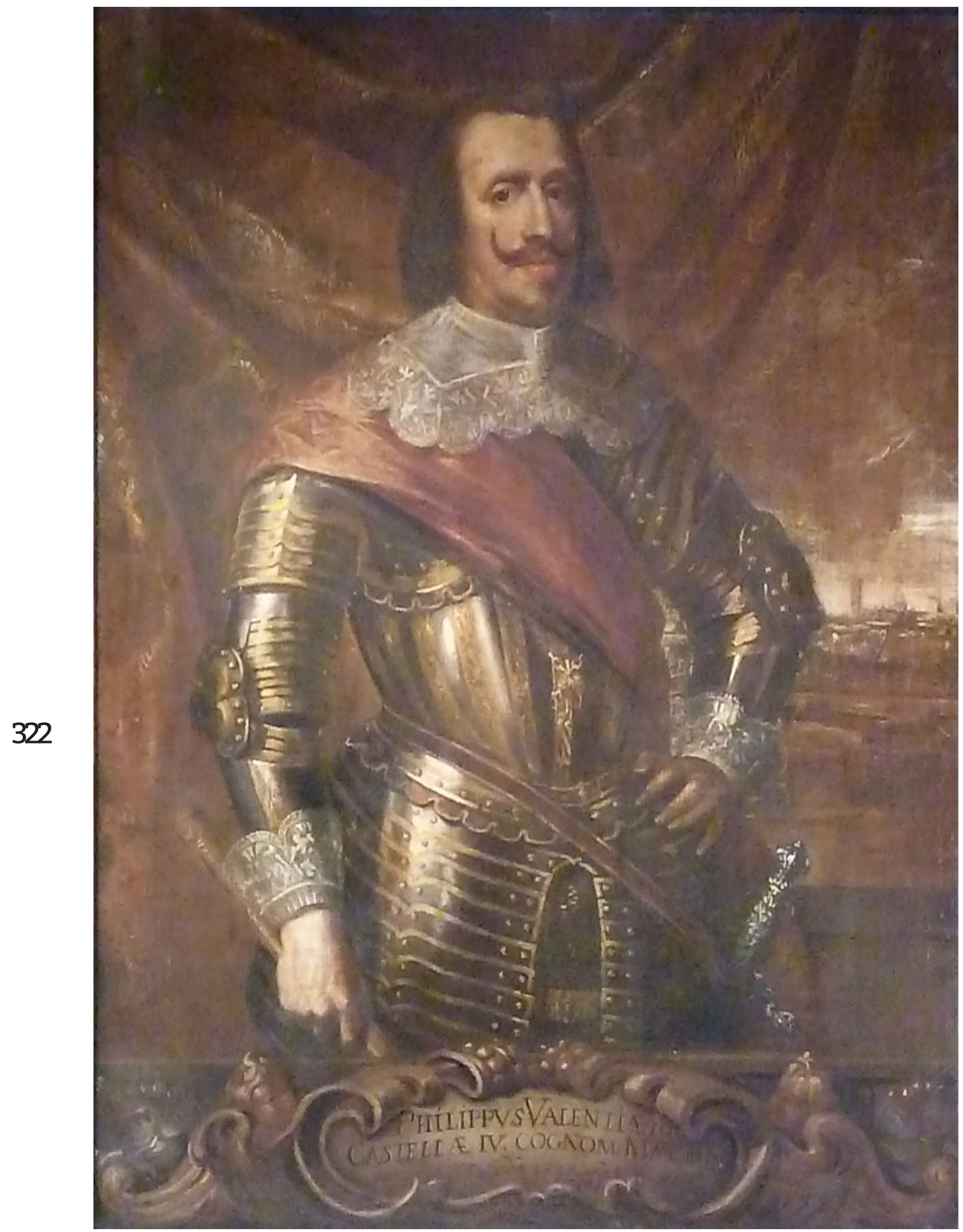

Fig. 3.74. Felipe IV, s. XVII, Valencia, palacio de la Generalitat. 
el linaje al que pertenece el Hechizado además de otros símbolos que proyectan constantemente la idea de su poder. Claro ejemplo es la obra Carlos II niño y sus antepasados (1670-1675, óleo sobre lienzo, Madrid, Museo Lázaro Galdiano), posiblemente elaborada por Sebastián Herrera Barnuevo con la ayuda de otro artista perteneciente a su taller. ${ }^{145}$ Así, la obra incluye las efigies de sus progenitores, Felipe IV y Mariana de Austria, de su hermana, Margarita y el emperador Leopoldo de Austria. También aparece el busto de Carlos V, un libro abierto con retratos familiares, que según las inscripciones se corresponden con Felipe I, Felipe II y Felipe III, y dos efigies ovaladas de dudosa identificación, sin llegar a determinar si se corresponden con los Reyes Católicos, o con la hermana del Hechizado, María Teresa, y su esposo Luis XIV. Otros elementos que se han incorporado son el cetro y la corona que sostienen un angelillo, y a los pies del monarca se encuentra el león en alusión a su poder.

La presencia de insignias reales y del león que posa sus garras sobre el orbe se dio en otros retratos del monarca desde su niñez. Sirvan de ejemplo la efigie pintada por el propio Herrera Barnuevo (1667-1671, óleo sobre lienzo, Madrid, Museo Lázaro Galdiano) y las piezas de Juan Carreño de Miranda Carlos II (1671, óleo sobre lienzo, Oviedo, Museo de Bellas Artes de Asturias) y Carlos II, como gran maestre de la orden del Toisón de Oro (1677, óleo sobre lienzo, Rohrau, Scholss Rohrau, Graf como conjunta, desempeñaban el cometido de legitimar su capacidad e idoneidad para estar al frente de la Corona y así combatir las constantes críticas entre la corte y en otras monarquías europeas que cuestionaban la aptitud de Mariana de Austria, por ser mujer, y de Carlos II, por su falta de salud, para cargar con el gobierno del reino. Sobre la creación de la imagen pública de ambos personajes véase a Álvaro Pascual Chenel, 'Retórica del poder y persuasión política. Los retratos dobles de Carlos II y Mariana de Austria.', Goya: Revista de arte, Vol. 331, 2010, pp. 124-145.

145 Víctor Mínguez, 'El espejo de los antepasados y el retrato de Carlos II en el Museo Lázaro Galdiano', Boletín del Museo e Instituto Camón Aznar, no. 45, 1991, pp. 71-82. Álvaro Pascual Chenel, El retrato de Estado durante el reinado de Carlos II: imagen y propaganda, (Fundación Universitaria Española, 2010), pp. 344-347. 
La imagen de Carlos II en la galería de la Generalitat [fig. 3.75] también ha otorgado un cierto énfasis a la introducción de las insignias reales a diferencia de lo que sucede en los retratos de aquellos que le precedieron. De hecho, en la figura de Carlos V, quien inaugura una nueva dinastía, y sus descendientes, no se ha incluido la corona, y se ha preferido aludir a las funciones militares y gubernamentales que desempeñaron los reyes. No obstante, ahora Carlos II apoya el sombrero sobre un bufete en el cual descansa la corona. Además, tras el mueble aparece un gran pedestal que sustenta una columna. Quizás se trate de una referencia más a la empresa de Carlos V y, por tanto, una alusión a ése deseo de vincularse con Hércules. Respecto a la inscripción, ésta indica que es: CAROLUS II HISPANIARUM REX. OBIIT. PRIMO DE NOVEMBRIS [...] AETA[...]. La disposición física, la indumentaria y los objetos complementarios a su vestuario casan con otros retratos del monarca. Con ello, estamos ante un signo más que evidencia la reproducción de la imagen oficial del rey. Sirvan de ejemplo dos lienzos, el primero de ellos elaborado en el taller de Claudio Coello (h. 1690, Munich, Altepinacothek) y el segundo, atribuido a Jan Van Kessel (h. 1690-1692, Bilbao, Museo de Bellas Artes). ${ }^{147}$

De los retratos analizados por el momento en esta galería, aquellos que se asemejan en mayor medida a la comentada serie de la Diputación de Aragón son los que inauguran la rama aragonesa en el reino de Valencia, es decir, desde Jaime I hasta Fernando el Católico, aunque también se acerca la representación de Carlos V. Sin embargo, las efigies del resto de los Austrias pudieron tomar como modelo otros retratos. Posiblemente esto se deba a que, en el siglo XVII había una mayor

146 Para la iconografía de Carlos II se ha seguido a Víctor Mínguez, La invención de Carlos II: apoteosis simbólica de la casa de Austria, (Centro de Estudios Europa Hispánica, 2013); Álvaro Pascual Chenel, El retrato de estado durante el reinado de Carlos II, (Universidad de Alcalá, 2009).

147 Ambas pinturas se han analizado con mayor profundidad en Pascual Chenel, El retrato de estado..., pp. 392 - 395. 


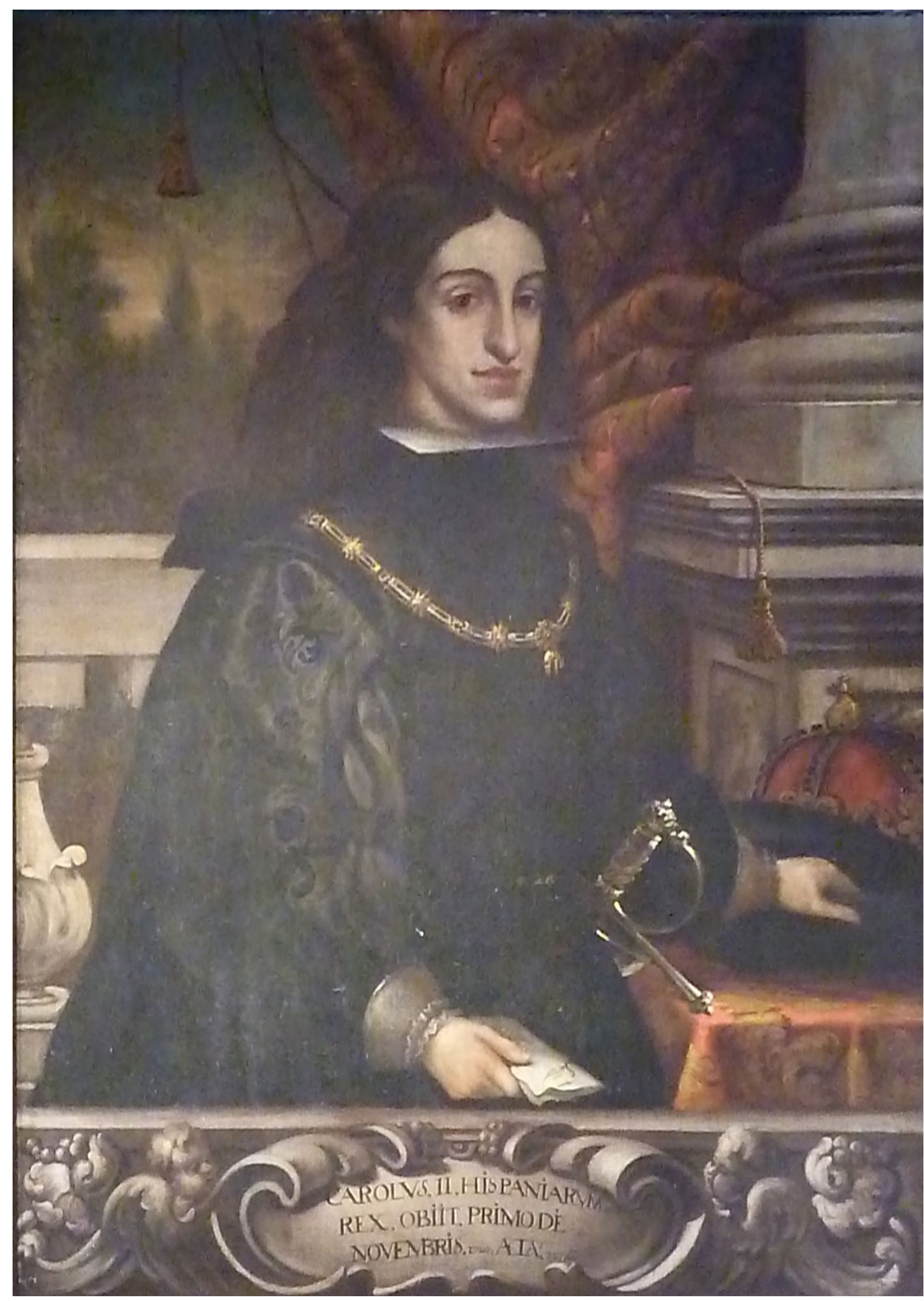

Fig. 3.75. Carlos II, s. XVIII, Valencia, palacio de la Generalitat. 
variedad y difusión de retratos de los monarcas contemporáneos y, por tanto, más opciones de conocer distintas obras que pudieran servir de patrón para el artista, y en cambio, los ejemplos de efigies de soberanos aragoneses eran más escasos y estaban más codificados por su lejanía temporal en relación al momento de creación de la serie.

\subsubsection{Soberanos de la Casa de Borbón:}

El grupo de efigies que clausuran este conjunto pertenecen a los Borbón y se han representado desde Felipe V hasta Alfonso XIII. Pese a haber un cambio de dinastía y extinguirse el gobierno de la Casa de Austria para asumir el mandato la Casa de Borbón, los retratos de Carlos II y Felipe V (1700 - 1746) [fig. 3.76] en esta serie presentan varios puntos en común. La disposición de ambos monarcas es similar, el rey de origen francés igualmente sostiene un documento y de sus vestiduras asoma la empuñadura de la espada. También, se le representa junto a un bufete donde aparece la corona y el cetro, ahora con forma de flor de lis a modo de referencia a sus raíces francesas. Aunque no luce el collar del Toisón, sí que ostenta la cruz de la orden del Espíritu Santo. La solución para el fondo es semejante y este se compone de un lujoso cortinaje, una balaustrada y un paisaje. La cartela insertada en la parte inferior del lienzo es una continuidad a las obras anteriores e identifica a: PHILIPUS HISPANIARUM REX CATHOLICUS VALENTIA CASTELLES.

Esta pieza concretamente se acerca más a la estética de los retratos de los Austrias que al lenguaje afrancesado propio de los Borbón. Por ello, hay retratos suyos donde va vestido a la española como el elaborado por Hyacinthe Rigaud [fig. 3.77]. ${ }^{148}$ Parece lógico que las primeras representaciones de Felipe d'Anjou como rey de España se correspondan con la tradición española, pues tuvo la necesidad de mostrarse como el legítimo rey. Cabe recordar que su llegada al trono se produjo al

148 Carmen García-Frías Checa y Javier Jordán de Urríes y de la Colina (coord.), El retrato en las colecciones reales..., pp. 288 - 292. 


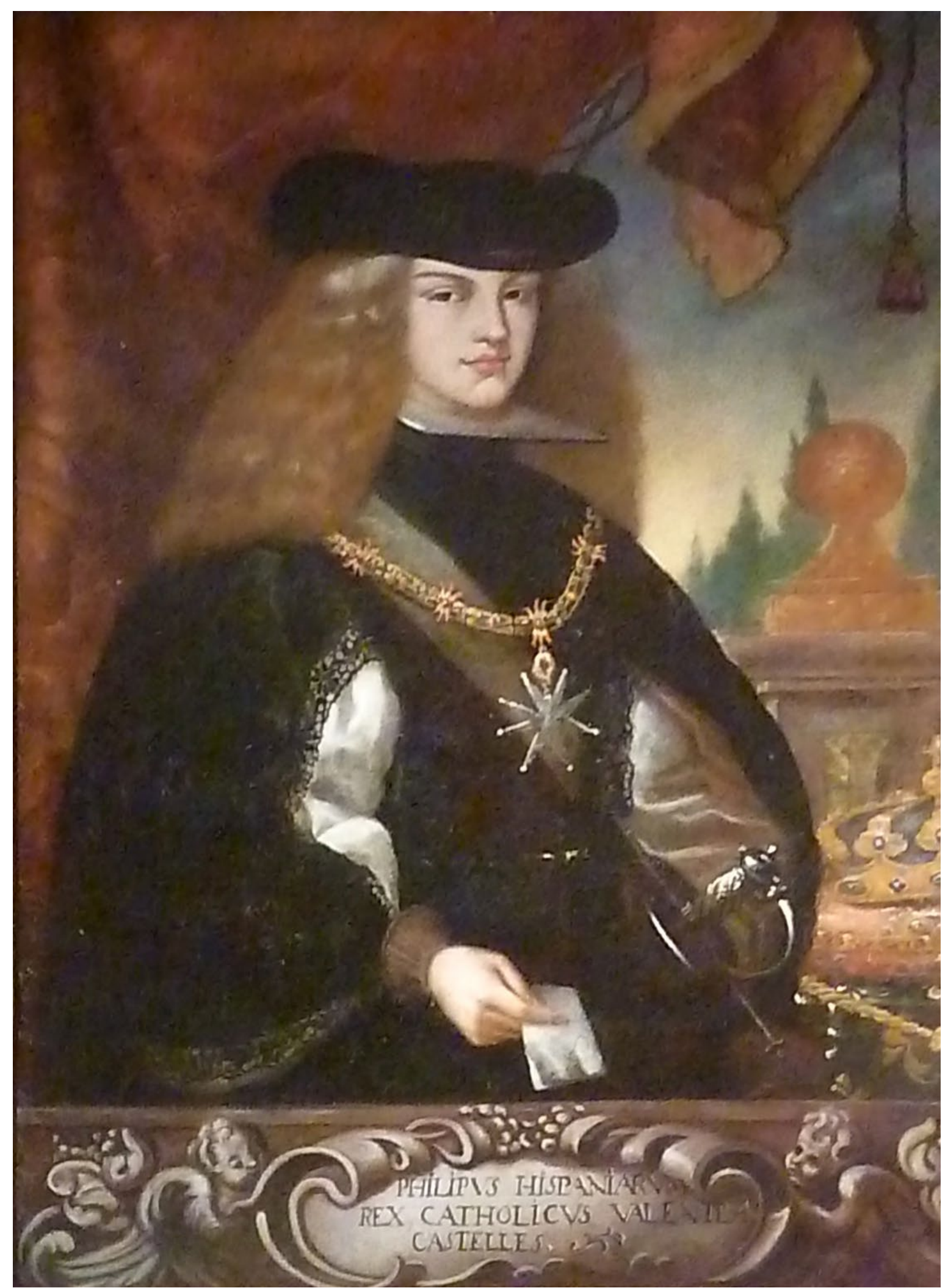

Fig. 3.76. Felipe V, s. XVIII, Valencia, palacio de la Generalitat. 


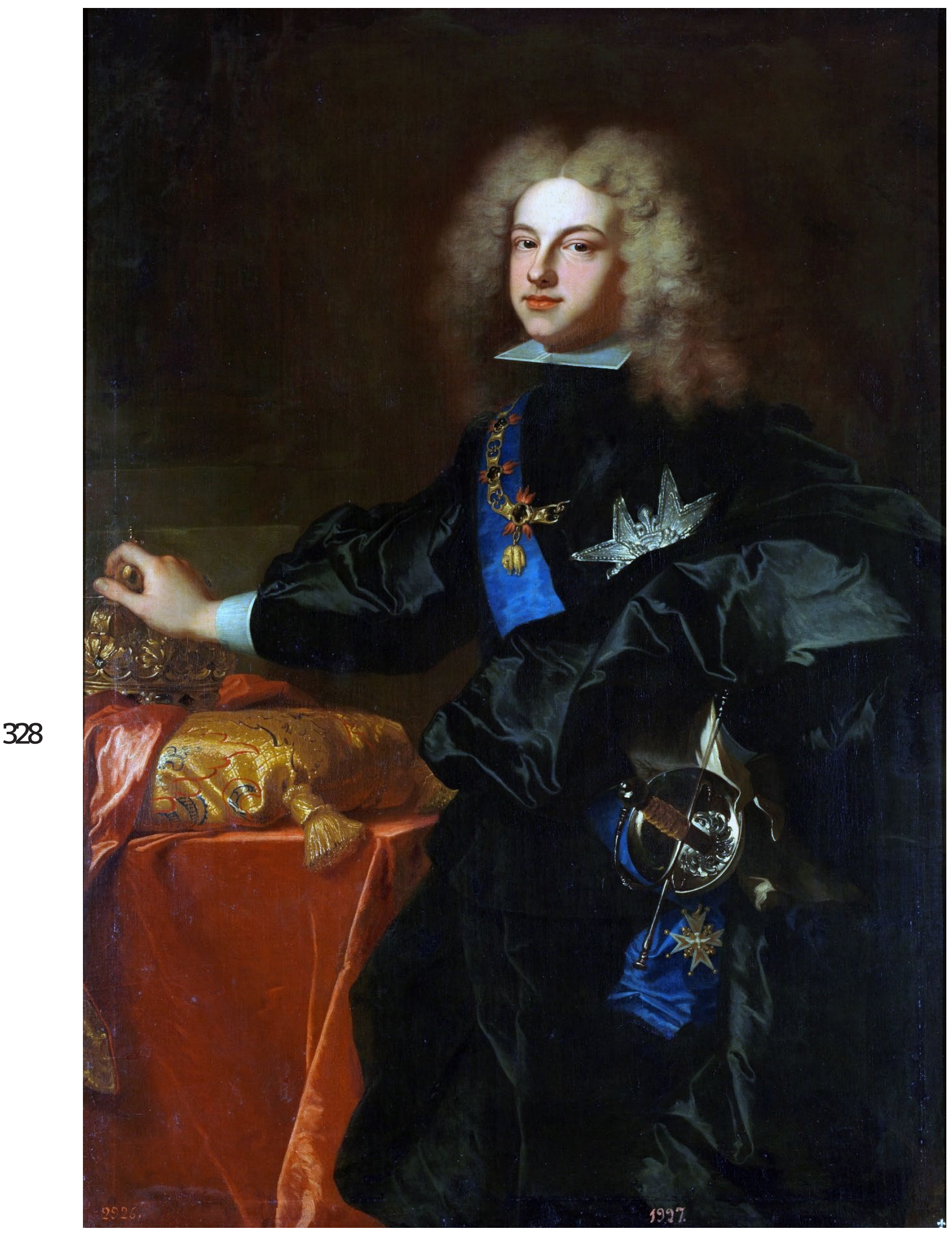

Fig. 3.77. Hyacinthe Rigaud, Felipe V, rey de España, 1701, óleo sobre lienzo, Madrid, Museo Nacional del Prado. 
vencer en la Guerra de Sucesión, y aunque contaba con el beneplácito de Carlos II por ser nieto de su hermana María Teresa, esposa de Luis XIV de Francia, la Corona de Aragón no apoyó a Felipe d'Anjou por miedo a la pérdida de autonomía de los territorios aragoneses en aras de un sistema centralizado propio de la Corona de Castilla y de Francia.

Por tanto, las primeras representaciones tratan de presentar al soberano como un continuador natural y no profundizan en mostrar el cambio de dinastía. La imagen conservada en el palacio de la Generalitat concuerda con la estética adoptada en los primeros retratos de Felipe d'Anjou como rey hispánico, cuando hay una búsqueda por hallar una representación en la que confluyan perfectamente el origen francés del monarca y el carácter español del trono que acaba de asumir. ${ }^{149}$ Por el contrario, esta clase de imágenes no se corresponde con otras efigies del mismo monarca que surgieron progresivamente y que sí evidencian la preponderancia y el triunfo definitivo de la moda francesa. Por ejemplo, aquellos pintados por los principales retratistas de este monarca, Jean Ranc (ca. 1723, óleo sobre lienzo, Madrid, Museo del Prado) y Louis-Michel van Loo (ca. 1739, óleo sobre lienzo, Madrid, Museo del Prado). ${ }^{150}$

Desde el retrato de Jaime I hasta Felipe V, la serie ha mantenido unas pautas iconográficas que no son primordiales en las efigies sucesivas. De hecho, no siempre se mantuvo la tipología de la imagen que ha imperado en este conjunto pictórico. Por ejemplo, la representación de Fernando VI (1746 - 1759) [fig. 3.78] se

149 Acerca de la búsqueda de una imagen idónea para Felipe V véase a Álvaro Pascual Chenel, 'De Austrias a Borbones: retrato, poder y propaganda en el cambio de siglo; continuidad o fractura.', en Marina Torres Arce y Susana Truchuelo García (eds.), Europa en torno a Utrecht, (Editorial de la Universidad de Cantabria: Santander, 2014), pp. 253-286.

150 Para la iconografía de Felipe V se recomienda consultar los estudios de José Miguel Morán Turina, 'El retrato cortesano y la tradición española en el reinado de Felipe V', Goya: Revista de arte, no. 159, 1980, pp. 152-161; José Miguel Morán Turina, 'Felipe V y la guerra: la iconografía del primer Borbón', Cuadernos de arte e iconografía, Vol. 1, no. 1, 1988, pp. 187-200. 
ha insertado en un óvalo, con una cartela de diseño completamente dispar al visto hasta ahora que reza: FERDIN. VI, HISPANIARUM REX. El monarca aparece vestido siguiendo la moda francesa, pues lleva una casaca roja ricamente ornamentada en oro, una chorrera de encaje, la banda azul de la orden del Espíritu Santo y el collar del Toisón. La mano izquierda reposa sobre el cetro y junto a él se ha colocado un bufete con la corona real.

La imagen de Carlos III (1759 - 1788) [fig. 3.79] también rompe con la norma tipológica dominante de esta serie. El retrato toma como modelo la efigie oficial creada por Antonio Rafael Mengs, aunque en este caso es una obra más austera y de menor calidad artística. Se ha dispuesto en un formato ovalado y sin ninguna inscripción identificativa. Así pues, aparece ataviado con una armadura completa, sobre la que se distingue el distintivo del Toisón, y luce la capa real de armiño. Igualmente apoya la bengala en un bufete donde también se encuentra la corona. Català Gorgues ha apuntado a Vergara como posi330 ble autor de dicha obra. ${ }^{151}$

El retrato de Carlos IV (1788 - 1808) [fig. 3.80] rescata nuevamente el patrón estipulado para el conjunto pictórico. Por ello, aparece representado de tres cuartos y con las insignias que lo vinculan a la orden de Carlos III dedicada a la defensa de Inmaculada Concepción. Así, lleva la correspondiente banda compuesta por tres franjas, dos blancas y estrechas a ambos lados y una azul y amplia en el centro, sobre ésta lleva la cruz de la mencionada orden. Otros elementos alusivos a su gobierno y a su dignidad son la bengala que sostiene en la mano derecha y la capa de armiño que aparece en un segundo plano. Siguiendo los parámetros de piezas anteriores, el fondo se ha resuelto incluyendo un cortinaje a través del que asoma el paisaje. Respecto a la cartela tan sólo contiene el nombre del rey: CARolus IV. En este caso, el artista probablemente se inspiró en alguna imagen oficial del monarca creada de la mano de

151 Miguel Ángel Català Gorgues, El pintor y académico José..., pp. 127128. 


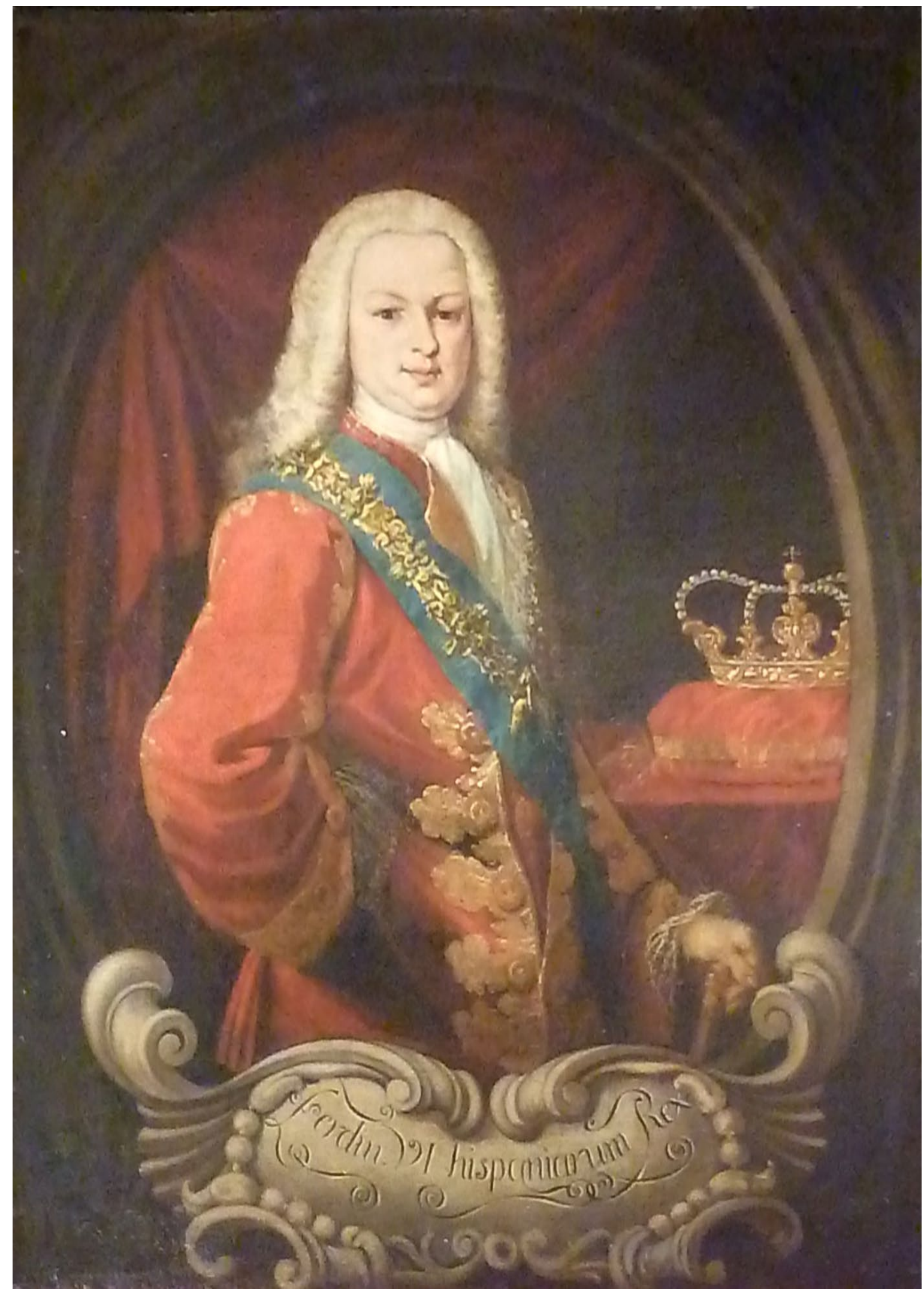

331

Fig. 3.78. Fernando VI, s. XVIII, Valencia, palacio de la Generalitat. 


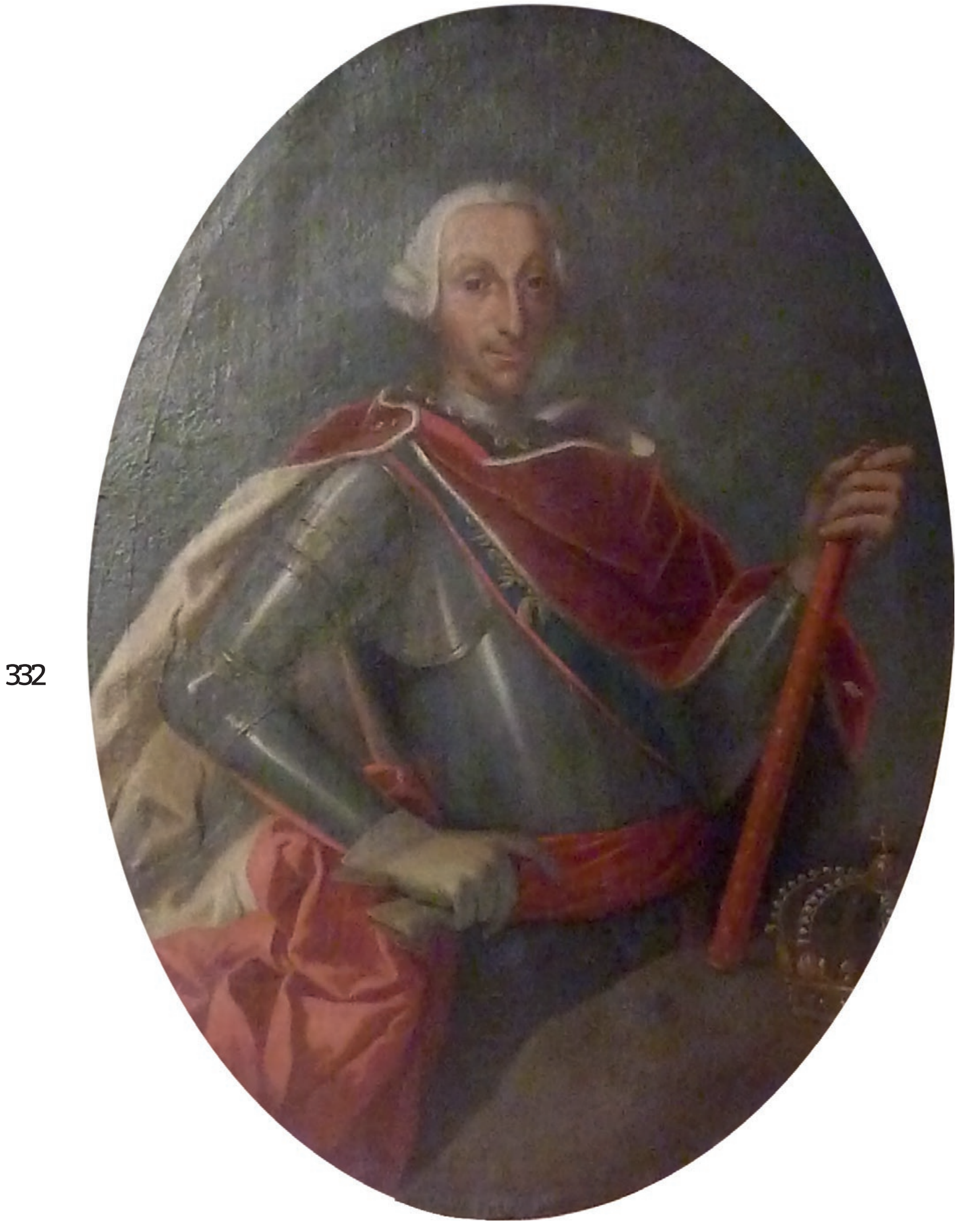

Fig. 3.79. Carlos III, s. XVIII, Valencia, palacio de la Generalitat. 


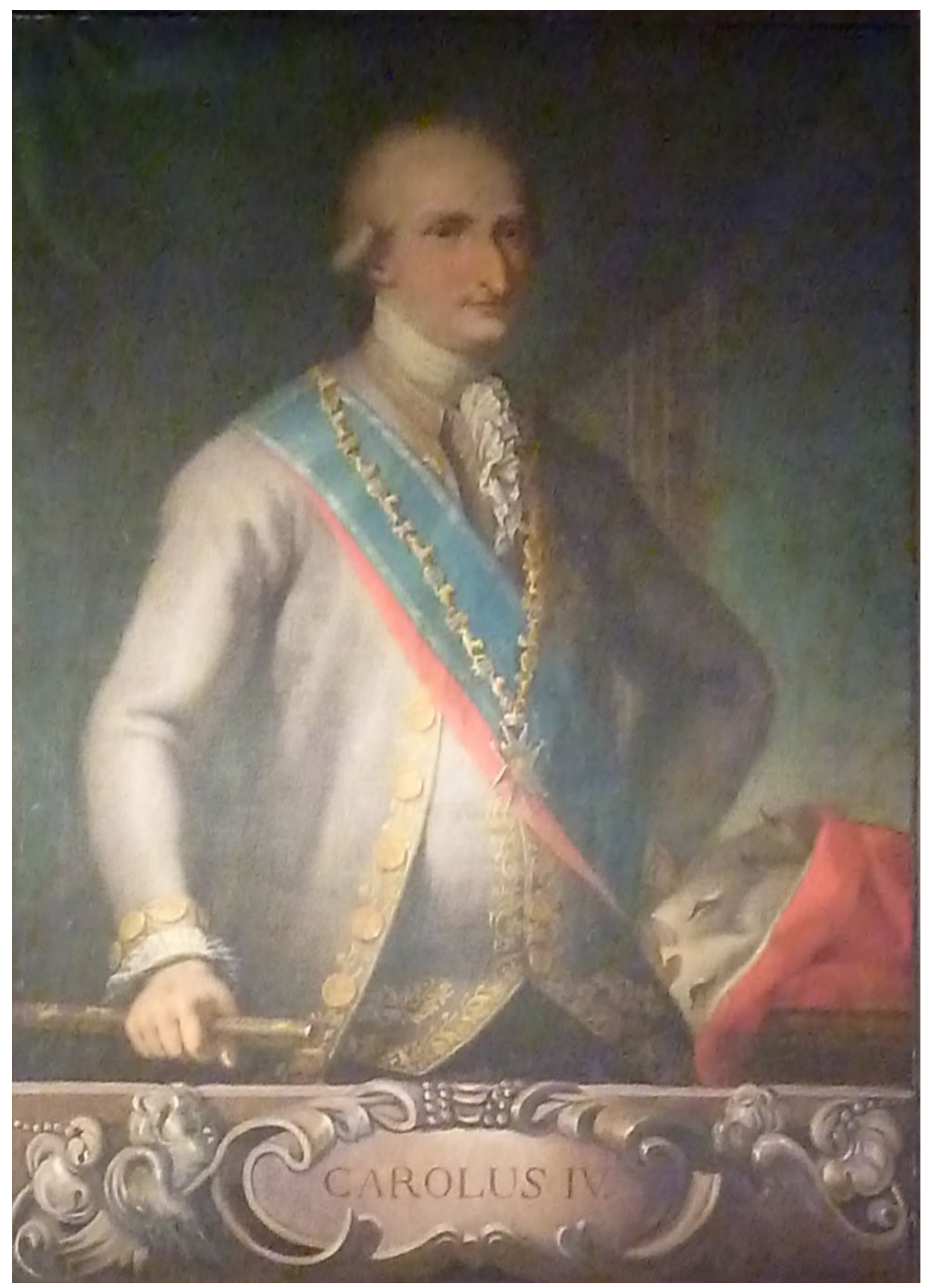

Fig. 3.80. Carlos IV, finales del s. XVIII - principios del s. XIX, Valencia, palacio de la Generalitat. 
Francisco de Goya (ca. 1789, óleo sobre lienzo, Madrid, Museo Nacional del Prado).

El resto de retratos ya deben datar de los siglos XIX y XX y a excepción de la efigie Alfonso XIII sí que se aprecia una voluntad por mantener la coherencia visual del conjunto. La imagen de Fernando VII (1808 - 1868) [fig. 3.81] se encuentra en la misma línea que el retrato de este monarca pintado por Vicente López Portaña (1814, óleo sobre lienzo, Madrid, Museo Nacional del Prado), donde aparece ataviado con el uniforme de capitán general. Sobre la casaca luce las mismas condecoraciones entre las cuales principalmente se distinguen el Toisón de Oro y la banda de la orden de Carlos III. Además, ostenta tres insignias más que no se aprecian con claridad, pero seguramente se correspondan con las representadas en el retrato oficial de Vicente López. Así, debe tratarse de las cruces de las órdenes de Isabel la Católica (creada por el propio rey), de Carlos III y la de San Fernando. La inscripción tan sólo especifica lo siguiente:

334 Fernando ViI. Rey de España. Murió en 29 de septiembre de 1855.

El retrato de Isabel II (1833 - 1868) [fig. 3.82] es una copia de otra efigie, en este caso de cuerpo entero, atribuida al artista Antonio Gómez Cros (1808 - 1863) y que forma parte de la colección pictórica de la Universitat de València. La pintura de Gómez debió realizarse a raíz de una visita de la reina a la ciudad en 1858, por ello, tras el cortinaje, la columna y la balaustrada el espacio se abre hacia un paisaje valenciano en el que distingue claramente el Micalet. ${ }^{152}$ Una vez más, la tipología del retrato se corresponde con las propias representaciones de corte y la imagen de poder de la reina, quien luce un fastuoso vestido ornamentado con encaje, aparece coronada y lleva un brazalete con el retrato de su esposo Francisco de Asís de Borbón y Borbón.

Amadeo I de España (1870 - 1873), al igual que Fernando VII,

152 Esta pieza ya ha sido estudiada en Daniel Benito Goerlich (ed.) y David Sánchez Muñoz (coord.), La Universitat de València y su patrimonio cultural, (Universitat de València: Valencia, 2008), Vol. II, pp. 222 - 223. 


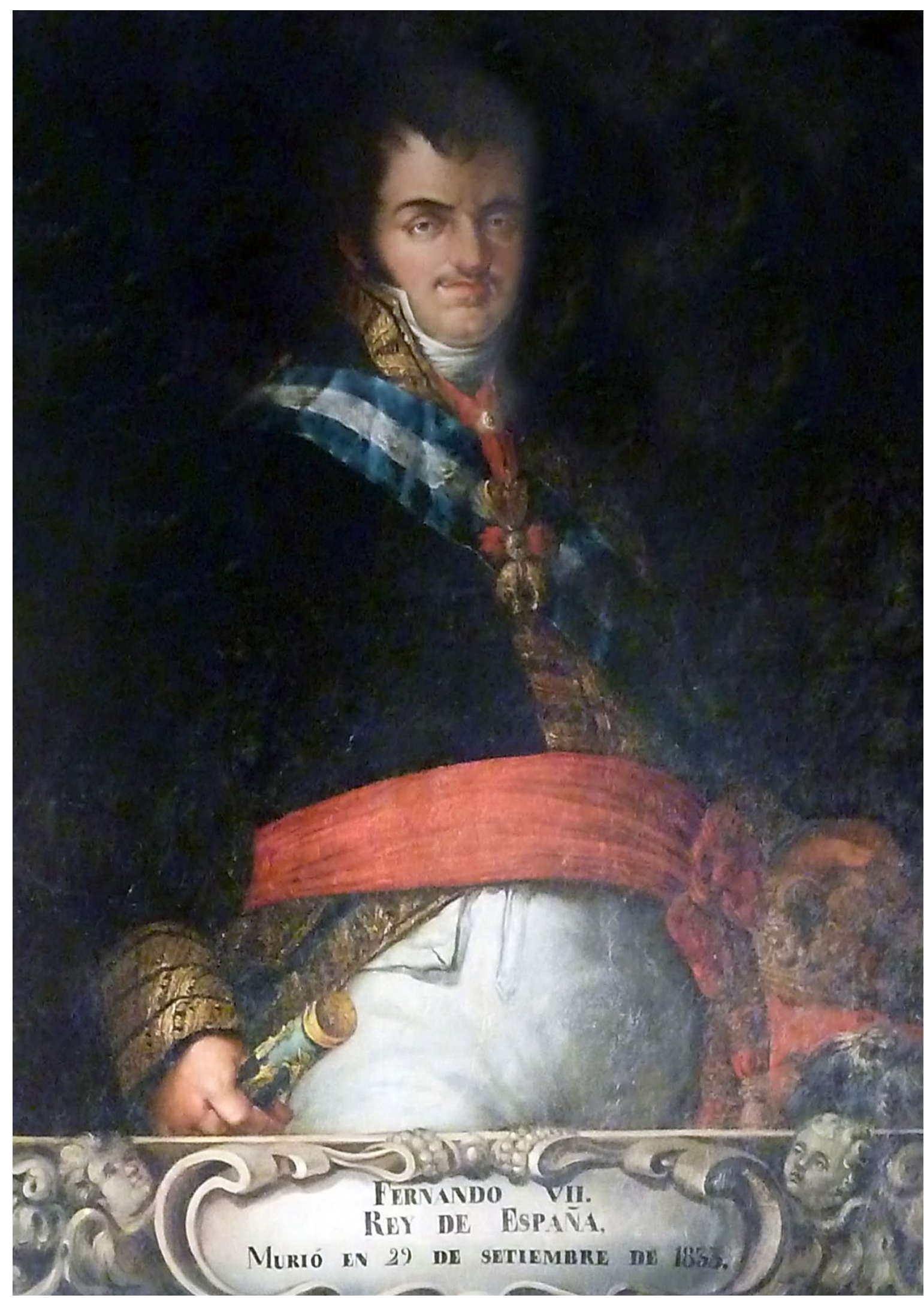

Fig. 3.81. Fernando VII, s. XIX, Valencia, palacio de la Generalitat. 


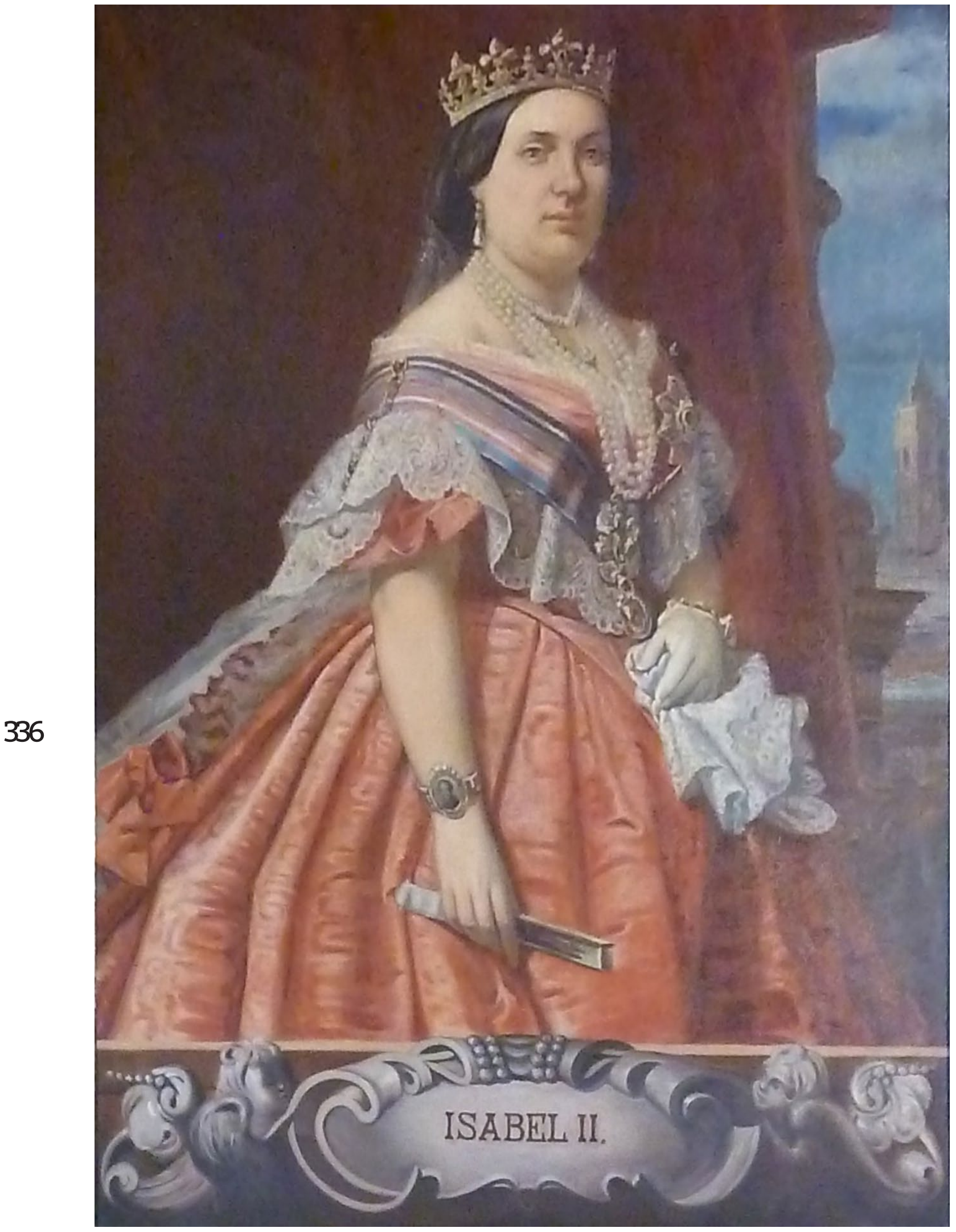

Fig. 3.82. Isabel II, s. XIX, Valencia, palacio de la Generalitat. 
viste con el uniforme de capitán general y concuerda con la imagen oficial de este monarca. La imagen de Alfonso XII (1874 - 1885) es una representación bastante austera del monarca, pues su efigie se ha dispuesto en un formato ovalado y sobre un fondo neutro. Viste un sencillo uniforme que lo representa en calidad de capitán general, llevando el Toisón, la cruz y la banda de la orden de san Fernando. Su figura conecta con el retrato póstumo que elaboró Federico de Madrazo (1886, óleo sobre lienzo, Madrid, Museo Nacional del Prado). La imagen de la reina Ma Cristina (1886 - 1902) como regente recuerda al lienzo que Vicente Cebrián pintó hacia el año 1890 para el Ayuntamiento de Valencia y que se conserva en el Palacio de Cervelló. En ambos casos se opta por representarla con un elegante vestido negro engalanado con las correspondientes medallas o la banda. La serie queda clausurada con el retrato de Alfonso XIII (1902 - 1941) que excede en tamaño y formato al resto de la galería, pues se trata de una representación de cuerpo entero donde aparece su uniforme de capitán general se ha revestido con el hábito de gran maestre de las cuatro órdenes militares de caballería, es decir, la orden de Santiago, Calatrava, Montesa y Alcántara.

La serie icónica que a día de hoy se puede contemplar en el palacio de la Generalitat es un ejemplo muy interesante por sus orígenes, pensada para lucir en el Real junto con otras imágenes de virreyes y capitanes generales. Pero resulta más relevante por la voluntad que hubo en el pasado de seguir completando la serie de modo que la destrucción del palacio a comienzos del siglo XIX no impidió que el conjunto se conservase unido aunque variase su lugar de destino. De esta manera, pervivió en el tiempo el deseo de mostrar a través de las imágenes la transmisión de la Corona conformando así una institución monárquica estable y duradera al paso de los años. 


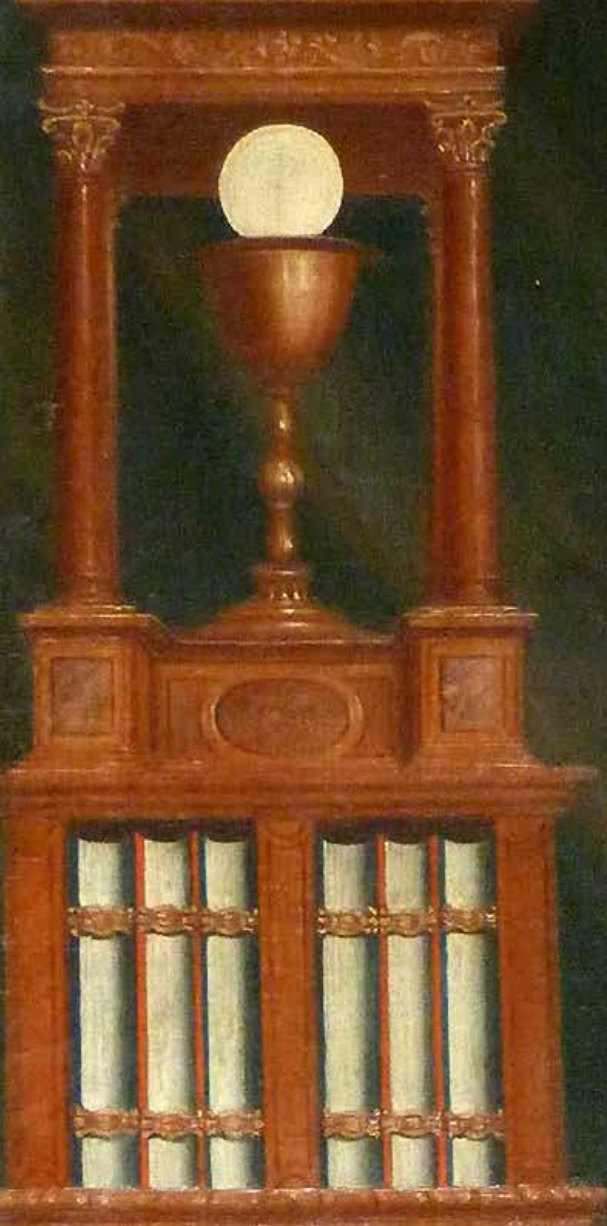




\section{Capítulo 4}

\section{Retratos eclesiásticos}

Después de estudiar algunos ejemplos de galerías de retratos de monarcas se debe valorar cómo este género también fue empleado por la Iglesia en diferentes ámbitos, pero siempre efigiando a personas que fueron un referente espiritual en la época. Los dos conjuntos que se analizan a continuación responden a circunstancias y características totalmente dispares, sin embargo, es importante apreciarlos y entender el funcionamiento del retrato en escenarios distintos. El primero de ellos es el correspondiente a los obispos y arzobispos de la diócesis valenciana. Se trata de una serie icónica de cariz institucional que muestra a los pastores y máximos dirigentes del catolicismo valenciano. De forma similar a los casos tratados en el capítulo anterior, aquí se evidencia la transmisión del poder de unos prelados a otros que si bien no configuran un linaje sanguíneo sí conforman una estirpe simbólica.

Totalmente distinta es la colección de efigies que san Juan de Ribera fue construyendo sobre aquellos frailes, venerables y beatos que fallecieron con fama de santidad. Estos retratos no tienen el aire oficial observable en los obispos y arzobispos por dos razones principales; por un lado, hay que tener en cuenta que fueron pinturas de uso particular. Por otro lado, son imá- 
genes fundamentalmente de hombres admirables en la época por su fe inquebrantable y su conducta modélica, por ello, eran ejemplos de personas humildes con opciones a alcanzar la santidad. El ejercicio de estudio y de reflexión en ambos conjuntos es una tarea que permite observar cómo el retrato fue eficaz para generar imágenes del poder espiritual en registros muy distintos. En cualquier caso, las efigies han perpetrado la imagen de personas modélicas para la Iglesia católica. Los prelados retratados han sido un referente para otros sacerdotes que han visto en sus superiores un ejemplo de pastor. Los frailes, beatos y venerables efigiados alimentaron la fe de la sociedad común y fueron imagen de la virtud espiritual.

\subsection{Retratos de la cúspide eclesiástica. La serie icónica de los prelados valentinos.}

La catedral de Valencia custodia una serie icónica con las efigies de los obispos y arzobispos que han estado al frente de la 340 sede valentina. En su conjunto suman un total de cincuenta y siete lienzos pintados desde 1568 hasta la actualidad. El retrato de Ferrer de Pallarés (arzobispo de Valencia entre los años 1240 y 1243) inauguró el grupo de imágenes por ser el primer prelado tras la reconquista cristina del reino. ${ }^{1}$ La localización exacta de las piezas en la catedral, como se verá, ha variado desde su comienzo. Pasando desde una estancia delante del archivo, a la antigua y nueva sala capitular hasta el día de hoy situados en la sacristía nueva, es decir, la sala que conecta la sacristía mayor con el aula capitular [fig. 4a-4d].

El nacimiento y el desarrollo de esta serie se deben contextualizar con la relevancia de la catedral de Valencia como receptora de las principales manifestaciones artísticas. Así, a finales del siglo XV y principios del XVI este edificio quedó revestido con excelentes obras de Paolo de San Leocadio, Francesco Pa-

1 José Sanchís y Sivera, La catedral de Valencia: guía histórica y artística, (Librerías París - Valencia: Valencia, 1990), pp. 235-236 y p. 252. 

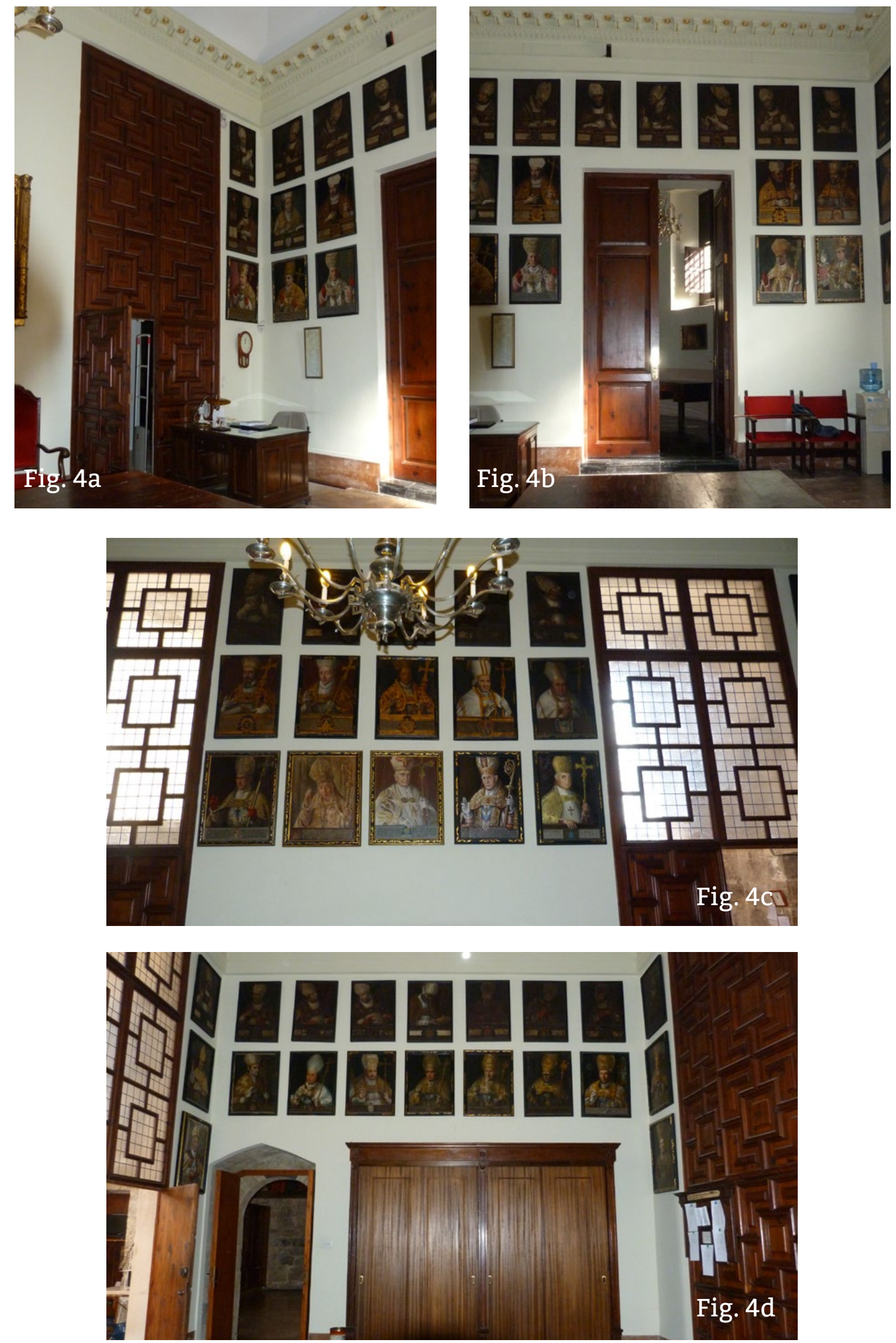

Fig. 4. (a-d).Vistas generales de la serie icónica de prelados de la catedral de Valencia. 
gano, Yáñez y Llanos. ${ }^{2}$ El siglo XVIII también fue clave para el templo, pues en 1774 se dio inicio a la reforma neoclásica de Antonio Gilabert que tuvo un gran impacto en la transformación de todas las capillas. ${ }^{3}$ Asimismo, las obras pictóricas que engalanaron los distintos espacios fueron encargadas a artistas procedentes de la Academia de Bellas Artes de San Carlos, quienes a su vez elaboraron algunos de los retratos que componen la galería de prelados. Por ejemplo, José Inglés retrató al arzobispo Fabián y Fuero, Vicente López a Despuig y Dameto, la efigie de Jiménez del Río también se ha asociado al taller de López y otros retratos se han atribuido a Miguel Parra.

Respecto a la creación de este tipo de galerías es una práctica que se remonta a los siglos XIV y XV y en ella se presenta al arzobispo como la más alta dignidad de la diócesis correspondiente. Aquellos investigadores que han estudiado previamente esta clase de conjuntos, como Inmaculada Rodríguez, han visto que detrás de estos proyectos subyacía la voluntad por ofrecer una imagen sólida del poder de la Iglesia. ${ }^{4}$ Por consiguiente, ésta mostraba ser una institución firme e imperecedera. Sin duda, era una solución inteligente y eficaz para poder proyectar una imagen de seguridad cuando la sociedad valenciana estaba atravesando tiempos de inestabilidad.

A día de hoy y respecto a los prelados de Valencia, no se cuenta con un estudio pormenorizado que reflexione acerca de la función cultural que ejerció, desde su comienzo, esta serie icó-

2 Miguel Falomir Faus, La pintura y los pintores en la Valencia del Renacimiento, 1472-1620, (Consell Valencià de Cultura: Valencia, 1994), p. 86.

3 Daniel Benito Goerlich y Amparo José Mora Castro, 'La iconografía de la catedral de Valencia. Un programa ilustrado', en Emilio Callado Estela (ed.), La catedral ilustrada: Iglesia, sociedad y cultura en la Valencia del siglo XVIII, (Valencia, 2014), pp. 323-371.

4 Inmaculada Rodríguez Moya, 'Dinastía de prelados. La serie de retratos de obispos de la diócesis de Segorbe', Sociedad Castellonense de Cultura: Castellón, Boletín de la Sociedad Castellonense de Cultura, no. 79, 1, 2003, pp. 253-274. 
nica. De hecho, los lienzos aparecen reproducidos en artículos y libros que tratan exclusivamente la biografía de cada uno los representados. Las obras simplemente han puesto un rostro al personaje descrito, pero no se han valorado colectivamente como tampoco se ha profundizado en el papel desempeñado por las mismas. En este sentido los retratos tan sólo han aportado la imagen al episcopologio, entendido como la «serie de obispos de una Iglesia o la relación de vidas de los obispos, no en general, sino en particular de algunas Iglesias. ${ }^{5}$

Según ha explicado Emilio Callado, el interés suscitado por conocer la figura del prelado valenciano tuvo su origen en el siglo XV. Tal y como se ha comprobado en el archivo de la catedral, en esta época ya se anotaron todos los nombres de los obispos locales incluyendo las fechas de inicio y finalización del cargo. En concreto se dejó constancia de los obispos desde la restauración de la sede valenciana hasta la llegada al papado de Alfonso de Borja en 1429. ${ }^{6}$ Además, el mismo autor ha estudiado todas las fuentes escritas que hablan del conjunto de prelados que ocuparon la sede valentina. Es conveniente ser consciente de la existencia de estas obras porque aportan un contexto a la creación de la serie icónica. Entre las referencias más destacables se encuentra una segunda relación escrita por José Esteve bajo el título Sumario de los obispos antiguos de Valencia en el siglo XVI. A mismo tiempo se escribió la Relación de los obispos y arzobispos de la Santa Iglesia de Valencia, desde la última vez que fue liberada hasta el año presente de MDXCIX, cuyo autor se desconoce. ${ }^{7}$

5 Definición empleada por el autor basándose en las acepciones establecidas por la Real Academia de la Lengua Española. Véase a Emilio Callado Estela, 'Breu història dels episcopologis valencians', Universitat de València, Scripta: revista internacional de literatura i cultura medieval i moderna, no. 1, 2013, pp. 159-172.

6 Callado Estela, íbidem. El autor localizó este documento en el Archivo de la Catedral de Valencia (ACV de ahora en adelante): Leg. 790, 1.

7 Emilio Callado ha localizado un ejemplar de esta obra en la Biblioteca Nacional de España, Ms. 732, ff. 248-251. 
No obstante, el trabajo que mayor vinculación puede tener con la serie pictórica es la obra de Gregorio Ivanyes, archivero de la catedral, quien elaboró un Resumen de les vides dels senyors bisbes $i$ arquebisbes de València. ${ }^{8}$ Se trata de un manuscrito probablemente contemporáneo a los retratos que además, al igual que el conjunto artístico, recoge las biografías de los prelados desde Ferrer de Pallarés hasta san Juan de Ribera. Es más, se debe remarcar que el autor fuese el archivero de la catedral pues como ya apuntó Sanchis y Sivera en 1585 la serie icónica se encontraba en la estancia situada delante del mismo archivo. ${ }^{9}$

Otra fuente escrita que cabe citar es el Episcopologio de Francisco Diago donde se anotaron los datos biográficos más significativos de los prelados desde Berenguer de Castellbisbal, quien fue el primer obispo propuesto que no electo, hasta otra vez el Patriarca Ribera. Este tipo de obras vieron la luz de forma actualizada incluso después del gobierno de Ribera, de modo que se aprecia un interés constante por dejar constancia de la identidad y biografía de los obispos y arzobispos poniendo de manifiesto que eran personajes ejemplares merecedores de perpetuar su memoria. De hecho, el Discurso de los obispos y arzobispos de esta iglesia publicado en la relación festiva por la beatificación de santo Tomás de Villanueva incluía al prelado Isidoro Aliaga, quien asumió la mitra valentina después del fallecimiento de san Juan de Ribera. Hasta el gobierno de Luis Alfonso de los Cameros recogió José Agramunt en su Memoria de todos los obispos y arzobispos que ha habido hasta el dia de oy en Valencia, realizada a mediados del siglo XVII. ${ }^{10}$ Similar 8 Callado ha facilitado la referencia para localizar este documento en el ACV: Leg, 44, 8.

9 Sanchís y Sivera, La catedral de Valencia..., p. 235. Este dato fue aportado por el autor a raíz de consultar el libro de obras de 1585 por el cual se conoce que se hicieron obras en la terraza «davant lo aposiento del archiu a hon están los retratos dels bisbes». ACV: Llibre de obres, 1585, fol. 24v.

10 Este episcopologio se forma parte del Libro de casos sucedidos en la ciudad de Valencia tanto antiguos como modernos, en donde se hallaran 
fue el Catálogo de los obispos y arzobispos de Valencia desde el primero de la muerte de Cristo, treinta y cuatro de la vida y tiempo de los apóstoles, hasta el presente año de 1672 de Joaquín Ballester que forma parte de una obra más amplia bajo el título Identidad de la imagen del santo Christo del Salvador de Valencia. ${ }^{11}$

En el siglo XVIII a medida que fue creciendo la serie pictórica siguieron viendo la luz otras relaciones escritas que incluían el paso de los prelados más recientes en la época. Por ejemplo, Joaquín Ortí Figuerola compuso el Díptico de los obispos y arzobispos de Valencia donde ya aparece Andrés Mayoral. Y José María Ortiz en 1763 terminó de elaborar el Cronicón o catálogo breve de los obispos y arzobispos de Valencia, desde su conquista, formado de los monumentos del archivo de su santa Iglesia. También en el siglo XIX, Joaquín Company Ferrer aportó su Catálogo de prelados de Valencia desde su Conquista. Cabía mencionar esta selección de obras para entender su importancia al recopilar las identidades de los dirigentes eclesiásticos, quienes perpetuaron su apariencia y exaltaron su poder a través de los retratos.

\subsubsection{El nacimiento de la serie en la segunda mitad del siglo XVI.}

Partiendo de las aportaciones de José Sanchís y Sivera en su investigación acerca de la catedral de Valencia se conoce, como ya se ha dicho, que las efigies se ubicaban delante del archivo a finales del siglo XVI. En 1909, cuando Sanchís publicó su estudio, los cuadros se encontraban en la antigua sala capitular. Por entonces la serie contaba con cuarenta y siete piezas. Se cree que fue Juan de Juanes, su taller y también,

muchas cosas curiosas y noticias de muchas fundaciones antiguas y noticias de todos los virreyes, obispos y arzobispos desde el primero hasta el dia de oy.

11 Juan Bautista Ballester, Identidad de la imagen de S. Christo de S. Salvador de Valencia, (Geronimo Vilagrasa: Valencia, 1672). 
su hijo Vicente Juan Macip, quienes realizaron las veinticuatro primeras efigies en guadamecíes, desde Ferrán de Pallarés hasta san Juan de Ribera. ${ }^{12}$ Según Felipe Garín los retratos permanecieron en la vieja sala capitular hasta el inicio de la Guerra Civil, después a partir de 1939 se colocaron en la nueva sala capitular. ${ }^{13}$

San Juan de Ribera debió de encargar o promover la realización de la serie a raíz de asumir la dirección de la diócesis valentina en el año 1568, pues se trataba de un proyecto artístico en el que él mismo sería uno de los distinguidos prelados. No es de extrañar este hecho teniendo en cuenta su gusto por formar parte de las salas de linajes y justificar así su ascendencia tanto familiar como profesional. En ese sentido se encuentra la galería, ya estudiada en el capítulo anterior, de retratos de la monarquía. Como consecuencia del deseo de poner de manifiesto la exclusividad del poder eclesiástico y de mostrar su pertenencia al reducido grupo de religiosos que alcanzaron las cotas más altas en la dirección de una diócesis, sería predecible que el Patriarca causase la elaboración de la dinastía de obispos y arzobispos.

Cuando en el siglo XVI se decidió pintar una serie icónica de prelados que abarcase la historia de los dirigentes de la diócesis valenciana, se tuvieron que elaborar en primer lugar diecinueve retratos en guadamecíes, fechados en 1568 y asociados al taller de Juan de Juanes. Entre los efigiados se han identificado a Ferrer de Pallarés (pontificado en 1240-1243), Arnaldo de Peralta (1243-1248), fray Andrés de Albalat (1248-1276), Jazperto de Botonach (1276-1288), Raimundo Despont (1289-

12 Sanchís y Sivera, La catedral de Valencia..., pp. 235-236. El autor se aventura a proponer el retrato de santo Tomás de Villanueva como obra del propio Juan de Juanes. Su hipótesis sobre el artista o el taller que llevó a cabo inicialmente esta empresa se relaciona con la existencia de un recibo en 1568 por la compra de un guadamecí que fue entregado al artista para pintar una obra para el cabildo.

13 Felipe Ma Garín Ortiz de Taranco, 'La serie iconográfica prelacial de Valencia', Saitabi: revista de la Facultat de Geografia i Història, no. 13, 1963, pp. 83-86. 
1312), Raimundo Gastón (1312-1348), Hugo de Fenollet (13481356), Vidal de Blanes (1365-1369), Jaime de Aragón (13691396), Hugo de Lupià y Bages (1398-1427), Alfonso de Borja Cabanilles (1429-1458) [fig. 4.1], Rodrigo de Borja (1458-1492) [fig.4.2], César de Borja (1492-1498), Juan de Borja Llançol de Romaní (1499-1500), Pedro Luis de Borja Llançol de Romaní (1500-1511), Alfonso de Aragón (1512-1520), Erardo de la Marca (1520-1538), Jorge de Austria (1538-1544) y Santo Tomás de Villanueva (1544-1555). Generalmente son retratos donde se aprecia una gran variedad de gestos y posiciones para representar a cada uno de ellos y cuyos rostros probablemente fueron idealizados, ya que se necesitaba crear la imagen de los primeros prelados en época medieval.

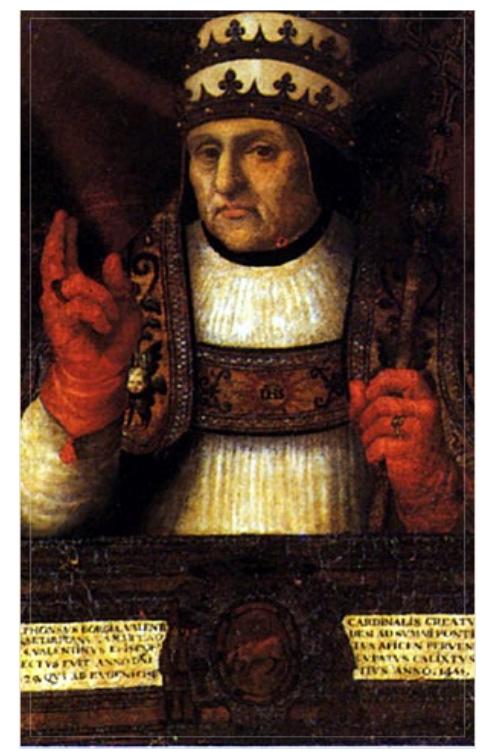

Fig. 4.1. Taller de Juan de Juanes, Alfonso de Borja Cavanilles, 1568, óleo sobre guadamecí, Valencia, catedral.

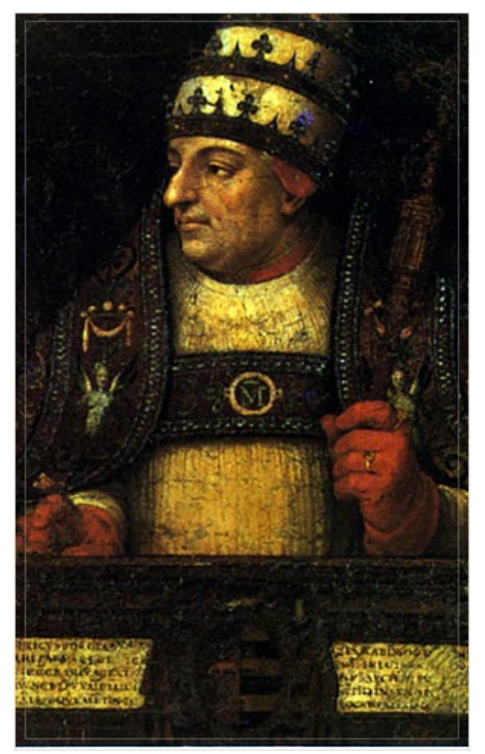

Fig. 4.2. Taller de Juan de Juanes, Rodrigo de Borja, 1568, óleo sobre guadamecí, Valencia, catedral.

Sin embargo en el caso de Alfonso de Borja Cavanilles y su sobrino Rodrigo de Borja sí que se disponen de otras efigies anteriores o contemporáneas a estos retratos, pues el llegar a ser pontífices produjo la difusión de su imagen. Por ejemplo Alfonso de Borja, también conocido como el papa Calixto III fue retratado en calidad de cardenal y como orante junto a san 
Idelfonso en la tabla derecha del retablo dedicado a santa Ana (Pere Reixach, 1452, Xàtiva, Museo de la Colegiata). Más numerosas son las imágenes de Rodrigo de Borja, quien gobernó bajo el nombre de Alejandro VI. En todas ellas son característicos sus ojos caídos y la nariz aguileña, mucho más acentuada por representarlo habitualmente de perfil. Así sucede en el anverso de la medalla conmemorativa de la reforma del castillo de Sant'Angelo, el cual aparece en el reverso [fig. 4.3]. También es característico su retrato pintado por Cristofano dell' Altissimo (s.XVI, Florencia, Galleria de los Uffizi) o la estampa conservada en la Biblioteca Nacional [fig.4.4], esta última además

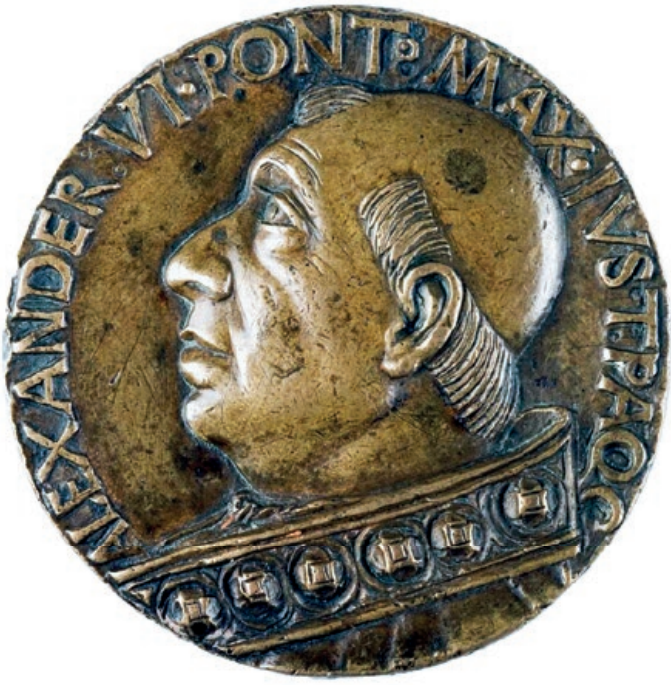

Fig. 4.3. Medalla de Alejandro VI, 1492-1503, bronce, acuñada en Roma, Madrid, Museo Arqueológico Nacional, $\mathrm{n}$ o de inventario 2002/96/104.

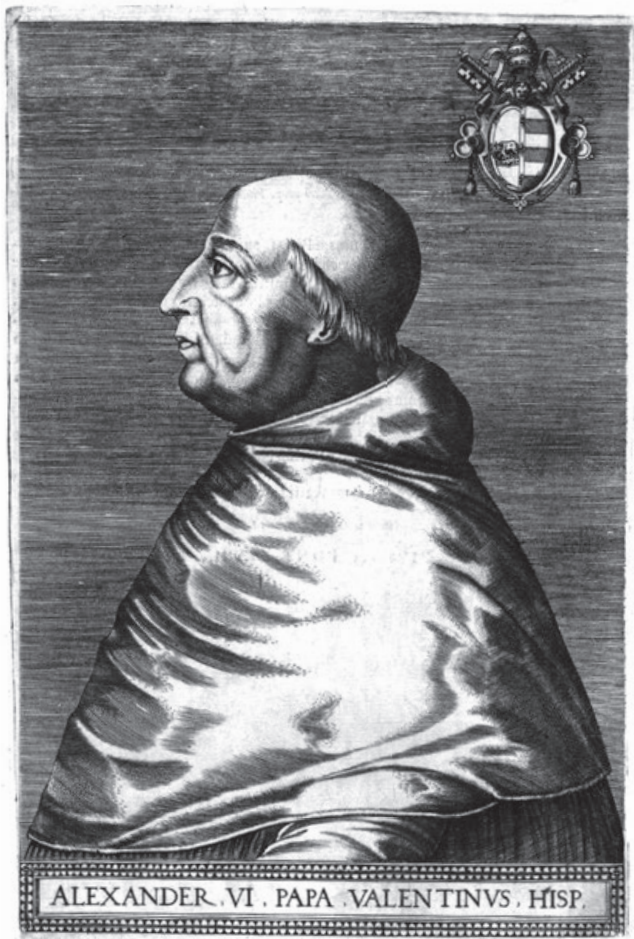

Fig. 4.4. Philippe Soye, Alejandro VI, 1568, estampa, Madrid, Biblioteca Nacional de España.

ha añadido el escudo heráldico que además está presente en la pintura de la catedral. Vicente Macip Comes, en 1585, pintó sobre cuero los retratos Francisco de Navarra (1556-1563), Acisclo de Moya Contreras (1564), Martín Pérez de Ayala (1564-1566) y Fernando de Loaces (1567-1568), este último fue el predecesor de Ribera con quien finalizaría este proyecto artístico en su primera etapa. Por tanto, los retratos que inauguran la serie han fijado el modelo de representación 
que se respetará a lo largo de los años para garantizar la homogeneidad de la serie. El esquema compositivo que se repite es una imagen de medio cuerpo con cierta variedad de posturas, o bien de frente o de perfil en cualquiera de los dos sentidos, así como diferentes gestos con los brazos y las manos. Siempre aparecen vestidos con la capa pluvial bordada con infinidad de motivos, la mitra y a veces, guantes. En alusión a su función pastoral, los prela-dos sostienen la cruz pastoral o el báculo.

La interpretación acerca del significado de estos elementos hallada en fuentes escritas hace hincapié en la función pasto-ral de los prelados. Por ello, se ha explicado que la forma rec-ta del cayado recuerda al oficio que desempeñan como guías, quienes conducen espiritualmente a los fieles para que estos caminen con rectitud. Del mismo modo, el báculo termina con una voluta para señalar que también atraen a los que no siguen el camino estipulado, a los que se alejan de Dios y de su Iglesia. Con la mitra hacen referencia a su conocimiento tanto del Antiguo como del Nuevo Testamento. En ocasiones el prelado cubre sus manos con guantes blancos o rojos. Con ellos remite a la actitud prudente y decorosa ante sus acciones. A su vez simbolizan la piel del cordero con la que Rebeca cubrió las manos de Jacob. ${ }^{14}$ También recuerdan que el prelado no debe disponer de culpas propias y debe revestirse con las fal-tas de los demás, emulando aquello que hizo Jesucristo. ${ }^{15}$ Con las manos cubiertas o no, siempre llevan una alianza de oro puro ornamentada con una piedra preciosa. Se trata del anillo que, desde el siglo XII y por voluntad de Inocencio III, se les en-tregaba a los obispos durante su ceremonia de consagración a modo de símbolo de su entrega a la Iglesia.

14 «Después Rebeca tomó una ropa de su hijo mayor Esaú, la mejor que había en la casa, y se la puso a Jacob, su hijo menor; y con el cuero de los cabritos le cubrió las manos y la parte lampiña del cuello.» (Gn 27:15-16)

15 Antonio Lobera y Abió, El por qué de todas las ceremonias de la Iglesia y sus misterios: cartilla de prelados y sacerdotes que enseña las ordenan-zas eclesiásticas que deben saber todos los ministros de Dios, (Ignacio Por-ter: Figueras, 1769), p. 83. 
Todos los retratos presentan en su parte inferior un texto en latín, interrumpido por el escudo de armas correspondiente al prelado, que identifica y menciona sus éxitos conseguidos. El distintivo heráldico junto con la descripción son instrumentos que individualizan al personaje, así como se utilizan para prolongar su fama mediante el reflejo de sus virtudes y la exaltación de su linaje. A través de la divisa del personaje también se le retrata genealógicamente. ${ }^{16}$

El nacimiento de la heráldica religiosa comenzó a finales del siglo XII, aunque su introducción en España se dio bien entrado el siglo XIII y su utilización se extendió en el siglo XV, cuando los clérigos no tenían escudo de armas pero eran hijos de nobles que sí las poseían y comenzaron a adoptarlos. A grandes rasgos, los escudos apreciables en los retratos estudiados en este apartado se corresponden con la tipología primitiva de las armas para clérigos y por ello, se han creado a raíz de los blasones gentilicios de sus respectivas familias. Podían emplearlos, aunque no fueran los primogénitos, por su condición eclesiástica ya que al no disponer de descendencia legal no había posibilidad de traspasar el escudo. Además, y como se aprecia en todas las pinturas, cada uno de ellos se timbraba, en este caso, con el sombrero episcopal por ser prelados. ${ }^{17}$ Por tanto, en la dinastía de obispos y arzobispos se puede vislumbrar como el representado pertenece a la élite desde dos perspectivas opuestas, la primera de ellas es debida a ser portado16 Se otorga relevancia a la heráldica en esta clase de retratos en Fernando Llamazares Rodríguez, 'Imagen e imágenes de los Arzobispos de Toledo', en Fernando Llamazares Rodrígues y José Carlos Vizuete Mendoza (eds.), Arzobispos de Toledo, mecenas universitarios, (Ediciones de la Universidad de Castilla-La Mancha, 2004), pp. 145-175.

17 Manuel Monreal Casamayor, 'Heráldica episcopal: Generalidades en las diócesis aragonesas', Aragonia Sacra, Vol. XVI-XVII, pp. 281-302. También recibe el nombre de capelo, tiene la forma propia de los sombreros de peregrinos, bajos y con un ala grande. Su uso en la heráldica comenzó en el siglo XIV en Avignon y se popularizó en el siglo XV. Véase a Vicente de Cadenas y Vicent, Tratado de genealogía, heráldica y derecho nobiliario: segundo curso de la Escuela de Genealogía, Heráldica y Nobiliaria, (Hidalguía: Madrid, 2001), p. 180. 
res de virtudes que lo han conducido a dirigir una diócesis y la segunda procede de la sangre, de su pertenencia a una familia renombrada y privilegiada.

\subsubsection{El conjunto pictórico en los siglos XVII y XVIII.}

El conjunto de imágenes de esta serie que se han analizado pormenorizadamente se inicia con el retrato de san Juan de Ribera (arzobispo entre los años 1568-1611). Esta pintura es una copia elaborada por Juan Sariñena de una efigie casi idéntica y anterior hecha por Vicente Macip Comes, hijo de Juan de Juanes y nieto de Juan Vicente Macip (1475 -1545) [fig. 4.5]. ${ }^{18} \mathrm{Si}$ bien sigue el ejemplo de efigie establecido mediante las obras de los prelados anteriores a su pontificado, en él se aprecia una mayor inclusión de elementos complementarios que configuran un retrato mucho más personal. Tampoco se observa en las representaciones de los obispos y arzobispos posteriores un afán marcado por añadir otros objetos que revelen más información del retratado. Quizás se deba a que él fue quien probablemente impulsó la creación de la galería para rendir homenaje a aquellos que asumieron la responsabilidad de dirigir la diócesis [fig. 4.6].

En este caso, se colocó un mueble auxiliar con seis libros y un cáliz del cual surge la Sagrada Forma. De toda el conjunto, éste es el único retrato donde se alude a la Eucaristía y ello pone de manifiesto la veneración y la defensa que el Patriarca hizo constantemente al dogma de la transustanciación hasta el punto de llegar a fundar el Real Colegio Seminario del Corpus Christi construido entre 1587 y 1615. Igualmente, bajo el mueble aparece un libro abierto al cual señala el prelado. Entre ambas páginas se puede leer un versículo que reza: «Tibi post haec fili mi ultra quid faciam?" es decir, "Después de esto, ¿qué más puedo hacer por ti, hijo mío?». Es el mismo lema que aparece en el escudo del colegio y que se corresponde con un

18 Raquel Rivera Torres, 'Imagen del prelado don Juan de Ribera. Estudio iconográfico', Universitat de València, Departamento de Historia del Arte, 2015, pp. 83-84. 


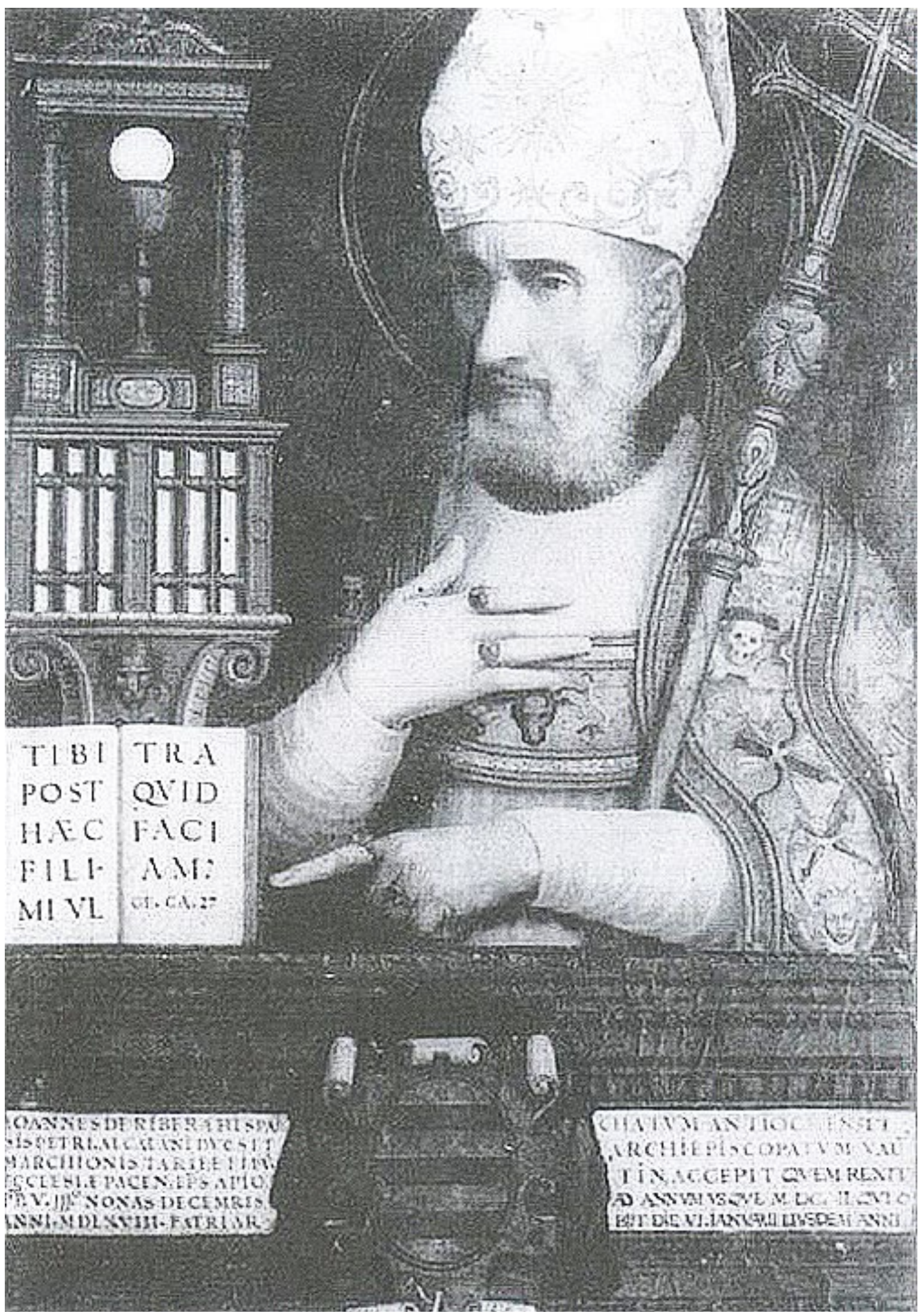

Fig. 4.5. Vicente Macip Comes, El arzobispo Juan de Ribera, 1585, óleo sobre guadamecí, Valencia, catedral (hoy en día perdido). 


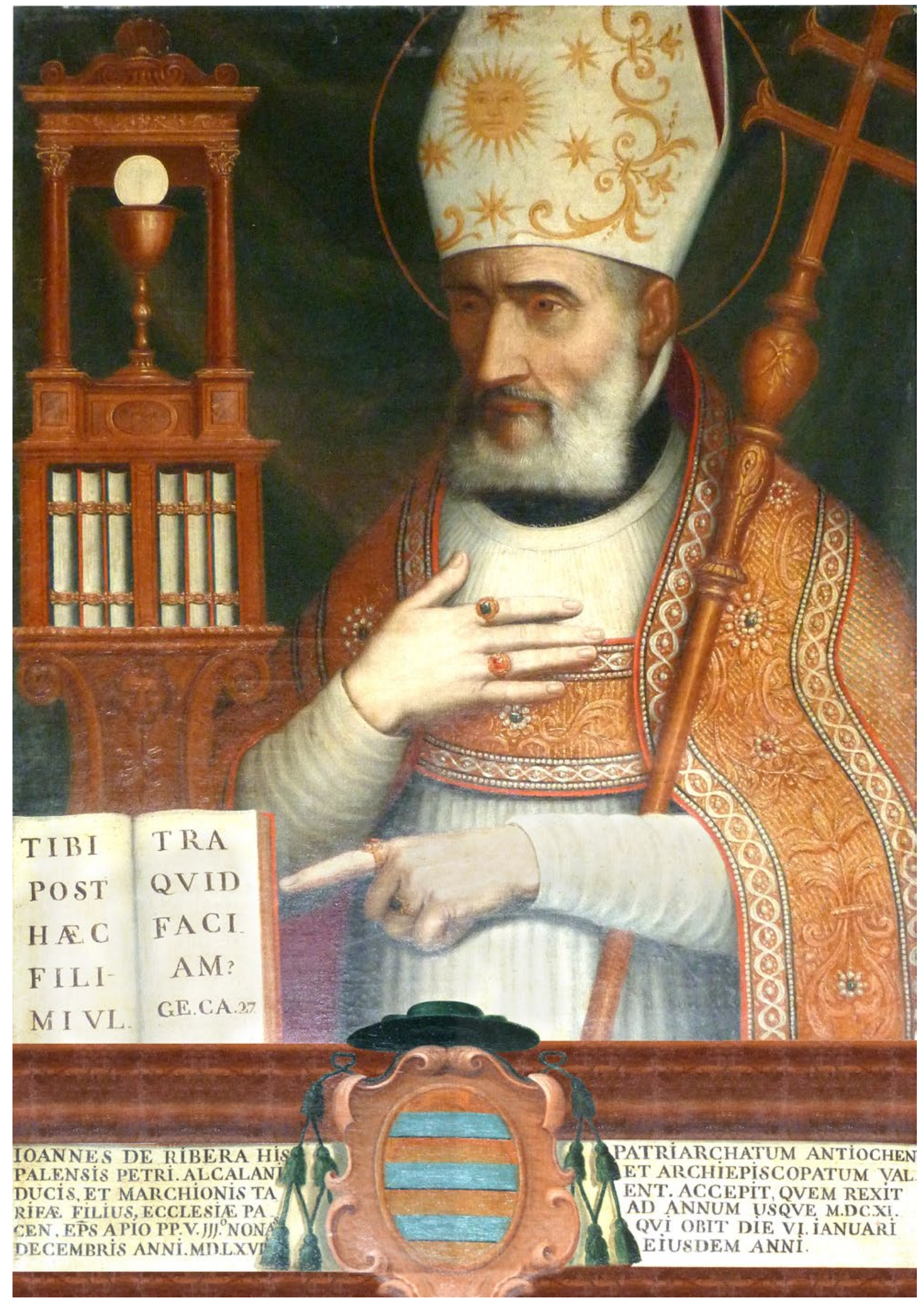

353

Fig. 4.6. Juan Sariñena, El arzobispo Juan de Ribera, 1611, óleo sobre lienzo, Valencia, catedral. 
fragmento extraído del Génesis, concretamente del capítulo 27 y versículo 37, que narra cómo Jacob suplantó a Esaú en la bendición paterna. Estas palabras fueron pronunciadas por Isaac conversando con Esaú, después de que Jacob hubiese engañado a su padre y este le hubiese favorecido entregándole a sus hermanos como siervos y abasteciéndole de trigo y vino. Por esa razón, cuando Esaú le preguntó si no había reservado algún obsequio para él, su padre tan sólo pudo espetar la mencionada cuestión. Del mismo modo que Isaac lo entregó todo por su hijo, Cristo entregó su vida para redimir a la humanidad del pecado original, haciendo el mayor gesto de amor y generosidad posible.

La breve inscripción que acompaña al retrato menciona la ciudad de Sevilla por ser la localidad natal de san Juan de Ribera, donde nació en 1532. También lo presenta como hijo del duque de Alcalá y marqués de Tarifa, Perafán de Ribera. Sin embargo, el cargo que principalmente destaca el texto es su 354 nombramiento como Patriarca de Antioquía, propuesta avalada por el papa san Pio V, además de su designación como arzobispo de Valencia. Igualmente se especifica la fecha de su muerte, acaecida el 6 de enero de $1611 .{ }^{19}$ El escrito latino se halla interrumpido por el escudo de armas del prelado, de forma ovalada, compuesto por tres bandas azules horizontales símbolo de la familia Ribera y timbrado con el capelo negro del que penden seis borlas a cada lado, como se corresponde a las dignidades de obispo y arzobispo.

IOANNES DE RIBERA HISPALENSIS PETRI, ALCALANI DUCIS ET MARCHIONIS TARIFAE FILIUS, EP[I]S[COPUM] A PIO P[A]P[A] V TERCIO. NONAS DECEMBRIS ANNI MDLXVII. PATRIARCHATUM ANTIOCHEN ET ARCHIEPISCOPATUM VALENT. ACCEPIT, QUEM REXIT AD ANNUM USQUE MDCXI, QUI OBIT DIE VI IANUARI EIUSDEM ANNI.

En la galería se decidió incluir la efigie de Pedro de Castro [fig.

19 Elías Olmos y Canalda, Los prelados valentinos, (Instituto Jerónimo Zurita: Madrid, 1949). 
4.7] quien falleció el 28 de octubre de 1611 en Alcalá de Henares antes de llegar a Valencia para tomar posesión del cargo de arzobispo. Fue presentado para tal ministerio por el rey Felipe III y aceptado por el papa Paulo V. Se trata de una copia de un original perdido. Siguiendo la costumbre española, el escudo de armas se ha timbrado con un capelo verde del que penden seis borlas a cada lado y una cruz latina, normalmente visible en los escudos de los obispos. En cuanto a la inscripción, esta indica lo siguiente:

D[ON] PETRUS DE CASTRO COLEG[IN] MAYOR[IS], CONQUEN[SI] ALUMNUS, ECCL[ESIE] ABULENSI ET TOLET[ANE] CAN[ONICU]S. SA[N]CTAE TERESIAE A[D] JESU A[D] CONFES[ORE], A[D] PHILIP[O] III EX LUCENSI ET SEGOV[IENSI] ECCL[ESIE] VA[L]E[N]T[IAE] SUFFECTUS OB[IT] 28 OCT[UBRE] 1611.

Isidoro Aliaga (arzobispo entre los años 1612-1648) estuvo al frente de la diócesis tras el mandato de san Juan de Ribera y la repentina defunción de Pedro de Castro. La efigie pintada por Juan Ayerbe en 1649 se encuentra en sintonía con el resto de piezas [fig.4.8]. El texto incluido en su memoria exalta su experiencia como obispo de Albarracín y Tortosa. Su propuesta para este cometido fue llevada a cabo por el monarca Felipe III, pues su confesor privado era hermano de Isidoro Aliaga. El pontífice Paulo V decidió preconizarlo el 26 de marzo de 1612. Poco después el 30 de mayo tomó posesión de la diócesis y el 4 de noviembre entró en la ciudad. Con el objetivo de dedicarse plenamente a su misión pastoral en Valencia decidió declinar los virreinatos de Aragón, Navarra y Valencia así como a los arzobispados de Santiago y Sevilla. ${ }^{20}$

Su escudo de armas se ha timbrado con el capelo verde y dispone de seis borlas a cada lado. Además, tiene forma ovalada y está atravesado por una barra, seguramente se trata de una hoja de sable, en el centro de la misma se encuentra una cruz

20 Vicente Cárcel Ortí, Historia de la Iglesia en Valencia, (Arzobispado de Valencia: Valencia, 1986). 


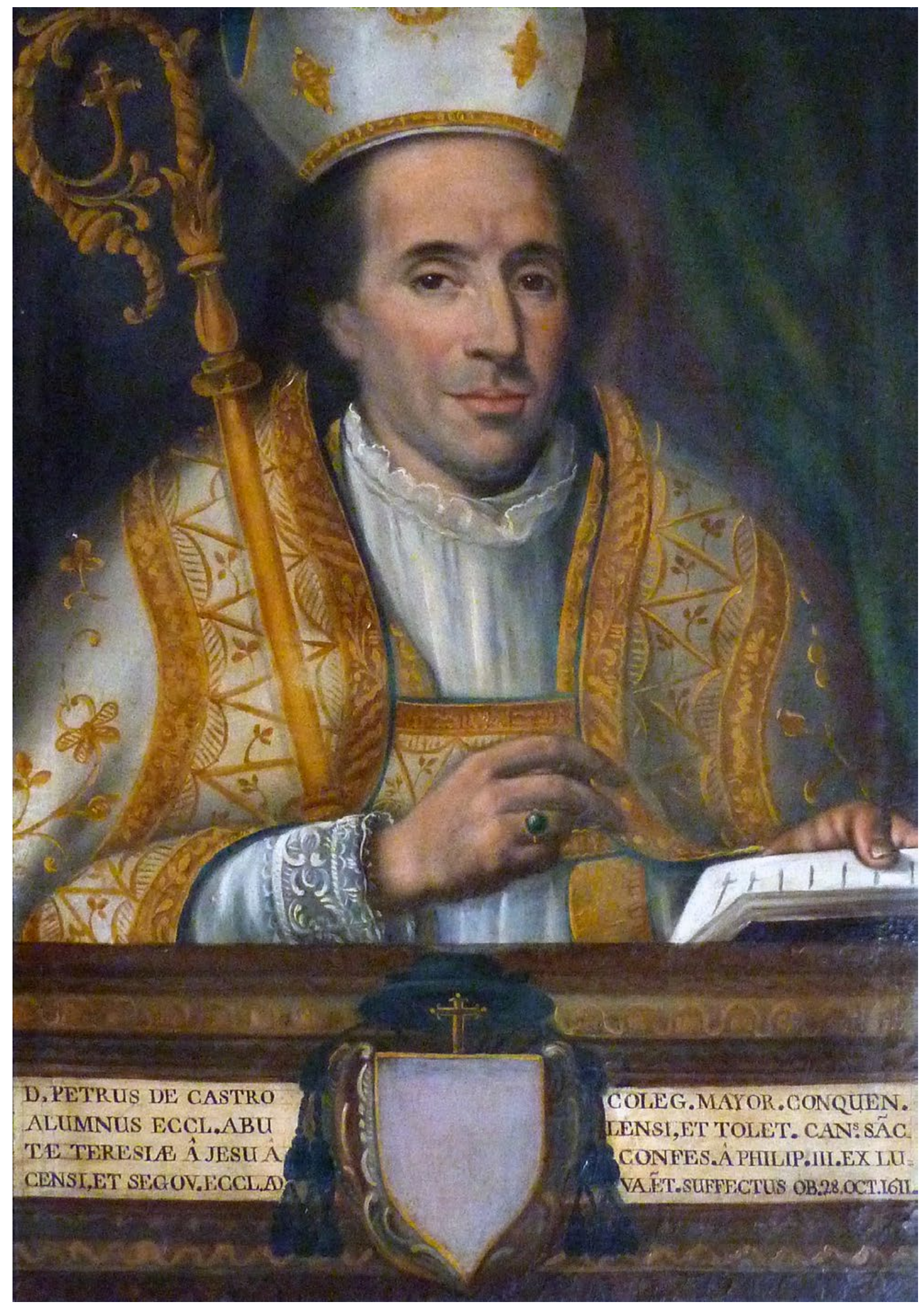

Fig. 4.7. Anónimo, Pedro de Castro, 1611, óleo sobre lienzo, Valencia, catedral (copia de un original ahora perdido). 


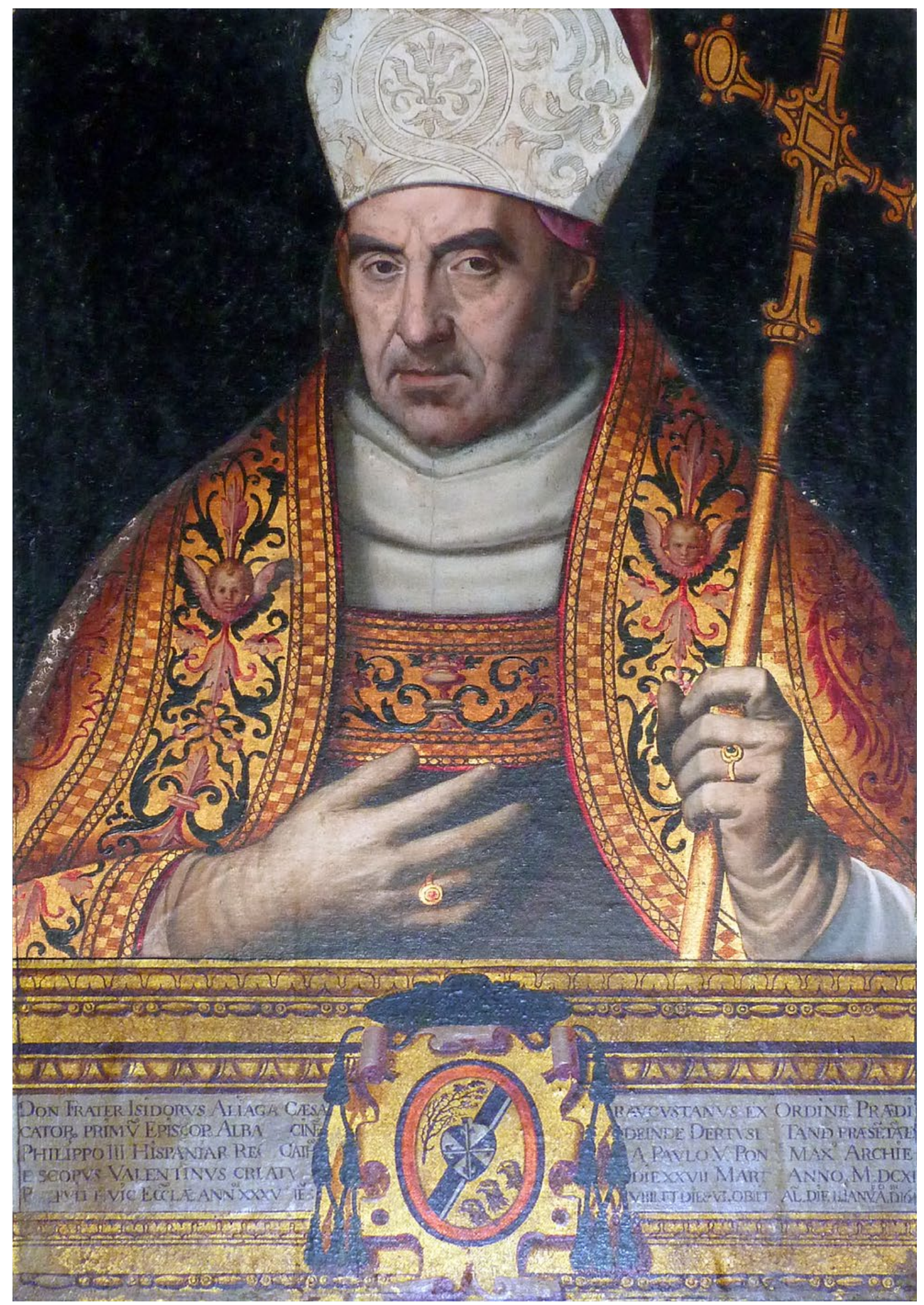

Fig. 4.8. Juan Ayerbe, Isidoro Aliaga, 1649, óleo sobre lienzo, Valencia, catedral. 
blanca y negra con flores de lis en sus extremos, es la propia de los dominicos, pues el prelado pertenecía a la orden de los Predicadores. En la zona superior parece distinguirse lo que probablemente sea una rama de aulaga, planta espinosa con hojas lisas y flores amarillas. En la inferior se han representado tres cabezas de águilas, vistas de perfil y dispuestas consecutivamente unas detrás de otras. De hecho, el escudo de armas se corresponde con la descripción hecha por Vicente Cadenas para el linaje de los Aliaga a excepción de incluir en el centro la referencia a los dominicos. Así, el blasón debe disponer de un fondo «en oro, una banda de sable, acompañada en lo alto de una mata de aliaga, de sinople y en lo bajo, de tres cabezas de águila con sus pescuezos, cruzadas las tres.» ${ }^{21} \mathrm{El}$ texto ubicado en la parte inferior de la pintura, en síntesis, hace referencia a sus cargos desempeñados en la diócesis de Albarracín y Tortosa a propuesta de Felipe III, su llegada a la diócesis valentina y la fecha de su fallecimiento:

DON FRATER ISIDORUS ALIAGA CAESAR AUGUSTANUS EX ORDINE PRAEDICATOR. PRIMU[M] EPISCOPO ALBA[RRA]CINE[NSIS], DEINDE DERTUSE[NSE]. TANDE[M] PRAESE[N]TA[N]TE PHILIPPO III, HISPANIAR[O/UM] RE[GIS] CATH[OLI]CO A PAULO V PON[TIFIC]E MAX[IM]O, ARCHIEPISCOPUS VALENTINUS CR[E]AT[US] DIE XXVII MART[II] ANNO MDCXII. P[OST] FUIT HUIC ECCLESIAE ANNOS XXXV, [D]IES VIIII ET DIES VI. OBIIT AL[...] DIE IL[LIUS] IANU[AR]II A[NN]O D[OMI]NI 1648.

El siguiente prelado fue Pedro de Urbina de Montoya (arzobispo entre los años 1649 - 1658) [fig. 4.9], como especifica la inscripción, era de origen avilense concretamente de Berantevilla. Asimismo, fue un religioso perteneciente a la orden de san Francisco. Sus méritos profesionales fueron verdaderamente amplios, pues además de estar frente a las diócesis de Coria y Plasencia obtuvo la cátedra de la Universidad de Alcalá y fue nombrado virrey y capitán general del reino de Valencia. El rey Felipe IV lo propuso para ser prelado después de la renuncia de fray Domingo Pimentel y el venerable Tapia y el beneplácito fue

21 Vicente de Cadenas y Vicent, Repertorio de blasones de la comunidad hispánica, vol. I, (Hidalguía: Madrid, 1987), p. 83. 


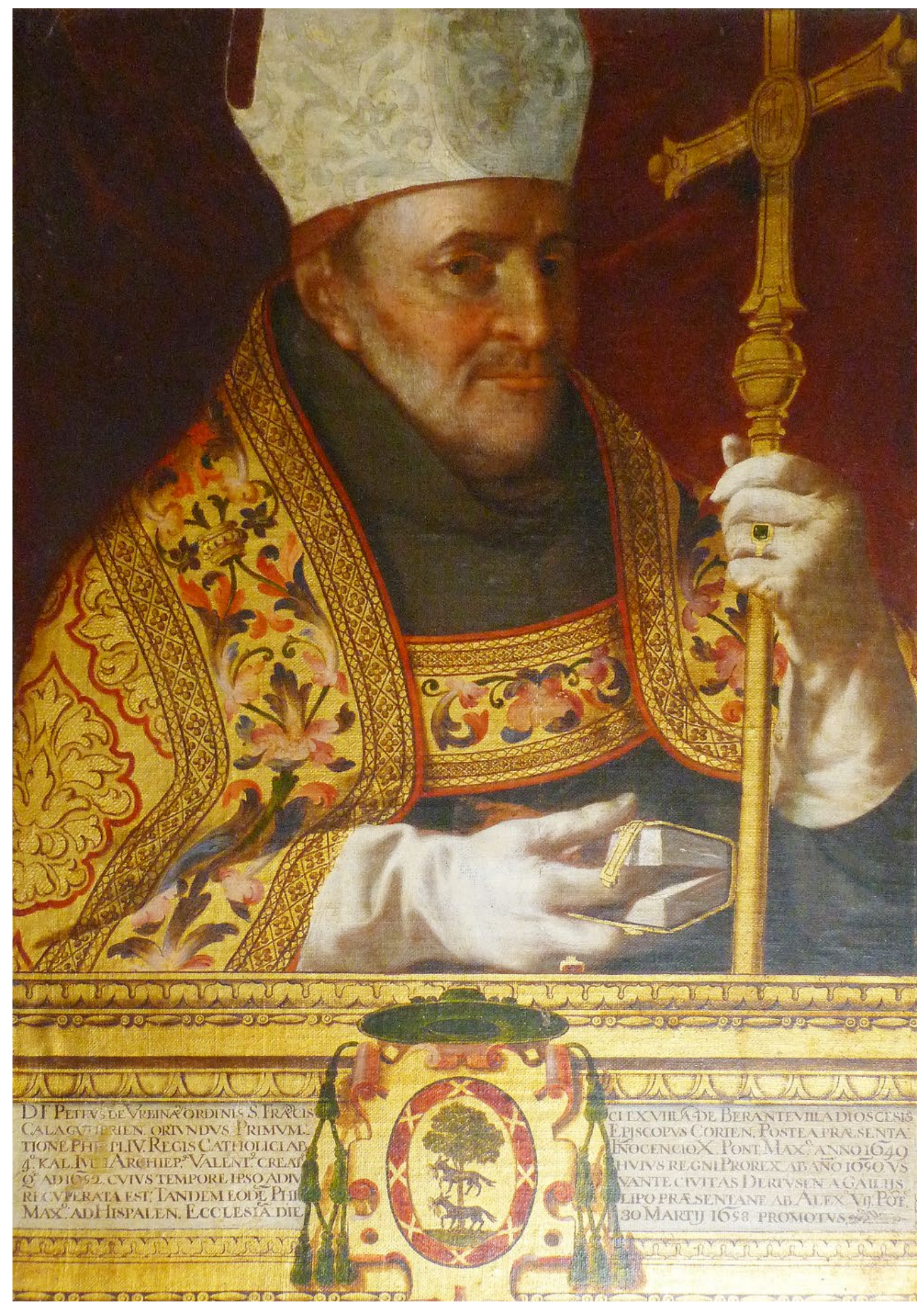

Fig. 4.9. Jerónimo Jacinto Espinosa, Pedro de Urbina de Montoya, 1659, óleo sobre lienzo, Valencia, catedral. 
otorgado por el papa Inocencio X.22 Su austeridad, humildad y humanismo quedó reflejado en su rechazo a las entradas triunfales y llegando a Valencia de manera clandestina. ${ }^{23}$ Durante su pontificado visitó numerosas parroquias de la diócesis y tenía por costumbre entregar los beneficios de la mitra a los desfavorecidos. Desde 1650 a 1652 fue virrey de Valencia y capitán general periodo en el cual comenzó la construcción de la basílica de Nuestra Señora de los Desamparados y donde colocó la primera piedra. El 29 de mayo de 1658 abandonó la diócesis valentina para trasladarse a la sevillana tras haber sido propuesto nuevamente por el rey y gozando del consentimiento del pontífice Alejandro VII. ${ }^{24}$

El escudo de armas, una vez más, se ha timbrado con el capelo verde y sus correspondientes seis borlas a cada lado. También tiene una forma ovalada y consta de una bordura que rodea el escudo en su interior. Esta bordura posee un fondo de gules y parece que se ha ornamentado con ocho cruces de san Andrés, que tienen forma de aspa por alusión a su martirio. Cabe recordar las

numerosas representaciones que existen de san Andrés con la cruz junto a san Francisco y que el prelado pertenecía a la orden franciscana. Por tanto, se debe considerar la posibilidad de que a través de la bordura se esconda una referencia a la mencionada orden. En cuanto a la iconografía del escudo, a diferencia del que se puede observar en otros retratos, aquí tan sólo se ha tomado el blasón propio del apellido rbina. La imagen se compone de un árbol de copa frondosa delante del cual hallamos una pareja de animales cazando, con la presa entre sus fauces. La efigie es obra del artista Jerónimo Jacinto Espinosa quien entregó la pieza a la catedral en 1659 y ganó por ella diez libras. A diferencia del resto de imágenes, en este caso el prelado parece vestir el hábi-

22 Cárcel Ortí, Historia de la Iglesia..., vol. I, p. 244.

23 Elías Olmos matiza que pese a la llegada secreta del prelado, las autoridades le obligaron a que hiciese una entrada solemne el primer domingo de Cuaresma, en marzo de 1650, por el portal de San Vicente. Olmos y Canalda, Los prelados..., p. 201.

24 Olmos y Canalda, Los prelados..., pp. 203-204. 
to de san Francisco bajo una capa pluvial excelentemente ornamentada con motivos florales. Así pues, siguiendo la estética imperante en la serie, Pedro de Urbina sostiene la cruz pastoral con la mano izquierda y un libro entreabierto con la mano derecha, ambas vestidas con guantes blancos. El texto en latín incluido en el retrato reza lo siguiente:

D[OMINUS] F[RATER] PETRUS DE URBINA ORDINIS S[ANCTI] FRANCISCI, EX VILLA DE BERANTE VILLA DIOSCESIS CALAGU[RRI]TI[NOS] PRIEN[SIS] ORIUNDUS PRIMUN EPISCOPUS CORIEN[SIS]. POSTEA PRAESENTATIONE PHI[LI]PI IV REGIS CATHOLICI AB IN[N]OCENCIO X PONT[IFICE] MAX[IMO] ANNO 1649. 4 KAL[ENDAS] IUL[I] ARCHIPIEP[ISCUPUS] VALENT[INUS] CREAT[US] HUIUS REGNI PRO REX AB ANNO 1650 USQ[UE] AD 1652 CUIUS TEMPORE IPSO ADIUVANTE CIVITAS DERTUSEN[SIS] A GALLIIS RECUPERATA EST: TANDEM EODE[M] PHILIPO PRAESENTANTE AB ALEX[ANDROS] VII: PO[N] T[IFIC]E MAX[IMO] AD HISPALEN[SIEM] ECCLESIA[M]: DIEM 30 MARTII 1658 PROMOTUS.

Espinosa también se encargó de llevar a cabo el retrato del prelado posterior, Martín López de Ontiveros (arzobispo entre los años 1659 - 1666) [fig. 4.10]. La efigie concuerda en gran medida con el caso de Urbina de Montoya aunque éste es el primer retrato del periodo barroco en el cual el arzobispo aparece con una joya no presentada hasta el momento, la cruz pectoral, la cual señala la confianza y dedicación a Cristo.

Una vez más, el texto descriptivo presenta a López de Ontíveros como un eclesiástico natural de Salamanca en cuya universidad se doctoró en derecho canónico. Previamente a ocupar este cargo fue arzobispo de Calahorra. La propuesta para gobernar la sede valentina se realizó en contra de su voluntad, pero tomó posesión de la misma el 6 de febrero de 1659 en presencia del Dr. D. José Sanz, arcediano de Alcira y canónigo de la catedral. ${ }^{25}$ Asimismo fundó el convento de Nuestra Señora

25 Olmos y Canalda, Los prelados..., p. 207. 


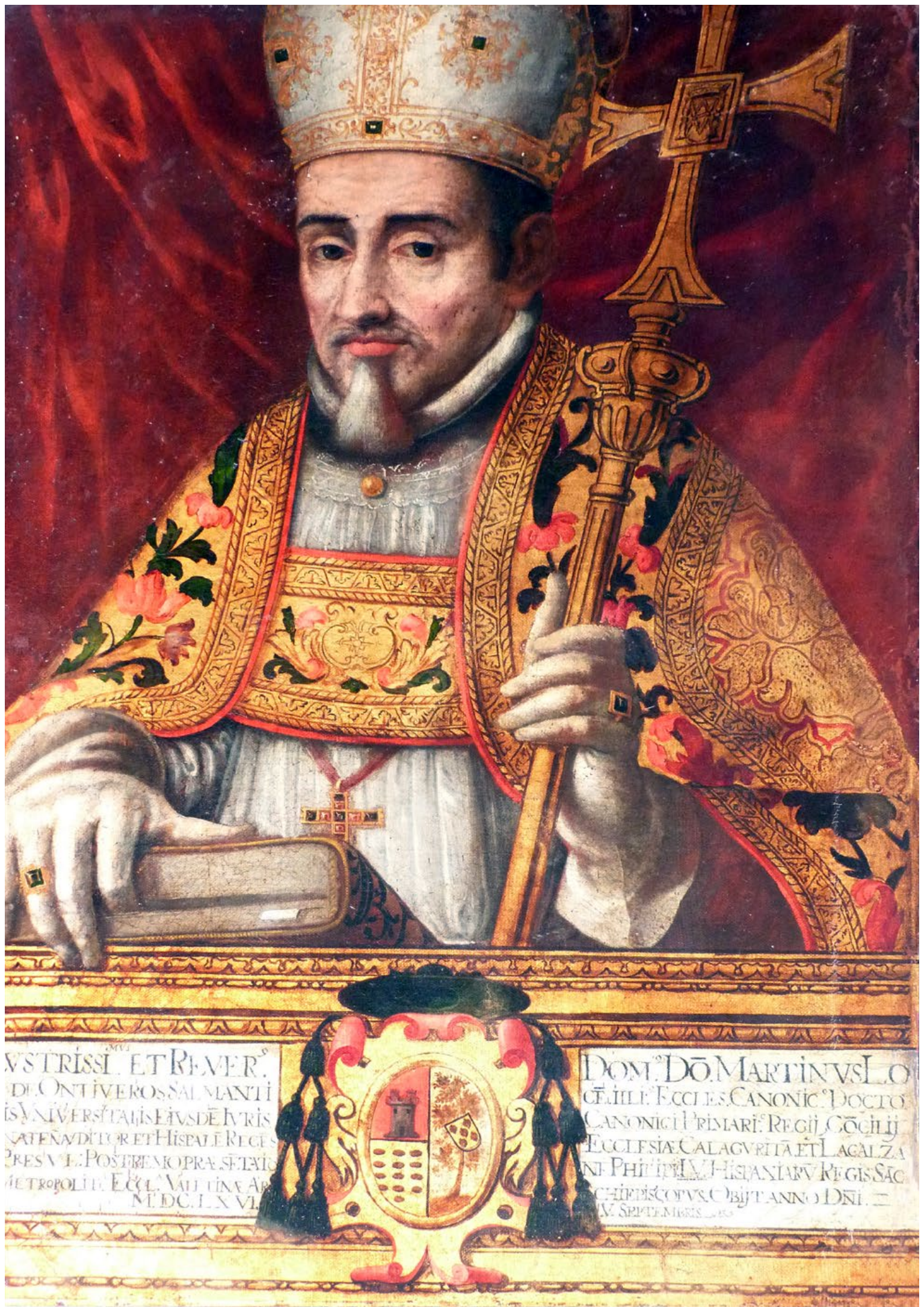

Fig. 4.10. Jerónimo Jacinto Espinosa, Martín López de Ontíveros, h. 1666, óleo sobre lienzo, Valencia, catedral. 
de los ngeles en Ruzafa, donde yace su tumba tras fallecer en septiembre de $1666 .{ }^{26}$

Respecto a su escudo de armas, nuevamente se ha timbrado con el capelo verde y las borlas. Se continúa empleando el formato ovalado y tiene una bordura en oro. El espacio interior dispone de una primera división en dos cuarteles exactamente iguales mediante un trazo vertical. A su vez, el lado izquierdo se ha separado en dos cuarteles menores donde se identifica una torre sobre gules en la parte superior y trece roeles sobre oro en la inferior. Los roeles son motivos tanto del blasón por parte de López como de Ontíveros. ${ }^{27}$ El cuartel de la derecha queda repleto por un árbol con el tronco ligeramente curveado donde se distingue un pequeño escudo. El correspondiente texto indica lo siguiente:

ILISTRISSIMS ET REVER[ISIMS] DOM[INS] DO[N] MARTINS LO-

PEZ DE ONTIVEROS SALMANTICE[NSIS], ILLIS ECCLES[IE] CANONIC[S], DOCTORALIS NIVERSITATIS EISDEM IRIS CANONICI PRIMARI[S] RE-

GII CONCILII GRANATEN[SIS] ADITOR ET HISPALE[NSIS] REGES ECCLESIA[E] CALAGRITA[NE] ET LA CALZATA PRESL: POSTREMO PRAESE[N] TATIONE PHILIPI IV HISPANIARM REGIS SA[N]CTAE METROPOLITA ECCLESIA[E] VALENTINAE ARCHIEPISCOPS OBIIT ANNO DOMINI MDCLXVI IV SEPTEMBRIS.

De una familia de noble linaje procedía el arzobispo Ambrosio Ignacio Spínola y Guzmán (arzobispo entre los años 1667 - 1668) [fig. 4.11], de origen madrileño y emparentado con el conde duque de Olivares. Por este motivo, se ocupó de la educación del príncipe Baltasar Carlos. Llegó a ser rector de la

26 Un Obrero albañil, Los concilios en Valencia: con una pequeñas biografía de todos sus obispos y una lista de todos sus papas desde S. Pedro hasta León XIII, (Librerías París-Valencia: Valencia, 1982), p. 22.

27 Vicente de Cadenas y Vicent, Repertorio de blasones de la comunidad hispánica, vol. IV, (Hidalguía: Madrid, 1987), p. 1297 y Cadenas y Vicent, Repertorio de blasones..., vol. I, p. 1021. 
niversidad de Salamanca, canónigo en la catedral de Toledo y obispo de Oviedo. El papa Alejandro VII lo designó arzobispo de Valencia. Con él se inauguró la basílica de la Virgen de los Desamparados iniciada con Pedro de rbina de Montoya. Tras estar un año al frente de la diócesis valentina realizó una breve estancia en Santiago para finalmente marchar a Sevilla en 1670 como su nuevo arzobispo, lugar donde expiró en $1684 .{ }^{28}$

Por el momento no se ha identificado al autor del retrato, sin embargo, el rostro del coincide con cualquiera de las varias réplicas que el sevillano Pedro Núñez de Villavicencio hizo de la efigie de este mismo prelado, así al menos se conoce cuál era la apariencia más difundida de este personaje [fig. 4.12]. El correspondiente escudo de armas se ha timbrado con el capelo verde como ya se ha observado en los casos anteriores. Además, se ha incluido una cruz latina en oro y trebolada en sus extremos, puesto que es la utilizada por obispos y arzobispos no primados. A través del escudo se puede conocer el linaje del prelado y de hecho, se ha mostrado su parentesco con la Casa nobiliaria de Olivares y de la Casa Guzmán a través de la corona, de la bordura con leones y castillos y el cuartel izquierdo. Este se ha segmentado en aspa, sobre azur se identifican las calderas de oro jaqueladas en gules de las que surgen siete cabezas de sierpes. Y sobre un campo de plata se disponen cinco motas de armiño. ${ }^{29} \mathrm{El}$ cuartel derecho hace referencia heráldicamente a la Casa Spínola a través de un campo de oro, atravesado por una franja ajedrezada y lo que parece ser media flor de lis en gules. El escudo interrumpe la pertinente inscripción que reza lo que se indica a continuación:

AMBROSIS IGNATS ESPINOLA ET GSM[A]N EXELE[N]T[I]SSIMORM MARCHIONM DE LEGANES, HISPANIAE MAGNAT[O/S] FILIS SALMA[N]T[I]SE[N]SIS ACADEMIAE. OLIM RECTOR EX EPISCOPS OVETE[N] SIS COMES HORONIAE ARCHIEPISCOPS VALENTINS DIAE 2 MAII 1667 ET POSTEA AD ARCHIEPISCOPA[TS] COMPOSTELLANM PRAESE[N]TA-

28 Cárcel Ortí, Historia de la Iglesia..., vol. I, pp. 245-246.

29 Cadenas y Vicent, Repertorio de blasones..., vol. I, p. 859. 


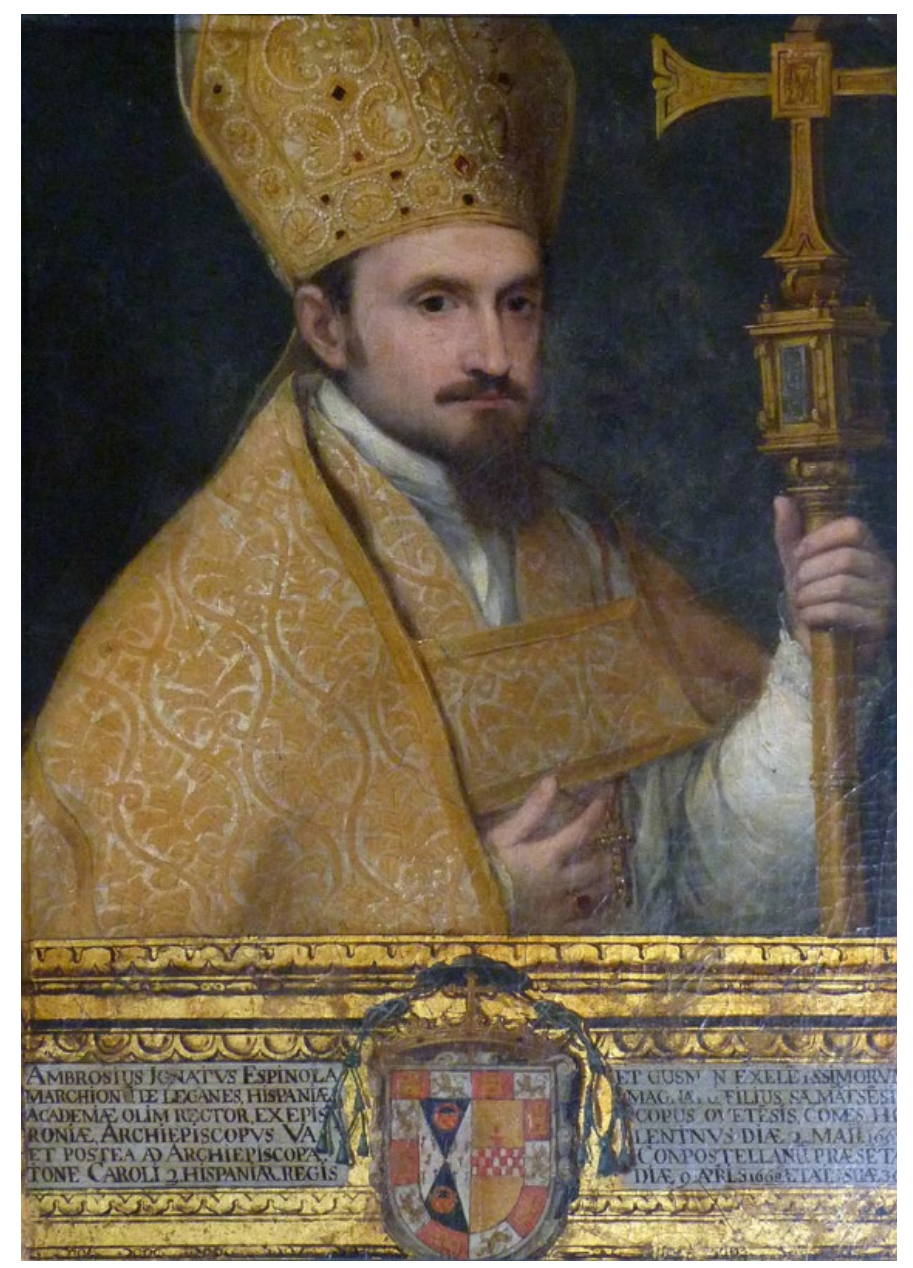

Fig. 4.11. Anónimo, Ambrosio Ignacio Spínola y Guzmán, h. 1668, óleo sobre lienzo, Valencia, catedral.

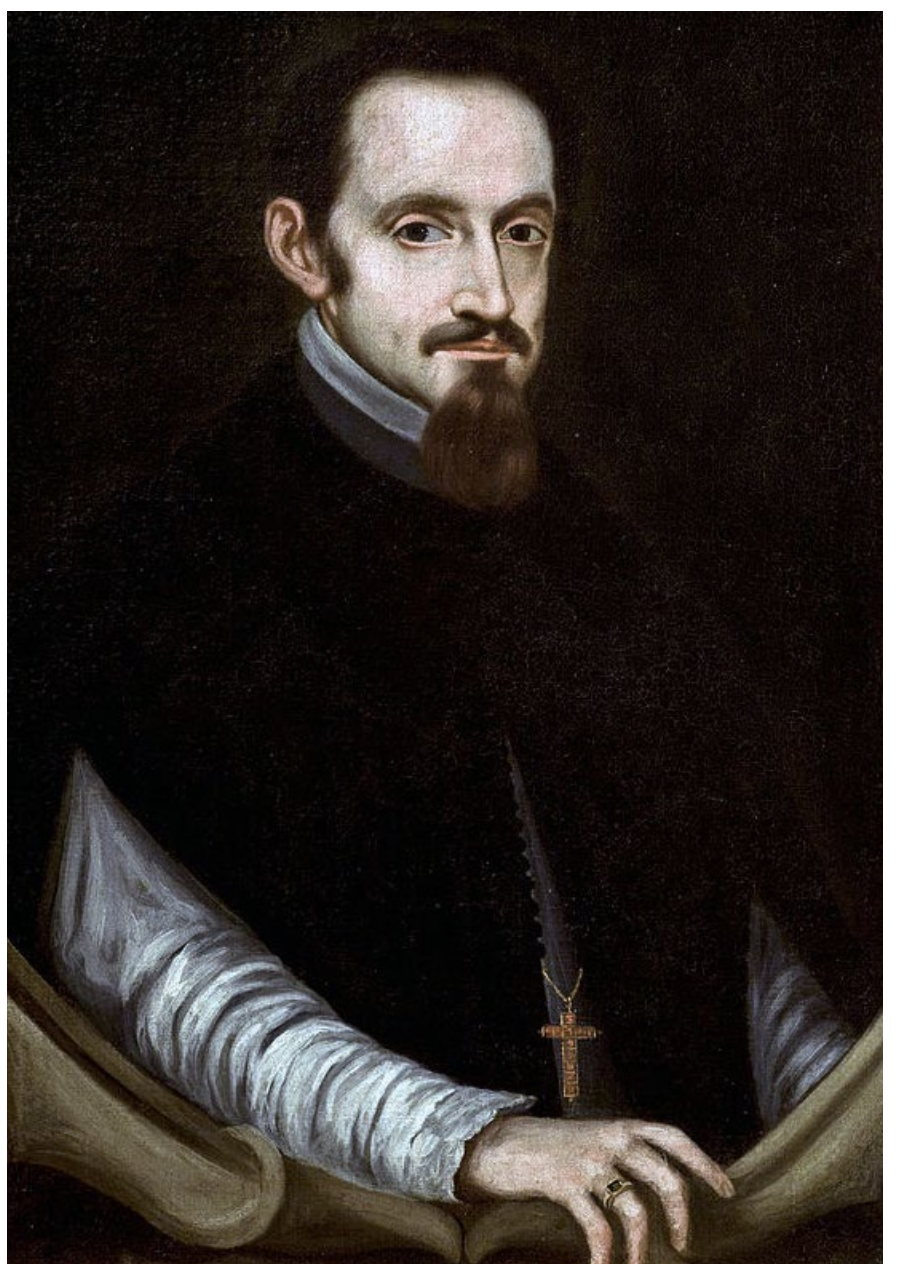

Fig. 4.12. Pedro Núñez de Cepeda (copia), Retrato del arzobispo don Ambrosio Spínola (detalle), 1670, óleo sobre lienzo, Sevilla, Ayuntamiento. 
TIONE CAROLI 2 HISPANIAR[UM] REGIS. DIAE 9 APRILS 1668 [A]ETAT[IS] SUAE 36.

A Spínola Guzmán le siguió Luis Alfonso de los Cameros (arzobispo entre los años 1668-1676) [fig. 4.13]. La correspondiente inscripción menciona desde un primer momento su origen gaditano. Antes de estar al frente de la sede valentina ya fue inquisidor, juez en Sicilia así como obispo de Patti y Monreal. La reina Margarita de Austria lo propuso para ser prelado en Valencia y el papa Clemente IX lo designó. Los autores lo ensalzan por ser un hombre humilde, benevolente y servicial con los desfavorecidos. Por ello, se dice que sentaba en su misma mesa a un pobre a diario y los viernes servía a cinco de ellos. ${ }^{30}$ Asimismo fundó la Casa de la Misericordia en 1671 y falleció cinco años más tarde, el 26 de julio de 1676. El artífice de su retrato ha sido, como en el caso de Pedro de Urbina y Martín López, Jerónimo Jacinto de Espinosa. De hecho, se aprecia la semejanza estética entre la efigie de Martín López de Ontíveros y Luis Alfonso de los Cameros es evidente. Ambas representaciones son casi idénticas a diferencia del semblante físico y del gesto hecho con la mano, pero la decoración de la mitra y de la capa pluvial, el modelo de cruz arciprestal, así como la pectoral apuntan a la manufactura del mismo artista. Respecto al escudo de armas se ha timbrado con el capelo verde $y$ una vez más tiene forma ovalada. En su interior se encuentra el blasón referente a Alonso. Por ello, sobre un campo azur se aprecia una banda de oro engolada en cabezas de dragones de sable y a ambos lados de la misma se encuentra una estrella de oro de ocho puntas. En cuanto a la inscripción se indica lo siguiente:

LUDOVICUS IDELFONSUS DE LOS CAMEROS IN C[....] [O]PIDO DE ALCALÀ DE LOS GAZULES, GADITANAE DIOCESIS ORTUS APUD SIO[...] LOS PRIMUM QUAE SIT OR FIDEL[II] APOSTOLICUS MONARCHIAE TRINACRIAE IUDEX L[...] DE PACTARU[M] SEDIS ANTISTES REGALIS MO[L]TIS ARCHIPRAESUL ET D[OMI]N[U]S PROMOVE[...] DEMUM CAROLO II HISPANIAR REGE A CLE-

30 Obrero albañil, Los concilios en Valencia..., p. 22. 
ME[NTE] IX P[ONTIFICE] M[AXIMO] ARCHIEPISCOP[US] VAL[ENSIS?] AT US PRIDIE IDUS MAII ANNO MDCLXVIII QUI ECCLESIA[M] HANC QUA[M] A[CC]EP[IT] CHR[IST]A[M] REDDIDIT PULCHRIORE[M]: ET PEREGRINARU[M] CAUTIU[M] VARIAT[I]S DU[M] S[A]CE[R...] MAIUS AUSTRUEBAT MAXIMU[M] MAGNITUDINI OPERIS INVIDE[N]TE FAT Q[UI] OBIIT VAL[ENTIA] 7 CAL[...]ND[...] ANNO A VIRGINIS PUERPERIO MDCLXXVI.

El último de los prelados del siglo XVII fue Juan Tomás de Rocabertí (arzobispo entre los años 1677-1699) [fig. 4.14]. Este prelado natural de Gerona, abandonó tempranamente su formación militar para ingresar en la Orden de los Predicadores como dominico. El texto biográfico presente en el retrato puntualiza que más tarde, estudió filosofía y teología en la Universidad de Valencia. Bajo la propuesta de Carlos II y la designación por parte de Inocencio XI se ocupó de la diócesis valentina desde el año 1677. A lo largo de este periodo, se edificó el colegio de San Pío V. También ejerció como virrey en dos ocasiones y fue escogido por el monarca como Inquisidor General en el año 1695. El 13 de junio de 1699 murió en Madrid donde reposan sus restos en la iglesia de Santo Domingo el Real. ${ }^{31} \mathrm{El}$ retrato de dicho personaje fue elaborado por Gaspar de la Huerta y su imagen se encuentra en sintonía con las obras de Espinosa, sobre todo con la imagen de Alfonso de los Cameros, pues el arzobispo aparece en el interior de una estancia completamente vestida por el lujoso cortinaje rojo, su capa pluvial se ha decorado con motivos vegetales y es coincidente la actitud de bendecir o el llevar la cruz tanto pectoral como arciprestal, salvo que en este segundo caso no se incluye un libro entre las manos del efigiado.

Por lo que respecta al escudo de armas, éste se encuentra timbrado con el capelo verde y tiene una forma ovalada y su interior está cortado. La iconografía de la zona superior es una alusión a la vinculación que el prelado mantuvo con los dominicos, por ello se ha incluido el stemma formatum o stemma mantelatum, es decir, el campo es de plata y está mantelado de

31 Cárcel Ortí, Historia de la Iglesia..., vol. I, pp. 246-247. 


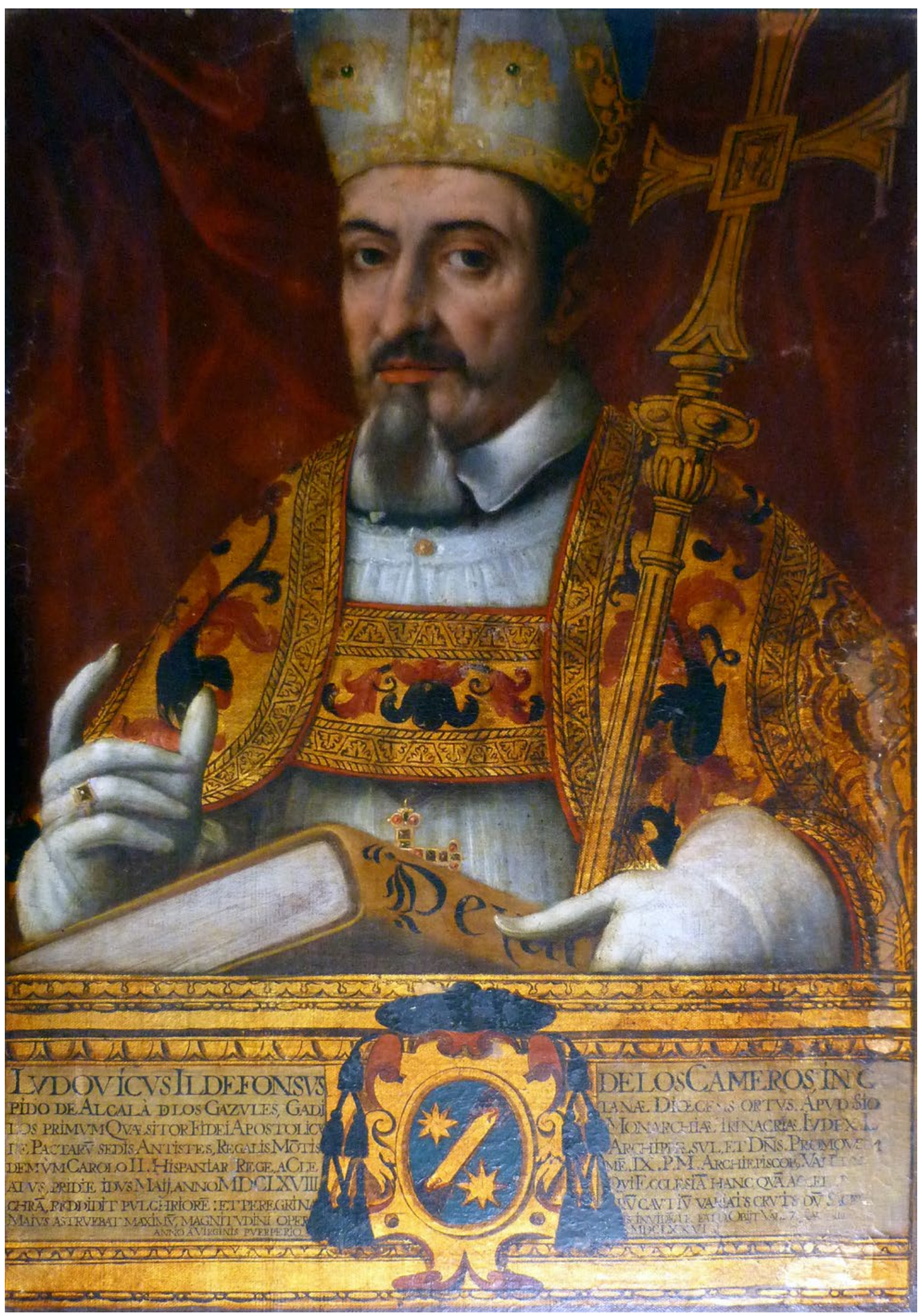

Fig. 4.13. Jerónimo Jacinto Espinosa, Luis Alfonso de los Cameros, h. 1676, óleo sobre lienzo, Valencia, catedral. 


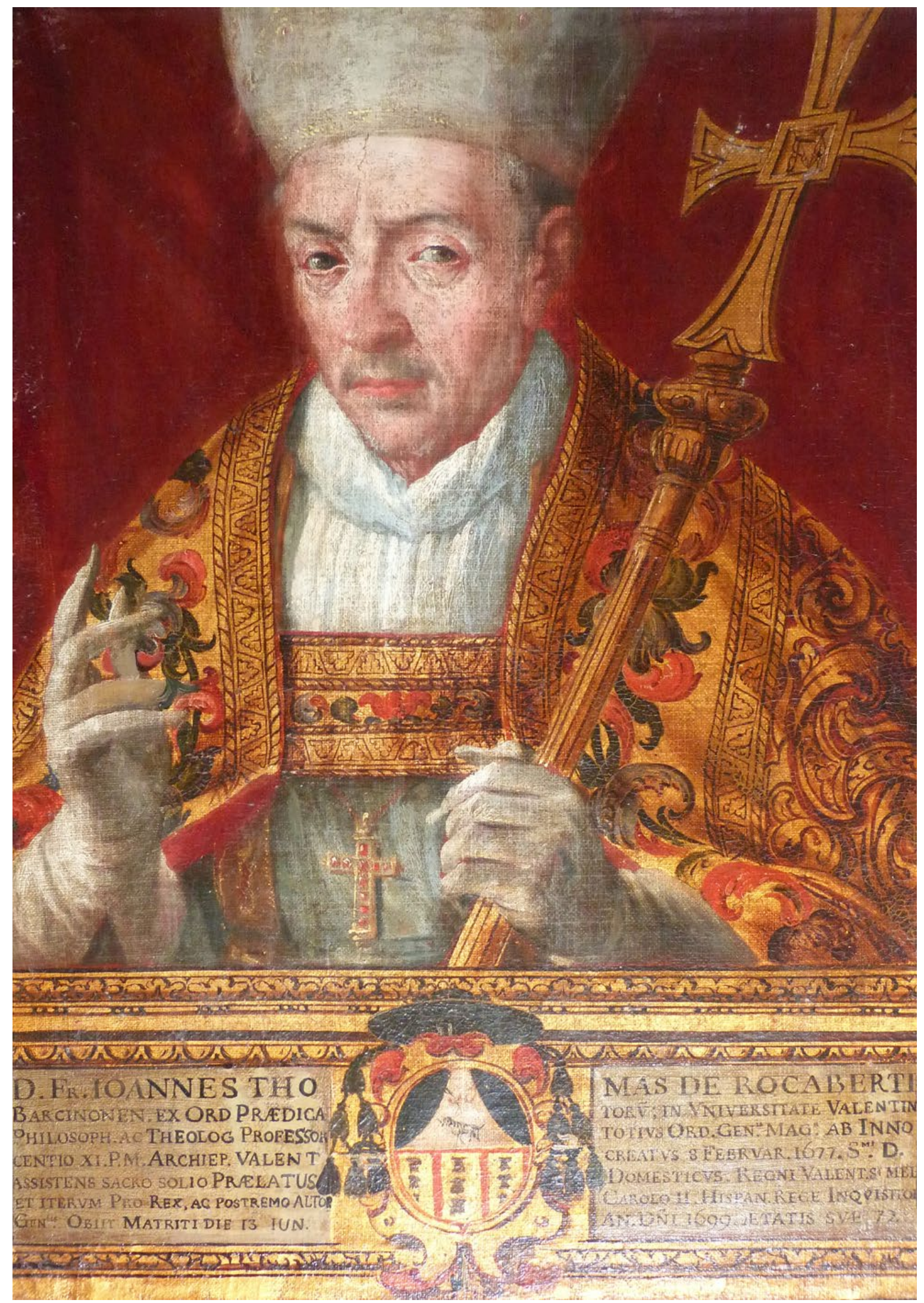

Fig. 4.14. Gaspar de Lahuerta, Juan de Tomás de Rocabertí, 1700, óleo sobre lienzo, Valencia, catedral. 
sable, así se remite al hábito blanco y a la capa negra de la orden. Se trata de una representación que encaja con las normas de la heráldica y suele hallarse en el interior de los escudos. Además y aunque no se aprecie con demasiada claridad, en el centro parece encontrarse una imagen alegórica de santo Domingo a través del perro con una tea en la boca símbolo de la predicación. ${ }^{32}$ En la parte inferior se identifica el blasón de los Rocabertí, el cual se compone de tres palos de oro sobre gules y en cada uno de ellos se han dispuesto tres roques de azur. La inscripción correspondiente indica que es el retrato de:

D[OMINUS] FR[ATER] IOANNES THOMAS DE ROCABERTI BARCINONEN[SIS] EX ORD[INE] PRAEDICATORU[M]; IN UNIVERSITATE VALENTIN[A] PHILOSOPH[IAE] AC THEOLOG[IAE] PROFESSOR TOTIUS ORD[...] GEN[ERAL] IS MAG[ISTE]R AB INNOCENTIO XI P[ONTIFICE] M[AXIMO] ARCHIEP[ISCOPO] VALENT[INO] CREATUS 8 FEBRUARI 1677 S[ANTISI]MI D[EI] ASSISTENS SACRO SOLIO PRAELATUS DOMESTICUS REGNI VALENT[IAE]SIMEL ET ITERUM PRO REX AC POSTREMO ALTOR CAROLO II HISPAN[IA] REGE INQUISITOR[IS] GEN[...]IS OBIIT MATRITI DIE 13 IUN[I] AN[NO] D[OMI]NI 1699 AETATIS SUAE 72.

El cambio de siglo se inicia con el mandato de Antonio Folch Cardona (arzobispo entre los años 1700 -1724) [fig. 4.15]. Pese a que a partir de este momento se dio un cambio de estilo artístico a raíz de la introducción del gusto francés, las nuevas pautas estéticas pasaron más desapercibidas en las series icónicas. La razón es sencilla, en este tipo de proyectos pictóricos impera la homogeneidad del conjunto y todos los retratos responden a unos parámetros de representación establecidos y respetados a medida que se incorporan a la serie. Folch Cardona, primer prelado del siglo XVIII, era valenciano de cuna y su familia quiso vincularle profesionalmente al ejército. Sin embargo, decidió ingresar en San Francisco de Palencia, de cuya orden ocupó el título de provincial. En 1700 y a petición del monarca Carlos II, el papa Inocencio X lo designó 32 Tomás Echarte y Alberto Montaner Frutos, 'Los emblemas en la orden de predicadores: El stemma liliatum y el stemma formatum', Emblemata: Revista aragonesa de emblemática, marzo 1997, pp. 393-434. 


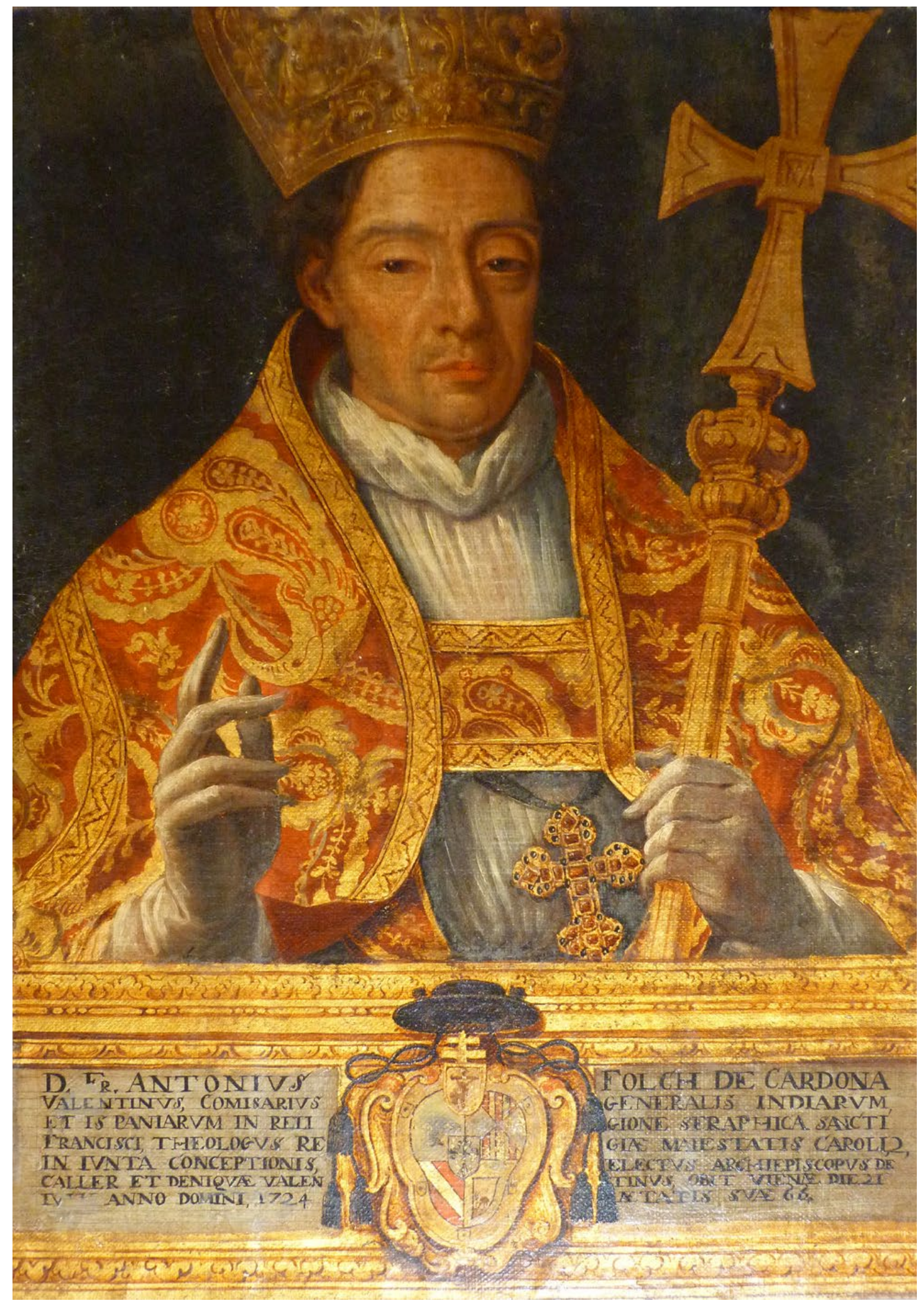

Fig. 4.15. Atribuido a Evaristo Muñoz, Antonio Folch de Cardona, 1724, óleo sobre lienzo, Valencia, catedral. 
arzobispo. Su posicionamiento durante la Guerra de Sucesión ha sido una cuestión debatible y no exenta de polémica, pues mientras que hay biografías que lo retratan como un claro defensor del candidato Borbón, ${ }^{33}$ hay otros estudios que indican tras un inicial apoyo a la causa de Felipe d'Anjou se sumó desde 1710 al bando del archiduque Carlos. ${ }^{34}$ Sus últimos años los pasó exiliado en Viena donde falleció el 21 de julio de 1724.

Como ya aportó Yolanda Gil, el retrato de Folch Cardona perteneciente a la serie de la catedral de Valencia era el único que por el momento se conocía. Es una pintura atribuida a Evaristo Muñoz que muestra al prelado vestido con el alba y una capa pluvial carmesí con ricos bordados en oro. La riqueza del textil va acorde con el fasto tanto de la cruz pectoral como pastoral. Sus manos, enfundadas en unos guantes blancos, sostienen la mencionada cruz y predicen el gesto de bendecir. Sin embargo, la mencionada autora ha puesto en valor una estampa de la efigie de arzobispo encontrada en el tercer volumen de la obra Rerum Italicorum Scriptores de Ludovico Antonio Muratori publicado en Milán en 1723, justo un año antes de su muerte. La imagen del prelado, acompañada de una dedicatoria, fue dibujada por Daniele Bertoli y grabada por Andrea Zucchi. Igualmente se incluye el escudo de armas del efigiado pero en este caso es ligeramente distinto al que, como se explicará seguidamente, empleó en Valencia. La pintura valenciana y la estampa italiana presentan diferencias en la fisionomía del retratado, ello invita a pensar que al menos el retrato de la catedral se elaboró a partir del recuerdo que se tenía de Folch Cardona dando lugar a una representación aproximada de este arzobispo exiliado. ${ }^{35}$

33 Así sucede en el capítulo biográfico de los prelados consultado en el catálogo de La llum de les imatges..., p. 414.

34 Yolanda Gil Saura, 'Antonio Folch de Cardona (1657-1724). Biografía cultural de un religioso y político, bibliófilo y coleccionista entre Valencia y Viena', Ars Longa: cuadernos de arte, no. 23, 2014, pp. 173-185.

35 Gil Saura, 'Antonio Folch de Cardona (1657-1724)...', p. 182. Como se explica en el artículo, los retratos de Folch Cardona son muy puntuales. 
A consecuencia del estado de la pintura el escudo de armas no se puede leer en su totalidad. Sin embargo, hay algunos elementos que sí se entienden. Se ha timbrado con un capelo de tres borlas a cada lado. Además, arriba se ha incluido una cruz patriarcal y una representación del abrazo de san Francisco, lo cual habla de su pertenencia a la orden. El escudo es cuartelado y en él se distinguen, principalmente, las barras de Aragón y la vaca pasante de Bearn. Hoy en día no se aprecian los tres cardos que remitirían al linaje de los Cardona. Sobre el escudo y en el centro del mismo, se ha incluido una cruz florlisada o trebolada sin llegar a distinguirse adecuadamente. En cuanto a la inscripción de la imagen, se indica lo siguiente:

D. FR. ANTONIUS FOLCH DE CARDONA VALENTINUS, COMISARIUS GENERALIS INDIARUM, ET [H]ISPANIARUM IN RELIGIONE SERAPHICA SANCTI FRANCISCI, THEOLOGUS REGIAE MAIESTATIS CAROLI 2, IN IUNTA CONCEPTIONIS, ELECTUS ARCHIEPISCOPUS DE CALLER ET DENIQUAE VALENTINUS, OBIT VIENAE DIE 21 IU[...] ANNO DOMINI 1724 AETATIS SUAE 66.

A Folch Cardona le siguió Andrés de Orbe y Larreátegui (arzobispo entre los años 1725 - 1737) [fig. 4.16]. Este prelado nació en Vizcaya, se formó en derecho canónico y civil, y ejerció como profesor de ambas disciplinas en Valladolid. También desempeñó funciones de fiscal de la Inquisición en Sevilla. Tras ser durante un tiempo arzobispo de Barcelona, el papa Benedicto XIII lo designó prelado de Valencia. Se mantuvo en dicho cargo hasta que Felipe $\mathrm{V}$ le propuso ser gobernador del Real Consejo de Castilla, cuya aceptación implicaba abandonar sus responsabilidades para marchar a la corte. En efecto, renunció a la mitra valenciana en 1736 y falleció cuatro años más tarde.

De hecho, tan sólo se tiene noticias de una efigie de cuerpo entero que se encontraba en la escalera del Colegio Mayor de san Pedro y san Pablo de Alcalá de Henares. Además, hay otra variante de la estampa encontrada en el Rerum Italicorum Scriptores localizable en la Biblioteca Nacional de Austria. 


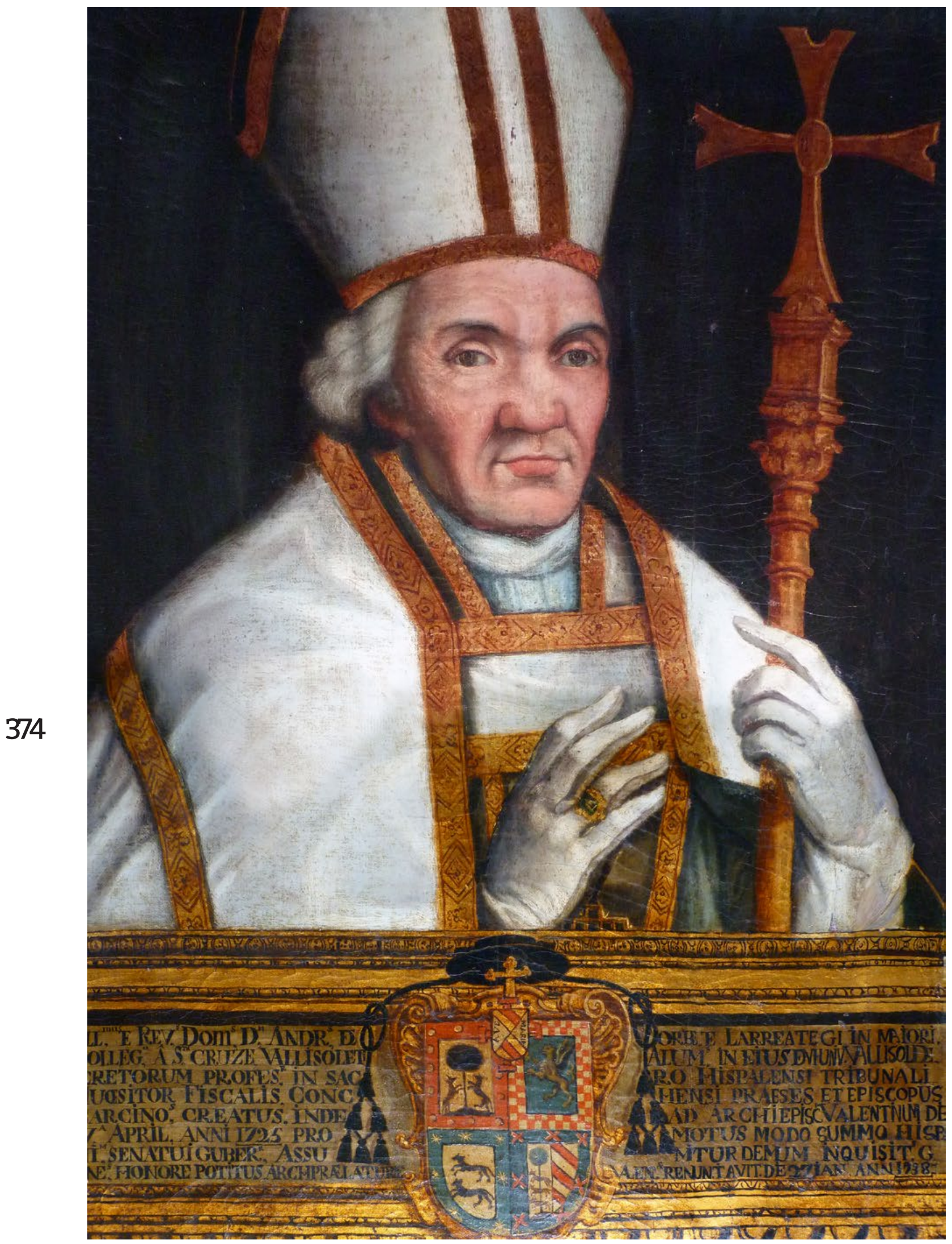

Fig. 4.16. Anónimo, Andrés de Orbe y Larreategui, 1737, óleo sobre lienzo, Valencia, catedral. 
A diferencia de las efigies de los prelados anteriores, la imagen de Orbe y Larreátegui es mucho más austera pues su capa pluvial y mitra carecen de casi toda ornamentación. Con la mano derecha sostiene la cruz pastoral y la izquierda, abierta $y$ con el anillo en el dedo anular, esconde casi en su totalidad la cruz pectoral. Sus rasgos faciales son similares, aunque más entrados en edad, a otros retratos de este personaje. Por ejemplo, muy parecida es la estampa incluida en el libro Retratos de españoles datado hacia 1831 y legado por Francisco Xavier Borrull Vilanova. ${ }^{36}$ El escudo de armas se ha timbrado con el capelo y caen seis borlas a cada lado. Además, se ha dispuesto un escudete sobre el principal con la leyenda Ave María. Se distinguen cuatro cuarteles, el primero de ellos alude al gentilicio de Orbe y en un campo de oro se ha incluido un pino de sinople y dos lobos empinados a cada lado del tronco, también dispone de una bordura de gules con trece roeles de oro ${ }^{37} \mathrm{El}$ segundo cuartel presenta el blasón de Larreátegui, por ello se aprecia un campo de sinople con un grifo de oro en el cen-tro y una bordura jaquelada en oro y gules. ${ }^{38} \mathrm{El}$ significado del tercer y cuarto cuartel, por el momento, se nos escapa. El de la izquierda es en plata y tiene dos lobos pasantes en sable y una bordura en sinople con siete estrellas de oro y ocho puntas. El de la derecha dispone de una bordura similar a la anterior, pero con siete cruces de gules en aspa. Su interior aún se ha partido y en primer lugar se han incluido tres lobos pasantes y un pino de sinople sobre plata. A continuación, se encuentran tres bandas de gules también en un campo de pla-ta. En cuanto al texto que se lee junto al escudo de armas, éste explica lo que continúa:

ILL. E REV. DOM. D. ANDR[E]S DE ORBE E LARREATEGI IN MAIORI. COLLEGㅇ A S. CRZE VALLISOLETALM IN EISDEM NIV. VALLISOL DECRE-

36 Disponible en: http://weblioteca.uv.es/cgi/view7.pl?div=08source=uv im i192829168sesion $=20190911205342130738 z$ zoom $=0$ 
TORUM PROFES[O]R IN SACRO HISPALENSI TRIBUNAL I[N]QUOESITOR FISCALIS CONCHENSI PRAESES ET EPISCOPUS BARCINOS, CREATUS, INDE AR ARCHIEPISC[U]M VALENTINUM DE 7 APRIL, ANNI 1725 PROMOTUS MODO SUMMO HISPANIM SENATU I GUBER, ASSUMITUR DEMUM INQUISIT. GNE HONORE POTITUS ARCH[I]PRAELATURE VALENT[I]AE RENUNTIAVIT DE 27 IAN. ANNI 1738.

Es necesario continuar con Andrés Mayoral Alonso de Mella (arzobispo entre los años 1737 - 1769) [fig. 4.17], efigie atribuida a José Vergara. ${ }^{39}$ Su entrega a la Iglesia fue muy valorada después de haber pasado unos años complicados que desencadenaban en la asidua ausencia de los prelados. Académicamente se cultivó en la Universidad de Alcalá. Antes de que Clemente XII le otorgase la diócesis de Valencia en 1737, había sido canónigo en León y Sevilla además de obispo en Ceuta. Sus buenas acciones hacia los desfavorecidos y su apoyo a las actividades culturales fueron la tónica general en el proceder de Andrés Mayoral. Por ello, fundó la casa de Santa Rosa de Lima, auxilió económicamente al Hospital General, la casa de la Misericordia o el colegio de San Vicente Ferrer. A su vez, colaboró con la Academia de Bellas Artes y ayudó otras actividades culturales. ${ }^{40}$ Este prelado, al igual que Orbe y Larreategui, también cuenta con su efigie entre los Retratos de españoles citado previamente.

Acerca del retrato de la catedral tan sólo cabe añadir que el escudo se ha timbrado con el capelo verde y diez borlas a cada lado. Los motivos incluidos en el mismo no coinciden con los blasones para los gentilicios de Mayoral y Mella. Sin embargo, es conocido que proviene del blasón para el Solar de Valdeosera, o valle de los osos, lugar en el cual se establecieron sus

39 Atribución propuesta por David Gimilio Sanz, 'José Vergara Gimeno y la retratística valenciana en el siglo XVIII', Ars Longa: cuadernos de arte, no. 12, 2003, pp. 75-82.

40 Luis Pinillos Lafuente, 'Don Andrés de Mayoral, arzobispo de Valencia, descendiente del Solar de Valdeosera (1685 - 1769)', Berceo. Revista riojana de Ciencias Sociales y Humanidades, no. 162, 2012, pp. 365-400. 


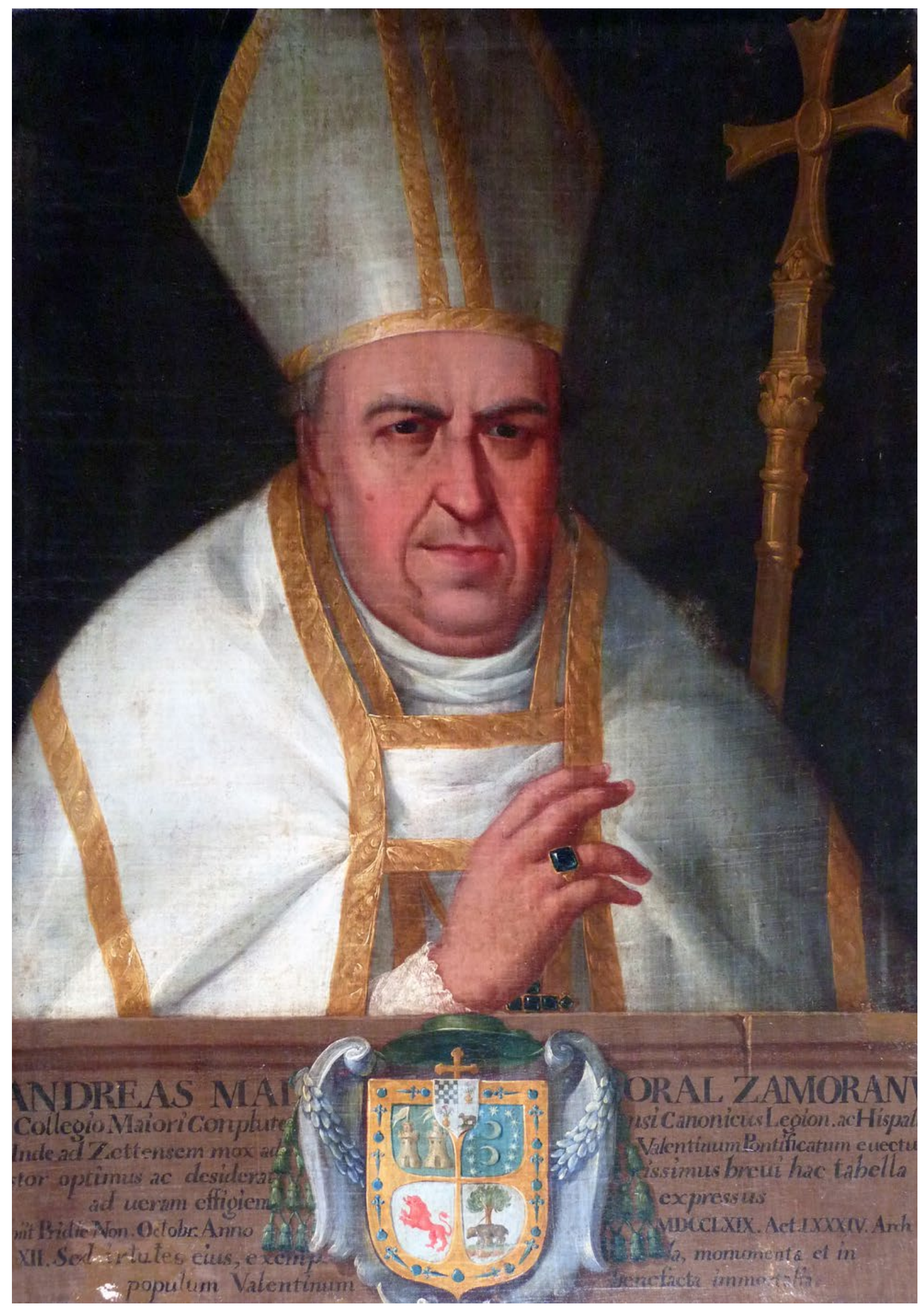

Fig. 4.17. Atribuido a José Vergara, Andrés de Mayoral Alonso de Mella, h. 1769, óleo sobre lienzo, Valencia, catedral. 
ascendientes varones. En su artículo Luis Pinillos, basándose en Elías Olmos, ha explicado la iconografía del sello de este prelado que es idéntica al escudo apreciable en el retrato. A grandes rasgos, es cuartelado y posee una bordura con veneras y cruces de Santiago. Concretamente, en el primer cuar-tel se identifican dos torres con una bandera cada una, en el segundo se han dispuesto dos lunas crecientes rodeadas de catorce estrellas de seis puntas. A continuación, se aprecia un león rampante y en el último cuartel se puede distinguir un árbol y un oso pasante a la derecha. Además, sobre el escudo principal se encuentra otro de menor tamaño copado por una cruz latina, el cual también se ha dividido en cuatro cuarteles, el primero de ellos es jaquelado, el segundo $\mathrm{y}$ tercero contiene un jarro con flores y el cuarto incluye, de nueve, el oso pasan-te. ${ }^{41}$ En cuanto a la inscripción conmemorativa que se ha in-cluido en la imagen, ésta reza lo siguiente:

ANDREAS MAIORAL ZAMORANUS. E Collegio Maiori Conplutensi Canonicus Legion ac Hispallensis Inde ad Zettensem mox ad Valenctinum Pontificatum evectus Pastor optimus ac desideratissimus brevi hac tabella [...] ad veram effigiem expressus. Obiit Pridie Non. Octobr. Anno MDCCLXIX. Ael. LXXXIV. Archi XXXII sed [v]irtutes eius, exempla momenta et in populum Valentinum benefacta immortalia.

La presencia de Tomás de Azpuru de Mella (arzobispo entre los años 1770 - 1772) [fig. 4.18] fue muy escueta. Su residencia en Roma y su repentina muerte en 1772 hicieron que nunca llega-se físicamente a las tierras valencianas una vez que el pontí-fice Clemente XIV hubiese aceptado la propuesta del monarca y lo hubiese designado prelado. Sin embargo, la galería de re-tratos también lo incluye como uno más de sus miembros por ello viste con el alba, la estola, la capa pluvial y la mitra con bordados en oro. El anillo y la cruz pectoral se han ornamenta-do con esmeraldas. Tras el cortinaje verde del fondo se percibe una estantería repleta de numerosos Hijorosildes defuente, 'Doń-Andrés de Mayoral...', p. 372. 
nico y la Biblia. El texto referente a Azpuru indica lo siguiente:

EX. E ILL. DOM. D. THOMAS AZPURU, CAESAR Augustanus qui post que in Hispaniae Curice Consiliis ob eloquentiam, ac juris intelligentiam, magni habitus fuit, ad Ecclesie Murciensis Canonicatum Doctoralem accitus est: inde ad S.R.R. Tribunal evocatus, ac negotiis Regis Catholici apud Sanctissimu[m] praelectus, nostrae Valentinem Metropolitanem Archipraesul creatur IV Idus Martii ann. MDCCLXX tandem[que] praecelentis Hispani Ordinis Caroli III nuper ab ipso institut magna cruce [...] gratiis ab eodem Monarcha munisicentissime in [...]

El sucesor en la diócesis fue Francisco Fabián y Fuero (arzobispo entre los años 1773 - 1794) [fig. 4.19]. Su formación académica fue muy amplia pues estudió filosofía, artes y teología. Carlos III lo presentó como oportuno candidato al cargo y Clemente XIV lo nombró prelado en 1773. Como otros antecesores suyos, se le ha alabado su candidez con los desfavorecidos. Asimismo, fundó el Seminario Diocesano. También ejerció un papel trascendental de la reforma universitaria, aunque tuvo alguna diferencia con Gregorio Mayans. En 1794 se vio obligado a dejar el cargo de prelado a raíz de los desencuentros que mantuvo con el capitán general, que desembocaron en la persecución, expulsión y destierro del Francisco Fabián y Fuero de Valencia.

El retrato, pintado por Vicente Inglés, lo ha inmortalizado vistiendo con el alba, sobre la que se ve la estola y la capa pluvial y, además lleva la mitra. Todas las piezas se han elaborado con textil blanco y están profusamente decoradas en oro. Con su mano izquierda sostiene la cruz pastoral y en la derecha hace ademán de bendecir. Cabe destacar que a modo de ornamentos luce la cruz pectoral y la medalla de la orden de Carlos III, fundada en 1771 y dedicada a la advocación de la Inmaculada Concepción. Igualmente, este detalle es sintomático de la buena relación que tuvo el prelado con el monarca. La postura del efigiado, pero principalmente su rostro, concuerdan con el 


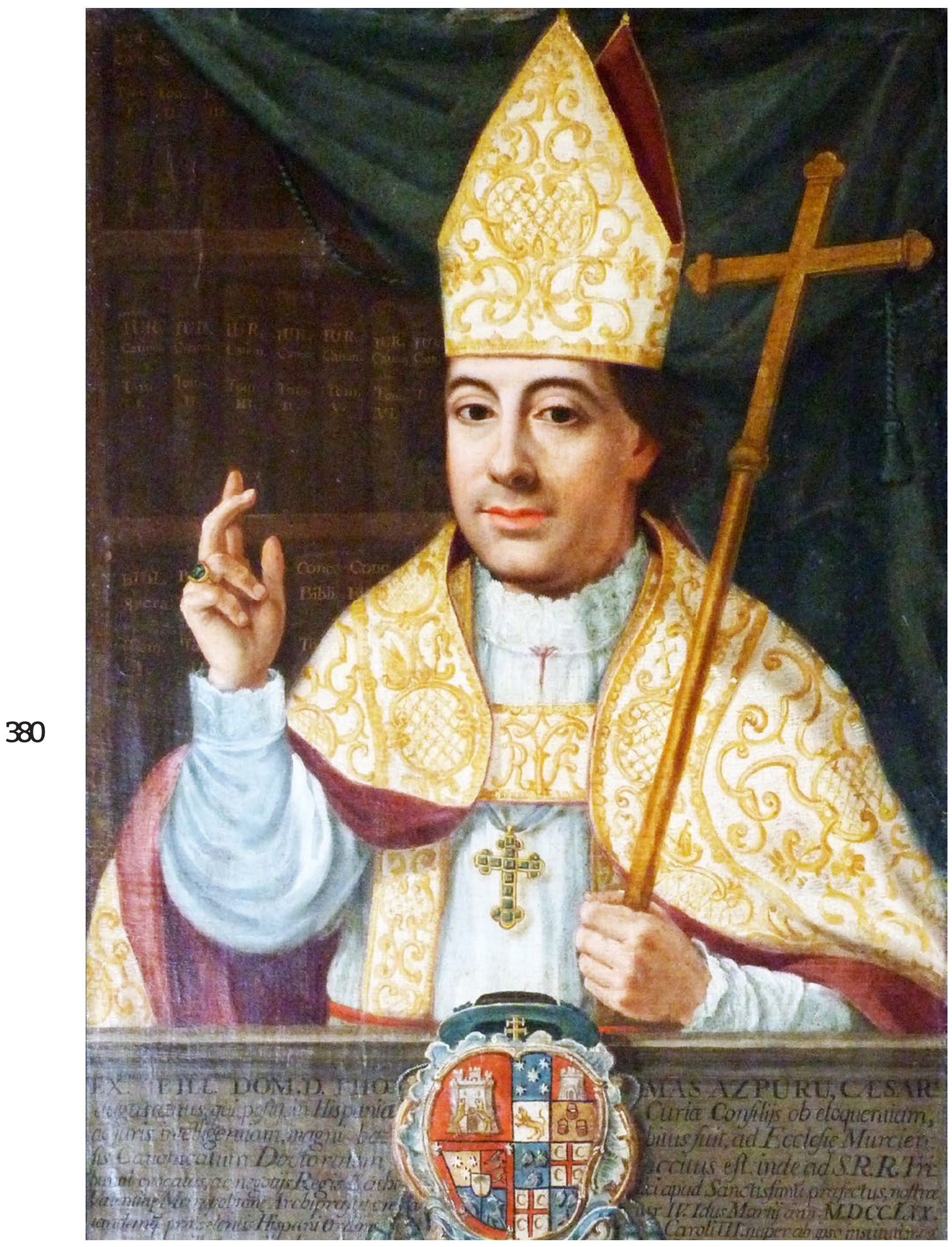

Fig. 4.18. Anónimo, Tomás de Azpuru de Mella, h. 1772, óleo sobre lienzo, Valencia, catedral. 


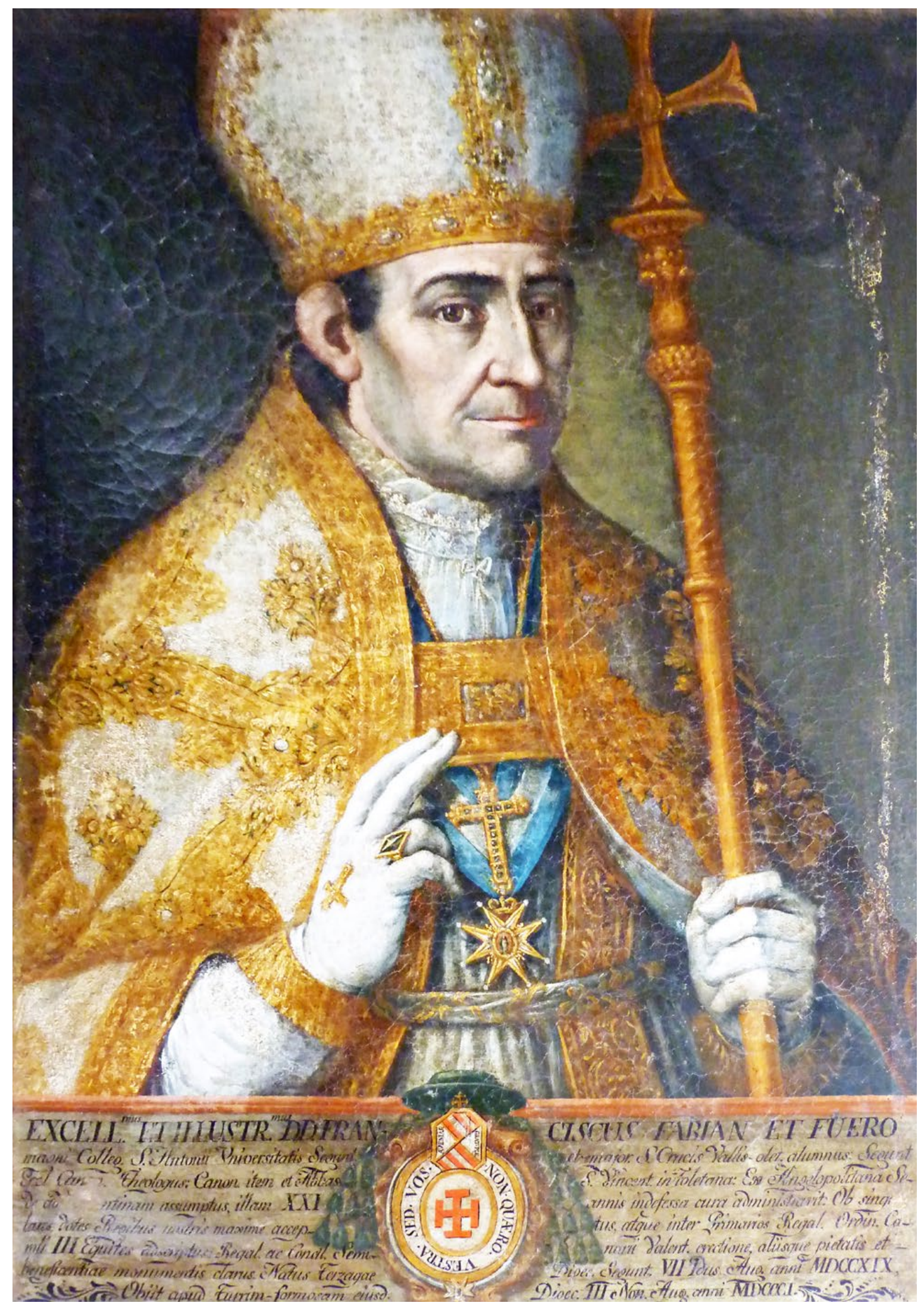

381

Fig. 4.19. Vicente Inglés, Francisco Fabián y Fuero, h. 1794, óleo sobre lienzo, Valencia, catedral. 
retrato que de este mismo personaje se hizo para el paraninfo de la Universitade Valèncidvéase la fig. 5.60), así en ambas imágenes se le ha mostrado como un hombre de rasgos marcados, nariz prominente, labios finos, tez blanquecina y barba sombreada que anuncia un generoso vello facial.

En la parte inferior de la pintura se ha dispuesto el escrito identificativo y descriptivo del efigiado y el escudo de armas. Este segundo se ha timbrado con capelo verde y diez borlas a cada lado. Posee una forma circular con una bordura en oro, campo de plata y una leyenda en latín que reza: «Non quaero vestra, sed vos». Se trata del catorceavo versículo extraído del capítulo doce de la segunda carta a los Corintios, en la que Pablo de Tarso defiende que lo importante del hombre no son sus bienes, sino el ser uno mismo. En el centro del blasón se ha dispuesto una cruz potenzada en gules. Además, se aprecia un escudete, coronado con una cruz patriarcal, que es cuartelado en aspa donde se ha escrito "Ave María, gratia plena».

Los otros dos cuarteles poseen tres bandas en gules sobre plata. Alrededor del escudo de armas principal se ha añadido la medalla de la orden de Carlos III, exaltando así la pertenencia de Fabián y Fuero a esta institución. Por último y respecto a la inscripción del retrato, ésta dice lo siguiente:

EXCELL. ET ILLSTR. D.D. FRANCISCS FABIAN ET FERO magni Colleg.

S. Antonii niversitatis Segunt et major. S. Crucis Vallis olet alumnus:

Segunt Eccl. Can[o]n Theologus: Canon ítem et Abbas S. Vincent. in Toletana: Ex Angelopolitana Sede ad[...]ntinam assumptus, illam XXI annis indefessa cura administravit: Ob sing[u]lares dotes Regibus nostris maxime acceptus: Regiit ac Concil. Seminaii Valent. Erectione aliisque pietatis et beneficentiae monumentis clarus Natus Terzagae Dioec[esim] Segunt VII Idus Aug. Anni MDCCXIX. Obiit apud Turrim formosam eiusd. Dioec[esim] III Non. Aug. Anni MDCCCI.

El mandato del mallorquino Antonio Despuig y Dameto [fig. 4.20] tan sólo abarcó unos meses durante el año 1795. Llegaba de la diócesis de Orihuela, fue nombrado como prelado de 


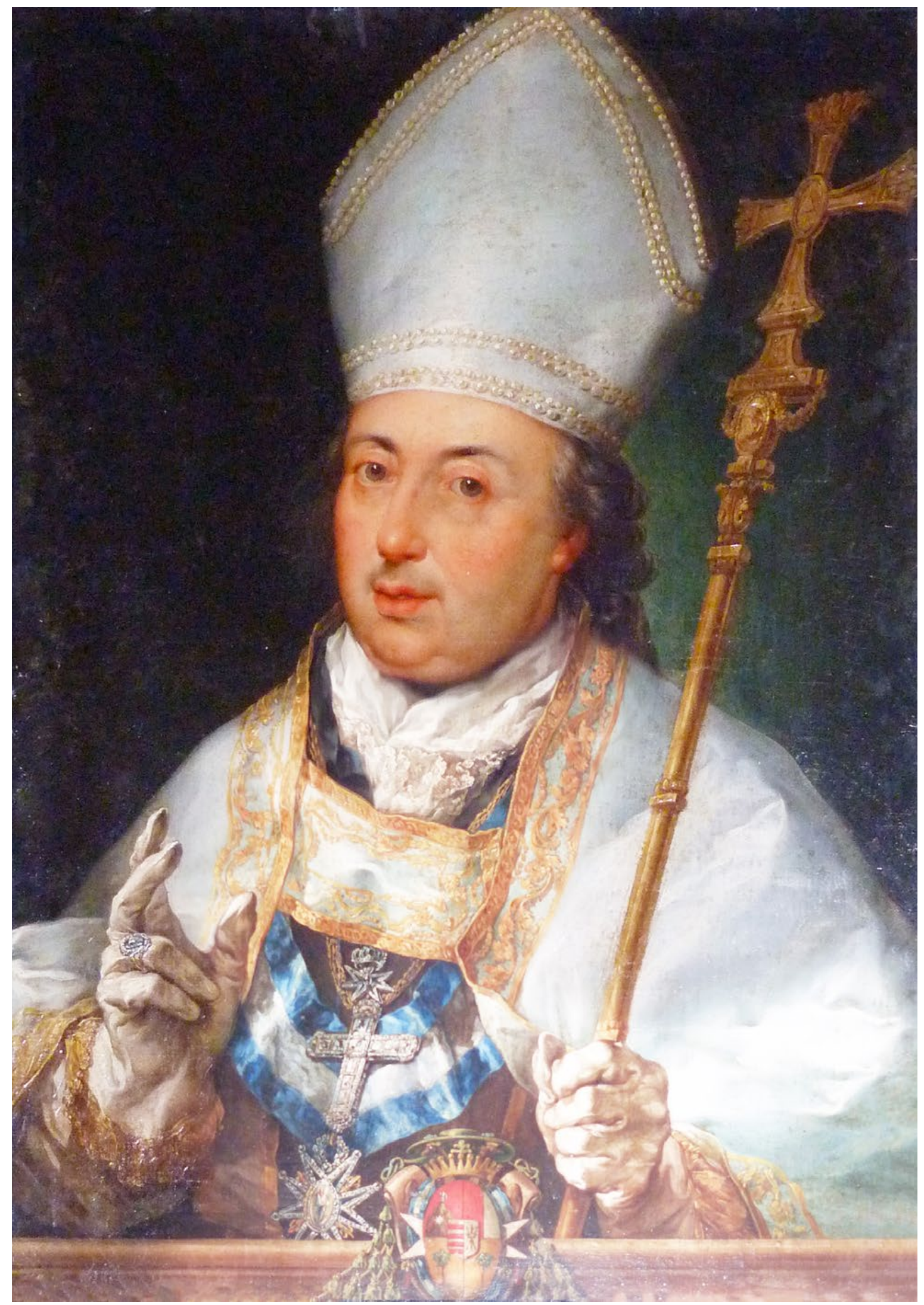

383

Fig. 4.20. Vicente López, Antonio Despuig y Dameto, h. 1795, óleo sobre lienzo, Valencia, catedral. 
Valencia por el papa Pío VI, pero pronto se trasladó a Sevilla. Más tarde llegó a ser cardenal bajo el título de San Calixto. Finalmente falleció en 1813. Su efigie fue elaborada por Vicente López y en él se aprecian las excelentes dotes del artista para pintar retratos. Así, el detallismo en los ropajes y elementos ornamentales contribuyen a crear una imagen fastuosa de este arzobispo. Siguiendo el prototipo de representación establecido para este conjunto, Antonio Despuig viste una capa pluvial blanca con un bordado en oro que recorre la caída y el cerramiento de la misma. Asimismo, lleva una mitra blanca también decorada de modo austero. Sostiene la cruz pastoral con su mano izquierda y con la derecha hace gesto de bendecir. Al igual que Francisco Fabián y Fuero, el arzobispo ostenta la cruz pectoral y la medalla de la orden de Carlos III dejando patente su cercanía a esta institución y su devoción a la Inmaculada.

A diferencia del resto de obras, este retrato no contiene la típica inscripción explicativa sobre el efigiado y el inferior de la obra tan sólo está ocupado por el escudo de armas. El blasón de este prelado se ha timbrado con el capelo verde y diez borlas a cada lado, tiene forma ovalada, es cuartelado y posee un escudete partido en el centro. En el primer cuartel se representa el gentilicio de Despuig, así se observa una montaña de oro con una estrella y coronada por una flor de lis en oro, todo ello sobre gules. El segundo cuartel remite a Dameto cuyo blasón es de plata y está partido en gules..$^{42}$ La iconografía de los dos cuarteles inferiores se repite, se trata un árbol de sinople sobre un campo de oro. Por el momento no se puede determinar a qué responde exactamente su presencia en el escudo. Sin embargo, si uno de ellos fuese un roble sobre oro y además apareciese un jabalí de sable empinado al tronco, coincidiría con la descripción que se hace del blasón del linaje Montenegro. Y si en el otro se identificase, sin lugar a dudas, un roble sobre oro y también contase con un toro al pie del tronco se co-

42 Cadenas y Vicent, Repertorio de blasones..., vol. I, p. 603 y p. 588. 
rrespondería con el gentilicio de Montoro. ${ }^{43}$ Ambas opciones serían lógicas y determinarían la nobleza de los ascendientes del arzobispo, pues era hijo de los condes de Montenegro y de Montoro. Provisionalmente, tampoco se puede ofrecer una lectura certera del escudete que se aprecia en el centro. Es partido y a la izquierda se han dispuesto cuatro bandas horizontales en gules y a la derecha hay un ramo. El escudo dispone de una corona en la parte superior e igualmente se le ha acolado la cruz de la orden de Malta puesto que el prelado era caballero de esta institución..$^{44}$ Asimismo, como en el escudo del arzobispo anterior se ha dispuesto la medalla de la orden de Carlos III.

El último prelado del siglo XVIII fue Juan Francisco Jiménez del Río (arzobispo entre los años 1796 - 1800) [fig. 4.21]. Su educación universitaria en teología transcurrió entre las universidades de Zaragoza y Valladolid. Posteriormente asumió la responsabilidad del arzobispado de Segovia. Carlos IV presentó su candidatura a la silla valenciana, el pontífice Pío VI lo designó y un año más tarde asumió definitivamente el cargo. Falleció pocos años después, en 1800. La pintura ha sido realizada por el taller de Vicente López. En la indumentaria del prelado predominan los tejidos blancos con bordados en oro que dibujan motivos vegetales, así se aprecia en la estola, la capa pluvial y la mitra. Sobre el pecho luce la cruz pectoral y en la mano izquierda porta otra cruz similar a la que, como se verá, se halla en el escudo. Al igual que otros predecesores suyos, con la mano derecha procede a dar la bendición. Los rasgos faciales concuerdan con otro retrato de este personaje hecho por Vicente López [fig. 4.22] en el que además, lleva la

43 Cadenas y Vicent, Repertorio de blasones..., vol. I, p. 1186 y p. 1191.

44 En la heráldica eclesiástica no estaba permitido acolar condecoraciones, estas debían ir colgadas en el inferior del escudo. Sin embargo, y como ejemplifica este caso, se hacía una excepción con los caballeros de las órdenes militares dependientes de la Iglesia, de la orden de Malta y del Santo Sepulcro. Véase a Monreal Casamayor, 'Heráldica episcopal...', p.20. 


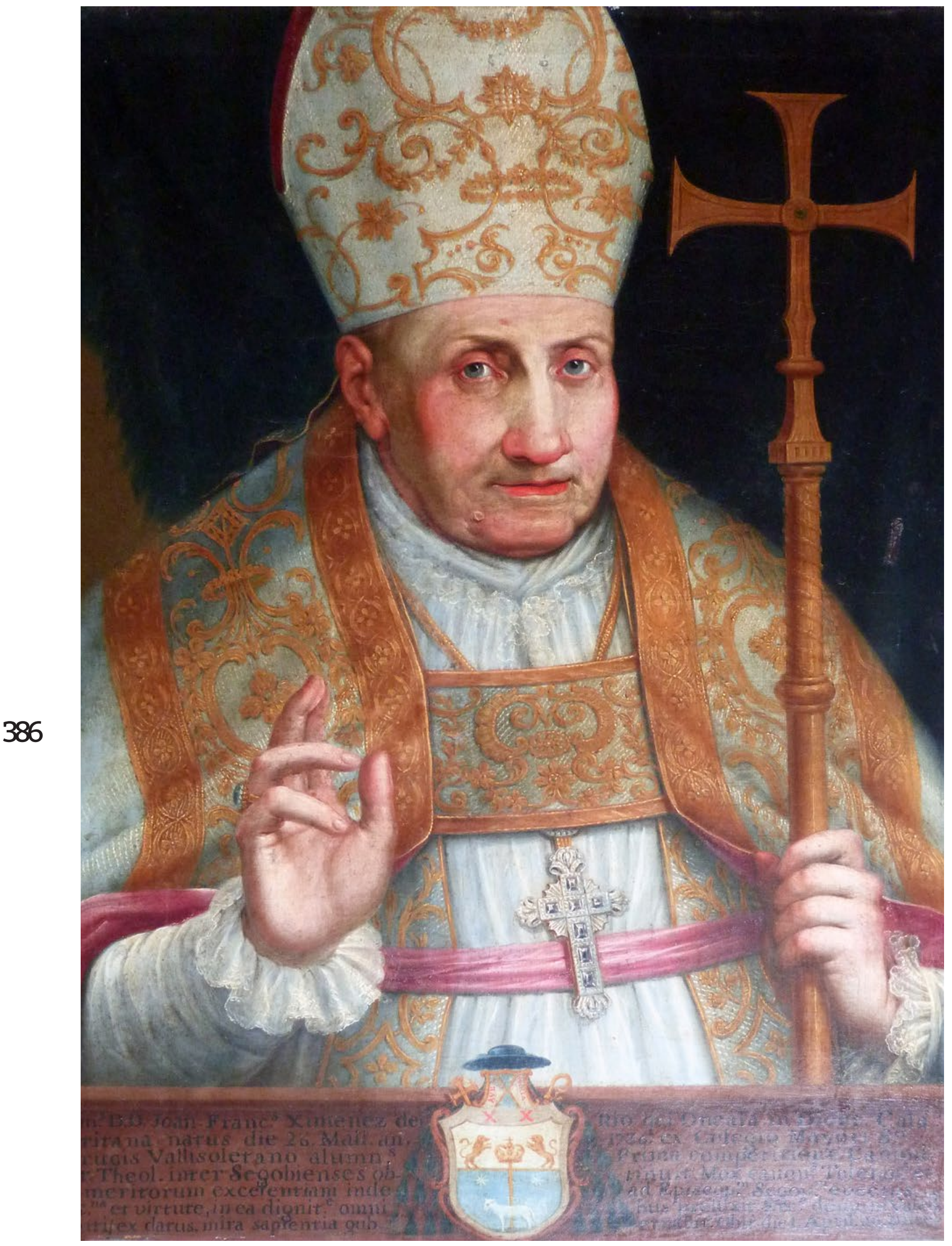

Fig. 4.21. Taller de Vicente López, Juan Francisco Ximenez del Río, h. 1800, óleo sobre lienzo, Valencia, catedral. 


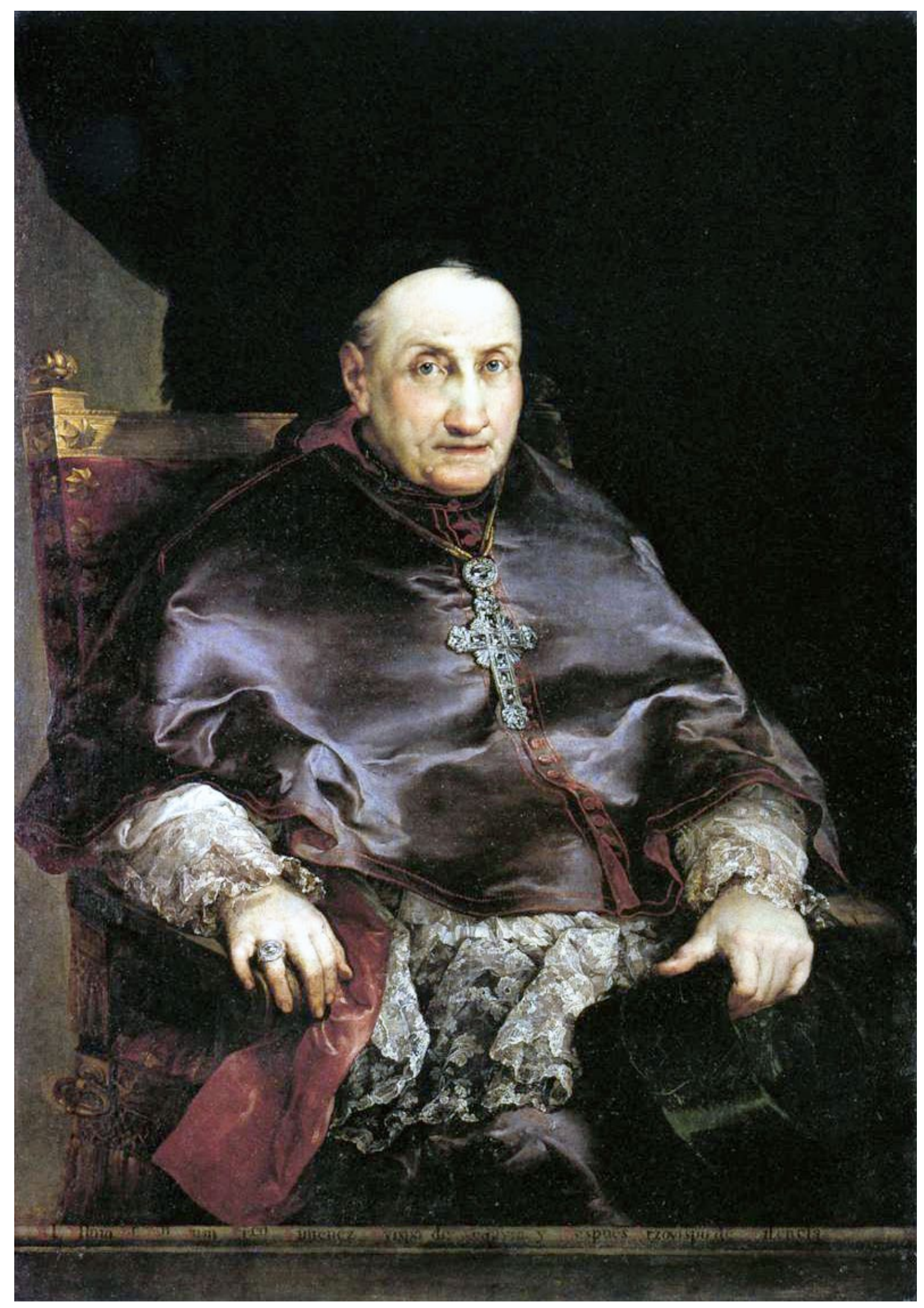

Fig. 4.22. Vicente López, Juan Francisco Ximenez del Río, h. 1799 1800, Bilbao, Museo de Bellas Artes. 
misma cruz pectoral repleta de piedras preciosas y sostiene el capelo verde con su mano izquierda. Es probable que esta pintura fuese un referente para la realización de la obra que ahora se analiza pues las semejanzas en el diseño del rostro son más que evidentes y su datación es de un momento muy cercano a su fallecimiento.

El escudo de armas que aparece en el retrato de la catedral está timbrado con el capelo verde y dispone de diez borlas a cada lado. Se ha acolado la cruz pastoral y el báculo, un detalle bastante típico en la heráldica episcopal pero que aún no se había apreciado en esta serie. En la parte superior se ha incluido un escudete en aspa con la inscripción Ave María, es un elemento propio de los escudos nobiliarios del linaje de Mendoza. La bordura es en plata y posee dos cruces en aspa. Los motivos centrales de la composición son una cruz de oro sobre la que se encuentra una corona y dos leones rampantes, uno frente a otro. En la zona inferior, sobre azur, hay un cordero acompañado por dos estrellas de ocho puntas. El escudo se ha tomado de los sellos empleados por el prelado durante su gobierno en Segovia y en Valencia respectivamente. De hecho, las diferencias con ellos son mínimas. Por ejemplo, el sello segoviano presenta cinco borlas y una cruz pastoral acolada al escudete pero no así el báculo. En el sello valenciano se ha añadido una cruz patriarcal o de doble travesaño, en la bordura junto a las cruces en aspa hay dos estrellas de seis puntas y cuatro más rodeando al cordero. El escrito incluido en la parte inferior del retrato dice lo siguiente:

Yllm. D.D. Joan. Franc. Ximenez del Rio qui Oncala in Dioec[esim] Calguritana natus die 26 Maii an. 1736 ex Colegio Mayori St. Cruci Vallisoletano alumn[...]s Prima competitione Canon cat. Theol. Inter Segobienses obtinuit Mox canon. Toletan. Ob meritorum excelentiam inde ad Episcop[u] $\mathrm{m}$ Ecc. Denum Valen. Pontifex datus. mira sapientia gubernabit. Obit die 1 April an. MDCCC.

La serie continuó retratando a los prelados del siglo XIX, des- 


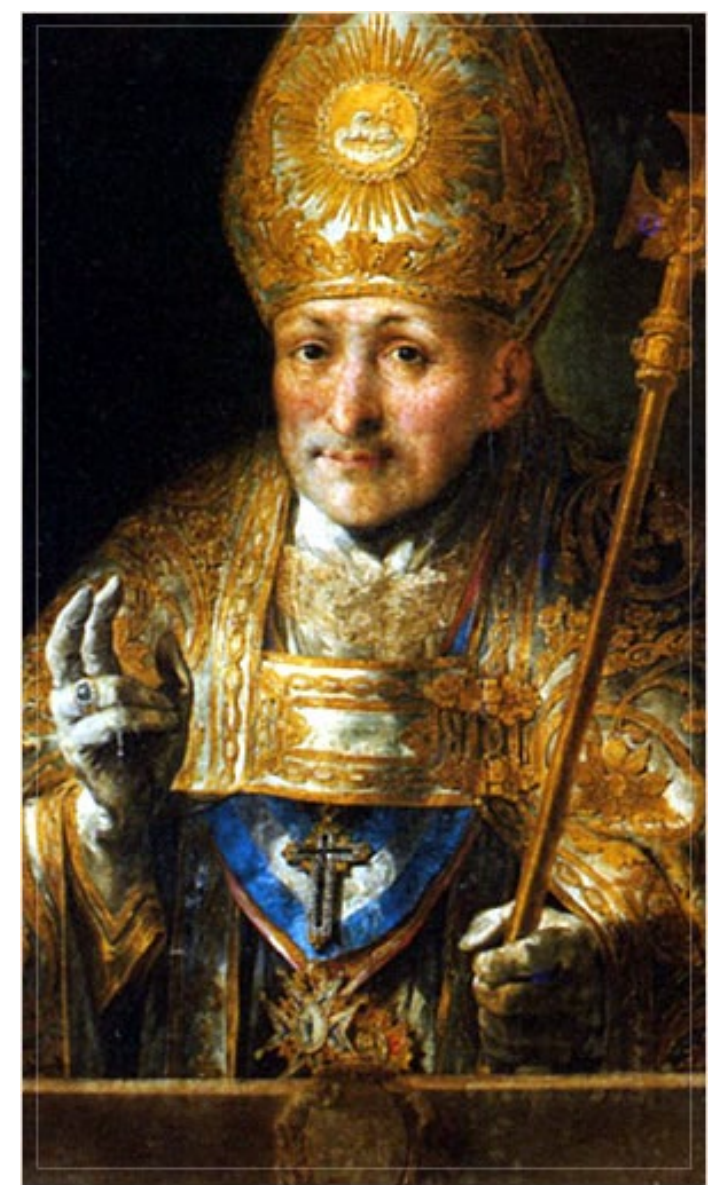

Fig. 4.23. Atribuido a Miguel Parra, Veremundo Arias Teixeiro, h. 1824, óleo sobre lienzo, Valencia, catedral.

de el gobierno de Joaquín Company Soler (arzobispo entre los años 1800 - 1813), hasta la más reciente actualidad con la efigie de Agustín García Gascó (arzobispo entre 1992 - 2009) de modo que la galería se mantiene viva y se mantiene la función desempeñada por los retratos. De entre todas ellas conviene mencionar las efigies de Joaquín Company Soler (1800-1813), Varemundo Arias Teixeiro (1815-1824) [fig. 4.23] y Simón López García (1824-1831) pues se han atribuido a la mano de Miguel Parra. Esta autoría pondría de manifiesto la participación del artista en diferentes conjuntos de retratos de cariz distinto, como la colección para la Real Academia de Bellas Artes de San Carlos que se verá más adelante. Tanto en estas tres efigies junto como en el conjunto de las obras desde el siglo XIX se observa una disposición similar en los retratados, mirando al frente, llevando guantes blancos o rojos, con la cruz pastoral, el anillo y en ademán de bendecir. También las vestiduras presentan ricos bordados en oro que ya no se ciñe de forma exclusiva a los motivos vegetales, sino que se introducen representaciones del Espíritu Santo y del cordero de Dios en las 
mitras y capas pluviales. Asimismo, es reiterativa la ostentación de la cruz pectoral y de la medalla de la orden de Carlos III con la imagen de la Inmaculada Concepción. Sin embargo, se ha perdido la homogeneidad en las inscripciones que cada vez son más extensas en contraposición del escudo de armas, el cual se introduce en un tamaño menor o incluso se llegó a eliminar en numerosos retratos del siglo XX.

\subsubsection{Otros episcopologios similares al ejemplo valenciano.}

La necesidad de configurar una dinastía de obispos y arzobispos en las diócesis españolas es un fenómeno común a otras sedes y presenta diversos factores habituales. El más importante de todos ellos es la función oficial que desempeña este tipo de efigies. Los representados son la imagen de una institución que se mantiene firme en el tiempo y contribuyen a construir la memoria de la Iglesia. Además de este papel exclusivamente representativo, los retratos de prelados también son el icono del pastor católico, asumen el rol del buen pastor, poniendo de manifiesto su intención de guiar la espiritualidad y aconsejar sobre la conducta de sus fieles. La reunión de estos retratos en una única serie potencia la idea de lo que se podría denominar linaje episcopal. ${ }^{45} \mathrm{~A}$ esta particular estirpe no se pertenece por méritos de sangre sino por logros terrenales. Además resulta notorio observar que estos conjuntos pic45 Armenini ya defendió que este tipo de imágenes eran apropiadas para decorar los muros exteriores de las iglesias. En este caso particularmente, habla de la inclusión de las efigies de cardenales dentro de todo el programa iconográfico: «Mas volviendo a las fachadas, considero que no será poco imitarlas simplemente con colores o simularlas de mármol o bronce, sobre todo para los ciudadanos de nuestro tiempo, y usaremos ejemplos para demostraros el verdadero modo que siguieron los mejores pintores. Entre los primeros estuvieron Baldassare da Siena y Polidoro de Caravaggio, y elegiré alguna de sus mejores obras que hay en Roma, porque hablar de todas sería excesivo. Hizo Baldassare cerca de la plaza de los Altieri una fachada de claroscuro en la que figuró las historias de Cesar cuando le son presentados los tributos de todo el mundo, y más arriba simuló el bulto redondo a los doce emperadores que, posados en ménsulas, muestran una visión de abajo a arriba que no creo se pueda fingir mejor. Bajo las historias hay un friso donde hizo unos tondos que eran retratos del natural de to- 
tóricos tienen un momento de esplendor a partir del siglo XVI, en el marco de la reforma católica, para defender la necesidad de someter a todos los creyentes bajo la dirección de la más alta dignidad en la tierra, es decir, el pontífice, representado en cada diócesis mediante la figura del prelado. ${ }^{46}$

Junto con el papel llevado a cabo por este tipo de imágenes, también se aprecian similitudes en el modelo de representación siempre enmarcado en el retrato de aparato. Así pues, la serie valenciana y la situada en Tarazona comparten un mismo cariz. El conjunto turiasonense es el más antiguo conservado en Aragón. Lozano López ha situado su creación alrededor del año 1556 cuando al frente del obispado se encontraba Juan González de Munébrega, quien ostentó dicho cargo desde 1547 hasta su fallecimiento en 1567. Igualmente, ha contemplado la posibilidad que fuese un proyecto realizado por el artista italiano Pietro Morone y se estableciese el modelo de representación para el conjunto. Respecto al prelado González de Munébrega, cabe destacar que tras ser nombrado obispo de Mondoñedo, fue inquisidor en Cerdeña, Valladolid, Sevilla, Cuenca y Valencia, donde vivió en torno al año $1541 .{ }^{47}$

Sería conveniente rastrear si durante su estancia en la ciudad

dos los cardenales de entonces, y debajo hizo dos grandes ríos con algunas virtudes y otros ornamentos muy bien entendidos.» Consúltese a Giovanni Battista Armenini y $\mathrm{M}^{\mathrm{a}}$ Carmen (trad.) Bernárdez Sanchís, De los verdaderos preceptos de la pintura, (Visor Libros: Madrid, 1999). Cap. XIV. Qué asuntos de pinturas deben hacerse en los muros exteriores de las iglesias, cómo decoraban los antiguos las fachadas de sus casas, de lo que conviene en nuestros tiempos y qué colores se adecuan más a ellas, pp. 256-257.

46 En relación a la finalidad abordada por estos retratos y para conocer el modelo iconográfico más utilizado en este tipo de conjuntos pictóricos, resulta interesante consultar a Juan Carlos Lozano López, 'Las galerías de retratos episcopales en las diócesis aragonesas', Aragonia sacra: revista de investigación, no. 16-17, pp. 303-318.

47 Los breves datos biográficos de este personaje ya han sido recogidos por Ana María Ágreda Pino, 'El terno de don Juan González de Munébrega. Estudio histórico artístico', Turiaso , no. 13, 1996, pp. 95-110. La autora, 
valenciana perteneció al círculo de amistades de san Juan de Ribera y valorar la posibilidad de si la empresa llevada a cabo por el eclesiástico aragonés sirvió como referente para que la diócesis valentina tomase la determinación de crear su propia serie icónica. De hecho, ambos conjuntos nacen en un periodo de tiempo bastante acotado, hacia 1556 la serie de Tarazona y hacia 1568 la de Valencia. A grandes rasgos, el patrón iconográfico en los dos casos es similar. Los obispos se han retratado de busto sobre un fondo neutro, luciendo la indumentaria pontifical, capturados en una amplia variedad de posiciones y gestos que le otorgan ritmo a la secuencia sin descuidar la homogeneidad del grupo. También se incluyen inscripciones en latín acerca de los hitos que certifican su ilustre condición. El escudo de armas es igualmente un elemento presente en las efigies que vienen a aludir su pertenencia a familias de buena fama, mostrando al mismo tiempo sus raíces sanguíneas.

El palacio arzobispal de Zaragoza alberga una serie de los dirigentes de su diócesis diferenciada en dos partes. La primera de ellas corresponde a imágenes bastante cercanas a la galería homónima de Valencia y los personajes retratados se extienden hasta el año 1319. A partir de entonces, la ciudad de Zaragoza elevó su rango a arzobispado. Para mostrar visualmente el salto cualitativo que asumió la ciudad, también se cambió el formato de los retratos, pasando a ser representaciones de cuerpo entero. La serie seguramente fue creada en el siglo XVII, pues Arturo Ansón atribuye el deseo de tener el conjunto pictórico al arzobispo Antonio Ibáñez de la Riva Herrera, quien cedió en 1693 un amplio lote de pinturas entre las cuales se hallaban las efigies de los prelados. El investigador también ha relacionado la autoría del encargo con el pintor Pablo Rabiella y Díez de Aux además de otros artistas como Jusepe Martínez, Asensio de Eleícegui, José Luzán Martínez o Juan Andrés Merklein. ${ }^{48}$

a su vez, se basa en la obra de Gregorio de Argaiz, Teatro monástico de la Santa iglesia, ciudad y obispado de Tarazona, tomo VII de La Soledad laureada de San Benito y sus hijos en las iglesias de España, Madrid, 1675.

48 Arturo Ansón Navarro, 'Colección de retratos de obispos y arzobispos 
Las obras se ubicaron en el Salón del Trono y tenían una labor de representación institucional y expresión de poder en consonancia con la finalidad del retrato barroco. Iconográficamente la serie se acerca más al tipo de retrato empleado en el Paraninfo de la Universidad de Valencia que al tradicional formato de retratos de prelados de la catedral valenciana. De esta manera se ha construido la imagen representativa de la institución. El personaje correspondiente ha sido efigiado de cuerpo entero, con una actitud distante, junto a un bufete donde se puede apreciar diversos objetos alusivos al ejercicio de su profesión, sosteniendo un documento o un libro, en una estancia engalanada por un cortinaje e incluyendo el correspondiente texto y el escudo de armas.

Asimismo se debe tomar como ejemplo la serie de retratos de los obispos de Jaén puesto que nació tras la necesidad de crear el episcopologio de la sede giennense en los últimos años del siglo XVI. ${ }^{49}$ Como puede haber sucedido en el proyecto valenciano, los retratos de los prelados de Jaén desde el siglo XIII han tomado los datos biográficos de las anotaciones recopiladas por Alonso de Salazar Frías y Gil Dávalos bajo el encargo del obispo Francisco Sarmiento de Mendoza (1580-1595), quien deseaba construir la genealogía de los obispos de esta diócesis. En efecto, tras la redacción y compilación de las vidas de los prelados en diversas obras escritas como la mencionada por Salazar y Dávalos o la elaborada por Martín Jimena Jurado ${ }^{50}$ se dio paso a la creación de la galería pictórica por voluntad

de Zaragoza, hasta el siglo XVIII', en María del Mar Agudo Romeo (coord.), El espejo de nuestra historia: la diócesis de Zaragoza a través de los siglos: San Juan de los Panetes, Lonja, Palacio Arzobispal, 5 octubre - 6 enero, 1991-1992, Zaragoza., (Arzobispado de Zaragoza: Zaragoza, 1991), pp. 145-148.

49 Francisco Juan Martínez Rojas, 'La galería de retratos de los obispos de Jaén', Memoria ecclesiae XXX, 2007, pp. 195-200.

50 Martín de Jimena Jurado, Catalogo de los obispos de las iglesias catedrales de la diócesis de Jaén y anales eclesiásticos de este obispado, (Madrid, 1654). 
del obispo Sancho Dávila y Toledo alrededor de los años 1600 y 1615. Los primeros ejemplares, se realizaron al fresco sobre yeso y posteriormente hacia el 1645 el cardenal Baltasar de Moscoso y Sandoval (1619-1646) decidió remodelar la serie y convertirla en óleos sobre lienzos. Resulta necesario destacar el deseo de la diócesis por encontrar y hacer valer sus raíces apostólicas, lo cual derivó en la publicación de numerosas obras a finales del siglo XVI y a lo largo del siglo XVII. El conjunto de efigies igualmente contribuyó a esa causa, queriendo vincular el cristianismo de Jaén con los inicios de la predicación del Evangelio. A todo ello, cabe añadir la voluntad de edificar la memoria histórica de la diócesis. ${ }^{51}$

Generalmente, las galerías de retratos de obispos y arzobispos gozaron de un punto álgido a raíz del Concilio de Trento (1545 - 1563) y en el marco de la reforma católica. Una de las más tempranas en la atmósfera tridentina, como ya se ha comentado, fue la de Tarazona que se fecha hacia el año 1556 cuando 394 la junta aún no había concluido. El resto, como los ejemplos aragoneses o el andaluz se elaboraron desde el siglo XVII. Sin embargo éstas no eran los primeros ejemplos de series icónicas de prelados, pues ya se venían haciendo desde los siglos XIV y XV. ${ }^{52}$ En este sentido, Toledo fue una de las primeras diócesis en llevar a cabo un proyecto de tal envergadura. El arzobispo Francisco Jiménez de Cisneros (prelado desde 1495 hasta 1517) fue el impulsor de la creación de una serie de retratos para lucir en la sala capitular de la catedral toledana..$^{53}$ Así pues Juan de Borgoña realizó las primeras representaciones siguiendo un mismo formato para todos los componentes

51 Idea defendida por Martínez Rojas, 'La galería de retratos...', íbidem.

52 Rodríguez Moya, 'Dinastía de prelados...'. Aunque el cuerpo principal del estudio es un análisis de la galería de arzobispos de la diócesis de Segorbe-Castellón, la autora ya ha reflexionado en torno a la motivación de la creación de estos grupos pictóricos, así como ha mencionado múltiples ejemplos.

53 Para conocer con detalle la serie toledana es necesario recurrir a Llamazares Rodríguez, 'Imagen e imágenes de...'. 
de la dinastía. Son retratos de tres cuartos, vestidos idénticamente, lucen una sotana roja y una muceta de armiño. Sobre ambas piezas, destaca la rica capa pluvial que lejos de recurrir a una simple ornamentación vegetal se ha decorado probablemente con la presencia de apóstoles o santos. Asimismo, también se le otorga una atención especial a la mitra y la cruz arciprestal que son los atributos por excelencia del prelado. Al estudiar este conjunto, Llamazares Rodríguez atisbó un paralelismo literario en Generaciones y semblanzas de Fernán Pérez de Guzmán, donde se venera la personalidad de algún personaje memorable. ${ }^{54}$ Como se ha visto, la serie valenciana ha compartido características y funciones con otros proyectos similares en otras diócesis españolas. De este modo, se fue construyendo un repertorio visual de multitud de obispos y arzobispos que ejercieron de espejos para la fe católica y por ello, merecieron perpetuar su memoria y legado a través de los tiempos siendo efigiados.

\subsubsection{Ideas sobre el arzobispo perfecto en el siglo XVII:}

Cualquiera de las series de prelados mencionadas anteriormente es un buen ejemplo de cómo el retrato fue utilizado para dar visibilidad a estos dirigentes eclesiásticos en calidad de modelos a seguir por su encomiable labor pastoral. Por esa razón, conviene reflexionar brevemente acerca de la idea del excelente prelado difundida en la época. Además, cabe recordar que, desde Trento especialmente, los obispos y los sacerdotes tomaron como referente a la figura del buen pastor y centraron su trabajo en la salvación de las almas. A ello debe sumarse la impermeabilidad de la Iglesia católica a los ataques protestante y la firme defensa de sus dogmas. ${ }^{55}$ Un buen punto de partida para conocer el prototipo de obispo en la época es la biografía de Baltasar Moscoso y Sandoval, prelado de Toledo

54 Llamazares Rodríguez, 'Imagen e imágenes de...', p. 163.

55 Esta consideración se ha tomado de un estudio específico acerca de Juan de Ribera. Consúltese a Ramón Robres Lluch, San Juan de Ribera, patriarca de Antioquía, arzobispo y virrey de Valencia, 1532-1611: un obispo 
a quien se le ha tildado de perfecto. Alfonso de Andrade, autor de la obra, recurrió a distintos textos bíblicos y patrísticos para determinar las características que debe poseer todo pastor católico. Por ello, ha sintetizado algunas ideas extraídas de las cartas de san Pablo a Timoteo y a Tito y especifica que: «El obispo debe ser de vida irreprehensible, sin culpa, ni pecado, dispensador de los bienes, que Dios le ha dado, esposo de una sola Iglesia, templado, prudente, sabio, humilde, caritativo, manso, y no iracundo, ni soberbio, y menos contencioso, y avaro, ni codicioso, modesto, casto, y santo, de buena, y santa doctrina, y que tenga su casa santamente gobernada; porque quien no atiende a gobernar la suya, más descuido tendrá las ajenas. ${ }^{56}$

Estas apreciaciones se pueden localizar en el capítulo tercero de la primera carta a Timoteo, donde san Pablo aportó las principales directrices para regir a la comunidad, y que, por tanto, serían extrapolables a las funciones del prelado. El escrito bíblico, desde su primer versículo ha valorado y ennoblecido la tarea de encabezar a una comunidad. Seguidamente se ha indicado qué requisitos debe reunir el buen gobernante entre los cuales destacan dos. El primero de ellos es la capacidad para dirigir a su propio núcleo familiar. En el hogar se encuentra la comunidad más pequeña y a la primera que se pertenece, por ello, es necesario saber conducirla. De esta manera, san Pablo ha equiparado a la familia con el colectivo cristiano. El segundo reside en tener una firme y consolidada fe de forma que se pueda evitar caer en el pecado.

Es muy cierta esta afirmación: «El que aspira a presidir la comunidad, desea ejercer una noble función». Por eso, el que según el ideal de Trento, (Juan Flors: Barcelona, 1960), p. 95.

56 Véase a Alfonso de Andrade, Idea del perfecto prelado en la vida del Eminentísimo Cardenal. D. Baltasar de Moscoso y Sandoval, (Joseph Fernández Buendia: Madrid, 1668). El fragmento concreto se localiza en la Parte tercera. En que se trata de sus virtudes, así personales, como de obispo, y prelado, por las cuales mereció el título de idea. Capítulo primero. Se propone la idea del perfecto prelado, p. 381. 
preside debe ser un hombre irreprochable, que se haya casado una sola vez, sobrio, equilibrado, ordenado, hospitalario y apto para la enseñanza. Que no sea afecto a la bebida ni pendenciero, sino indulgente, enemigo de las querellas y desinteresado. Que sepa gobernar su propia casa y mantener a sus hijos en la obediencia con toda dignidad. Porque si no sabe gobernar su propia casa, ¿cómo podrá cuidar la Iglesia de Dios? Y no debe ser un hombre recientemente convertido, para que el orgullo no le haga perder la cabeza y no incurra en la misma condenación que el demonio. También es necesario que goce de buena fama entre los no creyentes, para no exponerse a la maledicencia y a las redes del demonio (Timoteo 1: 3, 1-7).

El mensaje contenido en el capítulo inicial de la primera carta a Tito camina en la misma dirección que el anterior. San $\mathrm{Pa}-$ blo dejó una serie de instrucciones para aquellos que ejercerían de presbíteros en Creta. Nuevamente se ha recalcado que estos pastores debían tener una conducta impecable puesto que cada uno de ellos era, según dice literalmente, "un administrador de Dios», y por ello les debía caracterizar la moderación, la justicia, el dominio sobre su persona, la piedad y el obrar bien. Como se ha podido observar, el libro de Andrade sí que ha ofrecido una comparación clara entre el cómo debía de ser un dirigente eclesiástico cimentándose en las escrituras bíblicas y la trayectoria de Baltasar Moscoso. No obstante, hay otro texto importante que no ha hecho esta diferenciación y ha presentado al modelo de prelado a través de la vida de un personaje concreto. Así lo hizo Jacinto Busquets Matoses en su Idea ejemplar de prelados delineada en la vida y virtudes de san Juan de Ribera. ${ }^{57}$ En este caso todos los adjetivos que en la época se asociaban con el prototipo de dirigente eclesiástico se han presentado como virtudes de propio Ribera y se ha dedicado un capítulo a cada una de ellas. Por ejemplo, su sabiduría se ha justificado al hablar de su formación académica en Salamanca y su doctorado en sagrada teología. Su capacidad para dirigir a la comunidad, según san Pablo una tarea equiparable

57 Jacinto Busquets Matoses, Idea ejemplar de prelados, delineada en la 
a proteger a la familia, se aprecia en las secciones que tratan el excelente cuidado que tuvo con su familia y con los fieles. Asimismo, el libro tercero se ha destinado en su mayor parte a hablar de la templanza, la castidad, la humildad, la paciencia y la mansedumbre, la prudencia y la caridad que caracterizaron la vida del prelado.

Conviene remarcar la trascendencia que tuvieron las series de retratos de obispos y arzobispos a raíz del Concilio de Trento (1545 - 1563) puesto que las imágenes mostraban el modelo a seguir por el pastor católico. Pero este cometido no fue desempeñado tan sólo a través de las pinturas, sino que las obras escritas también contribuyeron a enseñar el tipo de prelado idóneo y a materializarlo en una persona en concreto. Incluso la difusión de estas ideas tuvieron su espacio en la emblemática, pues cabe recordar que Núñez de Cepeda diseñó numerosas empresas sacras para explicar la figura del buen pastor. ${ }^{58}$ Aunque los retratos de esta clase de galerías no contienen referencias emblemáticas, es importante apuntar que la transmisión del modelo de dirigente eclesiástico, quien gobierna una determinada comunidad y quien es considerado como un pastor no sólo encontró su espacio a través de las efigies y las obras escritas, sino que también tuvo cabida en la emblemática.

\subsection{Frailes, venerables y beatos del círculo de san Juan de Ribera. En el camino a la santidad.}

La colección artística que san Juan de Ribera (Sevilla, 1532 -

vida, y virtudes del venerable varón el ilustrísimo y excelentísimo señor don Juan de Ribera, patriarca de Antioquía, arzobispo de Valencia, su virrey y capitán general, fundador del Real Colegio de Corpus Christi, (Valencia, 1683).

58 Francisco Núñez de Cepeda, Idea del buen pastor copiada por los SS. Doctores representado en empresas sacras; con avisos espirituales, morales, políticos y económicos para el govierno de un principe ecclesiastico, (Anisson y Posuel: Leon, 1682); Rafael García Mahíques, Empresas sacras de Núñez de Cepeda, (Tuero: Madrid, 1988). 
Valencia, 1611) llegó a recopilar evidencia múltiples datos acerca de su personalidad e intereses. Como han estudiado Daniel Benito o Borja Franco, se componía de alrededor de trescientas cincuenta pinturas de calidad y temática dispar, variadas esculturas, reliquias y unos mil novecientos noventa libros de materia diversa. ${ }^{59}$ Se trataba de un gran compendio de obras que tenía por objetivo garantizarle la comprensión de la naturaleza y el conocimiento de Dios.

Entre todas ellas, y además de los otros conjuntos de retratos analizados en diferentes capítulos de este estudio, conviene reflexionar acerca de las efigies de numerosos personajes religiosos. Todos ellos estaban vinculados unos con otros por dos circunstancias muy concretas. La primera de ellas, es la rela-ción amistosa que tenían con Ribera y la segunda, eran sus po-sibilidades futuras de ser beatificados o canonizados. Ambos aspectos hacen de este grupo pictórico un caso interesante de investigar. Son obras encargadas por el Patriarca a finales del siglo XVI y principios del siglo XVII que cumplían una función muy precisa; encaminar a los retratados hacia la santidad.

Antes de profundizar en el análisis de este proyecto artístico concreto, es necesario contextualizarlo a grandes rasgos con la realidad hispánica y valenciana de ése momento. La Iglesia católica había iniciado su particular re-forma acordada durante el Concilio de Trento (1545 - 1563) y en contraposición a las medidas promovidas por Lutero y la Iglesia protestante. San Juan de Ribera fue un firme defensor de la transformación de la espiritualidad católica. El catolicismo también contaba con el apoyo de la monarquía hispánica, de hecho, es conocida la intensa piedad y devoción de la

59 Daniel Benito Goerlich, 'Juan de Ribera y las artes. Sensibilidad, gusto y aliño al servicio de una fe sincera.', en El legado del patriarca Juan de Ribera: Pastor Sanctus Virtutis Cultor, IV centenario, (Pentagraf, 2011), p. 221; Borja Franco Llopis, 'El patriarca Ribera y el uso del arte a finales del siglo XVI en Valencia', en El patriarca Ribera y su tiempo: religión, cultura y política en la Edad Moderna, (Institució Alfons el Magnànim, Diputació de València, 2012), pp. 591-608. 
familia de la Casa de Austria. Asimismo, existía un buen entendimiento entre Ribera y la Corona. Tan sólo dos detalles ya ponen de manifiesto la excelente sintonía entre ambas partes. El primero de ellos, es la misa oficiada por el Patriarca en la catedral de Valencia el 18 de abril de 1599 en honor de un doble desposorio; Felipe III con Margarita de Austria, y su hermana la infanta Isabel Clara Eugenia con el archiduque Alberto. El segundo es la deferencia que la reina tuvo con el Patriarca al hacerle llegar una reliquia: «un relicario de plata, dorado y ovalado con cristales con la quijada de san Anacleto papa y mártir la cual envió la majestad de la señora reina doña Margarita de Austria, mujer del señor rey don Felipe III a nuestro fundador y señor.» ${ }^{60}$ Igualmente, cabe recordar que Ribera se entendió con el monarca y defendió su determinación política de expulsar a los moriscos en el año 1609.

Los estudios iconográficos acerca de este personaje, como el llevado a cabo por Wifredo Rincón, ${ }^{61}$ demuestran otros aspectos de la personalidad de Ribera. Principalmente se alude a su intenso culto a la Eucaristía, de hecho, durante su mandato episcopal en la diócesis de Valencia celebró varios sínodos en los que principalmente apostó por la devoción al dogma de la transubstanciación. Por esta razón, Juan Sariñena retrató al Arzobispo san Juan de Ribera adorando la Eucaristía [fig. 4.24]. Por decisión de los colegiales perpetuos, esta pintura fue situada bajo el dosel del crucero de la iglesia, un lugar per-

60 Archivo del Real Colegio Seminario del Corpus Christi de Valencia (ACCV de ahora en adelante): Inventario de la sagristía. Año 1695. Fol. 10v.

61 Wifredo Rincón ha estudiado la iconografía pictórica y escultórica de san Juan de Ribera en un amplio marco cronológico, exactamente desde que fue obispo de Badajoz hasta el siglo XX, y teniendo en cuenta la clase de indumentaria y los atributos que habitualmente le acompañaron. El autor remarca que el conjunto de imágenes principalmente lo muestran en calidad de arzobispo y fundador del Colegio, aunque también aparece representado en diversos ciclos narrativos. Consúltese a Wifredo Rincón García, 'Iconografía de san Juan de Ribera', en Emilio Callado Estela y Miguel Navarro Sorní (coord.), El patriarca Ribera y su tiempo: religión, cultura y política en la Edad Moderna, (Institució Alfons el Magnànim, Diputació de València: Valencia, 2012), pp. 685-712. 


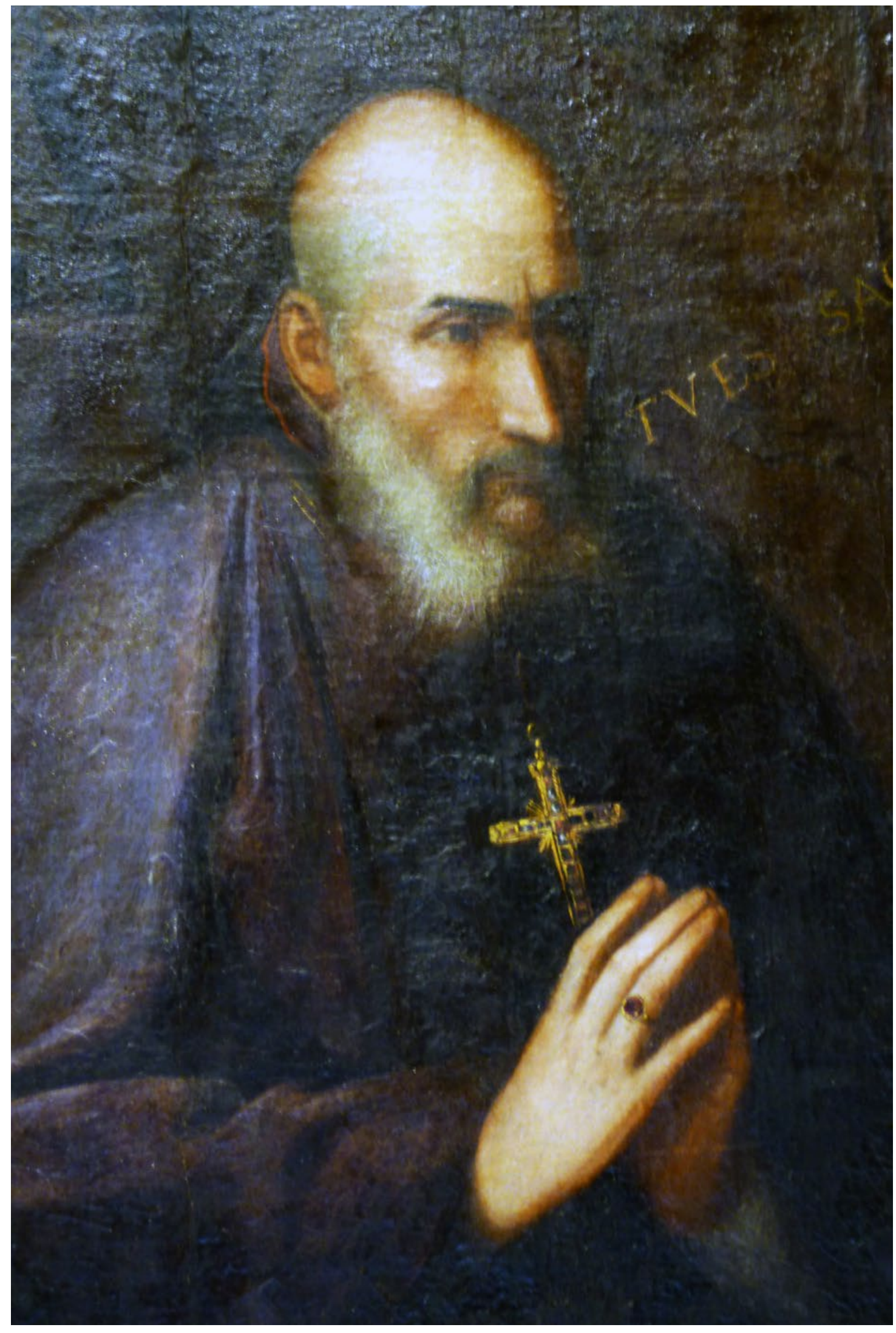

401

Fig. 4.24. Juan Sariñena, El arzobispo san Juan de Ribera adorando la Eucaristía (detalle), 1612, óleo sobre lienzo, Valencia, Real Colegio Seminario del Corpus Christi. 
fectamente visible por los feligreses. Sin embargo, para no fomentar el culto hacia el prelado y, en consecuencia, violar los edictos papales de Urbano VIII (pontificado entre 1623 - 1644) sobre la veneración a difuntos no canonizados, se optó por retirarla de su emplazamiento original. ${ }^{62}$ En 1688 se realizó una copia de este cuadro para destinarla a otra de sus fundaciones, el convento capuchino de la Sangre de Cristo, cumpliendo con el deseo de esta comunidad. Además, según Tarín y Juaneda algunos grabadores se inspiraron en ella y se reprodujo en varias estampas. ${ }^{63}$

Aunque en este ejemplo y en otros que le siguieron se deja constancia de su adoración a la Eucaristía, los primeros retratos de san Juan de Ribera respondían a efigies simples, de busto y sobre un fondo neutro donde era más relevante mostrar su fe y su labor pastoral, y no ensalzar sus méritos acumulados tras años de dedicación a la Iglesia. Se conocen dos retratos que concuerdan con esta tipología y cuyo encargo fue a petición del propio Ribera. El primero de ellos fue pintado por Luis de Morales en 1564 a raíz de convertirse en arzobispo de Badajoz. La segunda efigie es obra de Juan Sariñena en 1607, aquí aparece con un halo de santidad añadido en conmemoración de su beatificación celebrada en 1796. Ambas piezas presentan al prelado como hombre humilde y sencillo, valores propios de cualquier pastor de Cristo. Además, es notorio que estas pinturas concuerdan con las ideas promovidas por san Juan de Ribera durante el séptimo sínodo celebrado en Valencia, don62 Rincón García, 'Iconografía de...', p. 706. Es más, según quedó inventariado en 1745 en el archivo del Colegio se conservaba un documento de «Urbano Octavo acerca de la veneración de los santos no canonizados, y como se ha de proceder en la beatificación.» ACCV: «Del ramo 4ㅇ․ Auto de inventarios de los libros, papeles y alhajas del archivo del Colegio del Corpus Christi de la Ciudad de Valencia. Año 1745.» en Visita general del Real Colegio Corpus Christi y de sus administ..., fol. $4 \mathrm{v}$.

63 Francisco Tarín y Juaneda, Los retratos del beato Juan de Ribera: estudio iconográfico, (Imprenta de Francisco Vives y Mora: Valencia, 1891), p. 21. 
de se puso de manifiesto la necesidad de ver en los sacerdotes a un modelo de austeridad. ${ }^{64}$

En 1587 el Patriarca Ribera decidió fundar y construir, hasta 1615, el Real Colegio Seminario del Corpus Christi de Valencia. Este ha sido su gran legado y por ello, en el retrato del Patriarca hecho por Urbano Fos [fig. 4.25] se incluye este edificio en un segundo plano. Parece ser que el encargo fue elaborado por los propios colegiales para lucir en el salón rectoral. Según el inventario de 1891, por la obra se pagó 18 libras. ${ }^{65}$ La composición de la pieza sigue las directrices del retrato de corte, por ello san Juan de Ribera aparece de cuerpo entero, junto a una mesa de gobierno, un cortinaje en el fondo y un balcón que abre el espacio mostrando la arquitectura del seminario. Su mano izquierda sostiene un documento y la derecha reposa sobre el libro de las Constituciones de la Capilla I Colegio Corpus XPI. De esta manera, se remarca la labor que desempeñó este personaje para difundir los ideales católicos en la segunda mitad del siglo XVI, y para ello creó una institución que contaba con una dilatada recopilación de obras de arte y con una nutrida biblioteca para la formación de los colegiales. ${ }^{66}$

64 Rivera Torres, 'Imagen del prelado...', p. 137.

65 Tarín y Juaneda, Los retratos del beato..., p. 25.

66 Sobre la biblioteca se recomienda a Miguel Navarro Sorní, 'Los libros del Patriarca Ribera. Fe y cultura en el tránsito del Renacimiento al Barroco', en, El legado del patriarca Juan de Ribera: Pastor Sanctus Virtutis Cultor, IV centenario, (Pentagraf, 2011), pp. 45-53. El autor conoce el nivel y la calidad intelectual del prelado a partir del análisis de sus libros puesto que, como bien indica, una biblioteca personal también es una muestra de las inquietudes, de las intenciones y de las aspiraciones de cada uno. A grandes rasgos, esta colección bibliográfica estaba compuesta por ochenta Biblias, de forma completa, seccionada o tan sólo algunos libros de la misma. También contaba con un jugoso número de obras patrísticas en su lengua original tanto latinas como orientales. Asimismo, disponía de las hagiografías de distintos santos y de las obras escritas por ellos mismos. Junto con todo ello, poseía libros sobre derecho canónico y civil, filosofía, humanidades, historia, geografía, ciencias naturales e incluso música. 


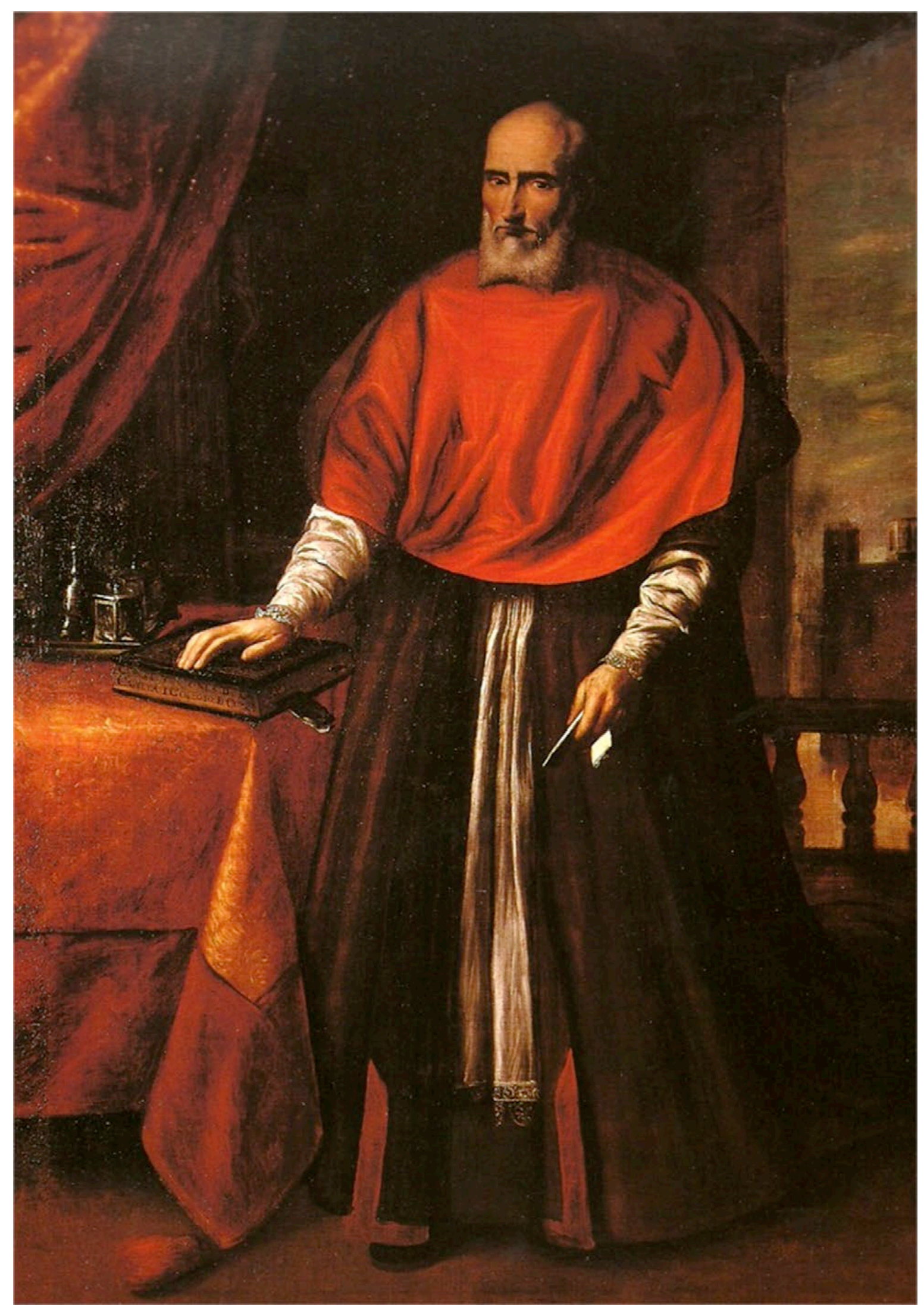

Fig. 4.25. Urbano Fos, El arzobispo San Juan de Ribera, h. 1654, óleo sobre lienzo, Valencia, Real Colegio Seminario del Corpus Christi. 


\subsubsection{Imágenes de la virtud católica. Las efigies de frailes, venerables y beatos.}

La colección de retratos que se estudian en este apartado son representaciones de la virtud según la fe católica.$^{67} \mathrm{La}$ imagen visual, escrita e incluso las reliquias de santidades o de personas que podían alcanzar tal dignidad, fueron herramientas eficaces para promover los ideales católicos en contraposición del credo protestante, el cual no reconocía la especial relación de los santos con Dios y, en consecuencia, negaba su capacidad para obrar milagros. En efecto y en este caso, lo más apreciado del seminario era la iglesia y sus sacristías por estar:

[...] tan llenas de cuerpos de santos, y reliquias de ellos, que es una de las mayores grandezas que tiene Valencia. La mayor parte de ellas estaban en poder de doña María de Cardona y Diatristán, mujer del mayordomo de la emperatriz de Alemania, doña María, hermana del rey Felipe III, la cual después de viuda se encerró con la Magestad Cesarea en el monasterio de las Descalzas Reales de Madrid. Y como tuvo rastro de ellas el dicho señor arzobispo, no perdonó trabajo ni gasto, hasta que vinieron a sus manos a veintinueve de noviembre, día de san Andrés del año mil seiscientos: y después de depositadas en el monasterio de los Capuchinos, fueron trasladadas al Colegio con solemnísima procesión. ${ }^{68}$

67 Las hagiografías sobre cada uno de los personajes dedican capítulos completos a explicar que eran personas templadas, humildes, pacientes, caritativas o prudentes, es decir, que poseían los valores del verdadero cristiano, del cristiano católico. En el caso de san Juan de Ribera, cabe destacar la aportación de Escrivá que además de incluir un relato biográfico, otorga un elevado protagonismo a las virtudes morales del prelado. Consúltese a Francisco Escrivà, Vida del ilustrísimo y excelentísimo señor don Juan de Ribera, patriarca de Antioquía y arzobispo de Valencia, (Pedro Patricio Mey: Valencia, 1612).

68 Gaspar Escolano, Decada primera de la historia de la ciudad y reino de Valencia; primera parte ...; contiene esta decada curiosas generalidades de España y la Historia de Valencia hasta el rey don Pedro hijo del rey don Jaime el Conquistador, (Pedro Patricio Mey: Valencia, 1610), p. 1071. 
Resulta especialmente significativo observar en los ejemplos siguientes que además de la elaboración de retratos de un fraile, venerable o beato concreto también se encargó la redacción de su biografía y se adquirieron sus reliquias. En consecuencia las efigies, las hagiografías y las reliquias se complementaron y de forma conjunta reflejaban la virtud católica.

Algunas de las representaciones que san Juan de Ribera coleccionó se corresponden con personajes ilustres por los que sentía una especial devoción. Eran hombres y mujeres con posibilidades de alcanzar la santidad, cuyas vidas, virtudes, imágenes y reliquias despertaban un gran interés. ${ }^{69}$ Así pues, se intuye que le gustaba rodearse de otros religiosos ejemplares que se estaban gestando como modelos de santidad, pese a que muy pocos consiguieron finalmente ser canonizados. De todos ellos, por lo general, se encargó la elaboración de retratos, la redacción de biografías y se adquirieron sus reliquias. El presente apartado se ha centrado en conocer las efigies de Ignacio de Loyola (1491 - 1556), Luis de Granada (1504 - 1588), Nicolás Factor (1520 - 1583), Luis Bertrán (1526 - 1581), Margarita de Agulló (1536 - 1600) o el Hermano Francisco del Niño Jesús (1544-1604).

Una colección de este cariz conviene valorarla más por su temática, mensaje y función desempeñada que por la relevancia artística, pues no se debe olvidar que pretende fomentar la fe católica y ser ejemplo de cómo vivir la espiritualidad. La admiración hacia las representaciones de los santos, y posiblemente de aquellos que se acercaban a la santidad, también era entendida como una forma de rendirle culto y alabar a Dios 69 De hecho se aborda esta idea en Felipe Guimerán, Breve historia de la Orden de Nuestra Señora de la Merced, de redención de cautivos cristianos y de algunos santos, y personas ilustres de ella, (Herederos de Juan Navarro: Valencia, 1591). «[...] porque es nuestro intento hacer de aquellas vidas de nuestros padres un pequeño espejo para los que en esta casa moramos, más que para ninguno de los otros lectores, para que en ellos mirándonos compongamos por sus santos ejemplos, si quiera por ser de personas de nuestra propia casa, nuestras vidas, y trabajemos por imitar sus virtudes.» fol. 4 r-v. Cabe añadir que el Patriarca poseía este libro en su biblioteca. 
según el catolicismo. ${ }^{70}$ Es más, su utilización ha sido apropiada porque tenían la capacidad de alimentar la fe y el amor de los creyentes en Jesucristo. ${ }^{71}$

La búsqueda realizada en el archivo del Real Colegio del Seminario del Corpus Christi de Valencia, por el momento, no revela datos que justifiquen el encargo y pago de efigies. ${ }^{72}$ Quizás esto se deba a las circunstancias propias de este género. En reiteradas ocasiones, su encargo se establecía mediante un acuerdo verbal con el pintor a consecuencia de la amistad o de la cercanía que se tenía con él. Por esa razón, hallar cartas de pago sobre este tipo de obras es una tarea complicada. Sin embargo, se han podido localizar algunas referencias principalmente en inventarios, mandatos de visitas y en el Libro de noticias y curiosidades del Real Colegio del Corpus Christi de José Ventura. ${ }^{73}$ Éste último libro, aunque es del siglo XIX, ha debido basarse en un inventario de 1611 (año en que falleció Ribera) y ha situado las imágenes de estos religiosos entre sus 70 «Y así con esto no sólo nos encomienda Dios la reverencia de estas imágenes, como de cosas que son retrato suyo y de sus santos, y que en ellas y por ellas es glorificado: pero muéstranos allende de esto la santidad de los que las hicieron, y la inspiración y autoridad de Dios, con que las propusieron a los pueblos para que por ellas le adorasen.» Jaime Prades, Historia de la adoración y uso de las santas imágenes, y de la imagen de la fuente de la Salud, (Felipe Mey: Valencia, 1597), Libro II, cap. II, pp. 96-97.

71 "[...] Y es el grande aprovechamiento y fruto espiritual que sacamos de las imágenes. Porque según Iesu Christo nos enseñó, el fruto que da cada cosa, es prueba eficaz por la cual se manifiesta su ser y naturaleza, y venimos nosotros en conocimiento de ella. Y el fruto que nos viene de ellas, es de tan subido quilate, que ha acaecido y acaece los muy solicitos de su salvación, divertirse tanto en la contemplación de las santas imágenes, que vienen a encenderse en vivo amor de Iesu Christo, y de sus santos, hasta llegar a exceso notable.» Prades, Historia de la adoración y uso de las santas imágenes..., Libro II, cap. VIII, pp. 121-122.

72 A día de hoy tan sólo se ha estado revisando la sección de gastos generales, donde se encuentran los pagos de todo tipo, así como los inventarios de la sacristía y los mandatos de visita. Por ahora, apenas se han localizado referencias hacia las obras artísticas en los inventarios de la sacristía y en los mandatos de visita.

73 ACCV: José Ventura, Libro de noticias y curiosidades del Real Colegio 
dependencias privadas. Por ejemplo, dice que había un cuadro de fray Luis de Granada en el aposento donde dormía el señor Patriarca, de la casa de la calle de Alboraya, extramuros de Valencia. En otro aposento de su palacio de Valencia tenía un cuadro de Luis Bertrán, de Nicolás Factor y fray Luis de Granada. Y, por último, había un cuadro del Padre Ignacio (es decir, san Ignacio de Loyola) en el Colegio, concretamente en el cuarto del sacristán.

En cuanto a los inventarios, no siempre han recogido este tipo de información. Se ha comprobado que el fechado el 27 de octubre de 1605, unos años antes del fallecimiento de san Juan de Ribera, no ha dejado constancia de la existencia de retratos u otras pinturas en la sacristía. De hecho entre sus secciones exclusivamente se incluyeron «los relicarios, la plata, el servicio de bronce, las capas, las casullas para misas rezadas y para semana santa, los frontales del altar mayor, de las capillas y frontales sueltos, los palios, para el monumento, los corporales con sus bolsas, palios, cajas y cofres respectivamente, misales y cubiertas y ropa blanca. ${ }^{74}$ No obstante, cabe esperar hasta el año 1695 (ochenta y cuatro años después de la muerte del Patriarca) para conocer la ubicación de retratos en las distintas dependencias cercanas o incluidas en la sacristía. De hecho, se especificó literalmente que «en el pasito que se entra de la Iglesia a la Sacrestia hay lo siguiente: Itt. Un quadro del Beato Inatio de Loiola (sic) $" .^{75} \mathrm{La}$ imagen de este beato lucía junto con las representaciones de san Simón el Estilita, san Jerónimo o santa Catalina Mártir, entre otros. En la sacristía primera, a la cual asiste el sacristán, había «un quadro del Hermano Francisco con marco de oro, un quadro de San Luis Bertrán, mas un quadro de la efigie entera de Sor Agullona

Corpus Christi y su Ilustre fundador don Juan de Ribera, Patriarca de Antioquía, Arzobispo, Virrey, Capitán General y Canciller de la Universidad de Valencia, s. XIX, s/f.

74 ACCV: Inventario de la Sagristía. Año 1605.

75 ACCV: Inventario de la Sagristía. Año 1695. Fol. 1r. 
(sic) ${ }^{76}{ }^{76}$ Seguidamente, se añadió el listado de los lienzos que se disponían en el aposento donde estaban los misales. Concretamente se inventarió «un quadro del Patriarca mi Señor esta en el aposento del sacristan, mas un lienzo del Beato Luis Bertran, mas un lienzo del Verdadero rostros de fray Luis de Granada, mas un lienzo del P. Nicolas Factor (sic)».77

Las imágenes de estos personajes de círculo de san Juan de Ribera se ubicaban junto con la verdadera efigie de san Vicente Ferrer además de las representaciones de san Francisco, santa Catalina de Sena, san Jacinto, san Vicente Mártir, san Jerónimo, santa Clara o del pontífice Sixto V. Finalmente, se ha encontrado otra referencia a un lienzo de sor Margarita Agulló en la sala de los corporales. ${ }^{78} \mathrm{El}$ conjunto de anotaciones han aparecido nuevamente en un inventario datado en 1711 que probablemente se realizó en base al de $1695 .{ }^{79}$ También se ha dejado constancia de las mismas en otro inventario posterior y una visita general, ambos documentos realizados en $1745 .{ }^{80}$ Por tanto, la ubicación de las imágenes, principalmente, se dio en espacios privados; o bien en dependencias particulares en alguna de las distintas propiedades o en la sacristía de la iglesia del Colegio. En un caso u otro, es perceptible que estos personajes fueron el modelo espiritual para san Juan de Ribera y para los colegiales que se formaron en el seminario fundado por él mismo.

76 ACCV: Inventario de la Sagristía. Año 1695. Fol. 7r.

77 ACCV: Inventario de la Sagristía. Año 1695. Fol. 8r.

78 ACCV: Inventario de la Sagristía. Año 1695. Fol. 26r. El corporal era el lienzo que se extendía en el altar, encima del ara, para poner sobre él la hostia y el cáliz.

79 ACCV: Inventario de la Sagristía. Año 1711.

80 ACCV: Inventario de la Sagristía. Año 1745 y ACCV: Visita general del Real Colegio Corpus Christi..., s/f. 
San Juan de Ribera encargó la mayor parte de estas piezas al artista Juan Sariñena (1545-1619) movido por el afecto que sentía hacia todos ellos. ${ }^{81}$ Por ejemplo, una de las primeras obras se corresponde con el retrato de san Ignacio de Loyola [fig. 4.26]. El fundador de los jesuitas falleció en 1556 y desde la Compañía de Jesús se le facilitó a Sariñena una imagen de san Ignacio que sirvió de modelo para la realización de esta pintura. Aunque su beatificación no se produjo hasta 1609 y su canonización hasta 1622, en la imagen aparece con una aureola para remarcar su santidad. ${ }^{82}$ Igualmente se aprecia el monograma IHS (Ihesus Hominum Salvator) relativo a la función redentora de Cristo. Sobre este personaje, san Juan no sólo poseía su retrato sino que también en su biblioteca personal contaba con un ejemplar de la Vida del P. Ignacio de Loyola fundador de la Religión de la Compañía de Iesus, publicada en 1583, escrita por Pedro Ribadeneyra (1526-1611). ${ }^{83}$ Se trata de una de las biografías más tempranas. Se compone de cinco libros, donde los cuatro primeros son de carácter estrictamente biográfico y el último pretende dejar constancia de los valores que se le atribuyeron. Por ese motivo, el autor elogió su don para la oración, su obediencia, su capacidad para vencer a las pasiones, su modestia, su perfecto equilibrio entre la blandura y la severidad, su compasión y misericordia y de los mila-

81 Se recomienda consultar a Fernando Benito Doménech, Juan Sariñena (1545-1619) : pintor de la Contrarreforma a Valencia : Museo de Bellas Artes de Valencia, del 19 de diciembre de 2007 al 23 de marzo de 2008, (Generalitat Valenciana, Consellería de Cultura i Esport, 2007).

82 Este elemento ha sido tomado del arte pagano que lo ha empleado para honrar a los emperadores, ilustres personalidades y deidades. Consúltese a Juan Ferrando Roig, Iconografía de los santos, (Omega: Barcelona, 1950). En cuanto a la estima que el patriarca tenía por san Ignacio de Loyola véase a Juan Ximenez, Vida y Virtudes del Ylmo. y Exmo. Señor D. Juan de Ribera, Patriarca de Antioquía..., (Ymprenta de Roque Bernabò: Roma, 1734), Libro III, cap. VII, p. 160.

83 Así lo certifica el inventario de libros del uso del patriarca (no1102). Además, tenía un volumen del Flos Sanctorum también de Ribadeneyra. Véase en el ACCV: Ventura, Libro de noticias y curiosidades del Real Colegio Corpus Christi..., s/f. 
gros que el Señor obró mediante su persona.

Otro ejemplo similar se da con el caso de fray Luis de Granada [fig. 4.27]. Lo más probable es que el artista elaborase la obra empleando unas pautas previas o basándose en algún otro modelo puesto que no hay noticias de que el religioso pisase tierras valencianas antes de su muerte en $1588 .{ }^{84}$ En efecto, el Patriarca remitió diversas misivas al convento de santo Domingo de Lisboa donde se hallaban los restos del fraile para conseguir sus cenizas. ${ }^{85}$ Incluso mandó «hacer las exequias a expensas de su gran fineza, y predicarle las honras a los 18 de abril del año 1589, en que se celebraron en el Real Convento de Predicadores de Valencia, en prueba del amor grande que le había profesado en vida [...]»" Además, también coleccionó otros vestigios suyos en un «arca de cosa de dos palmos y medio dada de charol antiguo, con sus pies, ansa y diferentes tachas todas de plata y dentro de ella, diferentes reliquias de P. F. Domingo Anadón, V.P.F. Luis de Granada, V.P.F. Nicolás Factor y otros venerables. ${ }^{87}$ »

Pese a no contar, por el momento, con la efigie de Nicolás Factor que se encontraba en el Colegio tal y como indican los

84 Benito Doménech, Juan Sariñena (1545-1619)..., p. 94.

85 Busquets Matoses explica con todo detalle: «Qué diligencia no hizo (referido a San Juan de Ribera), enternecido su afecto devoto, para alcanzar las cenizas del venerable padre fray Luis de Granada, escribió repetidas cartas al padre Francisco de Oliveyra, que se hallaba en Lisboa, en el convento de santo Domingo, de aquella ciudad, donde están sus huesos honoríficamente custodiados, como lo depone en el proceso, en el cual presentó la carta original del siervo de Dios, que le envió con inclusa para el Eminentísimo Cardenal Xavier, General entonces de la Ilustre familia de Santo Domingo; ofreciendo a los religiosos de aquel convento, crecidas limosnas." Jacinto Busquets Matoses, Idea exemplar de prelados, delineada en la vida, y virtudes del venerable varón el Ilustrísimo y Excelentísimo Señor D. Juan de Ribera, (Valencia, 1683), Libro IV, cap. 3, p. 212.

86 Ximenez, Vida y Virtudes..., Lib. III, cap. VII, p. 195.

87 ACCV: Inventario de la Sagristía. Año 1745, Fol. 12v. 


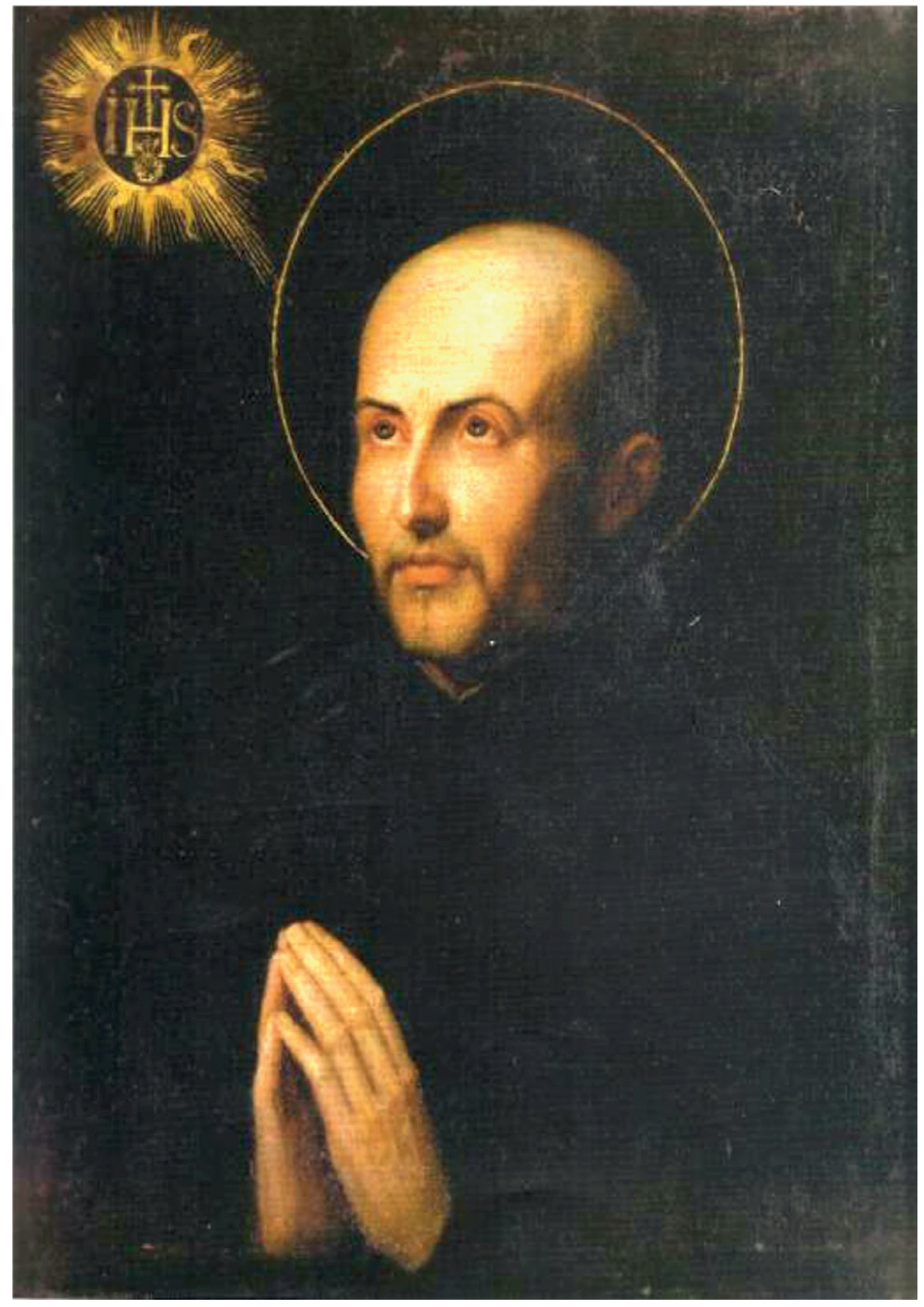

Fig. 4.26. Juan Sariñena, San Ignacio de Loyola, 1606, óleo sobre lienzo, Valencia, Real Colegio Seminario del Corpus Christi. 


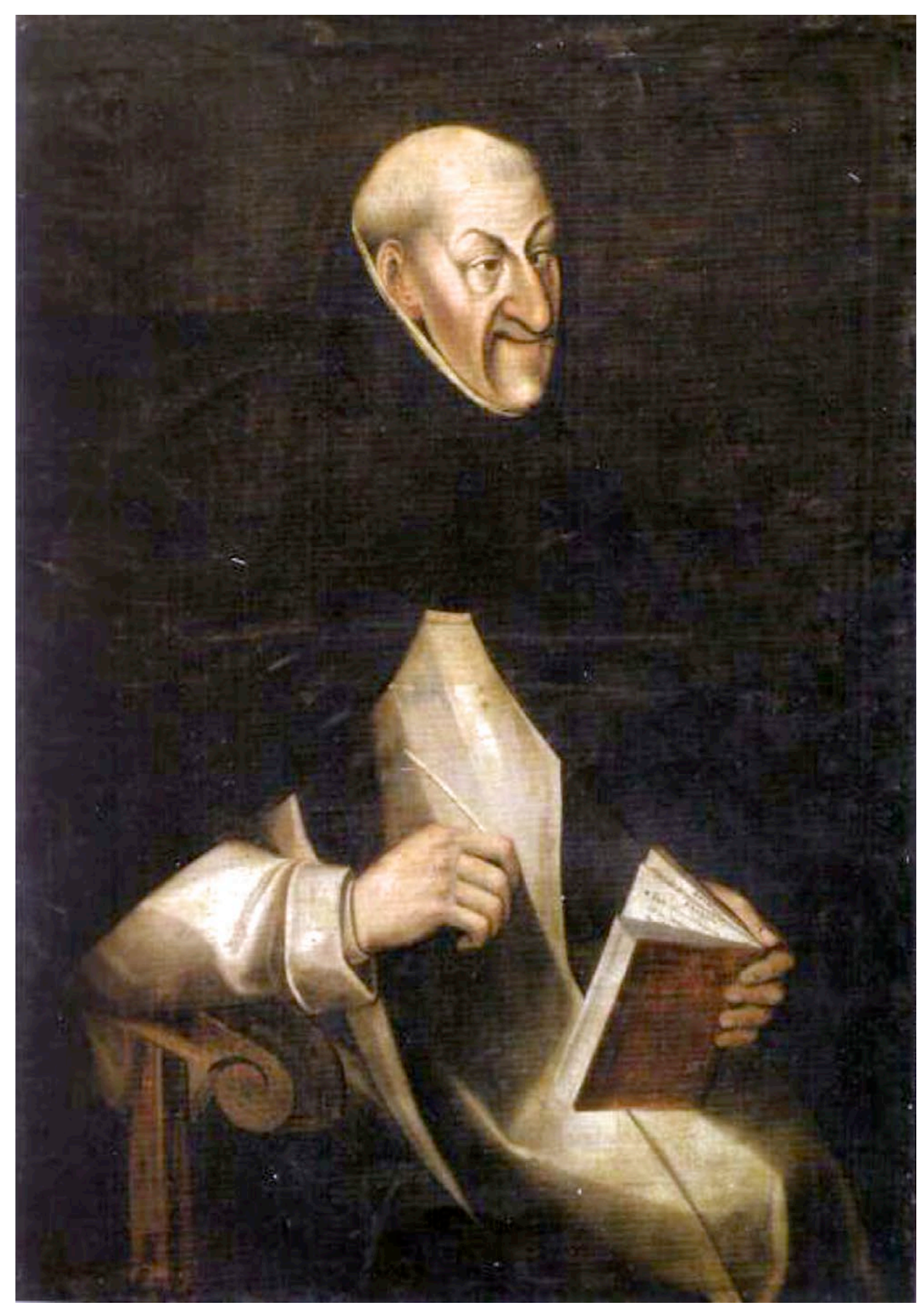

Fig. 4.27. Juan Sariñena, Fray Luís de Granada, 1585, óleo sobre lienzo, Valencia, Real Colegio Seminario del Corpus Christi. 
inventarios, se encuentra la opción de conocer obras que seguramente serían similares. De hecho, Sariñena pintó un retrato para el monasterio de las Descalzas Reales de Madrid y, al mismo tiempo, contribuyó a que la imagen se codificase y se representase de forma idéntica en distintas ocasiones a lo largo de los años [fig. 4.28]. Su tipo iconográfico fue ampliamente extendido y así lo constatan las estampas que se imprimieron con la efigie de Factor. Sirvan de ejemplo, el dibujo de José Camarón Bonanat y el grabado de Joaquín Ballester a caballo entre los siglos XVIII y XIX que conserva la Biblioteca Nacional de España [fig. 4.29]. También es ilustrativa la copia de Vicente Capilla, localizada en la Biblioteca Valenciana, que se empleó para ilustrar la Vida del B. Nicolás Factor hijo de la providencia de menores observantes de N.P.S. Francisco de Valencia escrita por fray Joaquín Company y publicada en 1787 [fig. 4.30].

Cuando Sariñena llevó a cabo el encargo para el monasterio 414 madrileño quizá conocía al franciscano pero en ése momento ya se le había retratado por deseo del arzobispo de Tarragona y cuando murió se le hizo una mascarilla funeraria que se conservaba en el convento de Santo Espíritu de Gilet. ${ }^{88}$ En cualquier caso, es la tipología más común para representar a los venerables de la época. El beato vestido con el hábito franciscano se dirige, en actitud contemplativa, hacia el cielo. Sus brazos y manos, en consonancia con el momento, se abren hacia Dios. La obra ha quedado completada al incluir una serie de inscripciones. ${ }^{89}$

Como se podrá apreciar, el modelo de retrato planteado por Sariñena fue adoptado por Juan Ribalta y su taller para incluir a Nicolás Factor en la serie de varones ilustres valencianos

88 Andrés Ivars, 'El beato Nicolás Factor en las Descalzas Reales de Madrid', Archivo de arte valenciano, no. 12, 1926, pp. 67-81; Benito Doménech, Juan Sariñena (1545-1619)..., p. 37.

89 Las inscripciones aparecen editadas en el catálogo de Fernando Benito acerca de Sariñena ya referido. 


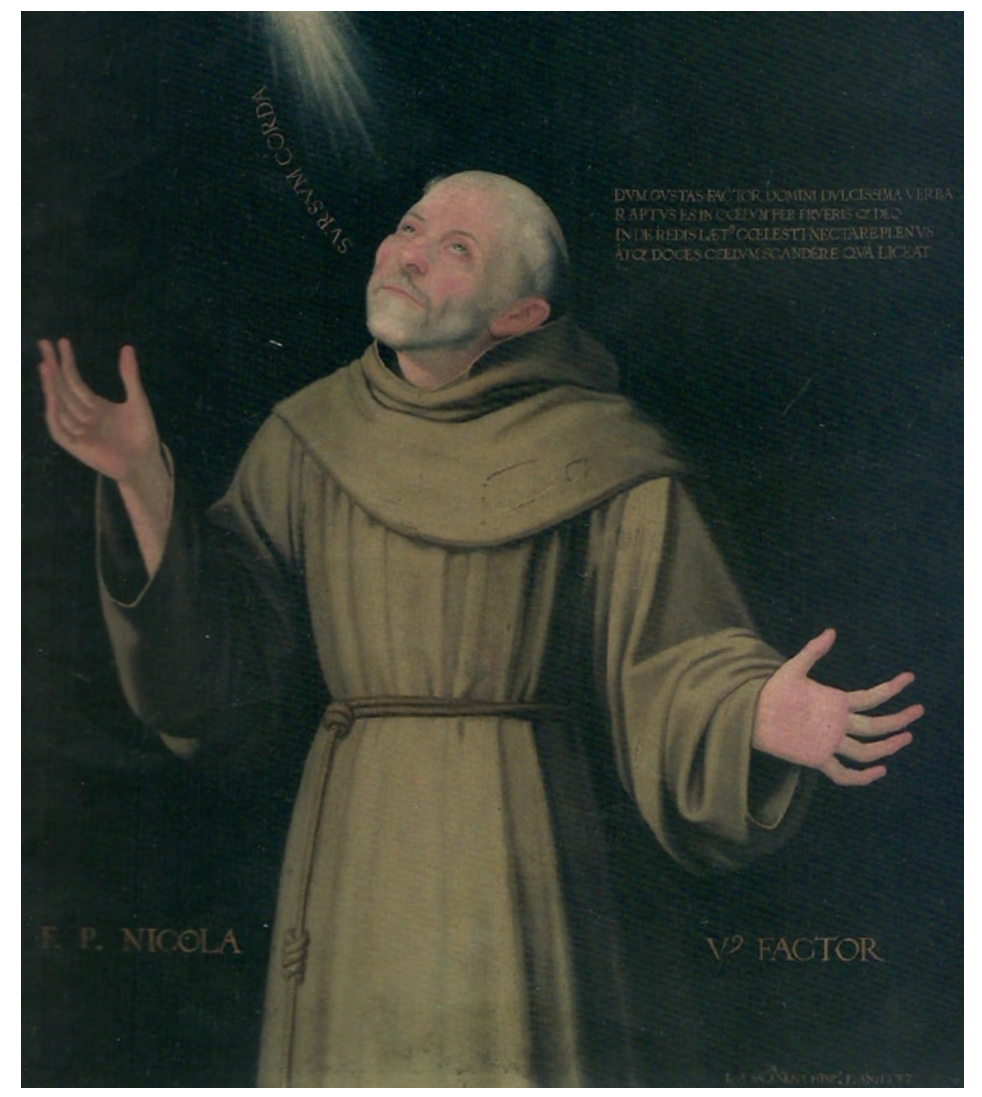

Fig. 4.28. Juan Sariñena, Beato Nicolás Factor, 1587, óleo sobre lienzo, Madrid, Real Monasterio de las Descalzas Reales.

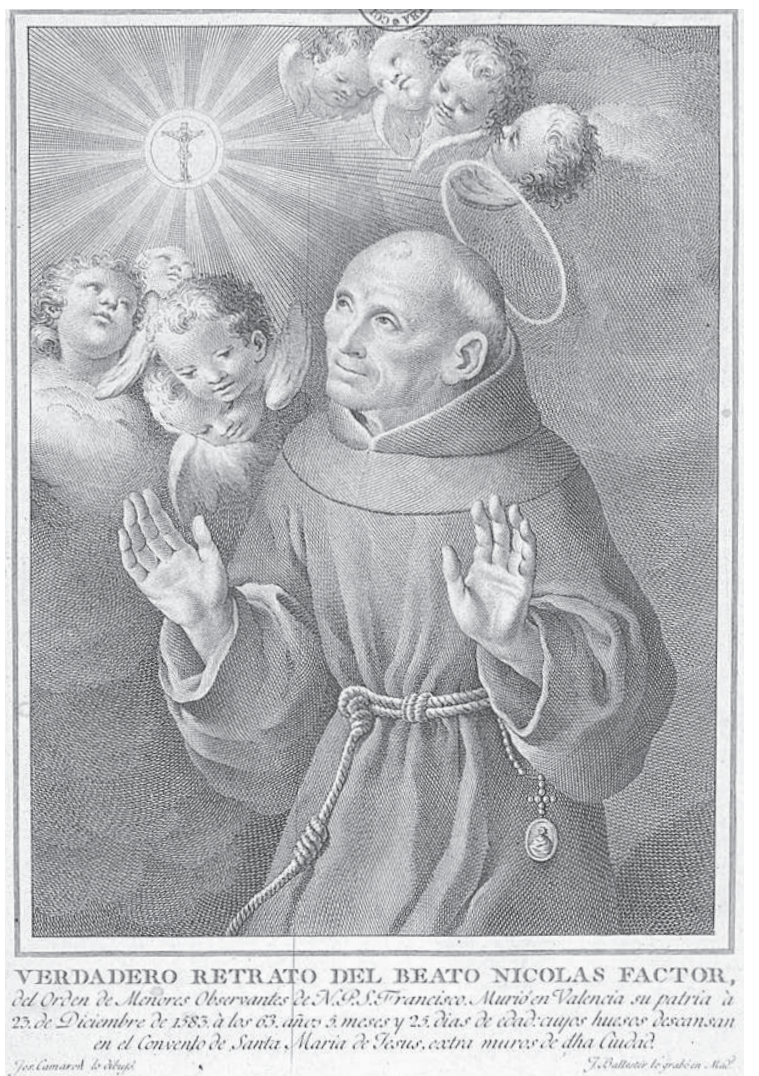

Fig. 4.29. José Camarón Bonanat y Joaquín Ballester, Verdadero retrato del beato Nicolás Factor, s. XVIII-XIX, Madrid, Biblioteca Nacional de España.

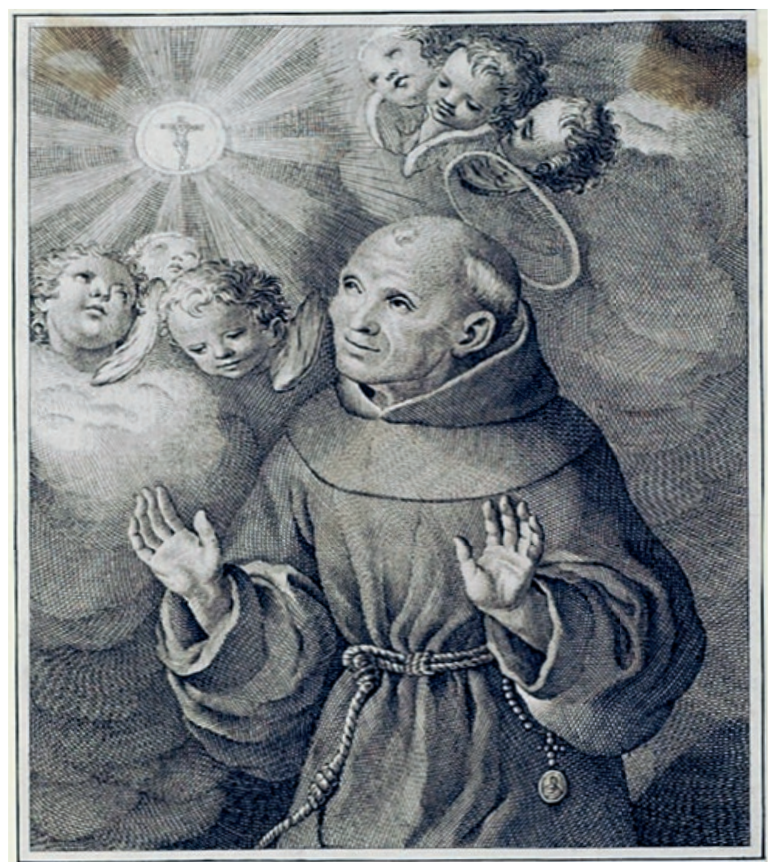

VERD. RETRATO DEL B. NICOLAS FACTOR, del Orden de Menores Observantes de N.P. S. Francisco. Muriò en Valencia su patria $a_{2} 3$ de Diciembre de $1_{5} 8_{3}$, $\dot{a}$ los $\sigma_{3}$ años 5 me ses y 25 dias de edad: cuyos buesos descansan en el Convento de sia Maria de Jesus, extra muros de dicha Ciud'ad. rapiand zo f......

Fig. 4.30. Vicente Capilla Gil, Verdadero retrato del beato Nicolás Factor, s. XVIII, Valencia, Biblioteca Valenciana. 
procedente del monasterio jerónimo de Nuestra Señora de La Murta que se ha estudiado en el capítulo dedicado a los retratos de hombres célebres (véase la fig. 5.4). Una vez más se le presenta en un momento de éxtasis. La estima hacia el franciscano estaba clara y ello justificaba la conservación de sus reliquias y efigies. Así Factor era mostrado como un hombre modélico y digno de admiración, ejemplaridad manifiesta no sólo a través del retrato sino también mediante las hagiografías, cuyo principal cometido era impulsar los procesos de beatificación y canonización. En este sentido, es necesario remitir al Libro de la Vida y Obras Maravillosas del Padre Fray Pedro Nicolás Factor, de la Orden de nuestro Padre S. Francisco de la Regular Observancia de la Provincia de Valencia escrito por Cristóbal Moreno y, nuevamente recogido por José Ximeno, publicado en 1618. La obra se definió como una herramienta muy productiva en el crecimiento espiritual de los feligreses y además era «un medio para inflamar los corazones de los fieles en el amor divino, y despertarles la devoción por imitar al sobredicho siervo de Dios». ${ }^{90}$ Una vez más, la hagiografía hizo un especial hincapié en mostrar las virtudes del religioso, por ello se destinaron capítulos completos a proclamar su humildad, caridad con los pobres, obediencia, abstinencia y amor a Dios y a la Iglesia. El retrato y la obra escrita, en definitiva, compartieron el cometido de crear una imagen que alentase la fe del pueblo.

Una de las personalidades claves de este pequeño conjunto, debido a la complicidad con san Juan de Ribera, fue fray Luis Bertrán, beatificado en 1608 y canonizado en 1671. El origen de su iconografía se ha encontrado en la imagen de su vera efigie, es decir, en un dibujo bosquejado poco antes - o después - de su fallecimiento en $1581 .{ }^{91} \mathrm{De}$ hecho, la hagiografía escrita por el

90 Cristóbal Moreno y José Ximeno, Libro de la vida y obras maravillosas del siervo de Dios el bienaventurado Padre Fray Pedro Nicolás Factor, de la Orden de nuestro Padre S. Francisco de la Regular Observancia de la Provincia de Valencia, (Sebastián de Cormellas: Barcelona, 1618), p. 2.

91 Fernando Benito Doménech (ed.), Los Ribalta y la pintura valencia- 
padre Justiniano Antist certificó que el santo fue retratado, en este caso, tras expirar. ${ }^{92}$ Aunque el relato no identificaba al artista que esbozó el retrato del difunto, quizá fue Juan Sariñena quien tomó las anotaciones del natural y creó el modelo representativo que se utilizó posteriormente. ${ }^{93}$ Efectivamente, a día de hoy en Zaragoza se conserva un óleo sobre tabla atribuido a Sariñena de la verdadera imagen de san Luis Bertrán [fig. 4.31]. La pintura data de 1581-1582 y es posible que se trate de la vera efigie. La obra adopta el tipo de representación que se empleará en la iconografía del dominico. Aparece de medio cuerpo, vestido con el hábito de la orden de los Predicadores, con su mano derecha extendida sobre el pecho y la izquierda que sostiene un crucifijo ligeramente orientado hacia el espectador. Los rasgos faciales son cadavéricos, lo cual concuerda con el rótulo situado en la parte superior derecha para indicar que estamos ante su verdadera imagen. De su boca nace otra inscripción con un fragmento de la famosa cita que solía decir: «Domine hic non parcas ut in aeternum parcas». Es una plegaria dirigida a Dios para pedirle el perdón no en la tierra sino en el cielo. El retrato de Luis Bertrán hecho por Sariñena para san Juan de Ribera se corresponde iconográficamente con el conservado en el museo zaragozano [fig. 4.32].

La excelente amistad cultivada entre san Juan de Ribera y fray Luis Bertrán conllevó a que el Patriarca no sólo desease tener la imagen del dominico sino también variadas reliquias y auténticas, es decir, los documentos acreditativos sobre la vera-

na de su tiempo: exposición Lonja de Valencia, octubre - noviembre 1987: Museo del Prado, Palacio de Villahermosa, diciembre 1987 - enero 1988, (Diputación Provincial de Valencia: Valencia, 1987), p. 100.

92 «Duronos este trabajo hasta las nueve de la noche, desseando nosotros que saliesse la gente para que un pintor lo pudiese sacar al natural, para que si quiera esta prenda y memoria nos quedasse dela figura de aquel cuyas virtudes, y exemplos nunca podremos olvidar. (sic)» Vicente Justiniano Antist, Verdadera relación de la vida y muerte del Padre Fray Luis Bertran, de bienaventurada memoria, (Juan Alterach: Zaragoza, 1583). Cap. XIX 'De la honra que nuestro Señor le hizo en su enterramiento', p. 230.

93 Benito Doménech, Los Ribalta y la pintura..., p. 93. 


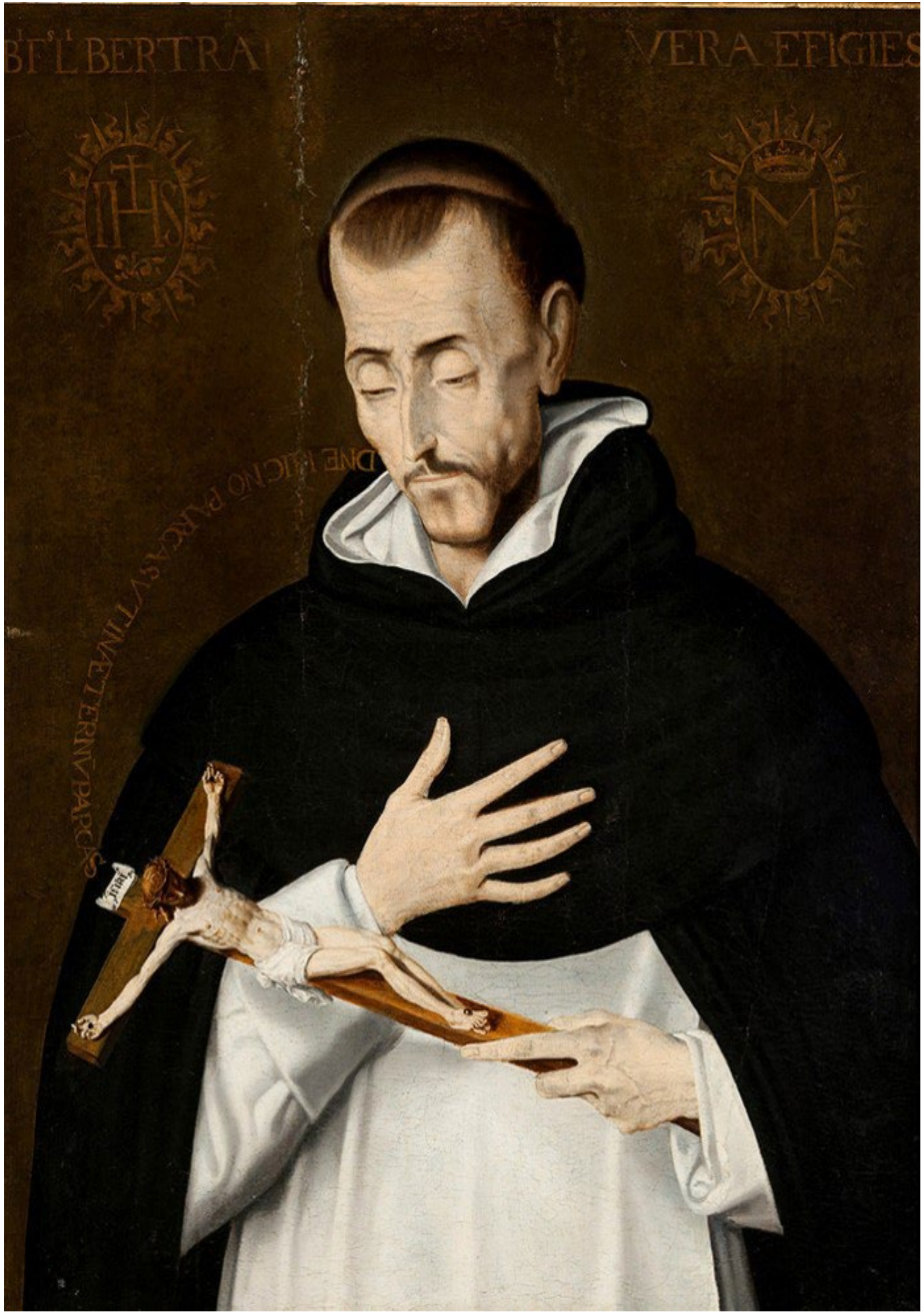

Fig. 4.31. Juan Sariñena, Vera efigie del venerable Luís Bertrán, 1581 - 1582, óleo sobre tabla, Zaragoza, Museo Camón Aznar. 


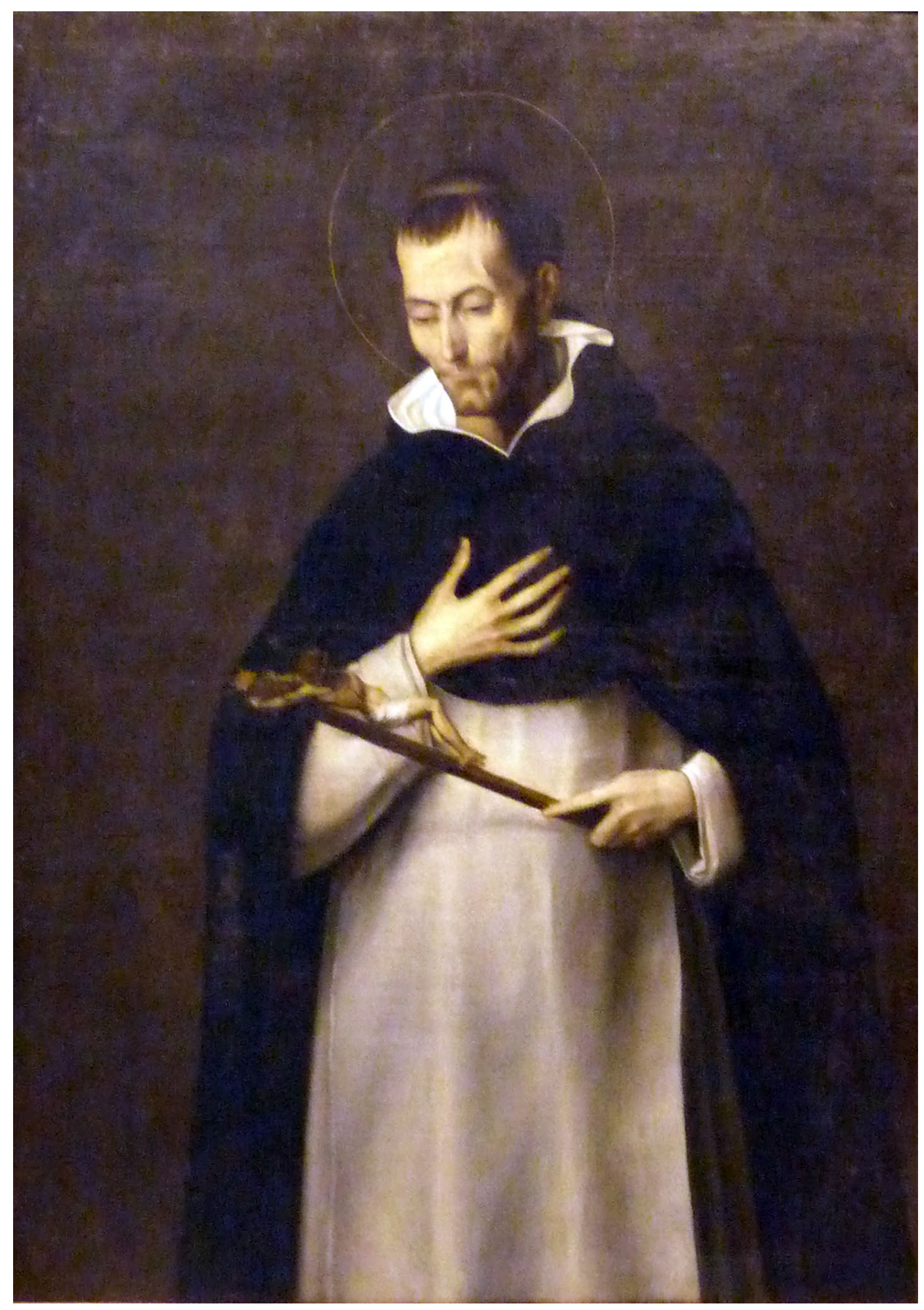

Fig. 4.32. Juan Sariñena, Fray Luís Bertrán, 1584, óleo sobre lienzo, Valencia, Real Colegio Seminario Corpus Christi. 
cidad de las reliquias. En concreto, había un báculo hecho con caña de las Indias, el indulto para poder rezarle expedido por Pablo V en Roma el 21 de marzo de 1609, un papel con la «auténtica» de ser polvo y sangre del dominico, un pedazo de su capa y otro fragmento de su correa. ${ }^{94} \mathrm{De}$ tan sólida relación se han hecho eco los hagiógrafos, quienes han remarcado las dilatadas conversaciones y reflexiones espirituales que tenían, de modo que el arzobispo valenciano procuró cuidadas atenciones durante la enfermedad de Bertrán.

A este veneró con tan amables respetos que en santa emulación se porfiaban los agasajos y cariño, visitándose muy de ordinario con íntima estrechez, y amistad. Cuantas visitas le hacía en su celda le retornaba el santo a palacio, siendo unas, y otras muy largas, y a puerta cerra$\mathrm{da}$, sus conversaciones era platicar del Cielo, agradables visitas para Dios estas; encendianse (sic) sus fervorosos espíritus en ardientes contemplaciones, en estos coloquios celestiales emplearon muchas horas, seguíanse (sic) a esta santa estrechez, y amistad regalar en el tiempo que estaba enfermo. [...] Le volvió a repetir la enfermedad, se le agravó cada día; continuó en su asistencia todos los días el venerable prelado, y uno entre otros, le dijo el santo: como dejan entrar acá mujeres, y admirado de ello el siervo de Dios el venerable patriarca averiguó el día siguiente, fue la extática Virgen Sor Margarita Agullona que deseando ver el santo fue llevada en espíritu a su celda, y le besó los pies antes que muriese. [... $]^{95}$

Las muestras de estima se materializaron incluso después del fallecimiento de su amigo, por ello predicó sus honras en el ritual fúnebre y llevó hasta el final de sus días, como recuerdo,

94 ACCV: Inventario de la Sagristía. Año 1711, Fol. 18v y ACCV: Visita general del Real Colegio Corpus Christi..., Fol. 29v-30r-30v. La correa también está referenciada por Busquets Matoses, concretamente en el Libro IV, cap. 3, p. 214.

95 Busquets Matoses, Idea exemplar de prelados..., Libro IV, cap. 3, pp. 335-338. 
el cinto de fray Luis Bertrán. ${ }^{96}$ Es más, Ribera instauró en 1608 (año de la beatificación de Bertrán) una fiesta en honor del dominico tanto en el Colegio como en el convento de la orden de los Predicadores e incluso, se ofreció a sufragar los gastos económicos que se pudiesen derivar de su canonización así como contener sus cenizas. Jiménez y Busquets Matoses lo relataron de la siguiente manera:

En la Real Capilla de su Colegio y en el Convento de Predicadores de la misma Ciudad fundó asimismo, es a saber, en este la fiesta de San Luis Bertrán, y en aquella las muchas de su particular devoción, en los Capítulos LXIII y LXX de su Loables Constituciones se refieren, dejando para solemnizar esta porción doble a sus Capellanes, y cuarenta escudos para celebrar aquella a los Padres Dominicos, de más de mandar al muy Ilustre rector de su Real Colegio, que en nombre suyo asista aquel día a todos los actos de Coro, Iglesia y Refectorio, para así en consuelo suyo poder dar a lo menos algún testimonio del amor grande, que viviendo había tenido siempre a su cordial amigo San Luis Bertrán. [... ${ }^{97}$

El mismo cuidado tuvo en solicitar luego que murió el santo Luis Bertrán, su glorioso cuerpo ofreciéndose a satisfacer los gastos que se hiciesen en su canonización, queriendo ilustrar su santa metropolitana iglesia, con las cenizas de su íntimo y querido amigo. ${ }^{98}$

El día de la fiesta conmemorativa, según dispuso el Patriarca en las Constituciones que redactó para el colegio, la pertinente reliquia debía ubicarse en:

96 Ximenez, Vida y Virtudes...,Lib. III, cap. VII, p. 152.

97 Ximenez, Vida y Virtudes..., Lib. III, cap. VII, pp. 150-151.

98 Busquets Matoses, Idea exemplar de prelados..., Libro IV, cap. 3, p. 212. Otra fuente fundamental se encuentra en el relato de Antist quien reconstruye los últimos instantes de vida de san Luis Bertrán. Antist, Verdadera relación de la vida..., cap. XVIII, 'De la muerte del siervo de Dios', p. 216. 
[...] el Tabernáculo de la Capilla de su invocación; y no habiéndola, en el tabernáculo del Ángel Custodio, mientras duraren los Divinos Oficios, desde las primeras Vísperas, hasta acabadas las segundas: y que esto haga el Sacristán acompañado de dos Capellanes, en esta forma. Que cuando se hubieren de comenzar las primeras Vísperas, se saque del Relicario la tal reliquia, y se ponga en el dicho Tabernáculo, el cual se cierre con llave acabada la Salve, y se volverá a abrir el día siguiente antes de comenzarse el Miserere, y antes de comenzar las segundas Vísperas, hasta acabada la Salve, que el Sacristán la volverá a encerrar en el Relicario. ${ }^{99}$

Además de escritores, los artistas recogieron visualmente la entrañable relación de estos personajes. Valga de ejemplo la representación de la muerte de San Luis Bertrán (h. 1653, óleo sobre lienzo, Museo de Bellas Artes de Valencia), obra de Jerónimo Jacinto Espinosa donde el dominico, ya difunto, está rodeado de sus allegados, alguno de ellos ya mencionados por Antist como Francisco Luis Blanes o san Juan de Ribera. ${ }^{100} \mathrm{O}$ incluso la estampa impresa a partir del grabado de Julián Mas, en el siglo XIX, donde la escena muestra principalmente los desvelos y cuidados que el prelado le procuró al santo valenciano [fig. 4.33].

Sor Margarita Agulló, otra venerable enormemente estimada en la época, falleció el 9 de diciembre de 1600 y, según el testimonio de Mosén Porcar, ${ }^{101}$ Sariñena la retrató sin vida. Di99 Constituciones, Cap. 46. 8. 'De las Reliquias'.

100 Vicente Justiniano Antist escribió, tan sólo un año después del fallecimiento de Bertrán, una biografía esencial para la construcción iconográfica de este personaje, pues las vivencias narradas (especialmente aquellas enmarcadas en las Indias) explican la riqueza de atributos característicos de este santo, como el crucifijo, la pistola o la copa con una serpiente o dragón en su interior. Vicente Justiniano Antist, Verdadera relación de la vida y muerte del padre Fray Luis Bertrán, de bienaventurada ceremonia, (Casa de la viuda Huete: Valencia, 1582).

101 Daniel Benito obtuvo esta información en Castañeda y Alcover, Coses 


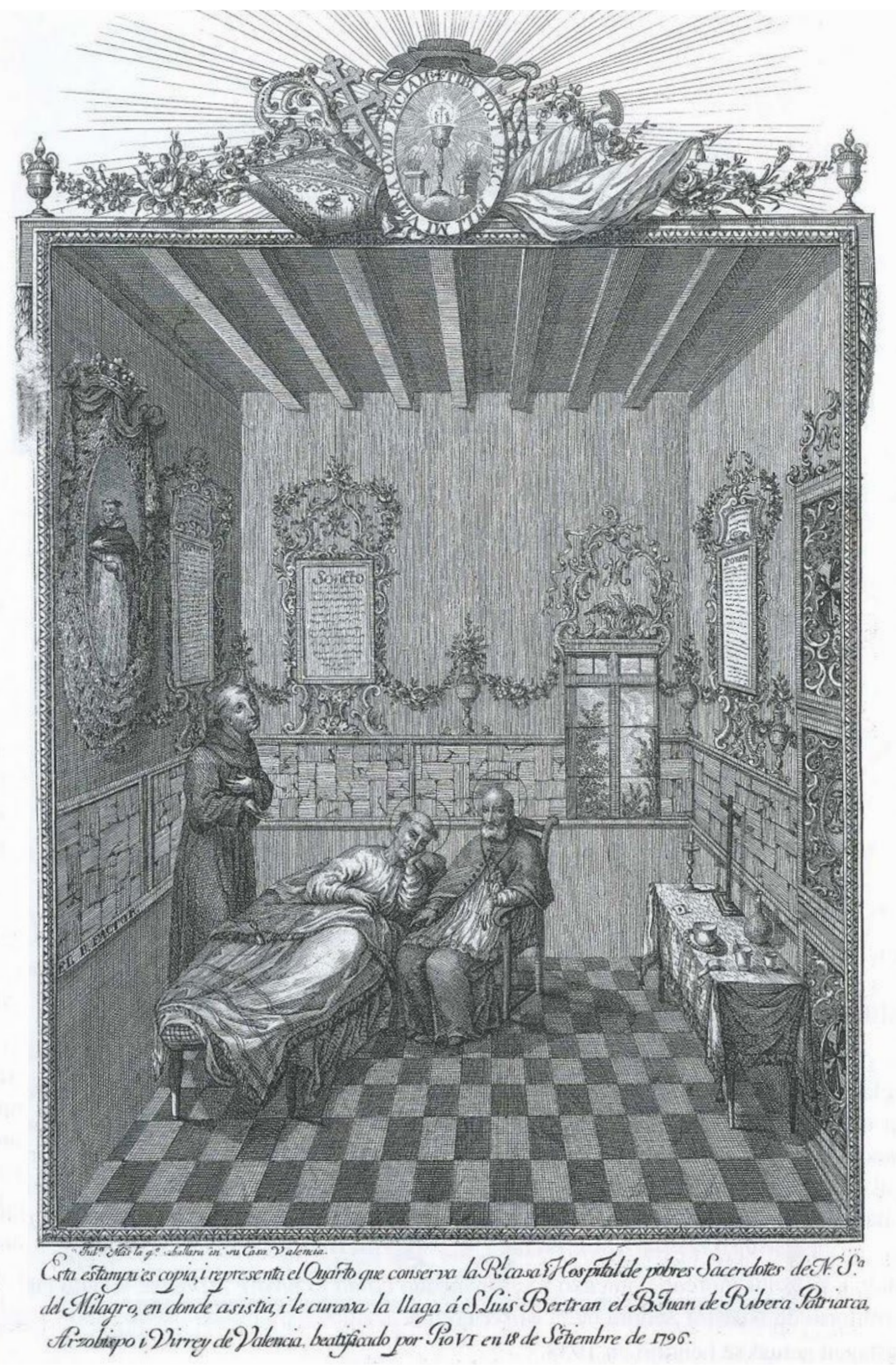

423

Fig. 4.33. Julián Mas, San Luis Bertrán asistido por San Juan de Ribera en el hospital de pobres sacerdotes de Nuestra Señora del Milagro, estampa, siglo XIX, Valencia, Biblioteca Valenciana. 
cho esbozo no se conserva en la actualidad, pero sí hay otra imagen del mismo autor que marca el tipo iconográfico que se representará reiteradamente [fig. 4.34]. Una de ésas obras que bebieron del retrato pintado por Sariñena, es la efigie elaborada por Ribalta [fig. 4.35]. Una vez más se la representa en estado de éxtasis, ahora de cuerpo entero y arrodillada frente a la cruz. De su boca nace la frase «si compartimur et conglarificavimur», asimismo se ha incluido el emblema del Colegio y otra inscripción a los pies de la efigiada: «Soror Margarita Agullona, Christi Virgo tertiae regulae Sancti Francisci Valentina. Obiit die nona decembris aetatis ipsi: 64 salutis omnius 1600». Aunque la bibliografía ha apuntado que la efigie de Sariñena actuó como fuente de inspiración para los retratos hechos por Ribalta, Kowal defiende la hipótesis de que el artista fue llamado para pintar versiones o réplicas de las representaciones de Sariñena. Para sostener dicha conjetura, argumenta que Ribalta recibió una menor recompensa económica por pintar a sor Agullona que Sariñena. ${ }^{102}$

En 1605 los restos de la religiosa se trasladaron desde el convento de los capuchinos de la Sangre de Cristo al Colegio del Corpus Christi, lugar donde siempre había querido ser enterrada. Por ello, los restos mortales de la religiosa aparecen enumerados entre las reliquias que poseía san Juan de Ribera según distintos autores. Por ejemplo, Juan Ximenez escribió que «las mismas piadosas diligencias aplicó, honrador asimismo de los buenos, ejemplares y virtuosos, para traer al santuario de su Real Capilla los cuerpos ya difuntos de la Venerable

avengudes en la ciutat i regne de València. Dietario de Mosen Juan Porcar, capellán de San Martín, 1584 - 1629, (Valencia, 1934). Véase Daniel Benito Goerlich, 'Imágenes para la reforma del arzobispo Juan de Ribera', en Emilio Callado Estela y Miguel Sorní Navarro (eds.), El patriarca Ribera y su tiempo: religión, cultura y política en la Edad Moderna, (Institució Alfons el Magnànim, Diputació de València, 2012), pp. 632-633.

102 David Martin Kowal, Ribalta y los ribaltescos: la evolución del estilo barroco en Valencia. Valencia: Diputación Provincial de Valencia, 1985, p. 62. 


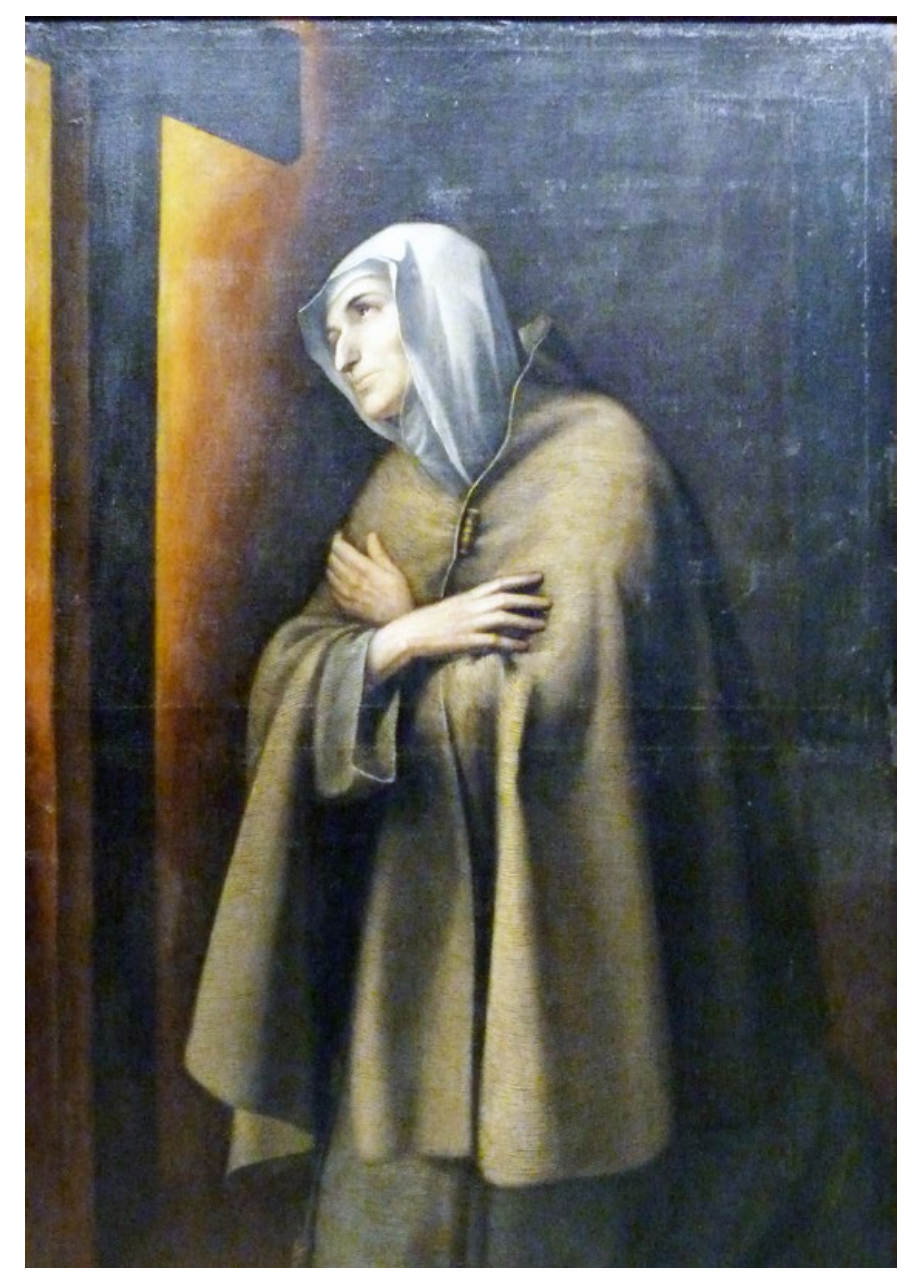

Fig. 4.34. Juan Sariñena, Sor Margarita Agulló, 1605, óleo sobre lienzo, Valencia, Real Colegio Seminario Corpus Christi.

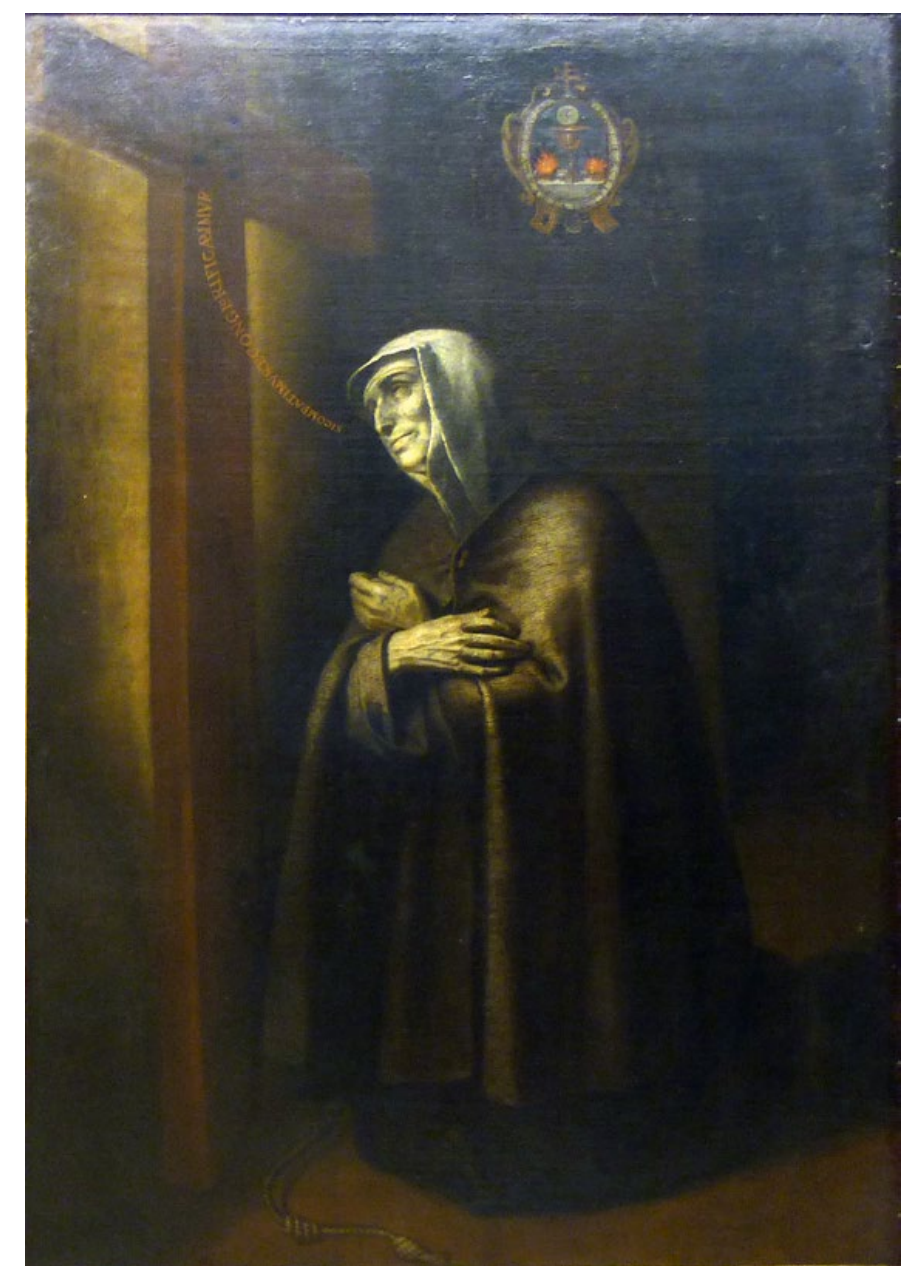

Fig. 4.35. Francisco Ribalta, Sor Margarita Agulló, 1600 - 1606, óleo sobre lienzo, Valencia, Real Colegio Seminario del Corpus Christi. 
Así pues, para conmemorar el quinto aniversario de su fallecimiento y la llegada del cadáver de Agullona, san Juan de Ribera optó por encargar a Ribalta una nueva representación de la franciscana en estado de éxtasis [fig. 4.36]. Esta imagen se destinó a la correspondiente sepultura, pues así lo indica la inscripción superior que especifica: «Hic iacet Soror Margarita Agullona». Este pasaje también lo explicó su confesor Jaime Sanchís, en su Relación breve de la Vida, Virtudes y Milagros de la humilde sierva del Señor Sor Margarita Agullona, Beata Profesa de la Orden del Seráfico Padre San Francisco, publicada en 1607, y encargada por el Patriarca bajo previo beneplácito de Nicolás Factor, Cristóbal Moreno, Rodrigo de Solís, fray Luis de Granada y san Luis Bertrán, a quien por aquel entonces ya le rodeaba una general opinión de santidad, como tributo a la venerable.

[...] y finalmente disponiendo que fuese enterrada en el suntuosísimo Colegio que su Ilustrísima ha mandado labrar a honra del Santísimo Sacramento, de quien fue devotísima, colocándola, no en el más íntimo lugar, sino en la mano derecha del crucero en un sepulcro muy curioso y bien labrado, sobre el cual hay colgada una figura, o un retrato muy al vivo de la Santa, a cuya honra se le ha ordenado que se le hagan y fiesta particular en que se predique sus virtudes y maravillas, habiendo su Ilustrísima sido el primero que dio principio a este misterio, y a tan piadosa memoria. ${ }^{104}$

Es más, en los gastos de la sacristía asumidos en el año 1606 se especifica que Marco Polo, el sacristán del Colegio, le pagó

103 Ximénez, Vida y Virtudes..., Libro III, cap. VII, p. 156. Lo mismo afirmaron Busquets Matoses, Idea exemplar de los prelados..., Libro IV, cap. 3. p. 214, y Escolano, Década primera de la historia..., p. 1074.

104 Jaime Sanchís, Relación breve de la vida, virtudes y milagros de de la humilde sierva del Señor Sor Margarita Agullona, Beata Profesa de la Orden del Seráfico Padre San Francisco, (Juan Crisóstomo Garriz: Valencia,1607), fol. b3-b4 (epístola y dedicatoria para san Juan de Ribera). 


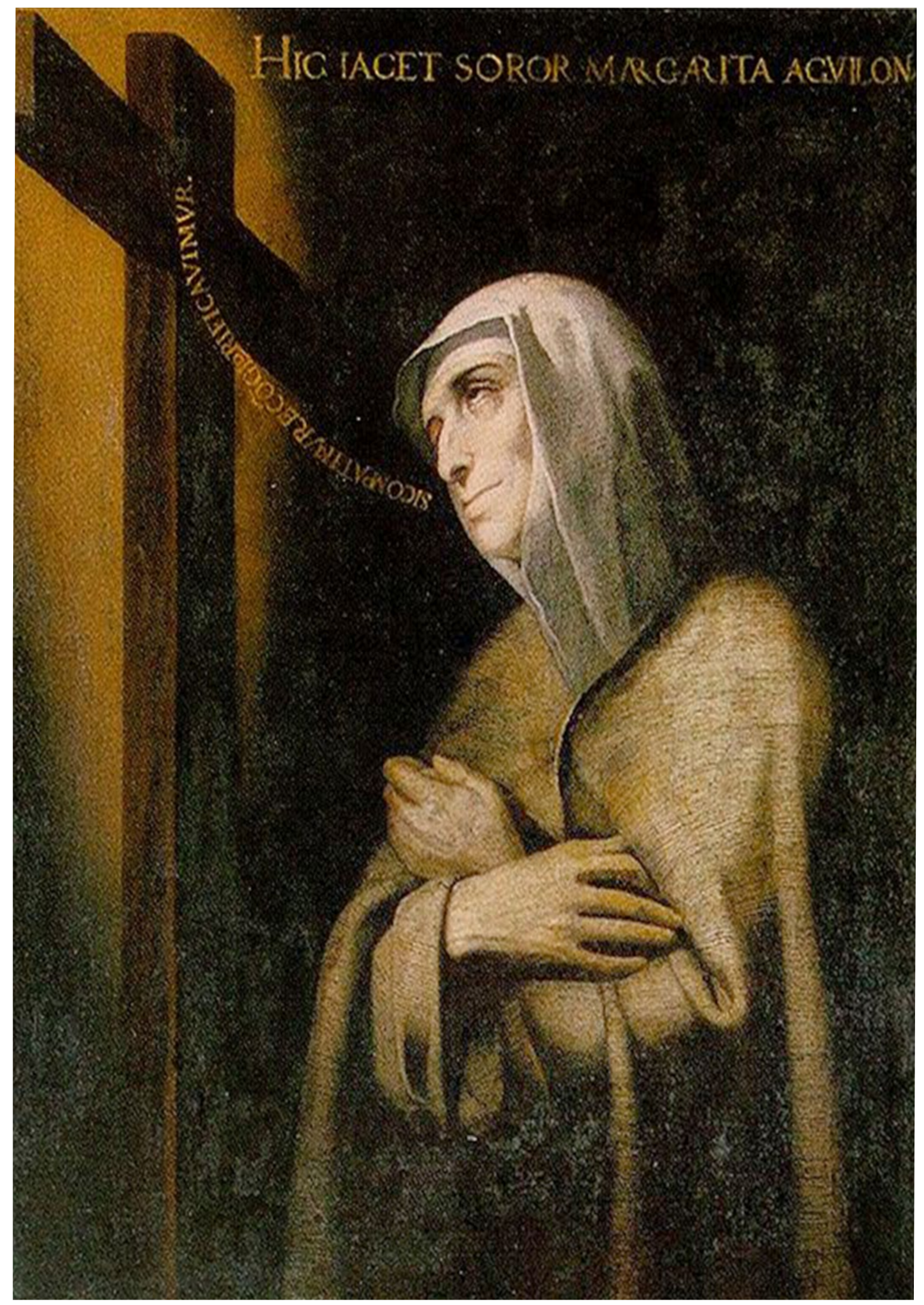

Fig. 4.36. Francisco Ribalta, Sor Margarita Agulló, 1606, óleo sobre lienzo, Valencia, Real Colegio Seminario del Corpus Christi. 
tres sueldos a Lorenzo Prats para la sepultura de la religiosa. ${ }^{105}$ Por tanto, la estima de san Juan de Ribera a dicha venerable se puso de manifiesto mediante la custodia de su cuerpo, el encargo de sus retratos y la elaboración de su hagiografía para presentarla como modelo de santidad. Así lo remarca en el prólogo que escribió para La relación breve, pues dejó claro que el objetivo del libro era hacer públicas las admirables actuaciones de sor Margarita "para ejemplo de muchos, y para satisfacer y pagar la deuda que los vivos tenemos con los muertos». ${ }^{106}$ Probablemente, el compromiso que se tiene con los difuntos es el de perpetuar su memoria y dejar constancia de aquellas acciones ejemplares que protagonizaron. En este sentido, Ribera narró con todo lujo de detalles las experiencias místicas y milagros logrados por la franciscana y que tan sólo se entienden con la intervención divina. Así, además se justificaba que fuese merecedora de una futura beatificación y canonización, la cual nunca llegó a alcanzar.

El respeto y admiración que san Juan de Ribera sentía hacia sor Margarita ha sido comparado con el afecto que san Carlos Borromeo le profesaba a sor Ángela Merici, la fundadora de la Compañía de Santa Úrsula, y quien gozó de gran devoción en el norte de Italia. De hecho, la iconografía que se había extendido de la religiosa italiana la mostraba orando ante un crucifijo y su aspecto facial indicaba que se había tomado a partir de sus restos mortales. ${ }^{107}$

El carmelita descalzo Francisco del Niño Jesús fue otro de los personajes apreciados por Ribera. Su retrato existente en el Colegio del Corpus Christi fue hecho por Sariñena en 1605 [fig. 4.37] y concretamente en agosto de ése año se le pagaron 105 «Yo mismo Lorenzo Prats digo como he recibido del señor Marco Polo tres sueldos los cuales son por tres onzas de [...] que entregué para la sepultura de sor Agullona a 9 de diciembre del año 1606." ACCV: Gasto de Sacristía, 1605-1607, s/f.

106 Sanchís, Relación breve..., prólogo dedicado al lector, fol. b5.

107 La comparación de ambos personajes femeninos se encuentra en Benito Goerlich, 'Imágenes para la reforma...', p. 635. 
al artista cien reales castellanos. ${ }^{108}$ Pero este retrato no era la primera ni la única efigie que se hizo. Unos meses antes, el mismo pintor ya había entregado una representación similar al Ayuntamiento de Valencia [fig. 4.38]. Ambas imágenes son coincidentes en el tipo iconográfico, pues el fraile aparece representado de tres cuartos, vestido con el hábito y adorando una aparición del niño Jesús en la derecha. La diferencia más destacable es el escudo de la ciudad situado a la izquierda y que alude al encargo del gobierno local. Esta pieza en concreto lucía en el despacho de la alcaldía y tuvo un coste de 20 libras valencianas. ${ }^{109}$ Respecto a la ubicación del retrato del Colegio, la efigie originariamente se localizaba en el dormitorio que tenía el prelado en su palacete de Burjassot. ${ }^{110}$ No obstante cabe recordar que según el inventario de 1695, en la sacristía primera en la cual asistía el sacristán había «un cuadro del Hermano Francisco con un marco dorado». ${ }^{111}$ Actualmente, la imagen se encuentra en la biblioteca del Colegio.

La presencia del Hermano Francisco en la ciudad del Turia comenzó cuando marchó allí para fundar una casa de mujeres arrepentidas 0 «Recogimiento». ${ }^{112}$ Pese a la desconfianza de los jurados, el hogar se abrió después que el religioso tuviese una revelación divina que auguraba una epidemia de peste en la urbe en caso de no abrir esta casa. En efecto cabe contemplar la posibilidad de que el ayuntamiento valenciano adqui-

108 Benito Doménech, Juan Sariñena (1545-1619)..., p. 112.

109 Benito cita a Tramoyeres Blasco, de 1891, quien da estos datos sobre el retrato encargado por el ayuntamiento. Benito Doménech, Juan Sariñena (1545-1619)..., p. 110.

110 Se cita el inventario postmortem de 1611 en Benito Doménech, Juan Sariñena (1545-1619)..., p. 112.

111 ACCV: Inventario de la Sagristía. Año 1695. Fol. 7r

112 La Casa de Arrepentida o de Recogimiento era un hogar para aquellas mujeres que abandonaban el ejercicio de la prostitución, aunque también se cobijaba a niñas huérfanas. La finalidad de esta casa era ofrecer cobijo y un hogar a estas mujeres. 


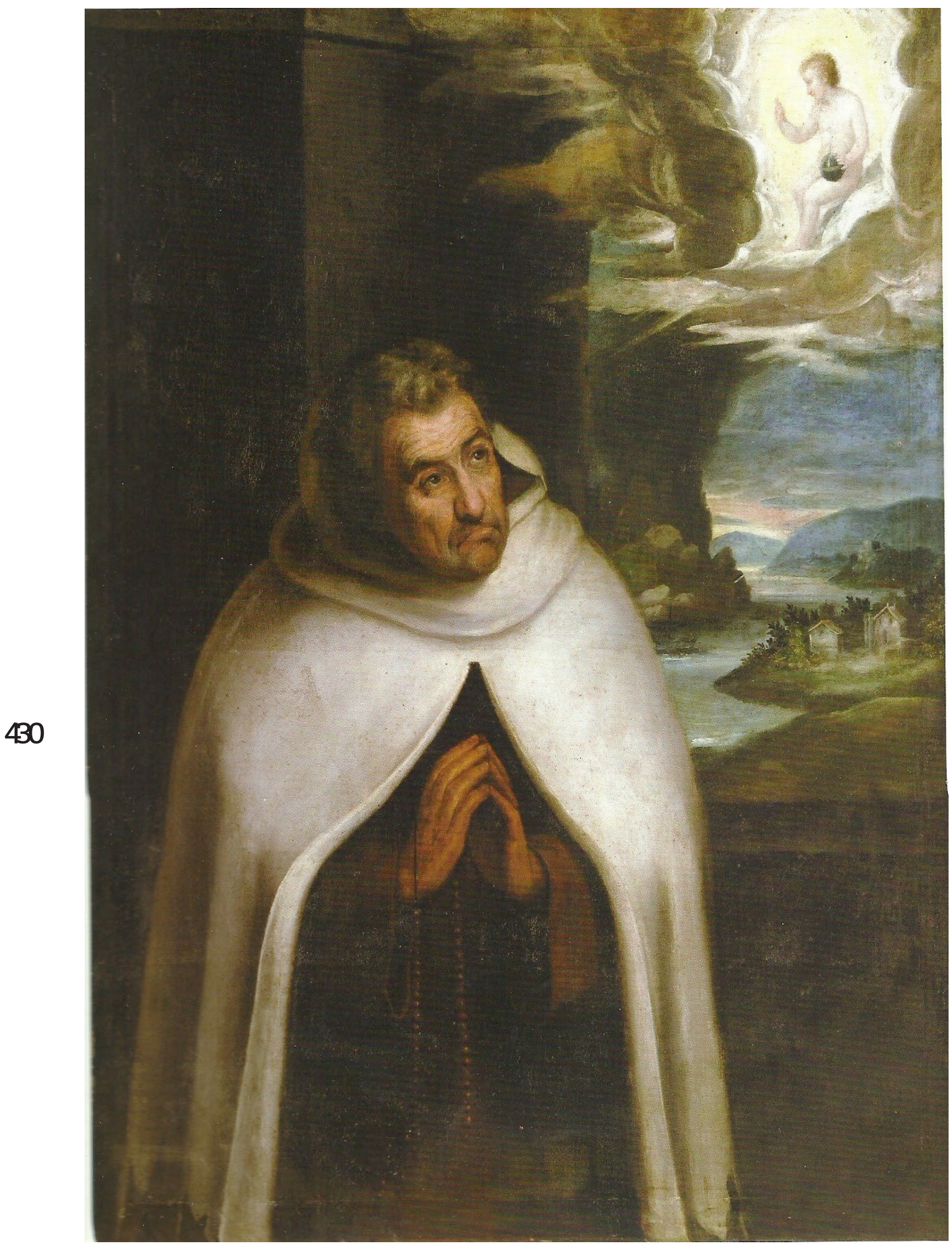

Fig. 4.37. Juan Sariñena, Hermano Francisco del Niño Jesús, 1605, óleo sobre lienzo, Valencia, Real Colegio Seminario de Corpus Christi. 


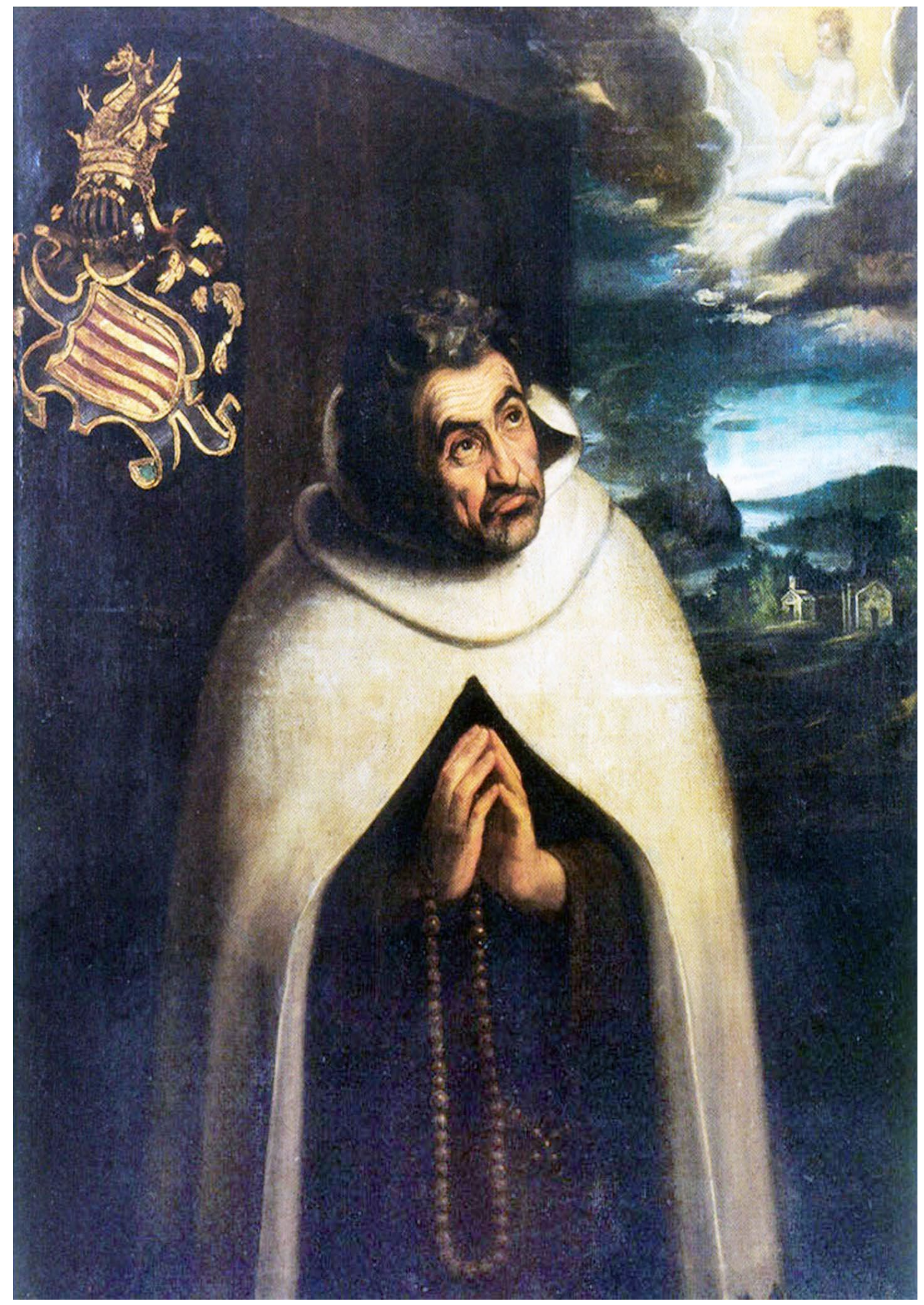

431

Fig. 4.38. Juan Sariñena, Hermano Francisco del Niño Jesús, 1604 - 1605, óleo sobre lienzo, Valencia, Museo de la Ciudad. 
riese el retrato en memoria y agradecimiento al religioso por haber conseguido proteger a la ciudad de la epidemia a través de sus plegarias y de la apertura del hogar de mujeres.

La estrecha amistad que existió entre el arzobispo y el religioso se ha puesto de manifiesto en textos hagiográficos que han relatado las numerosas visitas y charlas que tuvieron así como han explicado la voluntad de ambos por propagar la fe católica y convertir a los moriscos.

\begin{abstract}
[...] además de haberle visitado mientras vivía no pocas veces en Valencia hallándose conventual en el Convento de San Felipe, que en aquella ciudad tiene su sagrada religión, y estimado y honrado con expresiones de particular amor, hasta llevárselo consigo, no solo a su palacio de Burjassot, por gustar mucho de su santa, sencilla y amable conversación, sino también en las visitas que hacía por los lugares, ciudades y villas de su diócesis, y misiones que emprendía para convertir los moriscos a nuestra santa fe y católica religión. ${ }^{113}$
\end{abstract}

Tras la muerte del carmelita, san Juan de Ribera como había hecho en otras ocasiones puso un enorme empeño en adquirir sus reliquias. Por ejemplo, una de ellas fue «la mano derecha del venerable hermano Francisco del Niño Jesús, la cual recibió de su general con mucha estimación colocándola en un relicario". ${ }^{114}$ Asimismo, encargó la celebración de una ceremonia fúnebre en su honor bajo el fin de promover su santidad.

Y después habiendo tenido noticia de su muerte celebró su santidad, mandando hacerle las honras en su santa e ilustre catedral, además de haber querido ser el panegerista de sus virtudes, predicando aquel día de las muy excelentes de penitencia, oración, humildad, paciencia, y amor de Dios y del próximo que habían resplandecido en

113 Ximenez, Vida y Virtudes..., Lib. III, cap. VII, p. 155.

114 Busquets Matoses, Idea ejemplar de prelados..., Libro IV, cap. 3, pp. 212-213. 
aquel su amigo y verdadero ejemplar de toda perfección, con querer además de lo dicho ser el primero que diese principio a las informaciones, que con sus milagros han de servir para su beatificación y canonización. ${ }^{115}$

Mediante las obras analizadas se ha podido observar que el retrato en el marco de la reforma católica se utilizó para presentar a personajes ejemplares por ser portadores de numerosas virtudes. De hecho y como ya se ha comentado en esta tesis, la virtus se convirtió en un nuevo requisito para retratarse, puesto que el efigiado debía poseer una ética y moral impecables como así lo atestiguaron Givanni Battista Armenini o Giovanni Battista Agucchi en sus respectivos tratados. En este momento, la imagen sagrada era una herramienta útil para transmitir la doctrina católica y los santos eran personajes especialmente ejemplarizantes puesto que Dios se manifestaba mediante ellos y su capacidad para obrar milagros y, además influyeron en aumentar la fe en Cristo: "[...] se saca mucho fruto de todas las sagradas imágenes, no solo porque recuerdan al pueblo los beneficios y dones que Cristo les ha concedido, sino también porque se exponen a los ojos de los fieles los saludables ejemplos de los santos, y los milagros que Dios ha obrado por ellos, con el fin de que den gracias a Dios por ellos, y arreglen su vida y costumbres a los ejemplos de los mismos santos; así como para que se exciten a adorar, y amar a Dios, y practicar la piedad. [...]»

Sin embargo, también era fundamental mantener el decoro en el tratamiento de esta clase de imágenes. Por ello, cabía ser comedido en quién era efigiado y donde se ubicaba el retrato, convenía ser moderado en el culto a las reliquias y discreto en las fiestas honoríficas a los santos:

115 Ximenez, Vida y Virtudes..., Lib. III, cap. VII, pp. 155-156.

116 Mariano Latre, El Sacrosanto y ecuménico Concilio de Trento, (Benito Espona: Barcelona, 1845). Sesión XXV: Sobre la invocación, veneración, y reliquias de los santos, y de las sagradas imágenes, p. 331. 
[...] Destiérrese absolutamente toda superstición en la invocación de los santos, en la veneración de las reliquias, y en el sagrado uso de las imágenes; ahuyéntese toda ganancia sórdida; evítese en fin toda la torpeza; de manera que no se pinten ni adornen las imágenes con hermosura escandalosa; ni abusen tampoco los hombres de las fiestas de los santos, ni de la visita de las reliquias, para tener combitonas (sic), ni embriagueces: como si el lujo y la lascivia fuese el culto con que deban celebrar los días de fiesta en honor de los santos. (Salmo. 52). Finalmente pongan los Obispos tanto cuidado y diligencia en este punto, que nada se vea desordenado, o puesto fuera de su lugar, y tumultuariamente, nada profano y nada deshonesto; pues es tan propia de la casa de Dios la santidad. Y para que se cumplan con mayor exactitud estas determinaciones, establece el santo Concilio que a nadie sea lícito poner, ni procurar se ponga ninguna imagen desusada y nueva en lugar ninguno, ni iglesia, aunque sea de cualquier modo exento a no tener la aprobación del Obispo. Tampoco se han de admitir nuevos milagros, ni adoptar nuevas reliquias, a no reconocerlas y aprobarlas el mismo Obispo. Y este luego se certifique en algún punto perteneciente a ellas, consulte algunos teólogos y otras personas piadosas, y haga lo que juzgare convenir a la verdad y piedad. $[. . .]^{117}$

A partir de este proyecto artístico, san Juan de Ribera puede ser considerado como uno de los principales propulsores de esta clase de imágenes, elaboras a raíz del fallecimiento del efigiado y quien se encontraba en camino a la santidad. Se ha visto que el arzobispo no sólo encargó la elaboración de sus imágenes, sino que en muchos casos también asumió los costes de las honras fúnebres, consiguió reliquias y promovió la redacción de hagiografías de aquellos que pertenecieron a su círculo de amistades en aras de una futura beatificación y canonización. En este sentido, Miguel Falomir ha visto que la 117 Latre, El Sacrosanto y ecuménico..., Sesión XXV: Sobre la invocación, veneración, y reliquias de los santos, y de las sagradas imágenes, pp. 331332. 
promoción de estos personajes por parte de san Juan de Ribera ha sido un modo más de demostrar su integración en la sociedad valenciana, así el 24 de octubre de 1591 pidió «su naturalización como hijo y residente de Valencia». ${ }^{118}$

Después de haber mostrado pormenorizadamente este grupo de retratos, su lectura puede aún ser más interesante si se hace desde una perspectiva global y en conexión con otros dos conjuntos de efigies relacionados con la figura de san Juan de Ribera que ya se han estudiado en esta tesis doctoral. Así pues, conviene hacer una serie de reflexiones acerca de la trascendencia del género del retrato en el conjunto de la colección artística reunida por el Patriarca. Cabe recordar que la galería de la realeza perteneciente a la Corona de Aragón, a la de Castilla y a la dinastía de Austria de su aposento de los reyes ha tratado de enraizar a san Juan de Ribera con los soberanos españoles. No menos importante es la dinastía de prelados que como ya se ha comentado, cabe la posibilidad de que estuviese promovida por el Patriarca ya que su imagen correspondería con la del único arzobispo vivo y el último miembro de la galería. El conjunto de retratos regios, de prelados y de frailes, beatos y venerables han sido tres proyectos artísticos relacionados directamente, por distintas razones, con san Juan de Ribera. Se puede entender que dichos ejemplos han pretendido vincularlo a grupos reducidos y exclusivos pertenecientes a tres ámbitos de poder distintos: el civil, el episcopal y el divino. De estar en la dirección acertada, es probable que de esta manera san Juan de Ribera también estuviese haciendo su particular camino hacia la santidad.

118 Miguel Falomir Faus, 'El Patriarca Ribera y la pintura. Devoción, persuasión e historia', en Una religiosa urbanidad: San Juan de Ribera y el Colegio del Patriarca en su cultura artística de su tiempo, (Real Academia de Bellas Artes de San Carlos: Valencia, 2013), pp. 103-116. 


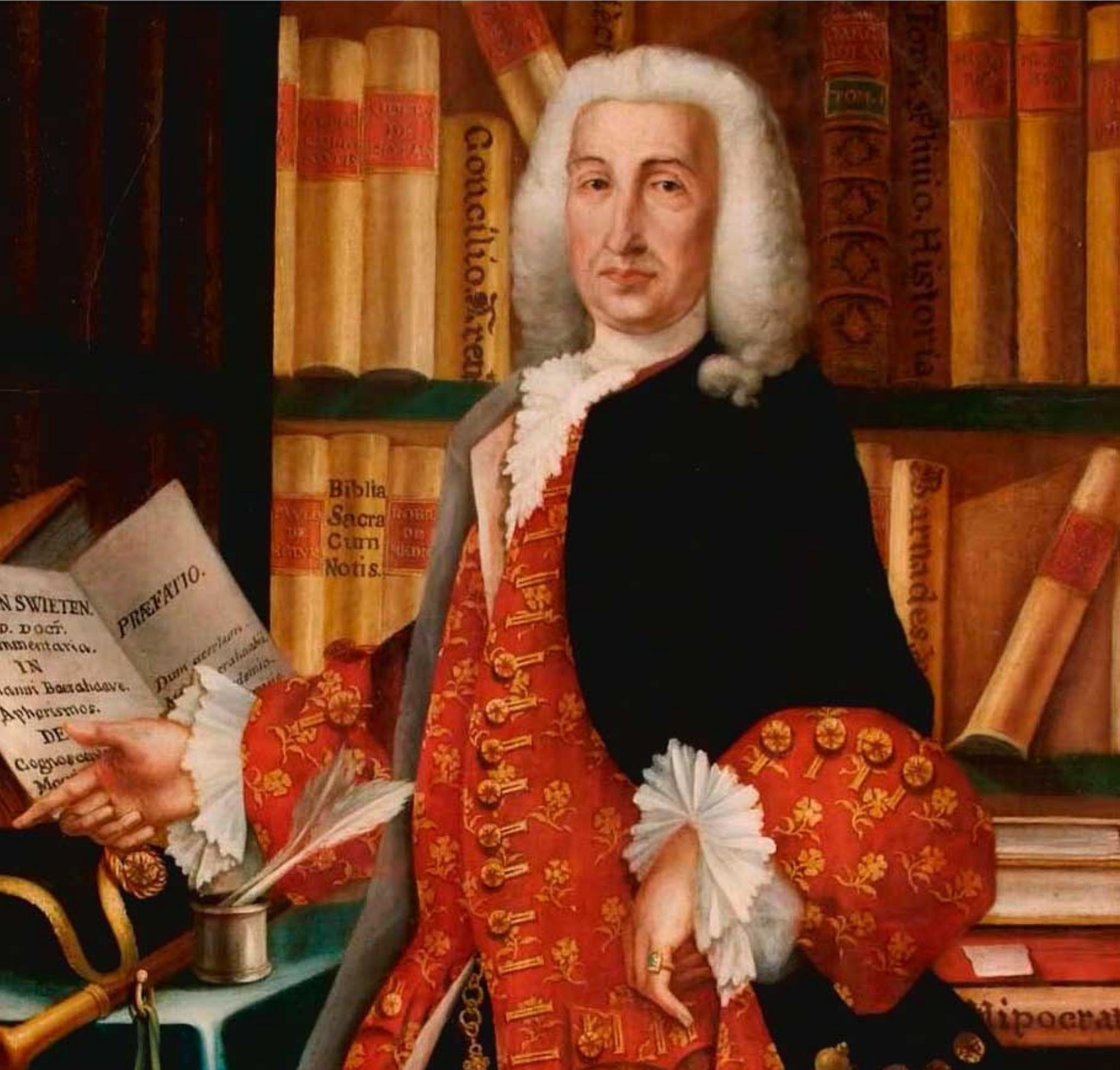

mmentario.

Ixis Bociaticave

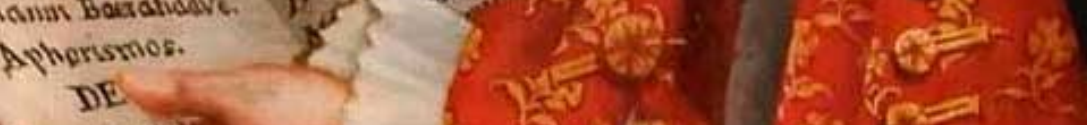

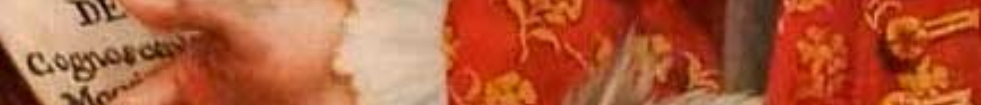

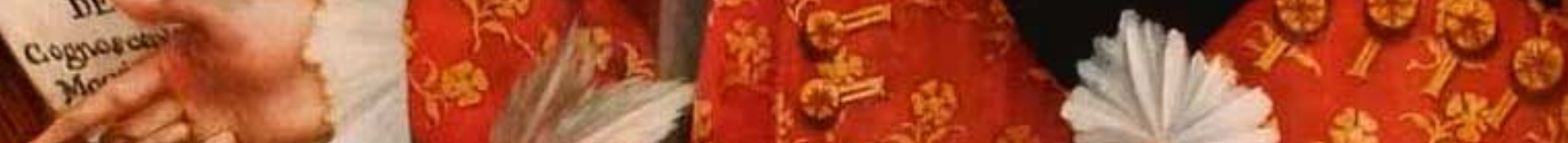

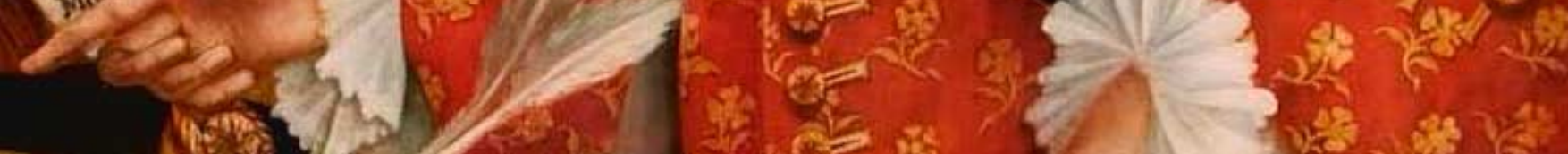

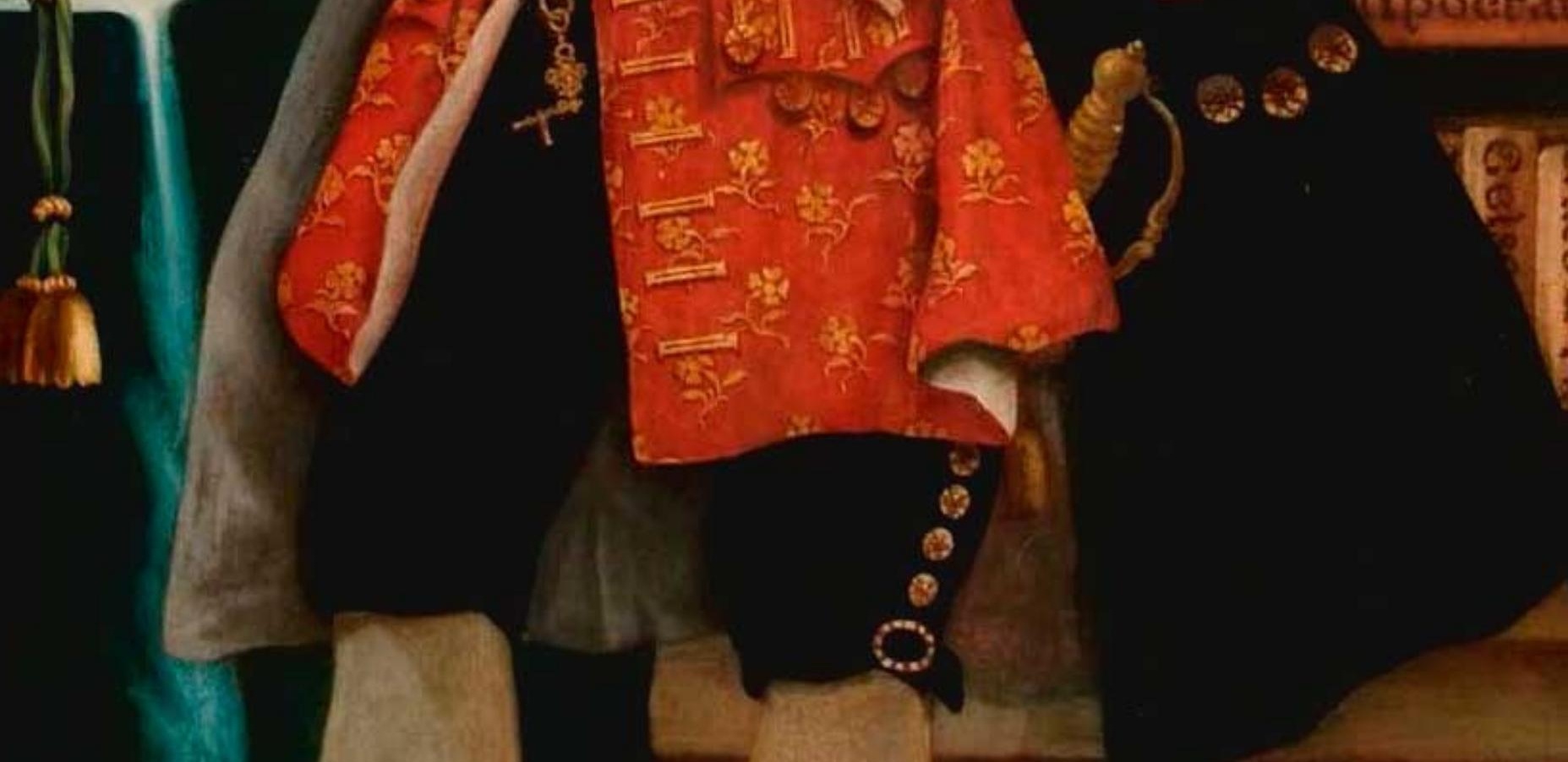




\section{Capítulo 5}

\section{Retratos de hombres ilustres}

El retrato de personajes ilustres es una tipología que pone de manifiesto la variedad de registros en los que tuvo cabida este género sin perder su esencia y la intención de ensalzar a los efigiados, de crear una imagen de poder en distintos ámbitos. Las representaciones de hombres ilustres se popularizaron a raíz de que, en época moderna, las actividades intelectuales ganaron una mayor consideración. En consecuencia, el retrato exhibió como referentes culturales a aquellos que brillaron tanto en las materias científicas, humanísticas como artísticas. Por ello, los tres conjuntos pictóricos que se estudian en este capítulo son distintos y a la par complementarios porque ejemplifican el uso del retrato en contextos distintos pero todos ellos alaban a un reducido grupo de intelectuales.

En la galería procedente del monasterio de La Murta se recopilaron las efigies de personajes procedentes de diferentes campos del saber de quienes, además, se ha remarcado su condición de valencianos. Las pinturas que ornamentan el paraninfo universitario muestran principalmente a hombres célebres que se han formado en la Universitat y que han desarrollado parte de su carrera profesional en esta institución. Al mismo tiempo, es la propia universidad la que se nutre de 
los méritos de sus efigiados, haciendo suyos los éxitos de sus efigiados. Y por último, la colección de retratos perteneciente a la Real Academia de Bellas Artes de San Carlos tiene una doble vertiente, política y académica. La primera de ellas ha dado visibilidad a aquellos que ostentaron la presidencia de la institución, cargo al que se accedía a través del corregimiento o intendencia de la ciudad. La segunda ha mostrado a aquellos que dirigieron la academia o cualquiera de alguna de sus ramas artísticas, era una labor reservada para los arquitectos, pintores, escultores y grabadores. De este modo, a través de sus retratos se contribuía a mejorar el prestigio y apreciación social de los artistas.

\subsection{La galería de Varones Ilustres Valencianos del Monaste- rio de Nuestra Señora de La Murta (Alzira).}

Como es sabido, las galerías de hombres ilustres proceden de la tradición italiana por representar a afamados varones pertenecientes a todos los ámbitos culturales. En España concretamente, Lucía Varela consideró que los conjuntos de retratos o la idea de llevar a cabo una empresa artística de estas características llegó de la mano de Benito Arias Montano y la biblioteca del Monasterio del Escorial, donde aparecen representados escritores, personajes históricos, emperadores, reyes y pontífices como modelos históricos a imitar. ${ }^{93}$ En este ambiente se debe valorar el conjunto de lienzos que tradicionalmente se han identificado con la galería de efigies sobre insignes varones valencianos pintados por Juan Ribalta junto con su taller. Los retratos que originalmente se encontraban en el monasterio alcireño de Nuestra Señora de la Murta, actualmente se conservan en el Museo de Bellas Artes de Valencia.

Ya se ha avanzado en el estado de la cuestión que las referencias bibliográficas, aunque no demasiado abundantes, son de gran importancia para estudiar esta galería. Además de 93 Lucía Varela, 'El rey fuera de palacio: la repercusión social del retrato regio en el Renacimiento español', en Santiago Saavedra (ed.), Alonso Sánchez Coello y el retrato en la Corte de Felipe II, (Museo Nacional del Prado: Madrid, 1990), pp. 99-133. 
las aportaciones realizadas por otros autores conviene revisar toda la documentación de archivo relativa a este conjunto pictórico y en este sentido, detenerse especialmente en la información registrada en las juntas de carácter ordinario o particular y en la prensa para conocer con sumo detalle la relevancia que tuvieron estos lienzos en el siglo XIX después de la desamortización. Además, aún es necesario reflexionar acerca de la trascendencia de esta galería y su identidad como grupo. No es menos importante realizar análisis individualizados de los retratos y vincularlos con otros retratos similares.

Antes de abordar con detenimiento la galería, conviene introducir brevemente a la orden jerónima a la cual pertenecía el monasterio de Nuestra Señora de La Murta. La institución monástica de la Orden de san Jerónimo surgió en España después de desarrollarse el movimiento eremítico en 1350 y, más tarde, en 1373 lograron el beneplácito del pontífice Gregorio XI. Tan sólo fue la rama masculina de dicha institución la que se vio afectada por la desamortización del siglo XIX sufriendo ataques que la debilitaron progresivamente hasta extinguirla por completo. El primero de los golpes se dio en 1809 cuando Napoleón decidió eliminar la tercera parte de los conventos y José Bonaparte se alzó con las posesiones de los religiosos. Nuevamente, en 1820 se determinaron nuevas leyes para desocupar los monasterios y otorgarles otra función. Tres años después, las circunstancias políticas, favorecieron que los religiosos regresasen a sus comunidades hasta que en 1835 fueron forzados a abandonar el convento definitivamente. Desde ese momento, los monasterios se vendieron a manos privadas, algunos siguieron albergando actividades de índole eclesiástico y otros desempeñaron otras funciones. ${ }^{94} \mathrm{Al}$ igual que con otros conjuntos pictóricos situados en conventos y monasterios, esta galería de hombres ilustres pasó a ser custodiada por

94 Estas apreciaciones generales se pueden consultar en David Rodríguez Luna, 'Desamortización y monjes jerónimos: Extinción y restauración de una orden monástica', en La desamortización: El expolio del patrimonio artístico y cultural de la Iglesia en España, (Instituto Escurialense de Investigaciones Históricas y Artísticas: Madrid, 2007), pp. 103-117. 
la Academia de Bellas Artes de San Carlos tras la desamortización y para ello, como se verá más adelante, jugó un papel clave Francisco Xavier Borrull por abanderar la iniciativa de recopilar estas efigies con el objetivo de conservarlas en la Academia.

\subsubsection{Un proyecto para memorar a celebridades valencia- nas.}

Cuando don Diego de Vich le encargó a Juan Ribalta la creación de una galería pictórica sobre afamados varones valencianos probablemente pensaba que sería un justo homenaje a personajes ilustres procedentes de muy distintas disciplinas y profesiones que debían honrarse, respetarse y presentarse como un ejemplo a seguir para el resto de la sociedad. El retrato, un género que capturaba el rostro de la persona, simbolizaba la superioridad y la exclusividad social, era capaz de reunir a un grupo de hombres que habían dejado su huella en la historia.

440 Don Diego de Vich, hijo de don Álvaro y doña Blanca Castellví, decidió retirarse al monasterio jerónimo de Nuestra Señora de la Murta huyendo de un mundo repleto de comodidades y lujos. Allí permaneció hasta su muerte en 1657. La elección de marchar a ese lugar estuvo influenciada por la simpatía que la familia Vich sentía hacia la orden de san Jerónimo y especialmente hacia el complejo de La Murta. De hecho, en el siglo XVI asumieron su protección, promovieron la construcción de una nueva iglesia de estilo renacentista, dejaron constancia de su patronazgo al colocar el escudo familiar en la fachada del templo y además, se construyó una cripta que ejercería de panteón. A raíz de que la estirpe Vich se vinculara al conjunto monacal, éste recibió la visita de las más célebres personalidades eclesiásticas y civiles, como pontífices, reyes, obispos y cardenales.

Como ha expuesto Justo Pastor Fuster, antes de que Vich se trasladase definitivamente al convento "remitió a él treinta y un retratos de los varones insignes naturales de Valencia y 
Reino, que copió Juan Ribalta, siendo su ánimo continuar la colección, lo que hubo de suspender como el mismo Vich dice por ciertos motivos. ${ }^{95} \mathrm{Y}$ seguidamente se especificó quienes pertenecieron a tan selecto círculo. Asimismo Marcos Antonio de Orellana ha dedicado un capítulo completo a exponer la biografía de los pintores Francisco y Juan Ribalta. ${ }^{96}$ Entre las páginas dedicadas al segundo artista, el autor ha proporcionado un listado de nombres referentes a las personas retratadas para formar parte de la galería de ilustres, la cual se ubicó en la librería del monasterio respetando el orden indicado por Vich. Según la acepción que en el siglo XVII se le concedió a la palabra «ilustre», aquellos calificados como tales eran considerados excelentes, honrados y de buena fama. En consecuencia, la galería alcireña ha integrado a personajes de éxito procedentes de distintos ámbitos como la teología, la medicina, la botánica, las humanidades o incluso, el ejército.

Conocer exactamente quiénes gozaron del privilegio de ser miembros de la galería de varones ilustres requiere cotejar diversas fuentes de información que han proporcionado sus nombres. Se debe partir de la aportación de Orellana quien reveló la identidad de los treinta y un hombres y se corresponden con los siguientes:

Luis Vives, Ausias March, Pedro Juan Nuñez, Jaime Ferrús, Jusepe Estevan, Padre Benito Pereyra, Gerónimo Muñoz, Francisco Gerónimo Simón, Jayme Juan Falcó, Dr. Juan Plaza, Honorato Juan, Francisco Tárrega, Pedro Juan Trilles, Jayme Roig, Francisco Collado, Dr. Miguel Salom, mínimo, Dr. Agustín Martí, Gaspar Aguilar (éste tiene a Virgilio entre las manos), Guillén de Castro, Baltazar Marrades (éste está bien vestido

95 Justo Pastor Fuster, Biblioteca valenciana de los escritores que florecieron hasta nuestros días con adiciones y enmiendas a la de D. Vicente Ximeno, Tomo I, (Imprenta de José Ximeno: Valencia, 1827), p. 253.

96 Marcos Antonio de Orellana, Biografía pictórica valentina o vida de los pintores, arquitectos, escultores y grabadores valencianos, (Ayuntamiento de Valencia: Valencia:, 1967). 
con malla), Gaspar Sapena (lo mismo), Juan Bautista Comes (primer Capilla del Colegio del Patriarca), Calixto III, Nicolás Factor (ahora beato), San Luis Bertrán, San Vicente Ferrer, San Bernardo Martyr, Padre Francisco de Borja (ahora canonizado), Alejandro VI, Hernando de Aragón y Federico Furió Seriol. ${ }^{97}$

La referencia de Orellana adquiere un notable interés porque además explicó que don Diego de Vich tan sólo anotó veintiocho de los lienzos en la carta que envió al monasterio comunicando su justificación. Según también aclara el autor, los últimos tres retratos fueron pintados poco después y entregados a la orden jerónima más tarde, junto con otras pinturas realizadas por distintos artistas como Paulo Bril, Bazán o Durero. Esto mismo se recogió en el Diario de Valencia de 25 de mayo de 1791. Justo Pastor Fuster también aportó el mismo listado en su Biblioteca valenciana. ${ }^{98}$

442 Seguidamente se tienen nuevas noticias y otra relación de nombres publicada, ésta vez, por el periódico El Censor en 1821. Como se comprobará más adelante, ello le dio un eco nacional a la labor de Borrull y a la intención de la Academia de adquirir las efigies. En este caso no se proporcionaron los treinta y un nombres con pulcritud a falta de José Esteve (nombrado por Orellana como Jusepe Estevan), Francisco Gerónimo Simón, Juan Plaza, Pedro Juan Trilles, Miguel Salom y Alejandro VI. Las razones por las que el diario madrileño no nombró el total de personajes son desconocidas por el momento.

Dos años después, en 1823, se redactó el expediente de entrega de las obras a la Academia y fue su secretario, Vicente María Vergara quien certificó el ingreso de las mismas. De los miembros que conformaban la colección en su integridad, Vergara acreditó la recepción de veintiún de ellos más dos efigies en formato ovalado sin identificar marcadas con el sello de 97 Orellana, Biografía pictórica valentina..., pp. 127-128.

98 Pastor Fuster, Biblioteca valenciana..., p. . 
la Murta, consiguiendo el total de veintitrés piezas. ${ }^{99}$ Las pinturas que señalaron tanto Orellana como Pastor y que no llegaron a la Academia de Bellas Artes son Jaime Roig, Miguel Salom, san Luis Bertrán, san Bernardo de Alzira, Francisco de Borja, José Esteve y Gaspar Aguilar. Obviamente, a excepción de los dos últimos, el resto de piezas no se han conservado. Respecto a la imagen de José Esteve se corresponde con una pintura muy deteriorada. La efigie de Aguilar fue encontrada más tarde, según se ha sabido a través de las noticias halladas en el archivo. También debió localizarse más tarde la imagen de Pedro Juan Núñez, ya que no consta en la información anotada por Vergara. En consecuencia, estas son las fuentes históricas que se han manejado para obtener los máximos datos posibles respecto a la identidad de los insignes hombres valencianos y conocer el legado que ha llegado a nuestros días.

En la actualidad, el Museo de Bellas Artes de Valencia tiene catalogadas veintitrés pinturas procedentes del monasterio jerónimo. Sin embargo, los retratados no concuerdan a la perfección con los nombrados por Vergara en 1823. De hecho, se podría decir que diecinueve son las que coinciden y presentan una alta probabilidad de formar parte de la serie originaria. Por el contrario, las imágenes de Benito Arias Montano, Juan Bautista Verge, Sebastián Vila y Leonardo de Argensola no tendrían cabida en la galería de ilustres valencianos principalmente porque no constan en el listado que hizo el propio Vich y sus efigies tampoco casan con los rasgos definitorios del conjunto alcireño.

No todas las personas representadas en este conjunto pictórico son contemporáneas a la elaboración de las obras. Por ejemplo, personalidades como san Vicente Ferrer o Luis Vives entre otros vivieron tiempo atrás. En esos casos, el retrato se realizó a partir de la imagen ya conocida y difundida del personaje. En cuanto al resto, coetáneos a Juan Ribalta y su taller, 99 Archivo de la Real Academia de Bellas Artes de San Carlos (ARABASC ahora en adelante): Libro de Actas de la Real Academia de San Carlos. Años: 1821-1827, s/f, junta ordinaria en 7 de diciembre de 1823. 
es complicado determinar con exactitud si el retrato fue tomado del natural. En cualquier caso, queda patente el minucioso tratamiento del rostro y las manos, incluyendo hasta el mínimo detalle físico. Las pinturas, por tanto, son ejemplo del pensamiento de los tratadistas que ponen de manifiesto la importancia del parecido por ser la raíz de un buen retrato como hemos apuntado en anteriores secciones de esta tesis.

Al examinar en profundidad las piezas, se observan diferencias entre unas y otras que hacen cuestionar de manera ligera la homogeneidad de la serie. Aún así, la tipología generalizada es la imagen de busto sobre un fondo neutro, mínimamente ladeada para poder observar casi al completo el rostro, vestido acorde con su posición social y una inscripción en la zona inferior del retrato que revela la identidad y las acciones importantes protagonizadas por el efigiado. Estas características, a grandes rasgos, ya evidencian la función laudatoria y conmemorativa del retrato. Asimismo, el diseño empleado 444 para la galería es deudor del tipo de retrato que se realiza para ilustrar los libros de hombres célebres en época moderna. El Libro de descripción del verdadero retrato de ilustres y memorables varones de Francisco Pacheco, ya publicado en 1599, es un buen ejemplo de ello. Aquí el encuadre de la imagen se centró en el rostro, un rostro que como dijo Pacheco era el más parecido al que él conoció y que en caso de no haber tenido contacto con el personaje se hizo a partir de otros retratos de él difundidos. Junto con la imagen se dispuso un texto acerca de la vida profesional del varón, aquí se sintetizaron los estudios, las lenguas habladas, las publicaciones y los cargos relevantes desempeñados por los efigiados.

Para abordar el análisis pormenorizado de los retratos se ha decidido ordenarlos bajo los criterios que se consideran más lógicos y que acercan al lector a componer una visión lo más cercana posible a lo que fue la galería en su origen. En este sentido, en primer lugar se debe centrar la atención en aquellos retratos que ingresaron en la Academia en 1823 proceden- 
tes del monasterio de La Murta como atestiguó el secretario de la institución, Vicente María Vergara. Dentro de este grupo, se deben diferenciar aquellas efigies que siguen la tipología más extendida para la serie de aquellas que no. En relación a las primeras, el punto de partida ha quedado situado con el estudio de los retratos de Pedro Juan Trilles y Benito Perera, puesto que Fernando Benito los ha considerado como piezas ejecutadas por la mano de Juan Ribalta, relegando el resto de obras al trabajo de taller. ${ }^{100}$ Tras el escrutinio de ambas efigies conviene continuar con el resto de ejemplos que siguen el modelo estipulado por las mismas. En el conjunto de pinturas de taller se encuentran personalidades pertenecientes a tiempos anteriores y más o menos coetáneos a la ejecución del grupo, lo cual también será un criterio a seguir para estructurar el estudio. Seguidamente, se verán aquellas obras que no siguen el modelo de representación más empleado para retratar a los varones ilustres. En un segundo y último bloque, se fijará la mirada en ejemplos puntuales de lienzos que se depositaron en la Academia más tarde, siguiendo o no la clase de representación.

Para el estudio individualizado de las imágenes conviene empezar por Pedro Juan Trilles (1566-1626) [fig. 5.1], quien ha sido considerado varón ilustre por haber obtenido el honorífico título de pavorde de la Universidad de Valencia. También se le ha destacado por ser el maestro de don Juan de Palafox, quien murió siendo obispo de Osma. ${ }^{101}$ Además del nombramiento universitario, la inscripción que acompaña su efigie remarca sus conocimientos en otras lenguas: "Pedro Juan Trilles Paborde de esta Universidad mui estimado por su ciencia y gran conocimiento de los idiomas Hebreo, Griego, Caldeo y Siriaco, murió en Valencia, su patria en 2 de Agosto de 1626.»

100 Fernando Benito Doménech, Los Ribalta y la pintura valenciana de su tiempo: exposición Lonja de Valencia, octubre - noviembre 1987: Museo del Prado, Palacio de Villahermosa, diciembre 1987 - enero 1988, (Diputación Provincial de Valencia: Valencia, 1987), p. 21.

101 Pastor Fuster, Biblioteca valenciana..., p. 229. 


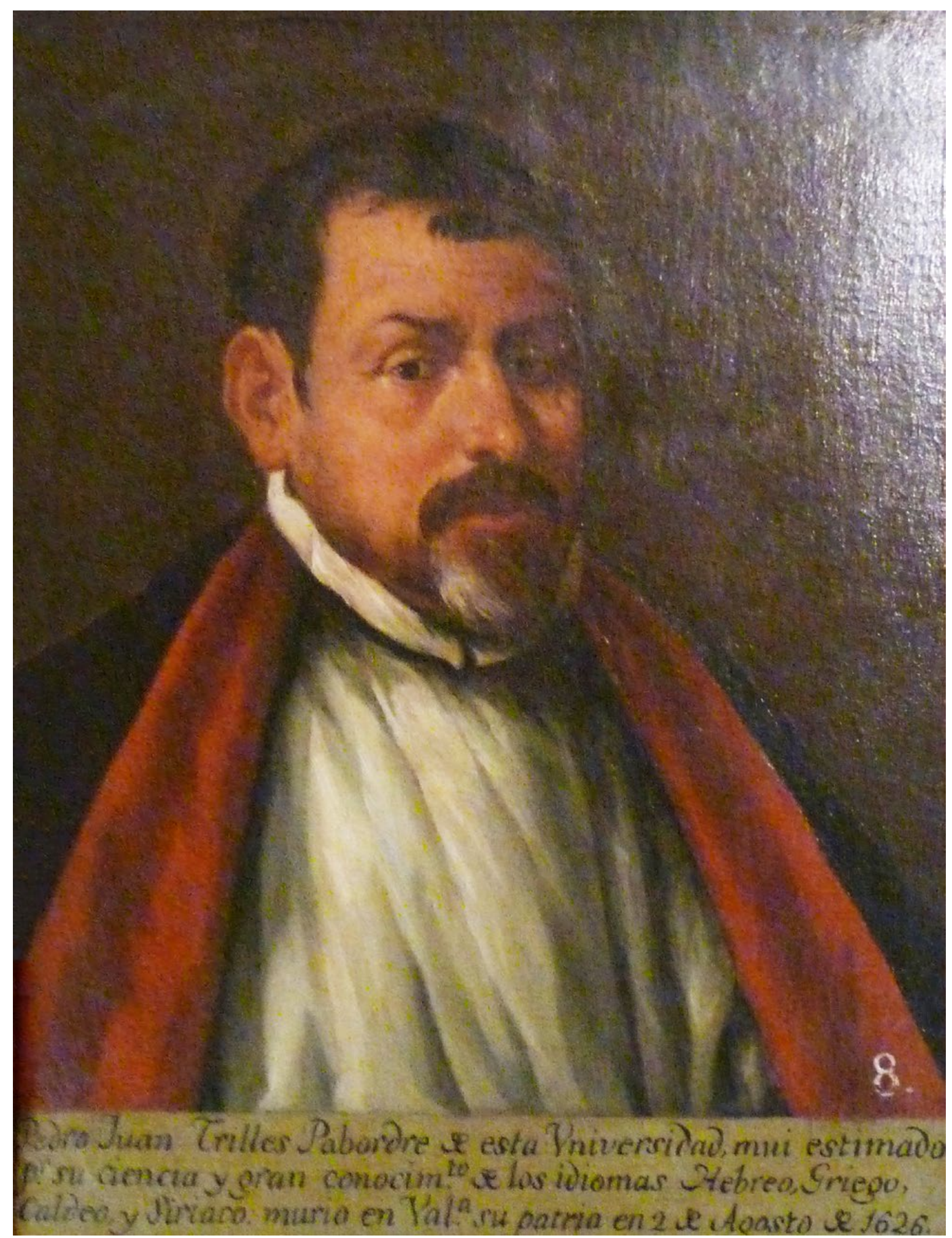

Fig. 5.1. Juan Ribalta, Pedro Juan Trilles, s. XVII, óleo sobre lienzo, Valencia, Museo de Bellas Artes. 
El retrato de Benito Perera (1535-1610) [fig. 5.2], también llamado Pereira, Pereyra o Pereda, no ofrece datos de enjundia en el escrito que acompaña la efigie de este varón vestido con ropajes oscuros y un bonete eclesiástico de cuatro puntas. Su bagaje cultural queda acreditado al ser doctor en teología, dominar otros idiomas como el hebreo y griego así como asumir la cátedra de escritura en el Colegio Romano durante su etapa final. ${ }^{102}$ No obstante, el texto suprime todos los detalles mencionados adquiriendo una perspectiva demasiado general: «Don Benito Perera de la Compañía de Jesús natural de Ruzafa, célebre en sus muchas elegantes y eruditas obras. Murió en Roma en 1610 en edad de 75 años.»

Una vez vistos los dos retratos que se consideran ejecutados por Juan Ribalta y que marcan el modelo oficial para la galería es necesario continuar estudiando el resto de obras que siguen este patrón. Como se ha mencionado previamente, algunos de los varones ilustres vivieron en siglos anteriores al XVII y su imagen se realizó a partir de otras obras ya conocidas. Así sucede con el dominico san Vicente Ferrer (1350-1419) [fig. 5.3], quien también ejerció como profesor de filosofía en el ámbito universitario y quien llegó a canonizarse en 1455. El santo aparece ataviado con el hábito propio de su orden. De la mano derecha, que señala al cielo con el dedo índice, surge una cartela en latín en la cual se puede leer un consejo dirigido a los fieles para temer al tribunal de Dios: «TIMETE DEUM IUDICI EIUS». El texto correspondiente al retrato dice del religioso que: "San Vicente Ferrer hijo de Valencia, insigne por sus virtudes $i$ ciencia, elegido por estos Reynos para declarar a quien tocaba la Corona de Aragón i por Dios para Apóstol de Europa, ilustrando su misión con innumerables milagros.»

102 Vicente Ximeno, Escritores del reyno de Valencia chronologicamente ordenados desde el año MCCXXXVIII de la cristiana conquista de la ciudad hasta el MDCCXLVIII, tomo II, (Joseph Estevan Dolz: Valencia, 1749), pp. 254-255. 
Fig. 5.2. Juan Ribalta, Benito Perera, s. XVII, óleo sobre lienzo, Valencia, Museo de Bellas Artes. 


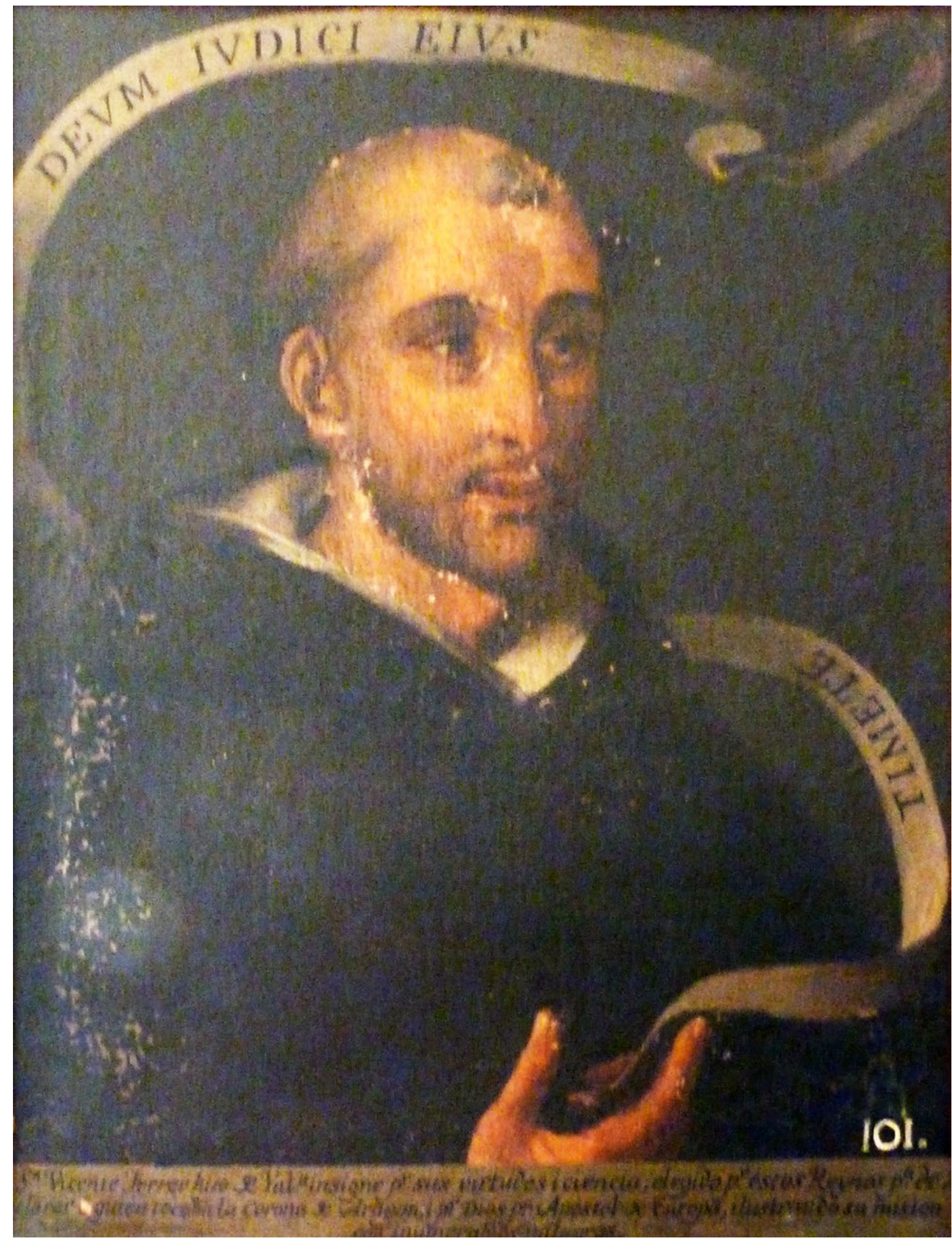

Fig. 5.3. Taller de Juan Ribalta, San Vicente Ferrer, s. XVII, óleo sobre lienzo, Valencia, Museo de Bellas Artes. 
Una situación similar se encuentra en la representación del beato Nicolás Factor (1520-1583) [fig. 5.4], construida a partir de su imagen más conocida. De hecho, visualmente recuerda al retrato que hizo Juan Sariñena en 1587 para el monasterio de las Descalzas Reales de Madrid, ya visto en el capítulo anterior. La iconografía una vez más es la propia del religioso. El estado de conservación del lienzo ha impedido transcribir la descripción de la cartela, sin embargo lo único que se puede apreciar es la fecha de su fallecimiento sucedido, a los sesenta y tres años edad, el 23 de diciembre de 1583.

Además de importantes religiosos, para la serie también se han retratado a célebres humanistas como Juan Luis Vives (1492-1540) [fig. 5.5]. Desde que inició su formación en París, el estudioso comenzó una trayectoria que le permitió consolidarse como un profesional de resonancia internacional. Llegó a ser docente de las universidades de Lovaina, Oxford y La Sorbona. Mantuvo contactos con otros intelectuales como

Erasmo de Róterdam o Tomás Moro. También se vinculó a los ámbitos de poder, pues fue preceptor de la princesa María Tudor, hija de Enrique VIII de Inglaterra. ${ }^{103}$ Un vez más el retrato se ha abordado a raíz de la imagen pública de humanista, por ello fácilmente se establece una correspondencia visual con otras obras. De hecho, la estampa incluida en la Colección de retratos de personajes ilustres de Philippe Galle [fig. 5.6], lo presenta bajo la propia estética renacentista y escribiendo, en señal de su labor intelectual. La apariencia física de la estampa y de la efigie alcireña es coincidente en su totalidad. Otro claro ejemplo se halla en la imagen de Edme de Boulonois de 1682 y también localizable en la Biblioteca Nacional [fig. 5.7]. En consecuencia esta es una breve muestra de la codificación que se llevó a cabo con las representaciones de Vives y que se mantiene en el lienzo de La Murta.

103 Véase la ficha de catálogo de A. Carrasco Martínez en Luis Miguel Enciso Recio y José Miguel Sánchez González (coord.), Reino y ciudad: Valencia en su historia, (Fundación Caja Madrid: Madrid, 2007), pp. 487-488. 


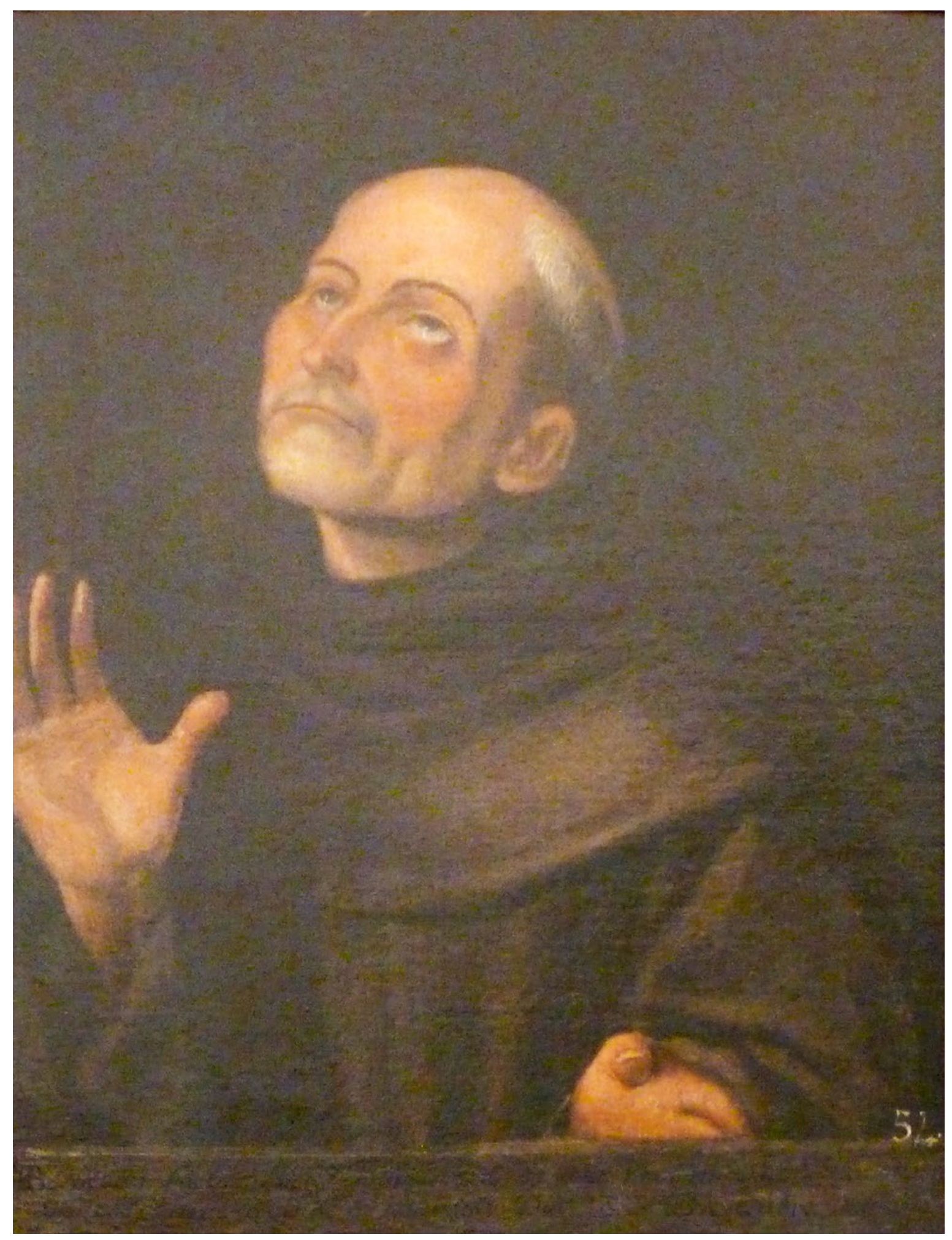

Fig. 5.4. Taller de Juan Ribalta, El beato Nicolás Factor, s. XVII, óleo sobre lienzo, Valencia, Museo de Bellas Artes. 


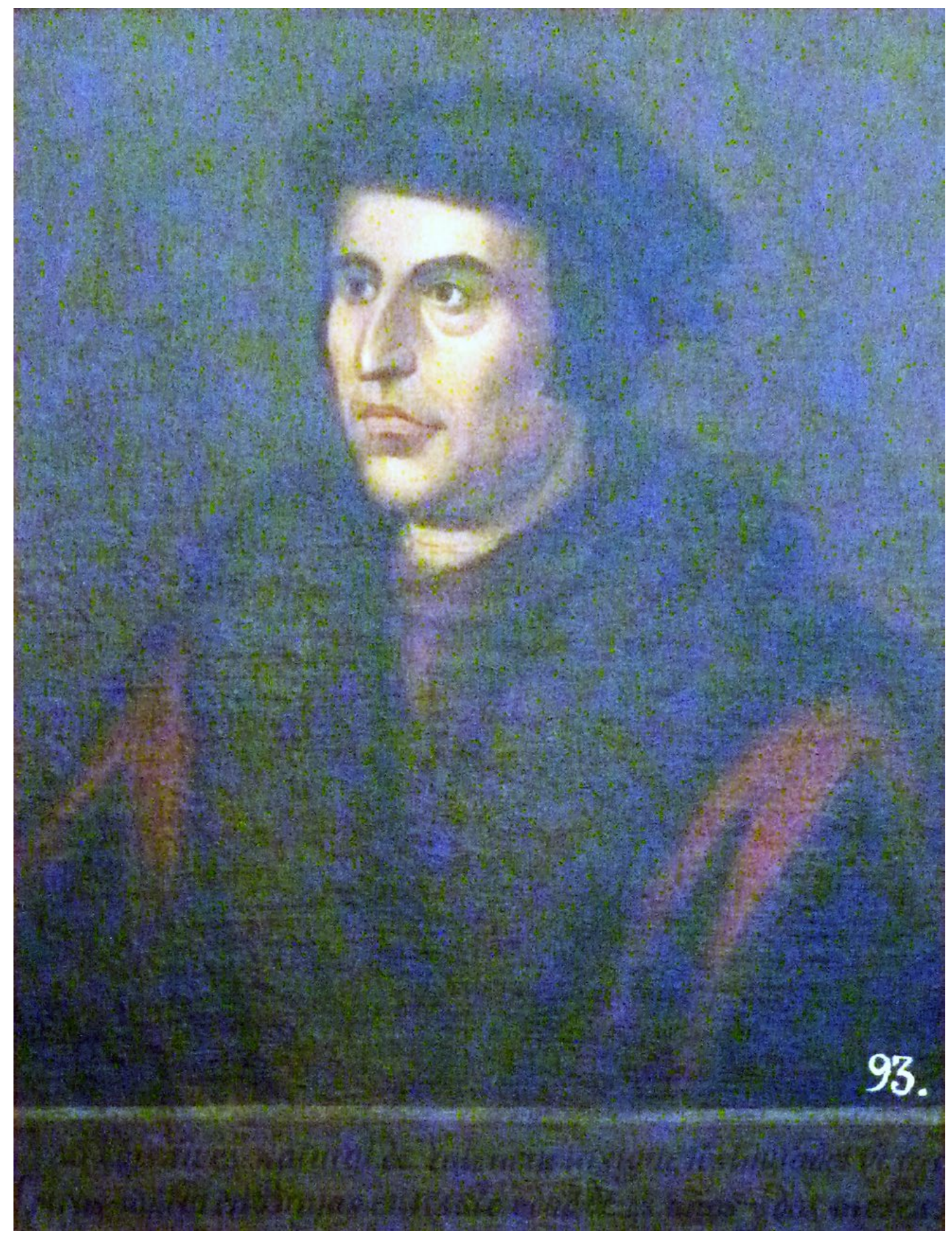

Fig. 5.5. Taller de Juan Ribalta, Juan Luis Vives, s. XVII, óleo sobre lienzo, Valencia, Museo de Bellas Artes. 


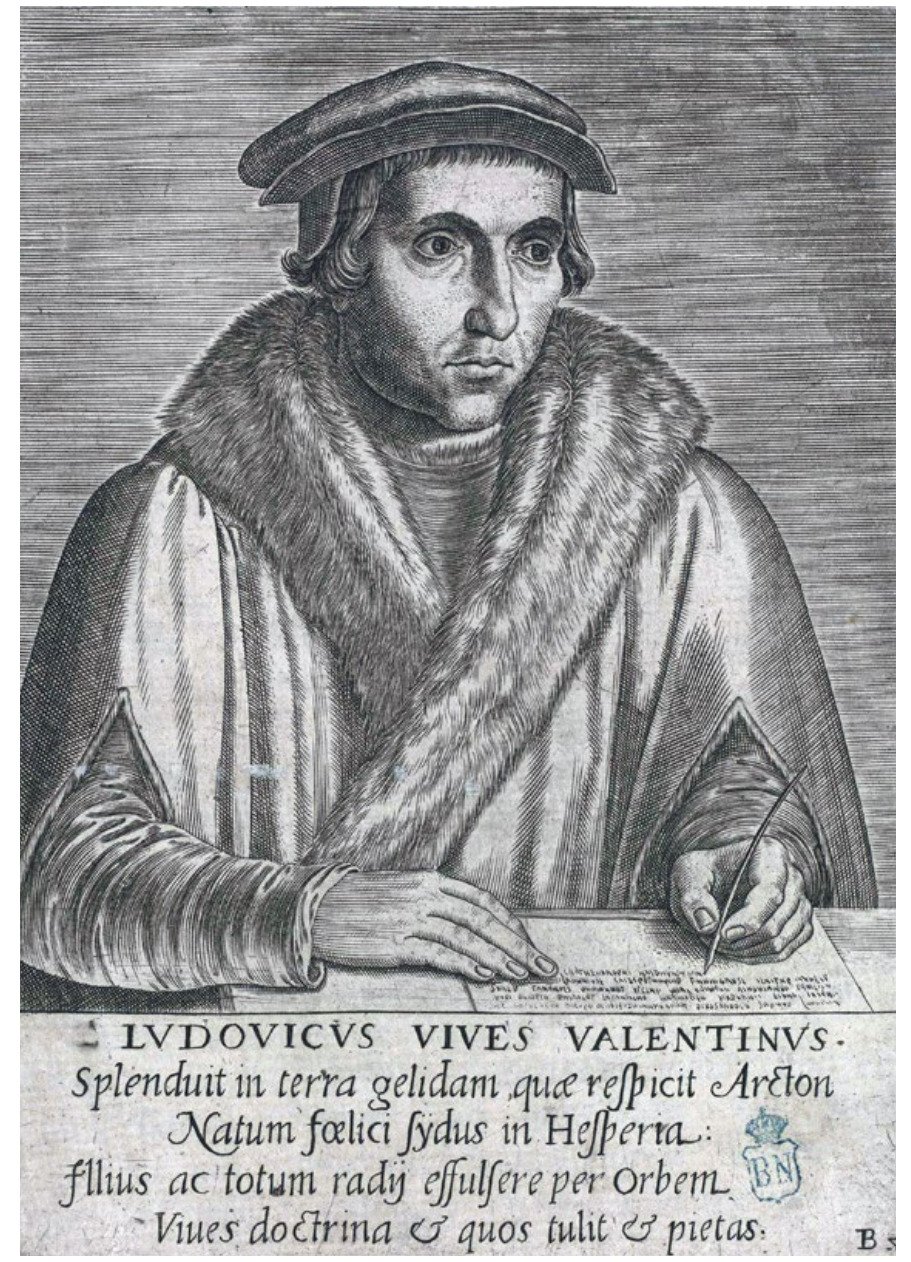

Fig. 5.6. Philippe Galle, Retrato de Luis Vives, finales del s.XVI, estampa, Madrid, Biblioteca Nacional de España.

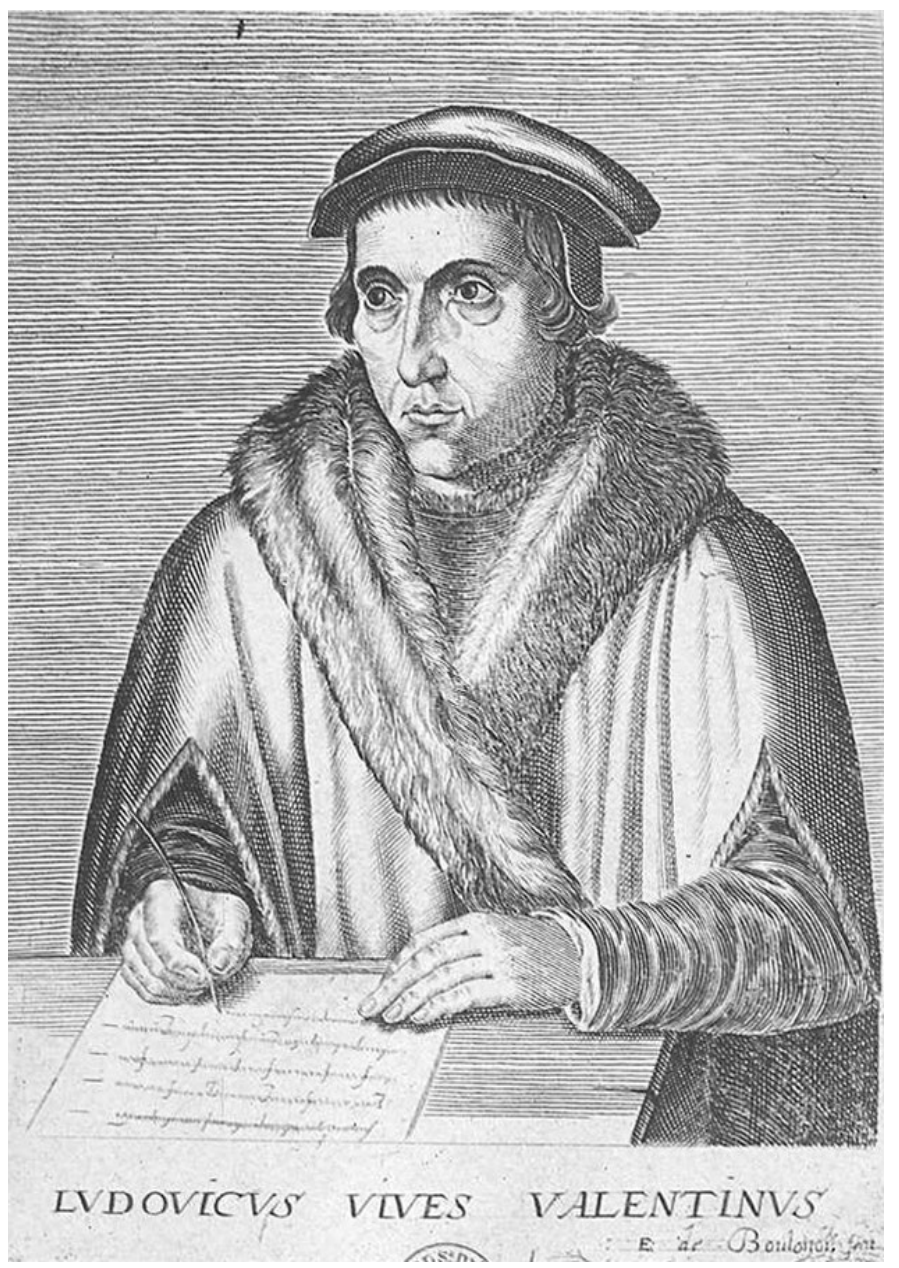

Fig. 5.7. Edme de Boulonois, Retrato de Juan Luis Vives, 1682, estampa, Madrid, Biblioteca Nacional de España. 
Siguiendo el prototipo se encuentra el retrato de Jaime Ferrús (1517 - 1594) o Ferruz [fig. 5.8]. Su biografía denota que protagonizó una larga andadura cultural como se alude al sostener un libro en la mano izquierda. De él resulta reseñable que fue catedrático de Símulas, también obtuvo el magisterio de lengua santa que regentó desde 1547 hasta 1553 y publicó las actas de los sínodos de 1578 y 1584 celebrados por san Juan de Ribera. ${ }^{104}$ La correspondiente inscripción simplifica los méritos profesionales y lo presenta como: «Don Jaime Ferrús, natural de Valencia, Catedrático de su Universidad, Teólogo y Orador en el Concilio de Trento, mui celebrado por su ciencia: uno de los primeros Pabordes de esta Catedral: murió en 1594.»

Juan Plaza (1520-1603) [fig. 5.9] fue una de las principales figuras de la botánica médica valenciana del siglo XVI. Llegó a ocupar la cátedra herbes de la Universidad de Valencia desde 1567 a 1583, dedicada a los medicamentos simples, es decir, a las plantas y productos de índole animal y mineral. Durante este periodo se fundó el que se considera el primer jardín botánico de España, un espacio donde lo novedoso era la valoración terapéutica de la historia natural. ${ }^{105}$ Cabe destacar que la inscripción nos habla de él como «Juan Plaza valenciano uno de los restauradores de la Botánica, el que exerció su Cátedra por más de 30 años y los viages por el Reyno le dieron tanto conocimiento de las plantas del mismo y tal fama que [quiso ci] tarle Clusio para enriquezer con sus luces la obra que trabajaba de los Europeos, murió en 1606.» El nombre de Clusio remite a su amigo y botánico holandés, Carolus Clusius o Charles de l'Écluse. Ambos mantenían contacto por correspondencia y el holandés manifestaba una gran consideración profesional hacia el varón ilustre, quien además gozaba de un notable

104 Pastor Fuster, Biblioteca valenciana..., pp. 159-169.

105 Sociedad Estatal para la Conmemoración de los Centenarios de Felipe II y Carlos V, Un príncipe del Renacimiento: Felipe II, un monarca y su época. Museo Nacional del Prado, 13 de octubre de 1998 - 10 de enero de 1999, (Sociedad Estatal para la Conmemoración de los Centenarios de Felipe II y Carlos V: Madrid, 1998), p. 484. 


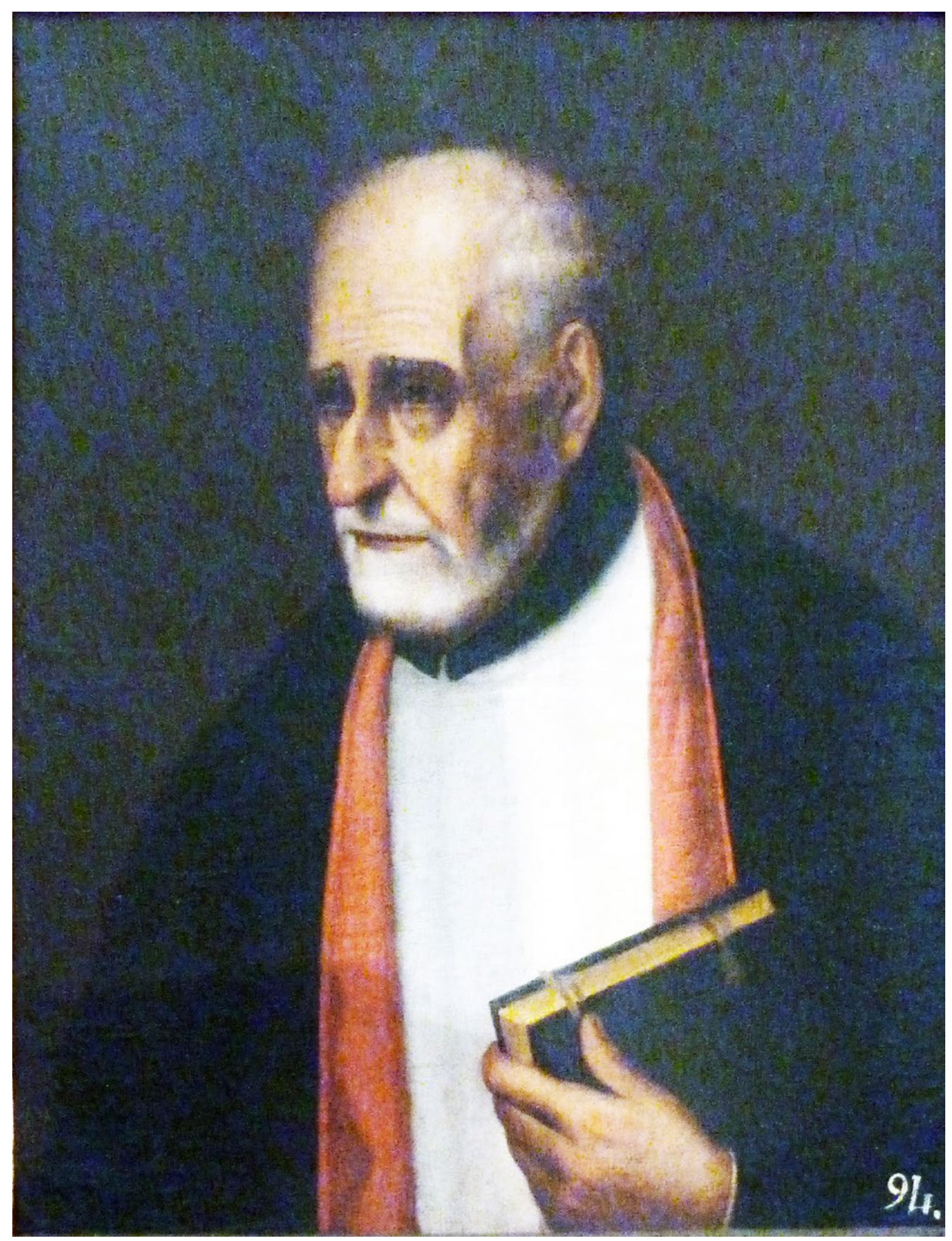

Fig. 5.8. Taller de Juan Ribalta, Jaime Ferrús, s. XVII, óleo sobre lienzo, Valencia, Museo de Bellas Artes. 


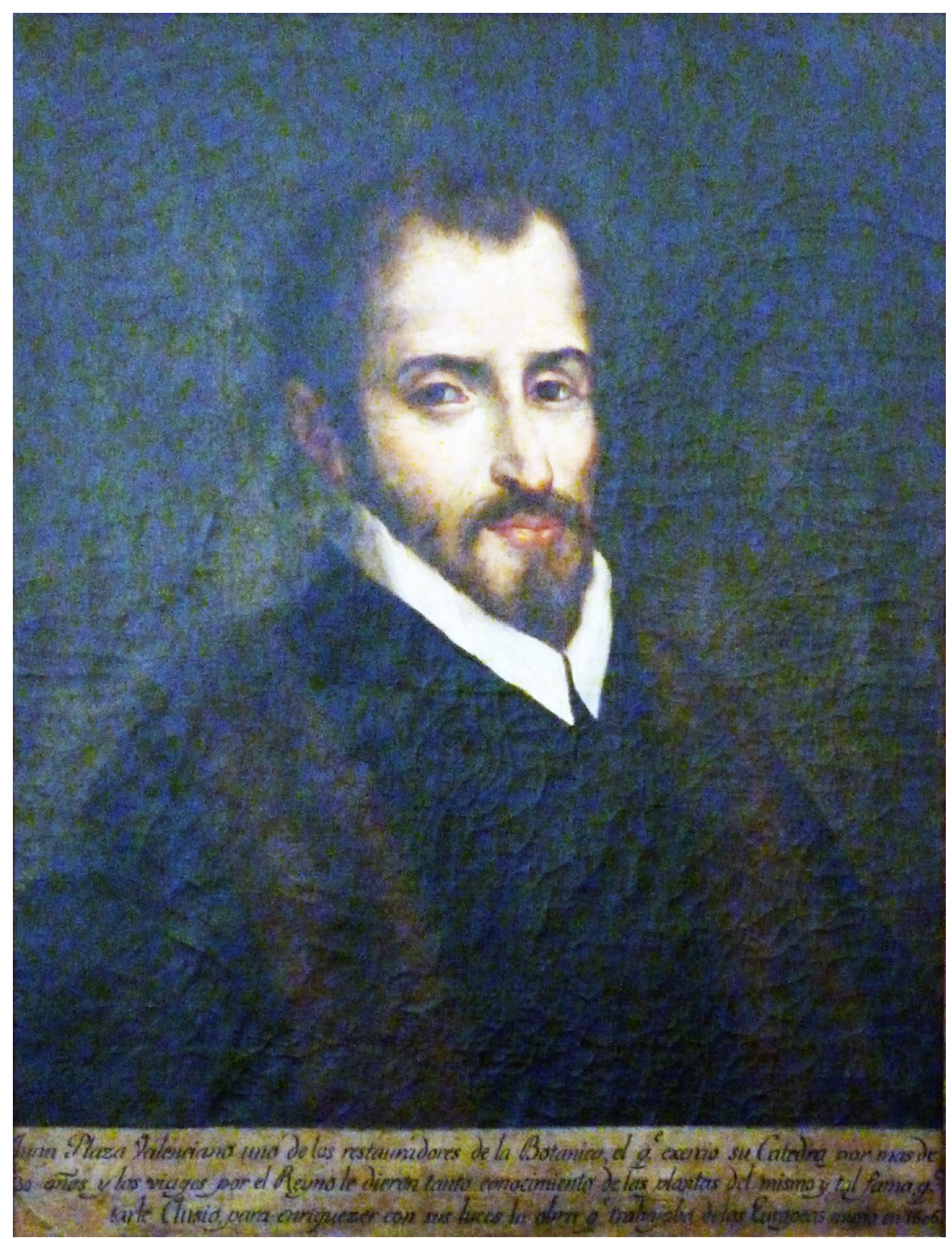

Fig. 5.9. Taller de Juan Ribalta, Juan Plaza, s. XVII, óleo sobre lienzo, Valencia, Museo de Bellas Artes. 
prestigio a nivel europeo. En efecto, Clusius elogió el trabajo de Plaza y lo citó en su estudio Rarium aliquot stirpium per Hispanias observatorum de 1576, pues gracias al valenciano se dieron a conocer numerosas especies de la flora autóctona del reino. Por ello, el retrato de Plaza es un vestigio que viene a recordar un tiempo de desarrollo científico y cultural.

En el área de medicina destacó el intelectual Luis Collado (ca. 1520-1578) [fig. 5.10]. A él se debe la consolidación de la escuela anatómica valenciana, seguidora del movimiento vesaliano, el cual diseccionaba cadáveres humanos y los utilizaba como fuente directa de conocimiento. ${ }^{106}$ Además de ello, el texto adjunto a la imagen del erudito señala uno de sus descubrimientos: «Luis Collado Catedrático de Medicina de esta Universidad, el Anatómico que descubrió el huesecito Estapeda, órgano del oído no conocido por los antiguos: murió en Valencia, su patria, en 1578.»

Como ya se ha podido apreciar, la galería de varones ilustres se nutre de la presencia de célebres personajes procedentes de distintos ámbitos, como la teología, las humanidades, la botánica o la medicina. Sin embargo, también tienen cabida los hombres sobresalientes en el ejercicio político y militar. Cumpliendo con este perfil se ha retratado a Federico Furió Ceriol (1527-1592) [fig. 5.11]. Sus principales datos biográficos se pueden extraer de las investigaciones publicadas sobre el testamento de este personaje. ${ }^{107}$ Se le presenta como un claro ejemplo del tópico renacentista que unifica el ejercicio de las armas y de las letras, por ello combinando su carrera militar con la formación académica se cree que pudo estudiar artes en Valencia hacia 1545-1546. También llegó a doctorarse en derecho canónico y civil y fue nombrado gentilhombre de la

106 Universitat de València, Cinc segles i un dia, (Fundació General de la Universitat de València: València, 2000), pp. 50-51.

107 Miguel Almenara Sebastià, 'Documentación testamentaria del humanista valenciano Fadrique Furió Ceriol (1527 - 1592)', Estudis: Revista de historia moderna, no. 21, 1995, pp. 89-112. 

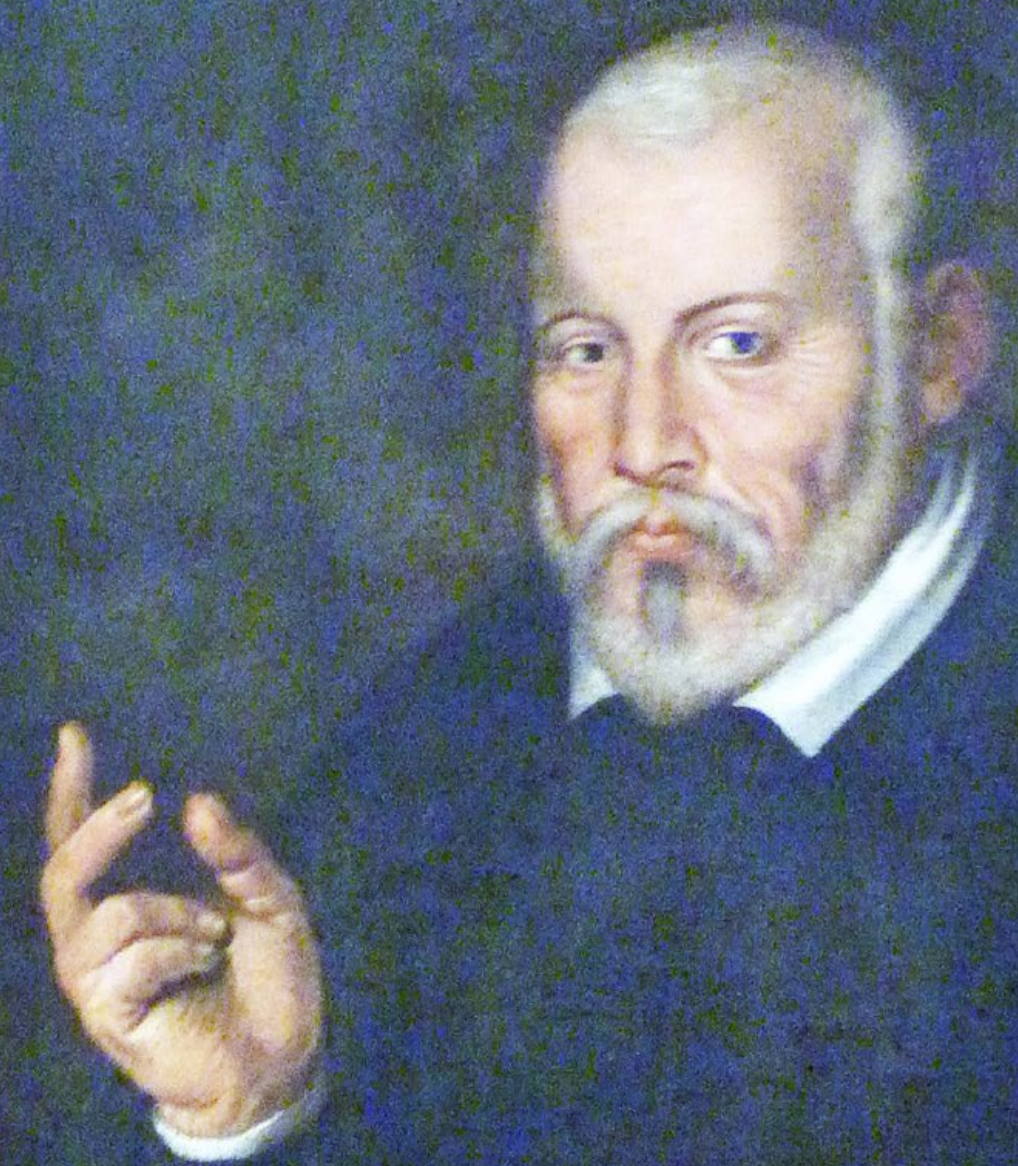

I02. this Callado Catcantico we unedicinase esta Pnivercidad, cl whitamico gite descubrio et huesecito Estapeda oreano del ol do no conocido pr. Los antiouos murio en Yala su patrin envs78.

Fig. 5.10. Taller de Juan Ribalta, Luis Collado, s. XVII, óleo sobre lienzo, Valencia, Museo de Bellas Artes. 


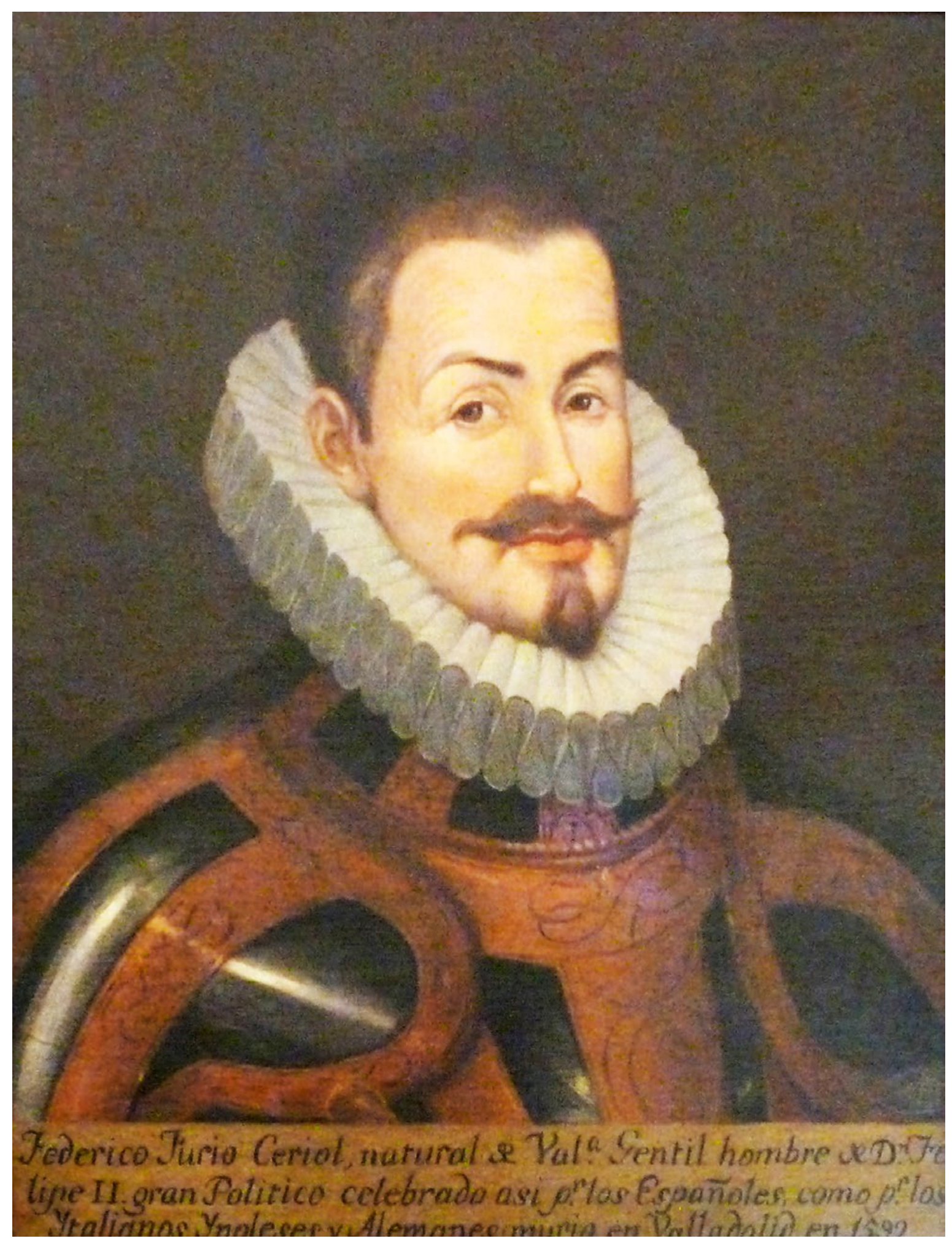

459

Fig. 5.11. Taller de Juan Ribalta, Federico Furió Ceriol, s. XVII, óleo sobre lienzo, Valencia, Museo de Bellas Artes. 
Casa del Rey de cuya corte formaba parte y seguía a excepción de la estancia que disfrutó en los Países Bajos (1574-1577). Su fallecimiento se produjo en Valladolid después que la corte se trasladase allí. Su retrato como varón ilustre enfatiza el perfil militar del efigiado, por ello va ataviado con una lujosa armadura y la firme golilla le enmarca el rostro. El correspondiente texto subraya su servicio al monarca: «Federico Furió Ceriol, natural de Valencia, Gentil hombre de Don Felipe II. Gran político celebrado así por los españoles como por los ytalianos, ynoleses y alemanes, murió en Valladolid en 1592.»

También se ha efigiado don Baltasar Marradas y Vich (15601638) [fig. 5.12], conde de Sellent y señor de la Baronía de Llaurí, por ser excelente en el ejercicio de las armas. Destacó por labrar una brillante carrera profesional, pues participó en la Guerra de los Treinta Años en Bohemia, Hungría y Alemania. Fernando II lo nombró conde del Sacro Imperio, fue su embajador en Munich, y se convirtió en el comandante supremo de Moravia y general de la corona de Bohemia. La imagen es la propia de un hombre de armas, donde llama la atención la medalla con la cruz de ocho puntas que luce sobre el pecho. Es la correspondiente a la orden de Malta, sus miembros también son conocidos como los Hospitalarios, por su misión, o caballeros de la orden de San Juan, en honor a su patrón. De hecho, la inscripción que acompaña al efigiado hace referencia a dicha institución. «Don Baltasar Marradas y Vich, nació en Valencia, fue cavallero de la Orden de San Juan, famoso General en servicio de los Emperadores Matías y Fernando 2으, Gentil hombre de [...]a y de su Conde de Gue. (sic)»

Iconográficamente, esta pintura se asemeja bastante a dos estampas conservadas en la Biblioteca Nacional. La primera es obra del pintor y grabador Aegidius Sadeler y se ha ubicado cronológicamente alrededor del siglo XVII [fig. 5.13]. Se ha optado por representar al caballero de busto dentro de un me- 


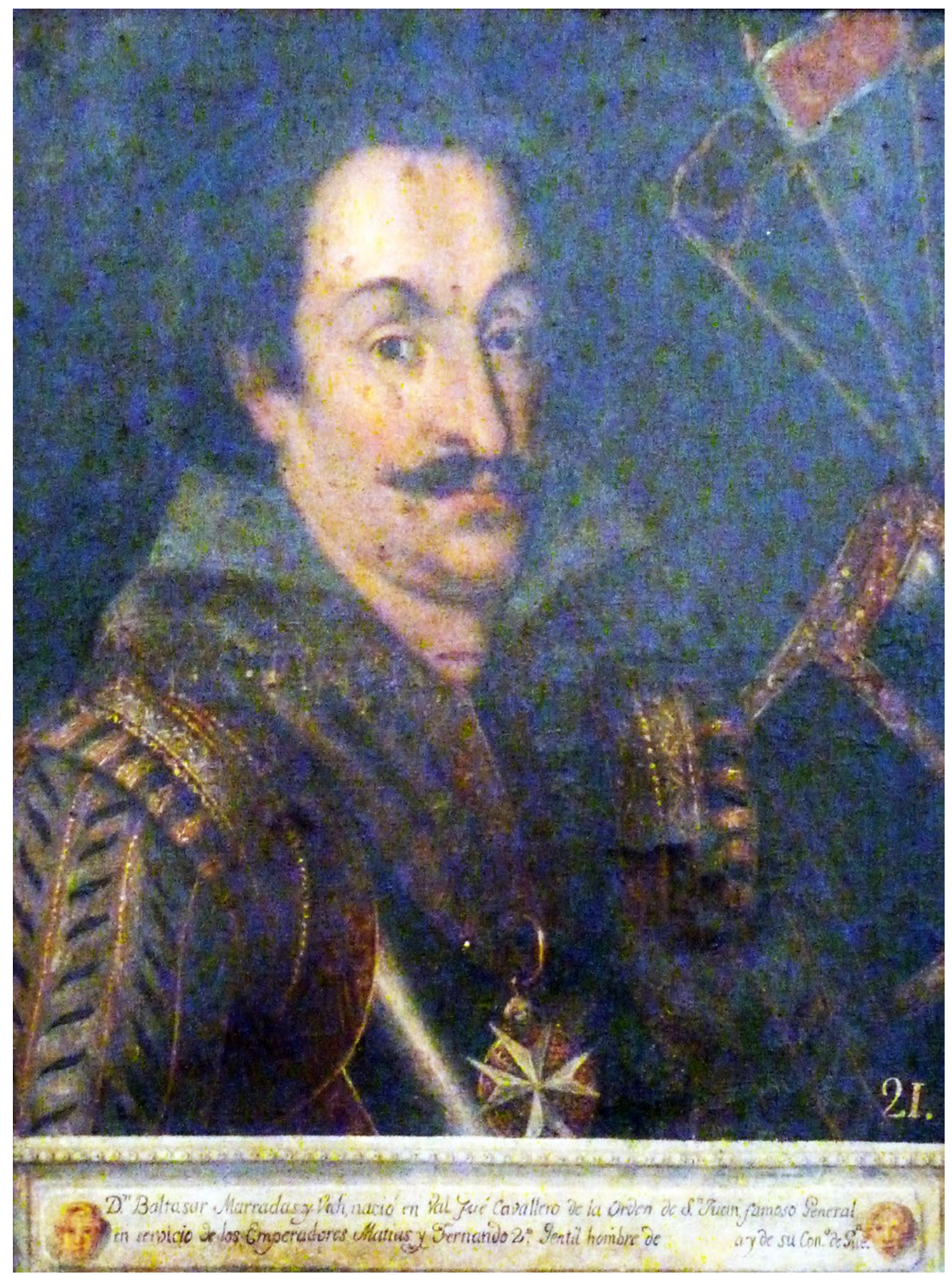

461

Fig. 5.12. Taller de Juan Ribalta, Baltasar Marradas y Vich, s. XVII, óleo sobre lienzo, Valencia, Museo de Bellas Artes. 


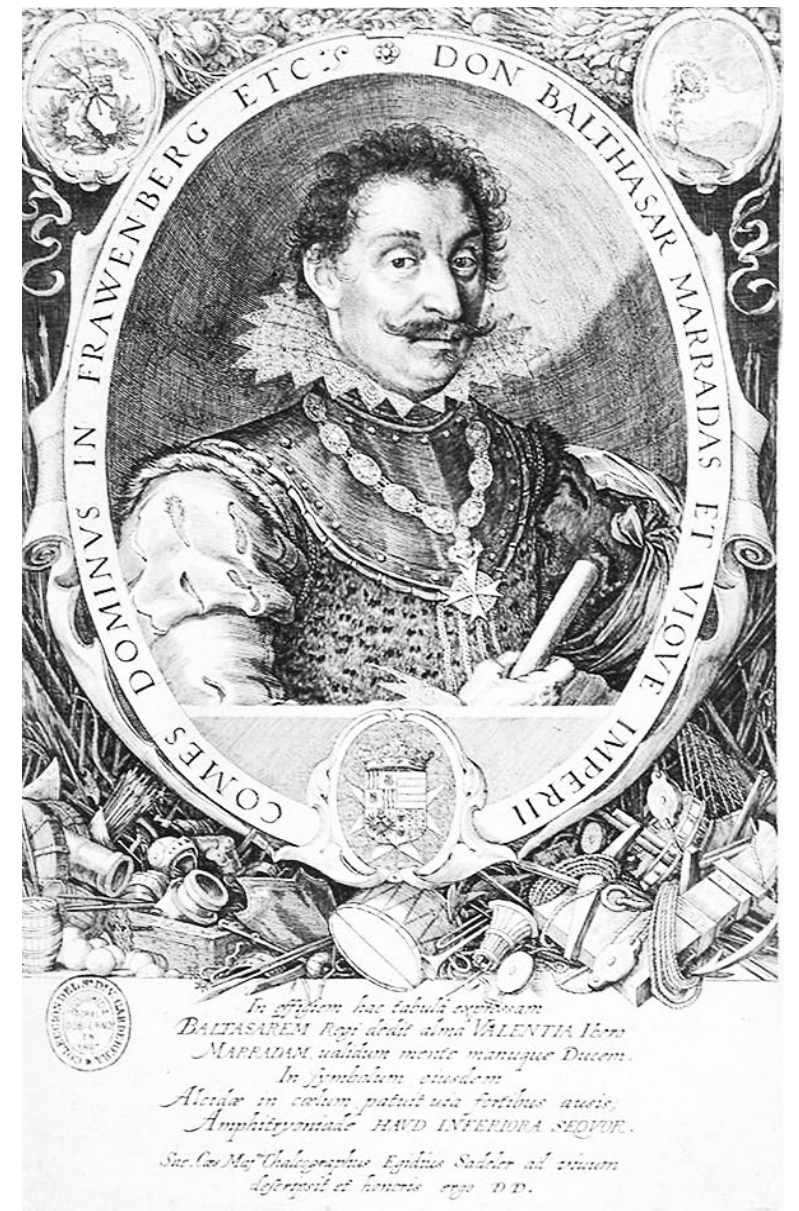

462

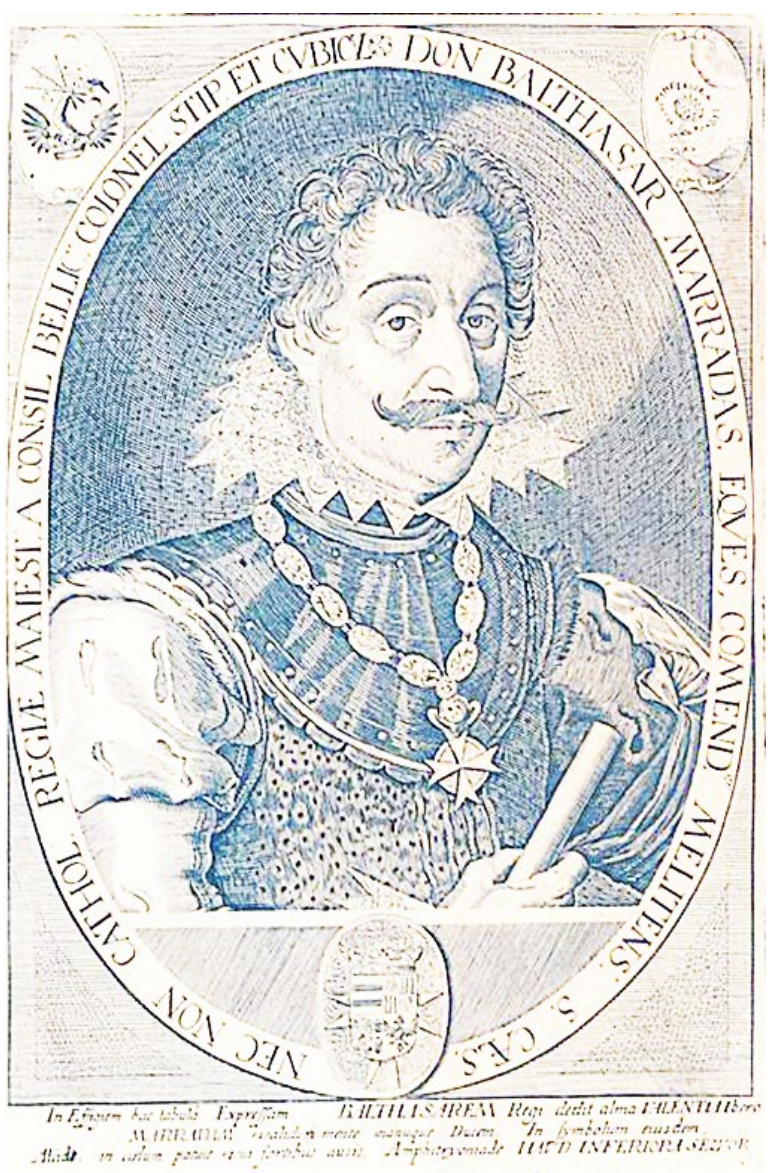

Fig. 5.13. Aegidius Sadeler, Retrato de Baltasar Marradas Vich, s. XVII, estampa, Madrid, Biblioteca Nacional de España.
Fig.5.14. Michael Caspar Lundorp, Johann Theobald Schönwette y Erasmus Kempfer, Retrato de Baltasar Marradas Vich, 1627, estampa, Madrid, Biblioteca Nacional de España. 
dallón con una inscripción identificativa que se inicia desde la derecha y presenta a: «DON BALTHASAR MARRADAS ET VIQUE IMPERII COMES DOMINUS IN FRAWENBERG ETC.»

La filacteria se ha interrumpido en la zona central inferior por el escudo, en el cual distinguimos la heráldica propia de las familias Marradas y Vich. En este caso, sobre la indumentaria del varón también resalta la cruz dela orden y lleva un pequeño bastón de mando, en señal de sus responsabilidades militares. Bajo el retrato se ha adjuntado un texto latino que presenta al efigiado y concretamente dice:

In effigiem hac tabula expressam

BALTASAREM Regi dedit alma VALENTIA Ibero MARRADAM validum mente manuque Ducem.

In symbolum eiusdem

Alcida in coelum patuit via fortibus ausis, Amphitryoniade HAUD INFERIORA SEQUOR.

La segunda ilustración, de 1627, es asociada a la autoría de Michael Caspar Lundorp, Johann Theobald Schönwette y Erasmus Kempfer [fig. 5.14]. Su iconografía es idéntica a la que acabamos de presentar. A lo largo del óvalo se dispone un extenso escrito que presenta a: «DON BALTHASAR MARRADAS, EQUES, COMEND, MELITENS: S. CAES. NEC. NON CATHOL: REGIAE MAIEST: A CONSIL BELLIC: COLONEL: STIP ET CUBICU».

Las estampas de la Biblioteca Nacional son la imagen de un valiente varón valenciano que cosechó grandes éxitos en su carrera militar y además, muestran conexiones visuales con el lienzo de La Murta, ello nos permite conocer cuál fue la imagen más difundida y conocida de este caballero por la sociedad. Además, no debemos obviar que don Baltasar Marradas era miembro de la familia Vich, linaje de aquel que encomendó la serie y no debió ser casualidad que un pariente del propio don Diego de Vich fuese uno de los privilegiados al formar parte de este grupo representativo de la élite cultural. 
De Jaime Juan Falcó Segura (1522 - 1594) [fig. 5.15] se ha querido remarcar su vinculación a la orden de Montesa: «Frei Don Jaime Juan Falcó, natural de Valencia, primer lugarteniente general de la Orden de Montesa, insigne matemático y excelente poeta latino: murió en Madrid en 31 de agosto de 1594.» Tuvo un hijo también llamado Jaime Juan que heredó la consideración de la orden. Sin embargo, como recoge Justo Pastor, decidió convertirse en dominico en ingresar en el Real Convento de Valencia en 1581. ${ }^{108}$

Otras imágenes igualmente llegaron a la institución valenciana en 1823 pero sin embargo, no han seguido el patrón de representación estipulado, puesto que no se han incluido las inscripciones explicativas en la parte inferior que permiten tener los principales datos biográficos del personaje y conocer la razón de la admiración que genera. En esta situación se encuentran las efigies de Alejandro VI, Fernando I, Honorato Juan y Gaspar Sapena. Quizá se puede llegar a comprender que 464 las imágenes del pontífice y del monarca no incluyan la cartela como sucede con el resto de obras. La magnitud de tales personalidades era superior al resto de miembros de la serie y su condición permitiría tomar estas licencias. Probablemente, al contemplar el retrato tanto el papa como el rey fuesen inmediatamente reconocidos y la justificación de su pertenencia al grupo de varones insignes no resultase necesaria. Sin embargo, de momento se escapa la explicación a que Honorato Juan tan sólo sea identificado por el nombre, sin ningún tipo de referencia a su trayectoria profesional, y que la imagen de Gaspar Sapena tampoco incluya ninguna referencia escrita.

El retrato de Rodrigo de Borja (1431 - 1503), siendo ya Alejandro VI (1492-1503) [fig. 5.16], debe ser una copia de la imagen que se encuentra en el episcopologio valenciano realizada a finales del siglo XVI por el taller de Juan de Juanes visto en el capítulo anterior (véase la imagen 4.2). Al comparar ambas 108 Los datos biográficos sobre Jaime Juan Falcó, hijo de Jaime Juan Falcó Segura, retratado para la serie de La Murta se pueden consultar en Pastor Fuster, Biblioteca valenciana..., pp. 242-243. 


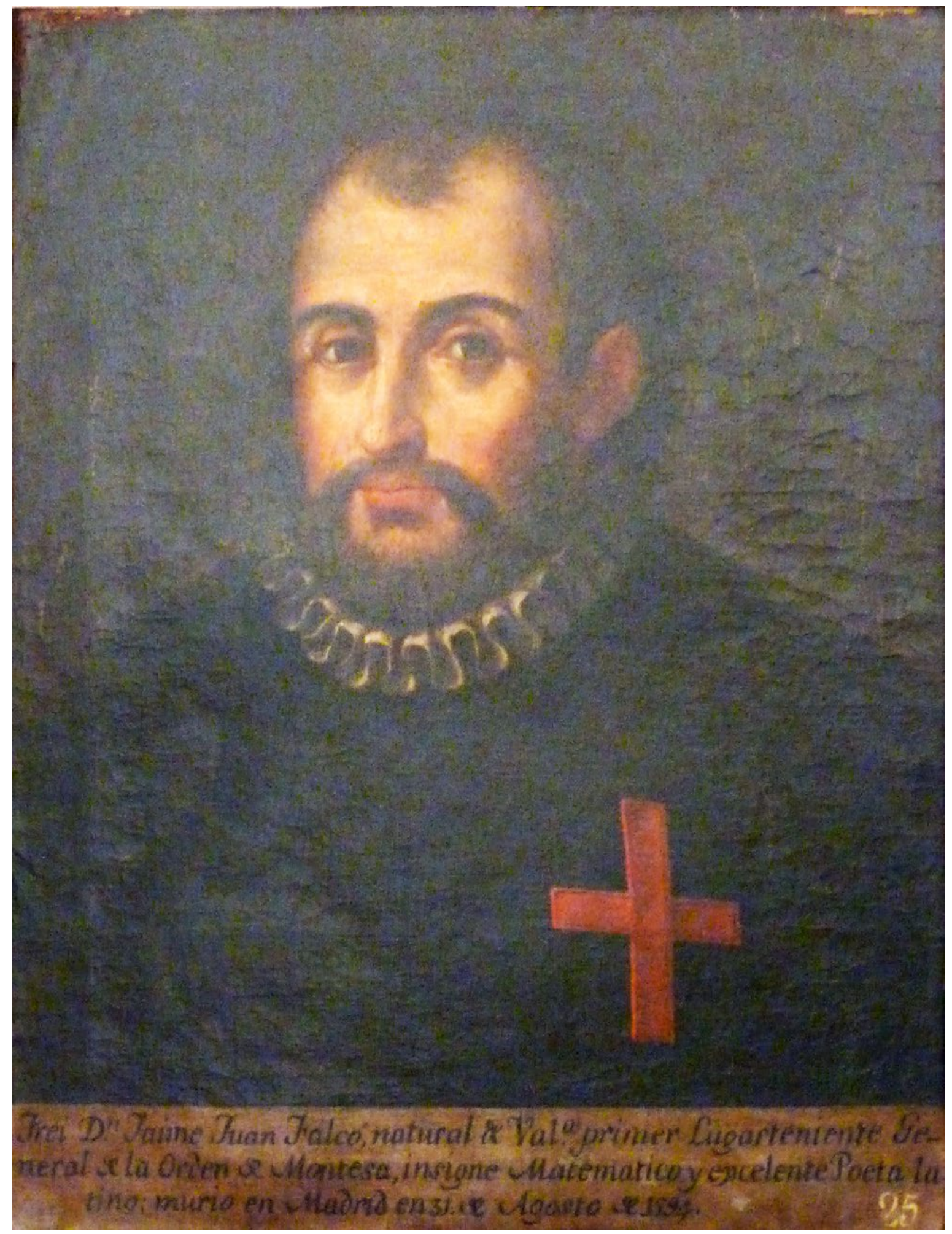

Fig. 5.15. Taller de Juan Ribalta, Jaime Juan Falcó, s. XVII, óleo sobre lienzo, Valencia, Museo de Bellas Artes. 


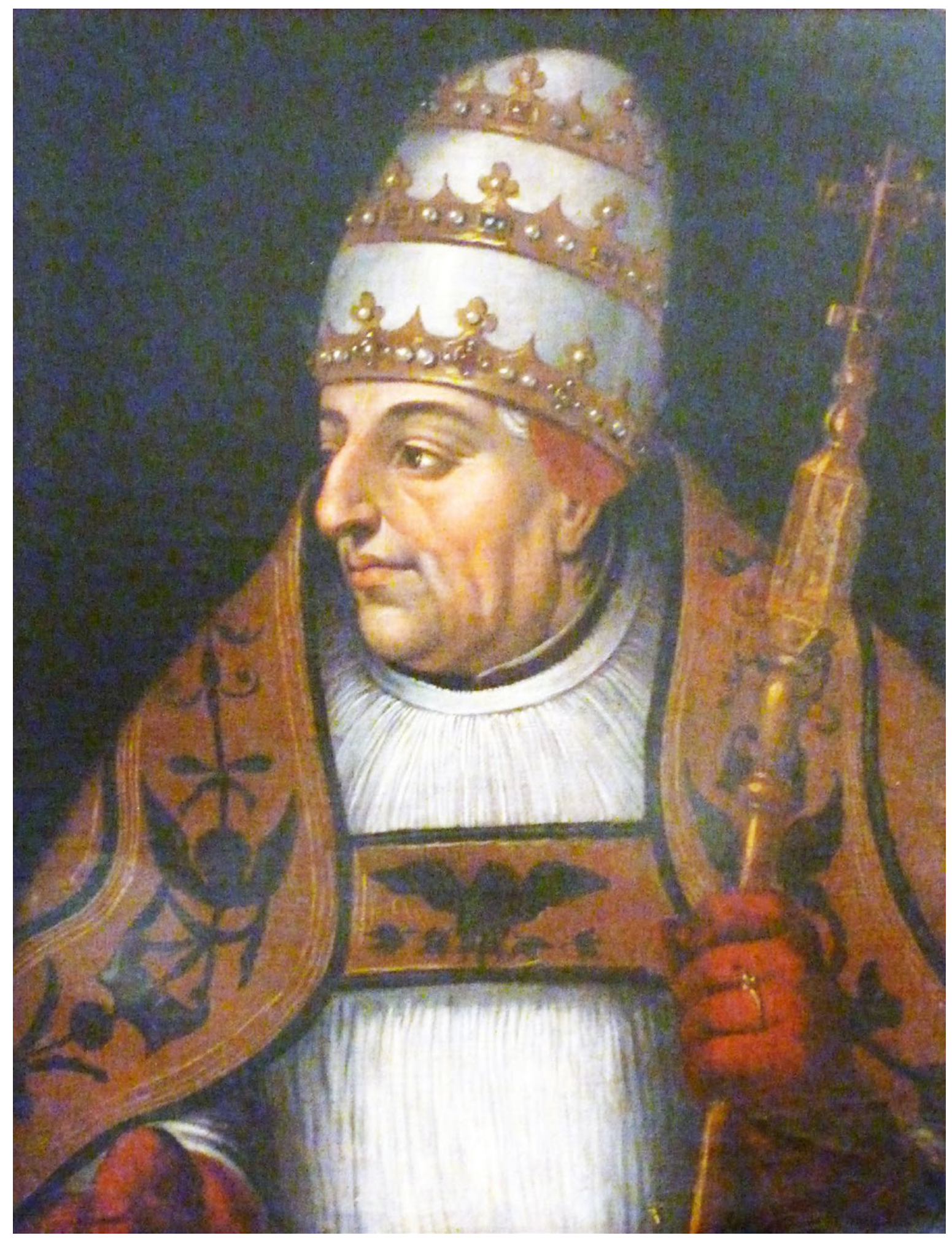

Fig. 5.16. Taller de Juan Ribalta, Alejandro VI, s. XVII, óleo sobre lienzo, Valencia, Museo de Bellas Artes. 
obras se aprecia la idéntica disposición del retratado, parcialmente ladeado permitiendo observar tres cuartas partes de su rostro y luciendo la tiara papal. Respecto a la capa pluvial que viste, ésta es mucho más ostentosa en la efigie de la sede valentina. En ese ejemplo también se mantiene la breve descripción en latín sobre el efigiado que en el lienzo de La Murta se ha decidido prescindir totalmente de él.

El retrato del rey de Nápoles, Fernando I [fig. 5.17] presenta una iconografía que casa perfectamente con la efigie procedente del monasterio de san Miguel de los Reyes analizada anteriormente (véase la fig. 3.31). De hecho, son totalmente coincidentes los rasgos faciales, la orientación y disposición en perfil del monarca así como el collar ornamentado con jeroglíficos relativos a sus ascendientes y el armiño. Es probable que la imagen de cuerpo entero actuase de referente para el retrato realizado por el taller de Juan Ribalta, pues la primera es mucho más explícita en el significado intrínseco del collar y contextualiza la disposición de perfil del rey y la dirección de su mirada en una escena que representa la entrega de la constituciones de la orden de San Miguel. La efigie perteneciente a La Murta parece que tan sólo haya reproducido literalmente el busto del monarca napolitano.

El humanista don Honorato Juan (1507 - 1566) [fig. 5.18] llegó a ser obispo de Osma pero sobre todo se le reconoce por ser el instructor del futuro Felipe II y su hijo, el príncipe don Carlos. Así pues, en la Biblioteca Nacional se puede consultar una estampa que retrata al intelectual en su condición de preceptor del príncipe [fig. 5.19]. Honorato Juan se ha efigiado en el interior de una estancia con un ventanal en la zona trasera que abre el espacio al exterior. Aparece vestido con la indumentaria masculina propia del siglo XVI, por ello lleva el sombrero de fieltro sin pluma, una fina camisa blanca bajo el jubón, gregüescos y capa. La representación procedente de La Murta es una imagen de busto pero guarda bastante fidelidad a la estampa en cuanto a la postura del humanista y los ropajes se 


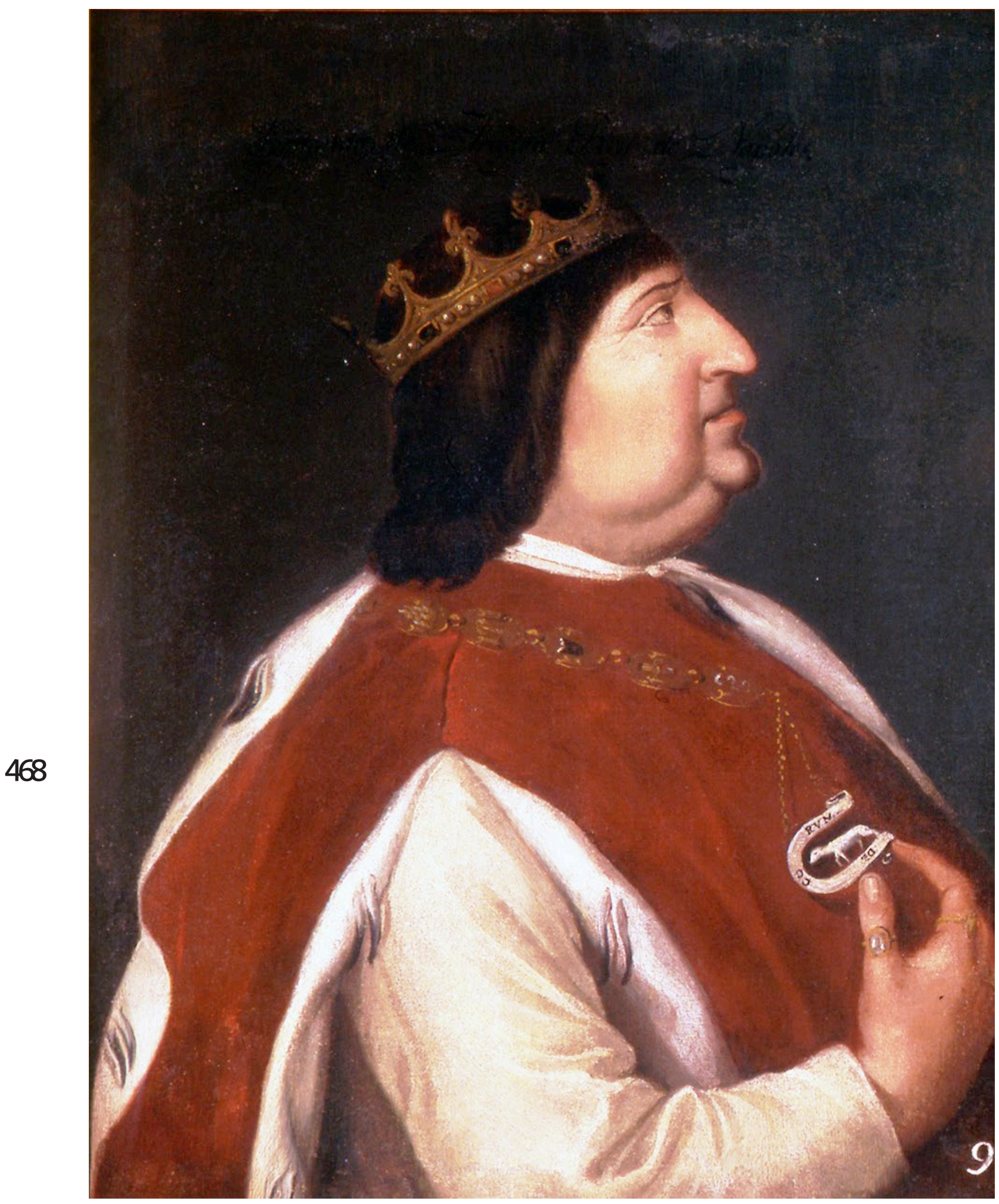

Fig. 5.17. Taller de Juan Ribalta, Fernando I, s. XVII, óleo sobre lienzo, Valencia, Museo de Bellas Artes. 


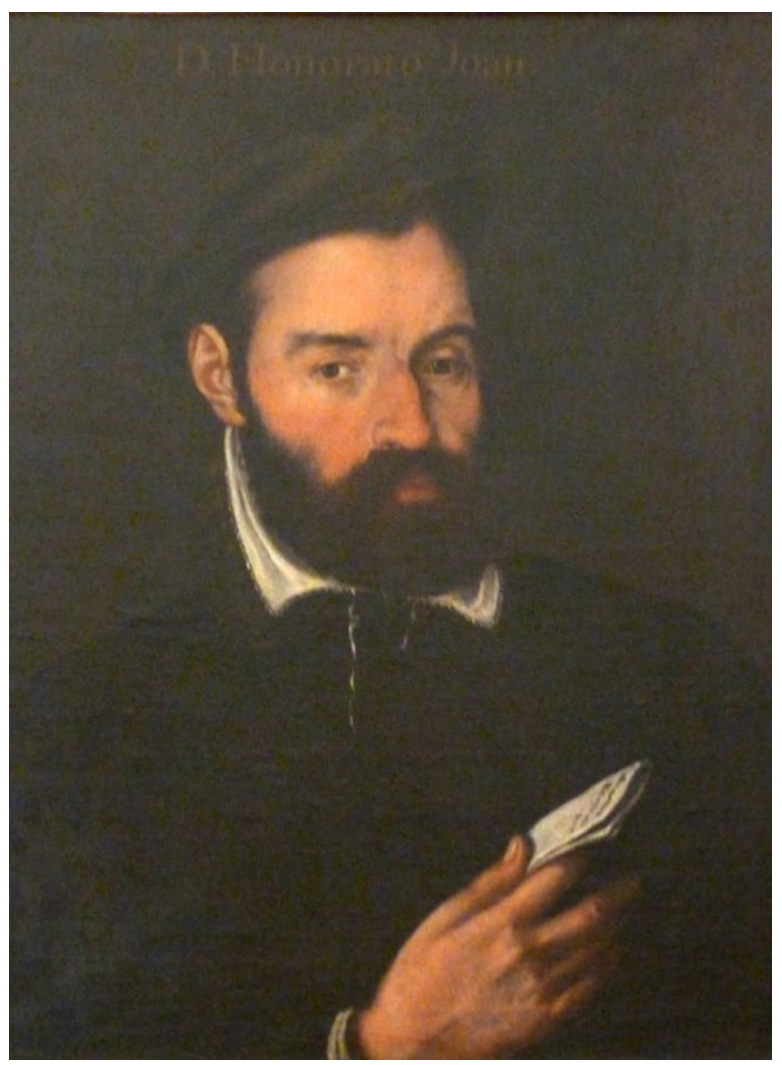

Fig. 5.18. Taller de Juan Ribalta, Honorato Juan, s. XVII, óleo sobre lienzo, Valencia, Museo de Bellas Artes.

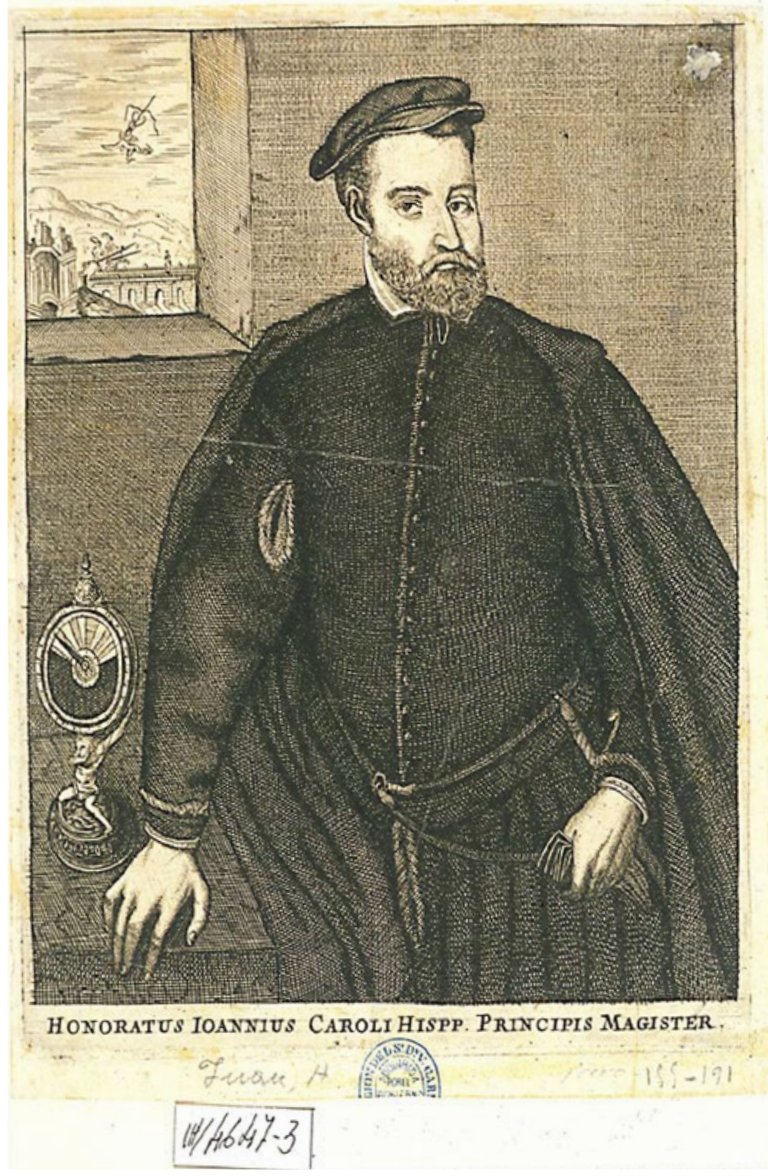

Fig. 5.19. Anónimo, Retrato de Honorato Juan, cronología sin determinar, estampa, Madrid, Biblioteca Nacional de España. 
refieren. En esta ocasión, su labor docente ha quedado reflejada mediante el documento plegado que sostiene con la mano derecha.

De Gaspar Sapena [5.20] ha sido complicado encontrar información biográfica que aporte una visión completa del retratado. Las referencias que se tienen sobre él son en el relato de un conflicto bélico, inmerso en una obra sobre la historia de España publicada en el siglo XIX, ${ }^{109}$ por lo cual se conoce que fue un hombre dedicado a la carrera militar, al servicio de Felipe II y quien participó en las guerras acaecidas en Flandes. Concretamente, se le presenta como un varón prudente, partidario de una retirada del enemigo antes que llevar a cabo un ataque. ${ }^{110}$ En consonancia a ello, el insigne Sapena se ha retratado vestido con armadura y una golilla que enmarca su rostro, una solución bastante similar a la efigie de Baltasar Marradas. Ambos son los dos únicos personajes representados como hombres dedicados al ejercicio de la guerra.

Del conjunto pictórico, tres retratos llegaron a la Academia más tarde, por esta razón Vergara no los menciona al redactar el certificado de depósito. En esas circunstancias se encuentran las representaciones de Pedro Juan Núñez, Gaspar Aguilar y José Esteve, de este último no se ha encontrado el correspondiente retrato. Por el momento, se desconocen las causas que motivaron que la imagen correspondiente a Pedro Juan Núñez [fig. 5.21] ingresase en la Academia después que la mayoría de obras. Tampoco se puede conocer el momento exacto y la razón por la cual terminó en la institución valenciana. Tan sólo se deduce con total seguridad que el lienzo ya se había reunido con las piezas restantes de la galería antes del 1 de junio 109 José Manuel Miñana, Continuación de la Historia General de España, Tomo octavo, (Madrid, 1828).

110 El fragmento que muestra la prudencia de este soldado lo describe del siguiente modo: «hombre de grande experiencia, y fue de dictáment que se debía primero explorar los designios del enemigo, tentar sus fuerzas, y obligarle con astucia á retirarse, sin aventurar la fortuna de una batalla.» en Miñana, Continuación de la Historia..., p. 540. 


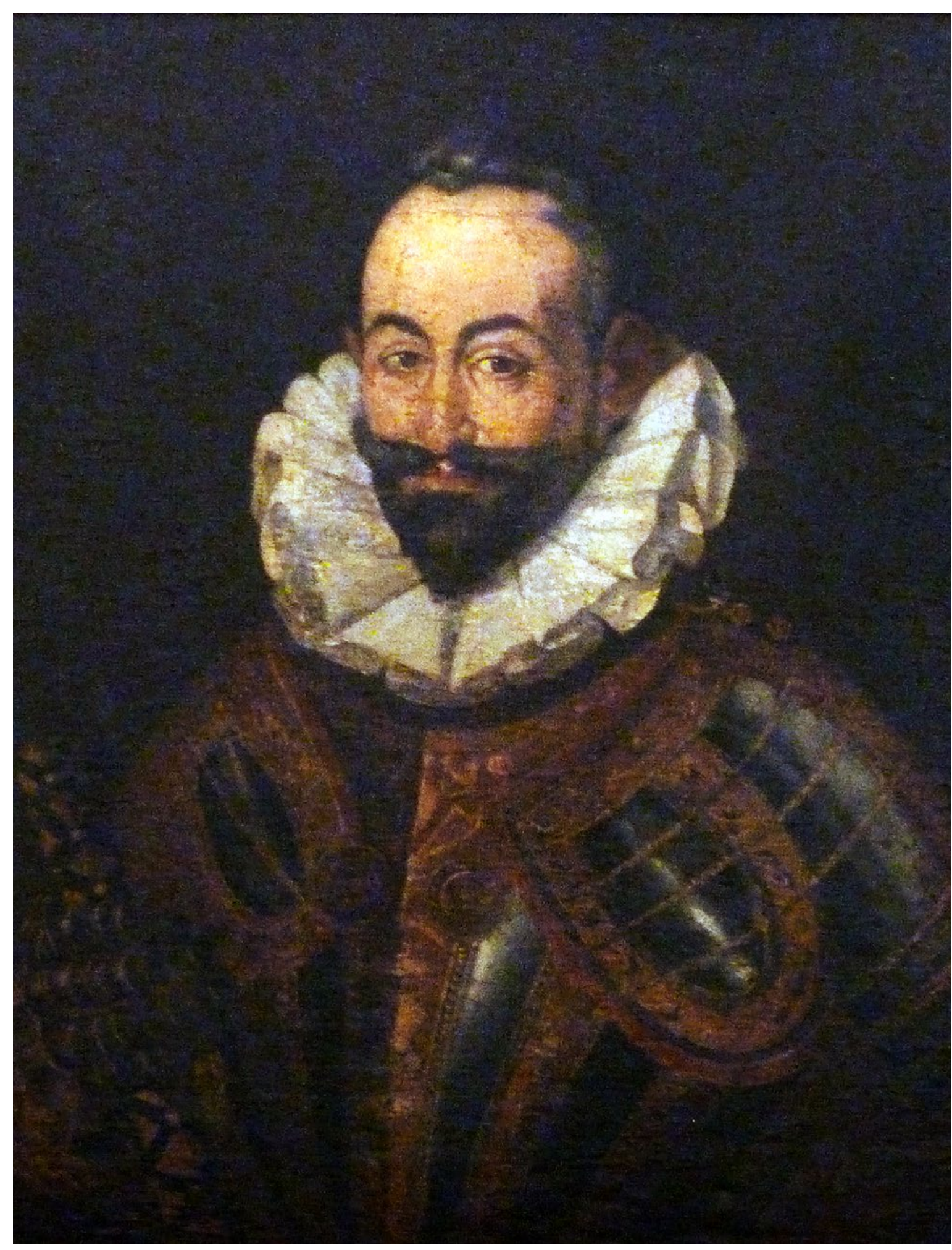

Fig. 5.20. Taller de Juan Ribalta, Gaspar Sapena, s. XVII, óleo sobre lienzo, Valencia, Museo de Bellas Artes. 


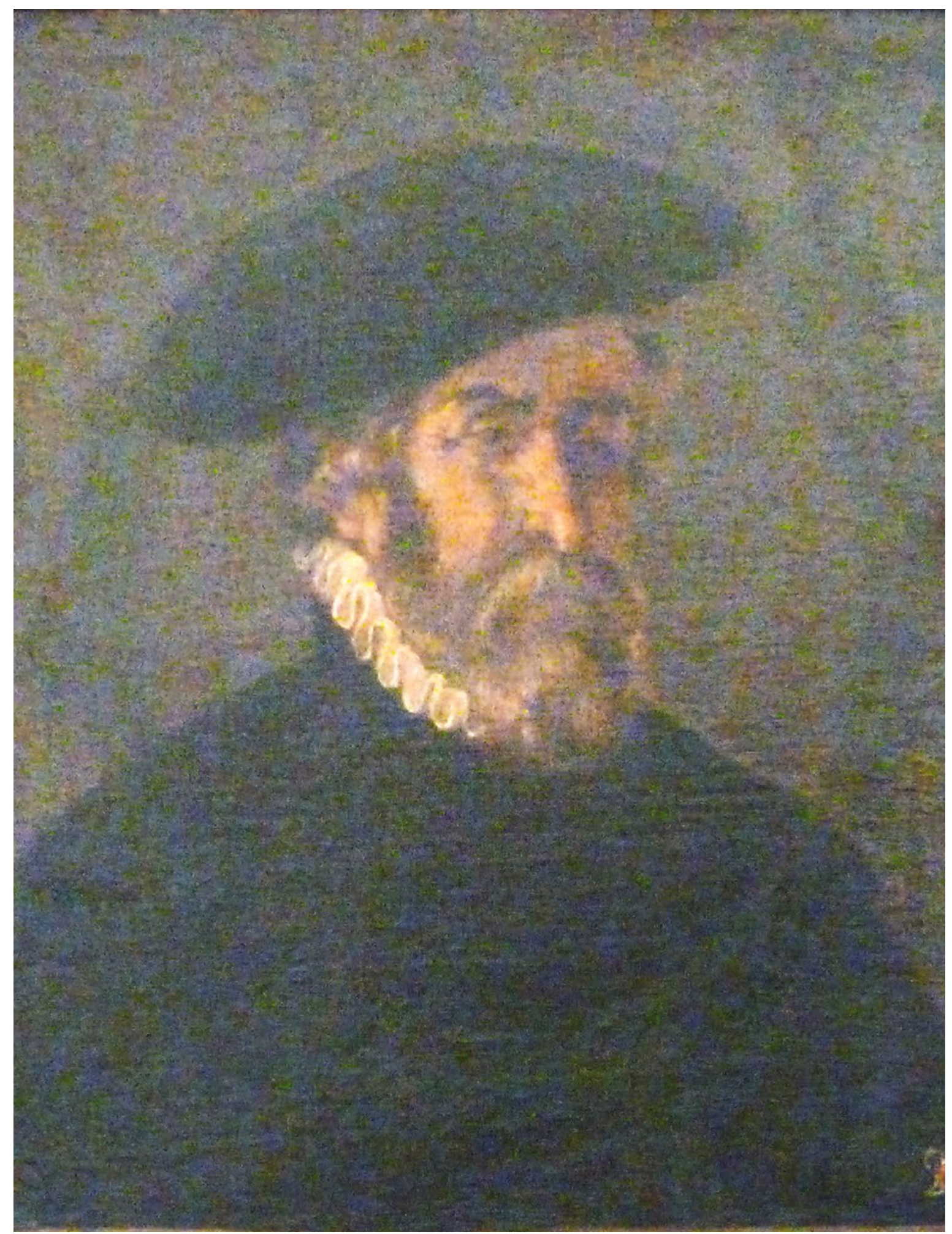

Fig. 5.21. Taller de Juan Ribalta, Pedro Juan Núñez, s. XVII, óleo sobre lienzo, Valencia, Museo de Bellas Artes. 
de 1842, puesto que el retrato de un valenciano ilustre aparece inventariado con el número veinte, cifra que coincide con la numeración de esta pintura. Así pues, al consultar dicho documento en el archivo se concluye que se trataba de la efigie de este varón y que junto con las representaciones de Pedro Juan Trilles o Baltasar Marradas, entre otros, estaba ubicada en la sala de juntas. Siguiendo el prototipo imperante para la serie, el escrito pone de manifiesto los logros académicos del intelectual: «Don Pedro Juan Nuñez natural de Valencia, Catedrático de su Universidad, de la Zaragoza y Barcelona, insigne Antiguario, [...]etor[...] Príncipe de los Filósofos Peripatéticos [...] murió en 12 de marzo de 1602, de edad cerca de 84 años.»

A diferencia de los anteriores, el retrato de Gaspar Aguilar (1561 -1623) sosteniendo un libro de Virgilio [fig. 5.22] se depositó en la Academia tan sólo unos meses después, tras encontrarlo entre las pertenencias de don Agustín Ricart. Así lo constata el acta redactada al celebrar la Junta Ordinaria el día 7 de marzo de 1824:

El Señor Académico de Honor Don Francisco Xavier Borrull hizo presente a la Junta que conforma a la comisión que juntamente con el Secretario de la Real Academia se le había conferido, habían pasado al Quarto de Don Agustín Ricart, Director que fue del Real Seminario de Nobles de esta Ciudad y que entre sus muebles sólo hallaron el retrato de Gaspar Aguilar uno de los de la colección del Convento de la Murta. La Junta quedó entendida de ello y dio las gracias a dichos Señores por el desempeño de este cometido y seguidamente encargó a los Señores Profesores se sirvan cuidar si se halla algún otro retrato de la mencionada colección. ${ }^{111}$

Por último, cabe mencionar a Jerónimo Funes y Muñoz [fig. 5.23] por ser otro de los varones célebres mencionados por Orellana y Vergara, aunque concretamente se refirieron a él como Jerónimo Muñoz. La efigie, a diferencia del resto, se catalogó en el inventario de 1842, situándola en el archivo de 111 ARABASC: Libro de Actas de la Real Academia de San Carlos. Años 1821-1827, s/f, junta ordinaria en 7 de marzo de 1824. 


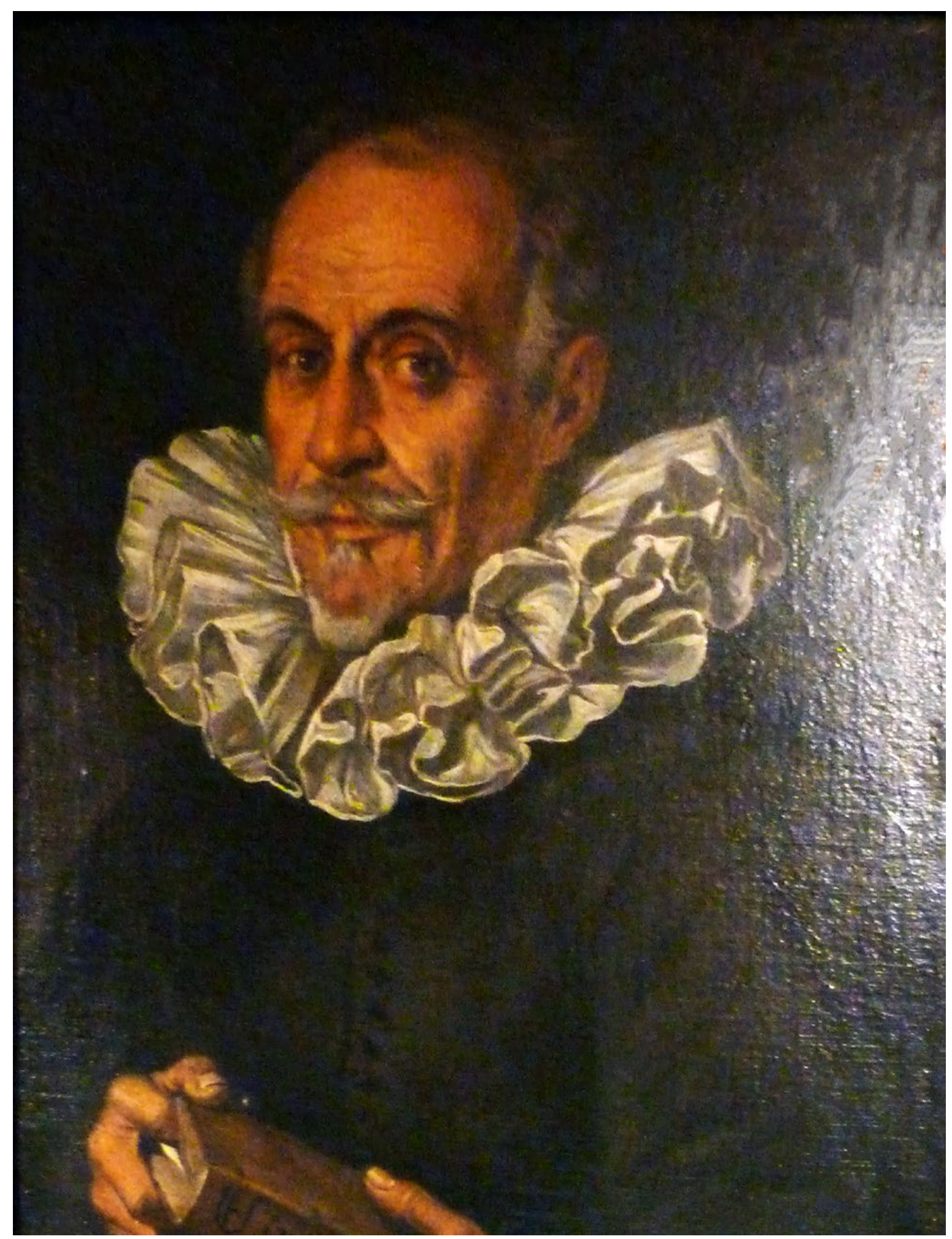

Fig. 5.22. Taller de Juan Ribalta, Gaspar Aguilar, s. XVII, óleo sobre lienzo, Valencia, Museo de Bellas Artes. 


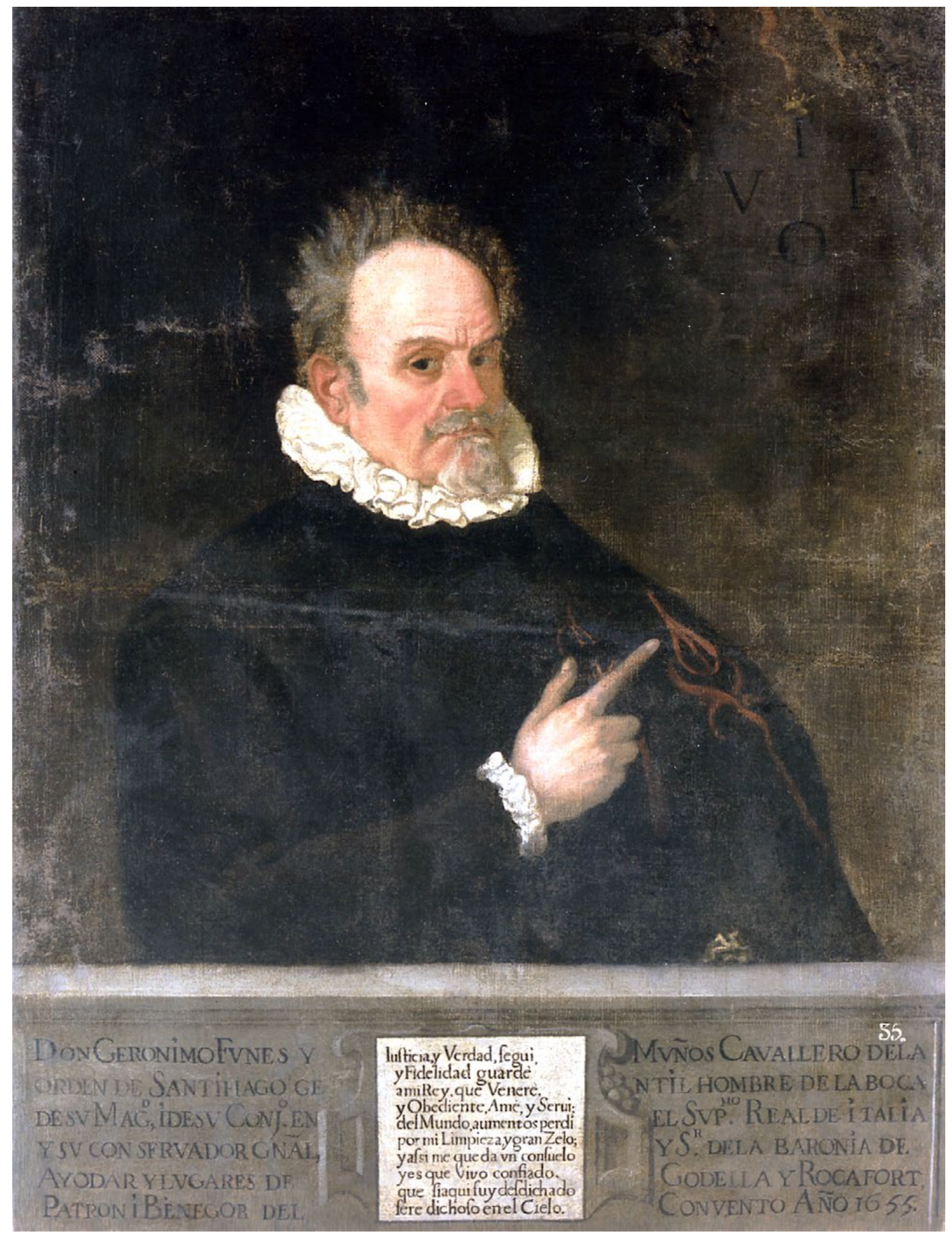

475

Fig. 5.23. Juan Sariñena, Jerónimo Funes y Muñoz, s. XVII, óleo sobre lienzo, Valencia, Museo de Bellas Artes. 
la Academia e identificándola como obra se Sariñena del siguiente modo: «35. Retrato de Gerónimo Muñoz, longitud de 4 palmos y 3 dedos, latitud de 3 palmos y 6 dedos. Autor Zariñena.»112

Pese a que esta pintura es de mayores dimensiones que las anteriores sí que se respeta, a grandes rasgos, la tipología de retrato. Por ello, el varón ha sido representado de busto, se ha vestido con ropajes oscuros en los que se distingue la cruz que lo acredita como caballero de la orden de Santiago y gorguera. Si figura se recorta sobre un fondo neutro y además, se han incluido dos cartelas más extensas que las vistas hasta ahora. La primera de ellas ha revelado los principales datos biográficos del retratado: «Don Geronimo Funes y Muños Cavallero de LA

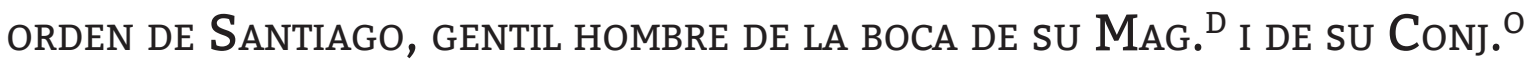
EN EL SUP. ${ }^{\text {MO }}$ REAL DE ITALIA Y SU CONSERVADOR GNAL Y S. ${ }^{R}$ DE LA BARONIA DE AyodAR Y LUGARES DE GODELLA Y ROCAFORT, PATRON I BENEGOR DEL CONVENTO AÑO 1655.»

Asimismo se ha dispuesto un breve texto en el centro de la anterior cartela para remarcar la lealtad a la monarquía: «Iusticia, y verdad, seguí, y fidelidad guardé a mi Rey, que venerè y Obediente, Amè y Serví: del Mundo, aumentos perdí por mi Zelo; $y$ assi me queda un consuelo y es que vivo confiado que si aqui fuy desdichado sere dichoso en el Cielo.»

Como se ha podido observar, el elenco de hombres ilustres que Diego de Vich encargó realizar a Juan Ribalta y su taller está compuesto por una amplia variedad de personajes excelentes en campos de saber muy distintos que en grupo conformaban la imagen de intelectuales arraigados a las tierras valencianas.

112 ARABASC: Inventario de los efectos artísticos, alhajas y demás existentes en la Academia de Nobles Artes de San Carlos, practicado el 1 de junio de 1842, Archivo 146, s/f. 


\subsubsection{El devenir de la galería en el siglo XIX.}

A partir del Decreto de octubre de 1820 por el cual se suprimían los monasterios y los conventos, Nuestra Señora de La Murta vivió la primera de las dos expoliaciones a las que se vería sometida, en ella los monjes tan sólo abandonaron temporalmente su hogar y se incautaron algunos de sus bienes. Teniendo en cuenta que las primeras noticias respecto a los lienzos de los varones datan de 1821 y que es en 1823 cuando finalmente llegaron a la Academia, cabe pensar que los retratos se incautaron desde el primer momento. Además se debe tener en cuenta que las pinturas se localizaban en la librería del convento y, como ya se ha citado, el artículo 27 de la ordenanza aludía directamente al reclutamiento de todos los bienes de las bibliotecas. Aunque los religiosos habitaron de nuevo el monasterio no fue por demasiado tiempo, pues sufrieron un segundo expolio en 1835 y fue entonces cuando se vieron obligados a abandonar definitivamente la Murta y se retuvo todo el patrimonio allí conservado. ${ }^{113}$ Desde aquel, la arquitectura religiosa inició un feroz proceso de deterioro del cual sólo quedan algunas ruinas en la actualidad.

El archivo de la Real Academia de Bellas Artes conserva los inventarios, los libros de actas redactadas tanto en juntas ordinarias como particulares, así como otros documentos que permiten componer, como si de un puzle se tratase, la historia de las efigies de los insignes varones. La llegada de las pinturas a la Academia se debe agradecer principalmente a la intercesión de Francisco Xavier Borrull de Vilanova, académico de honor, quien veló porque las obras finalmente fuesen custodiadas por la institución valenciana la cual garantizaría la protección y la conservación de las piezas. Para ello, en 1821 Borrull junto con don Francisco Peylorón entregaron sendos escritos para que atendiendo a lo estipulado en el Decreto de octubre de 1820 se reclamasen las pinturas de los monasterios desamortizados y concretamente, solicitaron la adquisi-

113 Aldea Hernández, 'La colección pictórica de Varones Ilustres...', p. 530. 
ción de los retratos de Juan Ribalta y su taller referentes a los hombres ilustres del Reino de Valencia. Así pues, dicha petición ha quedado registrada en la junta ordinaria celebrada el 23 de abril de 1821.

El Secretario hizo presente en la Junta que los Señores Académicos de Honor, Don Francisco Xavier Borrull, barón de Santa Bárbara, y Don Francisco Peylorón, le habían entregado dos escritos pero dirigidos a un propio fin, a saber para que conforme al Decreto de 25 de Octubre del año pasado, se pidieran al Gobierno, y en caso necesario a las Cortes las pinturas de los Conventos extinguidos y suprimidos, manifestando las muchas ventajas , que resultarían para las bellas artes, si la Academia formaba una colección de tan estimables obras, añadiéndose en los escritos de los Señores Borrull y Peylorón razones particulares de aprecio, respecto a la adquisición de los retratos de los célebres valencianos que existían en el Monasterio de Nuestra Señora de la Murta. A continuación, el Señor Borrull leyó su escrito, que mereció general aprobación de la Junta por las selectas noticias que comprende de los eminentes valencianos en virtud de armas, literatura y bellas artes, cuyos mencionados retratos forman la colección expoliada del Monasterio de la Murta. El Señor Barón de Santa Bárbara manifestó, que su escrito se había dirigido a procurar la instrucción de la juventud aplicada y la prosperidad de las bellas artes, y que daba las gracias al Señor Borrull por la ilustración que había dado esta propuesta. Lo mismo expresó el Señor Peylorón, añadiendo solo se tuviera presente lo último de su escrito, con que decía podría pedirse al Señor Gefe Superior Político, que se sirva comunicar a la Academia una nota de los retratos que se hayan encontrado en el mencionado Monasterio de la Murta, según resulten de los Inventarios, y que si se halla falta algunos tenga a bien mandar se indague su paradero, y que los entreguen sus a su directorio. Enterada de todo la Junta nombró una comisión compuesta de los Señores Académicos de Honor don Vicente Maria Vergara, D. Francisco 
Xavier Borrull y D. Francisco Peyloron a los que se encargó el Sr. Presidente que enseguidamente le pasaran nota de los expropiados retratos para hacer las diligencias que proponía la Academia y que después dispusiera la Comisión la representación pidiendo estos y demás obras que desea adquirir el Cuerpo, a la que daría el curso correspondiente con mucho gusto. ${ }^{114}$

Una de las razones más significativas de las expuestas por Borrull en su discurso era considerar que los retratos impulsaban a la sociedad valenciana a seguir el ejemplo de los efigiados y a trabajar intensamente con la aspiración de convertirse en excelentes profesionales de aquello que se dediquen. De este modo, se puede apreciar que perdura la función atribuida al género del retrato desde sus orígenes. Las imágenes de hombres ilustres, por tanto, pretendían ser un referente intelectual para la sociedad. Pero este argumento empleado por el académico no fue novedoso, pues anteriores autores, como se ha visto al inicio de este estudio, que reflexionaron sobre el género del retrato ya veían en esta clase de piezas la función de presentar a hombres modélicos que sirviesen de ejemplo para el resto.

En el mismo archivo también se han hallado otros escritos en relación a la intervención de Borrull para que la Academia albergase no sólo los retratos de La Murta sino todas las pinturas que procedían de los monasterios provincianos tras la desamortización. Por ejemplo, la Sociedad Económica de Valencia en fecha de 24 de mayo de 1821 manifestó recibir una copia de la petición del académico.

Esta Sociedad ha recibido con singular aprecio los ejemplares de la erudita exposición que hizo a esta Academia Nacional su Individuo de Honor el Señor don Francisco Xavier Borrull, sobre deberse trasladar a la misma los estimables cuadros que existían en los suprimidos mo-

114 ARABASC: Libro de Actas de la Real Academia de San Carlos. Años: 1821-1827, junta ordinaria de 23 de abril de 1821. 
nasterios de esta provincia, y al dar a ese cuerpo las debidas gracias en nombre de esta Sociedad por su atención y correspondencia con que se sirve continuar hacia la misma, debe manifestar los deseos que la animan de que S.E.V. se sirva aprobar los loables cuidados con que esta Academia atiende a los progresos de las Bellas Artes en esta Provincia, que si bien han logrado en nuestros días justa nombradía en la Nación mediante la adquisición de estos preciosos originales sin duda llegarían a aquella perfección que caracterizó a los eminentes Profesores Valencianos en el siglo diez y seis, en lo que tendrá la Sociedad la distinguida satisfacción de que se acrecienten las bellezas artísticas que hasta ahora ha difundido esta Academia entre las Artes útiles objeto de las atenciones confiadas a las Sociedades Económicas. ${ }^{115}$

Escasos meses después de tener los primeros datos respecto a la galería de los varones, su existencia se hizo extensible a la prensa madrileña. Este hecho invita a imaginar la repercu480 sión y notoriedad que debió tener en su momento el conjunto artístico. El sábado 30 de junio de 1821 se publicaba el número 48 de $E l$ Censor, periódico político y literario y, una de sus noticias se hacía eco de la petición realizada por Borrull así como describía a grandes rasgos las peculiaridades de la galería. Para ello, se especificó el número de pinturas (veinticuatro en este caso), se indicó quién había sido el artífice de la empresa artística y se mencionó a Diego de Vich por ser el autor del encargo además, se explicó que sucedió con las piezas tras el fallecimiento de Vich.

Don Diego de Vich, ilustre valenciano, no menos por la nobleza de su familia que por su amor a las bellas artes formó una colección de 31 retratos de los más célebres varones del Reyno de Valencia, obra de Juan Ribalta, gran pintor y célebre poeta del siglo XVII, al cual robó la muerte en el verdor de su juventud a las bellas artes y a la gloria de su patria. El señor Vich cedió esta colección, tan apreciable por la ejecución como por los recuerdos 115 ARABASC: Leg. 72/5/9 y Leg.72/5/9 A. 
nacionales que escita, al monasterio de Nuestra Señora de la Murta, sito en el término de la Villa de Alcira. Hacen mención honorífica de ella el presentado Fr. José Rodríguez, en su biblioteca valentina, escrita a fines del siglo XVII, D. Juan Agustín Ceán Bermúdez, en el diccionario de los ilustres profesores de bellas artes y últimamente el presentado Fr. Jayme Villanueva en su viaje literario a las Iglesias de España.

Entre los hombres ilustres cuyos retratos componen aquella colección se cuentan el sumo pontífice Calixto III, S. Bernardo de Alcira, S. Vicente Ferrer, S. Francisco de Borja, S. Luis Beltrán y el Beato Nicolás Factor que reunió al ejercicio de las virtudes cristianas la habilidad de la pintura. A estos nombres célebres en los anales de la Iglesia, se juntan el de D. Fernando rey de Nápoles, hijo de Alfonso V el Magnánimo, el de D. Baltasar Marradas, general español que sirvió en Alemania y el del maestre de campo Gaspar Sapena.

Se hallan además retratado Luis Vives cuyo nombre es superior a todo elogio, su discípulo Honorato Juan, obispo de Osma y maestro del príncipe D. Carlos, el paborde Jayme Ferrús, orador y teólogo del Concilio de Trento, de D. Benito Perera, gran teólogo y humanista, Federico Furió Ceriol, autor del excelente opúsculo del consejo y consejeros del príncipe, Luis Collado, médico y descubridor del huesecito Estupeda en el órgano del oído; su sucesor en la cátedra de Botánica, y que se considera como uno de los restauradores de esta ciencia, Pedro Juan Núñez, insigne filólogo y humanista, Gerónimo Muñoz, a quien Tico-Brahe cita como un gran matemático; D. Jayme Juan Falcó, matemático y poeta, Ausias March que es el Petrarca de la poesía provenzal; Jayme Roig, poeta y médico, Francisco Tárrega y Gaspar Aguilar, poetas celebrados por Lope en el laurel de Apolo; Mosen Juan Bautista Comes, célebre músico; y en fin, D. Guillem Castro, en cuyas escenas se ensayó el genio de Corneille para crear la tragedia moderna. 
La colección de que hablamos, contiene todos los títulos de gloria que posee el reino de Valencia. El Sr. Borrull tan excelente patricio así como amante instruido de las artes, presenta en su exposición todas las razones que hay para no defraudar a aquella provincia de un monumento tan insigne y nacional, que es al mismo tiempo una colección de buenos modelos para los alumnos de pintura y concluye que en ninguna parte estará mejor conservada que en la Academia de San Carlos de Valencia, cuerpo unas intercesado que otro alguno en transmitir a la posteridad, aumentada con sus tareas en las bellas artes, la gloria de los valencianos. Sus deseos son conformes al decreto de las Cortes de 25 de octubre de 1820, en que mandan destinar a los cuerpos literarios los cuadros, libros y efectos de las bibliotecas de los monasterios suprimidos, después de haber elegido para su biblioteca lo que parezca conveniente. Nosotros deseamos que su exposición tenga el éxito que desea su autor. ${ }^{116}$

Se ha podido observar que el escrito periodístico mencionó a aquellos autores que hablaron de este conjunto o dieron alguna noticia del monasterio de La Murta por aquella época. De entre ellas, cabe destacar el comentario de fray José Rodríguez, quien apuntó la existencia del conjunto pictórico al dedicar algunas páginas a la biografía de Vich. Concretamente escribió lo siguiente:

Haziale notable diversión, la Pintura, y después de aver conseguido Copias de muchas Imágenes Santas; solicitó, y hubo, los originales, de los más Ilustres Varones, en todas Ciencias, y Facultades, de nuestra Ciudad, y Reyno; que hoy, en Efigies de medio cuerpo, se conservan en el célebre Santuario, y Real Monasterio, de Nuestra Señora de la Murta, de la Orden de San Gerónimo, en este Arzobispado; del qual era Patrón, y à quien hizo heredero de sus bienes, y de su cuerpo; disponiendo se le enterrassen

116 Véase El Censor, periódico político y literario, no 48, 30 de junio de 1821, pp. 207 - 210. Además, el archivo de la Academia conserva un documento que resulta ser la copia de la nota de prensa. ARABASC: Leg. 72/5/14 y Leg. 72/5/14 A. 
en medio de la Iglesia, al pie de la Capilla mayor, sin más inscripción sobre la piedra, que la siguiente: Don Diego de Vich, que su abstracción, y buen ejemplo, en vida, también supo continuarles hasta su muerte. ${ }^{117}$

La institución valenciana tuvo que comunicar la propuesta de Borrull a la Academia madre, así pues la documentación de archivo ha dejado constancia del diálogo entre ambas. De hecho, desde Madrid se certificó a 9 de agosto de 1821 la recepción de las noticias de San Carlos.

La Academia de San Fernando recibió los ejemplares que V.S le remitió por mi mano de la exposición que hizo a la de San Carlos su individuo D. Francisco Xavier Borrull sobre deberse trasladar a esta última la colección de retratos de valencianos ilustres que existían en el suprimido monasterio de Nuestra Señora de la Murta, con los demás apreciables cuadros de los otros monasterios de la Provincia. La Academia de San Fernando ha recibido este obsequio con el aprecio que merece un escrito en que brilla el más ilustrado patriotismo a la par de un exquisita erudición y amor a las nobles artes, y desea que se cumplan los deseos de esa Academia para que logre presentar a los jóvenes que en ella se educan los buenos modelos de sus célebres artistas unidos al noble recuerdo de los varones ilustres que en diversas carreras y por diferentes medios lograron ser el ornamento y gloria de su patria. ${ }^{118}$

El documento de respuesta emitido por la Real Academia de Bellas Artes de San Fernando tras el envío del discurso de Borrull se leyó en la homónima valenciana durante la junta ordinaria de 30 de septiembre de 1821 y ello ha quedado recogido en un fragmento de la correspondiente acta redactada.

117 Fray José Rodríguez, Biblioteca valentina. Compuesta por el M.R.P. M. Fr. Josef Rodríguez, Ministro del Real Convento del Remedio de Valencia, Cronista General del Orden de la SS. Trinidad en la Provincia de Aragón, (Joseph Thomas Lucas: Valencia, 1747), p. 111. 
Se leyó un oficio de la Academia de San Fernando contestando con mucho aprecio al recibo de los exemplares del discurso del Señor Académico de Honor Don Francisco Xavier Borrull, sobre deberse trasladar a esta Academia los retratos de varones ilustres valencianos que existían en el extinguido Monasterio de la Murta, y pinturas de los demás de esta Provincia, manifestando haber celebrado el ilustrado patriotismo a por la exquisita erudición y amos a las nobles artes que brillan en este escrito, y que será muy satisfactorio para aquella Academia que se cumplan los deseos de esta de San Carlos para el adelantamiento de las actas, de lo que quedó entendida la Junta. ${ }^{119}$

Una vez realizados los trámites para manifestar el deseo de adquirir las pinturas, ya no hay nuevas noticias hasta 1823. El 7 de septiembre durante el transcurso de una junta ordinaria, Borrull preguntó por la localización de los retratos de esta galería:

El Señor Académico de Honor Don Francisco Xavier Borrull expuso si tenía alguna noticia de existir diferentes retratos de la colección de varones ilustres valencianos del Monasterio de Nuestra Señora de la Murta, y que a fin de que no se extraviaran estas apreciables obras, se podía oficiar al Señor Gobernador del Arzobispado para que en calidad de depósito y sin perjuicio de sus dueños se trasladaran a esta Real Academia. La Junta se conformó en un todo con esta propuesta. ${ }^{120}$

Más datos se recogieron en la sesión de 5 de octubre, cuando se notificó al procurador de la cartuja de Porta Coeli que la institución deseaba obtener el depósito de algunas de sus obras de arte como recursos para la formación de los alumnos de Bellas

119 ARABASC: Libro de Actas de la Real Academia de San Carlos. Años: 1821-1827, junta ordinaria de 30 de septiembre de 1821.

120 ARABASC: Libro de Actas de la Real Academia de San Carlos. Años: 1821-1827, junta ordinaria de 7 de septiembre de 1823. 
Artes. Después se puso de manifiesto la voluntad del Borrull por informar oficialmente al prior del interés de la Academia por acoger la galería de lienzos.

El Secretario hizo presente que conforme a la comisión que se le concedió en la Sesión anterior de 7 de septiembre manifestó al S. Procurador de la Real Cartuja de Porta Coeli que la Academia deseaba quedaran en depósito algunas Pinturas, que a más de parecerle no eran de precisión para el culto del Monasterio y por otra parte sería de mucha utilidad para el estudio de la juventud, dándose por la Academia la correspondiente cautela de ser propiedad de dicho Monasterio. Seguidamente expresó la contestación de dicho P. (Padre?) Procurador de que por haber quedado enteramente destruidos los retablos, con precisión necesitaban de las referidas Pinturas para formar interinos para la celebración, y a continuación leyó la lista de los Quadros que se entregaron al mencionado P. Procurador, de todo lo qual quedó enterada la Junta.

Igualmente quedó entendida la Junta de que habiendo manifestado el Señor Académico de Honor D. Francisco Xavier Borrull al Excmo. Señor Presidente, que antes de pasar al Señor Gobernador del Arzobispado el oficio acordado en la sesión anterior sobre Pinturas del Monasterio de la Murta, convenía se oficiara al P. (Padre) Prior del mismo, se había así practicado. ${ }^{121}$

Por último, resulta de gran relevancia la junta ordinaria celebrada el 7 de diciembre de 1823 donde se mostró el expediente para la definitiva adquisición de las pinturas. Éste constaba de cinco documentos que resumen los pasos seguidos para finalmente poseer las pinturas. Por ello, se adjuntó el comunicado oficial mediante el cual el presidente de la Academia avisaba al prior de La Murta de las intenciones de la institución. La respuesta del monje superior fue de aceptación de la petición. Acto seguido se añadió una relación de las imágenes de los va121 ARABASC: Libro de Actas de la Real Academia de San Carlos. Años: 1821-1827, junta ordinaria de 5 de octubre de 1823. 
rones que desde el monasterio se entregaron al secretario de la Academia. También se incluyó el beneplácito del presidente de la institución respecto a la entrega de las obras y por último, un comunicado para explorar la existencia de otros retratos pertenecientes a la serie o procedentes del monasterio jerónimo.

Se dio cuenta del Expediente que se ha firmado por acuerdo del Excelentísimo Señor Presidente, con el objeto de que el Monasterio de Nuestra Señora de la Murta permitiera se transfirieran a esta Real academia las pinturas en depósito de la colección de varones insignes valencianos que poseía pintados por el célebre Juan Ribalta, conforme a lo que expuso el Señor Académico de Honor Don Francisco Xavier Borrull, y se leyeron los documentos siguientes.

1으숭o del Excelentísimo Señor Presidente al P. (Padre) Prior de dicho Monasterio manifestándole lo que queda expresado.

20 Contestación de dicho Prior admitiendo a lo propuesto.

3ㅇ Nota de los retratos entregados al Secretario de esta Real Academia.

4을 Certificación que dió el mismo por acuerdo del Excelentísimo Señor Presidente.

5o Oficio del mismo Excelentísimo Señor Presidente al Señor Gobernador de este Arzobispado para que permita al Señor Académico Don Francisco Xavier Borrull y presente Secretario, puedan inspeccionar si entre los muebles de Don Agustín Ricart Director que fue del Real Seminario de Nobles, quedan aún algunos otros retratos de la mencionada Colección y otras obras pertenecientes al citado Monasterio. ${ }^{122}$

Una vez tratados los cinco puntos mencionados previamente, los académicos allí reunidos acordaron lo siguiente con el ob-

122 ARABASC: Libro de Actas de la Real Academia de San Carlos. Años: 1821-1827, junta ordinaria de 7 de diciembre de 1823. 
jetivo de agradecer el poder efectuar el depósito de los retratos así como recurrir al área de pintura para establecer unas medidas de conservación que frenen el proceso de deterioro en el que hallaban algunas piezas:

10 Que la certificación que dio el presente secretario al P. (Padre) Procurador del Expresado Monasterio se extienda literalmente a fin de la presente acta.

20 Que se den las gracias al Monasterio y para ello que se haga presente a la Junta Particular la generosidad de aquella Comunidad a fin de que sirva acordar lo que le pareciese conveniente para acreditar el aprecio que ha hecho la Academia a tan interesantes obras.

3ㅇ Que luego concluya la comisión su cometido se le den igualmente las gracias.

40 Que la clase de Pintura proponga el modo con que se pueda atender a la conservación de dichas pinturas respecto al estado de deterioro en que se hablan. ${ }^{123}$

Como se estipulaba en el primer apartado acordado, el acta levantada en la junta de la correspondiente sesión se redactó el certificado emitido por la Academia al convento jerónimo. El acuerdo viene encabezado por el nombre y méritos profesionales del secretario, Vicente María Vergara. El núcleo del escrito resulta interesante porque remarcaba el privilegio que le supondría a la Academia poder conservar y mostrar lo lienzos de los varones ilustres a todos aquellos que visitasen la capital del territorio valenciano y así, poder hacer alarde de tan relevantes personalidades en las letras o en las armas. Además la institución justificó sus intenciones puntualizando que Diego de Vich, aquel que encargó la serie, deseaba mantener vivo el recuerdo de los insignes hombres representados y que la Academia tan sólo va a seguir respetando y cumpliendo con la voluntad del señor Vich dando a conocer las pinturas de Juan Ribalta y su taller pertenecientes a esta galería.

123 ARABASC: Libro de Actas de la Real Academia de San Carlos. Años: 1821-1827, junta ordinaria de 7 de diciembre de 1823. 


\section{Certificación:}

Don Vicente María Vergara, Doctor en ambos Derechos, Abogado de los R. Consejos y del Colegio de Valencia, Académico de Honor de la Academia de Nobles Artes de San Fernando, Socio de la Real de Ciencias naturales y Artes de Barcelona, Individuo Numerario y Secretario perpetuo de la Real Sociedad Económica de Amigos del Pais de esta Ciudad, Académico de Honor, de Mérito por la Pintura y Secretario perpetuo con voz y voto de Consiliación de la Real Academia de San Carlos. Secretario de la Junta de Comisión de Arquitectura para el examen de obras públicas.

Certifico: Que considerando esta Real Academia de San Carlos que convendría para el honor de este Reyno, el que los retratos de los ilustres valencianos que poseía el Monasterio de Nuestra Señora de la Murta, se colocaran en esta Real Academia a fin de que los muchos extranjeros que acuden a esta Capital conocieran la gran alegría que aquel le cabe por la multitud de varones insignes en armas y letras que ha producido y se representan en dicha colección, que también convenía el bien público porque el pincel del célebre Juan Ribalta ilustraría mucho a la juventud envidiosa y que igualmente sería conforme a las ideas de don Diego de Vich, que se dirigieron a conservar la memoria de tan esclarecidos valencianos ofició en 17 de septiembre de este corriente año al 22ㅇ P. Prior de dicho monasterio manifestando que los deseos de la Academia que quedan expresados no se extendía a adquirir la propiedad de las obras mencionadas, y si solo de conservarlas por vía depósito por las razones referidas de utilidad pública y de las Nobles Artes. Igualmente certifico que mi vista de la contestación de R $\mathrm{a}$ P. Sr. Francisco de Santa Teresa Prior del mencionado Monasterio adhiriendo en un todo a lo propuesto por la Real Academia, y cediendo los retratos que existan o puedan existir pertenecientes al colección expresada en nombre de aquella Comunidad se procedió por le P. Mariano Codina Procurador del Monasterio a la entrega de los retratos, 
que existían en su poder en este día de la fecha que eran en número de veinte y tres, la mayor parte muy deteriorados los que yo el infrafirmado secretario de esta Real Academia recibí en su nombre para transferirlos a su Casa y entregarlos al Conserje de la misma para que los custodie por vía de depósito y reservando la propiedad en todo tiempo en favor del mencionado Monasterio. Los retratos entregados hasta el presente y varones que representan según relación de dicho P. Procurador son los siguientes:

1.San Vicente Ferrer; 2. Beato Nicolás Factor; 3. Calixto III; 4. Alejandro VI; 5. Francisco Tárrega; 6. Jayme Falcó; 7. Luis Vives; 8. D. Guillem de Castro; 9. Gaspar Sapena; 10. P. Francisco de Pereda; 11. Mosen Juan Bautista Comes; 12. D. Fernando rey de Nápoles; 13. Jayme Ferrús; 14. D. Baltasar Marradas y Vich; 15. Doctor Juan Plaza; 16. Gerónimo Muñoz; 17. Federico Furió Ceriol; 18. Doctor Martí; 19. Don Honorato Juan; 20. Don Pedro Juan Trilles; 21. Francisco Collado; 22. Un óvalo con solo su cabeza, se ignora su nombre y va signado con el de la Murta; 23. Ídem, ídem.

Son los veinte y tres retratos arriba expresados. Y para que conste por acuerdo de Excelentísimo Señor Don Felipe de Saint Marcos, Capitán General de este Reyno Presidente de esta Real Academia de San Carlos, y para que sirva de cautela en favor de la propiedad y dominio del Monasterio acerca de las pinturas expresadas doy la presente certificación, que firmo y sello con el de la Real Academia de Valencia a 23 de diciembre de 1823. Vicente María Vergara, Secretario. ${ }^{124}$

La documentación conservada en el archivo de la Real Academia de Bellas Artes de San Carlos es abundante y narra con todo detalle del proceso que se siguió para conseguir los retratos requisados tras la desamortización y que incrementasen la colección artística de la Academia. Una vez se recopilaron 124 ARABASC: Libro de Actas de la Real Academia de San Carlos. Años: 1821-1827, junta ordinaria de 7 de diciembre de 1823. 
las pinturas, su incorporación a los fondos artísticos ha quedado recogido en los inventarios y su lectura ha permitido conocer la ubicación exacta de algunos de los retratos cuando ya se encontraban en la institución valenciana.

\subsubsection{Ubicación y función de los retratos en su origen y en la actualidad.}

Como es sabido, en origen las efigies de los ilustres valencianos se emplazaban en la librería del monasterio. Tradicionalmente éste era un lugar adecuado para situar las imágenes de personalidades exitosas que se presentaban como espejos de comportamiento y que tenían por cometido animar a los jóvenes a ser brillantes en cualquiera que fuese su profesión. Ello ya estuvo defendido por autores del siglo XVI, como fue el caso de Armenini quien expuso el modo en que los antiguos ornamentaban este espacio y que además planteó un modelo adecuado para decorar la biblioteca del convento. ${ }^{125}$ De los ro490 manos explicaba su costumbre de añadir imágenes de poetas y otros insignes varones quienes mediante el estudio llegaban a conocer el mundo y a Dios.

Pasando pues, al convento, trataremos de aquellas cosas que se pintaban antes y ahora en las bibliotecas, por ser las partes más nobles. Yo creo que los excelentes antiguos las decoraban, además de con multitud de libros, con instrumentos matemáticos y todos los demás, como aquellos que hizo Posidonio, en los cuales los siete planetas se movían cada uno con movimiento propio. [...] Pero Tiberio Cesar después mandó poner allí las verdaderas

125 Los retratos de hombres insignes podían decorar las bibliotecas de los monasterios pero también eran adecuadas para «adornar los estudios, [...] aquí se pueden añadir cuadros al óleo o retratos del natural de personas ilustres pintados por excelentes maestros [...]" Armenini, De los verdaderos preceptos.., Capítulo XIII. De las pinturas que se hacen para los jardines y las casas de villa. Cuánta reprobación merecen los pintores que se sirven de los grabados en sus obras. Qué asunto sea mejor para hacer en los corredores, en las escaleras y en los estudios, y cuáles en los invernaderos, en los baños y otros lugares menores, p. 254. 
imágenes de los poetas antiguos, junto con otras efigies de grandes hombres para conmover con tales ejemplos e inflamar los ánimos de quienes ejercitan sus ingenios en el conocimiento de las cosas humanas y divinas. ${ }^{126}$

Respecto a su propuesta, ésta se sintetiza en pintar una alegoría de la Iglesia en la pared justo frente a la entrada, con un cordero y un templo circular a cada lado. Bajo dicha figura se representarían los siete pecados capitales vencidos por el cristianismo y su Iglesia. En los muros laterales se debían colocar escenas donde la fe de los santos triunfase sobre la adversidad y seguidamente, plasmar a las artes liberales. Sin embargo, resulta de especial interés el final de la descripción cuando se habla de las efigies de los fundadores y defensores de la fe, o bien retratados hasta los hombros o de medio cuerpo. Cabe destacar la importancia que le otorga el autor a elaborar imágenes fieles a la realidad puesto que la veracidad del retrato despertaba más admiración y estima por parte de aquel que lo contempla.

[...] Y no quiero dejar de decir que en aquellos frisos que se fingen por encima y todo alrededor estarían muy bien las imágenes de los grandes fundadores y defensores de la fe, y bastaría con hacerlos de medio cuerpo y, si no tan grandes, al menos hasta los hombros. Mas sus efigies deberíanse hacer próximas al natural cuanto fuese posible, porque el deseo y el amor crecen mucho al tener presente que ellos eran realmente así. Y quizá tampoco sería reprobable hacer algunos de cuerpo entero en los artesonados y en las ménsulas, que vistos desde abajo correspondieran muy bien al natural. En el restante espacio los ornamentos deberían estar realizados con una alegría, dignidad y orden extraordinarios, de modo que mantuviesen a los estudiosos alegres en sus maneras, y los atrajeran de tal modo que no supiesen irse de allí. Y de

126 Armenini, De los verdaderos preceptos..., Capítulo VI. Con qué pinturas decoraban los antiguos sus bibliotecas, y con qué fin. Lo que en el tiempo presente sería adecuado, y a qué efecto se hacen, p. 217. 
esto ya hemos dicho bastante..$^{127}$

La galería de La Murta cumplía con la idea planteada por Armenini y contaba entre sus retratados con relevantes hombres eclesiásticos y propagadores de la fe como sucede con el pontífice Alejandro VI, san Vicente Ferrer, el beato Nicolás Factor o el teólogo Jaime Ferrús, entre otros. También se correspondía con la práctica ya existente en época romana de incluir a sabios y poetas, como sucedería con el caso de Luis Vives, Gaspar Aguilar, Juan Plaza o Luis Collado, por mencionar algunos.

En el siglo XIX, cuando las pinturas llegaron a la Academia se colocaron en diferentes estancias y se dispersó el conjunto. Especialmente importante es el realizado en 1842 porque a través de su lectura se puede conocer en qué lugar exacto de la Academia se dispusieron algunos estos retratos. Para ello, ha sido clave la numeración que en algunas de las efigies a día de hoy se aprecia, pues esta permite identificar la pintura en el inventario. En consecuencia, se ha podido saber que en la sala de juntas se encontraban los retratos de Pedro Juan Trilles ( $\mathrm{n}$ 은 8), ${ }^{128}$ Fernando I (no 9), Pedro Juan Núñez (no 20), Baltasar Marradas y Vich (no 21), Luis Vives (no 93), Jaime Ferrús (no 94), san Vicente Ferrer ( $\mathrm{n}$ - 101), Luis Collado (no 102) y Benito Perera (no 103). Y en el recibidor se dispusieron las imágenes de Jaime Falcó (no 25) y del beato Nicolás Factor (no 34). Además de las ya mencionadas, había varias efigies más de hombres ilustres en la sala de juntas sumando un total de trece retratos que, como se verá más adelante, compartían espacio con efigies regias y representaciones de presidentes y directores de la Academia. No ha sido posible localizar a todos los varones ilustres en este inventario porque el documento no revela las identidades de los efigiados y algunas de las pinturas no con-

127 Armenini, De los verdaderos preceptos..., Capítulo VI. Con qué pinturas decoraban los antiguos sus bibliotecas, y con qué fin. Lo que en el tiempo presente sería adecuado, y a qué efecto se hacen, pp. 218-219.

128 La cifra entre paréntesis indica el número de la pintura en el inventario de 1842. 
servan la numeración que se les asignó en la época.

La pista de los retratos se pierde en el siguiente inventario consultado, redactado el 1 de mayo de 1847. Concretamente este documento es una relación de las piezas que existían en el museo de pinturas, que se estableció en el edificio del antiguo convento del Carmen de Valencia. Aquí en la sala de juntas también hay retratos procedentes de La Murta pero no se corresponden con los varones ilustres, a excepción de la efigie de Gaspar Aguilar, sino que son las representaciones de algunos miembros de la familia Vich, como son don Luis y don Gerónimo. Conviene recordar que el retrato de Gaspar Aguilar aparece en las listas de efigiados proporcionadas por todos los autores pero no en las anotaciones de Vicente Vergara, el secretario cuando se le entregaron los cuadros. Esta pieza se encontró más tarde, pues en la junta ordinaria del 7 de marzo se expuso que el retrato se halló en el cuarto de don Agustín Ricart, quien había sido director del Real Seminario de Nobles:

El Señor Académico de Honor Don Francisco Xavier Borrull hizo presente a la Junta que conforma a la comisión que juntamente con el Secretario de la Real Academia se le había conferido, habían pasado al Quarto de Don Agustín Ricart, Director que fue del Real Seminario de Nobles de esta Ciudad y que entre sus muebles sólo hallaron el retrato de Gaspar Aguilar uno de los de la colección del Convento de la Murta. La Junta quedó entendida de ello y dio las gracias a dichos Señores por el desempeño de este cometido y seguidamente encargó a los Señores Profesores se sirvan cuidar si se halla algún otro retrato de la mencionada colección. ${ }^{129}$

En la actualidad las imágenes de los varones ilustres valencianos procedentes del monasterio alcireño de Nuestra Señora de La Murta se pueden contemplar en la biblioteca del museo de Bellas Artes de Valencia. Así, de algún modo, los retratos lucen en un espacio similar al original. Este emplazamiento

129 ARABASC: Libro de Actas de la Real Academia de San Carlos. Años: 
se puede considerar acertado pues el lugar donde se sitúen las pinturas es clave para que los retratos sigan cumpliendo con el cometido para el que fueron creados. En este caso, las efigies se pintaron parar honrar la memoria de los ilustres valencianos en el ejercicio de las humanidades, de la teología, de la medicina, de la botánica o incluso en la actividad militar. También se crearon para mostrarlos como modelos a imitar para el resto de la sociedad y alentar a los jóvenes a alcanzar la excelencia en aquello que se dediquen. Por estas razones los retratos de los varones, ejemplos de orgullo y signo de patriotismo, debían lucir en la librería del monasterio, un espacio dedicado al cultivo del intelecto. A día de hoy, siguen formando parte de un lugar consagrado al estudio y desarrollo del conocimiento y aunque existen desde el siglo XVII no han perdido su capacidad para despertar la admiración y estimular a todo aquel que los contemple.

\subsection{Las efigies del paraninfo de la Universitat de València.}

El denominado teatro académico o paraninfo de la Universitat de València [fig. 5.24], situado en el primitivo edificio universitario del Estudi General, ha sido históricamente el espacio propicio para celebrar reuniones del profesorado, albergar negociaciones trascendentales de carácter político y cultural y, además, realizar debates intelectuales e incluso representaciones teatrales en griego y latín protagonizadas por el alumnado. A día de hoy, la sala se ha reservado para para llevar a cabo actos protocolarios. La relevancia de lo que en el paraninfo acontece desde su origen justifica que su decoración pictórica muestre a personas trascendentales para la institución. Por ello, la galería de retratos que aquí se conserva merece ser estudiada. De hecho este conjunto pictórico, como en otros casos, hizo uso de las efigies para configurar la imagen pública y oficial de la institución.

Se trata de un proyecto pictórico cuyas efigies comenzaron a 1821-1827, junta ordinaria de 7 de marzo de 1824. 
realizarse en el siglo XVII y fue creciendo en el tiempo durante los siglos XVIII y XIX principalmente. Pese a que la galería nació en tiempos barrocos, los retratados se corresponden con personajes tanto anteriores como contemporáneos al desarrollo del conjunto. De este modo, se ha querido rendir tributo a aquellos que sentaron las bases para el nacimiento de esta institución y formaron parte de la misma durante sus primeros años. En este sentido, son numerosos los retratos especialmente conmemorativos como Fernando el Católico, Alejandro VI, fray Juan Ruiz o fray Miguel Maíques, por citar algunos ejemplos. En cualquier caso, la Universitat se ha respaldado en los éxitos intelectuales de distintos personajes vinculados a ella a lo largo de su historia para fomentar su fama y prestigio con el paso del tiempo.

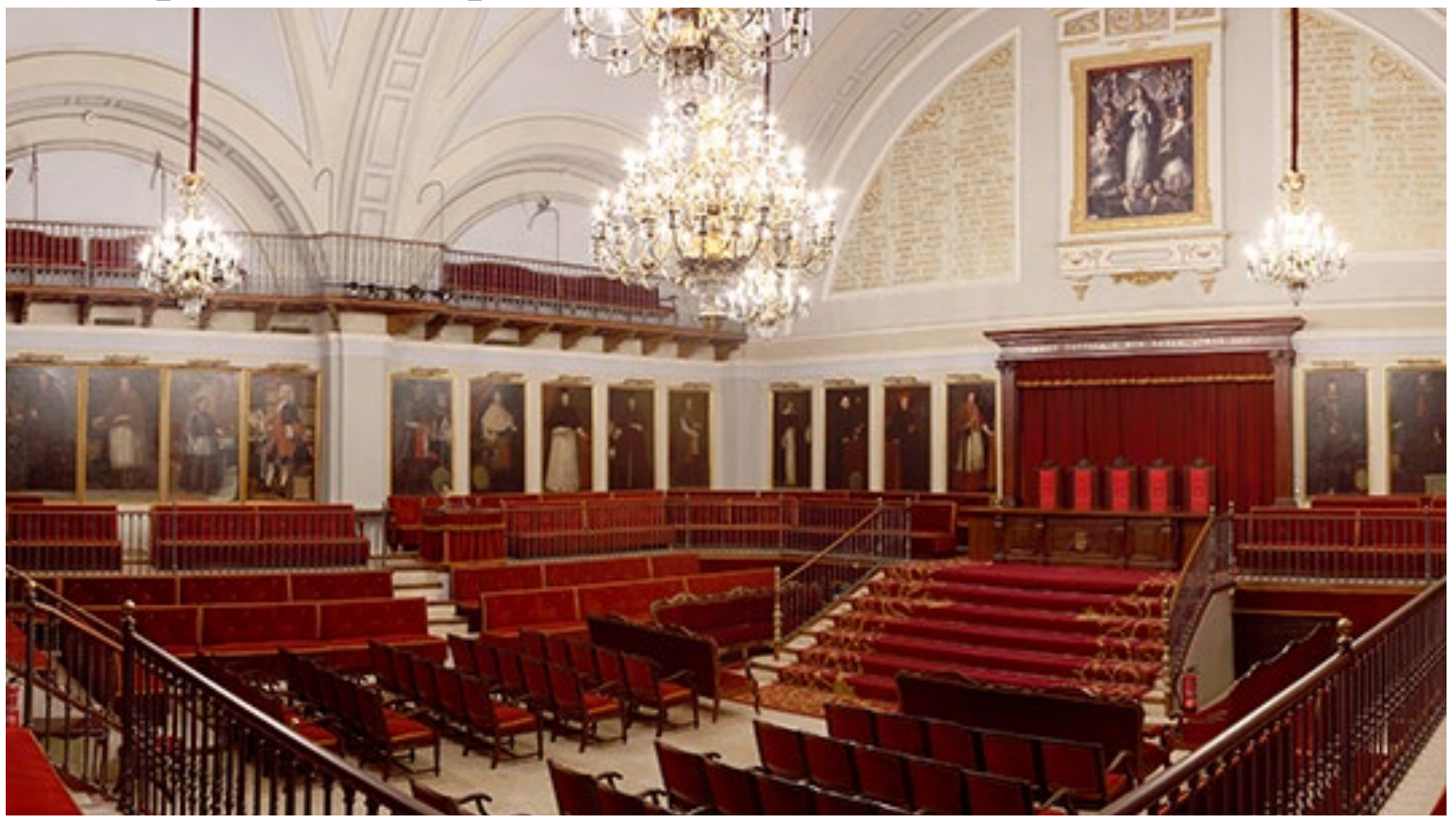

Fig. 5.24. Vista general del paraninfo de la Universitat de València.

\subsubsection{El teatro académico o paraninfo. Una decoración acor- de al uso del espacio.}

Las referencias más tempranas a la realización de actos en el teatro de la Universitat se remontan al año 1519 cuando Alonso de Proazes, catedrático de retórica desde 1505, recitó una oración latina de alabanza a la ciudad. ${ }^{130}$ Esta es una de 130 Francisco Ortí y Figuerola, Memorias históricas de la fundación y progresos de la insigne Universidad de Valencia, (Imprenta de Antonio Marín: 
las actividades que debían tener lugar en el paraninfo según estipulaba las propias constituciones del Estudi General. El reglamento especificaba que un catedrático de retórica o un discípulo suyo debía leer una oración el día de san Lucas o al día siguiente después de comer. Además, tenían cabida las ceremonias de grados y la lectura de conclusiones o asertos en las distintas especialidades. ${ }^{131}$ También hay noticias destacables en años posteriores. Por ejemplo, en 1599, a raíz de la visita de Felipe III, Margarita de Austria, el archiduque Alberto de Austria e Isabel Clara Eugenia a la ciudad para celebrar sus respectivos enlaces matrimoniales, ambas parejas estuvieron presentes en la función del grado de doctor en teología de Bernardo Delgado. ${ }^{132} \mathrm{El}$ teatro igualmente se utilizó para colocar las exequias del médico Andrés Sampere, quien además fue un personaje destacable por su contribución a la promoción y el culto a la Inmaculada Concepción. Por ello, se narra que:

procuró también avivar la devoción a este misterio, que ya de muy antiguo resplandecía en los hijos de la Universidad; para lo cual fomentó por todos los caminos las grandes fiestas con que la Universidad celebró el Breve de Alejandro VII. Contribuyó entonces con su exquisita erudición a la formación de muchos jeroglíficos, y versos primorosísimos, que adornaban el pórtico y paredes de los patios: hizo colocar en el teatro la hermosa imagen que se venera de la Concepción. [...] $]^{133}$

Madrid, 1730), p. 366 y p. 143.

131 Constitucions del Estudi General de la insigne ciutat de Valencia, (Juan Batiste Marzal: Valencia, 1642).

132 Este dato ya ha sido apuntado por Daniel Benito Goerlich y Amparo José Mora Castro, El Paraninfo de la Universitat de València y sus personajes retratados: testimonio de saber, historia y ceremonia, (Universitat de València: Valencia, 2014), pp. 15-16. Ambos autores se han basado en la novela picaresca que narraba la vida de Guzmán de Alfarache, véase: Mateo Luján de Sayavedra, Segunda parte de la vida del pícaro Guzmán de Alfarache, (Roger Velpius: Bruselas, 1604), p. 368. Además, se conserva la descripción de todo el ceremonial en Ortí y Figuerola, Memorias históricas de..., pp. 92 -93.

133 Ortí y Figuerola, Memorias históricas de..., p. 365. 
Así la decoración pictórica de este espacio en el siglo XVII además de algunos retratos de hombres ilustres contaba con dos pinturas de la Inmaculada Concepción. La primera de ellas fue pintada por Jerónimo Jacinto Espinosa y muestra a la Virgen acompañada de distintos símbolos extraídos de las letanías marianas. La segunda es autoría de José Orient y presenta a san Pedro Pascual ante la imagen de la Inmaculada. Ambas obras, de 1660, se encargaron a raíz de las fiestas celebradas en Valencia por esta advocación. ${ }^{134}$ Asimismo, cabe recordar que la Universitat juró la defensa de la pía opinión en 1530.135 Más tarde, en 1664, la institución decidió ampliar el tradicional juramento y este fue escrito en letras de oro en el denominado teatro bajo la imagen de la Inmaculada. ${ }^{136}$

Como ya ha explicado Daniel Benito en un exhaustivo estudio sobre el tema, la disposición original de los retratos en el paraninfo fue alterada en varias ocasiones. Ya hubo una transformación en 1732 siguiendo el proyecto planteado por Vicente Sarrió, Miguel Marco y Felipe Rubio. El cambio más sustancial en este momento fue la ampliación del teatro añadiendo dos metros a lo ancho y construyendo una bóveda de cañón con lunetos. Asimismo, los retratos de nuevos personajes se añadieron a esta serie quedando por tanto actualizada. Más tarde, en 1864, Sebastián Monleón Estellés llevó a cabo otra remodelación. Respecto a los retratos, estos se ampliaron con obras encargadas a Vicente López y sus hijos, Bernardo y Luis López.

134 Benito Goerlich y Mora Castro, El Paraninfo de la Universitat..., p. 17.

135 [...] Concluida la misa se puso el obispo, vestido de pontifical, en la grada más alta del altar mayor, y arrodillándose todos los maestros y doctores de la Universidad, prestaron juramento de mantener siempre la Concepción Inmaculada de la Virgen; y resolvieron no admitir en adelante a alguno para los grados de la Universidad, sin que se prestase primero el mismo juramento. [...] Véase a Ortí y Figuerola, Memorias históricas de..., p. 97.

136 [...] Y para que quedase eternamente a la posteridad un monumento de esta plausible acción, resolvió la Universidad escribir con letras de oro a los pies de una hermosa imagen de la Concepción, que tienen colocada en su teatro, las cláusulas del nuevo juramento. [...] Ortí y Figuerola, Memorias históricas de..., p. 104. 
Además, por entonces se inscribieron los nombres de otros personajes relevantes flanqueando el lienzo de la Inmaculada para completar la dilatada lista de eminencias recordadas en la sala. El citado autor ha distinguido, entre todo el conjunto de nombres, a santos y beatos, papas y arzobispos, políticos y juristas, matemáticos y físicos, médicos, intelectuales valencianos, poetas, historiadores y humanistas, principalmente. Algunos miembros de este gran elenco son santo Tomás de Villanueva, el beato Juan de Ribera, Calixto III, Andrés Mayoral, Benito Perera, Federico Furió Ceriol, Pedro Tarazona, Gerónimo Torrella, Juan Plaza, Luis Collado, Guillén de Castro o Gaspar Escolano entre muchos otros. Así se ha mantenido el salón y tan sólo se cometió una nueva intervención entre 1985 y 1987 cuando fue restaurado por completo. Tras esta última remodelación, las pinturas se debieron someter a delicados trabajos de conservación y restauración pues sus desperfectos eran notables teniendo en cuenta la antigüedad de las piezas, el deterioro de las mismas y el poco afortunado almacenamiento de los lienzos durante el periodo de restauración. Este proceso, abanderado por Ángel y José Manuel Barros, se dilató en el tiempo hasta 1992 y el principal objetivo era preservar la unidad icónica característica de la serie. ${ }^{137}$

El uso que, desde los inicios, se hizo de este espacio ha determinado el tipo de decoración pictórica. A través de ella se puede observar la implicación de la Universitat en dos cuestiones diferentes; por un lado la defensa del misterio de la Inmaculada Concepción, pues fue la primera institución universitaria española en posicionarse a favor de esta causa. Por otro lado, recordar a las personalidades más significativas vinculadas a ella pues se percibe el orgullo de la propia Universitat por estar relacionada con personajes de gran éxito y sus retratos se convirtieron en la imagen de un conjunto de hombres ilustres que constituyó un referente para las generaciones venideras. Así lo corroboran las palabras de Teodoro Llorente, en el siglo

137 Benito Goerlich y Mora Castro, El Paraninfo de la Universitat..., pp. 18-26. 
XIX, para describir este salón:

\begin{abstract}
Alma Mater Valentina! ¡Gloriosa Universidad de Valencia! ¡Cuántas veces, sentado yo en los duros bancos de tus aulas, aparté el vagabundo espíritu de la explicación minuciosa del profesor, y volando a otros tiempos, reanudaba la serie de los siglos, para evocar la memoria de tantos varones ilustres como han salido de tu seno! ¡Cuántas veces, en tus solemnes ceremonias escolares, al ver a los catedráticos y doctores subir a los estrados del paraninfo, con sus negras togas y sus borlas y mucetas teñidas con todos los matices del iris, imaginé que se mezclaban con ellos, desprendiéndose de sus lienzos ennegrecidos, aquellos sabios famosos que les precedieron, y cuyas imágenes veneradas proclaman tu gloria! Quizás soñé también que algún día pudiera formar parte de esa pléyade consagrada: si he de renunciar a ese honor, no por eso dejaré de proclamar los timbres de la escuela valenciana, cumpliendo con un deber filial, que no necesita ayuda de la lisonja, y puede encerrarse muy bien en los límites severos de la justicia. ${ }^{138}$
\end{abstract}

Asimismo, siguiendo con las palabras de Llorente él ya advertía de la necesidad de mantener la memoria de los efigiados, pues la gran mayoría de ellos pasaban desapercibidos a los ojos de otros estudiosos del siglo XIX: «Todos esos personajes fueron ilustres en su tiempo; pero ¡cuán pocos nombres flotan en la corriente arrolladora de los siglos! De esos treintaiséis doctísimos varones, hay muchos, la mayor parte, de quienes apenas guarda memoria algún investigador erudito.» ${ }^{139}$ Este conjunto de retratos, en definitiva, eran la imagen gloriosa de una institución que había dado sus mejores frutos en los éxitos de cada uno de los efigiados. Y además, animaba a aquellos que llenaban sus aulas a desear ser parte de este exclusivo grupo de intelectuales. Por tanto, la galería de efigies del para-

138 Teodoro Llorente, Valencia, (Cortezo, 1889), tomo II. Capítulo VI, La Universidad, pp. 191-192.

139 Llorente, Valencia..., tomo II. Capítulo VI, La Universidad, p. 220. 
ninfo mantiene las funciones propias de las series de varones ilustres y entronca perfectamente con el uso del retrato para ser imagen del poder cultural.

El grupo pictórico cuenta con un total de cuarenta retratos, treintaiocho de ellos dispuestos a modo de friso que nace desde ambos lados de la zona presidencial, con las imágenes de Fernando II el Católico a la derecha del espectador y Alejandro VI a la izquierda, y muere en la entrada con las otras dos obras restantes. Las primeras efigies datan del siglo XVII y los más recientes son de principios del siglo XX. Cumpliendo con las necesidades de una galería de estas características, el tipo de representación para todos sus retratados es común. Se ha apostado por una imagen contextualizada en el interior de una estancia engalanada por un cortinaje y muebles auxiliares. El personaje normalmente aparece de pie y se le ve de cuerpo entero. También se le presta una especial atención a la individualización de cada uno de ellos a través del rostro y se revela 500 la condición social y profesional del representado mediante la indumentaria. Además, en la zona inferior siempre se incluye un escrito insertado en una cartela o medallón para dejar constancia de la identidad y éxitos del efigiado. Igualmente puede añadirse el escudo de armas correspondiente para indicar la pertenencia a un determinado linaje o colectivo.

Respecto al orden de colocación de cada uno de los retratos, éste ha sido alterado con el paso del tiempo. Así, la disposición actual no concuerda con la descripción que ya hizo Teodoro Llorente en 1889. Según este autor, el friso se componía de treintaiséis efigies que nacían desde ambos lados de la zona presidencial. A la izquierda desde la posición del espectador, se ubicaban las imágenes del pontífice Alejandro VI, fray Bernardo Oliver, Luis Nicolau Vergara, Antonio José Cavanilles, Marcelo Marona, Damián Polou, fray Tomás Marín, fray Juan Tomás de Rocabertí, Manuel Martí, Juan Bautista Ferrer y Castro, Francisco Fabián y Fuero, Felipe Bertrán, Asensio Sales y Moreno, José Climent, José Tormo y Juliá, fray Vicente Blasco, 
Miguel Payá y Francisco Pérez Bayer. A la derecha, se dispuso en primer lugar el retrato del monarca Fernando el Católico, le seguía fray Jaime Pérez, Cristóbal Crespí de Valldaura, Tomás Vicente Tosca, José Sanchís, Juan Bautista Ibáñez, José Verge, Marcelino Siuri, Luis Crespí de Borja, fray Juan Ruiz, Antonio Ferrer y Milán, Gaspar Fuster, fray Miguel Maiques, Antonio García de Cervera, Francisco Borrull, Mariano Liñán, Juan Sala y Nicolás María Garelly. ${ }^{140}$

Debido a que las pinturas se han ido elaborando en un marco cronológico muy amplio, seguidamente se han analizado cada una de ellas habiéndolas clasificado, a groso modo, en su centuria correspondiente. Así igualmente resulta más sencillo observar que se trata de un conjunto vivo en la historia, que fue creciendo y adaptándose con el tiempo.

\subsubsection{Los retratos del siglo XVII.}

Si se analiza la galería frente a la presidencia hacia la derecha, el primer retrato es el de Fernando II el Católico (14521516) [fig. 5.25], pues gracias a él la Universitat se constituyó como la más relevante de la Corona de Aragón y se equiparó a la de Salamanca. El monarca viste con armadura y empuña la espada con su mano izquierda. El cetro, el collar y la capa real remiten a su condición de monarca. Estos dos últimos elementos se asemejan considerablemente a los que aparecen en el retrato de Ariosto para la serie de la diputación de Zaragoza y que se conocen a partir de las reproducciones conservadas en el Museo Nacional del Prado. Es más, se llega a copiar la empresa del rey compuesta por el lema «Tanto Monta», el yugo y el haz de flechas. La inscripción que acompaña al retrato especifica lo siguiente: «Seren[]mus et Catholicus Aragonum Rex Domine Ferdinandus hui[us] nom Secundo. An MDII. Inchitae huius Academiae Valentinae Erector Glorios[us].»

140 Llorente, Valencia..., tomo II. Capítulo VI, La Universidad, p. 220. 


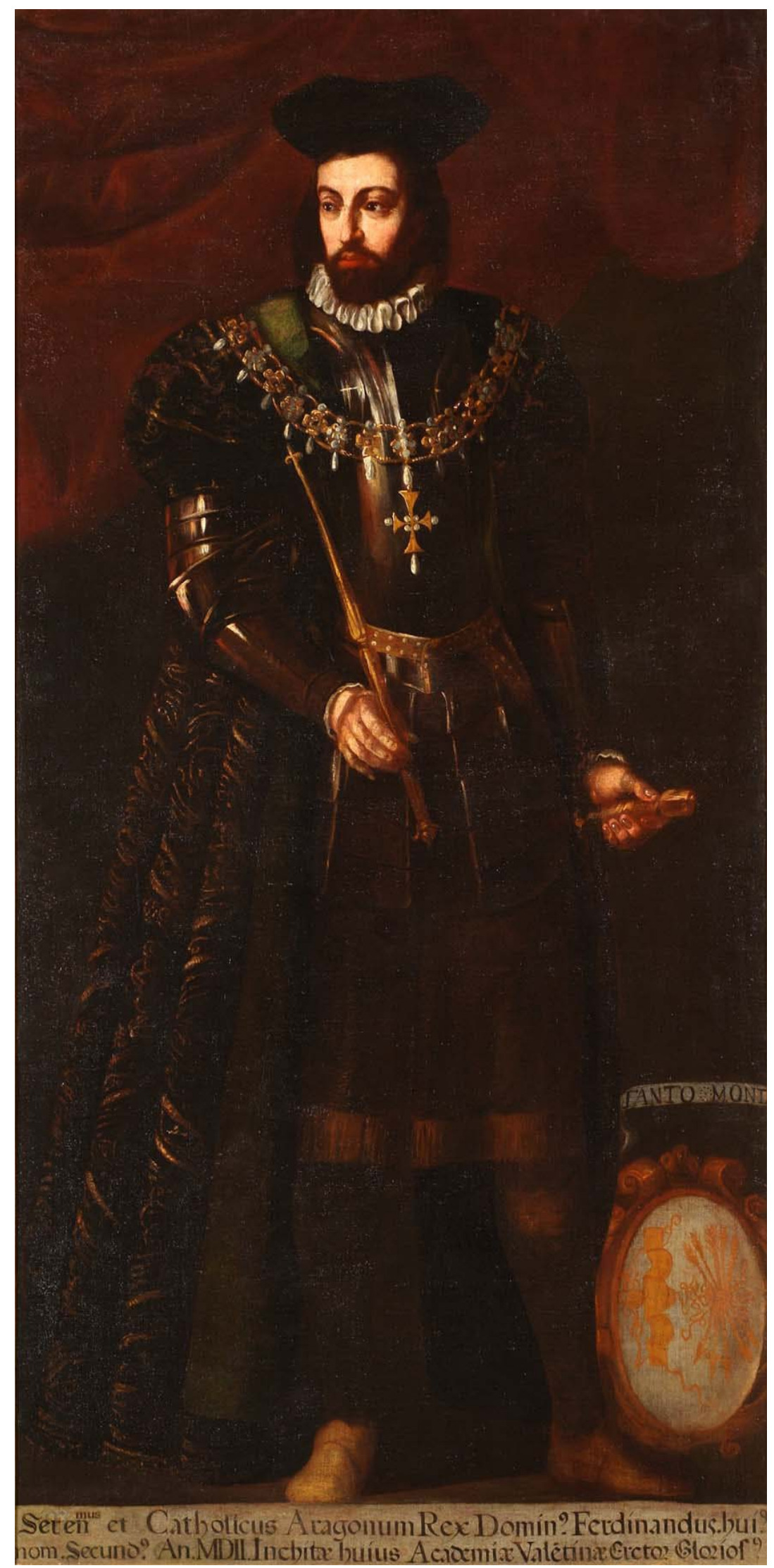

Fig. 5.25. Anónimo, Fernando II el Católico, s. XVII, óleo sobre lienzo, Valencia, paraninfo de la Universitat. 
Cristóbal Crespí de Valldaura (1599-1672) [fig. 5.26] fue catedrático ${ }^{141}$ de derecho en la Universitat valenciana. Su atuendo revela que formó parte de la orden de Montesa. ${ }^{142}$ En la mano derecha sostiene un documento donde se puede leer el encabezado de lo que parece ser una misiva con las palabras «Ilustrísimo Señor». La mano izquierda reposa sobre una mesa complementaria donde se distingue un escudo con la figura de la Inmaculada Concepción sobre un árbol. Posiblemente este detalle muestre que para el retrato de Cristóbal Crespí se ha optado por colocar el escudo de armas que modificó su hermano Luis Crespí de Borja al introducir la imagen de la Inmaculada como señal de su defensa de la pía devoción. ${ }^{143}$

En la parte inferior derecha se ha incluido una extensa inscripción biográfica en la que se presenta a: «Don Cristóbal Crespí de Valldaura, natural de san Mateo, hijo de don Francisco y doña Juana Brizuela y hermano del Venerable y Excelentísimo don Luis Crespí de Borja. Estudió gramática y filosofía en esta Universidad y Leyes en Salamanca, después restituyéndose a Valencia obtuvo cátedra de Jurisprudencia en esta Universidad, fue oidor criminal y civil de nuestra Audiencia, Gran Cruz y Clavero en la religión de Montesa, regente y vicecanciller del sacro Supremo Consejo de Aragón y otro de los gobernadores de la monarquía española a la menor edad del Señor Rey don

141 Se recomienda el catálogo de catedráticos y opositores del siglo XVII en: Amparo Felipo Orts, La Universidad de Valencia durante el siglo XVII (1611-1707), (Generalitat Valenciana: Valencia, 1991) pp. 293-396.

142 Consúltese la ficha de catálogo de Amparo José Mora en Daniel Benito Goerlich y David Sánchez Muñoz, La Universitat de València y su patrimonio cultural, (Universitat de València: Valencia, 2008), vol. II, pp. 172-173.

$143 \mathrm{El}$ antiguo escudo donde el motivo principal es el árbol aparece en la estampa que encabeza la obra de Tomás de la Resurrección, Vida del venerable Ilmo. y Excmo. Sr. D. Luis Crespí de Borja, obispo de Plasencia, y embajador por Felipe IV a Alejandro VII para la declaración del culto a la Concepción, Valencia: Lorenzo Cabrera, 1676. También se recomienda consultar la ficha de catálogo de Inés Cabrera Sendra en Pablo González Tornel (ed.), Intacta María. Política y religiosidad en la España barroca, (Museo de Bellas Artes: Valencia, 2017), pp. 260-263. 


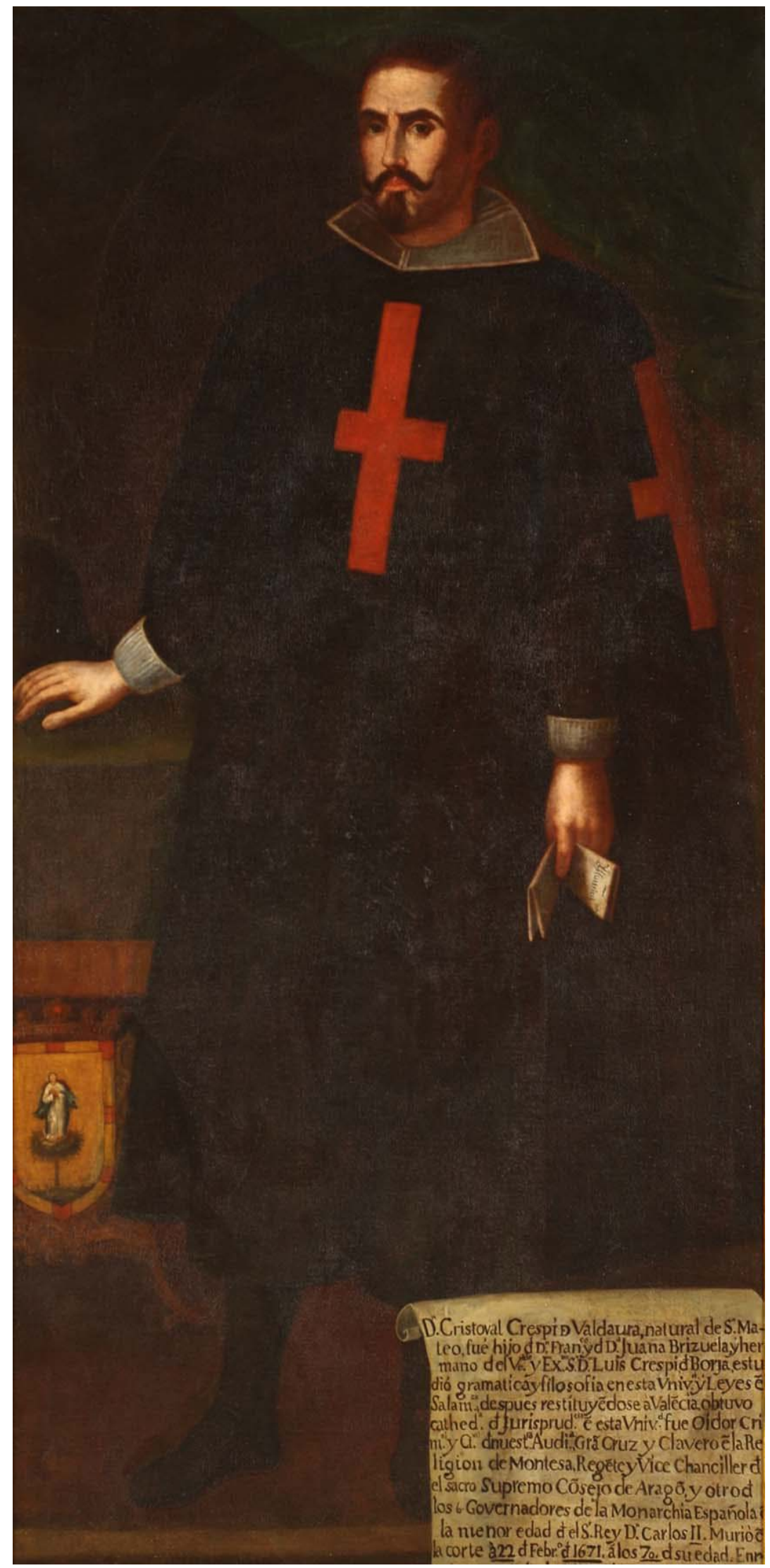

Fig. 5.26. Atribuido a José Orient, Cristóbal Crespí de Valldaura, h. 1665, óleo sobre lienzo, Valencia, paraninfo de la Universitat. 
Carlos II. Murió en la corte a 22 de febrero de 1671 a los 70 de su edad. Enriqueció el orbe literario con sus preciosas observaciones.» Este retrato se ha atribuido al pintor José Orient y se ha fechado hacia el año 1665, ello ha derivado de que el artista también hiciese, al menos, dos retratos de su afamado hermano. Uno de ellos forma parte de la presente serie pictórica, y se comentará más adelante, y el otro es de formato de busto. ${ }^{144}$

El retrato del mercedario fray José Sanchís Ferrandis (16221694) [fig. 5.27] es una de las pinturas, relacionadas con la mano del artista Jerónimo Jacinto Espinosa y fechada alrededor de 1660, que sigue configurando esta galería de efigies. Sobre una línea de horizonte muy baja en la cual se distingue el convento de la Merced se alza de forma imponente a la par que majestuosa la figura de José Sanchís. El hábito y el escudo igualmente lo vinculan a la orden mercedaria, además sobre éste último se aprecia el capelo de diez borlas, propio de los arzobispos, que recuerda a su experiencia al frente de distintas diócesis. De hecho, fue prelado de Segorbe entre 1673 y 1679, seguidamente en 1680 se convirtió en arzobispo de Tarragona, cargo que ostentó hasta su fallecimiento en 1694. Así pues, el retrato que recuerda su paso por la diócesis castellonense recuerda a la pintura de Espinosa, aunque en este caso se trate de una imagen de medio cuerpo llevada a cabo por un pintor valenciano anónimo de calidad inferior a la perteneciente a este conjunto. Respecto a su vinculación con la Universitat de València cabe recordar que fue profesor de filosofía y ostentó una cátedra desde 1644. La correspondiente inscripción, también se encuentra en latín e indica lo siguiente: «Ilmo. et R. D.D.F. Ioseph Sanchiz in Academia Valentina Philosophiae Prophessor, Regiiac Militaris Ord. B. Mariae de Mercede Commendatorgens Emporicensis, Segobricensis ac Tarraconensis Antistes, natus Valentiae 1622, Obiit 1694.»

144 La imagen de busto se corresponde concretamente con el Retrato de Luis Crespí de Borja, agente de Felipe IV en la causa de la Inmaculada Concepción (ca. 1674, óleo sobre lienzo, Valencia, Museo de la Ciudad). Un análisis pormenorizado de la obra se encuentra en la ficha de catálogo de Inés Cabrera Sendra en González Tornel (ed.), Intacta María..., pp. 256-258. 


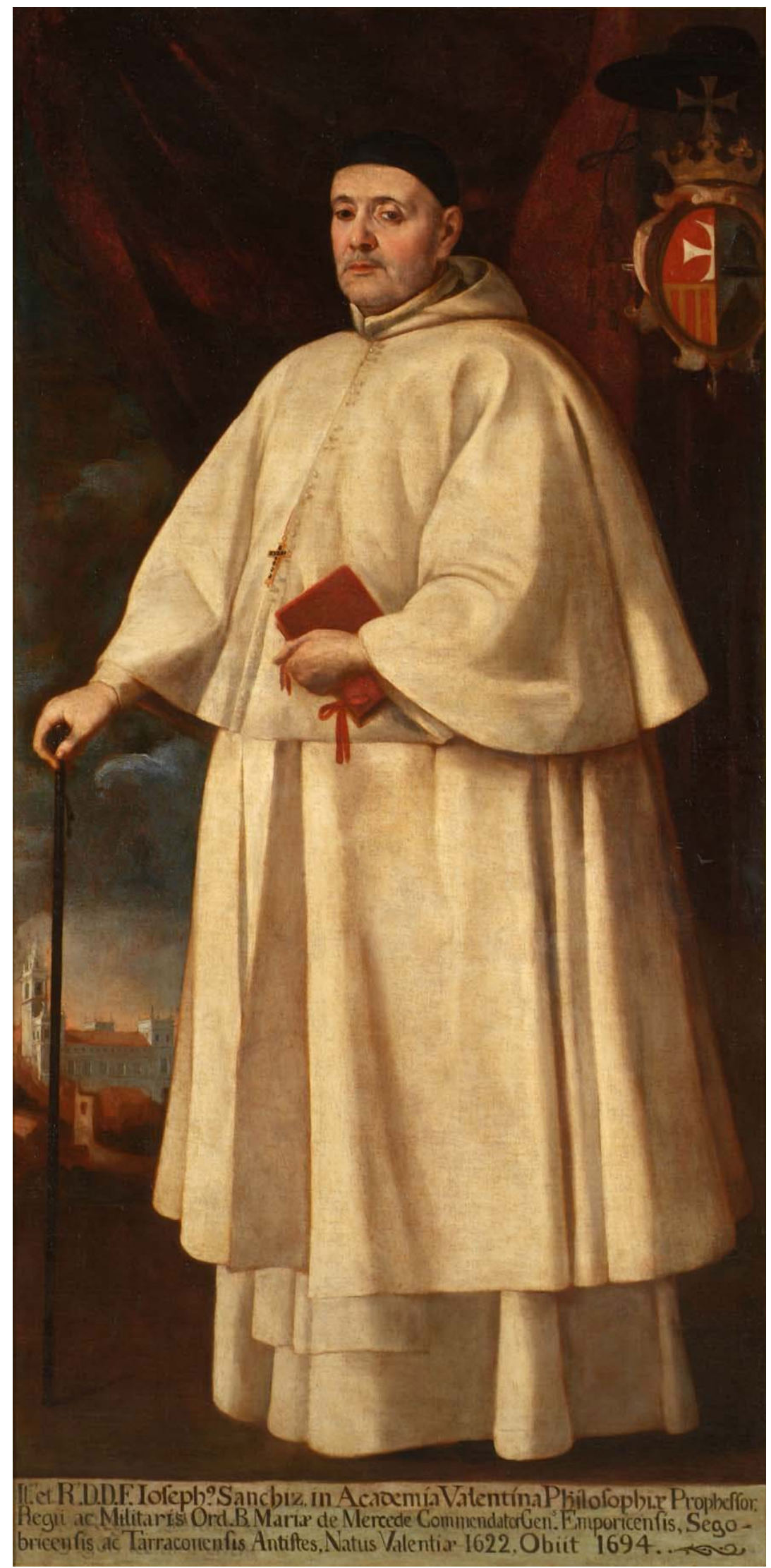

Fig. 5.27. Jerónimo Jacinto de Espinosa, Fray José Sanchís Ferrandis, h. 1660, óleo sobre lienzo, Valencia, paraninfo de la Universitat. 
Juan Bautista Ibáñez (1621-1681) [fig. 5.28], natural de Alcora, se formó en la institución valenciana en cánones, donde llegó a ser catedrático. Sus estudios le permitieron desempeñar el papel de canónigo doctoral en Segorbe y por tanto, asesorar jurídicamente al cabildo catedralicio. Así pues, en el retrato viste con el roquete y la muceta. Al mismo tiempo sostiene un pergamino con un breve texto latino interrumpido por la imagen de un cáliz y la Sagrada Forma. La inscripción, concretamente, dice lo siguiente: «CLEMENS P.P. IX DILECTO NOBIS IN CXPO JOANNES BAPTISTA IVAÑEZ.» En la mesa auxiliar se ha dispuesto un libro, un bonete negro y tras él, se deja entrever una mitra, probablemente una alusión al obispado de Orihuela, cargo que finalmente decidió renunciar. ${ }^{145}$ Como en otros retratos de la serie también se ha incluido el escudo de armas del efigiado y un escrito biográfico que presenta al: «El Ill ${ }^{\text {mo }} \mathbf{S}^{\mathrm{r}}$ D. Juan Bautista Ibáñez, canónigo doctoral de la iglesia catedral de Segorbe. Estudió en esta Universidad en la que se graduó de doctor en cánones y fue catedrático. Murió en Segorbe en 1681.»

El retrato de Luís Crespí de Borja (1607 - 1663) [fig. 5.29], hermano de Cristóbal Crespí como ya se ha puntualizado anteriormente, es otra de las obras relacionadas con el pintor José Orient. Si bien su expresión facial es similar a la de otras representaciones del mismo personaje, en esta ocasión se ha vestido con el hábito coral, es decir, llevando la sotana, el roquete y la muceta. Asimismo, sostiene en la mano izquierda el bonete y luce la cruz pectoral, detalles que recuerdan a sus cargos como prelado en Orihuela y Plasencia. Como es sabido, Crespí de Borja fue designado embajador de Felipe IV con el objetivo de marchar a Roma para conseguir que el papa Alejandro VII y, por extensión, la Iglesia católica defendiesen el misterio de

145 Algunas referencias biográficas mínimas acerca de este personajes entre las que cabe destacar su declinación a la diócesis de Orihuela se encuentran en: Enrique Flórez de Setién, España sagrada: theatro geográphico-histórico de la iglesia de España. Tomo XLII, (Viuda de Joaquín Ibarra: Madrid, 1801), p. 164 y Juan A. Balbás, El libro de la provincia de Castellón, (Imprenta y libreríade J. Armengot: Castellón, 1892), p. 447. 


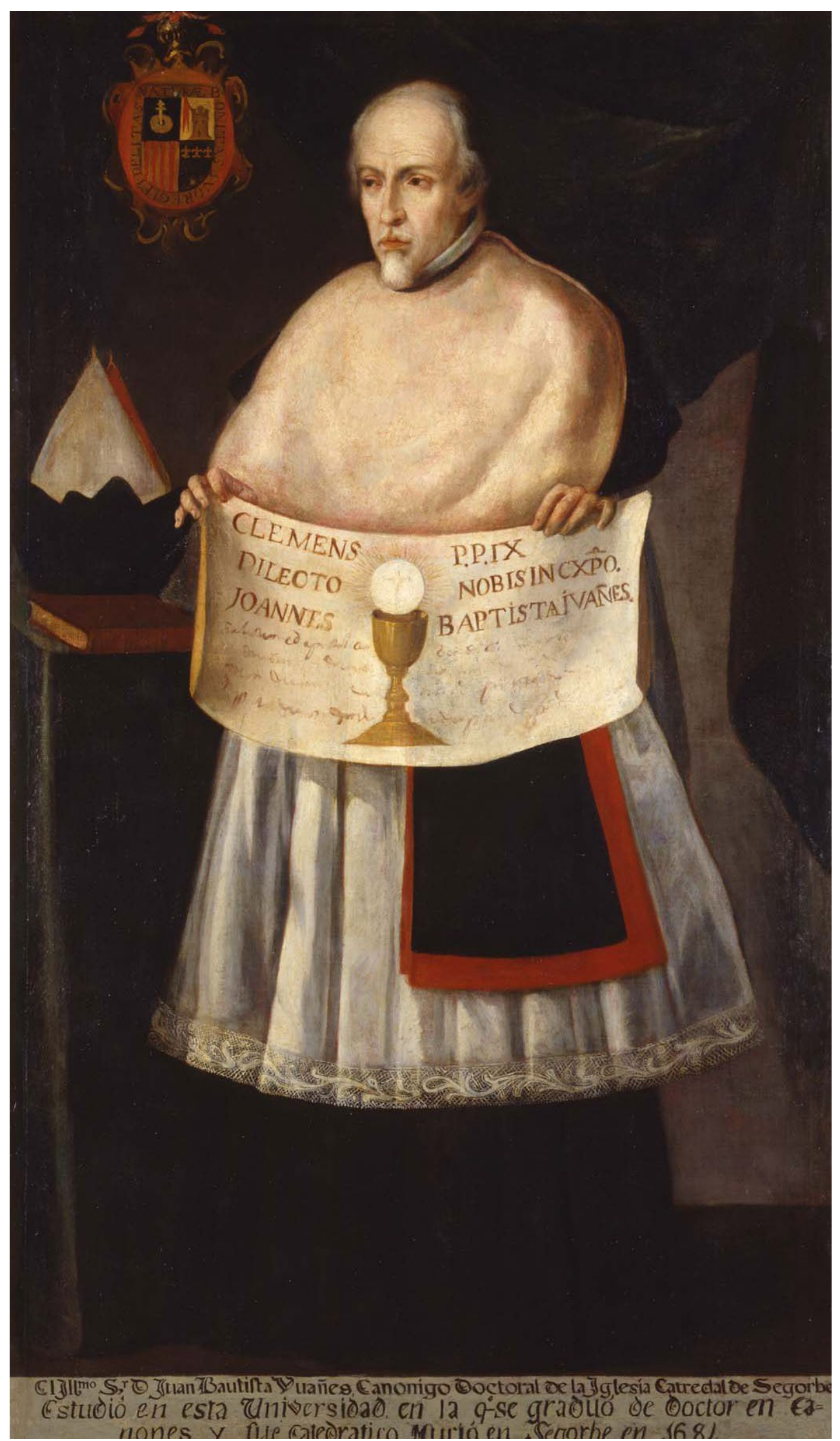

Fig. 5.28. Anónimo, Juan Bautista Ibáñez, finales s. XVII, óleo sobre lienzo, Valencia, paraninfo de la Universitat. 


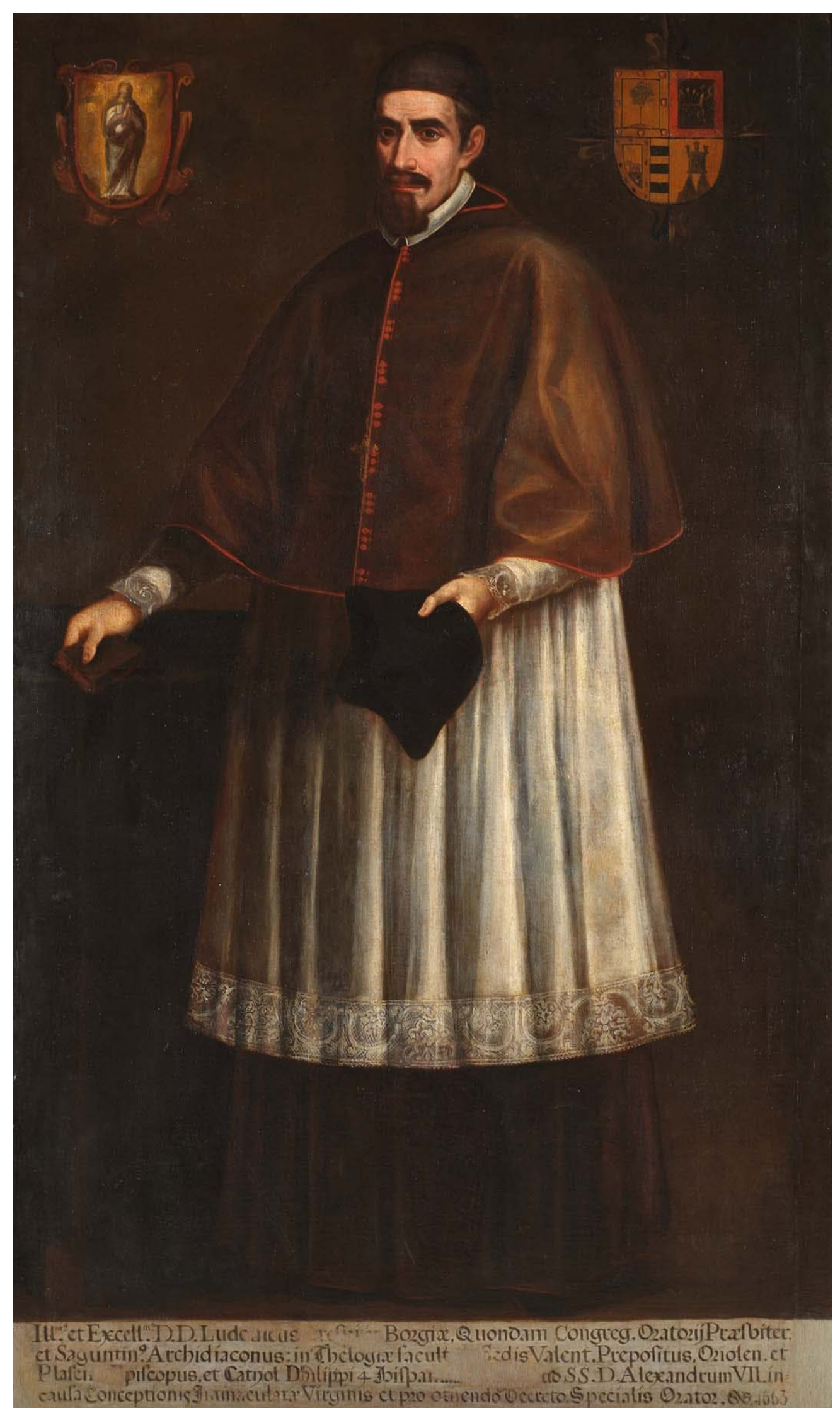

Fig. 5.29. José Orient, Luís Crespí de Borja, finales s. XVII, óleo sobre lienzo, Valencia, paraninfo de la Universitat. 
la Inmaculada Concepción. En este sentido, el retrato del paraninfo hace referencias puntuales a dicha cuestión a través del escudete que incluye la imagen de la Inmaculada y el breve texto biográfico situado en la zona inferior del lienzo. Además de este pequeño escudo, con leves diferencias al dispuesto en la efigie de su hermano, se ha colocado otro compuesto por cuatro cuarteles. Entre ellos, cabe remarcar que los dos de la izquierda se corresponden con la familia Crespí, en la parte superior, y la Casa Borja, en la zona inferior. De hecho, el motivo heráldico de los Crespí también aparece en el retrato ilustrativo del libro de Tomás de la Resurrección, Vida del venerable Ilmo. y Excmo. Sr. D. Luís Crespí de Borja, obispo de Plasencia y embajador por Felipe IV a Alejandro VII para la declaración del culto a la Concepción (Valencia: Lorenzo Cabrera, 1676).

Igualmente, a través de la mencionada obra se conoce que su formación académica tuvo lugar en la Universitat de València, donde se formó en lógica, filosofía y ciencias, y además se 510 doctoró en teología consiguiendo la cátedra en $1628 .{ }^{146}$ Estos datos tan relevantes, en síntesis, se han incluido en la inscripción: «Ill. ${ }^{\text {mo }}$ et Excell. ${ }^{\text {mo }}$ D. D. Ludovicus Crespi Borgiae. Quondam Congreg. Oratorii Praesbiter et Saguntin ${ }^{\circ}$ Archidiaconus: in Thelogiae facult [...] sedis Valent. Prepositus. Oriolen et Plasen[...] [E]piscopus et Catnol. D. Philippi 4 Hispan[...] ad S.S. D. Alexandrum VII in causa Concepcionis Inmaculata Virginis et pro[...]omendo decreto specialis orator. An. 1663.»

Del agustino fray Miguel Maiques [fig. 5.30] son numerosos los datos biográficos que se encuentran en la obra dedicada a la historia de la orden de san Agustín en la Corona de Aragón y que explican muchos de los detalles que se observan en el retrato. ${ }^{147}$ El religioso nació en Bocairente, su primera formación

146 Acerca de su formación académica véase a Tomás de la Resurección, Vida del venerable Ilmo. y Excmo. Sr. D. Luís Crespí de Borja, obispo de Plasencia y embajador por Felipe IV a Alejandro VII para la declaración del culto a la Concepción, (Lorenzo Cabrera: Valencia, 1676).

147 Los datos biográficos se ha extraído de Jaime Jordán, Historia de la 


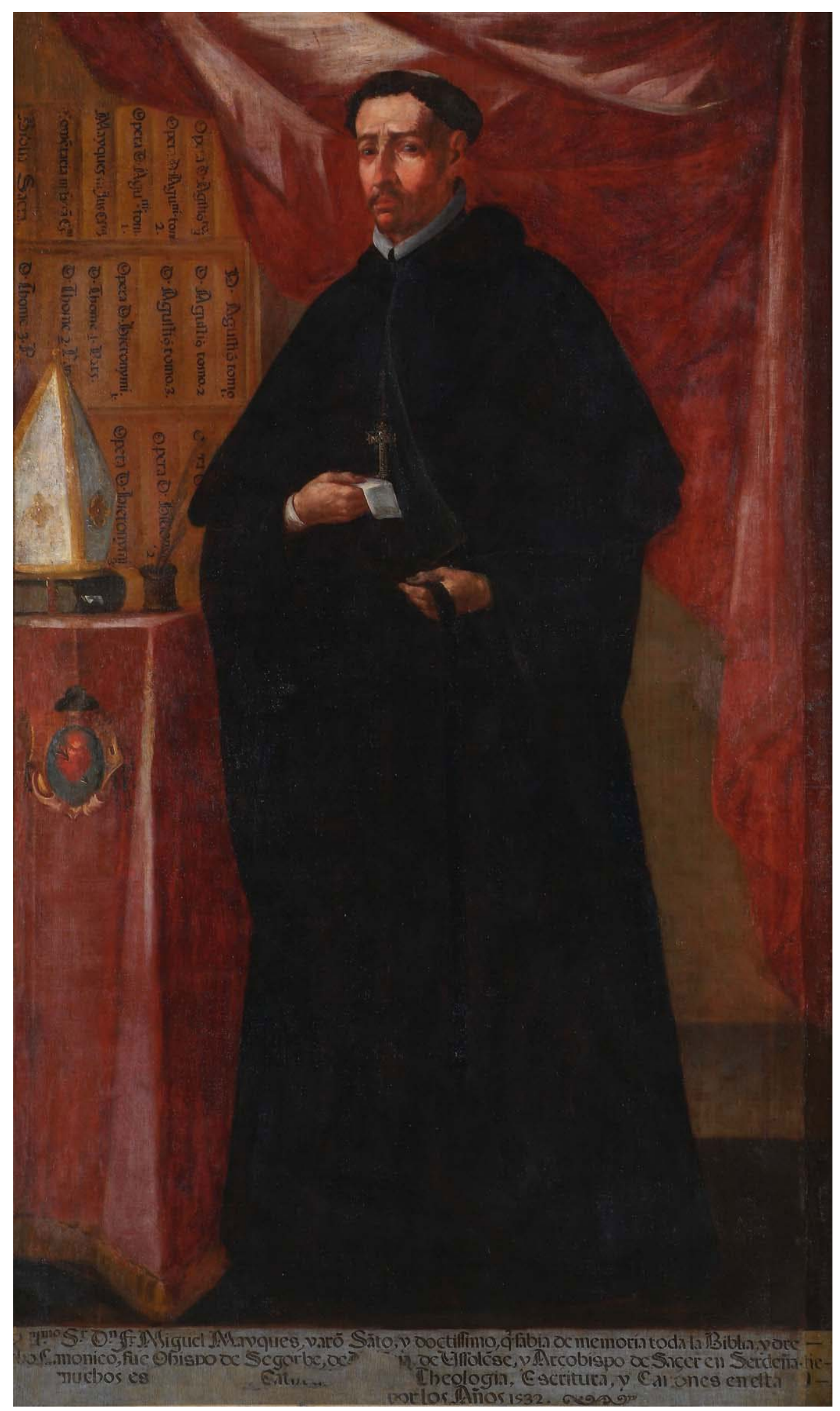

511

Fig. 5.30. Anónimo, Fray Miguel Maiques, s. XVII, óleo sobre lienzo, Valencia, paraninfo de la Universitat. 
estuvo centrada en las letras y humanidades y se convirtió en miembro de la orden de san Agustín en el convento mayor de Valencia. Así, en la imagen se aprecia un escudo timbrado con un capelo donde de se ha incluido el motivo principal de la orden agustina, el corazón en llamas. Estando en el convento amplió sus estudios en filosofía y teología y además, fue maestro en artes. A lo largo de su carrera académica consiguió distintas cátedras, de filosofía en Valencia y en Lérida. En esta última ciudad, asimismo, obtuvo el grado de doctor en teología y cánones, de cuyas especialidades también logró la cátedra. Más tarde, regresó a su universidad de origen.

Su especial dedicación al mundo intelectual se ha reflejado en el retrato mediante el libro, la pluma y el tintero que aparecen en el bufete y los numerosos libros que se observan tras él configurando parte de su biblioteca personal. Además, en 1538 se convirtió en obispo sufragáneo de Segorbe. Dos años después adquirió el cargo de gobernador del arzobispado de Valencia durante la prelatura de Jorge de Austria (h. 1504 1557), hermano de Felipe el Hermoso y tío del emperador Carlos V. También fue promocionado por su sobrino para ser obispo de Bossa y finalmente de Sácer (Cerdeña), donde pasó sus últimos años de vida y en cuya catedral fue enterrado. La mitra y la cruz pectoral, que igualmente se han incluido en el retrato, son una alusión a sus responsabilidades como prelado. Una síntesis de su biografía se halla en la correspondiente inscripción que dice lo siguiente: I I $^{\text {llmo }} \mathrm{S}^{\mathrm{r}} \mathrm{D}^{\mathrm{n}} \mathrm{Fr}$. Miguel Maiques, varo[n] sa[n]to y doctísimo, q[ue] sabía de memoria toda la Biblia y d[e]re[c]ho canónico, fue obispo de Segorbe, de [...], de [...] y arzobispo de Sácer en Cerdeña tie[...] muchos es[...] cat[...] teología, escritura y cánones en esta [...] por los años 1532.»

En cuanto a los retratos elaborados en el siglo XVII y que se han ubicado hacia el lado izquierdo frente a la presidencia se provincia de la Corona de Aragón de la sagrada orden de los ermitaños de nuestro gran padre san Agustín, compuesta de cuatro reinos, Valencia, Aragón, Cataluña y las islas de Mallorca y Menorca; y dividida en cuatro partes. Parte primera, (José García: Valencia, 1704), pp. 257-259. 
halla la efigie del pontífice Alejandro VI (ca. 1431 - 1503) [fig. 5.31] en primer lugar. Su papel fue trascendental respecto a la creación de la institución universitaria, pues a través de una bula firmada el 23 de enero de 1501 elevó la categoría del Estudi General al rango de Universitat. El retrato perteneciente a esta galería lo muestra con las vestiduras propias del cargo a desempeñar; así aparece ataviado con el roquete, la muceta roja de terciopelo, una estola y el camauro con el que se cubre la cabeza. Además, posa junto a una mesa auxiliar en la cual apoya la mano en un libro y se deja entrever la tiara papal. El detallismo de su rostro, mostrado casi plenamente de perfil, concuerda con otras efigies anteriores del mismo personaje y ya tratadas en este estudio. Recuérdese el retrato dispuesto en la serie icónica de la catedral y en la galería de hombres ilustres del monasterio de La Murta, donde también se ha retratado en calidad de papa. Ello ha dado pie a atribuir la autoría de esta pieza a Juan Ribalta u otro pintor de su taller, no obstante, por el momento no se tienen datos certeros que sostengan dicha afirmación. ${ }^{148}$ En cuanto a la inscripción latina que acompaña al efigiado, en un breve texto se indica lo siguiente: «S.S.D.N. Alexander, Pontifex hui. ${ }^{\circ}$ nom. VI. é nobil. ${ }^{\text {ma }}$ Borgiarum fam. ${ }^{a}$ progenit. ${ }^{\circ}$ et á Presulatu Valent. ${ }^{\circ}$ ad Summum evect. ${ }^{\circ}$ hui. ${ }^{\circ}$ Valent. Academiae gloriosus erector. Anno MD.»

También forma parte de la galería de ilustres una pintura relacionada con el círculo de Jerónimo Jacinto Espinosa. Se trata de fray Marcelo Marona (1612-1694) [fig. 5.32], formado en artes, filosofía y teología, y catedrático de esta última disciplina en la Universitat de València. Su trayectoria eclesiástica ha estado vinculada a la orden de los Predicadores, por esta razón se le ha retratado con el hábito de los dominicos. Junto a él se ha dispuesto un bufete con un libro y una mitra, pues cabe recordar que fue designado obispo de Orihuela pero por cuestiones de salud finalmente pudo ser sustituido y mante-

148 Véase el análisis de Nuria Blaya Estrada en Benito Goerlich y Sánchez Muñoz, La Universitat de València..., vol. II, pp. 186-187. 


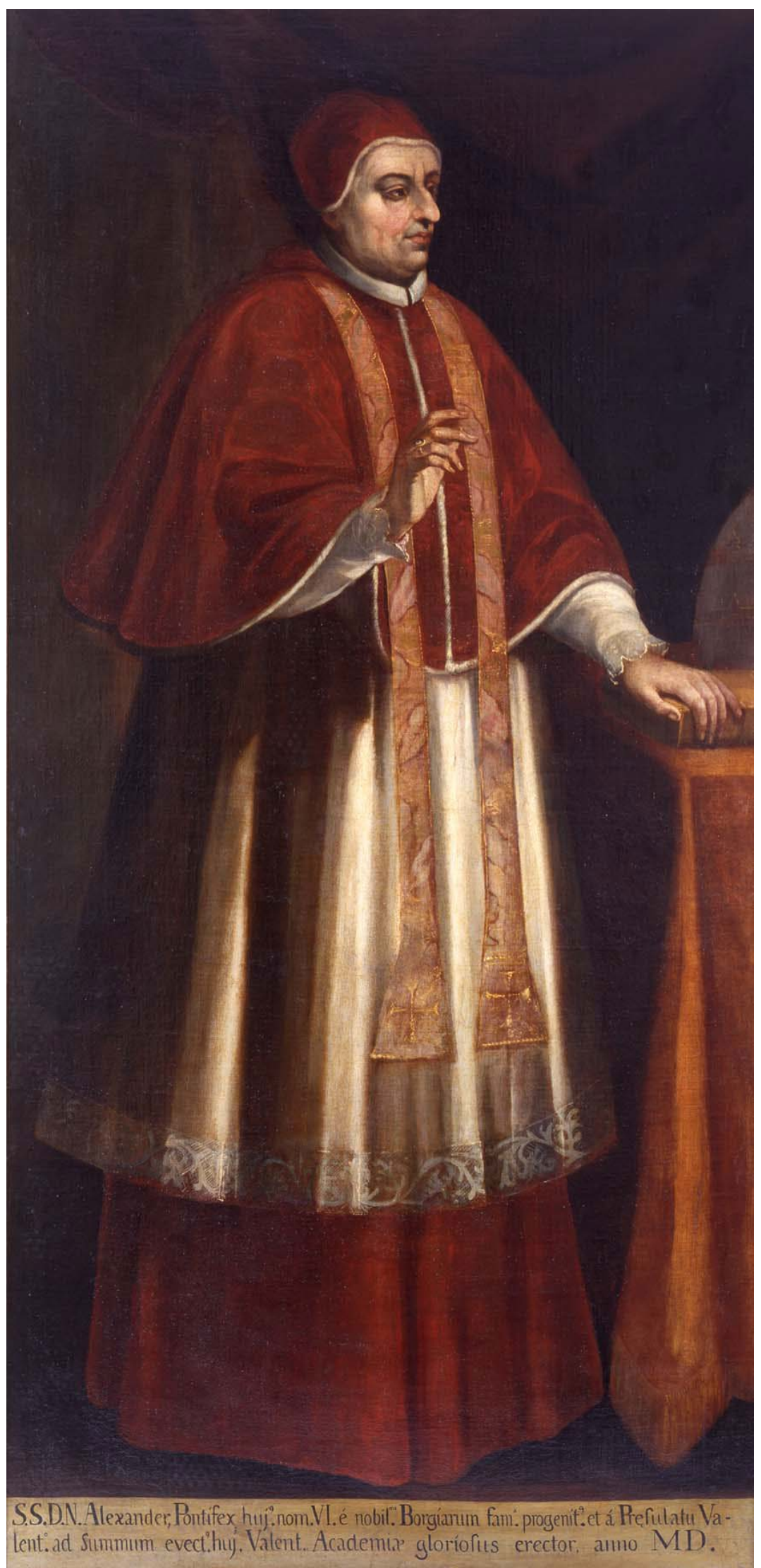

Fig. 5.31. Atribuido a Juan Ribalta o su taller, Alejandro VI, s. XVII, óleo sobre lienzo, Valencia, paraninfo de la Universitat. 


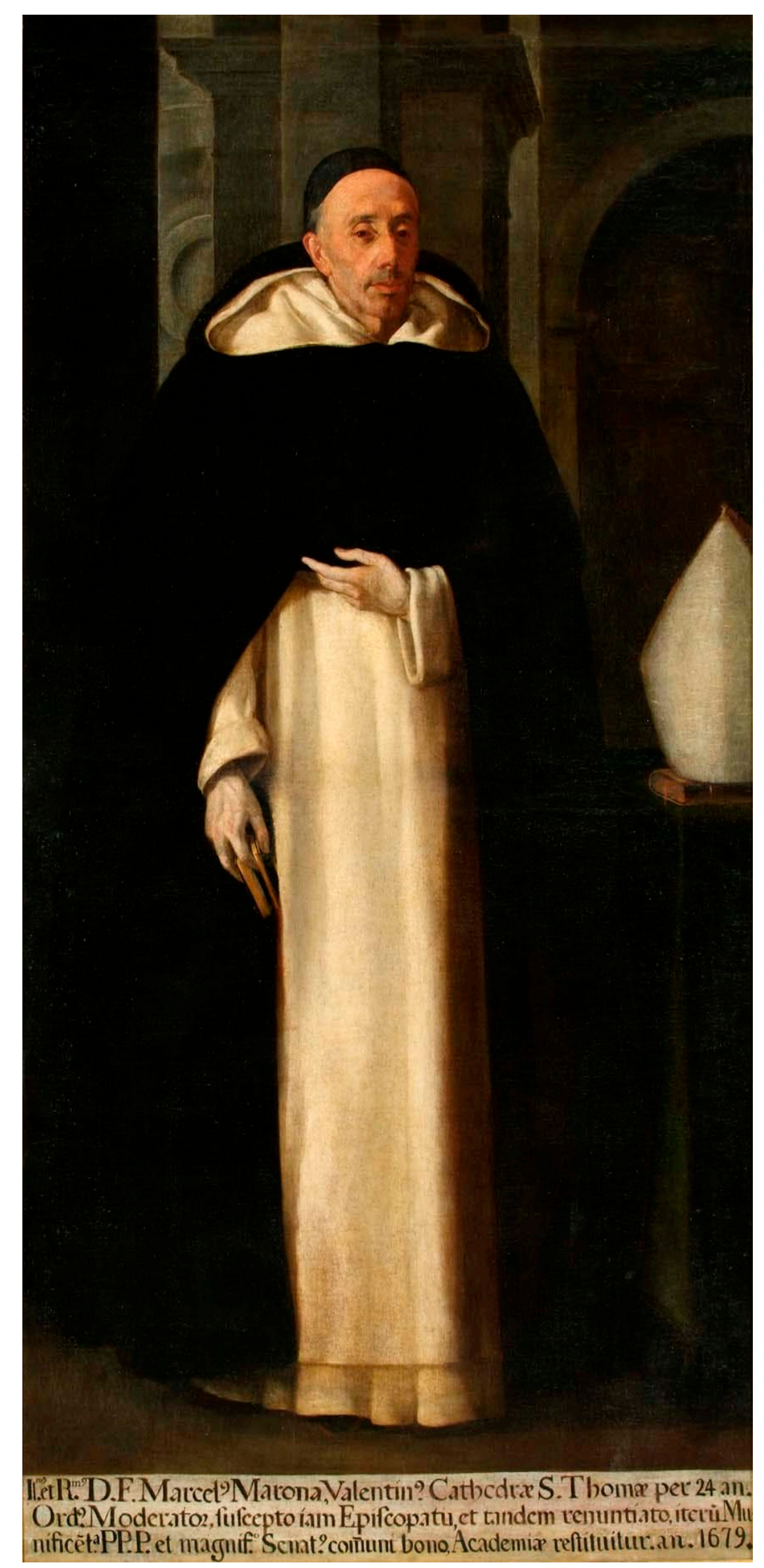

Fig. 5.32. Círculo de Jerónimo Jacinto Espinosa, Fray Marcelo Marona, finales s. XVII, óleo sobre lienzo, Valencia, paraninfo de la Universitat. 
nerse ocupado en su cátedra hasta 1689, cuando se jubiló. ${ }^{149} \mathrm{El}$ texto biográfico que acompaña la pintura del paraninfo reza lo siguiente: «Il. ${ }^{\mathrm{mo}}$ et R. ${ }^{\mathrm{m}} \mathrm{D}$. F. Marcel $^{\circ}$ Marona, valentin ${ }^{\circ}$ cathedrae S. Thomae per 24 an. Ord. Moderator, suscepto iam Episcopatu, net tandem renuntiato iteru[m]. Munifice[n]t ${ }^{\mathrm{a}} \mathrm{PP}$. P. et magnif. ${ }^{\circ}$ Senat. ${ }^{\circ}$ comuni bono, Academiae restituitur. An. 1679.»

Sus característicos rasgos faciales así como su vestimenta y el aparecer acompañado de la mitra están presentes en otros retratos del religioso. Por ejemplo, se debe mencionar la estampa que ha ilustrado la obra Lamentables suspiros [fig. 5.33], ${ }^{150}$ un libro conmemorativo de este fraile en cuyo interior se ha dispuesto su efigie enmarcada en un óvalo. Se le ha representado sedente, ataviado con su hábito, sosteniendo una pluma y papel en una mesa de trabajo, en cuyo fondo se ha incluido la mitra. Asimismo, se ha añadido una inscripción identificativa incluyendo el año de su fallecimiento en 1694, justo un año antes de que la obra de Antonio Prats viese la luz.

Por su trayectoria profesional, la efigie fray Juan Tomás de Rocabertí (1627-1699) [fig. 5.34] ha formado parte de galerías de retratos en más de una ocasión. De hecho, ya se ha visto que se encuentra entre las representaciones de prelados de la catedral de Valencia por haber estado al frente del arzobispado. Si bien la pintura catedralicia presenta a un hombre de edad avanzada mostrándose como la más alta dignidad de la sede valentina, el retrato del paraninfo ha optado por enseñar a un personaje más joven, vistiendo el hábito dominico, enjoyado con la cruz pectoral y cubriendo su cabeza con un bonete. Sus manos han quedado ocupadas por una misiva y su canutillo. Junto a él, se aprecia una mesa auxiliar vestida que ha servi-

149 Véase el análisis de Daniel Benito en Benito Goerlich y Sánchez Muñoz, La Universitat de València..., vol. II, pp. 192-193.

150 Antonio Prats, Lamentables suspiros del Real Convento de Predicadores de Valencia por la muerte de su sapientísimo hijo, y venerable padre maestro fray Marcelo Marona, (Diego de Vega: Valencia, 1695). 


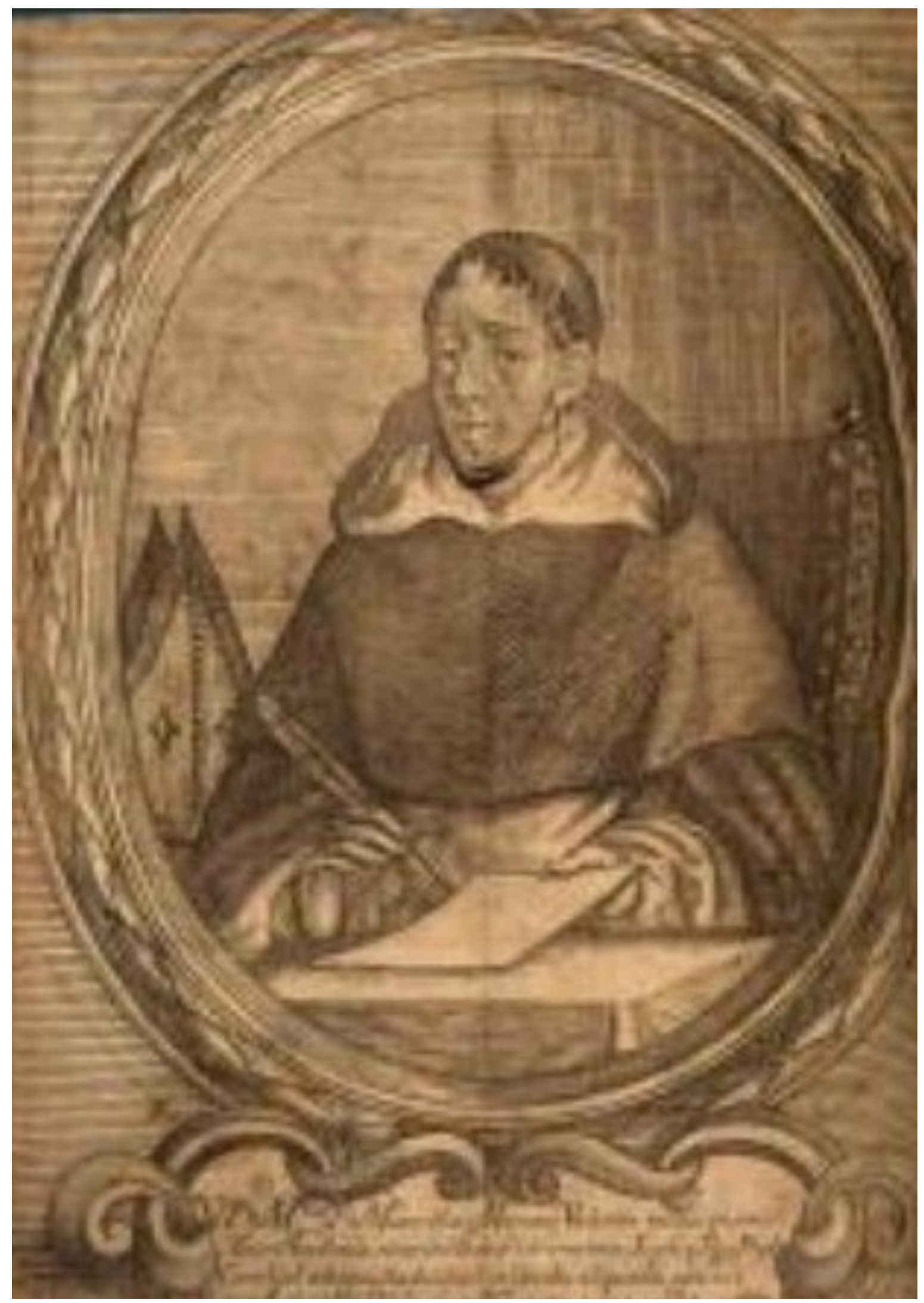

Fig. 5.33. Anónimo, Fray Marcelo Marona, estampa ilustrativa para el libro Antonio Prats, Lamentables suspiros del Real Convento de Predicadores de Valencia por la muerte de su sapientísimo hijo, y venerable padre maestro fray Marcelo Marona, (Diego de Vega: Valencia, 1695). 


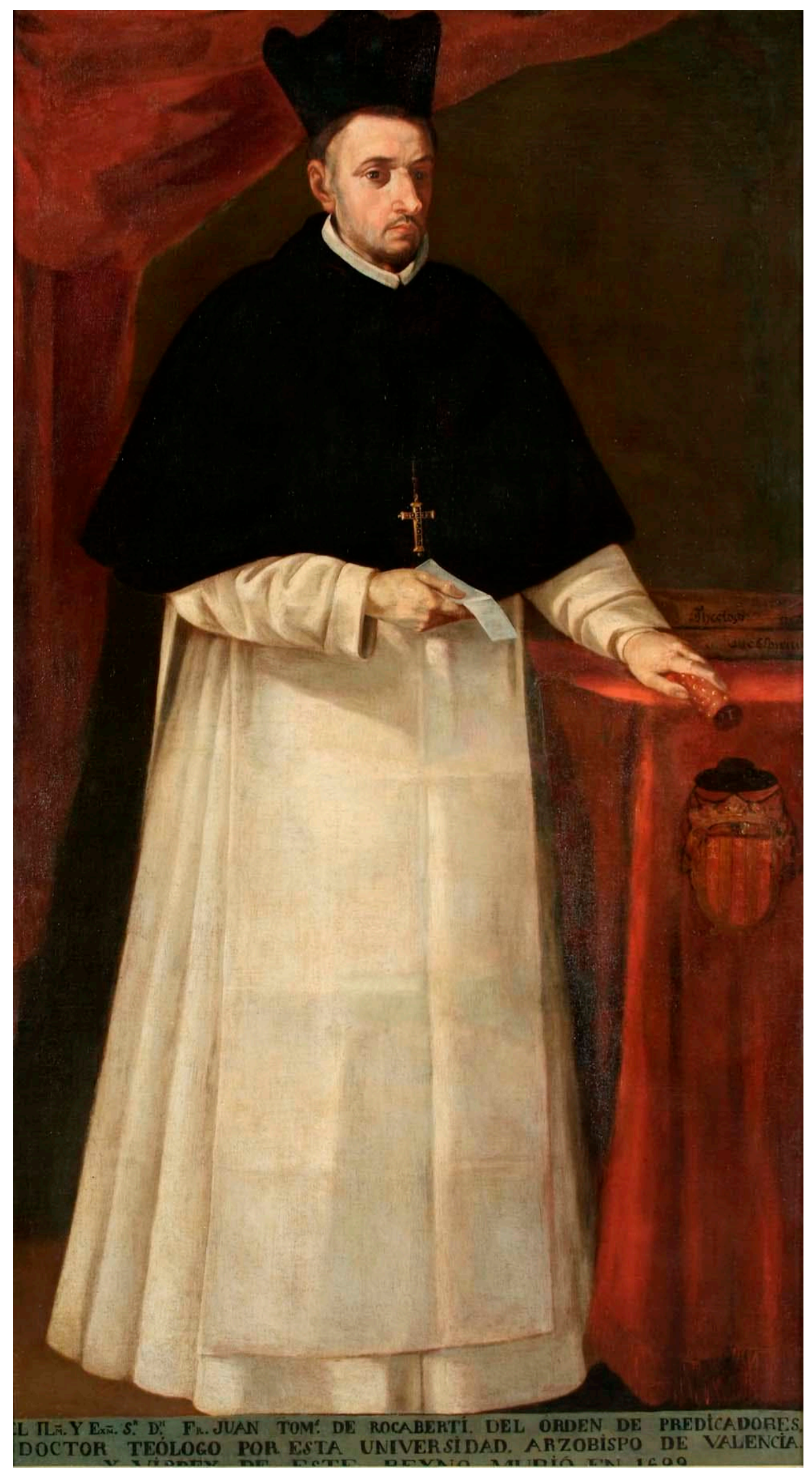

Fig. 5.34. Anónimo, Fray Juan Tomás de Rocabertí, h. 1675, óleo sobre lienzo, Valencia, paraninfo de la Universitat. 
do para colocar dos libros, uno de los cuales versa sobre teología, y añadir un escudo de armas, timbrado con el capelo pero mucho más simplificado que el hallado en otros de sus retratos. Se trata de un retrato datado alrededor del año 1675 y sin ninguna atribución clara. No obstante, en su composición y estética se puede vislumbrar una cercanía con otros retratos realizados por Gaspar de la Huerta que forman parte de los fondos del museo de Bellas Artes de Valencia [fig. 5.35]. La inscripción biográfica pone el acento en los hitos más relevantes de la carrera profesional de Rocabertí y reza lo siguiente: «El Il. ${ }^{\mathrm{m}}$ y Ex. ${ }^{\mathrm{m}}$ S. ${ }^{\mathrm{r}} \mathrm{D} .{ }^{\mathrm{n}} \mathrm{Fr}$. Juan Tom. ${ }^{\mathrm{s}}$ de Rocabertí, del Orden de Predicadores, doctor teólogo por esta Universidad, arzobispo de Valencia y virrey de este reino. Murió en 1699.»

Otro de los retratados en esta galería es José Vergé [fig. 5.36], quien también puede constar como José Berges (†1678). Sus datos biográficos conocidos son más escasos que en otros ejemplos, pero se sabe que fue párroco de Ruzafa, consiguió la cátedra de teología y llegó a ser vicerrector de la Universitat de València. Asimismo, se le concedió el título de pavorde de la catedral y por ello, viste con la indumentaria propia de los canónigos, es decir el roquete y la muceta. Su retrato es uno de los más austeros que se aprecian en el conjunto, pues como elementos auxiliares tan sólo se encuentran dos libros; uno de ellos lo mantiene entreabierto en la mano izquierda $\mathrm{y}$ el otro se halla en el bufete bajo la mano derecha. Ello recuerda a su labor intelectual, de hecho publicó una obra bajo el título De possibilitate praeservativa Deiparae redemptionis a peccato originali, (Orihuela: 1673). ${ }^{151} \mathrm{El} 28$ de mayo de 1666 comenzó a estar al frente de la diócesis de Orihuela, así luce la cruz pectoral y su escudo de armas personal está timbrado con un capelo. El escueto texto identificativo que complementa la representación de este eclesiástico especifica lo siguiente: «Ill. D.D. Iosephus Verge. Dignissimus Praepositus Valen-

151 El libro de José Vergé se ha citado en Nicolás Antonio, Bibliotheca Hispana nova sive Hispanorum scriptorum, (Joaquín Ibarra: Madrid, 1783), tomo 1, p. 823. 


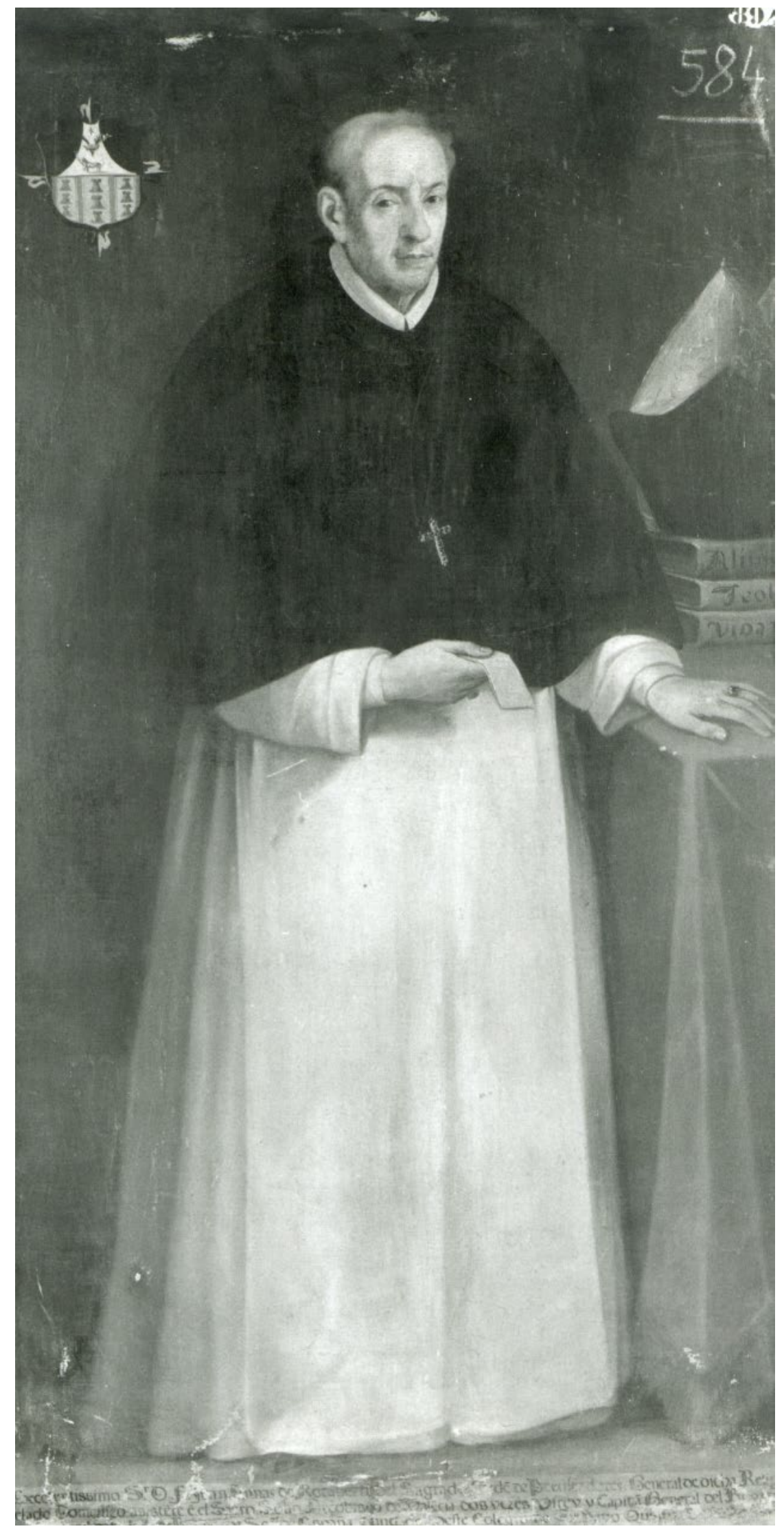

Fig. 5.35. Gaspar de la Huerta, Retrato del arzobispo Juan Tomás de Rocabertí, finales del s. XVII, óleo sobre lienzo, Valencia, Museo de Bellas Artes. 


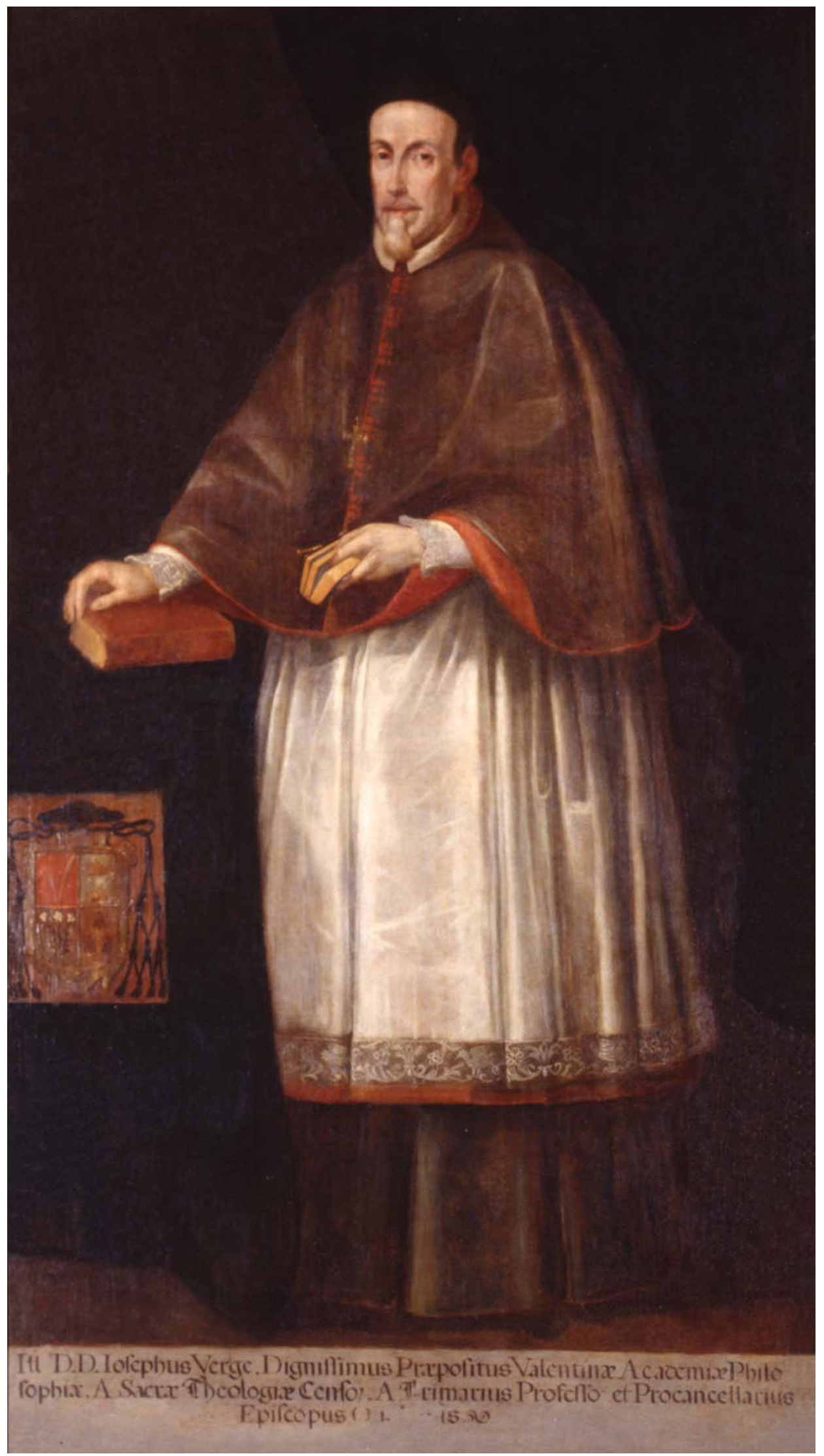

Fig. 5.36. Anónimo, José Vergé, finales del s. XVII, óleo sobre lienzo, Valencia, paraninfo de la Universitat. 
tinae Academiae Philosophiae. A Sacrae Theologiae Censor. A Primarius Professo[r] et Procancellarius Episcopus [...]» Al fallecer en 1678 lo hizo con opinión de santidad. ${ }^{152}$

Los datos biográficos que disponemos acerca de fray Juan Ruiz [fig. 5.37], otro de los retratados para esta galería, también son mínimos y controvertidos. Se ha puesto en cuestión que fuese arzobispo de Nápoles, sin embargo sí que se le ha vinculado al obispado de Neopatria y de Tortosa, en este último desde 1379. Su paso por la diócesis tortosina en el siglo XIV ha evidenciado la inexactitud de afirmar que fue profesor de teología de la Universitat de València, cuando seguramente compartió sus conocimientos en las primeras escuelas de Valencia, creadas anteriormente al Estudi General o Universitat. ${ }^{153}$

Su retrato remite visualmente a la escasa información que ha llegado de este personaje, así pues la cruz pectoral y la mitra sobre el bufete revelan su experiencia como prelado. Los numerosos libros hablan de su sólida formación y su dedicación a los saberes intelectuales. Asimismo, el escudo bordado en la tela que reviste la mesa auxiliar indica que fue miembro de la orden de san Agustín. El estado de conservación de la pintura ha dificultado la lectura completa de la inscripción que acompaña a la imagen, de la cual tan sólo se llega a entender con claridad lo siguiente: «El Il ${ }^{\mathrm{m}} \mathrm{S}^{\mathrm{r}} \mathrm{D}^{\mathrm{n}} \mathrm{F}^{\mathrm{r}}$ Juan Ruiz, obispo de Neopatria en Grecia y después [...] fue catedrático de la Universidad [...] Años de [...].» La composición de la obra tiene bastantes puntos en común con el retrato de fray Jaime Pérez, ya catalogado como pieza ejecutada en el siglo XVIII, lo cual apunta hacia una continuidad estética y visual en todas aquellas efigies que van acrecentando el conjunto pictórico con el paso del tiempo.

152 Apuntado por Vicente de la Fuente, Historia eclesiástica de España, (Compañía de impresores y libreros del reino: Madrid, 1874), tomo 5, p. 571.

153 Ortí y Figuerola, Memorias históricas de la fundación..., cap. 1, p. 13. 


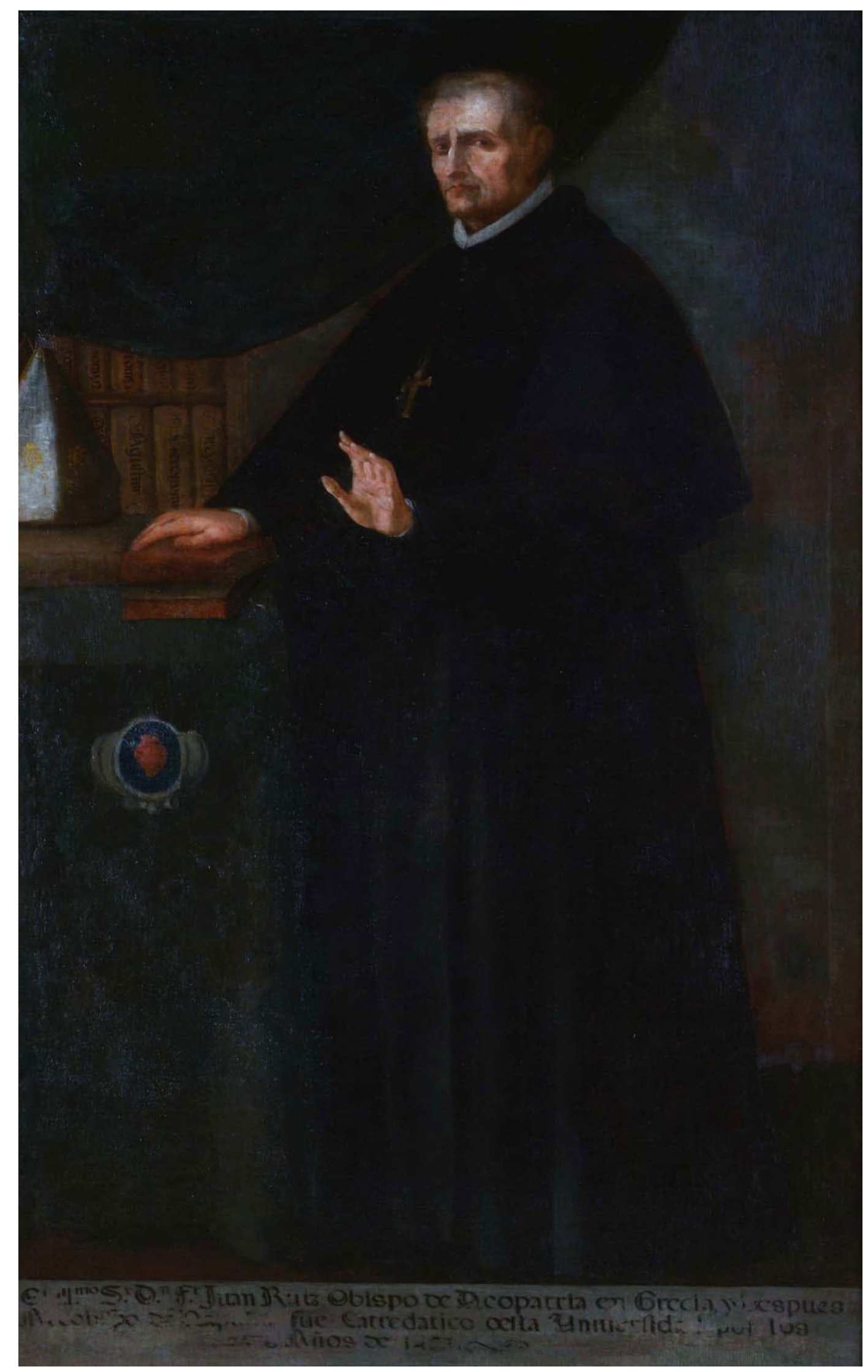

Fig. 5.37. Anónimo, Fray Juan Ruiz, s. XVII, óleo sobre lienzo, Valencia, paraninfo de la Universitat.

Retratos de hombres ilustres 


\subsubsection{Los retratos del siglo XVIII.}

Al centrarse en las pinturas datadas plenamente en el siglo XVIII se puede observar que son las más numerosas respecto a otras centurias. Desde la derecha del espectador, la primera efigie de este periodo representa a fray Jaime Pérez de Valencia (1408-1490) [fig. 5.38] fue catedrático de arte y teología en la Universitat de València. Asimismo fue obispo de Cristópolis y auxiliar del arzobispo Rodrigo de Borja, futuro Alejandro VI. Por tanto, ya fue un personaje próximo a la creación de la institución universitaria. La ubicación que ocupa a día de hoy, es decir, entre las representaciones de Cristóbal Crespí y José Sanchís, no se corresponde con la indicada por Garín anteriormente. El autor situó este retrato en la tribuna superior del muro que se enfrenta al muro testero, pero después se cambió a su localización presente intercambiándose con la efigie del padre Tosca. ${ }^{154} \mathrm{El}$ religioso se ha vestido con el hábito de la orden de san Agustín y luce una cruz pectoral aludiendo a su condición de prelado, circunstancia que también se aprecia al colocar la mitra en la mesa auxiliar, en cuyo revestimiento se ha dispuesto el escudo de la orden agustina. Los elementos complementarios que ornamentan el fondo de este retrato oficial son un cortinaje y una estantería repleta de libros, entre ellos la Biblia y obras de san Gregorio, san Jerónimo y san Agustín. La inscripción ubicada a los pies de la imagen reza lo siguiente: «Ilustrísimo Señor Don fray Jaime Pérez de Valencia. Obispo de Cristópolis, del orden de san Agustín, catedrático de Teología en esta Universidad aún no constituida legalmente por Bula Pont. y Privilegio Real. Murió 1490.»

De Antonio Ferrer Milán [fig. 5.39] cabe subrayar que fue catedrático en leyes y pavorde de la catedral. Poseer dicho título honorífico le permitió tener su asiento propio en el coro, después de los canónigos, y vestir hábitos canonicales, tal y como se aprecia en su retrato. En 1692 fue designado prelado de Se-

154 Véase el estudio de Amparo José Mora acerca de este retrato en Benito Goerlich y Sánchez Muñoz, La Universitat de València..., vol. II, pp. 170-171. 


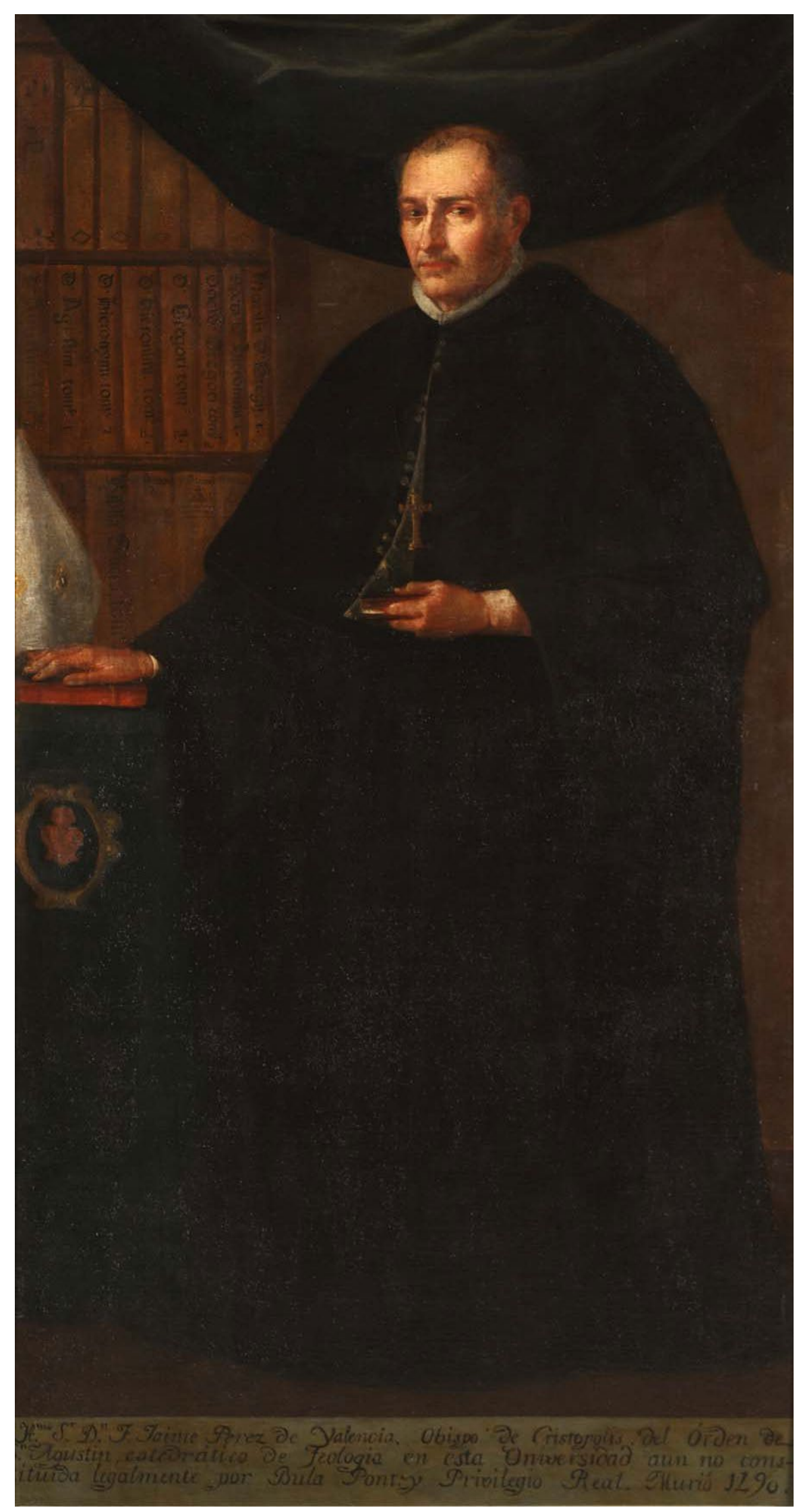

Fig. 5.38. Anónimo, Fray Jaime Pérez, 1700-1730, óleo sobre lienzo, Valencia, paraninfo de la Universitat.

Retratos de hombres ilustres 


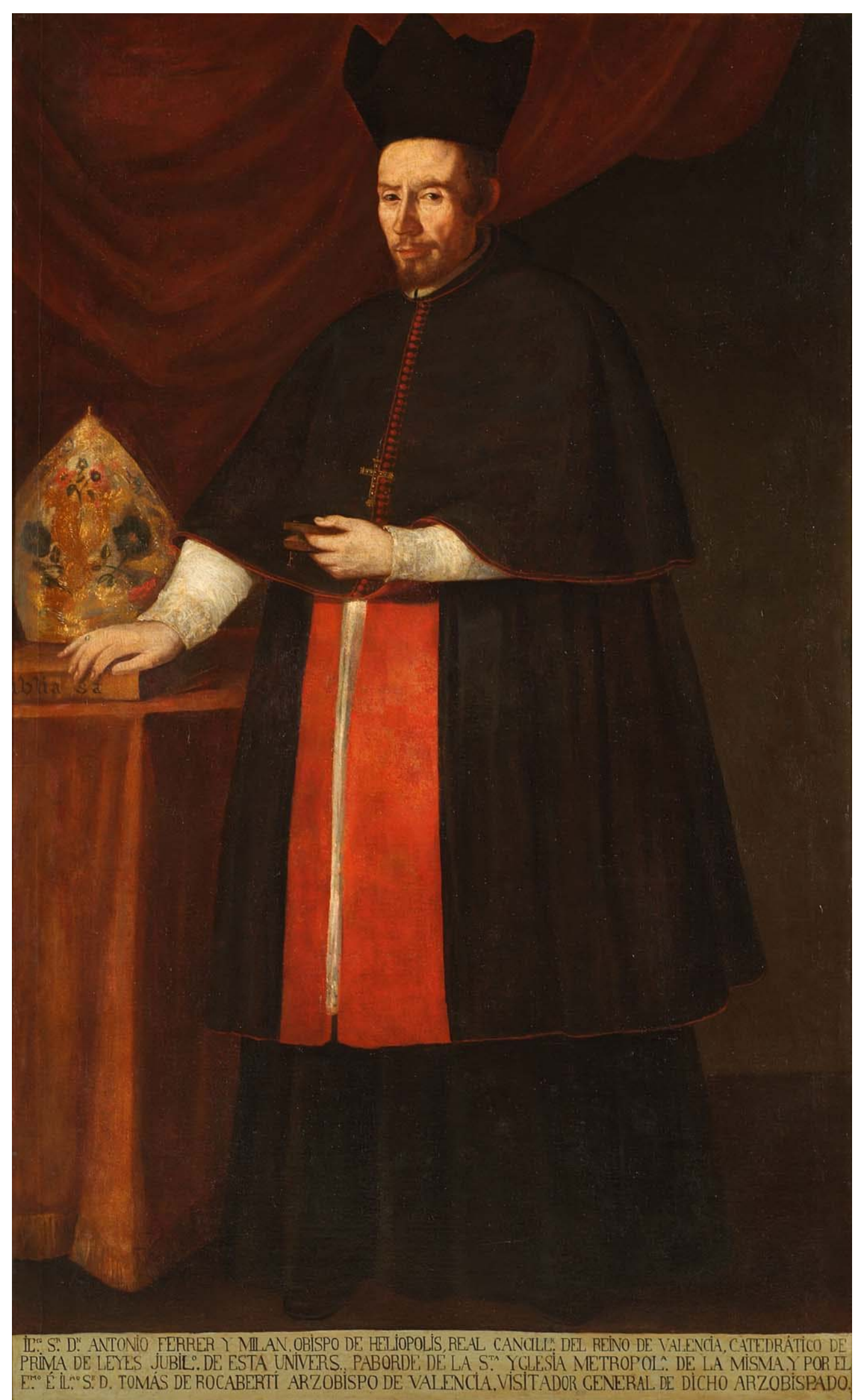

Fig. 5.39. Anónimo, Antonio Ferrer Milán, s. XVIII, óleo sobre lienzo, Valencia, paraninfo de la Universitat.

Retratos de hombres ilustres 
gorbe hasta 1707, ello explica que luzca la cruz pectoral y sobre la mesa auxiliar, detrás de un ejemplar de la Biblia, se haya colocada la mitra. Sus principales logros profesionales se han resumido en la inscripción que especifica lo siguiente: «Il ${ }^{\mathrm{mo}} \mathrm{S}^{\mathrm{r}}$ $\mathrm{D}^{\mathrm{n}}$ Antonio Ferrer y Milán, obispo de Heliópolis, real canciller del Reino de Valencia, catedrático de prima de Leyes jubil ${ }^{\circ}$ de esta Univers., pavorde de la Sta. iglesia metropol. ${ }^{\text {a de la mis- }}$ ma, y por el Ex ${ }^{\text {mo }}$ e Ill ${ }^{\text {mo }}$ S. D. Tomás de Rocabertí, arzobispo de Valencia, visitador general de dicho arzobispado.»

De la trayectoria profesional de Marcelino Siuri Navarro (1654-1731) [fig. 5.40] se ha destacado que fue maestro de colegiales en el Colegio de los Santos Reyes de Valencia, que obtuvo dos cátedras de filosofía y una de sagradas escrituras, y publicó De quatuor novissimis y tres volúmenes de su Tractatus exegeciti in Evangelia. ${ }^{155} \mathrm{Su}$ labor como escritor se percibe visualmente a través de las plumas, tinteros y libros dispuestos en el bufete. Además fue nombrado pavorde, razón por la cual luce las vestiduras canonicales. También fue obispo de Orense (1708-1717) y Córdoba (1717-1731), y a ello apuntan la mitra, la cruz pectoral y el anillo pastoral. El escudo, timbrado con el capelo, es el propio que le identifica como obispo y que está presente en la fachada barroca de la iglesia de santa María Madre (Orense). La correspondiente inscripción apunta lo siguiente: «El Ill ${ }^{\mathrm{mo}} \mathrm{y} \mathrm{R}^{\mathrm{mo}}$ Señor $\mathrm{D}^{\mathrm{n}}$ Marcelino Siuri, obispo de Orense, catedrático dos veces de filosofía, examinador y catedrático de teología expositiva en esta Universidad, fue electo el año 1708.»

El tipo de representación concuerda con la estampa que forma parte de la colección de retratos recopilada en la obra 155 Ortí y Figuerola, Memorias históricas de la fundación..., cap. 11, p. 426. Breves síntesis biográficas también se encuentran en: Andrés Ramos, Oración fúnebre en las honoríficas exequias, que el muy observante monasterio de religiosas cistercienses consagró a la dulce venerable memoria del Ilmo. y Rmo. Señor D. Marcelino Siuri dignísimo obispo de Córdoba, (Colegio de la Asunción: Córdoba, 1731), pp. 10-11 y en Juan Muñoz de la Cueva, Noticias históricas de la Santa Iglesia Catedral de Orense, (Imprenta Real: Madrid, 1727), pp. 293-294. 


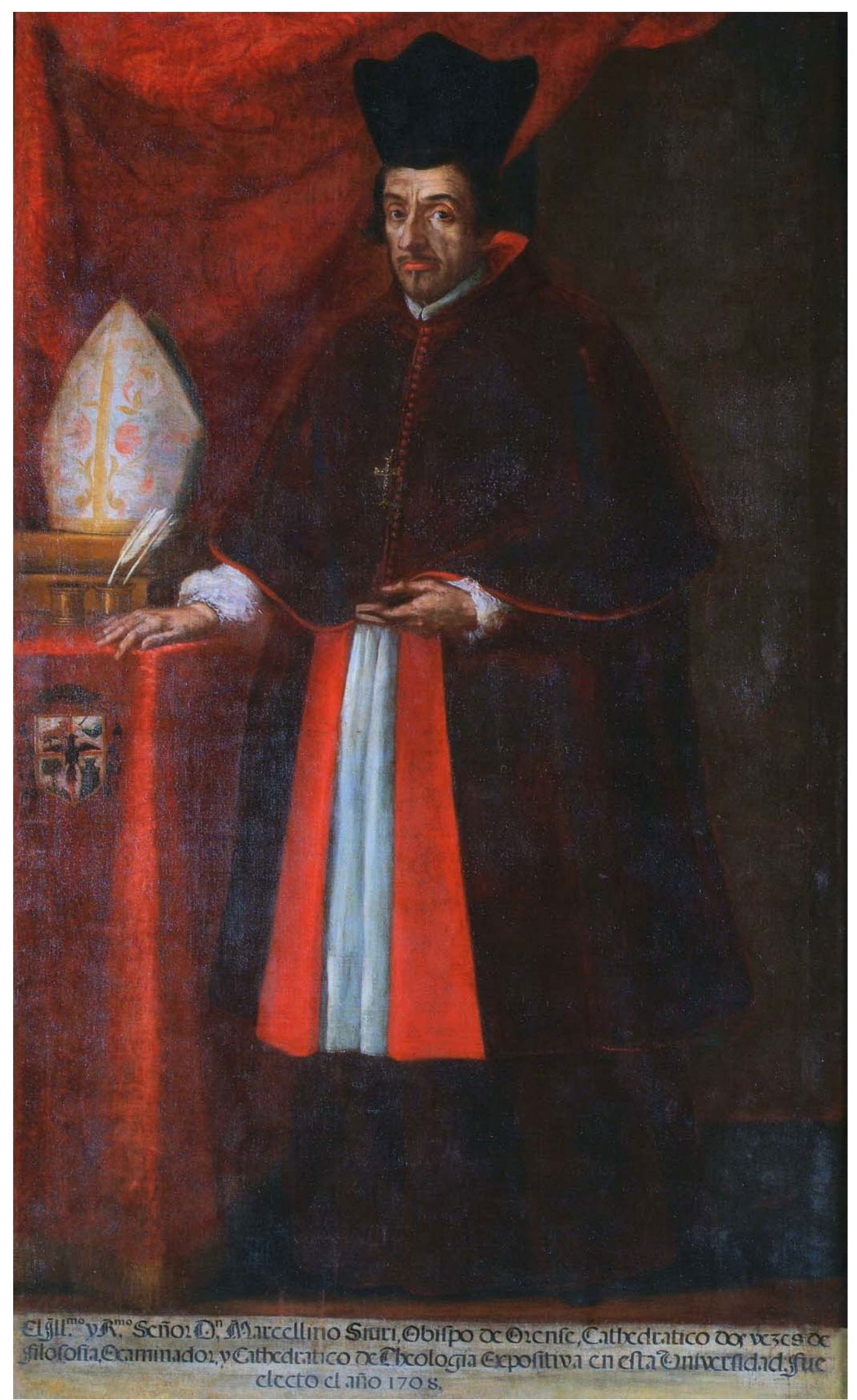

Fig. 5.40. Anónimo, Marcelino Siuri, s. XVIII, óleo sobre lienzo, Valencia, paraninfo de la Universitat. 
Valencianos ilustres en virtud, ciencias y armas [fig. 5.41]. ${ }^{156}$ Los escasos datos que se tienen de ella recaen en que fue una donación de Francisco Xavier Borrull Vilanova, se data alrededor de 1830 y reúnen diferentes efigies a través de estampas generadas en diversos siglos. Igualmente, sus marcados rasgos faciales se han reproducido en otras imágenes de este personaje, donde normalmente aparece ataviado con las vestiduras canonicales y se repiten los elementos secundarios como el cortinaje, libros, plumas y tinteros. Así lo ejemplifica la estampa que ilustra la biografía escrita por Felipe Seguer acerca de este religioso [fig. 5.42] ${ }^{157}$ Aquí, en concreto, aparecen los cuatro volúmenes de las dos obras que publicó y cuyos títulos se pueden leer en el lomo de los libros. También se ha añadido una breve descripción identificativa donde se pone de relevancia su paso por las diócesis orensana y cordobesa así como se especifica el año de su fallecimiento.

El retrato de Asensio Sales Moreno (1700-1766) [fig. 5.43] es otro ejemplo que se ajusta a las características particulares de la galería. Él fue catedrático de filosofía y además estuvo al frente de la diócesis de Barcelona desde 1755 hasta su defunción. Por esta razón, lleva la cruz pectoral y el anillo pastoral, aparece la mitra y el báculo en segundo plano. El medallón barroco adornado con el pertinente escudo de armas revela algunos datos biográficos más de este personaje: «El Ill ${ }^{\text {mo }} \mathrm{S}$. D. Assensio Sales y Moreno, beneficiado en la Igle ${ }^{a}$ de $\mathrm{S}^{\mathrm{n}}$ Lorenzo $\mathrm{M}^{\mathrm{r}}$ Cathed ${ }^{\mathrm{co}}$ y Exam ${ }^{\mathrm{r}}$ de filos ${ }^{\mathrm{a}}$ Vice Ret $^{\mathrm{r}}$ dos veces de la Univer. de Val. ${ }^{a}$ Prefecto de Estu. en el Cole ${ }^{\circ}$ de los S. Rey. ${ }^{s}$ y obis. ${ }^{\circ}$ de Barce. ${ }^{a}$ Consag. ${ }^{\circ}$ en Segorbe. Falleció en 17 de enero de 1766.» Probablemente el artista de esta pintura tuvo por referente otras imágenes del prelado, quizás conociese la estampa hecha por Vicente Galcerán Alapont (1726-1788) datada en 1761 y en la que Asensio Sales se muestra en calidad de obispo de Barcelo-

156 Valencianos ilustres en virtud, ciencias y armas, (1830).

157 Felipe Seguer, Vida ejemplar del Ilmo. señor don Marcelino Siuri, pavordre de la Santa Metropolitana Iglesia de Valencia, (Juan Rodríguez: Córdoba, 1775). 


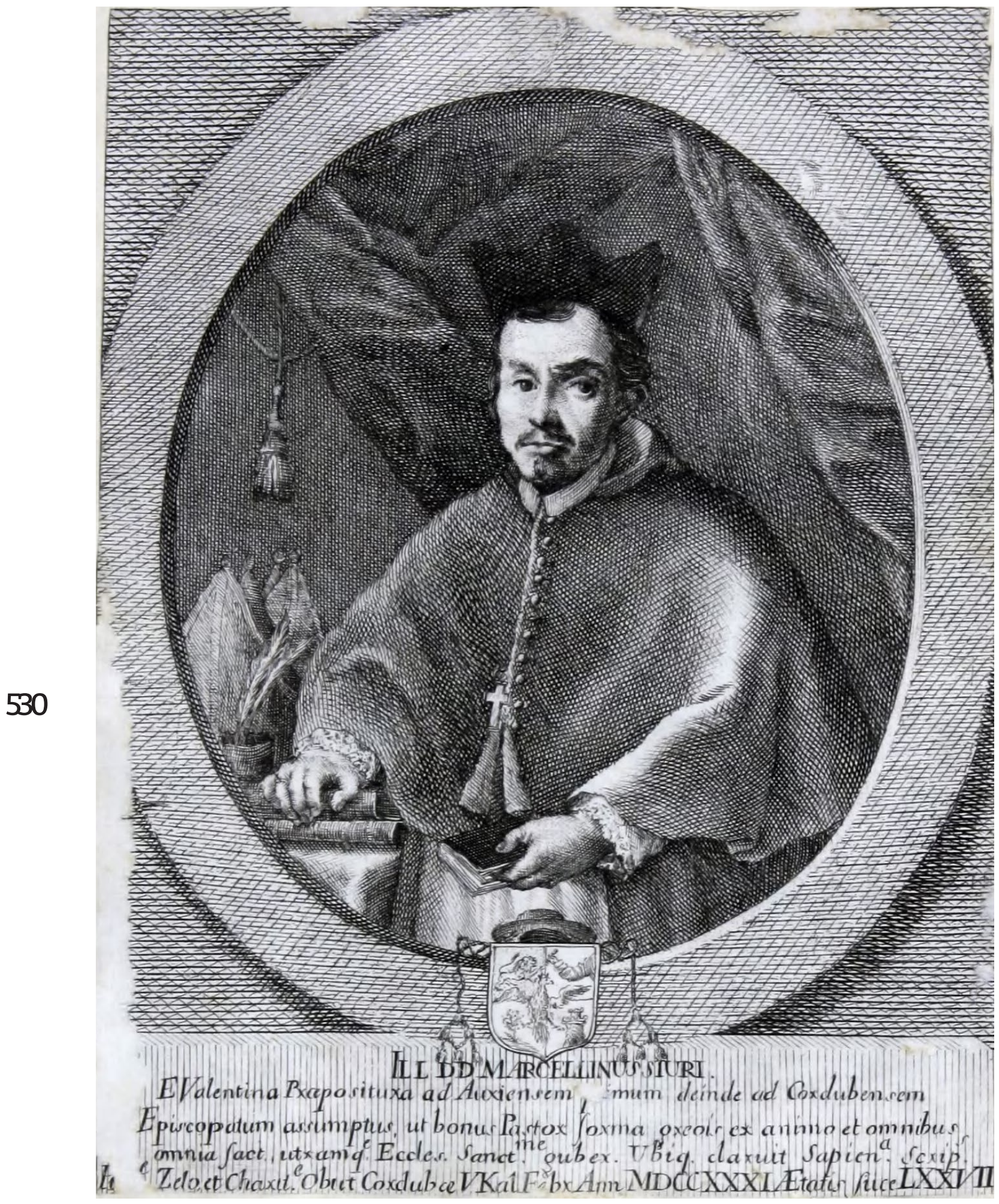

Fig. 5.41. Anónimo, Marcelino Siuri, 1830, estampa en la obra Valencianos ilustres en virtud, ciencias y armas, Valencia, Biblioteca de la Universitat. 


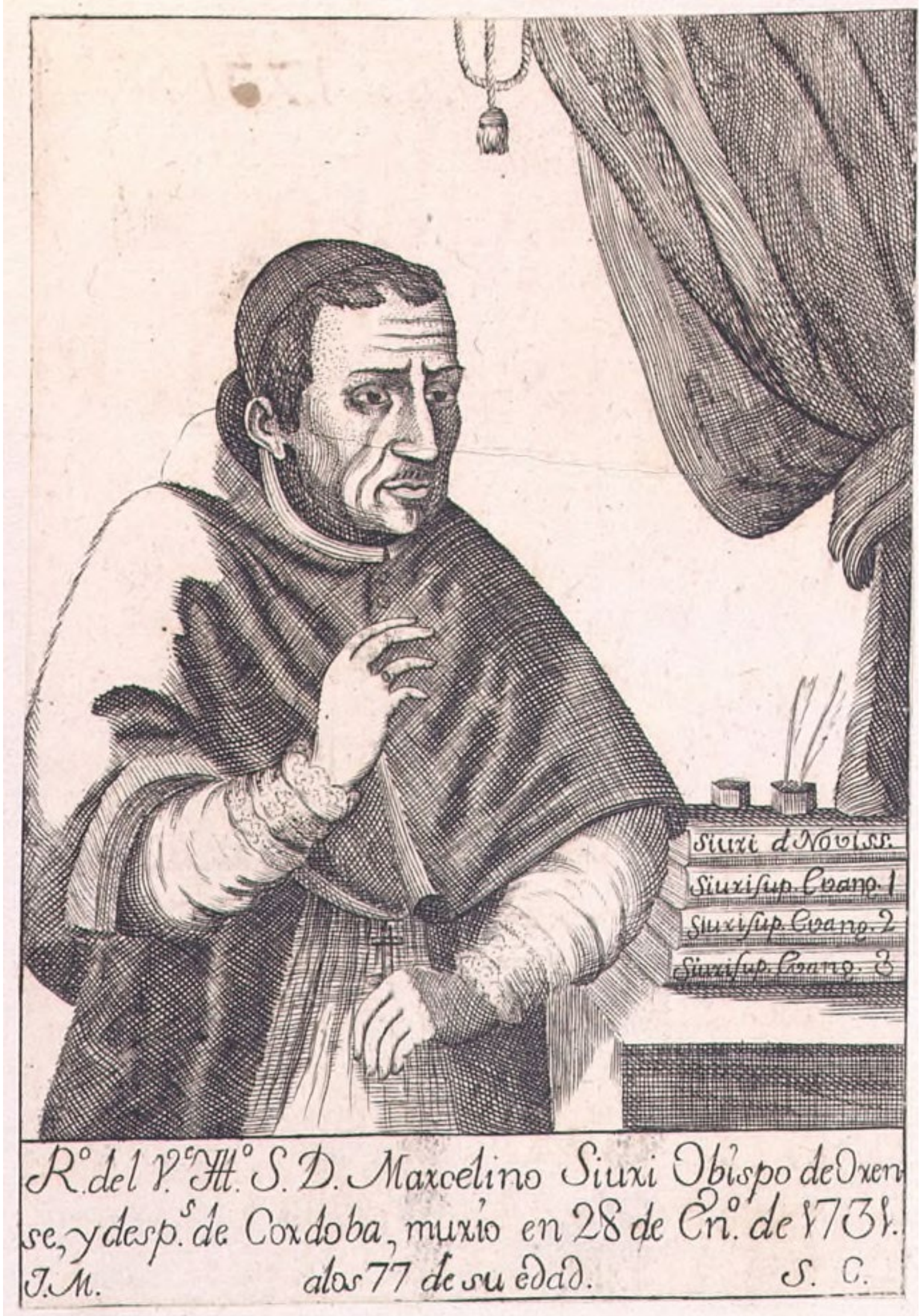

531

Fig. 5.42. Anónimo, Marcelino Siuri, h. 1775, estampa, Madrid, Biblioteca Nacional de España. 


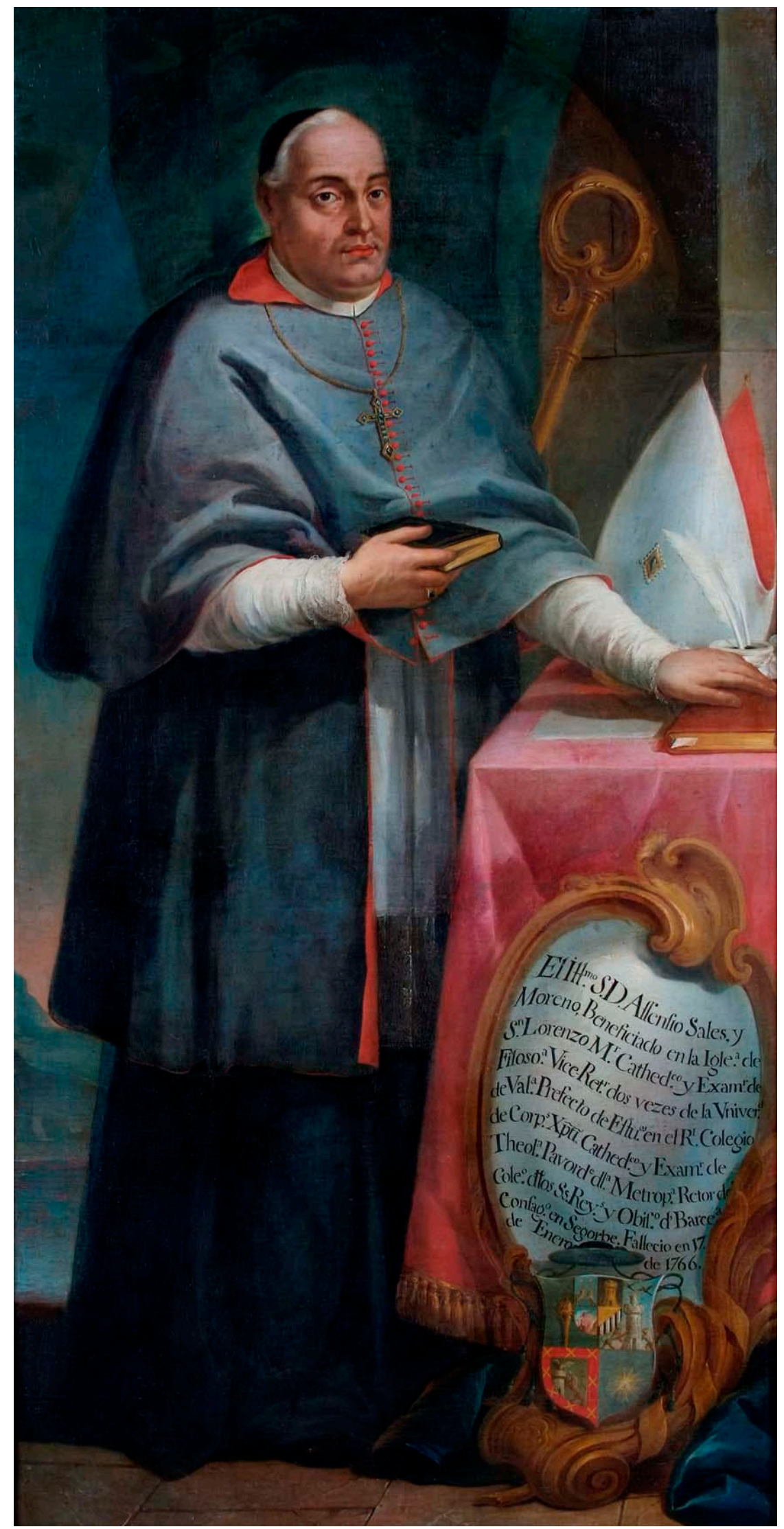

Fig. 5.43. Anónimo, Asensio Sales Moreno, segunda mitad del s. XVIII, óleo sobre lienzo, Valencia, paraninfo de la Universitat. 
na [fig. 5.44]. Dicha estampa se ha reproducido en varias ocasiones, por ejemplo en la obra Nomina et acta episcoporum barcinonensium de Mateo Aimeric ${ }^{158}$ y el ya citado catálogo de Valencianos ilustres.

La efigie de José Climent Avinent (1706-1781) [fig. 5.45], realizada alrededor de 1770, se ha considerado obra del artista José Vergara Gimeno, puesto que guarda notables similitudes formales con el retrato de Felipe Bertrán, que se ha estudiado más adelante, el cual sí que dispone de la firma del mencionado artista. ${ }^{159}$ Siguiendo con el prototipo de imagen para esta serie, José Climent posa junto a un bufete y sostiene un ejemplar de la Biblia Sacra, asimismo sobre otros libros se ha colocado la mitra, lo cual remite a su cargo como obispo de Barcelona desde 1766 hasta 1775. Igualmente una estantería repleta de libros que reviste el fondo del espacio habla de su faceta intelectual. Sin embargo, su vinculación con la institución universitaria comenzó con sus estudios de teología y filosofía, así pues en 1726 se licenció en teología y en 1727 se doctoró lo cual le permitió ocupar la cátedra de filosofía tomista en la Universitat de València en 1728 y 1731. Más tarde, ya se ordenó sacerdote y su carrera profesional le llevó a ser prelado de la ciudad condal. Por esta razón viste con la muceta y el roquete, además de lucir la cruz pectoral. Junto a él se distingue su escudo timbrado con el capelo. Respecto al texto descriptivo escrito en latín se especifica que estamos ante el: Ill. D.D. Josephus Climent et Avinent, Castellonensis $\mathrm{D}^{\mathrm{r}}$ Theo-

158 Mateo Aimeric, Nomina et acta episcoporum barcinonensium: binis libris comprehensa atque ad historiae et chronologiae rationem revocata, (Juan Nadal: Barcelona, 1760).

159 Esta atribución fue hecha por David Gimilio Sanz, 'José Vergara Gimeno y la retratística valenciana en el siglo XVIII', Ars Longa: cuadernos de arte, no. 12, 2003, pp. 75-82. Asimismo, el autor ha considerado que forman parte de la producción artística de Vergara las representaciones de José Tormo y Francisco Borrull que forman parte de este conjunto pictórico. También se recomienda consultar el análisis de Amparo José Mora en Benito Goerlich y Sánchez Muñoz, La Universitat de València..., vol. II, pp. 178-179. 


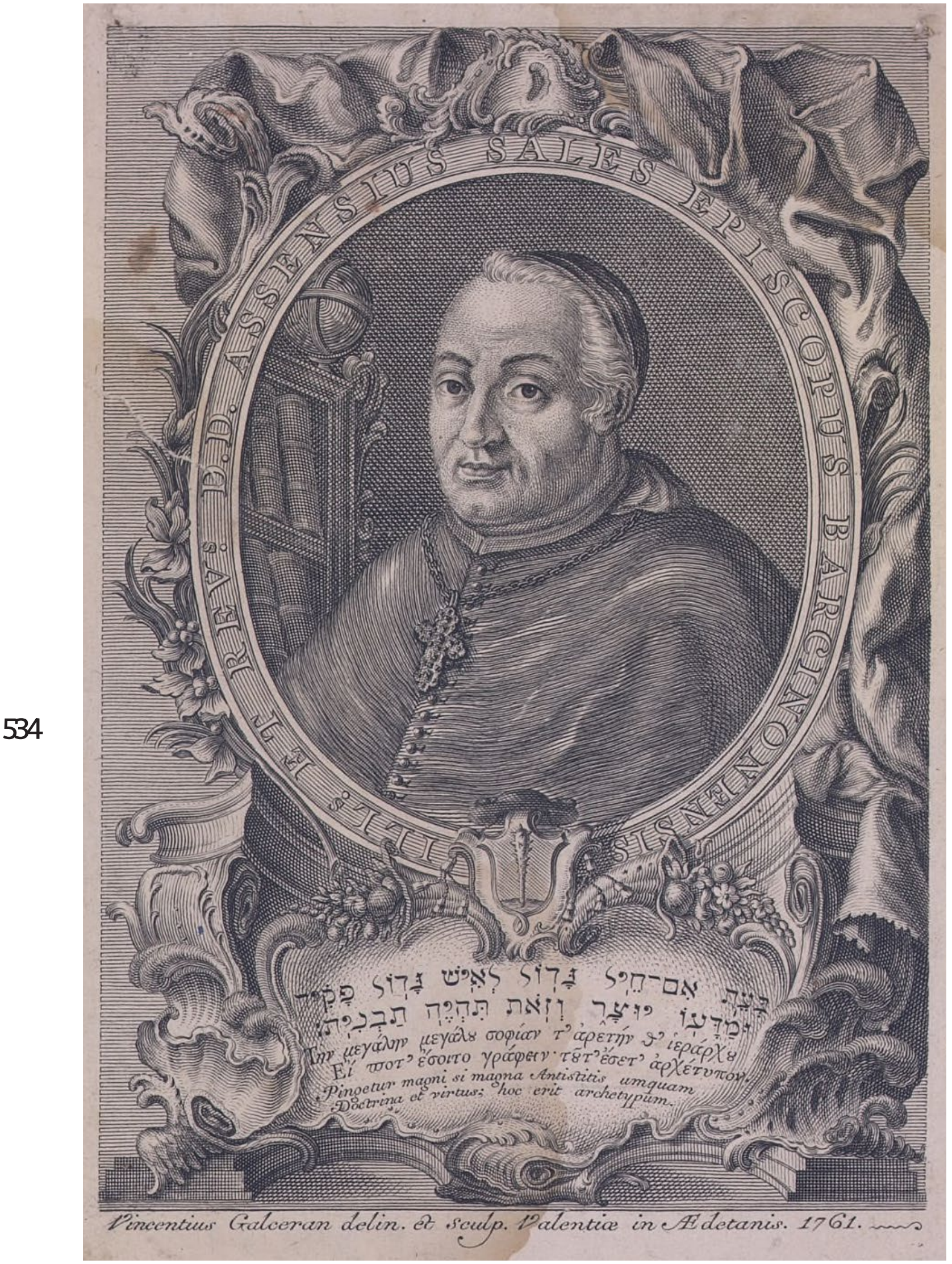

Fig. 5.44. Vicente Galcerán Alapont, Asensio Sales Moreno, 1761, estampa, Madrid, Biblioteca Nacional de España. 


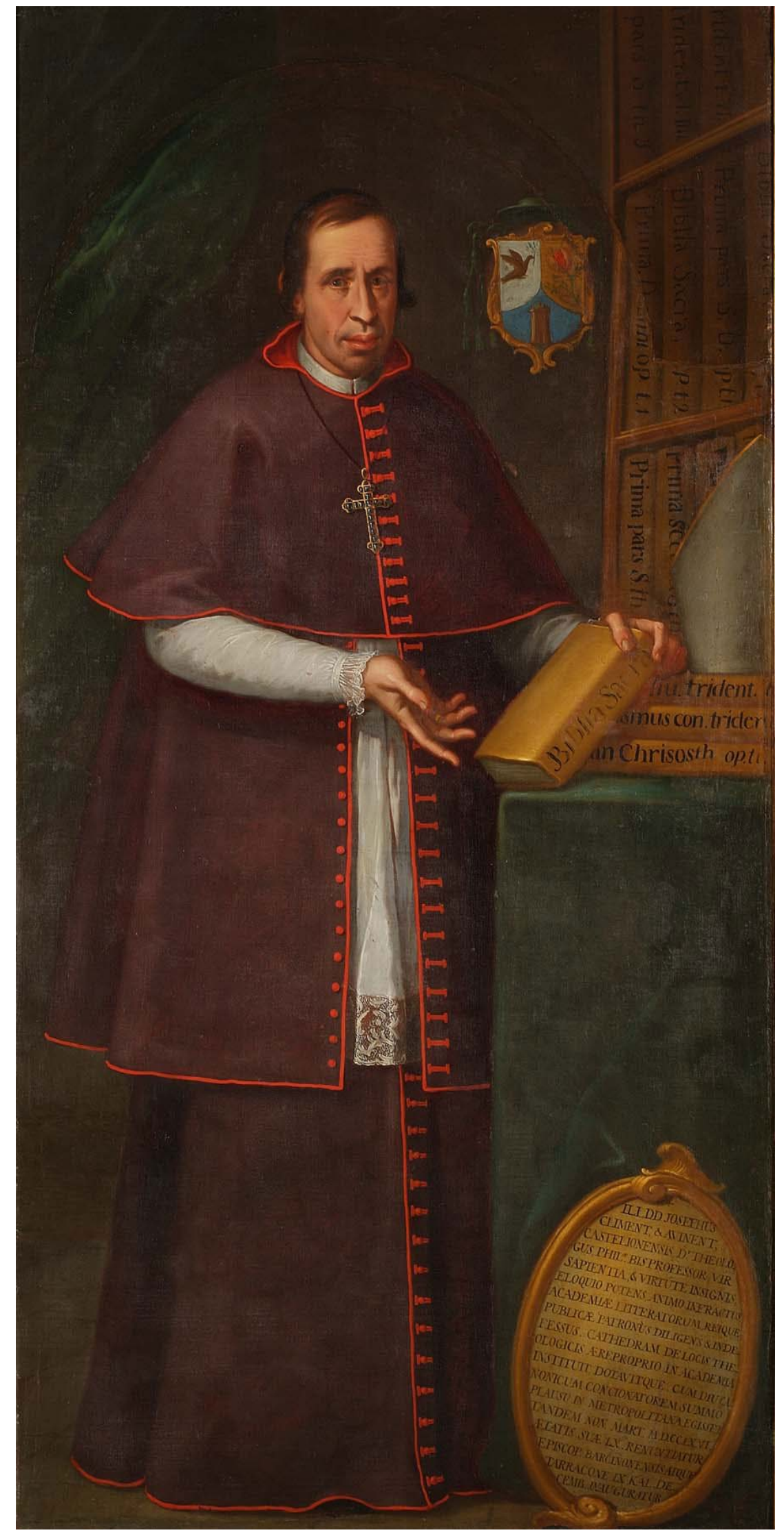

Fig. 5.45. Atribuido a José Vergara, José Climent Avinent, h. 1770, óleo sobre lienzo, Valencia, paraninfo de la Universitat. 
logus, Phil ae . Bis Professor Vir Sapientia et Virtute Insignis, eloquio potens, animo infractus, academiae literarum reique publicae patronus diligens et indefessus. Cathedram de locis theologicis aerepropio in academia instituit, dotavitque. Cum diu canonicum cancionatorem summo plausu in metropolitana egisset tándem non mart. MDCCLXVI. Aetatis suae LX. Renuntiatur episcop. Barcinonensis atque Tarracone. IX Kal. Decemb inauguratur.

Otra de las pinturas relacionadas con la mano de Vergara ha sido el retrato de José Tormo Julià (1721-1790) [fig. 5.46]. En este caso, su información biográfica también ha resultado ser bastante escasa. ${ }^{160}$ Sin embargo, se conoce que estudió filosofía y teología, se doctoró en ambas disciplinas y fue catedrático de filosofía además de rector de la Universitat de València (1762-1765). En 1755 entró como canónigo de la catedral valentina, por ello se le ha representado con el atuendo canonical. También fue auxiliar del arzobispo Andrés Mayoral en 1763 y desde 1767 estuvo al frente de la diócesis de Orihuela. Por esta razón, y siguiendo el modelo estipulado en este conjunto, se han incluido los elementos necesarios para aludir a sus funciones de prelado a través de la mitra, la cruz pectoral y el anillo pastoral. Igualmente ha incluido su escudo de armas en la parte superior izquierda. La inscripción de este retrato especifica lo siguiente:

Ill. ${ }^{\text {mus }}$ D.D. Josephus Tormo et Julià, Valentinus Albayden. Doctor Theologus in Valentin. Academ. Biblicus. Phil. Professor Metrop. Eccle. Canonic. [...] eruditione, ac prudencia conspiciendus $\mathrm{m}$. Pauperes vere misericors [...] et liberalis. Dei honoris ac Publice utilitatis studiossissimus. Integratatem [...] miasque dostes cum humilitate conjungens comis atque patrimonianse omnibus semper exibebat et placidus eius simulque servius vultus cunctorim benevol captabat. Huius celeb schole Rector evistens in Metrop. Eccl ${ }^{a}$ VII Kal Octobris MDC-

160 Una síntesis biográfica bastante completa la ha facilitado la Real Academia de la Historia. Disponible en: http://dbe.rah.es/biografias/8817/ jose-tormo-y-julia (Fecha de la última consulta: 14/05/2019). 


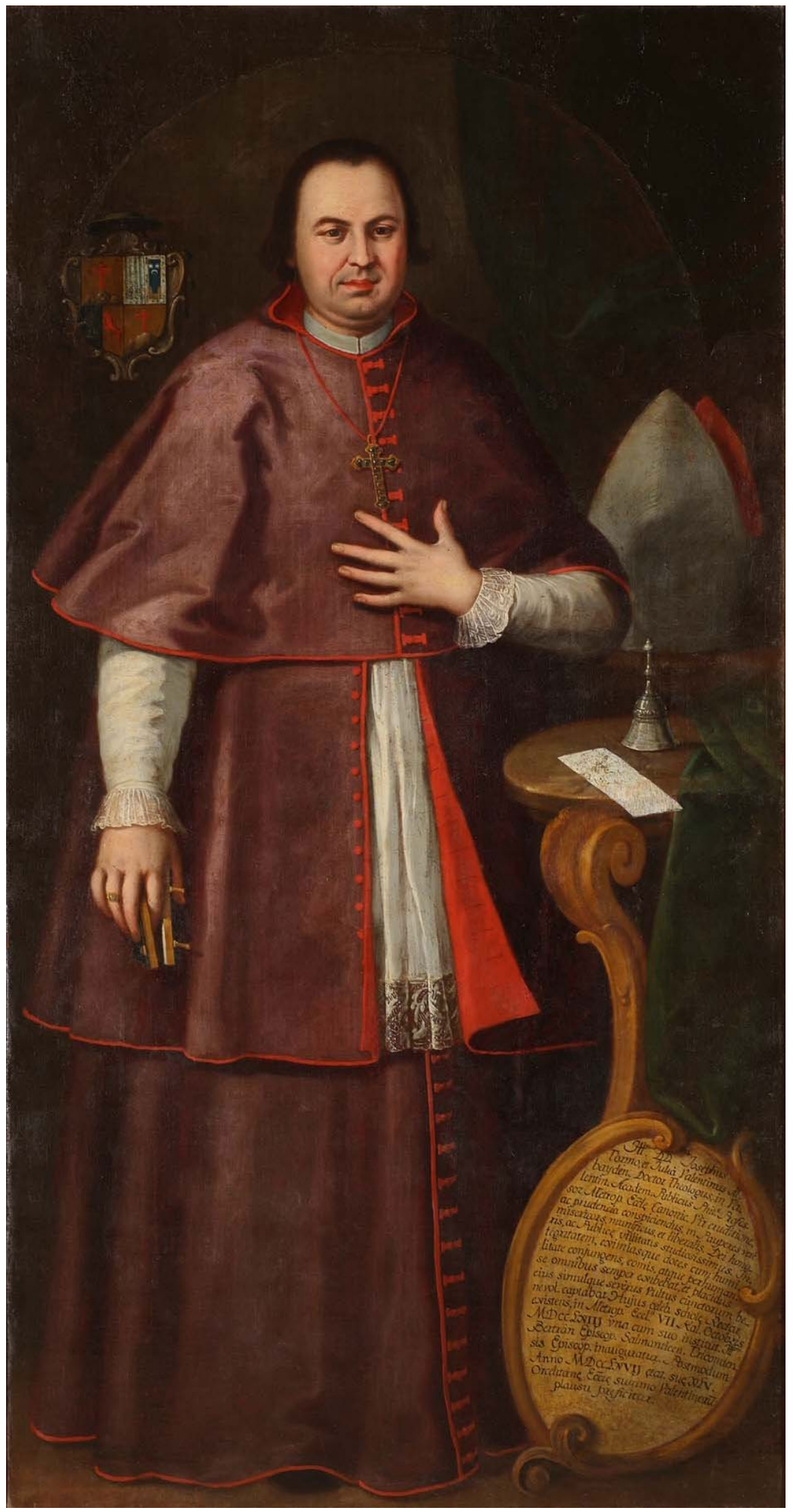

Fig. 5.46. Atribuido a José Vergara, José Tormo Julià, s. XVIII, óleo sobre lienzo, Valencia, paraninfo de la Universitat. 
CLXIII una cum suo institut. [...] Bertran Episcop. Salmanticen Tricomiensis Episcop. inauguratia Postmodum. Anno MDCCLXVII [...] XLV. [...] Eccle. Summo Valentine[...] [...] preficitur.

Este retrato, concretamente, guarda enormes similitudes con otras imágenes del personaje, lo cual indica la influencia de unas con otras para determinar la representación oficial de un personaje relevante. Por ejemplo, cabe tener en cuenta la estampa dibujada y grabada por Vicente Capilla en 1780 [fig. 5.47]. Se trata de un retrato enmarcado en un óvalo, donde Tormo está sedente, llevando las mismas vestiduras que la pintura del paraninfo y sosteniendo un documento en el que se ha escrito: «Aviso pastoral sobres los b[i]enes.» Probablemente, esta sea una referencia a su colaboración, en 1768, en el consejo extraordinario creado por Carlos III para tomar ciertas decisiones acerca del patrimonio acumulado por la Compañía de Jesús. De hecho, tras la expulsión de los jesuitas se le hizo entrega del colegio que tenían en Orihuela y al que este prelado le dio un nuevo uso. Asimismo, se han incluido otros elementos secundarios como el escudo de armas timbrado con el capelo, un libro y plumas en su tintero. También es parecida, aunque más austera, la efigie que adquirió el Ayuntamiento de Cox (Alicante) en 2007 a raíz de la importancia que este personaje tuvo en la localidad, pues fue durante su prelatura cuando se construyó el palacio arzobispal y la iglesia san Juan Bautista.

En sintonía con las efigies anteriores se encuentra el retrato de Felipe Bertrán García (1704-1783) [fig. 5.48], insigne prelado que ostentó la cátedra de filosofía desde 1752. Así pues, aparece ataviado con la muceta y el roquete, luciendo la cruz pectoral y el anillo pastoral, la mano izquierda descansa sobre la Biblia Sacra dispuesta en una mesa auxiliar junto a una pluma en su tintero y la mitra. El escudo también se ha timbrado con el capelo. Para exaltar aún más lo célebre de la persona, Felipe Bertrán aparece condecorado con el collar de la Orden de Carlos III. La certera catalogación de este retrato como obra de José Vergara ha sido posible gracias a que el artista firmase 


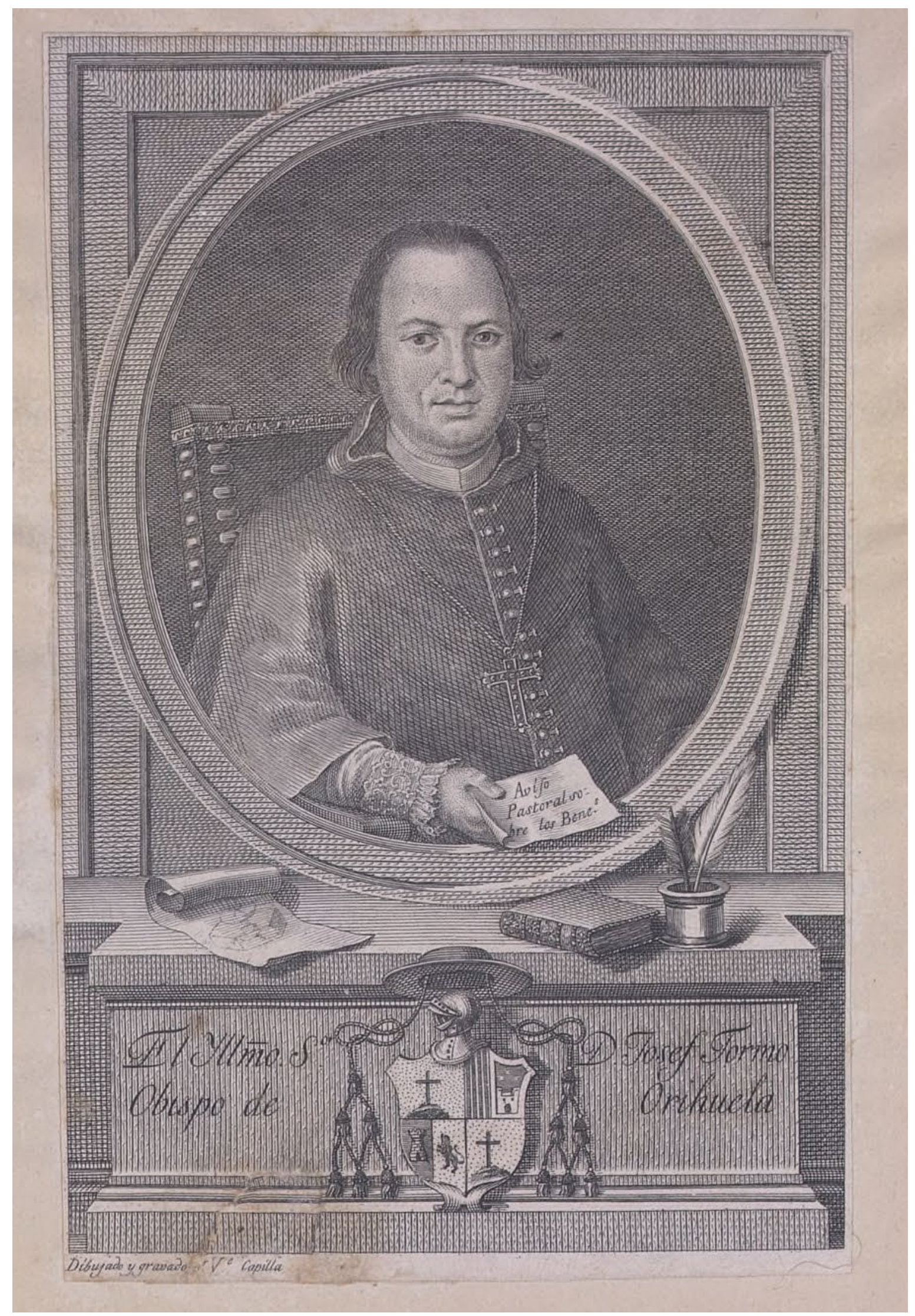

Fig. 5.47. Vicente Capilla, José Tormo Julià, 1780, estampa, Depósito Académico Digital de la Universidad de Navarra. 


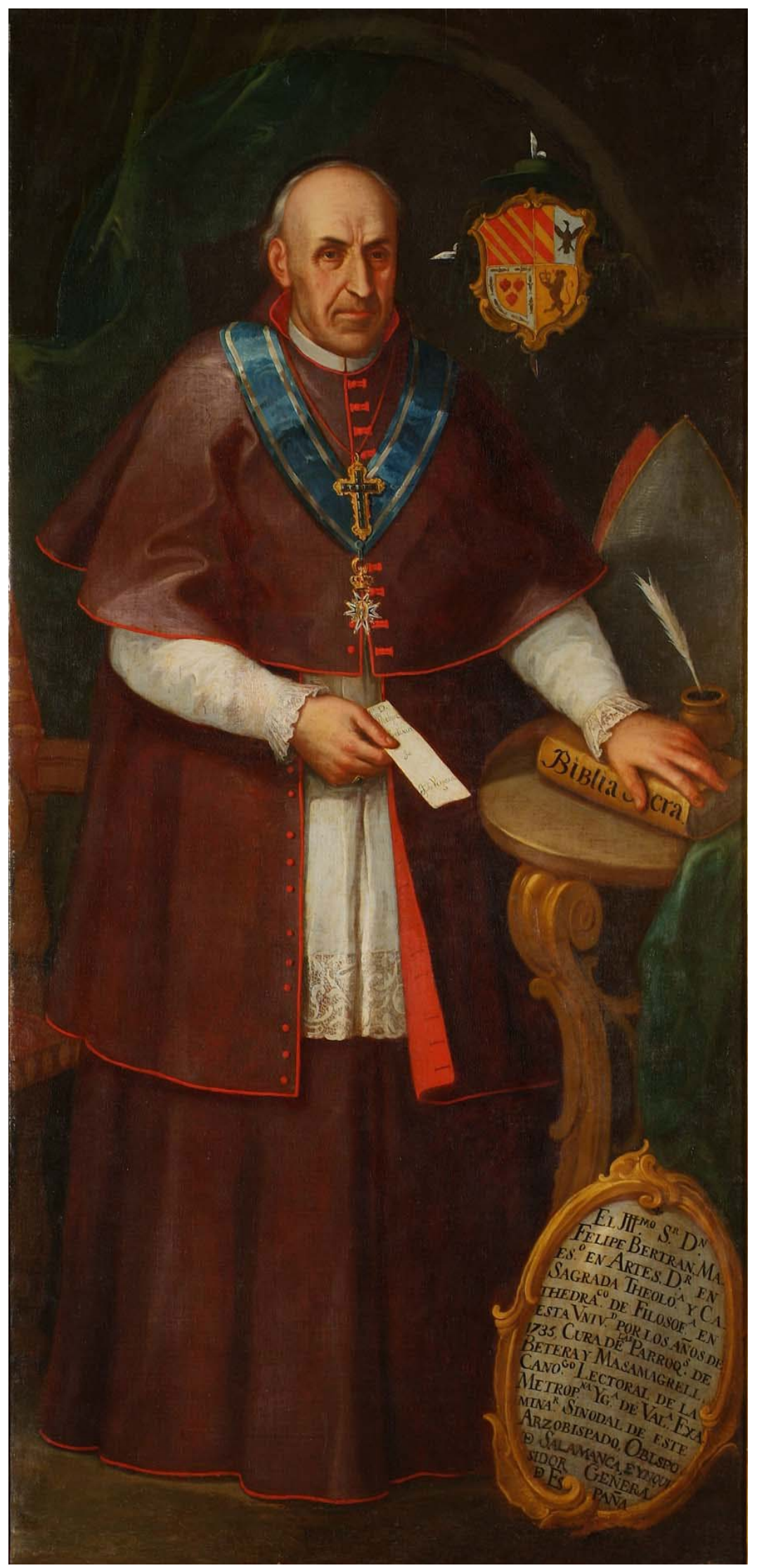

Fig. 5.48. José Vergara, Felipe Bertrán García, h. 1750-1800, óleo sobre lienzo, Valencia, paraninfo de la Universitat. 
la pieza en el documento que sostiene el propio efigiado donde se ha escrito lo siguiente: «Don Phelipe Bertran de Jose Vergara.» El breve texto biográfico presenta al: «Ill. ${ }^{\mathrm{mo}} \mathrm{S} .{ }^{\mathrm{r}} \mathrm{D} .{ }^{\mathrm{n}}$ Felipe Bertran Maes. ${ }^{\circ}$ en Artes. D. ${ }^{\mathrm{r}}$ en Sagrada Theolo. ${ }^{\mathrm{a}}$ y Cathedra. ${ }^{\mathrm{co}}$ de Filosof. ${ }^{a}$ en esta Univ. ${ }^{\mathrm{d}}$ por los años de 1735 . Cura de ${ }^{\text {las }}$ parroquias de Betera y Masamagrell. Cano. ${ }^{g 0}$ Lectoral de la Metrop. ${ }^{\text {na }}$ Yg. ${ }^{\mathrm{a}}$ de Val. ${ }^{\mathrm{a}}$ Examina ${ }^{\mathrm{r}}$ Sinodal de este Arzobispado, Obispo de Salamanca e Ynquisidor General de España.»

A continuación, conviene estudiar el último de los retratos vinculados a los pinceles de Vergara. ${ }^{161}$ Se trata de Francisco Borrull Ramón (1695-1758) [fig. 5.49], quien se doctoró en derecho civil y canónico y fue rector de la Universitat entre 1740 y 1743 . Asimismo fue nombrado canónigo de la catedral valenciana y ello explica el tipo de vestiduras con las que aparece representado. Además ostentó el título de auditor de la Rota y de obispo al solio pontificio. Desde 1757 se encargó de la diócesis de Tortosa, así los atributos propios de los prelados, como la mitra y la cruz pectoral, también forman parte de la imagen analizada. Su dilatada carrera académica e intelectual se aprecia en la cantidad de libros que aparecen de forma accesoria en el retrato. Sostiene un ejemplar de la Biblia y tras él se encuentra su biblioteca personal, lo cual también recuerda a sus diferentes publicaciones. Algunas de ellas fueron Dissertatio de legibus Hispaniae... (Roma, 1732), Decisiones S. Rotae Romanae (Roma, 1755-1757), Dissertatio canonica pro canonicis ecclesiae Metrop. Val... (Roma, 1755), Carta pastoral... (Roma, 1757) y Representación a S.M. oponiéndose a que se imponga a los pueblos del obispado de Tortosa tributo alguno sobre el vino... (Valencia, 1758). Finalmente falleció en la villa de San Mateo en 1758, en cuya iglesia parroquial se enterraron sus restos mortales. ${ }^{162}$ Estos datos biográficos, igualmente, se

161 Atribución hecha por Català Gorgues: El pintor y académico José..., pp. 184-188.

162 Para una síntesis biográfica del personaje consúltese a Basilio Sebastián Castellanos de Losada, Biografía eclesiástica completa: vida de los personajes del Antiguo y Nuevo Testamento: de todos los santos que venera la 


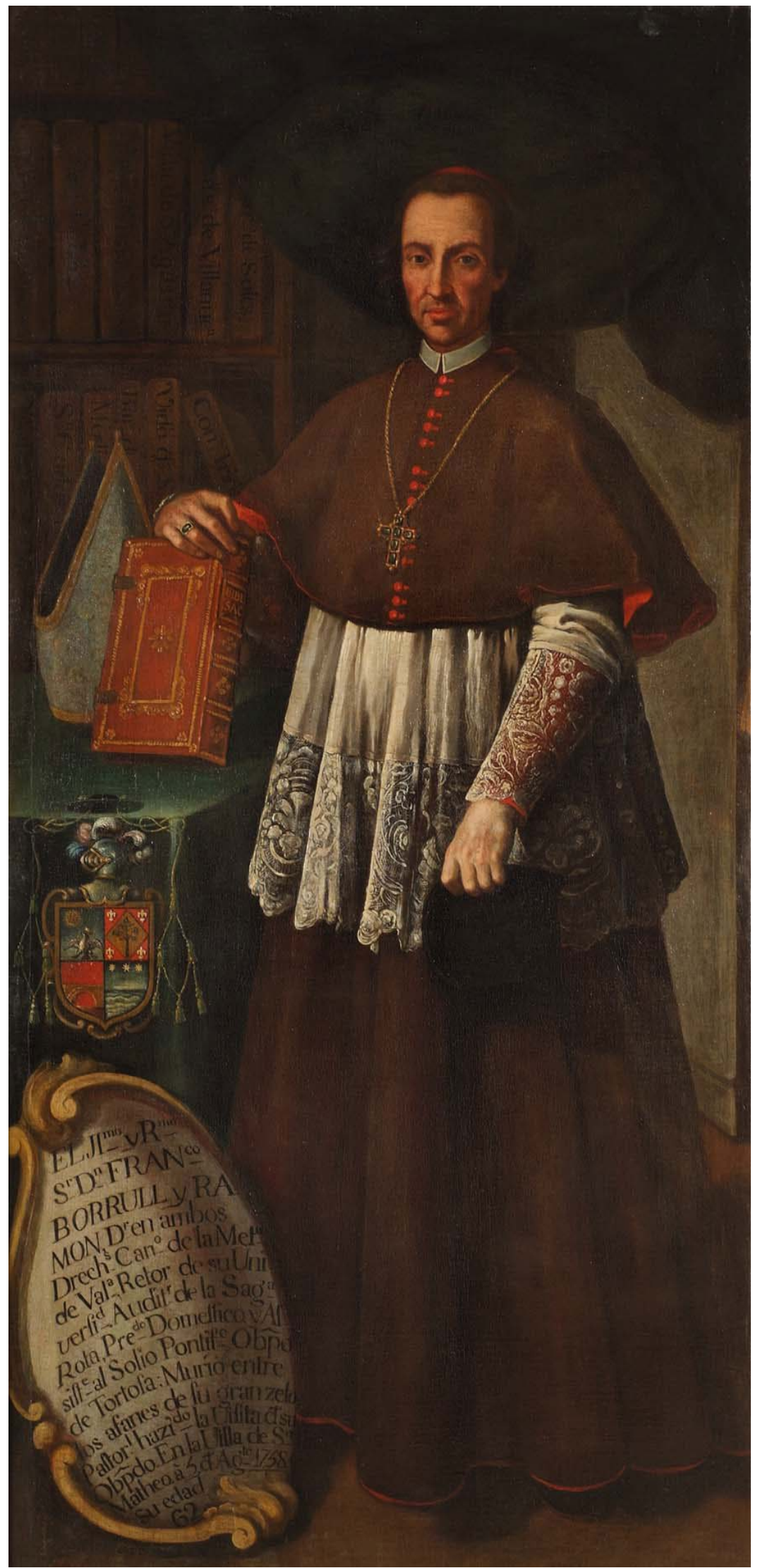

Fig. 5.49. Atribuido a José Vergara, Francisco Borrull Ramón, s. XVIII, óleo sobre lienzo, Valencia, paraninfo de la Universitat. 
han detallado en la mandorla barroca bajo el correspondiente escudo de armas: «El Il ${ }^{\mathrm{mo}}$ y $\mathrm{R}^{\mathrm{mo}} \mathrm{S}^{\mathrm{r}} \mathrm{D}^{\mathrm{n}} \mathrm{Fran}^{\mathrm{co}}$ Borrull y Ramon, $\mathrm{D}^{\mathrm{r}}$

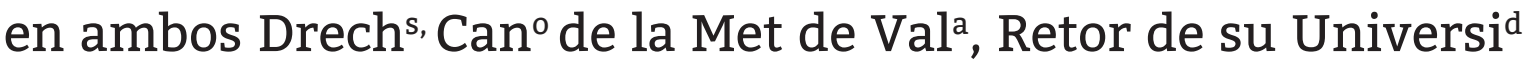
Auditr $^{r}$ de la Saga ${ }^{\text {Rota Pre }}{ }^{\text {do }}$ Domestico y Assiste al Solio Pontif ${ }^{\circ}$ Obpo de Tortosa: Murio entre los afanes de su gran zelo Pastor ${ }^{1}$ hazid ${ }^{\mathrm{d}}$ la Visita de si Obpdo. En la Villa de $\mathrm{S}^{\mathrm{n}}$ Matheo a $5 \mathrm{de} \mathrm{Ag}^{\text {to }}$ 1758, Su edad 62.»

El retrato de Luis Nicolás Vergara [fig. 5.50] está ubicado en la parte alta del muro opuesto a la presidencia. La principal información biográfica acerca de este personaje ha sido recogida por Vicente Ximeno en su obra dedicada a los escritores del Reino de Valencia. ${ }^{163}$ Allí se ha especificado que Vergara era natural de Moncada, que se formó en la Universitat de València donde obtuvo el grado de maestro en artes y doctor en medicina. Seguidamente consiguió la cátedra prima en medicina a la vez que desempeñó su labor en el Hospital Real y General de Valencia. Ximeno se hizo eco de este autor porque las obras más relevantes por las que se le conoce se publicaron en 1747 y principalmente son la respuesta intelectual a su disputa con el doctor Andrés Piquer. En este sentido, cabe destacar su Respuesta a la manifestación del doctor Andrés Piquer, catedrático de anatomía y médico titular de la misma ciudad (Valencia: 1746) y Disertación histórico-crítica con que se descubre directamente la insubsistencia de las reflexiones críticas del Dr. Andrés Piquer y de las razones... (Valencia: 1747).

Respecto al retrato, es uno de los ejemplos más austeros de entre aquellos que conforman la serie. Nicolás Vergara posa completamente de frente ante un gran cortinaje rojo que prácticamente domina todo el interior de la estancia y apenas deja entrever la biblioteca personal del efigiado. En definitiva,

Iglesia, papas y eclesiásticos célebres venerados por sus virtudes y talentos en orden alfabético, tomo II, (Eusebio Aguado: Madrid, 1849), pp. 983-987. 163 Vicente Ximeno, Escritores del reyno de Valencia chronologicamente ordenados desde el año MCCXXXVIII de la cristiana conquista de la ciudad hasta el MDCCXLVIII, tomo II, (Joseph Estevan Dolz: Valencia, 1749), pp. 302-303. 


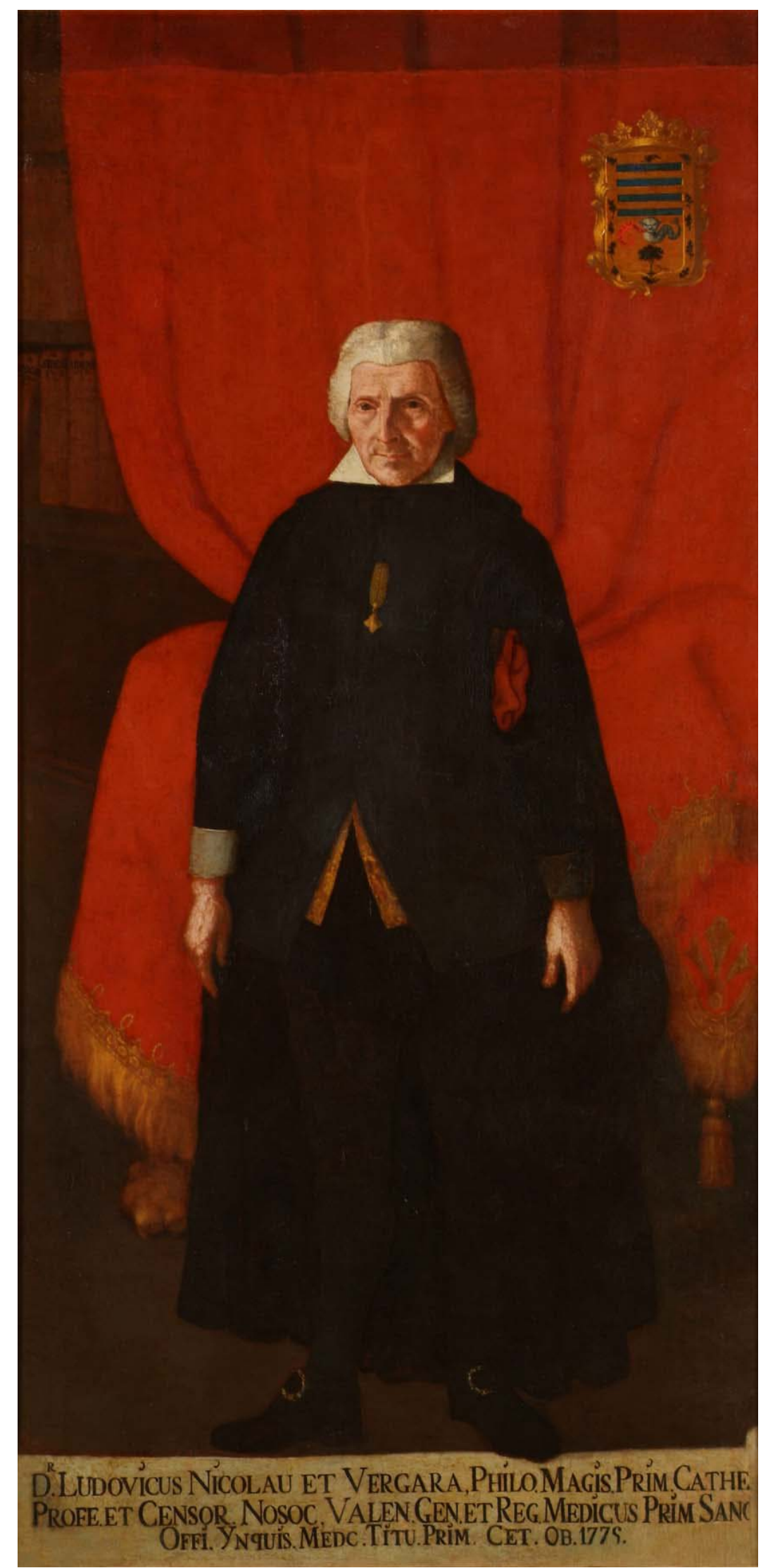

Fig. 5.50. Anónimo, Luis Nicolás Vergara, s. XVIII, óleo sobre lienzo, Valencia, paraninfo de la Universitat. 
se ha prescindido de mobiliario y otros objetos auxiliares que sí son comunes en otros retratos del presente conjunto. Sin embargo, sí que se ha mantenido el escudo de armas y el breve escrito para facilitar la identificación del personaje. Así pues, en la inscripción se especifica lo siguiente: «D. Ludovicus Nicolau et Vergara, Philo Magis, Prim, Cath. Profe. et Censor Nosoc. Valen. Gen. et Reg. Medicus Prim Sana. Offi. Ynquis Medc. Titu Prim. Cet. Ob. 1775.» La falta de imágenes de este hombre ilustre ha impedido que por el momento se puedan establecer vínculos visuales con otras estampas o pinturas que contribuyesen a difundir su retrato.

Situando de nuevo al espectador frente a la tribuna presidencial, y ahora hacia su izquierda, la primera pintura del siglo XVIII se ubica junto al retrato del Alejandro VI y se corresponde con fray Bernardo Oliver (h. 1280-1348) [fig. 5.51]. Se trata de un personaje vinculado a los inicios de las enseñanzas superiores en Valencia, pues ya impartía clases en la escuela catedralicia de teología antes, incluso, de la creación del Estudi General. ${ }^{164}$ Aparece ataviado con el hábito agustino, muceta, cruz pectoral y bonete. La mitra, que reposa en el bufete junto a unos libros, alude a su paso por la diócesis de Huesca, siendo el primer obispo agustino en España, para seguidamente ostentar la mitra de Barcelona y Tortosa. Todo ello ha quedado reflejado en el correspondiente texto descriptivo incluido en la imagen: «El E. ${ }^{\mathrm{xmo}} \mathrm{S} .{ }^{\mathrm{r}} \mathrm{D} .{ }^{\mathrm{n}} \mathrm{F}$. Bernardo Oliver, obispo de Huesca, Barcelona y Tortosa. Cardenal del título de san Marcos, creado por Clemente VI. Fue doctor parisiense y enseñó en Val. ${ }^{a}$ su patr. ${ }^{a}$ en las escuelas anteriores al Estudio General fundado por el municipio en 1411. Murió en Tortosa. Año 1348.»

A continuación se encuentra el retrato de Antonio José Cavanilles (1745-1804) [fig. 5.52], atribuido al círculo de Mariano Salvador Maella. Cavanilles inició su formación académica en la universidad valenciana concretamente en los ámbitos de 164 Datos biográficos más detallados también han sido proporcionados por la Real Academia de la Historia. Disponible en: http://dbe.rah.es/biografias/34688/bernardo-oliver. (Fecha de última consulta: 17/05/2019) 


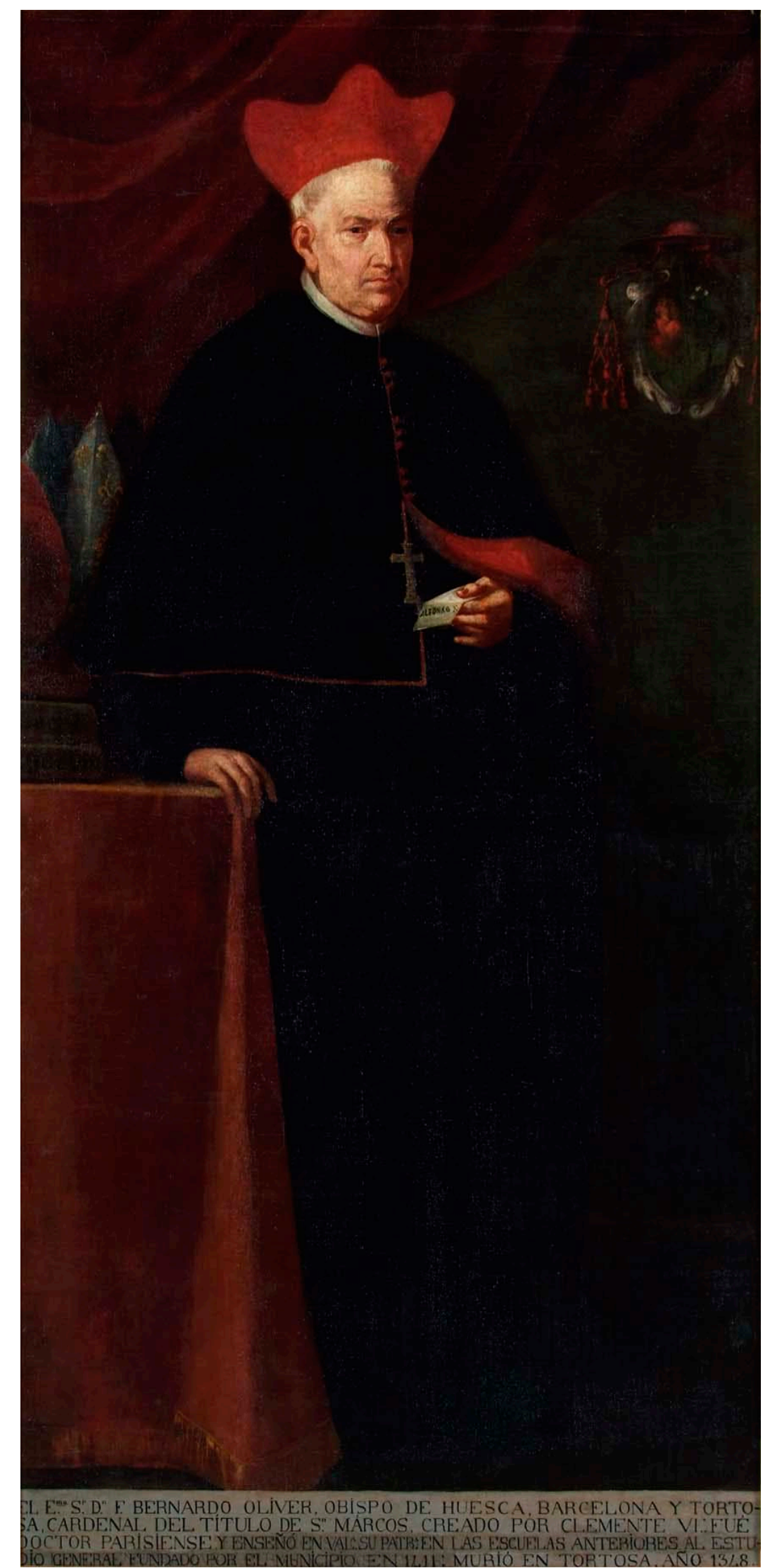

Fig. 5.51. Anónimo, Fray Bernardo Oliver, 1730-1760, óleo sobre lienzo, Valencia, paraninfo de la Universitat.

Retratos de hombres ilustres 


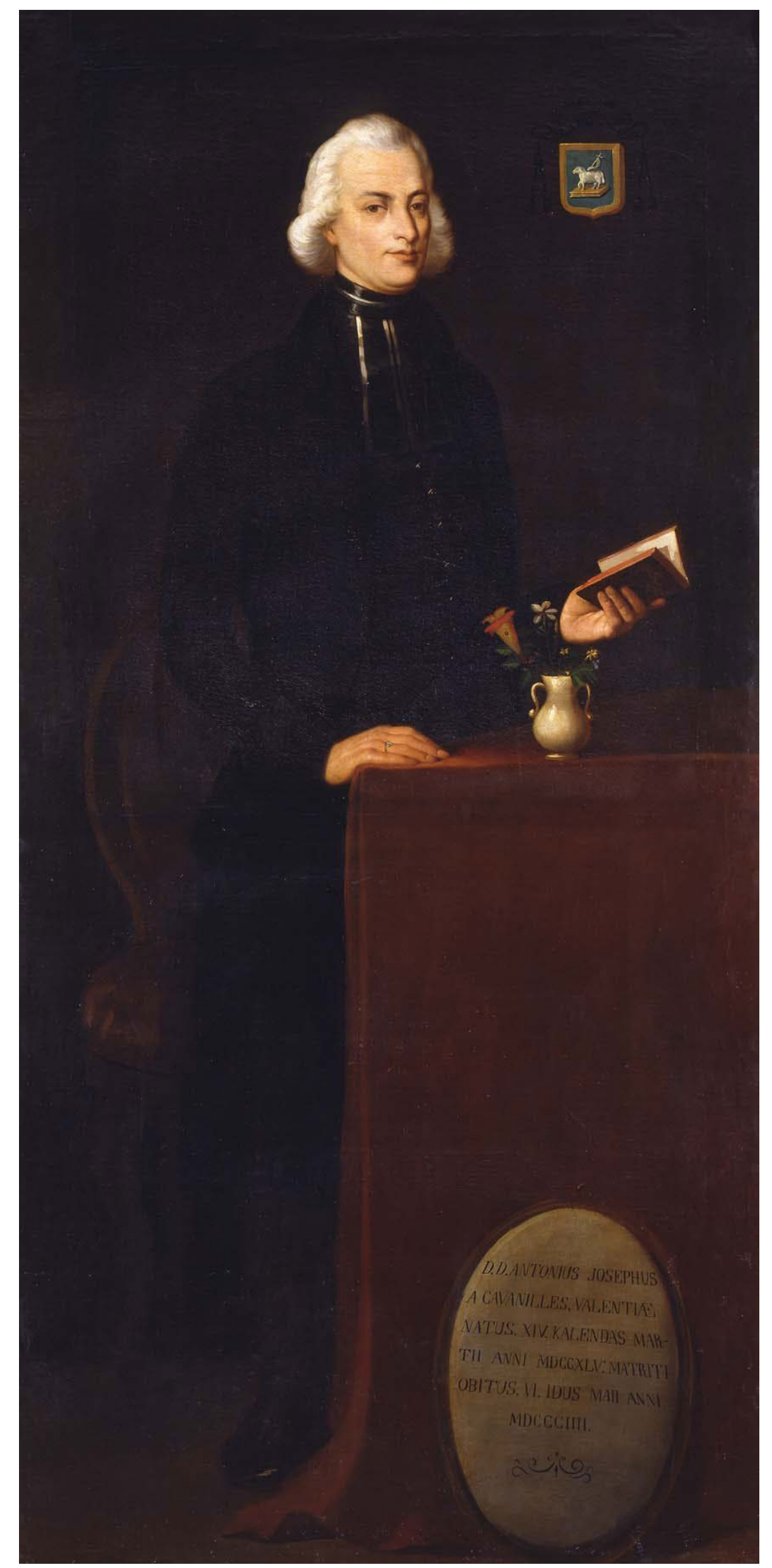

Fig. 5.52. Círculo de Salvador Maella, Antonio José Cavanilles, 1775-1800, óleo sobre lienzo, Valencia, paraninfo de la Universitat. 
la filosofía y de la teología. De la primera disciplina impartió clases y de la segunda consiguió el grado de doctor en 1777. Poco después, en 1780, comenzó una nueva etapa profesional en París estudiando botánica. A su regreso a España, en 1789, sus investigaciones se centraron en esta área de conocimiento dando lugar a relevantes publicaciones como, por ejemplo, Icones et descriptiones plantarum (1791-1801) y Observaciones sobre la historia natural, geografía, agricultura, población y frutos del Reino de Valencia (1795-1797). Asimismo, participó en el diseño y creación del jardín botánico de la Universitat de València pues además de haberse consolidado como un prestigioso botánico llegó a dirigir el correspondiente jardín en Madrid hasta su muerte acaecida en $1804 .{ }^{165} \mathrm{El}$ retrato alude a su faceta profesional centrada en la botánica a través del jarrón con flores dispuesto sobre el bufete. No obstante, también se remite a su trayectoria eclesiástica y su ordenación sacerdotal al verlo vestido con el antiguo traje clerical romano, denominado abate. Sobre un fondo oscuro destaca el escudo de armas asociado a Cavanilles con un cordero de gules dispuesto sobre un libro de oro y una bandera. La inscripción latina insertada en un medallón especifica que: «D. D. Antonius Josephus a Cavanilles, valentiae, natus XIV kalendas martii anni MDCCXLV: Matriti obitus VI idus maii anni MDCCCIIII.»

Damián Polou (1679-1755) [fig. 5.53], natural de Gandía, también llevó a cabo una larga formación académica en la Universitat de València donde obtuvo el grado de maestro en artes, el doctorado en ambos derechos y se convirtió en catedrático de jurisprudencia civil. Asimismo, fue designado pavorde de la catedral y ello explica que luzca las vestiduras canonicales. Desde 1727 fue nombrado arzobispo de Rijoles (Calabria), las únicas referencias visuales que aluden a su prelatura son la

165 Consúltese la ficha de catálogo de Amparo José Mora en Benito Goerlich y Sánchez Muñoz, La Universitat de València..., vol. II, pp. 190-191. Sobre Cavanilles también es interesante la aportación de Antonio González Bueno, 'Antoni Josep Cavanilles i el jardí botànic' en Universitat de València, Cinc segles i un dia, (Fundació General de la Universitat de València: València, 2000), pp. 89-92. 


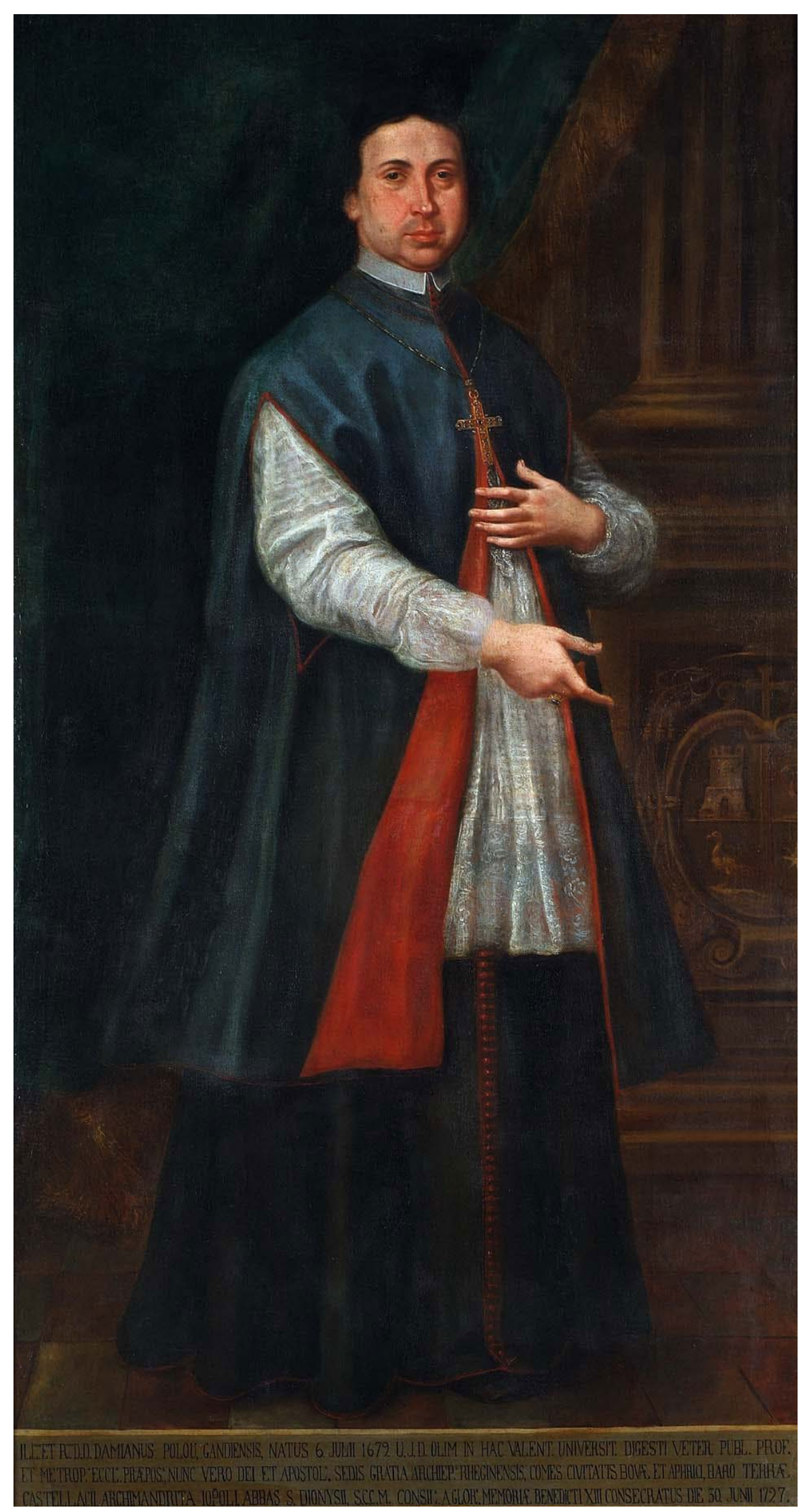

Fig. 5.53. Anónimo, Damián Polou, s. XVIII, óleo sobre lienzo, Valencia, paraninfo de la Universitat. 
cruz pectoral, el anillo pastoral y el haber timbrado el escudo de armas con un capelo. A diferencia de otros retratos, en este caso se ha evitado la inclusión de mobiliario auxiliar y otros objetos complementarios que remitiesen a la labor intelectual del representado. No obstante, Vicente Ximeno sí que lo ha mostrado como uno de los autores prolíficos del siglo XVIII citando sus principales obras escritas, como: Carta latina (Roma: 1727), Prima synodus diocesana... (Nápoles: 1730), o Appendix ad primam synodum diocesanam... (Nápoles: 1729$).{ }^{166}$ En cuanto a la inscripción que completa la imagen reza lo siguiente:

ILL. ${ }^{\text {mus }}$ ET R. ${ }^{\text {mus }}$ D.D. DAMIANUS POLOU, GANDIENSIS, NATUS 6 JULII U. J. D. OLIM IN HAC VALENT. UNIVERSIT. DIGESTI VETER PUBL. PROF. ET METROP. ECCL. PRAEPOS. NUNC VERO DEI ET APOSTOL: SEDIS GRATIA ARCHIEP. RHEGINENSIS. COMES CIVITATIS BOVAE ET APHRICI [...] TERRAE CASTELLA ARCHIMANDRITA [...] ABBAS S. DIONYSII S.CC.M. CONSIL ${ }^{a}$ A GLOR. ${ }^{a}$ MEMORIAE BENEDICTI XIII CONSECRATUS DIE 30.

Otro de los hombres ilustres que forman parte de este conjunto es fray Tomás Marín (1673-1730) [fig. 5.54], natural de la villa de Enguera. El 31 de marzo de 1688 tomó el hábito dominico en el Real Convento de Valencia, de hecho su permanencia a la orden de los Predicadores se ha mostrado en el escudo de armas que acompaña al retrato. Su formación académica fue dilatada, así se instruyó en artes y teología en el mencionado convento. El 17 de noviembre de 1696 obtuvo el doctorado en esta segunda disciplina. De hecho, el disponer de un ejemplar de la Biblia sobre la mesa auxiliar remite a su estudio de estas escrituras. Seguidamente consiguió la cátedra perpetua de filosofía. Marchó a Roma para ejercer de secretario del vicario 166 Ximeno, Escritores del reyno de Valencia..., tomo II, p. 219. Tomás Serrano también ha aportado una escueta biografía de Polou, ha exaltado su ejemplaridad como prelado y ha remarcado la veneración que se le profesaba tanto en el ámbito italiano como valenciano. Véase a Tomás Serrano, Fiestas seculares con que la coronada ciudad de Valencia celebró el feliz cumplimiento del tercer siglo de la canonización de su esclarecido hijo y ángel protector san Vicente Ferrer, apóstol de Europa, (Imprenta de la viuda de José de Orga: Valencia, 1762), lib. I, pp. 37-38. 


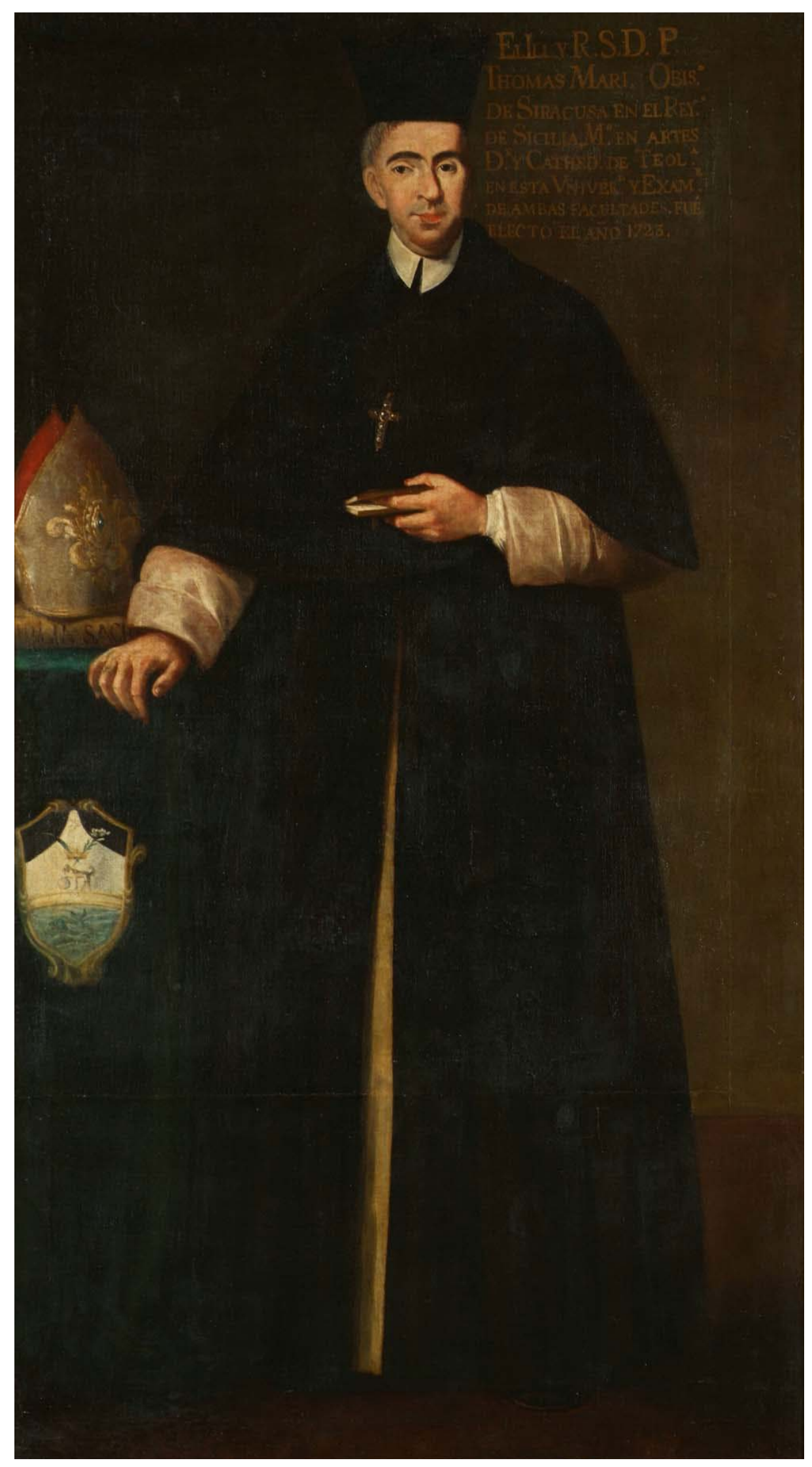

551

Fig. 5.54. Anónimo, Fray Tomás Marín, s. XVIII, óleo sobre lienzo, Valencia, paraninfo de la Univeristat.

Retratos de hombres ilustres 
general de la orden y consiguió el grado de maestro en teología sagrada. Además, tenía un elevado dominio de la lengua griega y hebrea así como sólidos conocimientos de historia eclesiástica. Su cargo más prestigioso llegó el 20 de febrero de 1724 cuando fue designado obispo de Siracusa. ${ }^{167}$ La mitra sobre el bufete y la cruz pectoral que luce Tomás Marín recuerdan a su etapa como prelado. En este caso, la inscripción no se ha colocado en un medallón o cartela como venía siendo habitual, sino que se trata de un sencillo texto colocado en la zona superior del lienzo y especifica lo siguiente: «El Ill. y R.S.D.P. Thomas Mari, obis ${ }^{\circ}$ de Siracusa, en el Rey ${ }^{\circ}$ de Sicilia. $\mathrm{M}^{\circ}$ en Artes, $\mathrm{D}^{\circ} \mathrm{y}$ Cathed ${ }^{\circ}$ de Teol. $^{\mathrm{a}}$ en esta Univer. ${ }^{\circ} \mathrm{y}$ exam. ${ }^{\circ}$ de ambas facultades. Fue electo el año 1723.»

Los méritos académicos y profesionales obtenidos Manuel Martí Zaragoza (1663-1737) [fig. 5.55] fueron numerosos y un aval suficiente para estar representado entre este grupo de dignidades intelectuales. Así, Ximeno incluyó una sustanciosa biografía en su obra dedicada a los escritores del reino valenciano basándose en la redactada por Gregorio Mayans en 1735, tan sólo dos años antes del fallecimiento de Manuel Martí. ${ }^{168}$ Natural de Oropesa, llegó a ser deán de Alicante por ello en el retrato luce las vestiduras canonicales. Su formación académica fue verdaderamente muy extensa, comenzando en Castellón por estudiar gramática. Después se trasladó a Valencia en cuya Universitat estudió filosofía, teología, letras y humanidades. Marchó a Roma para seguir aprendiendo y allí tuvo la oportunidad de adquirir sólidos conocimientos de griego, hebreo, francés e italiano. El cardenal José Sáenz de Aguirre lo designó comensal y bibliotecario personal, desde cuya posición se implicó en la edición de los concilios y sínodos de España. Se doctoró en ambos derechos. Los dos libros sobre el

167 Son interesantes los datos aportados por Ximeno, Escritores del reyno de Valencia..., tomo II, pp. 225-226; También se mencionan los principales logros académicos en Ortí y Figuerola, Memorias históricas de la fundación..., p. 426.

168 Véase a Ximeno, Escritores del reyno de Valencia..., tomo II, pp. 250256 y a Gregorio Mayans y Siscar, Emmanuelis Martini Ecclesiae Alonensis decani vita, (Juan de Zúñiga, 1735). 


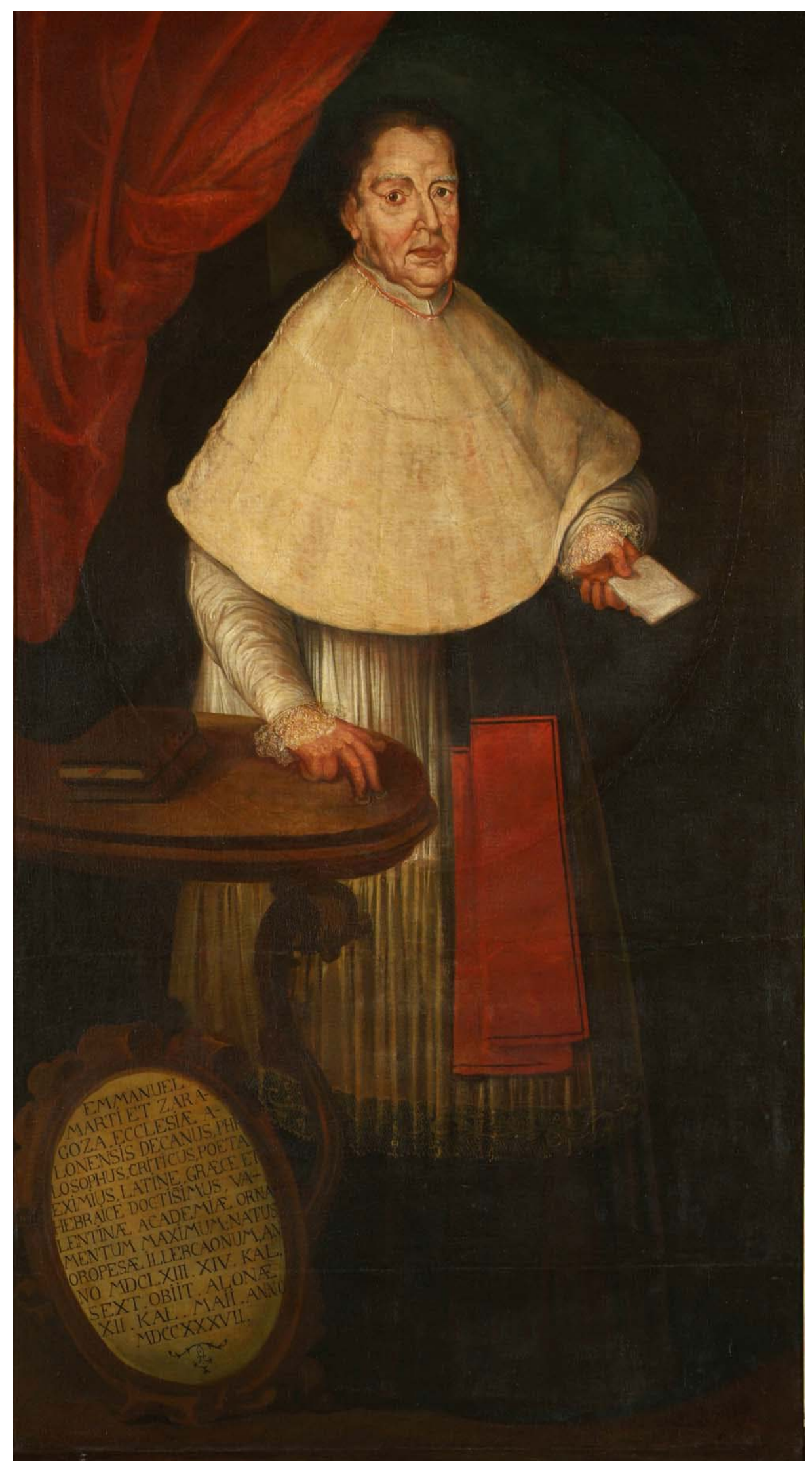

553

Fig. 5.55. Anónimo, Manuel Martí Zaragoza, s. XVIII, óleo sobre lienzo, Valencia, paraninfo de la Universitat. 
bufete o el documento que sostiene en la mano son símbolos de su amplio bagaje cultural.

En 1696 tomó rumbo nuevamente hacia Valencia y se ordenó sacerdote en Alicante. Tenía un especial respeto por los vestigios patrimoniales que se conservaban, así consiguió que el compromiso del gobierno de Sagunto para no maltratar o derribar restos antiguos. En 1704 estuvo en Madrid y allí recopiló monedas y medallas antiguas que estudió y le sirvieron para conformar una extensa colección. Finalmente, algunas de ellas las repartió entre sus amistades y otras, más de setecientas según Ximeno, las vendió a un comerciante inglés. Su interés por la numismática también se ha reflejado visualmente en el retrato, pues en la mesa auxiliar se aprecia que tiene dos monedas bajo los dedos índice y corazón de su mano derecha. Como en otros casos, una breve inscripción en latín presenta a: «Emmanuel Marti et Zaragoza, ecclesiae alonensis decanus philosophus, criticus, poeta eximios latine, graece 554 et hebraice, doctisimus valentinae academiae ornamentum maximum: Natus Oropesae, illercaonum, anno MDCLXIII, XIV Kal. Sext. Obiit. Alonae XII Kal. Maii anno MDCCXXXVII.»

Juan Bautista Ferrer Castro (1694-1748) [fig. 5.56] también forma parte del conjunto pictórico y su imagen se integra perfectamente con la tipología de efigies que caracteriza a esta serie. Su carrera académica en la universidad valenciana estuvo centrada en el aprendizaje de gramática, jurisprudencia canónica y civil. Allí obtuvo el grado de doctor en ambos derechos y consiguió una cátedra prima en cánones vinculada a una pavordía en la catedral, lo cual explica la clase de indumentaria que lleva. De su trayectoria profesional cabe reseñar labor como prelado. En mayo de 1745 fue promovido por Felipe $\mathrm{V}$ al obispado de Lugo, cuya elección fue avalada por el pontífice Benedicto XIV el 24 de agosto de ése mismo año. ${ }^{169}$

169 Ximeno, Escritores del reyno de Valencia..., tomo II, pp. 308-309. Una biografía similar se encuentra en Manuel Risco, España sagrada: theatro geographico-historico de la iglesia de España. De la santa Iglesia de Lugo, tomo XLI, (Oficina de la viuda e hijo de Marín: Madrid, 1798), pp. 250-253. 


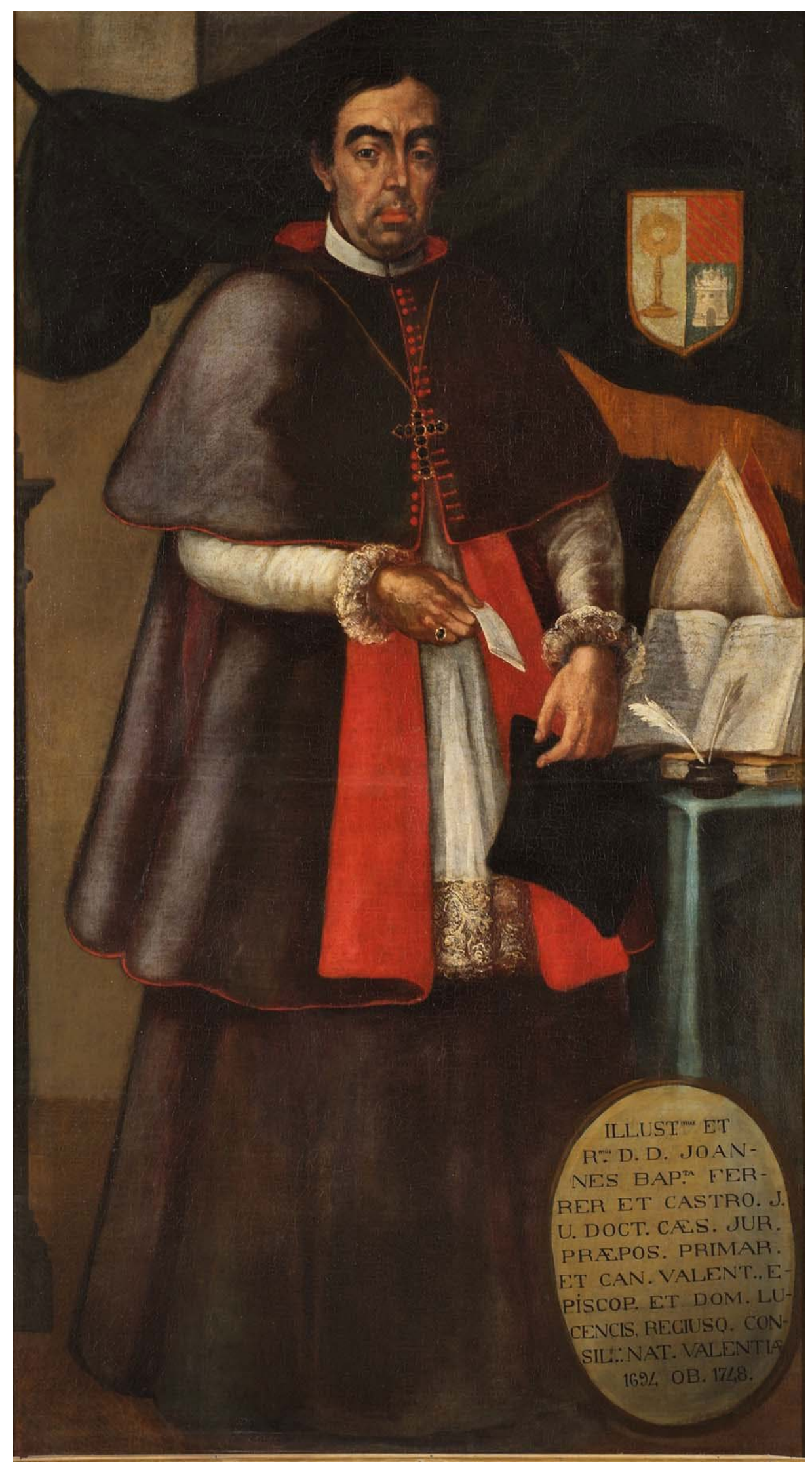

555

Fig. 5.56. Anónimo, Juan Bautista Ferrer Castro, s. XVIII, óleo sobre lienzo, Valencia, paraninfo de la Universitat. 
Dos años más tarde pasó a asumir la diócesis de Calahorra. Por tanto, la mitra, la cruz pectoral y el anillo pastoral aluden visualmente a sus cargos obispales. Además, se aprecia un libro abierto junto a unas plumas y un tintero que revelan su labor intelectual y se pueden asociar a su obra Dissertatio de antiquo primatu toletano (Valencia: 1728). Otros elementos identificativos de su persona son el escudo de armas y el texto biográfico que dice: «Illust ${ }^{\text {mus }}$ et R. ${ }^{\text {mus }}$ D.D. Joannes Bap ${ }^{\text {ta }}$ Ferrer et Castro. J.U. Doct. Caes. Jur. Praepos. Primar. et Can. Valent. Episcop. et Dom. Lucencis, regiusq. consilenat. Valentia 1694, ob. 1748.»

Antonio García Cervera (1682-1753) [fig. 5.57] comenzó sus estudios de medicina en 1701 y llegó a doctorarse en 1705. Posteriormente, comenzó su vinculación profesional con la Universitat al ocupar diferentes cátedras. Así, desde 1707 hasta 1721 ostentó la cátedra de teórica, en ése momento ganó la denominada de simples o herbes y desde 1732 hasta 1742, año de su jubilación, estuvo al frente de la cátedra prima o de práctica. Unos años más tarde, en 1751, fue reclamado en la corte para atender a los monarcas Fernando VI y su esposa Isabel de Braganza. ${ }^{170} \mathrm{Su}$ indumentaria, compuesta principalmente por la casaca y la peluca, relaciona al efigiado con la moda francesa del siglo XVIII. Sobre el bufete cabe destacar la inclusión de dos libros concretos cuyos autores fueron, también, médicos. Se trata de Comentarios de Gerhard van Swieten y de Aforismos de Hermann Boerhaave.

Su estudio de la medicina y otras disciplinas afines ha quedado patente a través de los numerosos volúmenes, que reposan en la estantería del fondo, pertenecientes tanto a autores clásicos como contemporáneos. Por ejemplo, se halla un libro de Hipócrates (460 a.C - 370 a.C), médico de la antigua Grecia y otro del bizantino Pablo de Egina, profesional del siglo VII especializado en la cirugía y la obstetricia. Igualmente se 170 Salvador Albiñana, 'Las cátedras de medicina en la Valencia de la Ilustración', Universidad de Valencia, Estudis: Revista de historia moderna, no. 14, 1988, pp. 171-210. 


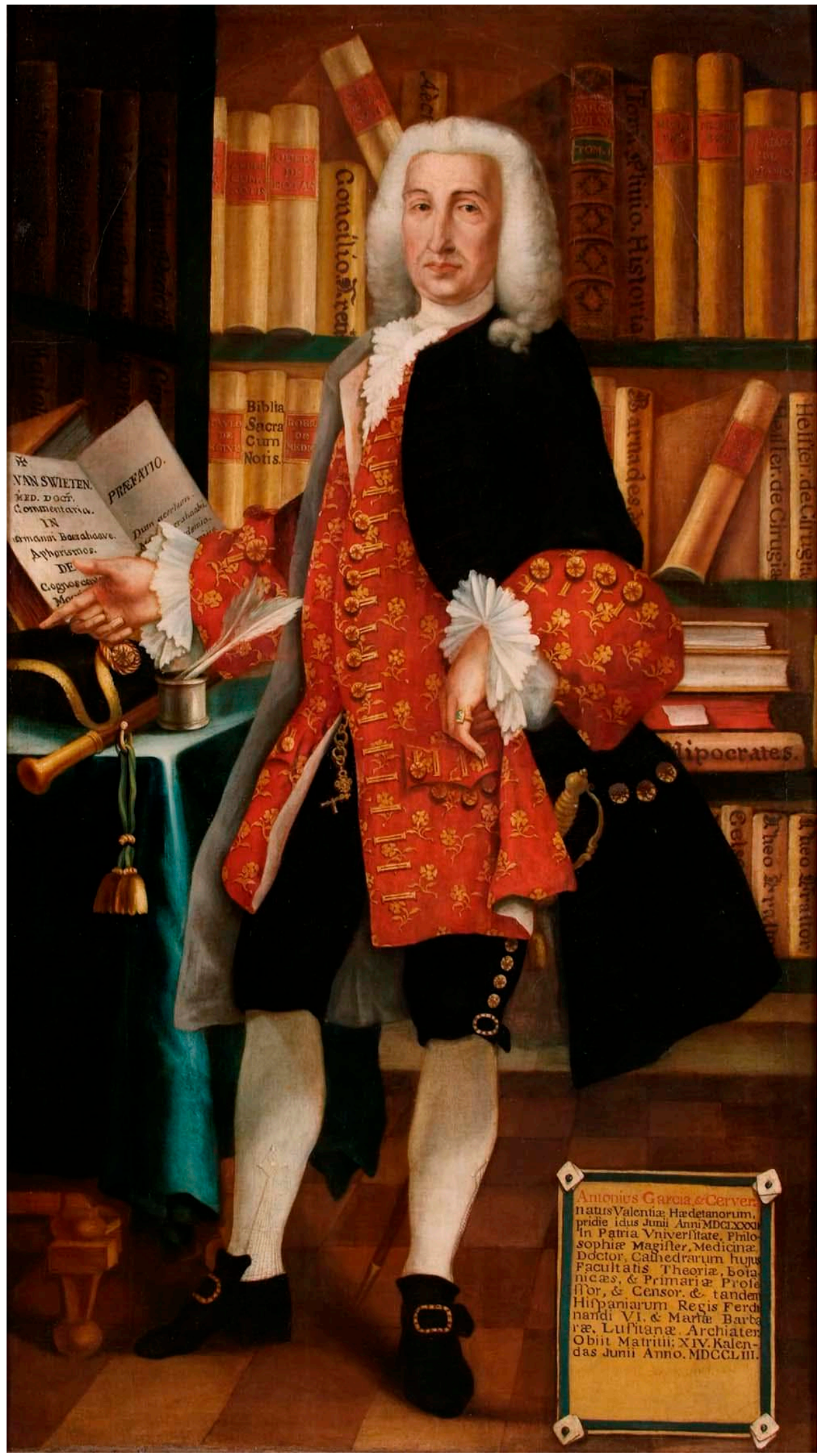

Fig. 5.57. Anónimo, Antonio García Cervera, 1730-1760, óleo sobre lienzo, Valencia, paraninfo de la Universitat. 
han observado dos volúmenes de la obra De cirugía de Lorenz Heister (1683-1758), médico alemán con sólidos estudios de anatomía. También cabe destacar un libro de Miguel Barnades (1708-1771), quien además de en medicina, se formó en botánica y zoología, y un tratado específico de botánica de cuyo autor no se ha dejado constancia. La presencia de ambas obras entre la biblioteca personal del efigiado apunta a su particular interés por dicho campo científico, pues entre 1721 y 1732 ostentó la cátedra de herbes destinada al estudio y utilización de planta y de productos de origen animal y mineral por sus propiedades curativas. Es más, trabajó para la creación de un jardín botánico vinculado a la Universitat. Además, se han incluido otras obras de materia diversa como la Biblia Sacra cum notis, otro que versa acerca del Concilio de Trento u otro sobre historia. La correspondiente inscripción especifica que estamos ante el retrato de: «Antonius Garcia et Cervera, natus Valentiae haedetanorum, pridie idus junii anni MDCLXXXII in patria universitate, philosophiae magister, medicinae, doctor, cathedrarum huius facultatis theoriae, botanicae et primariae profesor er censor et tándem Hispaniarum regis Ferdinandi VI et Martae Barbarae, lusitanae, archiatera. Obiit matritii; XIV kalendas junii anno MDCCLIII.»

Otro de los miembros que configuran el conjunto pictórico es Gaspar Fuster (1652-1720) [fig. 5.58], natural de Albocacer, quien comenzó sus estudios en gramática en San Mateo. Más tarde, su formación universitaria transcurrió en Valencia donde obtuvo el grado en artes y el doctorado en teología. En 1675 se ordenó sacerdote en Tortosa, en 1687 se le otorgó una pavordía de teología escolástica en Valencia y finalmente, fue designado arzobispo de Sácer (Cerdeña). El 28 de agosto de 1720 falleció gozando de muy buena fama y siendo considerado un prelado santo al que le avalaba una sólida carrera intelectual y profesional reflejada en las numerosas publicaciones que hizo. ${ }^{171}$ La efigie de Fuster sigue la tipología establecida para este

171 Véase a Ximeno, Escritores del reyno de Valencia..., tomo II, pp. 182184. 


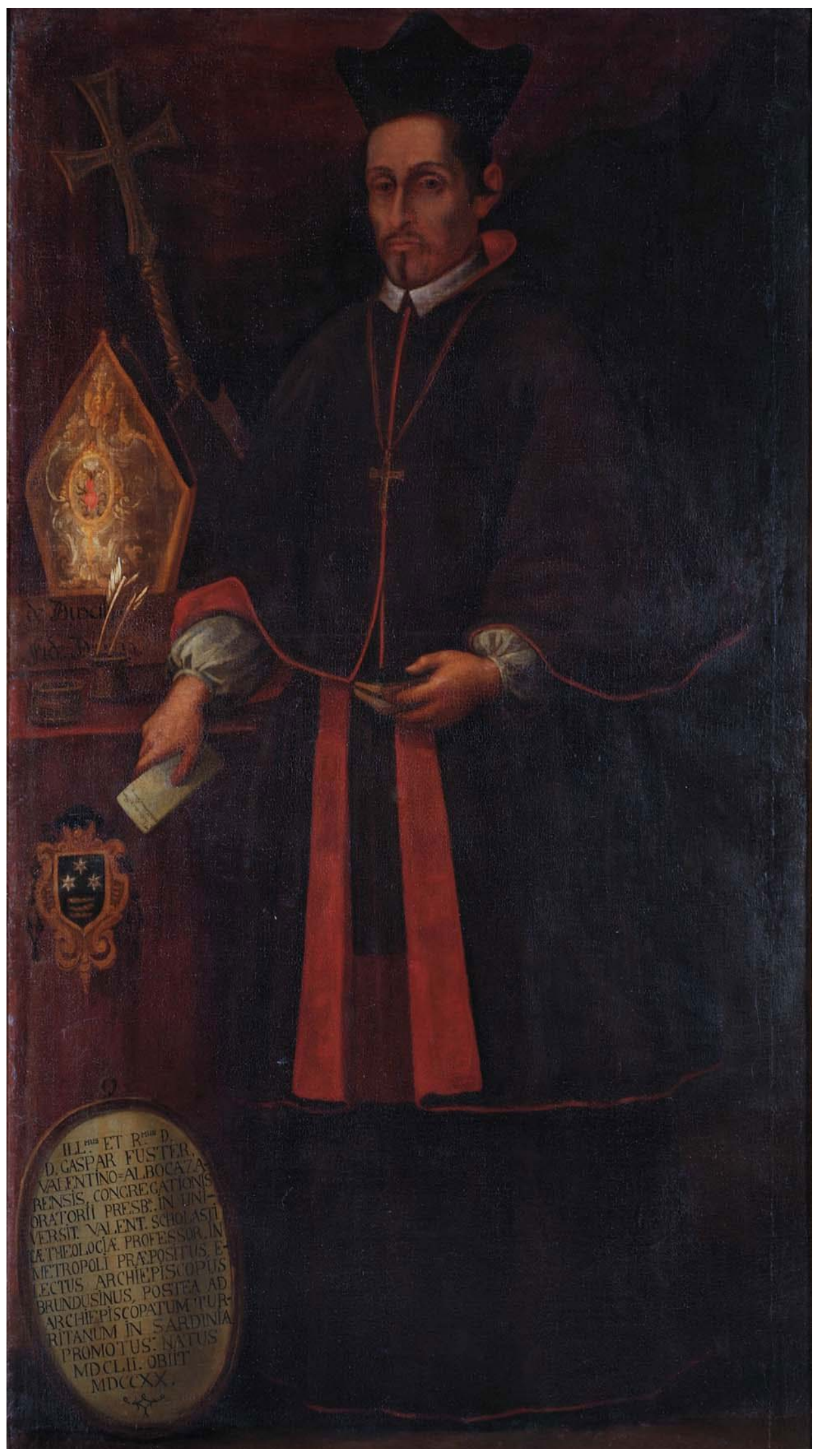

559

Fig. 5.58. Anónimo, Gaspar Fuster, s. XVIII, óleo sobre lienzo, Valencia, paraninfo de la Universitat.

Retratos de hombres ilustres 
conjunto, así cabe destacar la inclusión de la mitra, la cruz pectoral y otra pastoral en un segundo plano como elementos secundarios alusivos a sus hitos profesionales. El libro que tiene entreabierto en la mano izquierda, los dos volúmenes, plumas y tinteros dispuestos en el bufete, una vez más, remiten a su labor intelectual. La correspondiente inscripción dispuesta en un sencillo medallón especifica lo siguiente: «ILL ${ }^{\mathrm{MUS}} \mathrm{ET} \mathrm{R}^{\mathrm{MUS}}$ D.D. GASPAR FUSTER, VALENTINO, ALBOCAZARENSIS, CONCREGATIONIS, ORATII, PRESB ${ }^{R}$ IN UNIVERSIT VALENT. SCHOLASTICAE THEOLOGIAE PROFESOR IN METRÓPOLI PRAEPOSITUS ELECTUS ARCHIEPISCOPUS BRUNDUSINUS, POSTEA AD ARCHIEPISCOPATUM TURRITANUM IN SARDINIA PROMOTUS: NATUS MDCLII OBIIT MDCCXX»

El retrato de Francisco Pérez Bayer (1711-1794) [fig. 5.59] debió ser un encargo del claustro universitario para homenajear a este intelectual probablemente a raíz de que en 1785 donase su biblioteca personal a la Universitat. Es más, también se le encargó a la Real Academia de Bellas Artes de San Carlos la realización de un retrato escultórico que se ubicaría en la propia Universitat y que fue costeado por el propio gobierno municipal. Tal y como ha quedado reflejado en las actas de la institución, la tarea fue llevada a cabo por José Esteve, director de la rama de escultura por aquel entonces:

Yo presenté en esta Junta un oficio de la muy Ilustre Ciudad por el que manifiesta el deseo que tiene de manifestar su gratitud a los favores que ha recibido el Ilustrísimo Señor Don Francisco Perez Bayer, arcediano mayor, en cuya conformidad ha pensado el que se haga un busto, retrato de dicho Ilustrísimo Señor para colocar en la Biblioteca establecida en la Universidad compuesta toda de libros regalados por el mismo señor. Y para el acierto y perfección de dicho busto encarga la Ilustre Ciudad a la Academia la elección de artífice que pueda mejor desempeñar la mencionada obra. Y en su vista se acordó se pase un oficio de la Junta a D. Josef Esteve director actual de Escultura para que este forme una relación del coste 


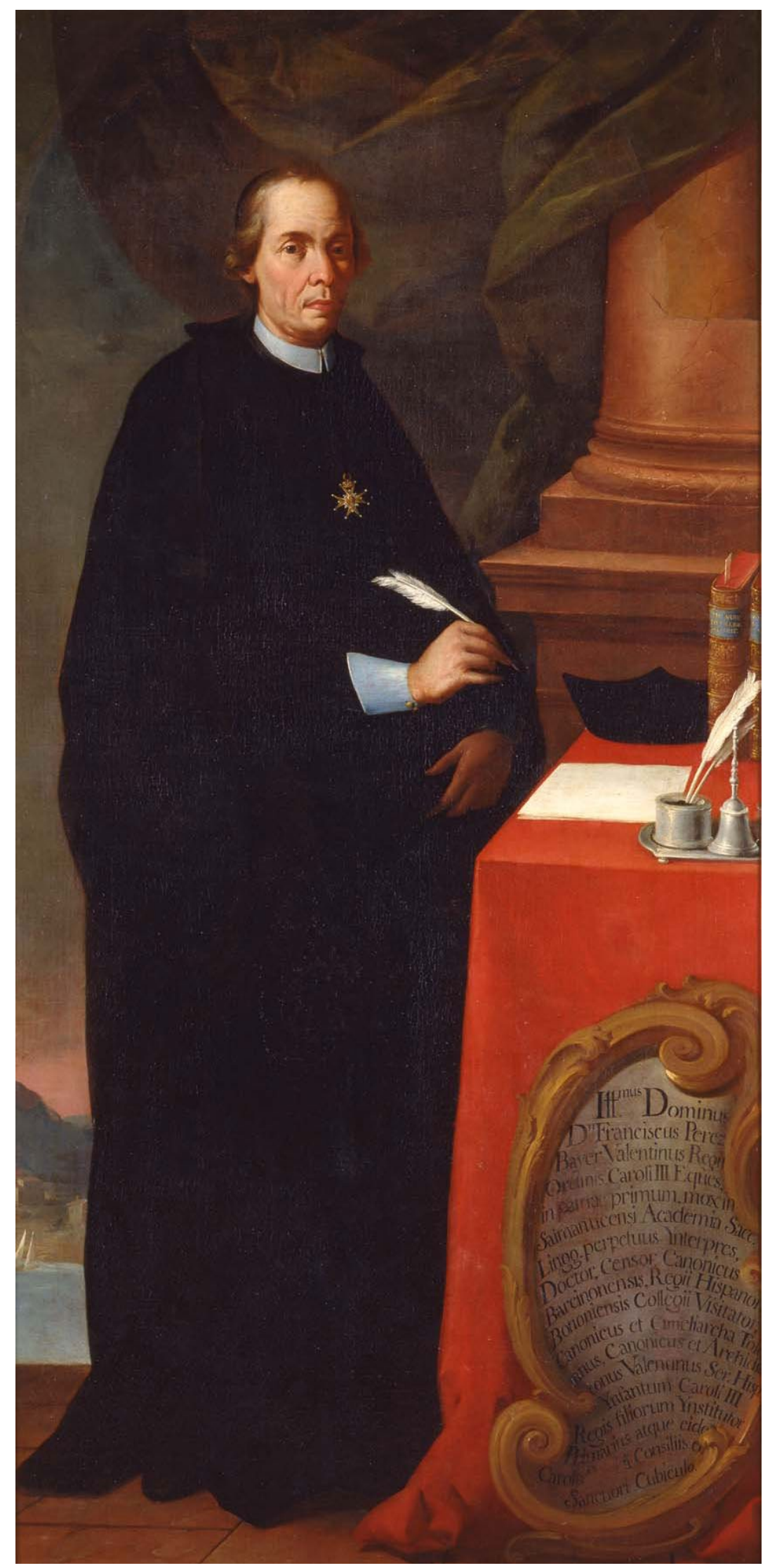

561

Fig. 5.59. Anónimo, Francisco Pérez Bayer, h. 1785, óleo sobre lienzo, Valencia, paraninfo de la Universitat.

Retratos de hombres ilustres 
que puede tener dicha obra y hecho lo entregue a la Junta, quedando nombrado por la misma para la dicha obra. Tomás Bayarri, secretario. ${ }^{172}$

José Esteve aceptó el encargo y estipuló el coste del mismo teniendo en cuenta el material, el pedestal y otros ornamentos previstos en el retrato:

\begin{abstract}
En esta Junta se vio la respuesta del director D. Josef Esteve concerniente a la comisión y nombramiento que hizo la misma a favor de este perteneciente al retrato o busto que se piensa hacer en mármol del Ilustrísimo Señor Don Francisco Pérez Bayer, y juntamente una nota individual del coste que puede tener dicho busto, con su pedestal y demás adornos, y se acordó se pase una copia de esta carta, y coste a la muy ilustre ciudad para su inteligencia y con esta conformidad se dio fin. Tomás Bayarri, secretario. ${ }^{173}$
\end{abstract}

562 Unos meses más tarde, el escultor presentó un proyecto de este retrato escultórico, que no se conserva en la actualidad pero sí que se ha dejado constancia documental de la existencia de esta obra.

Respeto que en la Junta ordinaria antecedente el Director de Escultura Don Josef Esteve, presentó un modelo del busto del Ilustrísimo S. Don Francisco Pérez Bayer, juntamente con los dibujos donde debe estar colocado el busto el que expresa de orden dórico, se acordó ponga en limpio el mencionado Director don Josef Esteve el dicho pedestal elegido, y hecho, se pase a la muy ilustre ciudad, como también el expresado modelo, en contestación al oficio que la Ilustre Ciudad, pasó a esta Real Academia.

172 ARABASC: Libro de Acuerdos de Juntas Particulares. Años: 1765-1786. Junta particular de 3 de julio de 1785.

173 ARABASC: Libro de Acuerdos de Juntas Particulares. Años: 1765-1786. Junta particular de 31 de julio de 1785. 
Tomás Bayarri, secretario. ${ }^{174}$

En cuanto a los principales datos biográficos de Pérez Bayer que permiten entender mejor su retrato, cabe mencionar que ostentó la cátedra de hebreo en Valencia y Salamanca, concretamente en 1745 y 1746. En 1775 se convirtió en arcediano de la catedral de Valencia. El último cargo que llevó a cabo fue el de director de la Biblioteca Real de Madrid, labor desempeñada hasta su fallecimiento en 1794. A lo largo de su carrera profesional recibió diversos nombramientos como miembro de la Academia de Bellas Artes de San Petersburgo, de la de Ciencias de Gottinga y de la de Bellas Artes de San Carlos de Valencia. ${ }^{175}$ Igualmente fue condecorado por la orden de Carlos III y así se percibe en su retrato, donde sobre la austera toga doctoral destaca la gran cruz de la mencionada orden. El bufete reúne varios elementos en alusión a su labor intelectual como las plumas y el tintero, un documento y los dos volúmenes de su obra De numis hebraeo samantanis, publicada en 1781. El fondo se ha vestido con el típico cortinaje y una columna sobre pedestal. Además se ha incluido un paisaje con un horizonte muy bajo contribuyendo a la monumentalidad de la figura. La inscripción dispuesta en el medallón dice que:

Ill. ${ }^{\text {mus }}$ Dominus D. ${ }^{\mathrm{n}}$ Franciscus Perez Bayer Valentinus Regni Ordinis Caroli III Eques in patria primum, max. in Salmanucensi Academia Sacc. Lingg. Perpetuus Ynterpres Doctor, Censor Canonicus Barcinonensis, Regii Hispanor Bononiensis Collegii Visitator Canonicus et Cimeliarcha Tol [...]mnus Canonicus et Archidiaconus Valentinus Ser. Hisp. Ynfantum Caroli III Regis filiorum Ynstitutor Primarius atque eide Carolo [...] Consilis Sanctori Cubiculo.

Antes de 2017, en el espacio que a día de hoy se encuentra el 174 ARABASC: Libro de Acuerdos de Juntas Particulares. Años: 1765-1786. Junta particular de 15 de octubre de 1785.

175 Respecto a este retrato consúltese la ficha de catálogo de David Sánchez Muñoz en Benito Goerlich y Sánchez Muñoz, La Universitat de València..., vol. II, pp. 200-201. 


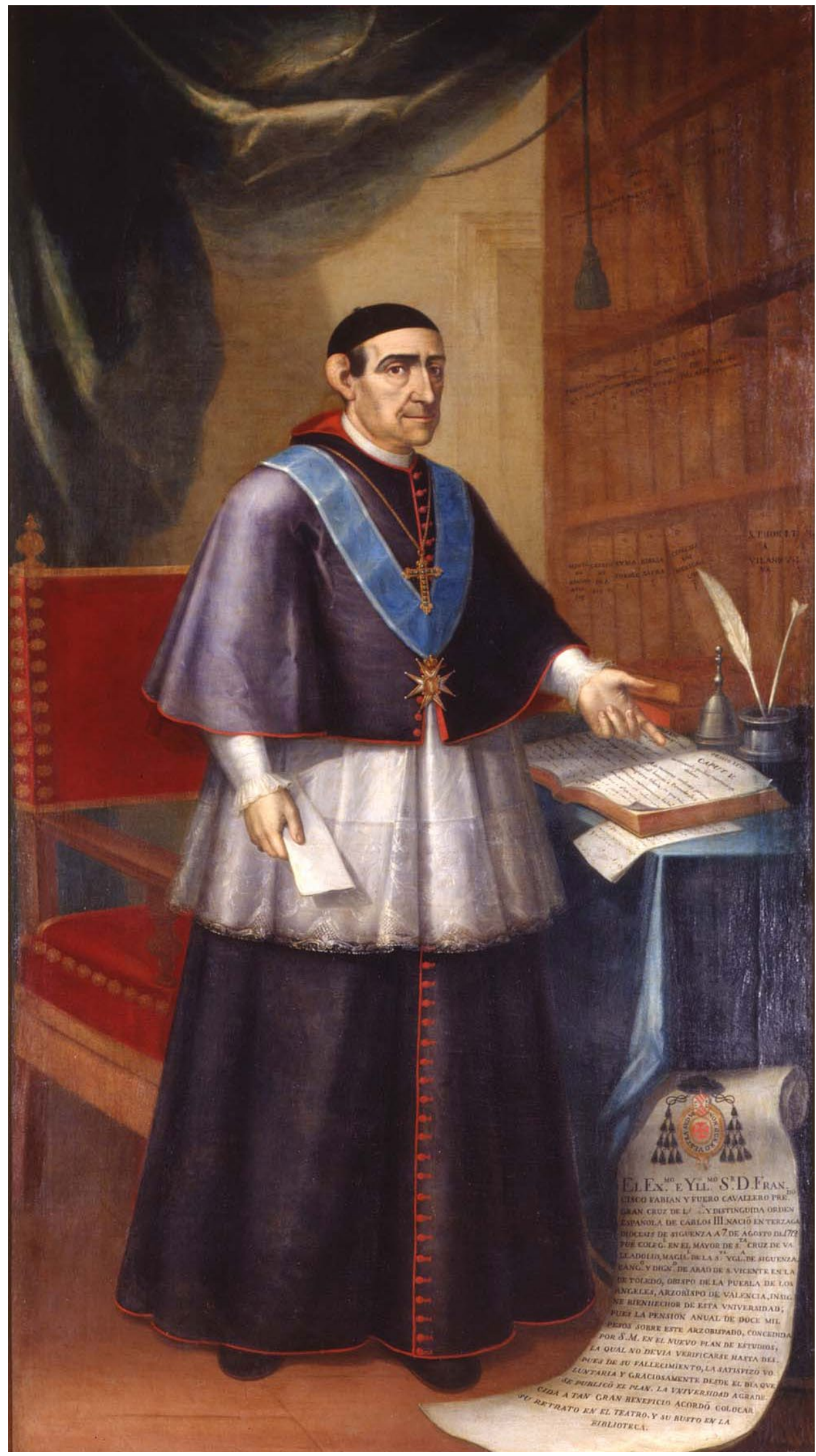

Fig. 5.60. Anónimo, Francisco Fabián y Fuero, finales del s. XVIII, óleo sobre lienzo, Valencia, paraninfo de la Universitat. 
retrato de Olimpia Arozena (1902-1971) se ubicaba la efigie de Francisco Fabián y Fuero (1719-1801) [fig. 5.60]. Su persona y su imagen ya han sido presentadas en la galería de prelados valencianos a cuya serie también pertenece este personaje. Cabe recordar que su formación estuvo centrada en el estudio de filosofía en Calatayud, de teología en Alcalá y de artes y sagrada teología en Sigüenza. Sin duda, tuvo una amplia educación que justifica la ambiciosa biblioteca personal que se observa a la derecha de la imagen, con obras de santo Tomás de Villanueva, entre otras. Fue designado canónigo tanto en las catedrales de Sigüenza como de Toledo, lo cual explica la tipología de indumentaria que lleva. El efigiado también luce la Gran Cruz de la orden de Carlos III de la cual era miembro desde 1780. Asimismo, este monarca en 1772 ya lo había propuesto para ostentar la mitra valenciana cuyo cargo mantuvo hasta 1794. Por entonces, ya había sido desde 1765 obispo de Puebla de los Ángeles (México). La cruz pectoral y el anillo pastoral aluden a este hecho. La relevancia de este varón respecto a la Universitat de València se ha dado a raíz de su apoyo incondicional al dotar de veinticuatro mil reales anuales a la institución. ${ }^{176}$ Asimismo, formó parte de la implantación de un nuevo plan de estudios publicado en 1787 lo cual le sirvió para que la institución decidiese incluir su retrato entre las personalidades más ilustres. ${ }^{177}$ Todo ello también se ha reflejado en un largo pergamino, encabezado por el escudo de armas del prelado, que reza lo siguiente:

176 Para los principales aspectos biográficos se ha consultado a Felipe Mirallas, Sermón fúnebre en las solemnes exequias que celebraron en la santa iglesia metropolitana de Valencia, su Excelentísimo, Ilustrísimo y Reverendísimo señor don Francisco Fabián y Fuero, el día 13 de octubre de 1801 predicado por su canónigo penitenciario el, (Oficina de Benito Monfort: Valencia, 1801); y Juan Carlos Esteban Lorente, 'Un obispo regalista del siglo XVIII natural de Terzaga: Don Francisco Fabián y Fuero, arzobispo de Valencia', Guadalajara, Wad-al-Hayara: Revista de estudios de Guadalajara, 1986, pp. 323-338.

177 Plan de estudios aprobado por S. M. y mandado observar en la Universidad de Valencia, (Viuda de Ibarra: Madrid, 1787). 


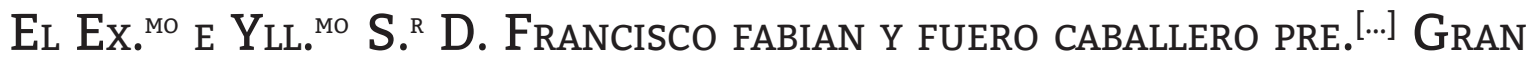
Cruz de la [Real] y Distinguida Orden Española de Calos III. Nació en Terzaga diócesis de Sigüenza a 7 de agosto de 1719. Fue coleg. ${ }^{\mathrm{L}}$ eN

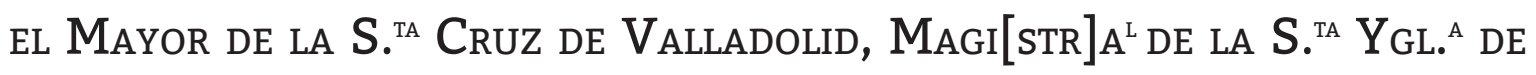
Sigüenza, CANG. ${ }^{\circ}$ Y Dign. ${ }^{D}$ De abad de S. Vicente en la de Toledo, obispo de Puebla de los Angeles, arzobispo de Valencia, insigne bienhechor DE ESTA UNIVERSIDAd: PUES LA PENSION ANUAL DE DOCE MIL PESOS SOBRE ESTE aRzobispado, concedida Por S.M. EN El NueVo Plan de estudios, la QUal NO DEVIA VERIFICARSE HASTA DESPUES DE SU FALLECIMIENTO, LA SATISFIZO VOLUNTARIA Y GRACIOSAMENTE DESDE EL DIA QUE SE PUBLICO EL PLAN. LA UNIVERSIDAD AGRADECIDA A TAN GRAN BENEFICIO ACORDO COLOCAR SU RETRATO EN EL TEATRO Y SU BUSTO EN LA BIBLIOTECA. (SiC) $)^{\text {MO }}$

En el muro opuesto a la zona presidencial, sobre la tribuna de los músicos, se ha colocado definitivamente el retrato del padre Vicente Tomás Tosca (1651-1723) [fig. 5.61], atribuido a Joaquín Giner y fechado alrededor del año 1750. De forma paralela llevó a cabo su carrera sacerdotal y académica, así en 1678 ingresó en la Congregación del Oratorio de san Felipe Neri y en 1683 se doctoró en Teología en la Universidad valenciana. ${ }^{178} \mathrm{La}$ efigie de Tosca es de los raros ejemplos en esta serie, además del de Juan Sala, donde el efigiado está sedente. No obstante, se mantienen los objetos complementarios propios del retrato barroco. Al sacerdote, ataviado con la sotana negra y un bonete, parece que se le haya interrumpido en la actividad que estaba llevando a cabo; dejar constancia de sus raíces genealógicas. Sus ascendientes se remontan a los abuelos maternos. De este modo se especifica que Esteban Mascó, ciudadano, casó con Serafina Roca. Del matrimonio nacieron Serafina y Francisca Mascó. La primera se emparentó con Jaime Busquets Matoses, ciudadano. La segunda, madre del representado, casó con Calixto Tosca y cuyo único hijo fue el propio sacerdote. En cambio la descendencia de su tía Serafina fue, como se puede observar, más dilatada. Tras él, una estantería repleta de libros inunda el espacio. Cada uno de los

178 Consúltese la ficha de catálogo de Amparo José Mora en Benito Goerlich y Sánchez Muñoz, La Universitat de València..., vol. II, pp. 174-175. 


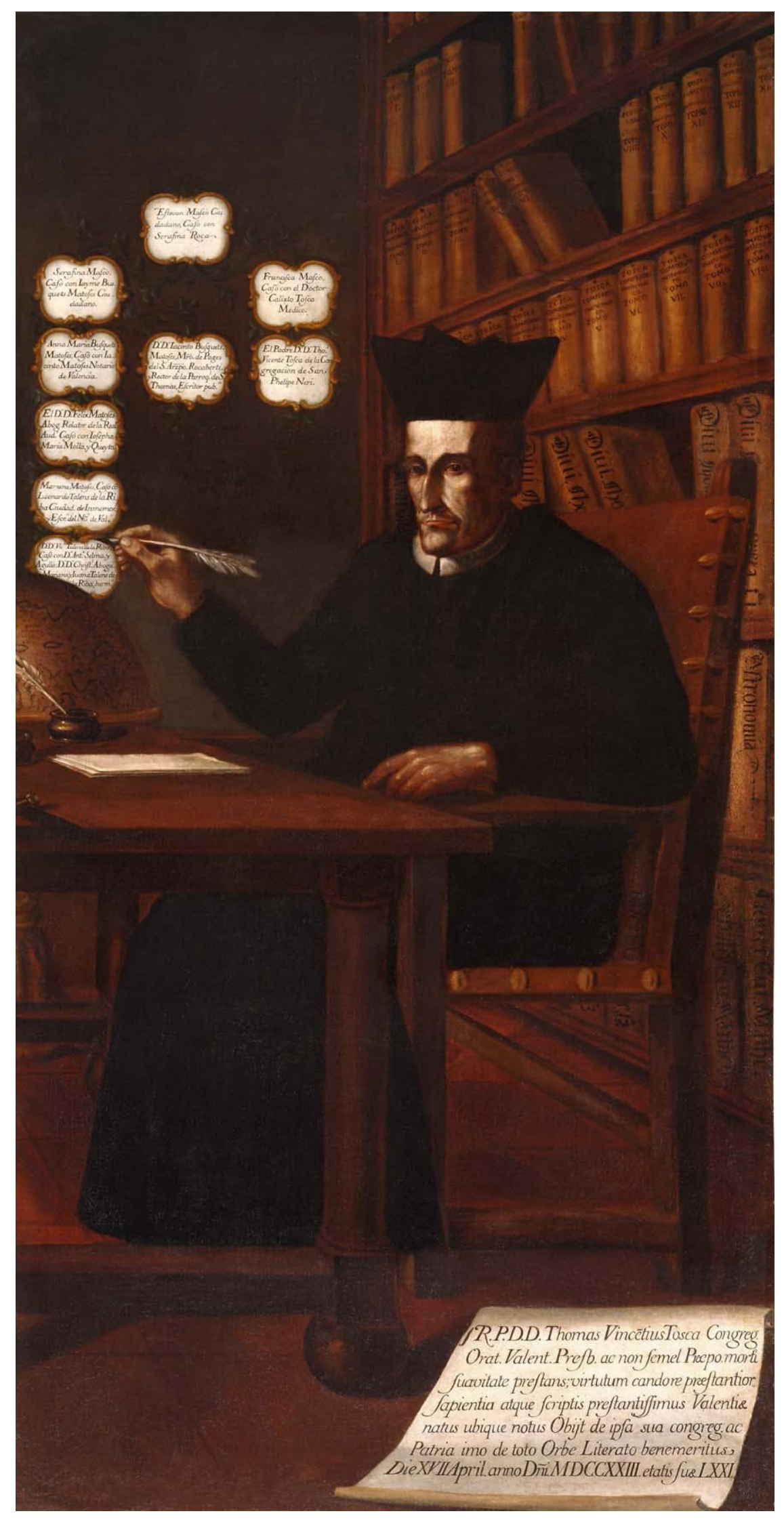

Fig. 5.61. Atribuido a Joaquín Giner, Tomás Vicente Tosca, h. 1750, óleo sobre lienzo, Valencia, paraninfo de la Universitat. 
volúmenes, con sus pertinentes títulos inscritos en el lomo, deja constancia de su ávida cultura y de su amplia producción científica. Entre sus principales aportaciones cabe destacar el Compendio Matemático, escrito entre 1707 y 1715, conformado por nueve volúmenes destinados a tratar las materias más relevantes al respecto. Asimismo un pergamino contiene un texto en latín que especifica lo siguiente: «R.P.D.D. Thomas Vincentius Tosca Congreg. Orat. Valent. Presb. Ac non semel Preapo. morti suavitate prestans; virtutum candore praestantior sapientia atque scriptis prestantissimus Valentiae natus ubique notus Orbe Literato benemeritus. Die XVII April anno Domini MDCCXXIII etatis suae LXXI.»

\subsubsection{Los retratos del siglo XIX.}

Las pinturas fechadas en el siglo XIX son menores respecto a la centuria anterior y tan sólo se cuenta con un total de siete obras. Una vez más, frente a la tribuna presidencial, hacia la derecha cabe detenerse en el retrato de Mariano Liñán Morelló (1769-1844) [fig. 5.62], quien fue catedrático de historia, lengua árabe y bibliotecario segundo desde 1797. Contribuyó notablemente a la recuperación de la biblioteca universitaria, que se había visto muy perjudicada a raíz del dominio napoleónico. Fue nombrado canónigo de la catedral de Valencia, por esta razón en el retrato aparece su hábito coral sobre un sillón en un segundo plano. También fue obispo de Teruel, cargo que no llegó a ostentar por su fallecimiento. Otro de los distintivos que luce, nos habla de su pertenencia a la orden de Carlos III. Por sus características estéticas este es otro de los retratos asociados a la mano de Bernardo López. La breve inscripción biográfica ha especificado lo siguiente:

MARIANUS LIÑAN ET MORELLÓ. COLL. MAI. DE THOMAE DE VILLANOVA ALUMNUS PARROCHIALIS ECCLESIAR S. NICOLAI BENEFICIARIUS PUBLICUS IN ACADEMIA VALENTINA, LINGUAE ARABICAE. DEIN HISTORIAE ECCLESIASTICAE PROFESS. AC DEMUM PRIMARIUS S. THEOLOG. PREPOSITUS ECCLES. TUROLENSIS EPIS- 


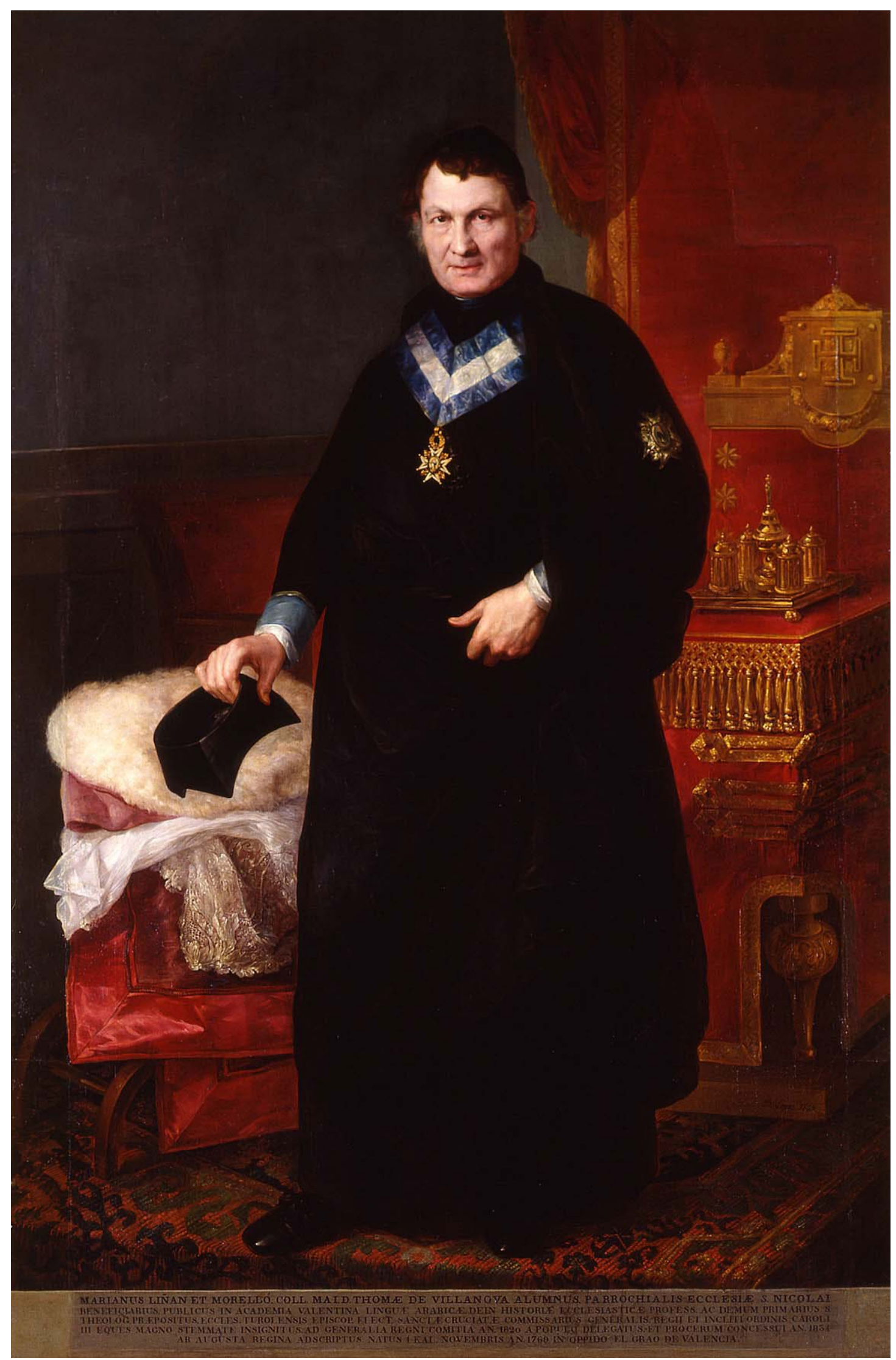

Fig. 5.62. Bernardo López Piquer, Mariano Liñán Morelló, 1840, óleo sobre lienzo, Valencia, paraninfo de la Universitat. 
COP. ELECT. SANCTAE CRUCIATAE COMMISSARIUS GENERALIS REGIT ET INCLITI ORDINIS CAROLI III EQUES MAGNO STEMMATE INSIGNITUS AD GENERALIA REGNI COMITIA AN. 1820 A POPULU DELEGATUS ET PROCERUM CONSENSSUI AN. 1834 AB AUGUSTA REGINA ADSCRIPTUS NATUS I KAL. NOVEMBRIS AN. 1760 IN OPPIDO EL GRAO DE VALENCIA. ${ }^{179}$

Además de la efigie de Tosca, el retrato de Juan Sala Bañuls (1731-1806) [fig. 5.63] es otra de las pocas representaciones donde el personaje se encuentra sedente. Pese a no mantener la atmósfera de solemnidad característica de este conjunto sí que se muestra ávido de cultura y con una gran formación intelectual. Así pues, Sala Bañuls, catedrático de leyes en la Universitat se encuentra inmerso en un ambiente de pleno trabajo por esta razón le inundan numerosos libros. Entre ellos hay algunos rotulados en su lomo que se corresponden con obras escritas por el propio retratado. Por ejemplo, Nueva recopilación situado entre todos los libros que conquistan el suelo de la estancia. Cabe recordar que fue pavorde de la catedral, y aunque no lleva las vestiduras canonicales como otros varones ilustres, sí que se encuentran a un lado de la imagen sobre algún elemento de mobiliario auxiliar. Además, en este mismo lugar se puede leer parcialmente el texto biográfico que revela lo siguiente: «D. Juan SALA y Bañuls doctor en AMbos DERECHOS, CATEdRatico de la Universidad, paVorde de la Metropolitana y Vicario g[ene] RAL DEL ARZOBISPADO DE VALENCIA, AUTOR DE LA [...]»

Conviene mencionar otra efigie de Juan Sala que aun siendo una representación tan sólo de su rostro, comparte el punto de vista y el detallismo en los rasgos faciales sin disimular, en ningún caso, el defecto ocular. Se trata de una pintura relacionada con el taller de Vicente López y conservada en los fondos del museo Lázaro Galdiano (Madrid) [fig. 5.64]. Es realmente llamativo cómo se ha mostrado sin tapujos las particularidades de la apariencia del efigiado, cuando los teóricos general-

179 Véase la ficha de catálogo de Daniel Benito en Benito Goerlich y Sánchez Muñoz, La Universitat de València..., vol. II, pp. 184-185. 


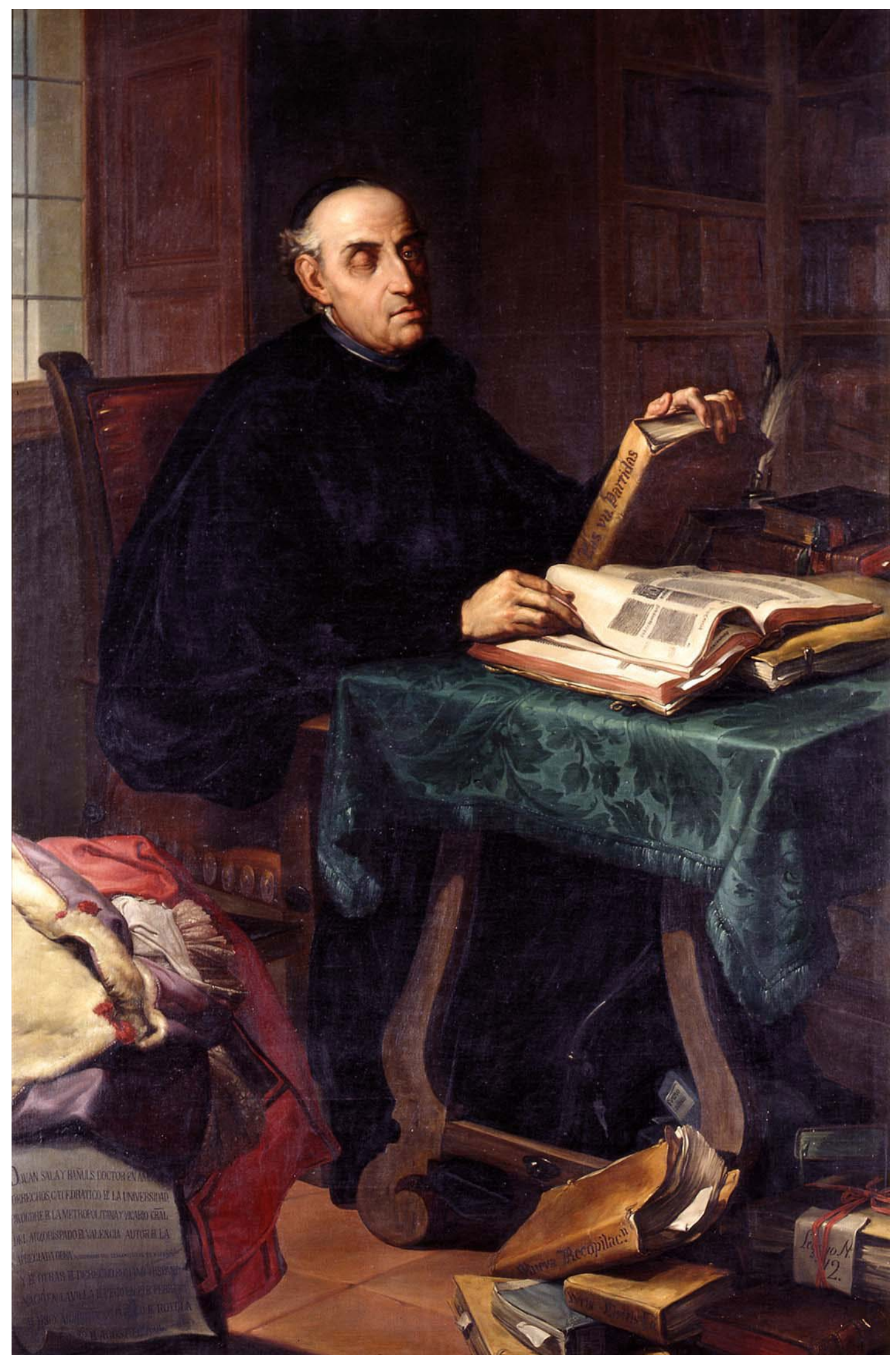

Fig. 5.63. Anónimo, Juan Sala Bañuls, s. XIX, óleo sobre lienzo, Valencia, paraninfo de la Universitat. 


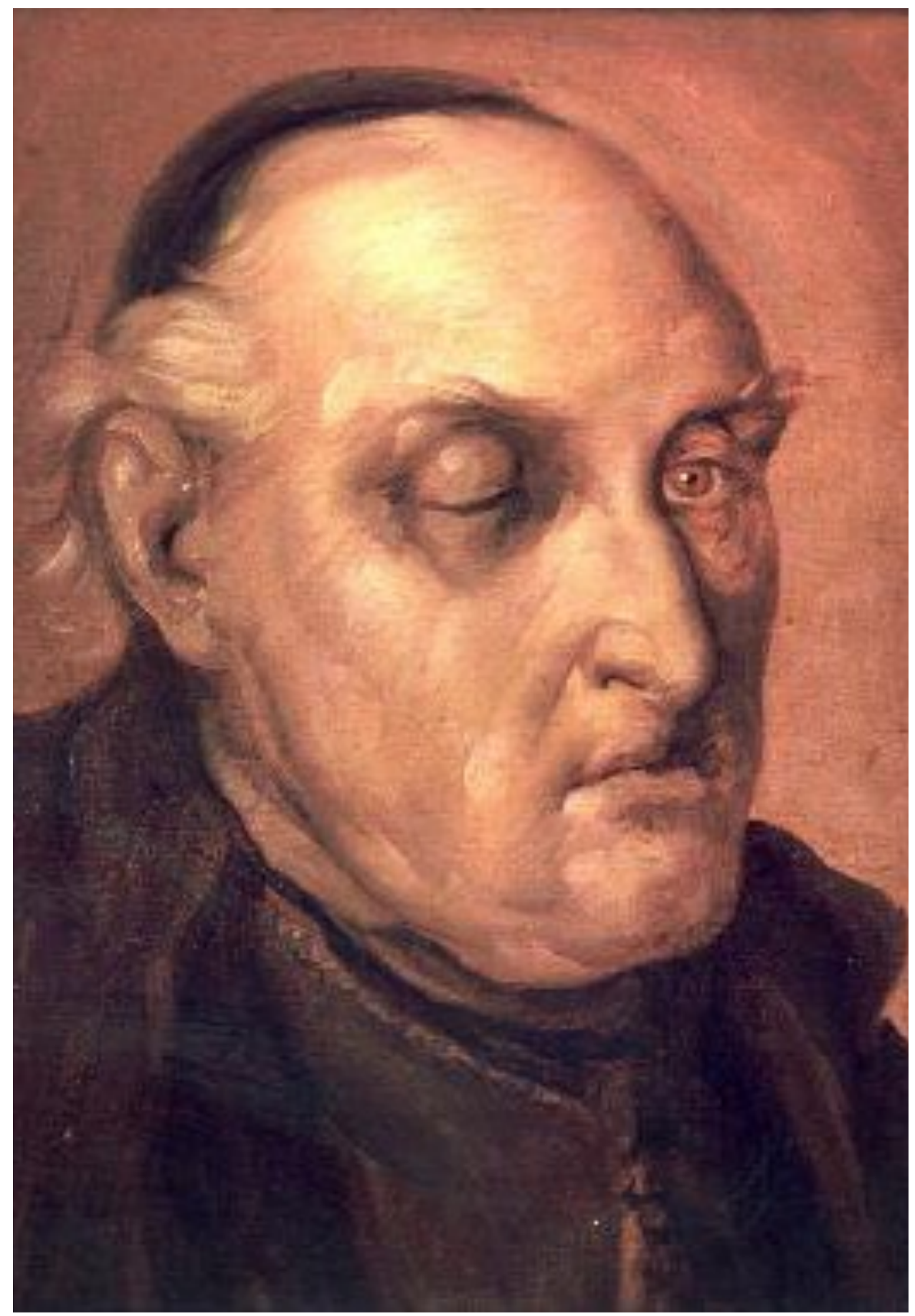

Fig. 5.64. Taller de Vicente López, Retrato del pavorde Juan Sala Bañuls, 1826-1875, óleo sobre lienzo, Madrid, Museo Lázaro Galdiano. 
mente habían apostado por disimular esta clase de características.

Hacia la izquierda del espectador se halla otra efigie siguiendo la estética de los retratos de esta serie y concretamente de aquellos elaborados por Bernardo López. Se trata de Nicolás María Garelli (1777-1850) [fig. 5.65], cuya imagen es una copiade la que ya había elaborado Vicente López en 1835. Así pues, pese a tratarse de una pieza no firmada se ha relacionado con el hijo de éste. Los estudios de Garelli se iniciaron en la Universitat, donde se formó en leyes y en 1814 se convirtió en catedrático de derecho civil. Asimismo, una de sus principales aportaciones fue la creación de la primera cátedra de constitución, algo totalmente novedoso en España. Sus logros académicos explican que se le haya retratado con la toga y collar doctoral. También justifican que se aluda a su cariz intelectual a través de ubicar varios escritos sobre el bufete, entre ellos Novísima recopilación y Leyes de partida. Otro galardón al que se alude mediante la imagen es su pertenencia a la Orden de Carlos III, cuya banda y cruz también destaca sobre la toga negra.

La carrera profesional de Garelli además de ser brillante en el ámbito académico fue muy prolífica en otros aspectos, pues entre 1820 y 1821 fue diputado en Cortes, en 1822 fue nombrado ministro de Gracia y Justicia, cargo del que fue cesado un año más tarde pero que volvió a ejercer entre 1834 y 1835 . Fue un personaje activo en la creación del Tribunal Supremo, de hecho presidió este organismo en 1843. También influyó en la modificación de los códigos dedicados al derecho comercial y penal, así como promovió la creación de uno de carácter civil. Su último cargo fue el de senador vitalicio en Valencia desde 1845 hasta su fallecimiento en 1850 . Una síntesis de sus méritos profesionales se ha incluido en el breve texto que se da en la parte inferior del lienzo y reza que: «El Excmo. e Ilmo. Señor don Nicolás María Garelli, doctor en ambos derechos, abogado, catedráticos y pavorde de Leyes, diputado en las Cortes de 1890 y 91 , ministro de Gracia y Justicia en 1822 - 1834 y 35, 


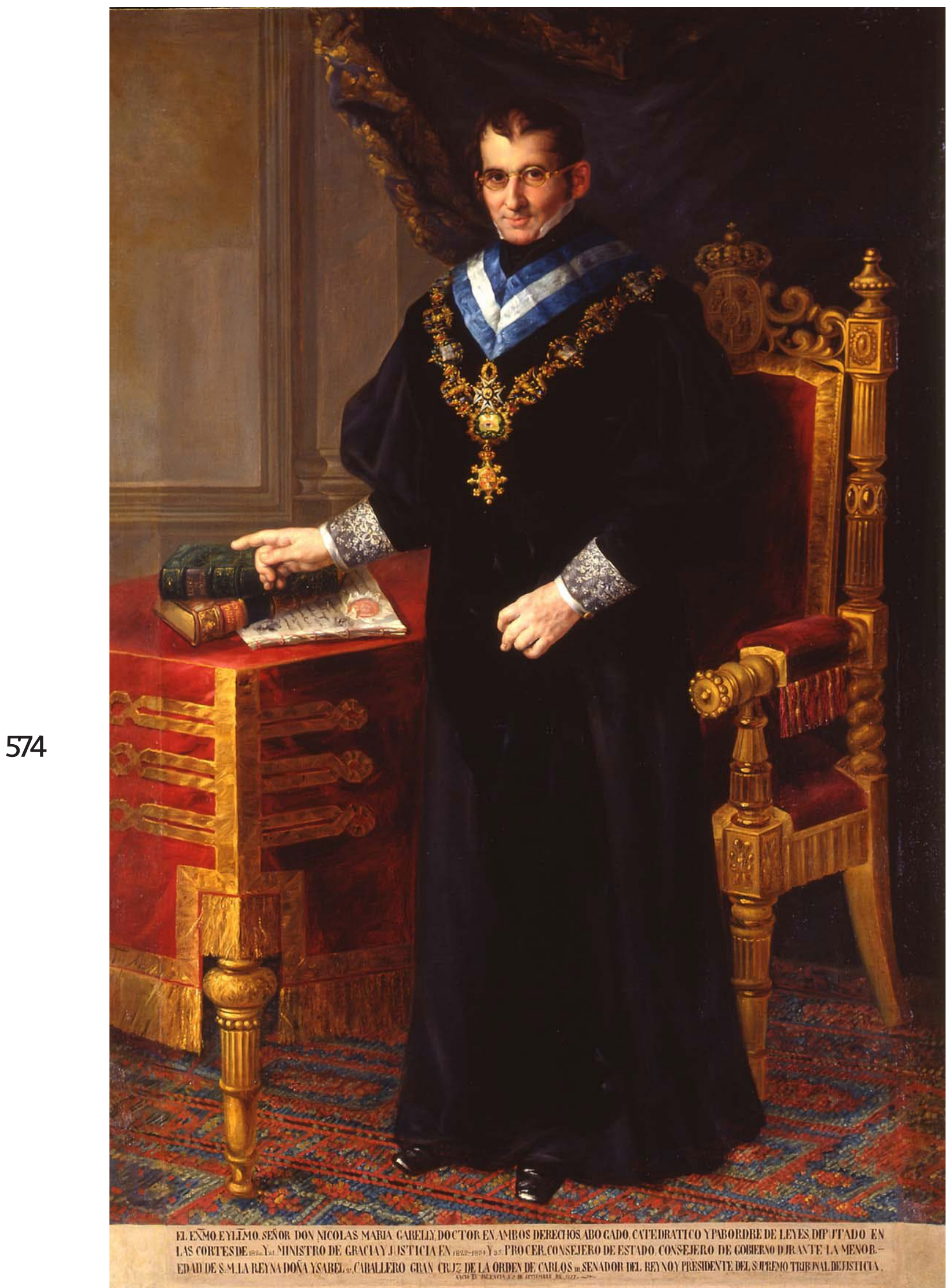

Fig. 5.65. Bernardo López, Nicolás María Garelli, h. 1840, óleo sobre lienzo, Valencia, paraninfo de la Universitat. 
prócer, consejero de Estado, consejero de Gobierno durante la menor edad de S. M. la reina doña Isabel II, caballero Gran Cruz de la Orden de Carlos III, senador del reino y presidente del Supremo Tribunal de Justicia. Nació en Valencia a 9 de septiembre de 1777.»180

A continuación se observa a Miguel Payá y Rico [fig. 5.66], quien centró sus estudios universitarios en las disciplinas de teología y filosofía. De hecho, llegó a ser catedrático de metafísica, literatura e historia en Valencia. Su trayectoria académica estuvo estrechamente relacionada con su carrera eclesiástica. Se ordenó sacerdote en 1836 y fue nombrado obispo de Cuenca en 1858, de Santiago de Compostela en 1875 y de Toledo en 1891. En 1877 fue nombrado cardenal, por ello se le ha representado con el hábito coral compuesto de una sotana y muceta roja, el roquete, el solideo y la birreta roja que se observa sobre la mesa auxiliar. Igualmente lleva la cruz pectoral y el anillo apreciable tanto en prelados como en cardenales. Otros distintivos que luce son las insignias y bandas de las órdenes de Isabel la Católica y Carlos III. Siguiendo las características de los retratos de esta serie, la imagen ha quedado completada por su correspondiente inscripción donde se especifica lo siguiente:

EL EXCMO. E ILLM. S. D. MIGUEL PAYÁ Y RICO, NACIDO EN BENEJAMA EL 20 DE DICIEMBRE DE 1811, COLEGIAL DEL R. ${ }^{\mathrm{L}}$ DE CORPUS CHRISTI. ALUMNO Y CATEDRATICO DE ESTA UNIVERSIDAD LITERARIA Y DEL SEMINARIO CONCILIAR DIOCESANO. DOCTOR EN LETRAS Y PREMIO EN SAG. ${ }^{\text {DA }}$ TEOLOGIA I RECTORAL DE LA S. ${ }^{\text {TA }}$ YGLESIA METROPOLITANA DE ESTA MISMA CIUDAD, OBISPO DE CUENCA, ARZOBISPO DE COMPOSTELA, CARDENAL DE LA S. YGLESIA ROMANA, OTRO DE LOS P.P. DEL CONCILIO VATICANO. SENADOR DEL REINO. CAPELLAN MAYOR DE S.M. [...] (Sic)

Respecto a la autoría de la pintura, una vez más se ha vincu180 Véase la ficha de catálogo de Amparo José Mora en Benito Goerlich y Sánchez Muñoz, La Universitat de València..., vol. II, pp. 204-205. 


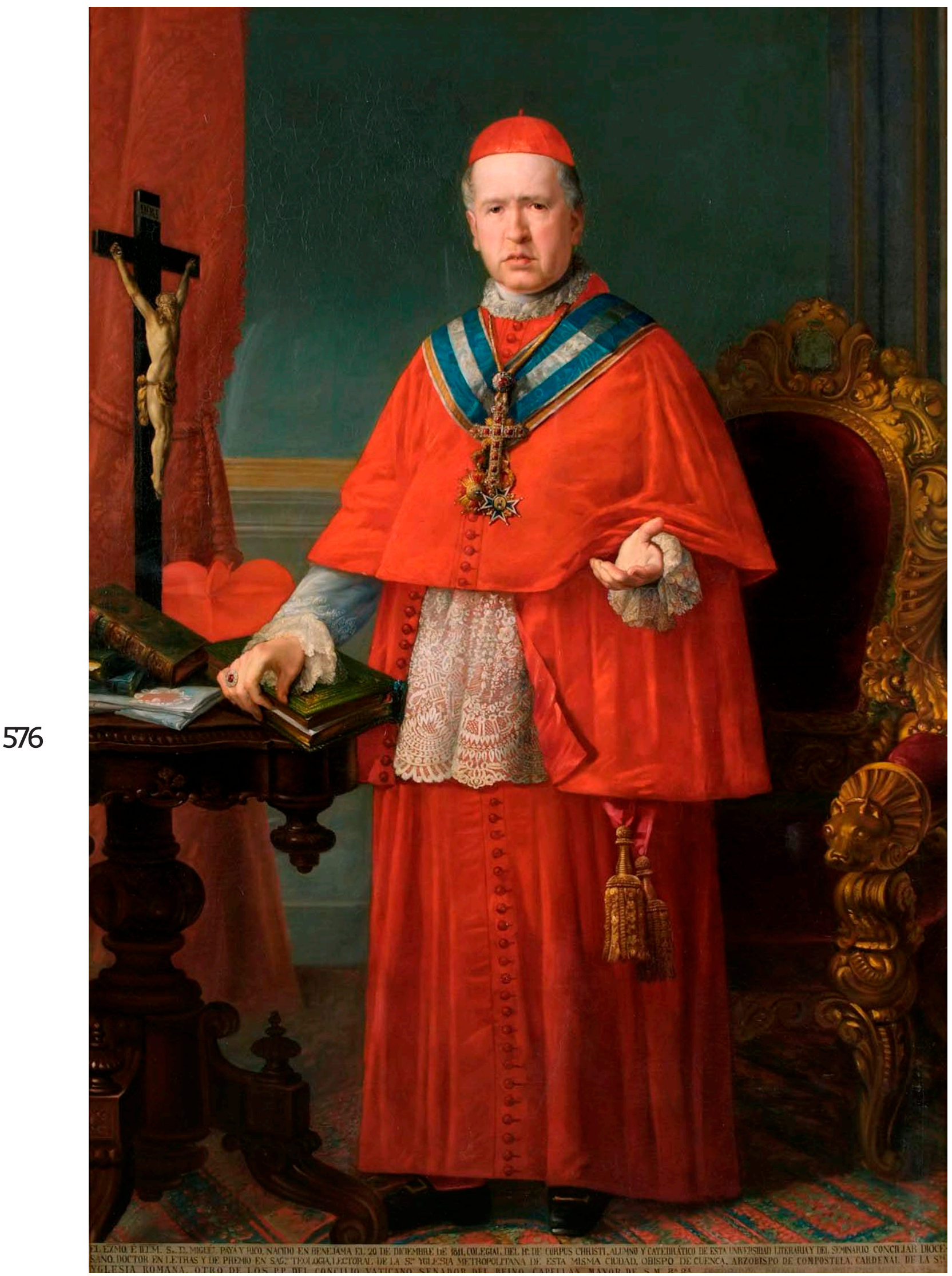

Fig. 5.66. Bernardo López, Miguel Payá y Rico, h. 1840, óleo sobre lienzo, Valencia, paraninfo de la Universitat. 
lado con Bernardo López y su taller. ${ }^{181}$ Esta atribución es lógica por varias razones; las características estéticas del efigiado hacen pensar que esta figura fue realizada por el propio Bernardo López. El resto de elementos, probablemente, fueron ejecutados por artistas de su taller, pues es palpable un leve cambio estilístico. La pintura, además, presenta varios objetos secundarios muy similares a otros retratos también vinculados con el mencionado artista. Por ejemplo, el suntuoso sillón, de decoración barroca y un escudo en la parte superior, la simplificación del interior de la estancia y la alfombra de decoración geométrica y colores vivos.

Por último, uno de los retratos más relevantes de la serie es el de Vicente Blasco García (1735-1813) [fig. 5.67]. ${ }^{182}$ Su formación académica se ha centrado en los ámbitos de la teología, filosofía y artes. De hecho, en 1760 obtuvo el grado de doctor en filosofía y poco más tarde, ganó la correspondiente cátedra en la Universitat. En 1768 asumió la educación de los hijos de Carlos III en calidad de preceptor. En 1781 regresó a Valencia al ser nombrado canónigo de la catedral y tres años más tarde se dio inicio a su periodo como rector en la universidad valenciana. A la institución le aportó una ambiciosa reforma plasmada en su plan de estudios aprobado en 1787, sobre cuyo documento apoya la mano derecha. Justo detrás se han dispuesto otros libros, entre ellos la Biblia y De los nombres de Cristo de fray Luis de León. A modo de elementos complementarios que se encuentran en la estancia, se aprecia una silla frailera donde se ha dejado caer el atuendo de canónigo. La pared se ha ornamentado con varias pinturas, entre los temas que se pueden reconocer se encuentra un paisaje y probablemente dos apóstoles. La pertinente inscripción especifica lo siguiente:

Vicentius Blasco et Garcia montesanus presbiter canonicus

181 Es referente la ficha de catálogo de Amparo José Mora en Benito Goerlich y Sánchez Muñoz, La Universitat de València..., vol. II, pp. 202-203.

182 Sígase la ficha de catálogo de Amparo José Mora en Benito Goerlich y Sánchez Muñoz, La Universitat de València..., vol. II, pp. 206-207. 


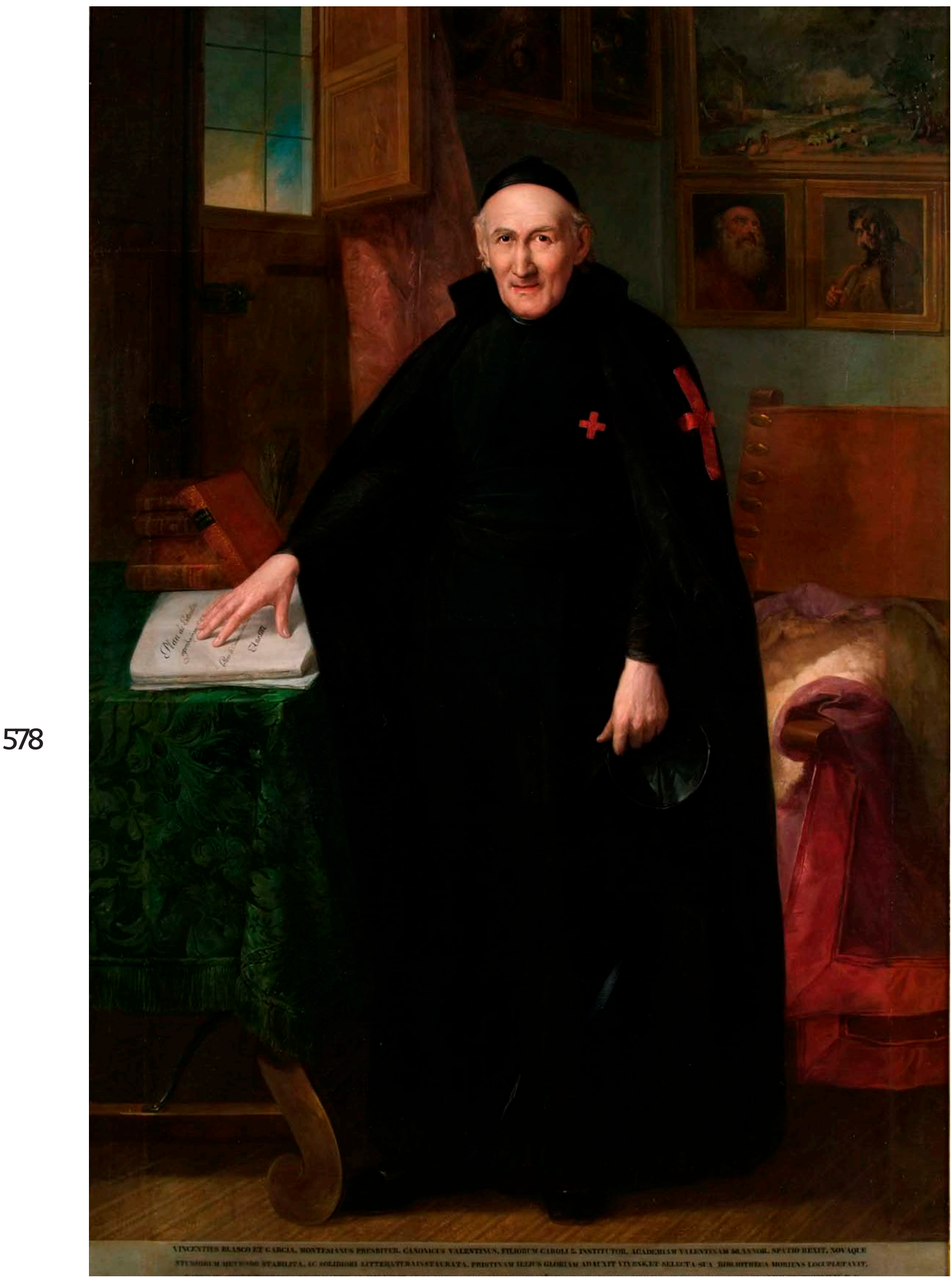

Fig. 5.67. Bernardo López, Vicente Blasco García, 1833, óleo sobre lienzo, Valencia, paraninfo de la Universitat.

Retratos de hombres ilustres 
valentinus, fliorum Caroli 3 institutor academiam valentiam 50 annos. Spatio rexit novaque studiorum metodo stabilita. Ac solidiori literatura instaurata, pristinam illius adauxit vivens, et selecta sua biblioteca moriens locupletavit natus en oppido Torrella 3 nov. martii an. 1735. Vixit an. 78. Mens. I dies 3 Marianus Liñan, sanct. cruciat. Comisarius generalis in grati animi testimonium F.C.

En cuanto a la autoría de la obra, se conoce que fue pintado por Bernardo López Piquer, hijo de Vicente López, en 1833. La obra ha tomado como modelo otras efigies del propio personaje y guarda numerosas similitudes con ellas. La más evidente es la representación que Vicente López hizo del rector alrededor de 1802 [fig. 5.68], optando por un formato de busto, vistiendo exactamente el mismo hábito negro con la cruz de Montesa y un breve texto en latín que reza: «Vincentius Blasco valentinus / cui pudor, et iustitiae soror, incorrupta fides, nudaque / veritas, quando ullum invenient parem». Se trata de una donación realizada en 1813 por parte del propio efigiado a la Academia de San Carlos. Como se puede comprobar, esta pintura ha servido de punto de partida para el retrato del paraninfo y además, se ha copiado fidedignamente en otra ocasión. De hecho, el museo Lázaro Galdiano conserva una reproducción de la obra cuya autoría se ha relacionado con el taller de Vicente López [fig. 5.69]. Es más, teniendo en cuenta todas las similitudes entre las dos pinturas y que el autor contase con el espacio previsto para incluir una inscripción se ha planteado la hipótesis que el retrato fuese realizado por Bernardo López Piquer y se tratase de un trabajo preparatorio para la representación de cuerpo entero que luce entre los varones ilustres de la Universitat. ${ }^{183}$

Si bien los ejemplos acabados de comentar son los más intere-

183 El retrato perteneciente a los fondos del museo de Lázaro Galdiano ha sido estudiado por José Luis Díez. Véase la correspondiente ficha en el catálogo del citado museo disponible en: http://catalogo.museolazarogaldiano.es $/ \mathrm{mlgm} / \mathrm{search} / \mathrm{pages} /$ Viewer? accion=48AMuseo=MLGME-

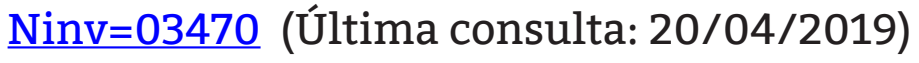




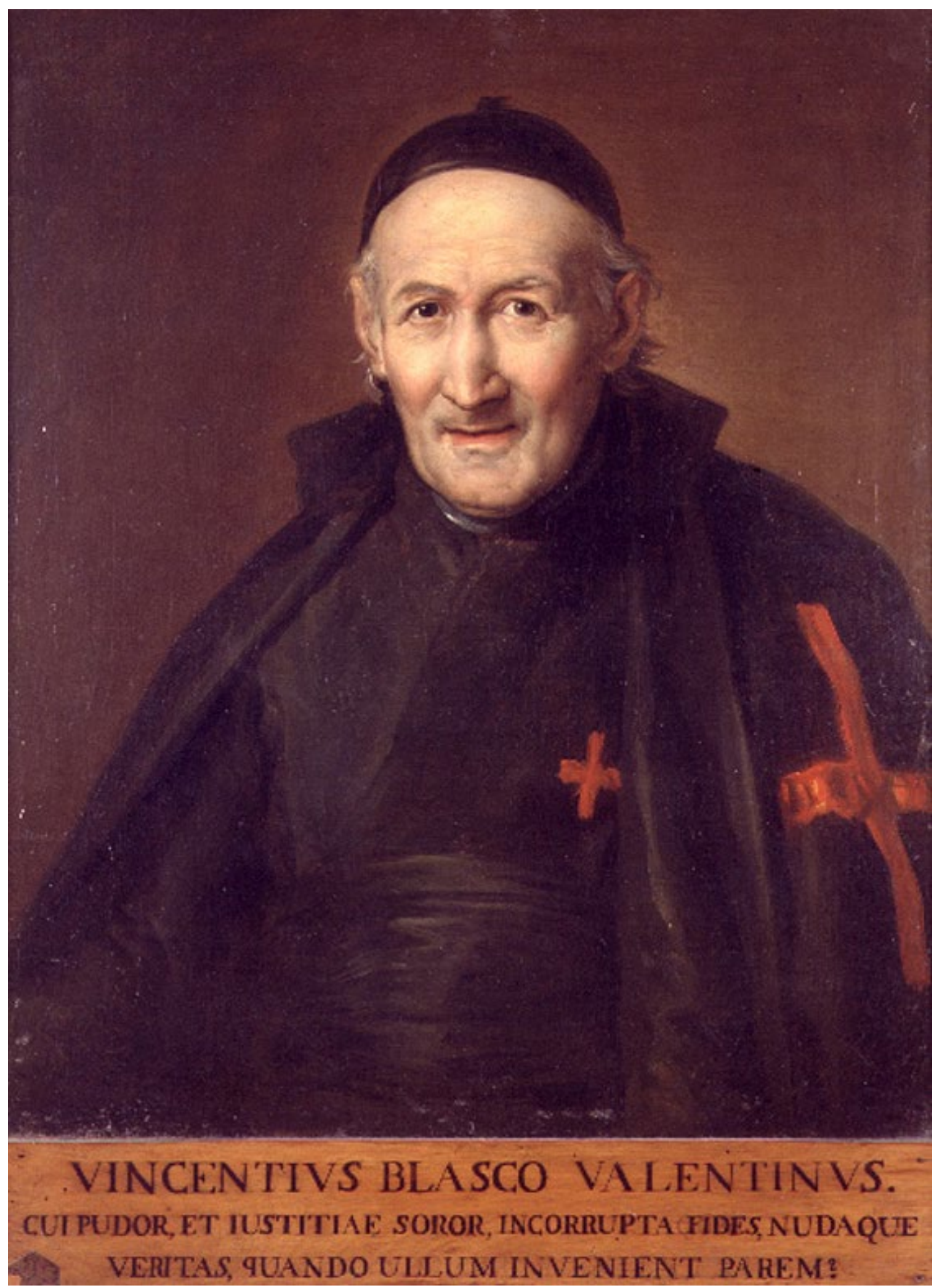

Fig. 5.68. Vicente López, Vicente Blasco García, rector de la Universitat de València, h. 1820, óleo sobre lienzo, Valencia, Real Academia de Bellas Artes de San Carlos. 


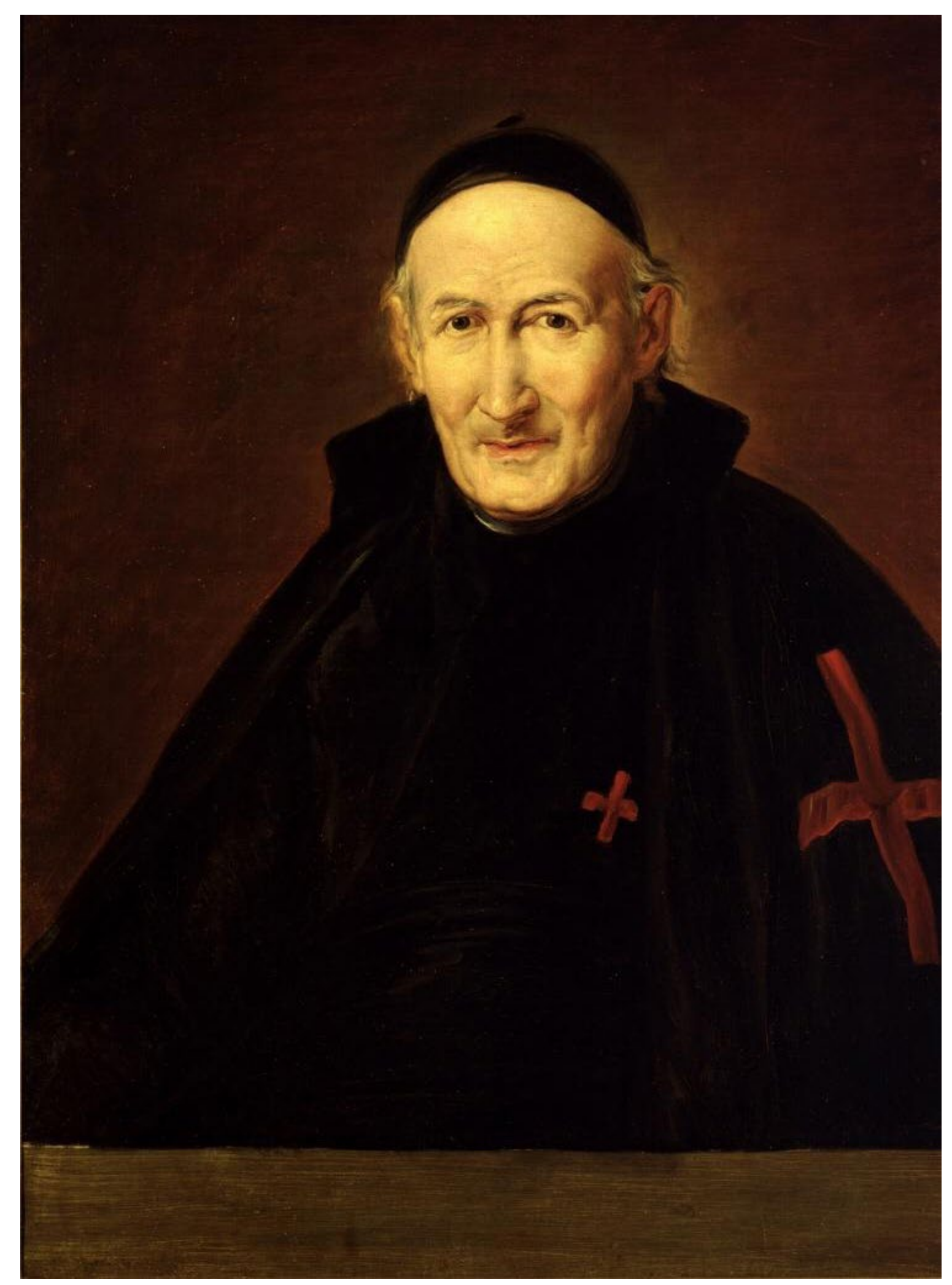

581

Fig. 5.69. Taller de Vicente López, Fray Vicente Blasco, rector de la Universitat de València, h. 1826-1850, óleo sobre lienzo, Madrid, Museo Lázaro Galdiano.

Retratos de hombres ilustres 


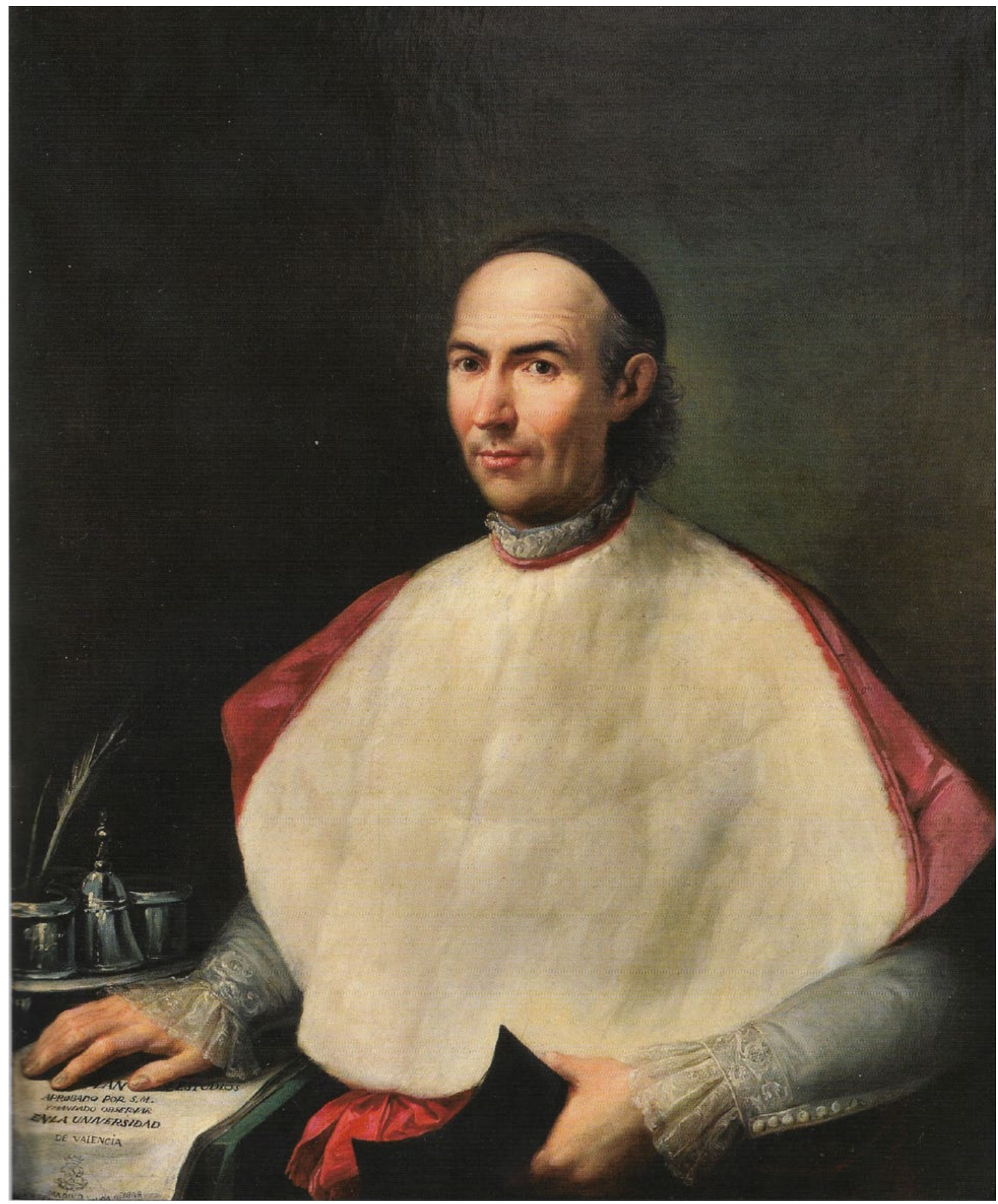

Fig. 5.70. Mariano Salvador Maella, Vicente Blasco García, 1787

santes por su vinculación al retrato de la galería ahora estudiada, igualmente cabe destacar la efigie que Mariano Salvador Maella hizo en 1787 y que también forma parte de la colección artística de la Universitat [fig. 5.70]. Es una imagen de Blasco siendo más joven que en las anteriores, aparece de medio cuerpo, sedente, vistiendo el traje canonical con el cuello y las mangas ricamente ornamentadas con bolillos y llevando 
el solideo. Bajo su mano derecha se encuentra el documento relativo al Plan de estudios aprobado por S.M. y mandado observar en la Universidad de Valencia. Madrid. En la imprenta de la viuda Ibarra. Año MDCCLXXXVII. La catalogación de la obra de la mano de Maella fue realizada por Felipe Mateu ya en la década de los 60 . Además, el autor indicó que originalmente el lienzo se encontraba en Estados Unidos en poder de M. R. Schweitzer y que posteriormente se repatrió y pasó a formar parte de los bienes de la Universitat y actualmente se ubica en la sala de juntas. ${ }^{184}$

A la segunda mitad del siglo XIX pertenecen las efigies de Eduardo Pérez Pujol (1830 - 1894) y José Domingo Costa Borrás (1805-1864). Pérez Pujol fue catedrático de derecho y rector de la Universitat entre los años 1868 y $1873 .{ }^{185}$ Por esta razón existe otro retrato suyo, ahora pintado por Cebrián Mezquita, que forma parte de la galería de rectores que ornamentan la sala de juntas de la Universitat. De Costa Borrás se debe subrayar que fue catedrático de derecho canónico y que de forma paralela a la carrera académica, ostentó las mitras de Lérida (18481849), de Barcelona (1849-1857) y de Tarragona (1857-1864). Las tres pinturas más recientes que lucen en el teatro académico son de los siglos XX - XXI. Entre ellas, Julio Cebrián Mezquita retrató a Amalio Gimeno Cabañas (1852-1936) en torno al 1900. José Renau Montoro efigió a Rafael Olóriz Martínez (1848 - 1913) en 1944.

Finalmente, el retrato más actual es el de Olimpia Arozena (1902 - 1971), realizado por Susana Roig Hervás en 2017. Se 184 Véase la separata de Felipe Mateu Llopis, 'El retrato del rector de la Universidad de Valencia, D. Frey Vicente Blasco, por Salvador Maella', Archivo de Arte Valenciano, 1960. También ha sido analizado por Daniel Benito en la ficha en Benito Goerlich y Sánchez Muñoz, La Universitat de València..., vol. II, pp. 226-227.

185 Una breve referencia a este rector se encuentra en el catálogo de una exposición dedicada a la historia de la Universitat. Véase concretamente: Universitat de València, Cinc segles $i$ un dia, (Fundació General de la Universitat de València: València, 2000), lámina XXVII. 
trata de la primera mujer que ha entrado a formar parte de esta serie de personajes ilustres. Respecto a su formación académica cabe destacar que se licenció en filosofía y letras en 1929, se doctoró en esta misma rama en 1949 y fue de las primeras docentes de esta institución en la disciplina de historia. Así pues, llegó a ser profesora adjunta a la cátedra de arqueología, epigrafía y numismática. Respetando las características de la serie, Arozena viste con la toga doctoral y la muceta azul correspondiente a su área de conocimiento y sostiene un libro en la mano derecha. Su figura se ha contextualizado en un espacio que viene a recrear la sala de juntas de la Universitat y en la parte inferior se ha dispuesto una inscripción sintética que presenta a: «Donya Olimpia Arozena Torres», La Laguna, 1902 - València, 1971. Llicenciada (1929) i doctora (1949) en filosofia i lletres. Va ser una de les primeres docents de la Universitat de València com a eminent professora adjunta a la càtedra d'arqueologia, epigrafia i numismàtica.» Su efigie pasó a formar parte de este conjunto pictórico en marzo de 2017, concretamente en conmemoración del Día Internacional de la Mujer.

El conjunto de efigies del paraninfo de la Universitat de València, cuyo origen se remonta al siglo XVII, entronca con la creación de otras series pictóricas de hombres ilustres. Todo ello, como ya se ha comentado, fue consecuencia de la transformación social que tuvo lugar en este momento encaminada a convertirse en más urbana y a valorar las actividades intelectuales. Así pues, es necesario tener en cuenta por un lado estas circunstancias y por otro, conviene remarcar el papel simbólico que ha desempeñado el retrato y la fuerza discursiva que ha adquirido al conformarse en galerías. De forma audaz, instituciones como la Universitat han visto en la elaboración de series de efigies un recurso útil para crear su propia imagen, mostrar los éxitos de sus miembros como un triunfo propio y cultivar su fama. El paraninfo ha sido, desde un principio, el lugar idóneo para custodiar las representaciones de estos hombres ilustres pues en él han tenido lugar los principales 
actos académicos. Los retratos, a su vez, lucen como ejemplos a seguir y animan a las generaciones venideras a llegar lo más lejos posible en sus carreras profesionales.

La Universitat, del mismo modo que otras instituciones, ha sido capaz de ver las posibilidades que encierran las galerías de retratos, por ello siguió acrecentándola durante los siglos venideros y es más, se dio comienzo a la configuración de otro conjunto. Quizás sin el precedente de las pinturas del teatro académico, no habrían tenido lugar las imágenes de busto de los rectores que se hallan en la sala de juntas. La relevancia de este conjunto se ha mantenido a lo largo de su historia y pervive en la actualidad. De hecho, es una galería que se ha sido sensible a las reformas del edificio, la original disposición de sus piezas ha sufrido algunos cambios e incluso, se ha decidido ampliar en el siglo XXI.

El estudio de estos retratos se debe hacer principalmente a partir del análisis de las imágenes y desde una perspectiva reflexiva acerca del significado y relevancia de este género. Asimismo, la falta de documentación de archivo con la que enriquecer el conocimiento de esta galería recuerda que los re-tratos normalmente fueron encargados verbalmente y ello es síntoma de la menor consideración que tenían respecto a otros géneros pictóricos.

La relevancia de esta galería de retratos es clara. Su importancia no recae tan sólo en el valor histórico y artístico que encierra o en el mensaje que se transmite, sino que además se debe valorar por la singularidad del proyecto. Al rastrear la realización de encargos similares en otras universidades españolas se aprecia que el caso valenciano fue de los más tempranos y particulares. De hecho, otro ejemplo parecido se ha encontrado en la Universidad Sertoriana de Huesca, donde originalmente su teatro académico estaba engalanado con retratos de personajes ilustres y eran pinturas del siglo XVIII. Algunas otras efigies de este mismo siglo fueron también el germen de 
la antigua iconoteca universitaria de Oviedo, cuyo grueso se correspondía con retratos del siglo XIX y ha derivado en una galería de rectores.

Muchas otras universidades han configurado sus particulares series pictóricas desde el siglo XIX. Todas ellas se han dedicado a los rectores por ser los máximos gobernantes de la institución. Por ejemplo, la Universidad de Salamanca dispone de las efigies del siglo XIX en el vestíbulo del edificio de rectorado $\mathrm{y}$ el resto de pinturas, pertenecientes a los siglos XX y XXI, se encuentran en una sala específica. La galería de rectores de Valladolid parte del año 1864. Julián Casaña, rector de la Universitat de Barcelona entre 1876 y 1896, impulsó la creación de una colección de retratos de rectores partiendo del año 1842, a raíz del traslado de la sede universitaria de Cervera a definitivamente Barcelona. La Universidad Complutense de Madrid asimismo cuenta, desde el siglo XIX, con una serie de representaciones de sus rectores y decanos. La Universidad de Sevilla cuenta con diversas galerías pero todas ellas también son decimonónicas. Así pues, en 1819 se inició una galería de ilustres universitarios; en 1846 se creó una colección de sevillanos ilustres para ornamentar la biblioteca provincial y universitaria; $y$ hay otra dedicada a los rectores que llega hasta el siglo XX. La Universidad de Granada ya contaba con algunos retratos, datados a finales del siglo XVIII, de jesuitas por ser hombres ilustres para la institución. No obstante, en el siglo XIX nació la galería de rectores y además, se empezaron a encargar efigies de reyes que presidían los actos oficiales.

El conjunto pictórico del paraninfo de la Universitat de València es, en definitiva, uno de los casos más antiguos que se han dado en España y que ha inmortalizado a través del retrato a sus principales eminencias. A raíz de este primer tipo de galerías institucionales en las universidades proliferaron, durante el siglo XIX, las colecciones de efigies de rectores para dar visibilidad a los más relevantes dirigentes universitarios y secuenciar el traspaso de poder de unos académicos a otros, 


\subsection{La colección de retratos en la Real Academia de Bellas Artes de San Carlos.}

La Real Academia de Bellas Artes de San Carlos, como se ha comentado anteriormente, se creó en 1766 al aprobar sus estatutos con el beneplácito del monarca Carlos III tras algunos intentos previos y fallidos. Entre sus bienes artísticos hay numerosos retratos que han llegado a formar parte de esta colección por diferentes razones, algunos han sido encargos de la propia institución, otros han sido producto de las donaciones privadas y otros de la desamortización. Sin embargo, resulta interesante analizar las efigies que, según indican los inventarios, ornamentaban la sala de juntas de la propia academia situada en las dependencias de la Universitat en momentos puntuales y distintos de finales del siglo XVIII y primera mitad del siglo XIX. Los inventarios consultados se corresponden con los años 1788, 1797 y 1842 respectivamente. Algunos incluso anteriores, datados en 1767 y 1769, no han aportado información sustancial al respecto. Tan sólo se mencionaba en ellos la existencia de dos retratos pertenecientes al escultor Domingo Olivieri y al canónigo pintor Vicente Vitoria en el de 1767 y la efigie del rey realizada por Vergara en el de 1769. ${ }^{93}$ Como se podrá observar a continuación, la colección de efigies era una miscelánea que representaba a monarcas, presidentes y directores que no hizo más que aumentar con el paso del tiempo, llegando a compartir espacio con otras galerías foráneas que desde entonces iban a ser conservadas por la institución.

Parece más apropiado hablar de colección en vez de considerarla una galería de retratos en su acepción tradicional, puesto que en este caso no se ha visto una clara voluntad por configurar un conjunto de imágenes que mostrasen a los miembros más relevantes de la academia. Seguidamente se

93 ARABASC: Inventario de todos los muebles que tiene esta Academia hecho en 24 de febrero de 1767 donde se continuarán los que vayan entrando de nuevo, Archivo, 153, s/f y Notas de los muebles que han entrado o adquirido la Real Academia de San Carlos en este año de 1769 y siguientes, s/f. 
verá que se efigiaron a presidentes y directores, pero tan sólo a algunos de ellos y no a todos como cabría esperar si el objetivo era crear una completa galería de retratos. Es cierto que, de todos modos, a grandes rasgos se guarda una coherencia formal entre las pinturas, ya que artistas como Vicente López o Miguel Parra principalmente elaboraron más de un retrato de esta colección y se respetaron unas pautas generales de representación. En cualquier caso, se debe valorar la existencia de un conjunto de estas características, pues se empleó el retrato para mantener la memoria de ciertos personajes ilustres vinculados a la institución y, además, engalanar la sala destinada a la celebración de las juntas.

El nacimiento de las academias de Bellas Artes en numerosas ocasiones estuvo ligado a la monarquía, así pues la dependencia de esta institución del poder político era clara. Por ello, era habitual colocar retratos regios bajo dosel en una estancia principal en señal de fidelidad y respeto a la monarquía. Como ya indicó Ma Victoria Alonso ${ }^{94}$ tras estudiar la Breve noticia de los principios y progresos de la Academia de pintura, escultura y architectura erigida en la ciudad de Valencia, baxo el título de Santa Bárbara; y de la proporción que tienen sus naturales para estas Bellas Artes (Madrid: Oficina de Gabriel Ramirez, 1757), al abrir la academia dedicada a la santa patrona de la reina en 1753 se colocaron los retratos de Fernando VI y Bárbara de Braganza bajo dosel. Fueron pintados por José Vergara y Cristóbal Valero respectivamente y estuvieron presidiendo la sala de juntas entre 1754 y 1758 según explicó David Gimilio. ${ }^{95}$

La autora citada también destacó que en 1754 los retratos de los monarcas ya presidían la sala de juntas, pues la academia valenciana fue por delante de la madrileña en este aspecto. De hecho, matizó que fue exactamente a mediados de 1754 cuan-

$94 \mathrm{M}^{\mathrm{a}}$ Victoria Alonso Cabezas, 'Los inicios de la galería de retratos de la Real Academia de Bellas Artes de San Carlos (1753-1840)', Archivo de arte valenciano, no. 99, 2018, pp. 133-144, p. 134.

95 Gimilio Sanz, 'José Vergara Gimeno y la retratística...', p. 76. 
do la academia de San Fernando se decidió a crear un conjunto de retratos «vinculados al poder mediante las efigies de la monarquía y de los protectores de la institución, a cargo de los artistas Andrés de la Calleja, Felipe de Castro y Domingo Olivieri.» $^{96}$

Por el inventario de 1788, catalogados con los números 54 y 55 correspondientemente, se conoce que ambas efigies formaban una pareja. La representación de Fernando VI [fig. 5.71 ] mantiene la estética afrancesada que casa con el retrato de corte de la dinastía de Borbón. Esta clase de imagen entronca con las pinturas de Jean Ranc (1674 - 1735) y Louis Michel Van Loo (1707 - 1771). Para remarcar su majestad, Fernando VI luce el Toisón, sostiene el cetro y la corona aparece en un primer plano sobre una mesa auxiliar. Pero este retrato regio realizado por Vergara no fue el primero que elaboró de Fernando VI, sino que ya había hecho uno similar alrededor de 1746 cuando el monarca de apariencia más juvenil subió al trono con treintaicuatro años. Gimilio, por tanto, la consideró como una de las pinturas más tempranas del artista. ${ }^{97}$

La imagen de la reina Bárbara que estaba asociada al retrato de su esposo fue realizada, como se ha dicho, por Cristóbal Valero. Se trata de una obra fuertemente influida por una pintura anterior también hecha por Vergara y que emparejaría con el retrato de Fernando VI de 1746. En ambos casos se sigue la tipología de retrato empleada por Jean Ranc a comienzos del siglo XVIII, donde ella aparece representada de medio cuerpo, junto a una columna o mueble complementario también de media altura, sobre este descansa un cojín de terciopelo carmesí que sirve para que la reina apoye su brazo izquierdo. Al lado derecho en un bufete se ha dejado la corona como símbolo de su majestad. En el inventario de 1842 se anotó que había una efigie de Bárbara de Braganza en la sala de arquitectura, cuya imagen debe ser la pintada por Valero. Además, había 96 Alonso Cabezas, 'Los inicios de la galería de retratos...', p. 135.

97 Gimilio Sanz, 'José Vergara Gimeno y la retratística...', íbidem. 


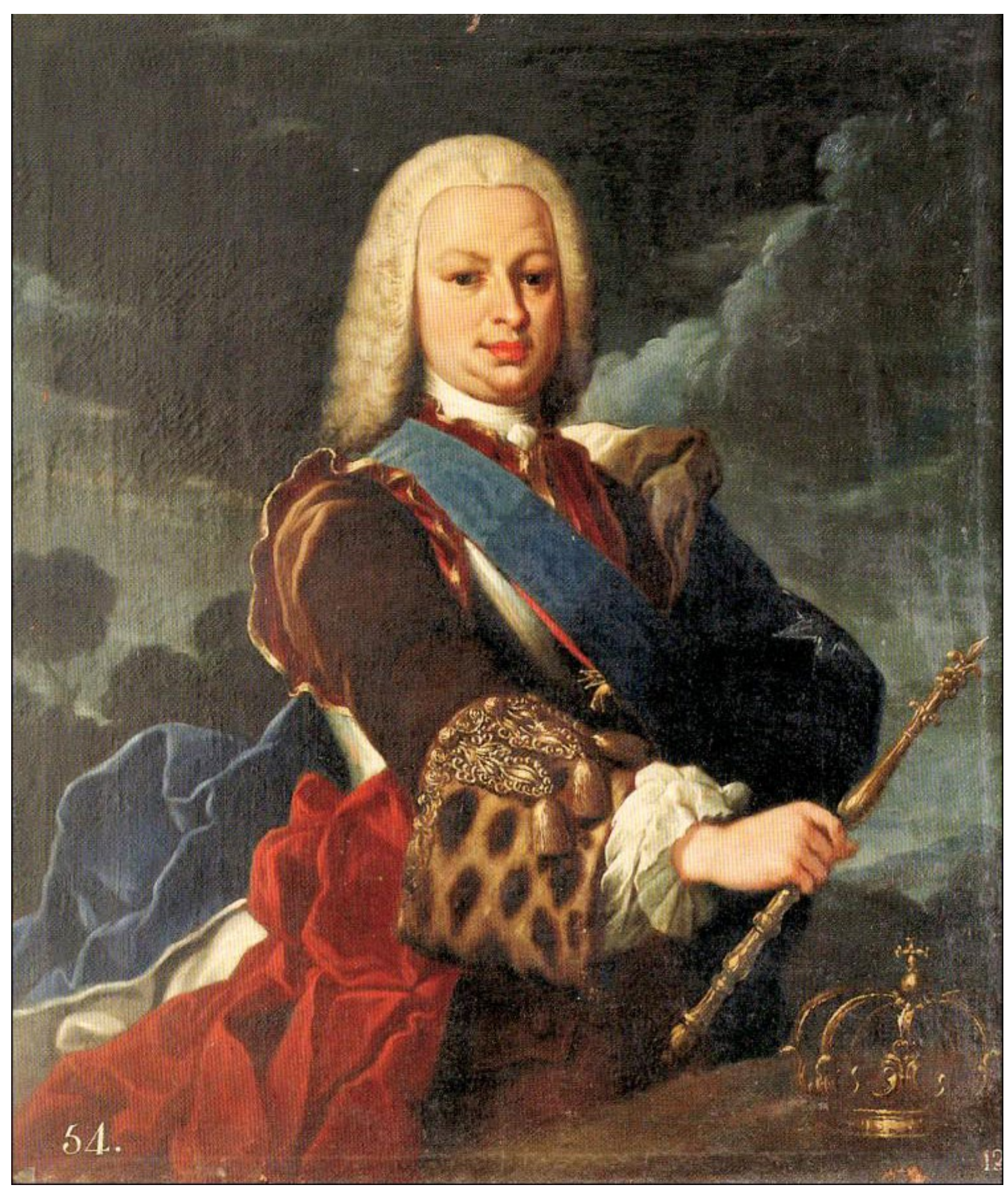

Fig. 5.71. José Vergara, Fernando VI, h. 1753, óleo sobre lienzo, Valencia, Real Academia de Bellas Artes de San Carlos.

otro retrato de la reina en la escalera, ahora el realizado por Vergara [fig. 5.72]. De hecho, en el documento se ha catalogado esta imagen con el número 29 y esta cifra se corresponde con la numeración visible en el retrato de Bárbara de Braganza pintado por Vergara.

Una vez constituida definitivamente una escuela de Bellas Artes y siguiendo la práctica de la época, la sala de juntas de 
la academia de San Carlos también estaba presidida por el retrato del monarca reinante bajo un dosel. Por ello, pese a que la colección contiene principalmente efigies de personajes vinculados con la institución, los retratos de algunos reyes determinados siempre estuvieron presentes en la sala. En este caso, por tanto, se aprecia que la imagen tenía un importante valor institucional. La primera de ellas se corresponde con el retrato de Carlos III realizado por José Vergara Ximeno [fig. 5.73], el cual fue un obsequio del propio artista a la academia: «El señor director de pintura don José Vergara ha regalado dos lienzos de su mano dignos de toda estimación: el uno de ellos es el retrato de nuestro soberano, de que la academia usa en sus funciones, y el otro representa a nuestros primeros padres arrojados del paraíso. ${ }^{98}$ En 1788 además se inventarió como la obra que estaba concretamente bajo el dosel durante su reinado. ${ }^{99}$ No obstante, el inventario de 1797, que es una actualización del anterior, ofrece un poco más de información y especifica claramente que la pintura número trece (dicha numeración coincide con la de esta efigie) es: «Un retrato de Carlos III de cinco y cuatro palmos con marco corlado, copiado del que tiene don Manuel Monfort por don José Vergara, director de pintura, y sirvió en el dosel durante el reinado de dicho monarca.»100

98 Continuación de la noticia histórica de la Real Academia de Nobles Artes establecida en Valencia con el título de San Carlos y relación de los premios que distribuyó en las juntas públicas de 6 de noviembre de 1776 y 26 del mismo mes de 1780, (Oficina de Benito Monfort: Valencia, 1781), p. 6.

99 ARABASC: Inventario de la Real Academia de San Carlos hecho en el año 1788 según el estado en que se hallaron todos sus muebles y alhajas a saber, Archivo, 159, s/f.

100 ARABASC: Inventario de las pinturas y dibujos de la Academia de San Carlos (1797-1815). Inventario General de las Pinturas, Flores pintadas y dibujadas, Modelos y Vaciados, Dibujos de todas las clases y Diseños de Arquitectura: Y también de las Obras pertenecientes al Ramo del Grabado: de los Libros e Impresiones; con alguna noticia de su ejecución y adquisición: ultimam. De los Muebles, Alhajas y demás que posee esta Real Academia de San Carlos. Hecho en el Año de 1797. Por el Secretario de la misma y algunos de sus más celosos Directores, Archivo, 149, s/f. 


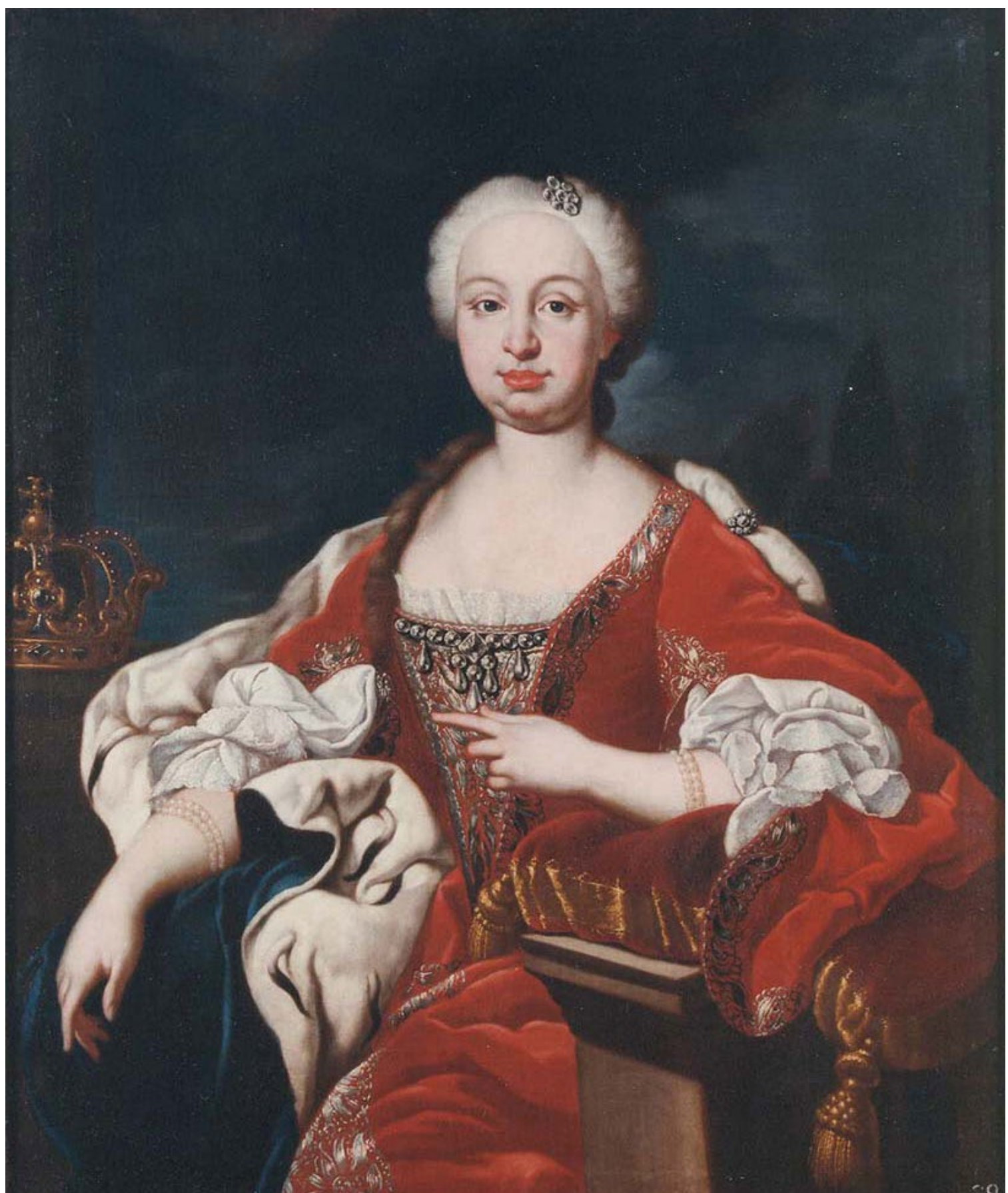

Fig. 5.72. José Vergara, Bárbara de Braganza, h. 1753, óleo sobre lienzo, Valencia, Real Academia de Bellas Artes de San Carlos.

La imagen respeta el modelo establecido para representar a este rey, vestido con armadura, sosteniendo el bastón de mando y luciendo la capa real y determinadas condecoraciones. El retrato elaborado por Mengs alrededor de 1765 se convirtió en la imagen oficial que sirvió de modelo para la realización de otros retratos como el de Vergara. En 1774, Mengs hizo una segunda versión con pequeñas variaciones, como el incorpo- 


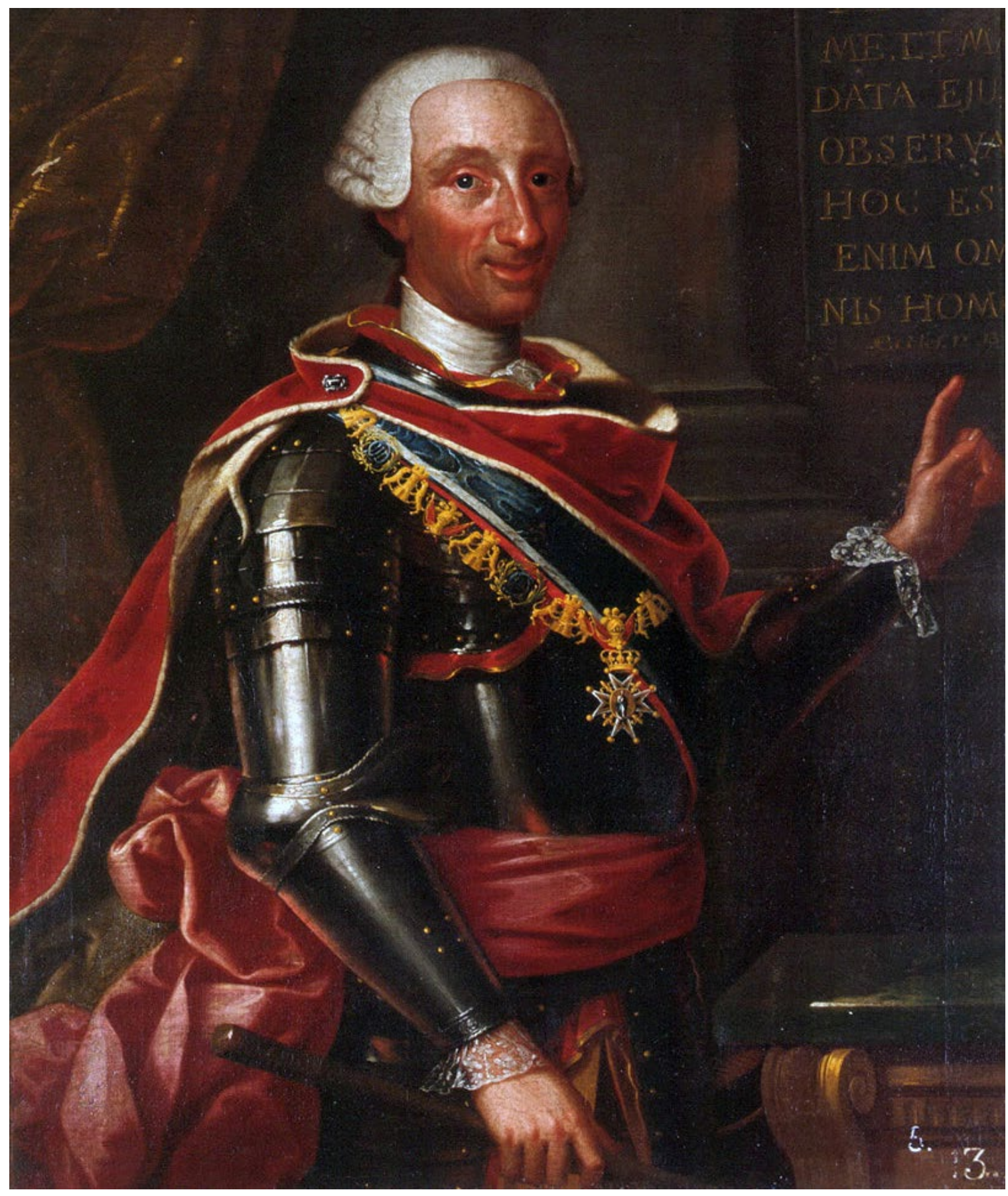

Fig. 5.73. José Vergara, Retrato de Carlos III, siglo XVIII, óleo sobre lienzo, Valencia, Real Academia de Bellas Artes de San Carlos.

rar el collar de la orden de Carlos III debido a que escasos años antes se había fundado esta institución dedicada a la Inmaculada Concepción, detalle que se reproduce en el lienzo ahora comentado [fig. 5.74; fig. 5.75].

Un hecho fundamental para la difusión de esta imagen fue el que Manuel Salvador Carmona se decidiera en 1783 a grabar 


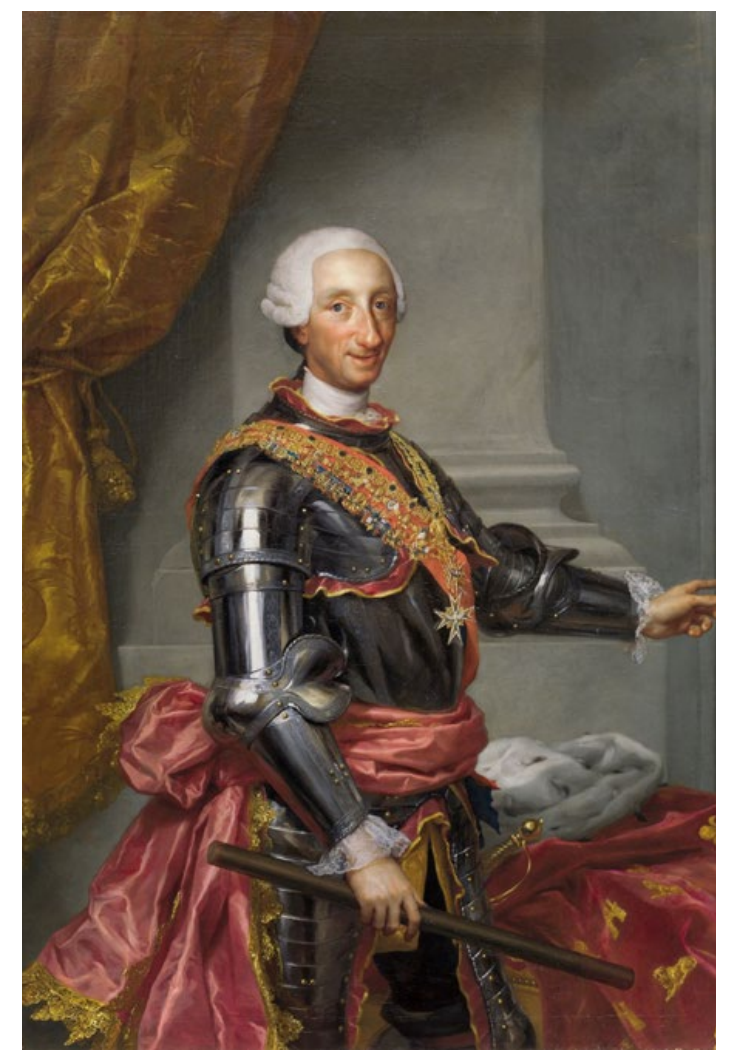

Fig. 5.74. Anton Rafael Mengs, Carlos III, h. 1765, óleo sobre lienzo, Madrid, Museo Nacional del

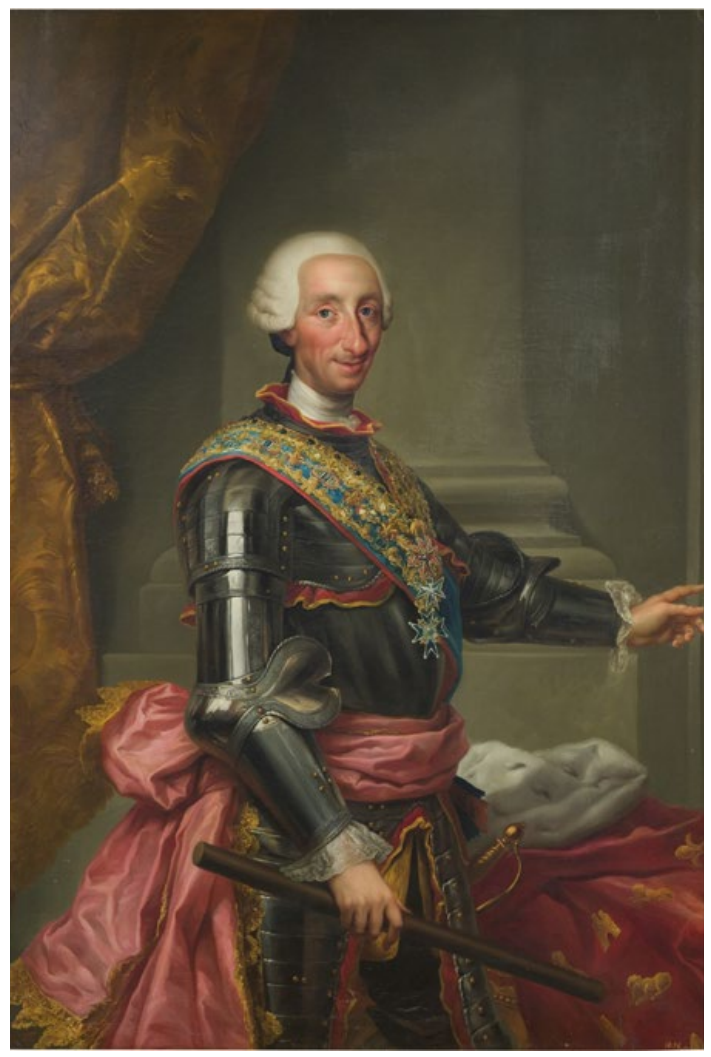

Fig. 5.75. Anton Rafael Mengs, Carlos III, h. 1774, óleo sobre lienzo, Madrid, Museo Nacional del Prado.

el retrato hecho por Mengs y generar numerosas estampas [fig. 5.76]. Aprovechando que el monarca señala con su mano izquierda hacia el fondo, el artista valenciano decidió incluir una breve inscripción latina que reza lo siguiente: « $\mathrm{DE}[\mathrm{UM}][\mathrm{TI}]$ ME ET [MAN]DATA EIU[S] OBSERVA HOC EST ENIM OM[I]NIS HOM[o]. ECCLE. 12, 13." Se corresponde con un versículo del Antiguo Testamento, concretamente del libro Eclesiastés que dice: «Teme al Señor y observa sus mandamientos, porque esto es todo para el hombre.» El mostrar a Carlos III dirigiendo al espectador hacia el versículo bíblico puede que sea una referencia a la legitimidad conferida por la divinidad para ser rey. Es sabido que cualquier dinastía regia defendió que su poder había sido conferido por Dios y pensaban que esta era la razón más sólida con la que cimentar su mandato. Así pues, de forma metafórica, la inscripción indica que el gobierno de este rey ha sido por voluntad divina. Según ha explicado Miguel Ángel Català, el retrato fue una donación realizada el 24 de abril de 1780 
por parte del artista a la academia y se puede relacionar con otra efigie similar situada en el Antiguo Seminario de Nobles. Puesto que en ambas aparecen el collar de la orden de Carlos III ha fechado las obras alrededor de 1771, año en el que tuvo lugar su creación. ${ }^{101}$

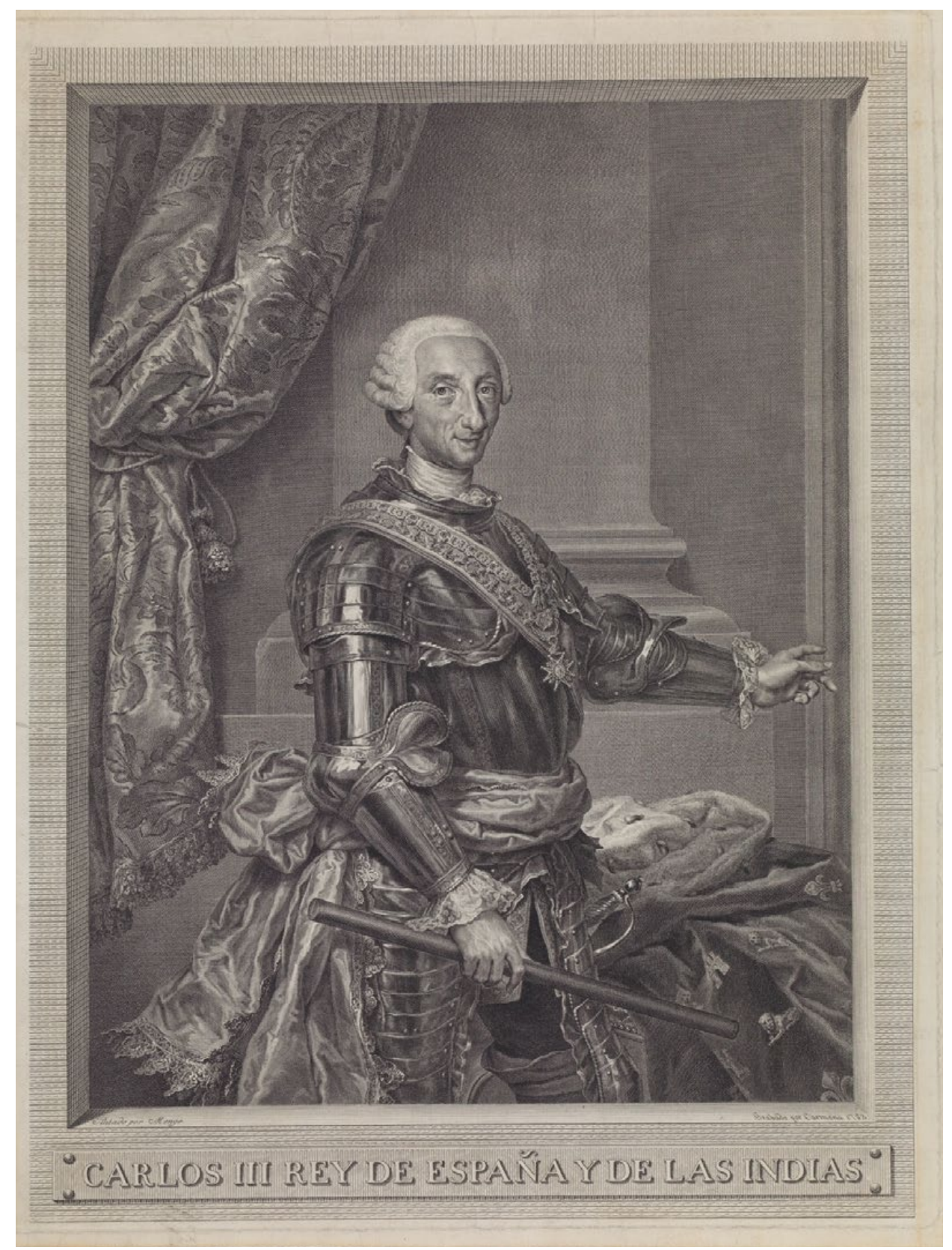

Fig. 5.76. Manuel Salvador Carmona, Carlos III, 1783, talla dulce, Madrid, Museo Nacional del Prado.

En 1788, año en el que falleció Carlos III, en la sala de juntas

101 Catalá Gorgues, El pintor y académico José..., pp.127-128. 
también existían dos retratos de Carlos IV pintados por Rafael Ximeno y Vicente López respectivamente. El primero de ellos se perdió, pero tanto en este inventario como en el de 1797 se catalogó como el retrato que había lucido bajo el dosel un determinado tiempo: «N. 49. Un retrato sin marco de nuestro actual monarca don Carlos IV que ha estado algún tiempo bajo el dosel de la sala de juntas, pintado por don Rafael Ximeno, discípulo de esta academia y actual director de la de México.» ${ }^{102}$

En cuanto al retrato hecho por Vicente López [fig. 5.77] también aparece en ambos inventarios, el segundo aporta más detalles que el primero: «N. 66. Un cuadro de cinco y cuatro palmos con marco grabado y dorado retrato de medio cuerpo del rey nuestro señor Carlos IV que se conserva debajo del dosel de la sala de juntas y le pintó en Madrid don Vicente López, copiado de otro que pintó de cuerpo entero don Mariano Maella.» ${ }^{103} \mathrm{El}$ monarca ha sido efigiado con varios atributos referentes a su condición como el collar de la orden del Toisón y de Carlos III, además del bastón de mando y la corona que reposa sobre un cojín a su derecha. El autor firmó la obra en una inscripción visible en el mueble auxiliar donde se dice: «VICENTE LóPEZ DISCIP. PENSIONA ${ }^{\mathrm{DO}}$ DE ESTA RE ${ }^{\mathrm{AL}}$ ACADEMIA.» Ciertamente, esta imagen está inspirada en el retrato que Mariano Salvador Maella realizó en 1792 para la Real Academia de Bellas Artes de San Carlos de México, pareja de otra representación similar de Carlos III [fig. 5.78]. ${ }^{104}$

Las obras de Maella y López son coincidentes en la postura 102 ARABASC: Inventario de las pinturas y dibujos de la Academia de San Carlos (1797-1815)..., s/f.

103 ARABASC: Inventario de las pinturas y dibujos de la Academia de San Carlos (1797-1815)..., s/f.

104 Ambos retratos han sido estudiados en Inmaculada Rodríguez Moya, El retrato en México, 1781-1867: Héroes, ciudadanos y emperadores para una nueva nación, (Madrid, 2006), p. 46; Inmaculada Rodríguez Moya, 'Los retratos de los monarcas españoles en la Nueva España, siglos XVI-XIX', Anales del Museo de América, no. 9, 2001, pp. 287-301, p. 298. 


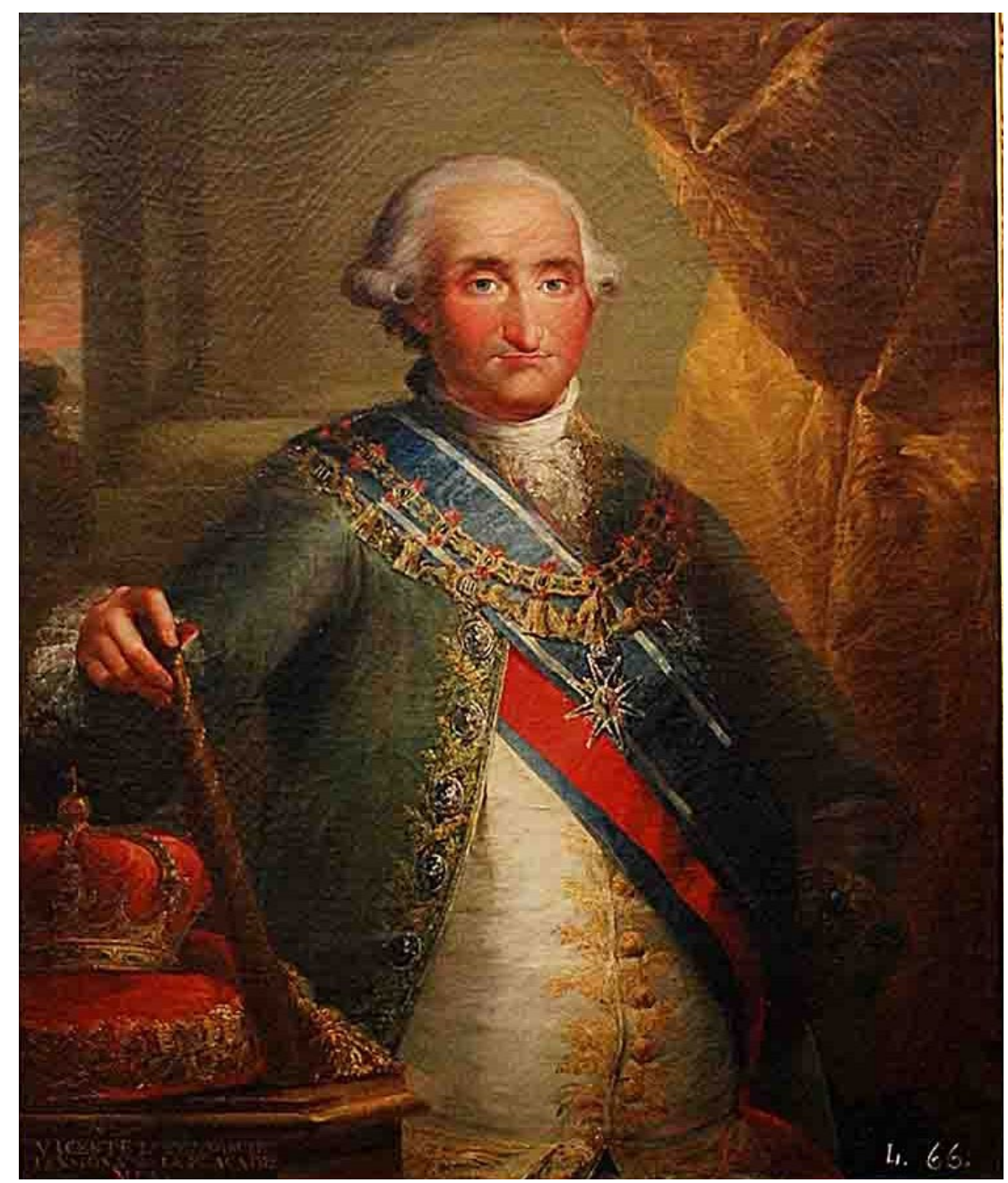

Fig. 5.77. Vicente López, Carlos IV, h. 1792, óleo sobre lienzo, Valencia, Real Academia de Bellas Artes de San Carlos.

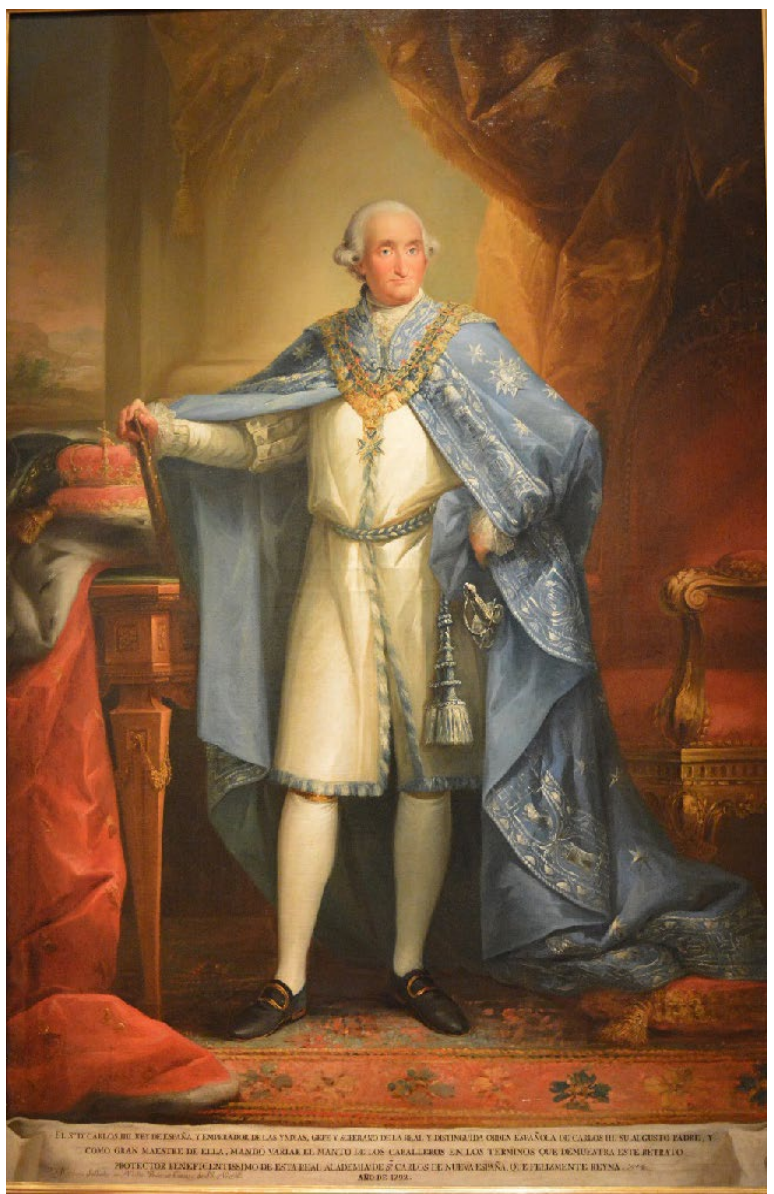

Fig. 5.78. Mariano Salvador Maella, Carlos IV, 1792, óleo sobre lienzo, México, Museo Nacional de San Carlos. 
adoptada por el efigiado, en el incluir un bufete a la derecha donde se apoya la bengala y reposa la corona y en el diseño para el fondo. Si bien Maella ha mostrado al monarca con el hábito de la orden carolina, López lo ha representado vistiendo una chupa y una casaca profusamente ornamentadas, pero respetando los colores blanco y azul, asociados a la mencionada orden. En la sala de juntas, desde 1788, también lucían los retratos de los infantes gemelos hijos de Carlos IV que se han estudiado en detalle en el epílogo de este trabajo. Como se ha podido observar, era imprescindible que la efigie del monarca reinante presidiese el espacio donde se reunían los miembros de la institución que podía incluso estar acompañada de las imágenes de familiares cercanos.

\subsubsection{Retratos en la sala de juntas a finales del siglo XVIII. De los orígenes al crecimiento de la colección.}

Las representaciones regias no eran las únicas que engalanaban la sala de juntas, de hecho también se consideró acertado incluir a otros personajes vinculados a la institución, presidentes y directores concretamente, que al mismo tiempo sirviesen de referente para el resto de componentes de la academia. De este modo, se aprecia el fuerte lazo existente entre la ciudad y la academia. Prueba de ello es que el cargo de presidente estuvo reservado para el poder político y era ocupado por el intendente o corregidor de la localidad. Así pues, se encontraban los retratos de Andrés Gómez de la Vega (1712-1776), Joaquín Pareja y Obregón y Pedro Caro, marqués de La Romana. El primero de ellos, obra de Cristóbal Valero, se debe a que fue el primer presidente de la academia, papel que desempeñó entre 1765 y $1768 .{ }^{105}$ Pudo asumir esta responsa-

105 Así se especifica en los inventarios de 1788 y 1797, en este último concretamente se dice lo siguiente: «N. 17. Un retrato de tres y cuatro palmos del señor don Andrés Gómez de la Vega, corregidor e intendente de esta ciudad, primer presidente de esta academia, porque lo fue de la junta preparatoria, contribuyó en gran parte a su establecimiento, propuso el arreglo y formación de estatutos, pintado por don Cristóbal Valero, primer director de pintura y el primero que lo fue general.» en ARABASC: Inventario 
bilidad porque ya era corregidor e intendente de la ciudad. ${ }^{106}$ Además se le ha destacado su contribución a la creación de los estatutos, pues presidió la junta preparatoria que desde 1765 llevó adelante los trámites jurídicos y consiguió que en 1766 se aprobase el correspondiente reglamento:

\begin{abstract}
[...] No puede la academia dilatar la expresión de su sentimiento por la muerte de este caballero acaecida en 15 de noviembre de 1776, habiendo sido quien, estando a la cabeza del ayuntamiento de esta M. I. ciudad solicitó con su acuerdo el establecimiento de la academia, continuando la pretensión con un celo infatigable, hasta que tuvo efecto. [...] Esta de San Carlos para perpetua memoria de su gratitud tiene colocado su retrato en distinguido lugar de la sala de juntas. ${ }^{107}$
\end{abstract}

El poseer la efigie del primer presidente tenía unas connotaciones conmemorativas y su objetivo era honrar la figura de este personaje. Sin embargo, la ejecución de un retrato de estas características no era una tarea especialmente codiciada por artistas afamados. La prueba de ello, ya aportada por Gimilio, ${ }^{108}$ fue la declinación de José Vergara, en 1770, para pintar la efigie del presidente excusándose en un viaje previsto a Villarreal que le impediría seguir adelante con el encargo. Además, según su modo de ver era competencia del director general el realizar el retrato del presidente. De hecho, Cristóbal Valero (1707-1789) era desde 1768 el primer director de pintura y director general de esta institución y fue quien asumió la responsabilidad de elaborar la efigie de Gómez de la Vega.

de las pinturas y dibujos de la Academia de San Carlos (1797-1815)..., s/f.

106 El reglamento, concretamente en su artículo tercero, reflejó quién podía ejercer de presidente. Véase, ARABASC: Estatutos. Artículo III, «Ha de ser presidente de la academia el actual intendente de Valencia y los que le suceden en su empleo, en calidad de corregidor de la ciudad y presidente de su ayuntamiento [...]»

107 Continuación de la noticia histórica..., pp. 17-18.

108 Gimilio Sanz, 'José Vergara Gimeno y la retratística...', p. 77. 
Asimismo, era conveniente disponer del retrato de aquel que ostentaba el cargo de presidente en la época. Ése era el caso de Joaquín Pareja y Obregón [fig. 7.79], quien fue presidente en dos momentos diferentes; entre 1778 y 1782, y entre 1785 y 1797. La información obtenida en el archivo, concretamente en el inventario del 97, alude a su segundo periodo a la cabeza de la institución: «N. 18. Un retrato de tres y cuatro palmos con un marco corlado, y remate de talla del señor don Joaquín Pareja y Obregón, corregidor dos veces de esta ciudad, y como a tal presidente de esta academia, pintado por don Vicente López, discípulo de la misma academia, y su pensionado que ha sido en Madrid, y con motivo de haber presentado otro retrato se le creó académico de mérito.» ${ }^{109} \mathrm{El}$ personaje va vestido siguiendo la moda afrancesada que ya imperaba en la época, con la peluca blanca, chupa y casaca concienzudamente engalanadas en plata. Además, el rostro es mucho más realista y poco complaciente con el efigiado, algo característico de la obras de López. Pareja se ha apoyado en su bastón de mando, 600 una alusión a su responsabilidad en el gobierno municipal.

A través de este ejemplo ya se observa una de las vías por las que se fueron recopilando retratos de este tipo, se trata de la presentación y entrega de efigies con el objetivo de conseguir el título de académico de honor o de mérito. Como se ha visto con Vicente López y sucederá con otros artistas, la academia recibió los retratos de sus máximos dirigentes realizadas por determinados pintores con la pretensión de escalar en la categoría de académicos y a su vez se fue nutriendo de estas imágenes que le permitían construir la historia visual de la institución.

Esta práctica estaba firmemente asentada en otras academias europeas como ha estudiado recientemente Hannah Williams. ${ }^{110}$ De hecho, la autora se ha basado en el ejemplo del 109 ARABASC: Inventario de las pinturas y dibujos de la Academia de San Carlos (1797-1815)..., s/f.

110 Hannah Williams, Académie Royale. A history in portraits, (Ashgate, 2015). 


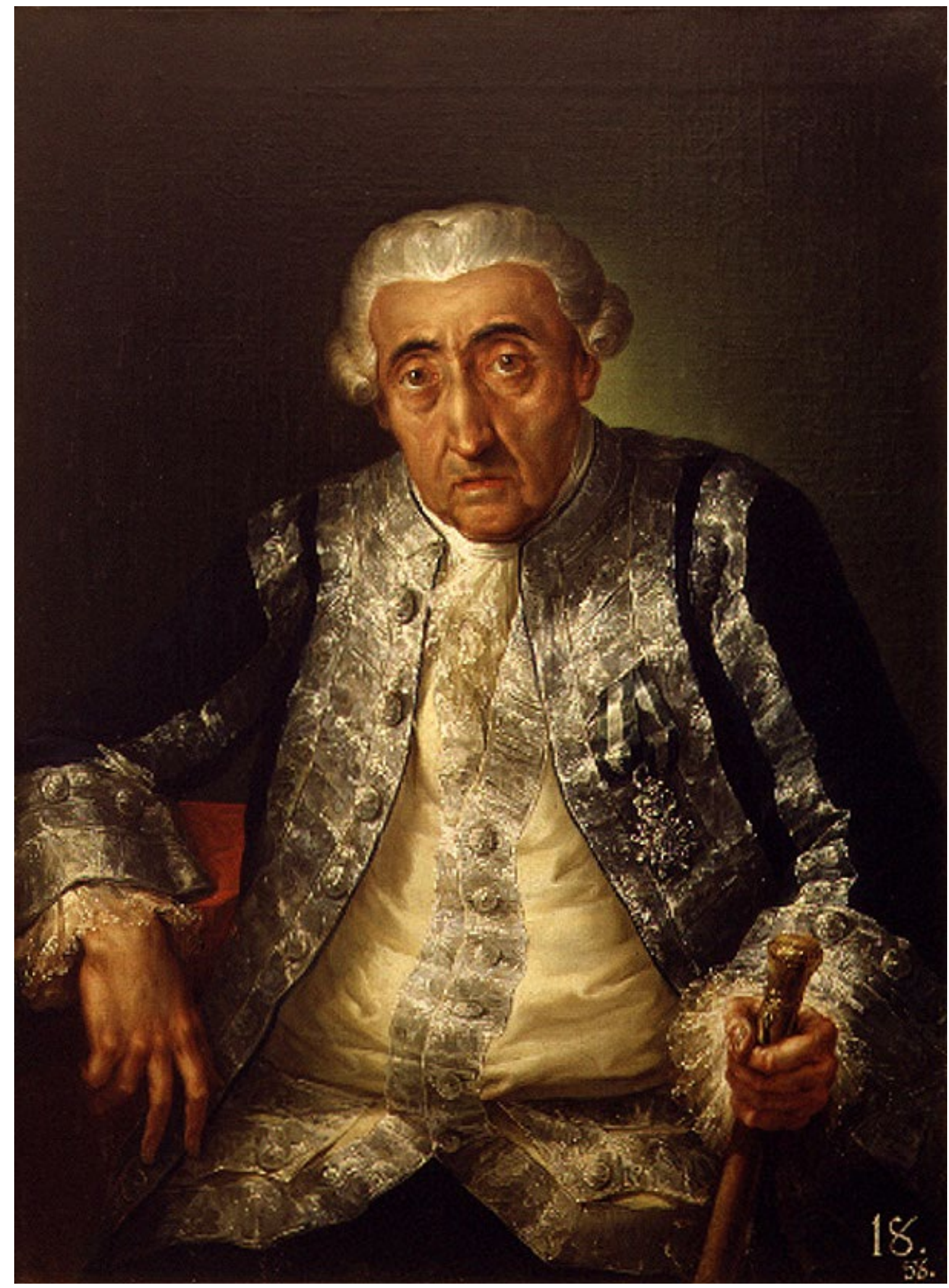

601

Fig. 5.79. Vicente López, Joaquín Pareja y Obregón, h. 1792, óleo sobre lienzo, Valencia, Real Academia de Bellas Artes de San Carlos. 
pintor François Lemaire quien en 1657 retrató al escultor Jacques Sarazin (1592 - 1660). Era la primera efigie de un académico que recibía la Real Academia de Pintura y Escultura de Francia, fundada en 1648. Lemaire, en definitiva, fue pionero en retratar a un componente de la institución y presentar esta obra para ser aceptado como miembro de la misma. Se trataba de una modalidad que incluso había llegado a la de San Fernando, donde al estar pensionado Vicente López pudo conocerla y después, actuar de manera similar en Valencia. ${ }^{111}$ La otra forma utilizada, como se constatará más adelante, fue a raíz de las donaciones privadas de los propios académicos 0 de sus familiares quienes mostraron un gran interés por que su pariente formase parte del elenco de personalidades que perpetuaba su memoria mediante el retrato.

Pedro Caro y Fontes (1717-1775) [fig. 5.80], II marqués de La Romana, también se encuentra entre los efigiados porque, entre otros motivos, en su momento fue designado académico de 602 mérito y de honor, este último nombramiento se hizo efectivo en la junta particular de 5 de enero de $1770 .{ }^{112} \mathrm{El}$ inventario de 1788 ya ubicaba este retrato en la sala de juntas y además revelaba la autoría de Luis Planes. En 1797 se fue más explícito y se indicaron las razones por las que representar al marqués: «N. 67. Un cuadro de tres y cuatro palmos con marco corlado y remate de talla de un retrato de medio cuerpo del marqués de La Romana, académico que fue de honor y mérito en la arquitectura, que pintó don Luis Planes de orden de la academia en memoria de un donativo que le hizo el señor marqués en su última disposición.» ${ }^{113}$ Por tanto, fue la propia institución

111 Esta circunstancia en la academia madre ha sido últimamente estudiada por: Ma Victoria Alonso Cabezas, 'Una galería de retratos en la Real Academia de Bellas Artes de San Fernando (1754-1833)', Archivo Español de Arte, Vol. 92, no. 366, 2019, pp. 191-202.

112 ARABASC: Extracto de Juntas Particulares: 1765-1827, p. 9.

113 ARABASC: Inventario de las pinturas y dibujos de la Academia de San Carlos (1797-1815)..., s/f. 


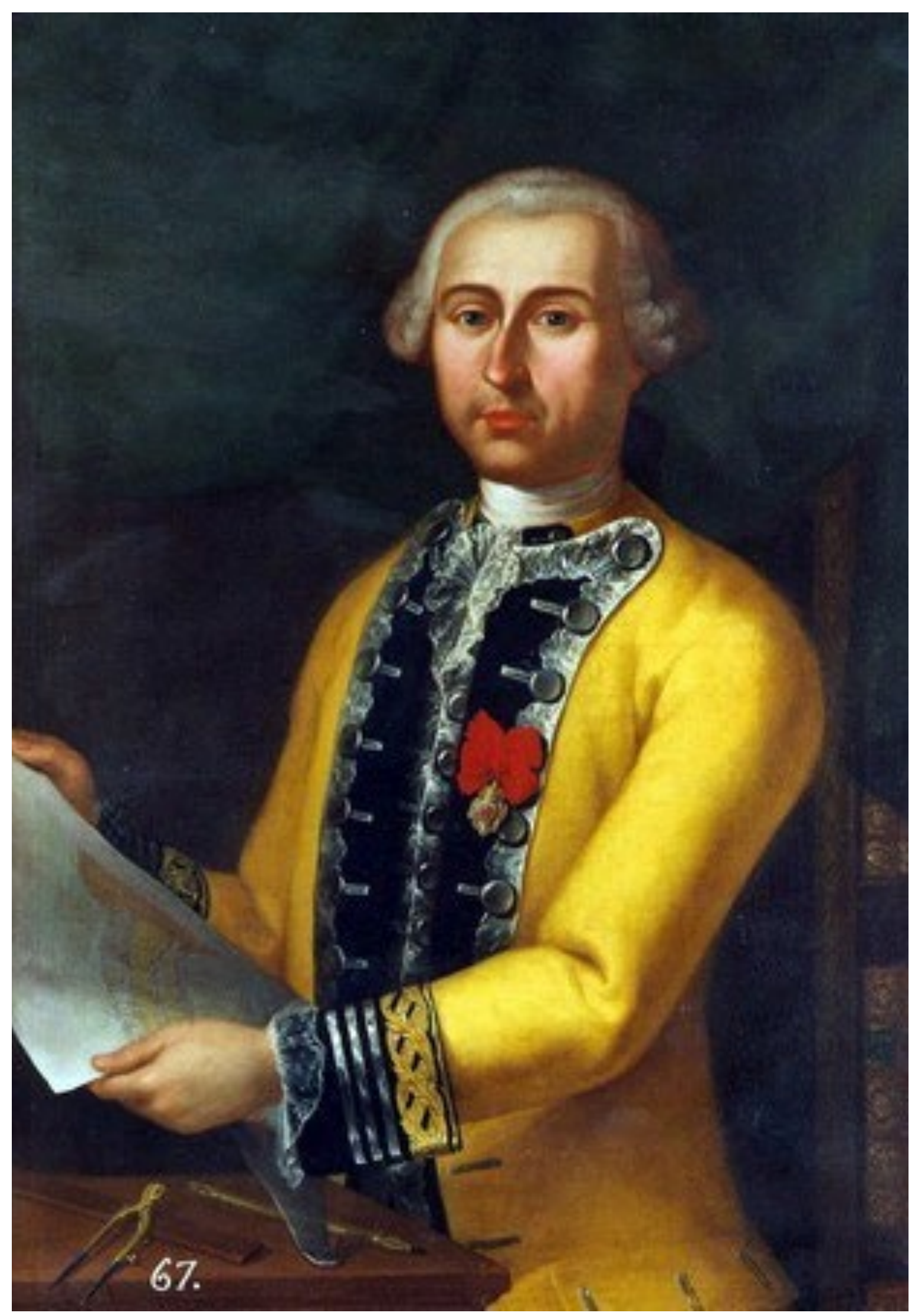

603

Fig. 5.80. Luis Planes, Pedro Caro y Fontes, 1779, óleo sobre lienzo, Valencia, Real Academia de Bellas Artes de San Carlos. 
la que encargó la elaboración de la imagen a título póstumo.

El retrato, en efecto, muestra al efigiado en un interior engalanado por un cortinaje y su biblioteca personal, donde él sigue la moda francesa, sostiene un plano y sobre el bufete se encuentran los instrumentos propios de su campo de conocimiento, la arquitectura. Además se aprecia claramente que el lienzo ha sido numerado con la cifra correspondiente al inventario de 1797, detalle que facilita su identificación. Cabe destacar que el acuerdo se alcanzó en una junta particular ${ }^{114}$ celebrada en 20 de junio de 1779 firmada por el secretario Tomás Bayarri, en la cual se especificó lo siguiente:

Se acordó asimismo: que respecto de haber percibido la academia $601.10 \mathrm{~s}$. por el legado que el difunto marqués de La Romana asignó a la misma en su testamento, según expresó el presente secretario, se ponga su retrato en la sala de juntas, por ser así correspondiente y haberlo prevenido en su testamento el expresado marqués quedando encargado el señor presidente del cumplimiento de esta diligencia y en esta conformidad se le dio fin a la junta. ${ }^{115}$

Es más, se conoce que la efigie se situó en la sala de juntas pero sobre el proyecto arquitectónico que presentó y le confirió el título de académico de mérito. Así se ha narrado en una crónica histórica de la academia:

114 La junta particular se llevaba a cabo contando con la presencia del presidente, del vicepresidente, de los consiliarios y del secretario. Por lo general se solían celebrar en la casa de la academia, pero también podían tener lugar en el hogar del presidente. En ellas se estudiaban los aspectos económicos y gubernativos de la institución, se reconocían o aprobaban las cuentas anuales y se adjudicaban incentivos para los estudiantes y para el resto de personal. Además, era el momento idóneo para nombrar a los regidores que se debían proponer para consiliarios y viceconsiliarios de la ciudad, designar a los académicos de honor, al director general, a los directores de cada especialidad y a los tenientes directores.

115 ARABASC: Libro de Acuerdos de Juntas Particulares: Años: 1765-1786, s/f, junta particular de 20 de junio de 1779. 
El señor marqués de La Romana, mariscal de campo de los reales ejércitos, y académico de honor y de mérito, que tan gloriosamente dio su vida en la guerra de Argel, dejó un legado pecuniario a la academia en prueba de la estimación, que profesó a este cuerpo; el cual por un efecto de su gratitud, y del amor debido a tan ilustre, y digno patricio, ha colocado su retrato en distinguido lugar de la sala de juntas sobre la obra de arquitectura, que dicho señor marqués presentó para ser creado académico de mérito; la cual contiene una exacta planta y mapa topográfico de la plaza y puerto de Mahon. ${ }^{116}$

Casi un año después, al haber concluido el encargo se decidió sobre el pago de la obra: «Habiendo el teniente de pintura don Luis Planes pintado un retrato del difunto marqués de La Romana, de orden de la junta, se acordó que se le librase 20 libras de gratificación y se dio fin a la junta.» ${ }^{117}$ La imagen, por tanto, se realizó cinco años después de su fallecimiento y tuvo un marcado valor conmemorativo. Además, es relevante el he605 cho que fuese el propio marqués quien ya dejase constancia de su voluntad por retratarse y colocar su imagen en la sala de juntas, concretamente cuando en esta estancia probablemente tan sólo lucían los retratos regios y del primer y del actual presidente respectivamente. Pedro Caro quizás inauguró la práctica de efigiar a otros académicos que no ostentaron la presidencia pero que también estuvieron en la cumbre de la institución.

En consecuencia, los datos recogidos en el inventario de 1788 son importantes porque hablan de los primeros retratos que compusieron la colección de efigies, y ésta se incrementó sustancialmente en el inventario de 1797. A partir de entonces, se fueron recogiendo de forma progresiva los retratos de nu-

116 Continuación de la noticia histórica..., p. 5.

117 ARABASC: Libro de Acuerdos de Juntas Particulares: Años: 1765-1786, s/f, junta particular de 21 de abril de 1780. 
merosos presidentes y directores principalmente. Si bien este segundo documento, a diferencia del primero, no especifica que las imágenes estuviesen situadas en la sala de juntas, por el cariz de los representados y por algunas descripciones cabe pensar que fue bastante posible. Asimismo, aunque el inventario se iniciase en 1797 su lectura revela que éste se fue actualizando periódicamente hasta el año 1831. Después, dos nuevas catalogaciones se efectuaron tras la desamortización, en 1842 y 1847 en concreto. Cabe recordar que hasta entonces las dependencias de la Academia y por tanto las pinturas se habían dispuesto en el edificio de la Universitat pues allí, se ocuparon las mismas aulas que en su día se habían cedido a la academia de Santa Bárbara. No fue hasta 1848 cuando se trasladaron al antiguo convento del Carmen, donde se ubicaron hasta el cambio definitivo en 1942 al convento de San Pío V.

En cuanto a los presidentes se realizaron un total de trece nuevas efigies en este periodo que no corresponden con el total de personalidades que ocuparon este cargo, probablemente debido a la circunstancia particular de recopilar los retratos o bien en calidad de obras de recepción o por donaciones particulares. ${ }^{118}$ La primera de ellas muestra a Francisco Xavier Azpíroz [fig. 5.81] quien además de encabezar la institución fue nombrado académico de honor en la junta particular del 5 de enero de $1800 .{ }^{119}$ Por lo que respecta a la presidencia, fue una responsabilidad asumida en dos ocasiones distintas, entre $1797 \mathrm{y}$ 1800 y 1807 y 1813. Manuel Camarón Meliá pintó este retrato, tarea que le valió para convertirse en académico de mérito: $:^{120}$ «N. 72. Un retrato de tres y cuatro palmos con marco dorado

118 En el archivo se puede consultar un libro donde se anotaron por orden todos los presidentes que estuvieron al frente de la academia desde 1768 hasta 1820. Seguidamente, también se indicó quiénes fueron y la fecha del nombramiento de secretarios, directores y teniente directores en cada especialidad y académicos de mérito. Véase Archivo de la Real Academia de Bellas Artes de San Carlos: Libro de Individuos desde su creación. Extracto. 1768-1820, s/f.

119 ARABASC: Extracto de Juntas Particulares: 1765-1827, p. 62.

120 Los académicos de mérito eran los profesores de arquitectura, pintu- 


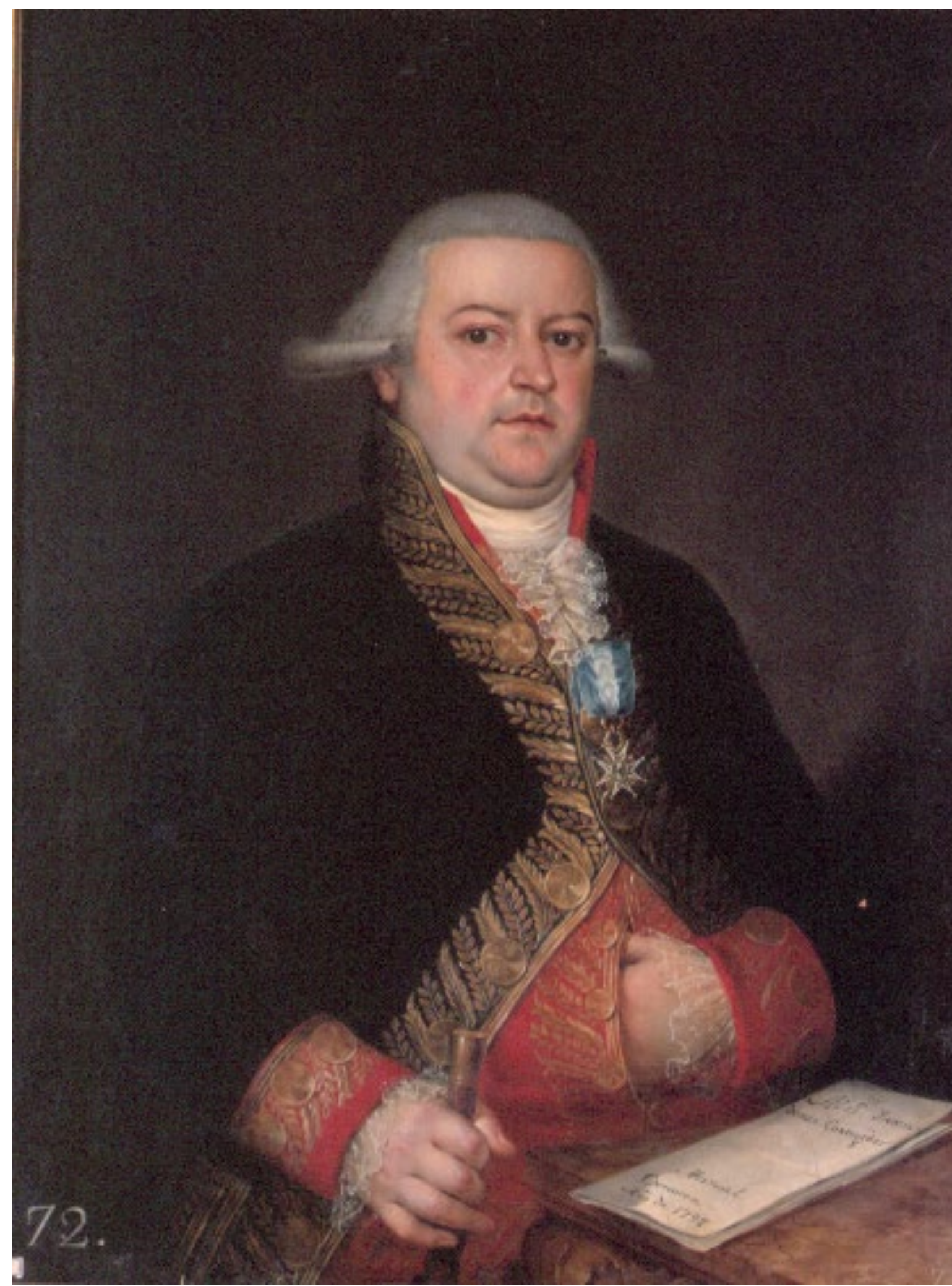

Fig. 5.81. Manuel Camarón Melià, Francisco Xavier Azpíroz, 1798, óleo sobre lienzo, Valencia, Real Academia de Bellas Artes de San Carlos. 
y remate de talla del señor don Francisco Xavier de Azpiroz actual presidente, obra de don Manuel Camarón y Meliá, por la cual se le creó académico de mérito en su clase de pintura el año 1798.»121 De hecho, se le ha representado de medio cuerpo y dirigiendo la mirada al espectador, en calidad de caballero de la orden de Carlos III como indica la medalla que luce y de corregidor al apoyarse en el bastón de mando. Asimismo, posa junto a un bufete donde se ha colocado un documento y en él puede leerse "Al señor Francisco Xavier, corregidor.» en la parte superior y «Manuel Camarón. Año 1798» en la parte inferior.

A continuación, se catalogó la efigie del vicepresidente Antonio Pascual, cuyas características eran similares al ejemplo anterior. Era una pintura con las mismas dimensiones, elaborada por el artista Luis Planes el menor (1772-1799) que igualmente le sirvió para obtener el grado de académico de mérito: «N. 73. Otro retrato en todo igual al antecedente que es del señor don Antonio Pascual, actual vice-presidente como consiliario más antiguo, obra de don Luis Planes y Domingo, por la que se le creó en 1798 académico de mérito en su clase.»122 La elección de Antonio Pascual como consiliario se produjo el 30 de abril de 1769 y tras obtener el beneplácito de la Real ra, escultura o grabado que hubiesen conseguido en sus disciplinas toda la habilidad oportuna para convertirse en distinguidos maestros. Debían servir de ejemplo para los alumnos y los animaban a mejorar en su pericia artística con la intención de llegar a ser tenientes o directores. Así se especifica en ARABASC: Estatutos. Artículo XV: «Académicos de Mérito: 1. Los Académicos de Mérito serán aquellos profesores de las tres artes y del grabado que hayan adquirido en sus respectivas profesiones toda la pericia necesaria para ser reputados maestros en ellas asistirán a los estudios con la posible frecuencia así para dar buen ejemplo a los discípulos como para irse perfeccionando más y más, a fin de merecer ser ascendidos a tenientes y directores. Voz y voto en la Junta General y pública y en las ordinarias que el Presidente les quiera convocar.»

121 ARABASC: Inventario de las pinturas y dibujos de la Academia de San Carlos (1797-1815)..., s/f.

122 ARABASC: Inventario de las pinturas y dibujos de la Academia de San Carlos (1797-1815)..., s/f. 
Academia de Bellas Artes de San Fernando tomó posesión del cargo. ${ }^{123}$ Por lo que respecta a la imagen, ésta concuerda con el retrato visto previamente en cuanto a la pose del efigiado, su estética afrancesada y la ubicación de un bufete con un libro y un documento a la derecha.

El siguiente presidente retratado fue Jorge Palacios de Urdániz y Chavier (1737-1802) [fig. 5.82], quien estuvo al frente de la academia entre 1800 y 1801. Según el correspondiente inventario se trataba de: «Un cuadro con marco dorado y remate igual a los compañeros, retrato de don Jorge Palacios, presidente que fue de esta academia pintado por Vicente López.» ${ }^{124}$ Su efigie casa con el tipo de representación reservada para los presidentes, vestido con una chupa y una casaca profusamente bordada en plata, escondiendo una mano en el pecho, luciendo la cruz que lo acredita como caballero de la orden de Santiago desde 1765 y apoyado en el bastón de mando por ser intendente y corregidor del Reino de Valencia. Asumió este cargo en 1799 pero al poco tiempo fue criticado por su gestión económica y en 1801, definitivamente, abandonó la ciudad. ${ }^{125}$ Este retrato realizado por López le sirvió para representar de nuevo a este personaje en otro lienzo, ahora también en calidad de corregidor de Murcia y mostrando las reformas que se llevaron a cabo en la ciudad. El dibujo preparatorio se conserva en la Biblioteca Nacional y la pintura se halla en el ayuntamiento, donde se puede observar una plena similitud al efigiar a Palacios tanto en la obra de la academia valenciana como en el ayuntamiento murciano.

Vicente López también pintó el retrato de Cayetano de Urbina,

123 ARABASC: Extracto de Juntas Particulares: 1765-1827, p. 7.

124 ARABASC: Inventario de las pinturas y dibujos de la Academia de San Carlos (1797-1815)..., s/f.

125 Una biografía más detallada se puede consultar en la Real Academia de la Historia, disponible en: http://dbe.rah.es/biografias/51022/jorge-palacios-de-urdaniz-y-chavier (Última consulta: 14/08/19) 


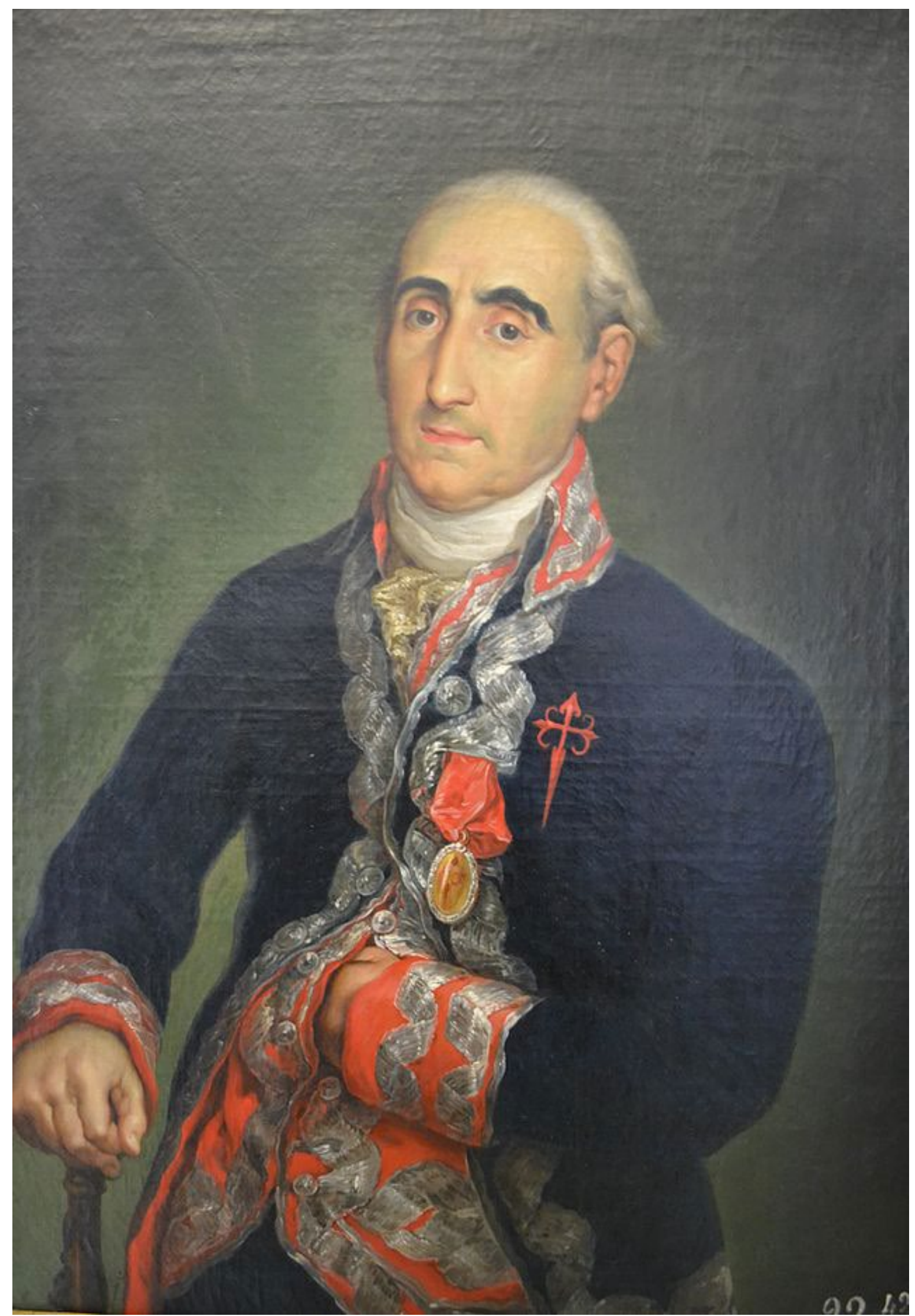

Fig. 5.82. Vicente López, Jorge Palacios de Urdániz y Chavier, h. 1801, óleo sobre lienzo, Valencia, Real Academia de Bellas Artes de San Carlos. 
quien fue presidente entre los años 1801 y 1807. Durante su gobierno, Ceán Bermúdez fue nombrado académico de honor en 1804 y la Biblioteca Nacional conserva una carta manuscrita de Urbina comunicándole la noticia a Bermúdez. ${ }^{126} \mathrm{El}$ inventario dice lo siguiente: «N. 108. Un cuadro de cuatro y tres palmos retrato de don Cayetano de Urbina, presidente que fue de esta academia, pintado por Vicente López que regaló a esta academia cuando concluyó su empleo, con marco dorado, remate de talla igual a los demás.» ${ }^{127}$

Los retratos de los siguientes presidentes fueron realizados completamente por Miguel Parra Abril (1780-1846) principalmente durante el primer tercio del siglo XIX, por lo cual se aprecia una mayor homogeneidad si cabe entre las piezas. Por entonces, Parra ya había sido nombrado académico de mérito por la pintura de flores en 1803 y académico de mérito por la pintura de historia en 1811, ambas categorías conseguidas en San Carlos. Poco tiempo después, en 1815 fue nombrado pintor de cámara de Fernando VII y en 1818 solicitó y le fue concedido el título de académico de mérito también en las especialidades de pintura de historia y de flores en San Fernando.

Francisco Javier Elío Olóndriz (1767 - 1822) estuvo al frente de la presidencia entre los años 1815 y 1818. Parte de su intensa carrera militar tuvo por escenario el otro lado del Atlántico, donde fue virrey de Río de la Plata (1810 - 1812). Después, ya fue en la última etapa de su vida cuando se convirtió en capitán general de Valencia. En consecuencia, Miguel Parra lo ha retratado luciendo el pertinente uniforme, complementado con varias bandas entre las cuales destaca la propia de la orden de Carlos III. Asimismo se distinguen todas las cruces que, en agradecimiento a sus servicios militares, le fueron entregadas. Concretamente se le otorgaron las cruces de las ór-

126 Disponible en: http://bdh-rd.bne.es/viewer.vm?id=00002300888page=1 (Última fecha de consulta: 27/08/2019)

127 ARABASC: Inventario de las pinturas y dibujos de la Academia de San Carlos (1797-1815)..., s/f. 
denes de Carlos III, Isabel la Católica, San Hermenegildo y San Fernando, estas tres últimas creadas por Fernando VII. El Museo Nacional del Prado posee una copia realizada por el mismo autor de esta efigie conservada en el Museo de Bellas Artes de Valencia [fig. 5.83].

Idelfonso Díez de Ribera (también Rivera) y Muro [fig. 5.84] fue uno más de los presidentes efigiados por el artista, tal y cómo se especificó en el inventario: «N. 153. Retrato de don Idelfonso Díez de Ribera, conde de Almodóvar, presidente que ha sido de esta academia, pintado y regalado por el director

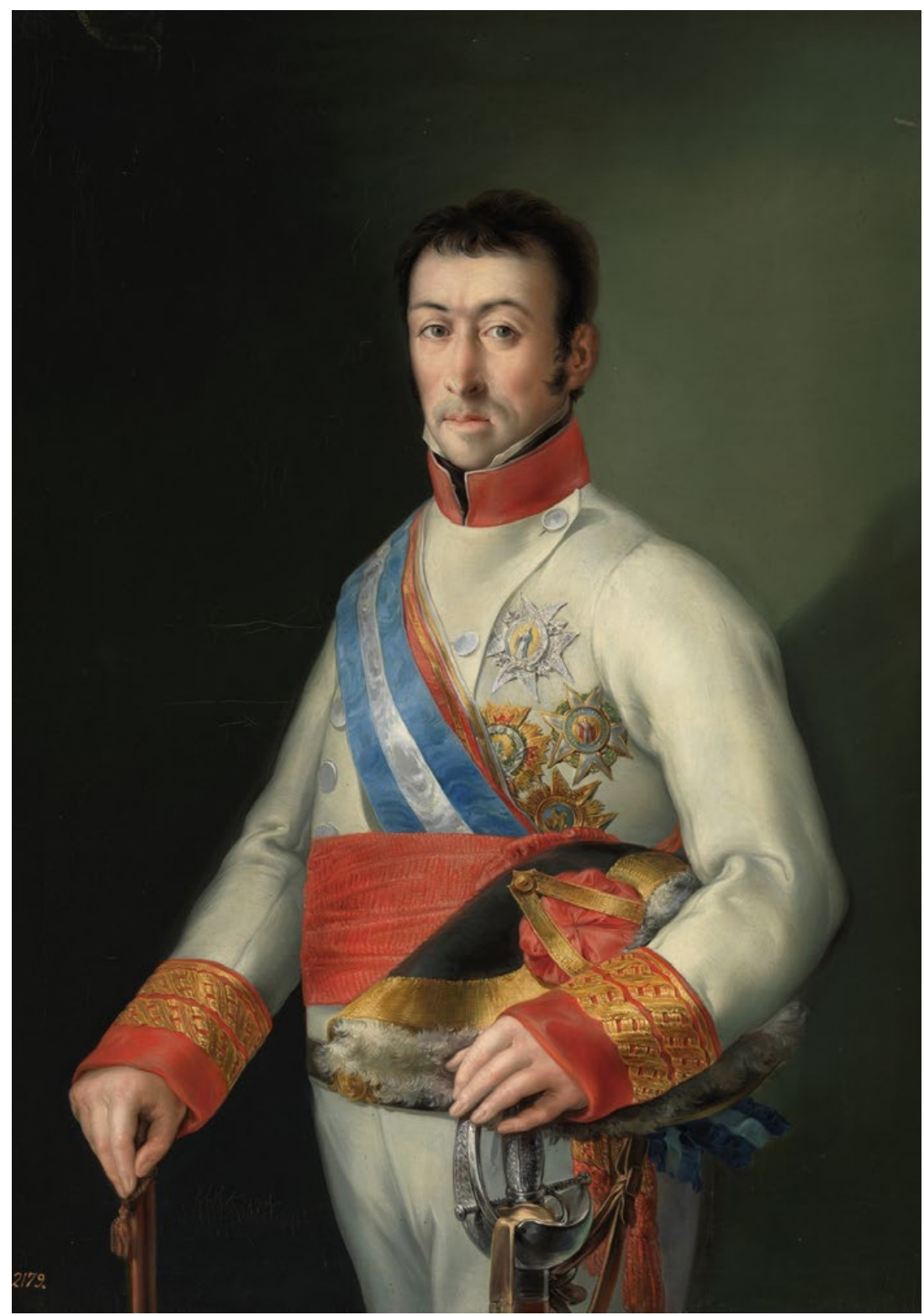

Fig. 5.83. Miguel Parra, Francisco Javier Elío Olóndriz capitán general de Valencia, h. 1815, óleo sobre lienzo, Madrid, Museo Nacional del Prado. 
don Miguel Parra, colocado dentro de un marco dorado.»128 Se le ha representado luciendo el uniforme militar, pues fue un brigadier que consiguió escalar en la carrera profesional a raíz de su implicación en la Guerra de la Independencia, como por ejemplo la batalla de Trafalgar (1805). El título de conde le llegó a partir de su enlace matrimonial con la tercera condesa de Almodóvar. Finalmente y tras el gobierno de Francisco Javier Elío, se convirtió en capitán general de Valencia y por ello, el bastón de mando se puede ver apoyado en la mesita auxiliar junto al retratado. ${ }^{129}$ Díez de Ribera tan sólo estuvo al frente de la academia en 1820 y fue un año después cuando el artista entregó a la institución este retrato de forma gratuita para seguir engrandeciendo la colección. ${ }^{130}$

Otro de los retratados por Parra fue Francisco Plasencia, quien estuvo al frente de la academia entre los años 1821 y 1822, y así lo constata el inventario: «N. 154. Retrato del señor don Francisco Plasencia, presidente de esta academia, que hizo procurado de la junta particular el mencionado director don Miguel Parra y lo regaló a la academia colocada dentro de un marco dorado. ${ }^{131}$ Este brigadier ha sido representado de medio cuerpo, dirigiendo la mirada hacia el espectador, con el uniforme militar y engalanado por numerosas condecoraciones como las cruces de san Fernando y san Hermenegildo. Resulta interesante que la documentación de archivo conserve un escrito firmado por el propio artista en el cual se remite a la entrega de esta pintura a la institución: «Habiéndome cabido la honra que la junta particular de la Academia Nacional de San Carlos me confiere hacer el retrato de su presidente el señor jefe superior político de esta provincia don Francisco 128 ARABASC: Inventario de las pinturas y dibujos de la Academia de San Carlos (1797-1815)..., s/f.

129 Para conocer los principales datos biográficos de Idelfonso Díez de Ribera se ha seguido a: Encarna García Monerris y Carmen García Monerris, La nación secuestrada. Francisco Javier Elío. Correspondencia y manifiesto, (Univeristat de València: Valencia, 2008), p. 61.

130 Alonso Cabezas, 'Los inicios de la galería de retratos...', p. 139.

131 ARABASC: Inventario de las pinturas y dibujos de la Academia de San Carlos (1797-1815)..., s/f. 


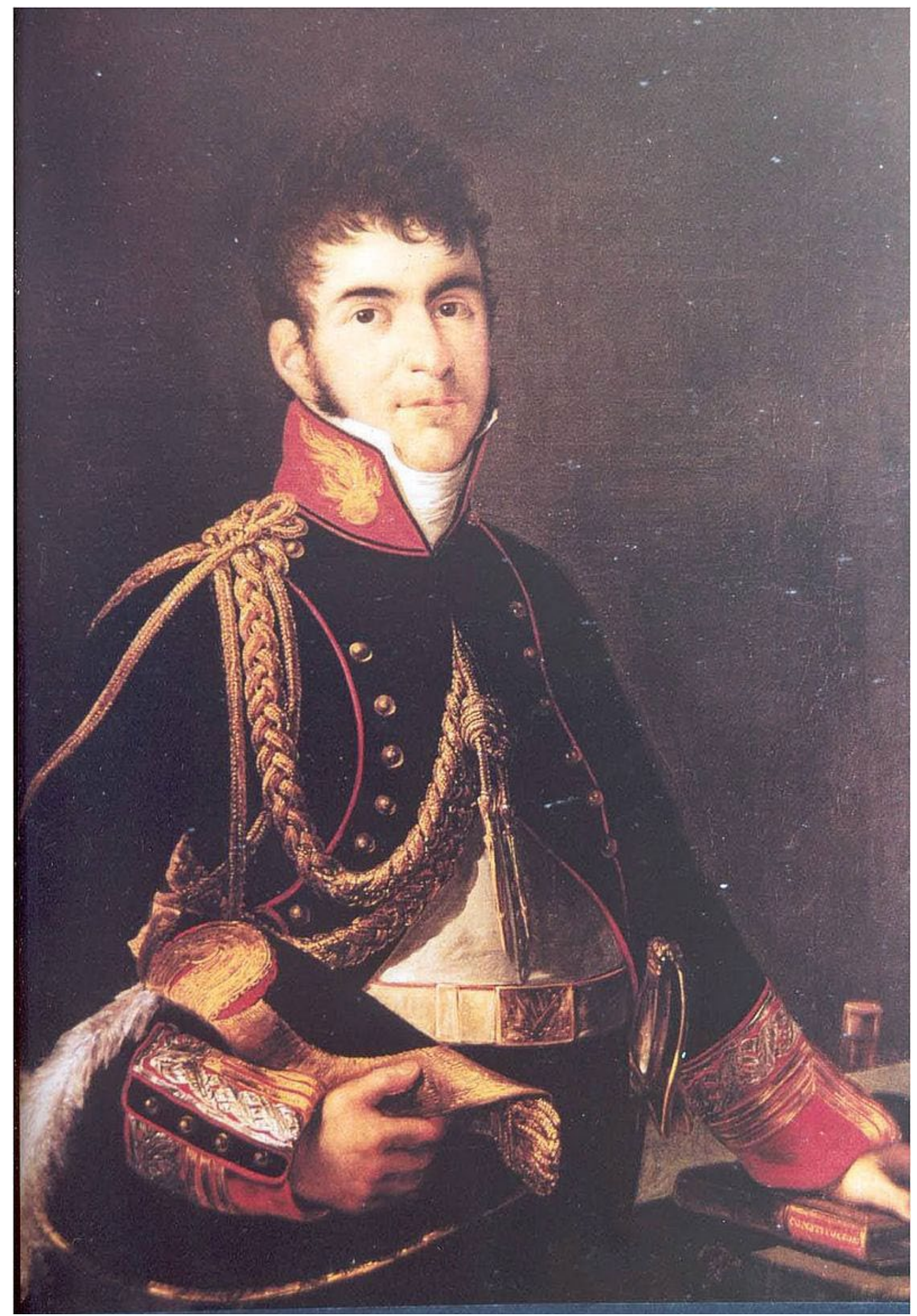

Fig. 5.84. Miguel Parra, Idelfonso Díez de Ribera y Muro, conde de Almodóvar, 1821, óleo sobre lienzo, Valencia, Real Academia de Bellas Artes de San Carlos. 
Plasencia, le acompaño a usted para que se sirva a presentarle a dicha ilustrada corporación y espero que sea de aprobación y agrado. Valencia 30 de septiembre de 1821.»132

En esta misma fecha se firmó el acta de una junta ordinaria para dar el visto bueno al retrato realizado por Parra:

Se dio escrito de un oficio del señor director don Miguel Parra, manifestando que conforme a lo dispuesto por la junta particular presentaba el retrato del señor presidente y jefe político superior don Francisco Plasencia. La junta oído unánime parecer de los [...] de la semejanza, bien pintado y apreciables circunstancias artísticas de la obra y de la digna memoria que acordaba el celo e interés por la prosperidad del instituto del actual señor presidente lo aceptó con mucha estimación, acordándose dieron las debidas gracias expresadas a don Miguel Parra por su repetida generosidad. ${ }^{133}$

La esplendidez atribuida a Parra, como se ha visto, ha sido consecuencia de regalar a la academia varios retratos hechos de su mano y así ir configurando la colección de algunos personajes ilustres vinculados a esta institución.

En una actualización del inventario fechada el 16 de febrero de 1824 se dejó constancia de la elaboración de otro retrato del mismo autor: «N. 180. El retrato del excelentísimo señor don Felipe de San Marcos, presidente que fue de esta real academia de medio cuerpo con marco dorado, igual a los demás señores presidentes, pintado por el director general don Miguel Parra.»134 Felipe Augusto de Saint Marcq d'Ostrel (17621831), asumió la presidencia entre 1823 y 1824 cuando estuvo al frente de la capitanía general de Valencia y como tal se le

132 ARABASC: Leg. 72/5/5.

133 ARABASC: Libro de Actas de la Real Academia de San Carlos. Años 1821-1827, junta ordinaria del 30 de septiembre de 1821.

134 ARABASC: Inventario de las pinturas y dibujos de la Academia de San Carlos (1797-1815)..., s/f. 
ha representado en esta efigie. Después también lo estuvo en Murcia y Aragón. Sin duda fue un hombre con una destacable trayectoria militar que le reportó ser honrado con numerosas condecoraciones, algunas de ellas incluso lucen sobre su uniforme. ${ }^{135}$ Por ejemplo en 1819 se le concedió la gran cruz de la orden de San Fernando en agradecimiento el servicio militar prestado a España. Con este distintivo se quiso reconocer la implicación de Saint-Marcq a la Guerra de la Independencia. Por esta misma razón, además, se le entregó la gran cruz de la orden de San Hermenegildo, surgida tras el conflicto con Francia.

Un año después, el 12 de febrero de 1825, se anotó la existencia de una efigie más a la colección: «N. 181. El retrato del excelentísimo señor don Luis Alejandro de Bassecourt, presidente que fue de esta academia, de medio cuerpo con marco dorado, igual a los demás señores presidentes pintado por el director general don Miguel Parra.»136 Luis Alejandro Bassecourt y Dupire (1769-1826) [fig. 5.85] protagonizó una dilatada carrera militar que tuvo a Valencia como escenario a partir del 4 de julio de 1824, cuando se convirtió en capitán general de Valencia y Murcia, y por ende asumió la presidencia de la institución. Así pues, se le ha retratado con el uniforme militar, cruzado con la correspondiente banda y luciendo numerosos galones, entre ellos la gran cruz de la Isabel la Católica concedida en 1825. En este mismo año dejó la capitanía valenciana para desempeñar el mismo cargo en Granada y Aragón. ${ }^{137}$

El 1 de marzo de 1828 se anotaron algunos retratos más en el inventario, todos ellos también elaborados por Parra. Un ejemplo de ello se encuentra en la efigie de José María de Carvajal y Urrutia (1762-1832) [fig. 5.86], presidente entre 1825 y 1826. La documentación de archivo especificó lo siguiente: «N. 193.

135 Una síntesis biográfica se puede consultar en la Real Academia de la Historia. Disponible en: http://dbe.rah.es/biografias/69653/felipe-augusto-de-saint-marcq-y-dostrel (Fecha de última consulta: 23/08/2019)

136 ARABASC: Inventario de las pinturas y dibujos de la Academia de San Carlos (1797-1815)..., s/f.

137 Para una biografía más detalla puede consultarse la Real Academia de Historia. Disponible en: http://dbe.rah.es/biografias/45602/luis-alejandro-bassecourt-y-dupire (Fecha de la última consulta: 26/08/2019) 


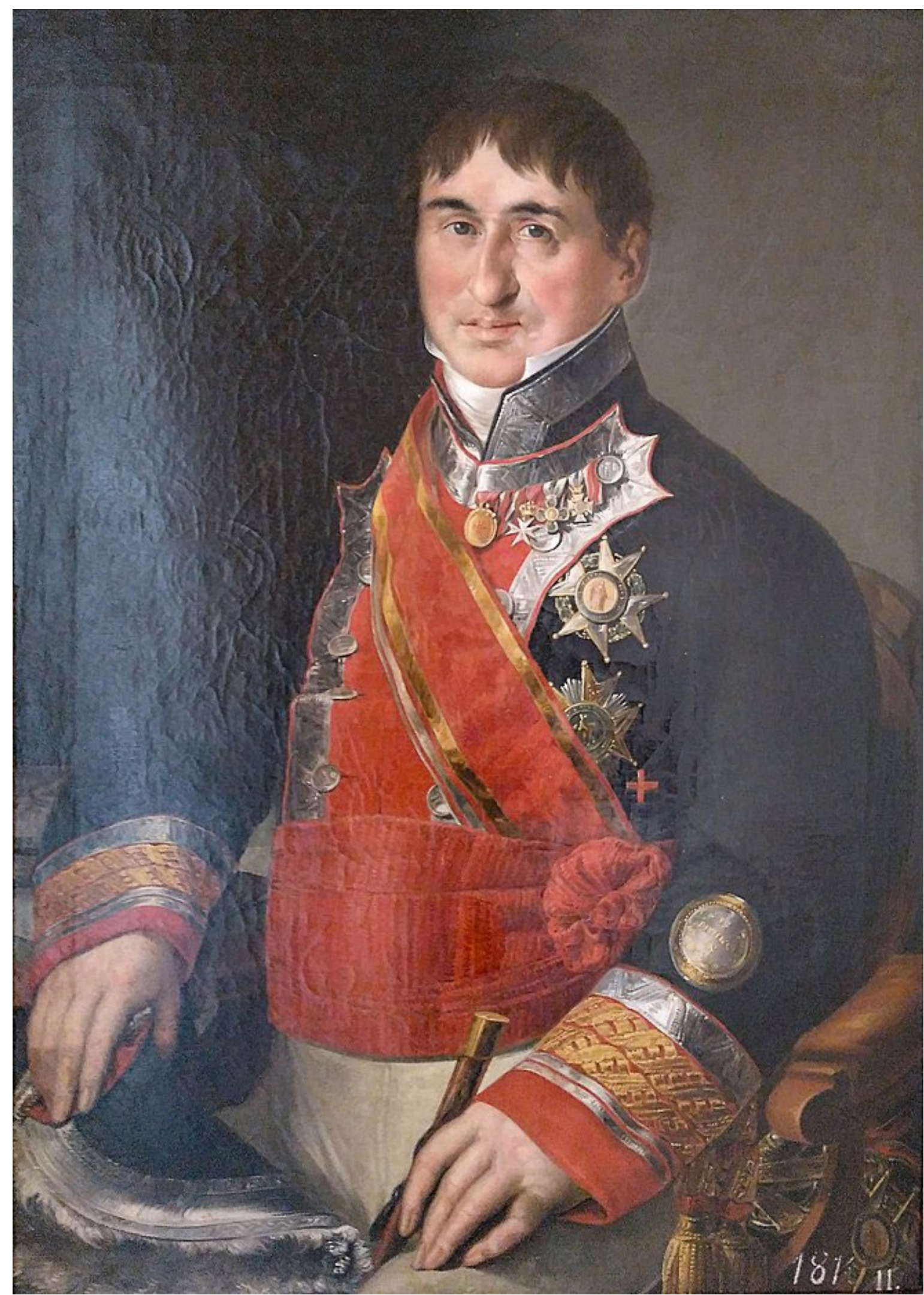

Fig. 5.85. Miguel Parra, Alejandro Bassecourt y Dupire, h. 1825, óleo sobre lienzo, Valencia, Real Academia de Bellas Artes de San Carlos. 
Un retrato del excelentísimo don Josef María Carvajal y Urrutia, presidente que fue de la Real Academia pintada por don Miguel Parra.» ${ }^{138}$ Fue un teniente general cuyo rango alcanzó en octubre de 1814 tras apoyar completamente el movimiento absolutista que respaldaba a Fernando VII. En 1815, de hecho, recibió las grandes cruces de San Fernando y San Hermenegildo, las cuales engalanan la parte izquierda de su uniforme militar. Antes de llegar a ser capitán general, ya desempeñó este cargo en 1820 en Castilla la Nueva. En 1825 abandonó dicha responsabilidad para asumirla en Valencia donde la mantuvo hasta 1826. Además, en 1825 obtuvo la gran cruz de Isabel la Católica que se corresponde con la tercera condecoración que ostenta en este retrato. Más tarde, en 1829 también recibió la cruz de la orden de Carlos III pero este mérito ya le llegó después de haber sido retratado por Parra. ${ }^{139}$

José O’Donnell Anethan (1768 - 1836) [fig. 5.87] fue presidente en dos momentos diferenciados, entre 1818 y 1820 y más tar618 de entre 1826 y 1827. Durante el primer gobierno por lo que respecta al ámbito militar llegó a ser segundo cabo en Valencia y Murcia y consiguió la cruz de San Hermenegildo. En el plano humanístico, fue designado miembro de la Sociedad Económica de Amigos del País, académico honorario de San Carlos y de la de Bellas Artes de la Purísima Concepción, situada en Valladolid. En 1826, por tanto, fue nombrado capitán general y en este tiempo abanderó varias iniciativas con el objetivo de mejorar la ciudad. Entre ellas se encontraron el comenzar el paseo de la Real Aduana, el encargar al arquitecto Cristóbal Sales la realización de una balaustrada para el jardín de la Glorieta, el levantamiento de un pabellón de música y el iniciar la construcción de un monumento al general Elío que

138 ARABASC: Inventario de las pinturas y dibujos de la Academia de San Carlos (1797-1815)..., s/f.

139 Véanse los datos proporcionados por la Real Academia de Historia. Disponible en: http://dbe.rah.es/biografias/25127/jose-maria-de-carvajal-y-urrutia (Fecha de la última consulta: 26/08/2019) 


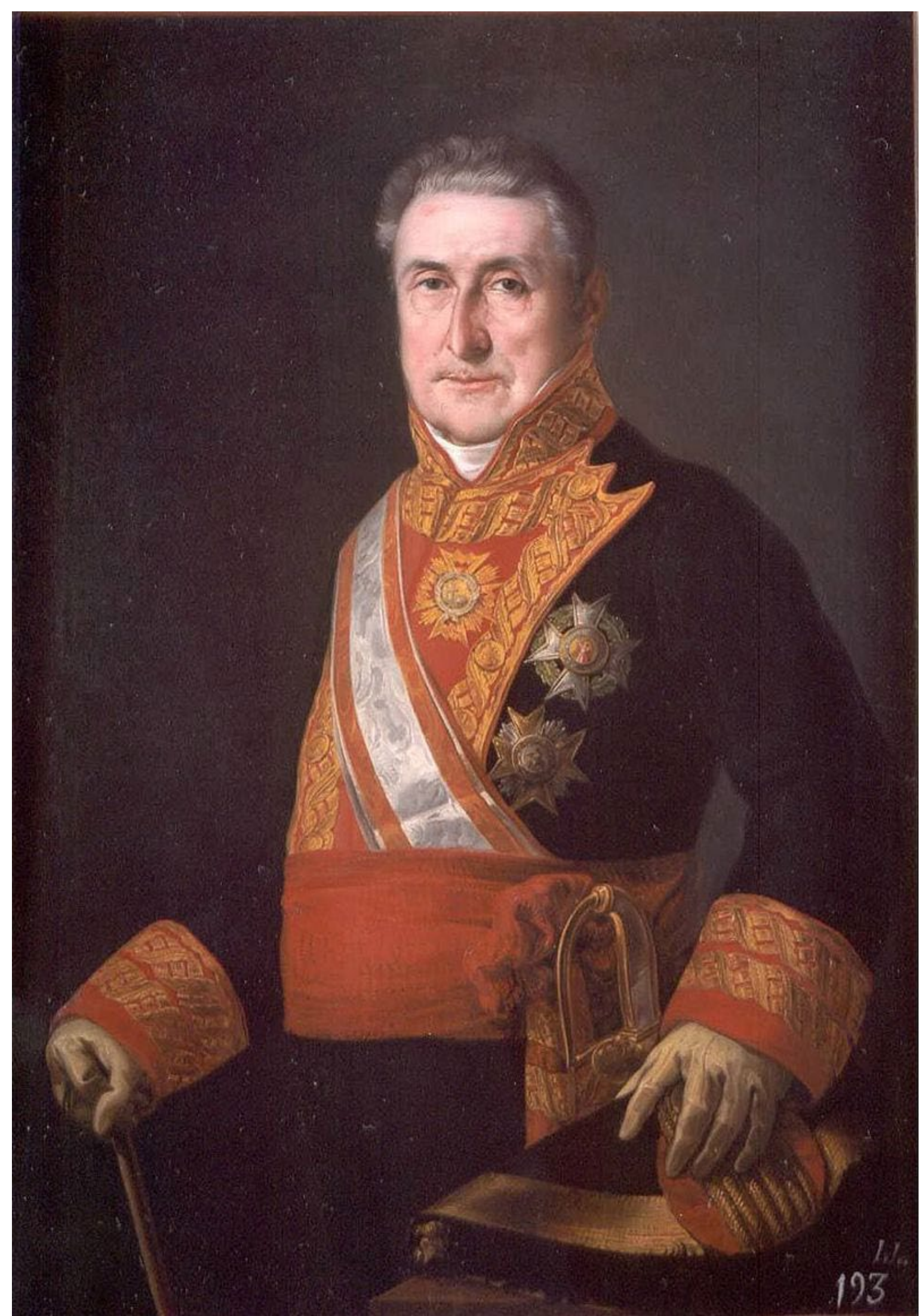

Fig. 5.86. Miguel Parra, José María de Carvajal y Urrutia, h. 1826, óleo sobre lienzo, Valencia, Real Academia de Bellas Artes de San Carlos. 


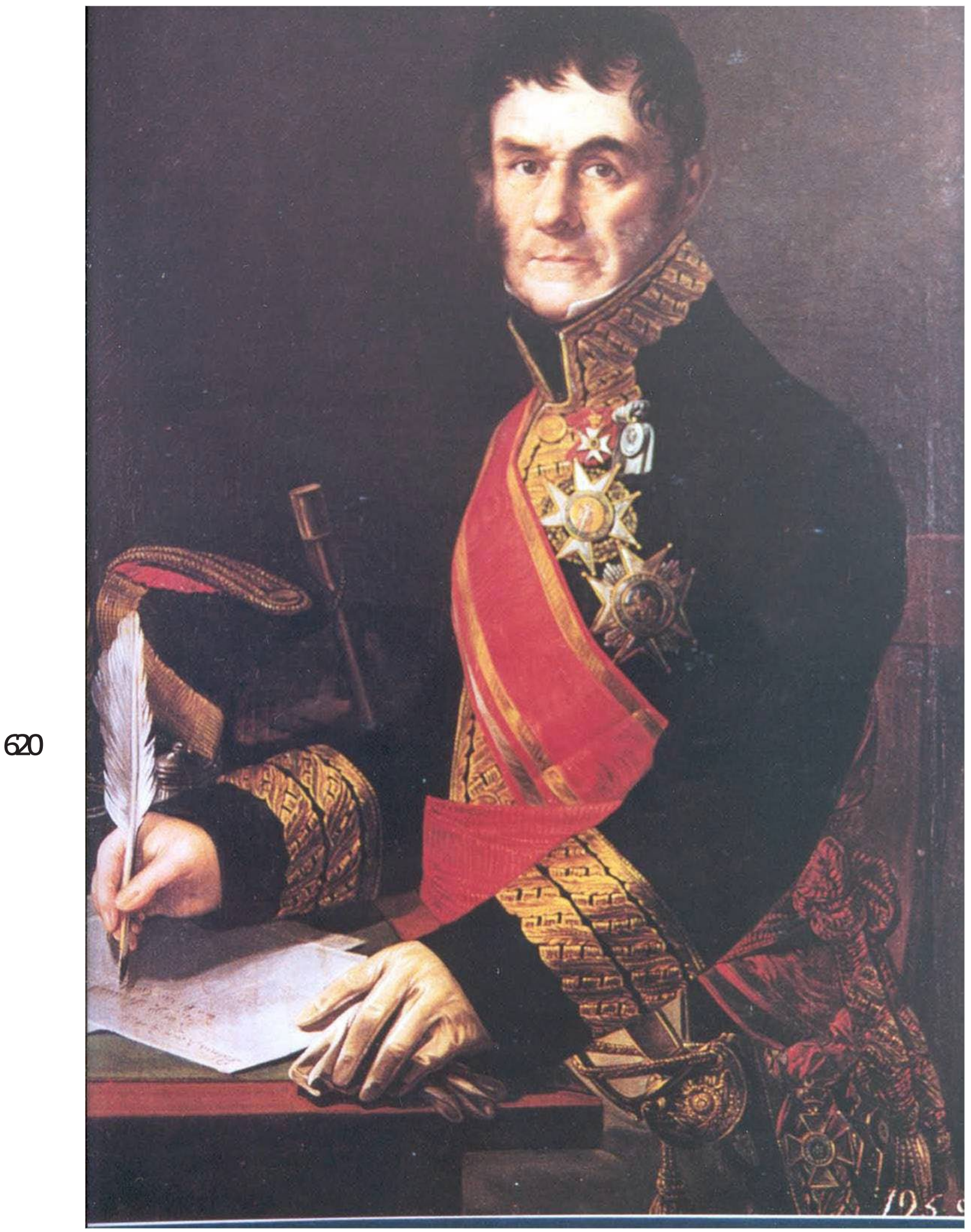

Fig. 5.87. Miguel Parra, José O'Donnel Anethan, h. 1827, óleo sobre lienzo, Valencia, Real Academia de Bellas Artes de San Carlos. 
no se llegó a concluir. ${ }^{140}$

La elaboración de su retrato se dio a raíz de su segundo mandato, pues se registró en el inventario concretamente en una actualización fechada el 1 de marzo de 1828 donde se catalogó con el número 195 un: «Retrato del Excelentísimo don Josef O'Donnell presidente que fue de esta academia pintado por don Miguel Parra.» ${ }^{141}$ Su imagen guarda una total coherencia con el resto de efigies realizadas por el artista. En este caso O'Donnell va ataviado con galas militares y luciendo las condecoraciones, aparece de pie junto a un bufete, donde pluma en mano ha interrumpido la redacción de un documento.

Con el retrato de Francisco Tomás Anchía y Urquiza (1783 1831), presidente en 1827 y 1828, se mantuvieron las mismas características que con las obras anteriores: «N. 196. Retrato del excelentísimo don Francisco presidente de la Real Academia con marco dorado de igual magnitud que los demás, pintado por el director don Miguel Parral.» Este teniente militar también fue conocido como Francisco Longa, cuyo nombre realmente corresponde al caserío donde nació. Sin embargo, se le ha registrado con este nombre en toda la documentación militar como si se tratase de su verdadero apellido. Tras una dilatada carrera dedicada al ejército, en 1825 asumió la capitanía de Castilla la Vieja. Poco después, el 3 de abril de 1827 se convirtió en capitán general de Valencia y Murcia y por tanto se vinculó a la Academia de San Carlos. Después de este cargo recibió la gran cruz y banda de la orden de San Fernando el 18 de diciembre de $1829 .{ }^{142}$

140 Se ha seguido la biografía facilitada por la Real Academia de Historia: Disponible en: http://dbe.rah.es/biografias/106705/jose-odonnell-y-anhetan (Fecha de la última consulta: 26/08/2019)

141 ARABASC: Inventario de las pinturas y dibujos de la Academia de San Carlos (1797-1815)..., s/f.

142 Consúltese la Real Academia de Historia. Disponible en: http://dbe. rah.es/biografias/26718/francisco-tomas-anchia-y-urquiza (Fecha de la última consulta: 27/08/2019) 
Asimismo se decidió incluir la representación del vicepresidente Nicolás Máñez, que como indica el inventario era una imagen en consonancia al resto de pinturas: «N. 197. Retrato de medio cuerpo del señor don Nicolás Máñez, vicepresidente de la misma magnitud del anterior y ejecutado por el expresado don Miguel Parra.» ${ }^{143}$ Una vez más, el artista ha representado a este personaje sedente, luciendo el uniforme militar, acompañado de algún libro y con un rostro bien detallado, enfatizando la individualidad.

El último de los presidentes retratado fue el teniente general José María de Santocildes (1771 - 1837) [fig. 5.88], cargo que ostentó en 1828 tras una dilatada carrera militar. En una nueva puesta al día del inventario, fechada el 21 de febrero de 1831, se incluyó la existencia de esta nueva efigie: «N. 241. Retrato del excelentísimo señor don José María Santocildes, presidente que fue de esta Real Academia pintado por el director don Miguel Parra. ${ }^{144}$ Como de costumbre, Parra le ha efigiado con el uniforme militar condecorado con las tres grandes cruces que consiguió, la de San Hermengildo en 1816, San Fernando en 1817 e Isabel la Católica en 1834. Asimismo, está apoyando una mano en el bastón de mando y la otra reposa sobre un plano, todo ello ambientado en un paisaje.

Además de los presidentes de la institución, esta colección de retratos también contaba con algunas efigies de los respectivos directores en las diversas especialidades artísticas. El cargo, a diferencia del presidente, no era de índole política sino que estaba reservado para artistas de reconocido prestigio procedentes de las distintas artes. Por tanto, incluir este tipo de efigies era el modo de dar visibilidad al trabajo e importancia de los artistas en el organigrama de la academia y en

143 ARABASC: Inventario de las pinturas y dibujos de la Academia de San Carlos (1797-1815)..., s/f.

144 ARABASC: Inventario de las pinturas y dibujos de la Academia de San Carlos (1797-1815)..., s/f. 


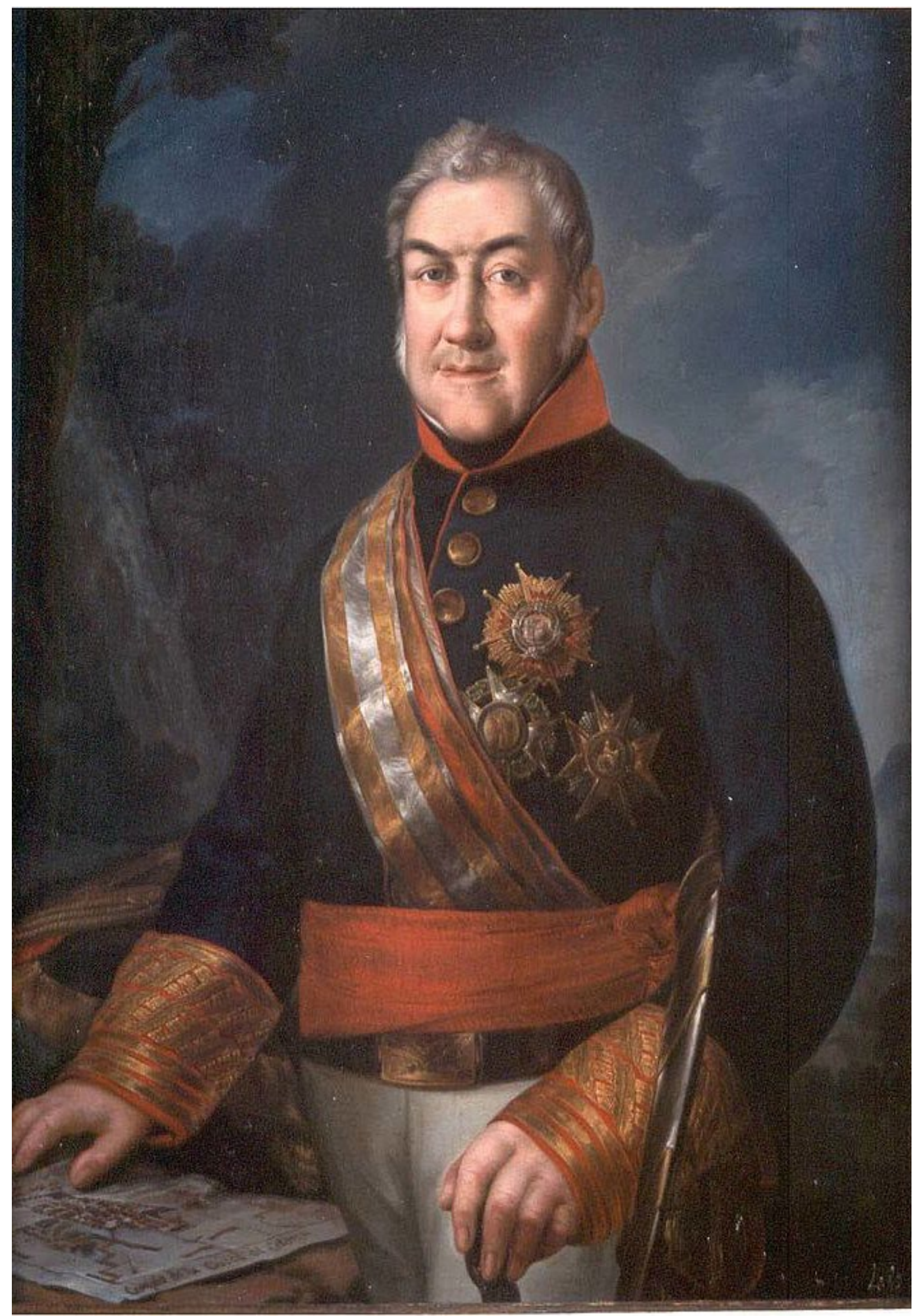

Fig. 5.88. Miguel Parra, José María de Santocildes, h. 1834, óleo sobre lienzo, Valencia, Real Academia de Bellas Artes de San Carlos. 
definitiva, se trataba de otro gesto significativo para mostrar la nueva condición del artista.

En este sentido, se debe tener en cuenta el retrato de Vicente Gascó Massot (1734 - 1802) [fig. 5.89] que siguiendo el inventario de 1797 respondía a la siguiente descripción: «N. 74. Otro retrato de marco corlado y remate de talla, de igual magnitud al antecedente que representa a don Vicente Gascó, director actual de arquitectura, obra de don Josef Zapata por la que se le creó académico de mérito el año $1798 .{ }^{145}$ Este ingeniero y arquitecto fue uno de los promotores de la enseñanza de la arquitectura en San Carlos y ostentó la dirección de esta escuela entre 1776 y 1779. Además, también fue miembro académico de San Fernando. José Antonio Zapata (1762 - 1837) lo ha retratado sedente en un elegante sillón de terciopelo carmesí, con un vestuario oscuro pero influido por el gusto francés tal y como se aprecia a través de la camisa ornamentada por una chorrera y puños de encaje. Además, lleva la típica peluca de 624 cabello blanco y bucles. Se dirige hacia el espectador con un rostro altamente detallista. El compás que sostiene en la mano izquierda y el libro de gran formato de Vitrubio dedicado a la arquitectura manifiestan su identidad profesional. Este es un nuevo ejemplo de retrato que ha servido como obra de recepción para ascender en la estructura de la academia.

El retrato de Ignacio Vergara [fig. 5.90] fue elaborado por José Vergara después de su fallecimiento acaecido el 14 de abril de 1776. Tan sólo dos años antes, en la junta de 23 de octubre de 1774 se le había jubilado con todos los honores y sueldo. ${ }^{146} \mathrm{El}$ inventario de 1797 ha recogido lo siguiente: «N. 75. Otro retrato con marco dorado y remate de talla, igual en tamaño al antecedente que representa a don Ignacio Vergara, hecho por su hermano don Josef, el que le presentó a la academia en prueba de su gratitud, y para la memoria de aquel distinguido profe145 ARABASC: Inventario de las pinturas y dibujos de la Academia de San Carlos (1797-1815)..., s/f.

146 ARABASC: Extracto de Juntas Particulares: 1765-1827, p. 14. 


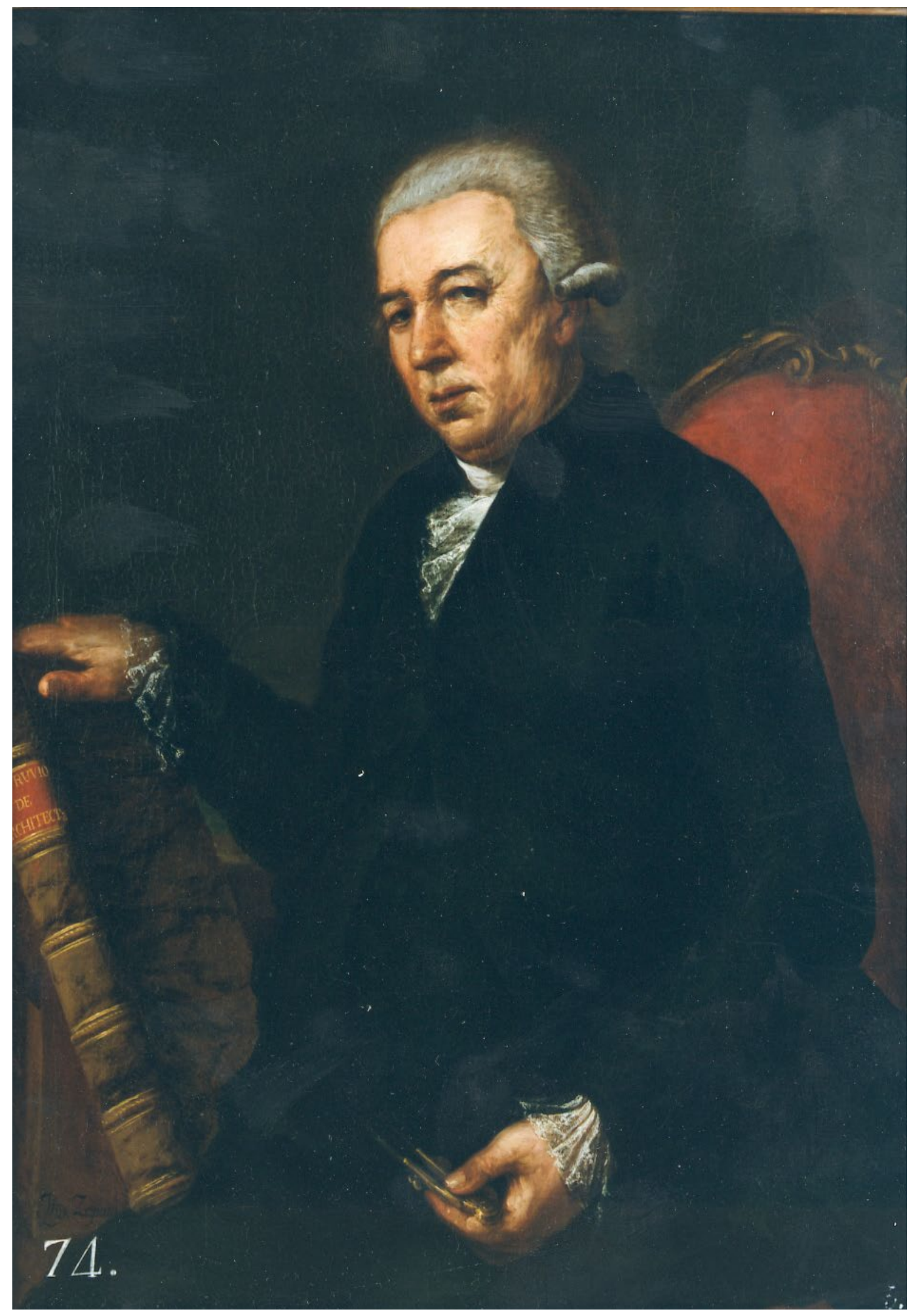

Fig. 5.89. José Zapata Nadal, Vicente Gascó Massot, 1798, óleo sobre lienzo, Valencia, Real Academia de Bellas Artes de San Carlos. 


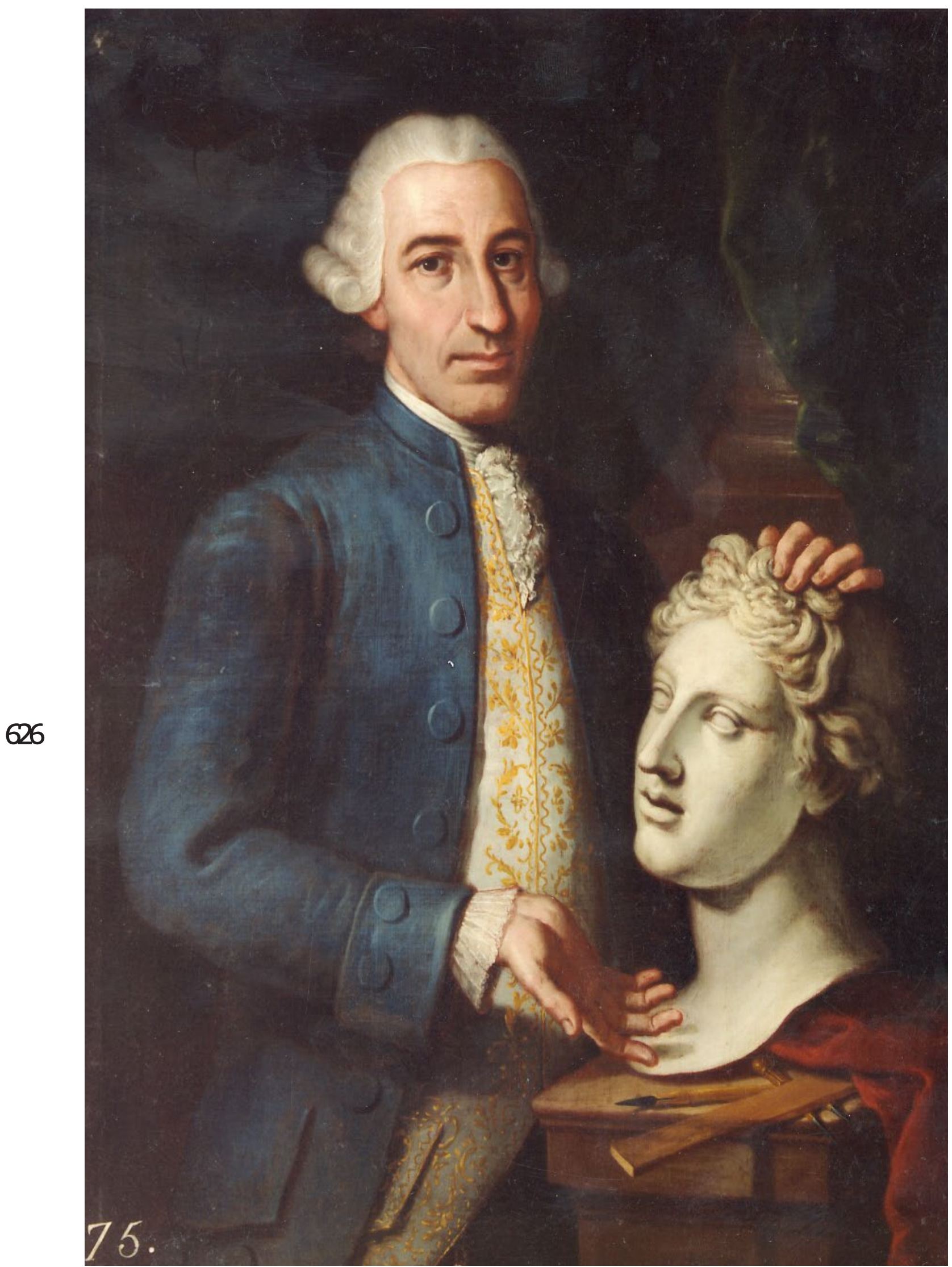

Fig. 5.90. José Vergara, Ignacio Vergara, 1798, óleo sobre lienzo, Valencia, Real Academia de Bellas Artes de San Carlos. 
sor el año 1798.»147 Por tanto, se trata de un nuevo ejemplo de retrato donado con la intención de perpetuar la memoria de este artista. Además, se conoce que la obra fue pintada de memoria tal y como se especificó en la junta de 28 de noviembre de $1798 .{ }^{148}$

El retrato casa con la tipología de efigies que tenían por finalidad reivindicar la profesión del artista. En efecto, aparece representado con una cabeza marmórea y varias herramientas de su trabajo, como el cincel, para dejar constancia de que la escultura fue la disciplina que trabajó. También se ha vestido con un elegante atuendo compuesto de una casaca azul, una chupa con bordados dorados, camisa con chorrera y puños de encaje, a lo cual debe sumarse la actitud noble del retratado. Todo ello habla de la nueva situación, consideración social y modo de trabajo del pintor, donde con motivo del surgimiento de las academias los gremios quedaron obsoletos. Aparte de este retrato, en el Instituto Amatller se ha encontrado la imagen de un pequeño lienzo o quizás un boceto de esta efigie relacionable con el estilo de Vergara. ${ }^{149}$

El mismo año que José Vergara donó la efigie de su hermano también presentó un autorretrato [fig. 5.91] con las mismas características formales que la obra anterior y de composición prácticamente simétrica, ello ha invitado a pensar que se tratase de una pareja de retratos. Asimismo, en este caso el artista igualmente sigue la moda de aire francés y se muestra junto a una paleta y varios pinceles relativos a su especialidad artística. Igualmente se ha incluido una regla y un compás para aludir al dibujo por ser la base de la pintura. En el inventario analizado se catalogó con la descripción siguiente: «N. 76. Otro retrato en todo igual al antecedente que representa a don Josef Vergara, hecho de su mano, como el anterior y pre147 ARABASC: Inventario de las pinturas y dibujos de la Academia de San Carlos (1797-1815)..., s/f.

148 Dato aportado por Catalá Gorgues, El pintor y académico José..., p. 208.

149 Gimilio Sanz, 'José Vergara Gimeno y la retratística...', p. 82. 


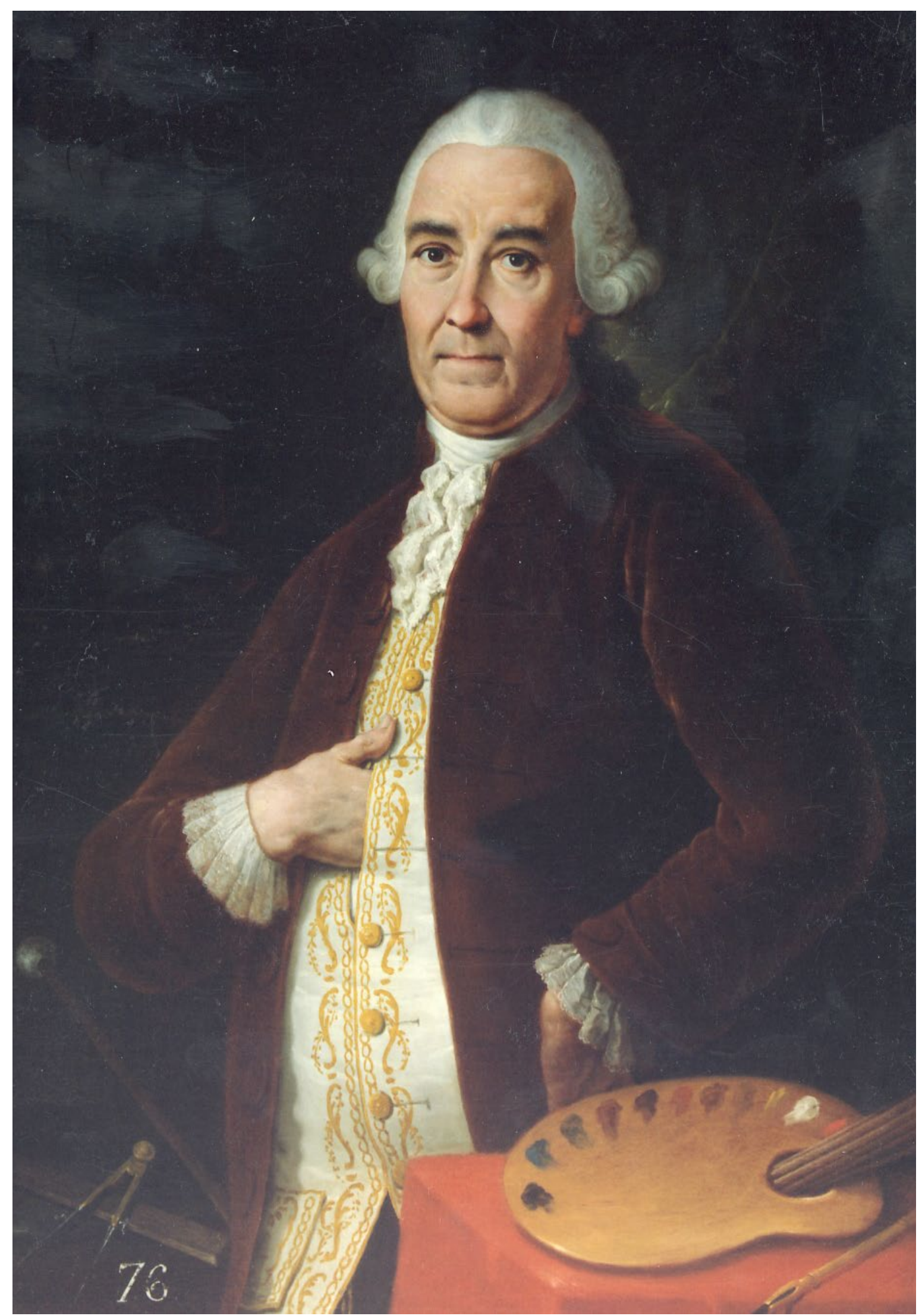

Fig. 5.91. José Vergara, Autorretrato, 1798, óleo sobre lienzo, Valencia, Real Academia de Bellas Artes de San Carlos. 
sentó en 1798.»150 Una imagen similar se conserva en la Real Academia de Bellas Artes de San Fernando, donde aparece con el cuerpo casi de perfil, dirigiendo la mirada hacia el espectador, vestido a la francesa y sosteniendo la paleta y los pinceles.

En el inventario de 1797 también se registró la ejecución del retrato del escultor José Esteve Bonet (1741 - 1802) [fig. 5.92], quien fue miembro académico de mérito y además dirigió la rama de escultura, para esta tarea fue propuesto en la junta particular de 11 de febrero de 1785 tras la jubilación de Jaime Molins. ${ }^{151}$ Sin embargo, la descripción del documento ha remarcado su faceta de director general, cargo que desempeñó en 1781: «N. 97. Un retrato de tres y cuatro palmos igual a los de demás de la sala con marco corlado y remate que representa a don Josef Esteve, director que fue de esta academia, y le pintó en Madrid su primo don Agustín Esteve y regaló a esta academia su esposa doña Josefa Vilella.»152

José Esteve ha sido retratado de medio cuerpo, sedente y luciendo ropajes de aire francés. No se ha incluido ninguna herramienta de trabajo que aluda a la disciplina artística trabajada por el efigiado. Sin embargo, el inventario también ha especificado que se trata de un retrato pintado en Madrid, concretamente durante la época en la que Esteve fue escultor honorario de cámara de Carlos IV, responsabilidad que asumió en 1790. Esta idea se corrobora con la propia imagen, pues en el documento que sostiene José Esteve se ha dejado constancia de su cargo y del autor del retrato mediante la siguiente inscripción: «Don José Esteve, escultor de cámara. Por su primo Agustín Esteve.» Cuando Agustín Esteve Marqués (1753 - 1820) pintó a su familiar ambos se localizaban en Madrid, José por

150 ARABASC: Inventario de las pinturas y dibujos de la Academia de San Carlos (1797-1815)..., s/f.

151 ARABASC: Extracto de Juntas Particulares: 1765-1827, pp. 23-24.

152 ARABASC: Inventario de las pinturas y dibujos de la Academia de San Carlos (1797-1815)..., s/f. 


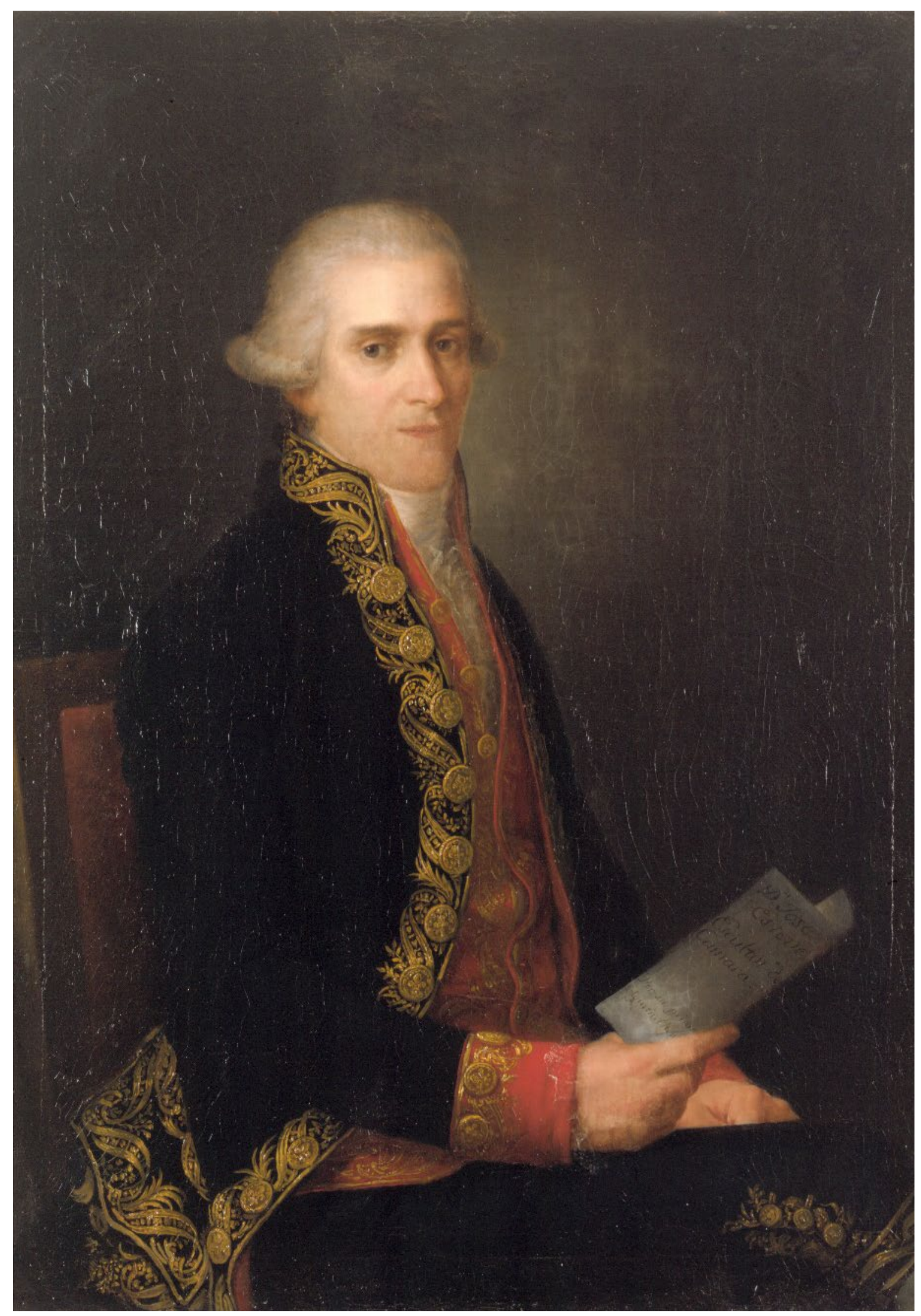

Fig. 5.92. Agustín Esteve, José Esteve Bonet, h. 1790, óleo sobre lienzo, Valencia, Real Academia de Bellas Artes de San Carlos. 
haber conseguido trabajar para el rey y Agustín porque desde 1770 se había vinculado a la academia de San Fernando, aunque previamente se había formado en San Carlos. Esta obra, por tanto, se debe considerar un retrato de carácter privado que representó a José Esteve en el punto álgido de su carrera profesional y que perteneció a su familia. Cabe suponer que su esposa Josefa Vilella regaló la obra a la academia a raíz del fallecimiento del escultor en 1802 con la intención de honrar la memoria del artista.

Otro retrato a tener en cuenta es el de Cristóbal Valero (1707 1789), quien participó en el nacimiento de la academia de Santa Bárbara y que más tarde, formó parte de San Carlos donde dirigió tanto la escuela de pintura como la institución en general. Así pues, se ha catalogado su efigie en el inventario de 1797: «N. 99. Un retrato igual a los demás que hay en la sala con su marco dorado y remate que representa a don Cristóbal Valero, presbítero, director que fue de pintura de esta y el primer director general.»153 En su imagen, cuyo autor se desconoce por el momento, impera la austeridad. Tan sólo se aprecia su figura de medio cuerpo recortada sobre un fondo neutro y trabajando con un carboncillo. En este caso en concreto, no hay rastro de la nobleza y suntuosidad propia de los retratos de otros artistas, quizás sea consecuencia de su doble perfil profesional, presbítero y pintor.

Manuel Monfort Asensi (1736 - 1803) [fig. 5.93], hijo del afamado impresor Benito Monfort fue un artista especialmente implicado en la creación, tanto de la academia de Santa Bárbara como de San Carlos. Durante la breve vida de la primera se convirtió en académico de mérito. Seguidamente conviene recordar que marchó a Madrid a presentar un Memorial entregado en la academia madre y que ésta intercediese con el rey para conseguir así su beneplácito y abrir esta institución en tierras valencianas. Fue entonces cuando viendo, además,

153 ARABASC: Inventario de las pinturas y dibujos de la Academia de San Carlos (1797-1815)..., s/f. 


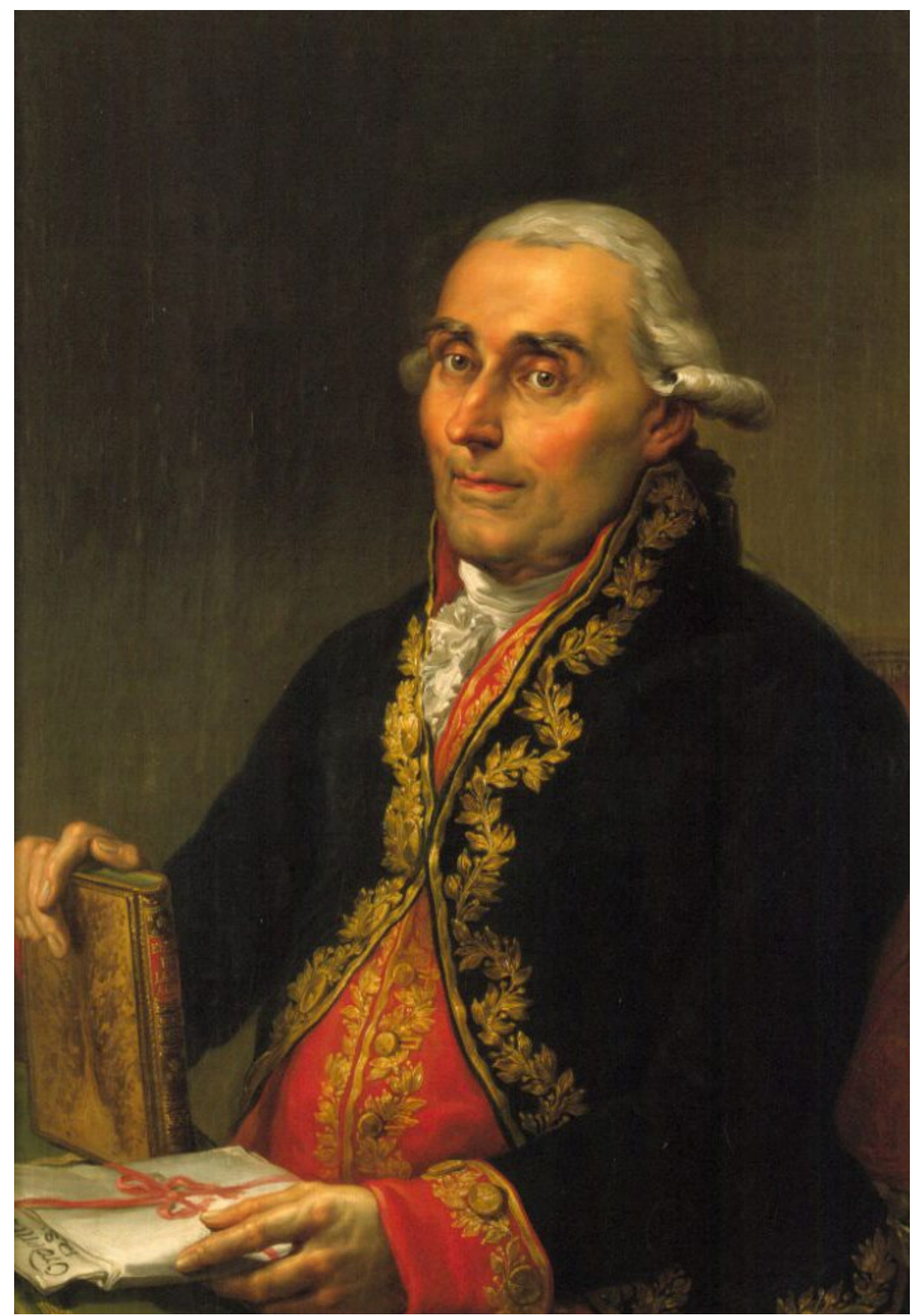

Fig. 5.93. Vicente López, Manuel Monfort Asensi, h. 1803, óleo sobre lienzo, Valencia, Real Academia de Bellas Artes de San Carlos. 
la valía de sus obras obtuvo el título de académico de mérito en San Fernando. ${ }^{154}$ Lo mismo les sucedió a Ignacio y José Vergara y Cristóbal Valero, quienes junto a Monfort presentaron sus obras en 1762 ante la academia fernandina con el objetivo último de mostrar la valía de los artistas valencianos y justificar la creación de una sede en la ciudad levantina. Todos ellos, en esta ocasión, fueron designados académicos de mérito en sus respectivas especialidades y se les concedió la antigüedad académica de 1754.

De nuevo en Valencia, el 11 de marzo de 1765 Monfort fue nombrado director de la rama de grabado, siendo el primero en esta categoría que tuvo la institución. Por esta razón, su imagen es una más en la colección de directores y se registró en el inventario de 1797: «N. 103. Un retrato de marco dorado y remate que representa al difunto don Manuel Monfort, pintado por don Vicente López y regaló a esta academia su sobrino don Manuel.»155 Manuel Monfort Roda, sobrino carnal y heredero de los bienes del afamado grabador fue quien donó la efigie de su familiar a la institución como ha sucedido en numerosas ocasiones. López lo ha representado vistiendo una casaca y una chupa con ricos bordados en oro y además lleva una camisa con chorrera. Entre las manos se le ha colocado un legajo de documentos donde tan sólo se llega a leer la palabra «órdenes». Deben ser las órdenes reales que aprobaban la puesta en marcha de la academia y designaban a los primeros directores para cada una de sus ramas. Además, sostiene un libro, que quizás pueda tratarse de los estatutos de la academia, pues Monfort fue miembro de la comisión encargada de redactarlos y así dotar de un marco reglamentario a la institución. De este modo, el retrato indica que el grabador fue un personaje involucrado en los orígenes de la academia de San Carlos.

154 Véase a José Ignacio Catalán Martí, 'Un documento inédito para la biografía del grabador valenciano Manuel Monfort y Asensi', Ars Longa: cuadernos de arte, no. 14-15, pp. 233-244.

155 ARABASC: Inventario de las pinturas y dibujos de la Academia de San Carlos (1797-1815)..., s/f. 
En una actualización fechada a 12 de febrero de 1822 en el inventario de 1797 se dejó constancia de la realización de un retrato póstumo de Luis A. Planes (1745 - 1821) [fig. 5.94] por deseo de la academia: «N. 155. Un retrato del difunto D. Luis Antonio Planes, director de pintura, ejecutado por acuerdo de la academia por el director Miguel Parra, colocado dentro de un marco dorado.» ${ }^{156}$ El encargo de esta obra pensada para lucir en la sala de juntas fue una decisión tomada en la junta ordinaria de 13 de enero de 1822 a raíz de que Fernando Ximeno Planes, sobrino del fallecido, donase a la institución una colección de dibujos:

Se dio cuenta de un escrito de don Fernando Ximeno y Planes del difunto director don Luis Antonio Planes en que manifestaba, que habiendo quedado heredero de dicho sitio separó de su estudio una porción de dibujos ejecutados por él mismo de figura, medios cuerpos, cabezas, manos y principios, que ascendían al número de ochenta y ocho papeles los que ofrecía a la Academia en vista de la estimación con que siempre había considerado las obras de este profesor y deseando con ello contribuir a los progresos de los estudios del cuerpo. La Junta recibió y aceptó con el mayor gusto esta apreciable colección y a fin de manifestar a don Fernando Ximeno así el debido aprecio de su generosidad, como la digna memoria que conserva el distinguido mérito, dilatados e interesantes servicios de su tío el director don Luis Antonio Planes deliberó, que a más de darles expresivas gracias se costea por la academia el retrato de dicho profesor y que se coloque en la sala de juntas, y para ejecutar esta obra se nombró al director don Miguel Parra. ${ }^{157}$

Una vez más, se observa un caso en el que después de una donación de carácter privado, en agradecimiento se acuerda la elaboración de un retrato. Al ser una obra destinada a la academia de uno de sus artistas que desempeñó la labor de direc156 ARABASC: Inventario de las pinturas y dibujos de la Academia de San Carlos (1797-1815)..., s/f.

157 ARABASC: Libro de Actas de la Real Academia de San Carlos: 18211827, junta ordinaria de 13 de enero de 1822. 


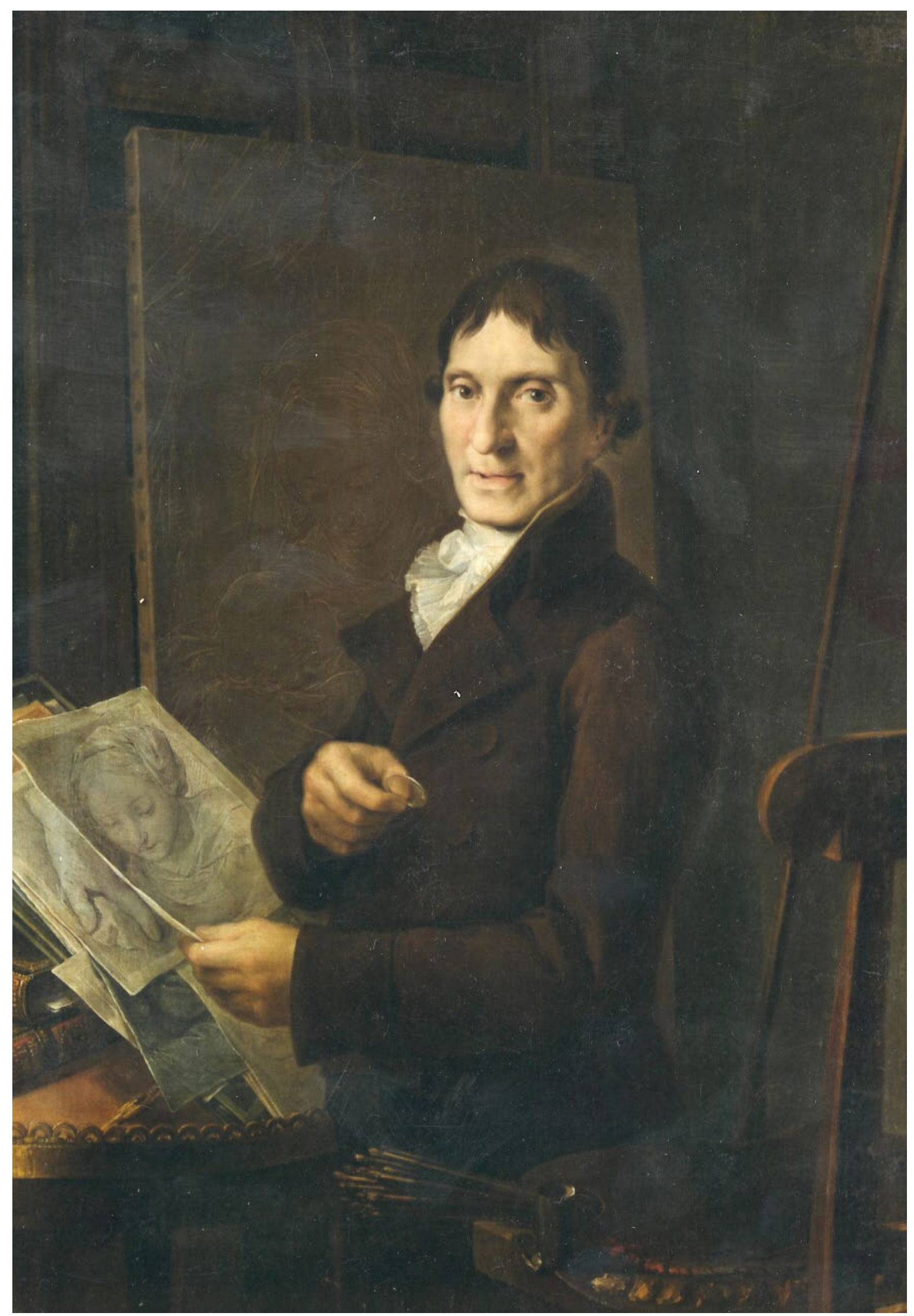

635

Fig. 5.94. Miguel Parra, Luis Antonio Planes, 1822, óleo sobre lienzo, Valencia, Real Academia de Bellas Artes de San Carlos. 
tor, Planes ha sido representado inmerso en el trabajo, concretamente estaba estudiando una serie de bocetos para pintar lo que parece ser una Virgen con el Niño que ya ha sido bosquejada en el lienzo. En definitiva, la imagen recoge su identidad profesional como pintor, por ello no podían faltar los pinceles y la paleta tan recurrente en esta clase de retratos.

Vicente Marzo (1760 - 1826) [fig. 5.95], otro de los directores retratados, se formó en la academia de San Carlos en escultura y arquitectura, siendo esta segunda disciplina en la que más destacó. De hecho, se tienen noticias de que ganó varios premios de arquitectura. Por ejemplo, en 1776 consiguió el premio de arquitectura en el concurso general, concretamente en la categoría de segunda clase, donde rivalizó contra Nicolás Minguet y se llevó una recompensa económica de veinte pesos. ${ }^{158}$ También en 1780 obtuvo un premio similar pero ahora compitiendo en primera clase. En esta ocasión, no se presentó ningún otro aspirante así que tras valorar sus ejercicios, comprobar que habían sido abordados satisfactoriamente y realizarle algunas preguntas que supo responder como se esperaba, la junta decidió concederle el premio valorado en cuarenta pesos. ${ }^{159}$ Con el tiempo alcanzó a ser académico de mérito, director de arquitectura y general, este último cargo lo asumió en dos periodos diferenciados, 1802 - 1805 y 1812 - 1814. Las anotaciones del inventario fechadas el 1 de marzo de 1828 catalogaron su imagen del siguiente modo: «N. 192. Retrato de don Vicente Marzo, director de arquitectura que son de esta real academia, igual a los demás directores con marco dorado que regaló su hijo don Vicente Marzo, pintado por el director don Miguel Parra.» ${ }^{160}$ En consecuencia, el artista lo ha representado en su mesa de trabajo, repleta de planos y compás en mano. Otros objetos accesorios como una regla o un par de li-

158 Continuación de la noticia histórica..., pp. 27-37.

159 Continuación de la noticia histórica..., pp. 40-51.

160 ARABASC: Inventario de las pinturas y dibujos de la Academia de San Carlos (1797-1815)..., s/f. 


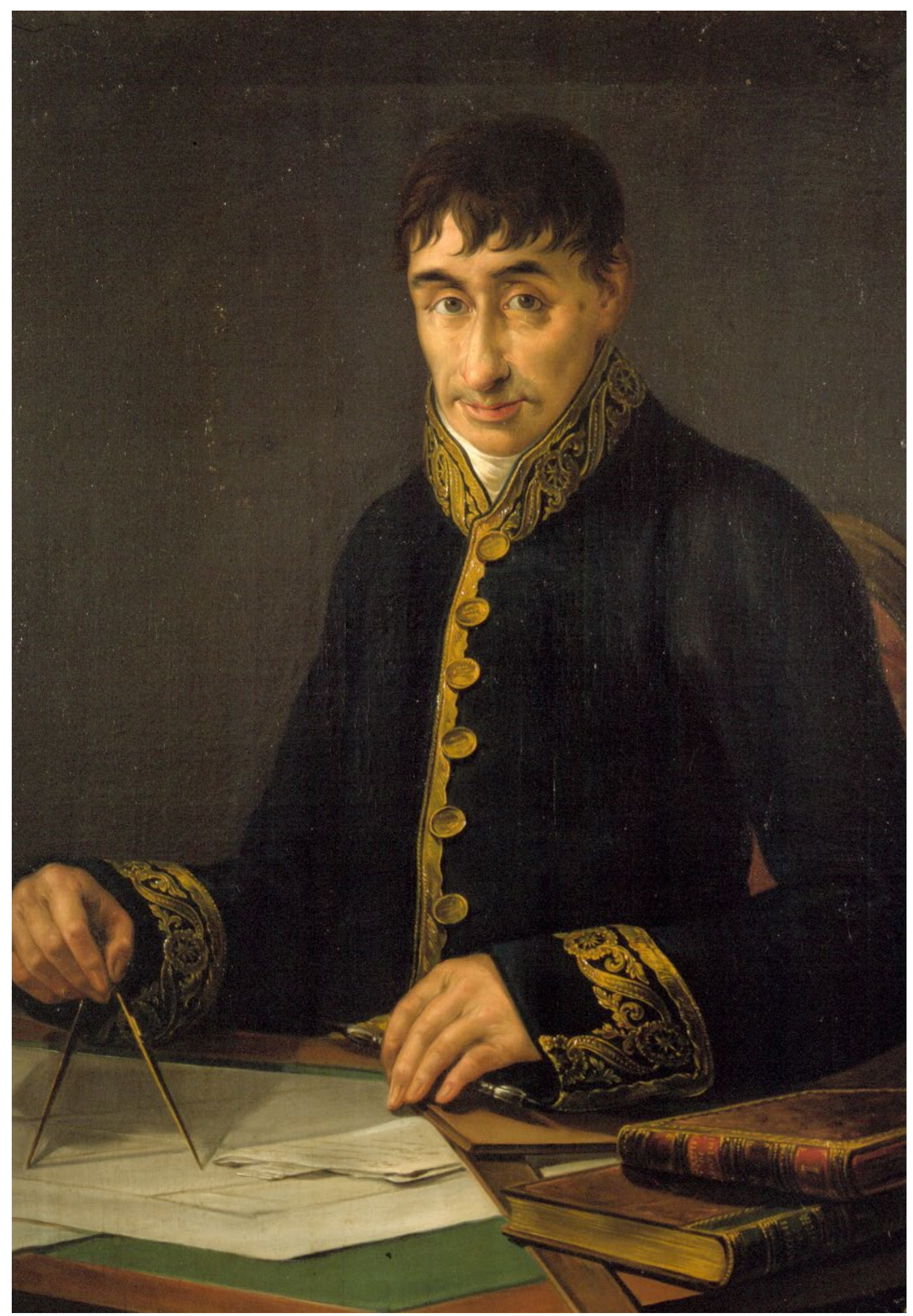

Fig. 5.95. Miguel Parra, Vicente Marzo, h. 1826, óleo sobre lienzo, Valencia, Real Academia de Bellas Artes de San Carlos. 
bros completan la imagen.

En la misma actualización del inventario que la obra anterior, se anotó la presencia de la efigie de Cristóbal Sales (1763 - 1806) [fig. 5.96], quien antes de convertirse en director ya había ganado el concurso general de pintura convocado en 1780 en la categoría de segunda clase y por el cual se le abonaron veinte pesos. ${ }^{161}$ La descripción recogida en el documento especifica lo siguiente: «N. 224. Retrato del director de arquitectura don Cristóbal Sales, que regaló su esposa e hijos a la real academia, obra del director [...] de flores y ornatos don [...] Zapata.»162

En sintonía con el resto de retratos, José Antonio Zapata ha retratado a Sales trabajando en un plano, rodeado de varios libros y un pequeño cuaderno con las actas de la junta de comisión de arquitectura, la cual se encargaba de todos los aspectos relativos a las construcciones públicas y de cuya junta era miembro por ser director de esta especialidad. ${ }^{163}$ El retrato de Sales es un ejemplo más de las donaciones privadas que los familiares del artista solían hacer a la academia para que la institución también velase por la memoria y fama del efigiado.

Uno de los retratos que se ha echado en falta por no constar en los inventarios analizados en esta ocasión es el de Benito Espinós (1748 - 1818) [fig. 5.97]. El registro de esta obra tan sólo aparece a partir del inventario de 1863, así que cabe suponer que la obra llegó a la academia después de 1842. Sin embargo, también se desconoce quién pudo realizar la donación. En cualquier caso, esta pintura encaja en el grupo de efigies que se acaban de tratar. Espinós se convirtió en el primer director 161 Continuación de la noticia histórica..., p. 49.

162 ARABASC: Inventario de las pinturas y dibujos de la Academia de San Carlos (1797-1815)..., s/f.

163 Colección de reales órdenes comunicadas a la Real Academia de San Carlos desde el año de 1770 hasta el de 1808, (Imprenta de Benito Monfort: Valencia, 1809), p. 77. 


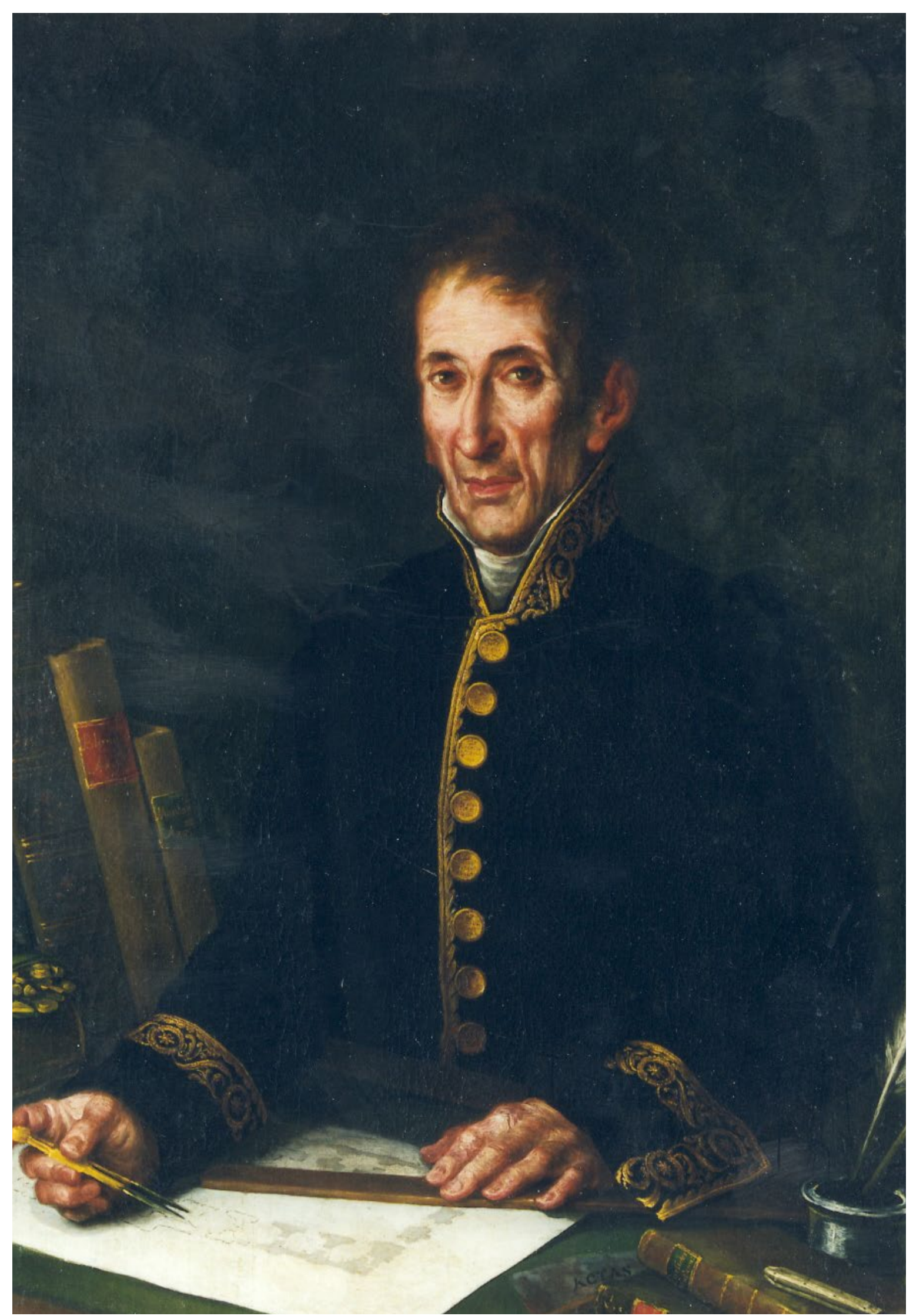

Fig. 5.96. José Zapata Nadal, Cristóbal Sales, h. 1806, óleo sobre lienzo, Valencia, Real Academia de Bellas Artes de San Carlos. 
de la clase de flores y ornatos aplicados a los tejidos cuando en 1778 se dio el visto bueno para abrir una nueva especialidad artística en San Carlos. Su nombramiento tuvo lugar el 30 de enero de 1784, el 6 de abril de 1815 se jubiló con todos los honores y sueldo y le siguió en el cargo José Antonio Zapata. ${ }^{164}$ Finalmente falleció el 23 de marzo de 1818. La efigie ha sido obra de José Romá (1784 - 1852) y el director se ha representado en el ejercicio de su trabajo. Con la paleta y el pincel en la mano, se dispone a continuar pintando el lienzo con flores que se observa en un segundo plano. Llama la atención el realismo con que ha sido retratado el académico, pues Romá no ha obviado un defecto ocular del artista cuando los teóricos del retrato de época moderna, como se ha comentado en su capítulo correspondiente, habrían optado por disimular este rasgo presentando a Espinós casi de perfil.

Algo similar al del retrato de Espinós sucede con la efigie de José Cloostermans [fig. 5.98], quien fue nombrado académico 640 supernumerario por la escultura en 1809 y director general entre 1836 y 1839. La efigie, pintada por Vicente Castelló (1787 -1860), representa al artista con casaca y camisa, mirando al espectador y apoyando su brazo izquierdo sobre un libro, debajo del mismo asoma un documento que identifica a la persona retratada. A su lado y en un segundo plano se ha dispuesto un relieve aludiendo así a la disciplina artística desempeñada por el artista.

Estas han sido los retratos que configuran esta colección de pinturas en la que los protagonistas son gran parte de los presidentes y directores que estuvieron al frente de la academia desde su creación hasta la primera mitad del siglo XIX. Para estudiar estas imágenes que, muchas de ellas y otras probablemente, decoraron la sala de juntas ha sido muy fructífero analizar diversos inventarios. Así se ha podido conocer el génesis y desarrollo de este conjunto, principalmente destinado a mostrarse ante otros miembros de la academia en sus

164 ARABASC: Libro de Individuos desde su creación. Extracto. 1768-1820. 


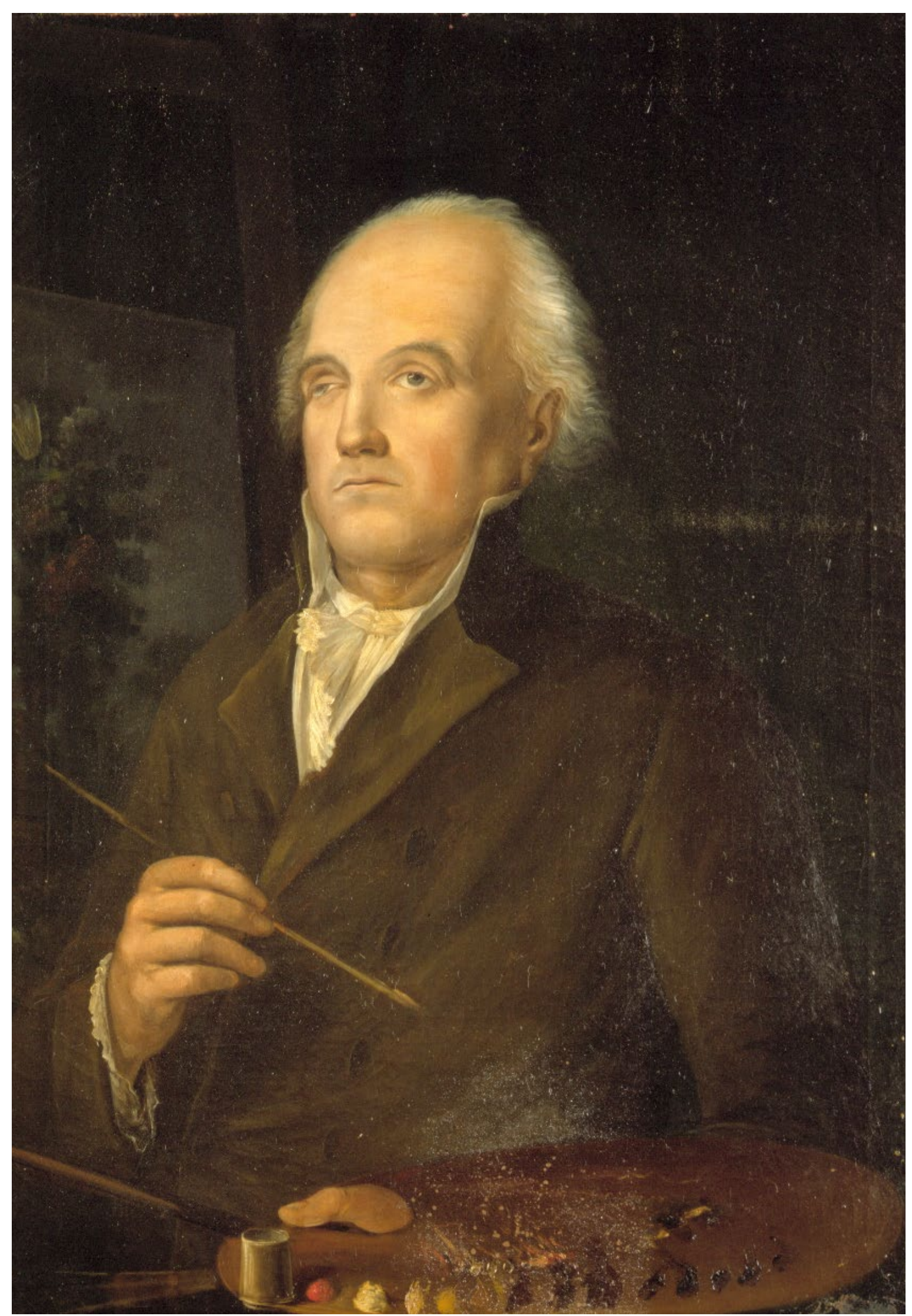

Fig. 5.97. José Romà, Benito Espinós, h. 1818, óleo sobre lienzo, Valencia, Real Academia de Bellas Artes de San Carlos. 


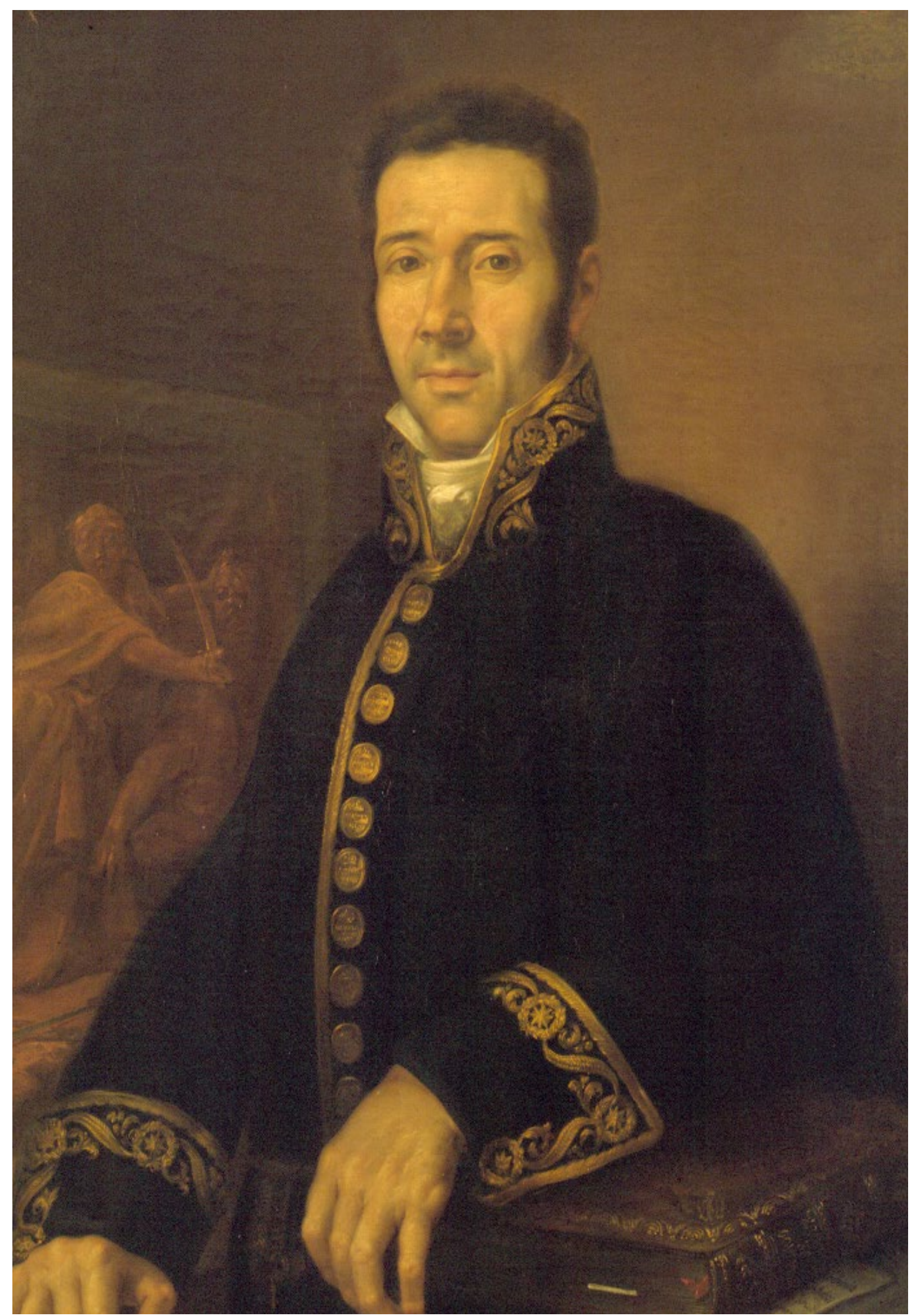

Fig. 5.98. Vicente Castelló, José Cloostermans, primera mitad del s. XIX, óleo sobre lienzo, Valencia, Real Academia de Bellas Artes de San Carlos. 
distintas reuniones. En sus comienzos, la institución tan sólo se preocupó de que este espacio estuviese presidido por el retrato del monarca reinante, pues la imagen desempeñaba una función protocolaria y simbólica que no se podía obviar. Más tarde, ya se comenzaron a introducir las primeras representaciones de presidentes y directores que de esta manera perpetuaban su fama. Especialmente interesante ha resultado observar las distintas vías por las que se fueron recopilando estas imágenes. En ocasiones, a raíz de la solicitud de un artista para conseguir un nombramiento, por lo general, de académico de mérito. Otras veces por ser una entrega de los familiares del efigiado. Y puntualmente, por ser un encargo de la propia institución en agradecimiento al legado del retratado.

\subsubsection{Retratos en la sala de juntas tras la desamortización. La llegada de conjuntos foráneos.}

El escrutar el inventario de 1842 ha sido importante porque aportan datos sobre la descomposición de la colección de retratos principalmente emplazada en la sala juntas y permiten conocer la nueva localización de muchas de las imágenes estudiadas. Este tráfico en la disposición de las pinturas de la academia, y en concreto de los retratos, probablemente fue fruto de la irrupción de una gran cantidad de obras artísticas procedentes de la desamortización que nutrieron sustancialmente los fondos de la institución. Además, cabe tener en cuenta que la facilidad con la que se movieron las efigies de presidentes y directores diseminándose por otras estancias avala la idea de que realmente no se pensó en crear y mantener una galería de retratos en su sentido convencional, es decir, en poseer un grupo de retratos que debía mostrarse unido porque de este modo adquiría su pleno sentido. Incluso las diferentes vías por las que se consiguieron los retratos, acabadas de tratar, también refuerzan esta idea.

Un inventario clave en este aspecto fue el realizado bajo el rei- 
nado de Isabel II (1833-1868) concretamente en $1842 .{ }^{165}$ Este documento ha clasificado las pinturas según la estancia en la que se encontraban, otorgando una nueva numeración y distinta de la de 1797 e independiente para cada sala. Así pues, en la mayor parte de los retratos analizados aún se puede ver que cuentan con dos numeraciones diferentes y son coincidentes con las escritas en la catalogación de 1797 y de 1842 respectivamente. Además de la sala y el número asignado a la pieza, se anotó el título, las medidas de la longitud y de la latitud y el autor en caso de conocerse.

Al valorar la tipología de retratos que engalanaban la sala de juntas se ha detectado un cambio sustancial respecto a épocas pasadas, y es que no consta ninguna de las efigies de presidentes y directores anteriormente analizadas. En este momento la colección de pinturas presente en la sala alcanzaba la cantidad de ciento cuatro piezas, entre las cuales casi una treintena de ellas eran retratos. Principalmente se trataban de efigies regias y algunos de los retratos de los varones ilustres procedentes de La Murta, pues cabe recordar que, a raíz del decreto de Fernando VII en 1820 para expropiar los bienes de monasterios y conventos, Borrull encabezó la tarea de conseguir las pinturas de La Murta para ser custodiadas y conservadas por la academia. Es significativo ver que las representaciones de estos hombres honorables y destacables en el pasado del Reino de Valencia dialogaban en la sala de juntas con un amplio repertorio de obras de arte.

De los retratos de la monarquía el primero en catalogar, lógicamente, fue el de la reina Isabel II pintado por Miguel Parra. Este mismo autor también realizó la efigie del predecesor de la reina, Fernando VII en calidad de capitán general. Junto a estas imágenes se encontraban los retratos de Fernando VI, de Isabel de Borbón, de Carlos IV pintada por Vicente López, de Carlos III realizada por José Vergara y de Mâ Luisa de Borbón 165 ARABASC: Inventario de los efectos artísticos, alhajas y demás existentes en la Academia de Nobles Artes de San Carlos, practicado el 1 de junio de 1842, Archivo 146, s/f. 
de Agustín Esteve. El único ejemplo de retrato regio que estaba en la sala de juntas y no pertenecía a la dinastía Borbón era una representación de Felipe II hecha por Antonio Moro, un claro ejemplo de retrato cortesano. Cabe destacar que además de las efigies de monarcas y de varones ilustres, también se colgaron otras obras relevantes para el mundo de las Bellas Artes, como el retrato de Sánchez Coello cuyo autor no se ha indicado, el de Murillo pintado por Velázquez y el autorretrato de este último artista.

La mayor parte de los retratos de presidentes se localizaron en el recibidor, donde había un total de cincuentaisiete pinturas. Entre ellas se hallaron las efigies de Joaquín Pareja y Obregón (no 53), ${ }^{166}$ Francisco Xavier Azpíroz (no 7), Jorge Palacios ( $\mathrm{n}$ 은 49), Cayetano de Urbina ( $\mathrm{n}$ ㅇ 8), Idelfonso Díez de Ribera ( $\mathrm{n}$ 은 14), Felipe Augusto de Saint-Marcq ( $n \circ$ 43), Luis Alejandro Bassecourt (no 11), ${ }^{167}$ José María de Carvajal y Urrutia (no 44), ${ }^{168}$ José O’Donnell (no 10), Francisco Tomás Anchía o Francisco Longa ( $n \circ$ 13), el vicepresidente Nicolás Máñez (nํ46) y José María de Santocildes (no 41). La colección estaba parcialmente completa a falta de los retratos del vicepresidente Antonio Pascual y de Francisco Plasencia, sin embargo, en el inventario tampoco se ha registrado el lugar en el que se encontraron. Respecto a las efigies de los directores que en origen comple-

166 De ahora en adelante, entre paréntesis se indica el número asignado en el inventario de 1842 en este caso alusivo a las pinturas ubicadas en el recibidor.

167 En el inventario se especifica lo siguiente: «№ 11. Idem del Señor Veracruz, longitud de 3 palmos y 8 dedos latitud de 2 palmos y 10 dedos.» Esta descripción debe corresponderse con el retrato de Bassecourt pues el lienzo se ha numerado con el 181 referente al documento de 1797 y el 11 que debe ser el inventario de 1842.

168 Es probable que exista un error en el inventario de 1842, pues el lienzo de Carvajal y Urrutia ha sido numerado con el 193 relativo al inventario de 1797 y el 44 referente al de 1842. Sin embargo, la descripción recogida en este segundo documento lo identifica con la imagen de Bassecourt: «Retrato de Bassecourt, longitud de 3 palmos y 8 dedos, latitud 2 palmos y 10 dedos. Autor Parra.» 
taban el conjunto, éstas se distribuyeron en diferentes salas según el perfil profesional de cada personaje. Por ejemplo, la sala de arquitectura estaba ornamentada por catorce pinturas y entre ellas se ubicaban los retratos de Cristóbal Sales (nํ 4), de Vicente Gascó (no 5) y de Vicente Marzo (no 6). Además, en este lugar lógicamente también se dispuso la efigie de Pedro Caro, marqués de La Romana. Cabe recordar que fue uno de los primeros académicos que dispuso de su retrato en la sala de juntas y que además estaba situado justo arriba del proyecto arquitectónico que presentó para convertirse en académico de mérito. La sala del natural, perteneciente al nivel más elevado de las clases de pintura y escultura, lucía con veinticinco pinturas entre las cuales se situaron los retratos de José

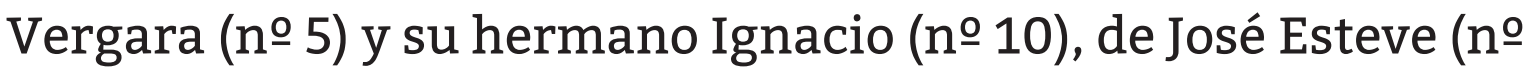
11), de Manuel Monfort ( $n$ 을) y de Luis Planes (no 25). No obstante, el retrato de Cristóbal Valero ( $\mathrm{n}$ ㅇ 45) se localizaba en el archivo.

646 El cambio en la ubicación de los retratos después de la desamortización y por tanto, del importante incremento de obras artísticas en los fondos de la academia, muestra la valoración que se dio a las pinturas recogidas. Ejemplo de ello, ha sido que se dispusiesen las efigies de insignes varones valencianos encargadas por Diego de Vich en la sala de juntas de la academia para que por un lado, hombres relevantes del pasado fuesen un referente para aquel que los contemplase y por otro lado, para ser testimonio de la importante responsabilidad que tenía la academia de ser, además, la institución que vela por la pervivencia del patrimonio histórico y artístico. 
Retratos de hombres ilustres 


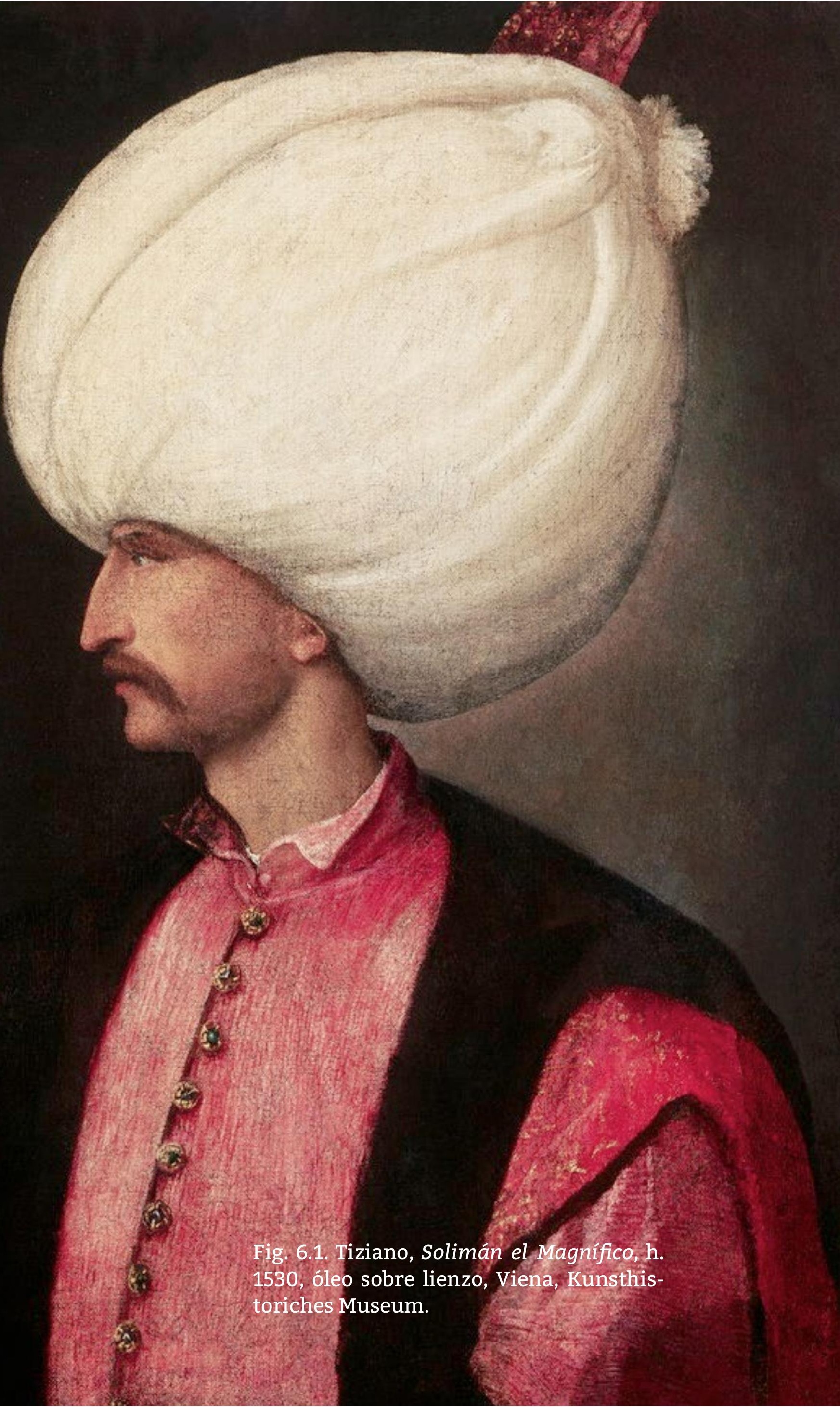




\section{Capítulo 6}

\section{Un caso particular. Retratos de turcos en el Real Colegio Seminario del Corpus Christi.}

Después de haber estudiado diferentes conjuntos de retratos de cariz monárquico, eclesiástico o ilustre conviene centrar la atención en otra galería pictórica que pese a no encajar en los capítulos anteriores también merece ser valorada. Su principal interés ha recaído en emplear el retrato para dar visibilidad a personajes orientales, hombres de religión distinta y considerados una amenaza europea. Las series ya estudiadas eran compilaciones de imágenes de personas que ostentaban algún tipo de autoridad o poder y que suponían un ejemplo a seguir para el resto de la sociedad. Algunas similitudes puntuales se aprecian en la galería que se va a tratar a continuación. Las efigies de tipos orientales retratan tanto a gobernantes, consejeros y guerreros como a mercaderes, así pues, se identifican en el enemigo aquellos hombres con poder gubernamental, militar y espiritual, además de mostrar algunos de los distintos roles de la sociedad. ${ }^{1}$

1 Una nueva lectura sobre la galería y síntesis de este capítulo fue compartido en el XX Congreso Nacional de Historia del Arte que tuvo lugar en Toledo durante 2014. Disponible en Cristina Igual Castelló e Inmaculada Rodríguez Moya, 'Sultanes, guerreros y mercaderes. Tipos orientales en el Real Colegio Seminario del Corpus Christi de Valencia', en Esther Almarcha Núñez-Herrador, Palma Martínez-Burgos García, y Maria Elena Sainz Magaña (eds.), El Greco en su IV Centenario: Patrimonio Hispánico y diálogo intercultural, (Ediciones de la Universidad de Castilla-La Mancha: Toledo, 2016), pp. 487-505. 
La existencia de este conjunto es sintomática de la atención suscitada en Occidente por conocer el alcance del imperio otomano, un interés más intenso tras el gobierno de Solimán el Magnífico (1520 - 1566) [fig. 6.1]. De hecho, el Gran Turco era muy conocido en Europa ya que su poder resultaba equiparable al de su principal rival, Carlos V. Así, tanto Solimán como el rey francés Francisco I promovieron los ataques de los piratas berberiscos a las costas e islas hispánicas, italianas y africanas. ${ }^{2}$ Por ello, a partir del siglo XVI fue trascendente la publicación de numerosos libros de viajes a Oriente, de crónicas que describían militar y socialmente al imperio otomano y de los compendios de indumentaria que, entre otras culturas, mostraban la manera de vestir de los llamados turcos. Todas estas fuentes fueron empleadas por los artistas para elaborar retratos de diversos personajes orientales. La finalidad última de los escritos y de las imágenes que circularon por Europa era conocer minuciosamente al enemigo. Pensaban que si entendían su estructura social, su ejército, sus costumbres y estilo 650 de vida, estarían más preparados para enfrentarse a él. Sin embargo no se debe olvidar que la fijación hacia lo turco persistió incluso durante el siglo XVII, ya que la victoria cristiana en la batalla de Lepanto (1571) alimentó el deseo de conocer al abatido adversario. ${ }^{3}$

2 Son numerosos los estudios que analizan el interés de Occidente por conocer Oriente. En este sentido, se ha consultado a José Julio García Arranz, 'Entre el miedo y la oscuridad: tendencias y variantes en la imagen europea del turco durante los siglos XV y XVI', en Fiestas y mecenazgo en las relaciones culturales del Mediterráneo en la Edad Moderna, (Universidad de Málaga: Málaga, 2012), pp. 231-260; Miguel Ángel Bunes Ibarra, 'El imperio otomano y la intensificación de la catolicidad de la monarquía hispana', AHIg, Vol. 16, 2007, pp. 157-167; Miguel Ángel Bunes Ibarra, 'La conquista turca de Bizancio según los cronistas europeos de los siglos XVI y XVII', Erytheia, Vol. 13, 1992, pp. 89-102.

3 Víctor Mínguez Cornelles, Infierno y gloria en el mar: los Habsburgo y el imaginario artístico de Lepanto (1430-1700), (Servicio de Publicaciones, 2017); Víctor Mínguez Cornelles, 'Iconografía de Lepanto. Arte, propaganda y representación simbólica de una monarquía universal y católica', Servicio de Publicacións e Intercambio Científico da Universidade de Santiago de Compostela, Obradoiro de historia moderna (Ejemplar dedicado 
Denominar con el término de "turco» a sociedades orientales es una categorización simple a consecuencia de dos cuestiones principales. La primera de ellas, es el incierto origen de esta cultura y la lectura que la historiografía occidental tradicionalmente ha hecho de ella. Se les ha presentado como musulmanes ubicados en Oriente desde la época de las cruzadas $\mathrm{y}$, por tanto, eran asiáticos que seguían el islam. La segunda responde a identificar y focalizar los ataques en un único peligro para el cristianismo. Por esta razón, se conocen textos hispánicos del siglo XVI que afirmaban lo siguiente: «los turcos son vasallos de la religión musulmana de los estados de la Casa de Osmán que conviven junto a personas de nación griega, hebrea y cristianos cautivos. ${ }^{4}$ " La principal diferencia entre los turcos y el resto de musulmanes, era que los primeros dependían de un soberano. Los escritos de época moderna justificaban su anexión al islam con el hecho de que así era legítimo emplear las armas para defender la religión, y ello conjugaba excelentemente con su personalidad belicosa. En cuanto a la denominación de las pinturas, tradicionalmente, se han hablado de ellas como retratos de turcos para referirse a los distintos personajes, unos pertenecientes al seno de la sociedad otomana y otros autóctonos de territorios que también rendían tributo al sultán turco. Este mismo término se seguirá empleando a lo largo de capítulo para mencionar a los hombres efigiados.

Además, cabe tener en cuenta que muchas de las obras redactadas en la época fueron hechas por religiosos católicos y por

a: Poder, imagen, opinión pública y propaganda en la Edad Moderna),no. 20, 2011, pp. 251-280; Víctor Mínguez Cornelles, 'Lepanto en los virreinatos americanos', en Rafael López Guzmán, Yolanda Guasch Marí, y Yolanda Romero Sánchez (eds.), América: cultura visual y relaciones artísticas, (Granada, 2015), pp. 175-182.

4 Fernando Fernández Lanza, 'Los turcos y lo turco a través de los impresos y manuscritos hispanos del siglo XVI. Propaganda y silencio', in Manuel (coord.) Casado Arboniés (ed.), Escrituras silenciadas en la época de Cervantes, (Universidad de Alcalá, Servicio de Publicaciones: Alcalá de Henares, 2006), pp. 75-96. 
tanto, los adjetivos calificativos que se asociaban a los turcos eran totalmente contrarios a sus valores. ${ }^{5}$ Pero las connotaciones negativas no sólo se encontraban en los textos cuyos autores eran cristianos, sino que también persistían en la definición oficial que Covarrubias dio de esta palabra: «TURCO, esta nación es más conocida de lo que habíamos menester, por haber venido a señorear tan gran parte del orbe, gente baja y de malas costumbres, que vivían de robar y maltratar a los demás.[...]" ${ }^{6}$ Así, se entiende que se denominaba turco a todo aquel vinculado, por diversas razones, al imperio otomano, cuya religión era el islam y que a consecuencia de la voluntad del sultán de expandir sus dominios y practicar una religión distinta ya eran etiquetados con un sinfín de adjetivos negativos.

Con esta realidad en la que existía un deseo por conocer la cultura oriental en Europa hay que relacionar la galería de retratos que se estudia en este capítulo.7 Se trata de un conjunto, localizado en el Real Colegio Seminario del Corpus Christi, exótico y particular que, por el momento, no se puede vincular a otros grupos pictóricos de similares características en el medio valenciano. Como resultado de ello, el presente capítulo a diferencia de los anteriores tan sólo recoge el análisis de un conjunto de efigies que igualmente debe estudiarse por su singularidad e importancia para la época. Pero antes de comentar en detalle las piezas de la referida serie conviene, detenerse en conocer las fuentes escritas occidentales que ofrecían los datos oportunos para crear el imaginario turco. De este modo es posible comprender a través de los retratos

5 Fernández Lanza, 'Los turcos y lo turco...'.

6 Sebastián de Covarrubias, Tesoro de la lengua castellana o española, (Imprenta de Luís Sánchez: Madrid, 1611).

7 El interés por el tema turco u oriental durante la Edad Moderna no se aprecia tan sólo en la pintura, sino también en las obras teatrales de la época. Consúltese la tesis doctoral de Mehmet Sait Sener, 'El tema turco en el teatro español de los siglos XVI - XVII', Universidad Complutense de Madrid, 2017. 
analizados cómo las imágenes dieron visibilidad a las ideas, concepciones y opiniones que en Occidente se formaron del mundo oriental.

\subsection{Crónicas de viajes y catálogos de indumentaria: la fuen- te visual de los retratos.}

La concepción visual y escrita que se difundió acerca de la sociedad turca desde el siglo XVI se puede entender al valorar las obras de tres autores principales; Nicolás de Nicolay, Césare Vecellio y Jerónimo Román. ${ }^{8}$ Las obras se complementaron unas a otras, pues mientras que en las dos primeras adquirieron un mayor protagonismo las imágenes, la tercera era interesante por sus minuciosas descripciones que definieron exhaustivamente la organización social y militar del imperio. ${ }^{9}$ Estos escritos, en síntesis, proporcionaron una visión común acerca de este contrario del cristianismo. El enfoque, de cariz negativo, manifestó que los turcos eran hombres con una ex-

8 Las siguientes fuentes escritas han sido clave para el desarrollo de este tema. Véase a Nicolás de Nicolay, Les quatre premiers livres des navigations et pérégrinations orientales, (Lyon, 1567); Jerónimo Román, Repúblicas del Mundo divididas en XXVII libros, (Medina del Campo, 1595); Cesare Vecellio, Habiti antichi, overo raccolta di figure delinéate dal Gran Tiziano, e Cesare Vecellio suo fratello, diligentemente intagliate, conforme alle Nationi del Mondo, (Venecia, 1664).

9 Otras fuentes escritas empleadas para conocer la organización social y la capacidad militar del imperio turco ha sido las siguientes: Antonio Herrera y Tordesillas, Crónica de los Turcos: la cual principalmente sigue a la que escribió Juan María Viçentino, cronista de Mahometo, Bayasit y Suleyman, (1565); Gonzalo de Illescas, Historia pontifical y católica, en la cual se contienen las vidas y hechos notables de todos los Sumos Pontífices Romanos: con más una breve recapitulación de las cosas de España y de la descendencia de los Reyes de ella, (Madrid, 1613); El libro de Illescas es especialmente útil para localizar narraciones sobre los pasajes de guerra protagonizados por Solimán. Vasco Díaz Tanco, Palidonia de los Turcos, (Diputación Provincial de Badajoz: Orense, 1547). Respecto a esta última referencia conviene matizar que se ha consultado el facsímil publicado por la Diputación Provincial de Badajoz en 1947. Esta fuente es de gran interés porque estamos ante un escrito puntero, impreso en España, al tratar plenamente el conflicto turco. 
quisita formación militar, obedientes y respetuosos con sus superiores, pero violentos y despiadados, asiduos pecadores de la avaricia, de la gula y de la lujuria. Así, se exaltó el carácter guerrero del pueblo otomano y se criticó su conducta constantemente reprochable según la moral católica. Además, ha sido necesario conocer las obras de los autores mencionados porque sus ideas e imágenes influyeron en la galería de retratos que ahora se estudia.

Nicolás de Nicolay (1517-1583) conoció las tierras orientales a raíz de su viaje a Constantinopla en 1549 con el embajador francés Gabriel de Luetz d'Aramont (1508-1553). Los dibujos realizados durante la travesía se mostraron en su obra Les quatre premiers livres des navigations et pérégrinations orientales publicada en Lyon en el año 1567, la cual también tuvo varias impresiones en 1568 [fig. 6.2].

A partir de 1572 aumentó el interés por poseer el libro y nuevas tiradas editoriales fueron viendo la luz en los años suce-

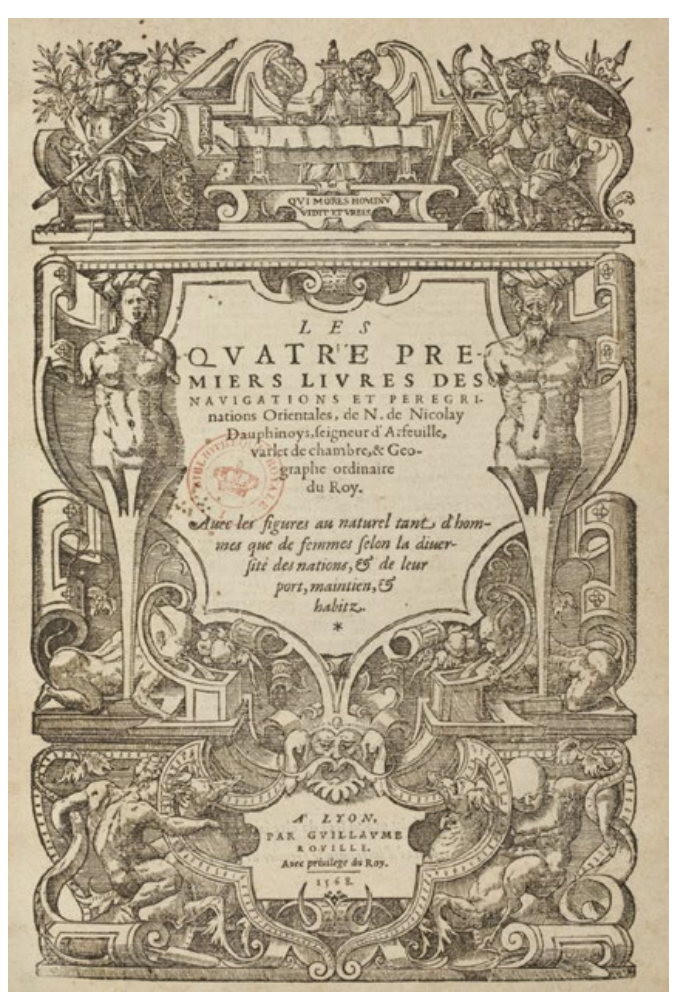

Fig. 6.2. Nicolás de Nicolay, Les quatre premiers livres des navigations et pérégrinations orientales, 1568, Lyon, Biblioteca Nacional de Francia. sivos, traduciéndolo al alemán, flamenco, italiano e inglés. ${ }^{10}$

Naturalmente el título o la dedicatoria del volumen estaban sujetos a leves variaciones según la edición. Por ello, los ejemplares

10 El dato se ha tomado de Benito Domenech, 'Una enigmática serie de pinturas de turcos en Valencia'. Respecto a otras ediciones de la obra de Nicolay, conviene destacar aquellas que se corresponden con Le navegationi et viaggi nella Turchia reproducida en Amberes en 1576 y traducida del francés al italiano por François de Flory, Le navegationi fatti nella Turchia publicada en Venecia en 1580 o Discours et histoire véritable des navigations, pérégrinations et voyages en Turquie localizada en Amberes en 1586. 
franceses de 1568 se han ofrecido al monarca Carlos IX, hijo y nieto de Enrique II y Francisco I respectivamente. En cambio, en una de las ediciones flamencas, concretamente la de 1576 se ha mencionado a Juan de Austria, hijo ilegítimo de Carlos $\mathrm{V}$, quien fue gobernador de los Países Bajos desde 1576 hasta 1578. En cualquier caso, tanto el contenido como las ilustraciones se han mantenido en las sucesivas ediciones.

El relato se ha seccionado en cuatro libros que albergaban sesenta figuras tomadas del natural, tanto de hombres como de mujeres, teniendo en cuenta la variedad de procedencias geográficas, comportamientos, gestos, indumentaria, leyes, ritos, costumbres y modo de vivir en tiempo de paz y de guerra. La narración comenzaba con el inicio de la aventura por explorar tierras lejanas y así se ha hablado de la llegada a Argelia, de la visita a Malta y a Trípoli y se introdujeron las imágenes de las mujeres autóctonas de cada lugar.

El segundo libro continuó desarrollando la ruta planificada por Levante, dando a conocer las islas griegas de Quíos y Paros o la fundación de Constantinopla. En sintonía con la sección precedente, se incluyeron representaciones de la gran dama turca y de otras mujeres enfrascadas en situaciones cotidianas y ligadas al rol que desempeñaron, como el pasear por la ciudad, ir al baño o cuidar a los hijos. En lo referente a la relación de las mujeres con el sultán, Nicolay explicó que más de doscientas mujeres y concubinas del Gran Turco componían su harén, teniendo a su disposición numerosas viviendas, con cocinas y otros servicios. ${ }^{11}$

La mayor parte de ellas eran hijas de cristianos capturadas en las empresas bélicas contra los griegos, húngaros, valacos e

11 En cuanto al diseño arquitectónico del palacio de Solimán el Magnífico, las funciones que desempeñaba cada uno de sus espacios y el harén se han consultado las aportaciones de Esin Atıl, The age of Sultan Süleyman the Magnificent, (National Gallery of Art (U.S), 1987) y a Vicente Moreno de la Tejera, Diario de un viaje a Oriente, Argel, Nápoles, Pompeya, el Vesubio, Sicilia, Grecia, el Archipiélago, Turquía y Egipto, (Madrid, 1877). 
italianos, entre otros pueblos. También podían ser compradas a comerciantes y seguidamente presentadas por los belerbeyes, bassas y capitanes al sultán, éste las acogía en su morada, las alimentaba y las vestía. Vivían bajo la vigilancia de los eunucos, quienes eran hombres castrados cuyo cometido, exclusivamente, era protegerlas. Cada diez de ellas, estaban sujetas a la directa supervisión de una matrona que las educaba y les enseñaba labores de costura. ${ }^{12}$ De entre todas ellas, destacaba la haseki o la favorita del Gran Turco y su principal función era engendrar hijos varones del sultán. Durante el gobierno de Solimán la haseki fue Roxolana (1500 - 1558) [fig.6.3], ${ }^{13}$ también conocida como Hürrem en Oriente, personaje que generó una gran expectación en Occidente por sus raíces europeas y a quien se le atribuyó una especial capacidad para influir en las decisiones políticas de Solimán. ${ }^{14}$ Su imagen se configuró teniendo en cuenta las descripciones de otros autores y los diseños que aparecieron en los libros de indumentaria para mostrar la apariencia de la gran dama turca [fig. 6.4]. ${ }^{15}$

12 Nicolay, Les quatre premiers..., p. 67.

13 Destacan dos fuentes escritas en época moderna que explican la polémica historia de Roxolana: Jean-Jacques Boissard, Vitae et icones sultanorum Turcicorum, principum Persarum aliorumq[ue] illustrium heroum heroinarumq[ue] ab Osmane usq[ue] ad Mahometem II, (Francf. and Moen, 1596) y Giovanni Sagredo, Memorie istoriche de monarchi ottomani, (Venecia, 1673).

14 Sobre la imagen de este personaje en la literatura y en las artes visuales se ha seguido a Leslie P Peirce, The Imperial Harem: Women and sovereignty in the Ottoman Empire, (Oxford University Press: Nueva York, 1993); Ana Pinto Muñoz, 'Roxolana in the Spanish Golden Age', Department of Spanish \& Portuguese, eHumanista: Journal of Iberian Studies, no. 19, 2011, pp. 376-389; Encarna Sánchez García, 'El mundo femenino turco en la literatura castellana del siglo XVI', en Antonio González Alcantud y André Stoll (eds.), El Mediterráneo plural en la Edad Moderna: sujeto histórico y diversidad cultural, (Anthropos, 2011), pp. 132-167; Galina I. Yermolenko (ed.), Roxolana in European Literature, History and Culture, (Ashgate, 2010).

15 La autora de la presente tesis ya ha planteado un análisis más concreto 


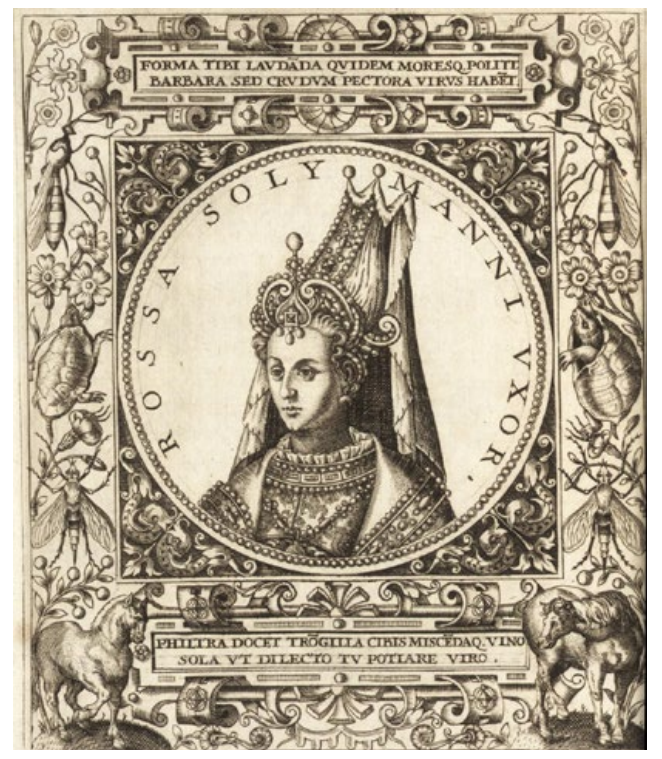

Fig. 6.3. Thèodore de Bry, Rossa Solimanni Uxor en Jean Jacques Boissard, Vitae et icones sultanorum Turcicorum, 1596.

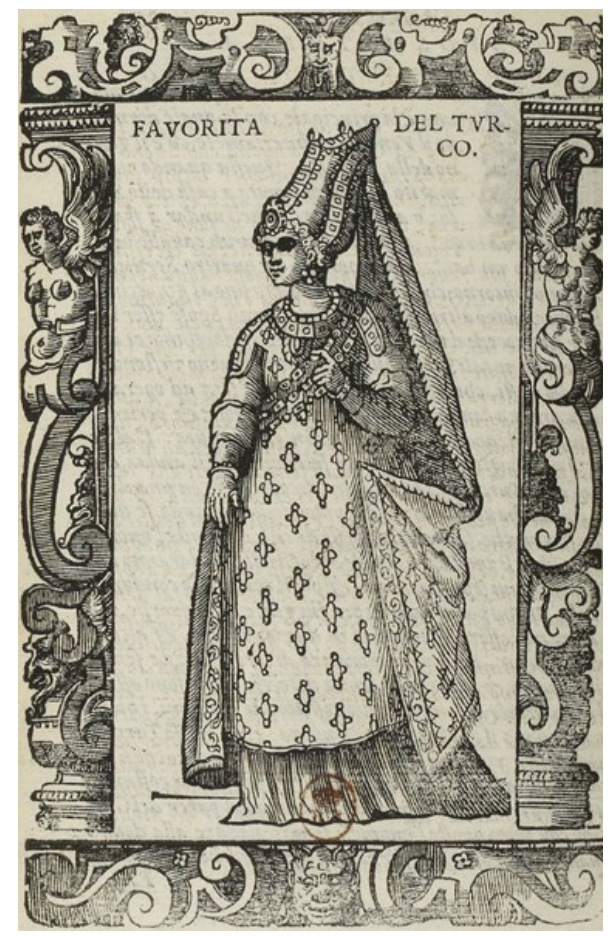

Fig. 6.4. Representación de la favorita del Gran Turco en Cesare Vecellio, Degli habiti antichi et moderni di diversi parti del mondo, 1590, Venecia, Biblioteca Nacional de Francia.

acerca de la imagen visual y escrita de Solimán el Magnífico y de Roxolana, disponible en: Cristina Igual Castelló, 'Solimán el Magnífico y Roxolana. El poder del turco en la cultura visual y escrita de Occidente', Grupo Europeo de Investigación Histórica: Religión, Poder y Monarquía, Potestas: Religión, poder y monarquía. Revista del Grupo Europeo de Investigación Histórica, no. 9, 2016, pp. 233-260. 
En la tercera parte de la obra de Nicolay ya queda constancia del marcado carácter militar que definió a los turcos. En este sentido, se le ha otorgado una amplia consideración a la orden de los jenízaros, quienes formaban parte del ejército del sultán, explicando su origen y matizando los diversos rangos que componían dicho grupo. Para poner de manifiesto más aspectos culturales, el autor trató temas como los hábitos alimenticios o los oficios, por mencionar algunos. En el último libro, se vierte el conocimiento sobre otras zonas geográficas como Arabia, Armenia, Atenas o Macedonia. No obstante, Persia ha concentrado la mayor parte de la atención, hablando del modo de vivir de sus gentes, la religión, las armas o las mujeres. La crónica, finalmente, concluyó con nuevas referencias a las mujeres turcas procedentes de distintos estamentos sociales, ilustrando la apariencia de la mujer de clase media o la cortesana.

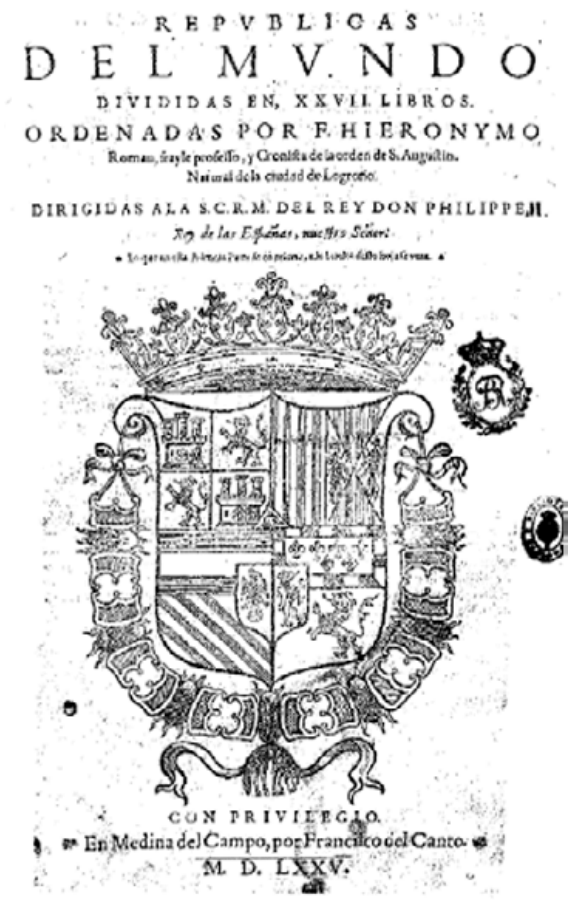

Fig. 6.5. Jerónimo Román, Repúblicas del mundo, 1575, Madrid, Biblioteca Nacional de España.
En sintonía con la aportación de $\mathrm{Ni}$ colás de Nicolay se encontraba la obra Repúblicas del mundo de Jerónimo Román (1536 - 1597), fraile y cronista de la orden de san Agustín, natural de la ciudad de Logroño, fechada en 1575 y dedicada al rey Felipe II [fig. 6.5]. Conviene recordar que la datación del libro indica que tan sólo habían transcurrido cuatro años de la victoria en la batalla de Lepanto $y$, por tanto, aún era reciente el conflicto y ello explica la sed por saber más de los otomanos. De especial relevancia es la tercera parte, donde se abordó la república de los turcos, además de Túnez y Fez. El autor ha otorgado connotaciones negativas a la información vertida sobre los turcos al denominarlos como «la secta de Mahoma» gobernada por «sucias 
y torpes leyes». Asimismo, al inicio del escrito ha quedado bien patente que la finalidad de Jerónimo era enseñar las tradiciones de otros pueblos.

Quien mirare atentamente la multitud de reinos y provincias que viven bajo la secta de Mahoma, podrá ver qué gran república es, pues tantas naciones y gentes se gobiernan por sus sucias y torpes leyes. A los moros, ya no podemos llamarlos gente que se gobierna por república, porque ya están sujetos casi todos a la potencia del gran Turco, y ya que haya diversos reyes y señores, son de tan flaca potencia que se han de llamar tetrarcas o régulos, que reyes: pero mirando a mi intento, que es mostrar las costumbres y manera de vivir de todas las gentes, no es impropio escribir la república de los turcos y moros, ni el escribir sus cosas sale del argumento que tengo entre manos. ${ }^{16}$

A lo largo de la obra, el autor ha dado su particular explicación al origen del imperio turco, ha hablado de su religión, de las supersticiones y cosas vanas que los caracterizaban, ha puesto de manifiesto cómo el sultán era tratado con total majestad, incidiendo en el modo de servirle, en sus costumbres alimenticias, en los ropajes que utilizaba, en las mujeres que le rodeaban y en su modo de proceder en la guerra. Al cotejar los textos del mencionado autor con las figuras de Nicolay, se observa una evidente correspondencia entre el contenido y la imagen. Para ilustrarlo, se tomarán como ejemplo a cuatro personajes religiosos, calificados de abominables y bellacos por Jerónimo Román, y cuyas descripciones entroncan perfectamente con los dibujos de Nicolay.

El primero de ellos fue el denominado giomalier y era retratado como un turco que peregrinaba por las regiones y provincias de Arabia, Egipto, Persia y todas las tierras de Turquía [fig. 6.6]. Aparecía con una piel de fiera sobre su espalda que se llegaba a confundir con su propio cabello y vestía unos exó-

16 Román, Repúblicas del mundo..., fol. 235v. 
ticos ropajes de los que pendían cascabeles. La descripción de Román describía el diseño de Nicolay y además equiparaba a este personaje a los monjes occidentales, remarcando su vinculación a las prácticas lascivas y lujuriosas, conductas inapropiadas en el orbe católico. De esta forma se pretendía dañar la visión de una religión opuesta a la católica.

[...] Los primeros son dichos giomalieres, estos comúnmente son gentiles hombres y bien dispuestos, son hijos de personas honradas, y tienen por principal instituto tratar de amores, y con sus movimientos y palabras despiertan a las mujeres y muchachos a todo género de lujuria, y son llamados de los turcos. [...] Estos para usar de este ejercicio y atraer muchos a sí, como sean gentiles y de buen parecer, se visten ricamente, así de paños finos,

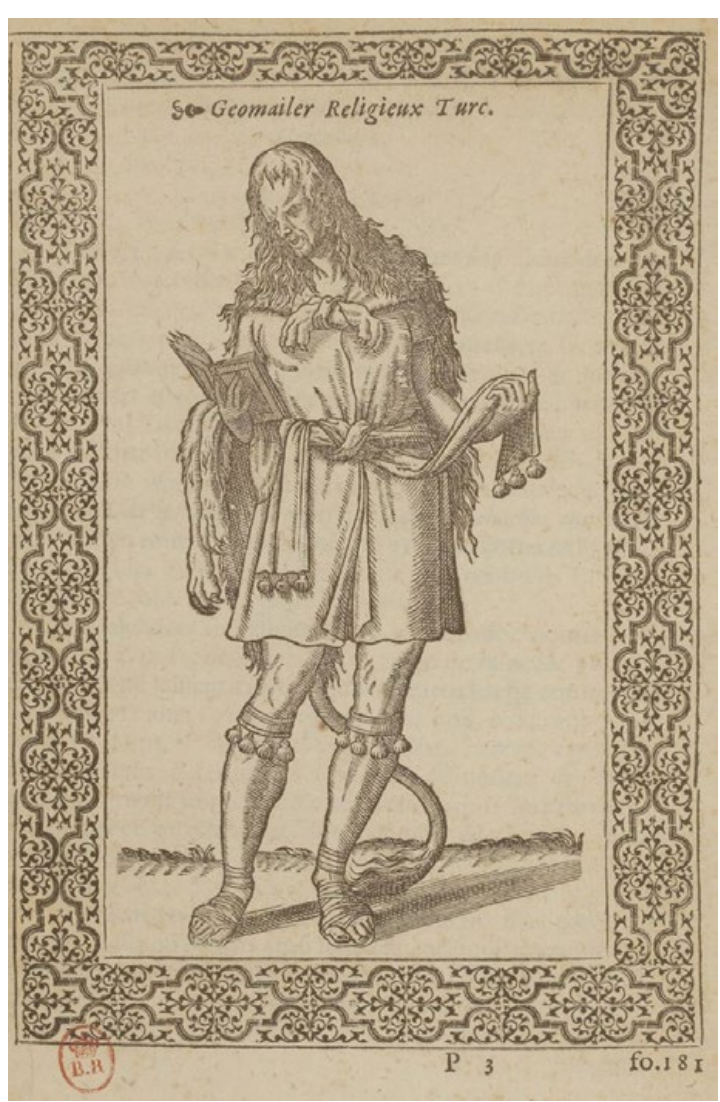

Fig. 6.6. Representación de un Giomalier en Nicolás de Nicolay, Les navigations, peregrinations et voyages faits en la Turquie, 1576, Amberes, Biblioteca Nacional de Francia. como de sedas de diversos colores, traen ceñidores tejidos de riza de oro y seda y en los cabos cuelgan cascabeles de seda con los cuales hacen mucho son y estruendo, traen sobre las espaldas unas pieles de leopardo, o de tigre o de pantera, o de otro animal bravo y feroz, y los brazos del animal tienden por los hombros, hacen crecer sus cabellos y los traen compuestos con arte y los componen hasta afeitarlos como mujeres, por parecer bien los dedos traen llenos de anillos, y traen ciertos libros en lengua persiana, llenos de cantares amorosos, y lascivos, y así van comúnmente muchos juntos, y con el son de los cascabeles, y con la música y can- 
ciones van por las calles haciendo visajes y momos, y adonde ven mucha gente se allegan, porque les den algo, y si topan en las calles mujeres hermosas y honestas, o muchachos hermosos bailan delante de ellos y les dicen palabras amorosas y torpes, incitadoras de toda deshonestidad, y así son ellos dados a todo género de vicios de esta manera, la juzgan ellos por buena y santa, y esta acerca de ellos canonizada por muy grata a Dios y a su profeta Mahoma. ${ }^{17}$

El siguiente tipo de religiosos turcos, y totalmente opuestos a los giomalieres, eran los calenders [fig. 6.7]. Estos hacían de la austeridad y de la castidad sus principales virtudes, por ello Nicolay presentó a un hombre de apariencia frugal e incluso con un aire tribal, acentuado por lucir anillos metálicos en las orejas y muñecas, además de otro en el falo que garantizaba su integridad sexual. Cabe recalcar que este grupo defensor de la castidad, más cercano a la moral cristiana, expresaba su descontento con el profeta musulmán y que por ello, sus componentes fueron perseguidos y asesinados. Nuevamente, Jerónimo Román ha asociado la defensa de la obscenidad al islam.

Otra orden hay, que es la segunda y se llama de calender, los religiosos de este instituto hacen vida áspera y rigurosa, porque para ellos y lo que su secta tiene guardan una cosa grande $\mathrm{y}$

17 Román, Repúblicas del mundo...,

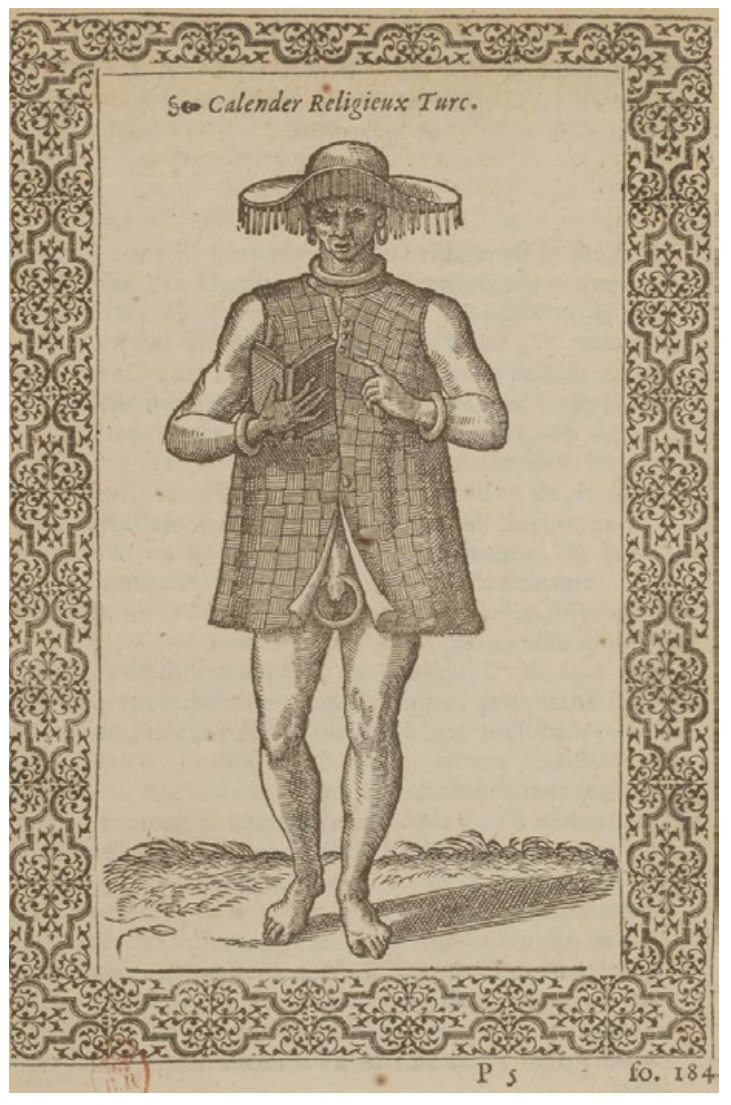

Fig. 6.7. Representación de un Calender en Nicolás de Nicolay, Les navigations, peregrinations et voyages faits en la Turquie, 1576, Amberes, Biblioteca Nacional de Francia.

fol. 240v. 
maravillosa, que es ser castos y comúnmente son vírgenes, viven en comunidad y juntos, y tienen sus mezquitas aparte, y en las porterías de sus monasterios están puestos unos letreros grandes que declaran la vida que han de hacer los que allí pretenden vivir, diciendo que el que quisiere ser compañeros de aquella vida ha de guardar castidad, y hacer los que los demás. Su hábito es áspero, como la vida, porque usan de unas mantas cuadradas, tejidas de lana y cerdas de caballo, andan todos rapados, y no se les permite criar cabello, y traen unos sombreros redondos con una falda mediana, y por pasamano, o franja una lista de ancho de una mano tejida de cerdas de bestias. Usan traer sortijas en las orejas, pero no son de plata, más de hierro, y las mismas traen también en la garganta y en las muñecas. Para conservar su castidad, traen unas sortijas, o anillos de plata, que son muy delicados, que les atraviesan el miembro viril, porque así al tiempo que les venga la tentación con el dolor se rinde la carne. Andan leyendo públicamente sus constituciones y manera de vivir para mover a otros a que se siga aquella vida menos torpe. Hizo esta manera de vivir uno llamado Nercemi, y porque habló libremente contra los desatinos de Mahoma fue después desollado vivo en Agania, ciudad de Turquía, y de muchas cosas que él dejó escrito, ha parecido a hombres doctos y sabios que sintió bien de nuestra religión cristiana. ${ }^{18}$

En cuanto a los religiosos denominados dirvisios, Nicolay los representó a través de la figura de un hombre ataviado con pieles de animal, sin vestir ni los brazos ni las piernas y con pendientes que engalanaban sus orejas [fig. 6.8]. No obstante, se le ha retratado con una actitud agresiva haciéndose el último de los numerosos cortes que marcaban su propia piel. Jerónimo Román también ha explicado la razón de esta extraña práctica dándole un completo sentido a la imagen.

La tercera orden de monjes turcos es la de los dirvisios, estos tienen muchos monasterios en diversas partes.

18 Román, Repúblicas del mundo..., fol. 240v-241r. 
No es gente melancólica, antes siempre tratan de regocijo y alegría, su hábito es donoso, porque andan casi desnudos y el más principal es dos pellejos de carnero secos al sol como los antiparas, o zamarras de los segadores nuestros. Traen los brazos y piernas descubiertos y las cabezas muy rapadas, traen en las cabezas unos bonetes blancos agudos y muy hondos, y por esencia de religión traen unos báculos en las manos muy nudosos, tienen horadadas las orejas, y meten por ellas sortijas, de las cuales cuelgan preciosísimas piedras y perlas de inestimable valor, porque se precian de ello [...]. ${ }^{19}$

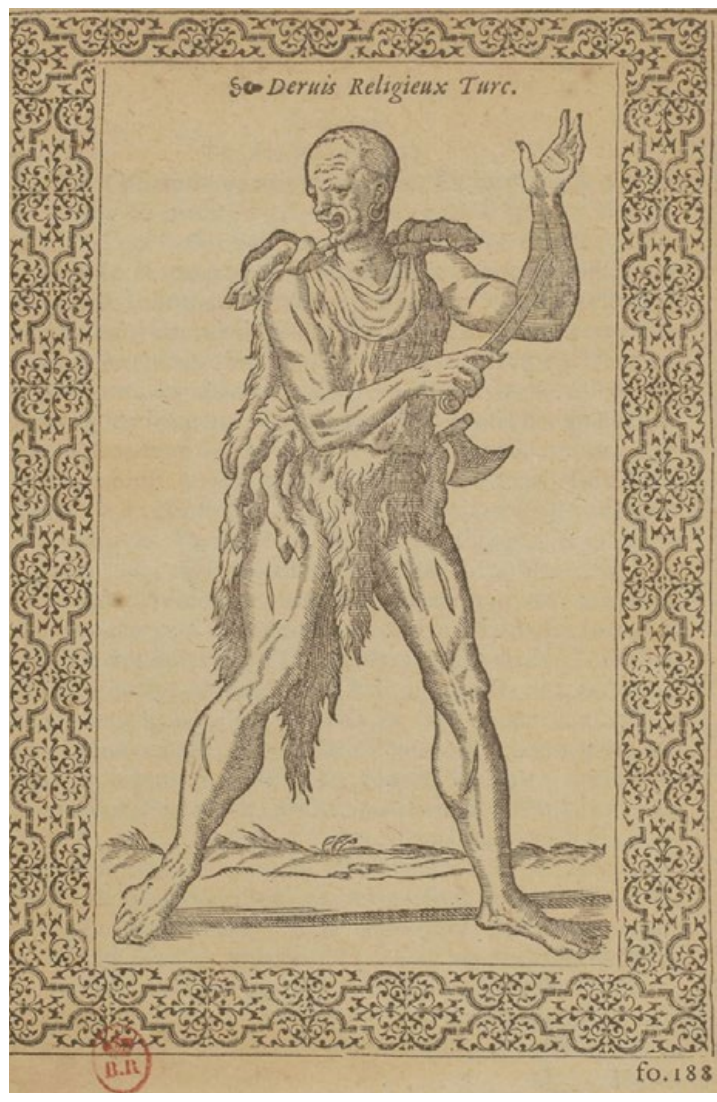

Fig. 6.8. Representación de un Dirvisio en Nicolás de Nicolay, Les navigations, peregrinations et voyages faits en la Turquie, 1576, Amberes, Biblioteca Nacional de Francia.

Los dirvisios además se sentían atraídos por las mujeres y realizaban rituales para demostrarles su amor. A estos se les acusaba de mentirosos y fanfarrones por exagerar en los relatos que contaban sus hazañas.

Otro día se hace congregación solemne, y de esta manera echan en un campo ancho más de cien cargas de leña, y les pegan fuego, y en ellos asidos de las manos, como eslabones de cadena danzan y cantan el estilo de nuestras mozas y mozos que hacen una rueda y bailan al son de cantar. Allí ensalzan su religión, y a los hombres que han sido más famosos, después movidos de un furor loco comienzan a sacarse sangre de diversas partes del cuerpo,

19 Román, Repúblicas del mundo..., fol. 241r. 
y pintan en los brazos y manos diversas cosas con puntas de cuchillos agudísimos, unos pintan flores, otros ramos de árboles, y otros corazones con saetas, y cada cual sin alguna vergüenza dice [...] que aquello hace por contemplación de su enamorada. Después se llegan al fuego y tomando de la ceniza y de sus orinas hacen un lodo y untan las heridas y las queman, y dentro de muy poco tiempo queda la señal muy clara y la herida sana, y después muestran aquellas señales a sus amigas en señal de amor $[\ldots] .^{20}$

La última clase de personajes religiosos son los denominados torlocos, los tildaron de ladrones y embusteros, equiparándolos a los gitanos por hacer creer que eran capaces de leer el futuro en la palma de la mano [fig. 6.9]. Así pues, la imagen de Nicolay ha reflejado a este personaje tomando la mano de una señora turca para descifrar su devenir.

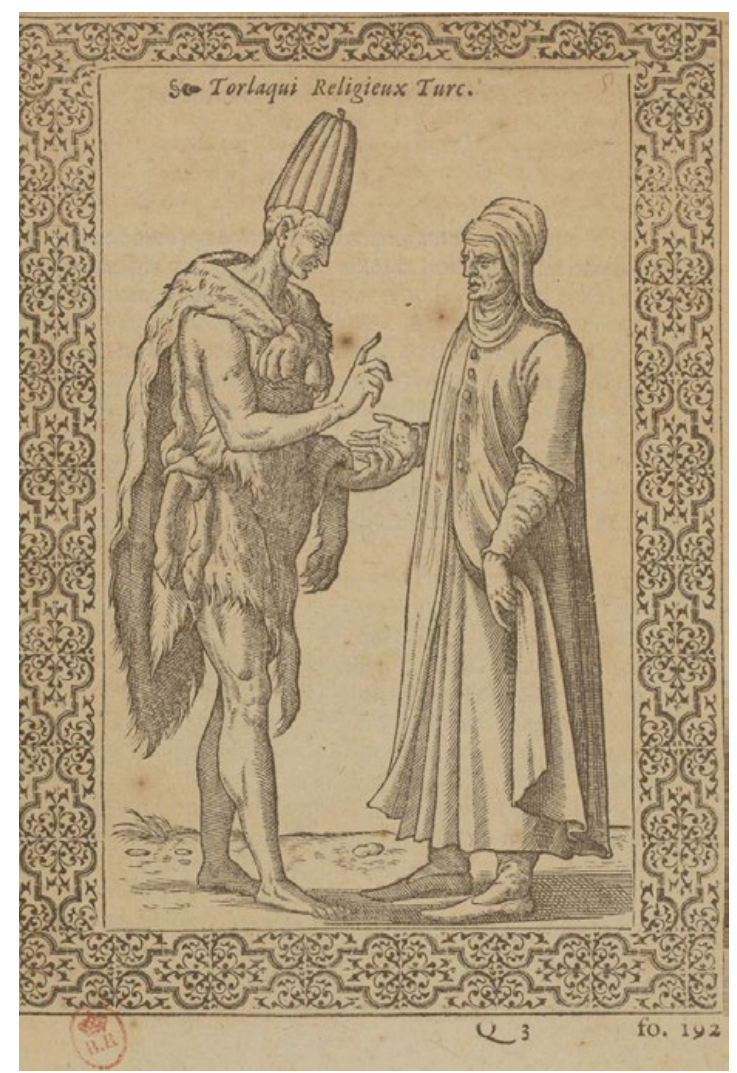

Fig. 6.9. Representación de un Torloco en Nicolás de Nicolay, Les navigations, peregrinations et voyages faits en la Turquie, 1576, Amberes, Biblioteca Nacional de Francia.

20 Román, Repúblicas del mundo..., fol. 241v. 
La cuarta orden de religiosos turcos es la de los torlocos, los cuales andan vestidos como los dervisos, de los cuales ahora cabe describir. [...] Estos monjes son muy necios, porque no saben leer, andan pidiendo por amor de Dios. Y el pueblo les da con que se mantengan, pero su religiosa vida para en ser ladrones, por lo que hallan a mal recaudo les parece que es suyo, y todo lo gastan después en bodegones y tabernas. Cuando caminan no van solos, más muchos juntos y esto hacen no por religión, más porque sean mayores sus fuerzas para saltear a los caminantes, y son tan crueles que por robar no perdonan ningún género de gente, porque en esto el moro y el cristiano no es una misma cosa. Acostumbran por las aldeas y caserías engañar a las mujeres, porque les hacen creer que adivinan, y mirando las rayas de las manos les dicen la buena ventura, como nuestros gitanos, y por ello les dan de comer, creyendo que con ello pagan las palabras que les dan llenas de burla y escarnio [...]. ${ }^{21}$

Se ha podido comprobar que las descripciones de Jerónimo Román encajaban con las imágenes de Nicolay, ello invita a pen665 sar que el fraile agustino conocía la publicación del geógrafo francés. Además, ha sido notorio observar que los comentarios realizados por escritores occidentales acerca de dirigentes religiosos turcos eran peyorativos y trataban de justificar el rechazo al islam.

Otro autor destacable y a tener en cuenta fue Cesare Vecellio (1521/1531-1601), un artista veneciano que dedicó gran parte de su vida a construir un repertorio de imágenes sobre la indumentaria empleada por hombres y mujeres procedentes de distintas clases sociales y países. Para llevar a cabo su tarea, Vecellio probablemente tuvo en cuenta la apariencia de los habitantes y visitantes de la cosmopolita Venecia, conoció pinturas y esculturas conservadas de la Antigüedad que le permitieron apreciar la moda clásica y quizás observó las pinturas de artistas contemporáneos que ilustraban tierras

21 Román, Repúblicas del mundo..., íbidem. 
lejanas. Además, trató tanto con la obra de Nicolay ${ }^{22}$ como con otros catálogos de indumentaria. ${ }^{23}$ A partir del bagaje y conocimiento recopilado, el artista compuso el libro Habiti antichi et moderni [fig. 6.10]. Inicialmente tuvo dos impresiones, una primera realizada en 1590 con la moda de la antigua Roma y una segunda edición publicada ocho años después donde se incluyeron las imágenes de la cultura americana. $\mathrm{Al}$ crear un amplio muestrario de imágenes, el autor recogió la indumentaria italiana, francesa, española, alemana, griega, turca, árabe, persa o egipcia, entre otras. Pero también,

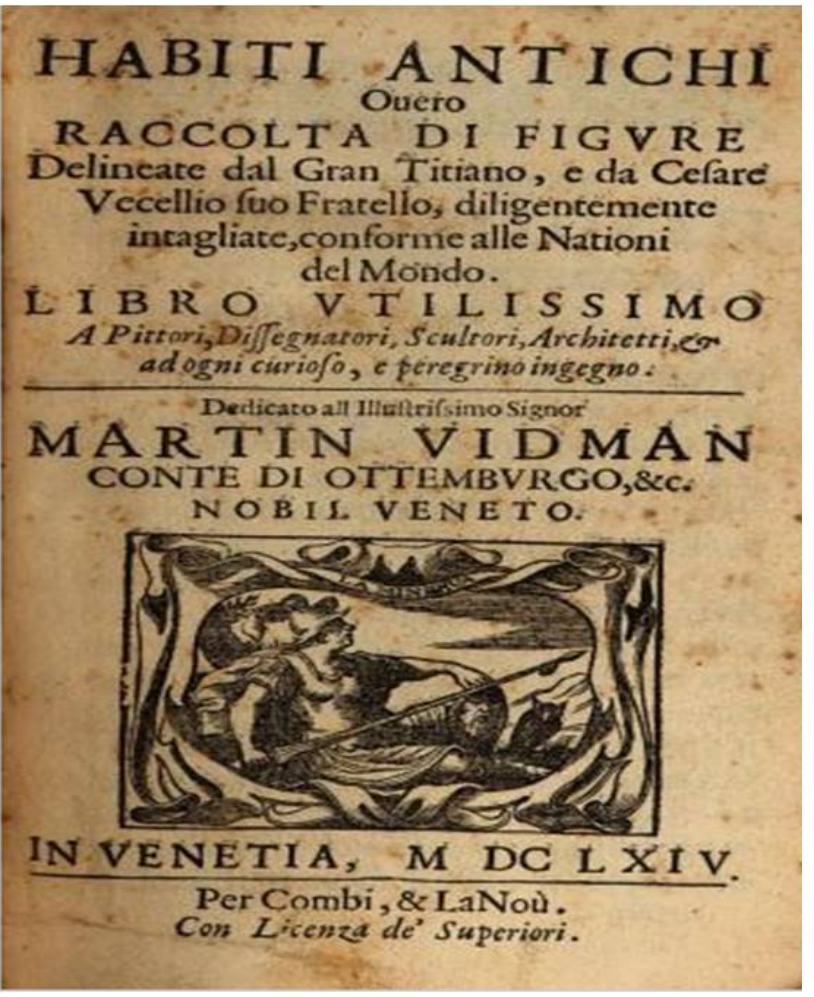

Fig. 6.10. Cesare Vecellio, Habiti antichi, overo raccolta di figure delinéate dal Gran Tiziano, e Cesare Vecellio suo fratello, diligentemente intagliate, conforme alle Nationi del Mondo, 1664, Venecia, Biblioteca Nacional de Francia. incluyó descripciones sobre el tipo de tejidos y colores empleados en cada uno de los modelos.

La obra de Vecellio, además, fue una herramienta al servicio de otros pintores puesto que les permitía recrear escenas con individuos y ambientes de diferentes lugares. Igualmente, podía servir como elemento de inspiración para representar entradas triunfales y vestir las fiestas cortesanas. Por ejem-

22 Dato aportado por Margaret F. Rosenthal and R. Jones, The clothing of the Renaissance World, (Thames and Hudson: Londres, 2008).

23 Véase a Jean Bellero y Gilles Van de Rade, Omnium fere gentium nostraeque aetatis nationum Habitus et Effigies, (1572); Pietro Bertelli, Diversarum nationum habitus centum et quattor iconibus in aere incissis, (1592); Jean-Jacques Boissard, Habitus variarum orbis gentium, (1581). 
plo, esta correspondencia se aprecia especialmente en una estampa de Antonio Tempesta (Florencia, 1555 - Roma, 1630) conservada en la Biblioteca Nacional donde se describe minuciosamente un desfile del Cortejo de Solimán el Magnífico. El diseño de Tempesta se compone de cinco partes que conjuntamente se han denominado como la Ordine que tiene il Gran Turco quando cavalca. Lo interesante es que el diseño para cada uno de los miembros que participan de la procesión son coincidentes con las figuras del libro Habiti antichi et moderni. De hecho, aparecen diversos personajes como los jenízaros y su capitán general, llamado Agah, el Muftí, varios tamborileros en camellos que anunciaban el paso del sultán, el boluch-bassi, los solaquis, el Gran Turco y tras él, otro grupo de solaquis y pajes a caballo concluyendo el fastuoso desfile. Es necesario recalcar que Solimán fue el único contemporáneo y equiparable a Carlos $\mathrm{V}$ por el alcance de su poder. Así pues los investigadores han visto en la cabalgata la intención de hacer visible los propósitos imperiales otomanos hacia Europa empleando el lenguaje discursivo del poder occidental. ${ }^{24}$

La relación entre los libros de indumentaria y los vestidos de las fiestas cortesanas era habitual. Muestra de ello se aprecia al cotejar la minuciosa descripción que Calvete de Estrella (h. 1510 - 1593) hizo sobre las fiestas organizadas en Milán en 1548 con motivo de la llegada del entonces príncipe y futuro rey Felipe II. ${ }^{25}$ Los trajes que lucieron todos los miembros de la corte y que describe el mencionado autor fueron tomados como referente para ilustrar Il libro del sarto, uno de los

24 Consúltese la ficha de catálogo de P. Vinatea Serrano, 'Cortejo de Solimán el Magnífico', en Museo Nacional del Prado (ed.), La fiesta en la Europa de Carlos V: Real Alcázar, Sevilla, 19 de septiembre - 26 de noviembre 2000., (Sociedad Estatal para la Conmemoración de los Centenarios de Felipe II y Carlos V: Madrid, 2000), pp. 294-296.

25 Cristóbal Calvete de Estrella, Felicissimo viaje del muy alto y muy poderoso principe don Phelippe, hijo del emperador don Carlos Quinto Maximo, desde España à sus tierras de la baxa Alemaña: con la descripción de todos los Estados de Brabante y Flandes, (Amberes, 1552). 
primeros repertorios europeos de indumentaria durante el renacimiento y al que le sucedió un momento de esplendor para los catálogos del traje. ${ }^{26}$

Además de los ejemplos ya comentados, y como se explicará a continuación, la obra de Nicolay y sobre todo la de Vecellio, tuvieron una clara relación con la galería estudiada y demuestra la estrecha relación que existió entre las fuentes escritas y las piezas pictóricas. Sin embargo, también se debe reflexionar acerca de la finalidad de cada uno de los libros, puesto que en principio hay ciertas diferencias entre la intención de estas obras. La crónica de Nicolay es una descripción detallada de un viaje a Turquía y otros lugares de Oriente, por esa razón las imágenes mostraron los distintos tipos que habitaban aquellas tierras así como hablaron sobre el modo de vestir en un sitio y momento concreto. Por el contrario, la aportación de Vecellio es estrictamente un catálogo amplio de la indumentaria de las diversas partes del mundo. En este sentido, el autor ha diferenciado la posición social tanto de hombres como de mujeres a través de la indumentaria.

En futuras investigaciones sería cerciorarse de si la intencionalidad de Le navegationi de Nicolay estuvo condicionada por su origen francés y por el pacto que dicho país mantuvo con el sultán Solimán el Magnífico, ya que a ambos les unía la enemistad con Carlos V. Cuando Nicolay realizó el viaje a Turquía tan sólo hacía dos años que el nuevo rey de Francia era Enrique II, hijo de Francisco I, y posiblemente hubo un deseo por conocer el territorio que aún estaba bajo el poder de Solimán el Magnífico. En cambio, el margen cronológico en el que se

26 La bibliografía acerca de este tema y las consideraciones en torno al mismo se presentaron en el XXI Congreso Nacional de Historia del Arte celebrado en 2016. Véase a Cristina Igual Castelló, 'Del traje al disfraz. Il Libro del Sarto y otros catálogos de indumentaria al servicio de la fiesta', en Begoña Alonso Ruiz, Javier Gómez Martínez, Luis Sazatornil Ruiz, and Fernando Villaseñor Sebastián (eds.), La formación artística: creadores historiadores - espectadores, (Universidad de Cantabria: Santander, 2018), pp. 1366-1379. 
produjo la primera publicación del libro y su difusión coincidió con el gobierno de Carlos IX, quien siguió la empresa iniciada por su padre, justo un año después del fallecimiento de Solimán en 1566. Por tanto, es posible relacionar la reciente muerte del poderoso sultán con el nacimiento de la obra de Nicolay, lo cual fue sintomático de la curiosidad que despertaba el enemigo turco. En cambio, las circunstancias que rodearon la publicación de la pieza de Vecellio no han dado pie a lecturas de tinte político por dos razones; porque se trataba de un ambicioso repertorio de indumentaria y porque su publicación tuvo lugar bastante tiempo después del fallecimiento de Solimán. Por ello, la obra de Vecellio puede considerarse como un documento de carácter etnográfico que exhibió la diversidad cultural de aquellos lugares más conocidos en Europa.

\subsection{Sultanes, consejeros, guerreros y mercaderes.}

El exotismo de la galería de retratos orientales ubicada en el Colegio del Corpus Christi hace de este conjunto un ejemplo verdaderamente interesante para las investigaciones histórico-artísticas. Los lienzos que ornamentan, a día de hoy, la escalera de acceso a la biblioteca y el claustro alto del seminario son un testimonio más de la atención que suscitó Oriente a los ojos occidentales en los siglos XVI y XVII. Para analizar este conjunto ha sido necesario establecer el punto de partida en el estudio de Fernando Benito sobre la serie. ${ }^{27}$ El investigador sustentaba la hipótesis según la cual un artista valenciano debió elaborar estas doce efigies, probablemente realizadas alrededor de año 1600 y de las cuales sólo se conservan diez puesto que dos de ellas se perdieron, concretamente las correspondientes al Gran Turco [fig. 6.11] y al Sofí de Persia [fig. 6.12]. Asimismo, consideraba que la fuente de inspiración del pintor había sido la ya citada crónica Navegationi et viaggi fatti nella Turchia (Amberes, 1576) de Nicolás de Nicolay, ya que la influencia visual era notable y san Juan de Ribera poseía un ejemplar del libro de Nicolay, sin especificar la edición, en su

27 Benito Doménech, 'Una enigmática serie...'. 
biblioteca personal.

670

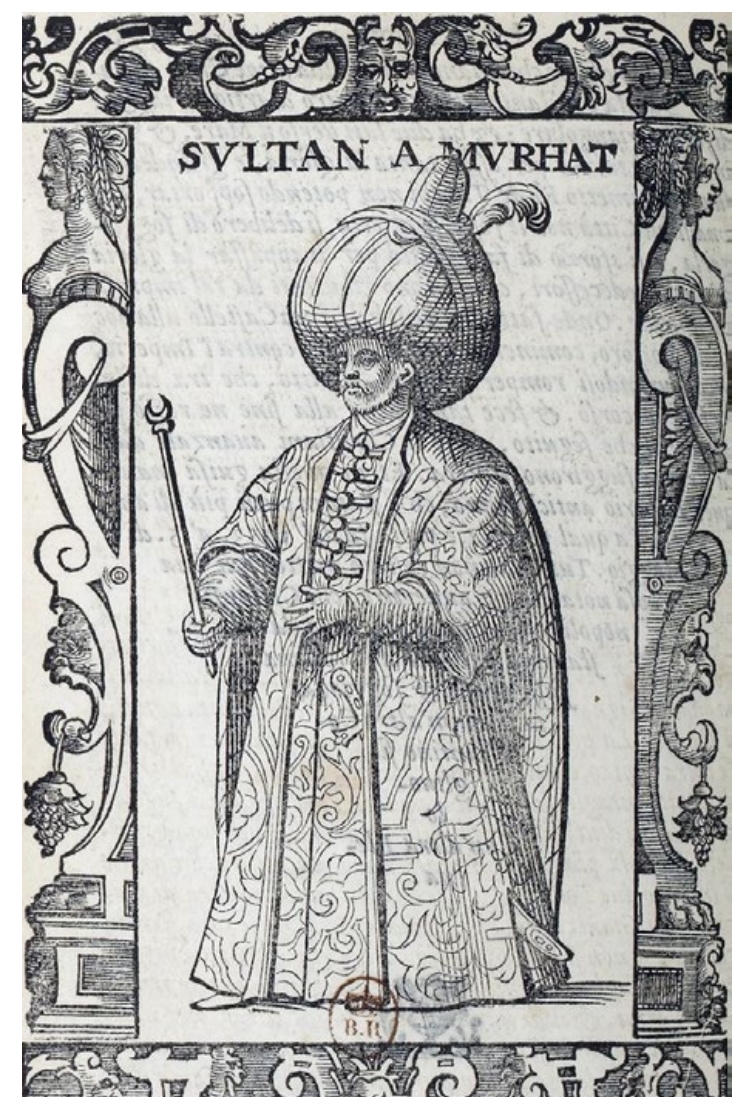

Fig. 6.11. Representación del Gran Turco en Cesare Vecellio, Degli habiti antichi et moderni di diversi parti del mondo, 1590, Venecia, Biblioteca Nacional de Francia.

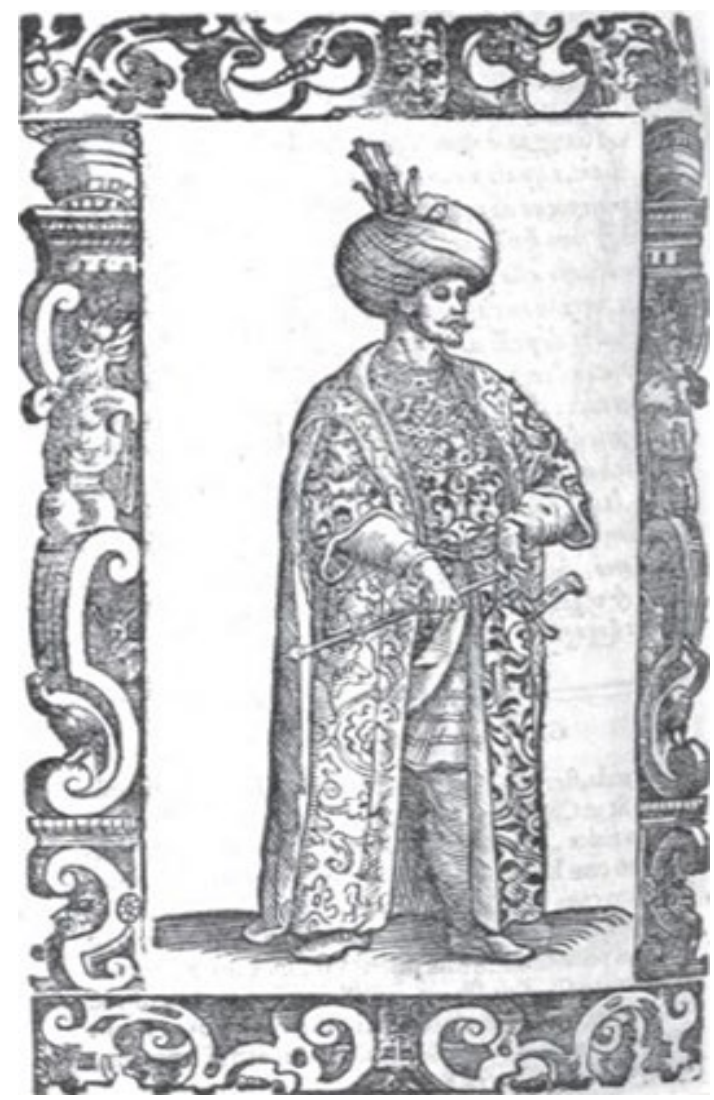

Fig. 6.12. Representación del Sofi de Persia en Cesare Vecellio, Habiti antichi et moderni di tutto il mondo, 1598, Venecia.

Tras consultar los diversos inventarios, ha sido complicado determinar con exactitud en qué momento la obra llegó a formar parte de la colección del Patriarca y si, verdaderamente, tanto el libro como los retratos fueron comprados por el mismo san Juan de Ribera. En la Memoria de los libros que he llevado al $S$. Real Colegio para la librería no se detalla la incorporación del volumen de Nicolay. Se trata de un listado de los volúmenes que se compraron en 1615, después del fallecimiento de Ribera, por tanto, es un dato más que apunta a que la obra de Nicolay ya había sido adquirida con anterioridad. ${ }^{28}$

28 Archivo del Real Colegio Seminario del Corpus Christi, Libros selectos de la biblioteca del Patriarca, 1615. 
Tampoco se ha registrado su existencia ni la presencia de las pinturas estudiadas en el Libro de noticias y curiosidades del Real Colegio Corpus Christi y de su Ilustre fundador don Juan de Ribera, Patriarca de Antioquía, Arzobispo, Virrey, Capitán General y Canciller de la Universidad de Valencia, escrito por el doctor José Ventura, Colegial perpetuo del mismo. ${ }^{29}$ Sin embargo, tan sólo se ha localizado la obra en la Noticia de los libros más selectos que se conservan en la Biblioteca del Colegio del Corpus Christi de la Ciudad de Valencia, probablemente compuesta en el siglo XIX, que calificó la crónica de curiosa pero no rigurosa. Aquí los ejemplares se han ordenado alfabéticamente según el autor y se han añadido unos mínimos datos biográficos sobre cada uno de ellos. En el caso de Nicolay se ha apuntado literalmente que: «nació en el delfinado en 1517 y murió en París en 1583, geógrafo de Carlos II. Tiene una obra de discursos e historia de la navegación a la Turquía con láminas, es historia curiosa pero no muy exacta.» ${ }^{30}$ Dicha apreciación incita a pensar que la edición hallada en la biblioteca quizás se corresponda con la publicada en francés, concretamente en Amberes el año 1586 bajo el título Discours et histoire véritable des navigations, pérégrinations et voyages en Turquie.

Aunque la calidad artística de la galería no es brillante, el proyecto importa más por las circunstancias que lo rodearon. La particularidad del tema así como el perfil de la persona que probablemente adquirió y poseyó la galería hacen de este grupo de retratos un ejemplo llamativo. Por estas razones, seguidamente se han analizado cada uno de los retratos y se ha valorado el cariz de la colección artística de san Juan de Ribera.

29 Archivo del Real Colegio Seminario del Corpus Christi, Libro de noticias y curiosidades del Real Colegio Corpus Christi y de su Ilustre fundador don Juan de Ribera, Patriarca de Antioquía, Arzobispo, Virrey, Capitán General y Canciller de la Universidad de Valencia, escrito por el doctor José Ventura, Colegial perpetuo del mismo. Esta fuente data del siglo XIX.

30 Archivo del Real Colegio Seminario del Corpus Christi, Libros selectos de la librería del Colegio del Corpus Christi, s/f (pág. 14 en su versión digitalizada). 
Los retratos de esta galería exhiben a un grupo reducido de hombres poderosos y representativos de la cultura turca, así pues se encuentran efigiados sultanes, consejeros, diversos guerreros y mercaderes. Como ya se ha avanzado, tras cotejar las pinturas con las ilustraciones de los libros de viajes o los catálogos de indumentaria de Nicolay y Vecellio se ha apreciado que ambas obras influyeron en el diseño de los lienzos. Por ejemplo, la representación del capitán persa y del mercader de Arabia se relaciona directamente con La navegationi de Nicolay. El primer personaje adopta una postura solemne y firme, apoyado sobre la pértiga, ataviado con un turbante y ricas vestiduras [fig. 6.13]. Aunque esta figura también fue incluida por Vecellio en la sección dedicada al vestir de Asia, el retrato estudiado ha copiado fielmente el diseño de Nicolay y se corresponde con la descripción que el mismo autor elaboró del personaje [fig. 6.14]:

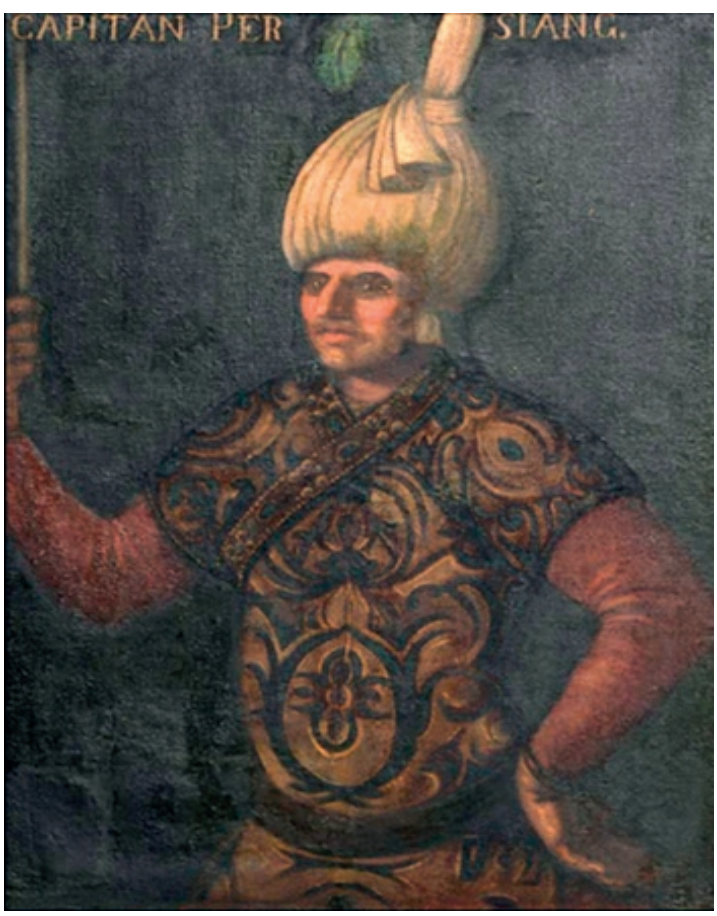

Fig. 6.13. Anónimo, Capitán Persiang, finales del siglo XVI o principios del XVII, óleo sobre lienzo, Valencia, Real Colegio Seminario del Corpus Christi.

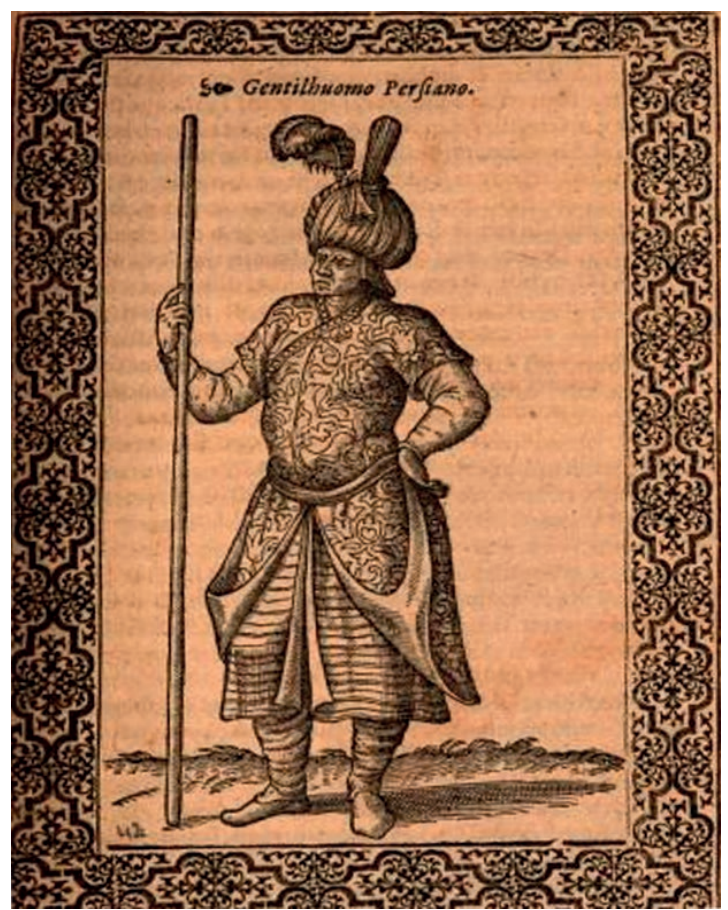

Fig. 6.14. Gentilhuomo persiano en Nicolás de Nicolay, Les navigations, peregrinations et voyages faicts en la Turquie, 1576, Amberes, Biblioteca Nacional de Francia. 
Onde i loro huomini d'arme sono armati di corazze scagliose, di corsaletti, scudi, rotelle et targhe; celate et morioni guarniti di pennachioni: havendo il braccio et la mano destra armata, et combattono con la lancia, overo Zagaglia con due ferri, la quale maneggiano per il mezzo. [...] Sono i deputati alla guardia del Sophy nudriti alle sue spese, et in tempo ordinato, dà loro per antica consuetudine arme, cavalli, panni, tende et vettovaglie. ${ }^{31}$

Además, el mismo texto especificó que este guerrero estaba a la disposición del Sofi de Persia, cuyo retrato según indicó Fernando Benito en el artículo ya citado debió pertenecer a la serie y más tarde se perdió. Que el capitán persa formase parte del conjunto, quizás respondiese a que, en 1548, cuando se publicó el libro de Nicolay, las huestes de Solimán el Magnífico estaban enfrascadas en un conflicto bélico con los persas (1532 - 1555), durante el cual el ejército otomano llegó a controlar diversos territorios. Así pues, se debe considerar que el personaje persa fue uno de los representados en la galería por su condición, en aquel momento, de vasallo del Gran Turco.

En lo referente al mercader árabe, el personaje tan sólo se ha localizado en la obra de Nicolay, concretamente en el capítulo XI del libro III dedicado a Arabia [fig. 6.15]. Aquí se ha relatado su costumbre por rasurarse la barba y dejarse un bigote largo. Por ello, la estampa ilustrativa de este pasaje muestra la figura de un hombre representado de medio cuerpo, con un gran turbante sobre la cabeza, una túnica y una capa rayada. La imagen se corresponde totalmente con la efigie estudiada. A nivel personal se les ha calificado de cautos y soberbios, pues se consideraban más valientes y apasionados que el resto de pueblos. Nicolay además advirtió que todos seguían la doctrina del islam y eran tributarios del sultán otomano. ${ }^{32}$ Esta es la razón por la que el mercader árabe aparece entre los tipos orientales, pues era un súbdito más del Turco [fig. 6.16].

31 Nicolay, Le navigationi et viaggi..., p. 230.

32 Nicolay, Le navigationi et viaggi..., p. 243. 


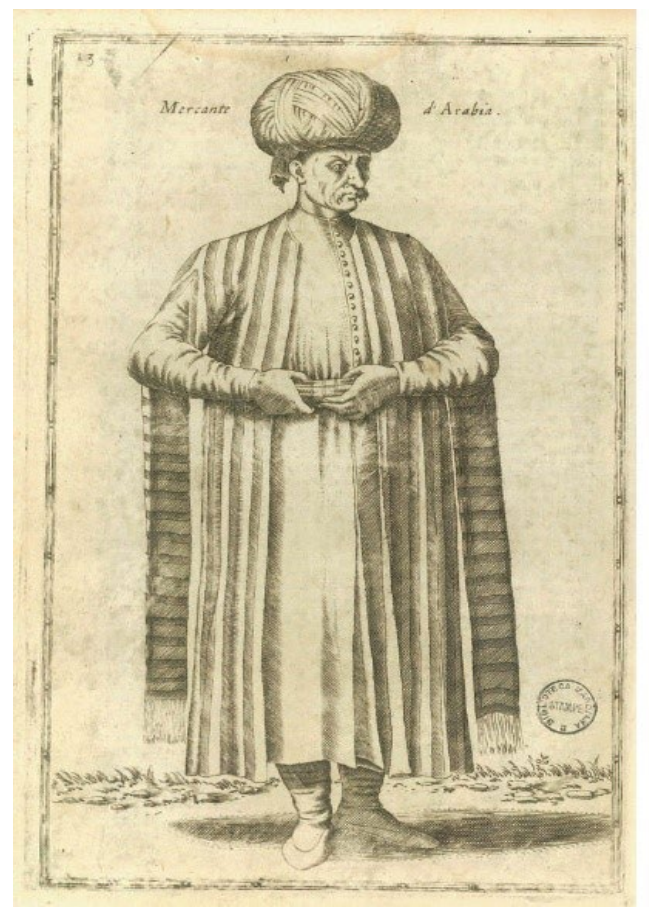

Fig. 6.15. Representación del Mercante d'Arabia en Nicolás de Nicolay, Les navigations, peregrinations et voyages faits en la Turquie, 1576, Amberes, Biblioteca Nacional de Francia.

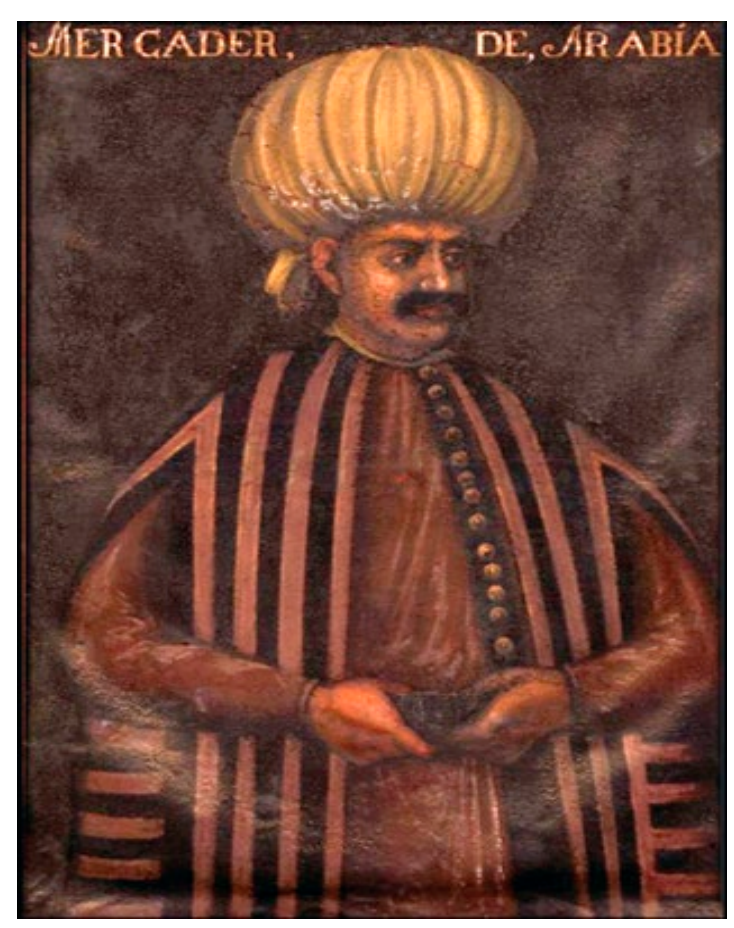

Fig. 6.16. Anónimo, Mercader de Arabia, finales del siglo XVI o principios del XVII, óleo sobre lienzo, Valencia, Real Colegio Seminario del Corpus Christi.

A excepción de los dos ejemplos ya presentados, el resto de lienzos se han basado completamente en los diseños vistos en Habiti antichi et moderni de Vecellio. Bajo estas circunstancias se encuentran las representaciones del Muftí, el solaqui, el Deli Cajssi, el Sfachiotto de Candía, el Gran Soldán, el consejero del anterior, el mercader armenio y el soldado georgiano. De entre todos ellos, el personaje más significativo y de elevado rango era el Muftí, un dirigente religioso capaz de emitir leyes religiosas también denominadas como fatuas y según Vecellio, este personaje era equiparable al patriarca de la cristiandad [fig. 6.17]. En un primer momento, Fernando Benito lo había relacionado visualmente con la estampa del Agà Capitano general de Giannizzeri y vestido de modo parecido al consejero del Gran Soldán, ambos aparecidos en el libro de Nicolay, ${ }^{33}$ pero las contradicciones visuales son evidentes. Sin embargo, Vecellio lo incluye entre sus figurines y sobre él especificó que:

33 Nicolay, Le navegationi et viaggi..., p. 160. 
Il Musti è simile al Patriarca Christiano. Questo è quello che ministra, e maneggia tutte le cose spirituali e massimamente sopra i religiose Turchi, e sopra tutto è quello di Constantinopli. Veste continuamente di ciambellotto verde con mariggi e alcuna siata bianca. Porta il dulipante molto maggiore degli altri, e il corno basso; ma tanto quanto si puo vedere simili sono di tempo e hanno moglie e siglivoli. ${ }^{34}$

Cabe remarcar la importancia de vincular a dicho asesor espiritual con el patriarca cristiano, poniendo de manifiesto la trascendencia de esta figura para el islam. Asimismo, se trata de un hombre religiosamente ejemplar y elevado a la misma categoría que san Juan de Ribera para el catolicismo, lo cual ya explica su pertenencia al conjunto de retratos [fig. 6.18].

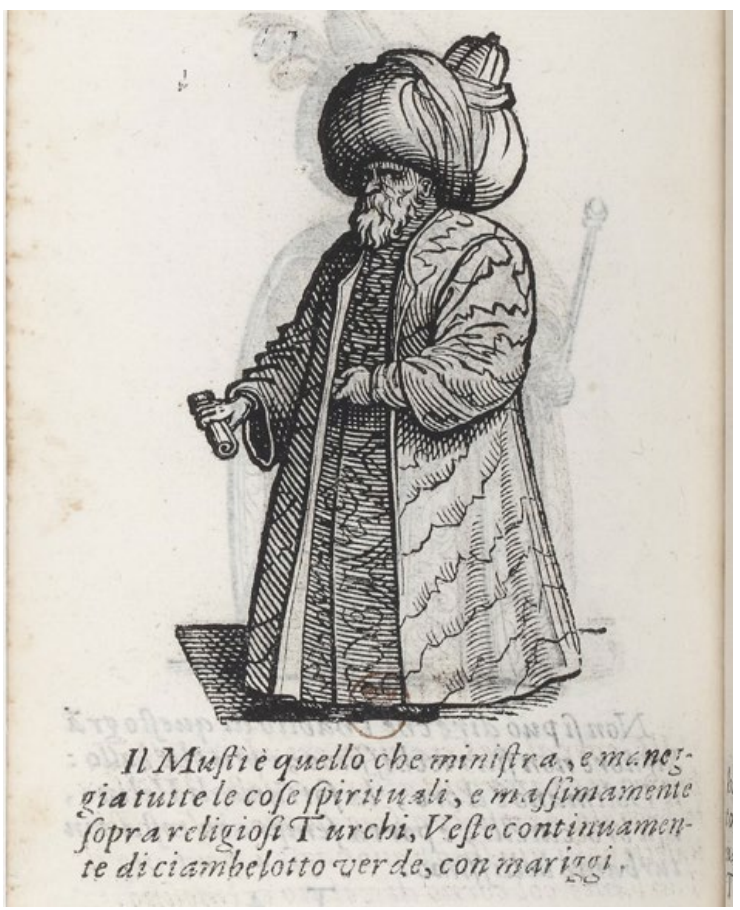

Fig. 6.17. Muftí en Cesare Vecellio Habiti antichi, overo raccolta di figure delinéate dal Gran Tiziano, e Cesare Vecellio suo fratello, diligentemente intagliate, conforme alle Nationi del Mondo, 1664, Venecia, Biblioteca Nacional de Francia.

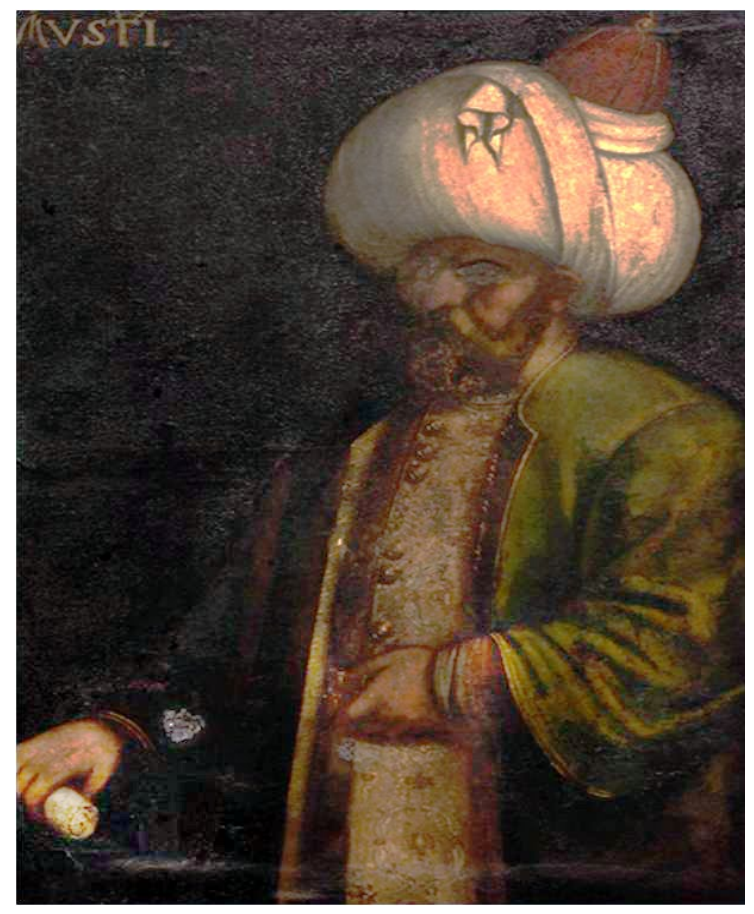

Fig. 6.18. Anónimo, Muftí, finales del siglo XVI o principios del XVII, óleo sobre lienzo, Valencia, Real Colegio Seminario del Corpus Christi.

34 Cesare Vecellio, Habiti antichi et moderni di tutto il Mondo, (Venecia, 1598)., Libro VIII, Degli habiti di Turchi, p. 359. 
Además de los orientadores espirituales, el sultán turco estaba rodeado de un asombroso ejército. Sus huestes se componían por miles de soldados jenízaros, ${ }^{35}$ de entre los cuales seleccionaba a cientos de arqueros, llamados solaquis [fig. 6.19].

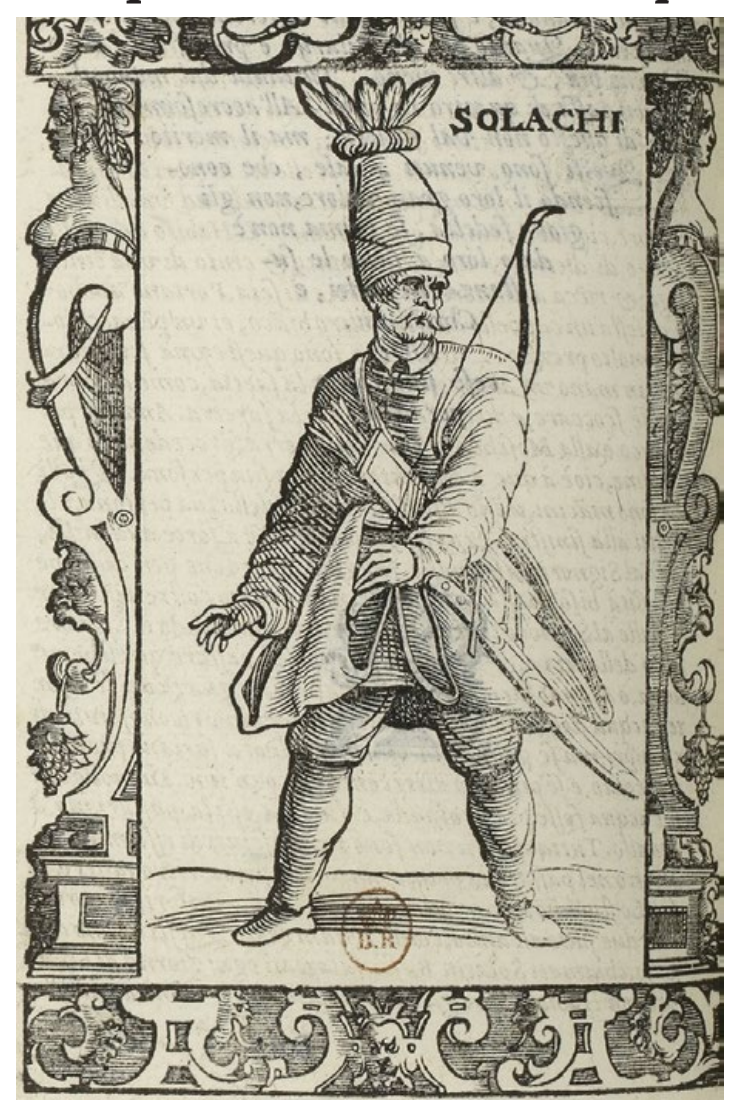

Fig. 6.19. Solaqui en Cesare Vecellio, Degli habiti antichi et moderni di diversi parti del mondo, 1590, Venecia, Biblioteca Nacional de Francia.

Los textos de la época indicaron el modo en que se vestían estos militares al ejercer su labor de proteger al sultán, así como detallaron la cantidad de la que se abastecía:

Un número de doscientos de los más grandes de persona y diestros flecheros, y estos se llaman solaches. Son diputados para mozos de espuelas del Gran Turco. [...] Traen ropetas más cortas que los otros jenízaros y en la cabeza un capillo de fieltro blanco a semejanza de un pan de azúcar y unos penachos pequeños. ${ }^{36}$

$35 \mathrm{El}$ término «jenízaro» tiene su origen en las palabras turcas yeni y çeri, que significan «tropa nueva». Véase a Fernández Lanza, 'Los turcos y lo turco...', p. 86.

36 Díaz Tanco, Palidonia de..., fol. 55v. 
La correspondencia entre las fuentes escritas, la estampa de Vecellio y el retrato de la serie es evidente. Por ello, el solaqui aparece rigurosamente vestido con una librea de damasco o raso blanco, con una túnica larga, un cinturón de seda y un sombrero alto de fieltro blanco, adornado con un gran penacho de plumas. En los desfiles se desplazaban sin dejar de defender al sultán, por ello lo rodeaban en fila de a dos y se armaban con la cimitarra y un arco dorado, teniendo a mano las saetas [fig. 6.20]. Estos miembros del ejército también han aparecido representados en acuarelas de Jacopo Ligozzi (1547 -1627). ${ }^{37}$

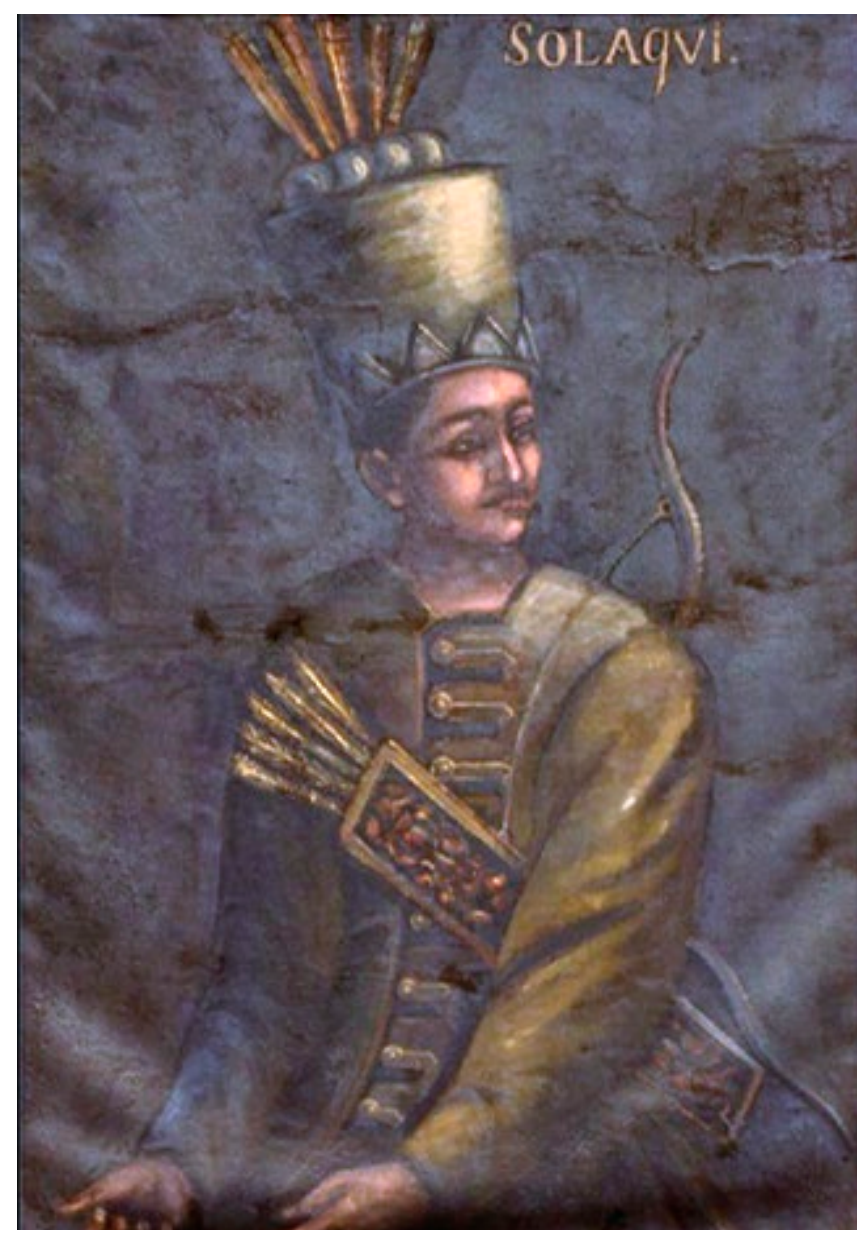

Fig. 6.20. Anónimo, Solaqui, finales del siglo XVI o principios del XVII, óleo sobre lienzo, Valencia, Real Colegio Seminario del Corpus Christi.

37 Williams Haydn, 'Additional Printed Sources for Ligozzi's Series of Figures of the Ottoman Empire', Master Drawigns, no 51 - 2, 2013, pp. 195229. 
Otro de los guerreros era Deli Cajssi, vestido con una capa, una túnica corta y un cinturón, calzado con botas y un tocado más discreto, simplemente adornado con una pluma. Siguiendo las descripciones de Vecellio, se conoce que sus principales armas eran el martillo y la cimitarra: "Questo è un' altra forte de bravi, ma più generosi, usano stivaletti ferrati, si tagliano un poco di pelle delle lor tempie per inferiui penacchi, portano celata di ferro, un martello e una scimitarra» [fig. 6.21]..$^{38} \mathrm{El}$ soldado georgiano igualmente fue un personaje de quien se ha destacado su condición de militar. Se le ha retratado como un varón en posición erguida y atenta, armado con la lanza, el arco y el carcaj. Vecellio lo describió del siguiente modo: «La Giorgia è Paese sterile habitato da Christiani, portano in capo una beretta fodrata de pelli con un capuccio, che gli pende in capo, hanno una Veste fino a mezza a gamba, portano arco e scimitarra.» [fig. 6.22]. ${ }^{39}$

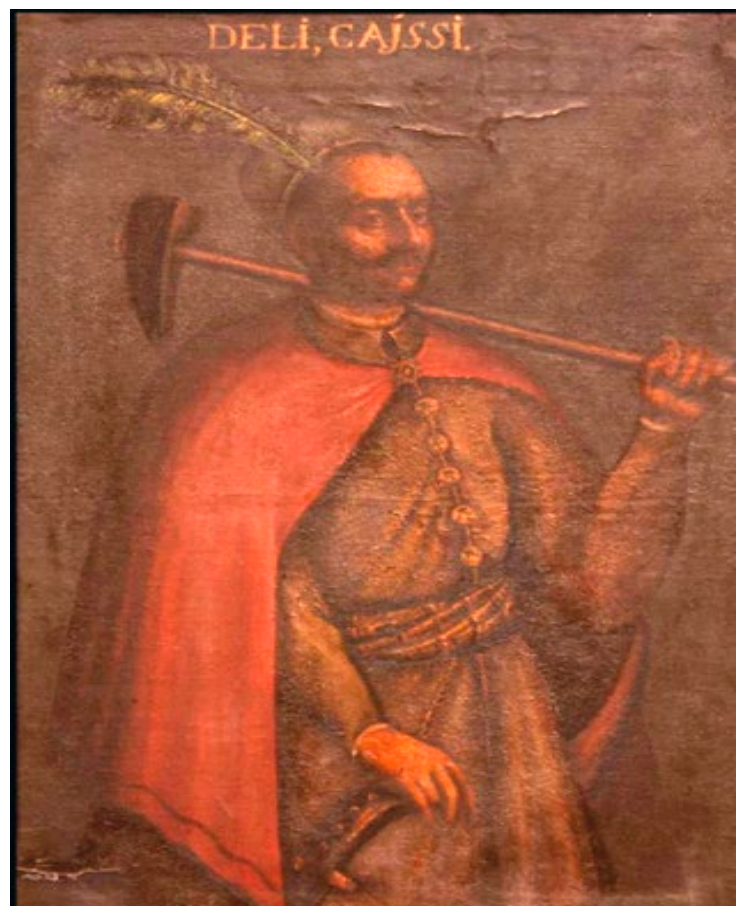

Fig. 6.21. Anónimo, Dejli Cassi, finales del siglo XVI o principios del XVII, óleo sobre lienzo, Valencia, Real Colegio Seminario del Corpus Christi.

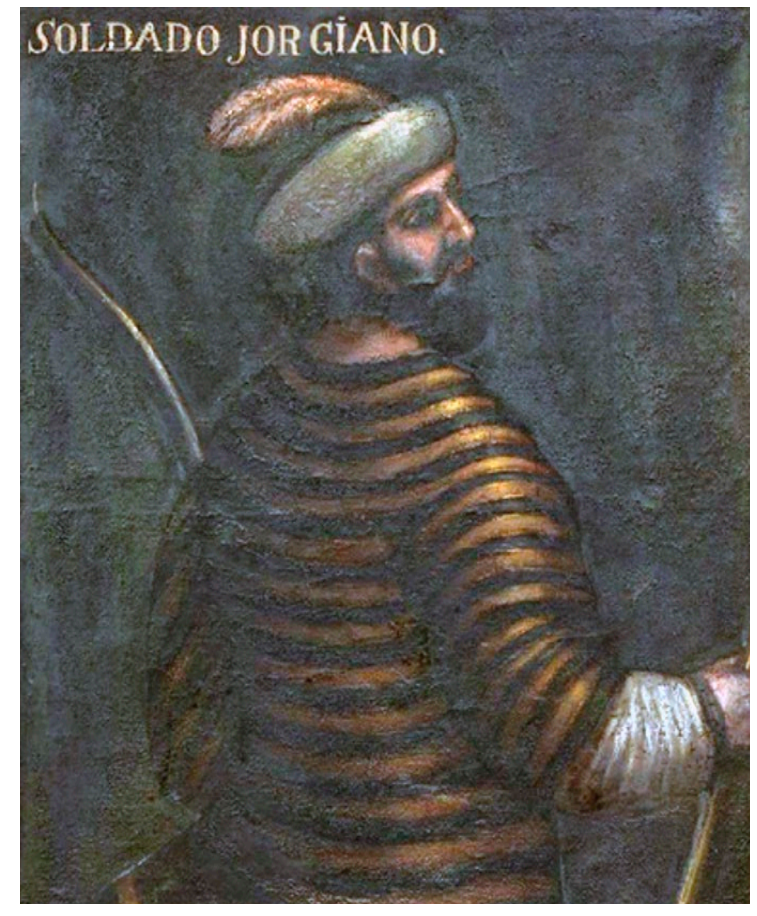

Fig. 6.22. Anónimo, Soldado georgiano, finales del siglo XVI o principios del XVII, óleo sobre lienzo, Valencia, Real Colegio Seminario del Corpus Christi.

38 Vecellio, Habiti antichi..., Libro séptimo, p. 314.

39 Vecellio, Habiti antichi..., Libro noveno, p. 378. 
Siguiendo con la representación de guerreros, hay que tener en cuenta el retrato del llamado Sfachiotto de Candía. La inclusión de este personaje en el libro de Vecellio y su correspondiente estampa concuerdan, generalmente, con la pintura de la galería. Si bien indicó que solía ir ataviado de cuero negro, la imagen lo viste con una túnica y un gorro, armado con un arco y sus flechas. No obstante, lo llamativo de este personaje es su ubicación en Habiti antichi según la edición. Lo más probable es que el artista conociese el ejemplar de 1598, donde Vecellio presentó al Sfachiotto en el libro octavo junto con otros personajes griegos, ya que Candía era el antiguo nombre de la isla de Creta [fig. 6.23]. Sin embargo, el volumen de 1664 colocó a este soldado en el libro séptimo entre el gran abanico de imágenes de turcos. El cambio de localización del Sfachiotto obedece a razones históricas que le confieren una lógica a esta modificación. Es necesario recordar que la república de Venecia y el imperio otomano se disputaron la posesión de Candía o de Creta, a lo largo de una guerra iniciada en 1645 y concluida en 1669 , cuando la mayor parte de la isla griega sucumbió al dominio turco. El conflicto bélico y su desenlace explican que el personaje figure como griego en 1598 pero se le considere turco en 1664, momento en que la batalla libraba su desenlace.
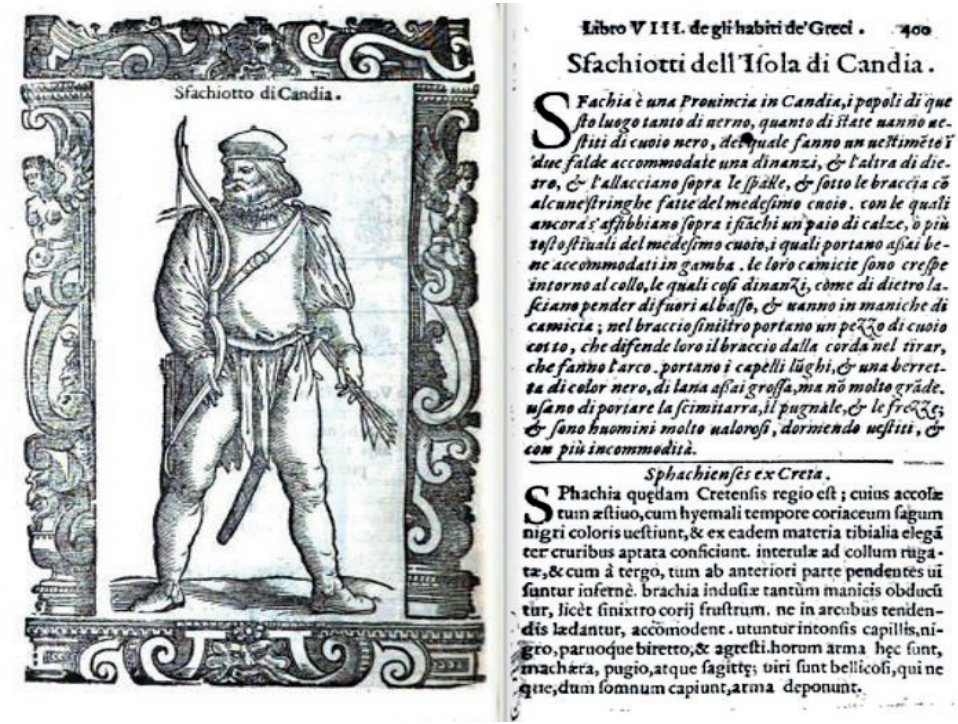

Fig. 6.23. Representación del Sfachiotto de Candía en Cesare Vecellio, Degli habiti antichi et moderni di diversi parti del mondo, 1590, Venecia. 
Por tanto, la explicación a que esta figura se encuentre entre los hombres representados quizás resida en que era un territorio susceptible de ser atacado y controlado por los otomanos [fig. 6.24].

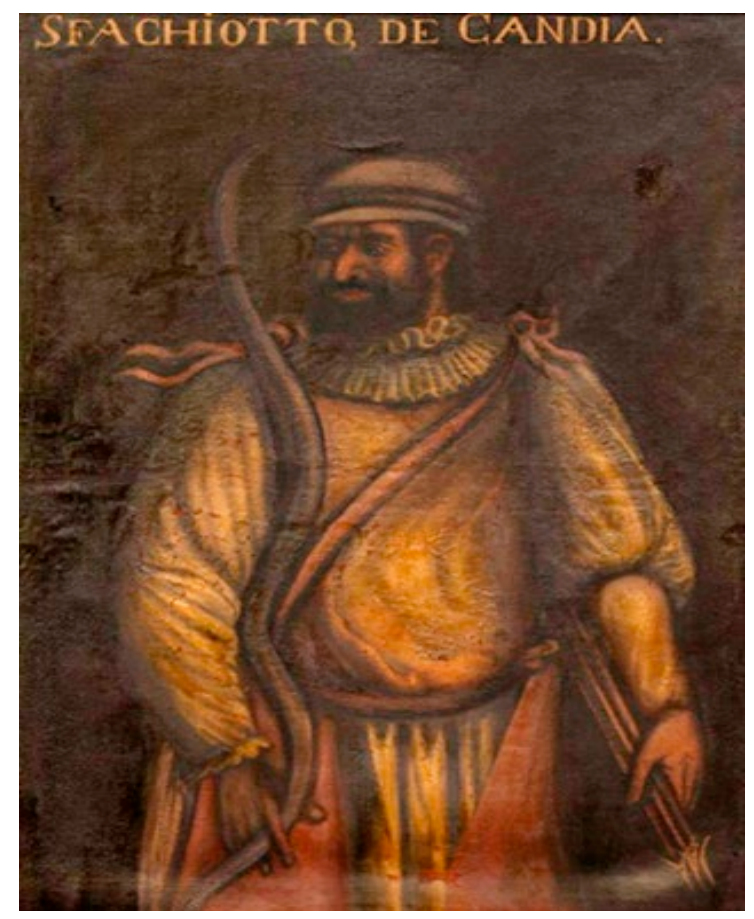

Fig. 6.24. Anónimo, Sfachiotto de Candía, finales del siglo XVI o principios del XVII, óleo sobre lienzo, Valencia, Real Colegio Seminario del Corpus Christi.

Otro de los retratos pertenece al hombre más poderoso de Egipto, el gran Soldán. El término «soldán» significa «sultán" y se utilizaba para referirse a los máximos gobernantes de Persia y Egipto. La efigie es reflejo de la magnificencia de este rey, elevado a su máxima expresión al llevar un exagerado turbante y lujosos ropajes. Aparece sentado, con las manos entrelazadas junto a un escudo y una espada [fig. 6.25]. Aunque en principio se pensase que la imagen se había inspirado en la estampa del Calidesquer à piedi del libro de Nicolay, al conocer la aportación de Vecellio se ha apreciado la notable influencia del autor veneciano. Es más, la comparación de las estampas en las variadas ediciones con el óleo sugiere que el artista se documentó en la correspondiente a 1590 o 1598 y no 
la perteneciente a 1664, pues el tipo de turbante es idéntico al del retrato. Este dato contribuye a considerar que los las pinturas se realizaron en torno al cambio de siglo. Nuevamente Vecellio identificó al sultán como el Capson Guari o el Gran Soldano del Cairo y especificó que: «Il Gran Soldano porta in capo una sessa con due corna simili al ritratto sopraposto. Và vestito d'una casacca di lisaro bianco cinta, e con una sopra veste di ciambellotto, ò zendale verde con mariggi di colore oscuro; mentre dà audientia tiene i piedi incrociati come le nostre donne, e hà il brocchiero e la scimitarra al lato...» [fig. 6.26]. ${ }^{40}$ Se trataba de otro personaje al servicio del dirigente turco pues, desde 1517 hasta el siglo XIX, Egipto fue un territorio más entre las amplias posesiones del imperio otomano a excepción del breve periodo de tiempo que abarcó la ocupación francesa (1798 - 1801).

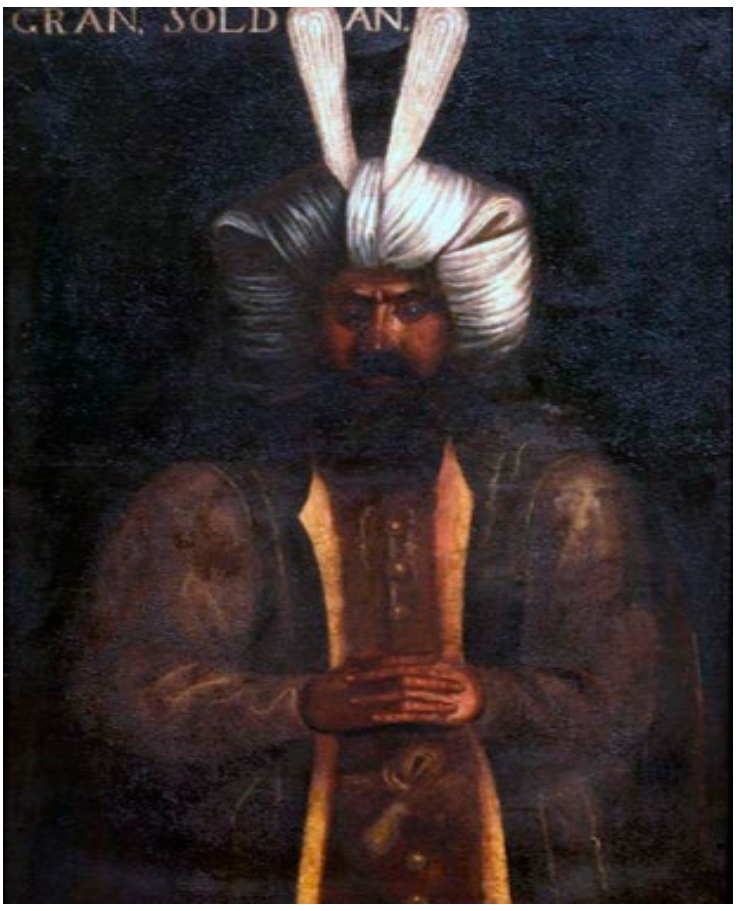

Fig. 6.25. Anónimo, Gran Soldán, finales del siglo XVI o principios del XVII, óleo sobre lienzo, Valencia, Real Colegio Seminario del Corpus Christi.

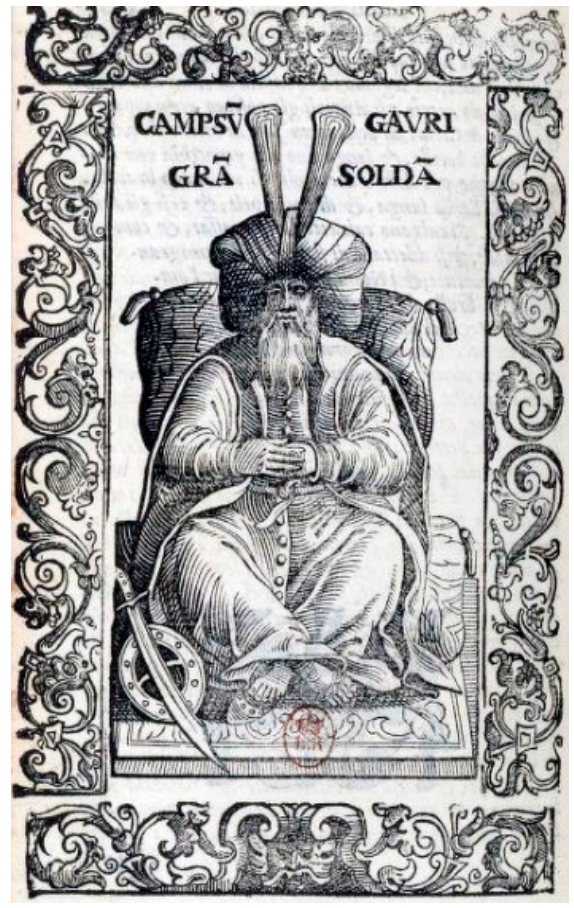

Fig. 6.26. Representación del Gran Soldán en Cesare Vecellio, Degli habiti antichi et moderni di diversi parti del mondo, 1590, Venecia, Biblioteca Nacional de Francia.

40 Vecellio, Habiti antichi et moderni..., Libro décimo, p. 422. 
A partir de las reflexiones de Fernando Benito, se creía que el artista se inspiró en el personaje de Boluch Bassi di cento Giannizzeri existente en la obra de Nicolay ${ }^{41}$ para pintar al consejero del gran Soldán [fig. 6.27]. No obstante, el modelo se ha encontrado nuevamente en uno de los tres personajes que Vecellio reprodujo en la estampa continua a la del sultán egipcio. En ella aparece un grupo de tres hombres, que sólo se distinguen por las variadas formas de los sombreros, siendo el de la izquierda del lector el consejero del monarca. Las distinciones físicas entre los retratados son imperceptibles, los rostros corresponden a tres hombres maduros y barbados. Probablemente la escasa personalización de cada uno de ellos se deba a la importancia de la indumentaria en su conjunto más que a la caracterización de los personajes. Igualmente la imagen se acompañó de un texto que los identificó como: «I Consiglieri e Ammiragli del gran Soldano vestivano tutto di bianco, con Dulipani alcunt lunghi, alquanto larghi appuntati dalle bande e alcuni simili a quello del gran Soldano» [fig. 6.28]. ${ }^{42}$

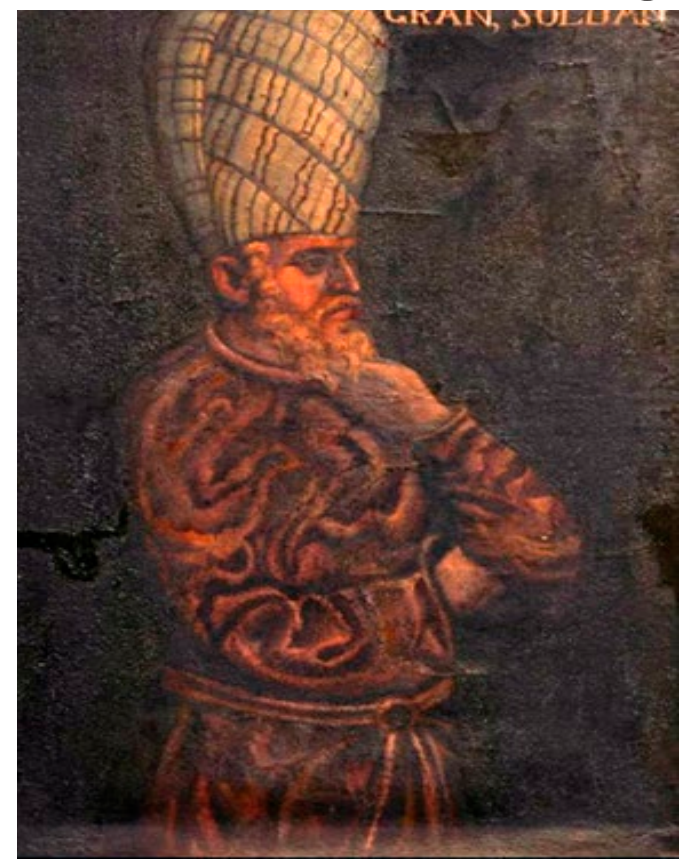

Fig. 6.27. Anónimo, Consejero del Gran Soldán, finales del siglo XVI o principios del XVII, óleo sobre lienzo, Valencia, Real Colegio Seminario del Corpus Christi.

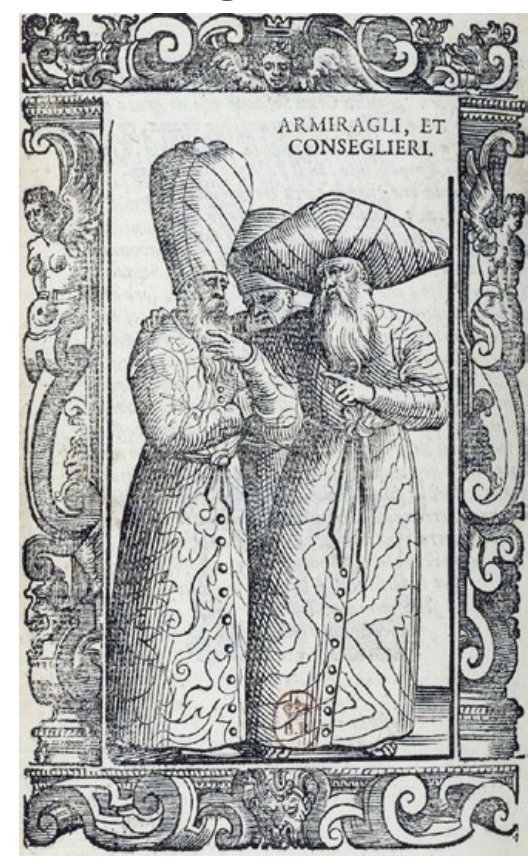

Fig. 6.28. Consejeros del Gran Soldán en Cesare Vecellio, Degli habiti antichi et moderni di diversi parti del mondo, 1590, Venecia, Biblioteca Nacional de Francia.

41 Nicolay, Le navegationi fatti..., fol. 157.

42 Vecellio, Habiti antichi..., Libro octavo, p. 353. 
Finalmente, es necesario tener en cuenta la efigie del mercader armenio. El varón se muestra en la actitud propia de su oficio, dialogante o negociante [fig. 6.29]. Aunque la pintura es máaustera, en el modelo proporcionado por Vecellio se le ha vestido con una túnica adornada con elementos vegetales, una capa y un gorro. Asimismo el personaje fue descrito del siguiente modo: «Gli mercanti Armeni, quelli però che sono Christiani, per comandamento del Turco sono ridotti, à portar in capo barrette simili alle nostre ò vero cappelli foderati di martori, ò d'altri pelli. vanno ordinariamente vestiti di panno nero e d'altro colore, come azurro, e pavonazo, e alle volte rasi e d'ormesini, ò d'altro, foderate di tela tistata, e il verno di peli. si calzano alcune calze di panno azurro con gli scarpini di cuoio, portano anco le scarpe alla Turchesca» [fig. 6.30].43

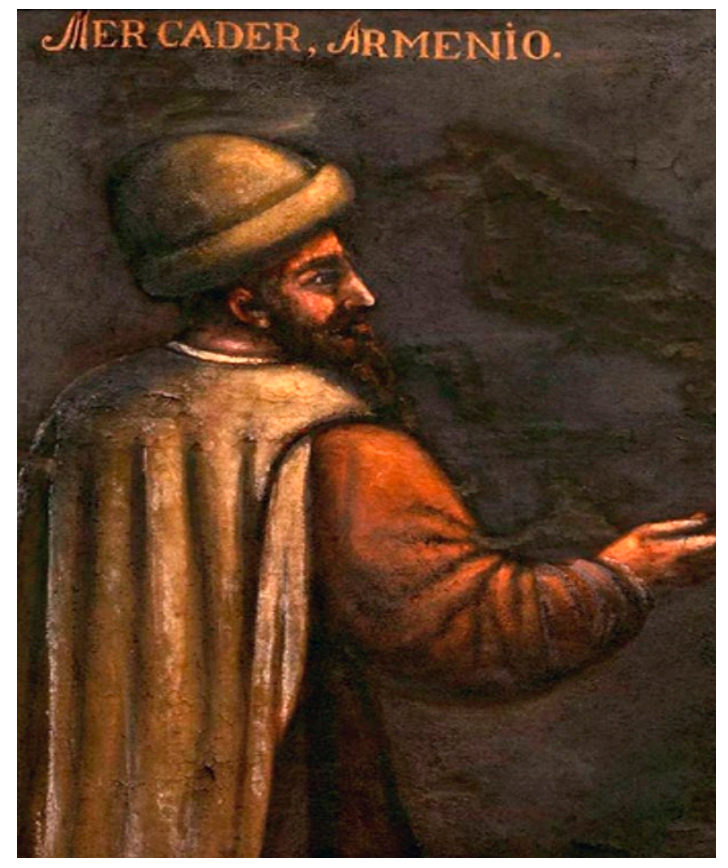

Fig. 6.29. Anónimo, Mercader armenio, finales del siglo XVI o principios del XVII, óleo sobre lienzo, Valencia, Real Colegio Seminario del Corpus Christi.

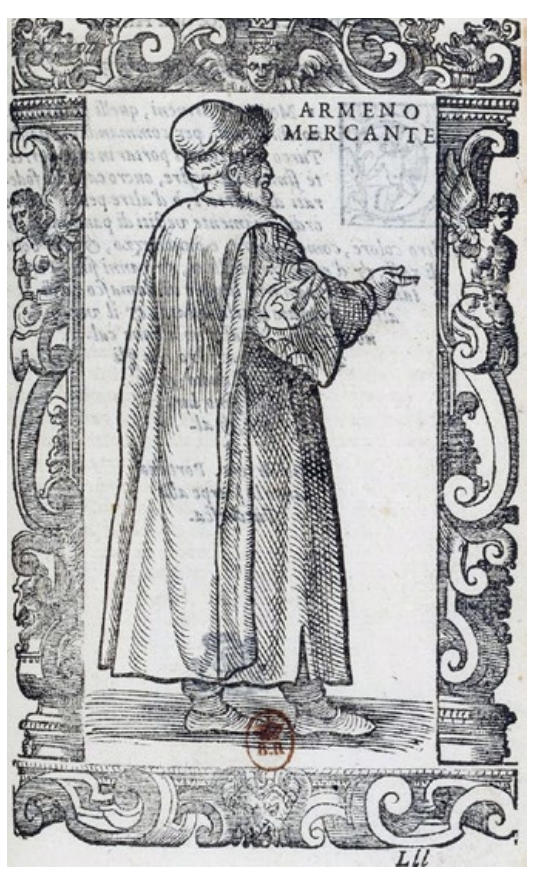

Fig. 6.30. Representación del Armenio mercante en Cesare Vecellio, Degli habiti antichi et moderni di diversi parti del mondo, 1590, Venecia, Biblioteca Nacional de Francia.

43 Vecellio, Habiti antichi et moderni..., Libro onceavo, p. 449. 


\subsection{Imágenes de poderosos orientales en la colección artís- tica de san Juan de Ribera.}

Las obras de arte, así como los libros que componen el repertorio particular de cualquier persona, son el reflejo de sus intereses e inquietudes por alcanzar determinados conocimientos. Por ello, es necesario reflexionar sobre el hecho de que posiblemente san Juan de Ribera decidiese adquirir el libro de Nicolay y las efigies analizadas para engrosar sus colecciones. La atmósfera cultural que se respiraba en su localidad de origen y su entorno familiar influyeron en que el Patriarca desease configurar su propia librería. ${ }^{44}$ Sevilla era el destino de muchísimos objetos y libros llegados desde el extranjero. Así pues, dicha ciudad era un hervidero cultural en el cual Fadrique Enríquez de Ribera, tío-abuelo del Patriarca, se había convertido en el modelo de hombre del renacimiento, aquel cultivado en el ámbito de las letras y de las artes. También el padre de san Juan de Ribera, Pedro Enríquez y Afán de Ribera 684 y Portocarrero, fue una persona culta que además heredó la significativa colección bibliográfica de su progenitor. Asimismo, el fundador del Colegio Corpus Christi recibió incunables y códices pertenecientes a Perafán.

Los volúmenes reunidos por san Juan de Ribera pasaron a ser propiedad del colegio, en 1602, tras manifestar sus últimas voluntades. También pidió que la biblioteca del seminario se localizase en un lugar predilecto del edificio, por ello se decidió situar esta estancia en la parte alta del claustro y así, como ha afirmado Navarro Sorní, 45 evitar las humedades y garantizar la adecuada conservación de las obras. Este inves44 Sobre la biblioteca personal de san Juan de Ribera conviene consultar la aportación de Miguel Navarro Sorní, 'La biblioteca de san Juan de Ribera, espejo de un humanista, exponente de la Reforma católica', en Francisco Tejada Vizuete (comisario), En torno a la biblioteca de San Juan de Ribera: exposición bibliográfica: libros impresos del siglo XVI: claustro de la S.I. Catedral Metropolitana de Badajoz, del 5 de mayo al 5 de junio de 2011, (Arzobispado de Mérida - Badajoz: Badajoz, 2011), pp. 13-31.

45 Navarro Sorní, 'La biblioteca de san Juan de Ribera...'. 
tigador igualmente ha apreciado el sentido simbólico del espacio al puntualizar que sobre la puerta se sigue encontrando la escultura de Hércules, héroe que mediante sus doce trabajos se convirtió en ejemplo de resistencia, de esfuerzo, de paciencia y de inteligencia, cualidades ineludibles para cultivar el saber. ${ }^{46}$ Como curiosidad, ha comentado que la puerta de la biblioteca y de la sacristía eran idénticas debido a que san Juan de Ribera quería vincular ambos espacios porque tanto la sacristía como la librería permitían el acceso a Dios. En el primero de los casos, se trata de la antesala al lugar de celebración de la Eucaristía, momento en el cual el sacerdote se encontraba con Dios. En la segunda opción, es el lugar donde trabajar el intelecto, adquirir el conocimiento y finalmente también poder llegar a Dios a través de la sabiduría. En este sentido, Ángel Campos - Perales ha profundizado en el análisis de la colección artística y científica de Ribera, pues buena parte de ella trataba de certificar la amplia variedad existente de seres humanos y especies animales a modo de testimonio de la creación de Dios. El mencionado autor, encontró la razón de este tipo de colección en las reflexiones de fray Luis de Granada, concretamente en su obra Introducción del símbolo de la $f e$, quien entendió que la naturaleza y las criaturas que en ella habitan son signo de la capacidad creadora de Dios. ${ }^{47}$

46 Además, en el inventario post-mortem quedó registrado que había «tres lienzos al temple con las fuerzas de Hércules» concretamente en el aposento de Pedro Martínez Santos del Palacio Arzobispal. Pero esta temática se repetía en la escalera de la casa de la calle Alboraya donde se inventariaron desde el número 271 hasta el 274 «cuatro lienzos pintados al temple de cuatro palmos de caída y seis de ancho con las fuerzas de Hércules» y además, "en el aposento de descanso de la Capilla de la misma casa» se anotó con los números 275, 276 y 277 la existencia de «tres lienzos pintados al temple de las fuerzas de Hércules de cuatro palmos de caída y seis de ancho con los marcos de madera blanca.» ACCV, Libro de noticias y curiosidades del Real Colegio..., pp. 220-221.

47 Ángel Campos-Perales, 'Ver y conocer a Dios en el mundo natural: Los intereses científicos de san Juan de Ribera (1532-1611) y su colección pictórica', POTESTAS. Estudios del Mundo Clásico e Historia del Arte, no. 12, Junio 2018, pp. 121-144. 
Por tanto, el conocimiento se cultivaba y crecía mediante los libros, pero las obras artísticas también eran una fuente para poseerlo. En este sentido, la obtención de esta galería de retratos no fue un hecho aislado, sino que forma parte de una larga lista de obras de temática exótica que engalanaban varias estancias en las distintas propiedades de san Juan de Ribera y que revelan asimismo los intereses intelectuales del propio Patriarca. De hecho, la documentación de archivo especifica que, en el palacio de Valencia, concretamente «en el aposento primero del cuarto del Sr. Patriarca llamado aposento del Conde» se inventariaron "doce lienzos pintados al temple de los triunfos del emperador Carlos V de cuatro palmos de caída y cinco de largo.. ${ }^{48}$ Probablemente en algunas de estas escenas ya aparecían personajes turcos en combate con las tropas del emperador Habsburgo.

En la casa de la huerta situada en la calle de Alboraya a extramuros de Valencia, concretamente «en el aposento donde dormía Gonzalo Suárez de Figueroa» había «tres lienzos pintados al temple de Asia, África y América viejos de cuatro palmos de caída y seis de ancho». En la entrada de la misma casa se encontró «un cuadro pintado al temple con el retrato de un elefante de ocho palmos de caída y dos de ancho con el marco jaspeado de colores», "un lienzo pintado al temple con el retrato de la abada o rinoceronte de ocho palmos de caída y doce de ancho con el marco de madera jaspeado de colores", también se dejó constancia de la existencia de «cuatro lienzos pintados al temple de montería de turcos», del «cuadro de la barbuda Brígida del río Peñaranda de seis palmos de caída y cuatro de ancho con marco de madera" y por último, «en su portal de la dicha huerta había tres lienzos pintados al temple rompidos y borrados, dos avestruces el uno macho negro y el otro hembra y dos cisnes hembras». Seguidamente se indicó que en la parte del estanque había un reloj solar, un puerco espín y dos jaulas grandes y finas en la pared con cuarentaicinco

48 Las obras se corresponden con las numeraciones del 96 al 107. ACCV, Libro de noticias y curiosidades del Real Colegio..., p. 210. 
clases distintas de pájaros. ${ }^{49}$

Seguramente la serie estudiada en el presente capítulo también estaba entre todas estas piezas y después del fallecimiento del arzobispo pasó a formar parte de la colección reunida en el Colegio. Así, en el siglo XVIII Antonio Ponz ya vio las efigies engalanando la escalera del seminario y las describió como «retratos de sujetos famosos, y los hay del Gran Turco, del Soldán de Egipto, deñ Sofi de Persia, y de varios jefes de oficios de sus familias. ${ }^{50}$ De ahí que se hayan podido identificar las dos pinturas perdidas. Como se ha comprobado, la colección más exótica se encontraba en la denominada casa de la huerta pero también acumuló numerosas especies botánicas y zoológicas en su propiedad de Burjassot. ${ }^{51}$

49 Las pinturas sobre los continentes se enumeraron del 296 al 297. En cuanto a las imágenes del elefante y del rinoceronte se contabilizaron como la 303 y 304 respectivamente. Las imágenes de montería de turcos se inventariaron desde el 307 al 310. Por último, el retrato de la mujer barbuda se inventarió con el número 315. ACCV, Libro de noticias y curiosidades del Real Colegio..., pp. 221-222.

50 Antonio Ponz, Viaje de España, (Viuda de Ibarra, Hijos y Compañía: Madrid, 1789), pp. 251-252.

51 Gaspar Escolano explicó el significado del topónimo Burjassot como torre en el bosque y entendió que el significado no estaba falto de razón porque, según dijo, «hoy día vemos un apacible bosque en este lugar, que lo es el señor don Juan de Ribera Patriarca de Antioquía, y arzobispo de Valencia: cuya vista es una de las famosas de la ciudad. Porque de más de los espesos y acopados olivos, pinos, carrascos y lentiscos, que de suyo lleva; la diligencia curiosa y grandeza de este príncipe ha recogido dentro de las más graciosas " y medicinales especies de hierbas, plantas, y animales salvajinos: y repartido todo esto con sumo artificio, le hace parecer un jardín de todos los bosques, o un bosque de todos los jardines.» Gaspar Escolano, Segunda parte de la década primera de la historia de la insigne y coronada ciudad del reino de Valencia, (Pedro Patricio Mey: Valencia, 1611), p. 326. 
En consecuencia y aunque por el momento no se hayan localizado referencias directas en el archivo hacia la galería de turcos, es palpable que la colección artística de san Juan de Ribera se excedía de la temática estrictamente religiosa y evidenciaba su deseo de saber acerca de diversas disciplinas, así como estudiar el mundo por entonces conocido. A ello, cabe sumarle el interés que tuvo por conocer al enemigo infiel. Pues se debe recordar que fue un acérrimo defensor de la religión católica, ostentó el cargo de virrey entre los años 1602 y 1604 y poco después, en 1609 se decretó la expulsión de los moriscos desde las costas valencianas.

La galería de efigies, como se ha podido observar, recoge en imágenes a personajes muy característicos y propios de distintos ámbitos de la estructura social turca. De este modo, se encuentran las representaciones de sultanes, consejeros, referentes espirituales, diferentes clases de guerreros y mercaderes. Si bien todas las obras tienen un interés y valor en sí mismo, su importancia es mucho mayor al conectarlas con los referentes visuales empleados para su elaboración y, sobre todo, al contextualizarlas con otro tipo de objetos artísticos que, en definitiva, señalan hacia la gran curiosidad que Oriente despertó en Occidente. 


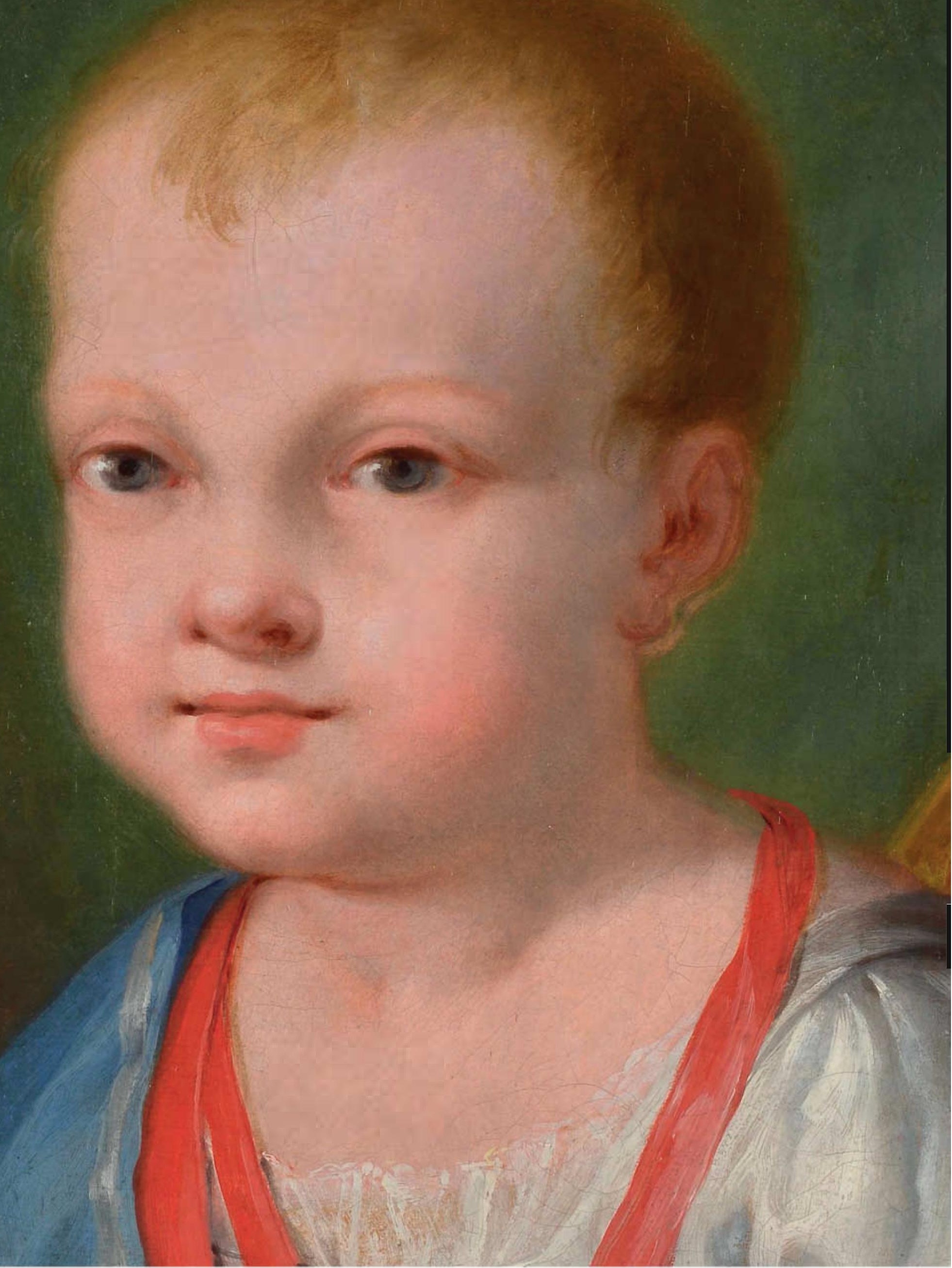




\section{Epílogo}

\section{El retrato y su implicación en la fiesta. Una futura investigación.}

Como se ha podido observar la presente tesis doctoral ha ceñido su análisis a la utilización de las efigies en las galerías de retratos, principalmente teniendo en cuenta el papel desempeñado por las imágenes en estos conjuntos. Sin embargo, a raíz de estudiar los fondos conservados en el Museo de Bellas Artes de Valencia y los inventarios de la Real Academia de San Carlos, ha sido posible abrir nuevas líneas de investigación que establezcan otros objetivos en el futuro. Así, el análisis de 691 un caso específico puede ser el germen de un estudio más amplio que planteará nuevas preguntas en cuanto a la elaboración, uso y función cometida por el retrato. Principalmente, el próximo marco de investigación se centrará en el empleo de este género en los actos festivos durante los siglos XVII y XVIII puesto que los retratos de monarcas y sus descendientes formaron parte del discurso político difundido en las celebraciones. El poder regio, tanto en la época de la dinastía Austria como Borbón, se esforzó por proyectar y diseminar una imagen concreta de sí mismo.

Para determinar esta posible futura vía de trabajo se parte, como se ha dicho, de un ejemplo concreto procedente de Valencia. Se trata de las efigies de los infantes gemelos, es decir, Carlos Francisco de Paula (5 de septiembre de 1783-11 de noviembre de 1784) y Felipe Francisco de Paula (5 de septiembre de 1783 - 17 de octubre de 1784), hijos del futuro Carlos IV y nietos del rey Carlos III, que la academia valenciana realizó 
con motivo de las fiestas organizadas por la ciudad para celebrar, en 1784, el nacimiento de los herederos al trono y la firma de paz con Gran Bretaña. Por esta razón, seguidamente se analizan los festejos que tuvieron lugar en la capital del Turia reflexionando acerca de la utilización de la imagen del rey, de los Príncipes de Asturias y de los infantes en todo el aparato festivo. Así se aprecia que el retrato siguió actuando como signo de poder y representación de la autoridad monárquica fuera del ámbito más institucional y solemne que se daba en las galerías de efigies, pero en un espacio igualmente de importante y a la vista de toda la sociedad. En los festejos, el pueblo podía ver las imágenes de los gobernantes ornamentando los carros triunfales o altares efímeros y, por tanto, junto con las instituciones y gremios mostrar la lealtad de la localidad a la Corona ${ }^{1}$. Además se han tenido en cuenta las composiciones literarias que se publicaron en la época, que pese a no pertenecer expresamente a Valencia sirven para conocer el tipo de creaciones literarias que vieron la luz en este momento.

1 En los dos últimos años, la autora de este trabajo, ha realizado estudios puntuales en torno a este tema que le han permitido tener un conocimiento más detallado del mismo y poder abrir nuevos interrogantes en la investigación. Cristina Igual Castelló, 'La alegría de Carlos III y su corte: Madrid y Valencia festejaron el nacimiento de los nietos infantes', en Inmaculada Rodríguez Moya (dir.), El rey festivo: Palacios, jardines, mares y ríos como escenarios cortesanos (siglos XVI - XIX), (Universitat Jaume I: Castellón), en prensa; Cristina Igual Castelló, 'Gozo y llanto por Carlos Clemente, Carlos Eusebio y los infantes gemelos. Fiesta, literatura y arte para mantener la esperanza en la Casa de Borbón', en Ma Carmen Pinillos Salvador y José Javier Azanza López (eds.), Teatro y fiesta en el Siglo de Oro: España y América, (EUNSA - Universidad de Navarra: Pamplona),en prensa; Cristina Igual Castelló, 'Con dos Infantes colma la Real Cuna. The festivals for twin grandchildren of Charles III and for the British peace in 1784', en Oskar Jacek Rojewski (ed.), Court, princes and festivals. Studies on the Early Modern visual culture, (Universidad de Silesia), en prensa; Cristina Igual Castelló, 'Presentación del infante Carlos Clemente a la Inmaculada Concepción', en Pablo González Tornel (ed.), Intacta María. Política y religiosidad en la España barroca, (Museo de Bellas Artes: Valencia, 2017), pp. 238-249; Cristina Igual Castelló, 'La institución de la orden de Carlos III ante la Inmaculada Concepción', en Pablo González Tornel (ed.), Intacta María. Política y religiosidad en la España barroca, (Museo de Bellas Artes: Valencia, 2017), pp. 234-237. 
Habitualmente en la realización de pinturas o en la composición de sermones y poemas laudatorios por parte de las parroquias, gremios e instituciones a raíz de una fiesta real se ha visto reflejado la concepción que el pueblo, súbdito de la Corona, tenía de su monarca. Sin embargo, cabe plantearse si esta lectura no debe hacerse con más recelo. Conviene preguntarse hasta qué punto las creaciones artísticas derivadas de la fiesta han reflejado objetivamente la idea que la sociedad tenía de la monarquía. Posiblemente, sea algo muy complicado de medir y tal vez responda a cuestiones culturales, donde la implicación de parroquias, gremios e instituciones ya se esperaba y en cierta manera, se había codificado.

Por tanto, es evidente que las fiestas han reflejado la aceptación y apoyo del pueblo a la monarquía, pero quizás más importante que ello era, para los grupos participantes, aprovechar las celebraciones, eventos de gran importancia y calado, como escaparate para exhibirse a sí mismos. Así, los gremios tenían la oportunidad de mostrar su capacidad económica a través de la construcción de magníficos carros y arcos triunfales o altares. Además, sus actuaciones piadosas y sus generosas contribuciones al festejo quedaban recogidas para la posteridad en documentos oficiales y relaciones festivas dejando constancia de la especial aportación de determinados grupos. En efecto, la fiesta sirvió para diversos aspectos; la especial exaltación de la Corona o de la Iglesia según el motivo de las celebraciones, la proyección pública de todos los participantes de las mismas y la configuración de una tradición y cultura festiva que integraba distintas disciplinas artísticas para emitir el mensaje político y religioso propio de la época. Aunque esta aportación puntual se centre en un ejemplo de imágenes y fiestas áulicas en el siglo XVIII, ${ }^{2}$ es perfectamente

2 Un referente para el análisis de las fiestas reales en Valencia durante el siglo XVIII ha sido la tesis doctoral y posteriores publicaciones de: María Pilar Monteagudo Robledo, El espectáculo del poder: fiestas reales en la Valencia moderna, (Ajuntament de València: Valencia, 1995); María Pilar Monteagudo Robledo, La monarquía ideal: imágenes de la realeza en la Valencia moderna, (Universitat de València: Valencia, 1995); María Pilar 
factible rastrear la presencia de retratos en festejos conmemorativos de personalidades políticas y religiosas tanto en el Seiscientos como en el Setecientos y observar que los mecanismos de representación del poder, en cualquiera que sea su ámbito, tienen numerosos puntos en común. En este sentido, antes de abordar el caso específico que se ha planteado se tratarán sintéticamente las festividades de los siglos XVII y XVIII para conocer la importancia de las fiestas como manifestación artística y cultural.

\section{E.1. Breve recorrido por los festejos celebrados en Valencia durante los siglos XVII y XVIII.}

Las fiestas han sido un acontecimiento cultural que por su carácter efímero tan sólo se han podido conocer a partir de los textos escritos y de las imágenes conservadas, ambas fuentes de información han permitido a los historiadores acercarse al mundo festivo en el pasado y estudiar las construcciones artísticas temporales que se materializaron en forma de altares, arcos de triunfo, carros, etc. y engalanaron las calles de numerosas ciudades. Por esta razón, las crónicas festivas tanto oficiales como extraoficiales son vestigios de gran valor que, pese a tener que ser leídas con ojos críticos, aportan abundantes datos sobre las celebraciones. En el caso valenciano, este tipo de obras fue adquiriendo una mayor importancia de forma progresiva desde el siglo XVI. Algunas de ellas eran libros repletos de estampas, normalmente de limitada calidad artística pero interesantes por su valor testimonial. Otras no relataban la fiesta al completo, sino que eran opúsculos centrados en la explicación de un elemento concreto que había formado parte del festejo, por ejemplo, las descripciones de carros triunfales, altares y otras decoraciones o la anotación de un sermón pronunciado en una determinada parroquia. Además, conviene añadir otro tipo de fuentes escritas que también son de utilidad como los libros de actas, libros capitulares y las

Monteagudo Robledo, 'El poder monárquico: fiestas reales e imagen de la monarquía en la Valencia del siglo XVIII', Universitat de València, 1994. 
cartas, dirigidas por ejemplo al Ayuntamiento, enviadas por los diversos gremios, parroquias e instituciones convocados a participar en las fiestas. ${ }^{3}$

Generalmente el tipo de celebración estuvo determinado, por un lado, por el propio personaje homenajeado en el evento y por otro, en función de la razón a festejar. Así se encuentran las fiestas monárquicas y las estrictamente religiosas, aunque la religión tenía también su espacio en las primeras a través de la realización de solemnes misas. En relación con la Corona se organizaban juras y proclamaciones, enlaces matrimoniales o nacimientos y en un ambiente de tristeza y dolor se hacían las honras fúnebres. Respecto a las celebraciones eclesiásticas tuvieron un especial festejo las beatificaciones y canonizaciones de santos, además de las devociones propias del lugar como la Virgen de los Desamparados o las asociadas a la Inmaculada Concepción. Independientemente de las razones que impulsasen a la fiesta, a través de ella se buscaba alegrar y distraer al pueblo, alejarlo por unos días de la dura realidad en la que vivía y sumirlo en la teatralidad barroca. A su vez, las celebraciones eran un camino efectivo para difundir la ideología de la monarquía y de la Iglesia y conseguir el aprecio de la población. De hecho Pilar Pedraza ya analizó, a través de las fiestas organizadas en honor de la Inmaculada Concepción en 1662, la efectividad propagandística y persuasiva de las celebraciones a causa del desconocimiento del pueblo. Por ello, pese a que los conceptos teológicos que rodeaban a este culto eran incomprensibles para gran parte de la sociedad, los festejos alimentaron la devoción a la Inmaculada. ${ }^{4}$

3 Se ha seguido un interesante capítulo centrado en el análisis de los libros de fiesta y las estampas como documentos testimoniales de la fiesta en el territorio valenciano, véase a: Víctor Mínguez, Pablo González Tornel e Inmaculada Rodríguez Moya, 'Libros de fiestas valencianos y la estampa barroca', en La fiesta barroca: El Reino de Valencia (1599-1802), (Universitat Jaume I. Consell Social: Castellón, 2010), pp. 23-31.

4 Pilar Pedraza, Barroco efimero en Valencia, (Ayuntamiento de Valencia: Valencia, 1982). 
El siglo XVII, sin duda, estuvo copado por la organización de muchísimos festejos extraordinarios además de los ya estipulados por el calendario litúrgico. ${ }^{5}$ Una buena selección de ellos se encuentra en la obra citada de Pedraza, donde es posible apreciar la diversidad de razones que los impulsaron. Por ejemplo, en el ámbito eclesiástico se celebraron la llegada de numerosas reliquias, como la perteneciente a san Vicente Ferrer traída desde Gran Bretaña (1600), la de santa Bárbara (1607) y el conjunto de reliquias que el virrey de Nápoles, Juan Pimentel de Herrera y Quiñones, envió a la ciudad (1610). También tuvieron sus correspondientes fiestas las beatificaciones y canonizaciones que mostraban a hombres y mujeres humildes y de fe inquebrantable como modelos de la espiritualidad católica. Así fueron proclamados como beatos fray Luis Bertrán (1608), Teresa de Jesús (1615), Pascual Bailón (1618), Tomás de Villanueva (1619) y Francisco de Borja (1625). Todos ellos y algunos otros adquirieron el grado de santidad pocos años después y este nuevo título igualmente fue celebrado. Cabe destacar las canonizaciones de san Raimundo Peñafort (1602), san Ignacio de Loyola (1622), san Francisco Javier (1622), santa Teresa de Jesús (1624), santa Isabel de Portugal (1628), san Pedro Nolasco (1628), santo Tomás de Villanueva (1659), san Juan de Malta (1668), san Francisco de Valois (1668), san Pedro de Alcántara (1671), san Luis Bertrán (1671), san Francisco de Borja (1671), san Pedro Pascual (1674) y san Pascual Bailón (1691).

Igualmente, a lo largo de la centuria tuvieron lugar celebraciones con el objetivo de promocionar el culto a la Inmaculada Concepción. La más relevante se produjo en 1622 a raíz de las constituciones de Gregorio XV en apoyo este misterio. En

5 En la primera mitad del siglo XX ya se hizo un compendio de referencias festivas que se sigue consultando en la actualidad. Véase a Jenaro Alenda y Mira, Relaciones de solemnidades y fiestas públicas de España, (Establecimiento tipográfico 'Sucesores de Rivadeneyra': Madrid, 1903); Francesc Carreres de Calatayud, Las fiestas valencianas y su expresión poética: siglos XVI-XVIII, (Consejo Superior de Investigaciones Científicas, Instituto Jerónimo Zurita: Madrid, 1949). 
1655 volvió a tener lugar el festejo inmaculista, esta vez por voluntad de la cofradía del Carmen y su juramento de defensa de la pía devoción. Y diez años después, en 1665 promovidas por Antonio Pedro Sancho Dávila y Osorio, virrey de Valencia. Asimismo se festejó, de forma excepcional, la entrada en la ciudad en 1612 del prelado Isidoro Aliaga. ${ }^{6}$

Las fiestas propias del ámbito áulico fueron más escasas y espaciadas en el tiempo. Se celebraron los nacimientos de los infantes Fernando y Felipe Próspero en 1609 y 1657 respectivamente. Además, se festejaron los enlaces matrimoniales, no sólo de miembros de la familia sino también de virreyes. Por ejemplo, en 1633 tuvo lugar la unión de los marqueses de Vélez, virreyes de Valencia. Y en 1690 se dio la boda de Carlos II con Ana de Neoburgo. Por último, igualmente se deben destacar las visitas a la ciudad, pues eran la ocasión oportuna para mostrar una vez más la fidelidad a la Corona. En 1632 se recibió a Felipe IV y sus hermanos, en 1645 dicho monarca volvió a la ciudad acompañado de su hijo Baltasar Carlos y en 1652 se festejó la entrada del virrey el duque de Montalto.7

Sin embargo, uno de los acontecimientos más relevantes que se dieron en Valencia en el límite del siglo XVI al XVII fue el enlace matrimonial de Felipe III y Margarita de Austria en 1599. Conviene detenerse brevemente en este caso porque es un ejemplo de cómo una fiesta de esta magnitud quedó inmortalizada en las obras de Juan Esquerdo y Gaspar Aguilar, escritos que aportaron la descripción de todos los actos festivos, especificando los itinerarios y las decoraciones efímeras que invadieron la ciudad. Asimismo, a través de los textos, hicieron constantes referencias a personajes de la Antigüedad asociados con los protagonistas de la fiesta y con el rito del matrimonio. Lo interesante de todo ello es que estos mismos recursos fueron empleados en otras celebraciones monárquicas durante el gobierno de los Austria y, como se podrá obser6 Pedraza, Barroco efímero..., pp. 26-32.

7 Pedraza, Barroco efímero..., íbidem. 
var, también de forma puntual en los festejos de la dinastía Borbón concretamente en aquellos que son objeto de estudio de este apartado.

El matrimonio, por tanto, dio lugar a numerosos actos que mantuvo a la ciudad en un ambiente festivo durante bastante tiempo. Como ya describió Juan Esquerdo 8 se trató de una boda doble, pues además del rey también se casaron la infanta Isabel Clara Eugenia y el archiduque Alberto. El monarca fue recibido en la iglesia de san Vicente por los jurados, otras autoridades y miembros de la nobleza, allí tuvo lugar el besamanos y seguidamente Felipe III bajo palio junto con toda la comitiva marcharon hasta la puerta de san Vicente donde se le hizo entrega de las llaves de la ciudad. Más tarde, continuó el itinerario fijado que tuvo su correspondiente parada en la catedral para cantarse un Te deum. La procesión regia siguió por las calles de la ciudad hasta llegar al palacio del Real. A lo largo del recorrido se levantaron numerosos arcos triunfales decorados con imágenes de temática clásica y de los antepasados del rey, reforzando así su linaje. Felipe III estuvo en Valencia a la espera de la llegada de Margarita de Austria y durante este tiempo también se celebró, el 28 de febrero, el acto de juramento de los fueros de la ciudad y del reino ante la presencia de san Juan de Ribera así como se organizaron distintos saraos. ${ }^{9}$

La obra de Esquerdo no ha sido el único vestigio escrito conservado sobre estas fiestas, también es interesante los poemas que escribió Gaspar Aguilar para loar estas celebraciones re-

8 Juan Esquerdo, Tratado copioso y verdadero, de la determinacio del gran Monarcha Phelipe II. para el casamiento del III. co[n] la Serenissima Margarita de Austria: y entradas de sus Magestades y Grandes por su orden en esta ciudad de Valencia: con las libreas, galas y fiestas q[ue] se hizieron, (Casa de Juan Grysostomo Garriz: Valencia, 1599).

9 Acerca de esta fiesta véase además a: Víctor Mínguez, Pablo González Tornel e Inmaculada Rodríguez Moya, 'Organización, tipologías y actores de la fiesta', en La fiesta barroca: El Reino de Valencia (1599-1802), (Universitat Jaume I. Consell Social: Castellón, 2010), pp. 41-61. 
gias. ${ }^{10}$ Así el autor redactó cuatro cantos para narrar ordenadamente la sucesión de hechos históricos y adornarlos con una serie de recursos comunes que en definitiva alababan tanto a los esposos como a la monarquía. Por ello, desde el inicio ensalzó a la princesa Margarita y alabó su linaje definiéndola como «la más bella mujer de todo el mundo. Su estirpe noble, antigua y generosa viene por línea recta de Faemundo, que es el origen de su esposa bella, y así ella viene de él, y él viene de ella.» ${ }^{11}$ La composición escrita también incluyó personajes de la Antigüedad al igual que las imágenes decorativas de los arcos triunfales. Por citar algunos ejemplos, mencionó a las ninfas, a la parca, a Júpiter, a Neptuno o a Himeneo, a éste último se le imploraba su bajada para darle a Felipe III «la posesión rica y dichosa de su querida regalada esposa.»12

Centrándose en el itinerario que siguió el monarca, el punto de partida se estableció en Denia, visita realizada a petición del marqués de dicha localidad, es decir Francisco Sandoval y Rojas (duque de Lerma y valido del rey). En esta estancia estuvo acompañado de su hermana, a quien se la ha equiparado con la diosa Diana: «Y aunque de Denia se ausentó Diana por evitar del tiempo la porfia, es fama que esta vez se volvió a Denia disfrazada en tu hermana Clara Eugenia. ${ }^{13}$ Si de la futura esposa se hicieron alusiones a su estirpe, igualmente sucedió con el rey, por ejemplo, al decir que: «en la proa, en la popa, en la crujía tenía más valor que Moctezuma rico señor del mexicano suelo, le dio a Cortés caudillo de tu abuelo.» ${ }^{14}$ Estas referencias al linaje de ambos tenían por función justificar la idoneidad de la pareja para asumir la Corona y el gobierno de

10 Gaspar Aguilar, Fiestas nupciales que la ciudad y reino de Valencia han hecho al casamiento del rey don Felipe III, (Imprenta de Manuel Pau: Valencia, 1910).

11 Aguilar, Fiestas nupciales..., Canto I. De las fiestas nupciales, p. 2.

12 Aguilar, Fiestas nupciales..., Canto I. De las fiestas nupciales, p. 3.

13 Aguilar, Fiestas nupciales..., Canto I. De las fiestas nupciales, p. 10.

14 Aguilar, Fiestas nupciales..., Canto I. De las fiestas nupciales, p. 13. 
los territorios bajo su dominio.

Seguidamente, centrando la fiesta ya en la ciudad de Valencia se celebró un besamanos y el monarca estuvo acompañado por los jurados. Se le entregaron las llaves de la localidad que, según el autor, era equiparable a Roma y, por tanto, Felipe III fue asociado con Pompeyo. A continuación, se dio paso a lo que, posiblemente, se trate de la ceremonia celebrada en la catedral. Del texto se puede deducir que el monarca fue recibido por el arzobispo y besó una reliquia muy venerada y apreciada que a juzgar por la descripción bien podría ser un lignum crucis: "Llegado al templo con grandeza tanta el sumo sacerdote, a quien le toca, te recibió con la reliquia santa, que al mismo cielo a devoción provoca. Y tú señor con humildad que espanta pusiste los corales de tu boca en ella, porque es parte del cayado del pastor que murió por su ganado.» ${ }^{15}$

$\mathrm{Al}$ caer la noche, el rey se retiró al palacio real desde donde pudo apreciar las calles repletas de luminarias. También dis-

frutó de los saraos y danzas que amenizaron las veladas posteriores y tuvo lugar la ceremonia del juramento. De forma paralela al viaje de Felipe III, en la parte final del primer canto, se ha explicado la llegada de Margarita de Austria y del archiduque Alberto a Vinaroz, el seguido traslado a San Mateo y su correspondiente besamanos, el paso por Sagunto y la definitiva venida a Valencia para el enlace matrimonial. ${ }^{16}$

El canto segundo se ha centrado específicamente en el relato de la boda. Así se han incluido exaltaciones de la ciudad y se han descrito algunos de los arcos triunfales que engalanaron las calles. Por ejemplo, el situado en la puerta de Serranos contenía, en su parte alta, una representación de Jaime I haciendo alusión a la reconquista cristiana. También se dispusieron las imágenes de cuatro archiduques (cuyas identidades no se especifican) con ramos de laurel y olivos por haber llevado a

15 Aguilar, Fiestas nupciales..., Canto I. De las fiestas nupciales, p. 29.

16 Aguilar, Fiestas nupciales..., Canto I. De las fiestas nupciales, p. 30-36. 
cabo acciones de paz. Además, había otro arco completamente decorado con motes y divisas componiendo un discurso visual centrado en la exaltación del linaje. Asimismo, se construyó otro arco triunfal en la puerta por la que había de llegar Margarita de Austria. Una vez más, la ornamentación hacía alusión a la genealogía de la infanta y sin dar más detalles, el autor indicó que además contenía las imágenes de cuatro diosas que le ofrecían presentes. ${ }^{17}$ Seguidamente se ha identificado y descrito la indumentaria de los hombres nobles e ilustres que llegaron a Valencia para asistir a la celebración. Después desfilaron los reyes de armas, el justicia de la ciudad y los príncipes de Italia y Flandes. Una vez pasado esto, se ha narrado la llegada de la infanta y el archiduque, su entrada en la catedral y la ceremonia y se ha concluido el capítulo haciendo referencia al sarao que tuvo lugar aquella noche. ${ }^{18}$ Finalmente, el tercer y cuarto canto han versado sobre el contento general del pueblo ante tal acontecimiento y han narrado la celebración de torneos, justas, banquetes y danzas, mencionando a los asistentes más afamados y describiendo sus trajes. ${ }^{19}$

701

Tras haber tratado brevemente las fiestas en el siglo XVII y haber incidido en uno de los numerosos ejemplos para conocer los mecanismos empleados por el poder en el ámbito festivo, conviene hacer algunas consideraciones en torno a las celebraciones del siglo XVIII. Como ha explicado Pilar Monteagudo la llegada de una nueva dinastía, iniciada con Felipe V, al trono español también supuso un cambio en la dinámica cortesana. Atrás quedó la corte compuesta por algunos hombres principales que gozaban de cargos políticos, de la cercanía y del amparo del monarca. No obstante, Felipe $\mathrm{V}$ había tenido como referente la corte de su abuelo Luis XIV la cual se entendió como: «el magnífico y costoso instrumento del prestigio monárquico, perdiendo completamente su papel político. Su cometido era realzar la gloria del trono mediante el esplen17 Aguilar, Fiestas nupciales..., Canto I. De las fiestas nupciales, p. 37-39.

18 Aguilar, Fiestas nupciales..., Canto I. De las fiestas nupciales, p. 39-68.

19 Aguilar, Fiestas nupciales..., Canto I. De las fiestas nupciales, p. 70-135. 
dor de la vida de sociedad, lo que hacía visible al monarca.» ${ }^{20}$ Siguiendo a la misma autora, se ha podido apreciar que los Borbón transformaron la corte española teniendo por modelo a Versalles, adentrándose en el absolutismo, donde el rey era el único señor del territorio y su palacio el elemento simbólico de su prestigio y poder, dejando en un segundo plano sus funciones políticas. El cambio no fue inmediato ni drástico con el reinado del nuevo soberano Borbón, sino que se produjo paulatinamente y fue más perceptible durante el gobierno de Fernando VI. ${ }^{21}$ Las variaciones que se dieron de una dinastía a otra fueron mínimas respecto a la fiesta. A grandes rasgos, se ha podido apreciar que los festejos mantuvieron, a lo largo del siglo XVIII, sus tipologías y mecanismos de exaltación del poder. Esta misma idea también ha sido expuesta por Víctor Mínguez al estudiar las arquitecturas efímeras dieciochescas en Valencia. ${ }^{22}$ Si bien es cierto que durante esta centuria las celebraciones fueron más sobrias, a excepción de algunos casos, que en los años anteriores. Ello fue consecuencia de una moral centrada en la austeridad que reducía, en medida de lo posible, los costes de los festejos y prefería destinar el dinero a acciones benéficas. Quizás de este modo, el rey buscaba el acercamiento y la simpatía del pueblo.

El cambio producido en la fiesta también ha tenido su explicación en las modificaciones de la realidad política en el territorio español y concretamente en el valenciano. Las ambiciosas 20 Monteagudo Robledo, La monarquía ideal..., p. 37.

21 Monteagudo Robledo, La monarquía ideal..., p. 37-38.

22 Víctor Mínguez, Art i arquitectura efímera a la València del segle XVIII, (Edicions Alfons el Magnànim: Valencia, 1990). Se trata de un estudio continuador de la investigación iniciada por Pilar Pedraza sobre el barroco efímero valenciano. El autor ha apreciado la pervivencia de la estructura, tipología y aparato ornamental de las festividades del siglo XVII en el XVIII centrándose en el minucioso análisis de tres casos concretos de gran trascendencia en la época; el quinto centenario de la conquista de Valencia por Jaume I (1738), el tercer centenario de la canonización de san Vicente Ferrer (1755) y el primer centenario del traslado de la imagen de la Virgen de los Desamparados a su basílica (1767). 
sumas de dinero invertidas en las celebraciones eclesiásticas y civiles propias de la época de los Austria se han podido explicar, además, a través del sistema pactista entre la Corona $y$ el Reino de Valencia. El respeto del monarca hacia los fueros se correspondía con la fidelidad del territorio local, consiguiendo el equilibrio entre ambas partes. Así, todos los organismos de poder en una u otra escala tenían espacio en la fiesta para mostrarse. Aquí se daba cabida al rey, al virrey, a la Iglesia, al poder civil y a numerosos gremios. Sin embargo, la Guerra de Sucesión y la consiguiente llegada de una nueva dinastía al trono español habían suprimido el respeto a las leyes valencianas en aras de centralizar el poder e imponer las normas castellanas. En este sentido, la fiesta se focalizó en la exaltación de la monarquía absolutista. Asimismo, la Corona, influida por la mentalidad de la Ilustración le otorgó una mayor importancia a invertir ayudas económicas en dotes a doncellas con el objetivo de formalizar nuevas familias que contribuyan a la prosperidad del pueblo español. ${ }^{23}$ La apuesta por el progreso, por la industria, por el comercio, por las artes y la continuada búsqueda de la paz fueron rasgos distintivos de la monarquía en el siglo XVIII que tuvieron su reflejo en las fiestas. Por ejemplo, varios de los carros triunfales que desfilaron en Madrid en 1784 para festejar el nacimiento de los infantes gemelos y el acuerdo de paz con Gran Bretaña aludieron a los aspectos mencionados.

Respecto a las celebraciones acaecidas específicamente en Valencia durante esta centuria cabe destacar algunas de ellas. Aquellas fiestas que rememoraban hechos importantes del pasado, de índole cívico o religioso, tuvieron un carácter extraordinario y fueron recogidas en sus respectivas crónicas. Por ejemplo, José Vicente Ortí y Mayor escribió sobre los actos conmemorativos de los quinientos años de la conquista cristiana de la ciudad. Tomás Serrano recopiló las celebraciones por los trescientos años de la canonización del dominico san

23 Monteagudo Robledo, El espectáculo del poder..., pp. 187-189. 
Vicente Ferrer. También se ha dejado constancia escrita, aunque con posteridad, del primer centenario del traslado de la imagen de la Virgen de los Desamparados a su correspondiente basílica. ${ }^{24}$

Una de las principales fiestas eclesiásticas de este periodo y exentas del calendario litúrgico fueron las beatificaciones. En 1786 adquirieron el título de beatos Nicolás Factor y Gaspar Bono. Sus fiestas se organizaron conjuntamente y como testimonio de ellas se ha conservado el escrito de Carmelo Espiau de Piquer. Unos años más tarde, en 1797, se produjo la beatificación de san Juan de Ribera, celebrada entre los días 26 y 28 de agosto del mismo año. Igualmente se conserva un breve texto de Luis Ballester donde se ha descrito pormenorizadamente toda la decoración efímera y emblemática que se dispuso en el convento de los Predicadores. ${ }^{25}$

Las festividades vinculadas a la monarquía organizadas durante el siglo XVIII también fueron puntuales y de distinta tipología, como sucedió en la centuria anterior. Así, en 1719 se produjo la visita de Felipe V, su segunda esposa Isabel de

24 José Vicente Ortí y Mayor, Fiestas centenarias, con que la insigne, noble, leal y coronada ciudad de Valencia celebró, en el día 9 de octubre de 1738, la quinta centuria de su cristiana centuria, (Antonio Bordazar: Valencia, 1740); Tomás Serrano, Fiestas seculares con que la coronada ciudad de Valencia celebró el feliz cumplimiento del tercer siglo de la canonización de su esclarecido hijo y ángel protector san Vicente Ferrer, apóstol de Europa, (Imprenta de la viuda de José de Orga: Valencia, 1762); Teobaldo Fajarnés y Castells, Recuerdos históricos de la Real Capilla de Nuestra Señora de los Desamparados: fiestas de inauguración y del primer centenario, (José Mateu Garín: Valencia, 1867). Cabe recordar que estas tres fiestas fueron objeto de estudio de Víctor Mínguez como se ha apuntado previamente (véase nota 22).

25 Carmelo Espiau de Piquer, Las fiestas de Valencia, idea, y descripción de las bellas funciones celebradas en esta Ilustre ciudad en los días $12 \mathrm{y}$ 19 de agosto de esta año 1787, con motivo de las beatificaciones de sus tiernos hijos Nicolás Factor y Gaspar Bono, (Imprenta de Salvador Fauli: Valencia, 1787); Luis Ballester, Breve descripción de las fiestas que hizo el Real Convento de Predicadores de Valencia en la beatificación del B. Juan de Ribera y sermón que predicó el R. P. M. Fr. Luis Ballester prior del mismo convento, (Imprenta de D. Benito Monfort: Valencia, 1797). 
Farnesio y el príncipe Luis. Poco después, en 1724, se celebró la proclamación de Luis I como monarca. En 1728 se festejó el enlace matrimonial del infante Carlos y Ma Amalia de Sajonia. Seguidamente, en 1759, tuvo lugar la proclamación de Carlos III. Por último, en 1784 se celebraron los nacimientos de los infantes gemelos, nietos del rey. De entre todas ellas, tan sólo se conservan las relaciones festivas de las proclamaciones. De hecho, sí que se dispone de las descripciones de las fiestas organizadas en la villa de Alzira con motivo de la subida al trono de Luis I y de las celebraciones de la ciudad de Valencia a raíz de la proclamación de Carlos III. ${ }^{26}$

Como se ha avanzado anteriormente, el caso concreto tratado en esta sección se ha elegido por la conservación de muchísima documentación original en el Archivo Municipal de Valencia. Sin embargo, no han perdurado, en esta ciudad, los legajos referentes a los festejos que seguramente tuvieron lugar pocos años antes con los nacimientos de los infantes Carlos Clemente y Carlos Domingo Eusebio, hermanos mayores de los gemelos. ${ }^{27}$

Cabe recordar que la llegada de infantes a la familia real alimentaba la esperanza dinástica y ofrecía una imagen de prosperidad y longevidad al linaje reinante. ${ }^{28}$ Desgraciadamente, las expectativas monárquicas de los Borbón se truncaron en

26 Bartolomé Casses, Festivas demostraciones con que la real, fiel y coronada villa de Alzira celebró la feliz proclamación de nuestro monarca Luis I, cuya relación, con la oración panegírica y gratulatoria en acción de gracias ofrece la misma villa, (Antonio Bordazar de Artazu: Valencia, 1724); Mauro Antonio Oller y Bono, Proclamación del Rey Ntro. Sr. D. Carlos III: (que Dios guarde) en su fidelísima ciudad de Valencia, (Oficina de la viuda de José de Orga: Valencia, 1759).

27 No obstante, sí que se conserva la documentación de estas celebraciones en la villa de Madrid. Una gran cantidad de información se localiza en Archivo de Villa, Madrid, sección 2, legajo 76, número 3, 1771. Festejos por el feliz parto de la Princesa de Asturias y el nacimiento del Infante don Carlos Clemente el 12 de septiembre de 1771, s/f.

28 Respecto a las fiestas monárquicas para festejar nacimientos, convie- 
numerosas ocasiones durante el gobierno de Carlos III. La primera de ellas fue con el prematuro fallecimiento de Carlos Clemente Antonio (19 de septiembre de 1771- 7 de marzo de 1774) y le siguió la muerte de Carlos Domingo Eusebio (5 de marzo de 1780 - 11 de junio de 1783) a los tres años de edad. Unos meses después, la alegría llegaba de nuevo cuando en septiembre de 1783 nacían los infantes gemelos. Con dos herederos más, se volvieron a avivar las esperanzas de mantener una descendencia fuerte, sana y duradera. No debieron imaginar que tan sólo un año después, en 1784, la muerte arrebataría la vida de ambos retoños.

En cualquier caso, al analizar cada uno de los ejemplos es evidente que los Príncipes de Asturias no cesaron en sus intentos por asegurar el futuro de la Corona. En este sentido, resulta de gran interés comprobar que las manifestaciones artísticas emplearon los recursos propios de la tradición festiva y similares en los festejos organizados tras el nacimiento de cada infante varón, llegando a hacer comparaciones literarias entre unos y otros e incluso reutilizando las imágenes. Por ello, aunque en el principal objeto de estudio del epílogo sean las festividades de los gemelos se incidirá en aquellos aspectos que guardan relación con los casos precedentes. En consecuencia, este apartado ha contribuido a defender la idea de que la Monarquía Hispánica empleó los diversos recursos artísticos y festivos con la finalidad suprema de ofrecer una imagen firme, consolidada y duradera de su poder.

\section{E.2. Escritos, imágenes y festejos en el siglo XVIII: Los ante- cedentes a las celebraciones dedicadas a los infantes geme- los.}

Tanto en el caso de los gemelos como en los herederos que les precedieron se escribieron poemas laudatorios, oraciones y ne consultar: Inmaculada Rodríguez Moya, 'La esperanza de la monarquía. Fiestas en el imperio hispánico por Felipe Próspero', en Inmaculada Rodríguez Moya y Víctor Mínguez (dirs.), Visiones de un imperio en fiesta, (Fundación Carlos de Amberes: Madrid, 2016), pp. 91-119. 
sermones en honor de los legatarios que en ocasiones tenían su impronta en las imágenes. Por ello, cuando los textos asociaron a los miembros de la familia real con divinidades de la Antigüedad, éstos aparecían en las imágenes vestidos según la moda clásica. También se daba el caso de relacionarlos con las virtudes de personajes bíblicos y así, las representaciones incluyeron versículos de las sagradas escrituras.

Uno de los ejemplos más tempranos que evidencian esta influencia entre las artes literarias y visuales ya se dio a raíz del nacimiento de Carlos Clemente. La Biblioteca Nacional conserva un soneto dedicado Al feliz nacimiento del Señor Don Carlos Clemente, hijo primogénito del Serenísimo Señor Don Carlos, Príncipe de Asturias, el cual valoró al infante como un ser heroico, fruto de la unión entre Venus y Marte, dioses del amor y de la guerra respectivamente, cuyo cometido era consolidar el gobierno de la monarquía. Asimismo, el texto ha permitido conocer las razones por las que al infante se le llamó Carlos Clemente. Ambos nombres fueron tomados de sus padrinos de bautismo (su abuelo y el pontífice) y a ellos se le vincularon una serie de virtudes que ya se presuponía que poseía el recién nacido. Por tanto, el nombre de Carlos se asoció a lo amado y el de Clemente a lo piadoso, dando por hecho que el heredero iba a ser estimado y bondadoso. La composición escrita concluyó con un interesante paralelismo que relacionaba al retoño con Carlos V y equiparaba el monasterio de El Escorial con la ciudad de Gante. De este modo, el autor se permitió hacer esta asociación entre el emperador de la Casa de Austria con el infante Carlos Clemente quien, en caso de llegar a ser rey tras el gobierno de su padre, también tomaría el nombre de Carlos V.

Si de Venus, y Marte la alianza un potentoso infante ha producido, ¡Feliz España! Pues que ha conseguido dichoso complemento en su esperanza.

En este héroe las dichas afianza, pues de ramas tan fértiles nacido, en él se ve mil veces repetido 
vivo retrato, viva semejanza.

En Carolus lo amado está patente, en Clemente lo pío está constante, por sus señas, y nombre se le pintó.

Pásmese el orbe, que claramente, porque en él ha nacido Carlos Quinto, vemos, que San Lorenzo es nueva Gante. ${ }^{29}$

Las referencias a la Antigüedad han estado presentes en las imágenes alegóricas de este suceso. Así, la estampa elaborada por Pasqual Moles Corones y Noël Hallé en 1771 [fig. E.1] ha situado la escena en el templo de la Inmortalidad, donde los miembros de la familia real van ataviados según la moda clásica y se encuentran junto con otras personificaciones. Una de

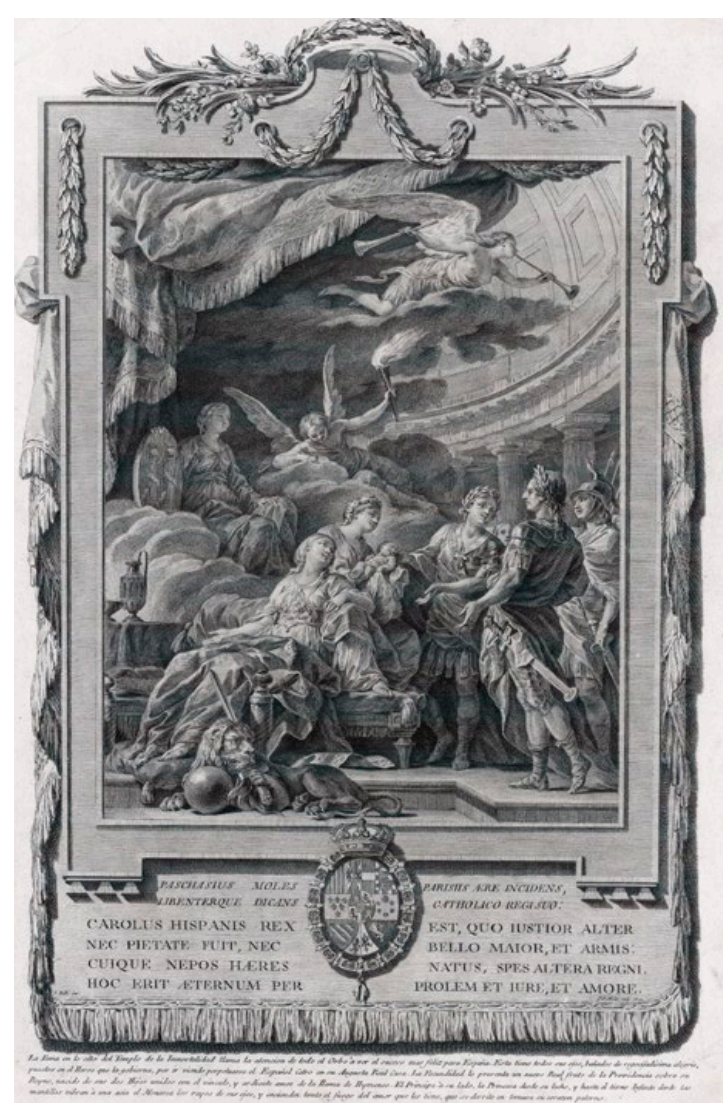

Fig. E.1: Pasqual Pere Moles y Noël Hallé, Alegoría del nacimiento del infante Carlos Clemente, 1771, estampa, Barcelona, Museu Nacional d'Art de Catalunya. ellas es la Fama anunciando el nacimiento de Carlos Clemente. También se ha identificado a España, bajo palio y sosteniendo la divisa instaurada por Carlos $\mathrm{V}$ con las dos columnas de Hércules y la cartela entrelazada que reza plus ultra. Ella dirije su mirada al rey vigente, Carlos III, coronado con hojas de laurel. La alegoría de la Fertilidad es quien sostiene al recién nacido y a cada lado aparecen los Príncipes de Asturias. A la izquierda, se ve a María Luisa de Parma extenuada tras el feliz parto. A la derecha, se encuentra el heredero Carlos coronado con laurel y luciendo el collar del

29 Anónimo, 'Varias poesías al feliz nacimiento del Señor Don Carlos Clemente, hijo primogénito del Serenísimo Señor Don Carlos, Príncipe de Asturias', en Papeles curiosos manuscritos, tomo 21, 1701-1800, p. 150v-151r. 
toisón. También se ha incluido a Himeneo como testigo de la escena, quien sostiene una antorcha. ${ }^{30}$

El león que tiene bajo su dominio una espada y el orbe, protege a la familia. El animal y el globo terráqueo han sido ampliamente utilizados en los libros de emblemas en alusión al poder del rey. En efecto, Saavedra Fajardo al presentar su modelo ideal de príncipe cristiano dedicó la empresa XXI Regit et corregit [fig. E.2] a la necesidad de amonestar las malas conductas como parte de la justicia. Por ello, el autor explicó que

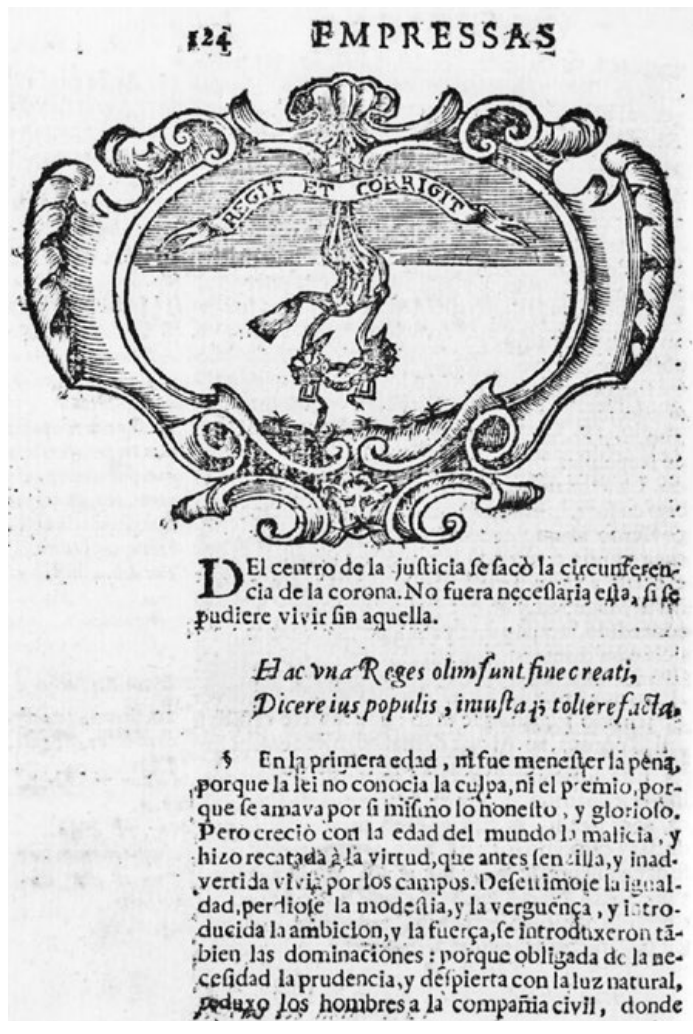
la espada también era símbolo de igualdad y rectitud «como lo dio a entender Trajano, cuando dándosela desnuda al prefecto pretorio, le dijo: "Toma esta espada y úsala en mi favor si gobierno justamente, y si no, contra mí." Los dos cortes de ella son iguales al rico y al pobre.» ${ }^{31}$

Fig. E.2: Empresa XXI Regit et corregit en Diego de Saavedra Fajardo, Idea de un príncipe político cristiano, representada en cien empresas, (Gerónimo Villagrasa: Valencia, 1665).

30 El personaje de Himeneo tradicionalmente ha estado presente en las alegorías nupciales pues en la Antigüedad era la divinidad protectora de los esposos. Era, por tanto, la deidad que presidía los cortejos nupciales y llevaba a la mujer hasta la casa del marido. Los recién casados debían consumir el matrimonio y tener descendencia, pues ése era el cometido de la alianza matrimonial. Por esta razón, tiene lógica que Himeneo también se encuentre en las representaciones alegóricas del nacimiento de los infantes como se ha visto. Consúltese a: Inmaculada Rodríguez Moya y Víctor Mínguez, Himeneo en la Corte: poder, representación y ceremonial nupcial en el arte y la cultura simbólica, (Consejo Superior de Investigaciones Científicas: Madrid, 2013).

31 Diego de Saavedra Fajardo, Idea de un príncipe político cristiano, representada en cien empresas, (Gerónimo Villagrasa: Valencia, 1665), p. 126. 
En la parte inferior de la estampa se ha incluido el escudo de la monarquía y un breve texto en latín con laudes al soberano acerca de su justicia, su lealtad y eficacia en la guerra así como pone de manifiesto la esperanza para la dinastía que supone el nacimiento ${ }^{32}$ de su nieto. Esta imagen, sin duda, es un ejemplo de cómo se readaptó y se empleó para elaborar una alegoría visual del nacimientos de los infantes gemelos.

Además se conservan otras pinturas alusivas a este hecho que fueron producto del concurso que la Real Academia de Bellas Artes de San Fernando convocó en 1771 y celebró en 1772, en cuya modalidad denominada pinura "de pensado" se debía "representar a Dios en forma de venerable anciano, en acción de encomendar la custodia del recién nacido infante a los santos ángeles, a san Lorenzo y a san Genaro". ${ }^{33}$ La colección artística del museo de la citada institución dispone de las obras que ganaron el primer y el segundo premio del concurso. El primer clasificado fue el artista Jacinto Gómez [fig. E.3]. ${ }^{34}$

En este caso, la personificación de la Corona española dirige la mirada y abraza amorosamente al infante. Se ha vestido de blanco y azul, concretamente los colores asociados a la Inmaculada Concepción y los mismos que adoptó la Orden fundada por Carlos III. Este detalle no es casualidad, pues cabe recordar que el propio rey creó la mencionada institu-

32 El texto concretamente dice: CAROLUS HISPANIS REX EST, QUO IUSTIOR ALTER NEC PIETATE FUIT, NEC BELLO MAIOR, ET ARMIS: CUIQUE NEPOS HAERES NATUS, SPES ALTERA REGNI. HOC ERIT AETERNUM PER PROLEM ET IURE, ET AMORE.

33 Isabel Azcárate Luxan, Victoria Durá Ojea, Ma Pilar Fernández Agudo, Elena Rivera Navarro y Ma Ángeles Sánchez de León Fernández, Historia y alegoría: los concursos de pintura de la Real Academia de Bellas Artes de San Fernando (1753-1808), (Real Academia de Bellas Artes de San Fernando: Madrid, 1994), p. 123.

34 Este dato también ha sido proporcionado por Azcárate Luxan, Durá Ojea, Fernández Agudo, Rivera Navarro y Sánchez de León Fernández, Historia y alegoría..., p. 124. 


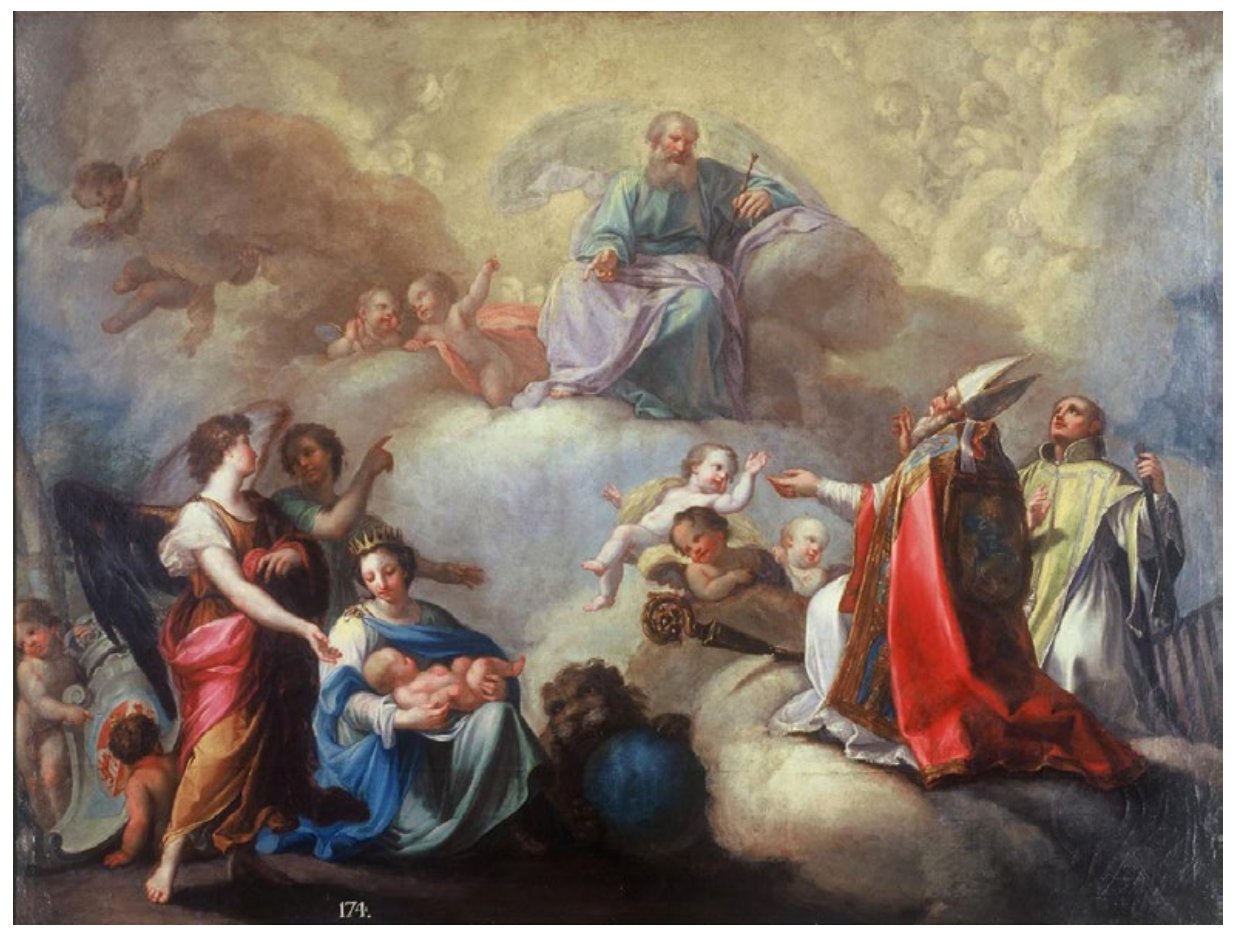

Fig. E.3: Jacinto Gómez, Alegoría del nacimiento del infante don Carlos Clemente, 1772, óleo sobre lienzo, Madrid, Museo de la Real Academia de Bellas Artes de San Fernando.

ción dedicada a la devoción de la Inmaculada en agradecimiento por la llegada del nuevo legatario. ${ }^{35}$

La actitud de la figura simbólica de la monarquía es la propia de una madre, ya que el heredero era descendiente de la Corona. Ambos están bajo la protección del león en cuyas garras tiene el orbe y dos ángeles, uno de ellos dirige al espectador hacia Dios, un hombre de edad avanzada y cabello blanco que

35 Acerca de las representaciones alusivas a la gratitud del monarca y a la creación de la Orden de la Inmaculada Concepción se ha seguido a: Fernando Benito Doménech, 'Sobre Agustín Gasull, José Vergara, y una traza de la antigua iglesia de la Compañía de Valencia', Archivo de arte valenciano, Vol. 63, 1982, pp. 66-68; Miguel Ángel Catalá Gorgues, El pintor y académico José Vergara (Valencia, 1726-1799), (Generalitat Valenciana: Valencia, 2004); Felipe Jerez Moliner y Ma José López Terrada, 'La Alegoría de la Orden de Carlos III, de Vicente López. Anotaciones al texto de Francisco José Fabre', Goya: Revista de arte, Vol. 258, 1997, pp. 322 - 332; Ma José López Terrada, 'El lenguaje alegórico al servicio del poder: el caso del nacimiento del infante Carlos Clemente de Borbón', en Víctor Mínguez (ed.), Las artes y aquitectura del poder, (Universitat Jaume I: Castellón, 2013), pp. 1665 - 1683; Wifredo Rincón García, 'Iconografía de la Real y Distinguida Orden de Carlos III’, Fragmentos, Vol. 12-13-14, 1988, pp. 145-161. 
a su vez señala hacia los santos. San Genaro es identificable por sus vestiduras pontificales y el báculo que tiene a sus pies. A su lado, es facilmente reconocible san Lorenzo con la parrilla en la mano izquierda a modo de atributo de su martirio. La aparición en la obra de ambos santos está plenamente justificada puesto que por un lado la festividad de san Genaro se celebra el 19 de septiembre, día del nacimiento del infante. Por otro lado, san Lorenzo referencia al monasterio de El Escorial, espacio en el que tuvo lugar el feliz alumbramiento.

La segunda posición fue para la obra de Gregorio Ferro [fig. E.4], donde en el centro de la misma se encuentra la alegoría de monarquía española representada a través de una figura femenina entronizada, vestida con una capa roja salpicada por flores de lis, alusivas al linaje Borbón, y un casco similar al de Minerva, hija de Júpiter. Ella presenta al infante al cielo presidido por Dios padre cuya representación conecta con el tipo iconográfico de Júpiter, el anciano de cabellos y barba canosa. También aparecen los personajes de san Lorenzo y san Genaro. Así de forma simbólica y a través de la imagen, la monarquía hispánica es hija de la divinidad, cuenta por tanto con el beneplácito y la protección de Dios para desempeñar su tarea gubernamental en la tierra.

Además, el artista se excedió en su obra de lo estrictamente dispuesto en las normas del concurso. Por ello, quiso traducir en imagen el paralelismo que ya se ha visto en el soneto procedente de la Biblioteca Nacional, el cual equiparaba al infante con Carlos V. La solución fue bastante aguda, aunque carente de novedad, e incluyó a un esclavo turco, maniatado y cabizbajo ante el escudo de España. Una figura similar ya se ha visto en la pintura de Felipe II ofreciendo al cielo infante don Fernando (Tiziano, 1573-1575, óleo sobre lienzo, Madrid, Museo Nacional del Prado), la cual en definitiva venía a conmemorar el triunfo en la batalla de Lepanto además de celebrar la llegada del infante Fernando. En consecuencia, se ha aludido a la victoria final sobre el enemigo turco, un triunfo que culminó en el reinado de Felipe II pero que hunde sus raíces en el reinado de su predecesor, Carlos V. Todo ello, ha dado pie a pensar que a través del personaje turco el artista hizo una referencia 
al emperador de la Casa de Austria y deseaba un poder y éxito equiparable para el futuro Carlos V de la Casa de Borbón.

En cuanto a las fiestas celebradas a raíz de este suceso se ha consultado la documentación encontrada en el Archivo de Villa (Madrid), puesto que en los fondos municipales de Valencia no se conserva ningún rastro de las mismas. En general, se

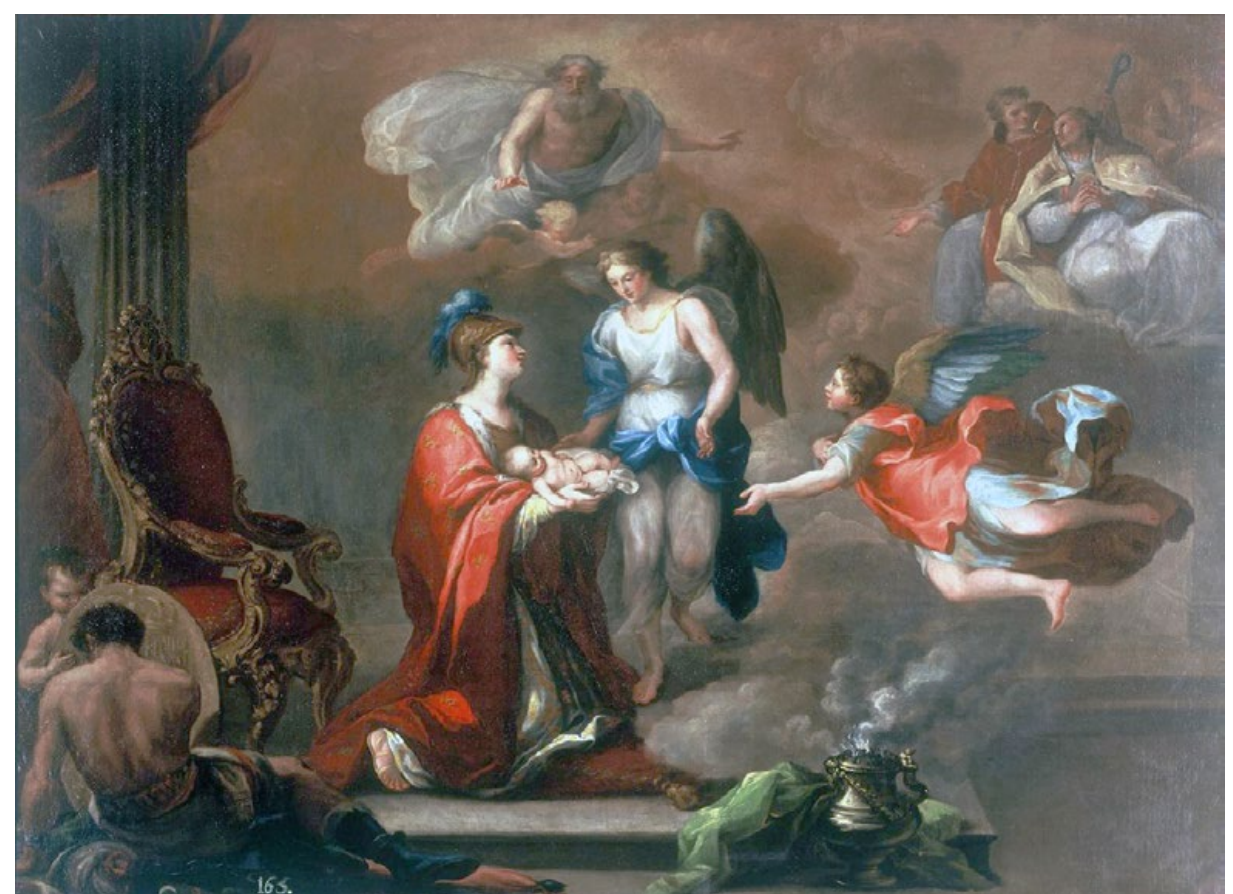

Fig. E.4: Gregorio Ferro Requeixo, Alegoría del nacimiento del Infante Carlos Clemente, 1772, óleo sobre lienzo, Madrid, Museo de la Real Academia de Bellas Artes de San Fernando

sabe que respetando la voluntad monárquica fueron comedidas. Prueba de ello es que la documentación Sobre la distribución del dinero que se emplearía en los regocijos públicos para celebrar el nacimiento de lo que diere a luz la Princesa Nuestra Señora ruega que en lugar de que el rey, la villa y los cinco gremios mayores invirtiesen sumas de dinero en lienzos, cartones y fuegos, prefiere que se destinasen íntegramente para las dotes de doncellas pobres, así como se pide a los gremios mayores y menores que los caudales también los utilicen para sufragar las dotes de las doncellas de su propio gremio y se propone cómo repartir las dotes..$^{36}$ Esta decisión truncó la voluntad del Ayuntamiento madrileño de elaborar unas fiestas igual de fastuosas que se habían hecho en el pasado. Es más, el

36 Archivo General de Palacio, Madrid, Sección Histórica, Nacimientos y Bautismos, caja 94, expediente 194. 
expediente dedicado a estas celebraciones está precedido por el listado de gastos que se asumieron en 1661 y 1707 tras los nacimientos de Carlos II y Luis I respectivamente.

Y según consta en la documentación, en vistas de la proximidad del parto de la princesa, el Ayuntamiento acordó el 3 de septiembre de 1771 conocer los dispendios realizados anteriormente en fiestas similares. ${ }^{37}$ El rey, muy agradecido, prefirió como se ha dicho destinar tan grandes sumas de dinero a otros fines. Así lo expresó el conde de Aranda al corregidor del Ayuntamiento a través de una carta fechada el 19 de septiembre de 1771, en la cual incidía en que el monarca estaba complacido por:

[...] las muestras de felicidad y amor a su augusta persona y real familia, con que todos el reino se distingue, y quiere repetirlo en esta ocasión; se ha excitado el paternal afecto y esmero con que S.M. desea en todos tiempos preferir cuanto pueda facilitar el bien y alivio de sus amados vasallos, para declarar le será más agradable que las crecidas sumas en semejantes ocasiones se han consumido y contribuido voluntariamente a costear dichos festejos, sirviendo estos distraer de su trabajo a las gentes, y de más servicio, que beneficio a la causa pública, si inviertan en dotes a doncellas pobres y huérfanas que faciliten sus matrimonios con proporción a sus clases. ${ }^{38}$

Respetando la voluntad regia, el gobierno madrileño finalmente optó por declarar tres días de gala y disfrutar de tres noches con luminarias. Asimismo, se acordó asistir al convento de Nuestra Señora de Atocha donde se celebró una misa con Te Deum y se rogó por el pronto restablecimiento de la Ma Luisa y la excelente salud del recién llegado. ${ }^{39}$ Después del 37 Archivo de Villa, Madrid (AVM ahora en adelante), Sección 2, legajo 76, número 3, 1771. Festejos por el feliz parto de la Princesa de Asturias y el nacimiento del Infante don Carlos Clemente en 12 de septiembre de 1771, s/f.

38 AVM, Sección 2, legajo 76, número 3, 1771. Festejos por el feliz parto de la Princesa de Asturias y el nacimiento del Infante don Carlos Clemente en 12 de septiembre de 1771, s/f.

39 AVM, Sección 2, legajo 76, número 3, 1771. Festejos por el feliz parto de 
fallecimiento de Carlos Clemente, el 5 de marzo de 1780 llegó un nuevo varón y, por tanto, candidato a ostentar la Corona. Era Carlos Domingo Eusebio (1780 - 1783) y le precedieron tres infantas: Carlota Joaquina (1775 - 1830), María Luisa Carlota (1777 - 1782) y María Amalia (1779 - 1798). Para este caso, en la actualidad, no se conservan referencias documentales a las fiestas que debieron organizarse, al menos, en las ciudades de Valencia y de Madrid. No obstante, sí que mantiene un punto en común al ejemplo de Carlos Clemente. En esta ocasión, la Real Academia de Bellas Artes de San Fernando, nuevamente, convocó un concurso de pintura en su modalidad "de pensado". Según las normas, los aspirantes debían pintar una escena alegórica emplazada en un paisaje fértil y muy frondoso, en el cual se podía incluir el palacio del Pardo. Una de las figuras protagonistas se correspondía con la personificación de España quien recibía al nuevo retoño y se disponía a dejarlo en su cuna. Al ser un concurso propuesto por la Academia también debían aparecer las representaciones de la Pintura con un tapiz, la Escultura con una imagen de las tres Gracias para referirse a las tres infantas y hermanas mayores de Carlos Domingo Eusebio y, por último, la Arquitectura junto a las columnas de Hércules y la inscripción plus ultra. Asimismo, era necesario introducir como figura simbólica al río Manzanares, además de representar al ayo del niño e incluir angelitos que portadores de atributos. ${ }^{40}$

La obra ganadora fue hecha por Zacarías González Velázquez (1763 - 1834) [fig. E.5], quien cumplió con las directrices de la Academia. La alegoría de España muestra al infante en su real cuna y junto a ella, se encuentra un ánfora repleta de monedas de oro en alusión a la prosperidad. Las personificaciones de las tres artes principales se reconocen con facilidad, pues llevan sus atributos identificativos. También forman parte de

la Princesa de Asturias y el nacimiento del Infante don Carlos Clemente en 12 de septiembre de 1771, s/f.

40 Azcárate Luxan, Durá Ojea, Fernández Agudo, Rivera Navarro y Sánchez de León Fernández, Historia y alegoría..., p. 141. 


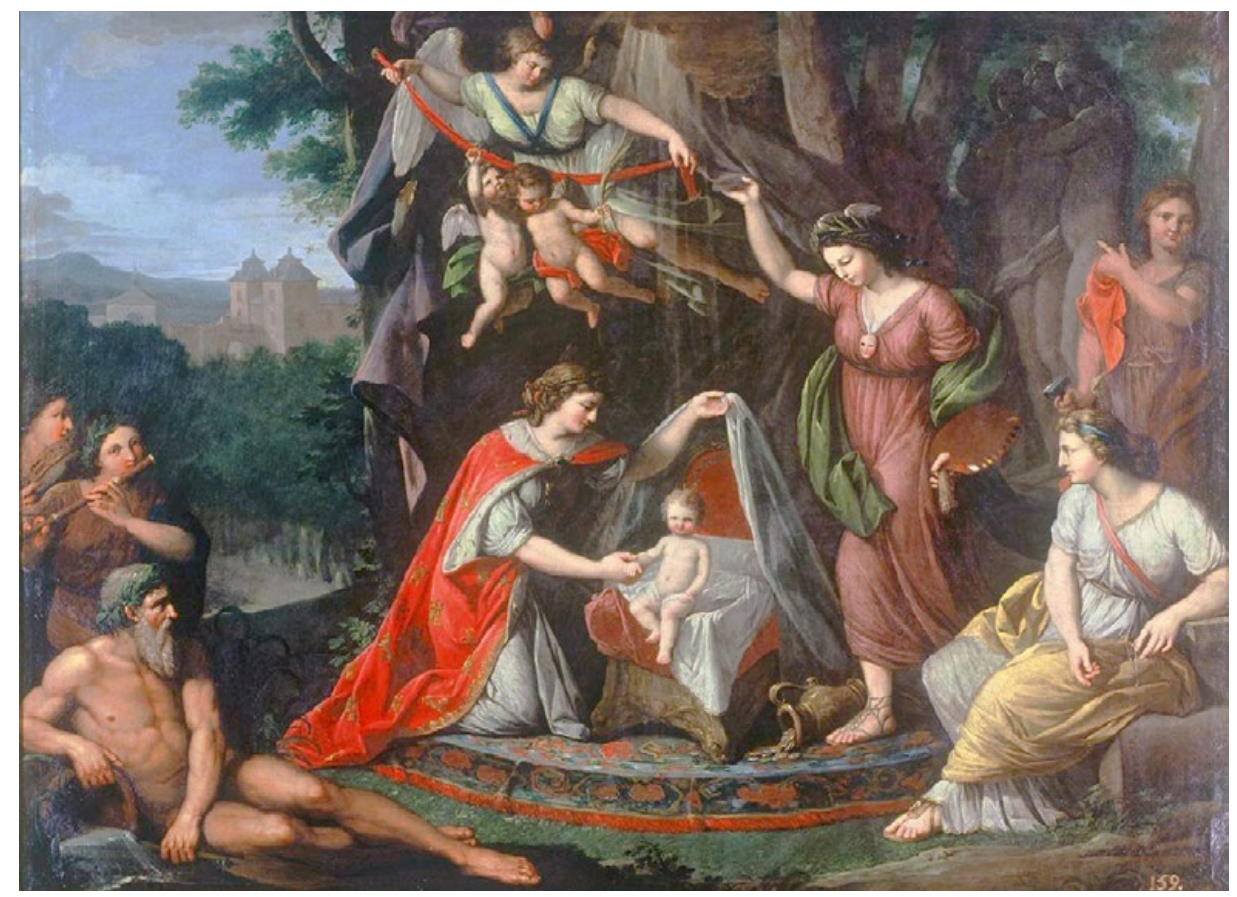

Fig. E.5: Zacarías González y Velázquez, Alegoría del nacimiento del infante Carlos Eusebio, 1781, óleo sobre lienzo, Madrid, Museo de la Real Academia de Bellas Artes de San Fernando.

la escena el ángel que ejerce de aya y otros que portan una palma en alusión a la victoria. Igualmente aparece el río Manza716 nares y dos ninfas tocando instrumentos.

En segunda posición quedó la pintura de Cosme de Acuña Troncoso (1758 - 1814) [fig. E.6]. Esta vez el aya presentaba al infante a la Monarquía y sobre la escena revoloteaban unos amorcillos para coronarlo con hojas de laurel y honrarle con las insignias de la Orden de la Inmaculada Concepción. Siguiendo con los requisitos del concurso, también aparecen las alegorías de las artes y del río Manzanares acompañado de tres ninfas. Asimismo, el artista quiso remarcar el carácter monárquico de la representación incluyendo el escudo de la Corona en un primer término.

Otra obra muy interesante, que representa este mismo tema pero no formó parte del concurso académico, fue la elaborada por Agustín Navarro (1754 - 1787) [fig. E.7]. La alegoría de España está entronizada, coronada y ataviada con un manto rojo salpicado por leones rampantes dorados y el armiño. Un varón situado frente a ella, y que posiblemente se trate del 


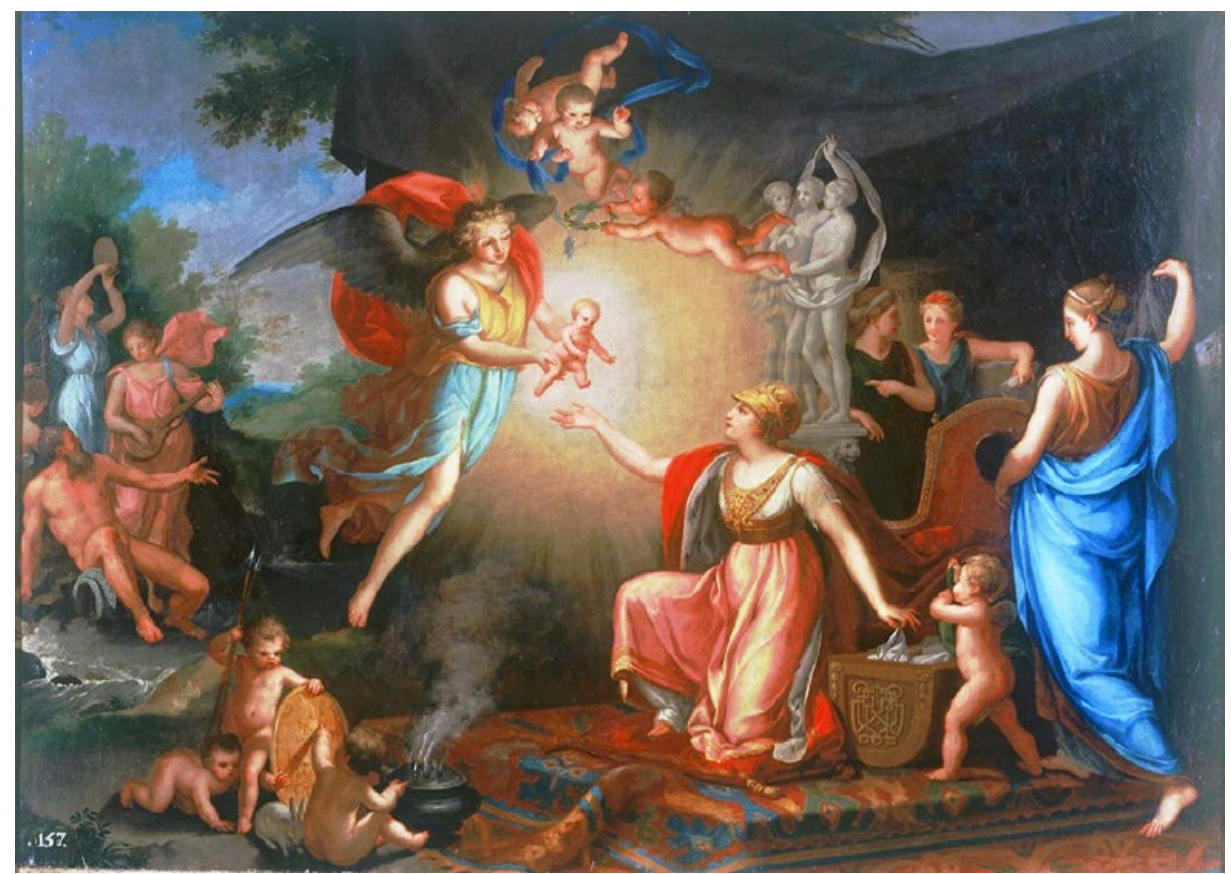

Fig. E.6: Cosme de Acuña y Troncoso, Alegoría del nacimiento del infante Carlos Eusebio, 1781, óleo sobre lienzo, Madrid, Museo de la Real Academia de Bellas Artes de San Fernando.

propio Carlos III o del Príncipe de Asturias, va vestido según la tradición clásica y se ha coronado con laurel, le hace entrega del infante. Junto a la figura simbólica principal aparece Minerva cuya función es proteger el reino. Se la ha identificado por llevar el casco, la lanza y una armadura con la cabeza de la medusa, obsequio de Perseo. Como en las imágenes anteriores, el pintor también ha incluido al río Manzanares entre el elenco de personajes.

En esta ocasión la vinculación de la monarquía con el mítico Hércules, la cual hunde sus raíces en la época de Carlos V, se ha presentado de forma muy clara. El héroe clásico se encuentra junto a la Corona vestido con la piel del león de Nemea y armado con una porra de madera. La imagen concuerda con la descripción que hizo Cesare Ripa de la virtud heroica, donde la piel de león remite al control sobre la concupiscencia y la maza alude a la capacidad de la razón para dominar el apetito. ${ }^{41}$ Hércules señala al infante bajo la intención de indicar al espectador que Carlos Eusebio ha sido el elegido para dar longevidad a la Casa de Borbón.

41 Cesare Ripa, Iconologia overo descrittione di diverse imagini cavate da- 


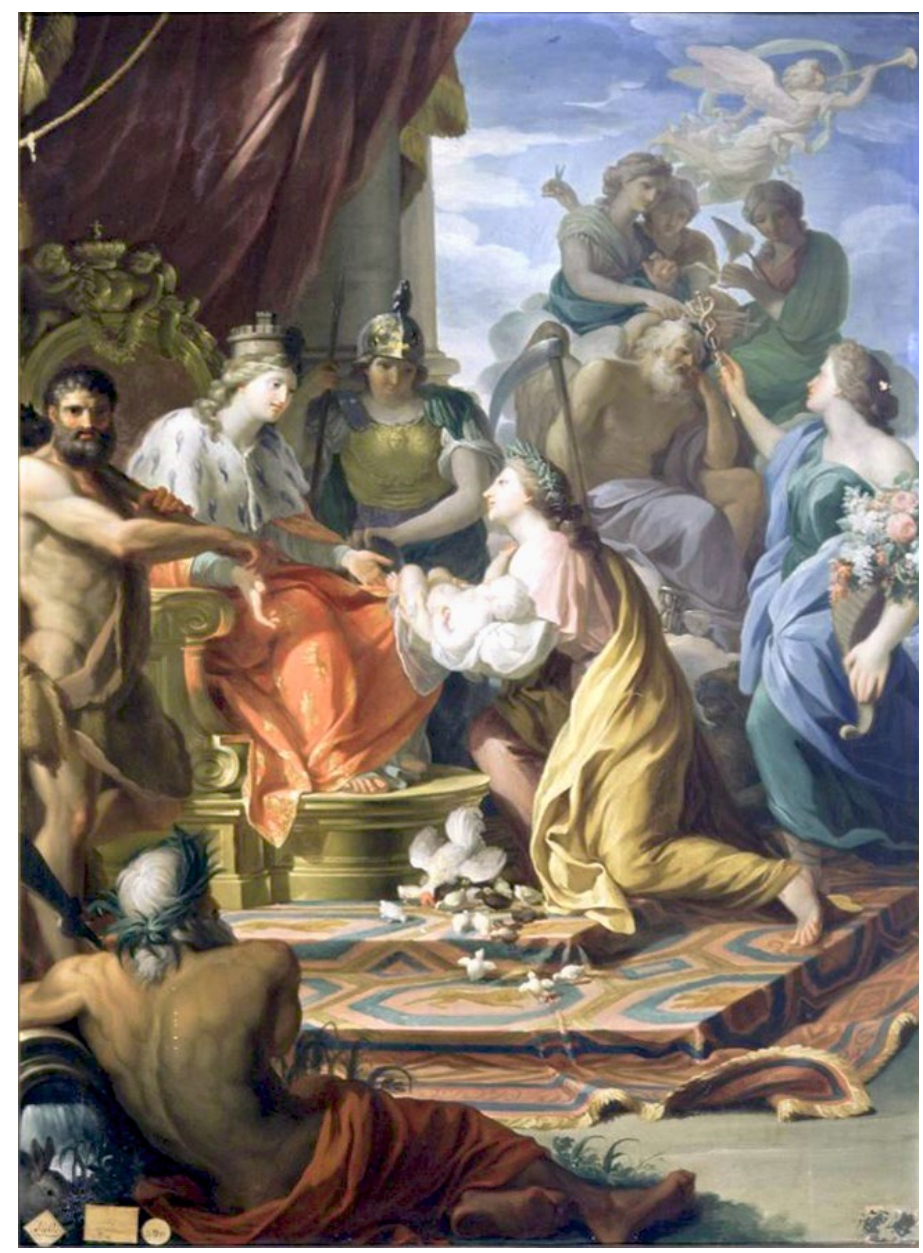

Fig. E.7: Agustín Navarro, Presentación alegórica del infante Carlos Eusebio, siglo XVIII, óleo sobre lienzo, Madrid, Museo de la Real Academia de Bellas Artes de San Fernando.

La obra del autor italiano, además, sirvió a Agustín Navarro para añadir otros personajes simbólicos. Por ejemplo, se ha representado a la felicidad pública a través de una mujer con una cornucopia llena de flores para manifestar la alegría del suceso, pues ésta siempre acompaña a la felicidad. También sostiene un caduceo para referirse a la paz y a la sabiduría. ${ }^{42}$ Por ello, esta figura habla del contento generalizado por tener un nuevo legatario. Además, otro conjunto de personajes hacen una clara referencia al destino de la vida humana. Este está compuesto por las Parcas, tres mujeres empleadas en tejer el devenir del infante y que normalmente aparecen representadas junto a Saturno, dios del tiempo, quien lleva una guadaña y ahora se encuentra adormecido pues aún es pronto ll'antichità e di propia inventione, (Roma, 1603), p. 507.

42 Ripa, Iconologia..., p. 154. 
para interrumpir la vida del recién nacido.

Es verdaderamente llamativo apreciar que las figuras alegóricas incluidas en las imágenes también estuvieron presentes en las composiciones poéticas. Así se observa con las Parcas, pues cabe recordar que tenían la potestad para determinar el momento del fallecimiento. Por ello se las ha mencionado en una égloga dedicada a las situaciones tan opuestas que vivió la familia real en 1783, ya que en pocos meses de diferencia la Casa de Borbón tuvo que afrontar la pérdida de Carlos Domingo Eusebio y más tarde nacieron los infantes gemelos. En consecuencia, en esta creación literaria Delio habla de la profunda tristeza que supuso la muerte del heredero.

Murió Carlos, murió nuestra alegría.

Temblaron al oírla los collados:

Pastores y ganados

lloraron de consuno.

Ó fracaso importuno!

ó tierna flor! Ó tela delicada,

cuyo precioso hilo,

torcido apenas, con agudo filo

cortó la Parca airada!43

Por el contrario, unos versos más adelante es el río Manzanares quien augura nuevas esperanzas para la monarquía que llegarán con los gemelos.

\author{
Ve aquí, dirá, jó preciada \\ Nación! Asegurada \\ la clara sucesión de tus Señores. \\ La pena se disipe \\ de dos Carlos con Carlos y Felipe. ${ }^{44}$
}

43 Diego González, Llanto de Delio y profecía de Manzanares: égloga, que con motivo de la temprana muerte del señor infante don Carlos Eusebio, y del felicísimo fecundo parto de la Princesa de Asturias, (Joaquín Ibarra: Madrid, 1783), p. 3.

44 González, Llanto de Delio..., p. 15. 
Los ejemplos de Carlos Clemente y Carlos Domingo Eusebio han marcado los antecedentes a la elaboración de creaciones literarias, construcciones efímeras y fiestas en honor de la llegada de los infantes gemelos. Aunque los casos analizados en este apartado son foráneos al ámbito valenciano sirven para establecer similitudes y diferencias con las celebraciones por los gemelos. De hecho, a grandes rasgos se ha apreciado la reutilización de imágenes para dar un mensaje similar ante la llegada de nuevos herederos. Las fuentes literarias realizaron numerosas oraciones en las que se valoraba en nacimiento de Carlos Francisco y Felipe Francisco por ser el milagro reparador a las tragedias sufridas con anterioridad al perder a dos infantes. Seguramente por ello, las fiestas de esta ocasión fueron mucho más fastuosas y ricas que con Carlos Clemente tanto en Valencia como en Madrid.

\section{E.3. Fiestas por el nacimiento de los nietos gemelos de Car- los III y la paz con Gran Bretaña en 1784.}

El mes de septiembre de 1783 estuvo repleto de alegrías para la monarquía hispánica. Por un lado España había firmado, el día 3, un acuerdo pacífico con Gran Bretaña mediante el cual el rey español conservaba los territorios de Menorca y Florida, recuperaba el litoral de Nicaragua, la costa hondureña de los Mosquitos y el Campeche, así como asumía el dominio de la colonia de la Providencia. Por otro lado, dos días más tarde se produjo el feliz nacimiento de los infantes gemelos, hijos del Príncipe de Asturias, el futuro Carlos IV y su esposa María Luisa de Borbón - Parma. La llegada nuevamente de dos herederos al trono, Carlos Francisco de Paula y Felipe Francisco de Paula, fue una gloriosa noticia que se debía festejar en todas las ciudades del reino.

Cabe recordar que las fiestas cumplían varias funciones a la vez; En primer lugar eran una manifestación del poder regio. También proyectaban una imagen de estabilidad monárquica 
y por último, expresaban la lealtad del pueblo a través de la implicación de las ciudades junto con sus instituciones y gremios en la organización y celebración de los festejos. La participación de las asociaciones gremiales era algo habitual y estaba presente en sus fiestas particulares y en las programadas por la ciudad con motivo de la beatificación o canonización de santos valencianos, boda, nacimiento de un príncipe, entrada real o victoria militar, y en las celebraciones anuales del Corpus Christi y los santos patronos ${ }^{45}$ Como se comprobará a continuación, en Valencia la participación fue masiva. Gremios, parroquias y diversas instituciones como la Real Academia de Bellas Artes de San Carlos celebraron de la mejor forma posible el alumbramiento de los descendientes de la dinastía Borbón.

En cuanto se tuvo noticia oficial del feliz parto de la princesa se acordó tocar las campanas y disponer de dos noches de luminarias, concretamente el 15 y 16 de septiembre. En este segundo día, además, se celebró una misa cantada con Te deum. El Real Acuerdo organizó otra misa en acción de gracias para el 17 de septiembre en el convento del Carmen. ${ }^{46}$

No obstante, la gran colaboración de la ciudad llegó a raíz de la publicación de la Real Cédula firmada por Carlos III el 22 de octubre de 1783 [fig. E.8], la cual animaba a formar parte de «las

45 Inmaculada Rodríguez Moya ha estudiado con detalle la implicación en del gremio de carpinteros de Valencia en las fiestas. Asimismo aporta una visión panorámica del papel de los gremios en las festividades y el arte efímero creado en aquellas ocasiones. Consúltese a Inmaculada Rodríguez Moya, 'Artefactos de madera. El gremio de carpinteros y el arte efímero barroco en la ciudad de Valencia', en Paula Revenga Domínguez (coord.), Arte barroco y vida cotidiana en el mundo hispánico: Entre lo sacro y lo profano, (Universidad de Córdoba - El Colegio de Michoacán, 2017), pp. 115-132.

46 Estas fiestas también han sido trabajadas por Ma Pilar Monteagudo, pero no ha profundizado en las creaciones efímeras elaboradas por los gremios y determinadas instituciones a excepción de describir el carro triunfal de los cortantes y el tabernáculo de los plateros. Por ello, en el presente epílogo sí que se ha hecho hincapié en las creaciones efímeras. Además, su 
demostraciones de piedad y regocijos públicos que deben hacerse en todo el reino con motivo de los prósperos sucesos que ha experimentado esta monarquía en el feliz parto de la princesa nuestra señora, nacimiento de los dos infantes Carlos y Felipe y el ajuste definitivo de paz con la nación británica.» ${ }^{47}$

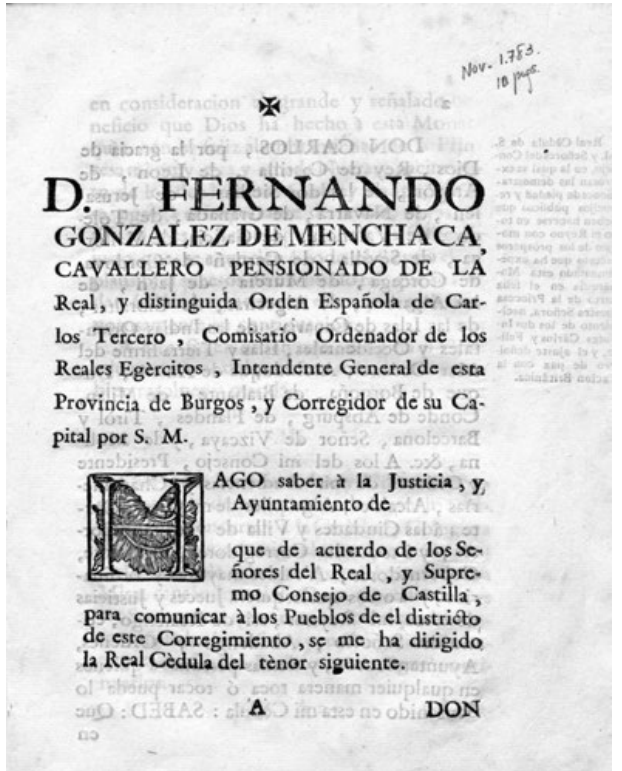

Fig. E.8: Real Cédula de 22 de octubre de 1783.

El documento redactado y emitido desde San Lorenzo de El Escorial contenía nueve disposiciones en las cuales se detallaban los actos que debieron tener lugar durante los días de fiesta. Se invitó a las ciudades y villas con voto en las cortes que acudiesen a la catedral, colegiata o parroquia más antigua para agradecerle a Dios los felices acontecimientos, celebranbúsqueda de archivo se ha centrado en el Libro de Instrumentos y Gobernación en el archivo municipal y las Deliberaciones y Acuerdos Capitulares en el archivo de la catedral. Así pues, el pormenorizado conocimiento de la participación en estas fiestas se ha conocido a través de otro tipo de documentación también conservada en el archivo municipal. Véase a María Pilar Monteagudo Robledo, 'Arte efímero en el siglo XVIII. Expresión y marco en una fiesta real', en Primer Congreso de Historia del Arte Valenciano: actas, mayo 1992, (Generalitat Valenciana: Valencia, 1993), pp. 313-318; Monteagudo Robledo, El espectáculo del poder..., p. 32.

47 AVM, sección 2, legajo 162, número 79: Cédula de 22 de octubre de dicho año [1783] por la que se manda celebrar fiestas y diversiones públicas en celebridad del feliz alumbramiento de la Princesa nuera de Su Majestad y nacimiento de los infantes Carlos y Felipe. 
do una misa en la cual se cantaba un Te deum y se pronunciaba un sermón para comunicar al pueblo las dos buenas noticias. Además se pidió que los ayuntamientos de las ciudades $\mathrm{y}$ villas capitales invirtiesen los fondos necesarios del dinero público en la compra de cera para disfrutar de tres días de luminarias.

En consonancia al dictamen del rey, el Archivo Histórico Municipal de Valencia conserva numerosas solicitudes expedidas al Ayuntamiento para requerir la aprobación en la contribución a las fiestas, ya sea formando parte de la procesión, levantando un altar o un arco, desfilando con un carro triunfal, o repartiendo limosnas entre los más necesitados. ${ }^{48} \mathrm{El}$ tipo de festividades y la clase de participación de los gremios pervivió en las celebraciones tanto de la dinastía Austria como Borbón principalmente repartiendo dotes y formando parte de las procesiones. Muchos de ellos desfilaban con carros triunfales que solían tener forma de animal o de navío, escenificaban determinados pasajes y trataban de interaccionar con los espectadores. ${ }^{49}$

En cualquier caso, a través del estudio de este ejemplo valenciano es posible observar que, una vez más, la monarquía ha empleado la fiesta como vehículo para exaltar su poder y como instrumento para comprobar la lealtad del pueblo. De ese modo, puso de manifiesto su autoridad y propició que la sociedad mostrase su fidelidad a la Corona con la complicidad de las instituciones, parroquias y gremios, así como con la colaboración de artistas y escritores.

48 Aunque este apartado se haya dedicado a las festividades organizadas y celebradas en la ciudad de Valencia, el Archivo de Villa también conserva una gran cantidad de documentación que relata exhaustivamente los festejos llevados a cabo en Madrid. Las referencias más importantes sobre estas celebraciones se encuentran en Archivo de Villa, sección 2, legajo 77, número 5, 1784; sección 2, legajo 77, número 6, 1784; y sección 2, legajo 77, número 3, 1783.

49 Rodríguez Moya, 'Artefactos de madera...', pp. 121-122. 


\section{E.3.1. Oraciones, poemas y estampas en honor de los infan- tes gemelos.}

Respecto a las creaciones literarias con motivo del nacimiento de los gemelos también cabe destacar algunos otros ejemplos. En ellos, principalmente, se incluyen referencias a personajes del Antiguo Testamento y a las virtudes que les caracterizaban. En cambio, no hay alusiones a la Antigüedad pero sí que se ha apreciado una clara reutilización de las imágenes. El 14 de diciembre de 1783 se pronunció una Oración eucarística o panegírico en el Real Monasterio de san Benito, ubicado en Zamora. ${ }^{50}$ Fray Plácido Vicente, el autor del escrito, era monje profeso del Real Monasterio de Santo Domingo de Silos. En su composición asoció, en varias ocasiones, miembros de la dinastía Borbón con personajes bíblicos. Por ejemplo, la Princesa de Asturias se equiparó con la figura de Rebeca: «El Dios de nuestros padres ha visitado en la plenitud de sus misericordias a nuestra muy augusta y cara princesa, y en ella, como en 724 otra Rebeca, nos ha concedido de una sola vez dos príncipes gemelos herederos del imperio.. ${ }^{51}$ La comparación es lógica puesto que, como explica el Génesis, Rebeca era la esposa de Isaac y era estéril. Sin embargo, Dios le permitió procrear y quedó embarazada de mellizos, Esaú y Jacob (Gn 25, 21-24). Así pues, en el personaje de Rebeca tradicionalmente se ha visto un símbolo de fertilidad.

Seguidamente, el autor equiparó al monarca con el rey David, a quien Dios le prometió conferirle salud, prosperidad y estabilidad al trono. Esta misma concesión se le había otorgado a la Corona española y de igual forma que el rey David «invitó, convocó y llamó a todos los que temían a su Dios, que viniesen a admirar y ver las grandes maravillas, que había obrado en

50 Plácido Vicente, Oración eucarística o panegírico que en acción de gracias por los dos infantes gemelos, dados a luz por nuestra augusta princesa...dijo en el Real monasterio de San Benito de Zamora, (Joaquín Ibarra: Madrid, 1784).

51 Vicente, Oración eucarística o panegírico.... p.5. 
su alma, y sobre todo en su reino.. ${ }^{52}$, Carlos III anunció a todos sus súbditos los triunfos del imperio y les reclamó para propagar las buenas noticias y celebrar una fiestas para compensar los dones provistos por Dios. De hecho, según Plácido Vicente, el rey bíblico se preguntaba: “¿Cómo podré yo sólo publicar dignamente la magnificencia de unos dones más elevados que los cielos? [...] ¿Cómo anunciar una gloria, que de un extremo a otro ha llenado de júbilo y alegría a toda la tierra?» ${ }^{53}$ Siguiendo con el símil, Carlos III se ayudó de todas las agrupaciones para extender las buenas noticias por los rincones del reino.

También cabe destacar el Sermón en la solemnidad de acción de gracias, que de orden del Rey Nuestro Señor por el nacimiento de los dos Señores Infantes Gemelos Carlos y Felipe, y por la paz concluida, escrito por José Antonio Porcel y Salablanca (1715-1794), canónigo de la catedral de Granada, donde se leyó en $1784 .{ }^{54} \mathrm{El}$ texto, en definitiva, alabó la llegada de los retoños después de que los Príncipes de Asturias ya hubiesen tenido que afrontar la pérdida de dos hijos varones, Carlos Clemente Antonio y Carlos Domingo Eusebio. Así pues la llegada de dos nuevos niños a la Corona reforzaba la imagen de estabilidad de la monarquía. A todo ello, es necesario sumarle el acuerdo de paz sellado con Gran Bretaña:

Sabed, que después que a nuestros amables Príncipes les llevó el cielo sucesivamente dos infantes, con los que pensábamos segura la sucesión del trono, les ha dado en estos días (y también a nosotros) otros dos de un sólo feliz parto, un Carlos, y un Felipe, preciosísimos geme-

52 Vicente, Oración eucarística o panegírico.... p.10

53 Vicente, Oración eucarística o panegírico..., pp. 10-11.

54 José Antonio Porcel, Sermón en la solemnidad de acción de gracias, que de orden del Rey Nuestro Señor, por el Nacimiento de los dos Señores Infantes Gemelos Carlos y Felipe, y por la paz concluida, celebró en su Catedral el Cabildo de la Santa Iglesia Metropolitana de Granada, asistido de su Ilustrísimo Prelado, y del muy Noble, y Leal Ayuntamiento de la misma Ciudad, (Imprenta Real: Granada, 1784). 
los, no solamente para restaurar la falta de los otros dos, que de ángeles del imperio, subieron a serlo del imperio, sino también para traernos la deseada paz, después de una porfiada guerra, en que ha ardido la España en uno, y otro continente..$^{55}$

El contraste de vivencias que soportaron el príncipe Carlos y su esposa María Luisa con la muerte de dos hijos y la alegría del nacimiento de otros dos, ha sido reflejado por otros autores además de Porcel. Así lo ha mostrado el soneto escrito por José de Viera y Clavijo (1731-1813) que se ha dedicado Al felicísimo nacimiento de los dos Serenísimos Infantes Gemelos, que ha dado a luz la Princesa. A través del uso de la repetición como recurso literario, el autor ha subrayado la circunstancia de que el parto haya sido gemelar, el cual apaciguó el dolor por la defunción previa de dos hijos. También especificó que se trataba de un acontecimiento que desataba una alegría universal entre la clase social más humilde y la más acomodada.

Dos veces, justo y compasivo el cielo, nos da un Infante, que consuela a España;

Y otras dos veces la mortal guadaña por orden suya nos le quita al vuelo. Dos veces a sus padres y a su abuelo el gozo inunda, y dos el llanto baña: Dos veces el palacio y la cabaña pasan de la alegría al desconsuelo. En esta alternativa, malos jueces culpábamos al cielo, y la fortuna; Mas ved aquí, que atento a nuestras preces, con dos Infantes colma la Real Cuna; Y los que otorga y quita de dos veces, liberal nos los vuelve sola de una. ${ }^{56}$

55 Porcel, Sermón en la solemnidad..., fol. 1-2.

56 José Viera y Clavijo, Al felicísimo nacimiento de los dos Serenísimos Infantes Gemelos, que ha dado a luz la Princesa, (Joaquín Ibarra: Madrid, 1783). 
Junto con las composiciones poéticas, oraciones y sermones igualmente se conservan algunas descripciones de los regocijos organizados en distintas villas, como en Madrid, Sevilla, Murcia, Granada o Logroño. ${ }^{57}$ No obstante, a día de hoy no se ha encontrado una relación descriptiva de los festejos realizados concretamente en Valencia.

Se ha podido comprobar que la primera manifestación que el rey hizo de su autoridad, como era lo habitual, fue ordenar a las ciudades y villas que se mostrasen públicamente felices a través de los festejos. La estabilidad se identificó con la paz británica y con la llegada de dos varones dispuestos a asumir su responsabilidad como futuros gobernantes. La principal virtud que se les presuponía a los pequeños era el ser justos, así lo ilustra la Alegoría del nacimiento de dos infantes gemelos, hijos de Carlos IV y Ma Luisa de Manuel Salvador Carmona (1783, Madrid, Biblioteca Nacional) [fig. E.9]. Este es un claro ejemplo de la adaptación de imágenes anteriores para dedicarlas a nuevos infantes, pues la estampa bebe indiscutiblemente de la obra de Pasqual Pere Moles y Noël Hallé para Carlos Clemente. De hecho, las diferencias entre una y otra 57 A continuación se presentan algunas de las relaciones festivas más importantes que denotan la repercusión de los festejos: Bernardo Vicente Lobón y Pascual López, Elogio poético en alabanza del nacimiento, y feliz entrada en la corte de Madrid de los dos infantes gemelos Carlos y Felipe de Borbón, (Oficina de Pantaleón Aznar: Madrid, 1783); Matías Moreno, Festivas demostraciones con que la M. N. muy leal ciudad de Logroño manifestó su júbilo, por el feliz nacimiento de los dos señores infantes gemelos, y conclusión de la paz, en los días veintitrés, veinticuatro y veinticinco de noviembre de este presente año por un apasionado vecino, y muy obsequioso servidor suyo, (Imprenta de Matías Moreno: Logroño, 1783); Real Colegio Seminario de San Telmo, Descripción de las festivas demostraciones de júbilo con que el Real Colegio Seminario del Sor. Sn. Telmo y Universidad de Mareantes de Sevilla, celebraron en los días 17 y 18 de diciembre de 1783 el feliz nacimiento de los Infantes gemelos de España D. Carlos y D. Felipe y la paz ajustada con Inglaterra se da a luz por acuerdo del señor Juez Conservador, (Imprenta de Vázquez, Hidalgo y compañía: Sevilla, 1783); Gaspar Zavala y Zamora, Descripción de las plausibles fiestas, que al feliz nacimiento de los serenísimos infantes gemelos celebró la muy noble y leal villa de Madrid los días 13, 14, 15 de julio de 1784, (Joaquín Ibarra impresor de cámara de S. M.: Madrid, 1784). 
son mínimas. Ahora, la princesa está rodeada de tres niñas que representan a las tres hijas del matrimonio, aún vivas en 1783, Carlota Joaquina, María Amalia y María Luisa Josefina. Y además se han incluido diversas inscripciones latinas que completan el significado de la imagen. Por ejemplo, la alegoría de la Fama anuncia el nacimiento de los infantes a través de una frase extraída de la Eneida, «Geminam partu dabit ilia protem.» (En. 1, v.27, 8). Sobre ella, aparece una balanza con un texto latino que significa «esto nos servirá de señal» (Reyes I, $14,10)$. Por ello, la báscula, a su vez símbolo de Libra (signo zodiacal de los infantes), alude a la capacidad y deber de los dos hermanos gemelos de ser justos como futuros monarcas. Las referencias a la justicia se han completado en la parte inferior de la estampa al incluir un versículo del libro de Isaías cuando habla del reinado del nuevo David, a quien «la justicia ceñirá su cintura.» (Is. 11, 5). Cabe recordar que Cristo ha sido considerado como descendiente del rey David y que además, por ser una representación de Dios en la tierra se le ha otorgado la potestad de impartir justicia. En efecto, la monarquía utilizaba citas bíblicas con el objetivo de mostrarse autorizada para

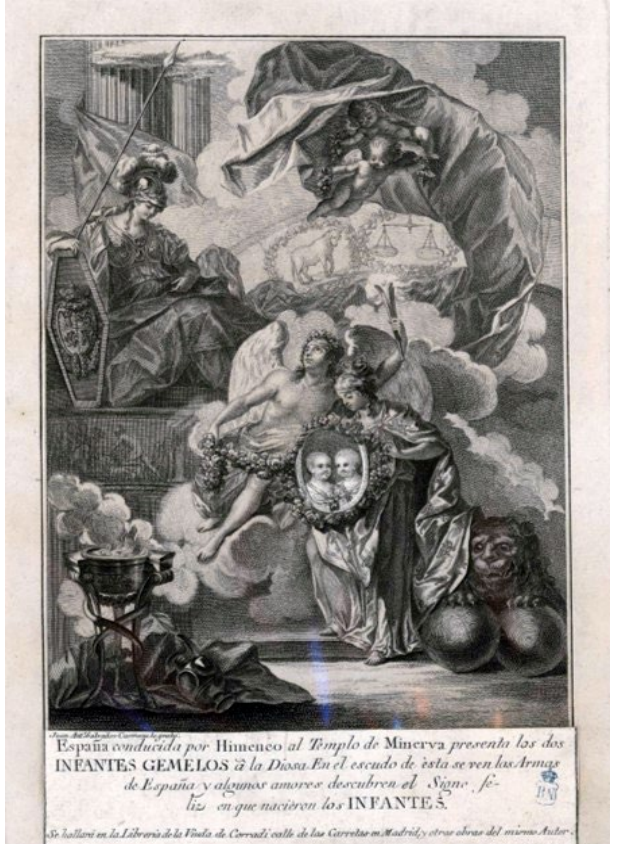

Fig. E.9: Juan Antonio Salvador Carmona y Luis Peret y Alcázar, Alegoría de los infantes gemelos Carlos y Felipe, 1783, estampa, Madrid, Biblioteca Nacional.

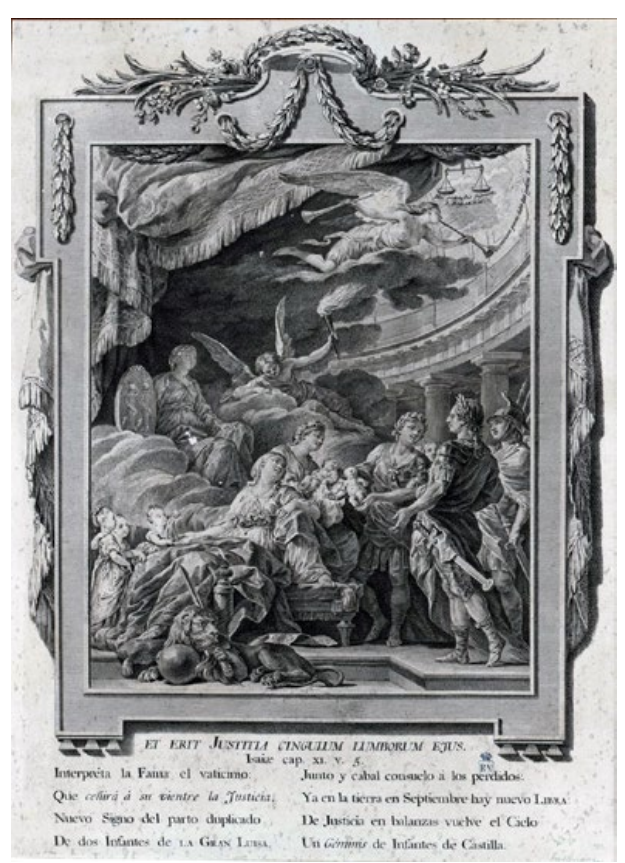

Fig. E.10: Manuel Salvador Carmona, Alegoría del nacimiento de dos infantes gemelos, hijos de Carlos IV y Ma Luisa de Parma, 1783, estampa, Madrid, Biblioteca Nacional. 
ser ecuánime. Otra muestra de la reutilización de imágenes se ha apreciado en la estampa grabada por Juan Antonio Salvador Carmona (1740 - 1805) correspondiente con una Alegoría de los infantes gemelos Carlos y Felipe en 1783 a partir de un dibujo atribuido a Luis Paret y Alcázar (1746 - 1799) [fig. E.10]. En efecto, se han recuperado los diseños para los nacimientos alegóricos de Carlota Joaquina, María Amalia y Carlos Eusebio también realizados por Carmona. ${ }^{58}$ España muestra el retrato de los infantes enjoyados con el collar del Toisón. A sus pies, se encuentra el león con los dos orbes. Himeneo acompaña a España hacia el templo de Minerva. La diosa, sedente, con una lanza y un escudo donde aparecen las armas del reino, está recibiendo la efigie de los herederos.

Las oraciones y poemas que se compusieron a raíz de la llegada de los gemelos han puesto de manifiesto la especial consideración que tuvo este hecho en el pasado. Posiblemente ello se deba a la falta de esperanza de la familia real por tener un infante varón, sano y fuerte que pudiese ser el heredero de la Corona y cimentase la longevidad y estabilidad del linaje Borbón. Por ello, y como se aprecia a través de los textos, el nacimiento de los gemelos se consideró un regalo que reparaba el daño sufrido anteriormente. Si bien las creaciones literarias fueron más personalizadas e incidían en ése carácter reparador del alumbramiento de la princesa, para las imágenes se fue mucho más práctico. En este sentido, se prefirió reutilizar estampas anteriores e incluir los retratos de los gemelos. Sin embargo, con las fiestas también hubo una diferencia princi-

58 Las estampas se encuentran en la Real Academia de Bellas Artes de San Fernando, pertenecieron a la colección de Antonio Correa y sus referencias son las siguientes: Juan Antonio Salvador Carmona, Alegoría al nacimiento del Infante Carlos Eusebio, 1780, 308 x 198 mm. AC 2511, Caja 18; Juan Antonio Salvador Carmona, Alegoría al nacimiento de las dos infantas Carlota Joaquina y María Amalia, ca. 1782-1783, 308 x 198 mm. AC 2512, Caja 18; Juan Antonio Salvador Carmona, Alegoría al nacimiento de los dos infantes gemelos Carlos y Felipe, 1783, 308 x 198 mm. AC 3543. AC 3544, Caja 18. Además de estampas se hicieron medallas como las consultadas en: Martín Almagro-Gorbea, María Cruz Pérez Alcorta y Teresa Moneo, Medallas españolas, (Real Academia de la Historia: Madrid, 2005). 
pal: la austeridad manifestada con Carlos Clemente y con Carlos Eusebio no tuvo continuidad en las fiestas por los gemelos, pues un hecho considerado tan excepcional también debía de tener unas pomposas celebraciones.

\section{E.3.2. Valencia festeja las alegrías de la monarquía en 1784.}

A partir de la documentación trabajada ha sido posible conocer detalladamente la organización, participación y celebración de estas fiestas en la ciudad de Valencia. El 20 de noviembre de 1783 Juan Pablo de Salvador Asprer, corregidor, justicia mayor y capitán de guerra de Valencia mandó que todos los alguaciles convocasen a los clavarios y mayorales de los distintos gremios y colegios a reunirse al día siguiente, a las nueve de la mañana y en la casa del propio corregidor, para conocer lo expresado en la Real Cédula. ${ }^{59}$ La ciudad había planificado las celebraciones durante el mes de diciembre. Sin embargo, la fiesta de la Purísima Concepción y las continuadas lluvias invernales obligaron al Ayuntamiento a aplazar los regocijos al mes de mayo. Por ello, el 9 de marzo de 1784 se volvieron a llamar a los representantes de los gremios y comunes para reiterar su invitación a formar parte de las fiestas nuevamente programadas en los días 9, 10 y 11 de mayo.

Para la primera jornada se había dispuesto una procesión en honor a la Virgen de los Desamparados, patrona de Valencia. El recorrido de la misma debía reproducir el itinerario seguido en la celebración centenaria de la ubicación de la imagen en su correspondiente basílica, es decir, la ruta era la misma que se siguió en $1767 .{ }^{60}$ De este modo, la catedral era el punto 59 Archivo Municipal, Valencia (AMVa ahora en adelante), Legajo 3, año 1784, sección primera, subsección I, clase I, subclase B, número 1. Documento firmado el 20 de noviembre de 1783 mediante el cual se comunica la noticia de la Real Cédula a gremios y comunes, entre todos ellos se encontraban los mesoneros, los atuneros, los posaderos, los peluqueros, los libreros, los comerciantes de especias, los taberneros o los campaneros, por mencionar algunos.

60 Una interesante relación festiva acerca del traslado de la imagen de la 
de partida, siguiendo por la calle de Caballeros, Tosal, Bolsería, la plaza del Mercado, de la Merced a los pórticos, por la bajada de san Francisco, calle de las Barcas, se seguía por delante del convento de las monjas de santa Catalina de Siena, la plaza de santo Domingo, por la calle del Mar hasta llegar a la calle Campaneros, entrando a la plaza del Miguelete e inmediatamente a la plaza de la Seo para dejar nuevamente la figura de la Virgen en su basílica. La documentación, fechada en 15 de abril, también ha revelado que hubo opiniones contrarias respecto al recorrido de la procesión entre el cabildo catedralicio y el Ayuntamiento. De hecho, los gobernantes de la ciudad iniciaban el itinerario en la calle Caballeros pero en cambio, el cabildo prefería comenzar del revés, por la calle que gira al Miguelete. La ciudad cedió y además permitió que los gremios y los comunes exhibiesen sus invenciones antes y durante el desfile así como el resto de días festivos, como ya se había anunciado. Aunque la procesión estaba programada para el 9 de mayo, ése día las inclemencias meteorológicas obligaron a aplazar la carrera hasta el día 13 de ése mismo mes. ${ }^{61}$

La implicación de todas las agrupaciones de la ciudad fue, en general, muy elevada a la vez que variopinta en función del nivel adquisitivo de cada una. Por ello, algunos que no disponían de recursos económicos como el gremio de los cesteros o los tejedores de lana, declinaron su participación en cualquiera de los actos. Otros, como los tundidores, tan sólo pudieron formar parte de la procesión llevando ciriales.

También eran válidas las muestras de caridad. Se otorgaban limosnas a los desfavorecidos vinculados al oficio en cuestión o a los presos de las distintas cárceles. Por ejemplo, el gremio de

Virgen de los Desamparados se encuentra en: Francisco de la Torre, Reales Fiestas que dispuso la noble, insigne coronada, y siempre leal ciudad de Valencia, a honor de la milagrosa imagen de la Virgen de los Desamparados, en su traslación a su nueva suntuosa capilla, (Gerónimo Vilagrasa, impresor de la ciudad: Valencia, 1668).

61 Monteagudo Robledo, El espectáculo del poder..., p. 36. 
los plateros destinó 150 pesos para ayudar a los maestros colegiales pobres, sus viudas e hijas huérfanas. Los mercaderes entregaron 40 libras a cada una de las cinco huérfanas pobres e hijas de individuos que hubiesen formado parte del gremio, elegidas por sorteo, para su futuro desposorio carnal o místico. El colegio de cereros y confiteros convino destinar perpetuamente diez libras anuales para socorrer a los maestros pobres de su colectivo. Igualmente los impresores, los mercaderes de libros y los músicos en conjunto acordaron distribuir dos reales y medio de vellón en alimentos a los reclusos de Serranos, la Galera y san Narciso. Asimismo, donaron dos camas, dos bancos embarnizados, dos colchones de lana, dos sábanas, una almohada y una colcha para la enfermería de ésta última. El gremio de peluqueros consiguió reunir 1.275 reales de vellón que se reservaron íntegramente para obsequiar con la comida de tres días a los encarcelados de la ciudad.

Generalmente, las asociaciones como mínimo se implicaban

en la participación de la procesión llevando ciriales, luciendo su estandarte y portando un anda con la imagen del patrón. Por citar algunos ejemplos, el gremio de los sastres asistió al desfile con el tabernáculo de san Vicente Mártir, los fabricantes de sombreros con la representación de san Jaime, los enjalmeros con la figura de san Antonio Abad, los esparteros sacaron a san Onofre, los molineros llevaron en andas a María Santísima la Morenita, o los sogueros participaron llevando las dos imágenes que tenía su gremio: la Virgen de los Desamparados y san Juan Bautista.

Entre la documentación estudiada se han encontrado descripciones detalladas sobre los espectáculos y construcciones efímeras que llevaron a cabo los gremios e instituciones con más posibles económicos. De entre todos ellos, se han seleccionado aquellas aportaciones que aluden directamente a las glorias de la monarquía. Por el contrario, otros gremios mostraron los quehaceres de su oficio mediante carros triunfales y otras de- 


\section{mostraciones públicas. ${ }^{62}$}

En efecto, los mercaderes notificaron al Ayuntamiento que además de proveer con una dote a las huérfanas, también aportarían un arco triunfal, el cual se ubicaría en el recorrido de la procesión y frente a la calle conocida como "La Puerta Nueva". La construcción contaba con un zócalo cuadrado de ocho palmos de alto y doce de ancho, sobre éste había doce columnas, cuatro por cada lado de la arquitectura. Entre las mismas, se colgaron un total de dieciséis arañas para poner luces. En la parte superior se encontraba una cornisa de seis palmos de alto. En medio del arco y sobre la línea de imposta cuatro óvalos contenían representaciones pictóricas del rey, del príncipe, de las armas reales y de las armas de la ciudad.

Por encima del arco corría una galería y sobre ella se construyó un pedestal de dieciséis palmos de alto y diez de ancho, donde se colocó una bola y en su remate se ubicó la imagen del patrón del gremio, san Antonio de Padua. A los lados del santo, se representaron a los príncipes de Asturias ofreciendo a los recién nacidos a san Antonio. Esta imagen en la que se pedía la protección de los niños a san Antonio era apropiada por dos razones; la primera porque se trataba del santo titular del gremio. La segunda porque de él se han narrado numerosos milagros hechos tan sólo gracias al rezo y las plegarias de las familias al santo. Por lo general siempre eran salvaciones a niños que accidentalmente se habían ahogado o estaban en peligro de ello.

De hecho, en una de sus hagiografías publicadas en 1759 se cuenta que el 11 de junio de 1673, Francisco Balderich un niño de cuatro o cinco años procedente de Reus cayó en un pozo y

62 Por ejemplo, los herreros y los cerrajeros mostraron un carro triunfal en el cual había una fragua y dos maestros trabajaban en el oficio. Los fabricantes de vidrio desfilaron enseñando cómo se hacían distintas piezas de vidrio. Asimismo, el gremio de chocolateros mostraba el proceso de elaboración del chocolate y lo repartía entre los asistentes. Todos los documentos se encuentran en: AMVa, Legajo 3, año 1784, sección primera, subsección I, clase I, subclase B, número 1. 
no se ahogó gracias a san Antonio. ${ }^{63}$ También el 12 de junio de 1674 , Jaime Navarro un joven de nueve años cayó en un estanque profundo cercano al convento de Jesús, situado extramuros de Barcelona. Dos mancebos encontraron al muchacho e invocaron la intercesión del santo, entonces el cuerpo se elevó y pudieron sacarlo del estanque. ${ }^{64}$ Además, se le han atribuido algunas resurrecciones. Una de ellas fue al hijo de la sobrina de san Antonio, en Lisboa, quien cayó de un barco al mar y se ahogó. La madre desesperada se negó a enterrar los restos del niño e imploraba su resurrección, y a los tres días el muchacho cobró de nuevo la vida. ${ }^{65}$ Otro suceso de los que se cuentan tuvo lugar en Padua donde vivía un matrimonio con su hijo de siete años. Éste jugaba con otros muchachos cerca de la presa de un molino cuando ésta se rompió y el agua arrolló a los pequeños. Ante la tristeza de los familiares por la desgracia, el padre del pequeño rezó a san Antonio y su hijo, junto con el resto de muchachos, aparecieron incólumes. ${ }^{66}$

Al pasar la imagen de la Virgen de los Desamparados, estaba previsto que desde el centro del arco principal descendiese una tramoya con un ángel recitando versos y echando flores. En los arcos laterales se representó una batalla marina con barcos atacándose a cañonazos con un puerto de fondo. En las cuatro esquinas de la construcción se colocaron las banderas, insignias y divisas de las naciones que componen el gremio: España, Francia, Malta y Génova. Esta magnífica arquitectura efímera estaba completamente iluminada con ciriales, princi63 Miguel Mestre, Vida y milagros del glorioso San Antonio de Padua, sol brillante de la Iglesia, lustre de la religión seráfica, gloria de Portugal, honor de España, tesorero de Italia, terror del infierno, martillo fuerte de la herejía, entre los santos por excelencia el milagrero, (Imprenta de María Ángela Martí, viuda: Barcelona, 1759), pp. 389-390.

64 Mestre, Vida y milagros del glorioso San Antonio de Padua..., pp. 391-392.

65 Mestre, Vida y milagros del glorioso San Antonio de Padua..., pp. 297298.

66 Mestre, Vida y milagros del glorioso San Antonio de Padua..., pp. 298299. 
palmente en las zonas donde se hallaban las representaciones de la familia real. En el lugar exacto donde se dispuso el arco de triunfo se concentraron allí un grupo de diputados, prohombres, comisarios y otros miembros del gremio para recibir a la Virgen y a la correspondiente comitiva en procesión. ${ }^{67}$

El gremio de los atuneros construyó dos carros triunfales, uno de ellos alusivo a su oficio y otro concerniente a los prósperos sucesos. El primero tenía forma de atún y sobre el lomo del pez se colocó una torre, todo ello guiado por un ángel. Seguidamente, desfilaba el anda de san Roque, patrón de los atuneros, y daba paso a "otro carro triunfal más vistoso que representará la festividad del día pues llevará al Rey Nuestro Señor, a los Serenísimos Príncipes de Asturias, con los dos gemelos infantes; además se verán en dicho carro cuatro embajadores firmando las paces y en su centro la mar con un vistoso navío.» ${ }^{68}$ Aquí una vez más se incluyeron las imágenes del monarca y los herederos, por tanto sus retratos debieron desfilar reiteradamente por las calles de la ciudad. A continuación, se realizaba una danza de niños indios ${ }^{69}$ que anunciaba la llegada de la imagen de la Virgen de los Desamparados, una escultura que era propiedad del gremio y según ellos, de la misma calidad que la custodiada en la basílica. Se cerraba la contribución de esta agrupación con la representación de las cuatro partes del mundo: África, Asia, América y Europa.

La colaboración de la asociación de carniceros, también denominados cortantes, fue muy rica. Así pues, para la ocasión construyeron un carro triunfal que:

67 AMVa, Legajo 3, año 1784, sección primera, subsección I, clase I, subclase B, número 1, documento del 8 de mayo de 1784.

68 AMVa, Legajo 3, año 1784, sección primera, subsección I, clase I, subclase $B$, número 1, documento del 4 de mayo de 1784.

69 Acerca del mestizaje en la fiesta véase a: Víctor Mínguez, Inmaculada Rodríguez Moya, Pablo González Tornel y Juan Chiva Beltrán, La Fiesta barroca: los virreinatos americanos (1560-1808), (Universidad de Las Palmas de Gran Canaria: Las Palmas, 2012). 
en cuya parte superior se presentará a España, sobre un arco iris, vestida de peto, manto real de púrpura, sembrado de leones y castillos, corona real en su cabeza y apoyando los pies sobre dos mundos: Llevará en cada mano una corona de laurel con ademán de ponérselas sobre las cabezas de los dos infantes reales, los cuales estarían un poco más bajos, en un magnífico trono, puestos a sus pies sobre almohadas carmesíes y a cada lado un león. Irán vestidos a la española antigua, con las insignias de bandas, toisón de oro y manto púrpura. Junto a estas personas reales estarán la Justicia y la Prudencia con sus respectivos atributos, ricamente adornadas. A los pies de esta estará Asia y América, atadas de cadenas, que descendían de los Infantes, como a presidios de España. En la proa del carro irá un hermoso mancebo, vestido de tonelete, ${ }^{70}$ guiando los cuatro toros que tirarán del carro, y estos irán custodiados de seis mancebos, vestidos de volante. Delante del carro, irá abriendo camino, sobre otro toro la Liberalidad, que llevará una cornucopia llena de cruces, de encomiendas, joyas, collares de oro, esparciendo versos que manifiesten la generosidad de dichas personas reales. ${ }^{71}$

El conjunto de barberos notificó el 27 de abril de 1784 su decisión de levantar un altar en el cual también se situó un retrato del monarca y los príncipes presentando a los infantes. En él, igualmente se colocaron las imágenes de sus santos patronos, san Cosme y san Damián. Además se completó la ornamentación incluyendo un jardín, fuentes, pirámides y otros adornos. Aquí ya se puede observar signos del cambio de gusto estético propio de la época, cuando a raíz del neoclasicismo hay preferencia por introducir formas clásicas como las pirámides. A su vez, dicho gremio solicitó ubicar el monumento

$70 \mathrm{El}$ vestido de tonelete se refiere a un traje con falda que usaban los niños.

71 AMVa, Legajo 3, año 1784, sección primera, subsección I, clase I, subclase B, número 1, documento del 22 de marzo de 1784. 
en «la rinconada de la Puerta de la Puridad o en su defecto en la bocacalle que enfrenta al sagrario de dicho convento o en el pasaje que se destine por el señor corregidor.» ${ }^{72}$

Como se ha podido comprobar mediante estos ejemplos puntuales la intervención de los gremios fue notable. Además, gustaban de ser muy explícitos en las cartas que enviaban al Ayuntamiento, explicando con todo lujo de detalle las construcciones efímeras que iban a elaborar para los días festivos o la cantidad de dinero que iban a invertir en obras piadosas. Sin embargo, quizás resulte sorprendente ver que un referente institucional como lo fue la Real Academia de Bellas Artes de San Carlos, no especificase el nivel de su implicación con la fiesta en la respuesta oficial remitida al Ayuntamiento, amparándose en la brevedad del tiempo disponible para la preparación de los festejos. Cabría esperar que la Academia fuese modélica en la participación de los regocijos para testimoniar su fidelidad a la Corona, pues se debe recordar que la institución fue fundada por el propio monarca Carlos III. A través de las noticias recogidas en el archivo de la institución es posible conocer una descripción, mucho más general que la aportada por los gremios, acerca de su contribución.

En la Junta Ordinaria celebrada el 21 de abril de 1784, la Academia encomendó a los consiliarios Antonio Pascual y Joaquín Esteve, al viceconsiliario Mauro Oller, y a los directores generales José Esteve y José Vergara, el programar y llevar a cabo la demostración que estimasen oportuna. ${ }^{73}$ Principalmente, fue en los dos últimos en quienes recayó la responsabilidad de componer, adornar y custodiar la obra efímera. En conse72 AMVa, Legajo 3, año 1784, sección primera, subsección I, clase I, subclase B, número 1, documento del 27 de abril de 1784.

73 ARABASC, Actas de la Real Academia de San Carlos. Continuación de las Actas de la Real Academia de las Nobles Artes establecida en Valencia con el título de San Carlos y relación de los premios que distribuyó en 9 de octubre de 1786. Valencia, en la oficina de Benito Monfort, Impresor de la Real Academia, año 1787, s/f. Se trata de una especie de memoria o noticiario del curso académico, donde se especifican el nombre de los premiados 
cuencia, se acordó decorar la fachada de la escuela con «tapices y colgaduras, y pinturas de autores valencianos, como también de varias obras de escultura, arquitectura, grabado y obras de flores correspondientes a todos los ramos del instituto de esta Real Academia, acompañando al objeto principal cual es el retrato de Su Majestad y de los dos infantes gemelos, sus nietos, bajo dosel.»74 Asimismo, el coste total de todo ello ascendía a doscientas treinta y siete libras, seis sueldos y dos dineros. ${ }^{75}$

Aunque no se han hallado imágenes que documenten el aspecto de la fachada, al menos se conserva un retrato de uno de los infantes gemelos en los fondos de la Academia y del Museo de Bellas Artes de Valencia [fig. E.11].

Además, en los inventarios de los bienes en propiedad de la institución, redactados pocos años después de 1784, se ha constatado la existencia de las dos efigies de los infantes que lucieron en la decoración efímera. Se trata de una representación de un niño vestido con sus mejores galas que se corresponde con uno de los «dos retratos ideales de los infantes de dos palmos y medio con marcos dorados que se hicieron para colocar en las demostraciones públicas que hizo la Academia en las funciones, obra el uno de don José Vergara y el otro de don Luis Planes. ${ }^{76}$ Pasados los festejos y como atestigua el

y se deja constancia de otros hechos significativos.

74 ARABASC, Libro de Acuerdos de Juntas Particulares. Años 1765-1786, s/f. Resulta especialmente interesante el acta redactada por el secretario Tomás Bayarri en la Junta Particular de 21 de mayo de 1784, en la cual se deja constancia de la descripción y pago de la obra una vez ya se han celebrado las fiestas.

75 Además se conserva el pago acordado en esa Junta Particular. Leg. 1/4/118A (Cuentas que da Antonio Rodríguez, Conserje de la Real Academia de San Carlos empezando desde el 1 de enero hasta el 31 de diciembre de 1784): En la Junta Particular de 23 de mayo «se libraron a favor del conserje dos pesos, otros dos para el portero y cuatro para los dos modelos» es decir, un total de ocho libras.

76 ARABASC, Inventario de la Real Academia de San Carlos hecho en el 


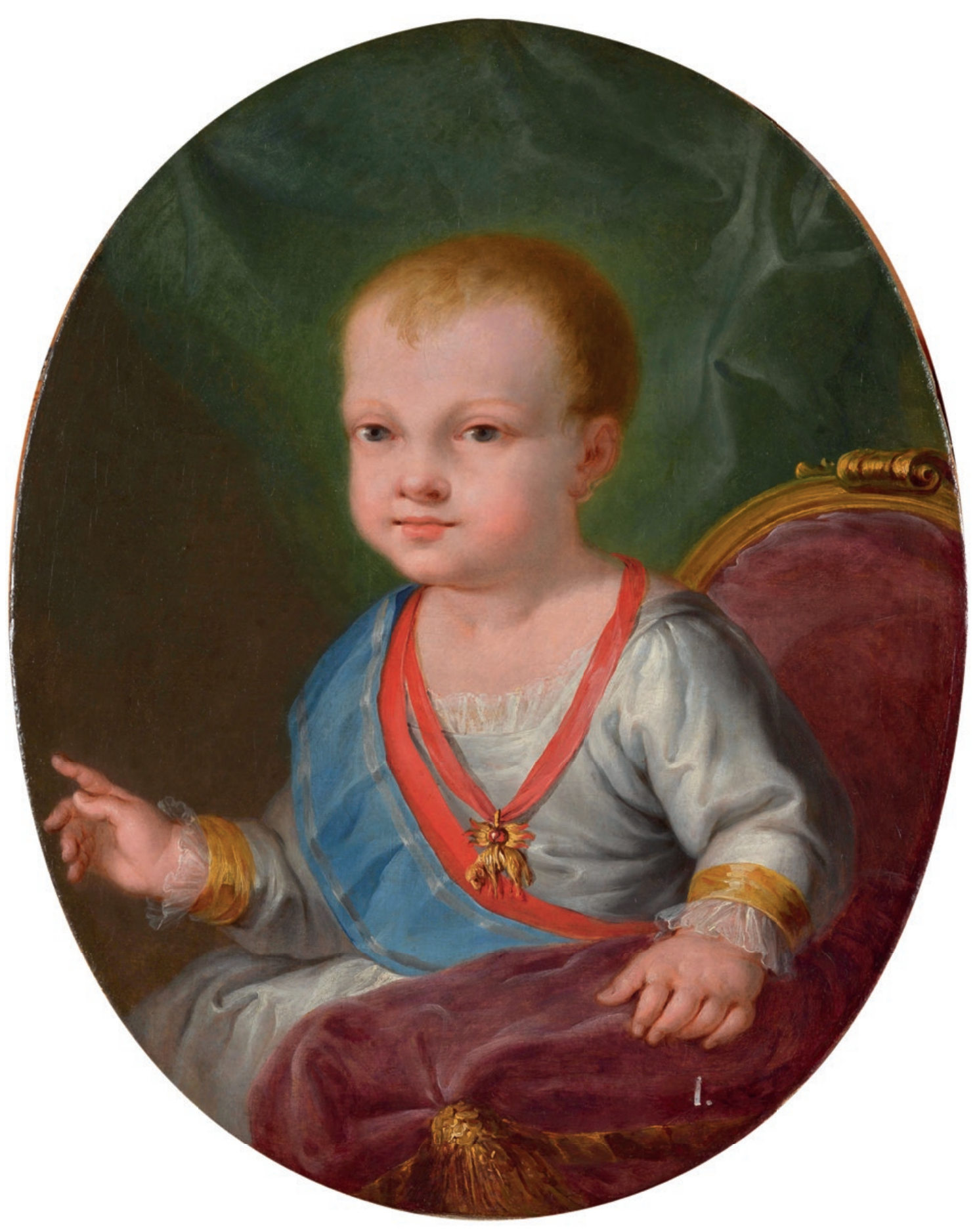

739

Fig. E.11: José Vergara/ Luis Planes, Retrato ideal de un infante que hizo la Academia para colocar en las demostraciones públicas, 1784, óleo sobre lienzo, Valencia, Real Academia de Bellas Artes de San Carlos. 
mencionado inventario, ambas piezas engrosaron la lista de retratos que engalanaba la sala de juntas de la Academia de Bellas Artes, siempre presidida por la efigie del monarca reinante.

A raíz de este ejemplo particular es reseñable observar que el retrato recibió un especial protagonismo en el conjunto de las fiestas. Por ello no sólo mantuvo su función memorial y de exaltación del poder a través de las galerías de efigies, sino que también recordaba al pueblo por quién se estaba celebrando, quién era el ejemplo a seguir e imagen del poder y por tanto, capaz de reunir a las masas y de conseguir la participación de parroquias, gremios e instituciones en una fiesta general. Para la monarquía hispánica, en este caso, la fiesta fue un recurso más para reafirmar su autoridad y legitimar su mandato del mismo modo que se hacía con los retratos. Por esta razón, el incluir las imágenes de los festejados en altares, carros y arcos triunfales casó perfectamente con el sentido de la fiesta. En consecuencia, se ha visto que el retrato siguió desempeñando su función en otros contextos y analizar el papel de las efigies en la fiesta es una línea de investigación más que contribuye a obtener un conocimiento más completo acerca del significado, usos y relevancia de los retratos en el pasado.

año 1788 según el estado en que se hallaron todos sus muebles y alhajas a saber, s/f. 
El retrato y su implicación en la fiesta 
H.

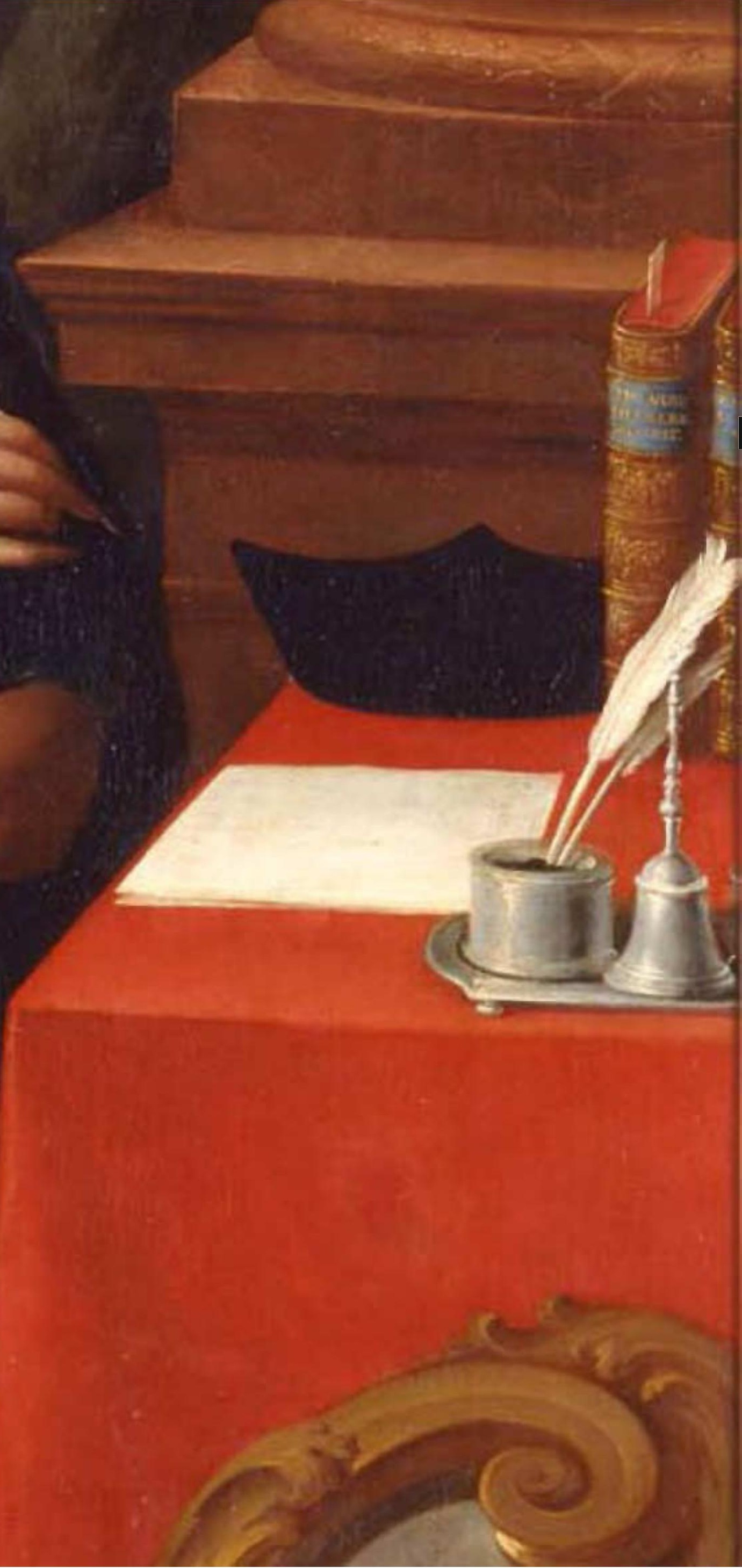




\section{Conclusiones.}

El nacimiento del retrato ha ido ligado a superar la ausencia permanente o temporal de la persona amada. Puesto que el ser humano está condenado a encontrarse con la muerte, hay un deseo natural de acercarse a la inmortalidad. La única forma para conseguirlo es, sin duda, perpetuar el recuerdo de las personas que ya han partido. En este sentido, el retrato surgió para capturar la imagen de alguien en concreto y alimentar constantemente su recuerdo. La importancia de este género se cimienta en las reflexiones que los teóricos hicieron sobre el mismo y acerca de cuatro conceptos estrechamente relacionados con el retrato; imitación, idealización, virtud y decoro. Respecto a los dos primeros se ha constatado la variedad de opiniones. Unos defendieron la estricta copia de la naturaleza, otros su idealización, y otros escogieron una posición intermedia, es decir, se decantaron por la imitación levemente mejorada. Esta última opción quizá sea la que se acerque en mayor medida a los retratos analizados en esta investigación. Una copia embellecida probablemente era la posibilidad más conveniente porque se contentaba a la persona representada, quien se reconocía en la imagen y además se veía favorecida. Igualmente, esta opción era apropiada para aquellos retratos que además incluían otros elementos secundarios y que de forma conjunta creaban una imagen de poder.

Otros dos conceptos íntimamente vinculados a los retratos fueron la virtud y el decoro. Ambos términos se emplearon para dotar de exclusividad a este género y, sin lugar a dudas, hacer de él una herramienta de exaltación de uno mismo. La virtus se encontraba principalmente en reyes, príncipes, em- 
peradores, futuros santos y otras personas que por sus hazañas habían ganado la consideración del resto de la sociedad. La virtud, por tanto, pasó a ser un requisito para retratarse. Así, algunas personas en concreto fueron proclamadas modelos a seguir por sus contemporáneos y al mismo tiempo la cúspide de la sociedad determinó qué valores, qué conducta, qué pensamiento y qué éxitos eran los necesarios para ser la imagen de la virtud. La variedad de tipos de personajes que han sido retratados explica los distintos enfoques que se le otorgaron al término virtud. En reyes, emperadores y príncipes se vieron fundamentalmente los dones de los óptimos gobernantes, de las personas buenas, justas y rectas, de aquellas capaces de regir los designios de su pueblo. En los obispos y arzobispos se apreció y valoró la capacidad para dirigir a la comunidad católica de su diócesis, la valía para ser un pastor modélico y excelente guía de su rebaño. A través de la imagen de frailes, venerables y beatos se mostraron a personas consideradas cercanas a Dios por su fe inquebrantable, eran la visibilidad de 744 la virtud católica. Los personajes calificados de hombres ilustres principalmente eran ejemplo del conocimiento en distintos ámbitos. De hecho, su fama llegó tras ser sobresalientes en el campo de la ciencia, de las letras, de las artes y también en el ámbito militar. La virtud intelectual, por tanto, no era aquella que exclusivamente se transmitía mediante los lazos de sangre, tampoco aquella que procedía directamente de la gracia divina como se pensaría en la época, sino era más bien el resultado de los logros personales, fruto del trabajo perseverante en cualquier disciplina.

La definición de decorum implicó hacer distinciones entre los retratados y dejar siempre constancia de la posición social de cada uno. En este sentido, jugaron un papel esencial los objetos complementarios alusivos a los poderes de la monarquía o de la Iglesia, por ejemplo. También fueron importantes aquellos atributos que definían a los intelectuales, revelando su campo de estudio e inquietudes científicas mediante la representación de instrumentos propios de su profesión o de 
determinados libros, cuyo título se puede leer en el lomo del volumen. Si bien los retratos analizados guardan las normas del decoro, se observa que en cualquier caso subyace el deseo de crear la imagen de uno mismo hacia el otro y sobresalir entre el resto de la sociedad. Esta pretensión se da en el propio hecho de retratarse y en utilizar las características de las efigies cortesanas para representar a personajes de otras clases sociales. Al retratar a obispos, arzobispos y varones ilustres se optó, en numerosas ocasiones, por pintarlos en interiores revestidos con un cortinaje y acompañados de mobiliario accesorio que daban pie a colocar toda clase de objetos para hablar acerca de la personalidad del efigiado. Más información se revelaba, si cabe, al incluir un escudo de armas y una inscripción.

El retrato individualizado, junto con los instrumentos auxiliares, escudos e inscripciones construían la identidad del efigiado, pero esta además contribuía a crear identidades colectivas puesto que formaba parte de una serie icónica, una galería o una colección de retratos. Por esta razón ha sido especialmente fructífero analizar estos conjuntos pictóricos. Las galerías de retratos de la realeza daban visibilidad al linaje de una determinada dinastía, pues en la genealogía se escondía la transmisión del poder. En consecuencia, el retrato regio en sus distintas versiones (pictórico, escultórico, grabado en libros o reproducido en monedas y medallas) incidía de forma notoria en la pertenencia a una dinastía concreta y justificaba su continuidad. De hecho, las series icónicas mostraban el traspaso del poder de unos monarcas a otros como se ha visto en el salón de reyes del palacio de la Generalitat de Valencia. Otras galerías compuestas por efigies de miembros de la realeza tan sólo pretendían dibujar las raíces genealógicas de algún personaje concreto, como hizo san Juan de Ribera al recopilar retratos de reyes, reinas, príncipes y princesas de la Corona de Aragón, de Castilla y de la Casa de Austria. En otros casos, además, se recurría a la genealogía para reivindicar el legítimo poder de aquel que no lo pudo ejercer. Así pues, los 
retratos de los monarcas aragoneses que ocuparon el trono de Nápoles tenían por finalidad justificar y reivindicar la legitimidad del duque de Calabria para reinar en dicho territorio, reinado que nunca tuvo lugar.

La creación de series icónicas y galerías de retratos monárquicos, por tanto, construían una identidad basada en razones de sangre. En otros casos se empleó la misma fórmula para crear linajes metafóricos que, asimismo, participaban de construir una identidad colectiva. Un ejemplo ilustrativo acerca de ello se ha visto en la serie de prelados de la catedral de Valencia, donde el gobierno de la diócesis ha pasado de unos a otros no por el parentesco sino por haber sido electos para el cargo. De este modo se configuraba una genealogía simbólica de obispos y arzobispos que venía a mostrar la continuidad y la estabilidad de la Iglesia. Una situación similar se ha apreciado en las diferentes galerías y colecciones de hombres ilustres estudiadas en esta investigación. Las diversas efigies que lucen en

el paraninfo de la Universitat de València son los rostros de los exitosos padres e hijos de la institución. Muchos de aquellos que se formaron en las aulas de esta universidad después fueron docentes en ella, así se dio lugar a un círculo en el que la Universitat se retroalimentaba de los logros y avances intelectuales de sus egresados.

La Real Academia de Bellas Artes de San Carlos progresivamente fue creando su propia imagen a partir de los retratos de sus presidentes y sus directores. Ambos cargos, aunque eran de naturaleza distinta, se complementaban y conseguían transmitir el mensaje de que la Academia estaba fuertemente vinculada a la ciudad y que además, garantizaba la calidad artística de la enseñanza allí impartida. Por esta razón, el papel de presidente era asumido por el intendente o corregidor de la ciudad y la dirección tanto general como particular de cada una de las ramas artísticas estaba reservada para afamados arquitectos, escultores, pintores y grabadores. Los retratos de la Universitat y de la Academia, en definitiva, conformaban la 
imagen identificativa de ambas instituciones. No obstante, la galería de valencianos ilustres perteneciente al monasterio de La Murta asimismo ponía su granito de arena para crear una identidad colectiva y presentar el territorio valenciano con la cuna de insignes hombres en las letras, las ciencias y las armas. Entre los ejemplos analizados en esta investigación también se encuentran los retratos de tipos orientales que al fin y al cabo dan visibilidad a otra cultura y otra identidad, en aquel tiempo considerada enemiga y que suscitaba un gran interés.

Los conjuntos pictóricos estudiados ponen de manifiesto la proliferación de series icónicas, galerías y colecciones en el ámbito valenciano desde finales del siglo XVI, que se desarrollaron de forma exponencial entre los siglos XVII y XIX principalmente. Como se ha visto, a grandes rasgos, son los mismos artistas los que elaboraron retratos para distintos proyectos. Por citar algunos ejemplos, Sariñena estuvo estrechamente vinculado a san Juan de Ribera, pues para él pintó varias efigies de religiosos con opinión de santidad, representó a algunos monarcas y además, copió el retrato del Patriarca que Vicente Juan Macip realizó originalmente para la serie de prelados valentinos. Perteneciente a la mano Jerónimo Jacinto Espinosa se han localizado obras tanto en la serie icónica catedralicia como en la galería de académicos de la Universitat. José Vergara fue uno de los artistas con una amplia producción de retratos y así lo muestran las obras atribuidas a sus pinceles en la catedral de Valencia y las efigies que hizo tanto para el paraninfo como la Academia. Miguel Parra y Vicente López también retrataron a algunos de los obispos y arzobispos que estuvieron al frente de la diócesis valenciana y personajes vinculados con la Real Academia de Bellas Artes de San Carlos.

Del mismo modo que algunos artistas trabajaron en distintos conjuntos, también hay personajes que aparecen efigiados en varios de ellos. Algunos ejemplos se observan en Ferrante I, quien se encuentra tanto en la galería de retratos de San Mi- 
guel de los Reyes como en la procedente de La Murta. Alejandro VI se ha retratado en la serie de prelados y en las galerías del monasterio alcireño y del paraninfo. Tomás de Rocabertí y Francisco Fabián y Fuero, ambos obispos de Valencia, son miembros de la serie catedralicia y del conjunto universitario.

El estudiar proyectos artísticos que se han configurado en un marco cronológico amplio supone ver reflejado el gusto estético de distintas épocas pero supeditado a las características particulares del conjunto pictórico. Además cabe tener en cuenta que en ocasiones, por ejemplo en numerosas representaciones monárquicas, las efigies tan sólo reproducen el modelo cortesano establecido en el siglo XVI. Otras veces se copian retratos o estampas previas que sirven de modelo. Aún así es palpable la austeridad propia del siglo XVII a través de las figuras recortadas en fondos oscuros y neutros como se ha observado en los retratos de los valencianos ilustres o en las imágenes de frailes, beatos y futuros santos. Con el paso del tiempo y sobre todo en el siglo XVIII se apreciará un mayor trabajo en las cartelas y medallones que incluyen escritos biográficos o el deseo de incluir muchos más objetos secundarios que ayudan a definir la personalidad del retratado. Así sucede con la galería del teatro académico de la Universitat. A principios del siglo XIX, en los casos estudiados, tampoco se volverá a la sobriedad de los tiempos iniciales del barroco y seguirá perviviendo el detallismo bajo el objetivo ofrecer la imagen visual y conceptual más completa posible acerca del efigiado como es patente en las representaciones de los dirigentes de la Academia de San Carlos.

La realización de un retrato o la creación de un grupo de efigies no fue un hecho aislado, sino que se debe contextualizar principalmente con la producción de obras escritas. Como se ha visto en esta investigación, a la vez que surgieron galerías y series icónicas de retratos de reyes a finales del siglo XVI y durante el siglo XVII se publicaron diferentes obras escritas que recogían la historia de la monarquía. Entre ellas se debe men- 
cionar la Crónica de Aragón de Luca Marineo, Decada primera de la historia de la ciudad y reyno de Valencia de Gaspar Escolano, Anales del Reyno de Valencia de Francisco Diago y Los reyes de Aragón en anales históricos de Pedro Abarca. Tanto los retratos como las crónicas que surgieron de forma pareja compartieron el deseo recopilar el pasado de la monarquía y construir su memoria.

Lo mismo sucedió con otra clase de representaciones, como los retratos eclesiásticos y de hombres ilustres. Cabe recordar las numerosas relaciones escritas que recogieron a todos los prelados que estuvieron al frente de la sede valentina. Por ejemplo, José Esteve escribió el Sumario de los obispos antiguos de Valencia, Gregorio Ivanyes hizo un Resumen de les vides dels senyors bisbes i arquebisbes de València, Francisco Diago también redactó un Episcopologio, José Agramunt fue el autor de Memoria de todos los obispos y arzobispos que ha habido hasta el dia de oy en Valencia y Joaquín Ballester también incluyó un catálogo de prelados en su obra Identidad de la imagen del santo Christo del Salvador de Valencia.

La elaboración de retratos de religiosos con posibilidades de santidad coleccionados por el Patriarca Ribera fue acompañada de la redacción de su biografía donde, además, se dejaba constancia de sus virtudes y de los hechos milagrosos que protagonizó. Además hubo un interés por conseguir reliquias procedentes de objetos o de los restos mortales del propio personaje. Ya se ha comentado que Pedro de Ribadeneyra escribió la hagiografía de Ignacio de Loyola o Cristóbal Moreno fue autor del Libro de la Vida y Obras Maravillosas de [...] Nicolás Factor. Asimismo, Vicente Justiniano Antist redactó la Verdadera relación de la vida y muerte de [...] Luis Betran, de quien también se recopilaron numerosas reliquias suyas como una muestra de su sangre, un fragmento de su capa y su cinturón. Muy similar fue el caso de Margarita Agulló, una religiosa muy apreciada por Ribera. Así Jaime Sanchís recogió por escrito su vida y sus restos mortales descansan y son venerados 
en la iglesia del Real Colegio Seminario del Corpus Christi.

El interés por los hombres ilustres también tuvo su eco en las fuentes escritas. Una obra cumbre en este sentido fue el Libro de descripción de verdaderos retratos de ilustres y memorables varones de Francisco Pacheco. No obstante, asimismo se deben tener en cuenta las biografías realizadas en la época de algunos de los insignes personajes del momento. Por ejemplo, Tomás de la Resurrección recogió la vida de Luís Crespí de Borja y Felipe Seguer relató la biografía de Marcelino Siuri. Además, cabe mencionar diversas publicaciones que surgieron a lo largo de los siglos XVIII y XIX y por tanto, aparecieron a la vez que la galería del paraninfo y la colección de la Academia se fueron desarrollando. Vicente Ximeno fue autor de Escritores del Reyno de Valencia en 1749, Nicolás Antonio de Bibliotheca Hispana nova en 1783 y Justo Pastor Fuster de Biblioteca valenciana de los escritores en 1827. En este tipo de obras se ha hecho referencia a la producción escrita de numerosos efiT50 giados en las galerías analizadas y ello es señal del interés que suscitó la labor intelectual de los académicos. Otras publicaciones como la Biografía pictórica valentina de Marcos Antonio de Orellana centró la atención sobre la vida y obras de los artistas valencianos, así se comprueba que las obras escritas también se implicaron en mejorar la consideración social de los artistas.

Incluso la elaboración de las imágenes de tipos orientales fue acompañada de obras escritas acerca de los turcos, revelando la curiosidad que despertaba esta cultura a raíz de su enemistad con Occidente. Entre los relatos y descripciones surgidos a lo largo del siglo XVI han sido significativas las obras de Vasco Díaz Tanco, Palidonia de los Turcos en 1547, de Antonio Herrera Tordesillas, Crónicas de los Turcos en 1565 y de Jerónimo Román, Repúblicas del Mundo en 1595. Los distintos perfiles de efigiados, es decir, personajes de la monarquía, de la Iglesia, del ámbito intelectual y del medio turco han tenido su eco en numerosas obras escritas y esto es algo fundamental porque 
las palabras, junto con los retratos, configuraron la imagen de aquellos hombres representados.

El rico papel que ha desempeñado el retrato, asimismo, estuvo estrechamente ligado a la zona en la que lucían. Por esta razón, al estudiar las series, las galerías y colecciones de retratos se ha tenido en cuenta el lugar donde se encontraban y el uso que se hacía del espacio en la época. La galería de retratos de miembros de la realeza que compró san Juan de Ribera lucía en uno de los aposentos de su residencia ubicada en la calle Alboraya a las afueras de la ciudad. Las pinturas, por tanto, se encontraban en un espacio privado e ilustraban la frecuente práctica de engalanar las casas privilegiadas con este tipo de efigies. Su ubicación original encajaba perfectamente con el sentido que se le ha otorgado a este conjunto. Los retratos, en definitiva, pretendían emparentar genealógicamente al Patriarca con la monarquía y de este modo, se enaltecía a sí mismo. A día de hoy, las imágenes lucen en la biblioteca del Real Colegio Seminario del Corpus Christi entre otras obras pictóricas, pero aún así casan con la tradición de engalanar las bibliotecas con retratos.

Los retratos regios de miembros de la Corona de Aragón para el Reino de Nápoles también respondieron a cuestiones genealógicas y de exaltación personal, en concreto, del duque Calabria. En este caso no se ha conocido con exactitud el lugar en el que se hallaban las pinturas en el monasterio de san Miguel de los Reyes pero teniendo en cuenta que fue fundado por el duque y allí mismo descansan sus restos mortales, es natural que además se contase con un grupo de efigies de los antepasados de Fernando de Aragón que cuidaba su memoria y legitimaba y reivindicaba el derecho al trono que le fue negado.

En cuanto a la serie icónica de reyes que en la actualidad se conserva en el palacio de la Generalitat de Valencia se debe remarcar que su emplazamiento original era el palacio Real donde además de las tareas propias de la administración y go- 
bierno del Reino, tenían lugar actos sociales. En consecuencia, las efigies de los monarcas que se habían ido sucediendo en el territorio valenciano lucían en el palacio, sede arquitectónica de su poder, y mostraban la solidez y la estabilidad de la autoridad regia al componer una larga cadena de soberanos. Esta imagen era contemplada por todos aquellos cortesanos, embajadores y diplomáticos que podían participar del ceremonial y de los festejos que tendrían cabida en este espacio. En el presente, la serie icónica sigue siendo testigo de los actos protocolarios celebrados en el salón de reyes.

Los retratos de obispos y arzobispos de la catedral de Valencia también han visto alterada su localización con el paso del tiempo. En origen las pinturas se encontraban en la estancia delante del archivo y después estuvieron tanto en la antigua como nueva sala capitular. Por tanto, se dispusieron en un lugar de reunión para que fuesen inspiradores para aquellos que los contemplaban a la par que daban imagen a la cúspide de la Iglesia valenciana. Ahora se sitúan en la sacristía nueva y siguen estando a la vista de los sacerdotes para que continúen encontrando en ellos un modelo a seguir. Respecto a la colección de efigies de frailes, venerables y beatos como el resto de conjuntos de retratos pertenecientes a los bienes artísticos de san Juan de Ribera se distribuían entre los aposentos de sus residencias. Después se situaron en la misma sacristía del Colegio o dependencias más próximas. Consecuentemente se trataban de imágenes para la contemplación particular que fomentaban el culto de aquellos que habían sido un referente espiritual.

La galería de varones ilustres realizada para el monasterio de Nuestra Señora de La Murta se localizaba en la biblioteca del complejo monacal donde debía servir de inspiración a aquellos que la viesen. A día de hoy, estos retratos se siguen conservando en un lugar dedicado al estudio y se pueden apreciar en la biblioteca del Museo de Bellas Artes de Valencia para seguir animando a la juventud a cultivar el intelecto y alcanzar la ex- 
celencia. El conjunto pictórico del paraninfo de la Universitat de València fue creado pensando en engalanar concretamente ése espacio y así se ha hecho a lo largo del tiempo. Se trata de un ejemplo más en el que los retratos de insignes personajes ensalzan el espacio donde se ubican y otorgan solemnidad al ceremonial que allí tiene lugar. Los efigiados de esta galería no han dejado de cumplir con su cometido en el presente y siguen honrando los actos académicos que tienen cabida en el salón más fastuoso de la Universitat. Como en otras ocasiones en las que este género ha adornado salones donde se realizaban reuniones, la colección de efigies de presidentes y directores de la Real Academia de Bellas Artes de San Carlos lucía en la sala de juntas. Así se creaba la imagen de la institución y al celebrar las distintas sesiones estaban a la vista de los académicos que la regían y admiraban a aquellos que les habían precedido.

Por último, la galería de efigies turcas al igual que el resto de conjuntos de retratos acumulados por el Patriarca Ribera se encontraba en una de las estancias de su morada. A día de hoy, se aprecian en la escalera que sube a la biblioteca del Colegio del Corpus Christi. Eran, por tanto, unas imágenes empleadas para el conocimiento personal de otra cultura lejana a la propia. Además, que san Juan de Ribera poseyese distintas galerías y colecciones de retratos revela dos aspectos fundamentales como son sus intereses y su posición social. En consecuencia, según la razón por la que se crearon y su función a desempeñar las series icónicas, galerías y colecciones de retratos se dispusieron en un tipo de espacio u otro. Así, los conjuntos encargados por alguien en concreto, como Ribera, se emplazaron en lugares estrictamente privados. Sin embargo, un público más amplio tuvo aquellos grupos de efigies que conformaron la imagen simbólica de otros poderes e instituciones como la monarquía, la Iglesia, la universidad o la Academia. De todos modos, los retratados se consideraron personas que merecieron el honor de ser efigiadas y vieron así, dilatarse su memoria. Retratarse fue un privilegio alcan- 
zado por ser modelo de virtud y haber conseguido suficientes méritos para ello. Independientemente de que los retratos pudiesen ser contemplados por más o menos personas, coincide que los personajes representados fueron encumbrados y presentados como un ejemplo a emular.

Esta investigación que ha analizado el retrato y la creación de series, galerías y colecciones en el ámbito valenciano durante la Edad Moderna, ha observado el uso que se hizo de este género para configurar la imagen del poder regio, eclesiástico y cultural. El enfoque tomado en este estudio ha originado que asimismo se considere interesante la utilización que se hizo del retrato, como expresión del poder, en las fiestas tanto cívicas como religiosas. Una pequeña muestra de ello ha sido el conocer los festejos celebrados en Valencia en 1784 con motivo del nacimiento de los infantes gemelos y la firma de paz con Gran Bretaña. En el epílogo se ha tratado tan sólo un caso concreto pero significativo porque da pie a abordar estudios 754 más amplios donde se valoren todas las posibilidades que el género del retrato encierra, empleándolo como una eficaz herramienta de exaltación personal y colectiva. 


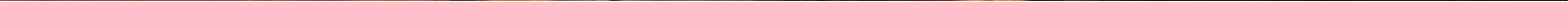




\section{Fuentes y bibliografía}

\section{Fuentes escritas:}

Abarca, Pedro, Los reyes de Aragón en anales históricos, distribuidos en dos partes., (Lucas Pérez, impresor de la Universidad: Salamanca, 1684).

AcEtтo, Torquato, Rime di Torquato Accetto, (Herederos de Tarquino Longo: Nápoles, 1621).

Aguilar, Gaspar, Fiestas nupciales que la ciudad y reino de Valencia han hecho al casamiento del rey don Felipe III, (Imprenta de Manuel Pau: Valencia, 1910).

AIMERIC, Mateo, Nomina et acta episcoporum barcinonensium: binis libris comprehensa atque ad historiae et chronologiae rationem revocata, (Juan Nadal: Barcelona, 1760).

Alenda y Mira, Jenaro, Relaciones de solemnidades y fiestas públicas de España, (Establecimiento tipográfico 'Sucesores de Rivadeneyra': Madrid, 1903).

Álvarez de Colmenar, Juan, Les delices de l'Espagne e du Portugal, (Leide, 1707).

Álvarez Tejero, Luis Prudencio, Antigüedades y objetos notables de Valencia, (Imprenta de La Opinión, a cargo de D. José Doménech: Valencia, 1863). 
Amman, Jost, Habitus praecipuorum populorumtam virorum quam foeminarum singulari arte depicti..., (1577).

AndRADE, Alfonso de, Idea del perfecto prelado en la vida del Eminentísimo Cardenal. D. Baltasar de Moscoso y Sandoval, (Joseph Fernández Buendia: Madrid, 1668).

Anónimo, Constitucions del Estudi General de la insigne ciutat de Valencia, (Juan Batiste Marzal: Valencia, 1642).

- 'Varias poesías al feliz nacimiento del Señor Don Carlos Clemente, hijo primogénito del Serenísimo Señor Don Carlos, Príncipe de Asturias', en Papeles curiosos manuscritos, tomo 21, pp. 150v-151r.

- Colección de reales órdenes comunicadas a la Real Academia de San Carlos desde el año de 1770 hasta el de 1808, (Imprenta de Benito Monfort: Valencia, 1809).

- Continuación de la noticia histórica de la Real Academia de Nobles Artes establecida en Valencia con el título de San Carlos y relación de los premios que distribuyó en las juntas públicas de 6 de noviembre de 1776 y 26 del mismo mes de 1780, (Oficina de Benito Monfort: Valencia, 1781).

- Retratos de Españoles ilustres con un epítome de sus vidas, (Imprenta Real, siendo su regente D. Lázaro Gacquer: Madrid, 1791).

- Plan de estudios aprobado por S. M. y mandado observar en la Universidad de Valencia, (Viuda de Ibarra: Madrid, 1787).

-Inventario de los libros de Don Fernando de Aragón, Duque de Calabria, (Imprenta Aribau: Madrid, 1875).

- Valencianos ilustres en virtud, ciencias y armas, (1830). 
- Historia de la corona de Aragón (la más antigua de que se tiene noticia) conocida generalmente con el nombre de Crónica de san Juan de la Peña, (Diputación Provincial: Zaragoza, 1876).

Antonio, Nicolás, Bibliotheca Hispana nova sive Hispanorum scriptorum, tomo 1, (Joaquín Ibarra: Madrid, 1783).

Armenini, Giovanni Battista, De' veri precetti della pittura, (Francesco Tebaldini: Rávena, 1587).

- De los verdaderos preceptos de la pintura, (Visor Libros: Madrid, 1999).

Avilés, Ángel, El retrato: conferencias pronunciadas en el Círculo de Bellas Artes., (Tipografía de los Huérfanos: Madrid, 1886).

BalbÁs, Juan A., El libro de la provincia de Castellón, (Imprenta y librería de J. Armengot: Castellón, 1892).

Balboa y Paz, Francisco de, Monarchia regum, siue accurata imperii synopsis., (Herederos de Juan Domingo Tarini: Turín, 1630).

Ballester, Juan Bautista, Identidad de la imagen del S. Christo de S. Salvador de Valencia, (Geronimo Vilagrasa: Valencia, 1672).

BALLESTER, Luis, Breve descripción de las fiestas que hizo el Real Convento de Predicadores de Valencia en la beatificación del B. Juan de Ribera y sermón que predicó el R. P. M. Fr. Luis Ballester prior del mismo convento, (Imprenta de D. Benito Monfort: Valencia, 1797).

Bella, Stefano della, Trattato della pittura di Lionardo da Vinci ridotto alla sua vera lezione sopra una copia a penna di mano, (Giovacchino Pagani y Iacopo Grazioli: Florencia, 1792). 
Bellero y Gilles VAn de Rade, Jean, Omnium fere gentium nostraeque aetatis nationum Habitus et Effigies, (1572).

BERTELLI, Pietro, Diversarum nationum habitus centum et quattor iconibus in aere incissis, (1592).

BLANCAS, Jerónimo de, Explicación histórica de las inscripciones de los retratos de los reyes de Sobrarbe, condes antiguos, y reyes de Aragón: puestos en la Sala Real de la Diputación de la Ciudad de Zaragoça, y colocación del retrato del Rey N. Señor Don Carlos Segundo, (Cortes de Aragón: Zaragoza, 1996).

BoIsSARD, Jean-Jacques, Vitae et icones sultanorum Turcicorum, principum Persarum aliorumq[ue] illustrium heroum heroinarumq[ue] ab Osmane usq[ue] ad Mahometem II, (Francf. and Moen, 1596).

- Habitus variarum orbis gentium, (1581).

Boyl, Francisco, N.S. del Puche: cámara angelical de María Santísima, (Silvestre Esparza: Valencia, 1631).

Busquets Matoses, Jacinto, Idea exemplar de prelados, delineada en la vida, y virtudes del venerable varón el ilustrísimo y excelentísimo señor don Juan de Ribera, patriarca de Antioquía, arzobispo de Valencia, su virrey y capitán general, fundador del Real Colegio de Corpus Christ, (Valencia, 1683).

Butrón, Juan, Discursos apologéticos en que se defiende la ingenuidad del arte de la pintura; que es liberal de todos los derechos, no inferior a las siete que comúnmente se reciben., (Luís Sánchez: Madrid, 1626).

Calvete de Estrella, Cristóbal, Felicissimo viaje del muy alto y muy poderoso principe don Phelippe, hijo del emperador don Carlos Quinto Maximo, desde España à sus tierras de la baxa Alemaña: con la descripción de todos los Estados de Brabante 
y Flandes, (Amberes, 1552).

CAPRIolo, Aliprando, Ritrati di cento capitani illustri, (Filippo Tomassino y Giovan Turpino: Roma, 1600).

CARDucho, Vicente, Diálogos de la pintura: su defensa, origen, esencia, definición, modos y diferencias, (Francisco Martínez: Madrid, 1633).

CASSES, Bartolomé, Festivas demostraciones con que la real, fiel y coronada villa de Alzira celebró la feliz proclamación de nuestro monarca Luis I, cuya relación, con la oración panegírica y gratulatoria en acción de gracias ofrece la misma villa, (Antonio Bordazar de Artazu: Valencia, 1724).

Caspar Lavater, Johann, Physiognomy or the corresponding analogy between the conformation of the features and the ruling passions of the mind, (Cowie: Londres, 1826).

CASTellanos de Losada, Basilio Sebastián, Biografía eclesiástica completa: vida de los personajes del Antiguo y Nuevo Testamento: de todos los santos que venera la Iglesia, papas y eclesiásticos célebres venerados por sus virtudes y talentos en orden alfabético, tomo II, (Eusebio Aguado: Madrid, 1849).

Covarrubias, Sebastián de, Tesoro de la lengua castellana o española, (Imprenta de Luís Sánchez: Madrid, 1611).

Diago, Francisco, Anales del Reyno de Valencia, que corre desde su población después del diluvio hasta la muerte de don Jayme el Conquistador, (Pedro Patricio Mey: Valencia, 1613).

- Apuntamientos para continuar los anales del Reino de Valencia desde el rey Pedro III hasta Felipe II; con un prólogo de José $M^{a}$ Garganta, (Imprenta Hijo de F. Vives Mora: Valencia, 1936).

Díaz Tanco, Vasco, Palidonia de los Turcos, (Diputación Provin- 
cial de Badajoz: Orense, 1547).

Diderot, Denis, Essais sur la peinture, (Buisson: París, 1765).

Dolce, Lodovico, Diálogo de la pintura, titulado Aretino, y otros escritos de arte, (Akal: Madrid, 2010).

Domenichi, Lodovico (trad.), La pittura di Leo Baptista Alberti, (Gabriel Giolito de Ferrari: Venecia, 1547).

Escolano, Gaspar, Segunda parte de la década primera de la historia de la insigne y coronada ciudad y Reino de Valencia, (Pedro Patricio Mey: Valencia, 1611).

- Decada primera de la historia de la ciudad y reyno de Valencia; primera parte...; contiene esta decada curiosas generalidades de España y la Historia de Valencia hasta el rey don Pedro hijo del rey don Iayme el Conquistador, (Pedro Patricio Mey: 762 Valencia, 1610).

Escrivà, Francisco, Vida del ilustrísimo y excelentísimo señor don Juan de Ribera, patriarca de Antioquía y arzobispo de Valencia, (Pedro Patricio Mey: Valencia, 1612).

Estiau de Piquer, Carmelo, Las fiestas de Valencia, idea, y descripción de las bellas funciones celebradas en esta Ilustre ciudad en los días 12 y 19 de agosto de esta año 1787, con motivo de las beatificaciones de sus tiernos hijos Nicolás Factor y Gaspar Bono, (Imprenta de Salvador Fauli: Valencia, 1787).

Espinalt y García, Bernardo, Atlante Español, ó Descripcion general geográfica, cronológica, é histórica de España, por Reynos y Provincias, de sus ciudades, villas... : [tomo VIII: Descripción del Reino de Valencia Parte I] (Imprenta de Hilario Santos: Madrid, 1784).

Esquerdo, Juan, Tratado copioso y verdadero, de la determina- 
cio del gran Monarcha Phelipe II. para el casamiento del III. co[n] la Serenissima Margarita de Austria: y entradas de sus Magestades y Grandes por su orden en esta ciudad de Valencia: con las libreas, galas y fiestas q[ue] se hizieron, (Casa de Juan Grysostomo Garriz: Valencia, 1599).

Fajarnés y Castells, Teobaldo, Recuerdos históricos de la Real Capilla de Nuestra Señora de los Desamparados: fiestas de inauguración y del primer centenario, (José Mateu Garín: Valencia, 1867).

FeRNÁNDEZ, Ramón, Rimas de Don Juan de Jáuregui, tomo VI, (Imprenta Real: Madrid, 1819).

- Rimas de Don Juan de Jáuregui, tomo VI, (Imprenta Real: Madrid, 1786).

FLÓREZ DE SETIÉN, Enrique, España sagrada: theatro geográphico-histórico de la iglesia de España. Tomo XLII, (Viuda de Joaquín Ibarra: Madrid, 1801).

FRANCHI LuCCHESE, Antonio, La teorica della pittura: ovvero Trattato delle materie piu' necessarie, (Salvatore e Giandomenico Marescandoli: Lucca, 1739).

FRESNE, Rafaelle du, Trattato della pittura di Lionardo da Vinci, (Giacomo Langlois: París, 1651).

Fuente, Vicente de la, Historia eclesiástica de España, (Compañía de impresores y libreros del reino: Madrid, 1874).

Garibay Çamallora, Esteban de, Compendio historial de las chronicas y universal historia de todos los reinos de España, donde se ponen en suma los condes, señores de Aragón, con los reyes del mismo reino, y condes de Barcelona, y reyes de Nápoles y Sicilia., (Sebastián de Cormellas: Barcelona, 1628). 
Giovio, Paolo, Diálogo delas empresas militares, y amorosas, compuesto en lengua italiana..., (Guillielmo Roville: Lyon Francia, 1562).

Gómez Miedes, Bernardino, De vita et rebus gestis Iacobi I, Regis Aragonum, cognomento expugnatoris, Libri XX, (Viuda de Pedro de Huete: Valencia, 1582).

González, Diego, Llanto de Delio y profecía de Manzanares: égloga, que con motivo de la temprana muerte del señor infante don Carlos Eusebio, y del felicísimo fecundo parto de la Princesa de Asturias, (Joaquín Ibarra: Madrid, 1783).

Guimerán, Felipe, Breve historia de la Orden de Nuestra Señora de la Merced, de redención de cautivos cristianos y de algunos santos, y personas ilustres de ella, (Herederos de Juan Navarro: Valencia, 1591).

764 Herrera y Tordesillas, Antonio, Crónica de los Turcos: la cual principalmente sigue a la que escribió Juan María Viçentino, cronista de Mahometo, Bayasit y Suleyman, (1565).

Holanda, Francisco de, De la pintura antigua, (Jaime Ratés: Madrid, 1921).

ILlescas, Gonzalo de, Historia pontifical y católica, en la cual se contienen las vidas y hechos notables de todos los Sumos Pontífices Romanos: con más una breve recapitulación de las cosas de España y de la descendencia de los Reyes de ella, (Madrid, 1613).

Jimena Jurado, Martín de, Catálogo de los obispos de las iglesias catedrales de la diócesis de Jaén y anales eclesiásticos de este obispado, (Madrid, 1654).

JORDÁn, Jaime, Historia de la provincia de la Corona de Aragón de la sagrada orden de los ermitaños de nuestro gran padre 
san Agustín, compuesta de quatro reynos, Valencia, Aragón, Cataluña y las islas de Mallorca y Menorca; y dividida en quatro partes. Parte primera., (José García: Valencia, 1704).

Justiniano Antist, Vicente, Verdadera relación de la vida y muerte del Padre Fray Luis Bertrán, de bienaventurada memoria, (Juan Alterach: Zaragoza, 1583).

- Verdadera relación de la vida y muerte del padre Fray Luis Bertrán, de bienaventurada ceremonia, (Casa de la viuda Huete: Valencia, 1582).

Latre, Mariano, El Sacrosanto y ecuménico Concilio de Trento, (Benito Espona: Barcelona, 1845).

LLoRente, Teodoro, Valencia, (Cortezo, 1889).

LoBera y ABió, Antonio, El por qué de todas las ceremonias de la Iglesia y sus misterios: cartilla de prelados y sacerdotes que enseña las ordenanzas eclesiásticas que deben saber todos los ministros de Dios, (Ignacio Porter: Figueras, 1769).

LoBón, Bernardo Vicente y Pascual López, Elogio poético en alabanza del nacimiento, y feliz entrada en la corte de Madrid de los dos infantes gemelos Carlos y Felipe de Borbón, (Oficina de Pantaleón Aznar: Madrid, 1783).

Lomazzo, Giovanni Paolo, Trattato dell'arte della pittura, scoltura et architettura, (Paolo Gottardo Pontio: Milán, 1585).

Luján de Sayavedra, Mateo, Segunda parte de la vida del pícaro Guzmán de Alfarache, (Roger Velpius: Bruselas, 1604).

Marineo, Luca, Crónica de Aragón, (Juan Jofre: Valencia, 1574).

Martínez, Jusepe, Discursos practicables del nobilísimo arte de la pintura: Sus rudimentos, medios y fines que enseña la experiencia, con las ejemplares obras insignes de artífices ilustres, 
(M. Peiró Coso: Zaragoza, 1853).

Mayans y Siscar, Gregorio, Arte de pintar, (Imprenta de José Rius: Valencia, 1854).

- Emmanuelis Martini Ecclesiae Alonensis decani vita, (Zúñiga, Juan de, 1735).

Mengs, Antón Rafael, Obras de D. Antonio Rafael Mengs: primer pintor de cámara del rey, (Joseph Nicolás de Azara: Madrid, 1780).

Mestre, Miguel, Vida y milagros del glorioso San Antonio de Padua, sol brillante de la Iglesia, lustre de la religión seráfica, gloria de Portugal, honor de España, thesorero de Italia, terror del infierno, martillo fuerte de la herejía, entre los santos por excelencia el milagrero, (Imprenta de María Ángela Martí, viuda: Barcelona, 1759).

Miñana, José Manuel, Continuación de la Historia General de España, (Madrid, 1828).

Mirallas, Felipe, Sermón fúnebre en las solemnes exequias que celebraron en la santa iglesia metropolitana de Valencia, su Excelentísimo, Ilustrísimo y Reverendísimo señor don Francisco Fabián y Fuero, el día 13 de octubre de 1801 predicado por su canónigo penitenciario el doctor Felipe Mirallas, (Oficina de Benito Monfort: Valencia, 1801).

Monzón, Francisco de, Libro segundo del Espejo del perfecto príncipe cristiano, (SIELAE: A Coruña, 2012).

Moreno, Cristóbal, y José Ximeno, Libro de la vida y obras maravillosas del siervo de Dios el bienaventurado Padre Fray Pedro Nicolás Factor, de la Orden de nuestro Padre S. Francisco de la Regular Observancia de la Provincia de Valencia, (Sebastián de Cormellas: Barcelona, 1618). 
Moreno, Matías, Festivas demostraciones con que la M. N. muy leal ciudad de Logroño manifestó su júbilo, por el feliz nacimiento de los dos señores infantes gemelos, y conclusión de la paz, en los días veinte y tres, veinte y cuatro y veinte y cinco de noviembre de este presente año por un apasionado vecino, y muy obsequioso servidor suyo, (Imprenta de Matías Moreno: Logroño, 1783).

Moreno de la Tejera, Vicente, Diario de un viaje a Oriente, Argel, Nápoles, Pompeya, el Vesubio, Sicilia, Grecia, el Archipiélago, Turquía y Egipto, (Madrid, 1877).

Muntaner, Ramón, Chronica, o descripcio dels fets, e hazanyes del inclyt rey don Iaume primer, Rey Daragon, de Mallorques, $e$ de Valencia: Compte de Barcelona, e de Muntpesller: e de mols de sos descendents, (Iaume Cortey: Barcelona, 1562).

Muñoz de la Cueva, Juan, Noticias históricas de la Santa Iglesia Catedral de Orense, (Imprenta Real: Madrid, 1727).

Nicolay, Nicolás de, Discours et histoire véritable des navigations, pérégrinations et voyages en Turquie, (Amberes, 1586).

- Le navegationi fatti nella Turchia, (Venecia, 1580).

- Navegationi et viagi fatti nella Turchia, (Amberes, 1576).

- Les navigations, pérégrinations et voyages faicts en la Turquie, (Amberes, 1576).

- Les quatre premiers livres des navigations et pérégrinations orientales, (Lyon, 1567).

NÚÑEZ DE CEPEDA, Francisco, Idea del buen pastor copiada por los SS. Doctores representado en empresas sacras; con avisos espirituales, morales, políticos y económicos para el govierno de un principe ecclesiastico, (Anisson y Posuel: León, 1682). 
Oller y Bono, Mauro Antonio, Proclamación del Rey Ntro. Sr. D. Carlos III: (que Dios guarde) en su fidelísima ciudad de Valencia, (Oficina de la viuda de José de Orga: Valencia, 1759).

Orellana, Marcos Antonio de, Valencia antigua y moderna, (Librerías París - Valencia: Valencia, 1924).

- Biografía pictórica valentina o vida de los pintores, arquitectos, escultores y grabadores valencianos, (Ayuntamiento de Valencia: Valencia, 1967).

ORTí Y Figuerola, Francisco, Memorias históricas de la fundación y progresos de la insigne Universidad de Valencia, (Imprenta de Antonio Marín: Madrid, 1730).

ORTí y MAYOR, José Vicente, Fiestas centenarias, con que la insigne, noble, leal y coronada ciudad de Valencia celebró, en el día 9 de octubre de 1738, la quinta centuria de su cristiana 768 centuria, (Antonio Bordazar: Valencia, 1740).

Pacheco, Francisco, Libro de descripción de verdaderos retratos, de ilustres y memorables varones, (Sevilla, 1599).

Palomino de Castro y Velasco, Antonio, El museo pictórico y escala óptica, (Aguilar: Madrid, 1988).

PAstor Fuster, Justo, Biblioteca valenciana de los escritores que florecieron hasta nuestros días con adiciones y enmiendas a la de D. Vicente Ximeno, (Imprenta de José Ximeno: Valencia, 1827).

Pino, Paolo, Dialogo di pittura di messer Paolo Pino nuovamente dato in luce, (Paulo Gherardo: Venecia, 1548).

Ponz, Antonio, Viaje de España, (Viuda de Ibarra, Hijos y Compañía: Madrid, 1789). 
Porcel, José Antonio, Sermón en la solemnidad de acción de gracias, que de orden del Rey Nuestro Señor, por el Nacimiento de los dos Señores Infantes Gemelos Carlos y Felipe, y por la paz concluida, celebró en su Catedral el Cabildo de la Santa Iglesia Metropolitana de Granada, asistido de su Ilustrísimo Prelado, y del muy Noble, y Leal Ayuntamiento de la misma Ciudad, (Imprenta Real: Granada, 1784).

PRADEs, Jaime, Historia de la adoración y uso de las santas imágenes, y de la imagen de la fuente de la Salud, (Felipe Mey: Valencia, 1597).

Prats, Antonio, Lamentables suspiros del Real Convento de Predicadores de Valencia por la muerte de su sapientísimo hijo, y venerable padre maestro fray Marcelo Marona, (Diego de Vega: Valencia, 1695).

Pulgar, Hernando del, Crónica de los señores reyes católicos Don Fernando y Doña Isabel de Castilla y Aragón, (Imprenta de Benito Monfort: Valencia, 1780).

Ramos, Andrés, Oración fúnebre en las honoríficas exequias, que el muy observante monasterio de religiosas cistercienses consagró a la dulce venerable memoria del Ilmo. y Rmo. Señor D. Marcelino Siuri dignísimo obispo de Córdoba, (Colegio de la Asunción: Córdoba, 1731).

Real Colegio Seminario de San Telmo, Descripción de las festivas demostraciones de júbilo con que el Real Colegio Seminario del Sor. Sn. Telmo y Universidad de Mareantes de Sevilla, celebraron en los días 17 y 18 de diciembre de 1783 el feliz nacimiento de los Infantes gemelos de España D. Carlos y D. Felipe y la paz ajustada con Inglaterra se da a luz por acuerdo del señor Juez Conservador, (Imprenta de Vázquez, Hidalgo y compañía: Sevilla, 1783).

Resurrección, Tomás de la, Vida del venerable Ilmo. y Excmo. 
Sr. D. Luís Crespí de Borja, obispo de Plasencia y embajador por Felipe IV a Alejandro VII para la declaración del culto a la Concepción, (Lorenzo Cabrera: Valencia, 1676).

RIPA, Cesare, Iconologia overo descrittione di diverse imagini cavate dall'antichità e di propia inventione, (Roma, 1603).

Risco, Manuel, España sagrada: theatro geographico-historico de la iglesia de España. De la santa Iglesia de Lugo. Tomo XLI, (Oficina de la viuda e hijo de Marín: Madrid, 1798).

Robres Lluch, Ramón, San Juan de Ribera, patriarca de Antioquía, arzobispo y virrey de Valencia, 1532-1611: un obispo según el ideal de Trento, (Juan Flors: Barcelona, 1960).

Rodríguez, Josep, Biblioteca Valentina. Compuesta por el M.R.P. M. Fr. Josef Rodríguez, Ministro del Real Convento del Remedio de Valencia, Cronista General del Orden de la SS. Trinidad en 770 la Provincia de Aragón, (por Joseph Thomas Lucas, se hallará en la sacristía del Real Convento del Remedio: En la misma [Valencia], 1747).

Rodríguez Villa, Antonio, Crónicas del Gran Capitán, (Madrid, 1908).

Román, Jerónimo, Repúblicas del Mundo divididas en XXVII libros, (Medina del Campo, 1575).

SAAVEDRA FaJARDo, Diego de, Idea de un príncipe político cristiano, representada en cien empresas, (Gerónimo Villagrasa: Valencia, 1665).

SAGREDO, Giovanni, Memorie istoriche de monarchi ottomani, (Venecia, 1673).

Salvador y MonTSerRat, Vicente, Guia urbana de Valencia, antigua y moderna. Tomo II, (Imprenta de José Rius: Valencia, 1876). 
SANCHís, Jaime, Relación breve de la vida, virtudes y milagros de de la humilde sierva del Señor Sor Margarita Agullona, Beata Profesa de la Orden del Seráfico Padre San Francisco, (Juan Crisóstomo Garriz: Valencia, 1607).

Santos, Francisco de los, Descripción del Real Monasterio de San Lorenzo del Escorial, única maravilla del mundo, fábrica del prudentísimo rey Felipe II, coronada por el católico rey Felipe IV el Grande, con la majestuosa obra del panteón y traslación de los cuerpos reales, reedif, (Imprenta de Bernardo Villa: Madrid, 1681).

SEGUER, Felipe, Vida exemplar del Ilmo. señor don Marcelino Siuri, pavordre de la Santa Metropolitana Iglesia de Valencia, (Juan Rodríguez: Córdoba, 1775).

SERRANO, Tomás, Fiestas seculares con que la coronada ciudad de Valencia celebró el feliz cumplimiento del tercer siglo de la canonización de su esclarecido hijo, y ángel protector san Vicente Ferrer, apóstol de Europa, (Viuda de Joseph de Orga: Valencia, 1762).

Sigüenza, José, Historia de la orden de San Jerónimo, (Bailly Baillière e hijos: Madrid, 1907).

Summonte, Giovanni Antonio, Dell' Historia della citta e regno di Napoli, (Antonio Bulifon: Nápoles, 1675).

TARín y JuANEdA, Francisco, Los retratos del beato Juan de Ribera: estudio iconográfico, (Imprenta de Francisco Vives y Mora: Valencia, 1891).

ToRre, Francisco de la, Reales Fiestas que dispuso la noble, insigne coronada, y siempre leal ciudad de Valencia, a honor de la milagrosa imagen de la Virgen de los Desamparados, en su traslación a su nueva suntuosa capilla, (Gerónimo Vilagrasa, impresor de la ciudad.: Valencia, 1668). 
Vecellio, Cesare, Habiti antichi, overo raccolta di figure delinéate dal Gran Tiziano, e Cesare Vecellio suo fratello, diligentemente intagliate, conforme alle Nationi del Mondo, (Venecia, 1664).

- Habiti antichi et moderni di tutto il Mondo, (Venecia, 1598).

- De gli habiti antichi, e moderni di diverse parti del mondo, 1590.

VICENTE, Plácido, Oración eucarística o panegírico que en acción de gracias por los dos infantes gemelos, dados a luz por nuestra augusta princesa...dijo en el Real monasterio de San Benito de Zamora, (Joaquín Ibarra: Madrid, 1784).

VIERA y CLAVIJo, José, Al felicísimo nacimiento de los dos Serenísimos Infantes Gemelos, que ha dado a luz la Princesa, (Joaquín Ibarra: Madrid, 1783).

Ximenez, Juan, Vida y Virtudes del Ylmo. y Exmo. Señor D. Juan de Ribera, Patriarca de Antioquia..., (Ymprenta de Roque Bernabò: Roma, 1734).

XIMENo, Vicente, Escritores del reyno de Valencia chronologicamente ordenados desde el año MCCXXXVIII de la cristiana conquista de la ciudad hasta el MDCCXLVIII, tomo II, (Joseph Estevan Dolz: Valencia, 1749).

ZaVAla y Zamora, Gaspar, Descripción de las plausibles fiestas, que al feliz nacimiento de los serenísimos infantes gemelos celebró la muy noble y leal villa de Madrid los días 13, 14, 15 de julio de 1784, (Joaquín Ibarra impresor de cámara de S. M.: Madrid, 1784). 


\section{Bibliografía:}

AA. VV., Los Austrias. Grabados de la Biblioteca Nacional, (Julio Ollero: Madrid, 1993).

Afeda Villar, Mercedes, (ed.), Antonio Rafael Mengs, 1728 - 1779. Museo del Prado, junio-julio, 1980, (Ministerio de Cultura, Dirección General del Patrimonio Artístico, Archivos y Museos: Madrid, 1980).

Ágreda Pino, Ana María, 'El terno de don Juan González de Munébrega. Estudio histórico artístico', Turiaso, no. 13, 1996, pp. 95-110.

Alba Pagán, Ester, 'La génesis del Museo de Bellas Artes de Valencia y la polémica en torno a los bienes desamortizados a través de la prensa valenciana', en Francisco Javier Campos y Fernández de Sevilla (ed.), La desamortización: el expolio del patrimonio artístico y cultural de la Iglesia en España: actas del Simposium 6/9-IX-2007, (Estudios Superiores del Escorial: Madrid, 2007), pp. 723-739.

Albiñana, Salvador, 'Las cátedras de medicina en la Valencia de la Ilustración', Estudis: Revista de historia moderna, no. 14, 1988, pp. 171-210.

Aldana Fernández, Salvador, Sala Nova del Palau de la Generalitat Valenciana, (Institut Valencià de Conservació i Restauració de Béns Culturals: Valencia, 2007).

- Real Academia de Bellas Artes de San Carlos de Valencia: historia de una institución, (Real Academia de Bellas Artes de San Carlos: Valencia, 2001).

- El Palau de la Generalitat valenciana, (Generalitat Valenciana: Valencia, 1995). 
-'Iconografía de la Sala Nova del Palau de la Generalitat Valenciana. Nuevas aportaciones', Goya: Revista de arte, no. 246, 1995, pp. 322-327.

Aldea Hernández, Ángela, 'La colección pictórica de Varones Ilustres Valencianos pertenecientes al Monasterio Jerónimo de Nuestra Señora de la Murta de Alzira', en F. Javier Campos y Fernández de Sevilla (ed.), La Orden de San Jerónimo y sus monasterios: actas del simposium (II), (Madrid, 1999), vol. I, pp. 529-554.

- y Francisco Javier Delicado Martínez, El Archivo Histórico de la Real Academia de Bellas Artes de San Carlos y sus fondos documentales, (Diputació de València, Area de Cultura: Valencia, 2007).

Almagro-Gorbea, Martín, María Cruz Pérez Alcorta y Teresa Moneo, Medallas españolas, (Real Academia de la Historia: Ma774 drid, 2005).

Almenara Sebastià, Miguel, 'Documentación testamentaria del humanista valenciano Fadrique Furió Ceriol (1527 - 1592)', Estudis: Revista de historia moderna, no. 21, 1995, pp. 89-112.

Alonso Cabezas, Ma Victoria, 'Los inicios de la galería de retratos de la Real Academia de Bellas Artes de San Carlos (1753-1840)', Archivo de arte valenciano, no. 99, 2018, pp. 133-144.

- 'Una galería de retratos en la Real Academia de Bellas Artes de San Fernando (1754-1833)', Archivo Español de Arte, Vol. 92, no. 366, 2019, pp. 191-202.

Ansón Navarro, Arturo, 'Un retrato de Fernando VII (1808) obra de Agustín Esteve', Ars Longa: cuadernos de arte, no. 21, 2012, pp. 351-356.

- 'Colección de retratos de obispos y arzobispos de Zaragoza, 
hasta el siglo XVIII', en María del Mar Agudo Romeo (ed.), El espejo de nuestra historia: la diócesis de Zaragoza a través de los siglos: San Juan de los Panetes, Lonja, Palacio Arzobispal, 5 octubre - 6 enero, 1991-1992, Zaragoza, (Arzobispado de Zaragoza: Zaragoza, 1991), pp. 145-148.

Arciniega García, Luis, y Amadeo Serra Desfilis, 'Cort e Palau de Reu. El Palacio Real en época medieval', en El Palacio Real de Valencia. Los planos de Manuel Cavallero (1802), (Ayuntamiento de Valencia: Valencia, 2006), pp. 83-90.

- 'El palacio como escenario de Austrias y Borbones, residencia de virreyes y capitanes generales', en El Palacio Real de Valencia. Los planos de Manuel Cavallero (1802), (Ayuntamiento de Valencia: Valencia, 2006), pp. 91-108.

- 'Santa María de la Murta (Alzira): Artífices, comitentes y la «Damnatio Memoriae» de D. Diego de Vich', en F. Javier Campos y Fernández de Sevilla (ed.), La Orden de San Jerónimo y sus monasterios: actas del simposium (II), (Madrid, 1999), vol. I, pp. 269-292.

AtıL, Esin, The age of Sultan Suleyman the Magnificent, (National Gallery of Art,U.S., 1987).

AzcÁrate Luxan, Isabel, Victoria Durá Ojea, Ma Pilar Fernández Agudo, Elena Rivera Navarro, y Ma Ángeles Sánchez de León Fernández, Historia y alegoría: los concursos de pintura de la Real Academia de Bellas Artes de San Fernando (1753-1808), (Real Academia de Bellas Artes de San Fernando: Madrid, 1994).

AzcÁrraga, Adolfo de, Arte y artistas valencianos, (Ajuntament de València: Valencia, 1999).

BARRETO, Joana, La majeste en images: portraits du pouvoir dans la Naples des Aragon, (Ecole fran-caise de Rome: Rome, 2013). 
Benito Doménech, Fernando, Juan Sariñena (1545-1619): pintor de la Contrarreforma en Valencia: Museo de Bellas Artes de Valencia, del 19 de diciembre de 2007 al 23 de marzo de 2008, (Generalitat Valenciana, Consellería de Cultura i Esport, 2007).

- y Ferran Olucha Montins, Urbano Fos, pintor (h. 1615-1658): Museu de Belles Arts de Castelló del 13 de marzo al 15 de junio de 2003, (Generalitat Valenciana: Valencia, 2003).

-El Museo de Bellas Artes de Valencia San Pío V: su historia y sus colecciones, (Generalitat Valenciana: Valencia, 1999).

- 'El retrato moralizado en España: Contrarreforma e influencia del retrato como género', en Javier Portús Pérez (ed.), El retrato en el Museo del Prado, (Anaya: Madrid, 1994), pp.183-191.

- Los Ribalta y la pintura valenciana de su tiempo: exposición Lonja de Valencia, octubre - noviembre 1987: Museo del Prado, 776 Palacio de Villahermosa, diciembre 1987 - enero 1988, (Diputación Provincial de Valencia: Valencia, 1987).

- 'Sobre Agustín Gasull, José Vergara, y una traza de la antigua iglesia de la Compañía de Valencia', Archivo de arte valenciano, Vol. 63, 1982, pp. 66-68.

-'Una enigmática serie de pinturas de turcos en Valencia', Boletín de la Sociedad Castellonense de Cultura, Vol. 57-2, 1981, pp. 19-29.

- Pintura y pintores del Real Colegio del Corpus Christi, (Valencia, 1980).

Benito Goerlich, Daniel, y Amparo José Mora Castro, 'La iconografía de la catedral de Valencia. Un programa ilustrado', en Emilio Callado Estela (ed.), La catedral ilustrada: Iglesia, sociedad y cultura en la Valencia del siglo XVIII, (Valencia, 2014), pp. 323-371. 
- El Paraninfo de la Universitat de València y sus personajes retratados: testimonio de saber, historia y ceremonia, (Universitat de València: Valencia, 2014).

Benito Goerlich, Daniel, 'Imágenes para la reforma del arzobispo Juan de Ribera', en Emilio Callado Estela y Miguel Sorní Navarro (eds.), El patriarca Ribera y su tiempo: religión, cultura y política en la Edad Moderna, (Institució Alfons el Magnànim, Diputació de València, 2012), pp. 609-638.

- y Miguel Navarro (ed.), Pastor Sanctus Virtutis Cultor: el legado del Patriarca Juan de Ribera en su IV Centenario, (Pentagraf, 2011).

- y David Sánchez Muñoz (coord.), La Universitat de València y su patrimonio cultural, (Universitat de València: Valencia, 2008).

-'Lectura iconográfica de los Desposorios místicos del Venerable Agnesio de Juan de Juanes', Saitabi: revista de la Facultat de Geografia i Història, no. 45, 1995, pp. 53-68.

Bodart, Diane H., Pouvoirs du portrait sous les Habsbourg d'Espagne, (CTHS: París, 2011).

Breuer-Hermann, Stephanie 'Alonso Sánchez Coello. Vida y obra', en Juan Miguel Serrera (ed.), Alonso Sánchez Coello y el retrato en la corte de Felipe II, (Museo Nacional del Prado: Madrid, 1990), pp. 14-35.

Bunes Ibarra, Miguel Ángel, 'El imperio otomano y la intensificación de la catolicidad de la monarquía hispana', AHIg, no. 16, 2007, pp. 157-167.

- 'La conquista turca de Bizancio según los cronistas europeos de los siglos XVI y XVII', Erytheia, no. 13, 1992, pp. 89-102. 
BuRKe, Peter, ¿Qué es la historia cultural?, (Paidós: Barcelona, 2006).

- 'La sociología del retrato', en Rafael Argullol (ed.), El retrato, (Galaxia Gutenberg: Barcelona, 2004), pp. 91-126.

CADENAS y Vicent, Vicente de, Tratado de genealogía, heráldica y derecho nobiliario: segundo curso de la Escuela de Genealogía, Heráldica y Nobiliaria, (Hidalguía: Madrid, 2001).

- Repertorio de blasones de la comunidad hispánica, (Hidalguía: Madrid, 1987).

Caldas de Monbuy, Marqués de, Los descendientes legitimados de Alfonso el Magnánimo en el trono de Nápoles, (Barcelona, 1951).

Callado Estela, Emilio, 'Breu història dels episcopologis valen778 cians', Scripta: revista internacional de literatura i cultura medieval i moderna, no. 1, 2013, pp. 159-172.

-y Miguel Navarro Sorní (coord.), El Patriarca Ribera y su tiempo. Religión, cultura y política en la Edad Moderna, (Institució Alfons el Magnànim: Valencia, 2012).

Calvo SeRRAller, Francisco, La Teoría de la pintura en el Siglo de Oro, (Cátedra: Madrid, 1981).

Campos-Perales, Ángel, 'Ver y conocer a Dios en el mundo natural: Los intereses científicos de san Juan de Ribera (1532-1611) y su colección pictórica', Potestas. Estudios del Mundo Clásico e Historia del Arte, no. 12, 2018, pp. 121-144.

Capilla Aledón, Gema Belia, 'El poder representado: Alfonso V el Magnánimo (1416-1458)', Universitat de València, 2015.

-'El poder representado: Alfonso V El Magnánimo (1416-1458)', 
Res publica, no. 18, 2007, pp. 375-394.

CÁrcel OrTí, Vicente, Historia de la Iglesia en Valencia, (Arzobispado de Valencia: Valencia, 1986).

Carreres de Calatayud, Francesc, Las fiestas valencianas y su expresión poética: siglos XVI-XVIII, (Consejo Superior de Investigaciones Científicas, Instituto Jerónimo Zurita: Madrid, 1949).

CarRete Parrondo, Juan, 'Diego Antonio Rejón de Silva y la colección de retratos de españoles ilustres', Revista de Ideas Estéticas, Madrid, Instituto Diego Velázquez, n¹35 t.XXXIV, 1976, pp. 211-219.

CarRió-Invernizzi, Diana, 'Las galerías de retratos de virreyes de la Monarquía Hispánica, entre Italia y América (siglos XVI-XVII)' en Daniel Aznar, Guillaume Hanotin y Niels F. May (eds.), À la place du roi. Vice-rois, gouverneurs et ambassadeurs dans les monarchies française et espagnole, (Casa de Velázquez: Madrid, 2014), pp. 113-134.

CASTAÑEda BeCERRA, Ana María, El retrato granadino en el barroco, (Universidad de Granada, 2006).

Catalá Gorgues, Miguel Ángel, El pintor y académico José Vergara (Valencia, 1726-1799), (Generalitat Valenciana: Valencia, 2004).

Catalán Martí, José Ignacio, 'Un documento inédito para la biografía del grabador valenciano Manuel Monfort y Asensi', Ars Longa: cuadernos de arte, no. 14-15, pp. 233-244.

Centellas Salamero, Ricardo (coord.), Los reyes de Aragón, (Caja de Ahorros de la Inmaculada de Aragón: Zaragoza, 1993).

Centre Cultural la Beneficència, La cultura ceñida: las joyas en la pintura valenciana siglos XV a XVIII: Centre Valencià de Cul- 
tura Mediterrània La Beneficència, Valencia del 19 de diciembre de 2000 al 5 de febrero de 2001, ([Generalitat Valenciana]: Valencia, 2000).

CheCA Cremades, Fernando, Tiziano y las cortes del Renacimiento, (Marcial Pons Historia: Madrid, 2013).

- Los inventarios de Carlos $V$ y la familia imperial. The inventories of Charles $V$ and the imperial family, (Fernando Villaverde: Madrid, 2010).

- 'Fiestas, bodas y regalos de matrimonio. Del tesoro principesco al inicio del coleccionismo artístico en las cortes habsbúrgicas de la época de Juana de Castilla (1498 - 1554)', en Miguel Ángel Zalama Rodríguez (ed.), Juana I en Tordesillas: su mundo, su entorno, (2010), pp. 135-162.

- 'El retrato del rey: la construcción de una imagen de la ma780 jestad en la casa de Austria durante el siglo XVI', en Sociedad Estatal para la Conmemoración de los Centenarios de Felipe II y Carlos V (ed.), Carlos V. Retratos de familia, (Madrid, 2000).

- Felipe II: mecenas de las artes, (Nerea: Madrid, 1993).

- Carlos V y la imagen del héroe en el Renacimiento, (Taurus: Madrid, 1987).

CIVIL, Pierre, 'La familia de Carlos V: Representaciones y política dinástica', en El linaje del emperador: Iglesia de la Preciosa Sangre, Centro de Exposiciones San Jorge, Cáceres, del 24 de octubre de 2000 al 7 de enero de 2001, (Sociedad Estatal para la Conmemoración de los Centenarios de Felipe II y Carlos V: Madrid, 2000), pp. 41-60.

CLot, André y Matthew Reisz, Suleiman the Magnificent, (Saqi Books, 2012). 
Company Climent, Ximo, Paolo da San Leocadio i els inicis de la pintura del Renaixement a Espanya, (CEIC Alfons el Vell: Valencia, 2006).

Delicado, Francisco Javier, 'Los orígenes del Museo de Pinturas de Valencia y la Comisión provincial de Monumentos Históricos y Artísticos', Archivo de arte valenciano, no. 95, 2014, pp. 123-165.

-'La desamortización eclesiástica de Mendizábal y las comisiones provinciales de monumentos históricos y artísticos de Valencia, Castellón y Alicante', Archivo de arte valenciano, no. 87, 2006, pp. 81-90.

Díez, José Luis, Vicente López: 1772-1850, (Fundación de Apoyo a la Historia del Arte Hispánico: Madrid, 1999).

- 'El retrato español del siglo XIX', en Javier Portús Pérez (ed.), El retrato español en el Museo del Prado, (Anaya: Madrid, 1994), pp. 323-349.

-'La imagen del artista en la pintura española del siglo XIX', en Artistas pintados. Retratos de pintores y escultores del siglo XIX en el Museo del Prado, (Museo Nacional del Prado: Madrid, 1997), pp. 39-61.

Egido Martínez, Aurora, 'Retratos de los Reyes de Aragón; de Andrés de Uztarroz y otros poemas de Academia', Cuadernos de historia Jerónimo Zurita, no. 33, 1979, pp. 173-223.

Enciso Recio, Luis Miguel, y José Miguel Sánchez González (ed.), Reino y ciudad: Valencia en su historia, (Fundación Caja Madrid: Madrid, 2007).

Espinós Díaz, Adela, Vicente López en el Museo de Bellas Artes de Valencia, (Generalitat Valenciana: Valencia, 2013). 
EstebAn LoRente, Juan Carlos, 'Un obispo regalista del siglo XVIII natural de Terzaga: Don Francisco Fabián y Fuero, arzobispo de Valencia', Wad-al-Hayara: Revista de estudios de Guadalajara, 1986, pp. 323-338.

Esteban LoRente, Juan Francisco, 'El influjo de la emblemática en el arte aragonés', en José Javier Azanza López y Rafael Zafra (coord.), Emblemata aurea: la emblemática en el arte y la literatura del Siglo de Oro, (Akal Ediciones: Madrid, 2000), pp. 144-162.

Falomir Faus, Miguel, 'El Patriarca Ribera y la pintura. Devoción, persuasión e historia', en Una religiosa urbanidad: San Juan de Ribera y el Colegio del Patriarca en su cultura artística de su tiempo, (Real Academia de Bellas Artes de San Carlos: Valencia, 2013), pp. 103-116.

- 'El retrato de corte', en Miguel Falomir Faus (ed.), El retrato 782 del Renacimiento, (Museo Nacional del Prado: Madrid, 2008), pp. 109-123.

- Tiziano: 10 de junio-7 de septiembre 2003, Museo Nacional del Prado, (Museo Nacional del Prado: Madrid, 2003).

- 'Imágenes de poder y evocación de la memoria. Usos y funciones del retrato en la corte de Felipe II', en Sociedad Estatal para la Conmemoración de los Centenarios de Felipe II y Carlos V (ed.), Un príncipe del Renacimiento: Felipe II, un monarca y su época. Museo Nacional del Prado, 13 de octubre de 1998 - 10 de enero de 1999, (Madrid, 1998), pp. 203-228.

- 'La pintura valenciana del último tercio del siglo XVI y el Colegio de Pintores de 1607', en Miguel Falomir Faus, La pintura y los pintores en la Valencia del Renacimiento,1472-1620, (Consell Valencià de Cultura: Valencia, 1994), pp. 45-59.

FatÁs, Guillermo, Prontuario aragonés del Reino y de la Corona 
de Aragón, (Cortes de Aragón, 2014).

Felici CASTell, Andrés, 'La santidad local valenciana: la tradición de sus imágenes y su alcance cultural', Universitat de València, 2016.

FeLIPo ORTs, Amparo, La Universidad de Valencia durante el siglo XVII (1611-1707), (Generalitat Valenciana: Valencia, 1991).

Fernández Castiñeiras, Enrique, 'Retrato de familia, genealogía de santidad: los principios de un género pictórico a través de la obra de Gregorio Ferro Requeijo en San Salvador de Celanova', en Ana Goy Diz y Juan Manuel Monterroso (dir.), De nombres y obras: Opus monasticorum VII, (Andavira: Santiago de Compostela, 2014), pp. 136-159.

FeRnÁndez LANZA, Fernando, 'Los turcos y lo turco a través de los impresos y manuscritos hispanos del siglo XVI. Propaganda y silencio', en Manuel Casado Arboniés (ed.), Escrituras silenciadas en la época de Cervantes, (Universidad de Alcalá, Servicio de Publicaciones: Alcalá de Henares, 2006), pp. 75-96.

FERRANDo RoIG, Juan, Iconografía de los santos, (Omega: Barcelona, 1950).

Fetvaci, Emine, 'From Print to Trace: An Ottoman Imperial Portrait Book and Its Western European Models', The Art Bulletin, vol. XCV, $n^{\circ} 2$, June 2013, pp. 241-268.

FLETCHER, Jennifer, 'El retrato renacentista: funciones, usos y exhibición', en Miguel Falomir Faus (ed.), El retrato del Renacimiento, (Museo Nacional del Prado: Madrid, 2008), pp. 71-89.

Fossi, Gloria, 'Il ritratto tra memoria, realtà e immaginazione', en Gloria Fossi (ed.), Il ritratto, gli artista i modelli, la memoria, (Giunti, 1996), pp. 9-27. 
Francastel, Galienne y Pierre Francastel, El retrato, (Cátedra: Madrid, 1978).

FRANCO LLOPIS, Borja, 'El patriarca Ribera y el uso del arte a finales del siglo XVI en Valencia', en Emilio Callado Esta y Miguel Navarro Sorní (coord.) El patriarca Ribera y su tiempo: religión, cultura y política en la Edad Moderna, 2012, (Institució Alfons el Magnànim, Diputació de València, 2012), pp. 591-608.

-'Releyendo la obra de Joan de Joanes. Nuevas aportaciones en torno al Bautismo de Cristo de la Catedral de Valencia y la conversión morisca', Espacio Tiempo y Forma. Serie VII, Historia del Arte, no. 25, 2012, pp. 67-82.

Fundación de la Comunidad Valenciana La luz de LAS IMÁGenes, La llum de les imatges: guia de visita: València, del 4 de febrer al 30 de juny de 1999, (Generalitat Valenciana: Valencia, 1999). FuRIó, Antoni, Història del País Valencià, (Alfons el Magnànim: 784 Valencia, 1995).

GÁlLEGo, Julián, 'Retratos y autorretratos', en Artistas pintados. Retratos de pintores y escultores del siglo XIX en el Museo del Prado, (Museo Nacional del Prado: Madrid, 1997), pp. 13-38.

- El pintor, de artesano a artista, (Diputación Provincial de Granada: Granada, 1995).

García Arranz, José Julio, 'Entre el miedo y la oscuridad: tendencias y variantes en la imagen europea del turco durante los siglos XV y XVI', en Fiestas y mecenazgo en las relaciones culturales del Mediterráneo en la Edad Moderna, (Universidad de Málaga: Málaga, 2012).

García MAHíQues, Rafael, Iconografía e iconología. Cuestiones de método, (Encuentro: Madrid, 2009).

- Iconografía e iconología, (Encuentro: Madrid, 2008). 
- Empresas sacras de Núñez de Cepeda, (Tuero: Madrid, 1988).

García Martínez, Luis, 'La configuración de una colección nobiliaria. El ejemplo de la Casa de Parcent (1656-1927)', Ars bilduma: Revista del Departamento de Historia del Arte y Música de la Universidad del País Vasco, no. 6, 2016, pp. 43-60.

García-Frías Checa, Carmen, 'La retratística de la Casa de Austria en el Monasterio del Escorial', en F. Javier Campos y Fernández de Sevilla (ed.), El Monasterio del Escorial y la pintura: actas del Simposium, (Madrid, 2001), pp. 395-420.

- y Javier Jordán de Urríes y de la Colina (coord.), El retrato en las colecciones reales de Patrimonio Nacional: de Juan de Flandes a Antonio López, (Patrimonio Nacional: Madrid, 2014).

GARCÍA MonerRis, Encarna y Carmen García Monerris, La nación secuestrada. Francisco Javier Elío. Correspondencia y manifiesto, (Univeristat de València: Valencia, 2008).

García SAINz, Ana y Leticia Ruiz Gómez, 'Linaje regio y monacal. La galería de retratos de las Descalzas Reales', en El linaje del emperador: Iglesia de la Preciosa Sangre, Centro de Exposiciones San Jorge, Cáceres, del 24 de octubre de 2000 al 7 de enero de 2001, (Sociedad Estatal para la Conmemoración de los Centenarios de Felipe II y Carlos V: Madrid, 2000), pp. 135-158.

Garín Llombart, Felipe, 'Historia, concepto y prototipo del retrato como género artístico', en Rafael Argullol (ed.), El retrato, (Galaxia Gutenberg: Barcelona, 2004), pp. 9-20.

Garín Ortiz de Taranco, Felipe María, La Academia Valenciana de Bellas Artes: el movimiento academista europeo y su proyección en Valencia, (Real Academia de Bellas Artes de San Carlos: Valencia, 1993). 
GIL SAURA, Yolanda, 'La invención de la genealogía: La galería de retratos de la familia Cervellón', Ars Longa: cuadernos de arte, no. 21, 2012, pp. 277-294.

- 'Les galeries de retrats a la València barroca. La construcció de la memòria', Afers: fulls de recerca i pensament, Vol. 26, no. 70, 2011.

-'Antonio Folch de Cardona (1657-1724). Biografía cultural de un religioso y político, bibliófilo y coleccionista entre Valencia y Viena', Ars Longa: cuadernos de arte, no. 23, 2014, pp. 173-185.

Gimilio SANZ, David, 'La galería de retratos de la casa real de Aragón en Nápoles', Potestas. Revista del grupo europeo de investigación histórica. Religión, poder y monarquía, no. 9, 2016, pp. 167-196.

786 - José Vergara 1726-1799 : Del tardobarroco al clasicismo dieciochesco, (Conselleria de Cultura, Educació i Esport: Valencia, 2005).

-'José Vergara Gimeno y la retratística valenciana en el siglo XVIII', Ars Longa: cuadernos de arte, no. 12, 2003, pp. 75-82.

González Baldoví, Mariano y Vicente Pons Alós (ed.), El hogar de los Borja: Xàtiva: Museu de l'Almodí, Antic Hospital Major, del 16 de diciembre de 2000 al 28 de febrero de 2001, (Generalitat Valenciana: Valencia, 2001).

GonzÁlez Tornel, Pablo (ed.), Intacta María. Política y religiosidad en la España barroca, (Museo de Bellas Artes: Valencia, 2017).

GonzÁlez Zymla, Herber, Catálogo de pinturas de la Real Academia de la Historia, (Real Academia de la Historia: Madrid, 2003). 
Gómez-FerRer Lozano, Mercedes, El Real de Valencia, 1238-1810: historia arquitectónica de un palacio desaparecido, (Institució Alfons el Magnànim: Valencia, 2012).

GraCiA, Carmen, Arte valenciano, (Cátedra: Madrid, 1998).

Halcón, Fátima y Francisco Javier Herrera García, 'Entre Sicilia y España: nuevas aportaciones a la colección artística de Luis Guillermo de Moncada, duque de Montalto (1614-1672), Anuario del Departamento de Historia y Teoría del Arte, no. 28, 2016, pp. 113-139.

Haydn, Williams, 'Additional Printed Sources for Ligozzi's Series of Figures of the Ottoman Empire', Master Drawigns, $\mathrm{n}^{\circ}$ 51 - 2, 2013, pp. 195-229.

Hernández Guardiola, Lorenzo, 'Un discípulo de la Academia de San Carlos: José Aparicio Inglada (1770-1838), pintor neoclásico español', Archivo de arte valenciano, no. 88, 2007, pp. 319-332.

Hidalgo Ogáyar, Juana, 'Doña Mencía de Mendoza y su residencia en el Palacio del Real en Valencia', Archivo español de arte, Vol. 84, no. 333, 2011, pp. 80-89.

Ivars, Andrés, 'El beato Nicolás Factor en las Descalzas Reales de Madrid', Archivo de arte valenciano, no. 12, 1926, pp. 67-81.

Jerez Moliner, Felipe y Ma José López Terrada, 'La Alegoría de la Orden de Carlos III, de Vicente López. Anotaciones al texto de Francisco José Fabre', Goya: Revista de arte, Vol. 258, 1997, pp. $322-332$.

JoRDAn GsCHWEND, Annemarie, 'Los retratos de Juana de Austria posteriores a 1554. La imagen de una princesa de Portugal, una regente de España y una jesuita', Reales Sitios: Revista del Patrimonio Nacional, no. 151, 2002, pp. 42-65. 
Junta de Iconografía Nacional, Retratos de personajes ilustres: indice ilustrado de la Junta de Iconografía Nacional, (Madrid, 1914).

Kusche Zattelmeyer, María, Juan Pantoja de la Cruz y sus seguidores. Bartolomé González, Rodrigo de Villandrando y Antonio López Polanco, (Fundación Arte Hispánico: Madrid, 2007).

- 'El retrato de D. Carlos por Sofonisba Anguissola', Archivo español de arte, Vol. 73, no. 292, 2000, pp. 385-393.

- 'La antigua galería de retratos del Pardo: Su importancia para la obra de Tiziano, Moro, Sánchez Coello y Sofonisba Anguissola y su significado para Felipe II, su fundador', Archivo español de arte, Vol. 65, no. 257, 1992, pp.1-36.

-'La antigua galería de retratos del Pardo: su reconstrucción pictórica', Archivo español de arte, Vol. 64, no. 255, 1991, pp. $788 \quad 261-292$.

-'La antigua galería de retratos del Pardo: su reconstrucción arquitectónica y el orden de colocación de los cuadros', Archivo español de arte, Vol. 64, no. 253, 1991, pp.1-28.

LAFUente FeRrari, Enrique, El retrato como género pictórico, (Madrid, 1951).

León Tello, Francisco José, y María M. Virginia Sanz Sanz, La estética académica española en el siglo XVIII: Real Academia de Bellas Artes de San Carlos de Valencia, (Servicio de Estudios Artísticos, Institución Alfonso el Magnánimo, Diputación Provincial de Valencia: Valencia, 1979).

Llamazares Rodríguez, Fernando, 'Imagen e imágenes de los Arzobispos de Toledo', en Fernando Llamazares Rodríguez y José Carlos Vizuete Mendoza (eds.), Arzobispos de Toledo, mecenas universitarios, (Ediciones de la Universidad de Castilla-La 
Mancha, 2004), pp. 145-175.

López Azorín, Ma José, Documentos para la historia de la pintura valenciana en el siglo XVII, (Madrid, 2006).

López PozA, Sagrario, 'Recursos para el conocimiento y reconocimiento de las divisas y los emblemas artístico-literarios', Emblemata, Vol. 20-21, 2014-2015, pp. 87-119.

-'Fuentes de información y recursos de utilidad para el estudio e investigación de la emblemática.', Imago. Revista de Emblemática y Cultura Visual, Vol. 6, 2014, pp. 147-157.

- 'Empresas o divisas de Isabel de Castilla y Fernando de Aragón (los Reyes Católicos)', SIELAE, Janus: estudios sobre el Siglo de Oro, no. 1, 2012, pp. 1-38.

López TERRADA, María José, 'El lenguaje alegórico al servicio del poder: el caso del nacimiento del infante Carlos Clemente de Borbón', en Víctor Mínguez (ed.), Las artes y arquitectura del poder, (Universitat Jaume I: Castellón, 2013), pp. 1665-1683.

López-Yarto ElizALDE, Amelia, Isabel Mateo Gómez y Juan Antonio Ruiz Hernando, 'El monasterio jerónimo de Santa María de la Murta (Valencia)', Ars Longa: cuadernos de arte, no. 6, 1995, pp. 17-23.

LozANo LóPEZ, Juan Carlos, 'Las galerías de retratos episcopales en las diócesis aragonesas', Aragonia sacra: revista de investigación, no. 16-17, pp. 303-318.

LunA, Juan J., 'La pintura de retrato en las colecciones del Museo del Prado. De la Edad Media a fines del siglo XIX', en El retrato español en el Museo del Prado, (Museo Nacional del Prado: Madrid, 2015), pp. 9-33.

- 'La internacionalización del retrato en el siglo XVIII', en Leti- 
cia Ruiz Gómez (ed.), El retrato español en el Prado. Del Greco a Goya, (Museo Nacional del Prado: Madrid, 2007), pp. 133-139.

Martín Bourgon, María Teresa, La monarquía española en la pintura: los Austrias, (Carroggio: Barcelona, 2004).

Martínez Aloy, José, La casa de la diputación, (Establecimiento tipográfico Doménech: Valencia, 1909).

MaRtínez Marín, Cruz María, 'El mecenazgo artístico de María de Hungría en el contexto europeo', en VI Congreso virtual sobre Historia de las Mujeres, (Archivo Histórico Diocesano de Jaén: Jaén, 2014), pp. 21-35.

MaRtínez del VALLE, Gonzalo, La imagen del poder: el retrato sevillano del siglo XVII, (Sevilla, 2010).

Mateu Llopis, Felipe, 'El retrato del rector de la Universidad de 790 Valencia, D. Frey Vicente Blasco, por Salvador Maella', Archivo de Arte Valenciano, 1960, (separata).

Mínguez, Víctor (dir.), El linaje del rey monje. La configuración cultural e iconográfica de la Corona Aragonensis (1164-1516), (Universitat Jaume I: Castellón, 2018).

- Infierno y gloria en el mar: los Habsburgo y el imaginario artístico de Lepanto (1430-1700), (Universitat Jaume I: Castellón, 2017).

-'Elías Tormo iconógrafo', en Luis Arciniega García (ed.), Elías Tormo, apóstol de la historia del arte en España, (Institución Alfonso el Magnánimo: Valencia, 2016), pp. 207-218.

-'Lepanto en los virreinatos americanos', en Rafael López Guzmán, Yolanda Guasch Marí, y Yolanda Romero Sánchez (eds.), América: cultura visual y relaciones artísticas, (Granada, 2015), pp. 175-182. 
- La invención de Carlos II: apoteosis simbólica de la casa de Austria, (Centro de Estudios Europa Hispánica, 2013).

- 'Iconografía de Lepanto. Arte, propaganda y representación simbólica de una monarquía universal y católica', Obradoiro de historia moderna, no. 20, 2011, pp. 251-280.

-'El espejo de los antepasados y el retrato de Carlos II en el Museo Lázro Galdiano', Museo Lázaro Galdiano, Boletín del Museo e Instituto Camón Aznar, no. 45, 1991, pp. 71-82.

- Art i arquitectura efímera a la València del segle XVIII, (Edicions Alfons el Magnànim: Valencia, 1990).

- e Inmaculada Rodríguez Moya, 'La historia cultural de las imágenes. Una propuesta metodológica en la Universitat Jaume I aplicada al arte de la Edad Moderna', Archivo de arte valenciano, no. 93, 2012, pp. 175-194.

- Inmaculada Rodríguez Moya, Pablo González Tornel, y Juan Chiva Beltrán, La Fiesta barroca: los virreinatos americanos (1560-1808), (Universidad de Las Palmas de Gran Canaria: Las Palmas, 2012).

- Pablo González Tornel e Inmaculada Rodríguez Moya, 'Libros de fiestas valencianos y la estampa barroca', en La fiesta barroca: El Reino de Valencia (1599-1802), (Universitat Jaume I. Consell Social: Castellón, 2010), pp. 23-31.

-Pablo González Tornel e Inmaculada Rodríguez Moya, 'Organización, tipologías y actores de la fiesta', en La fiesta barroca: El Reino de Valencia (1599-1802), (Universitat Jaume I. Consell Social: Castellón, 2010), pp. 41-61.

Molina, Álvaro, 'Retratos de Españoles ilustres con un epítome de sus vidas. Orígenes y gestación de una empresa ilustrada', 
Archivo español de arte, Vol. 89, 2016, pp. 43-60.

MonTANer Frutos, Alberto y Tomás Echarte, 'Los emblemas en la orden de predicadores: El stemma liliatum y el stemma formatum', Emblemata: Revista aragonesa de emblemática, no. 3 1997, pp. 393-434.

Monterroso Montero, Juan Manuel, 'El Retrato como imagen de una sociedad', en Asociación Galega de Historiadores (ed.), $V e$ VI Semanas Galegas de Historia: Morte e sociedade no noroeste peninsular [e] Un percorrido pola Galicia cotiá, (Santiago de Compostela, 1998), pp. 397-416.

Monreal Casamayor, Manuel, 'Heráldica episcopal: Generalidades en las diócesis aragonesas', Aragonia Sacra, Vol. XVI-XVII, pp. 281-302.

- 'Las divisas eclesiásticas', Emblemata. Revista aragonesa de 792 emblemática, Vol. XX-XXI, 2015, pp. 283-330.

Monteagudo Robledo, María Pilar, El espectáculo del poder: fiestas reales en la Valencia moderna, (Ajuntament de València: Valencia, 1995).

- La Monarquía ideal: imágenes de la realeza en la Valencia moderna, (Universitat de València: València, 1995).

- 'El poder monárquico: fiestas reales e imagen de la monarquía en la Valencia del siglo XVIII', Universitat de València, 1994.

- 'Arte efímero en el siglo XVIII. Expresión y marco en una fiesta real', en Primer Congreso de Historia del Arte Valenciano: actas, mayo 1992, (Generalitat Valenciana: Valencia, 1993), pp. 313-318.

MorÁn TuRINA, José Miguel (coord.), El arte en la corte de Felipe 
V : del 29 de octubre de 2002 al 26 de enero de 2003, Palacio Real de Madrid, Museo Nacional del Prado, Casa del las Alhajas, (Museo Nacional del Prado: Madrid, 2002).

-'Felipe V y la guerra: la iconografía del primer Borbón', Cuadernos de arte e iconografía, Vol. 1, no. 1, 1988, pp. 187-200.

- y Fernando Checa Cremades, El coleccionismo en España: de la cámara de maravillas a la galería de pinturas, (Cátedra: Madrid, 1985).

-y Fernando Checa Cremades, 'Las colecciones pictóricas de El Escorial y el gusto barroco', Goya: Revista de arte, no. 179, 1984, pp. 252-261.

- 'El retrato cortesano y la tradición española en el reinado de Felipe V', Goya: Revista de arte, no. 159, 1980, pp. 152-161.

Morte García, Carmen, 'Enseñas, blasones, emblemas, divisas y motes en las series icónicas reales', Emblemata: Revista aragonesa de emblemática, no. 20, 2014, pp. 351-377.

- 'Pintura y política en la época de los Austrias. Los retratos de los reyes de Sobrarbe, condes antiguos y reyes de Aragón para la Diputación de Zaragoza (1586), y las copias de 1634 para el Buen Retiro de Madrid (II)', Boletín del Museo del Prado, Vol. 12, no. 30, 1980, pp. 13-28.

- 'Pintura y política en la época de los Austrias. Los retratos de los reyes de Aragón para la Diputación de Zaragoza (1586), y las copias de 1634 para el Buen Retiro de Madrid (I)', Boletín del Museo del Prado, Vol.11, no. 29, 1980, pp. 19-36.

Navarro Sorní, Miguel, 'Los libros del Patriarca Ribera. Fe y cultura en el tránsito del Renacimiento al Barroco', en El legado del patriarca Juan de Ribera: Pastor Sanctus Virtutis Cultor, IV centenario, (Pentagraf, 2011), pp. 45-53. 
- 'La biblioteca de san Juan de Ribera, espejo de un humanista, exponente de la Reforma católica', en Francisco Tejada Vizuete (ed.), En torno a la biblioteca de San Juan de Ribera: exposición bibliográfica: libros impresos del siglo XVI: claustro de la S.I. Catedral Metropolitana de Badajoz, del 5 de mayo al 5 de junio de 2011, (Arzobispado de Mérida - Badajoz: Badajoz, 2011), pp. 13-31.

Oliver-Copóns, Eduardo de, El Alcázar de Segovia: monografía histórica, (Maxtor: Valladolid, 2002).

OlleRo Butler, Jacobo, El Retrato renacentista y barroco, (Historia 16: Madrid, 1992).

Olmos y Canalda, Elías, Los prelados valentinos, (Instituto Jerónimo Zurita: Madrid, 1949).

Palacios Somoza, Belén y Amparo Beguer, 'Junta de Iconografía 794 Nacional', en Ciclo Pieza del mes del Museo de la Biblioteca, (Biblioteca Nacional de España: Madrid, 2012).

Pascual Chenel, Álvaro, 'De Austrias a Borbones: retrato, poder y propaganda en el cambio de siglo; continuidad o fractura.', en Marina Torres Arce y Susana Truchuelo García (eds.), Europa en torno a Utrecht, (Editorial de la Universidad de Cantabria: Santander, 2014), pp. 253-286.

- 'Retórica del poder y persuasión política. Los retratos dobles de Carlos II y Mariana de Austria.', Goya: Revista de arte, Vol. 331, 2010, pp. 124-145.

- El retrato de Estado durante el reinado de Carlos II: imagen y propaganda, (Fundación Universitaria Española, 2010).

- El retrato de estado durante el reinado de Carlos II, (Universidad de Alcalá, 2009). 
PedRAzA, Pilar, Barroco efimero en Valencia, (Ayuntamiento de Valencia: Valencia, 1982).

PeIRCE, Leslie P., Empress of the east : how a European slave girl became queen of the Ottoman Empire, (2017).

-The Imperial Harem: Women and sovereignty in the Ottoman Empire, (Oxford University Press: Nueva York, 1993).

Pérez SÁnchez, Alfonso E., Pintura barroca en España (16001750), (Cátedra: Madrid, 2010).

- Jerónimo Jacinto de Espinosa, 1600-1667: the Spanish Institute, Nueva York (USA), del 19 de noviembre de 2002 al 31 de enero de 2003, (Consorci de Museus de la Comunitat Valenciana: Valencia, 2002).

- De pintura y pintores: la configuración de los modelos visuales en la pintura española, (Alianza: Madrid, 1993).

- 'La personalidad artística de Vicente Castelló y Amat', Ars Longa. Cuadernos de arte, 1990, pp. 9-25.

Pérez de Tudela Gabaldón, Almudena, 'Nuevas noticias sobre el primer viaje de Antonio Moro a la Península Ibérica y su entrada al servicio de Felipe II', Archivo Español de Arte, Vol. 89, 2016, pp. 423-429.

Pinilla Pérez de Tudela, Regina, 'Germana de Foix, una virreina per a València', en Germana de Foix i la societat cortesana del seu temps, (Generalitat Valenciana: Valencia, 2006), pp. 51-67.

Pinillos Lafuente, Luis, 'Don Andrés de Mayoral, arzobispo de Valencia, descendiente del Solar de Valdeosera (1685 - 1769)', Berceo. Revista riojana de Ciencias Sociales y Humanidades, no. 162, 2012, pp. 365-400.

Pinto Muñoz, Ana, 'Roxolana in the Spanish Golden Age', eHu- 
manista: Journal of Iberian Studies, no. 19, 2011, pp. 376-389.

Pope-Hennessy, John, El retrato en el Renacimiento : conferencias sobre arte, (Akal: Torrejón de Ardoz, 1985).

Pommier, Édouard, Théories du portrait. De la Renaissance aux Lumières, (Gallimard: Paris, 1998).

PoRTús PÉREz, Javier, José Miguel Morán Turina y Andrea Sommer-Mathis, Velázquez y la familia de Felipe IV : (1650-1680), (Museo Nacional del Prado, 2013).

-'El siglo XVII: la madurez del género', en Leticia Ruiz Gómez (ed.), El retrato español en el Prado. Del Greco a Goya, (Museo Nacional del Prado: Madrid, 2007), pp. 83-89.

- (ed.), El retrato en el Museo del Prado, (Anaya, 1994).

796 RAINER, Johann, 'Tú, Austria feliz, cásate. La boda de Margarita, princesa de Austria Interior, con el rey Felipe III de España: 1598/99', Investigaciones históricas: Época moderna y contemporánea, no. 25, 2005, pp. 31-54.

Reguera, Francisco de la y Nieves Pena Sueiro, Empresas de los reyes de Castilla : con máximas y documentos para príncipes, (SIELAE, 2011).

Reyero, Carlos y Mireia Freixa, Pintura y escultura en España, 1800-1910, (Cátedra: Madrid, 2005).

Rincón GARCíA, Wifredo, 'Iconografía de san Juan de Ribera', en Emilio Callado Estela y Miguel Navarro Sorní (eds.), El patriarca Ribera y su tiempo: religión, cultura y política en la Edad Moderna, (Institució Alfons el Magnànim, Diputació de València: Valencia, 2012), pp. 685-712.

- 'Iconografía de la Real y Distinguida Orden de Carlos III', 
Fragmentos, Vol. 12-13-14, 1988, pp. 145-161.

RIVERA TORREs, Raquel, 'Imagen del prelado don Juan de Ribera. Estudio iconográfico', Universitat de València, Departamento de Historia del Arte, 2015.

Rodríguez Barral, Paulino, 'Eiximenis y la iconografía de san Miguel en el gótico catalán', Annals de l'Institut d'Estudis Gironins, Vol. XLVI, 2005, pp. 111-124.

RodRíguez Luna, David, 'Desamortización y monjes jerónimos: Extinción y restauración de una orden monástica', en La desamortización: El expolio del patrimonio artístico y cultural de la Iglesia en España, (Instituto Escurialense de Investigaciones Históricas y Artísticas: Madrid, 2007), pp. 103-117.

RodRíguez Moya, Inmaculada, 'La construcción dinástica de la monarquía: libros iluminados, genealogías y retratos', en Víctor Mínguez (ed.), El linaje del Rey Monje. La configuración cultural e iconográfica de la Corona aragonensis (1164-1516), (Universitat Jaume I: Castellón, 2018), pp. 273-297.

- y Víctor Mínguez, El retrato del poder, (Universitat Jaume I: Castellón de la Plana, 2019).

- 'Artefactos de madera. El gremio de carpinteros y el arte efímero barroco en la ciudad de Valencia', en Paula Revenga Domínguez (ed.), Arte barroco y vida cotidiana en el mundo hispánico: Entre lo sacro y lo profano, (Universidad de Córdoba - El Colegio de Michoacán, 2017), pp. 115-132.

- 'La esperanza de la monarquía. Fiestas en el imperio hispánico por Felipe Próspero', en Inmaculada Rodríguez Moya y Víctor Mínguez (eds.), Visiones de un imperio en fiesta, (Fundación Carlos de Amberes: Madrid, 2016), pp. 91-119.

- y Víctor Mínguez, Himeneo en la Corte: poder, representación 
y ceremonial nupcial en el arte y la cultura simbólica, (Consejo Superior de Investigaciones Científicas: Madrid, 2013).

- 'La Junta de Iconografía Nacional (1876-1961) y el retrato del poder', en Víctor Mínguez (ed.), Las artes y la arquitectura del poder, (Universitat Jaume I: Castellón de la Plana, 2013), pp. 271-296.

- El retrato en México, 1781-1867: Héroes, ciudadanos y emperadores para una nueva nación, (Madrid, 2006).

- 'Dinastía de prelados. La serie de retratos de obispos de la diócesis de Segorbe', Sociedad Castellonense de Cultura: Castellón, Boletín de la Sociedad Castellonense de Cultura, no. 79, 1, 2003, pp. 253-274.

- La mirada del virrey: iconografía del poder en la Nueva España, (Universitat Jaume I, 2003).

- 'Los retratos de los monarcas españoles en la Nueva España, siglos XVI-XIX', Anales del Museo de América, no. 9, 2001, pp. 287-301.

Rosenthal, Norman, Citizens and kings: portraits in the age of revolution, 1760-1830., (Royal Academy of Arts: Londres, 2007).

Ruiz Gómez, Leticia, 'La creación del retrato español en el siglo XVI', en Leticia Ruiz Gómez (ed.), El retrato español en el Prado. Del Greco a Goya, (Museo Nacional del Prado: Madrid, 2007), pp. 37-43.

SÁEZ, Emilio, Los ascendientes de san Rosendo. Notas para el estudio de la monarquía astur-leonesa durante los siglos IX$X$, (Consejo Superior de Investigaciones Científicas, Instituto Jerónimo Zurita: Madrid, 1948). 
SAIt Sener, Mehmet, 'El tema turco en el teatro español de los siglos XVI - XVII', Universidad Complutense de Madrid, 2017.

SÁNChEZ García, Encarna 'El mundo femenino turco en la literatura castellana del siglo XVI', en Antonio González Alcantud y André Stoll (eds.), El Mediterráneo plural en la Edad Moderna: sujeto histórico y diversidad cultural, (Anthropos, 2011), pp. 132-167.

SANChís y Sivera, José, La catedral de Valencia: guía histórica y artística, (Librerías París - Valencia: Valencia, 1990).

SAN RUPERTo Albert, Josep, 'Apuntalarse como noble: cultura, arte y mecenazgo en la Valencia del siglo XVII. Representación y perpetuidad en la familia Cernesio, condes de Parcent', en Amparo Felipo Orts y Carmen Pérez Aparicio (eds.), La nobleza valenciana en la edad moderna: Patrimonio, poder y cultura, (Universitat de València: Valencia, 2014), pp. 237-286.

Sebastián Lozano, Jorge, 'Imágenes femeninas en el arte de corte español en el siglo XVI', Universitat de València, 2005.

SeRna Alonso, Justo y Anacleto Pons, La historia cultural: autores, obras y lugares, (Akal: Tres Cantos, 2005).

SeRRA Desfilis, Amadeo, 'La historia de la dinastía en imágenes: Martín el Humano y el rollo genealógico de la Corona de Aragón', Locus amoenus, no. 6, 2002, pp. 57-74.

SERRANO Coll, Marta, Effigies Regis Aragonum: la imagen figurativa del rey de Aragón en la Edad Media, (Institución Fernando el Católico, Diputación de Zaragoza: Zaragoza, 2015).

- 'Programas ideológicos a través de la imagen: algunos ejemplos de la Edad Media', Medievalista, Vol. no. 9, 2011.

- Jaime I el Conquistador: imágenes medievales de un reinado, 
(Institución 'Fernando el Católico': Zaragoza, 2008).

SerRera, Juan Miguel, 'Alonso Sánchez Coello y la mecánica del retrato de corte.', en Santiago Saavedra (ed.), Alonso Sánchez Coello y el retrato en la corte de Felipe II, (Museo Nacional del Prado: Madrid, 1990), pp. 37-63.

Sociedad Estatal para la Acción Cultural Exterior (ed.), la corona de Aragón: el poder y la imagen de la Edad Media a la Edad Moderna, siglos XII-XVIII, (Lunwerg: Madrid, 2006).

Soler del CAMpo, Álvaro (coord.), El arte del poder: la Real Armería y el retrato de corte, (Museo Nacional del Prado: Madrid, 2010).

Sousa Congosto, Francisco de, Introducción a la historia de la indumentaria en España, (Istmo, 2007).

800 Syson, Luke, 'Testimonio de rostros, recuerdo de almas', en Miguel Falomir Faus (ed.), El retrato del Renacimiento, (Museo Nacional del Prado: Madrid, 2008), pp. 29-39.

Tormo y Monzó, Elías, Las viejas series icónicas de los reyes de España, (Junta de Iconografía Nacional, 1917).

Tramoyeres Blasco, Luis, Un colegio de pintores: documentos inéditos para la historia del arte pictórico de Valencia en el siglo XVII, (Librería General de Victoriano Suárez: Madrid, 1912).

Universitat de València, Cinc segles i un dia, (Fundació General de la Universitat de València: València, 2000).

VARELA, Lucía, 'El rey fuera de palacio: la repercusión social del retrato regio en el Renacimiento español', en El linaje del emperador: Iglesia de la Preciosa Sangre, Centro de Exposiciones San Jorge, Cáceres, del 24 de octubre de 2000 al 7 de enero de 2001, (Madrid, 2000), pp. 99-133. 
Vilanova y Pizcueta, Francisco de P., Guía artística de Valencia, (Imprenta y litografía de José Ortega: València, 1922).

Vinatea Serrano, P., 'Cortejo de Solimán el Magnífico', en Museu Nacional del Prado (ed.), La fiesta en la Europa de Carlos V: Real Alcázar, Sevilla, 19 de septiembre - 26 de noviembre 2000., (Sociedad Estatal para la Conmemoración de los Centenarios de Felipe II y Carlos V: Madrid, 2000), pp. 294-296.

WALDMANN, Susann, El artista y su retrato en la España del siglo XVII: una aportación al estudio de la pintura retratista española, (Alianza: Madrid, 2007).

Williams, Hannah, Académie Royale. A history in portraits, (Ashgate, 2015).

Woods-MARSDEN, Joanna, 'El autorretrato del Renacimiento', en Miguel Falomir Faus (ed.), El retrato del Renacimiento, (Museo Nacional del Prado: Madrid, 2008), pp. 91-107.

- Renaissance self-portraiture: the visual construction of identity and the social status of the artist, (Yale University Press: Londres, 1998).

Yermolenko, Galina I. (ed.), Roxolana in European Literature, History and Culture, (Ashgate, 2010).

Zapata Fernández de la Hoz, María Teresa, 'Atlas - Hércules. Metáfora del poder y gobierno de los Austrias', en Emblemática trascendente: hermenéutica de la imagen, iconología del texto, (Universidad de Navarra, 2011), pp. 785-797.

Zonzi, Renzo, Le metamorfosi del ritratto, (L.S. Olschki: Florencia, 2002).

Zuffi, Stefano, El retrato, (Carroggio, 2004). 


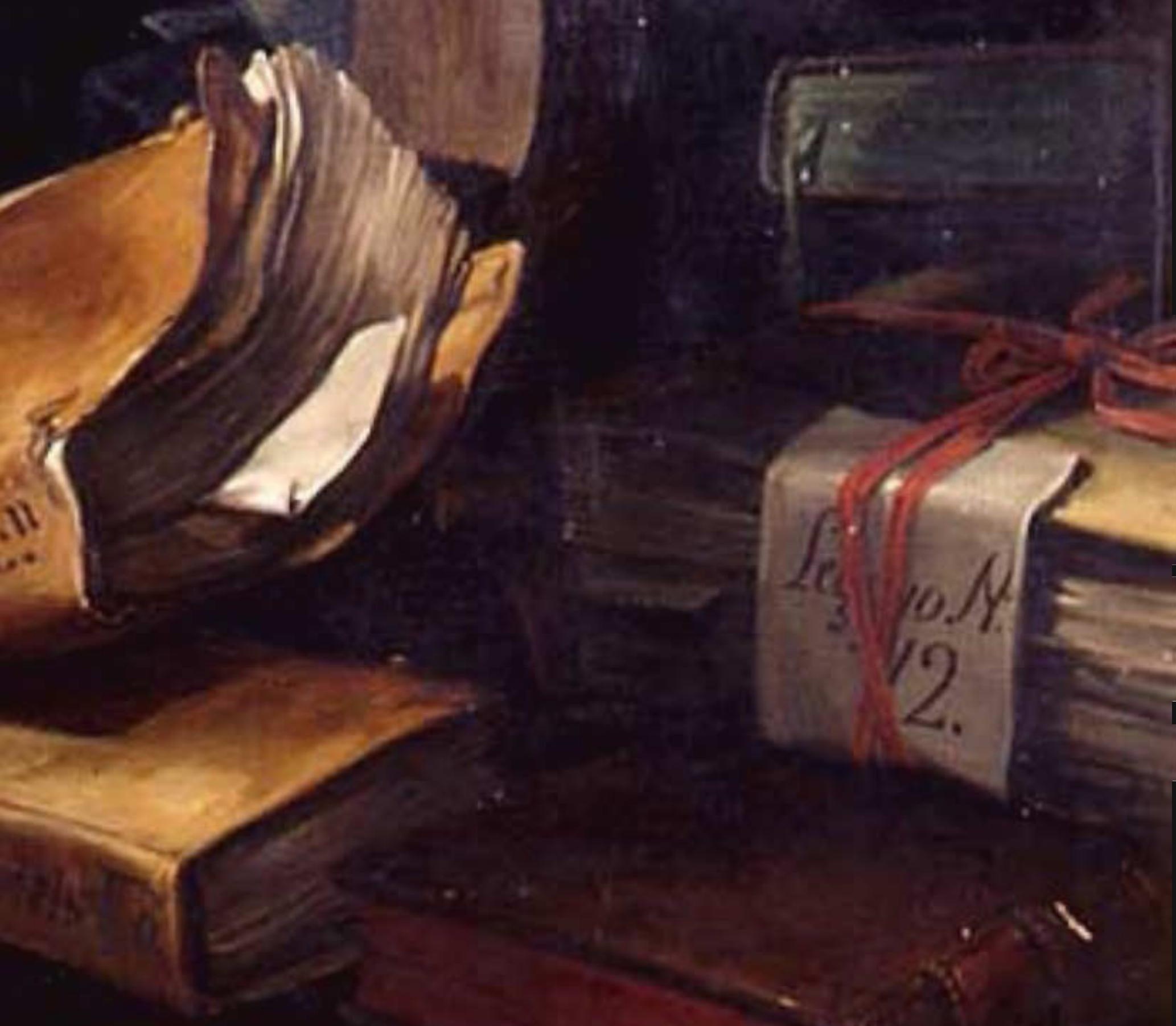




\section{Listado de imágenes}

Capítulo 1. El retrato: Teoría y debate en la Edad Moderna.

Fig. 1.1. Giovanni Paolo Lomazzo, Trattato dell'arte della pittura, scoltura et architettura, Milán, 1585.

Fig. 1.2. Vicente Carducho, Diálogos de la pintura: su defensa, origen, esencia, definición, modos y diferencias, Madrid, 1633.

Fig. 1.3. Francisco Pacheco, Arte de la pintura, su antigüedad y grandezas, Sevilla, 1649.

Fig. 1.4. Antonio Franchi Lucchese, La teorica della pittura: ovvero Trattato delle materie piu' necessarie, Lucca, 1739.

Fig. 1.5. Giovanni Battista Armenini, De' veri precetti della pittura, Rávena, 1587.

Fig. 1.6. Detalle del Salón de Reyes del alcázar de Segovia.

Fig. 1.7. Jaume Mateu - Gonçal Peris, Jaime I el Conquistador, 1427, temple sobre tabla, Barcelona, Museu Nacional d'Art de Catalunya.

Fig. 1.8. Anónimo (copia de Felipe Ariosto), Petronila Ramírez y Ramón Berenguer IV, 1634, óleo sobre lienzo, Madrid, Museo Nacional del Prado.

Fig. 1.9. Juan Pantoja de la Cruz, El emperador Carlos V, 1605, óleo sobre lienzo, Madrid, Museo Nacional del Prado. 


\section{Capítulo 2. Los retratos y sus artífices en el medio hispano y valenciano. De la reforma católica a la desamortización (1835).}

Fig. 2.1. Paolo da San Leocadio, La Virgen del caballero de Montesa, 1472 -1476, óleo sobre tabla, Madrid, Museo Nacional del Prado.

Fig. 2.2. Juan de Juanes, Bautismo de Cristo, 1535, óleo sobre tabla, Valencia, Catedral.

Fig. 2.3. Juan de Juanes, La Virgen del venerable Agnesio, 1553 - 1558, óleo sobre tabla, Valencia, Museo de Bellas Artes.

Fig. 2.4. Juan de Juanes, Alfonso V de Aragón, 1557, óleo sobre tabla, Zaragoza, Museo de Zaragoza.

Fig. 2.5. Giovanni Brito, El emperador Carlos V, h. 1540, estampa.

Fig. 2.6. Rubens (copia de Tiziano), Carlos V con armadura, 1603, óleo sobre lienzo, Gran Bretaña, colección particular.

Fig. 2.7. Tiziano, El emperador Carlos V con un perro, 1533, óleo sobre lienzo, Madrid, Museo Nacional del Prado.

Fig. 2.8. Tiziano, Carlos V en la batalla de Mülhberg, 1548, óleo sobre lienzo, Madrid, Museo Nacional del Prado.

Fig. 2.9. Tiziano, Carlos V sentado, 1548, óleo sobre tela, Múnich, Bayerische Staatgemäldesammlungen, Alte Pinakothek.

Fig. 2.10. Antonio Moro, El emperador Maximiliano II, 1550, óleo sobre lienzo, Madrid, Museo Nacional del Prado.

Fig. 2.11. Antonio Moro, La emperatriz María de Austria, esposa de Maximiliano II, 1551, óleo sobre lienzo, Madrid, Museo Nacional del Prado. 
Fig. 2.12. Alonso Sánchez Coello, El príncipe don Carlos, 15551559, óleo sobre lienzo, Madrid, Museo Nacional del Prado.

Fig. 2.13. Anónimo, Carlos V, h. 1599, óleo sobre lienzo, Valencia, dependencias rectorales de la Universitat de València.

Fig. 2.14. Anónimo, Felipe II, h. 1599, óleo sobre lienzo, Valencia, dependencias rectorales de la Universitat de València.

Fig. 2.15. Anónimo, Felipe III, h. 1599, óleo sobre lienzo, Valencia, dependencias rectorales de la Universitat de València.

Fig. 2.16. Juan Pantoja de la Cruz, Felipe III como generalísimo en el sitio de Ostende, h. 1601-1602, óleo sobre lienzo, Viena, Kunsthistoriches Museum, Gemäldegalerie.

Fig. 2.17. Vista general de la Sala Nova, Valencia, Palacio de la Generalitat.

Fig. 2.18. Jerónimo Jacinto Espinosa, Fray Jerónimo Mos, h.1628, óleo sobre lienzo, Valencia, Museo de Bellas Artes.

Fig. 2.19. Vicente López, Carlos IV y su familia homenajeados por la Universidad de Valencia, 1802, óleo sobre lienzo, Madrid, Museo Nacional del Prado.

Fig. 2.20. Vicente López, Ramón María de Narváez, h. 1849, óleo sobre lienzo, Valencia, Museo de Bellas Artes.

Fig. 2.21. José Aparicio, Teodoro Reding de Biberegg, h.1815, óleo sobre lienzo, Madrid, Museo Nacional del Prado.

Fig. 2.22. Francisco Díaz Carreño, Melchor de Macanaz, h. 1878, óleo sobre lienzo, Madrid, Museo Nacional del Prado.

Fig. 2.23. Matías Moreno, Don Diego Covarrubias y Leiva, h. 1878, óleo sobre lienzo, Madrid, Museo Nacional del Prado.

Fig. 2.24. Matías Moreno, El cardenal Cisneros, arzobispo de Toledo, h. 1878, óleo sobre tabla, Madrid, Museo Nacional del 
Prado.

Fig. 2.25. Matías Moreno, El arquitecto Juan Guas, h. 1877, óleo sobre lienzo, Madrid, Museo Nacional del Prado.

Fig. 2.26. Salvador Martínez Cubells, San Juan de Ribera, 1865, óleo sobre lienzo, Madrid, Museo Nacional del Prado.

\section{Capítulo 3. Retratos de la realeza.}

Fig. 3.1. Vista general del muro izquierdo de la biblioteca con los retratos de Alfonso X el Sabio y Juan II de Aragón.

Fig. 3.2. Vista general del muro izquierdo de la biblioteca con los retratos de Isabel Clara Eugenia, Margarita de Austria y Felipe III.

Fig. 3.3. Vista general del muro izquierdo de la biblioteca con los retratos del príncipe Carlos, Fernando el Católico y Jaime I.

Fig. 3.4. Vista general del muro derecho de la biblioteca con los retratos de Isabel la Católica, Carlos V e Isabel de Portugal.

Fig. 3.5. Vista general del muro derecho de la biblioteca con los retratos de María de Austria, Felipe II, Juana de Austria y Enrique IV de Castilla.

Fig. 3.6. Anónimo, Enrique IV de Castilla, finales del s. XVI principios del XVII, óleo sobre lienzo, Valencia, Real Colegio Seminario del Corpus Christi.

Fig. 3.7. Juan Sariñena, Jaime I, 1597, óleo sobre lienzo, Valencia, Real Colegio Seminario del Corpus Christi.

Fig. 3.8. Juan Sariñena, Juan II, 1597, óleo sobre lienzo, Valencia, Real Colegio Seminario del Corpus Christi. 
Fig. 3.9. Antonio Ricci, Alfonso X el Sabio, 1592, óleo sobre lienzo, Valencia, Real Colegio Seminario del Corpus Christi.

Fig. 3.10. Antonio Ricci, Isabel la Católica, 1592, óleo sobre lienzo, Valencia, Real Colegio Seminario del Corpus Christi.

Fig. 3.11. Anónimo, Isabel la Católica, siglo XVII, óleo sobre lienzo, Madrid, Museo Nacional del Prado.

Fig. 3.12. Anónimo, Isabel la Católica, siglo XVII, óleo sobre lienzo, Granada, Ayuntamiento.

Fig. 3.13. Juan Sariñena, Fernando el Católico, 1597, óleo sobre lienzo, Valencia, Real Colegio Seminario del Corpus Christi.

Fig. 3.14. Atribuido a A. Ricci, Carlos V, 1592, óleo sobre lienzo, Valencia, Real Colegio Seminario del Corpus Christi.

Fig. 3.15. Atribuido a A. Ricci, Isabel de Portugal, 1592, óleo sobre lienzo, Valencia, Real Colegio Seminario del Corpus Christi.

Fig. 3.16. Tiziano, Isabel de Portugal, 1548, óleo sobre lienzo, Madrid, Museo Nacional del Prado.

Fig. 3.17. Atribuido a A. Ricci, María de Austria viuda, 1592, óleo sobre lienzo, Valencia, Real Colegio Seminario del Corpus Christi.

Fig. 3.18. Juan Pantoja de la Cruz, María de Austria, h. 1590, óleo sobre lienzo, Madrid, Monasterio de las Descalzas Reales.

Fig. 3.19. Atribuido a A. Ricci, Felipe II, 1592, óleo sobre lienzo, Valencia, Real Colegio Seminario del Corpus Christi.

Fig. 3.20. Juan Pantoja de la Cruz, Felipe II, h. 1592, óleo sobre lienzo, Madrid, Monasterio de San Lorenzo del Escorial.

Fig. 3.21. Atribuido a A. Ricci, Juana de Austria, princesa de Portugal, 1592, óleo sobre lienzo, Valencia, Real Colegio Semi- 
nario del Corpus Christi.

Fig. 3.22. Alonso Sánchez Coello y taller, Juana de Austria, h. 1560, óleo sobre lienzo, Madrid, Monasterio de la Descalzas Reales.

Fig. 3.23. Atribuido a A. Ricci, El príncipe Carlos, 1592, óleo sobre lienzo, Valencia, Real Colegio Seminario del Corpus Christi.

Fig. 3.24. Sofonisba Anguissola, El príncipe Carlos de Austria, 1566, óleo sobre lienzo, Oviedo, Museo de Bellas Artes de Asturias.

Fig. 3.25. Atribuido a A. Ricci, Isabel Clara Eugenia, 1592, óleo sobre lienzo, Valencia, Real Colegio Seminario del Corpus Christi.

Fig. 3.26. Anónimo, Isabel Clara Eugenia (detalle), 1591-1592, 808 óleo sobre lienzo, Madrid, Museo Nacional del Prado.

Fig. 3.27. Atribuido a A. Ricci, Felipe III, 1592, óleo sobre lienzo, Valencia, Real Colegio Seminario del Corpus Christi.

Fig. 3.28. Atribuido a A. Ricci, Margarita de Austria, 1597, óleo sobre lienzo, Valencia, Real Colegio Seminario del Corpus Christi.

Fig. 3.29. Francisco de Balboa y Paz, Monarchia regum siue accurata imperii synopsis, Herederos de Juan Domingo Tarini, Turín, 1630.

Fig. 3.30. Retrato de Ferrante I en Giovanni Antonio Summonte, Dell' Historia della citta e regno di Napoli, Antonio Bulifon, Nápoles, 1675.

Fig. 3.31. Gregorio Bausá o Antonio Bisquert, Retrato de Ferrante I, finales del s. XVI - mediados del s. XVII, óleo sobre lienzo, Valencia, Museo de Bellas Artes. 
Fig. 3.32. Detalle de los jeroglíficos en el collar de Ferrante I.

Fig. 3.33. Gregorio Bausá o Antonio Bisquert, Retrato de Isabel de Chiaramonte finales del s. XVI - mediados del s. XVII, óleo sobre lienzo, Valencia, Museo de Bellas Artes.

Fig. 3.34. Gregorio Bausá o Antonio Bisquert, Retrato de Alfonso II de Nápoles, finales del s. XVI - mediados del s. XVII, óleo sobre lienzo, Valencia, Museo de Bellas Artes.

Fig. 3.35. Gregorio Bausá o Antonio Bisquert, Retrato de Hipólita María Sforza, finales del s. XVI - mediados del s. XVII, óleo sobre lienzo, Valencia, Museo de Bellas Artes.

Fig. 3.36. Gregorio Bausá o Antonio Bisquert, Retrato de Ferrante II o Fernando II, finales del s. XVI - mediados del s. XVII, óleo sobre lienzo, Valencia, Museo de Bellas Artes.

Fig. 3.37. Gregorio Bausá o Antonio Bisquert, Retrato de Federico I, finales del s. XVI - mediados del s. XVII, óleo sobre lienzo, Valencia, Museo de Bellas Artes.

Fig. 3.38. Gregorio Bausá o Antonio Bisquert, Retrato de Isabel de Baucio, finales del s. XVI - mediados del s. XVII, óleo sobre lienzo, Valencia, Museo de Bellas Artes.

Fig. 3.39. Gregorio Bausá o Antonio Bisquert, Retrato de Fernando de Aragón, duque de Calabria, finales del s. XVI - mediados del s. XVII, óleo sobre lienzo, Valencia, Museo de Bellas Artes.

Fig. 3.40. Gregorio Bausá o Antonio Bisquert, Retrato de Úrsula Germana de Foix, duquesa de Calabria, finales del s. XVI - mediados del s. XVII, óleo sobre lienzo, Valencia, Museo de Bellas Artes.

Fig. 3.41. Vista general del Salón de Reyes del palacio de la Generalitat, Valencia. 
Fig. 3.42. Plano del piso principal del palacio Real de Valencia según Manuel Cavallero en 1802. Véase el Salón de los Retratos (letra B) y el Salón de los Ángeles (letra C).

Fig. 3.43. Jaime I de Valencia y de Aragón, el Conquistador, s. XVII, Valencia, palacio de la Generalitat.

Fig. 3.44. Pedro I de Valencia y III de Aragón, el Grande, s. XVII, Valencia, palacio de la Generalitat.

Fig. 3.45. Anónimo (copia de Ariosto), Pedro III, el Grande, 1634, óleo sobre lienzo, Madrid, Museo Nacional del Prado.

Fig. 3.46. Alfonso I de Valencia y III de Aragón, el Liberal, s. XVII, Valencia, palacio de la Generalitat.

Fig. 3.47. Jaime II de Valencia y de Aragón, el Justo, s. XVII, Valencia, palacio de la Generalitat.

Fig. 3.48. Anónimo (copia de Ariosto), Jaime II, el Justo, 1634, óleo sobre lienzo, Madrid, Museo Nacional del Prado.

Fig. 3.49. Alfonso II de Valencia y IV de Aragón, el Benigno, s. XVII, Valencia, palacio de la Generalitat.

Fig. 3.50. Anónimo (copia de Ariosto), Alfonso IV, el Benigno, 1634, óleo sobre lienzo, Madrid, Museo Nacional del Prado.

Fig. 3.51. Pedro II de Valencia y IV de Aragón, el Ceremonioso, s. XVII, Valencia, palacio de la Generalitat.

Fig. 3.52. Anónimo (copia de Ariosto), Pedro IV, el Ceremonioso, 1634, óleo sobre lienzo, Madrid, Museo Nacional del Prado.

Fig. 3.53. Juan I de Valencia y de Aragón, s. XVII, Valencia, palacio de la Generalitat.

Fig. 3.54. Anónimo (copia de Ariosto), Juan I, 1634, óleo sobre lienzo, Madrid, Museo Nacional del Prado. 
Fig. 3.55. Martín I de Valencia y de Aragón, el Humano, s. XVII, Valencia, palacio de la Generalitat.

Fig. 3.56. Anónimo (copia de Ariosto), Martín I, el Humano, 1634, óleo sobre lienzo, Madrid, Museo Nacional del Prado.

Fig. 3. 57. Fernando I de Valencia y de Aragón, el Honesto, s. XVII, Valencia, palacio de la Generalitat.

Fig. 3.58. Alfonso III de Valencia y $V$ de Aragón, el Magnánimo, s. XVII, Valencia, palacio de la Generalitat.

Fig. 3.59. Pisanello, Medalla de Alfonso V de Aragón, 14481449, Madrid, Museo Arqueológico Nacional.

Fig. 3.60. Anónimo (copia de Ariosto), Alfonso V, el Magnánimo, 1634, óleo sobre lienzo, Madrid, Museo Nacional del Prado.

Fig. 3.61. Juan II de Valencia y Aragón, el Grande, s. XVII, Valencia, palacio de la Generalitat.

Fig. 3.62. Fernando II de Valencia y de Aragón, el Católico, s. XVII, Valencia, palacio de la Generalitat.

Fig. 3.63. Representación de Jaime I en el Libro de armas y blasones..., s. XVI, manuscrito, Madrid, Biblioteca Nacional de España.

Fig. 3.64. Representación de Alfonso IV el Benigno en el Libro de armas y blasones..., $\mathrm{s}$. XVI, manuscrito, Madrid, Biblioteca Nacional de España.

Fig. 3.65. Representación de Carlos I de Austria en el Libro de armas y blasones..., s. XVI, manuscrito, Madrid, Biblioteca Nacional de España.

Fig. 3.66. Representación de Felipe II de Austria en el Libro de armas y blasones..., s. XVI, manuscrito, Madrid, Biblioteca Nacional de España. 
Fig. 3.67. Carlos I, s. XVII, Valencia, palacio de la Generalitat.

Fig. 3.68. Anónimo (copia de Ariosto), Carlos I emperador, 1634, óleo sobre lienzo, Madrid, Museo Nacional del Prado.

Fig. 3.69. Felipe II, s. XVII, Valencia, palacio de la Generalitat.

Fig. 3.70. Sofonisba Anguissola, Felipe II, 1573, óleo sobre lienzo, Madrid, Museo Nacional del Prado.

Fig. 3.71. Anónimo (copia de Ariosto), Felipe II el Prudente, 1634, óleo sobre lienzo, Madrid, Museo Nacional del Prado.

Fig. 3.72. Felipe III, s. XVII, Valencia, palacio de la Generalitat.

Fig. 3.73. Bartolomé González, Felipe III, h. 1615, óleo sobre lienzo, Madrid, Museo Nacional del Prado).

Fig. 3.74. Felipe IV, s. XVII, Valencia, palacio de la Generalitat. Fig. 3.75. Carlos II, s. XVIII, Valencia, palacio de la Generalitat. Fig. 3.76. Felipe V, s. XVIII, Valencia, palacio de la Generalitat. Fig. 3.77. Hyacinthe Rigaud, Felipe V, rey de España, 1701, óleo sobre lienzo, Madrid, Museo Nacional del Prado.

Fig. 3.78. Fernando VI, s. XVIII, Valencia, palacio de la Generalitat.

Fig. 3.79. Carlos III, s. XVIII, Valencia, palacio de la Generalitat.

Fig. 3.80. Carlos IV, finales del s. XVIII - principios del s. XIX, Valencia, palacio de la Generalitat.

Fig. 3.81. Fernando VII, s. XIX, Valencia, palacio de la Generalitat.

Fig. 3.82. Isabel II, s. XIX, Valencia, palacio de la Generalitat. 


\section{Capítulo 4. Retratos eclesiásticos.}

Fig. 4. (a-d).Vistas generales de la serie icónica de prelados de la catedral de Valencia.

Fig. 4.1. Taller de Juan de Juanes, Alfonso de Borja Cavanilles, 1568, óleo sobre guadamecí, Valencia, catedral.

Fig. 4.2. Taller de Juan de Juanes, Rodrigo de Borja, 1568, óleo sobre guadamecí, Valencia, catedral.

Fig. 4.3. Medalla de Alejandro VI, 1492-1503, bronce, acuñada en Roma, Madrid, Museo Arqueológico Nacional, no de inventario 2002/96/104.

Fig. 4.4. Philippe Soye, Alejandro VI, 1568, estampa, Madrid, Biblioteca Nacional de España.

Fig. 4.5. Vicente Macip Comes, El arzobispo Juan de Ribera, 1585 , óleo sobre guadamecí, Valencia, catedral (hoy en día perdido).

Fig. 4.6. Juan Sariñena, El arzobispo Juan de Ribera, 1611, óleo sobre lienzo, Valencia, catedral.

Fig. 4.7. Anónimo, Pedro de Castro, 1611, óleo sobre lienzo, Valencia, catedral (copia de un original ahora perdido).

Fig. 4.8. Juan Ayerbe, Isidoro Aliaga, 1649, óleo sobre lienzo, Valencia, catedral.

Fig. 4.9. Jerónimo Jacinto Espinosa, Pedro de Urbina de Montoya, 1659, óleo sobre lienzo, Valencia, catedral.

Fig. 4.10. Jerónimo Jacinto Espinosa, Martín López de Ontíveros, h. 1666, óleo sobre lienzo, Valencia, catedral.

Fig. 4.11. Anónimo, Ambrosio Ignacio Spínola y Guzmán, h. 1668, óleo sobre lienzo, Valencia, catedral. 
Fig. 4.12. Pedro Núñez de Cepeda (copia), Retrato del arzobispo don Ambrosio Spínola (detalle), 1670, óleo sobre lienzo, Sevilla, ayuntamiento.

Fig. 4.13. Jerónimo Jacinto Espinosa, Luis Alfonso de los Cameros, h. 1676, óleo sobre lienzo, Valencia, catedral.

Fig. 4.14. Gaspar de Lahuerta, Juan de Tomás de Rocabertí, 1700, óleo sobre lienzo, Valencia, catedral.

Fig. 4.15. Atribuido a Evaristo Muñoz, Antonio Folch de Cardona, 1724, óleo sobre lienzo, Valencia, catedral.

Fig. 4.16. Anónimo, Andrés de Orbe y Larreategui, 1737, óleo sobre lienzo, Valencia, catedral.

Fig. 4.17. Anónimo, Andrés de Mayoral Alonso de Mella, h. 1769, óleo sobre lienzo, Valencia, catedral.

Fig. 4.18. Anónimo, Tomás de Azpuru de Mella, h. 1772, óleo sobre lienzo, Valencia, catedral.

Fig. 4.19. Vicente Inglés, Francisco Fabián y Fuero, h. 1794, óleo sobre lienzo, Valencia, catedral.

Fig. 4.20. Vicente López, Antonio Despuig y Dameto, h. 1795, óleo sobre lienzo, Valencia, catedral.

Fig. 4.21. Taller de Vicente López, Juan Francisco Ximenez del Río, h. 1800, óleo sobre lienzo, Valencia, catedral.

Fig. 4.22. Vicente López, Juan Francisco Ximenez del Río, h. 1799 - 1800, Bilbao, Museo de Bellas Artes.

Fig. 4.23. Atribuido a Miguel Parra, Veremundo Arias Teixeiro, h. 1824, óleo sobre lienzo, Valencia, catedral.

Fig. 4.24. Juan Sariñena, El arzobispo san Juan de Ribera adorando la Eucaristía (detalle), 1612, óleo sobre lienzo, Valencia, Real Colegio Seminario del Corpus Christi. 
Fig. 4.25. Urbano Fos, El arzobispo San Juan de Ribera, h. 1654, óleo sobre lienzo, Valencia, Real Colegio Seminario del Corpus Christi.

Fig. 4.26. Juan Sariñena, San Ignacio de Loyola, 1606, óleo sobre lienzo, Valencia, Real Colegio Seminario del Corpus Christi.

Fig. 4.27. Juan Sariñena, Fray Luís de Granada, 1585, óleo sobre lienzo, Valencia, Real Colegio Seminario del Corpus Christi.

Fig. 4.28. Juan Sariñena, Beato Nicolás Factor, 1587, óleo sobre lienzo, Madrid, Real Monasterio de las Descalzas Reales.

Fig. 4.29. José Camarón Bonanat y Joaquín Ballester, Verdadero retrato del beato Nicolás Factor, s. XVIII-XIX, Madrid, Biblioteca Nacional de España.

Fig. 4.30. Vicente Capilla Gil, Verdadero retrato del beato Nicolás Factor, s. XVIII, Valencia, Biblioteca Valenciana.

Fig. 4.31. Juan Sariñena, Vera efigie del venerable Luís Bertrán, 1581 - 1582, óleo sobre tabla, Zaragoza, Museo Camón Aznar.

Fig. 4.32. Juan Sariñena, Fray Luís Bertrán, 1584, óleo sobre lienzo, Valencia, Real Colegio Seminario Corpus Christi.

Fig. 4.33. Julián Mas, San Luis Bertrán asistido por San Juan de Ribera en el hospital de pobres sacerdotes de Nuestra Señora del Milagro, estampa, siglo XIX, Valencia, Biblioteca Valenciana.

Fig. 4.34. Juan Sariñena, Sor Margarita Agulló, 1605, óleo sobre lienzo, Valencia, Real Colegio Seminario Corpus Christi.

Fig. 4.35. Francisco Ribalta, Sor Margarita Agulló, 1600 - 1606, óleo sobre lienzo, Valencia, Real Colegio Seminario del Corpus Christi. 
Fig. 4.36. Francisco Ribalta, Sor Margarita Agulló, 1606, óleo sobre lienzo, Valencia, Real Colegio Seminario del Corpus Christi.

Fig. 4.37. Juan Sariñena, Hermano Francisco del Niño Jesús, 1605, óleo sobre lienzo, Valencia, Real Colegio Seminario de Corpus Christi.

Fig. 4.38. Juan Sariñena, Hermano Francisco del Niño Jesús, 1604 - 1605, óleo sobre lienzo, Valencia, Museo de la Ciudad.

\section{Capítulo 5. Retratos de hombres ilustres.}

Fig. 5.1. Juan Ribalta, Pedro Juan Trilles, s. XVII, óleo sobre lienzo, Valencia, Museo de Bellas Artes.

816 Fig. 5.2. Juan Ribalta, Benito Perera, s. XVII, óleo sobre lienzo, Valencia, Museo de Bellas Artes.

Fig. 5.3. Taller de Juan Ribalta, San Vicente Ferrer, s. XVII, óleo sobre lienzo, Valencia, Museo de Bellas Artes.

Fig. 5.4. Taller de Juan Ribalta, El beato Nicolás Factor, s. XVII, óleo sobre lienzo, Valencia, Museo de Bellas Artes.

Fig. 5.5. Taller de Juan Ribalta, Juan Luis Vives, s. XVII, óleo sobre lienzo, Valencia, Museo de Bellas Artes.

Fig. 5.6. Philippe Galle, Retrato de Luis Vives, finales del s.XVI, estampa, Madrid, Biblioteca Nacional de España.

Fig. 5.7. Edme de Boulonois, Retrato de Juan Luis Vives, 1682, estampa, Madrid, Biblioteca Nacional de España.

Fig. 5.8. Taller de Juan Ribalta, Jaime Ferrús, s. XVII, óleo sobre lienzo, Valencia, Museo de Bellas Artes. 
Fig. 5.9. Taller de Juan Ribalta, Juan Plaza, s. XVII, óleo sobre lienzo, Valencia, Museo de Bellas Artes.

Fig. 5.10. Taller de Juan Ribalta, Luis Collado, s. XVII, óleo sobre lienzo, Valencia, Museo de Bellas Artes.

Fig. 5.11. Taller de Juan Ribalta, Federico Furió Ceriol, s. XVII, óleo sobre lienzo, Valencia, Museo de Bellas Artes.

Fig. 5.12. Taller de Juan Ribalta, Baltasar Marradas y Vich, s. XVII, óleo sobre lienzo, Valencia, Museo de Bellas Artes.

Fig. 5.13. Aegidius Sadeler, Retrato de Baltasar Marradas Vich, s. XVII, estampa, Madrid, Biblioteca Nacional de España.

Fig.5.14. Michael Caspar Lundorp, Johann Theobald Schönwette y Erasmus Kempfer, Retrato de Baltasar Marradas Vich, 1627, estampa, Madrid, Biblioteca Nacional de España.

Fig. 5.15. Taller de Juan Ribalta, Jaime Juan Falcó, s. XVII, óleo sobre lienzo, Valencia, Museo de Bellas Artes.

Fig. 5.16. Taller de Juan Ribalta, Alejandro VI, s. XVII, óleo sobre lienzo, Valencia, Museo de Bellas Artes.

Fig. 5.17. Taller de Juan Ribalta, Fernando I, s. XVII, óleo sobre lienzo, Valencia, Museo de Bellas Artes.

Fig. 5.18. Taller de Juan Ribalta, Honorato Juan, s. XVII, óleo sobre lienzo, Valencia, Museo de Bellas Artes.

Fig. 5.19. Anónimo, Retrato de Honorato Juan, cronología sin determinar, estampa, Madrid, Biblioteca Nacional de España.

Fig. 5.20. Taller de Juan Ribalta, Gaspar Sapena, s. XVII, óleo sobre lienzo, Valencia, Museo de Bellas Artes.

Fig. 5.21. Taller de Juan Ribalta, Pedro Juan Núñez, s. XVII, óleo sobre lienzo, Valencia, Museo de Bellas Artes. 
Fig. 5.22. Taller de Juan Ribalta, Gaspar Aguilar, s. XVII, óleo sobre lienzo, Valencia, Museo de Bellas Artes.

Fig. 5.23. Juan Sariñena, Jerónimo Funes y Muñoz, s. XVII, óleo sobre lienzo, Valencia, Museo de Bellas Artes.

Fig. 5.24. Vista general del paraninfo de la Universitat de València.

Fig. 5.25. Anónimo, Fernando II el Católico, s. XVII, óleo sobre lienzo, Valencia, paraninfo de la Universitat.

Fig. 5.26. Atribuido a José Orient, Cristóbal Crespí de Valldau$r a$, h. 1665, óleo sobre lienzo, Valencia, paraninfo de la Universitat.

Fig. 5.27. Jerónimo Jacinto de Espinosa, Fray José Sanchís Ferrandis, h. 1660, óleo sobre lienzo, Valencia, paraninfo de la Universitat.

Fig. 5.28. Anónimo, Juan Bautista Ibáñez, finales s. XVII, óleo sobre lienzo, Valencia, paraninfo de la Universitat.

Fig. 5.29. José Orient, Luís Crespí de Borja, finales s. XVII, óleo sobre lienzo, Valencia, paraninfo de la Universitat.

Fig. 5.30. Anónimo, Fray Miguel Maiques, s. XVII, óleo sobre lienzo, Valencia, paraninfo de la Universitat.

Fig. 5.31. Atribuido a Juan Ribalta o su taller, Alejandro VI, s. XVII, óleo sobre lienzo, Valencia, paraninfo de la Universitat.

Fig. 5.32. Círculo de Jerónimo Jacinto Espinosa, Fray Marcelo Marona, finales s. XVII, óleo sobre lienzo, Valencia, paraninfo de la Universitat.

Fig. 5.33. Anónimo, Fray Marcelo Marona, estampa ilustrativa para el libro Antonio Prats, Lamentables suspiros del Real Convento de Predicadores de Valencia por la muerte de su sapientísimo 
hijo, y venerable padre maestro fray Marcelo Marona, (Diego de Vega: Valencia, 1695).

Fig. 5.34. Anónimo, Fray Juan Tomás de Rocabertí, h. 1675, óleo sobre lienzo, Valencia, paraninfo de la Universitat.

Fig. 5.35. Gaspar de la Huerta, Retrato del arzobispo Juan Tomás de Rocabertí, finales del s. XVII, óleo sobre lienzo, Valencia, Museo de Bellas Artes.

Fig. 5.36. Anónimo, José Vergé, finales del s. XVII, óleo sobre lienzo, Valencia, paraninfo de la Universitat.

Fig. 5.37. Anónimo, Fray Juan Ruiz, s. XVII, óleo sobre lienzo, Valencia, paraninfo de la Universitat.

Fig. 5.38. Anónimo, Fray Jaime Pérez, 1700-1730, óleo sobre lienzo, Valencia, paraninfo de la Universitat.

Fig. 5.39. Anónimo, Antonio Ferrer Milán, s. XVIII, óleo sobre lienzo, Valencia, paraninfo de la Universitat.

Fig. 5.40. Anónimo, Marcelino Siuri, s. XVIII, óleo sobre lienzo, Valencia, paraninfo de la Universitat.

Fig. 5.41. Anónimo, Marcelino Siuri, 1830, estampa en la obra Valencianos ilustres en virtud, ciencias y armas, Valencia, Biblioteca de la Universitat.

Fig. 5.42. Anónimo, Marcelino Siuri, h. 1775, estampa, Madrid, Biblioteca Nacional de España.

Fig. 5.43. Anónimo, Asensio Sales Moreno, segunda mitad del s. XVIII, óleo sobre lienzo, Valencia, paraninfo de la Universitat.

Fig. 5.44. Vicente Galcerán Alapont, Asensio Sales Moreno, 1761, estampa, Madrid, Biblioteca Nacional de España.

Fig. 5.45. Atribuido a José Vergara, José Climent Avinent, h. 
1770, óleo sobre lienzo, Valencia, paraninfo de la Universitat.

Fig. 5.46. Atribuido a José Vergara, José Tormo Julià, s. XVIII, óleo sobre lienzo, Valencia, paraninfo de la Universitat.

Fig. 5.47. Vicente Capilla, José Tormo Julià, 1780, estampa, Depósito Académico Digital de la Universidad de Navarra.

Fig. 5.48. José Vergara, Felipe Bertrán García, h. 1750-1800, óleo sobre lienzo, Valencia, paraninfo de la Universitat.

Fig. 5.49. Atribuido a José Vergara, Francisco Borrull Ramón, s. XVIII, óleo sobre lienzo, Valencia, paraninfo de la Universitat.

Fig. 5.50. Anónimo, Luis Nicolás Vergara, s. XVIII, óleo sobre lienzo, Valencia, paraninfo de la Universitat.

Fig. 5.51. Anónimo, Fray Bernardo Oliver, 1730-1760, óleo sobre lienzo, Valencia, paraninfo de la Universitat.

820 Fig. 5.52. Círculo de Salvador Maella, Antonio José Cavanilles, 1775-1800, óleo sobre lienzo, Valencia, paraninfo de la Universitat.

Fig. 5.53. Anónimo, Damián Polou, s. XVIII, óleo sobre lienzo, Valencia, paraninfo de la Universitat.

Fig. 5.54. Anónimo, Fray Tomás Marín, s. XVIII, óleo sobre lienzo, Valencia, paraninfo de la Univeristat.

Fig. 5.55. Anónimo, Manuel Martí Zaragoza, s. XVIII, óleo sobre lienzo, Valencia, paraninfo de la Universitat.

Fig. 5.56. Anónimo, Juan Bautista Ferrer Castro, s. XVIII, óleo sobre lienzo, Valencia, paraninfo de la Universitat.

Fig. 5.57. Anónimo, Antonio García Cervera, 1730-1760, óleo sobre lienzo, Valencia, paraninfo de la Universitat.

Fig. 5.58. Anónimo, Gaspar Fuster, s. XVIII, óleo sobre lienzo, 
Valencia, paraninfo de la Universitat.

Fig. 5.59. Anónimo, Francisco Pérez Bayer, h. 1785, óleo sobre lienzo, Valencia, paraninfo de la Universitat.

Fig. 5.60. Anónimo, Francisco Fabián y Fuero, finales del s. XVIII, óleo sobre lienzo, Valencia, paraninfo de la Universitat.

Fig. 5.61. Atribuido a Joaquín Giner, Tomás Vicente Tosca, h. 1750, óleo sobre lienzo, Valencia, paraninfo de la Universitat.

Fig. 5.62. Bernardo López Piquer, Mariano Liñán Morelló, 1840, óleo sobre lienzo, Valencia, paraninfo de la Universitat.

Fig. 5.63. Anónimo, Juan Sala Bañuls, s. XIX, óleo sobre lienzo, Valencia, paraninfo de la Universitat.

Fig. 5.64. Taller de Vicente López, Retrato del pavorde Juan Sala Bañuls, 1826-1875, óleo sobre lienzo, Madrid, Museo Lázaro Galdiano.

Fig. 5.65. Bernardo López, Nicolás María Garelli, h. 1840, óleo sobre lienzo, Valencia, paraninfo de la Universitat.

Fig. 5.66. Bernardo López, Miguel Payá y Rico, h. 1840, óleo sobre lienzo, Valencia, paraninfo de la Universitat.

Fig. 5.67. Bernardo López, Vicente Blasco García, 1833, óleo sobre lienzo, Valencia, paraninfo de la Universitat.

Fig. 5.68. Vicente López, Vicente Blasco García, rector de la Universitat de València, h. 1820, óleo sobre lienzo, Valencia, Real Academia de Bellas Artes de San Carlos.

Fig. 5.69. Taller de Vicente López, Fray Vicente Blasco, rector de la Universitat de València, h. 1826-1850, óleo sobre lienzo, Madrid, Museo Lázaro Galdiano.

Fig. 5.70. Mariano Salvador Maella, Vicente Blasco García, 1787, Valencia, sala de juntas de la Universitat. 
Fig. 5.71. José Vergara, Fernando VI, h. 1753, óleo sobre lienzo, Valencia, Real Academia de Bellas Artes de San Carlos.

Fig. 5.72. José Vergara, Bárbara de Braganza, h. 1753, óleo sobre lienzo, Valencia, Real Academia de Bellas Artes de San Carlos.

Fig. 5.73. José Vergara, Retrato de Carlos III, siglo XVIII, óleo sobre lienzo, Valencia, Real Academia de Bellas Artes de San Carlos.

Fig. 5.74. Anton Rafael Mengs, Carlos III, h. 1765, óleo sobre lienzo, Madrid, Museo Nacional del Prado.

Fig. 5.75. Anton Rafael Mengs, Carlos III, h. 1774, óleo sobre lienzo, Madrid, Museo Nacional del Prado.

Fig. 5.76. Manuel Salvador Carmona, Carlos III, 1783, talla dulce, Madrid, Museo Nacional del Prado.

Fig. 5.77. Vicente López, Carlos IV, h. 1792, óleo sobre lienzo, Valencia, Real Academia de Bellas Artes de San Carlos.

Fig. 5.78. Mariano Salvador Maella, Carlos IV, 1792, óleo sobre lienzo, México, Museo Nacional de San Carlos.

Fig. 5.79. Vicente López, Joaquín Pareja y Obregón, h. 1792, óleo sobre lienzo, Valencia, Real Academia de Bellas Artes de San Carlos.

Fig. 5.80. Luis Planes, Pedro Caro y Fontes, 1779, óleo sobre lienzo, Valencia, Real Academia de Bellas Artes de San Carlos.

Fig. 5.81. Manuel Camarón Melià, Francisco Xavier Azpíroz, 1798, óleo sobre lienzo, Valencia, Real Academia de Bellas Artes de San Carlos.

Fig. 5.82. Vicente López, Jorge Palacios de Urdániz y Chavier, h. 1801, óleo sobre lienzo, Valencia, Real Academia de Bellas Artes de San Carlos. 
Fig. 5.83. Miguel Parra, Francisco Javier Elío Olóndriz capitán general de Valencia, h. 1815, óleo sobre lienzo, Madrid, Museo Nacional del Prado.

Fig. 5.84. Miguel Parra, Idelfonso Díez de Ribera y Muro, conde de Almodóvar, 1821, óleo sobre lienzo, Valencia, Real Academia de Bellas Artes de San Carlos.

Fig. 5.85. Miguel Parra, Alejandro Bassecourt y Dupire, h. 1825, óleo sobre lienzo, Valencia, Real Academia de Bellas Artes de San Carlos.

Fig. 5.86. Miguel Parra, José María de Carvajal y Urrutia, h. 1826, óleo sobre lienzo, Valencia, Real Academia de Bellas Artes de San Carlos.

Fig. 5.87. Miguel Parra, José O'Donnel Anethan, h. 1827, óleo sobre lienzo, Valencia, Real Academia de Bellas Artes de San Carlos.

Fig. 5.88. Miguel Parra, José María de Santocildes, h. 1834, óleo sobre lienzo, Valencia, Real Academia de Bellas Artes de San Carlos.

Fig. 5.89. José Zapata Nadal, Vicente Gascó Massot, 1798, óleo sobre lienzo, Valencia, Real Academia de Bellas Artes de San Carlos.

Fig. 5.90. José Vergara, Ignacio Vergara, 1798, óleo sobre lienzo, Valencia, Real Academia de Bellas Artes de San Carlos.

Fig. 5.91. José Vergara, Autorretrato, 1798, óleo sobre lienzo, Valencia, Real Academia de Bellas Artes de San Carlos.

Fig. 5.92. Agustín Esteve, José Esteve Bonet, h. 1790, óleo sobre lienzo, Valencia, Real Academia de Bellas Artes de San Carlos.

Fig. 5.93. Vicente López, Manuel Monfort Asensi, h. 1803, óleo sobre lienzo, Valencia, Real Academia de Bellas Artes de San 
Carlos.

Fig. 5.94. Miguel Parra, Luis Antonio Planes, 1822, óleo sobre lienzo, Valencia, Real Academia de Bellas Artes de San Carlos.

Fig. 5.95. Miguel Parra, Vicente Marzo, h. 1826, óleo sobre lienzo, Valencia, Real Academia de Bellas Artes de San Carlos.

Fig. 5.96. José Zapata Nadal, Cristóbal Sales, h. 1806, óleo sobre lienzo, Valencia, Real Academia de Bellas Artes de San Carlos.

Fig. 5.97. José Romà, Benito Espinós, h. 1818, óleo sobre lienzo, Valencia, Real Academia de Bellas Artes de San Carlos.

Fig. 5.98. Vicente Castelló, José Cloostermans, primera mitad del s. XIX, óleo sobre lienzo, Valencia, Real Academia de Bellas Artes de San Carlos.

824 Capítulo 6. Un caso particular. Retratos de turcos en el Real Colegio Seminario del Corpus Christi.

Fig. 6.1. Tiziano, Solimán el Magnífico, ca. 1530, óleo sobre lienzo, Viena, Kunsthistoriches Museum.

Fig. 6.2. Nicolás de Nicolay, Les quatre premiers livres des navigations et pérégrinations orientales, 1568, Lyon, Biblioteca Nacional de Francia.

Fig. 6.3. Thèodore de Bry, Rossa Solimanni Uxor en Jean Jacques Boissard, Vitae et icones sultanorum Turcicorum, 1596.

Fig. 6.4. Representación de la favorita del Gran Turco en Cesare Vecellio, Degli habiti antichi et moderni di diversi parti del mondo, 1590, Venecia, Biblioteca Nacional de Francia.

Fig. 6.5. Jerónimo Román, Repúblicas del mundo, 1575, Madrid, 
Biblioteca Nacional de España.

Fig. 6.6. Representación de un Giomalier en Nicolás de Nicolay, Les navigations, peregrinations et voyages faicts en la Turquie, 1576, Amberes, Biblioteca Nacional de Francia.

Fig. 6.7. Representación de un Calender en Nicolás de Nicolay, Les navigations, peregrinations et voyages faicts en la Turquie, 1576, Amberes, Biblioteca Nacional de Francia.

Fig. 6.8. Representación de un Dirvisio en Nicolás de Nicolay, Les navigations, peregrinations et voyages faicts en la Turquie, 1576, Amberes, Biblioteca Nacional de Francia.

Fig. 6.9. Representación de un Torloco en Nicolás de Nicolay, Les navigations, peregrinations et voyages faicts en la Turquie, 1576, Amberes, Biblioteca Nacional de Francia.

Fig. 6.10. Cesare Vecellio Habiti antichi, overo raccolta di figure delinéate dal Gran Tiziano, e Cesare Vecellio suo fratello, diligentemente intagliate, conforme alle Nationi del Mondo, 1664, Venecia, Biblioteca Nacional de Francia.

Fig. 6.11. Representación del Gran Turco en Cesare Vecellio, Degli habiti antichi et moderni di diversi parti del mondo, 1590, Venecia, Biblioteca Nacional de Francia.

Fig. 6.12. Representación del Sofí de Persia en Cesare Vecellio, Habiti antichi et moderni di tutto il mondo, 1598, Venecia.

Fig. 6.13. Anónimo, Capitán Persiang, finales del siglo XVI o principios del XVII, óleo sobre lienzo, Valencia, Real Colegio Seminario del Corpus Christi.

Fig. 6.14. Representación del Gentilhuomo persiano en Nicolás de Nicolay, Les navigations, peregrinations et voyages faicts en la Turquie, 1576, Amberes, Biblioteca Nacional de Francia.

Fig. 6.15. Representación del Mercante d'Arabia en Nicolás de 
Nicolay, Les navigations, peregrinations et voyages faicts en la Turquie, 1576, Amberes, Biblioteca Nacional de Francia.

Fig. 6.16. Anónimo, Mercader de Arabia, finales del siglo XVI o principios del XVII, óleo sobre lienzo, Valencia, Real Colegio Seminario del Corpus Christi.

Fig. 6.17. Respresentación del Muftí en Cesare Vecellio Habiti antichi, overo raccolta di figure delinéate dal Gran Tiziano, $e$ Cesare Vecellio suo fratello, diligentemente intagliate, conforme alle Nationi del Mondo, 1664, Venecia, Biblioteca Nacional de Francia.

Fig. 6.18. Anónimo, Muftí, finales del siglo XVI o principios del XVII, óleo sobre lienzo, Valencia, Real Colegio Seminario del Corpus Christi.

Fig. 6.19. Representación de un Solaqui en Cesare Vecellio, Degli habiti antichi et moderni di diversi parti del mondo, 1590, Venecia, Biblioteca Nacional de Francia.

Fig. 6.20. Anónimo, Solaqui, finales del siglo XVI o principios del XVII, óleo sobre lienzo, Valencia, Real Colegio Seminario del Corpus Christi.

Fig. 6.21. Anónimo, Dejli Cassi, finales del siglo XVI o principios del XVII, óleo sobre lienzo, Valencia, Real Colegio Seminario del Corpus Christi.

Fig. 6.22. Anónimo, Soldado georgiano, finales del siglo XVI o principios del XVII, óleo sobre lienzo, Valencia, Real Colegio Seminario del Corpus Christi.

Fig. 6.23. Representación del Sfachiotto de Candía en Cesare Vecellio, Degli habiti antichi et moderni di diversi parti del mondo, 1590, Venecia.

Fig. 6.24. Anónimo, Sfachiotto de Candía, finales del siglo XVI 
o principios del XVII, óleo sobre lienzo, Valencia, Real Colegio Seminario del Corpus Christi.

Fig. 6.25. Anónimo, Gran Soldán, finales del siglo XVI o principios del XVII, óleo sobre lienzo, Valencia, Real Colegio Seminario del Corpus Christi.

Fig. 6.26. Representación del Gran Soldán en Cesare Vecellio, Degli habiti antichi et moderni di diversi parti del mondo, 1590, Venecia, Biblioteca Nacional de Francia.

Fig. 6.27. Anónimo, Consejero del Gran Soldán, finales del siglo XVI o principios del XVII, óleo sobre lienzo, Valencia, Real Colegio Seminario del Corpus Christi.

Fig. 6.28. Representación de los Consejeros del Gran Soldán en Cesare Vecellio, Degli habiti antichi et moderni di diversi parti del mondo, 1590, Venecia, Biblioteca Nacional de Francia.

Fig. 6.29. Anónimo, Mercader armenio, finales del siglo XVI o 827 principios del XVII, óleo sobre lienzo, Valencia, Real Colegio Seminario del Corpus Christi.

Fig. 6.30. Representación del Armenio mercante en Cesare Vecellio, Degli habiti antichi et moderni di diversi parti del mondo, 1590, Venecia, Biblioteca Nacional de Francia.

\section{Epílogo. El retrato y su implicación en la fiesta. Una futura investigación.}

Fig. E.1: Pasqual Pere Moles y Noël Hallé, Alegoría del nacimiento del infante Carlos Clemente, 1771, estampa, Barcelona, Museu Nacional d'Art de Catalunya.

Fig. E.2: Empresa XXI Regit et corregit en Diego de Saavedra 
Fajardo, Idea de un príncipe político cristiano, representada en cien empresas, (Gerónimo Villagrasa: Valencia, 1665).

Fig. E.3: Jacinto Gómez, Alegoría del nacimiento del infante don Carlos Clemente, 1772, óleo sobre lienzo, Madrid, Museo de la Real Academia de Bellas Artes de San Fernando.

Fig. E.4: Gregorio Ferro Requeixo, Alegoría del nacimiento del Infante Carlos Clemente, 1772, óleo sobre lienzo, Madrid, Museo de la Real Academia de Bellas Artes de San Fernando.

Fig. E.5: Zacarías González y Velázquez, Alegoría del nacimiento del infante Carlos Eusebio, 1781, óleo sobre lienzo, Madrid, Museo de la Real Academia de Bellas Artes de San Fernando.

Fig. E.6: Cosme de Acuña y Troncoso, Alegoría del nacimiento del infante Carlos Eusebio, 1781, óleo sobre lienzo, Madrid, Museo de la Real Academia de Bellas Artes de San Fernando.

Fig. E.7: Agustín Navarro, Presentación alegórica del infante Carlos Eusebio, siglo XVIII, óleo sobre lienzo, Madrid, Museo de la Real Academia de Bellas Artes de San Fernando.

Fig. E.8: Real Cédula de 22 de octubre de 1783.

Fig. E.9: Juan Antonio Salvador Carmona y Luis Peret y Alcázar, Alegoría de los infantes gemelos Carlos y Felipe, 1783, estampa, Madrid, Biblioteca Nacional.

Fig. E.10: Manuel Salvador Carmona, Alegoría del nacimiento de dos infantes gemelos, hijos de Carlos IV y Ma Luisa de Parma, 1783, estampa, Madrid, Biblioteca Nacional.

Fig. E.11: José Vergara/ Luis Planes, Retrato ideal de un infante que hizo la Academia para colocar en las demostraciones públicas, 1784, óleo sobre lienzo, Valencia, Real Academia de Bellas Artes de San Carlos. 


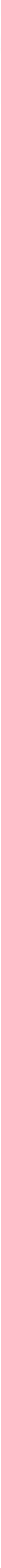

